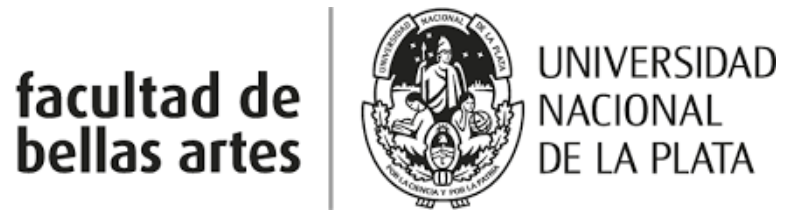

Doctorado en Artes

\title{
Viejos Sonidos Subalternos
}

Vacancias y disponibilidad de la historiografía musical para el estudio de la música popular en la larga duración histórica

Un problema de compresión analítica

Tesista: Martín R. Eckmeyer

Directora: María Elena Larrègle 
A Paula y Agustín

Gracias a ellos toda nuestra vida tiene música. 


\section{Indice}

$\begin{array}{ll}\text { Agradecimientos } & 6\end{array}$

$\begin{array}{ll}\text { Introducción } & 7\end{array}$

0.1 La música popular frente a los paradigmas de la historiografía musical afirmativa. Algunos antecedentes

0.2 La historiografía musical y las formas de deshacerse del pueblo 10

0.3 La historiografía musical como cultura afirmativa 15

0.4 Hipótesis de trabajo para una ampliación de la dimensión histórica de la música popular

0.5 Conceptos extranjeros para un marco de sustento teórico 25

0.5.1 Historicidad del mercado musical, musicar y performance presentacional 25

0.5.2 El musicar común como transculturación y mestizaje 32

0.5.3 El Mundo Popular Subalterno 35

0.6 Sobre la Metodología 41

0.6.1 Diseño de un objeto de estudio que reside en los sujetos de la performance y el sonido41

0.6.2 Unidades de análisis y fuentes de datos 43

\section{Primera parte: La música no es popular $\quad 47$}

$\begin{array}{ll}\text { Capítulo } 1 & 48\end{array}$

Del desinterés acerca de los primitivos, sus vidas y sus músicas 48

1.1 Personalistas $\quad 54$

1.1.1 Un peregrinaje al son de los himnos 66

1.1.2 La autonomía musical como operación afirmativa del canon musical occidental $\quad 80$

1.1.3 ¿Qué cultura afirma la cultura afirmativa?

1.2 Positivistas $\quad 86$

1.2.1 ¿Qué tiene de "positivista" la musicología histórica? 93

1.2.2 Del fetichismo de la partitura al fetichismo de las obras. 98

1.2.3 La obra-objeto reemplaza al acontecimiento 102

1.2.4 El estilo como concepto normativo de la historiografía afirmativa 108

1.2.5 El carácter ideológico de la persistencia del positivismo. 113

Capítulo $2 \quad 118$

La segunda vida del pueblo $\quad 118$

2.1 El Pathos de la distancia o "pues de este modo todos seríamos iguales" $\quad 118$

2.2 El universo subalterno de los ruidos: de la proscripción a la domesticación $\quad 125$

2.2.1 Lo carnavalesco y la carnivalización del musicar $\quad 144$

2.2.2 Una música de incultos, para los locos y los tontos $\quad 149$

2.3 El Pathos de la transformación o la inversión carnavalesca del paradigma
musicológico

$\begin{array}{ll}2.4 \text { Representación por estilización } & 171\end{array}$ 
El ritmo del descenso 183

3.1 La tradición como fuente 191

Segunda parte: El pueblo no es el pueblo 207

Capítulo $4 \quad 208$

De las radios a los ranchos $\quad 208$

4.1 Acerca de la pureza de los manantiales y la orografía del pueblo 209

4.1.1 Cuchillos de palo 218

4.1.2 Gauchos porteños $\quad 221$

4.1.3 El Pozo de Vargas se convierte en manantial del folklore 226

4.1.4 El sonido de Vargas $\quad 234$

4.2 Patria, raza y autenticidad. Del escenario a la academia 242

4.2.1 El naturalismo musical de los cuerpos $\quad 249$

4.2.2 La raza como garantía de autenticidad 253

4.2.3 Cartografías del extractivismo epistémico 256

4.3 Del Típico exótico al objeto etnológico como estilo 268

4.3.1 A fakesong folk-market o una "saladita de canciones de dudosa procedencia" $\quad 278$

4.3.2 El consenso de la Zamba: Recuerdos del porvenir que también evocan grandes éxitos296

4.3.3 Agitando pañuelos en el país de Goofy 299

4.4 El folklorista y el juglar 301

Capítulo 5

Ministriles transmodernos 306

5.1.1 La domesticación de los juglares $\quad 315$

$\begin{array}{ll}\text { Origen popular } & 318\end{array}$

$\begin{array}{ll}\text { Ciudadanía } & 320\end{array}$

$\begin{array}{ll}\text { Relación de dependencia y cuentapropismo } & 320\end{array}$

Especialización y profesionalización 322

5.1.2 Ministriles y ministriles: los domésticos 325

5.1.3 Músicos municipales profesionales 328

Una falacia evolucionista: los músicos no son vigilantes 332

5.1.4 Formas de organización de los músicos municipales 336

$\begin{array}{ll}\text { Confraternidades y cofradías } & 338\end{array}$

Gremios $\quad 341$

5.2 La música en la dualidad urbana latinoamericana 344

$\begin{array}{ll}\text { 5.2.1 Partituras blancas, sonidos ch'ixi } & 348\end{array}$

5.2.2 - El riesgo del mestizaje 355

5.2.3 - Los cuerpos grotescos del Corpus también pueden ser cobrizos 362

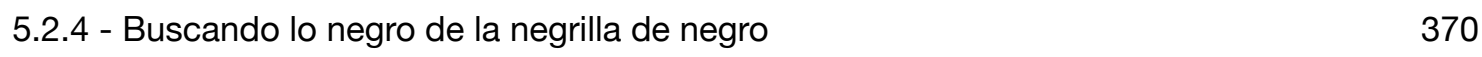


5.2.5 - Ichapekene Piesta, o los ministriles transmodernos de la selva tan distintos a los gauchos del bosque

5.2.6 - La subversión del baile negro del obispo 384

$\begin{array}{ll}\text { Conclusiones } & 397\end{array}$

6.1 Estamos en esto sólo por el dinero $\quad 397$

6.2 Balada para un juglar 403

6.3 ¿Qué hacemos con el pueblo? Las tres modernidades de la historiografía musical 407

6.4 Algunos indicadores para (re)pensar la música popular en la historia 411

6.4.1 El cuerpo de la performance como forma popular 411

6.4.2 Mestizaje y nomadismo. 412

6.4.3 Carácter dialógico $\quad 414$

6.4.4 integralidad y trascendencia $\quad 416$

6.4.5 Lo transcultural como continuidad y potencialidad transmoderna 416

$\begin{array}{ll}\text { Anexos } & 419\end{array}$

$\begin{array}{ll}\text { Bibliografía referida } & 419\end{array}$

Discografía $\quad 439$

Referencias en video $\quad 441$ 


\section{Agradecimientos}

Buena parte de los problemas y discusiones que dan cuerpo a esta tesis provienen de la aventura en la que me embarqué cuando me propusieron ser profesor de Historia de la Música I de la Facultad de Bellas Artes de la UNLP. En especial al iniciarse ese derrotero en simultaneidad con la creación y apertura de la carrera de Música Popular. Por lo tanto puede entenderse este texto como un resultado algo tardío del trabajo en pos de generar un corpus histórico que incluyera a la música popular desde el inicio de la narrativa en las cursadas. Por lo tanto estoy muy agradecido a las y los docentes que me han acompañado en la construcción de la asignatura desde hace ya más de doce años. Sus ideas, aportes, dedicación en la tarea y fundamentalmente su compañerismo son los verdaderos responsables de que hayamos podido articular con cierta coherencia una historia en la que caben muchas historias, y sobre todo, las de las clases populares y sus músicas.

Los estudiantes, tal vez para su desdicha, han protagonizado una extensa experimentación programática y didáctica sobre todos estos temas, que ha incluido para ellos no sólo el estudio de bibliografías engorrosas y fragmentarias, sino también el hacer música como parte de la experiencia de cursada, incluyendo danzas, carnavales, tocotines y otros fragmentos del pasado musical popular. Pero fundamentalmente su condición masiva y la predisposición a discutir sin reparos y de igual a igual, han sido -y son- una fuente de estímulo permanente que nos lleva a empujar la frontera del conocimiento histórico de las músicas populares.

También quiero agradecer al Dr. Daniel Belinche, profesor y amigo, por impulsar el Doctorado en Artes en nuestra Facultad, poblarlo de un carácter latinoamericano y convocar a una serie de figuras muy relevantes del pensamiento y la producción artística para que ofrecieran seminarios y cursos. También ha sido el principal responsable de la creación de la carrera de Música Popular y de reconciliar las identidades del "pueblo" con los sectores populares dentro de la universidad, sin eufemismos ni falsos relativismos. Sin ese contexto académico que transformó radicalmente nuestra casa de estudios, tal vez nunca se hubieran planteado los problemas de investigación que orientaron esta tesis.

El diálogo con mi compañera de vida y colega, Dra. María Paula Cannova, ha sido la verdadera condición de posibilidad de todo este trabajo. Por un lado asumió el difícil rol de ser quien adelanta las preguntas más complejas e incisivas, cuando es más fácil callar de forma complaciente y dejar que otros personifiquen las críticas. En nuestras conversaciones y debates aprendí a dar forma a muchas de las argumentaciones que aquí se presentan. Pero además ha tenido una increíble paciencia y generosidad que me permitieron abusar del tiempo en nuestra ajustada cotidianeidad, por lo que es directamente responsable de que este trabajo se haya podido terminar.

Finalmente vaya mi admiración y gratitud para el enorme trabajo y la serena paciencia de mi directora de tesis, María Elena Larrègle, que ha dedicado valiosas horas a la lectura y corrección de estas páginas. En buena medida muchos de los planteos de índole más filosófica que subyacen a los temas centrales de esta tesis, fueron puestos ante mi atención por ella como mi profesora de Apreciación Musical, el año que comencé mi carrera de grado. La confianza con la que hemos trabajado en todos estos años se expresó una vez más en el acompañamiento que recibí para la escritura de estas páginas. 


\title{
Introducción
}

"Así como es el vencedor quien escribe la historia, esto es, quien se crea su propio mito, así también es él quien determina qué es lo que

ha de tener vigencia como arte.»

Ernst Jünger (1990)

\subsection{La música popular frente a los paradigmas de la historiografía musical afirmativa. Algunos antecedentes}

«Estudios ocasionales y aislados, comentarios tangenciales, notas a pie de página»1. Durante casi dos siglos el estudio de la música popular pareció relegado a un plano marginal dentro de la investigación en música. La musicología histórica directamente ignoró el asunto y se ocupó de la música culta o académica sin dar mayores explicaciones, colaborando esta ignorancia voluntaria en la universalización forzada de la música de las élites europeas occidentales como "lenguaje universal" 2 que todos en todas partes deberíamos interpretar y comprender como "lenguaje común" 3 . Lenguaje basado en el predominio de la valoración estética del ordenamiento de las alturas y sobre todo en sentido vertical o simultáneo. Es decir, un lenguaje musical que consiste en lo que tradicionalmente la teoría musical -desde por lo menos la Edad Media- denominó "armonía"4. No hay que ser muy aventurado en la interpretación para conectar el contexto de formación de la musicología como disciplina -el siglo XIX-con el estilo de la música de élite que hizo del

\footnotetext{
1 Con esta descripción sobre el lugar reservado al estudio de la música popular comenzaban Richard Middleton y Edward Horn el prefacio al primer número de la revista Popular Music: Folk or Popular? Distinctions, Influences, Continuities (1981, pp. 1-2).
}

\begin{abstract}
2 Es más comprensible la aparición de este tipo de pensamiento en los testimonios de músicos de esa élite, como son los casos de Haydn o Wagner, que la defensa que de él se hace todavía en los libros de texto: ejemplos recientes son la Guía Universal de la Música Clásica de Josep Pascual (2008) o Cómo leer música de Roger Evans (2004), por no mencionar a un intelectual de la talla de Hans-Georg Gadamer, quien también reafirma esta creencia, lo cual no hace más que confirmar el carácter de "sentido común ilustrado" que en base a la historiografía musical ha naturalizado nociones al menos polémicas. Dice Gadamer que la música culta «es la forma suprema y propia de la música de la cual tenemos una experiencia totalmente increíble. Pues se ha convertido en una lengua universal» (Gadamer, 2001, pág.21) Consúltese también la definición de "música" del Atlas de la Música de Michels (1992, p. 11). Es interesante además observar que actualmente la única sección cuestionada del artículo de Wikipedia sobre "música" es justamente la que abre explícitamente la discusión sobre la supuesta universalidad musical, mientras que la propia definición (en sí misma universalista) y la inclusión del apartado "notación musical occidental" (que reafirma tal posición) no han perturbado las condiciones de neutralidad exigidas por la enciclopedia digital.
\end{abstract}

\footnotetext{
3 Dentro de la tradición de la música culta occidental -y demostrando el sesgo estético y metodológico de la musicología tradicional- se denomina "lenguaje común" o "práctica común" a la música tonal funcional, particularmente la compuesta entre mediados del siglo XVII y comienzos del XX. Véase por ejemplo el tratado de Armonía de Walter Piston (1991). Es decir, la que corresponde exactamente con el canon de obras maestras y grandes compositores que representa el núcleo de la historia de la música positivista. Es al menos simpática la utilización del término "común" para una forma de producción artística que hoy solo identifica a una minoría cultural muy reducida y que no representa como tal a ningún sector, clase o subcultura mayoritaria de la sociedad contemporánea. Más adelante desarrollaremos este tema en profundidad y buscaremos contrastarlo con otras opciones de "costumbre en común", "música común" o "lenguaje musical común".

${ }^{4}$ Es muy significativo que en el reemplazo y actualización de las asignaturas denominadas "armonía" en planes de estudio de música de educación superior y universitaria, casi sin excepción se ha optado por la denominación "lenguaje musical". Como no se modificó significativamente el contenido de las mismas, esta operación profundizó la confusión que centraliza el lenguaje en el ordenamiento de las alturas.
} 
manejo armónico no sólo un arte sino también un medio de generar diversificación y variedad en un mercado musical pujante ${ }^{5}$-el Romanticismo.

Por lo tanto, al menos en su configuración básica, la musicología histórica orientó sus estudios irradiando -entre muchas otras cosas- sus valores estéticos relativos a la armonía musical, construyendo categorías de estilo a partir del uso armónico. Puede leerse por ejemplo en el comienzo del Atlas de la Música de Ulrich Michels:

La idea intelectual convierte el material acústico en arte de los sonidos. Con el intelecto la música adquiere historia. Esto vale en especial para la música polifónica de Occidente desde el siglo XII, y menos para ciertas prácticas populares (usos tradicionales invariados en lo posible) y para gran parte de la música extraeuropea. En este sentido la historia de la música es, en cierto modo, autónoma: es una historia de la técnica de la composición, de las formas, de los estilos, de los géneros, etc." (Michels, 1992, p. 11).

Polifonía, es decir, superposición y articulación armónica de las alturas. No hay un momento primigenio más mimado y custodiado por la musicología histórica que el "nacimiento de la polifonía". Mediante esta estrategia, la musicología histórica procedía a evaluar, hacia atrás y hacia adelante en el tiempo, qué músicas valdría la pena incorporar a su relato en función de sus reglas internas (Dahlhaus, 1997).

Estas nociones tan específicas sobre la música, junto con las valoraciones que conllevan, suelen asociarse con el carácter escrito de la música culta, subrayando este aspecto no sólo en términos de sofisticación, sino elevándolo al rango de condición para poder realizar un estudio histórico válido. La partitura -una anomalía que sólo existe como tal en el repertorio musical minoritario de Europa Occidental a partir del siglo IX- se convierte así en rasgo universal de la música y única fuente historiográfica válida.

En general, estos aspectos estéticos y valorativos han sido esgrimidos por la musicología para desentenderse del estudio de las músicas producidas bajo otras coordenadas, generando al mismo tiempo comparaciones valorativas que siempre han desestimado a la música popular por sencilla o menos evolucionada, cuanto menos. De forma tal que la música popular queda al margen de la historia por cuestiones metodológicas, aunque si no existieran habría que inventarlas. A tal punto la valoración estética se sobreimprime como criterio historiográfico, que la música popular es expulsada además del ámbito de la creación y hasta de la cultura ya que sus practicantes "incultos" son «cantores de canciones de otros hombres» (Hoppin, 2000, p. 280). De esta forma toda música que no coincida con el carácter notacional y objetual de la música culta occidental, por su propia naturaleza, no puede integrarse a la historia.

No deberá sorprendernos entonces que la historia de la música se hace comenzar justamente cuando aparece una forma de escribir -más o menos con precisión- las alturas de la música, ${ }^{6}$ aún si ese comienzo quede en una época, la Edad Media, que hasta en su denominación está "en el medio" y no "en el principio". Nada más natural, bajo este paradigma, que una historia de las manifestaciones musicales escritas antes que sonoras. Aunque la música consista fundamentalmente en una articulación temporal del espacio acústico y, por lo tanto, un fenómeno efímero antes que un objeto inmutable, la historia de la

\footnotetext{
5 «La música es el primer campo en el que la determinación científica del concepto va a imponerse, y en el que la economía política conquistará la victoria» (Attali, 2011, p. 91)

6 Como la escritura histórica está siempre abierta a reescrituras, la periodización exacta de este momento fundacional de la música culta occidental ha experimentado cambios, aún dentro de las corrientes historiográficas más conservadoras, a medida que se desarrollan las investigaciones sobre la notación musical medieval. Pero como la notación es producto de una cultura que es específicamente medieval, la Edad Media es -y seguirá siendo- el primer período de la historia musical tradicional.
} 
música ha negado doblemente el carácter performativo en su configuración, desarrollando una relato escrito de los escritos musicales, es decir, de las partituras, hayan sido puestas en sonido -interpretadas- alguna vez o no.

Como remedio para todas aquellas músicas que suscitaban el interés de las clases hegemónicas del siglo XIX pero que no tenían lugar en el paradigma musicológico, "caerían en la esfera del folclor"7, de tal suerte que los flamantes estudios sobre folklore o "musicología comparada"8 (como gustaba llamarse al ancestro de la etnomusicología) se apuraron en aclarar que sus objetos de estudio no eran las músicas del aquí y ahora, ni mucho menos sus antecedentes: el mismísimo Herder escribió que «el pueblo no es la turba de las calles, que nunca compone o canta, sólo chillan y destruyen» ${ }^{9}$. Él y sus colegas abogaban así por realizar distinciones claras y sin ambigüedades entre Volk y Pöbe/10, protegiendo a una idealizada cultura en estado natural, pastoril y de un pasado remoto, ${ }^{11}$ de las manifestaciones y expresiones de las masas urbanas de trabajadores que también en ese mismo siglo XIX se hacinaban rápidamente en las ciudades del pujante capitalismo industrial. Trabajadores que pronto comenzarán a organizarse y a disputarle a las élites la hegemonía de la sociedad capitalista. En este aspecto resulta esclarecedora la coincidencia en la pertenencia social de musicólogos y folkloristas. Los primeros en general no consideraban importante declarar su condición de clase, situación que produjo la naturalización de tal identificación; por esta razón es muy raro encontrar datos vinculados a la situación social de la música culta en sus estudios. Los segundos, en cambio, debían declarar la distancia; al no identificarse con el "pueblo" que estudiaban, consideraban un auténtico safari sus paseos etnográficos. Como señala Burke, "La mayoría de ellos, sin embargo, pertenecían a las clases dirigentes [...] Para algunos especialmente a finales del siglo XVIII, el pueblo era interesante desde el punto de vista de lo exótico» Por ejemplo, recorriendo las islas de Escocia en búsqueda

de los vestigios de la vida pastoril [el folklorista] Boswell indica al doctor Johnson que "era exactamente como encontrarse una tribu de indios», ya que sus pobladores "tenían una apariencia tan negra y salvaje como la que mostraban los indígenas americanos» (Burke, 2014, 42-43)

De esta suerte, y como señalamos al comienzo, la música popular urbana permaneció durante muchos años marginada e ignorada. Una práctica musical audible y omnipresente en la vida cotidiana, silenciada y omitida en la investigación, los textos, los programas académicos sobre música. $\mathrm{O}$ a lo sumo, relegada a las notas marginales, mencionada al pasar. Esta situación comenzó a modificarse a ritmo acelerado a partir de la década de 1980. Surgió así el conjunto de lo que hoy se suele llamar Estudios sobre Música Popular

\footnotetext{
7 Entrada "música" en el diccionario enciclopédico VOX.

8 «en el sobreentendido de que los modelos siempre provenían de una misma fuente emisora y las copias, del ultramar extraeuropeo, luego objeto de estudio de la musicología "comparada" (comparada siempre en desventaja con el modelo establecido como perfecto), de la etnología musical (la de los pueblos "primitivos") y, finalmente, de la etnomusicología» (Paraskevaídis, 1999).

9 «Volk heisst nicht der Pöbel auf den Gassen, der singt und dichtet niemals, sondern schreit und verstümmelt» (Herder,1967, p. 323). Citado a su vez por Burke (2014, p. 60).

10 El alemán se adecúa mejor a esta distinción folklórica, separando dos "tipos" de pueblo con términos que imprimen valoraciones. En español si bien Pöbel suena más parecido a pueblo, suele traducirse como populacho, gentío, vulgo, plebe o, como elige el traductor del texto de Herder que citamos, turba, con el fin de trasladar la valoración despectiva.

11 «... el pueblo era un misterio. Algo que describían en términos de todo aquello que sus descubridores no eran (o pensaban ellos que no eran): el pueblo era natural, sencillo, iletrado, instintivo, irracional, anclado en la tradición y en la propia tierra, y carente de cualquier sentido de individualidad (lo individual se había perdido en lo colectivo)» (Burke, 2014, 43).
} 
(PMS por sus siglas en inglés), denominación que recoge una colección bastante ecléctica (en todo sentido: filosófico, metodológico, ideológico...) de investigaciones sobre un universo musical amplísimo. Una de las principales instituciones que nuclea estas investigaciones es la descentralizada IASPM, Organización Internacional para el Estudio de la Música Popular. Y una de las publicaciones más prestigiosas -y pionera- es la ya citada Popular Music publicada por la Universidad de Cambridge.

Sin embargo, un rastreo sobre el contenido de los PMS y de las huellas de las tradiciones epistemológicas que suelen preponderar en sus marcos teóricos, arroja como resultado un campo mucho más acotado y pequeño de lo que parece. Como señala Elizabeth Eva Leach, el principal precursor con el que los investigadores de los PMS dialogan y discuten permanentemente es Theodor W. Adorno (Leach, 2009, 194). Como este importante autor circunscribió su planteo crítico a la música producida por la industria cultural de los medios técnicos a partir del cambio entre el siglo XIX y el XX, los investigadores acotan sus estudios a las músicas que se inscriben en dicho recorte, ya sea que recurran a los postulados teóricos de Adorno y los apliquen a nuevas músicas -como el Rock-, o aprueben o discutan su posicionamiento acerca de la música popular, que según Adorno emana de los medios de comunicación con el doble objetivo de hacer dinero y distraer a las masas alienándolas (Leach, 2009, 194). La presencia de Adorno como figura epigonal en los trabajos sobre música popular podría hasta pensarse como hegemónica. Esta situación, sumada al interés personal que muchos de los investigadores tienen por algunas músicas en particular -como el Rock, el Jazz, o distintas músicas de América Latina- hacen que los Estudios de Música Popular se concentren exclusivamente en las músicas vinculadas a la fonografía y la radiodifusión, a partir de principios del siglo XX. Además, en la mayoría de los casos, estos estudios se basan también en la biografía y analizan o discuten como unidad de análisis privilegiada la obra de los músicos populares (sean canciones, discos, conciertos, etc.). Cuando este análisis es sobre el lenguaje musical, en buena medida lo que se analiza es el tipo de procedimientos en torno a la armonía. Muchos de ellos intentan además generar agrupamientos por estilo. De modo que la mayoría de las nociones nucleares del paradigma objetual de la musicología son transferidas al estudio de la música popular al considerarlas parte de la naturaleza misma de la música, aunque esto signifique emplear herramientas analíticas que, por un lado, no están desarrolladas específicamente para el estudio de la música popular y que, además, fueron esgrimidas para desvalorizarla históricamente.

\subsection{La historiografía musical y las formas de deshacerse del pueblo}

La historiografía de la música puede ser comprendida como una producción en la cual confluyen diferentes tradiciones disciplinares vinculadas a la investigación musical. Si consideramos a la historia de la música como «recuerdo científicamente formulado» (Dahlhaus, 1997), elaboración y relato (Carr, 2006, p. 91; White, 2010, p. 13; Veyne, 1984, p.13; Chartier, 2007, p.19), más allá de las denominaciones de las producciones o el corpus de cada disciplina particular abocada al estudio de la música, toda investigación que persigue como objetivo historizar el devenir musical participa de la historiografía de la música. Fundamentalmente por esta última razón -la vocación cuanto menos declarativa de desplegar una perspectiva histórica, al menos parcialmentereconoceremos como constitutivas de la historiografía musical a tres disciplinas: 
- la musicología histórica (en ocasiones, sin el agregado de este particularismo, se denomina musicología a secas ${ }^{12}$ ), pionera de los estudios sobre música a partir de su despliegue a fines del siglo XVIII;

- el folklore, la musicología comparada y la etnomusicología, que comprenden fases metodológicas sucesivas aplicadas sobre similares objetos de estudio;

- y los estudios de música popular que consideraremos, por la raigambre anglonorteamericana de su emergencia y perspectivas, mediante su denominación en inglés popular music studies (en adelante PMS), que configuran un conjunto -algo ecléctico- de estudios más recientes que se referencian -y a veces confunden- con las teorías críticas, el posmodernismo, los estudios culturales, la semiótica, la sociología musical, etc.

Existen, claro está, otras disciplinas dentro del estudio científico de la música [todo lo cual podría, aunque no sucede y a esta altura no sería deseable, llamarse musicología]. Pero en nuestro caso los demás campos importantes no los incluimos dentro de la historiografía musical precisamente porque priorizan enfoques que no son fundamentalmente históricos: la rama conocida como teoría musical (o musicología sistemática) se especializa en el análisis formal, acudiendo a metodologías que van de la semiótica a las neurociencias, entre muchas otras, pero que no basan sus tópicos en la historia. De ahí que prioriza el «proveernos una imagen mental de la música» mientras que «muy raramente nos lleva a lo que los compositores hicieron en el pasado» ${ }^{13}$ (Beckles Willson, 2009, p. 39). La teoría musical analiza la música como si ocurriese en el presente, independientemente que haya sido compuesta, tocada o disfrutada en otro tiempo histórico. Del mismo modo, la sociología musical, como se enfoca, precisamente, en las relaciones entre los grupos sociales y la música, prioriza los estudios sincrónicos, incluso cuando estudia fenómenos sociomusicales de otras épocas. Dentro de la sociología musical, un aspecto importante es el debate en torno a las categorías de "música culta" y "música popular" (Ellis, 2009, p. 47), que influirá muchísimo en las perspectivas de los PMS, siendo esto en parte responsable de su carácter "presentista" de lo que entienden por música popular (Johnson, 2018, p. 15). Por último, el enorme campo de la etnomusicología (casi una disciplina paralela frente a la musicología en sentido amplio) tiene su principal objetivo en el estudio de las músicas de otras culturas o aún de las músicas del mundo (Stobart, 2009 , p. 104). Justamente por esta razón ha permanecido como recorrido paralelo a la historiografía musical, dado que el etnocentrismo proveniente del contexto de fundación de la musicología no reconocía un carácter histórico por fuera de la civilización occidental, al punto de considerarlo una de sus cualidades identitarias más sobresalientes. De hecho, al tiempo en que la musicología desarrollaba esta perspectiva etnocéntrica, el estudio de los otros musicales era considerado bajo un signo primitivista, tanto en el folklore (para los otros internos, es decir "el pueblo"), como en lo que se llamó musicología comparada (para los otros exóticos), de cuyos resultados se pretendía obtener una formulación científica de la superioridad de la cultura occidental. Precisamente como reacción a este carácter racializado y colonial, la etnomusicología se propuso como campo alternativo a mediados del siglo XX y la herramienta que encontró para reconsiderar con mayor justicia a las músicas no europeas fue la aplicación de una perspectiva antropológica, abandonando la dimensión histórica que, entre otras cosas, había producido la imagen de que las culturas asiáticas, africanas o indoamericanas eran equivalentes primitivos del pasado prehistórico

12 Lo cual llevó a los etnomusicólogos, como Charles Seeger, a quejarse de que los historiadores "han secuestrado el término musicología" (citado en Pelinski, 2000, p. 21). Este comentario prácticamente nos exime de explicar los motivos por los cuáles no incorporamos a la etnomusicología como parte de la historiografía musical, ya que no pareciera reconocerse entre los "historiadores", lo cual es congruente con su aplicación de una perspectiva fundamentalmente antropológica y no histórica.

13 «can provide a mental representation of music [...] rarely leads us to what composers did in the past» (Beckles Willson, 2009, p. 39) [traducción del autor] 
de Europa. Precisamente, las historias de la música del siglo XIX solían rellenar el espacio vacante de la prehistoria musical con un examen de la música egipcia, griega, china o hindú, para luego pasar a lo "verdaderamente importante" (Cook, 2001) que comenzaba con la escritura musical en la Edad Media cristiana. Por lo tanto, si bien la etnomusicología presenta tantos problemas como aciertos en su derrotero epistemológico cuasi centenario, decidimos dejar fuera a esta disciplina en lo que aquí estamos considerando como un modelo de historiografía musical ampliada, comprendido por las tres disciplinas que mencionamos antes. El añadido de ampliada es para reforzar que no sólo está presente la musicología histórica (a la que, invirtiendo la queja de Seeger, deberíamos acusar de haber pretendido secuestrar la dimensión histórica de la música) sino también el Folklore y los PMS.

Las principales diferencias entre estos tres componentes de la historiografía musical ampliada se dan no sólo por los enfoques metodológicos y sus inscripciones teóricas e ideológicas, sino también porque abordan objetos de estudio diferentes, de tal suerte que una hipotética articulación de todas ellas nos devuelve un panorama altamente fragmentado (Kerman, 1985) según el cual

- la musicología histórica estudia analíticamente los estilos compositivos de la tradición culta (o "clásica") europea occidental (Treitler, 1996);

- la etnomusicología recopila las tradiciones recónditas, no-occidentales, en su mayoría extintas;

- y a los PMS les queda una particular versión de la "música popular"1415 (opuesta al folklore "auténticamente" popular) que pasa a entenderse como objeto comercial técnicamente reproducible, de mediana calidad, producto de la sociedad urbana industrial y que se divulga a partir de los medios masivos de comunicación, y de la cual puede estudiarse el contenido de las letras, las estadísticas de consumo, las significaciones culturales y cualquier otra cosa que no esté relacionada con lo que de musical pueda tener la música popular.

El esquema resultante produce una cantidad de sesgos que se traducen en una serie de problemas, habitualmente invisibilizados y fuera del radar de las preocupaciones de los investigadores, pero no por ello menos graves. Por un lado, el abordaje artificialmente diferenciado de los objetos de estudio de cada disciplina fuerza a una situación en la cual no existe diálogo ni discusión entre ellas -de hecho bajo sus paradigmas no puede existir ningún diálogo. Esto dio como resultado un esquema de cotos académicos y parcelaciones de los estudios musicales que no responden a las músicas mismas sino a las formas de observarlas y estudiarlas. Pero más grave aún es el resultado historiográfico general cuando se ubican en yuxtaposición los resultados de estas disciplinas: dado que no existe relación entre ellas, se multiplican las lagunas y zonas no estudiadas alrededor de sus contornos, lo cual da lugar en los imaginarios sociales y en el sentido común a falacias históricas graves, algunas de las cuales ya comentamos:

- la única tradición musical histórica es la que pertenece a la música culta, historia que ya terminó a principios del siglo XX;

\footnotetext{
14 Un ejemplo legendario y autóctono es Vega (1997): «La mesomúsica, entonces, convive en los espíritus de los grupos urbanos al lado de la "música culta" y participa en la vida de los grupos rurales al lado de la música folklórica.»

15 Para distinguir este particular acepción de la música popular y revelar el sesgo anglomericano presente en su perspectiva, algunos autores lo distinguen manteniendo la denominación en inglés popular music en contraste con el español de "música popular" (González y Smith, 2012). Preferimos en este trabajo mantener la denominación en español y en cambio acentuar el carácter anglófilo de la perspectiva reservando el inglés para la disciplina PMS: Popular Music Studies
} 
- el arte popular remoto es folklore, no historia, y por lo tanto es estático, rural, ingenuo y reaccionario; como también ya terminó, sólo es posible su preservación patrimonial;

- la música popular no tiene historia y tampoco tradición, sino que ocupa, con sus productos comerciales y masivos, la contemporaneidad sujeta al cambio permanente de la moda. Son productos efímeros ya que están concebidos únicamente para el consumo y su posterior desecho, según la lógica del capitalismo de consumo.

Como es inusual que las producciones de estas disciplinas convivan en congresos o papers, es en los libros de texto para el grado universitario o de divulgación ${ }^{16}$, que por fuerza deben brindar un panorama abarcativo, donde podemos encontrar de forma explícita los sesgos más importantes que resultan de este panorama. En un breve recorrido por sus contenidos podremos formarnos algunas nociones sobre la música, como por ejemplo que "las culturas no occidentales encarnan los comienzos y la cultura occidental el progreso" (Cook, 2001). Pero además, la concepción de una música culta de concierto "muerta", o mejor dicho "histórica", lo que de paso la hace canónica, clásica y venerable. Su apéndice, esto es la continuidad de esta tradición a partir de 1900, se eterniza como algo "contemporáneo", aunque hayamos superado ya el centenario de tal contemporaneidad, que siempre es experimental, rara o si se quiere "del futuro". Entonces, y convenientemente (¿para no ahuyentar a los lectores?), el foco de interés se traslada a la música de la cultura de masas, en especial la de la industria cultural anglo-norteamericana de la segunda mitad del siglo XX. En resumen: las músicas no occidentales corresponden a la "antigüedad" o la prehistoria, y aunque sigan vigentes son tradicionales e inmutables (lo cual coincide con el núcleo difusionista del folklore); la "Música" es la música culta, escrita en partitura, del occidente europeo, con una larga, esotérica e ineludible historia que abarca aproximadamente el milenio entre los siglos IX y XIX, aunque es heredera a su vez de la Grecia Clásica o hasta de Dios ${ }^{17}$; y la música popular inicia su breve y poco gravitante historia en los comienzos del siglo XX, convirtiéndose en la música masiva y comercial de la actualidad.

Podemos resumir las consecuencias de este esquema general de la investigación musical observando algunos conceptos nucleares que se reproducen en general de forma acrítica u oculta y configuran una suerte de "verdades" que han demostrado ser muy resistentes al cambio. Conceptos que fueron desarrollados para el estudio de la música culta y que, por lo tanto, no necesariamente aplican de modo satisfactorio al estudio de otras músicas. De este problema ha dado cuenta la etnomusicología al estudiar los repertorios comunales y extraeuropeos basándose en la antropología y la etnografía; o los PMS, apoyados en la sociología musical y los estudios culturales. Sin embargo, cuando se menciona la música popular occidental, al menos para justificar su segregación del pasado histórico, se la coteja en base a un modelo epistemológico deudor del positivismo (Kerman, 1985; Bermúdez, 1982; Pérez González, 2010). Dicho modelo está basado en una

16 El clásico es el texto de Grout (1984) y también Michels (1983). Pero el libro Listen de Joseph Kerman junto a Gary Tomlinson (2012) es un ejemplo similar, aunque mucho más reciente y producto de un autor que dice ser crítico de estas posiciones. Entre los de divulgación podemos citar Van Der Meer (1995) y Mundy (1982).

\footnotetext{
17 Nuestra intención no es hacer aquí una humorada. La historia de la música tradicional reprodujo durante muchísimos años la noción de que el primer repertorio de la música occidental, el canto gregoriano, fue producto del Papa Gregorio I (Magno). Esta concepción se basaba en una adjudicación medieval de fuerte raigambre religiosa, que sostiene la revelación del canto cristiano al Papa a través del Espíritu Santo, quién lo dicta al oído del pontífice transformado en una paloma posada sobre su hombro. Coincidentemente con todos los postulados de la estética medieval -que constituyen la base de la estética musical occidental- el canto era demasiado perfecto para ser obra del hombre (música humana): necesariamente debía ser obra de Dios (música mundana). Tal el mito fundante de la tradición clásica europea occidental, presente hasta el día de hoy en los textos de historia de la música. Abordajes críticos de este tema pueden encontrarse en Griffiths (2009) y Taruskin (2005a).
} 
concepción objetual (Goehr, 1992; Attali, 2011, Small, 1999) que entiende a la música como obra (idea objetivada antes que fenómeno sonoro efímero), producto de un compositor individual cuyas intenciones constituyen su sentido último (Cook, 2001). Bajo esta concepción, la historia de la música debe (Stanley, 2001) agruparse según los cambios en el estilo de composición, por medio del estudio de su lógica interna y autónoma (Dahlhaus, 1997; Shreffler, 2003). Por lo tanto, sólo será posible estudiar las músicas discernibles únicamente a través del cotejo analítico de cualidades tales como la complejidad armónica, la coherencia formal o la homogeneidad y cohesión de los materiales musicales. El vehículo último de todo este proceso se encuentra en la partitura, que simultáneamente se erige con exclusividad como registro de las intenciones del compositor, material de análisis estructural y fuente histórica (Cook, 2001). Este proceso tiende irremediablemente a la reificación, ya que la partitura pasa a ser considerada como "la música", lo cual nos introduce en un sesgo musicológico muy importante que podemos denominar "centrismo notacional" (Middleton, 1990 , p. 105) Pero estos conceptos son aplicables, en todo caso, al repertorio del canon académico, la música de los "grandes maestros" que van de Bach a Wagner, resultado más de un ejercicio de crítica estética que de un trabajo historiográfico en términos científicos (Dahlhaus, 1997). Es justamente su circularidad, al constituir la definición misma de "música", la que produce una jerarquía valorativa en cuya cúspide aparece la música culta, auténtica, progresiva, compleja y universal; le sigue el folklore, auténtico y tradicional, aunque comunal, sencillo, local y primitivo; llegando en tercer y último término a la "música popular", contemporánea, comercial, interesada y simple, recién llegada a su consideración de "arte" -que algunos todavía incluso discuten (Sammartino y Rubio, 2008). Además, lo cual constituye un rasgo habitual en los trabajos más importantes de los PMS, generalmente se discute para el estudio de esta música popular presentizada la pertinencia de establecer relaciones en torno a la estratificación social. Por un lado, es interesante que no haya un mecanicismo sociológico que vincule formas musicales con clases sociales. Pero se ha terminado configurando una especie de relativismo social en los PMS que finalmente desdibujó y opacó el carácter específico en términos socioculturales. Todo esto, en una música que se sigue denominando precisamente "popular", problematización que se multiplica cuando los practicantes de los PMS (entre ellos el mismo Frith) han llegado a preguntarse directamente cómo "deshacerse" del adjetivo "popular" a la hora de estudiar la música popular. Esta discusión no ha quedado saldada ni ha producido el abandono o modificación del término, pero nos indica cierta perspectiva intrínseca a los PMS, más preocupados por establecer relaciones entre los medios de difusión y circulación comercial de la música que entre las músicas y los sectores sociales y políticos presentes en una cultura o subcultura.

Por lo tanto, como intentaremos desarrollar en los capítulos de este trabajo, los mismos textos y argumentos de los musicólogos, los folkloristas y -al menos parcialmente- los integrantes de los PMS, resumen posiciones frente al "pueblo" que resultan en cierto grado de convergencia. Podríamos sintetizar esto tomando algunas expresiones que surgen de textos célebres de la historiografía musical que estudiaremos más adelante en extenso y decir entonces que para la musicología histórica convencional la Música -con mayúsculasno es popular, para el folklore el pueblo no es el pueblo; y para los PMS la música popular esta vez en minúscula- no es popular.

Aquí se manifiesta como característica de la historiografía musical ampliada lo que denominaremos su carácter afirmativo, entre cuyas consecuencias se genera la noción de que la música popular, producida por profesionales y a la vez relacionada con los sectores populares o subalternos, es una expresión sin historia, localizada y acotada en el mejor de los casos a una cultura presentizada y despolitizada, únicamente posible dentro de las sociedades industriales avanzadas. A lo sumo se le permite ser descendiente de alguna tradición que no va más allá de unos cien años hacia atrás, que habitualmente se reducen a 
cincuenta para hacerlos coincidir con la hegemonía de las industrias culturales y del entretenimiento de la posguerra. Como las músicas folklóricas son descritas como privativamente rurales, comunales y anónimas, debemos suponer que, en el largo período que va desde la fundación de Occidente, pasando por el auge expansionista de la modernidad, y hasta el imperialismo decimonónico, las clases populares, desde los "artesanos" medievales o los mineros "modernos" latinoamericanos, hasta el proletariado que sirvió de modelo vivo a Marx, nunca tuvieron música. ¿Cuál era la banda sonora de las clases subalternas en la Baja Edad Media, la modernidad temprana o los inicios de la sociedad industrial? Según el esquema que poseemos, o vivían en silencio, o cantaban las mismas canciones rurales que sus parientes "del campo", o consumían la misma música que las élites ¿Es que en el pasado remoto no existía una música para las mayorías urbanas? ¿Es que podemos sostener como intrínsecamente silenciosa la vida de las clases populares antes de la aparición de la radio o el fonógrafo?

Hasta ahora hemos reflexionado fundamentalmente sobre cómo hemos llegado a este panorama de segregación de las músicas populares de la historiografía musical. Antes de aportar elementos al debate sobre estas preguntas, que será el cometido de nuestra investigación, nos parece pertinente adelantar alguna reflexión conceptual sobre esta tradición epistemológica de la historiografía moderna que ofrezca alguna hipótesis acerca de los motivos o intereses que hacen que, al menos hasta ahora, las respuestas a estas preguntas permanezcan a todas luces como áreas de vacancia.

\subsection{La historiografía musical como cultura afirmativa ${ }^{18}$}

El concepto de "cultura afirmativa" fue acuñado por el frankfurtiano Herbert Marcuse, en un ensayo originalmente de 1937 en el cual introduce una crítica a lo que entiende como función de la cultura y el arte: la legitimación del orden social existente. Esto es muy interesante al menos por dos razones: por un lado se invierte la desgastada tesis de la ortodoxia marxista que señala que la cultura es un reflejo de las condiciones de la infraestructura; ahora la cultura es, en todo caso, la que produce las condiciones para que las desigualdades se acepten, perpetúen y profundicen. Además, encontrar la afirmatividad en el arte -y en el pensamiento en torno a él, como es su historización- es contrario al habitual imaginario que le adjudica al arte -sobre todo "culto"- un carácter renuente a todo tipo de convencionalismos. Desde el esteticismo romántico, lo artístico pareciera más bien oponerse al mundo de la burguesía capitalista, su contabilidad, su seriación alienada. Por estas dos razones es muy interesante recuperar la propuesta de Marcuse sobre la cultura e intentar una caracterización del arte en términos de su función conciliatoria con el orden existente.

Si pensamos que la hegemonía es por sobre todas las cosas una forma de cultura,

un sentido de la realidad para la mayoría de las gentes de la sociedad [...] un vívido sistema de significados y valores -fundamentales y constitutivos [...] pero que debe ser considerada asimismo como la vívida dominación y subordinación de clases particulares" (Williams, 2000, p. 132),

podremos también sostener, a la inversa, que la cultura es una forma de producir hegemonía. En función de esto podemos observar que en la sociedad burguesa capitalista es evidente el esfuerzo por producir un corpus estético denso, profundo y apuntalado de forma potente por la teorización. Desde la llustración en adelante no puede menos que sorprendernos la prioridad asignada a lo estético en el pensamiento occidental.

\footnotetext{
18 El esquema básico de la consideración de la historiografía musical en términos de la afirmatividad de Marcuse
} fue adelantado en un artículo específico sobre el tema (Eckmeyer, 2019). 
Si la categoría de lo estético asume la importancia que tiene en la Europa moderna es porque al hablar de arte habla también de todas estas cuestiones que constituyeron el meollo de la lucha de las clase media por alcanzar la hegemonía política (Eagleton, 2006, p. 53).

Para que el arte habite esta construcción hegemónica, deberá participar de "un sentido de lo absoluto" (Williams, 2000, p. 132) y es allí donde el idealismo cobra la mayor relevancia para la estética y la teoría del arte. La inferioridad de la realidad social, mundo de lo necesario, ámbito carente de libertad y de verdad, está presente desde las formulaciones más antiguas del idealismo, que ubica en un mundo trascendente a lo bueno, lo bello y lo verdadero, más allá de esas relaciones materiales. Si bien esto está presente desde la Antigüedad, es específicamente en el idealismo burgués en donde el arte jugará un rol capital, ubicándose precisamente en una esfera apartada y exclusiva.

Cuando la reproducción de la vida material se realiza bajo el imperio de la mercancía, creando continuamente la miseria de la sociedad de clases, lo bueno, lo bello y lo verdadero trascienden a esta vida.[...] Aquello que verdaderamente interesa a los hombres: las verdades supremas, los bienes y las alegrías supremas están separados por un abismo de sentido, de lo que es necesario, y por consiguiente son un "lujo" (Marcuse, 1967, p. 46).

Así, la distancia entre idea y factibilidad se profundiza, de forma tal que podría pensarse en que el idealismo adquiere una faceta consoladora en donde se evade, deja el mundo material a la sociedad burguesa y se refugia en el mundo utópico de sus propias ideas "al conformarse con el cielo y con el alma" (Marcuse, 1967, p. 54). Pero en la escisión entre el mundo ideal y el material, que es también la separación entre la razón y lo sensual, habita un rechazo de raigambre aristocrática a ciertas formas reprobables de la vida y la existencia. En el punto de partida del idealismo, el mundo material y sensible es, en sí, inferior, cuya posibilidad reside únicamente en que participe del mundo ideal.

Aparecen así toda una serie de connotaciones que ubicarán a lo corporal, lo funcional, lo colectivo $-\mathrm{y}$, como es fácil comprender, a lo popular- en la última posición de la escala de valoración artística; arraigadas en la distinción kantiana entre los espiritual y los aspectos materiales de la vida, que en el campo académico dará lugar a la principal disciplina alemana de las humanidades, la Geisteswissenschaften (literalmente "ciencia del espíritu") de la cual dependieron en buena medida los estudios estéticos, la teoría del arte y la historiografía musical (Shreffler, 2003, p. 503) La cultura hegemónica es entonces fundamentalmente evasión, en cuanto a que su componente idealista huye del mundo material y rechaza ocuparse de él. Pero si bien lo desaprueba desde el aspecto discursivo, en los hechos lo legitima al no confrontar directamente con las condiciones del mundo social. Es en este sentido que para Marcuse la cultura es cómplice de la sociedad burguesa: «el idealismo capitula ante las contradicciones sociales [...] La historia del idealismo es también la historia de su aceptación de lo existente». (Marcuse, 1967, p. 47-48)

Este componente legitimador de la cultura, el arte y la música, es lo que lleva a Marcuse a plantear su famosa tesis: "Este es el verdadero milagro de la cultura afirmativa. Los hombres pueden sentirse felices, aun cuando no lo sean en absoluto» (Marcuse, 1967, p. 70). Pero lo interesante es que no se trata de fuerzas contrapuestas o que provienen de campos sociales diferentes, ya que tanto la estética clásica como la configuración de las relaciones materiales del mundo capitalista contemporáneo son ambos programas de la burguesía. Este sector que llega al poder y vence al antiguo régimen mediante la articulación de las mayorías en base a un programa igualitario, una vez que ese poder se conquista, la igualdad comienza a tornarse abstracta, es decir, ideal. Por eso la burguesía despliega un discurso, del que forman parte el arte y su historiografía, en el cual todos los individuos son iguales. Pero en el ámbito de las condiciones sociales dicha igualdad no puede funcionar dentro del marco de la sociedad burguesa. La igualdad abstracta posibilita 
la praxis burguesa, es condición de la sociedad capitalista moderna ya que, en este plano particular, pasar de lo ideal a lo concreto, de lo abstracto a lo material es justamente la mayor amenaza al dominio hegemónico de la burguesía. Esta es «la gran función educativa de esta cultura: disciplinar de tal manera al individuo - para quien la nueva libertad había traído una nueva forma de servidumbre - que sea capaz de soportar la falta de libertad de la existencia social» (Marcuse, 1967, p. 69).

De este modo podemos pensar a la cultura como una forma de respuesta de la burguesía frente al problema de tener que lidiar con la desigualdad sin poder refugiarse en justificaciones aristocráticas o teocráticas. Se trata de conquistar a las masas en pos de un orden social inherentemente ilegítimo en el plano material. Es decir, crear una nueva hegemonía.

\begin{abstract}
A las demandas acusadoras la burguesía dio una respuesta decisiva: la cultura afirmativa. Esta es, en sus rasgos fundamentales, idealista. A la penuria del individuo aislado responde con la humanidad universal, a la miseria corporal, con la belleza del alma, a la servidumbre externa, con la libertad interna, al egoísmo brutal, con el reino de la virtud del deber. Si en la época de la lucha ascendente de la nueva sociedad, todas estas ideas habían tenido un carácter progresista destinado a superar la organización actual de la existencia, al estabilizarse el dominio de la burguesía, se colocan, con creciente intensidad, al servicio de la represión de las masas insatisfechas y de la mera justificación de la propia superioridad (Marcuse, 1967, p. 52).
\end{abstract}

Por lo tanto, la cultura afirmativa es una forma histórica de cultura, la que corresponde con la sociedad burguesa capitalista y particularmente una vez que la burguesía se instala definitivamente en el poder (Marcuse, 1967, p. 50). Es importante comprender que en el razonamiento de Marcuse "toda la cultura» $(1967$, p. 78$)$ es la que afirma las condiciones existentes, de forma tal que no se trata de ciertas prácticas o costumbres ligadas únicamente al consumo minoritario de las clases dirigentes, como podía ocurrir con el arte cortesano. La potencia hegemónica de la cultura afirmativa radicará en incluir a toda la sociedad en el patrimonio cultural, en hacer partícipes de la cultura a todos sus individuos. De hecho la cultura afirmativa vuelve obligatorios sus valores, los cuales dejan de ser vistos como "de clase" o "burgueses" y se transforman en un repertorio social común. Se configura así un reino de unidad, coherencia y, muy especialmente, de igualdad y libertad, que es internalizado como propio aún por los sectores más explotados de la sociedad. Pero es un reino ideal, en el cual la belleza sublime y gratuita, porque es desinteresada, está absolutamente alejada de la lucha por la vida y las contradicciones de la sociedad.

Bajo cultura afirmativa se entiende aquella cultura que pertenece a la época burguesa y que a lo largo de su propio desarrollo ha conducido a la separación del mundo anímico-espiritual, en tanto reino independiente de los valores, de la civilización, colocando a aquél por encima de ésta. Su característica fundamental es la afirmación de un mundo valioso, obligatorio para todos, que ha de ser afirmado incondicionalmente y que es eternamente superior, esencialmente diferente del mundo real de la lucha cotidiana por la existencia, pero que todo individuo "desde su interioridad", sin modificar aquella situación fáctica, puede realizar por sí mismo (Marcuse, 1967, p. 50).

Precisamente porque afirma las condiciones desiguales de la existencia, la cultura oculta las relaciones existentes en el orden material de la vida. Es decir, la cultura funciona en la medida en que logra una importante autonomía de las condiciones sociales de producción y reproducción de la vida. La cultura y la producción artística, en tanto esferas ideales, se hacen cargo del anhelo de una vida más solidaria, justa y feliz. Pero al pertenecer a un mundo trascendente, superior, ideal, apartado de lo cotidiano, se convierten en afirmativas del mundo existente. Si en el arte triunfa la justicia de la verdad, en el mundo cotidiano esto no pasa y, peor aún, nos es dado a pensar que sería vano que buscáramos que eso pase, porque allí triunfa la (in)justicia de la realidad. Separar al arte de la realidad cotidiana es el 
gesto afirmativo por excelencia. Producir un mundo bello y explícitamente irreal, dentro del cual, únicamente, ocurre la reconciliación y la promesa de felicidad. El arte se mueve en un universo no vinculante, ya que la belleza desactualiza la verdad y la aleja del presente. «Lo que sucede en el arte no obliga a nada [...] En el médium de la belleza los hombres pueden participar de la felicidad» (Marcuse, 1967, p. 64)

Para Marcuse es todo el arte de la burguesía el que participa de la cultura afirmativa. Por eso es posible considerar que algunos de los conceptos constitutivos del canon de la música culta son curiosamente coincidentes con el carácter afirmativo de la cultura. Queremos aclarar que no nos referimos de esta forma a la afirmatividad en tanto acto compositivo o performativo, sino a los discursos y sobre todo a la historiografía en torno a estas prácticas que les otorgan un determinado signo, en ocasiones a pesar incluso de las intenciones de sus practicantes. Es claro, por ejemplo, en las óperas comerciales de Monteverdi o en los últimos cuartetos de Beethoven, el sentido explícitamente subversivo del que habla Jacques Attali (2011). Por lo tanto no son "las intenciones del compositor" lo que buscamos denunciar como parte de la afirmatividad. Es, en todo caso, lo que de esos músicos y su música ha hecho la cultura burguesa de la mercancía y la respetabilidad, en nombre de esas supuestas intenciones que muchas veces no son más que ficciones. Lo cual no exime en modo alguno, a su vez, a los compositores e intérpretes de sus intencionalidades, conscientes o inconscientes, afirmativas o subversivas. El mismo Marcuse, en sus textos tardíos, nos advierte sobre esto y pone el acento en la utilización o significación que del arte y la música puede hacerse, operación que puede invertir su signo:

El fuerte énfasis en el potencial político de las artes, que es una característica de [la oposición radical] representa, antes que nada, una expresión de la necesidad de una comunicación efectiva de la denuncia de la realidad establecida y de los objetivos de la liberación. Es este esfuerzo por encontrar formas de comunicación, lo que puede romper el dominio opresivo del lenguaje utilizado y de las imágenes establecidas en la mente y el cuerpo del hombre; lenguaje e imágenes que hace mucho se convirtieron en medios de dominación, de indoctrinamiento y de engaño (Marcuse, 1973, p. 91)

En consecuencia nos referiremos en lo sucesivo a los componentes que suponen el carácter afirmativo de aquello instalado como música por la cultura burguesa occidental. Es decir, el canon estético, en cuanto a los repertorios interpretativo e historiográfico de la música culta, que incluyen también a las diferentes vanguardias y la producción contemporánea subsiguiente. Una producción canónica en la cual el rol de la historia de la música ha sido central, fundamentalmente al construir artefactos conceptuales y analíticos específicos para ese proceso de afirmatividad.

Esto no pretende negar que la música popular y los discursos en torno a ella no participen del carácter afirmativo. Por el contrario, al menos parcialmente, no cabe duda que esto es así, y en muchos casos los PMS justifican ese carácter conciliador y de renuncia a la confrontación con la realidad social, a pesar de que la música popular suele considerarse mucho más ligada a su contexto. Pero tal vez porque es mucho menos usual, queremos resaltar aquí algunas concepciones sobre la música que, al mismo tiempo que sintetizan el carácter afirmativo, han permeado desde la música culta hacia la música popular. Por lo tanto, y a contramano del sentido común, la afirmatividad no es una cualidad inherente a la música popular o de la industria cultural, que luego contamina a la música seria (Adorno, 2009 , p. 16) y la convierte en fetiche. La propia definición de cultura afirmativa, con su enmascaramiento de las condiciones de producción, su individualización y su carácter de patrimonio universal impuesto nos dará la clave para comprender que el paradigma estético musical más coincidente es precisamente el de la música culta moderna. Veamos por ejemplo cómo opera la huida hacia el mundo ideal en una formulación histórica de la estética musical. 
La creencia de Schenker en que la música representa una incursión de alguna forma de realidad más elevada en el mundo humano era absolutamente literal. "La Música», afirma (y se trata de la Música con mayúsculas), utiliza al compositor de genio «como un médium, por decirlo así, y de un modo enteramente espontáneo [...] Los genios a los que se refiere Schenker son, por supuesto, los compositores cuyas obras han sido admitidas en el museo musical, y Schenker afirma que sus obras perduran independientemente del tiempo y el lugar en los que vieron la luz; habitan en un ámbito propio, inmaterial e inmutable (Cook, 2001, p. 49).

Podemos encontrar aquí prácticamente todos los elementos importantes de la cultura afirmativa mencionados por Marcuse: la construcción de un mundo superior e idealizado donde reina la belleza y la coherencia; la belleza, encarnada aquí no solo como obra sino también en la figura del compositor, como medium de acceso a la felicidad; la temporalidad propia del arte, o la inmutabilidad de la belleza, que se actualiza en la apariencia deberíamos decir aquí en la interpretación del músico genio- y al hacerse actual «tranquiliza el anhelo de los rebeldes» (Marcuse, 1976, p. 69).

¿Cuáles son los artefactos específicos, como diría Eagleton, que poseen fuertes resonancias de potencia afirmativa y que han sido centrales para la construcción de la historiografía de la música hegemónica? Aquellos que hemos asociado al comienzo con los elementos que privilegia la musicología histórica en su paradigma convencional, del cual Schenker fue uno de sus padres fundadores. Si releemos la cita de Cook, los encontraremos mencionados explícitamente: la obra musical que es objeto -estético pero también de cambio-; el compositor genio, cuya personalidad espontánea y divergente habita más el mundo ideal que el de las relaciones materiales y es utilizado por la música; el "ámbito propio e inmutable" que representa la autonomía musical; la universalidad que emana de que el valor artístico es independiente del tiempo y del lugar.

Pero también, como contracara de la cultura dominante y el arte culto, se configura, en el mismo momento histórico y social, un mundo idealizado y romántico en el cual los sectores populares pueden tener una existencia evasiva, idealizada y fundamentalmente ahistórica.

[El] Folklore capta ante todo un movimiento de separación y coexistencia entre dos "mundos" culturales: el rural, configurado por la oralidad, las creencias y el arte ingenuo, y el urbano, configurado por la escritura, la secularización y el arte refinado; es decir, nombra la dimensión del tiempo en la cultura, la relación en el orden de las prácticas entre tradición y modernidad, su oposición y a veces su mezcla (Martín-Barbero, 1991, p. 19).

Lo primitivo, lo irracional, lo bucólico e incluso lo exótico que se atribuye al pueblo folklorizado también logra así constituir un mundo apartado, desarticulado del mundo de las relaciones materiales. Los moradores del folklore, que se convierte de este modo en una suerte de país de Cucaña, no tienen nada que ver con el mundo de todos los días de la sociedad burguesa, que explota de contradicciones y rebosa de conflictos. Esta identidad común entre el arte oficial y el folklore se potencia precisamente a partir de esa mezcla que señala Martín-Barbero, que folkloristas como Vega ven en términos de una continuidad concreta

El salón aristocrático, en cuanto escenario, equivale a la sala burguesa, a la habitación modesta, al patio suburbano, al rancho campesino, a la pista de las ramadas, al descampado cubierto de cielo. Una misma música al servicio de las mismas danzas, de las mismas canciones, pasa de uno a otro escenario, por imperceptibles gradas, camino de la muerte. Una misma música en todos los lugares, pero en diferente tiempo: la música folklórica de hoy es, originariamente, la música superior de ayer; la música de la campaña fue antes la música de las ciudades. Eso sí, no ha descendido intacta, pues cada ambiente social le exigió reacomodamiento, transacción. La instalación en el campo folklórico impone a la música que llega el proceso que llamamos de folklorización (Vega, 1944, p.78). 
Como veremos en el estudio particular del folklore, como disciplina y configurador de sentidos específicos sobre el pueblo y su música participa de la cultura afirmativa y su construcción mediante sus propios útiles de conocimiento, como el objeto etnologizado de cancioneros, folksongs y danzas, o el sujeto colectivo del volkgeist, junto a una particular clase de autonomía derivada de la territorialización y el abuso de la dicotomía extremadamente burguesa- de lo urbano contra lo rural. Estos elementos convergerán en un modelo de epistemología musical racializado que será el homólogo del paradigma de los estilos de la musicología histórica. El modelo objetual/personalista también informa al folklore, incluso con mayor grado de sofisticación. Si bien los PMS en su especificidad no participan de los alcances de este estudio, y no profundizaremos en sus categorías, podemos decir aquí a modo tentativo que ni el estatuto de obra -fundamentalmente trasladada al fonograma más que a la canción- ni el de personalidad artística -incluso amplificado y hasta hiperbolizado en la figura del pop star- son abandonados o puestos entre paréntesis en los estudios de música popular.

Podemos establecer entonces una relación funcional entre la cultura afirmativa -que posibilita la participación de todos los sectores de la sociedad en el proyecto hegemónico burgués- con la construcción del paradigma objetual/personalista de lo que llamaremos historiografía musical afirmativa en un sentido ampliado, como apuntamos antes, y que incluye específicamente para este estudio a la musicología histórica en su formulación convencional y al folklore entendido como disciplina de estudio musical. Esta historiografía afirmativa, en sus resultados más que en sus proclamas, eliminará toda posibilidad de que la música popular entre en la historia. Porque sus propios presupuestos, su búsqueda de sentido en el mundo del idealismo y la evasión -aspectos infrecuentes de las poéticas de la cultura popular- pero fundamentalmente sus artefactos conceptuales y sus metodologías, no son compatibles con las prácticas de la música popular que, al contrario de la estética dominante y la música culta, por su misma constitución, como intentaremos mostrar en nuestra investigación, sí exhibe relaciones profundas y notorias con las condiciones existentes en el orden material de la vida, relaciones que son además sociales y políticas.

Si dejamos de lado por un momento el paradigma objetual de la historiografía, la música puede ser comprendida ante todo como práctica social, a condición de que en lugar de reconocerla como objeto nos enfoquemos en su aspecto práxico o performativo, lo cual debería incluso ser parte de nuestro sentido común sobre ella. Y de hecho lo es, aunque por fuera de la academia, habitando el imaginario social sobre las músicas que escuchan, consumen - ¿padecen?-, tocan y piensan las mayorías en su vida cotidiana. Esto quizás revele otra definición de "música popular", entre cuyos componentes identitarios están la acción y la transformación continua. Aún cuando a partir de la fonografía la música popular habitó diversos objetos que la mediatizaron -vinilos, cassettes, CDs- todos entendemos que antes que cualquier otra cosa la música es un hacer. ensayar, cantar, tocar, escuchar, tararear, corear, componer, arreglar, producir, mezclar, remezclar, emitir... y una larga lista de etcéteras. La música comprendida de esta forma necesita objetos -instrumentos, amplificadores, tocadiscos, radios, computadoras, y claro está, incluso partituras- pero no es un objeto. Y en la medida que esto sea así, constituye mucho más un proceso que una obra, en el sentido de modificación y creación permanente. No queremos negar aquí las importantes aportaciones que la teoría estética contemporánea ha realizado al referirse al carácter abierto de la obra de arte, su recepción e interpretación polisémicas, su condición "formante". Pero sí queremos advertir que la música popular jamás necesitó de tales remiendos y reflexiones, vinculadas en cambio con la música escrita ${ }^{19}$, papel antes que

\footnotetext{
19 Puede leerse en el prólogo de Obra abierta de Umberto Eco (1990) el relato, a modo de anécdota, de las provechosas conversaciones del autor con el compositor de vanguardia Luciano Berio, al coincidir sus oficinas de investigación en el mismo edificio.
} 
sonido, obra fija de un autor que necesita de un esfuerzo intelectual para reconsiderarse y poder así hacerse dinámica.

El presente trabajo intentará, por consiguiente, problematizar la concepción tradicional o hegemónica de la historiografía musical, con el fin de contribuir a la elaboración de bases conceptuales que posibiliten (re)integrar a la historia de la música las prácticas musicales profesionales relativas a las clases populares urbanas a lo largo del desarrollo histórico de la cultura occidental. Para ello será necesario perfilar un modo de aproximación conceptual a dichas prácticas sonoras que comprenda y respete algunas de sus características identitarias, las cuales podrán ser a su vez propuestas para ampliar el horizonte analítico desplegado en otros repertorios, especialmente el de la música culta occidental. Dentro de nuestros objetivos concretos de investigación podemos enumerar los siguientes

- Identificar las características comunes a diversas prácticas musicales profesionales del pasado medieval y moderno, en Europa y Latinoamérica, que pueden emparentarse con definiciones de la música popular compatibles con los postulados por la nueva historia, las ciencias sociales, las teorías críticas y los estudios culturales.

- Establecer similitudes entre las características de dichas prácticas musicales y las coordenadas conceptuales que son consideradas definitorias de la música popular contemporánea, identificando los casos en que corresponde entenderlas como procesos de continuidad histórica

- Abstraer las características de las prácticas musicales presuntivamente populares del pasado medieval y moderno, en Europa y Latinoamérica que no pueden ser abordadas por la epistemología de la historiografía musical

- Identificar las características de la historiografía musical occidental que son funcionales a la afirmación de la cultura musical dominante como único producto histórico válido

- Identificar la filiación -en términos institucionales, de financiación, de asunción directa- de los textos histórico musicales con movimientos políticos y/o hegemónicos, particularmente en lo referido a los procesos de consolidación del capitalismo moderno y del imperialismo europeo/estadounidense sobre América Latina

- Establecer si existe una relación funcional, de simultaneidad, de complementación y/ o de filiación socio política entre la musicología histórica y el folklore, que explique su mutuo rechazo a la incorporación de las músicas populares urbanas profesionales en sus respectivos corpus

- Identificar, definir y clasificar las herramientas conceptuales de las historiografías musicales derivadas de la acentuación o privilegio de determinado/s componente/s sonoros, y establecer su correlación con el encumbramiento de determinados repertorios musicales en la narración histórica habitual.

- Estudiar el grado de historicidad, la naturaleza de las fuentes y la crítica de las mismas en la disciplina del folklore, y establecer si existe o no un correlato entre estos rasgos y su rechazo a las manifestaciones populares vigentes en el momento de realizar los estudios.

- Identificar y conceptualizar las herramientas epistemológicas y nociones de la historiografía musical incompatibles con el estudio de la música popular y generan compresión de sus características identitarias básicas

- Compilar las características o condiciones nucleares de las músicas para ser descriptas como populares, en términos de las definiciones de las ciencias sociales y la nueva historia 
- Establecer relaciones significativas y explicativas entre las características de la cultura popular de un momento histórico dado -según las ciencias sociales y la nueva historia- y las prácticas musicales populares que le son contemporáneas

- Establecer el grado de compatibilidad entre las condiciones nucleares de las músicas populares y los rasgos identitarios de otros repertorios -como la música culta- a los fines de evaluar la posibilidad de su inclusión en un proyecto historiográfico integral de la música

\subsection{Hipótesis de trabajo para una ampliación de la dimensión histórica de la música popular}

Como hemos referido en el planteo del problema, desde la imagen que nos devuelve la historiografía de la música a partir de sus diferentes disciplinas y tradiciones, la música popular urbana, producida por profesionales, es una expresión sin historia, localizada y acotada a la "cultura contemporánea" de las sociedades industriales avanzadas. Aunque por otro lado sabemos que las concepciones, actividades y costumbres de las clases populares urbanas de la Baja Edad Media y la modernidad temprana poseen una singularidad tal que han llevado a acuñar la idea misma de "cultura popular" y reclamar el estudio de la historia de su conformación. Ya existe una tradición de estudios al respecto, con figuras muy prominentes de la talla de Stuart Hall, Edward P. Thompson, Peter Burke o Carlo Ginzburg, a los que podemos añadir los trabajos precursores de Antonio Gramsci, Mijail Bajtín y, aunque tal vez un poco aparte, Michel Foucault20. Todos ellos nos han mostrado las cosmovisiones, las posturas ideológicas, las costumbres, los modos de organización y las formas artísticas y culturales de las clases populares occidentales, desde la Edad Media hasta bien entrado el siglo XX. Han desarrollado para ello metodologías, conceptos y marcos epistemológicos completos. $\mathrm{Y}$, tal vez lo más importante, se han enfrentado en todos los casos con éxito a la prerrogativa positivista que pretendía imposible, además de innecesaria, la empresa de estudiar la historia de los sin historia. Fundamentalmente, han podido sortear la ausencia de "documentos escritos" en términos de fuentes primarias, desarrollando por ejemplo modelos indiciarios, genealógicos, microhistóricos o iconográficos. Y aún más importante, todos ellos, a la hora de abordar la problematización de la cultura popular y sus posibles definiciones, proponen un abordaje dialéctico en donde la única posibilidad de conceptualizar y hacer historia de la cultura popular es considerándola en oposición, en conflicto, con la cultura de élite. Jamás el campo de estudios puede pensarse fragmentando, constituido por un archipiélago de subdisciplinas cómodamente aisladas.

Dado este panorama ¿es aún sostenible la tesis de que no puede estudiarse la música popular anterior al siglo XX porque no hay registros ciertos de ella (notacionales 0 fonográficos)? ¿Realmente creemos que podemos contar la historia de un molinero piamontés del siglo XVI, sus creencias y convicciones políticas, pero no saber absolutamente nada de la música que escuchaba o tal vez hacía? ¿Es verosímil describir y conceptualizar el carnaval medieval con lujo de detalles en todos sus aspectos, con la sola excepción de las músicas que en él se tocaban y cantaban? ¿Alguien puede todavía pensar que un obrero inglés del siglo XVIII canturreaba la Pequeña música nocturna en la taberna de su barrio proletario?

En función de la consideración del carácter afirmativo de la historiografía musical occidental, de la fragmentación epistemológica que ha derivado en la expulsión del pueblo

20 Hall, S. (1984); Thompson, E. P. (2000, y 2012); Burke, P. (2014); Ginzburg, C. (1986); Bajtín, M. (2005); Gramsci, A. (2011); Foucault, M. (2002, y 2010). 
de los estudios histórico musicales, pero a su vez de considerar como entidades históricas concretas las prácticas performativas sonoras de las clases subalternas presentes a lo largo de la historia de Occidente, presentamos las siguientes hipótesis de trabajo:

1. La música popular posee atributos que pueden ser considerados dinámicos:

- un carácter performativo, procesual, dinámico y fenomenológico (opuesto a la idea de obra y objeto fijo)

- un sentido social y económico (opuesto a la autonomía y el desinterés estéticos)

- una condición mestiza y transcultural (opuesta a la noción esencialista de estilo)

- una condición profesional, individualizable y especializada de sujetos actuantes (opuesta al personalismo del compositor idealizado)

2. A partir de este carácter transcultural, performativo y social es posible determinar la existencia a lo largo de la historia de Occidente de manifestaciones musicales urbanas y profesionales anteriores a la aparición del fonógrafo que pueden ser consideradas "música popular" y que poseen una larga duración susceptible de rastrearse hasta la fundación de la cultura occidental.

3. La historiografía musical dejó fuera de la Historia a la música popular -la cual desde sus perspectivas sólo es posible considerar "contemporánea"- a través de un proceso de afirmación de la cultura musical dominante que produjo una epistemología objetual/personalista que le es funcional.

4. La historiografía de la música (como Musicología [histórica] y también como Estudios de Música Popular), por medio de un proceso de compresión, adecúa la música popular al modelo epistemológico objetual/personalista en el cual predominan lo autónomo, lo armónico, lo homogéneo, lo estilístico, las esencias, lo estático y lo reificado (todos aspectos ausentes o marginales en la música popular)

5. Los atributos dinámicos de la música popular son irreductibles al modelo objetual/ personalista de la historiografía musical en todas sus variedades disciplinares, ya que ponen en crisis las nociones de obra, objeto, compositor, estilo, autonomía musical, predominio armónico y hegemonía de la notación musical, entre otras.

6. Para (re)integrar las músicas populares a la Historia es necesario trascender el modelo epistemológico objetual/ personalista hacia uno performativo/ social/ transcultural, aplicable al estudio de la música popular y a la de la música de la cultura dominante.

Hipótesis secundarias:

1. Los procesos de estratificación social y clivaje de las prácticas musicales son parte constitutiva de la cultura musical occidental y se remontan a la fundación de la misma

2. La historiografía de la música en Occidente posee en su gestación una voluntad afirmativa que construye hacia atrás una narrativa histórica que consolida y naturaliza la proyección estratificada [hacia adelante] de la música de los sectores hegemónicos a lo largo de la historia

3. La cultura musical occidental, tanto en su núcleo geográfico fundante como en la situación colonial/imperial, posee un carácter transcultural

4. La música popular es parte de la cultura popular, entendida ésta como conjunto presente en la larga duración histórica, heterogéneo y ambiguo, de prácticas mestizas y contradictorias en tensión permanente (relación, influencia y antagonismo) con la cultura dominante, sea como identificación, camuflaje, contracultura o práctica emergente. En tal sentido es indisociable de su condición social, económica y material. 
La hipótesis principal de este trabajo descansa justamente en que es posible intentar un vínculo entre los estudios de la cultura popular -fundamentalmente la historia de la cultura popular y los estudios culturales- con la apertura y transformación disciplinar de la historia de la música propugnada desde la musicología crítica y los estudios de música popular, pero intentando restablecer el carácter histórico de las músicas populares urbanas producidas por profesionales al desarrollar una perspectiva histórica general y una periodización de sus manifestaciones en Occidente -incluyendo a Latinoamérica- desde la Edad Media hasta nuestros días.

Estudiaremos entonces la historia de músicas que, al haber generado serios problemas epistemológicos y metodológicos, y por revelar aspectos ideológicos de las historiografías tradicionales, han sido entonces segregadas por la musicología histórica, despreciadas por el folklore e incluso desatendidas por los estudios de música popular. Particularmente estas músicas:

- presentan problemas a la hora de aplicar las herramientas analíticas convencionales en torno a sus registros y fuentes

- ponen permanentemente en crisis a las periodizaciones convencionales y las categorías de análisis basadas en la organización de las alturas de la armonía tonal

- presentan características identitarias que no permiten hablar de obra terminada, de autores únicos o de la separación entre compositores e intérpretes, aunque sus agentes sean profesionales y actúen en un mercado musical.

En base a estos aspectos intentaremos trazar un recorrido de largo alcance en términos cronológicos, que a un tiempo permita poner en relación estas formas de producción musical popular y simultáneamente trace una genealogía de las posiciones ideológicas y de clase detrás de la estratificación de las músicas en la historia. Para ello necesitaremos desarticular las tradiciones más resistentes del estudio musicológico y la historiografía de la música, crítica que produciremos a partir de los aportes de la historiografía general contemporánea, en concreto los de la historia social y la historia de la cultura, a partir del trabajo de los ya citados Hall, White, Thompson, Burke, Bajtín y Gramsci, entre otros. En ellos buscaremos conceptos y formas de historiografía de las prácticas culturales del pasado que fundamentalmente no las violenten analíticamente, es decir no las compriman eliminando los rasgos dinámicos que forman parte de su núcleo identitario.

La segunda hipótesis general se refiere a la incompatibilidad entre las estrategias convencionales del análisis musicológico y las dimensiones más habituales que identifican a la música popular urbana profesional previa al registro fonográfico. En este sentido, a una caracterización de las músicas populares como dinámicas e incluso dinamogénicas (Andrade, 1984) -en el sentido de praxis en transformación, recontextualización y apropiación activa y permanente, ocurriendo de forma presentacional y fenoménica, y por lo tanto efímera- opondremos la noción de compresión analítica o conceptual, musicológica y folklórica, en el sentido de reducir a categorías y dimensiones analíticas concebidas y desplegadas para producir un análisis por proyección en objetos cristalizados y definitivos. Utilizamos conscientemente aquí como metáfora el proceso de compresión de la fonografía, que justamente está concebido para producir un resultado acústico que reduzca el "rango dinámico" de una grabación y cristalice en una sonoridad homogénea, en la que se han "recortado los picos" al aplicar una "tasa" de compresión. A este proceso y a sus efectos no deseados se lo suele llamar también "achatamiento" de la dinámica. Pensamos que la analogía vale para el caso de estas músicas, ya que los resultados, una vez que logran llamar la atención de la investigación musical, resultan en la ausencia de toda consideración sobre sus fenómenos cambiantes y dinámicos; lo que se produce es un recorte y un achatamiento estético, cosa que, en definitiva, conlleva su desvalorización al encontrarlas poco interesantes desde el punto de vista de las categorías de análisis convencionales de la 
musicología. Esto es parte de un proceso que también puede ser analizado en términos más amplios dentro del programa estético de la modernidad y su mirada sobre las prácticas de los sectores populares. Es lo que Adolfo Colombres llama «la estática del sentido» (2004, p. 81), precisamente en cuanto a la incapacidad -o la decisión- de la cultura afirmativa y sus teorizaciones para reconocer el carácter intrínsecamente dinámico de las culturas populares.

\subsection{Conceptos extranjeros para un marco de sustento teórico}

Como creemos que se hará evidente durante la lectura del trabajo, lo que proponemos para superar esta compresión historiográfica de la cultura afirmativa puede sintetizarse en un concepto extremadamente específico de las culturas populares, como es el de inversión. Si bien, como expresaremos a continuación, esta inversión se da en términos formales que también son políticos, como esta indagación persigue dar cuenta no sólo de las prácticas musicales populares en la historia sino también deshilvanar el carácter afirmativo de la historiografía musical que las silencia, comencemos entonces con el planteo de una inversión historiográfica, un mundo al revés que permita vislumbrar el ingreso de las músicas populares a la historia -un segundo mundo histórico- tomando como referencia algunas propuestas teóricas producidas, en su mayoría, por outsiders de la academia musicológica, entre los cuales sobresalen Jacques Attali (2011), Christopher Small (1999), Charles Keil (2001), Ángel Quintero Rivera (2009), Adolfo Colombres (2004), Ticio Escobar (1991), Susanne Langer (1966), junto a algunos díscolos de los estudios y la crítica musicales, como Simon Frith (2014) y Simon Reynolds (2010), entre otros.

\subsubsection{Historicidad del mercado musical, musicar y performance presentacional}

En primer lugar, tomamos lo que puede pensarse como ampliación cronológica de la idea de mercado musical -e incluso de la Industria Cultural- con el objetivo de reunir prácticas musicales provenientes de diversos contextos y que poseen resultantes estéticas muy variadas, pero que comparten su carácter profesional en base a la remuneración, permanente o esporádica, de sus practicantes y a la producción experta por repetición o en serie. En este sentido las ideas tradicionales del folklore acerca de la comunalidad y la ausencia de especialización en la producción musical no podrán ser aplicadas a estos repertorios. A la vez se podrán utilizar algunos de los aportes metodológicos de los estudios de música popular corriendo la barrera de la fonografía hacia una historia mucho más amplia y antigua, examinando las relaciones de producción de estas músicas, sus públicos y formas de difusión y circulación. Aunque esta longeva historicidad del mercado musical es mencionada por Simon Frith (2006), para este aspecto consideramos como referencia principal el trabajo del economista Jacques Attali, particularmente en lo referido al carácter profético de la música en relación con la economía y la política, sus propiedades como banda audible y útil de conocimiento y la preponderancia de los procesos de transformación de la música en bien de cambio a partir de finales de la Edad Media y durante toda la modernidad (Attali 2011). Esta particular concepción de la música tiene como ventaja la supresión de algunas de las nociones musicológicas enumeradas anteriormente, en particular las vinculadas a la escisión artificial del campo y la periodización estilística a partir del análisis armónico autonomista, además de aportar fuentes históricas alternativas que desplazan la necesidad de la partitura como registro. Otros aportes significativos son los de Henry Raynor (1986) y Stephen Rose (2005).

Una vez despejado el artificio en torno a la pretensión de presentismo de la música popular a partir de considerarla únicamente mediatizada por el mercado contemporáneo, nos encontramos con que la reificación y deriva en objeto de cambio de la música se opera en la música culta varios siglos antes que en la fonografía popular del siglo XX. Esto nos 
lleva a proponernos una desobjetualización de la música popular: volverla fenómeno acústico, sonido de alcance momentáneo, cuya re-actualización -que es actuacióninvolucra una transformación dinámica permanente a lo largo del tiempo. Aquí se nos revela imprescindible, para dar cuenta de este carácter histórico y a la vez dinámico, el concepto de musicar desarrollado por Christopher Small (1998). Es ésta una particular formulación de una concepción performativa de la música, que intenta discutir el significado mismo de lo que entendemos por música ${ }^{21}$ porque propone transformar lo que tradicionalmente denominamos como sustantivo en verbo: de 'música' -es decir objeto- a 'musicar', por lo tanto acción presentacional. Esta operación con las palabras es más profunda de lo que aparenta. Significa dejar a un lado las concepciones de la "música como cosa" y "propiedad de unas pocas estrellas y sus cuidadores" para pasar a pensar que "la naturaleza básica de la música no reside en objetos, sino en la acción, en lo que hace la gente»; o que "cada obra musical es autónoma, es decir, existe sin relación a ningún acontecimiento, ni conjunto de creencias religiosas, sociales o políticas», para pasar a comprender que

una actuación musical es una cosa mucho más rica y más compleja que lo que permiten quienes se concentran sólo en la obra musical y en su efecto sobre un oyente individual. Si ampliamos nuestra atención hasta el conjunto de relaciones que constituyen una actuación vamos a ver que los significados primarios de la música no son nada individuales sino sociales" (Small, 1999, p. 3-4).

La concepción performativa de la música, entenderla como musicar, es prioritaria «no sólo para expresar la idea de actuar, tocar o cantar; ya tenemos palabras para eso; sino para expresar la idea de tomar parte en una actuación musical». Es decir pasar de la música-objeto a la música como práctica y como "ritual en el espacio social".

En ese mundo real donde la gente en realidad toca y canta y escucha la música, en salas de concierto y salones aburguesados y cuartos de baño y en mítines políticos, y en supermercados e iglesias, en tiendas de discos y templos, y prados y clubes nocturnos, discotecas y palacios, estadios y ascensores, es la actuación que es central para la experiencia de la música. No hay música aparte de la actuación, sea en vivo o grabada. No hace falta ninguna obra de música; en muchas de las grandes culturas musicales del mundo no hay tal cosa; y no hace falta oyente; por lo menos aparte de los mismos músicos. Pero no hay música si nadie está actuando; tocando o cantando. Y cuando hablo de actuar no sólo me refiero a un acontecimiento público y formal. Me refiero a cualquier acontecimiento donde alguien canta o toca, sea para sí mismo o para un pequeño grupo de familia o amigos, o para un público de miles. Entonces, me parece evidente que el punto para empezar a pensar sobre el significado de la música no son las obras musicales sino la acción (Small, 1999, p. 5).

De esta forma la música (ya deberíamos decir el musicar) recupera la condición de práctica dinámica y efímera, en permanente proceso de producción y apropiación y vuelve obsoletas las concepciones tradicionales de la "obra musical" y la separación entre autor o compositor e intérprete o performer, funcional únicamente bajo las coordenadas de la música culta de concierto y el paradigma de los derechos de autor de la industria fonográfica.

Pensar la música como acción es pensar que el arte está inscrito en el cuerpo, que es a la vez un cuerpo individual y social, o incluso un cuerpo cuya subjetividad depende íntimamente de las relaciones sociales, con otros cuerpos que comparten la ocasión musical. Esto es lo que sugiere Adolfo Colombres cuando advierte que los mayores logros expresivos se dan en la acción -no en los objetos cristalizados- pues ponen en escena el

21 "These days the problem not only concerns what is meant by the "popular", but what we mean by the very notion of music» [actualmente el problema no es solamente qué quiere decirse con "popular", sino qué pretendemos significar mediante la noción misma de música] (Hesmondhalgh y Negus, 2012, p. 2) [traducción del autor] 
imaginario tanto social como personal, tornando más perceptibles los significados profundos de la experiencia colectiva (Colombres, 2004, p. 178). Podemos concebir a partir de aquí al musicar, sobre todo en sus aspectos estéticos, como un «desplazamiento en el ámbito de lo extracotidiano» sin que por ello pierda significación social, ya que la producción de sentido ocurre en la propia dinámica actante del cuerpo performático, dentro del cual sobresale el artista, pero que no se reduce sólo a él.

El ritual verdadero, que es el compartido, proporciona un sentido al individuo mediante la relación con los otros y con la cultura, en cuyos argumentos lo sumerge. A través de él, la comunidad se reconoce a sí misma, reafirmando o reelaborando su imaginario (Colombres, 2004, p. 60)

Aquí vuelve la idea de ritual en el espacio social, que llamaremos también ocasión musical (Camacho, 2011), que será la denominación para la cosa, el fenómeno musical que no es obra sino performance: «La ocasión puede ser definida como el punto focal que comprende la percepción, la actuación y la creación de la música [...] la pregunta, por lo tanto, es '¿cuándo es la música?'»22 (Herndon y McLeod, 1979). Ocasión musical que podemos pensar también en términos de «acontecimiento inestable» (Frith, 2014, p.358). Pero que conlleva inscrito el cuerpo del performer, del músico -cantante, instrumentista, productor- y del mismo modo incluye la corporeidad de todo el colectivo que participa, con mayor o menor intensidad, del musicar. Colombres también incluye al cuerpo social en la práctica artística pues la autonomía no tiene ningún sentido cuando pasamos a considerar, desde la performance, a las músicas populares. El ritual -o mejor, la confluencia de rituales específicos- aglutina los diversos roles en torno a la música y el arte que incluyen no sólo la producción en sí, sino la recepción y la circulación (Colombres, 2004, p. 66), que adquieren formas específicas que son también históricas.

El carácter corporeizado en el músico-performer nos lleva también a considerar lo que Simon Reynolds estima una cualidad física de la música popular, en tanto vinculada en el ritual con el baile. El apelar a los reflejos psicomotores del cuerpo no vuelve a la música menos ligada con lo racional o lo conceptual. Al contrario, justamente el carácter físico de la performance musical popular que la vincula inextricablemente con el ritual, "disuelve la dicotomía entre cuerpo y mente, entre música "seria" para escuchar en casa y música "estúpida" para la pista de baile [por el contrario, la música popular] hace que la mente baile y el cuerpo piense» (Reynolds, 2010, p. 180). De hecho, la idea de que los bailarines "escuchan" con el cuerpo es muy recurrente a la hora de considerar las particularidades de las músicas populares. Aparece aquí con énfasis la estrecha relación entre sonido, escucha y cuerpo, que nos invita a salir de todo modelo objetual y autónomo de la música. Si en la música popular "el cuerpo entero se vuelve oído» (Reynolds, 2010, p. 180) el medio que envuelve al cuerpo en el ritual del musicar es justamente el sonido que permite establecer una relación dialógica multidireccional, en tanto que son «expresiones de individualidad en una labor en conjunto» (Quintero Rivera, 2009, p. 98) entre los cuerpos, entre los músicos y los bailarines, entre el público -ya sea que participe más o menos activamente del ritual-, y entre los instrumentos y los cuerpos actuantes y danzantes.

Es por eso que consideramos que, frente a la unicidad autónoma que se privilegia en la concepción de la música culta desde la cultura afirmativa, debemos considerar a la música popular en términos de lo que Ticio Escobar plantea como integralidad del arte popular con el tejido social, en el sentido de no detenerse en la mera complacencia sensible sino en devenir verdadera acción artística, performance, lo que le otorga la capacidad de reformular la realidad. «La práctica artística constituye una actividad socialmente cohesionante: los

22 «The occasion may be defined as the point of focus encompassing the perception, performance or creation of music[...] The question, then, is 'When is music?'» (Herndon y McLeod, 1979) [traducción del autor] 
objetos y el propio cuerpo se estetizan para ingresar a un nivel ritual que sintetiza la experiencia colectiva» (Escobar, 1991, p. 108).

Si el cuerpo del músico es parte del musicar, o mejor, si el performer subjetiva la música en la ocasión musical integral, potenciando el sentido colectivo de la acción, podemos pasar a proponer que la música y el musicar son transitoriamente la misma cosa, de forma tal que la música popular adquiere así las cualidades de lo móvil, cambiante, vivo, es decir, lo dinámico. Lo que además se vincula con una condición inestable y de cuestionamiento, que «han sido siempre un aspecto de la performance popular» (Frith, 2014, p. 358)

Podemos pensar que la forma en que el cuerpo del performer habita la ocasión musical se acerca a las formas rituales en que la performance adquiere el carácter de trance, que se enlaza con las raíces de las prácticas religiosas precristianas en Europa y de las culturas animistas africanas y americanas, en donde el trance es posesión a través del ritual colectivo en el cual el cuerpo y el sonido adquieren un rol protagónico. En esto descubriremos un aspecto muy ligado a lo que podemos considerar lo popular, en cuanto a un colectivo social poblado de contradicciones y diversidades

La música, más que producir el trance, ejerce sobre todo una función identitaria, respecto a una identidad que comunica que se reconoce múltiple y heterogénea; conformada por diferencias y contrastes que sólo se unifican en la comunicación y en la unidad de propósito que simboliza el rito (Quintero Rivera, 2009, p. 97).

A este carácter heteróclito del trance y el ritual social podemos relacionarlo con lo que Homi Bhabha denomina "la naturaleza performativa de las identidades diferenciales» (Bhabha, 2013, p. 264) que promueven espacios sociales dinámicos, que se rehacen continua y contingentemente, y en el que habitan reivindicaciones múltiples, diversas, superpuestas e incluso contradictorias, como son en sí mismos los sectores populares y subalternos. Más adelante desarrollaremos esta condición heteróclita de 10 popular, pero aquí podemos introducir una categoría que nos permite densificar los conceptos de musicar y performance, proveyéndonos de cierta dimensión analítica que pueda evitar el "armonicocentrismo" y el "notacionalcentrismo" del modelo objetual/ personalista afirmativo. Se trata de la noción de las discrepancias participatorias propuesto por Charles Keil como parte de su groovología que, precisamente, entre sus objetivos se propone dar consistencia epistémica al musicar de Small. Pero aquí es relevante en términos de su especificidad social y la relación con la inversión de la música popular y su carácter litigante.

El poder de la música reside en sus discrepancias participatorias, las cuales pertenecen básicamente a dos categorías: procesual y textural. Para poder producir una implicación personal y ser socialmente valiosa, la música ha de ir "a destiempo" y estar "desafinada" (Keil, 2001, p. 261)

Es decir que en la música considerada como performance, ocasión musical en el ritual social, de carácter integral aunque inestable y dinámica -todas coordenadas mediante las cuales consideraremos la música popular- lo definitorio no es la configuración melódica ni la estructura armónica, sino la materialidad sonora que emerge de la trama de inflexiones y articulaciones dialógicas, el tejido del ritmo que dependerá a su vez de variantes en el tono y el timbre, desvíos entre los participantes y, con respecto al pulso, variantes mínimas o explícitas en la emisión de la voz o de los instrumentos. En definitiva, lo que desde nuestros restringidos marcos conceptuales llamamos el "timbre" y la "textura", y que justamente han recibido esos nombres tan poco elocuentes, que deben tanto a otras dimensiones y sentidos que no son musicales, porque fueron despreciados por el pensamiento musical afirmativo de la modernidad al considerarlos elementos disruptivos, "ruidos" a purgar en un 
proceso de estilización de las prácticas musicales. Canalización de sus elementos subversivos, que Attali vincula con la naturaleza de la música popular.

El hecho de que estos elementos esenciales de la música apenas sean "figurados" [...] y realmente no se hallen "representados colectivamente" con cierta claridad en el lenguaje, es evidencia, pienso, de su poder participatorio original y activo (Keil, 2001, p. 261).

Precisamente esta condición contenciosa y cuasi contrahegemónica que implica la participación actuante de los cuerpos dialógicos, es todo un manifiesto de la música popular, vinculada específicamente con su carácter popular, que implica la necesidad de una nueva perspectiva para su abordaje histórico, ya que solo «si el momento de la performance es considerado como un acto potencial de composición, podrá emerger una perspectiva diferente» ${ }^{23}$ (Middleton, 1990, p. 53). De hecho, así como el trance forma parte de los rituales populares de formaciones culturales tan heterogéneas como los afroamericanos o las comunidades célticas consideradas paganas por el cristianismo medieval, es notable la importancia que la performance, entendida como variación y creación repentista y momentánea, posee en prácticamente todos los tipos de música popular así como en las músicas extraeuropeas (Middleton, 1990, p. 56). Que la performance sea considerada entonces una "actividad fundamentalmente variativa» (Middleton, 1990, p. 137), es decir, de cambio, nos vuelve a la centralidad que la dinámica histórica adquiere como condición definitoria de la música popular.

La performance es así un concepto, no un procedimiento de decodificación o el subproducto, necesario aunque repudiado, de la circulación de una obra musical. Y justamente en este cambio de estatuto de la performance, que conlleva el cambio de música a musicar, se da un movimiento que se aleja del énfasis en la "música per se" (Herndon y McLeod, 1979, p. 26) y nos revela lo inseparable del aspecto social que toda actividad musical posee. La performance por lo tanto no se trata, bajo ningún concepto, de un modo o medio para interpretar un texto -que además es concebido como autónomo-, sino que es su opuesto: es algo diferente, algo "no-textual" (Frith, 2014, p. 359) que adquiere significación en la integralidad del ritual social, y valor en base a las discrepancias que producen, en el sonido, los participantes del ritual, sean considerados "músicos" o no. La condición performativa de la música popular, mediante la ambigua subjetivación y objetivación simultáneas del artista que se funde con la música y la comunidad del musicar, provoca, por su sola presencia sonora, la ruptura del modelo objetual/personalista.

Esto nos devuelve al problema del musicar frente a la compresión de las categorías de la historiografía y lo inadecuado de los modelos analíticos concebidos por la historiografía afirmativa. En este sentido queremos introducir aún un aspecto, puesto que considerar la performatividad como condición de posibilidad de lo popular implica desechar también la noción de representación, ya que el sujeto popular mestizo no puede estar afuera de la música; justamente por esta afuera de la sociedad y habitar el conflicto con la visión consensual afirmativa, su lugar de enunciación está integrado, fundido, con las condiciones de las que su enunciación emerge. Por eso la música popular es presentacional, opera en términos actanciales y momentáneos, que impiden reducir su dinámica en la fijación del objeto. Por ejemplo, para el caso de la música electrónica de baile, Reynolds plantea lo que llama localización específica, es decir, una condición según la cual el valor simbólico de la música popular tiene sentido en la ocasión musical, en el musicar que practican quienes están ahí, en este caso en la discoteca y su sistema de sonido, ritual irreproducible en una casa o un escenario (Reynolds, 2010, p. 193). Es decir que para tener una experiencia completa hay que vivenciar el ritual, dado que la música por fuera de ese marco ocasional

23 «if the moment of performance is considered as potentially an act of composition, a different perspective can emerge» (Middleton, 1990, p. 53) [traducción del autor] 
pierde todo sentido. Como veremos, ya en la ocasión del carnaval, en los albores de la cultura occidental, la idea de lo vivencial es precisamente la que otorga sentido a las prácticas de la cultura popular, que también son sonoras.

Los espectadores no asisten al carnaval, sino que lo viven, ya que el carnaval está hecho para todo el pueblo. Durante el carnaval no hay otra vida que la del carnaval. Es imposible escapar, porque el carnaval no tiene ninguna frontera espacial (Bajtín, 2005, p. 13)

Susanne Langer (1957, p. 63) proporciona una categoría simbólica específica para el arte -en el cual va incluida la música- que es la que le otorga la cualidad de ser no-discursivo, una modalidad opuesta a la configuración lógica del lenguaje (verbal) que es proposicional y opera mediante un procedimiento de proyección, una especie de traducción de las ideas en palabras, a partir de una serie secuencial de derivaciones lógicas que nos permite volver a la idea a partir del lenguajes, es decir, leerla. Aquí Langer sigue el pensamiento de Wittgenstein y es muy significativo que el caso que elige para ejemplificar el procedimiento proposicional-discursivo, que Langer cita, es la lectura de una sinfonía en la partitura por parte de un músico (Langer, 1957, p. 64). Existe una ley de proyección que permite al músico leer la sinfonía en la partitura que es análoga a la que nos permite reconstruir la misma música en nuestra escucha a partir de la línea del fonógrafo. Más que traducción podríamos hablar incluso de transducción. Pero aquí viene lo relevante para nuestro caso, y es que para Langer todo esto no es la forma en que se despliega el sentido simbólico del arte, ya que "la transformación que experimenta la realidad (facts) cuando es traducida a proposiciones es que las relaciones que anidan en su interior son convertidas en algo así como objetos"24 (Langer, 1957, p. 66). En el lenguaje proposicional el símbolo no se parece a la realidad, ya que no resiste la contradicción -pues es un artefacto lógico- y de esta forma no puede contener como parte del símbolo lo que debe ser parte del significado. De allí que en la lógica de los objetos -en donde nosotros incluimos el concepto de obra musical de la historiografía afirmativa- exista una distancia simbólica muy profunda entre la partitura, la idea/obra del compositor y su actualización mediante la ejecución sonora. Cuanto menos se parecen los sonidos a su codificación discursiva -la partitura-, tanto mejor para el modelo objetual/personalista. De aquí es muy sugestivo seguir el derrotero de la semiótica musical y su impacto en los PMS, parte muy importante en el proceso de compresión conceptual y de ruptura histórica, ya que consideran a la música popular como "discurso", "lenguaje" y sobre todo, "texto" (González, 2014, p. 108). Transforman así en objeto a la música popular, incluso cuando aparentan buscar lo contrario 25

Por ende, si seguimos a Langer en que los procedimientos proposicionales y discursivos no son los del arte, estamos oponiendo lo musical a esa proyección objetual del lenguaje. De hecho, parte de la comparación de las formulaciones verbales aparentemente sin sentido, como las exclamaciones o la risa (que como veremos tiene un rol más que protagónico en la definición de lo específico de la cultura y la música popular). Todas estas formulaciones, "como la poesía y la música" (Langer, 1957, p. 68) son expresiones, que solo

\footnotetext{
24 «The transformation which facts undergo when they are rendered as propositions is that the relations in them are turned into something like objects» (Langer, 1957, p. 66) [traducción del autor]

25 En el capítulo "De la canción objeto a la canción proceso" de Juan Pablo González (2014), tal vez el mayor referente latinoamericano de los PMS, puede verse su preocupación por considerar a la música popular como texto con el fin de producir una "intertextualidad analítica" que reúna a la "tradicional relación sintáctica y semántica" con "texto, música y expresión" junto al "grano de la voz, el gesto y la performance" y los contraste a "los discursos que todo esto produce". La recurrencia de la jerga lingüística es tan profusa que casi no hay frase que no contenga un artefacto conceptual que remita a la idea de que la música es un lenguaje. De hecho, se leen asertos como el que nos invita a partir "de la base de que una canción es una pluralidad de textos" (González, 2014, p. 108). Langer, que escribió su propuesta filosófica medio siglo antes que González emprendiera el estudio de la música popular, podría haber utilizado su capítulo como ejemplo de las formas discursivas, lógicas y proposicionales, es decir, las que no se corresponden con los modos expresivos de la música y el arte
} 
pueden ser consideradas carentes de sentido o ilógicas en la medida en que no se las comprende -a lo cual nosotros añadimos, se las comprime. Todas aquellas formulaciones o articulaciones que no se ajustan a la estructura gramatical del lenguaje -la ley de proyección objetual- deben ser consideradas en función de una interpretación simbólica que las diferencia del lenguaje discursivo, proposicional. Son articulaciones muy complejas, en las cuales existen tantas relaciones internas, dentro de otras relaciones sucesivas, tantas partes diminutas y simultáneamente relacionadas entre sí, que no pueden proyectarse en un objeto, en formas discursivas del lenguaje verbal. Son «demasiado sutiles para el habla» (Langer, 1957, p. 77). Y a la vez son demasiado importantes, ya que conceptualizan el flujo de configuraciones que nos permite asignar sentido al caleidoscopio de colores y ruidos. Podríamos pensar en la articulación de esta teoría epistemológica de lo simbólico con la hipótesis en torno al ruido de Attali que referimos antes, que en su caso nos proveen de un sentido social y político a lo que, para Langer, es un modo de producir expresión, pensamiento no discursivo, es decir, conocimiento en paralelo al que produce la ciencia y sus proposiciones lógicas. Lo cual en Attali se formula considerando a la música, canalización del ruido, como "útil de conocimiento" de la sociedad y la economía política en la historia (Attali, 2011, p. 12). Para este modo de conocimiento específico del arte y la música, Langer acuña un término que intenta reunir el modo simultáneo en que se nos revela la música, que es no discursivo y expresivo, no traducible ni reificable en términos de objeto. Así podríamos sostener que la música en términos de articulación material, ocasión sonora, en fin, musicar

sólo pueden comprenderse a través del sentido de la totalidad, a través de sus relaciones con la estructura total. Su funcionamiento específico como símbolos depende del hecho de que participan en una presentación simultánea, integral. Podemos denominar a este tipo de semántica "simbolismo presentacional", para caracterizar su distinción esencial frente al simbolismo discursivo, es decir el lenguaje propiamente dicho'26 (Langer, 1957, p. 79).

Como puede verse, esta cualidad presentacional que asociaremos a la música popular en tanto musicar, Langer la piensa desde el contraste, desde «todo aquello que se resiste a ser proyectado en la forma discursiva del lenguaje» (Langer, 1957, p. 80). Esto nos permite profundizar en nuestra hipótesis de que la música popular se resiste a ser proyectada como objeto, es decir, comprimida a las formas y metodologías de la historiografía afirmativa, y que es en su carácter de presentación

Uniendo nuevamente con los postulados de Attali que, como veremos, considera que la puesta en escena de la sociedad hegemónica de la modernidad es específicamente posible mediante el desarrollo de la música culta tonal, momento histórico que el autor francés identifica con el procedimiento de la "representación" -pensemos en la ópera y el estilo representativo de los italianos del XVII- es mediante el objeto, la obra que es derivación de la ópera que

La sociedad se espectaculariza y todo se vuelve una gran plataforma, escenario donde se canjean al mejor postor gente, realidades, tragedias, masacres: todo se vuelve objeto de 'representación' y, con ello, de intercambiabilidad (Díaz, 2013, p. 1)

Resistir la objetualidad, entonces, es más que escabullirse de los métodos de análisis y evadir una sinonimia con la idea de lenguaje. Justamente todo un sentido de lo popular estará intrínsecamente relacionado con este carácter presentacional, sonoro, actuante y performativo. Las resistencias en términos formales, de naturaleza simbólica, son

26 «are understood only through the meaning of the whole, through their relations within the total structure. Their very functioning as symbols depends on the fact that they are involved in a simultaneous, integral presentation. This kind of semantic may be called "presentational symbolism," to characterize its essential distinction from discursive symbolism, or "language" proper» (Langer, 1957, p. 79) [traducción del autor] 
correspondientes a las resistencias en términos políticos que podemos relacionar con lo que de popular tiene la música popular

Presentacional es aquello que abandona y se resiste a la re-presentación que es reproducción de un texto, ejecución de la seriación del mundo objetualizado, para en cambio presentarse como acontecimiento fugaz y etéreo. Este énfasis en la situación, en el momento, en el aquí y ahora del tiempo, convierten al músico en performer y hacen que el musicar habite en su propia corporeidad y localización específica (Reynolds, 2010, p. 193). El performer es la música. Por eso trazar una historia presentacional de la música es antes que nada focalizar en los sujetos y no en los objetos. La música popular considerada a la luz -o al ruido- de su condición presentacional se revela resistente al modelo objetual/ personalista, ya que

no tolera más el poder central del texto y clama por desplazarse de la autoridad a la alteridad, sino -y sobre todo- se resiste al fortalecimiento de cualquier fórmula que se genere desde las lógicas de la representación, del intercambio (Díaz, 2013, p. 2)

Aquí reside el sentido político que emerge cuando a la música popular la entendemos como performance, un musicar en tanto ocasión social situada, localizada. Ya que así podemos reintroducirla al conjunto histórico de los «eventos inesperados, es decir impropios para entrar en el eje de la intercambiabilidad» (Chevalier como se citó en Díaz, 2013, p. 3). Resistirse a repetir el modelo, resistirse a la autoridad del texto proyectado en objeto/obra, es resistir a la autoridad del autor, pero sobre todo a la de la cultura dominante. Lo presentacional implica, entonces, suspender desde la forma, desde la praxis musical, la afirmatividad.

\subsubsection{El musicar común como transculturación y mestizaje}

Volviendo a Christopher Small, tomaremos de este autor otra noción perturbadora del statu quo musicológico, que enlazaremos con la noción de "costumbres en común" del historiador E. P Thompson (2000): nos referimos al traslado de contexto de la concepción de práctica común, que según Small no es (y nunca ha sido) la música tonal de concierto de las élites de Europa occidental, sino las músicas afroamericanas (o afrodescendientes), originadas en toda la extensión de América como músicas de resistencia bajo las coordenadas del colonialismo y el tráfico esclavista y convertidas a partir de los siglos XX y XXI en "música de la lengua común". ${ }^{27}$ Tal el objetivo de su trabajo,

mostrar que, tomando en consideración cualquier reconocimiento que hagamos de la función de la música en la vida humana, la tradición Afroamericana es la música más importante de Occidente en el siglo XX, mucho más significativa para la humanidad que los vestigios de la gran tradición clásica europea que todavía pueden escucharse, tanto en Occidente como en Oriente, en las salas de concierto y los teatros de ópera del mundo industrial28 (Small, 1998, p.4)

Esta perspectiva tan particular (y rotundamente ignorada por la academia musicológica y también por los estudios de música popular) nos será de gran ayuda a la hora de producir categorías de análisis que nos permitan resolver los problemas y contradicciones de los

27 Music of the common tongue es la denominación original en inglés, que el propio autor traduce como Música de la lengua común en la conferencia ya citada, aunque se disculpa por su uso elemental del español (Small, 1999).

28 «[...] to show that, by any reasonable reckoning of the function of music in human life, the Afro-American tradition is the major music of the west in the twentieth century, of far greater human significance than those remnants of the great European classical tradition that are to be heard today in the concert halls and opera houses of the industrial world, east and west» (Small, 1998; p. 4). [traducción del autor] 
métodos analíticos que mencionamos como parte de la segunda hipótesis. Además, esta perspectiva, que otorga un peso ineludible a la música popular urbana en la sociedad occidental contemporánea, nos servirá de guía a la hora de reconstruir los diversos recorridos de su pasado histórico.

Será importante entonces deconstruir el canon musicológico para permitirnos observar a la tradición clásica europea occidental como una rama más dentro de la enorme variedad de tradiciones musicales a nivel global, que de hecho puede representar más una excepción o un particularismo -en sus singulares formatos vinculados a la partitura, el compositor, la teoría armónica- que una forma "común" universalizable. En esta necesaria digresión tomaremos al mismo Small, quien ha realizado una disección minuciosa del modelo occidental de "sala de conciertos y cadencia perfecta" (Small, 1989), revelando sus relaciones íntimas con el auge del capitalismo y la ciencia moderna y contrastándolo ya con las tradiciones africanas y afrodescendientes. Intentaremos articular este análisis con las críticas formuladas por el ya citado Nicholas Cook, y los aportes de Leo Treitler, Richard Taruskin y Anne Shreffler, y los también ya citados Middleton y Frith entre otros investigadores afines a los estudios culturales en música. ${ }^{29}$

Por último, y como aporte desde nuestra propia situacionalidad socio cultural, consideraremos incorporar ciertos marcos teóricos desarrollados principalmente en Latinoamérica, algunos de los cuales tuvieron como objetivo central definir las particularidades de nuestra región pero que, explícita o implícitamente, se han erigido como propuestas teóricas de alcance mundial. En primer lugar, y tramando una fuerte relación con la revalorización de lo afroamericano defendida por Small, tomaremos los conceptos de mulatería, mestizaje y transculturación, aplicándolos en un primer momento al análisis de las músicas afrodescendientes -o mulatas- de América, pero con el propósito de generalizar algunos de sus indicadores y su potencial valor explicativo al fenómeno general de las músicas populares urbanas. Según el principal teórico de estas músicas, Ángel Quintero Rivera, el universo de las músicas mulatas «es y no es -simultáneamenteOccidente» (Quintero Rivera, 2009; 69) Esto encierra a nuestro juicio una enorme potencialidad conceptual: por un lado rechaza de plano cualquier concepción esencialista acerca de la música y sus "raíces" 30 , apartando el análisis tanto de los esquemas de la musicología y sus categorías de estilo, como del folklore y su vocación de hallar espíritus de pueblos. Pareciera que, casi sin proponérselo, este autor se saca de encima uno de los problemas más importantes de la investigación musical que ha sido interminablemente debatido a lo largo de los siglos, y uno de los factores de desprestigio permanente de la música popular urbana: la autenticidad. Así no sólo se rescatan las prácticas musicales afrodescendientes al convertir en positivo el signo de lo ensamblado, interesado, funcional y por lo tanto, inauténtico -o si se quiere, lo trucho o pirata, asociando términos utilizados para el desprestigio actual de las músicas populares y sus prácticas. También se denuncia, casi sin decirlo, la quimera y falsedad de la autonomía artística, la autenticidad, la estratificación y el desinterés estético, aplicados a cualquier música, inclusive a las músicas de concierto de la élites de Europa Occidental. Músicas que en su genealogía muestran altos grados de heterogeneidad a través de múltiples influencias y apropiaciones, provenientes de diversas culturas, tradiciones y clases sociales. Y estudios sobre esas músicas que, si algo han sido,

29 Cook (2001); Cook y Everist (2010); Treitler (1990); Taruskin (2010); Shreffler (2003); Clayton, Herbert y Middleton (2012).

30 «Entre comillas, pues la metáfora de la raíz para referirse a las tradiciones culturales europea, africana e indoamericana que se entrecruzaron en la compleja conformación del mundo americano ha resultado bastante problemática, ya que tiende a homogeneizar, en tres grandes conjuntos, tradiciones muy heterogéneas, y a ejercer un corte temporal que pasa por alto continuados procesos de inter-fecundidad posteriores al momento del "encuentro» (Quintero Rivera, 2009, p. 72). 
es interesados y funcionales, nada autónomos frente a la vocación universalizante del imperialismo europeo. ${ }^{31}$

Profundizando este sentido, complementario de los conceptos ya referidos de musicar y de dinámica de la música popular, consideramos que la categoría de mestizaje es la que tal vez expresa mejor lo heterogéneo, heteróclito, inestable, impreciso, lo conflictivo, el nomadismo (Laplantine y Nouss, 2007). Una identidad movible, que se demora en los pasajes, en las preposiciones y conjunciones, en un carácter permanentemente transicional. El mestizaje es así lo contrario a la idea de mezcla o más aún, de fusión, tentación pseudouniversalista que intenta reparar las fallas, las fisuras y rajaduras, resolviéndolas en la integración, en la reabsorción de lo múltiple en lo Uno. El mestizaje, pero también la mulatería, permiten a su vez expresar con crudeza y sin eufemismos la realidad política y conflictiva de todo proceso histórico de gestación cultural: «...este mestizaje no es resultado de un acuerdo, de un diálogo, de una relación armónica, simétrica, entre dos sociedades, sino de una violencia que opera en un marco de colonialismo» (Colombres, 1991). El mestizaje no otorga ningún lugar a las ideas de reunión, consenso, reconciliación, con toda la carga ideológica que arrastran. Tampoco a la idea de cultura como síntesis, que automáticamente detiene el flujo dinámico del musicar y convierte a la música en objeto, en obra. Además la noción de estilo, principal argumento esencialista, carece en este contexto de todo valor explicativo.

Pensar desde estos conceptos es pensar desde lo impuro, lo no-esencial, casi forzando la misma idea de identidad hacia su límite. Así, la subjetividad es posible en la medida de la apertura al otro, junto al otro. Como en el musicar, posee una significación fundamentalmente social. Es una intersubjetividad que se convierte en transubjetividad. Esa diversidad estaría poblada de una otredad que no se construye como oposición, sino que da lugar a ese otro, está incluyéndolo en la identidad y definición del sujeto. Es el pasaje de lo monádico a lo nomádico (Laplantine y Nouss, 2007), de la autonomía y la autosuficiencia a la apertura relacional del devenir. Es más, no habría un mestizaje, sino en todo caso, mestizajes en tanto series de precarias e inestables relaciones históricas, en un constante juego disonante de descentración y relocalización. Buscar los "principios", los "orígenes", lo primigenio es "perder toda posibilidad de percibir los procesos de transmutación mestiza» (Laplantine y Nouss, 2007).

Al detenerse a reflexionar sobre la naturaleza social y cultural de América Latina, Fernando Ortiz aporta todavía otro concepto que podría resultar complementario: la transculturación. En palabras del mismo autor

expresa mejor las diferentes fases del proceso transitivo de una cultura a otra, porque este no consiste solamente en adquirir una distinta cultura [aculturación] sino que el proceso implica también necesariamente la pérdida o desarraigo de una cultura precedente, lo que pudiera decirse una parcial "desculturación", y además, significa la consiguiente creación de nuevos fenómenos culturales [...] una transición [hacia] una nueva realidad de civilización (Ortiz, 1940; citado en Podetti, 2004).

Mediante la apelación a estos nuevos fenómenos culturales o esa nueva realidad de civilización, la transculturación aclara definitivamente que el mestizaje y la mulatería no pueden entenderse como mero ensamble o articulación de partes que, además de permanecer reconocibles, podrían descomponerse para restaurar un supuesto estado primigenio, "puro-esencial". En simultáneo, el énfasis en considerar las producciones transculturales como entidades nuevas, en donde «todo suena diferente» (Acosta, 1984)

31 "No puede sorprendernos en absoluto que este tipo de pensamiento fuera un lugar común en los años del cambio de siglo (XIX al XX), la época en la que no se ponía nunca el sol en el Imperio Británico" (Cook, 2001, p. 72). 
por más que encontremos herencias, tradiciones y procedimientos reconocibles que provienen de diversas fuentes, potencia el valor historiográfico de este término, ya que lo convierte en un útil de conocimiento para comprender como creación las prácticas populares habituales que se basan en la reelaboración y arreglo de músicas preexistentes, además de permitir la visualización de las identidades musicales populares no como rasgos estilísticos, sino como modos a la vez sonoros, culturales, políticos, económicos y sociales. Nunca como fenómenos autónomos. Adviértase además la complementariedad que el concepto de transculturación ofrece a los de mestizaje y mulatería, al subrayar lo que aparece como transicional. La transculturación no se centra solo en la propia identidad, porque es la identidad misma la que está cuestionada. Por definición, es una identidad en crisis permanente que se realiza gracias a la misma polaridad identidad-alteridad. Entonces

la transculturación significa asumir la condición transitoria de la mezcla [...] una de las características de este pensamiento es la consciencia de la insuficiencia. Por lo tanto, lo que caracteriza a este proceso, más que un afán de completarse en sí mismo, es una permanente apertura (Podetti, 2004).

Desde ese punto de vista, tanto el mestizaje y la mulatería como la transculturación, aparecen como la contracara de las hegemonías raciales y culturales que encierran un designio universalista. «Reaseguro contra la irrupción de conciencias que asuman su raza como sujeto privilegiado de la historia, o que perciban el fin de la historia en el fin de sus propias posibilidades históricas» (Podetti, 2004).

Estas categorías no solo son importantes para explicar las músicas locales, sino que pueden transformarse en útiles de conocimiento general de la música como alternativa al universalismo de la globalización (Podetti, 2004). Si repensar las vertientes que confluyen con violencia en la historia de la música mestiza latinoamericana nos revela cuán heterogéneas han sido las músicas provenientes de Europa, en grado similar a las amerindias o las africanas, el mestizaje puede ser entonces una característica que se integre a la misma idea de historia de la música, reemplazando los esencialismos y los orígenes. "Sin purezas y con mezclas» (Sánchez Canedo, 2010) son claramente conceptos que explican la conformación histórica de la música afrodescendiente de Bolivia. Pero ¿qué sucede si los tenemos presentes al estudiar las raíces griegas y germanas, mediterráneas y bárbaras, del canto romano-franco (gregoriano) medieval, es decir, la piedra fundamental de la cultura musical occidental?

Un pensamiento musical latinoamericano no pone en crisis a la música europea culta sino que, por su sola presencia, horada el fundamento de los principales conceptos de la historiografía musical tradicional: la transculturación mestiza transforma los esencialismos, la autonomía musical y el foco individualista en excentricidades, aún para el estudio del canon musical. $\mathrm{Si}$, como parece ser cierto, lo latinoamericano desaparece cuando no consideramos los procesos históricos, la función social, los colectivos y la significación de cada música en contexto, podemos invertir la ecuación y repensar toda la historia musical desde esos indicadores. Para nosotros debiera ser más natural pensar la música así.

\subsubsection{El Mundo Popular Subalterno}

No podemos iniciar nuestra indagación sin establecer al menos esquemáticamente a qué nos referimos por "popular". La respuesta más breve, que estimamos sigue teniendo potencia en nuestra sociedad contemporánea, fundamentalmente latinoamericana, es que popular es aquello relativo al "pueblo". Pero como sabemos, este término es considerado sumamente problemático ya que lo popular expresa una complejidad y heterogeneidad similar a la categoría de mestizaje que acabamos de introducir en nuestro marco conceptual. De hecho, en el transcurso del trabajo ensayaremos una suerte de identidad 
entre las dos categorías, o cuanto menos pretendemos mostrar una homología entre ellas, de suerte que de un modo circular se impliquen mutuamente y advirtamos que lo popular es mestizo en la medida en que el mestizaje no puede eludir la incorporación de las culturas populares en su configuración conceptual (Laplantine y Nouss, 2007). Al mismo tiempo la heterología e inestabilidad del mestizaje pueden ser vías más que interesantes para explicar la condición contradictoria, heterogénea y altamente diversa que reúne aquello que llamamos "pueblo".

Como vimos en la mayoría de los estudios que informan, en los PMS se rechaza definir a lo popular y aún menos al pueblo. No lo desarrollaremos en este trabajo pero, a modo de hipótesis, podríamos plantear que este rechazo a incorporarlos como categoría es en parte responsable del desacople que las narrativas de los PMS producen entre la "música popular" y la cultura popular y su historia. Además priman las perspectivas derivadas del posmodernismo y el poscolonialismo que, justamente, rechazan las categorías que tienden a generalizar, acusándolas de homogeneizantes, lo cual en gran medida ha sido cierto en el positivismo y el colonialismo epistémicos. Sin embargo, abandonar la posibilidad de definir los alcances de lo "popular" y desentenderse de la relación entre música popular y pueblo es, según entendemos, funcional a la perpetuación de los reduccionismos y de las homogeneizaciones, que continúan formando parte de la cultura afirmativa sin haber perdido nada de su potencia hegemónica. Por lo tanto, para los fines de este trabajo, música popular es aquella estrechamente vinculada con el espacio vital de la cultura popular, entendida ésta en relación estrecha con la categoría "pueblo".

Ahora bien, definir al pueblo no es nada fácil y lo más sencillo sería decir que no existe tal cosa. Enrique Dussel señala que Gramsci, precisamente para evitar caer en la trampa de una discusión sin fin sobre un concepto pretendidamente monolítico, utiliza el término "bloque" para referirse a los sectores populares, lo cual introduce un criterio multidimensional al término que, a nuestro juicio, las tendencias y disciplinas de la historiografía musical afirmativa intentan neutralizar con el fin de estabilizar una definición homogénea de lo popular. En cambio, un

\footnotetext{
"bloque" no es una piedra, en cuanto a su consistencia, sino es un conjunto integrable y desintegrable; puede tener "contradicciones" en su seno (como lo proponía Mao Tse-tung) [de ahí que el pueblo] Es un "bloque social' porque procede desde los conflictos de los campos materiales (extinción ecológica, pobreza económica, destrucción de la identidad cultural), y que lentamente pasa el primer umbral de la sociedad civil, y de allí el segundo umbral de la sociedad política (Dussel, 2006, p. 92).
}

Es desde estos conflictos y esta consistencia múltiple que para nosotros existe el pueblo y tiene validez como categoría para poder estudiar sus músicas, es decir, la música popular. Ciertamente porque -y no a pesar de que- es una categoría difusa, ambigua, heterogénea y... mestiza. Indicadores que expresan todo lo contrario al aparato epistemológico de la cultura afirmativa y sobre todo del folklore. De ahí a que nuestro particular concepto de pueblo, en inversión a la tesis de Herder, no es el volk del folklore, ideal imaginario que solo existió en la mente de la burguesía (Keil, 1978).

En cambio, el pueblo de la música popular es ambiguo y abierto a una pluri-significación (Rincón, 2015). Es un pueblo hecho de muchos pueblos, en que algunos se identifican con las clases dominantes, otros con las narrativas revolucionarias y otros, las mayorías tal vez, simplemente están ahí, "oprimidos pero no vencidos» (Cusicanqui, 1986), a veces en "posición de descanso» (Grignon y Passeron, 1992), viviendo sus vidas, que no es poco, y en las cuales la música es un aspecto de gran relevancia para las pequeñas cosas cotidianas, como el aseo, la cocina, el trabajo manual, el juego, en donde la cultura de la 
risa y el sentido intersubjetivo de la identidad colectiva adquieren un valor social que imprime sentido a la música y la integra inseparablemente a esas formas de vida.

Pero las prácticas convivenciales de la música popular, en la cuales coexisten el arte de los profesionales con la infinita gama del humilde musicar de los millones de seres que son el pueblo; esas prácticas, las de la every day life, se expresan en términos de discrepancias, y he ahí su potencial. Pues son discrepancias participatorias, como vimos, categoría analítica de los procedimientos populares, y al mismo tiempo, en tanto la música popular se expresa en la integralidad del ritual social (Colombres, 2007) y es expresión de la máxima intensificación de éste (Escobar, 1991), las discrepancias adquieren un valor disruptivo e incluso un sentido político.

Es en función de reunir estas dimensiones de lo popular y el pueblo -hecho de muchos pueblos- que proponemos para el estudio de la música popular considerar como horizonte conceptual la noción de Mundo popular Subalterno introducida por Ernesto de Martino en la cual se incluyen

los pueblos coloniales y semicoloniales, y del proletariado obrero y campesino de las naciones hegemónicas [sector que es] directamente afectado por el carácter fundamental de una sociedad fundada en la división en clases, y que toca de lleno los motivos de la explotación y del predominio (De Martino, 2008, p. 77).

Es decir que el mundo popular subalterno, que no es una mera clase, una etnia o un grupo lingüístico/cultural específico, es un colectivo transcultural y mestizo definido en contraste con los sectores dominantes y la estratificación social que los grupos dominantes proponen, desplegada a partir de fuerzas como la explotación o el saqueo colonial. Cuestión que se articula con la noción de "pueblo" en Gramsci, que es recuperada y ampliada por Enrique Dussel: «Pueblo es un bloque social "de los oprimidos" y excluidos [...] Puede ahora entenderse que lo "popular" es lo propio del pueblo en sentido estricto (lo referente al "bloque social de los oprimidos")»(2006, p. 92). En este mismo sentido de categoría surgida desde la confrontación y el contraste, podemos pensar en que lo popular emerge de una posición asimétrica de ciertos sectores frente a otros, lo cual introduce otra forma de complejidad o pluralidad: la de los factores

que intervienen en las situaciones de subordinación entendidas en su sentido más amplio como el conjunto de las distintas formas de opresión, explotación, marginación o discriminación, realizadas en lo político, económico, cultural, social, religioso, etc., en perjuicio de los grandes sectores mayoritarios o de las minorías excluidas de una participación social efectiva (Escobar, 1991, p. 88).

Es en la continuidad de los procesos de opresión en donde se fundan entonces las dimensiones que dan entidad al concepto de pueblo y de lo popular, y allí debemos hacer ingresar también, en términos de "sur global» (De Sousa Santos, 2014) aquello que fue racializado por el folklore y que los posmodernos prefieren llamar "étnico": en cuanto los pueblo indígenas son ingresados a las lógicas de dominación de la conquista, es decir son subalternizados, «ingresan en la condición que aquí consideramos definitoria de lo popular» (Escobar, 1991, p. 88). Por lo tanto, en un nuevo gesto de inversión popular, contrastaremos el principio de continuidad de la cultura popular del folklore, que se despliega en el tiempo aunque con carácter ahistórico, con la continuidad del mundo popular subalterno, en la cual habitan prácticas discontinuas, contradictorias y heterogéneas, pero a las cuales las hace confluir un sentido histórico emergente de la condición subalterna, a partir de la estratificación y la configuración de la opresión. Si para el folklore el pueblo es local, para el mundo popular subalterno es global; incluso podría pensar a éste desplazando la pretendida universalidad de la cultura oficial si en un análisis de las relaciones transoceánicas y transmodernas priorizamos el estudio de las relaciones entre vertientes 
culturales e históricas que el orden mundial de la modernidad occidental y su expansión colonial puso en contacto ${ }^{32}$.

Efectivamente, en esta línea nos resulta muy sugerente la presencia de una noción en el mundo andino colonial, como es la idea de Mundo al Revés, evocada por Felipe Guamán Poma de Ayala en su Nueva Crónica y Buen Gobierno de 1615. Es una noción que intenta dar cuenta del vuelco del mundo operado por la conquista y la colonización, en términos de eliminación de toda coordenada social y cultural, de lo conocido y lo común, por la imposición de nuevas reglas y normas. Para Silvia Rivera Cusicanqui (2015) Mundo al Revés forma parte de una teorización del sistema colonial, en términos visuales más que verbales -lo cual nos reenvía a la discusión sobre el carácter performativo, no prescriptivo ni proposicional de lo popular.

Mundo al Revés es una idea recurrente en Waman Puma, y forma parte de lo que considero su teorización visual del sistema colonial. Más que en el texto, es en los dibujos donde el cronista despliega ideas propias sobre la sociedad indígena prehispánica, sobre sus valores y conceptos del tiempo-espacio, y sobre los significados de esa hecatombe que fue la colonización y subordinación masiva de la población y el territorio de los Andes a la corona española (Cusicanqui, 2015, p. 177)

Este carácter de formulación sobre la explotación en los ojos de un mestizo, que compone una crónica para los opresores, en la cual al mismo tiempo que describe con mucha crudeza la opresión de su pueblo se identifica con el sector dominante, en tanto procede de una élite indígena aculturada; esta contradicción y heterogeneidad, esta posibilidad de reunión inestable de lo opuesto, lleva a que Cusicanqui considere que la idea de Mundo al Revés «tiene múltiples resonancias en las culturas populares de varias partes del mundo» (Cusicanqui, 2015, p. 85). Pero a la vez que descriptivo, debemos entender que la idea de inversión de lo popular presenta un cariz antes propositivo y presentacional.

Como señala Néstor García Canclini «Lo popular es en esta historia lo excluido» (1992, p. 191), y justamente el sentido popular de la reversión, en términos de memoria y también de historia, es hacer frente a esa exclusión para trastocarla y poder así hacer ingresar en la historia a las manifestaciones de las culturas populares. Esto también debe leerse como inversión y así lo ensayaremos en tanto inversión historiográfica, producto de la lectura del mundo al revés que propone, frente a la cultura afirmativa, el mundo popular subalterno. Para Cusicanqui es el mundo al revés del colonialismo el que a su vez debe ser revertido: «el mundo al revés se revolverá, nacerán los reversos de la historia» (2015, p. 225). Una lectura que nos lleva nuevamente a considerar la idea de pasar el peine a contrapelo de la historia, como imaginaba Walter Benjamin. La inversión, entonces, debe leerse en términos estéticos, como un lenguaje específico, el de la plaza pública y la risa teorizado por Bajtín (2005); pero también en clave política y transcultural, ya que en todo el mundo «las masas populares luchan por entrar en la historia, para invertir el orden que las mantiene subalternas» (De Martino, 2008, p. 86).

La homología de lo subalterno con lo mestizo y transcultural, nos lleva además a incorporar la idea de culturas bastardas de Omar Rincón (2015), cuya síntesis, que se nutre de teorías de lo popular muy diversas, puede orientarnos en el vínculo entre lo popular y lo mestizo, despejando así la necesidad de recurrir a consideraciones homogeneizantes y unitarias sobre lo popular. De hecho en la propuesta de Rincón (2015, pp. 29-32) se nos invita a considerar incluso dentro de la heterología de lo popular aquellas definiciones o miradas provenientes de la cultura afirmativa, como el popular auténtico y el popular

32 Esto es por ejemplo la hipótesis de Christopher Small (1998) sobre la universalidad de las músicas afroamericanas, actualmente de mayor alcance mundial que la música occidental culta, erigida por la historiografía afirmativa como universal. 
artístico del folklore, que deriva en la hiperbolización del volk en un "porno-popular"; el popular tecnológico, que nosotros podemos identificar con los PMS, que es también el popular mainstream; junto al "popular político" que está presente en las construcciones del pueblo revolucionario, así como también el "popular subalterno", como dominado y excluido y el popular apoyado en las nuevas sensibilidades colectivas que no se basan en la síntesis de lo occidental, lo blanco universalizado y lo patriarcal

Las culturas populares son bastardas porque en nuestro tiempo sabemos quién es nuestra madre cultural pero no quiénes son nuestros padres [...] Hablamos de culturas bastardas cuando se reconoce que no hay purezas, ni esencias: ¡Qué más popular que lo bastardo! (Rincón, 2015, p. 34).

Es imposible no escuchar cómo resuenan aquí las palabras de Bolívar en el discurso de Angostura de 1819:

Tengamos presente que nuestro pueblo no es el europeo... que más bien es un compuesto de África y América que una emanación de Europa; pues que hasta España misma deja de ser europea por su sangre africana, por sus instituciones y por su carácter. [...] Nacidos todos del seno de una misma madre, nuestros padres difieren en origen y en sangre [...] Nosotros somos un pequeño género humano, poseemos un mundo aparte

Justamente lo criollo, lo emergente del conflicto, es aquello a identificar con lo popular que incluye pero no se reduce sólo a las culturas indígenas o las campesinas, puesto que se expresa "desde la trama espesa de los mestizajes y las transformaciones de lo urbano» (Martín-Barbero, 2008, p. 54). En palabras que surgen del habla popular, como quilombo o sancocho (Quintero Rivera, 2005), este popular bastardizado reúne las ideas de autenticidad, resistencias, sumisiones, complicidades, innovaciones y aberraciones (Rincón, 2015 , p. 33). Sin embargo, ya que la perspectiva afirmativa es unidimensional, responde a una lógica dualista que no resiste la contradicción ni la convivencia -lo cual expresa de forma contundente y gráfica su expansión colonial-; los sentidos que se neutralizan en la noción de mundo popular subalterno, que es bastardo, son la apelación a la autenticidad y lo puro, lo rural y lo bucólico, dominios mistificados reservados al pueblo por la cultura afirmativa y que no hacen más que reflejar del modo más crudo "las necesidades, los intereses y la completa limitación humanista de la clase dominante: la burguesía" (De Martino, 2008, p. 77)

En cambio, desde una teoría gozosa de lo popular (Quintero Rivera, 2009) podemos entender que la música popular se relaciona con lo inauténtico, lo trucho, lo corporal y sobre todo lo que hace al "cuerpo bajo"; además se despliega en el espacio público invadiendo todo con su aquelarre festivo en el que pulula el ruido entre carrozas y desfiles de mojiganga. Por eso se opone a lo virtuoso, lo puro, lo culto y lo privado (Rincón, 2015, p. 40) y se expresa en forma vivencial, presentacional, performativa; desaparece la obra y lo que emerge es la corporalidad de los sujetos populares. De ahí que estudiemos más a los performers, en cuyo cuerpo se inscribe la música popular. Éstos son el objeto de investigación, desplazando al objeto/obra en que la modernidad cosifica el musicar. Lo gozoso no implica banalización; por el contrario, puede reenviarnos al intrínseco sentido social -o socializante- de la música popular que establecimos en torno a la categoría del musicar, y reforzar así su sentido político, ya que disfrutamos de la música siguiendo juntos el ritmo, entonando juntos el estribillo, haciendo palmas o, desde luego, bailando juntos. Quintero Rivera incluye a la música popular dentro de lo que llama «movimientos sociales para el disfrute de la vida», los que tienen vínculo específico con el pueblo.

Se trata de un fenómeno que he denominado provisoriamente como movimientos sociales para el disfrute de la vida, refiriéndome a la acción social dirigida a incidir en la forma y carácter que toma o asume el disfrute de la comunalidad, el goce del intercambio social, de la 
relación social misma. Este fenómeno tiene, a mi juicio, un profundo significado político pues atenta contra uno de los pilares de la cosmovisión burguesa contemporánea, de la ideología dominante en la gran mayoría de nuestros países: el hedonismo o la identificación del goce con los sentidos, a nivel individual del organismo receptor (del cuerpo de cada persona) (Quintero Rivera, 1994, p. 1)

La articulación gozosa de las músicas populares, especialmente cuando se despliegan en la ocasión social de la fiesta pública, posibilita la existencia simbólica del pueblo, de las clases populares que configuran ese colectivo heteróclito, mestizo y bastardizado. Este es el pueblo del que vamos a intentar reconstruir algún derrotero histórico sobre su música, una larga duración que implica antes que nada reconocer «el derecho a significar desde la periferia» (Bhabha, 2013, p. 19).

El sentido litigante y contencioso de la música popular, por su carácter bastardo y mestizo, antes que por una actitud "combativa" que suele encontrarse más cerca de la burguesía que del pueblo, nos acerca a una última cualidad o propiedad de lo popular: al depender su existencia misma del cotejo con la cultura dominante, no puede representarse más que como un escenario, una suerte de tablado de disputas simbólicas. Es decir que la música popular, como parte de la cultura popular, no es un repertorio exclusivo y excluyente de prácticas sonoras cuya identidad depende de que podamos aislarla de otros repertorios y grupos sociales. Este es el equívoco de la otra autonomía musical, la del folklore -y en parte todavía de la etnomúsica- que cree que lo popular habita en lo profundo del monte o en lo insondable de la montaña; manifestación de esos gauchos de la selva de Ricardo Rojas. Justamente, la lectura que vamos a proponer en este trabajo parte de una noción inversa: la cultura popular -y como parte de ella la música popular- no pueden explicarse por fuera de la relación permanente con la música culta y la cultura oficial o dominante; relación que parte de la tensión, del litigio, pero que también acepta el diálogo, la negociación y las apropiaciones en ambos sentidos. Esto es lo que Jesús Martín-Barbero rescata de los aportes de Carlo Ginzburg, en tanto que lo específico popular

emerge del conflicto, mezcla de choque y diálogo, entre lo oral y lo escrito, de la confrontación cultural que lo que lee produce en su tradición oral; y a la vez de la circularidad cultural que convierte su lectura en portadora de las palabras que le permitieron expresar lo que bullía en sus adentros (Martín-Barbero, 2002, p. 51)

Pensar lo popular como campo de disputa y escenario de una circulación conflictiva de prácticas culturales de los diferentes espacios sociales de producción musical, introduce la principal categoría del mestizaje y lo bastardo, como es el conflicto intrínseco a la heterogeneidad. Consideramos que es aquí, y no en una carencia -de racionalidad, de pensamiento estético, de pericia de cualquier tipo- donde reside esa inarticulación de lo popular observada por Gramsci. Es decir, en el rechazo a la constitución de una cultura homogénea, que es un valor únicamente para la burguesía moderna. Evidentemente así podemos pensar que lo popular es lo opuesto a lo afirmativo, pero no en cuanto a un repertorio o lista de contenidos y procedimientos estrictamente diferenciado, o a un enfrentamiento abierto de tipo combativo; lo popular se opone a lo afirmativo porque exhibe los conflictos y contradicciones en lugar de atenuarlos y silenciarlos, y porque rechaza la visión conciliatoria a partir, precisamente, de hacer proliferar lo discontinuo, lo heterogéneo, lo superpuesto, el sancocho, lo cimarrón o el quilombo. De ahí la potencia de lo popularmestizo. Y se apoya para ello en «la oposición clave: el pueblo/no del pueblo [...] entre lo que pertenece al dominio central de la cultura de élite o dominante y la cultura de la "periferia"» (Hall, 1984, p. 7). Lo popular, si se quiere, es entonces lo que no forma parte de la élite (Burke, 2014, p. 30), pero que no posee tampoco una existencia autónoma frente a ésta, lo cual consideramos una imposibilidad histórica. Por eso aclaramos que no queremos con esto modificar simplemente los parámetros de la división artificial entre folklore y música 
popular. Consideramos que toda música popular es posible únicamente en este marco de conflicto y retroalimentación simbólica que es la cultura popular. Si no existe el pueblo por fuera del cotejo con los sectores dominantes, mucho menos podemos pensar la existencia de cualquier tipo de manifestación musical en el aislamiento social e histórico.

Por lo tanto estas tensiones y oposiciones serán para nosotros el principio estructurador de la música popular y por ello nuestro estudio, antes que considerar la descripción de una serie de rasgos o cualidades pretendidamente "únicas" de lo popular, buscará los conflictos, las manifestaciones del litigio que la música popular, en su materialidad sonora, en sus discrepancias participatorias, ofrece como acto gozoso/contencioso de desafío a la cultura dominante, en el espacio de disputa por el sentido musical que es, en definitiva, la cultura popular.

\subsection{Sobre la Metodología}

\subsubsection{Diseño de un objeto de estudio que reside en los sujetos de la performance y el sonido}

Dado que en los objetivos propuestos se pretende atribuir una condición particular a ciertas prácticas musicales al mismo tiempo que se indaga sobre las causas por las que algunas frecuencias temáticas han permanecido sistemáticamente ausentes de la historiografía musical, esta investigación presenta en sus hipótesis una articulación entre diferentes tipologías de predicaciones. Pero además, como tanto en un caso como en el otro los rasgos no son evidentes ni necesariamente explícitos, para producir tales objetivos, así como para extraer de los mismos un resultado significativo, fue necesario establecer un sentido específico a los rasgos o atributos que pudieron obtenerse como resultado de la construcción de datos a partir de las fuentes.

Por un lado, se buscó la identificación de rasgos sonoros, sociales y culturales en músicas pretéritas, que permitan clasificarlas como música popular. En este sentido, la recolección de datos a partir de las prácticas musicales y sus posibles sentidos culturales permitió establecer una taxonomía sobre la música popular en la historia, extendiendo la actual e incidiendo además en la clasificación general que las diferentes subdisciplinas de la musicología han hecho de las músicas. Esto requirió, en primer término, de una fase descriptiva, ya que la hipótesis es que lo popular habita la propia materialidad sonora de la música y no es meramente una significación operada "desde fuera" del musicar. En función de la concepción litigante y contenciosa de la música popular que funciona como punto de partida, buscamos antes que nada aquellos atributos que se ubican específicamente como rasgos de tensión o subversión de la cultura musical dominante, particularmente en su carácter performativo o presentacional, y en la condición de los sujetos actuantes en tanto contenido de la manifestación. En un primer nivel buscamos lo más explícito, es decir, aquellas sonoridades que establecen su poética y se demoran en lo que es censurable para la cultura dominante; si ésta ha construido su estética musical a partir de depurar ciertas formas de producción musical, segregando sonoridades concretas, encontrar que es en éstas que la música popular se organiza activamente fue muy revelador. Para poder dar cuenta de estos fenómenos en el análisis, aquí adquirieron toda su potencia los conceptos ya mencionados en la fundamentación como el de musicar (Small, 2010), discrepancias participatorias (Keil, 2001), la performance (Frith, 2014) el concepto de sonido (Quintero Rivera, 2009) y la relación entre textura-ritmo vs. armonía y melodía (Reynolds, 2010). Como segundo nivel, realizamos un cotejo entre las categorías conceptuales y los 
descriptores que para la cultura popular en general produjeron las ciencias sociales, con la intención, en nuestro caso, de convertir estos indicadores en herramientas de análisis musical. Entre estos podemos mencionar algunos útiles analíticos como la integralidad (Escobar, 1991), la trascendencia social (Frith, 2014), la ritualidad vinculada con la performance y el musicar (Colombres, 2004), la carnivalización como procedimiento (Bajtín, 2005), las identificaciones (Bernand, 2014), lo ch'ixi (Cusicanqui, 2015), entre otros. También buscamos extrapolar en la medida de lo posible los indicadores que los PMS utilizan para las músicas posteriores al inicio del siglo $\mathrm{XX}$ (fundamentalmente a partir de la obra de Frith (2014) y Middleton(1990)), con el fin de establecer comparaciones que permitan argumentar una continuidad histórica entre estas prácticas musicales y las que son objeto de la presente investigación. En síntesis, aplicamos una versión sistematizada ad-hoc de los estudios culturales, la historiografía social y los estudios de música popular, a objetos y repertorios no explorados por estas disciplinas, lo cual implicó una necesaria reconfiguración y adecuación de sus términos y herramientas.

Esta aplicación no buscó ser exhaustiva, pues consideraremos cumplidos los objetivos que nos propusimos en este nivel en la medida en que pudimos detectar de modo muy preliminar la mera existencia de músicas populares en la historia. Es decir, en la medida en que encontramos en nuestra pesquisa suficientes evidencias que permitieron hablar de música popular en momentos históricos anteriores a la aparición de los medios técnicos de grabación del sonido, consideramos cumplidos nuestros objetivos. Por supuesto, para lograrlo fue necesario configurar una caja de herramientas analítica y descriptiva como indicamos antes, pero queremos aclarar que consideramos que será tarea de trabajos futuros el indagar en profundidad acerca de los repertorios y modos de producción que potencialmente podamos encontrar, así como establecer cronologías precisas, periodizaciones específicas y relaciones históricas diacrónicas que puedan configurar una historia popular de la música, tareas que exceden ampliamente este trabajo.

En lo que hace al otro gran objetivo de la investigación, es decir, la indagación y teorización sobre los motivos por los cuales las músicas populares anteriores al siglo XX y la invención del fonógrafo han sido ignoradas por la historiografía musical, nos abocamos a establecer una explicación de los mismos a partir de una lectura crítica de las metodologías, los contenidos ideológicos y las premisas estéticas de la musicología histórica y el folklore. A tal fin, fue necesaria primero una sistematización de ciertas regularidades metodológicas y frecuencias temáticas. Esta necesidad se fundamenta en que el estado del arte sobre estos temas registra una muy baja producción de textos referidos específicamente a la historiografía de la música (Pérez González, 2010; Bermúdez, 1982). De la relación de determinación multicausal entre las variables que implementamos sobre los textos a estudiar, se buscó extraer una primera significación interpretativa, no sólo epistemológica sino también y fundamentalmente ideológica, que hizo posible acceder al sentido de tales razones, y poder así comprender su longevidad y resistencia al cambio.

A su vez, y como tercer momento, buscamos establecer relaciones de determinación entre la mera existencia y los atributos sonoros materiales de las músicas populares históricas y las razones ideológicas que motivaron su segregación de los estudios musicales. De esta manera confluyeron, funcionando en diferentes niveles de análisis, todas las variables que construimos como útiles de estudio, es decir, tanto las referidas a una primera unidad de análisis -que son las músicas populares históricas en sí mismas-, como las que aplicamos sobre los textos de historiografía musical y folklore que representan la segunda unidad.

De todo esto se desprende que la naturaleza última de esta investigación se encuentra en la posibilidad de interpretar de forma crítica rasgos a la vez musicales y musicológicos, con el fin de obtener nuevas significaciones que aporten a una reconfiguración de la 
historiografía musical -en sentido amplio- en cuanto a sus objetivos, sus métodos y sus significados culturales y sociales. Por esto consideramos parte de nuestro cometido el haberle pasado "a la historia el cepillo a contrapelo" y para lograrlo habernos servido "de hasta el último de los recursos» (Benjamin, 2008, p. 93). Por lo tanto, en sentido general, esta investigación responde en última instancia a un diseño interpretativo, en el sentido de extraer "un significado o nuevo sentido» a través de "producir un nuevo texto cuyo sentido surja de un marco referencial vinculado a los modelos o teorías que orientan la investigación» (Ynoub, 2015, 161)

\subsubsection{Unidades de análisis y fuentes de datos}

Hemos llamado a la primera unidad de análisis Músicas de Latinoamérica y Europa originadas con anterioridad a la aparición de la grabación, la cual fue descompuesta en dos subunidades en función de hacer un corte histórico a partir de la irrupción del orden capitalista y burgués en la modernidad temprana. Es decir que, por un lado, tomamos en cuenta para el análisis las prácticas musicales que podemos denominar músicas premodernas u occidentales iniciales: entre ellas figuran canciones, danzas, gestas y música instrumental en la práctica de juglares, goliardos, trovadores, troveros, ministriles, skop, mimos; que a su vez ocurren en la ocasión del carnaval y otras celebraciones rituales de fiesta popular, incluidas las peregrinaciones. Se consideraron en la muestra aquellas de las que existan mayor cantidad de registros históricos provenientes de diferentes tipos de fuentes, y también de las que existan mayor cantidad de versiones grabadas por distintos intérpretes musicales reconocidos y que ofrecen algún criterio histórico para organizar su versión.

Por otro lado, las músicas de la modernidad temprana que también, a partir del vuelco cultural sin precedentes que ocasionó la conquista y colonización de América, podemos llamar más específicamente occidentales modernas y transmodernas: música de circunstancia, danzas y canciones de músicos agremiados, profesionales, urbanos, municipales en Europa y América Latina, que responden a denominaciones tales como: Ministriles, Ayllu, Waits, Pifferi, StadtPfeifer, Cofradías; que a su vez ocurren en ocasiones denominadas fiesta, areito, taki, mitote, etc. En el caso particular de las músicas para las ocasiones festivas latinoamericanas durante los siglos XVI a XVIII, se incluyeron las que contienen elementos indígenas, mestizos y afrodescendientes. Para la muestra se tuvo en cuenta, como primer aspecto, la disponibilidad de casos, debido a que estas prácticas presentan una intensidad de registro formal muy baja, por lo cual se apeló a un conjunto muy diverso de fuentes. También se seleccionaron, entre los registros disponibles, aquellos que resultaron paradigmáticos en la bibliografía especializada sobre el tema. Como en el caso anterior, se tuvieron en cuenta las grabaciones de solistas y grupos musicales considerados referentes en estos repertorios según la bibliografía y la prensa especializadas.

Precisamente en torno a las fuentes de datos para el estudio de toda esta unidad de análisis, es decir, en vistas a nuestro primer grupo de objetivos -la posibilidad histórica de la música popular- acudimos a una combinación muy ecléctica -o bastardizada, para ser coherentes- entre fuentes convencionales y alternativas. Por un lado, relevamos la presencia en partituras, tablaturas, letras y otros registros escritos (completos o parciales) de músicas populares del pasado, en Europa y Latinoamérica. Esto sin embargo, como descubrimos rápidamente -y era de presumir-, demostró poco provecho, a excepción de establecer y confirmar el carácter conflictivo de las relaciones de apropiación entre la música culta y la música popular y, fundamentalmente, la compresión conceptual operada por la musicología y aún más por el folklore a partir de la pautación de las prácticas populares y su consecuente encierro en las categorías analíticas del paradigma objetual/ personalista. En cambio, entre las fuentes que nos aportaron mayor información aparecen las que suelen considerarse como "alternativas", tales como la iconografía e imágenes 
descriptivas de las prácticas musicales populares; crónicas y descripciones escritas; descripciones de objetos arqueológicos como instrumentos musicales y otros objetos relativos a la práctica musical; datos notariales, estadísticos, contables, judiciales y administrativos sobre los músicos y las prácticas musicales, entre otras.

Pero aquí aparece un aspecto que queremos subrayar y que es parte del proceso de investigación que modificó nuestro modo de abordaje, especialmente el analítico: a lo largo del trabajo, y en la intención de generar indicadores y variables que fueran específicas para la música popular -es decir que evitaran la compresión analítica-, tuvimos que poner a prueba nuestros prejuicios metodológicos y comenzar a considerar como fuente de información primaria a las grabaciones. Como creemos que se hará evidente durante la lectura de los análisis y descripciones de las músicas populares en este trabajo, la necesidad de poner en primer plano las consideraciones sobre la localización del hecho musical en el cuerpo y en los sujetos actuantes, las condiciones de mestizaje y nomadismo sonoros, la circulación conflictiva entre espacios sociales, la integralidad de las ocasiones musicales, en síntesis, la omnipresencia de la performance $\mathrm{y}$, fundamentalmente, de la materialidad sonora en la música popular -que habita en lo que el paradigma moderno considera accidental, mero color ornamental y no estructura- nos llevó a adoptar una metodología y un formato de presentación que, aunque ahora nos resulta cuasi natural, es nada frecuente en la historiografía musical. Nos referimos a la necesidad de introducir menciones a grabaciones concretas de las músicas estudiadas y a vincular el análisis a las versiones, sus diferencias y continuidades y a la materialidad emergente de la escucha. Para el lector se hace imprescindible escuchar estos casos, pues de otro modo el contenido del texto se vuelve abstracto. Además, salvo alguna excepción en el último capítulo, hemos considerado contraproducente incluir transcripciones en partitura de las músicas analizadas, por las razones antes expuestas. Porque, como hemos mencionado, advertimos un carácter ideológico en la notación musical, un carácter afirmativo, particularmente refractario a la música popular. Sin embargo, la enorme mayoría de los textos sobre música -incluidos los de música popular- no incluye referencias directas a material audicionable, y es más sorprendente aún que los libros que comienzan a incorporar este recurso, de muy fácil acceso actualmente, son manuales de musicología histórica, como el legendario de Donald Grout en sus nuevas ediciones. Esto también nos dice algo de las perspectivas y metodologías de los PMS, que todavía discuten cuestiones relativas a la textualidad de la música popular o de las formas de operar la transcripción sin ejercer una violencia analítica. Para nosotros, esta violencia es intrínseca a los útiles de investigación, a la partitura y la consideración -semiótica y posmoderna- de la música en tanto texto. En cambio, si partimos de una idea de musicar, o de ocasión musical (Herndon y McLeod, 1979), que son también términos metodológicos y no solo teóricos, nociones como texto y contexto pierden todo sentido, del mismo modo que sujeto y objeto se vuelven ambiguos, ya que es en la corporeidad de los sujetos actuantes donde se encuentra el musicar, que es performativo y presentacional. De esta forma el carácter efímero de la música, su condición temporal irrecuperable, se transforma en un aspecto positivo y no en un impedimento para su consideración histórica.

Desde luego fue necesario configurar una matriz para poder comparar las versiones utilizadas para el análisis. Pero insistimos en que, si como se verá, encontramos relevantes variables como la proporción de ruidos no tónicos en la práctica instrumental, en los desfasajes producidos adrede con fines expresivos, en la búsqueda de una estética de la heterogeneidad sonora, todo tipo de reducción de lo sónico a cualquier idea de texto sólo nos conduciría a resultados negativos o sesgados. En cuanto a las fuentes que constituyeron estas grabaciones, seleccionamos entre aquéllas producidas por intérpretes (solistas y/o conjuntos) históricamente informados, aun cuando sus visiones son contrastantes entre sí y con la musicología, pero que son tenidos en cuenta como 
autoridades en los repertorios estudiados, de acuerdo a la opinión de la crítica, los expertos y/o la bibliografía especializada. Incluso los folletos, notas e información escrita que acompañan las ediciones de las grabaciones de estos intérpretes funcionaron también como fuentes de información, revelando verdaderos procesos de investigación que existen detrás de cada interpretación y producción fonográfica.

Como el lector podrá apreciar, en todos los capítulos aparecen vínculos interactivos a vídeos o audios de las músicas estudiadas, los cuales figuran a pie de página como llamada en la mención a la música o la versión correspondiente cuando aparece en el texto por primera vez. La escucha de estos materiales es, en nuestra opinión, indispensable para comprender toda la argumentación que intentamos construir en este trabajo, motivo por el cual instamos al lector a no relegar la escucha, puesto que tal vez una de las conclusiones más claras que tenemos luego de terminar esta tarea es la de que todo estudio teórico o conceptual sobre la música debe volver a la materialidad del sonido como fuente y no reemplazarla bajo ningún pretexto con otro tipo de modelizaciones o dispositivos, llámense cifrados, nomenclaturas, esquemas estructurales, o partituras, las cuales, en todo caso, de ser necesarias, deben proceder luego de encontrarse con el sonido como primer material de estudio.

La segunda unidad de análisis sí la conforman textos, pues en este caso se trata de lo producido por la musicología histórica y el folklore en tanto disciplina teórica. Es decir que se trata de libros y artículos científicos correspondientes a estudios consagrados por los círculos académicos y la circulación en el mercado editorial a nivel global y local, lo cual ha permitido a sus autores ser considerados referentes en el campo de la historiografía musical. Pensemos en que algunos de ellos produjeron textos utilizados por generaciones de docentes y estudiantes de música de todas las latitudes; otros han prestado su nombre a cátedras o institutos de investigación musical, algunos de alcance nacional y de órbita estatal; otros han producido discursos ante asambleas internacionales y multilaterales y sus escritos se archivan en las bibliotecas de los congresos nacionales de varios países del mundo.

Dentro de estos textos distinguimos dos subunidades, que corresponden grosso modo con las disciplinas a escrutar. Es decir que por un lado abordamos lo musicológico histórico, presente en los libros de texto de historia de la música y artículos sobre la totalidad de la historia musical o algún período en particular, dentro de la tradición de la musicología histórica, desde el siglo XIX hasta finales del XX, de Europa, EEUU y Latinoamérica. Por otro lado los libros y artículos folklóricos (científicos y/o de divulgación) producidos por representantes reconocidos del Folklore como disciplina teórica, desde aproximadamente 1840 hasta 1970, en Europa y Latinoamérica.

Para toda esta segunda unidad de análisis, hacia la cual se orientó una búsqueda en términos de consideración crítica de la historiografía musical afirmativa y su segregación histórica de la música popular que desarrollamos fundamentalmente en los capítulos uno, tres y cuatro, acudimos a fuentes naturalmente más convencionales, fundamentalmente bibliográficas: textos de musicología histórica (manuales de "historia de la música", libros y artículos abordando un recorrido histórico extensivo o un momento o período en particular) y textos de folklore musical (libros y artículos abordando conceptualizaciones del folklore en general o algunos repertorios en particular). En ambos casos se tuvieron en cuenta aquellos textos de mayor circulación en el mercado, presencia en las bibliotecas y mayor frecuencia de utilización en programas universitarios de estudios específicos, especialmente en el medio académico de nuestro país y la región. Especialmente trabajamos con autores y textos reconocidos como fundantes de ambas disciplinas y que directa o indirectamente estudiaron -u omitieron estudiar- los repertorios a trabajar en la investigación. De tal suerte que podríamos pensar en que a lo largo de nuestro trabajo existe una suerte de diálogo 
crítico y contencioso -desde una posición de periferia- con figuras emblemáticas de la historiografía musical, especialmente Paul Henry Lang, Carl Dahlhaus, Carlos Vega, Robert Stevenson y, de forma más solapada pero no por ello menos presente, Theodor Adorno.

En todos los casos, los indicadores más importantes que tuvimos en cuenta se relacionaron con la presencia de una voluntad afirmativa, que pudimos detectar mediante una asunción explícita en títulos, prólogos, presentaciones y/o índices, o hemos derivado del contenido abordado en los textos y/o de afirmaciones valorativas contenidas en ellos. Del mismo modo, las ideologías estéticas y valorativas presentes también de forma explícita o implícita, dejaron entrever la aparición del etnocentrismo, el dominocentrismo o el exotismo, entre otros sesgos que pudimos relacionar con los criterios de periodización histórica, las explicaciones causales y fundamentalmente los criterios de inclusión y exclusión de las músicas del cuerpo de la narración histórica. El tipo de fuentes utilizadas y los atributos del lenguaje musicales priorizados en el análisis también fueron de provecho, permitiendo encontrar verdaderas convergencias entre líneas de investigación aparentemente inconexas. Finalmente relevamos la pertenencia institucional y las conexiones a nivel académico y editorial de algunos de los autores, información relevante y valiosa a los fines de generar una periodización posible de tendencias historiográficas dentro de las disciplinas afirmativas.

Por estos motivos en algunos casos, para completar la descripción conceptual o refutar algunos de los presupuestos encontrados en los textos historiográficos, acudimos a las partituras -y sus respectivas grabaciones- de las músicas paradigmáticas presentes en los textos de musicología histórica y del folklore. 


\section{Primera parte: La música no es popular}

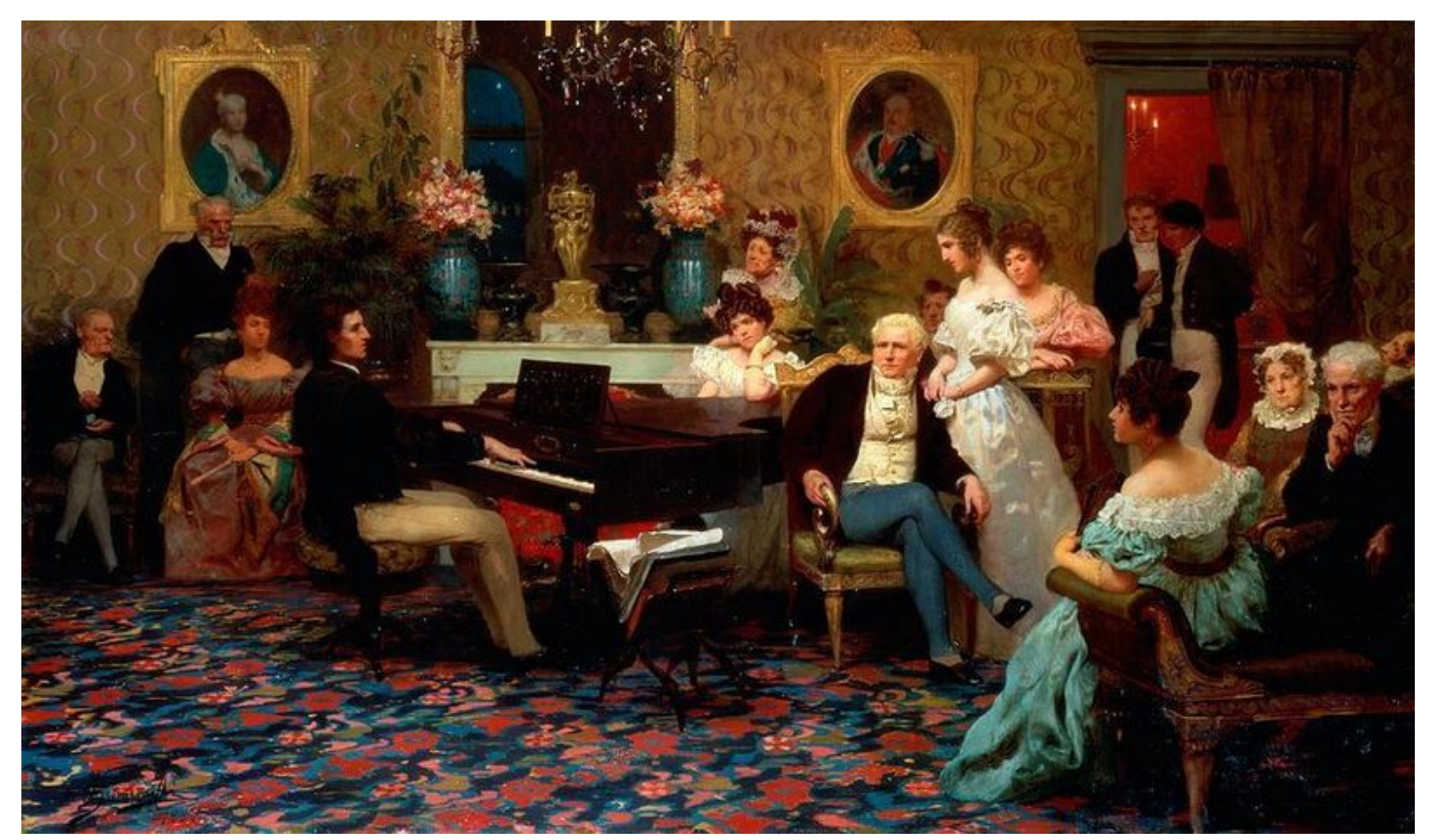

Chopin tocando el piano en el salón del Príncipe Radziwill. Óleo de Henryk Siemiradzki, 1887. 


\title{
Capítulo 1 \\ Del desinterés acerca de los primitivos, sus vidas y sus músicas
}

\begin{abstract}
"La historia de la música se divide en dos grandes secciones de las cuales la primera trata de la variedad de pueblos que se encuentran por fuera del círculo actual de naciones civilizadas, y cuya actividad musical no ha afectado a estas últimas, mientras que la segunda sección abarca los grandes pueblos históricos desde los clásicos hasta el presente. La primera sección es mucho menos importante, y puede ser tratada sólo de manera descriptiva y sumaria. La segunda presenta una clara continuidad y un desarrollo orgánico» Waldo Selden Pratt (1905)
\end{abstract}

«La historia musical de la obra [...] se apoya en el concepto moderno de arte»

Carl Dahlhaus (1997)

«El historiador, antes de ponerse a escribir historia, es producto de la historia»

Edward Carr (2006)

Como punto de partida nos propondremos un recorrido que atraviese las principales categorías de la musicología histórica, la primera y más consolidada de las disciplinas que configuran la historiografía musical afirmativa. Nuestra hipótesis central aquí es que, si bien por un lado es explícito el rechazo hacia la música popular por parte de este campo de estudio, es en sus propias categorías que hay que buscar el cifrado que sella la imposibilidad de que las músicas subalternas ingresen en la historia. Aunque tal vez habría que pensarlo a la inversa: para que las músicas populares queden excluidas de la historia y no rivalicen con el repertorio culto en términos de "gran tradición", la musicología histórica desarrollará una serie de útiles conceptuales que, sin expresarlo explícitamente, establezcan las coordenadas históricas y encumbren al canon culto como única posibilidad de pasado musical. En esta operación descansa tal vez el núcleo principal de la afirmatividad historiográfico musical: se ocultan las relaciones de producción de la diferencia musical naturalizando las categorías y conceptos de una parte del universo sonoro, para luego comparar con ellas los diferentes repertorios. El resultado no puede ser otro que el establecimiento de la tradición culta y escrita como fuente de todo posible desarrollo musical.

La literatura sobre historia de la música que responde a estos criterios es, desde luego, la más vasta, universal y omnipresente en bibliotecas, librerías, currículas e incluso en blogs y otros sitios de Internet ${ }^{33}$. Son libros cuyo título suele restringirse a un "historia de la música", en dónde no se aclara ni de qué música se trata ni dónde esa música está localizada. Lo mismo ocurre con las denominaciones de las asignaturas sobre el tema, tanto en el nivel secundario como en los profesorados y las carreras terciarias y universitarias sobre música. También se llaman "historia de la música" y cuando se dan algunas precisiones, como podría ser el caso de "historia de la música argentina", son cursos sucesivos o seminarios que se derivan de los que reproducen el nombre genérico.

\footnotetext{
33 Por ejemplo un sitio de internet como la Biblioteca Erik Satie, blog sobre textos de música que ofrece una gran diversidad temática, muestra en sus estadísticas que los libros de "Historia de la música" son los más buscados y entre ellos, por notable diferencia, el de Donald Grout.
} 
Nada de esto debiera ser un problema. De hecho no pretendemos aquí promover el uso de nomenclaturas excesivas, denominaciones compuestas ni eufemismos; todos ellos recursos a los que el posmodernismo pretendió acostumbrarnos para, a fin de cuentas, no modificar la sustancia de la historiografía musical. Deberíamos poder estudiar, escribir y leer sobre la historia de la música y encontrar dentro de este campo de estudio una vastísima multitud de manifestaciones, épocas, colectivos y sonoridades. Pero casi nunca esto funciona así. La música de los libros de historia de la música se restringe a la tradición culta europea occidental (Treitler, 1996), una tradición que en tanto tal es "selectiva" (Williams, 2000) e "inventada" (Hobsbawm, 2015), y por lo tanto es modelada a partir del núcleo estético de la sociedad burguesa moderna que, como ya señalamos, juega en el terreno de la estética mucho más que simples cuestiones de gusto. Por lo tanto, la musicología histórica, en su formulación más consolidada y que continúa definiendo con gran vigencia nuestros imaginarios musicales, establece una proyección histórica que organiza el devenir temporal a partir del rastreo de aquellas músicas que pueden entenderse como antecedentes de la música de la burguesía moderna, sintetizada en la estética del romanticismo musical del siglo XIX, que es el momento en que empieza a configurarse la disciplina. La historia retrocederá todo lo más que permita la existencia de algún repertorio que funcione como predecesor de estas músicas que se definen a partir de dimensiones muy concretas: la organización centrada en las alturas y sobre todo en su relación vertical (la "armonía"), que produce estructuras; la subordinación e intercambiabilidad de los sonidos concretos (los instrumentos, la forma de tocarlos, los sujetos que los tocan, etc.) a las relaciones lógicas entre esas estructuras abstractas; la definición de las músicas del repertorio en función de las cristalizaciones recurrentes de estas estructuras (las "formas"); la escritura como manifestación de la creación musical y de la identidad de la música en sí; entre algunas otras de menor jerarquía, como la mensuración proporcional y metronómica de duraciones y acentos o la equivalencia entre emocionalidad individual y configuraciones armónicas.

Por lo tanto, establecer cuándo comenzaron todas estas cosas será la tarea central de la musicología histórica, alentada por la preocupación por los orígenes de la cultura del siglo XIX (Gelbart, 2007), cuya máxima intensidad llegará con el positivismo. Todos esos comienzos se establecerán en función del repertorio burgués contemporáneo, independientemente de si esos parámetros y dimensiones habían sido o no importantes en las músicas del pasado. La metonimia y la selectividad producen la tradición histórica de la música de la burguesía, expulsando a las demás músicas de una larga duración dinámica y plausible de ser investigada y contada. $Y$ esto se transfiere al corpus de la literatura musicológica y por extensión a los ámbitos musicales académicos, incluidas las asignaturas de historia de la música.

En las bibliotecas de las universidades de arte, en las de los conservatorios, en los blogs y foros en que se comparten versiones digitales de "libros de texto" sobre música, hay un libro, uno, que recibe la preferencia de contar con mayor cantidad de ejemplares, de solicitudes de préstamo, de lecturas, de descargas; en fin, de atención. Es a su vez el texto que más aparece en las bibliografías de los programas de estudio sobre historia de la música, en todos los niveles de estudio. De hecho, muchos programas se estructuran en base al índice de este libro, verdadero best-seller de la musicología histórica. Nos referimos, por supuesto, a la Historia de la Música Occidental de Donald Jay Grout, cuya primera edición es de 1960 y que, sobreviviendo largamente al autor, ya va por la décima edición en inglés (octava en español) y el tercer autor que toma el relevo (Peter Burkholder luego de Claude Palisca). En el sitio de Alianza Editorial, responsable de la edición en español, puede leerse que "Esta "historia de la música occidental" ha sido calificada por críticos y expertos como el mejor compendio del desarrollo de la música en el mundo occidental desde las civilizaciones más antiguas hasta nuestros días». Y en el portal de W. W. Norton \& Company, editorial del original inglés, se nos dice que este libro posee la virtud de 
indicarnos «qué es lo importante, dónde encaja, por qué es importante y a quién le interesa» ${ }^{34}$. Es decir que nos interesa lo que el texto nos señala como importante y a la vez encaja en un devenir histórico, que si bien se presenta como "occidental", al incorporar las "civilizaciones más antiguas" tiene en realidad pretensiones de historia global. Es toda una confesión que no puede sino construir una jerarquía en la cual lo moderno se identifica con lo occidental. Pero hasta aquí podríamos pensar que únicamente se trata de un sesgo occidentalocéntrico que arroja a las "civilizaciones" no europeas a un pasado remoto que funcione en términos de antecedentes y preámbulos. Pero existe una segunda segregación, más intensa, pues ni siquiera se nombra lo que se elimina de este "desarrollo de la música en el mundo occidental". La exploración del índice no deja dudas de que se trata solamente de la historia de la música culta, encarnada primero por la música sacra de la institución eclesiástica, luego por la música de la aristocracia y finalmente por la de la burguesía, en un orden ternario homólogo al de las etapas del desarrollo del espíritu de Hegel. Como es una historia de la escritura de la música, el tiempo comienza a contarse con la notación y si bien es necesario un prolegómeno que garantice la transferencia de la antigüedad oriental a Europa mediatizada por la Grecia clásica, la historia comienza en la Edad Media, pues es en ese tiempo que aparece la notación musical y junto con ella, la ideología musical que paulatinamente coloca como prioridades las dimensiones que enumeramos antes. Con la notación aparece una forma de comprender la identidad de la música en base a sus alturas, sus "notas"; con la notación comienza la colección de formas musicales; con la notación comienzan las valoraciones cuantitativas en base a las escalas y las armonías; con la notación se objetualiza la música y permite que se la confunda con su soporte de registro. Sin embargo, ninguna de estas funciones estaba presente en el desarrollo tecnológico que significó la notación musical en la Edad Media. Son atributos que la musicología histórica moderna introdujo en la práctica musical medieval al contar su historia. Más adelante volveremos sobre esta operación historiográfica con algunos ejemplos.

En el prólogo a la segunda edición de sus Philosophies of Music History, Warren Dwight Allen incorpora el por entonces reciente libro de Grout y lo valora como una saludable actualización de la historiografía musical:

Actualmente la única historia general que puede con justicia llamarse trabajo académico es la Historia de la música occidental de Donald J. Grout [...] Es un texto para el que existía una gran necesidad [...] El libro de Grout [...] es la primera historia de la música escrita recientemente que se basa en la "crítica de estilo" [...] y hace la confesión de que se ocupa únicamente de la "música artística"35 (Allen, 1962, p. vii)

Es decir que, hacia 1962, el libro de Grout se constituye en una solución muy esperada: aportaba una narración total de la música occidental configurada como una historia de los estilos (Samson, 2009). Ya nos ocuparemos de este concepto y sus implicaciones para la historiografía musical, pero por el momento tengamos presente que el abordaje estilístico de la historia, formulado de forma programática y simultánea a principios del siglo XX por Guido Adler (1911) y Charles Hubert Parry (1911), se intensifica como metodología historiográfica a partir de la década de 1940 y sobre todo en la posguerra, en autores que también editan en W. W. Norton \& co., como Manfred Bukofzer ([1947]1986) o Gustave Reese ([1940-54]1988). Estos autores, sin embargo, producen historias sobre períodos específicos (el Barroco, el Renacimiento, la Edad Media), no una historia general como dice Allen. Es decir que si «Adler describe en Der Stil in der Musik a la historia de la música

\footnotetext{
34 «What's important, where it fits, why it matters, and who cares» [traducción del autor]

35 «Today, the only general history that can be called a scholarly work is Donald J. Grout's A History of Western Music [...] "This is a greatly needed text [...] Grout's book is [...] the first recent history of music based upon 'stylecriticism.' [...] and he makes the confession that he deals only with "art-music"» (Allen, 1962, p. vii) [traducción del autor]
} 
como historia de los estilos, [este] enfoque encuentra su culminación en la Historia de la música occidental de Donald J. Grout» ${ }^{36}$ (Beard \& Gloag, 2005, p. 129).

Pero el libro de Grout también puede entenderse como una síntesis a otro nivel, más en términos de relicto que dé cumplimiento metodológico. Porque por un lado es cierto que la historia de los estilos, en tanto rechaza las formas de hacer historia de la música del siglo XIX, se propone lo que el historiador del arte Heinrich Wölfflin (2007 [1915]) había denominado como "historia sin nombres", es decir, un relato que prescinde del acento en la biografía. Sin embargo, existe en la historia de los estilos una fuerte concepción organicista -que preferimos llamar "personalista"- mediante la cual subsisten no sólo las personalidades artísticas de los compositores, que son el motor de la historia, sino una personificación de los estilos en sí mismos. Grout, por ejemplo, nos hablará de un "Barroco temprano" que se desarrolla hasta llegar al "Alto Barroco" (1960, pp. 319-369), del mismo modo que el organum medieval evoluciona desde su formulación "primitiva" (p. 98) hasta convertirse en "florido" (p. 101) y permitir así "el nacimiento" del motete (p. 120). Las "fuentes del estilo clásico", uno de los estilos centrales de este tipo de historia de la música, se explican en base al nacimiento, desarrollo y crecimiento de "la sonata, la sinfonía y la ópera en el siglo XVIII" (p. 489), que son los verdaderos sujetos de la historia de Grout. Carl Dahlhaus, el gran musicólogo del siglo XX, defenderá, una década más tarde (en 1977), este tipo de configuración historiográfica en términos de "técnica narrativa", ya que es menester preservar el sujeto de la historia de la música, «el elemento que brinda coherencia, esa coherencia que permite que la historia sea narrable» (Dahlhaus, 1997, p. 57). Para este berlinés occidental las "metáforas biográficas" de la historia de los estilos eran cuanto menos tolerables siempre y cuando pudieran contener el peligro que el marxismo cernía sobre la musicología histórica: desplazar el foco del "carácter artístico" en favor de la función social de la música (Dahlhaus, 1997, p. 67).

El estilo, en sus formulaciones conceptuales iniciales -que distan de las que podemos encontrar en la época de Grout si atendemos a los temores de Dahlhaus- se propone como solución superadora de la biografía, elemento central de la musicología histórica. Pero esto no significa que la personalidad del compositor se desplace del centro de la historia. Es el modo de explicar los cambios y transformaciones -o no explicarlos en absoluto- lo que está en discusión. Por eso Grout compone su capítulo sobre "los comienzos del siglo XVIII" (1960, p. 441) en base a los siguientes apartados: "Antonio Vivaldi, Jean Philippe Rameau, Johann Sebastian Bach, Georg Friedrich Händel». Y todavía más, luego del capítulo sobre «las postrimerías del siglo XVIII» (p. 523) que pivota, como es de esperar, sobre las personalidades de Joseph Haydn y W. A. Mozart, el siguiente capítulo directamente se denomina «Ludwig Van Beethoven» (p. 561), él mismo un estilo personificado, encarnado en el cuerpo de un compositor, tan único que no pertenece ni a lo clásico ni a lo romántico. Por si quedaran dudas de la convergencia del estilo con el personalismo, Grout nos enseña que es desde la personalidad de Beethoven donde tenemos que buscar las explicaciones de su genio musical:

La música de Beethoven, más que la de cualquier otro compositor precedente, da la impresión de ser una efusión directa de su personalidad. Por ello, para entender su música, es útil conocer algo del propio hombre (Grout, 1960, p. 563).

Como sabemos, Beethoven es una figura emblemática, casi una vaca sagrada de la musicología. Pero es muy indicativo de esta articulación entre lo estilístico y lo personalista que el recurso a figuras individuales se dé también en los comienzos de la narración histórica. Tal vez esto puede considerarse un refuerzo de la estrecha necesidad recíproca

36 «In his Der Stil in der Musik (1911), Adler described the history of music as the history of style, an approach that found its culmination in Donald J.Grout's History of Western Music» (Beard \& Gloag, 2005, p. 129) [traducción del autor] 
entre notación musical, análisis de obras y categorización de estilos que la musicología exhibirá en su fase positivista, que es la que Grout consolida y ayuda a convertir en hegemónica. Por eso podemos leer que, si la música occidental se inicia como un traslado o apropiación de las músicas orientales (aún del Oriente europeo), los responsables de tal cosa pueden ser individualizados: San Ambrosio, Gregorio Magno, Carlomagno, Guido d'Arezzo, etc (Grout, 1960, pp. 30-36-58). Es interesante que, mientras se nos cuenta la historia de un momento que carecía de notación musical, se ilustra el relato con partituras antiguas, pero muy posteriores (Grout, 1960, p. 32). Así, una imagen del siglo XI se convierte en evidencia de la música del siglo $\mathrm{V}$, de tal suerte que, aunque no se nos lo dice explícitamente, la apariencia que deja el relato es que existen autores de unos objetos, las partituras, que suponen composiciones en el sentido moderno del término.

Más aún, la insistente prioridad que se da a lo que Dahlhaus llamará "carácter artístico" por sobre la "historicidad" (Dahlhaus, 1997, p. 29) puede leerse en Grout cuando en el "inicio", es decir cuando comienza el relato sobre el canto gregoriano, se nos explica la música medieval mediante la exposición de un repertorio que es del siglo XVI (o incluso del $\mathrm{XX}$ ) y no de la Edad Media. Porque no se nos explica su historia, sino su naturaleza (Grout, 1960, p.52). La excusa de Grout es que es una música «con la que mucha gente no está familiarizada» (1960, p. 51), que el Concilio Vaticano dejó obsoleta y ya nunca volverá a resurgir. Por lo tanto lo más importante es estudiar sus características estructurales, y esto es más sencillo si abandonamos la historia, larga y complicada, de su formación como repertorio, y nos abocamos directamente al análisis estilístico de la cosa terminada. Es una forma de expulsión de lo histórico de la historia que, curiosamente, es muy habitual en la musicología histórica. Y es también una forma muy clara de afirmatividad historiográfica, ya que se desprecian directamente los procesos por los cuales una música se convierte en lo que es, que son procesos de producción en los cuales habitan relaciones de poder.

Es entonces mediante el análisis estilístico, que esconde la historia y consolida de manera afirmativa a la cultura musical de la burguesía moderna, sus antecedentes y predecesores, que Grout, en su segunda edición de 1973 que revisa y amplía a la original, no nos dejará lugar a dudas acerca de "por qué es importante" la Edad Media como momento histórico, la forma en que la música eclesiástica "encaja" como fundacional, y el por qué no nos debe importar la música que queda fuera de esta narrativa musicológica:

En la medida en que hemos podido confirmarlo, el principal desarrollo musical del Medioevo fue el canto gregoriano; en comparación con él, los primeros ejemplos existentes de formas musicales profanas contemporáneas pueden calificarse casi de primitivos. Tenemos la certeza de que el canto llano se anotó y, que por ende, se conservó de una manera bastante completa, pero si tuviéramos un conocimiento igualmente completo acerca de la música profana de los siglos VI a XI, ¿la hallaríamos igualmente interesante? (Grout, [1973] 1980, p. 80).

Dwight Allen, casi sin querer, confiesa esta relación estrecha entre análisis estilístico y expulsión de la música popular de la historia, aclarando que Grout, en tanto "crítico estilístico, está únicamente interesado en el uso [de la música popular] como cantus firmus en las composiciones de Dufay, Ockeghem y Josquin. La tonada en sí 'simplemente apareció', surgió de un modo confuso» ${ }^{37}$ (Allen, 1962, p. viii). Las sucesivas ediciones del texto de Grout confirman esta imposibilidad voluntaria de afirmar un repertorio en base a una metodología historiográfica que, se sabe, expulsa la música popular. En la séptima edición, Burkholder nos aclara que si bien ha «ampliado el relato para abarcar más música de América, incluyendo el jazz y la música popular» esto no quita que se mantiene «el énfasis sobre la música culta» (Grout y otros, 2008). De hecho esta versión presenta entre sus características innovadoras las «biografías de los compositores [...] comentarios sobre

37 «the 'style-critic' is only interested in [the popular music as] its use as a cantus firmus in the compositions of Dufay, Okeghem, and Josquin. The tune itself, like Topsy, 'just grew» (Allen, 1962, p. viii) [traducción del autor]. 
la innovación en la música [...] escritos de personajes centrales de la historia» (p. 15). Además aunque los capítulos ya no reciben la denominación de los estilos, como en la edición de 1960, dentro del capítulo sobre el siglo XVII se nos cuenta sobre el paso «del Renacimiento al Barroco» (p. 343) o «las características de la música barroca» (p. 352). Y si bien el capítulo sobre Beethoven ya no se llama como antes, la nueva configuración tal vez es más explícita y afirmativa aún: el capítulo se llama Revolución y cambio y luego de una breve contextualización en torno a la revolución francesa se nos dice que «un miembro de esta generación, Ludwig van Beethoven, lideraría una revolución de importancia similar en la historia de la música» (Grout y otros, 2008, p. 643). El resto del capítulo contiene los apartados Ludwig van Beethoven, en el que se nos vuelve a dejar en claro que es la torturada personalidad del compositor y el accidente de su sordera lo que «refleja los cambios de estilo" (p. 646); y "Beethoven como punto central", sitio que deriva de que «Muchas de las composiciones de Beethoven [...] se hicieron inmediatamente populares y lo han seguido siendo desde entonces» (p. 668). Es un argumento que ya estaba cifrado en la edición original. Por eso Grout, al abordar el canto gregoriano, desliza este recurso que la historia de los estilos esgrime siempre que necesita justificar la ausencia de la música popular en su corpus: "en el Medioevo la gente no consideraba la música sacra como totalmente separada de la experiencia cotidiana. Muchas de las melodías gregorianas eran tan familiares como lo son actualmente, cualesquiera de las melodías populares» (Grout, 1960 , p. 52). Por más que Burkholder intenta dar cuenta en sus nuevas versiones de inquietudes derivadas de las críticas que a lo largo del siglo XX recibió la musicología histórica, nada perturba el paradigma historiográfico, ya que los términos nucleares permanecen intactos: el personalismo, el estilo, la objetualidad de la "obra musical".

Incluso es sorprendente encontrar afirmaciones de este tipo justamente en los textos de historia de la música de los campeones de la revuelta disciplinar:

Los primeros momentos de la historia de la música occidental estuvieron determinados por la Iglesia Cristiana a tal punto que nos es difícil comprender su real dimensión. [...] Todos los compositores pertenecían a alguna orden sacra y todos los músicos se formaban como niños de coro. Habría que hacer una excepción con los músicos populares -conocidos como ministriles y juglares- pero no sabemos casi nada sobre sus vidas y su música ${ }^{38}$ (Kerman \& Tomlinson, 2015, p. 48).

Para la musicología histórica entonces, la música popular de ayer es la música culta, porque no podemos saber casi nada de los otros músicos, los que sí son populares. 0 porque si pudiésemos, lo que encontrásemos no nos interesaría en lo más mínimo. La musicología histórica funciona en base a este mecanismo circular en donde una aparente imposibilidad metodológica sustenta el juicio estético que prefiere que esa imposibilidad exista. Al punto de que, si se confirma que no es una imposibilidad, continuamos pensando que existe.

Esquematizando, podemos decir entonces que la musicología histórica, como parte de la historiografía musical afirmativa, contiene dos intensidades: una que podríamos emparentar con el romanticismo y tal vez el nacionalismo; la segunda es claramente positivista, heredera del historicismo rankeano y de la teoría de los estilos de Adler, pero también de Wölfflin. Como si se tratara de una encarnación de la filosofía de la historia de Hegel, esta segunda sustituye, incorpora y sintetiza a la anterior. Por eso preferimos no entenderlas estrictamente como etapas, aunque una es más intensa en el siglo XIX y la otra en el XX, sobre todo durante la Guerra Fría. Esto no es casual y veremos que el estilo será una forma de contrarrestar los análisis socio-históricos que habían comenzado a aparecer en

\footnotetext{
38 "The early history of Western music was determined by the Christian church to an extent that is not easy for us to grasp today [...] All composers were in holy orders, and all musicians got their training as church choirboys. Exception must be made for popular musicians -called minstrels and jongleurs (jawn-glérs)- but we know next to nothing about their lives or their music» (Kerman \& Tomlinson, 2015, p. 48) [traducción del autor]
} 
Occidente en la década del '30, pero que luego habían recibido un fuerte espaldarazo en la musicología desarrollada dentro del bloque del Pacto de Varsovia. Por eso la historiografía musical de los estilos será también un componente central del panamericanismo musicológico que se volverá hegemónico en Latinoamérica y que tendrá consecuencias en el estudio del otro repertorio afirmativo: el folklore musical.

Debemos considerar como rarezas las frases que hemos referido, en donde los musicólogos exhiben directamente un desdén esteticista hacia la música popular. Este no es el procedimiento habitual de la historiografía afirmativa, ya que podría impugnarse por arbitrario y subjetivo. En cambio, es a través de la generación y la aplicación sistemática de los conceptos mismos que la musicología histórica, con su modelo objetual personalista, rechaza la posibilidad de integrar a la dimensión histórica las manifestaciones sonoras del mundo popular subalterno. Este es el carácter afirmativo de la musicología histórica, establecer categorías que canonizan un repertorio culto al colocarlo en una posición de ventaja frente a toda comparación, al tiempo que lo sancionan como obligatorio, universal y modélico en relación con toda otra música. Todo esto es efectivo sólo si se oculta el punto de vista, si se difuminan las relaciones de clase y de poder en torno a la producción de esta música, si se naturalizan sus atributos y se hacen necesarios sus componentes y procedimientos. El rechazo histórico a la música popular hay que buscarlo cifrado en los términos categoriales de la musicología histórica.

\subsection{Personalistas}

Existe un texto que podemos considerar la transición entre esa intensidad más romántica de la musicología y el positivismo de los estilos. Es precisamente de quien fuera también el editor de W. W. Norton, responsable de las primeras ediciones de los pioneros del positivismo. Se trata de Paul Henry Lang. Su llegada a Estados Unidos fue producto de una beca financiada por la fundación Rockefeller, institución de fuerte impronta en la diplomacia cultural tendiente a consolidar al país del norte de América como jugador central de la producción musical y musicológica ${ }^{39}$. Lang era húngaro y había estudiado en Europa con Kodaly, Bartok y Pirro. De hecho es en parte responsable de la introducción de Bartok en la academia norteamericana. También formó parte del primer profesorado en musicología de Estados Unidos e intervino en la formación de una generación de musicólogos que participarán del giro metodológico de fines de siglo XX, como Rose Subotnik o Richard Taruskin. Justamente, si la nuestra fuese una perspectiva como la de Lang, tenderíamos a pensar que en él se sintetizan las principales tendencias de la musicología histórica occidental y que, en parte, los logros y transformaciones de ésta son producto de su actividad y clarividencia. Sin embargo, preferimos considerar un marco explicativo alternativo y un poco más amplio.

El texto de Lang, La música en la Civilización Occidental, cuya primera edición es de 1941, es el directo antecesor del libro de Grout. Y comienza con una frase muy esclarecedora: «Toda civilización es una síntesis de la conquista de la vida por el hombre. El arte es el supremo símbolo de esta conquista» (Lang, 1963 [1941], p. xiii). Nada más sincero que orientar la narración historiográfica en función de celebrar, mediante la música culta, el triunfo de la conquista del mundo por parte de Europa. Y de paso, definir en la misma operación lo que significa "civilización occidental". Podemos perfectamente tomar esta relación y analizar el desarrollo histórico de la música culta occidental, especialmente la del sistema tonal, en base a lo que Christopher Small llama «el dominio de la

39 En nuestro país baste recordar la creación y financiamiento del CLAEM en el Instituto Di Tella durante la década de 1960, con el fin de generar un centro de estudios que disputase con Europa la formación de los compositores latinoamericanos. Puede consultarse King (1985) 
naturaleza». Para este autor, la cultura occidental posrenacentista está centrada en el deseo y la necesidad de dominación. Exactamente como lo piensa Lang, para Small la actitud del "hombre occidental" ante la naturaleza es de desafío, lucha y voluntad de doblegación y control. Así la naturaleza se transforma en recurso, luego en commodity, y simultáneamente en colección de muestras intercambiables. La ciencia moderna y la producción industrial se basan profundamente en estas ideas. $Y$ de manera similar, dice Small, la música "clásica" no se interesa por los sonidos en sí mismos, sino por sus relaciones abstractas, racionalizables, controlables. Los timbres, los instrumentos e incluso los instrumentistas, son intercambiables. Y quien controla esto no es otro que el compositor, epígono aquí del conquistador que disciplina la naturaleza en su provecho.

la importancia que se da al sometimiento de los materiales sonoros (aquí una metáfora del sometimiento de la propia naturaleza) por el compositor, quien considera a sus materiales como una sustancia recalcitrante que ha de ser trabajada, configurada y ordenada por el poder de la voluntad y del intelecto humanos (Small, 1989, p. 90)

Resultado de esta concepción dualista y cartesiana entre los seres humanos y la naturaleza, que según Grosfoguel (2014) es el componente fundacional de la modernidad occidental, fue naturalmente el imperialismo decimonónico, el momento en que efectivamente, según Dussel (2007), Europa toma el control del mundo. Y dentro de esa relación de dominación, el imperio británico es la mayor fuerza, la cual a su vez consagra el dominio de la naturaleza a través de colocar las manufacturas en el centro de la economía mundial. Así como las escenas de los exploradores y cazadores británicos en África o América del Sur forman parte de nuestro imaginario, fecundado por la literatura de aventuras, la otra gran postal imperial la configuran las exposiciones universales, verdaderos muestrarios de los objetos naturales procedentes de las colonias, clasificados y rotulados, dispuestos para el espectáculo público y la autoglorificación de la modernidad triunfante. 


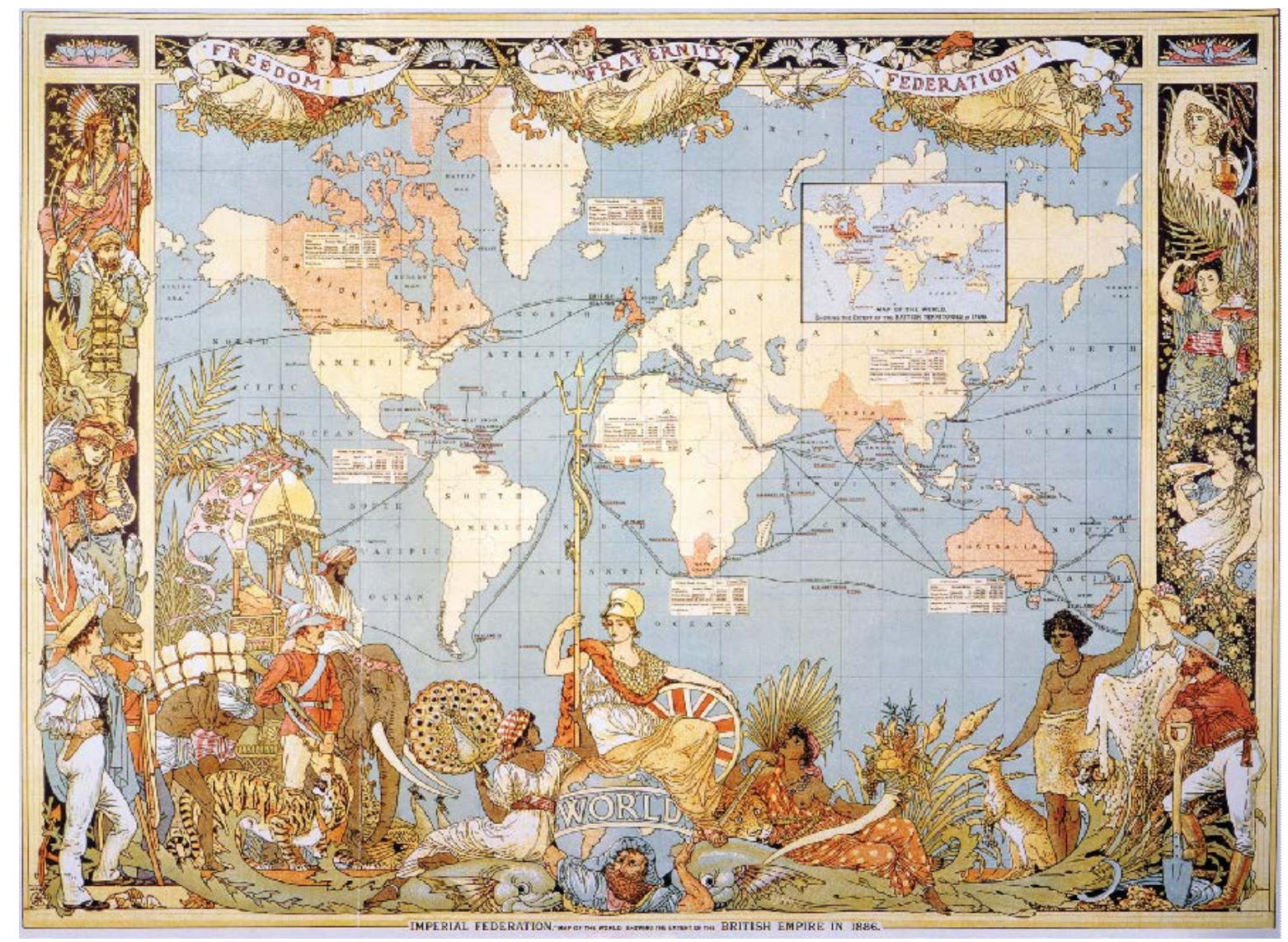

Un mapa del imperio británico en 1886, señalando en color los territorios de ultramar de Gran Bretaña y las principales rutas comerciales de transporte de materias primas. En el centro de la imagen una personificación de "Britania" descansa sobre el orbe, al cual domina con su grácil figura. Colomb (1886)

La primera de estas exposiciones, realizada en 1851, se denominó Gran Exposición de los trabajos de la Industria de todas las naciones y fue ideada por el Príncipe Alberto, el consorte de la Reina Victoria de Inglaterra, como parte de su actividad política. Es curioso que, con las ganancias de esa exhibición, el príncipe compró una serie de terrenos que hoy en día forman parte del distrito londinense de Kensington, en torno al Hyde Park. Allí, junto al Royal Albert Hall, que fue proyectado por el mismo Alberto como sala de conciertos, Victoria hizo construir a la muerte de su esposo el monumento que se conoce como Albert Memorial. Es un conjunto escultórico dominado por la figura del príncipe consorte, sentado y sosteniendo el catálogo de la exhibición, realizada en oro de 24 kilates. En torno al pabellón que alberga su figura se ubican, equidistantes, cuatro grupos de esculturas que representan los continentes dominados por el Imperio: Asia, Europa, América y África. 


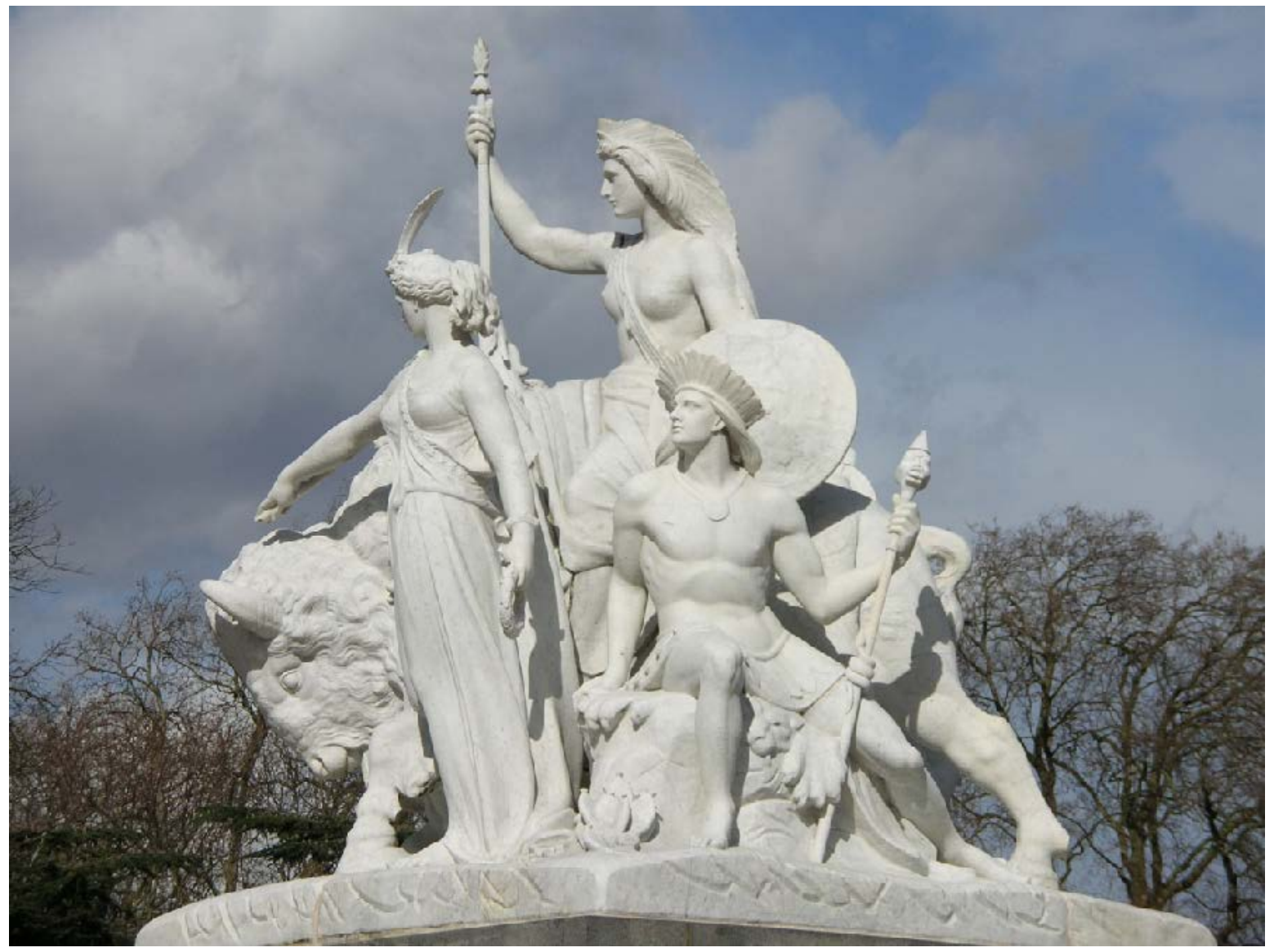

El grupo de América flanqueando la estatua central del Albert Memorial

Para asociar la memoria del príncipe con su accionar como estadista, el monumento diseñado por el arquitecto George Gilbert Scott pretendía representar también las ciencias, los oficios y las artes. De hecho hay otros cuatro grupos de figuras, más cercanas a la de Alberto, que simbolizan el comercio, la agricultura, la ingeniería y las manufacturas. Pero, aparte de la figura dorada del príncipe, la mayor gloria del monumento es el friso esculpido directamente en la piedra que rodea toda la base, formando cuatro caras habitadas por una multitud de personalidades. Se llama "Friso del Parnaso", en alusión al famoso monte de los dioses griegos. Contiene 169 figuras en tamaño natural y cada cara está compuesta por un conjunto relativo a una disciplina artística: arquitectos, pintores, escultores y finalmente, poetas y músicos. Ésta última es la cara que coincide con el frente del monumento, por lo cual son los músicos quienes primero se muestran. Al menos en pretensión, sobre todo en el caso de las figuras medievales, los músicos son todos compositores y, por supuesto, todos hombres. ${ }^{40}$

40 De hecho en todo el friso hay una sola mujer, la faraona egipcia Nictoris. Pero su inclusión se debe a que en la época de Alberto se la creía responsable del diseño de la tercera pirámide del grupo de Guiza. Por lo tanto si el memorial se construyera hoy, sería reemplazada por Micerino y el friso contaría exclusivamente 169 hombres. Lo cual sin dudas responde mejor a las concepciones de la era victoriana. 


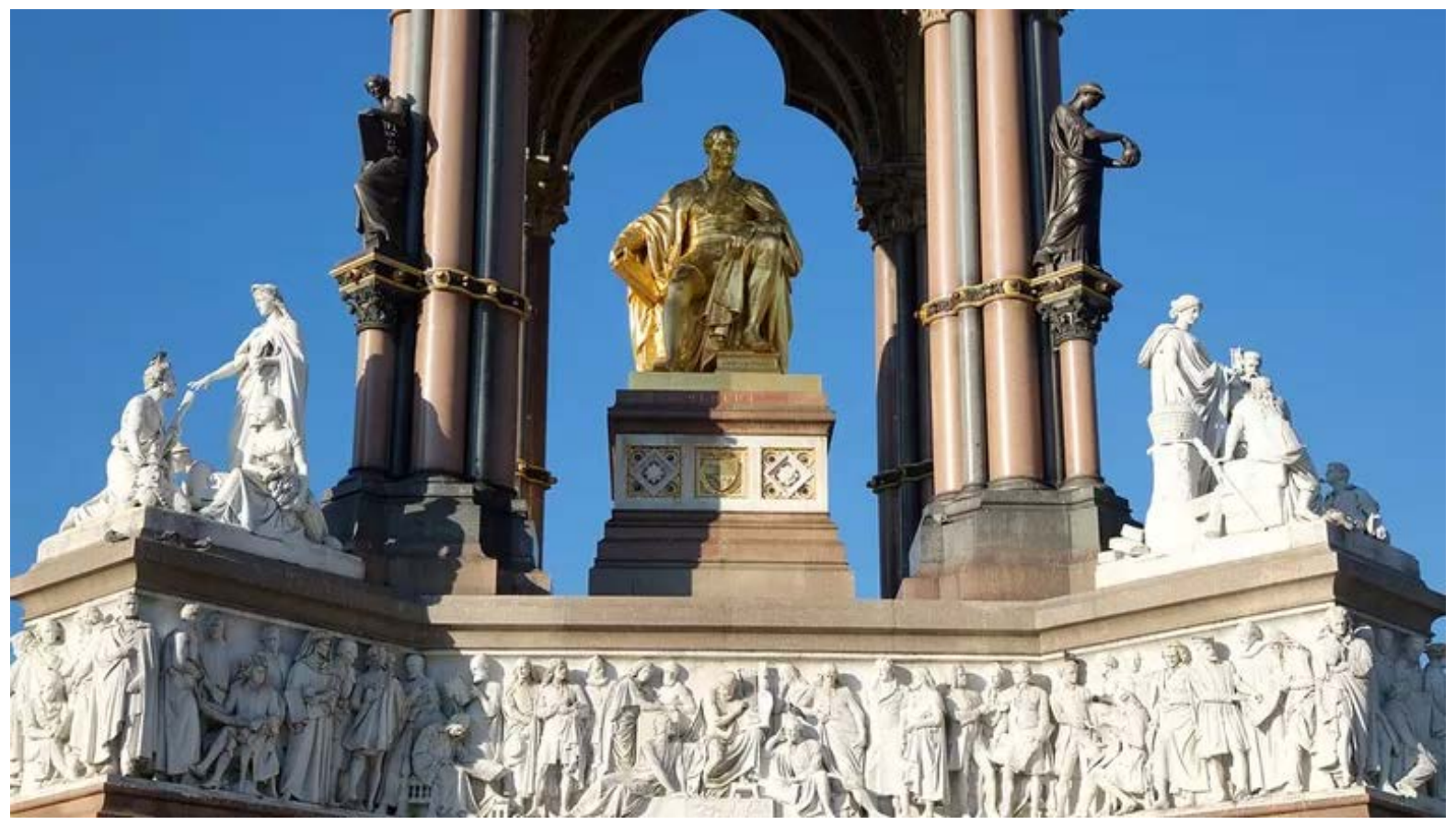

Cara principal del Albert Memorial. Al centro la figura de Alberto. A la derecha las manufacturas y a la izquierda la agricultura. Debajo, el friso del Parnaso mostrando a los poetas en el centro con Homero y su lira,

flanqueado por Virgilio, Dante y Shakespeare. El resto de las figuras son todos compositores, ordenados anacrónicamente de acuerdo a un criterio nacionalista. Podemos ver a la izquierda los compositores franceses como Lully, Rameau o el flamenco Des Prez. Siguen los Italianos, donde junto a Monteverdi aparece sentado Guido d'Arezzo y detrás San Ambrosio de Milán. Del otro lado están los alemanes, de Bach a Beethoven -de rostro adusto y con la mano dentro del abrigo-. Cierran el friso los compositores ingleses, de fama local aunque menos notorios, salvo Purcell.

La selección, disposición y ordenamiento de los compositores del friso del Parnaso es un excelente ejemplo visual del canon de la musicología histórica. Por un lado, los músicos se reducen a los compositores, únicos responsables de la música, fuente de su origen que en el siglo XIX, para el caso de la música culta, se ubica en el genio individual que expresa sus pasiones, su subjetividad (Gelbart, 2007). Además, la clasificación en función de las naciones responde a criterios esencialistas y racializados que luego se despliegan hacia las músicas del resto del mundo dominado. Pero tal vez lo más curioso es la disposición eternizante y anacrónica, que no responde en lo más mínimo a una secuencia temporal, en la cual parecieran entregados en una animada conversación compositores que no fueron contemporáneos y cuyas vidas en algunos casos están separadas por varios siglos. La disposición en base a un criterio de mausoleo que busca la eternización -y no la historicidad- no es una particularidad del monumento de Alberto. La historiografía de la música basa su propio repertorio, su colección de objetos de estudio, con igual criterio. Y mientras los compositores no son tratados como sujetos históricos, sino que se los aparta de las circunstancias de su tiempo, poco importa su correlación temporal, a no ser que establezca un criterio -y lo hará- que nos permita organizar la colección con fines comerciales. Basta ver las ilustraciones de revistas y textos dedicados a la historia de la música, como el siguiente, que se denomina The Musical Hall of Fame, publicado en una revista musical en 1913 (tomado de Treitler, 1991, p. 288). 


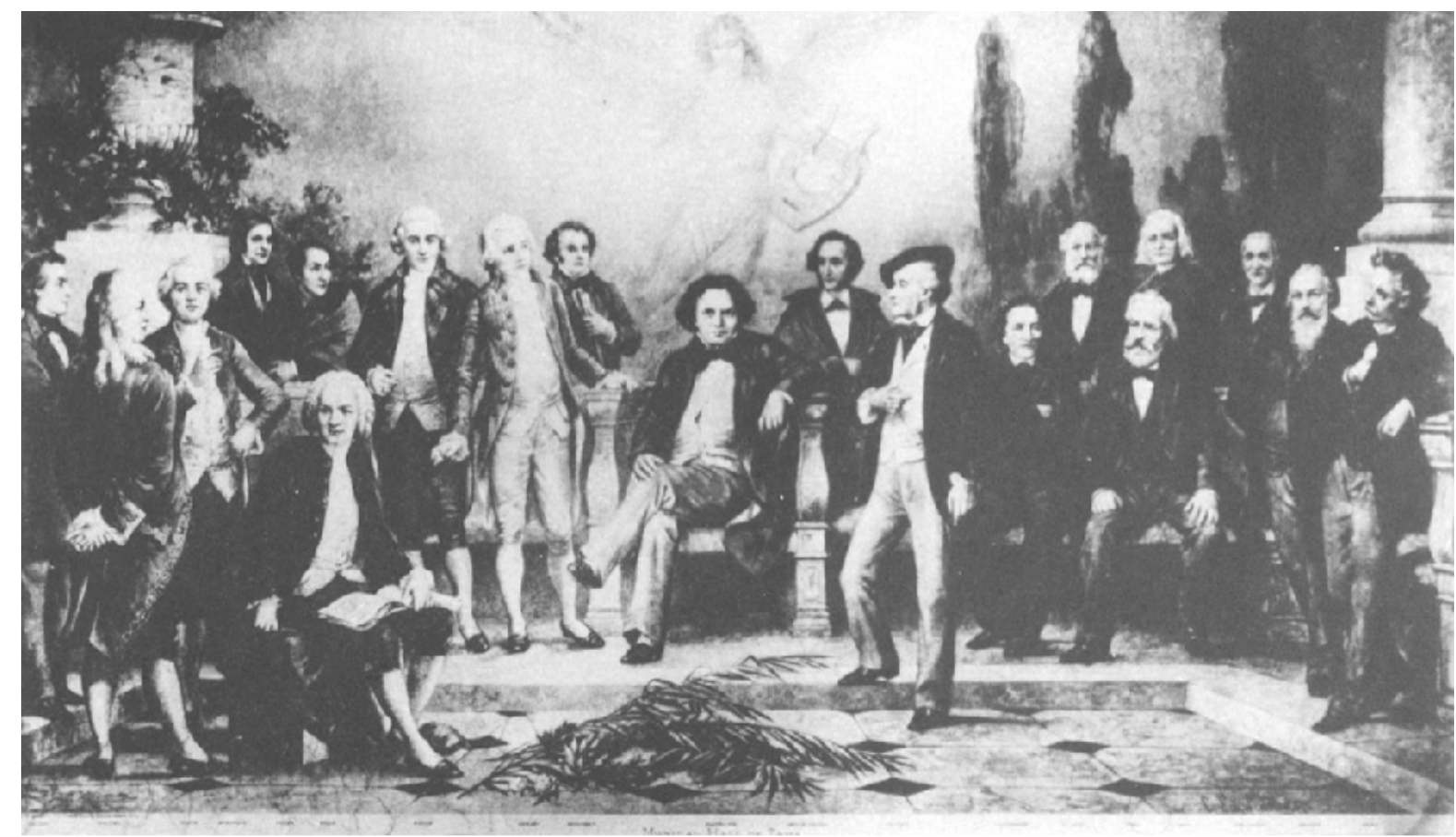

El canon musicológico representado como The musical hall of fame. De izquierda a derecha: Chopin, Handel, Gluck, Schumann, Weber, Bach, Haydn, Mozart, Schubert, Beethoven, Mendelssohn, Wagner, Meyerbeer, Verdi, Tschaikowsky, Liszt, Bruckner, Brahms y Grieg.

Es curioso (o más bien lógico) que al describir la ilustración Treitler menciona que Beethoven está ubicado como «la figura regente (un Apolo) de este parnaso musical europeo» 41 (Treitler, 1991, p. 288). Es que se trata de una forma en que la modernidad europea piensa su propia cultura y la música, que en lugar de explicarla a partir de la historia la convierte en monumento, localizándola en ese mundo apartado, en el universo idealizado de renuncia al que refiere Marcuse. Un sitio para tranquilizar el anhelo de los rebeldes a partir de conjurar ese devenir histórico que nos remite a la transformación y la dinámica permanente de la sociedad y la cultura. Podemos encontrar monumentos de este tipo por toda Europa. También Ludovico I de Baviera erigió en 1842 su propio Parnaso cerca de la ciudad de Regensburg (Ratisbona), esta vez a imagen de la mitología de los nórdicos y no de los helénicos, aunque el edificio es una réplica exacta del Partenón de Atenas. Es una interesante síntesis de lo que la Europa triunfal decimonónica construyó como mito de sus orígenes: la combinación de la herencia de la Grecia clásica que sólo adquiere valor a partir de la irrupción histórica de los Bárbaros, que resignifican y reelaboran selectivamente esa herencia (Michaud, 2017). Dentro del monumento no hay objetos históricos, ilustraciones ni textos explicativos. Sólo hay bustos, puesto que la tradición dominante occidental se manifiesta exclusivamente a través de personalidades. Por eso en el monumental Walhalla de Ludovico, que domina desde lo alto el Danubio, también aparecen eternizados en mármol los mismos compositores que vimos en las imágenes anteriores, junto con el caudillo "bárbaro" Arminio, terror de los romanos en el siglo I. Se trata justamente de una retórica esencialista y ahistórica de celebración de la germanidad.

41 «The reigning figure (Apollo) in this European Musical Parnassus» (Treitler, 1991, p. 288) [traducción del autor] 

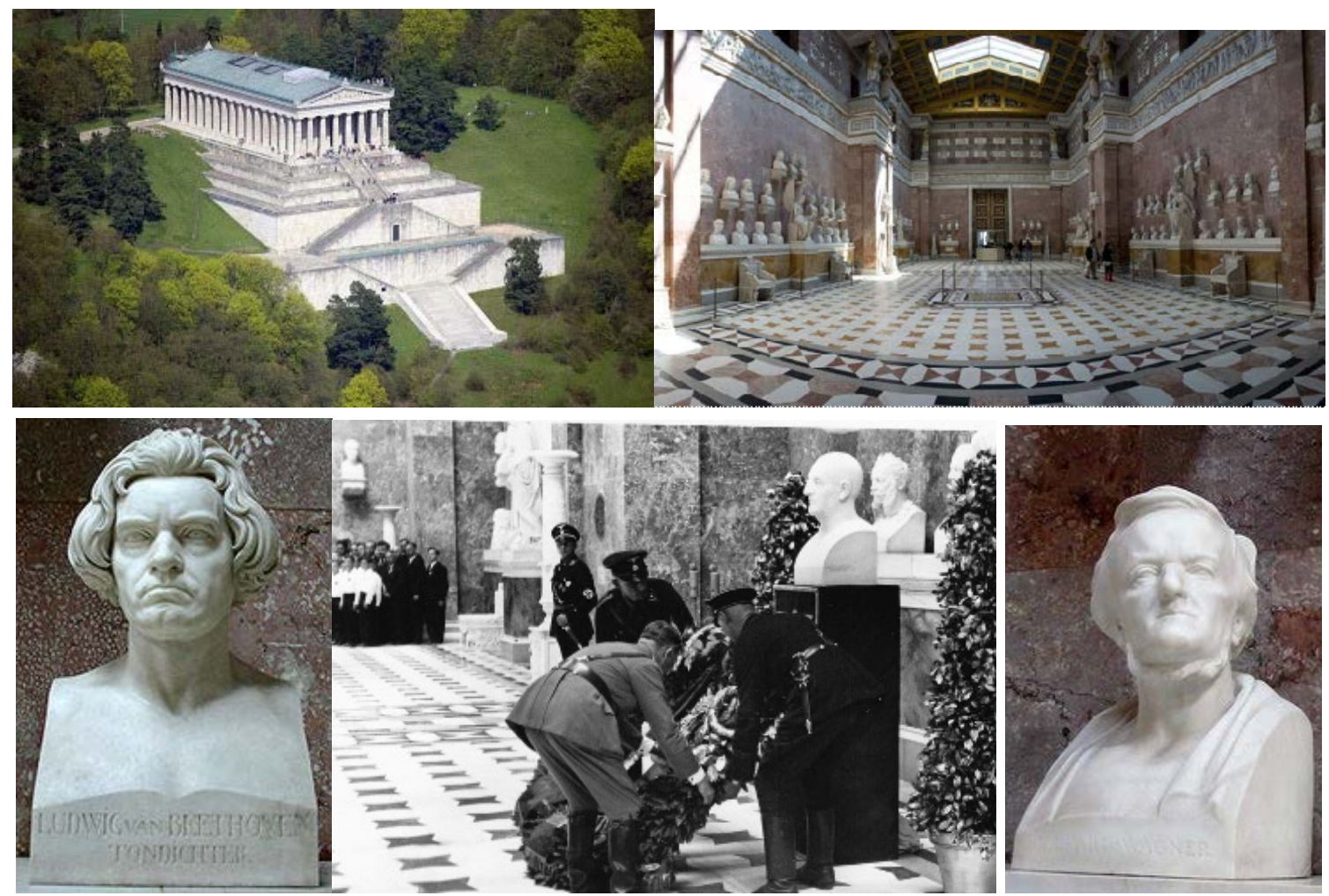

Arriba: Vista aérea e interior del Walhalla de Ludovico I. Debajo: a los lados, bustos de Beethoven y Wagner, y en el centro ceremonia de inauguración del busto de Bruckner encabezada por Adolf Hitler en 1937

Las personalidades no se forman como respuesta a la historia. No son el emergente de la sociedad ni se consagran a propuesta del colectivo. Su particularidad sólo puede buscarse en el carácter de la subjetividad, aspecto personalísimo y reñido con la idea de conjunto o multitud. Por eso es que la historia de la música afirmativa se basa en el recurso a las personalidades de los compositores, ya que cifradas en ellas se encuentran las fuentes musicales -aunque no las explicaciones, que permanecen como arcanos. "La concepción artística y las formas de expresión dependen [...] del temperamento del artista» (Lang, 1963 [1941], p. xiii).

Hacer de una historia de la música una narración que oculte las relaciones históricas no es nada sencillo. Dahlhaus sugiere que la biografía orientó la escritura convirtiendo a la personalidad, y a la explicación psicológica o ambiental, en el elemento narrativo que brinda una coherencia. La idea misma de un sujeto en la historia musical es factible a partir de basar en la biografía los componentes centrales del relato. Como vimos en el caso de Grout, y esto es una muestra del alto grado de convivencia entre las intensidades del romanticismo y el positivismo, cuando la historiografía se propone hacer un relato alejado de la biografía, los géneros musicales y los estilos serán narrados mediante el uso de metáforas biográficas que señalan "edades" de cada período: el Barroco "temprano" (frühbarock), el Romanticismo "pleno", etc. «se enfocan como analogías de las de una persona, para que la historia relatada adquiera estructura y contornos firmes» (Dahlhaus, 1997, p.58). Sin embargo el mismo Dahlhaus, al comentar un pasaje del musicólogo Hugo Riemann, quien sostenía que los dramas musicales de Wagner habían ejercido una influencia sobre la producción musical total de la segunda mitad del siglo XIX, suscribe la hipótesis personalista y reafirma que la sinfonía de fines de siglo "se sometió a la influencia de Wagner en una doble aspecto», positivo y negativo (Dahlhaus, 1997, p. 64). La continuidad del personalismo en la musicología histórica de fines del siglo XX pareciera quedar así garantizada. 
Estas historias, que buscan explicaciones en la influencia colosal de personalidades heroicas, son las que Nicos Hadjinicolaou denominó «historia del arte como historia de los artistas». Para este autor responden con claridad al modelo de la burguesía liberal al instaurar al "hombre", el individuo creador, como centro del universo artístico. "La ideología del "hombre creador" es la ideología burguesa constante en todas las formaciones sociales con dominante capitalista» (Hadjinicolaou, 2005, p. 43). Son múltiples los obstáculos y las limitaciones de estas narrativas personalistas. Pero en el caso particular de la música esto se acentúa incluso en la elección misma de las figuras que presiden estas galerías de nombres. Especialmente en el culto a Beethoven. Nicholas Cook subraya el peligro que encierra la paradoja del modelo beethoveniano y su rol en la separación definitiva del ideal musical silente y su manifestación sonora concreta.

La sordera de Beethoven [...] actúa como un potente símbolo de la independencia, o alejamiento, de Beethoven respecto de la sociedad en la que vivió: reducida su comunicación con el mundo exterior a los cuadernos de conversación [...] el compositor se disoció de preocupaciones mundanas como la búsqueda del éxito social o económico y se dedicó enteramente a su musa. $O$ eso es lo que cabría pensar a partir de una gran parte de la iconografía y la literatura mitificadoras en torno a Beethoven [...] Pero la verdad era muy diferente. [...] Las distorsiones que conforman el mito de Beethoven son tan significativas como la verdad que subyace en ellas, porque reflejan los valores y las inquietudes de los constructores del mito" (Cook, 2001, p. 44)

Como si se tratara de la realización definitiva del ideal medieval de la música mundana (música de las esferas), tan perfecta que se vuelve inaudible para la imperfección de los humanos (y más si forman parte de las masas), como superación y extremo de la división monástica entre musicus y cantor (músico intelectual y músico práctico), es la imagen de un sordo la que consiguió establecerse como modelo universal de músico. La música de las esferas se transustancia en ideas de una mente genial aunque incapaz de oír. Aunque tal vez de esta misma condición provenga su genio, que ya no necesita ni siquiera del sonido para hacer música.

Hay tipos humanos que sólo pueden caminar erguidos, y para quienes la vida sería inconcebible de otro modo. En cada nota y palabra de Beethoven, desde el instante de su primer balbuceo, esta mole erguida que cobija una orgullosa majestad de alma, habló con aplomo profético. Sentía en él una fuerza creadora y sabía que contra ella había de estrellarse toda oposición, si iba ésta dirigida a detener la plasmación de su obra, obra que él formaba a imagen de su voluntad y llenaba con el contenido de su alma. Nació así una música singular, encarnación del poder y la integridad [...] las emociones le nacen de intenciones magnánimas y conscientes, gobernadas por las ideas y de ahí su unidad insólita. Ningún otro compositor se ha acercado jamás a esta gigantesca y tenaz fuerza de voluntad; nadie atinó a obligar a una naturaleza así impetuosa, demoníaca, a seguir los dictados de la propia voluntad en cualquier circunstancia, convirtiendo sus energías en pura fuerza creadora (Lang, 1963, p. 598)

En la alabanza de Lang está cifrada «la imagen de la forma heroica de la cultura afirmativa» (Marcuse, 1967, p. 74). El de la musicología histórica es un relato prometeico, mítico, pero que se cuida muy bien de mantener a la inmanencia ajena de todo aquello que podría recordarnos la ligazón del compositor con su realidad circundante. El poder, la naturaleza, la voluntad, la fuerza residen exclusivamente en el interior de la subjetividad del artista. Si hay conflicto, nunca es en los términos que deseaban Hadjinicolaou, o Lukács o Hauser. Jamás es una lucha de clases, un conflicto real de poder. Es una lucha interior, tránsito necesario del proceso que implica la manifestación de la voluntad expresiva del autor, que es un tránsito doliente, cuasi mesiánico. De hecho, el oyente empatizará y apreciará correctamente la obra en la medida en que refuerce ese sufrimiento apasionado. Cook denomina a todo este esteticismo historiográfico «disfrutar sufriendo» (Cook, 2001, p. 34). 
El aspecto silente de la "obra" musical es constitutivo del paradigma de la musicología histórica, para nada periférico ni anecdótico: la música del compositor, al ser inaudible, es tan ideal que, al mismo tiempo que cualquier realización sonora la degrada, y de ahí el sufrimiento, nos habla simultáneamente de esa belleza del alma que por su distancia ideal implica forzosamente el renunciamiento y la aceptación de lo existente. El ideal beethoveniano es la historiografía musical afirmativa en su expresión más directa. La renuncia a dirimir todo asunto en el mundo actual, material, lleva a que la musicología se ocupe de un objeto mudo creado por sordos.

La personalidad es el depositario del ideal cultural [...] tiene que presentar la felicidad, tal como esta cultura la proclama, como bien supremo: la armonía privada en medio de la anarquía general, la alegre actividad en medio del trabajo amargo [...] La realización de la personalidad debe ocurrir en la inmanencia de las leyes del orden existente [...] tiene que respetar los fundamentos de lo existente; el respeto por las relaciones de poder ya dadas, es una de sus virtudes [...] La cultura afirmativa reproduce y sublimiza con su idea la personalidad, el aislamiento y el empobrecimiento social de los individuos. (Marcuse, 1967, p. 70)

Todo análisis derivado de esta concepción personalista está destinado a subordinar aquellos aspectos de la música que podemos asociar con la ocasión sonora, el musicar y el ritual social que éste implica. Estas dimensiones, como la trama textural, las sonoridades instrumentales y sus articulaciones, los desfasajes y discrepancias temporales y de alturas, que en las músicas populares y especialmente latinoamericanas son vitales, pasan al fondo de la descripción musicológica, si es que aparecen. Porque la única vía de acceso a esas intenciones silentes e idealizadas del compositor es la partitura, útil favorito sino exclusivo de la musicología. Y del mismo modo que el personalismo no es más que la expresión modulada en términos estéticos de una ideología, la partitura como instrumento es un mapa de una concepción hegemónica de la música que entroniza algunos parámetros en detrimento de otros. Hasta no hace mucho, los buenos maestros de composición preferían que sus estudiantes trabajaran "en el papel" mediante el auxilio de la "escucha interna", rechazando al mismo tiempo las grabaciones y ejecuciones en vivo de los avances y bosquejos de los alumnos. Esto no solo lleva a que los compositores se formen pensando fundamentalmente bajo las categorías musicales de la modernidad europea. También produce una sensación de naturalidad en la separación del compositor frente a la sociedad, haciendo de su tarea un oficio solitario, silencioso y de enclaustramiento. Entre tanto, esta misma concepción guía también el trabajo historiográfico, convirtiéndolo en paleografía, en hermenéutica de textos, haciendo que la historia busque únicamente la "empatía con el autor" (Dahlhaus, 1997, p. 59). Esto ofrece una solución a la "historia sin historia" del esteticismo afirmativo, ya que las explicaciones de las transformaciones e innovaciones se garantizan mediante el recurso a las personalidades que, en tanto sujetos con conciencia histórica de la continuidad biográfica, se reconocen en sus maestros y proyectan en sus discípulos. La historia se cuenta "desde adentro", es una introspección espiritual antes que una descripción cronológica o una explicación sociohistórica.

En virtud de estos valores, la historiografía personalista pondrá el foco en el "alma" del compositor, pensándose en consecuencia a la musicología como parte de esa ciencia del espíritu (Geisteswissenschaften). Esto es parte del mecanismo de aceptación de la realidad material por parte de la cultura afirmativa, ya que la idea de alma no se puede relacionar con la praxis de la sociedad burguesa y la lucha por la existencia. «En el proceso social del trabajo, el alma no tiene participación alguna» (Marcuse, 1967, p. 58). El alma, que será personificada por el compositor, cuando habla, trasciende la contingencia de la vida de los seres que son sujetos sociales e históricos. Es el alma un desarrollo exclusivamente interior, asocial, que mediante la retórica romántica y el idealismo se transforma en una proyección universal al infinito. «Tal ha sido la forma como la cultura afirmativa en su período clásico ha ensalzado siempre al alma [...] En primer lugar, se contrapone el alma al cuerpo del 
individuo» (Marcuse, 1967, p. 61). Mientras la sociedad es concebida como el terreno de oposición entre individuos independientes, la relación de estas mónadas autosuficientes con el mundo se vuelve abstracta y el mundo pasa a residir en el interior del individuo aislado. Es importante, no sólo para la estética hegemónica sino para la política, que el aislamiento no sea puesto en cuestión ni se supere por parte del individuo. Desdibujar la personalidad, poner en relación al músico con el colectivo del que forma parte, significaría el establecimiento de una solidaridad real. La cultura de la modernidad burguesa depende de que esto no suceda. Podemos comprender entonces que «personalidad es, sobre todo, el hombre que renuncia, el que impone su propia realización dentro de las circunstancias ya dadas por más pobres que éstas sean» (Marcuse, 1967, p. 72). Una singularización cultural de los individuos que deben permanecer encerrados en sí mismos, preocupados únicamente por su propia realización. Para la modernidad, el culto a la subjetividad, la celebración de la personalidad artística, no son aspectos menores, temas de segundo orden que corresponden al "lujo inocente" del mundo del arte. En la estética romántica, en la historiografía historicista afirmativa, se discuten los temas centrales del proyecto civilizador de la modernidad, que es imperial y geopolítico. "Particularidades libres» denomina Terry Eagleton (2006, p.65) a la forma de concebir la política y la estética por parte de la generación que consolida el poder de la burguesía y despliega el programa romántico. Es una metáfora acertada que explica la personalidad artística autónoma y la práctica individual como proyecto de realización social. Por eso no es demasiado arriesgado suponer que

la innovación más importante de este período fue lo que podría llamarse la construcción de la subjetividad burguesa. Con esto quiero decir que exploraron y celebraron el mundo interior de sentimiento y emoción; la música, en concreto, se apartó del mundo y pasó a ocuparse de la expresión personal (Cook, 2001, p. 34)

Podríamos argumentar, en contra de lo que venimos sosteniendo, que el culto a la personalidad no es un atributo específico de la música culta. $Y$ es cierto. De hecho existe el "Rock and Roll Hall of Fame", en cuyas ceremonias se "induce" a grupos y solistas legendarios. Más aún, la música popular contemporánea está absolutamente atravesada por el desarrollo de lo que Attali llama la vedette popular (2011, p. 105). Sin embargo debemos hacer dos salvedades que podrían convertirse en impugnaciones, más allá de la apariencia que el mercado musical pop nos presenta como un hecho cotidiano: por un lado estas personalidades de la música popular, que en su mayor parte corresponden con el intérprete y no con el compositor, son absolutamente contingentes. Se agotan con una intensidad y velocidad proporcionales a como el público las consume. A tal punto que sería un tanto irrisorio que nos propusiésemos esculpir un friso del Parnaso de los músicos populares: o vaciamos las canteras de mármol del mundo para fabricar un relieve tan largo como la Muralla China, que además habría que continuar casi en tiempo real al ritmo de los charts; o la discusión para decidir a quiénes incluir podría prolongarse eternamente. Pero además está, como segundo argumento, el estatuto histórico: la genealogía de la vedette popular coloca a ésta como un desarrollo posterior y en cierto sentido a la saga de la construcción de la vedette clásica (Attali, 2011, p. 103). Además este autor aclara que el surgimiento de la vedette clásica es una consecuencia del establecimiento del código, es decir de la concepción estética burguesa derivada de la abstracción que la musicología ubica en el solfeo y la pauta notacional. Esta es la matriz que, puesta en escena en la representación, en el espectáculo musical burgués, desencadena un proceso de selección y competencia (Attali, 2011, p 103). Incluso esto potencia el aislamiento del músico, su apartamiento de otros colegas que no son tan rentables, su individualización como genio, incluso en la interpretación. Podemos recordar a Liszt, a Paganini, a Caruso. El éxito, regla del cambio competitivo al que es arrojada la música, produce la necesidad de la vedette. Es, junto con la regulación del derecho autoral, una de las condiciones técnicas del 
mercado musical del siglo XIX (Attali, 2011, p 104). Pero lo más importante es que todo este sistema mercantil y de regulación de la producción necesita que el canon pétreo de los compositores ya esté constituido. Es su consecuencia, no su origen.

El star-system, desenlace de la competencia, comienza desde mediados del siglo XIX, cuando se constituye un repertorio, es decir, aproximadamente cuando, a partir de 1830, Liszt ejecuta en concierto la música de otros compositores contemporáneos y Mendelssohn la de Bach (Attali, 2011, p. 105)

Esto coincide con lo que para Martin Kaltenecker es un componente imprescindible del nuevo espacio sonoro que emerge, para la música culta, en el siglo XIX y su mercado de conciertos: la reactualización del pasado sonoro (Kaltenecker, 2004, p. 113), que justamente irrumpe en escena con la ejecución de Bach por Mendelssohn que menciona Attali, y que permite extender un repertorio demasiado exiguo para un mercado y un público crecientes. También William Weber describe con agudeza cómo el mercado de conciertos que surge a partir del siglo XVIII y fundamentalmente en el XIX se basa en un repertorio de música seria, es decir composiciones cultas, incluso en su faceta más popular: los conciertos promenade, con selecciones de danzas y popurrís de óperas. «El concierto promenade marcó un nuevo rumbo en la actividad de los conciertos: el concierto "pop" nació en este contexto. Identificó un punto de encuentro crítico entre el gusto y la actividad social» (Weber, 2011, p. 303). Por eso Attali sostiene que el proceso de selección y de emergencia de las vedettes en la canción popular en los siglos XVIII y XIX remite a la misma dinámica de centralización musical, cultural y económica que emergió antes para la música culta. A diferencia de ésta última, de toda la proliferación de la economía musical de la ópera del siglo XVII y XVIII y del concierto público del XVIII,

[h]asta entonces, la canción popular se expresa esencialmente en la calle, dominio tradicional de los juglares. Su entrada en el mercado y la competencia supone su reclusión y su tarifación, primero en los cabarets y después en los cafés-concierto. A partir de mediados del siglo XIX, el corazón de la economía de la música estará en esas salas (Attali, 2011, p. 109).

En síntesis: cuando la musicología histórica se demora y entretiene en la descripción minuciosa de la personalidad artística, de lo particularísimo del individuo y su genio, configura la imagen de la historiografía afirmativa según la cual la historia de la música está jalonada por grandes personalidades que encarnan la transformación del material en sus obras. Estas historias confunden «el producto en sentido estricto» (Rubio, 2008, p. 54) con la composición y asumen así una concepción personalista y objetual de la música. De esta forma, la historia de la composición se convierte en un sinónimo de historia de la música, en lugar de ser un subconjunto dentro de ella (Shreffler, 2003, p. 4). Esto es problemático cuando se pasa a hablar de la música popular ya que, aún aquella que ocupa posiciones centrales en el mercado, se configura antes como performance que como obra y procede de relaciones intersubjetivas y dialógicas en lugar de la verticalidad (Cook, 2001) que supone en la música de concierto la estructura compositor-director-intérprete-auditor. Se producen así equívocos al pensar que «en la música popular o ligera [...] los espacios de invención y cambio son muy acotados» (Rubio, 2008, p. 55). Justamente es el mercado, en convergencia con la academia musicológica, el responsable de posar sobre la música culta los atributos de originalidad, novedad y unicidad que pueden clasificarse a partir de la autoridad que se desprende de la figura del autor.

[L]a industria musical clásica comercializa a los grandes intérpretes en su papel de creadores, o «autores», y no como simples reproductores de música [...] Pero es en los libros de música clásica donde la distinción entre autores y reproductores puede encontrarse en su forma más literal. En su mayor parte se refieren a «música», pero en realidad tratan de compositores [en casi todos ellos] encontraremos un aluvión de información sobre los compositores incluso más desconocidos, pero los intérpretes brillan por su ausencia. Es como el papel de los criados en 
la sociedad victoriana: tienen que estar ahí, pero no hay que hablar de ellos (Cook, 2001, p.

28)

Precisamente, comprender las relaciones entre las lógicas de producción del capitalismo y la música es muy complejo, por no decir imposible, si se parte de la concepción objetualpersonalista. Este es otro milagro de la historiografía afirmativa. Justamente nuestra hipótesis es que esa concepción, a través del programa del arte burgués moderno y la historiografía afirmativa, tiene como una de sus funciones ocultar dichas relaciones, promoviendo el estatuto autónomo de la obra musical y del compositor enclaustrado en su propio mundo sonoro. Es necesario recurrir a alguna alternativa que permita trascender este paradigma y hacer audibles las relaciones de producción musical. Attali (2011, p. 59) por ejemplo, piensa al compositor, culto o popular, como matricero, lo cual señala la falta de correspondencia entre el esquema clásico de los medios y relaciones de producción capitalista acerca de cualquier objeto (como un automóvil o una heladera) y la generación de músicas como bienes de cambio ${ }^{42}$. Si seguimos este razonamiento, esta peculiaridad hace que haya sido tan tardío y problemático el desarrollo de las leyes de autor y sus regulaciones, ya que lo generado en el acto de composición no es la cosa en sentido estricto, sino la idea, las instrucciones, el código que otros tomarán como matriz y a partir de ella generarán la música en base a otras condiciones y relaciones de producción de las que no participa la composición: el concierto público, el disco, la radiodifusión, la circulación por medios digitales, etc. De hecho, Attali define la música de la modernidad 43 a través de dos acciones en las cuales no interviene directamente la composición: representar y repetir. Además de indicadores de momentos históricos y funciones sociales de la música, estas dos categorías significan relaciones de producción diferenciales. Pero que están íntimamente relacionadas: la representación, es decir la música en vivo pública, único medio del capitalismo hasta comienzos del siglo XX, se transforma en «vitrina de la repetición» (Attali, 2011, p. 127), es decir, en anuncio de la grabación como objeto de cambio. De esto el mismo Adorno parece haber tomado nota: «la ejecución como tal [es] un reclamo para la compra de reducciones a piano y de discos gramofónicos» (Adorno, 2009, p. 25). Pero esto no responde, como suponía el pensador de Frankfurt, a una estrategia de idiotización por estandarización sino a la propia solvencia económica de la música en el capitalismo, inconseguible únicamente por medio de la representación pública (Attali, 2011, p. 125)

Ahora bien, en la producción de la mercancía puede utilizarse cualquier matriz, incluso -y cada vez más- una compuesta en el pasado. Por esta razón es que homologar relaciones de producción con composición resulta al menos cuestionable, sobre todo cuando se trata de la música popular. De hecho, Attali reservará el uso del término composición para la última etapa de su narración histórico musical, aunque nuevamente no se refiera a un empoderamiento de los compositores profesionales, sino a lo contrario: el rasgo sobresaliente de la contemporaneidad en el cual la matriz es puesta en crisis y rearticulada por el público que ahora puede convertirse en usuario (Attali, 2001).

Esto es lo que Christopher Small (1998) tuvo en cuenta cuando desarrolló el neologismo musicar, para evitar referirse a la música como un objeto y subrayar en cambio su condición procesual, fenomenológica. Así, desde hacer una playlist personalizada en el "walkman" (con cassettes, con mp3 o con Spotify) hasta participar de una rave o modificar y

\footnotetext{
42 Justamente en este apartamiento de la concepción tradicional objetual-personalista que exhibe el núcleo de pensamiento de Attali, puede advertirse que no es un continuador de la crítica de Adorno, como se ha sugerido (Mendívil, 2016), más allá de interesarse por temas comunes y aplicar un modelo económico de derivación marxista.

43 En este caso en el sentido de aquella música producida bajo (y a su vez productora) del capitalismo clásico, lo cual en términos temporales equivaldría a la producción entre principios del siglo XVII y casi todo el XX.
} 
remezclar una canción mediante las herramientas de la web, no existe para Small situación musical que no involucre una acción colectiva, existan en ella o no profesionales. Si bien el autor propone esta concepción alternativa para todas las músicas, incluida la "música culta occidental", es en la música popular donde estos rasgos son muy fácilmente verificables.

Una actuación musical es una cosa mucho más rica y más compleja que lo que permiten quienes se concentran solo en la obra musical y en su efecto sobre un oyente individual. Si ampliamos nuestra atención hasta el conjunto de relaciones que constituyen una actuación vamos a ver que los significados primarios de la música no son nada individuales sino sociales. Además, estos significados no deben estar escindidos en algo que se llama una sociología de la música, apartada de los sonidos y de sus significados, porque son centrales para entender la actividad llamada música. (Small, 1999, p. 5)

\subsubsection{Un peregrinaje al son de los himnos}

El concepto de musicar en historia implica reconstruir la ocasión musical, intentar penetrar en el sentido temporal de la actuación, la performance. $Y$ eso, aunque suene simple y hasta banal, va justamente en contra de lo que afirma la historiografía personalista. Aún en los periodos históricos en que la personalidad no existe, en que la cultura no fomenta sino que desalienta el culto al individuo y la diferenciación en base a la originalidad, la historiografía afirmativa se las arregla para encontrar un sujeto narrativo y convertirlo en matricero. Así, aun cuando debe vérselas con el corpus del canto cristiano medieval, necesita que aparezcan figuras desde cuya personalidad, su carácter, se hilvane el relato. Paul Lang es capaz de definir el origen de toda una forma de producción musical, vastísima, a partir de la circunstancia biográfica de un personaje más mítico que histórico; de una música que está presente en varios cultos religiosos, que por otra parte fue la unidad sonora de los estados nación y que, atravesando los más sinuosos recorridos transculturales, se integra en la estructura básica de la canción popular, incluso del presente; todo eso pareciera tener origen en un acontecimiento que se explica mediante el recurso a una personalidad: "Los primeros himnos cantáronse cuando San Ambrosio, acompañado por sus feligreses, huyó de los arrianos» (Lang, 1963 [1941], p. 39). Y une su personalismo con una cita en donde hace decir a San Agustín lo que al personalista le conviene: «Entonces fue cuando se estableció que cantasen los fieles himnos y salmos, según se acostumbraba en las iglesias de Oriente». Antes Lang deposita en el santo milanés «la tarea de aclimatar el canto hímnico en Occidente». Por si nos quedan dudas, continúa más adelante «Los himnos ambrosianos son obras de arte [...] Trasuntan ideas cristianas dentro de formas clásicas magníficas» (Lang, 1963 [1941], p. 39). Si bien dice que es imposible responder a si las melodías «estaban compuestas por el mismo San Ambrosio», recurre nuevamente al santo de Hipona para hacerle decir que cuatro son indudablemente obra del milanés. Es que para Lang la Edad Media se define de acuerdo a un friso imaginario como «los tiempos de San Agustín, Boecio, Abelardo, Santo Tomás de Aquino, Wolfram, San Francisco, Dante y multitud de autores» (Lang, 1963 [1941], p. 30). La primera etapa, en donde irrumpe la figura de Ambrosio dando la chispa creadora de la música occidental, «termina con el reinado de Gregorio el Grande» (Lang, 1963 [1941], p. 34). Richard Hoppin refuerza esta idea sobre los himnos y la personalidad del santo milanés: "Cualquier estudio de la himnodia en el occidente latino debe comenzar con Ambrosio, porque los procedimientos que estableció son todavía los principios que determinan la escritura de los himnos» (Hoppin, 2000, p. 126). Así se despliega uno de los recursos básicos de la historiografía musical hegemónica, afirmativa, que consiste en hacernos creer que toda música debe tener un autor individual, en cuyas intenciones está contenida cualquier significación que podamos atribuir al artefacto sonoro. Cuando la autoría no está presente, o es muy difícil adscribirla, la musicología histórica entra en problemas, ya que su núcleo conceptual depende de la posibilidad de ubicar a las músicas no en sus momentos de actuación, de sonorización, sino únicamente en cuanto a su 
génesis intelectual, es decir, su composición. Como ya dijimos, esto funciona solamente en el reducidísimo marco de la música culta de la modernidad europea occidental. Es un modelo que se basa en la autoridad del autor, juego de palabras que para Nicholas Cook (2001, p. 40) describe una dimensión de la concepción musical afirmativa que encarna la musicología histórica. De allí que se hable de ediciones e interpretaciones "autorizadas". Finalmente, dice este autor, toda nuestra idea de interpretación descansa en una concepción bastante autoritaria (Cook, 2001, p. 41)

Como estas ideas son decimonónicas -Cook las asocia con la época de Beethovenincluso deberíamos acotar aún más el tipo de música al que sí se puede aplicar el modelo de la autoridad compositiva personalista, ya que únicamente a partir de que las músicas son puestas a la venta en el mercado del concierto público y la imprenta es que nacen tanto el artista como la inspiración (Attali, 2011, p. 73). No es una casualidad que la máxima intensidad del paradigma personalista en musicología coincida con la creación de las sociedades de derechos de autor y la consolidación de la legislación autoral, todo lo cual ocurre entre 1850 y 1930. De hecho las categorías de música seria o artística y música ligera o popular tienen un desarrollo muy fuerte en ese momento (Scott, 2014), porque sirven para clasificar las músicas en función del mercado, permitiendo especializar la producción, la distribución y la generación de la demanda (Frith, 2006). Esto hace que la música menos auténtica -incuso podríamos decir que es "menos música"- sea la que menos tiene que ver con la creación autoral. Si en el trono del Hall of Fame de la música se sienta, como vimos, el mayor representante de la figura del compositor, los músicos populares son arrojados del Walhalla, proscritos de todo paraíso musical. «No toda música es arte» dice Héctor Rubio (2008) en un trabajo que retoma los postulados de Theodor Adorno (2002) sobre la música popular. Del mismo modo, quienes producen la música popular son expulsados de la categoría de artistas y ni siquiera se los puede llamar artesanos, dado que su producción es inauténtica, interesada, manipuladora y burdamente comercial, a diferencia del folklore.

Los músicos pop, por contraste, son las marionetas del negocio musical, que satisfacen cínica o ingenuamente los gustos populares, e interpretan música compuesta y arreglada por otros; les falta autenticidad y, como tales, se sitúan en lo más bajo del escalafón de la musicalidad. Por decirlo de otro modo, el escalafón de la musicalidad eleva a los creadores de música -los autores, si queremos decirlo así- por encima de aquellos otros cuyo papel es de mera reproducción, en otras palabras, los intérpretes (Cook, 2001, p. 25).

A partir de lo que señalamos en Lang y Hoppin podemos tomar al himno medieval como metáfora y caso ejemplar del personalismo musicológico -y también de la objetualidad. Su repertorio presenta una ambigüedad que la musicología histórica intentó estabilizar con mucho esfuerzo en una dirección, muy selectiva, considerando exclusivamente los elementos asociados con lo compositivo y la teorización musical, es decir el pensamiento especulativo sobre la música, que es otra faceta del personalismo y la cultura musical hegemónica. Pero en los himnos también reside una importante potencia performativa, imposible de reducir a la abstracción y la categoría de obra/objeto. Así que tomaremos dos ejemplos muy clásicos y conocidos para referirnos a estas divergencias o discrepancias y establecer con más claridad ciertos modismos selectivos de la musicología histórica sobre las músicas.

El primer caso es el himno a San Juan Bautista, probablemente del siglo VIII y conocido también por el texto de su primer verso: Ut queant laxis. Es muy famoso porque a través de él comienza la saga histórica del solfeo musical, de un primer nivel de reemplazo y abstracción del sonido para su racionalización objetual, que consiste en asociar fonemas con determinadas alturas sonoras. En otras palabras, los nombres de las notas, que hasta para los niños se transforman en sinónimo del sonido musical: re, mi, fa, sol, etc. Sol-fa-ut 
es la jerigonza que da pie al desarrollo del "solfeo". Es el comienzo del desprendimiento de la materialidad sonora de la música, la conversión en abstracción matemática, en proporción de acuerdo con la máxima de San Agustín de Hipona quien había sentenciado que musica est scientia bene modulandi, es decir, la ciencia del "buen medir". Quien realiza la operación sustitutiva con el himno a San Juan no es otro que Guido Mónaco o Guido d'Arezzo (ca. 990-1033), monje benedictino y casualmente la otra figura religiosa del friso del parnaso del Albert memorial. Junto a San Ambrosio además representan las dos personalidades musicales más antiguas.

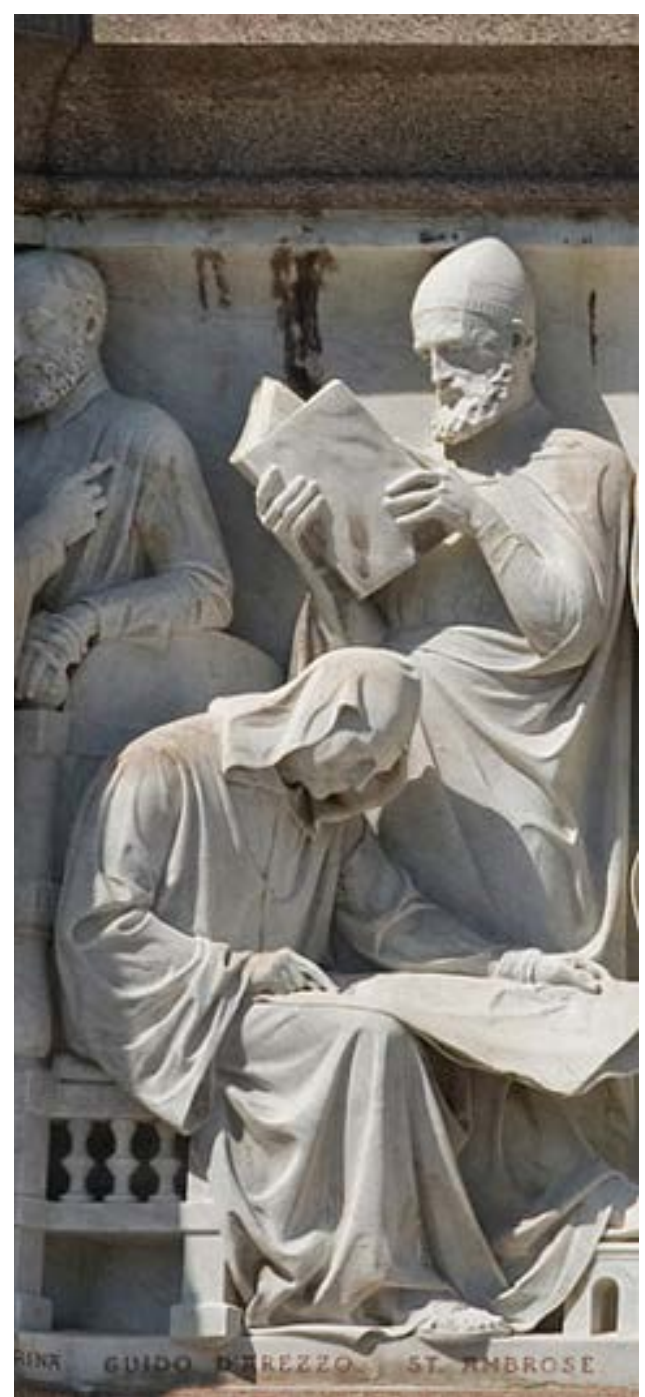

Detalle de las figuras de Guido d'Arezzo (sentado) y San Ambrosio en el Friso del Parnaso del Albert Memorial. Tienen folios y libros en las manos, no instrumentos. Tampoco están cantando. Todo lo cual desliza una pista sobre la concepción que la musicología deriva de estos personajes históricos. 
Pues bien, en una carta que Guido dirige a otro monje, Miguel, conocida como la Epístola del canto desconocido [Epistola de ignoto cantu] ${ }^{44}$ que pretende servir de auxilio metodológico a la hora de tener que cantar melodías que no se recuerdan muy bien o directamente no se conocen, el monje de Arezzo "descubre" en el himno a San Juan una extraña particularidad: cada frase comienza con un sonido que es un grado más alto que el del inicio de la frase anterior.

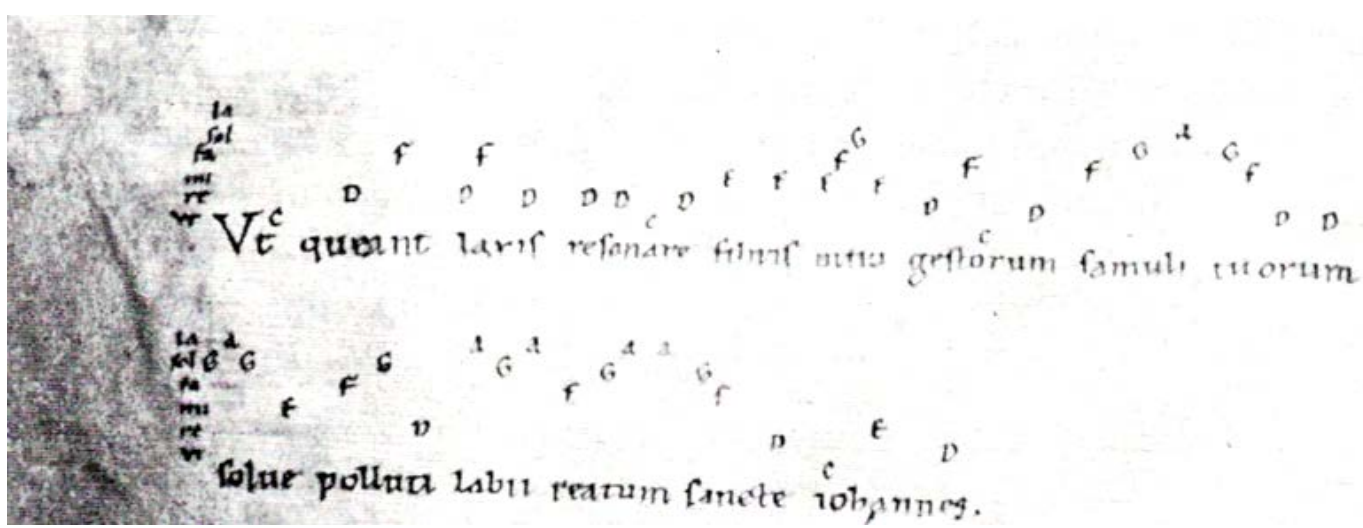

Una versión manuscrita del Himno a San Juan (Ut queant laxis) de principios del siglo XI, la época de Guido, en el que puede verse a la izquierda, en columna vertical, que ya está en uso el solfeo propuesto por el monje.

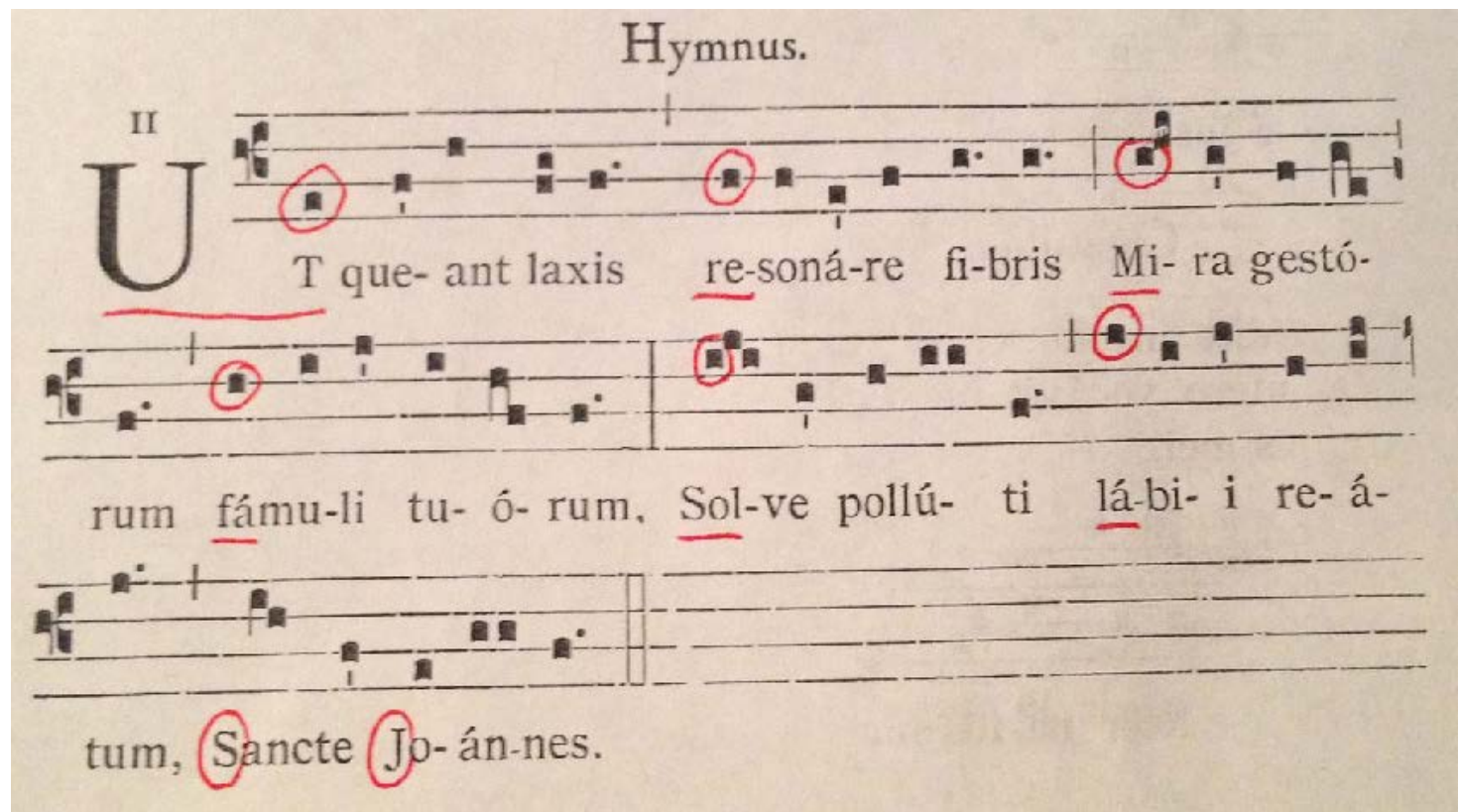

Transcripción gregoriana (s.XX) del himno con marcas que señalan el "hallazgo" de Guido d'Arezzo y los fonemas que a partir de allí quedaron asociados al solfeo universal

44 En un trabajo de traducción y comentario de la epístola realizado por un equipo de investigadores de la Universidad Nacional de Mar del Plata puede leerse que para sus realizadores dicha tarea significó «rendir homenaje a quien posibilitó interpretar a Bach, Mozart, Elvis Presley, una melodía para koto o quizás, cánticos rituales de los papúas [...] Es sin lugar a dudas, un aspecto de la escritura mucho más revolucionario que la letra carolina hacia el siglo IX o la imprenta, con posterioridad. Es tan decisivo, que marca un antes y un después [...] pero creemos que no pudo atisbar o darse cuenta de lo relevante de su obra: había inventado el lenguaje musical autónomo y libre de marcas o letras» (Rigueiro García, 2015, p. 1). En estas líneas el compilador y director del trabajo, un historiador, nos brinda todos los argumentos de por qué debemos ocuparnos de esta música y esta historia cuando pretendemos indagar sobre la historicidad de la música popular. Todos los presupuestos de la musicología afirmativa y su prepotencia colonial para pensarse en posesión de la genealogía de todas las músicas, incluida la música popular, están presentes en esta primera página, escrita recientemente en Argentina y en una Universidad pública, gratuita y de ingreso irrestricto. 
Como puede verse, la tarea pasa por anular el devenir musical para quedarnos únicamente con las referencias (ya no con los sonidos) que nos interesan puesto que, si conservamos las notas y los fonemas señalados, en el orden que aparecen en la partitura, y eliminamos todo lo demás, lo que resulta no es otra cosa que una escala diatónica mayor de seis grados, con las dimensiones interválicas que ya conocemos: tono-tono-semitonotono-tono. Pero es importante resaltar que el resto del canto, en tanto totalidad de la materialidad sonora, incluido el texto, nos estorba, es algo que hay que apartar, correr, difuminar, para ver (y ya no escuchar) la música, que de esta forma ya está operando de forma abstracta, ideal, aritmética y por sobre todo, silente. Toda la significación sonora que tenía el himno, su deambular melódico, su resonancia circular, el sostenimiento de ciertas notas con las consecuentes tensiones y cesuras, la expectativa en la ampliación del ámbito hacia el agudo, gradual y siempre sorprendente. Y además, todo lo que no muestra el papel: las discrepancias de afinación, de textura y sincronismo entre todos los que cantan, la heterogeneidad de los timbres vocales, mucho mayor cuanto más numerosos son los cantantes y menos profesionales, es decir cuanto más devocional y popular es la ocasión musical. Podemos tomar como un buen ejemplo de todo esto que queda fuera del solfeo, la performance del himno por el músico aficionado italiano Dante Basili, acompañado por un armonio de fuelle ${ }^{45}$. Es muy interesante reparar en la forma de fonación del cantante, cuya sonoridad nasal y rugosa despierta ciertas asociaciones con sonidos de Medio Oriente o a lo sumo de Europa del Este. Es un modo de canto que se desvía notablemente de la sonoridad "gregoriana" a la que estamos acostumbrados.

Al contrario de todas estas marcas performativas del musicar, la operación de Guido se enmarca históricamente en lo que Leo Treitler (1991) caracteriza como la victoria del norte europeo sobre el sur mediterráneo, Occidente sobre Oriente, que es además la victoria de la racionalidad sobre la sensualidad, de la medida sobre la exuberancia sonora, que fueron algunas de las pocas pautas comunes en las músicas de culturas muy diversas de Medio Oriente, el norte de África y Europa del este. Es el momento que emerge luego del ciclo carolingio que, sin ir más lejos inaugura Occidente por contraste con ese otro, "Oriente". La abstracción del esquema racionalizado, la forma, el código (Attali, 2011), es un paso necesario que en el inicio de la modernidad permitirá inscribir a la música en el cambio. Es decir que, para transformar el musicar en objeto y luego introducirlo en el mercado, era necesario contar con la racionalización y la abstracción convertida en código, operada por el ars teorica medieval. El medioevo monástico, que privilegia al teórico por sobre el músico que hace y manipula los sonidos, construye la teoría sobre la cual la burguesía moderna desarrollará su repertorio. De esta forma, muchos de los atributos y procedimientos que forman parte de la composición "en papel" despegan con el himno de Guido. Pues la notación musical tal como la conocemos requiere de este tipo de abstracción. Justamente a partir de esta época en que el monje de Arezzo escribe su famosa carta, la notación dejará de "copiar" al sonido de forma analógica, es decir simulando con sus trazos la trayectoria temporal del sonido, para dar lugar a un sistema notacional abstracto, sígnico, en el cual los grafismos ya no se parecen en nada a lo que suena. La notación deja de emular la materialidad sonora para comenzar a regularla, puesto que la partitura que, como los nombres de las notas, es convertida en sinónimo de música, pasará en la modernidad a ser punto de partida del musicar, a su vez transformado en representación pública. Al propio Guido se le atribuye el organizar esa notación abstracta a partir de introducir las líneas horizontales y las claves que fijan la referencia de las alturas.

${ }^{45}$ El ejemplo 1 puede escucharse aquí https://www.youtube.com/watch?v=cINIYThgCKs 


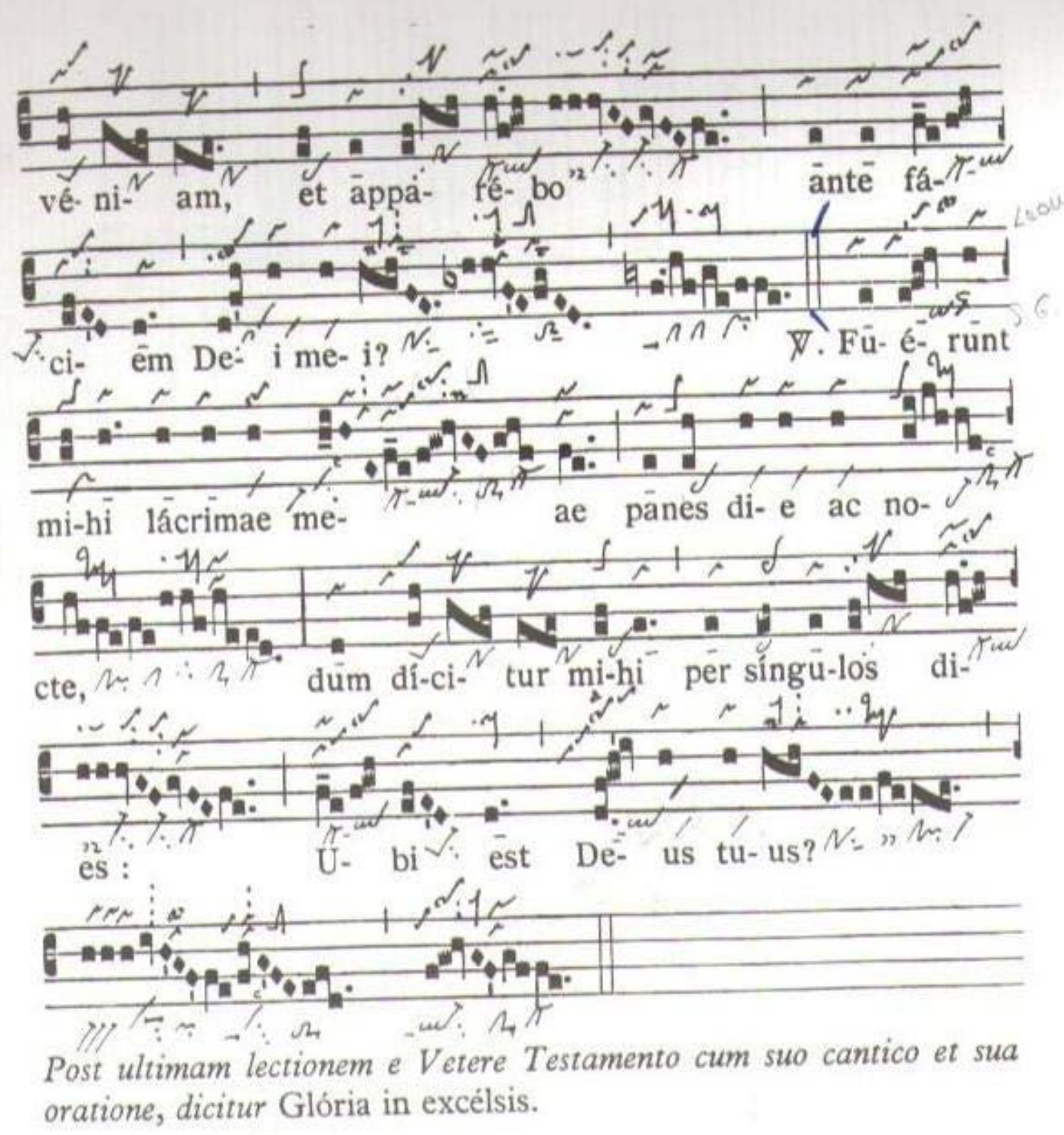

Transcripción gregoriana que conserva como referencia, por encima y por debajo del tetragrama, la notación neumática antigua. De este modo puede verse el contraste entre la concepción analógica y la abstracción que manifiestan ambos códigos.

Como reconoce Paul Lang, "Solamente al introducirse la importante innovación de la pauta llegaron los neumas a significar algo más que un simple auxiliar de la memoria» (1963 [1941], p. 68). Ese "algo más" es precisamente lo que abre las puertas de toda estratificación musical posible ${ }^{46}$, lo que hará que esta música, la que se deriva de las pautas y del solfeo de los monjes medievales, sea denominada culta. Por eso la epístola y el otro tratado de Guido, el muy famoso Micrologus ([1026]1904), que convierten ese canto

46 Keir Keightley, ocupándose de la estratificación en el Rock (un repertorio en apariencia muy lejano a los himnos medievales), establece precisamente la emergencia de la actitud de superioridad y desdén en esa pretensión de que el Rock es "algo más" que música popular. «El pop engloba la música popular que no puede «tomarse en serio» (o que no tiene que tomarse en serio, o que jamás podría tomarse serio). Muy al contrario, el rock es la música perteneciente al torrente masivo que sí es tomada en serio (o que debería tomarse en serio)» (Keightley, 2006, p. 178). Recordemos que para la musicología anglo y germanoparlante, la música "culta" se denomina música "seria". Deberíamos tomar "en serio" estas recurrencias de la estratificación y pensarlas como "algo más" que casualidades. 
desconocido en poder instrumental del saber, son elevados por la musicología al rango de momento fundacional de la historia de la música. Para Howard Goodall, autodenominado "distinguido historiador de la música» (Goodall, 2019), representan el primer "big bang" de la historia musical (Goodall, 2001). No es poca cosa. Bien merecida tiene el monje su escultura en el friso del Parnaso. Así como celebran a San Ambrosio, Lang y también Hoppin reservan loas para Guido. "La obra de Guido [es] una de las de mayor trascendencia en la historia de la música» (Lang, 1963 [1941], p. 68). Pero Hoppin es también consciente de la estratificación que conlleva la abstracción y racionalización del sonido, la valoración diferencial que emerge de las pautas y los fonemas que desmaterializan la música

Armado con estos nuevos avances, Guido era capaz de producir un cantor perfecto en el espacio de un año, o a lo más, de dos, mientras que anteriormente, diez años de estudios habían logrado sólo un conocimiento imperfecto del canto. El gran cambio era, por supuesto, que los cantores podían ahora leer e interpretar una melodía que no habían oído nunca antes. Guido era muy consciente de la importancia de su contribución y del vacío que ésta llenaba. Como él dijo, con una limitación quizás innecesaria, en nuestros tiempos, de todos los hombres, los cantores son los más necios. (Hoppin, 2000, p. 74)

Pero hay más historia afirmativa cifrada en los himnos: de hecho el vínculo con la himnodia griega es una de las frecuencias temáticas más recurrentes de la musicología para ligar la tradición clásica -y su venerable pasado- con la historia de la música occidental (probablemente la razón por la cual Homero, Pitágoras y Virgilio aparezcan en el friso del Parnaso). Además, se creyó durante mucho tiempo que en los versus del siglo XII que acompañan la himnodia de la abadía de San Marcial de Limoges aparecía nada menos que el primer contrapunto, es decir, el origen de la armonía, rasgo que la musicología histórica atribuye con exclusividad a la música occidental culta; de hecho es en base al himno Pange Lingua que Josquin des Prés compone a comienzos de la modernidad la misa homónima que representa una de las primeras músicas del canon musicológico. Recordemos que estos tres personajes (Ambrosio, Guido y Josquin) son las personalidades "musicales" del Albert Memorial que van trazando una línea histórica desde los "orígenes" hacia la modernidad. Mediante el himno guidoniano podríamos seguir hilvanando la producción de muchos otros compositores del friso del parnaso: Palestrina, Monteverdi, Bach, Mozart47, Beethoven, etc. Por lo tanto, en la medida en que la musicología histórica hace descansar en este monje buena parte de los procedimientos, la estructura y la teoría de la música culta occidental, deberíamos concluir que los himnos, fundamentalmente el himno "originario" medieval, están en las antípodas de la música popular, tan alejados como las músicas de los compositores del friso a las que nos referimos antes.

Todo esto nos devuelve a una pregunta muy importante a la hora de discutir sobre la naturaleza de la música popular, la estratificación musical y el carácter afirmativo de la musicología ¿Es que la afirmatividad o, para el caso, el carácter popular, son una condición inherente a las formas de la música, algo que está impreso en su estructura? ¿O, como suele ser el caso para los estudios culturales y el relativismo posmoderno, no importa cómo es la música sino las actitudes que las personas tenemos hacia ella? ¿Podemos parafrasear a Arthur Danto (2010) y decir que cualquier música puede ser popular o culta mientras haya alguien que diga o piense que es tal cosa? Ensayemos una indagación sobre

47 Palestrina publica en 1589 un ciclo de más de treinta composiciones polifónicas sobre himnos medievales; las vísperas de Monteverdi de 1610 contienen una composición sobre el himno Ave Maris Stella; los corales de Bach, que constituyen la piedra angular de todo su repertorio, son himnos protestantes; Mozart compone "dos himnos alemanes para voz y órgano" en 1779, y a fines del siglo XX la Unión Europea elige como el himno de Europa la "novena sinfonía" de Beethoven. El penúltimo compositor del friso del Parnaso es Thomas Arne, autor de la primer versión del God save the Queen, es decir, el himno británico. Incluso en la Inglaterra victoriana existió un auge del himno cuyo clímax lo representa la publicación de los Hymns Ancient and Modern en 1861, justamente el año de la muerte del príncipe Alberto. 
los himnos medievales, repertorio impensado si los hay a la hora de acometer un estudio sobre la música popular, y veamos qué podemos encontrar además del ejemplo disciplinador de Guido, que hasta aquí claramente está del lado de la música culta, casi como piedra fundamental de todo su edificio.

Cuando Marta Zátonyi (2007, p. 31) quiere referirse a las diferencias entre la cultura de élite y la cultura popular, elige ilustrar su descripción con la película El séptimo sello, de Ingmar Bergman. Aunque es un film que no forma parte del mainstream y tampoco es muy popular, Zátonyi se las arregla para utilizarlo como metáfora de las figuras que simbolizan el arte de uno y otro ámbito, el juglar y el trovador. En la película hay una larga escena que ficcionaliza una ocasión que tiene lugar en la plaza central de una aldea medieval. En ella se puede ver y escuchar a un grupo de músicos ambulantes sobre una precaria tarima, llevando a cabo una sencilla presentación de canciones, danzas y pantomimas frente a un público de campesinos y artesanos. El contenido musical de la escena descansa sobre algunas reconstrucciones que diversos ensambles y conjuntos de "música antigua" suelen presentar, por ejemplo el Studio der Frühen Musik48 ([1970] 1985) o Atrium Musicae 49 (1976). En el próximo capítulo analizaremos algunas de estas músicas que, al menos en apariencia, nada tienen que ver con los himnos. Volvamos a la escena. Transcurridos varios minutos -y estrofas- de una canción de los juglares, éstos se ven súbitamente interrumpidos por la aparición, en el mismo espacio público, de una procesión de penitentes y flagelantes ${ }^{50}$. El contraste es muy vivo y notorio, y lo más perceptible y abrupto deriva fundamentalmente de lo musical más que de lo visual, ya que anuncia el cambio. La canción de los músicos ambulantes es silenciada, justamente, por un himno. Este momento podría interpretarse como el enfrentamiento que desarrolla Attali retomando otra escena, la que pinta Pieter Brueghel en el combate de carnaval y cuaresma. Es el conflicto entre «dos poderes, dos procesiones, dos campos, dos vías, dos relaciones con el mundo [...] Armonía y Disonancia. Orden y Desorden» (Attali, 2011, p. 36). Son tanto estrategias culturales como políticas las que están en lucha, pero que se reúnen en un aspecto común: la Fiesta que hace tolerable la desdicha común de las mayorías y la Austeridad que promete la eternidad a cambio de «tolerar la enajenación de lo cotidiano» (Attali, 2011, p. 36).

\footnotetext{
${ }^{48} \mathrm{El}$ ejemplo 2 puede escucharse aquí https://www.youtube.com/watch?v=Jht2Ehdo4zk

$49 \mathrm{El}$ ejemplo 3 puede escucharse aquí https://www.youtube.com/watch?v=PotHYm2- Wc

$50 \mathrm{El}$ momento referido, ejemplo 4, puede verse aquí https://www.youtube.com/watch?v=VhnWf $6 \mathrm{Pf98}$
} 


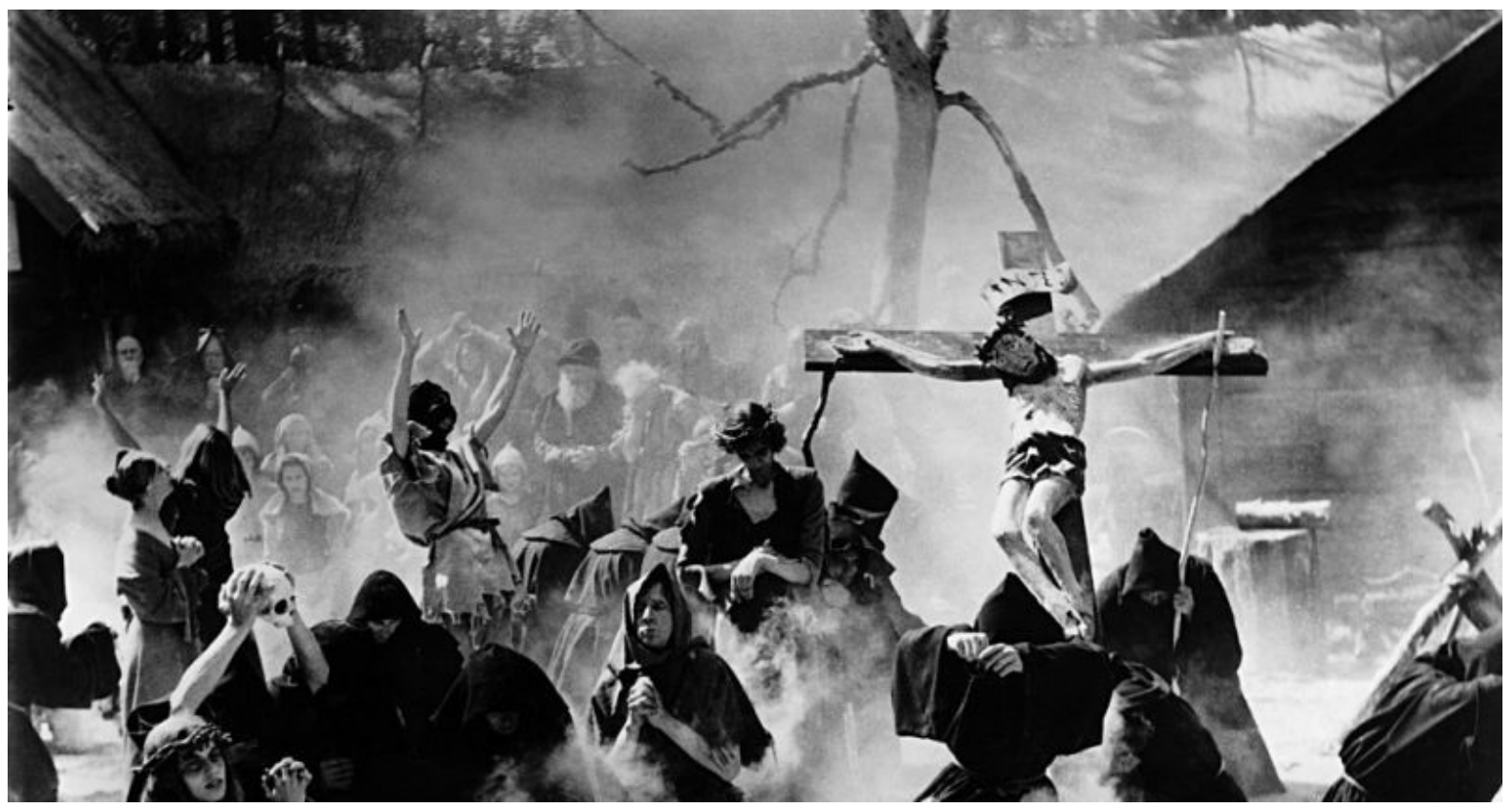

Fotograma del film El séptimo sello, de Ingmar Bergman, donde se muestra el arribo a una aldea de una procesión medieval.

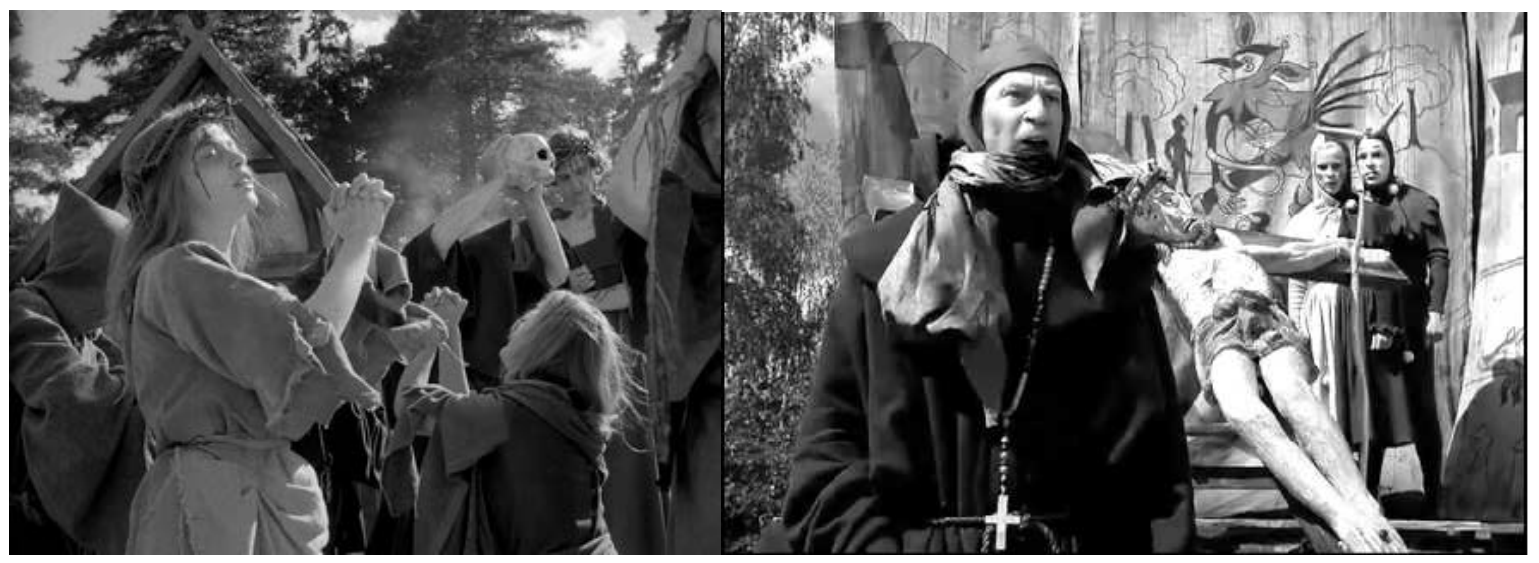

Izq: fervor popular religioso en la aldea medieval. Der: el clérigo y los juglares, notable síntesis del mundo popular medieval que propone esta escena del séptimo sello

Sin embargo la secuencia visual de El séptimo sello nos muestra también otro registro, que no contradice este dualismo, sino que más bien refuerza la forma desarticulada y contradictoria en la cual ambas actitudes se integran en el mundo popular subalterno. Los personajes que podríamos asociar con "el pueblo", los campesinos y campesinas, artesanos, soldados, músicos y artistas, no se resisten a la interrupción, sino que modifican su actitud, casi como respondiendo a un automatismo, para adecuarse a la presencia de las reliquias que transporta la procesión y al marco penitencial que la rodea. Todos se conmueven ante la presencia del grupo, de los símbolos como la gran cruz, el relicario, las coronas de espinas y los látigos. En un primer plano vemos cómo las lágrimas escapan de los ojos de una joven campesina que hasta hace unos instantes reía ininterrumpidamente ante la canción popular. En la escena, no vemos a quienes cantan el himno. Pero podemos suponer que tanto el grupo procesional como los aldeanos han de unirse en el canto. La música de la banda sonora reproduce una de las versiones de himno latino más habituales, en canto al unísono aunque, por tratarse de una procesión, lleva añadido un tambor que marca un pulsar regular. Es decir, no estamos simplemente ante la presencia de un choque entre la música culta que se sobreimpone a partir de la represión de cualquier otra manifestación, sino que debemos comprender que el universo mítico de la cultura popular 
medieval está atravesado también por la religiosidad y sus valores en torno a la penitencia y la carestía. Es un mundo donde por momentos lo apolíneo y lo dionisíaco conviven, aunque en realidad esas categorías no sirven en absoluto para describir la cultura popular, justamente porque están concebidas desde un antagonismo que no permite la coexistencia. La irrupción de la procesión no es la aparición de la autoridad, de la cultura legítima que representan Guido d'Arezzo y la intelectualidad monástica que formula la doxa musical. Ni los flagelantes ni el clérigo que los conduce son parte de los príncipes eclesiásticos de Roma, ni de la aristocracia de las cortes feudales o los castillos imperiales. En el barro de la aldea tanto las canciones como los himnos religiosos, sobre todo si son de alabanza o de penitencia, responden a formulaciones sonoras que forman parte del mundo popular. Nada tienen que ver con la teoría guidoniana, la notación musical, el solfeo y la armonía.

Para hacernos una idea, podemos ahora introducir ese otro himno medieval que prometimos tratar más arriba, en contraste con el himno a San Juan. Esta otra canción deriva de la necesidad de poner música al caminar, como en la procesión y también en la peregrinación. Es muy conocido porque en algún momento se lo transcribió en notación aquitana y terminó como añadido, en una suerte de segundo anexo, del famoso manuscrito E-SC del siglo XII, conocido como Codex Calixtinus. Las particularidades de su notación, que difiere frente a la de otras músicas contenidas en el primer anexo, hacen pensar a algunos investigadores que este himno, aunque se escribió con posterioridad al resto del códice (Gómez, 2009, p. 200), es en realidad bastante anterior a la compilación del mismo (Solana, 2014). 


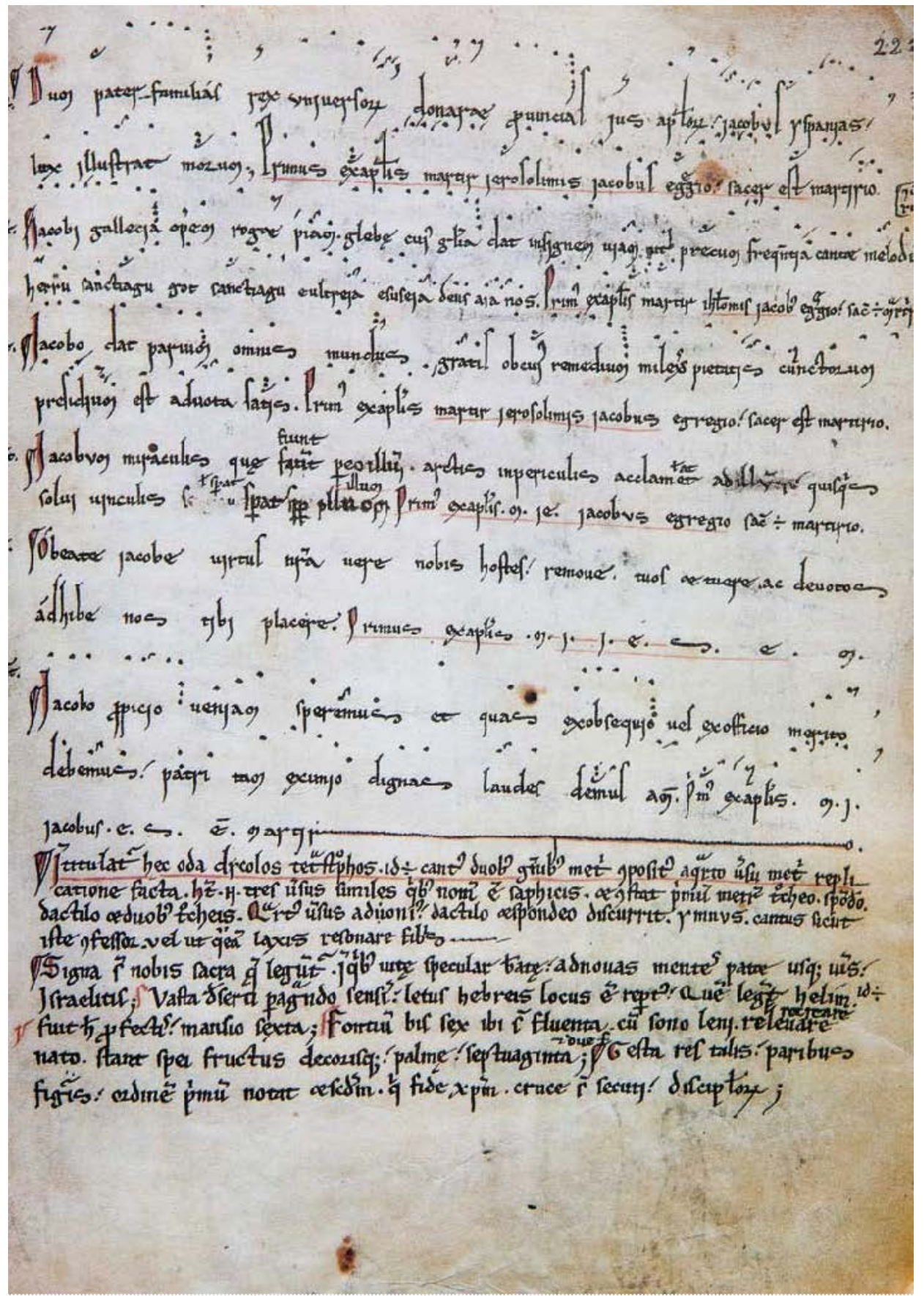

Folio del Codex Calixtinus con la "partitura" del himno Dum pater Familias

El himno se llama Dum pater familias (tomando como es costumbre las primeras palabras del verso inicial) y, si bien se halla en un códice de la Iglesia, no es una música litúrgica, sino devocional. Es una canción que muy probablemente cantaran los peregrinos que se dirigían al santuario del apóstol Santiago, en la ciudad de Compostela, en la actual Galicia. Algunas hipótesis afirman que se lo entonaba principalmente en el momento en que los peregrinos llegaban a la plaza frente a la catedral. Como puede verse, la notación es muy imprecisa, aún en cuanto a las alturas, ya que es adiastemática: no hay líneas ni claves, es decir, ninguna de las "innovaciones" de Guido d'Arezzo. Todavía menos el manuscrito nos ofrece información acerca de cualquier otra dimensión musical: no hay signos ni indicaciones sobre la textura, el ritmo, las articulaciones, la intensidad, la sonoridad, la densidad, etc. Recordemos el peso histórico que Lang le otorgaba a la pauta 
de Guido, ya que constituía una importante innovación frente a este tipo de registros que transcriben una música que ya forma parte de una práctica musical muy conocida. Son un ayuda memoria, un recordatorio de lo que ya se sabe, que es la forma de funcionamiento principal de la notación musical medieval (Treitler, 1981, p. 474; Taruskin, 2005a, p. 213). Pero para que eso funcione hay que saberse la música y, en ese sentido, se trata de un saber que podríamos llamar localizado o local, no porque pertenezca a una región o geografía sino porque está inscripto en las personas que lo saben y porque depende de la continuidad de las prácticas (Treitler, 1981, p. 475), es decir del musicar, que es precisamente lo que suele asociarse con la música popular. Nadie tiene la llave maestra que abre las puertas de todas las canciones, pretensión que sí habita en cambio en las líneas y el solfeo de Guido, y que la musicología afirmativa convertirá en pauta universal, manifestación de poder sobre todas las demás formas de musicar. Por el contrario, quienes hayan escrito esta página del Dum Pater Familias no estaban componiendo en el sentido moderno, ni pretendían fijar esta música para la posteridad. Hacían un bosquejo de lo que ya se cantaba de oído, mediante la práctica y la participación. De allí que hoy en día existan numerosas versiones de este himno, muy diferentes entre sí de acuerdo a cómo se interpreten las coordenadas históricas de esta música que, más que en ninguna otra interpretación, vienen aquí a poblar los numerosos huecos y vacíos que deja la notación. Si en la ejecución de una partitura moderna la carga estética e histórica modifica sensiblemente lo sonoro, en estas músicas prácticamente representan la totalidad de la significación. Estas "lagunas" en la partitura pueden darnos una sensación de vacío, lo que lleva a que generalmente consideremos este tipo de notación como "deficiente", ya que le falta "información" y no transmite de la música "todo lo que debería". Pero en esa queja está hablando la afirmatividad musicológica que, insistimos, transformó en norma lo que en realidad es una anomalía, ya que la música no está en el papel, sino en la ocasión sonora. Esta es la razón por la cual el investigador y músico Marcel Pérès, director del Ensemble Organum, señala que la notación medieval anterior a la pauta deja libradas al intérprete muchas decisiones, justamente porque considera estos aspectos demasiado importantes como para dejarlos librados a la escritura:

La llamada música medieval considera el ritmo tan importante que su realización es responsabilidad del intérprete. Es una dimensión ajena al solfeo contemporáneo, lo que explica por qué el ritmo de la música anterior al siglo XIII le ha ocasionado tantos problemas a los hombres de los siglos XIX y XX" (Stan, 2016, p. 7)51.

Peres no está refiriéndose a los compositores contemporáneos sino a los musicólogos y especialmente a quienes son responsables de la forma del canto cristiano que emergió a fines del siglo XIX y principios del XX de los estudiosos de la abadía de Solesmes, y que es el que todos asociamos con el estándar de "canto gregoriano". No es la sonoridad que escuchamos en la versión del himno a San Juan antes referida sino la que encuentra su modelo en las grabaciones de los monjes benedictinos de la Abadía de Santo Domingo de Silos. Su versión de este himno es muy diferente 52 . Este sonido no está inscripto en la notación ni responde a una forma de producción continua. Es un consenso relativamente actual y no una tradición medieval, salvo que volvamos sobre la definición de Raymond Williams (2000) de tradición selectiva. Como dice Paul Griffiths (2009), es una sonoridad tan antigua como el paraguas o el avión. No es medieval, y claramente podemos asociarla a la afirmatividad de la musicología, de la que es estrictamente contemporánea que, como ya señalamos, ve en lo histórico un problema.

51 «La musique dite médiévale, considère le rythme avec une telle importance, que sa réalisation relève de la responsabilité propre de l'interprète. C'est une dimension étrangère au solfège contemporain, ce qui explique que le rythme des musiques antérieures au XIIle siècle ait posé tant de problèmes aux hommes des XIXe et XXe siècles» (Stan, 2016, p. 7) [Traducción del autor]

52 El ejemplo 5 puede escucharse aquí: https://www.youtube.com/watch?v=UpolqkdLOAk 
Pérès y el Ensemble Organum, en cambio, han trabajado mucho a partir del estudio histórico para construir alternativas sonoras a este consenso de la tradición "gregoriana". Por eso seleccionamos su hipótesis interpretativa del Dum Pater Familias, que grabaron en el fonograma Compostela. Ad vesperas Sancti lacobi (Ensemble Organum, 2004)53, que es precisamente una compilación de varias piezas del Códice Calixtino. Ya desde el comienzo, esta versión es llamativamente divergente al modelo que acostumbramos tener en el oído sobre la música medieval. Los primeros sonidos, el comienzo de la primera estrofa por el cantante que oficia de guía, irrumpen con decisión, con una articulación casi percusiva de bordes duros. No se esconden las consonantes ni se suavizan los timbres. Por el contrario pareciera que se busca la heterogeneidad del sonido, lo cual es mucho más evidente cuando aparece el coro en su totalidad. Es un buen ejemplo de las discrepancias participatorias de Charles Keil (2001). Si éstas se encuentran, como señala su autor, en el ritmo, el sonido y la textura, el Dum Pater Familias de Pérès es un caso paradigmático. Es un efecto que además se refuerza porque la melodía de la canción es ornamentada permanentemente por melismas extensos que incorporan microtonos, lo cual hace muy heteróclito el trazo grueso que configura la suma de las voces. Además la emisión vocal es casi de garganta, sobre todo en los bajos. Esto es una aproximación al canto medieval que Pérès decide en base a sus investigaciones, mediante las cuales sostiene la hipótesis de que la sonoridad medieval europea tenía conexiones muy estrechas con la Iglesia Ortodoxa bizantina y otras culturas musicales de Medio Oriente. La hipótesis, que pone en crisis todo nuestro imaginario de la música medieval, se deriva de que en varios enclaves occidentales se han mantenido formas de cantar aparentemente muy antiguas, por ejemplo en Córcega (una isla) o España (separada de la cristiandad durante prácticamente toda la Edad Media). Sin embargo hay que tomar con mucho cuidado esto, ya que no se trata de reemplazar un dogmatismo por otro, razón por la cual no debemos considerar la versión de Pérès en términos positivistas, es decir, como el sonido "tal cual fue".

En todo caso, hay ciertos elementos de la versión que pueden ayudarnos al menos a penetrar en la historia con la cual el himno de Santiago está emparentada. El Dum Pater Familias que escuchamos tiene peso, cuerpo, cadencia. Si algo no propone, es la abstracción. Avanza con paso firme, rasgando el silencio, imponiéndose sobre cualquier otra sonoridad que pudiera salirle al paso. Como en la escena de Bergman, irrumpe y se impone. Si hay una música que se propone convencer, en sentido retórico, al punto de conmover un sistema de creencias, esta versión del himno jacobeo es un buen ejemplo. Y esto no es casual ni un capricho esteticista de los intérpretes. Como dijimos, procede de una hipótesis histórica, la de la peregrinación al santuario más popular de Europa después de Roma, Santiago de Compostela. Este canto es producto de las ocasiones musicales asociadas a los rituales, a la devoción y la aventura que significaba el peregrinar a uno de los puntos más remotos del mundo medieval, desafiando no sólo los peligros "habituales" sino además la proximidad del mundo musulmán del Al andaluz ibérico. El camino de Santiago es una ruta muy particular ya que, como un río de múltiples afluentes, va concentrando las vertientes para hacerlas converger en el punto límite occidental del continente. Compostela es un vórtice cultural. Es el emergente de una cultura medieval en la cual confluyen las maneras musicales de toda Europa occidental e incluso de algunas culturas orientales. $Y$ es así que peregrinos que hablan diferentes lenguas, que pertenecen a clases sociales distintas, practicantes de oficios de los más diversos, desposeídos, junto a señores y clérigos, se unen en la ruta, situación que continuará también en la modernidad. «A los peregrinos de modesta condición social se une una masa pintoresca de pícaros, vagos y maleantes, que van de santuario en santuario haciendo profesión de su condición de peregrinos» (Lacarra, 1966, p. 38). Es este un conjunto bastante estrafalario que, si contrastamos con la pintura de la cual Attali extrae su confrontación, se asemeja más a la

53 El ejemplo 6 puede escucharse aquí https://www.youtube.com/watch?v=K40YdA1xe9c\& 
procesión del Carnaval que al desfile que sigue la figura de la Cuaresma. Esto puede advertirse en el propio himno, ya que su estribillo contiene exclamaciones y vítores al santo en varias lenguas romances y germánicas: "erru Sanctiagu / Got Santiago / e ultreia e suseia / Deus aia nos». El término ultreia incluso conforma una denominación alternativa con la cual también se conoce al Dum Pater Familias. Es una invitación a sumarse en el canto, a cantar juntos. En opinión de Alberto Solana (2014) esta característica, que también comparte con otros cantos del Códice Calixtino, es un indicio del carácter conocido y popular de la canción jacobea. Pedro Calahorra (2003) reafirma esta percepción del carácter popular del Dum Pater Familias, justamente porque su estribillo invariable permite la participación de todo el colectivo y por la misma configuración del estribillo, regular, recurrente, pegadizo, de fácil memorización. En su relato analítico, este autor construye una escena imaginaria que protagoniza la multitud incesante de los peregrinantes en la meta final del camino. Compara esta escena con la de otro sitio de peregrinación medieval, el santuario mariano de Montserrat. Podríamos añadir que no es difícil imaginar a los personajes de la aldea de Bergman protagonizando estas peregrinaciones, cantando sus canciones y tomando parte en las danzas y festejos.

\begin{abstract}
No podemos ver a los peregrinos llegar cantando a la tumba del Apóstol y a continuación sentirlos silenciosos en su vigilia ante la misma. Al contrario, oímos un canto masivo, rudo, vociferante, imponente, constante, difícil de acallar. El templo compostelano era el lugar donde explotaban sonoramente todos los sentimientos que habían ido naciendo y creciendo durante el camino hasta eclosionar con fuerza al final, en la meta, en el bronco saludo a Santiago [...] Alguien ha traído fuego y unas brasas de una girola [...] y en grandes recipientes se prepara un reconfortante caldo gallego. Mientras, unos han empezado a puntear y soplar distraídamente sus instrumentos. Alguien ha añadido su voz, otros se han puesto en pie y, en un momento, la cerca compostelana es un recinto rebosante de fiesta, música y danza. [...] No es difícil transportar la escena de los peregrinos danzando dentro y fuera de la iglesia del monasterio de Montserrat a la catedral compostelana, a sus plazas y a los soportales de sus rúas, en los que hemos dejado "los mil peregrinos de cada día", en torno a las hogueras, contentos, danzando, girando, cantando cánones y canciones. (Calahorra, 2003, pp. 142-148)
\end{abstract}

De modo similar, Margot Fassler nos invita a imaginar a una «multitud cantando el himno de los peregrinos, Dum Pater Familias [tocando] los instrumentos musicales mencionados en el segundo libro [que] recuerdan a los que aparecen en el Pórtico de la Gloria de la Catedral de Compostela» (Fassler, 2014, p. 117). ${ }^{54}$ Esto se asemeja a otras hipótesis sonoras, por ejemplo la del New London Consort (1991), con dirección de Philip Pickett ${ }^{55}$ y la de New Orleans Música de Cámara (2000)56. En ambos se refuerza la ligazón con sonoridades atravesadas por el canto colectivo, la danza y el movimiento. En todo caso, se alejan muchísimo del ideal gregoriano y de la doxa teórica de las pautas y el solfeo guidonianos.

Pero en lo que escuchamos de la versión del Ensemble Organum hay todavía más elementos importantes: aparece la polifonía improvisada o performática (ya que la fuente escrita no la prescribe) con una nota pedal que va realizando una suerte de acompañamiento de sostén. Esto es interesante pues esa nota de apoyo facilita la entonación para unos cantantes que, como en las escenas referidas, son aficionados y no expertos músicos profesionales. Y también es sorprendente que hay un ritmo muy marcado y regular, casi pulsado. La explicación de esto es muy sencilla, pues se trata de una canción

\footnotetext{
54 «We can imagine the throng singing the pilgrims' hymn Dum Pater familias [...] The musical instruments mentioned in Book 2 recall those shown on the Portico de la Gloria of Compostela Cathedral» (Fassler, 2014, p. 117) [Traducción del autor]

55 El ejemplo 7 puede escucharse aquí: https://www.youtube.com/watch?v=n-5mx508YYs\&

56 El ejemplo 8 puede escucharse aquí: https://www.youtube.com/watch?v=-zStMPCafLU\&
} 
para cantar mientras se camina. Pero es tan fuerte la huella musicológica de la sonoridad "gregoriana" que percibir un pulso regular en esta música nos interpela, cuando debería ser un sobreentendido. Estas son las consecuencias de apartar de la realidad sociocultural el estudio de la música. La afirmatividad esconde incluso lo obvio y convierte en una excentricidad lo que deberíamos percibir sin sorpresas. Puesto que el proceder hegemónico necesita que lo artificioso y lo abstracto, marcas de la cultura de élite, se nos aparezcan como lo natural.

Estos dos elementos de la versión del himno, conjugados con la estructura estrófica (eso es después de todo un himno), hacen que lo que escuchamos se parezca mucho a un cántico popular. Hay cierto fervor en el canto, una especie de carácter proactivo, nada contemplativo, que podríamos vincular más con un sentimiento de identificación, de expresión y defensa de una convicción, antes que un música para el recogimiento, la meditación expectante o la huida hacia una realidad suprasensible e incorpórea, cosas que sí presenta el paradigma gregoriano. Además, esta sensación se emparenta con el cantar una canción conocida, una actualización de lo que ya se sabe que produce el refuerzo identitario del grupo, el reconocimiento de los que comparten esa localización del saber. Pérès señala que el folio del Códice parece estar escrito de modo precipitado, pues se estaba anotando una canción muy conocida. Por eso el escriba la registra de modo resumido, sin copiar las repeticiones. «El Dum Pater Familias podría ser el himno de "ralliement" que identificaba a los peregrinos en su camino hacia Santiago de Compostela» (Pérès, 2004, p. 15). Este reconocimiento es un factor socialmente trascendente (Frith, 2014, p. 475) en el sentido de una regeneración simultánea de la identidad subjetiva y colectiva a partir de la música, la cual también es al mismo tiempo recreada a partir de esa identificación social e intersubjetiva. Esto implica un "ponernos fuera de sí" que emerge del musicar, pero que no implica la autonomía frente a las fuerzas sociales, valor central de la afirmatividad. La trascendencia (social) nos presenta "un tipo de experiencia alternativa" a esas fuerzas y relaciones existentes en la sociedad, mediante la cual se articula "un sentido de la identidad que puede ajustarse o no al lugar en que otras fuerzas sociales nos colocan" (Frith, 2014, p. 477) ya que nuestro sistema de valores musicales, el que emerge de las prácticas sonoras en las que participamos, «no provienen solamente de nuestras identidades socialmente construidas; también ayudan a darles forma» (Frith, 2014, p. 477). Salirse del propio mundo social, construir un mundo "al revés", un mundo alternativo no es equiparable a la huida del idealismo de la afirmatividad. Porque implica reconocer el propio lugar, hacer participar a la discrepancia, satirizar a esas fuerzas sociales hegemónicas que disciplinan y organizan el código. Este juego del extrañamiento, del disfraz y la máscara para ser por un rato otro, marca del carnaval, es lo contrario al ocultamiento y enmascaramiento de las relaciones sociales. La inversión que propone el mundo popular subalterno, que también es la del proscrito que se hace peregrino para redimirse, es la contracara de la afirmatividad, pues ésta necesita de la autonomía para construir su doxa.

\subsubsection{La autonomía musical como operación afirmativa del canon musical occidental}

Como vimos, la cultura afirmativa opera por abstracción, generando un mundo superior, una realidad poblada por ideas, objetos que están desacoplados de sus condiciones de producción y de la realidad de la existencia. No debiera sorprendernos que su autoimagen se construya como heredera de las teorizaciones (o invenciones) musicales de Guido d'Arezzo. Este carácter abstracto y objetual es un requisito para que en el universo de la cultura, en el mundo del arte y dentro de él, de la música, funcionen las coordenadas que permiten hacer vivenciar esa felicidad posible a quienes acceden a esos objetos. El 
artefacto principal sobre el cual el idealismo y su estética montarán su operatoria es el concepto de obra, que pasará a ser entendida como ideal.

La construcción de la noción moderna de artefacto estético no se puede por tanto desligar de la construcción de las formas ideológicas dominantes de la sociedad de clases moderna, así como, en realidad, de toda una nueva forma de subjetividad humana apropiada a ese orden social (Eagleton, 2006, p. 53)

No por nada la música será la disciplina artística mimada por el romanticismo y la estética idealista. En su caso, justamente, la obra no es más que una idea, la composición que este paradigma supone como las verdaderas intenciones del compositor, las cuales pueden encontrarse en la partitura, es decir, en la matriz silenciosa, que por lo tanto se transforma en la obra. Este pensamiento circular y cerrado sobre sí mismo excluye desde el vamos a la materialización de la música, es decir, ni más ni menos que su concreta existencia sonora. La obra es pensada así como «autónoma, individual, irrepetible, basada en sí misma y existente por sí misma» (Dahlhaus, 1997, p. 20)

La historia de la música que deviene de este modelo idealista, que no es otra que la historia de los estilos que aún hoy es hegemónica, será la historia de las composiciones, de las obras, y su metodología residirá en el análisis de sus partituras. Aún hoy existen clases de historia de la música en las cuales no se escucha ni se toca música. Clases silenciosas en las que se evidencia que lo que importa es una realidad idealizada y desligada de sus coordenadas, precisamente, históricas. Este divorcio riguroso entre el valor estético y la realidad histórica de la música se corresponde con la abstracción de los sujetos y sus relaciones que, como vimos, es un asunto clave para el sostenimiento de la hegemonía burguesa.

En tanto seres abstractos, todos los hombres deben tener igual participación en estos valores. Así como en la praxis material se separa el producto del productor y se lo independiza bajo la forma general del "bien", así también en la praxis cultural se consolida la obra, su contenido, en un "valor" de validez universal [...] sin que interese su posición en el proceso de producción, todos los individuos tienen que someterse a los valores culturales. Tienen que incorporarlos a su vida, y dejar que ellos penetren e iluminen su existencia (Marcuse, 1976, p. 49)

Como puede verse, la abstracción de las condiciones de producción de la música, que no es otra cosa que la autonomía de la forma, es necesaria para la creación de un canon estético que, como veremos más adelante, se universaliza y transfigura en patrimonio obligatorio de esos hombres que participan de la idea de igualdad en la medida en que aceptan dicho canon. No es casual que el parámetro para construir el repertorio ideal obligatorio, que será el único contenido admitido en la historia de la música, es la forma, que para la modernidad es "el atributo esencial de la "música occidental" a lo largo de su historia [...] (forma) que aparece flanqueada por todos su cualificadores (racional, lógica, unitaria, concisa, simétrica, orgánica, etc. )» ${ }^{57}$ (Treitler, 1994, p. 287)

Para el influyente historiador de la música Carl Dahlhaus, uno de los principales adalides de la autonomía musical, la historia de la música debe centrar su relato en las obras musicales que tienen valor estético. Este valor procede de considerar la supervivencia del «carácter artístico (Kunstcharakter) de una música particular más allá del paso del tiempo, porque para Dahlhaus la obra de arte (idealmente) posee una presencia estética que trasciende su propia época» (Schreffler, 2003, p. 7). Este arte que para Dahlhaus posee valor, es elevado al rango de clásico y por lo tanto es necesariamente apartado de la

57 «If there is a single word that can express what is for the modern period the essential attribute of 'Western music' throughout its assigned history, that word is 'form', flanked by all its qualifiers (rational, logical, unified, concise, symmetrical, organic, etc.)» (Treitler, 1994, p. 287) [traducción del autor] 
historia. Podemos entrever aquí un procedimiento que se inserta en el marco de la cultura afirmativa. De hecho, será esa afirmatividad, esa proyección en un mundo superior ideal, la coartada para justificar la valoración diferencial de ciertas músicas de élite y mudarlas de un ámbito restringido y exclusivo hasta convertirlas en patrimonio cultural de la humanidad. Las coordenadas histórico sociales de la producción de estas músicas, suerte de barro de la historia, harían naufragar estas pretensiones ya que en muchos casos delatarían su pertenencia de clase. Pensemos en las obras de las personalidades del friso del Parnaso: la música de Haydn para los Esterhazy, el Ballet de la noche de Lully para que danzara Luis $\mathrm{XIV}$, o los divertimentos sonoros de Handel para los paseos en bote de Jorge I de Inglaterra. Difícilmente un obrero milanés o un campesino peruano de principios del siglo XX fundarían en estos elementos su identificación con tales músicas. Por ende, la historia de la música, la de las obras y los estilos, sólo será posible cuanto menos tenga, justamente, de histórico. Este es el milagro afirmativo de la historia de la música: hacer que los hombres reconozcan como propias las prácticas musicales concebidas para celebrar el poder de aquellos que los someten.

Asunto paradojal a la hora de hacer historia, ya que desde esta perspectiva lo historificable de la música es posible «en la medida en que no participe, justamente, de la idea de arte [...] El que se pueda afirmar algo decisivo acerca de una obra si se la ubica históricamente, se considera como una mácula estética» (Dahlhaus, 1997, p. 36). Por lo tanto, una historia de la música en tanto historia de las obras, es decir, una historia de los estilos musicales, de su evolución, que se revelará a su vez como una historia positivista, se nutre de la idea del arte autónomo.

Esta distinción categórica entre los aspectos internos y externos de la obra de arte no es circunstancial, sino que determina a qué llamamos Arte y a qué no: una obra de arte, por medio de su lógica musical interna y sus aspectos originales, reclama sus pretensiones de "autosuficiencia" (Autonomieanspruch). En el uso que le da Dahlhaus, el principio de autonomía está absolutamente cargado de valor. Incluso tiene una dimensión moral, que aparece en los casos en los que la integridad del compositor le permite resistir frente a las presiones sociales. No importa cuanto Dahlhaus relativice y modere la noción de autonomía musical, llegando a considerarla en sí misma un fenómeno histórico; continúa siendo el concepto central de lo que entiende por historia de la música (Shreffler, 2003, p. 516) ${ }^{58}$

En la actividad historiográfica de Dahlhaus y de los muchos historiadores que han escrito bajo este paradigma, es patente el esfuerzo permanente por trazar una clara distinción entre aquello que es "interno" y lo que es "externo" a la música. Términos como "extramusical", "contexto", o "información histórica complementaria" son palabras clave de los textos de la historia de la música tradicional. En todos los casos, sean estos excursos más superficiales o profundos, se nos deja en claro qué es la música y qué no lo es, colocando la información histórica, es decir periférica, en apartados. Estos pueden darse en forma de un capítulo o tabla cronológica al final del libro, de introducciones acerca de "la época", o de recuadros que aparecen esporádicamente alternando con lo que verdaderamente importa: el relato de la mutación en los procedimientos compositivos a lo largo del tiempo, lo cual, repetimos, es accesible únicamente a partir del análisis de la estructura musical, de su estudio autónomo.

58 «This categorical distinction between internal and external aspects of the work of art is not incidental, but rather determines how we tell what is Art and what isn't: An artwork, by means of its internal musical logic and its novel aspects, claims its "self-sufficiency" (Autonomieanspruch). In Dahlhaus's usage, the autonomy principle is unabashedly value-laden. It even has a moral dimension, apparent in cases where the composer's integrity allows him to resist social pressures.65 However much Dahlhaus relativized and qualified the notion of musical autonomy and even viewed it as itself a historical phenomenon, it remains the central concept of his understanding of writing music history» (Shreffler, 2003, p. 516) [traducción del autor] 
Gracias al imperturbable foco puesto en el interior de las obras musicales autónomas, la investigación de la forma siempre ha emergido como alternativa, y por lo tanto como forma de evasión, de la investigación del mundo de la ética y la política en el que se han formado la música y nuestro paradigma estético. Esto produce, tan a menudo como lo necesitemos, la ilusión de que nuestra música tiene forma y otras músicas no, como resguardo contra el miedo al desorden y la decadencia que ha caracterizado la actitud hacia los Otros. Pero por su misma persistencia esta actitud da testimonio de la actitud política que la sostiene pero que pretende pasar desapercibida (Treitler, 1994, p. 297) ${ }^{59}$

La forma musical es, por lo tanto, una forma de evasión, de huida del mundo, de desconexión entre la música y la historia. Forma musical que no es más que un arreglo rudimentario de partes y que estará sometido a principios estéticos que generarán valor, al interior de la cultura occidental -separando lo culto de lo popular- y en el análisis comparado entre culturas. Un sentido de la forma que será utilizado como indicador de la música occidental y de cuyo devenir temporal, moldeado convenientemente como una evolución continua, se ocupará en exclusividad la historia musical. Los hechos que pertenecen al asunto dependen de una instancia: la relación funcional interna de la obra. La contingencia histórica de la música que, para este paradigma, es un mero estatus documental, confunde el valor artístico al revelar una condición social. «Ese desciframiento dejaría de lado la obra por la obra misma, aun cuando la 'explicara' impecablemente. El cambio de categoría -de obra a documento- no cumpliría la exigencia impuesta por la música como arte y por la cual existe» (Dahlhaus, 1997, p. 74)

Desde el canto gregoriano en adelante, la forma -entendida como producto racional, estructura y orden compositivo- es considerada por la musicología histórica como atributo de occidentalidad. Un rasgo que se construye mediante la concurrencia y reiteración de la narrativa de un sinnúmero de obras musicológicas durante el siglo XIX y XX. La forma es lo que le falta a ese otro cuyas expresiones musicales serán excluidas del canon: los sectores populares, el Oriente venerado pero estigmatizado, y fundamentalmente el mundo colonizado a sangre y fuego por las potencias europeas. Poder económico, científico y también musical celebrado a viva voz en piedra y oro, como en los monumentos que ya analizamos.

No puede sorprendernos en absoluto que este tipo de pensamiento fuera un lugar común en los años del cambio de siglo, la época en la que no se ponía nunca el sol en el Imperio Británico [...] Es difícil pensar en otro campo en el que este tipo de concepciones etnocéntricas y elitistas, que no han pasado la prueba de la crítica, hayan prevalecido de tal modo hasta fechas tan recientes (Cook, 2001, p. 62)

La forma autónoma, la lógica musical inmanente, interna, es lo que no tienen los otros musicales (Treitler, 1994, p. 289). Eduard Hanslick (1947), representante paradigmático del pensamiento musical y estético decimonónico, genera un verdadero culto de la autonomía de la forma, que se proyectará como proclama de la cultura eurocéntrica: «trátase de penetrar las obras para explicar la fuerza específica de su efecto a través de las leyes de su propio organismo» (21) «el independiente bello de la música [...] su reino, en efecto, no es de este mundo» (58) «no admite más explicación que, a lo sumo, la utilidad intrínseca del fenómeno, la armonía de sus partes, sin relación con un tercero fuera del mismo» (61) En sintonía, Benedetto Croce sentenciaba que «el acto estético es forma y nada más que forma» $(1926$, p. 61)

59 «For in the unblinking focus on the interior of autonomous works the investigation of form has always been seized as an alternative to, and therefore an evasion of, the investigation of the world of ethics and politics in which music and our paradigms for the aesthetic have been fashioned. It produces as often as we require it the result that form is what our music has and other music has not, as a security against the fear of disorder and decadence that has characterized the attitude toward the Other. But by its very persistence this attitude gives witness to the politic that maintains it but does not want to be seen» (Treitler, 1994, p. 297) [traducción del autor] 
En ese independiente bello que toda música merecedora de estudio debe contener, repertorio que "no es de este mundo», se concentra la operatoria de la cultura musical afirmativa, generando ese sistema de sentido, impuesto a la sociedad, obligatorio, que se convertirá en un modo natural e invisible de pensar en la música. Así, las valoraciones en torno a la complejidad, la expresión de la subjetividad, la relevancia de la lectoescritura musical, el desarrollo técnico instrumental como indicador de calidad y cualidad artísticas, se introducirán en un sentido común que compartirán incluso todos aquellos que desde la perspectiva del gusto no se reconozcan cercanos al repertorio de la música culta occidental. Es un modo de pensar, una cadena de supuestos interrelacionados y no por eso menos arbitrarios, que configuran nuestro imaginario sobre la música: tener oído pero saber "por música", atribuir al dominio de la armonía prácticamente todo el saber musical, identificar en los compositores la única posibilidad de originalidad y expresión, que aprender música culta permite el acceso a cualquier otro repertorio musical, que es más difícil y hasta honorable tocar música clásica que música popular. Frases que recurren en boca de conductores de taxis -que por todo lo demás no consumen música clásica-, padres sin experiencia musical que aconsejan a sus hijos a la hora de comenzar el aprendizaje de un instrumento, locutores y programadores de radio al comparar y comentar la producción musical y las influencias de un determinado artista, periodistas que utilizan por analogía alguna de estas problemáticas musicales para ilustrar una opinión o noticia. En suma, una idiosincrasia musical que no terminamos de entender muy bien de dónde proviene ya que, justamente, su potencia descansa en desacoplarse de sus propias condiciones de producción, en ocultar su verdadero propósito político y proyectarse a un infinito ideal por fuera de toda relación material y social. Una verdadera cultura hegemónica en la que,

como estas suposiciones se han incorporado a nuestro lenguaje, no podemos hablar fácilmente de ellas; ni siquiera podemos verlas como lo que son. En una palabra, son transparentes. Parecen naturales del mismo modo que el blues parece natural, o que la economía de mercado parece natural, o el modo en que cocinamos. Pero lo cierto es que ninguna de estas cosas son naturales; todas ellas son construcciones humanas, productos de la cultura (Cook, 2001, p. 32)

\subsection{3 ¿Qué cultura afirma la cultura afirmativa?}

Hanslick afirma que el análisis estético autónomo, sustentado en la forma y su lógica interna, descansa en leyes de la naturaleza, dado que lo estéticamente satisfactorio de las formas musicales «se basa en leyes básicas primitivas que la naturaleza implantó en la esencia del hombre» (1947, p. 59). Por lo tanto, al ser lo estéticamente valioso algo natural, se convierte en universal. Condición necesaria para que se transforme en repertorio obligatorio tal cual exige la cultura afirmativa. Al abstraerse el mundo espiritual de la cultura de la totalidad social, se lo proyecta como ideal y se lo transforma en categoría de "un (falso) patrimonio colectivo y de una (falsa) universalidad» (Marcuse, 1967, p. 50). La cultura termina así enfrentada al mundo material e incluso a la misma idea de civilización, lo cual refuerza el alejamiento valorativo de la cultura frente a la sociedad. «El individuo es situado en una colectividad falsa (raza, pueblo, sangre y tierra) [el objetivo de esto, como en la internalización y aislamiento del sujeto, es] el renunciamiento e integración en lo existente» (Marcuse, 1967, p. 72)

Del mismo modo, la narrativa historiográfica sobre la música, porque es un requisito de su carácter afirmativo, se ve «reforzada mediante categorizaciones explícitas e implícitas en torno a la raza, la nacionalidad o el género, articuladas entre el siglo XIX y el XX a partir de disciplinas humanísticas y sociales» (Treitler, 1994, p. 284)60. La universalidad de la música

60 «enhanced with explicit and implicit categories of race, nationality and gender that had become highly articulated during the nineteenth and early twentieth centuries in non-musical humanistic and sociological fields» (Treitler, 1994, p. 284) [traducción del autor] 
culta europea occidental se ve así potenciada a partir de naturalizar ciertos rasgos como exclusivos de la cultura europea, naturalizándolos y ligándolos a consideraciones raciales y nacionalistas, muchas veces implícitas o edulcoradas a partir de comentarios un tanto frívolos acerca de los supuestos "caracteres nacionales", o de ciertas particularidades pintorescas de algunos pueblos: el apasionamiento de los italianos, la racionalidad francesa, la rigurosidad estructural alemana, el primitivismo eslavo, el ritmo del África subsahariana, la melodiosidad de Oriente medio, etc. Son posiciones esencialistas, que buscan identidades homogéneas y congeladas. "Garantías" como las llama Stuart Hall (2010). Esto se contradice con el marcado carácter transcultural de las ocasiones musicales concretas, europeas o no, incluso de aquellas vinculadas con ciertos rituales oficiales, como vimos antes en la canción procesional de los peregrinos de Compostela. Pero se trate de alegatos declaradamente etnocéntricos o de manifestaciones más bien sinuosas, el resultado siempre confluye en reforzar la noción de que todos esos atributos que, como vimos, se asocian a la forma -y por lo tanto al auténtico carácter artístico de la música- son características excluyentes de la música occidental, cualidades que a la vez suponen los sucesivos logros de sus etapas históricas.

La polifonía es Occidente. El teórico medieval sabe sintetizar y de la [conjunción] de dos o más melodías independientes, puede crear una nueva melodía-resultante [...] este fenómeno, con sus peculiares características, es casi exclusivo de Occidente y de un determinado momento litúrgico y religioso en general; los grandes polifonistas del siglo XIII parecen haber sido siempre grandes espíritus religiosos mientras que las instituciones o sociedades no-religiosas de tipo cristiano o de tipo "arcaico" parecen apartarse de las complejidades y riquezas intelectuales del juego polifónico (Soler, 1987, p. 63)

Ya discutimos antes que la sonoridad del momento fundacional de Occidente se asemeja mucho más a los modos de cantar orientales, bizantinos y hasta del Asia menor; y por supuesto incluyen la polifonía, como escuchamos en la hipótesis interpretativas de los himnos por Pérès y Basili. Sin embargo la sentencia de Soler forma parte de una concepción musicológica absolutamente vigente, a pesar del rechazo que hoy pueda producirnos cualquier atisbo de etnocentrismo en los discursos políticos y la producción científica en general: «la polifonía tiene que haber aparecido en la Europa medieval, dado que allí las personas experimentan placer en la cualidad sensorial de la música y en la riqueza sonora de las melodías entrelazadas con su correspondiente resultado armónico» (Kerman \& Tomlinson, 2015, p. 56) ${ }^{61}$. De modo tal que no sólo la posibilidad de la forma racional, de la coherencia y el equilibrio que dotan a la música de valor estético, son patrimonio del Occidente europeo culto. De Europa también son las gentes sensibles que, de modo generoso y desinteresado, nos regalan su privilegiada condición que les permitió trazar una estrecha relación con ese mundo superior de las verdades musicales.

Toda la historia de la música será considerada, a partir de la afirmatividad de la cultura musical europea, como el proceso de contraste progresivo de Occidente frente a Oriente, su antecedente pero, por sobre todo, su gran otro cultural. Y de paso, esto creará las condiciones para lanzarse al dominio liso y llano del milenario continente, que lejos de resistirse deberá ver en el conquistador, en su amo, el regalo de la superioridad cultural.

La historia de la música es en definitiva, la de la asimilación progresiva de la música oriental al espíritu de Occidente [que] resulta de la diferencia esencial entre ambos continentes de un orden jerárquico trascendental [...] así la variedad espiritual y anímica del ser humano está en potencia en el Oriente milenario y sin evolución visible, para ser "desarrollada" en Occidente [...] No conoció Oriente la polifonía, es decir, la simultaneidad de distintos sonidos, en la

61 «Polyphony must have arisen in medieval Europe because people took pleasure in the sensuous quality of music, in the rich sounds of intertwining melodic lines with their resulting harmony» (Kerman \& Tomlinson, 2015, p. 56) [traducción del autor]. 
antigüedad; no la conoce en el presente [...] La armonía en Occidente resulta de la combinación de sonidos armónicos, concomitantes de un sonido fundamental. Así aparecen acordes cada vez más complejos mediante la materialización progresiva de los sonidos parciales inherentes a un sonido fundamental (Leuchter, 1946, p. 16)

Estas líneas de Erwin Leuchter condensan todos los elementos que venimos describiendo: la fundamentación en leyes naturales y en la propia cualidad sonora; el estatismo y el atraso del otro musical; la historia como propiedad de Occidente; la fundamentación extraída únicamente del examen de la lógica interna y las cualidades inmanentes de la obra musical. Es paradójico que Leuchter, un músico alemán con simpatías socialistas, emigrado a la Argentina huyendo del nacionalsocialismo, comparta espontáneamente estas nociones sobre la música que defenderán también los musicólogos precursores del nazismo, como Hans Moser. Allí también vemos cómo se articula la cultura afirmativa, haciendo participar de una misma idea fuertemente racializada a sectores opuestos de la realidad política y social.

La cultura musical europea, el discurso historiográfico idealista, se construye entonces en base a dualismos, todos los cuales se corresponden entre sí: lo bello autónomo frente a lo funcional y contingente; lo masculino y auténtico, frente a lo femenino, lujurioso y decadente; lo racional, estructurado y progresivo de lo occidental versus lo sensible, ornamental y atrasado de lo oriental. Una realidad política e imperial racionalizada, sublimada en la teoría intelectual y el esencialismo idealista. Porque en el centro de la discusión siempre reaparece la división del idealismo, ya inscripta en la antigüedad, entre lo inteligible y lo sensible que, articulándose permanentemente en favor de lo primero, contribuye a construir un otro diferenciado. Lo que con claridad se advierte como una relación de la política del mundo de la existencia, entre dominadores y dominados, se esconde en virtud de la afirmatividad.

Lo interesante, sin embargo, es que la permanente insistencia en estos temas, la abrumadora posición hegemónica de esta perspectiva historiográfica y estética es, tal vez, la que mejor revela esta actitud política que pretende invisibilizarse y hacerse natural. La pretensión de que lo bueno, lo bello y lo verdadero sean valores universalmente válidos y universalmente obligatorios, que iluminan "desde arriba" la vida y la existencia, es justamente lo que revela que "sólo cuando se pretende esto, se crea el concepto de cultura, que constituye un elemento fundamental de la praxis y de la concepción del mundo burguesas» (Marcuse, 1967, p. 47)

\subsection{Positivistas}

El investigador colombiano Egberto Bermúdez escribía en 1982 que la musicología histórica había asumido tardíamente, hacia la década del ' 60 , los postulados rankeanos ${ }^{62}$ del positivismo historiográfico, con su obsesión por la acumulación de datos, la búsqueda de orígenes y el establecimiento de leyes generales, universales y evolucionistas. Es decir que, casi un siglo más tarde que para el caso de la historiografía general, esta metodología se hace hegemónica en la historia de la música. Lo cual la acerca a nuestra época, salteando las fuertes objeciones y contrapropuestas que hacia ella habían levantado numerosos movimientos historiográficos durante todo el siglo XX. Así,

esta transposición mecánica que se comenzó a efectuar en el siglo XIX sigue trabajando hoy en día como idee recu y se ha tomado como legítima metodología histórica [aunque] Es obvio

62 Por Leopold von Ranke, a quien se lo reconoce como fundador de la escuela historiográfica científica, motivo por el cual suele llamarse al tipo de historiografía positivista, "rankeana", además de "acontecimental". 
que una disciplina definida en estos términos y en los que se han citado antes, no contribuya a ampliar de ninguna manera el conocimiento histórico. (Bermúdez, 1982, p. 10-15).

El ensayo de Bermúdez se llama La pobreza del positivismo. Como ya dijimos, se escribió a principios de la década del ' 80 . Sin embargo, el propio autor aclara que no pudo ser leído en el congreso para el cual fue pensado y que sólo pudo publicarse dos décadas después, en las actas de otro congreso, que ya ni siquiera están disponibles para su consulta. El texto se consigue gracias a que el propio autor lo incluyó en su perfil de una red social académica63. Además no aparece como resultado en el buscador, hay que navegar los archivos del autor hasta el final para encontrarlo y está catalogado como "miscelánea". Se lee mal, porque el archivo digital está en baja resolución. Casi como si estuviese borrándose. $Y$ de hecho, cual si se tratara de una operación de edición orwelliana del pasado, este texto permanece ignorado, sin que haya tenido el menor impacto en el desarrollo historiográfico musical regional y mucho menos internacional. La conclusión cuasi profética está contenida en el propio texto que pareciera anunciar que todavía hoy, como hace 35 años, «se hace musicología y se reflexiona poco sobre la teoría» (Bermúdez, 1982, p. 4).

En 1985, tres años después del ensayo de Bermúdez, la Universidad de Harvard publicaría un ensayo del estadounidense Joseph Kerman que causaría cierto revuelo en los espacios académicos angloamericanos, desconocedores absolutos de las reflexiones de Bermúdez. En el texto de Kerman podía leerse lo siguiente:

Se percibe a la musicología como ocupada esencialmente con lo fáctico, lo documental, lo verificable, lo analizable, lo positivista. El respeto hacia los musicólogos proviene de su saber sobre los hechos de la música. No se los admira por vivenciar la música como experiencia

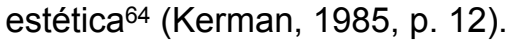

Y en consonancia con Bermúdez, «no hay ni que decirlo: hubo una falta de interés por hacer filosofía o teorizar acerca de qué era lo que los musicólogos estaban haciendo» 65 (Kerman, 1985, p. 43).

Mucho se ha dicho sobre este trabajo, que provocó sensaciones encontradas, sobre todo en la comunidad musicológica angloamericana. Se escribieron muchos papers y reseñas, algunas a favor y otras en contra de lo que se percibió como una denuncia radical: toda la musicología, al menos hasta esa fecha, podía (¿debía?) considerarse positivista. Y más allá de los problemas de definición y las polémicas acerca de la delimitación de la disciplina, a lo que se refería Kerman por musicología era básicamente esa fosilización del canon que ya venimos analizando en torno a los monumentos y las efigies, con su producción de historias de la música "culta" y occidental (Kerman, 1985, p. 36). De modo tal que para Kerman la historia de la música se podía resumir en la construcción de un relato acerca de las músicas compuestas en partitura por autores provenientes de esos pocos territorios.

63

https: //www.academia.edu/33884388/ La_pobreza del_positivismo_el quehacer_musicologico en_Am\%C3\%A9rica_Latina

64 «Musicology is perceived as dealing essentially with the factual, the documentary, the verifiable, the analysable, the positivistic. Musicologists are respected for the facts they know about music. They are not admired for their insight into music as aesthetic experience» (Kerman, 1985, p. 12) [traducción y énfasis del autor]

65 «needless to say, there was a dearth of interest in philosophizing or theorizing about what musicologists were doing». Este argumento también se encuentra en otros autores, como Anne Shreffler, autora que señala el "desafasaje" entre la reflexión de la historiografía general y su ausencia en la musicología "Cómo escribir historia -cómo coleccionar, organizar e interpretar la infinita cantidad de información disponible y cómo presentarla en forma inteligible- es un tema que ha recibido una abundante atención de parte de los historiadores generales, pero mucho menos de los musicólogos" (Shreffler, 2003, p. 498) 
Casi nada se ha dicho en cambio de otro texto de Bermúdez, también de 1985, pero publicado con menos potencia en una revista de la Universidad Nacional de Colombia. En este segundo texto insiste sobre el carácter positivista de la historiografía musical. De hecho podemos considerar que las descripciones de este autor son muchísimo más específicas que las de Kerman y constituyen un intento real de análisis epistemológico del "quehacer musicológico". Allí donde Kerman sólo declara una adscripción a una etiqueta, lo cual se parece más a una denuncia que a una explicación -el contenido de la cita antes referida nunca es desarrollado en el libro-, Bermúdez realiza lo que tal vez sea el primer intento a nivel internacional de descripción del paradigma historiográfico hegemónico en la investigación musical. De hecho, este autor concibe a dicho paradigma como síntesis de aspectos románticos (idealistas) con otros positivistas lo que, para la mayoría de los académicos anglosajones, siguen siendo dos posturas opuestas, sucesivas y mutuamente excluyentes (Stanley, 2001). Bermúdez analiza como indicadores de este modelo historiográfico el historicismo, la autonomía y el fetichismo de la obra musical, el pretendido universalismo, la búsqueda de los orígenes, la renuncia a las explicaciones históricas, el acento en la biografía de 'genios' y en las periodizaciones por estilo, entre otros: "una historia musical divorciada de los contextos que la afectan y a los que afecta, perteneciente a la 'historia interna' de G. Weber, quien la diferenciaba de la 'historia externa' es decir, la social, económica y política» (Bermúdez, 1985, p. 7), lo cual, a nivel más intuitivo, estaba presente a modo de crítica al encierro disciplinar en su texto anterior: "¿Para qué sociología, antropología, ciencia política o historia social; si como piensa Manfred Bukofzer, existe ese humanismo 'científicamente concebido' que permite el entendimiento total del hombre?» (Bermúdez, 1982, p. 6). Es decir que todas las características y nociones de la musicología afirmativa aparecen amplificadas en el positivismo. Cierta ingenuidad, tal vez un rasgo de la época (evidentemente esperanzada en la superación del positivismo), lleva al autor a pensar que esta forma de concebir la historia es cosa del pasado, "del siglo XIX", y que su continuidad en América Latina hasta nuestros días es producto únicamente de una actitud de sometimiento cultural (Bermúdez, 1985, p. 5-8).

Han pasado más de tres décadas desde la aparición de estos textos, que no han tenido continuidad específica en otros autores. Dice Juliana Pérez González sobre el texto de Bermúdez: «Los interrogantes que planteaba el autor, hace treinta años, no se han vuelto a tratar de manera explícita, y las veces que han sido sugeridos, las respuestas han sido evasivas, por lo tanto continúan siendo preocupaciones sin solución». En la revisión de su texto, el mismo autor lo comprendía: «¿Conclusiones? Ninguna». (Pérez González, 2010, p. 38)

Sí en cambio, en todo este tiempo han surgido, como en un estallido, múltiples formas que se asumen nuevas de hacer historia de la música. La mayoría declara justamente su antipositivismo, como si después de los ' 80 s la discusión estuviese saldada66. En el entorno de la musicología anglonorteamericana, este movimiento pasó a conocerse como new musicology, pero en muchos otros lugares se habla desde hace tiempo de una musicología crítica o hasta una musicología radical. El auge del posmodernismo y el postestructuralismo -si es que pueden diferenciarse-, transformados en lingua franca al calor de la globalización del neoliberalismo, conllevó la promoción de algunos conceptos e intereses que pudieron incorporarse a estas nuevas escuchas académicas, como el multiculturalismo -y el relativismo paternalista que contiene-, las problemáticas de género -derivadas del feminismo y las reivindicaciones LGBT-, junto a discusiones acerca de la ideología y las

66 Lo cual, como programa, ya estaba contenido en el texto de Kerman: "Such intellectual interest as musicology can show today emerges out of several strains of reaction to positivism, and out of attempts, either associated with them or not, to develop a new musicology." (Kerman, 1985, p. 58). [Este interés intelectual que hoy demuestra la musicología emerge como resultado de diferentes vertientes que reaccionan contra el positivismo, y de intentos por generar una nueva musicología, asociados o no con dicho rechazo] [Resaltado y traducción del autor]. 
"políticas", fundamentalmente en clave foucaultiana. Es decir que, más allá de los aportes fundamentales de estos estudios en cuanto a la reivindicación de músicas no occidentales, de personas y comunidades musicales por fuera del androcentrismo y de la detección de trazas del micro-poder en una actividad cultural que hasta entonces parecía inocente y desinteresada, la discusión acerca de las relaciones de poder hegemónico, de dominación económica y cultural, o las perspectivas de clase social, permanecieron ausentes. Pero todavía más: los conceptos centrales de la musicología afirmativa, suerte de "verdades", fundamentalmente el personalismo y la objetualidad de las obras, continuaron configurando sino ya el contenido, al menos la estructura de la narración histórica. Así se nos cuenta del signo paternalista de la quinta sinfonía de Beethoven, lo cual abre la puerta a las problemáticas de género, pero se nos sigue hablando de Beethoven, la gran personalidad, y de su sinfonía/obra, en tanto tales. Esto es parte del comportamiento habitual de los trabajos de la nueva musicología que, rechazando la idea de generalización (y de totalidad) en base al credo crítico lyotardiano de los grand récits, se concentraron en producir reducidos estudios de caso centrados en compositores y sus obras. De este modo los aportes, muy significativos en muchos casos, quedan restringidos al estudio de pequeños repertorios, a escalas microscópicas: la música de tal o cual autor en tal año en que visitó tal ciudad; la presencia de tal o cual técnica instrumental en este o aquél tratado teórico; la relectura "en clave" feminista o gay del repertorio clásico y las personalidades musicales; las significaciones identitarias en cuanto a lo racial en las canciones de tal o cual disco de música negra; las formas de financiamiento de la música de tal dinastía aristocrática en el último tercio del siglo tal; y la lista es interminable ${ }^{67}$. Los aportes de estos trabajos -en cuanto a metodologías, e incluso información- junto a un espíritu reparador y hasta justiciero, son innegables. La prueba es que algunos de ellos han desatado escándalos y discusiones encendidas en la academia. Sin embargo, la música popular continúa participando en clara desventaja, ocupando mucho menos espacio y tiempo de investigación y publicación y reforzando así el imaginario que la ubica como sin historia. Porque la renuncia a la totalidad y la generalización produjo indudablemente un retiro de estas nuevas perspectivas del escenario de debate con los textos paradigmáticos del modelo cuestionado, generando un hueco -significativo en términos de una disciplina histórica- que continúa llenándose con la reproducción de las historias tradicionales.

Esto es así porque se rehúye a uno de los tópicos centrales de la historia, la generalización que, podríamos decir, equivale a la asignación de sentido o significación de los procesos históricos. Edward Carr nos recuerda justamente que «El estudio de la historia es un estudio de causas. El historiador [...] pregunta continuamente ¿Por qué?» (Carr, 2006, p. 167). Sin que por ello caigamos en el determinismo, es necesario observar que la fragmentación que abonaron tanto la tradición historiográfica liberal como la posmoderna nos dispara a un mosaico de objetos y acontecimientos que carecen de relación entre sí y que por lo tanto se constituye en una narración descriptiva antes que explicativa (Pérez González, 2010). Como sucede en las distopías, se nos impide lograr una comprensión del presente a partir de considerar el pasado, lo cual era una ley del historicismo rankeano y es una consecuencia, no declarada aunque tampoco visibilizada, del de la historia posmoderna. Dado que la consideración de que "no hay causas", de que todo es azaroso y posible (Popper, 1957) es una abstracción que, si no falsa, es al menos impracticable en cualquier orden de la vida. "La pesadilla que emana de las obras de Kafka proviene de que nada de lo que ocurre parece tener causa [...] lo que conduce a la total desintegración de la personalidad humana que se basa en la suposición de que los acontecimientos tienen causa» (Carr, 2006, p. 174). O si se prefiere en términos de Husserl, es la «totalidad interminable, en su movimiento incesantemente infinito, [la que] está orientada hacia una

67 Nos referimos, entre otras, a las obras de Kerman (1985), Treitler (1991), McClary (1991), Goehr (1992), Walser (1992), Solie (1993), Tomlinson (1993), Citron (2000), Korsyn (2003), Scott (2003), DeNora (2004) y Brett (2006). 
unidad de sentido» (citado por Eagleton,2006, p. 72). De modo tal que, tanto si como los positivistas, creemos que nuestra tarea es únicamente compilar los documentos considerados sinónimo de "hechos"- y que la divina providencia se ocupará de interpretarlos y significarlos; o si, como posmodernos, rehusamos a generalizar en la creencia de que cualquier tipo de explicación es determinista y manipuladora, el resultado es el mismo. De hecho, omitiendo únicamente la referencia a las fechas, resulta realmente difícil saber si la autora de la siguiente cita nos habla del positivismo o del posmodernismo historiográficos:

hacia finales del siglo [...] resultaba más difícil de lo previsto el emprender la síntesis de resultados, el escribir compendios históricos capaces de hallar una significación coherente [...] Eso era exactamente en lo que se había ido convirtiendo la historiografía, un repertorio de hechos dispersos, fragmentario por fuerza (Sandoica, 2004, p. 63).

Por lo tanto, los recursos de que disponemos para hacernos una idea del sentido de la historia, de las razones de las presencias o ausencias en su narración, del valor que obtienen sus objetos, o están ocultos y operan como rasgo de afirmatividad de la cultura dominante (Marcuse, 1978), o no tienen nada que ver con la historia. Es ahí, en esa fisura de la musicología, en donde los libros de texto despliegan su potencial valorativo y adquieren su dominio reproductivista.

Podemos decir entonces que la New Musicology, al menos en aspectos historiográficos clave, no es tan "nueva", mientras que aquello que tiene de "crítica" ha quedado atrapado en su propia discusión, fundamentalmente porque los libros de texto sobre historia de la música ${ }^{68}$, los programas de televisión 69 y el periodismo especializado ${ }^{70}$ suelen reproducir sin problemas ni estorbos los preceptos más acendrados del positivismo que tanto cuestionaron Bermúdez y Kerman tres décadas atrás. Esto no sería demasiado inconveniente -siempre le podemos echar la culpa a la televisión o a la industria editorial- si no fuese porque es justamente en los ámbitos de formación musical profesional -que también son los de producción de conocimiento- que estos (¿viejos?) materiales circulan con mucha fuerza y persistencia, reproduciendo en los nuevos músicos e investigadores el credo positivista y proyectando a futuro esa percepción sobre la disciplina vinculada al acopio de datos duros y positivos. Podemos encontrar un indicador en el hecho de que los aportes y avances de las musicologías "críticas" configuran casi exclusivamente materia de estudio de seminarios de posgrado no troncales, los cuales siguen denominándose "nuevas

68 En general son textos revisados y ampliados a partir de primeras ediciones que datan de mediados del siglo XX, época de pleno auge del positivismo musicológico. Nos referimos fundamentalmente a los ya citados Reese (1940 y 1954), Bukofzer (1947), Grout (1960), Palisca (1968), o Michels (1985), entre otros.

69 Una muestra cercana y significativa puede ser la programación del canal Encuentro, perteneciente al Ministerio de Educación de la Nación. En su programación conviven aquellos programas sobre historia social y política, principalmente de la Argentina y Latinoamérica, que se posicionan explícitamente desde los múltiples revisionismos historiográficos que atravesaron a la historia general durante más de un siglo; junto a documentales en los cuales se da a entender que la historia de la música se aprende si vamos "tras los pasos de..." el reducido y repetido grupo de compositores del romanticismo europeo. Además los programas sobre música popular también suelen recostarse y hasta generar conceptos que reproducen nociones centrales del positivismo musicológico. Para esto último véase Cannova, M. P. (2017).

70 Podría pensarse que el periodismo musical, como ejercicio asociado fundamentalmente a la crítica, no requiere de los rigores de la investigación científica. Sin embargo las relaciones entre crítica e historia de la música son mucho más estrechas de lo que podría pensarse, a tal punto que podemos considerar a la historiografía como derivación de la crítica musical a partir de la elaboración de un canon de obras maestras y de colocar en el centro del relato histórico a los juicios de valor estéticos sobre la música. Al respecto véanse Stanley (2001), Stevenson (1970a) y Dahlhaus (1997). 
tendencias" "nuevos enfoques" o "tendencias actuales" cuando, como vimos, esas actualidades cumplieron ya más de treinta años ${ }^{71}$.

Naturalmente esto es más visible en nuestras "periferias" en donde el modelo afirmativo, además de hegemónico, se aporta un componente de colonialidad del saber (Quijano, 2014) Así su adopción local conlleva automáticamente la asunción del universalismo que detenta, en detrimento de las perspectivas asuntivas y las historias de las músicas de nuestra región. Tanto es así que una recorrida por los planes de estudio de nuestras universidades e instituciones de nivel superior configuran una imagen vívida de esta situación. Hace unos años, la música y pedagoga Silvia Carabetta (2008) publicó un agudo análisis de los habitus y arbitrarios acerca de la música que subyacen a los programas de estudio de un conservatorio de la Provincia de Buenos Aires. En un apartado titulado ¿Qué conserva el conservatorio?, la autora expone lo que, según ella, son los dos casos paradigmáticos que aparecen anclados en una mirada profundamente anacrónica, uno de los cuáles es la asignatura "Historia de la Música":

El otro caso representativo de la música clásica como género convertido en parámetro desde donde comprender, analizar y jerarquizar la música general, es el de la asignatura Historia de la Música [...] los contenidos están organizados siguiendo una línea evolutiva del desarrollo de la música académica occidental, presentando una fuerte similitud con el tratamiento que dan a la historia de la música y a la estética los libros y enciclopedias que sobre el tema dispone la biblioteca de la institución (Carabetta, 2008, p. 41).

Evidentemente, al conservatorio de la autora tampoco llegaron las tendencias de la "nueva musicología". Y esos "libros y enciclopedias" desde los cuales estudian los alumnos han sido publicados por lo menos medio siglo atrás. Es natural concluir, como lo hace la autora, que la historia de la música se convierte en el repositorio de los rasgos más conservadores de la formación musical; pero también es dable imaginar que, si se quisiera modificar esa perspectiva, la dificultad para ofrecer a los estudiantes materiales bibliográficos actuales, en español, abarcativos y con alguna preocupación didáctica sería un obstáculo muy complicado de superar. De hecho, hemos podido corroborar esto en dos oportunidades por medio de un relevamiento de las bibliografías más frecuentemente utilizadas como textos obligatorios de las asignaturas "Historia de la Música" de grado universitario.

Con casi diez años entre una y otra pesquisa, ${ }^{72}$ los resultados en cuanto a este aspecto particular son prácticamente idénticos. De tal forma que podemos afirmar que en la mayoría de las asignaturas afines a la disciplina se continúan utilizando los mismo libros de texto, que no solo proveen los repertorios, conceptos, ejemplos y esquemas analíticos que terminan configurando el saber disciplinar sino que además estructuran, a partir de sus nociones centrales, la secuenciación y los criterios didácticos de los mismo planes de estudio. El libro con el que abrimos esta sección, la Historia de la Música Occidental de Donald Grout, aporta con su índice la estructura de los contenidos de muchos programas de estudio y detenta el privilegio de ser prácticamente la única bibliografía que deben estudiar los alumnos. De todas formas, debemos señalar que entre ambas investigaciones aparece un aspecto contrastante: los programas más actuales (2016-17) contienen una introducción a modo de justificación o marco teórico, en algunos casos bastante extensa, que da cuenta

\footnotetext{
71 Los hay muchos y variados en las principales universidades de Hispanoamérica, pero como caso puede consultarse el programa de la Maestría en Música de la UNAM, cuyo seminario "Corrientes actuales de la musicología", contiene la siguiente descripción: «Este seminario está dedicado al estudio del desarrollo de la disciplina musicológica a partir de la década de los 1980s, momento en que ocurre una ruptura que dará origen a nuevas visiones y aproximaciones».

72 Nos referimos al proyecto de investigación PPID/UNLP El sonoro pasado silente, dirigido por quien suscribe y desarrollado durante 2009-2012; y la investigación que da cuerpo al trabajo de tesis del Doctorado en Artes de la FBA-UNLP, en el marco del cual se ubica el presente trabajo.
} 
de algunos de los avances de la disciplina y que, en ocasiones, deslizan un posicionamiento epistemológico de parte del cuerpo docente. Algunos incluso citan explícitamente a la "nueva musicología" y otros problematizan la denominación de la asignatura desde alguna perspectiva crítica. Esto es un gran avance ya que, precisamente, la musicología afirmativa nunca sintió la necesidad de justificar su posición pues, por el contrario, en ocultarla residía el secreto de su potencia hegemónica y su obligatoriedad. Todos los libros que referimos antes, especialmente los de la editorial W. W. Norton, adolecen de fundamentaciones, introducciones metodológicas o asunciones epistemológicas. Por lo tanto, existe una gran diferencia a partir de la aparición de este tipo de reflexión y asunción teórica en los programas de grado. Sin embargo, lejos de transponer esta conciencia disciplinar al programa, reiteran el esquema tradicional en cuanto a los contenidos, los objetivos, la metodología o las formas de acreditación, con lo que reproducen el divorcio epistemológico y configuran especies de "mónadas" capaces de contener tal grado de inestabilidad conceptual sin disgregarse. Es cierto que este carácter dual es quizás, como apuntábamos antes, resultado de la dificultad para reemplazar fácilmente las bibliografías tradicionales por otras críticas. Es una realidad que existe y más aún en los países hispanoparlantes. Pero hay otra cosa, cierto factor de persistencia que no puede ser explicado mediante el análisis de la industria editorial. Tampoco por una supuesta despreocupación de los investigadores en aspectos educativos o didácticos, lo cual puede refutarse fácilmente mediante el alto grado de participación de los investigadores en congresos sobre pedagogía o educación musical, o en las publicaciones específicas como el Journal of Music History Pedagogy 73 , publicación perteneciente a la American Musicological Society, es decir la asociación oficial de musicología en donde se originó el movimiento de la New Musicology; - la Action, Criticism, and Theory for Music Education, ${ }^{74}$ revista del May-Day Group, asociación internacional cuyo objetivo principal es «identificar, criticar y cambiar los esquemas naturalizados que [...] amenazan la efectiva comunicación práctica y crítica en la educación musical». ${ }^{75}$ Sin embargo, y aunque pueda resultar algo asombroso, muchos de los investigadores que desarrollan y exponen el andamiaje crítico frente a la musicología tradicional, cuando deben publicar un texto para la enseñanza, un "manual", reproducen con mucha fuerza -y de manera particularmente acrítica- los postulados y resultados del positivismo musicológico.

Este hecho en particular nos lleva a preguntarnos si no existe alguna otra razón para la desactualización curricular, más allá de las dos que esbozamos: la fragmentación de los estudios típica del posmodernismo que no produce textos abarcativos y, derivada de la anterior, la escasez o baja disponibilidad de textos críticos realmente útiles para la formación de grado. ¿Es que habrá algún otro motivo para sostener desde la academia la hegemonía de la historiografía musical positivista?

Como expusimos hasta aquí, existe un claro espectro ideológico que dota a la musicología histórica de los recursos para desplegar su afirmatividad y consagrar a la música de las élites, particularmente de la burguesía moderna, como la única tradición musical posible. Dentro de estos útiles epistemológicos, la autonomía y el personalismo son los de mayor potencia, al esconder las relaciones que atraviesan a quienes participan de las ocasiones musicales, las producen y las significan. El positivismo, entonces, viene a sellar el carácter afirmativo al desarrollar artefactos que resisten incluso la aparición de nuevos

\footnotetext{
73 ISSN 2155-109X. Disponible en http://www.ams-net.org/ojs/index.php/imhp/

74 ISSN 1545-4517. Disponible en http://act.maydaygroup.org/about-us/

75 «identify, critique, and change taken-for-granted patterns of professional activity, polemical approaches to method and philosophy, and educational politics and public pressures that threaten effective practice and critical communication in music education» http://www.maydaygroup.org/about-us/\#.WXo7FlqQyRs [traducción del autor]
} 
repertorios y de ciertos datos periféricos que, como un contexto, pasan a ornamentar la narrativa histórica. Tal es la fuerza de estos conceptos que incluso la musicología crítica o los PMS continúan utilizándolos.

¿Es posible escindir el componente ideológico y afirmativo de estos conceptos historiográficos de su uso metodológico? ¿Son útiles neutros, que no arrastran necesariamente la huella cultural de la cultura burguesa de la modernidad? ¿O es en ellos que efectivamente habita al carácter afirmativo de la historia de la música? Responder estos interrogantes es clave para descomponer un paradigma historiográfico que, tal como vimos grabado en piedra, impreso en los manuales o en los temarios de los congresos posmodernos, impulsa la noción de que la música, al menos en términos históricos, no es popular. Porque si así lo fuese, no nos interesaría. Necesitamos comprender cuál es la naturaleza del positivismo en la musicología histórica, pues nuestra hipótesis reside en que no se trata de un mero asunto metodológico sino que, una vez más, la metodología es la respuesta a un modo de pensar la música hecho a la medida para que coincida únicamente con la producción de la cultura de la modernidad. De ser así, el positivismo musicológico es una forma de ideología cuya función principal es construir un imaginario musical que vuelva extraño lo que suena familiar y convierta en cotidiano lo esotérico y lejano.

\subsection{1 ¿Qué tiene de "positivista" la musicología histórica?}

Si efectivamente como señalamos más arriba, la "conciencia" disciplinar en musicología recién asomaba hacia la década de 1980, existe un atraso epistemológico de por lo menos unos 50 años con respecto a la irrupción de los revisionismos en la historia general. Si bien en esta última el positivismo parece estar siempre a la vuelta de la esquina, ya que «sus elementos fundacionales, muchas de sus pautas clásicas [...] siguen vigentes hoy albergadas en la disciplina que llamamos "historia", aunque no lo parezca a simple vista» (Sandoica, 2004, p. 48), es bien conocida la fuerte impugnación que formularon en la década de 1930 los historiadores franceses agrupados en torno a la revista Annales d'histoire économique et sociale. Aunque la atribución es más simbólica que real, a partir de allí se desencadenó una serie de procesos de revisión y transformación radical en cuanto a las metodologías, los presupuestos, los objetos de estudio o la posición de los historiadores, entre muchos otros temas. Podría pensarse que durante buena parte del siglo pasado la disciplina de la historia general fue reconfigurada en varias oportunidades a partir de un minucioso examen de su propia naturaleza, lo cual derivó hacia el último cuarto del siglo XX en un conjunto de líneas historiográficas que algunos autores nuclean en torno a la denominación Historia social (Sandoica, 2004) o Nueva historia (Burke, 2003) y que comprende, por ejemplo, a la historia cultural, los estudios culturales, la microhistoria o la(s) historiografía(s) de raíz marxista, entre otras. Un conjunto diverso integrado por tendencias intelectuales que suelen entrar en pugna y contradicción pero que, en definitiva, comparten la capacidad de haber logrado desplazar los conceptos nodales del historicismo: lo importante en la historia ya no depende del carácter y comportamiento de los individuos, particularmente de los "grandes hombres" (Burke, 2003, p. 15) ni es causada por inevitabilidades como la particular forma de "la nariz de Cleopatra" (Carr, 2006, p. 59) y, en cambio, se favorecen los estudios de colectivos sociales o culturales y las perspectivas de clase o género. Tampoco las divisiones temporales corresponden a un aglomeramiento de acontecimientos "únicos", sino que el devenir histórico comienza a estar poblado de transiciones, superposiciones, convivencias, largas duraciones y sincronismos. Y, finalmente, la historia no es ya algo que depende de documentos oficiales, reconociéndose como fuentes válidas por ejemplo a la iconografía o a la transmisión oral (Burke, 2003, p. 16). Lo que es más importante, es que estos cambios paradigmáticos han logrado impactar en el sentido común, lo cual devuelve un resultado contundente: nuevos sujetos y colectivos fueron incorporados a la historia, particularmente los sectores populares junto a sus tradiciones, costumbres e idiosincrasia. Así se generaron nuevas explicaciones históricas 
que superaron el personalismo del historicismo decimomónico y que, como nos permiten repensarnos como sociedad y cultura en el presente, posibilitaron construir otras historias de las clases populares o desde abajo. Todas estas perspectivas están ausentes en la historiografía musical, o aparecen desdibujadas y fragmentadas en jirones desarticulados formando parte de un mosaico de papers y articulaciones formales que no trascienden las estrechas fronteras de pequeños congresos y academias. Contraste que resulta evidente en el acceso del público general a los cambios de perspectiva: mientras los dibujos animados del canal infantil del Ministerio de Educación de Argentina adoptan estos nuevos posicionamientos de la historiografía general, el canal cultural del mismo Ministerio emite una serie importada que reproduce todos y cada uno de los aspectos centrales del positivismo musicológico.

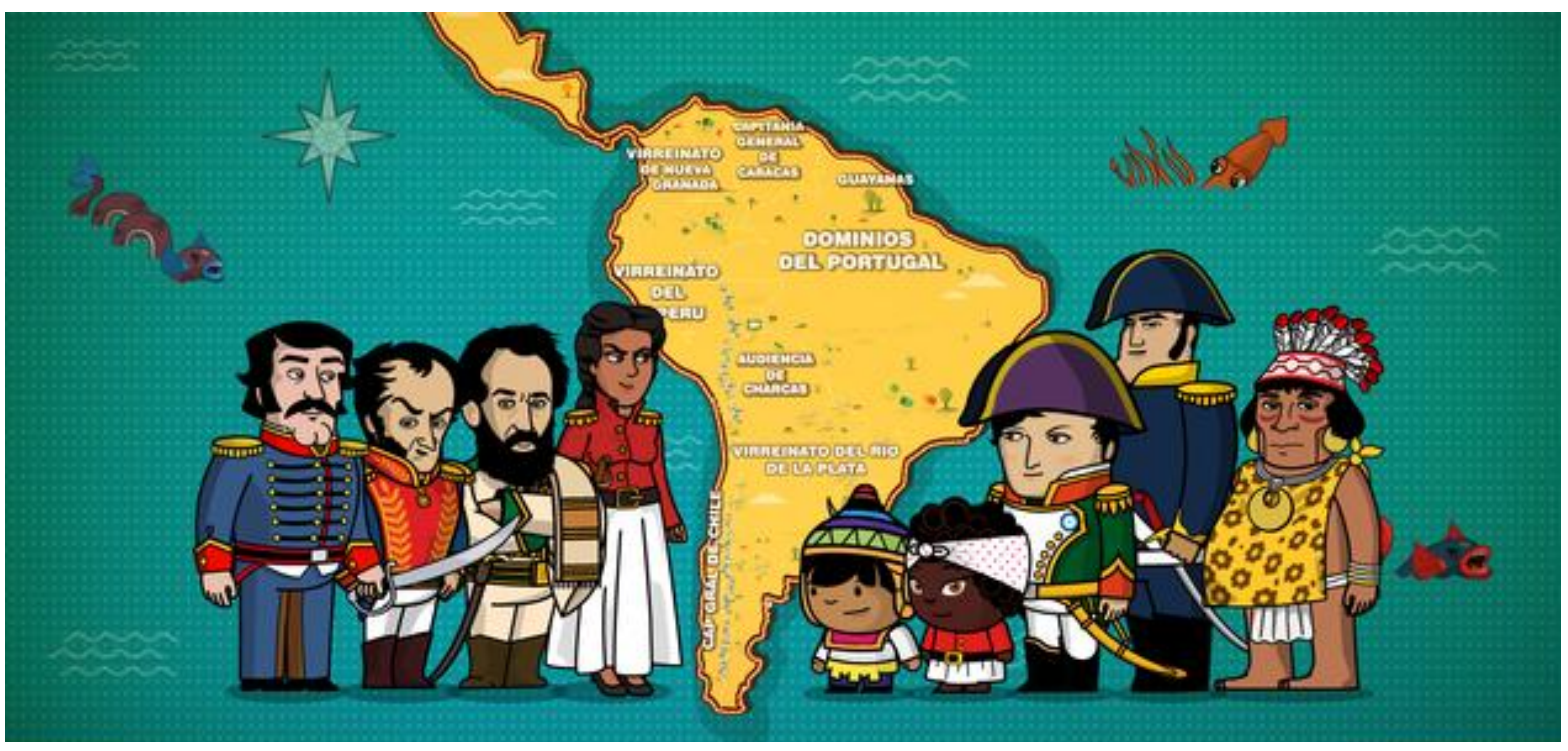

Fotograma de los dibujos animados "La asombrosa excursión de Zamba a la Patria Grande”, emitidos por el canal estatal infantil Paka-Paka a partir de 2012, en el cual puede verse al pequeño protagonista junto a figuras tradicionales de la historiografía (como San Martín o Belgrano) junto a otras reivindicadas por el revisionismo por su rol en la independencia americana, como Juana Azurduy o los pueblo originarios. Los niños pueden acceder a la nueva historia. 


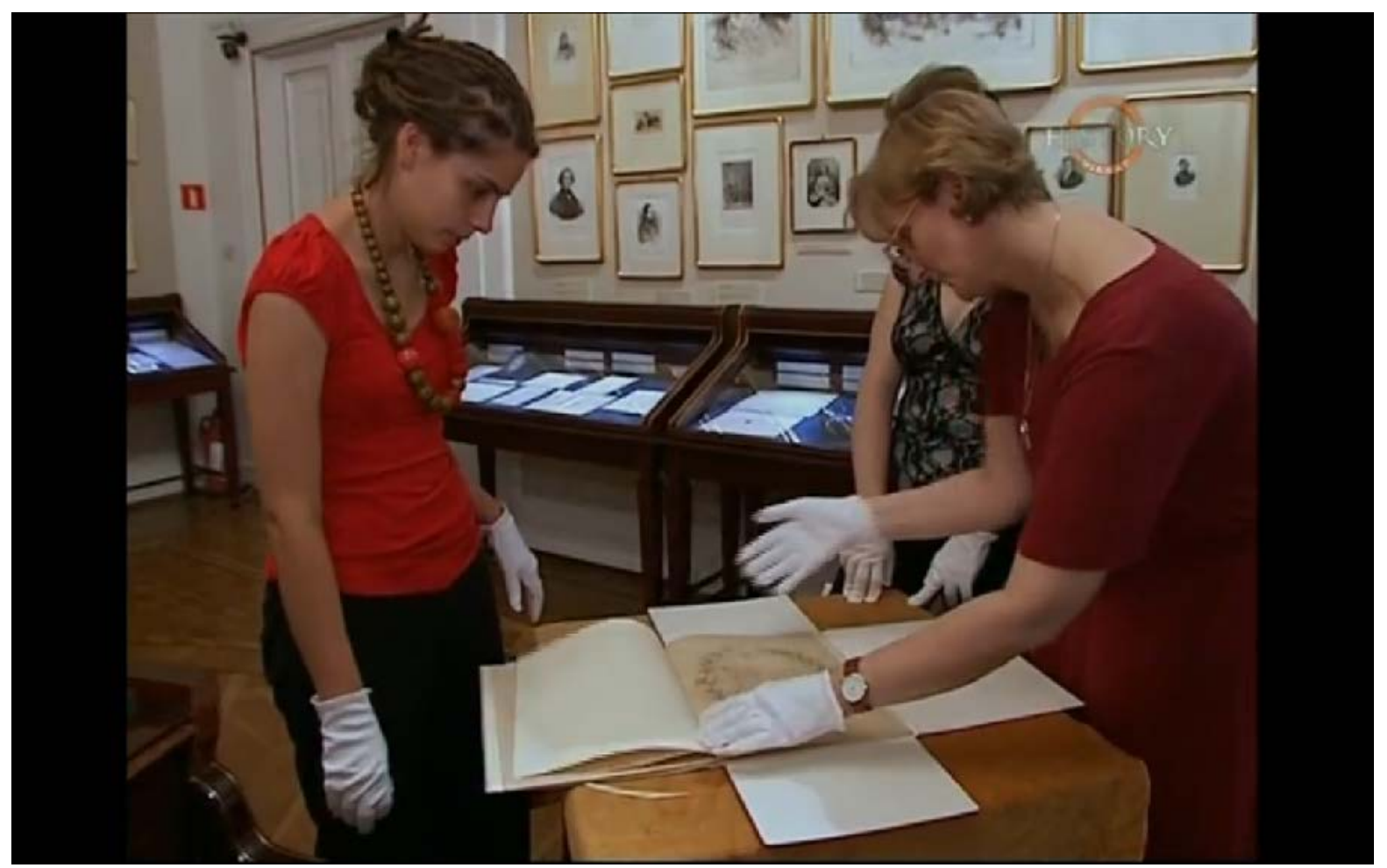

Fotograma del documental canadiense "Tras los pasos de Chopin" de Stéphane Ghez (2012), emitido por Canal Encuentro, en el que podemos ver a la presentadora junto a una paleógrafa examinando objetos y partituras autógrafas del compositor. Un maridaje excepcional entre el personalismo y el positivismo de la musicología histórica. La serie se denomina "Tras los pasos de..." y contiene episodios de otros compositores del canon musicológico, comenzando por supuesto con Beethoven, y continuando con Schubert, Berlioz,

Tchaikovsky, entre otros románticos. Es decir que para los adultos, según el mismo ente estatal, la historiografía musical continúa siendo afirmativa en la Argentina del siglo XXI.

Este conglomerado de movimientos historiográficos de muy variada raigambre y orientación confluyó en la crítica al paradigma predominante desde la fundación de la historia como disciplina científica en el siglo XIX, que comenzó a ser denominado modelo historicista, «una mezcla de idealismo y de positivismo historiográfico» (Sandoica, 2004, p. 58 ), algo bastante similar a la combinación de romanticismo y positivismo que planteaba Bermúdez. Los aspectos centrales sobre los que se configuró la profesión del historiador suelen caracterizarse en torno a los postulados de algunos historiadores como Jules Michelet o el ya mencionado Leopold von Ranke.

Muy imbuida por el positivismo de mediados de siglo XIX, la premisa fundamental de Ranke sostenía que la historia debía relatar los hechos «tal cual sucedieron». En vistas de alcanzar tal objetivo, este modelo censura fuertemente toda intervención del historiador que lo lleve a «trascender la literalidad de sus fuentes» (Sandoica, 2004, p. 53), motivo por el cual la investigación se reduce al análisis de fuentes escritas provenientes de documentos públicos y oficiales a los que se considera más exactos, auténticos y duraderos. Es un método inductivo que persigue abstraer leyes históricas a partir del estudio pretendidamente objetivo del archivo documental y que encuentra regularidades entre los eventos aislados asentados en las fuentes. Por lo tanto

lo histórico deberá ser expresado exclusivamente sobre la trama de lo individual [y será] algo por tanto eminentemente localizado y circunscrito, todo aquello que se [muestre] irreductible en su concreta especificidad. Esa es la idea que todo el historicismo alemán logrará imponer [...] un método histórico en esencia crítico filológico (Sandoica, 2004, p. 54,58). 
Lo individual de la historia puede observarse con mucha claridad en cuanto a que lo que anima el cambio histórico se concibe como producto de individuos aislados dotados ${ }^{76}$ que «presenta una vista desde arriba, en el sentido de que siempre se ha centrado en las grandes hazañas de los grandes hombres [...] Al resto de la humanidad se le asignaba un papel menor» (Burke, 2003, p. 15). Esta es una concepción que desde los revisionismos es calificada como "desde arriba", dadas sus estrechas vinculaciones con las doctrinas políticas del siglo XIX tendientes a estabilizar el orden social y construir la hegemonía del nuevo sistema burgués. Particularmente el liberalismo destaca como aquella ideología que saca provecho del desarrollo tanto del idealismo como del historicismo y, fundamentalmente, el positivismo, lo cual puede rastrearse en la militancia de varios historiadores y científicos como Droysen o Darwin (Mosse, 1997, p. 235). Incluso hay que recordar que el programa de August Comte incluía una propuesta de gobierno y orden social basado en el conocimiento positivo.

Las implicaciones de este modo de pensamiento y sus relaciones con la burguesía del siglo XIX son tan estrechas que se hacen evidentes incluso en la aparentemente neutral y apolítica historiografía musical: «En aquel tiempo, una sociedad económica nueva se instala con un código dominante, el de la representación (interpretación) que producirán las grandes figuras: sólo Haydn y Mozart serán recordados por la historia» (Attali, 2011, p. 69). Esto no impedirá que un siglo más tarde esa huella ideológica intente borrarse, posicionando a la historiografía musical positivista del lado de la corrección epistemológica, tachando a sus adversarios de poseer finalidades políticas ocultas artífices de un «sometimiento de la historia a la política» que los lleva, en su equivocación, a negar los fenómenos que auténticamente "pertenecen a la historia» y demostrando una "mala voluntad hacia los grandes hombres» en pos de una actitud demagógica de «simpatía hacia las masas» y su música -trivial- que forma parte de «la escoria que resta al constituirse la historia» (Dahlhaus, 1997, p. 17)

Al tiempo que el despliegue del orden burgués propicia la transformación de la composición musical de oficio o trabajo en relación de dependencia a profesión liberal y free lance, la musicología expurga toda connotación histórica y social del fenómeno musical en virtud de la estética romántica que entroniza las nociones de autonomía creativa del genio y la unicidad de la historia del arte (Lanza, 1986, p. 30). El sujeto individual, genio y dotado de una voz interior única, es así una categoría que implica necesariamente su estudio a través de objetos también individuales e irrepetibles: las obras.

Encontramos aquí un paralelo muy fuerte entre musicología e historicismo, ya que esta reducción a lo individual del positivismo se despliega con toda fuerza en aquello que tal vez represente su centro epistemológico: la concepción acontecimental según la cual la historia se produce a partir de eventos claramente circunscritos, datables y tangibles, que se convierten en parteaguas y configuran un "antes y después" histórico. A partir de aquí, la categoría de acontecimiento se convertirá en la definición de hecho histórico, de forma tal que los hechos de la historia son acontecimientos producidos por esos grandes hombres de la política, en base a sus impulsos, criterios y golpes de genio. (Burke, 2003, p. 17). Pero además, en la obsesión por la objetividad y por exorcizar cualquier mácula en la investigación producto de la proyección subjetiva del historiador, los hechos pronto pasaron a considerarse datos objetivos. "Los positivistas, ansiosos por consolidar su defensa de la historia como ciencia, contribuyeron con el peso de su influjo a este culto de los hechos» (Carr, 2006, p. 12). Las conclusiones, las interpretaciones, las explicaciones, nada

76 La relación íntima entre esta concepción historiográfica y la ideología del liberalismo (la cual gracias a su parentesco e identidad con la del neoliberalismo sirve de nexo, como vimos, entre este paradigma y buena parte del posmodernismo que dice cuestionarlo) puede apreciarse con crudeza en las actuales reinterpretaciones de los próceres argentinos como "emprendedores" por parte de la coalición liberal-conservadora gobernante: «A 167 años de su partida recordamos al padre de la patria, un emprendedor que nos dejó el legado de la libertad. Un orgullo» (https://www.pagina12.com.ar/57166-mas-que-un-libertador-un-emprendedor) 
tienen que hacer aquí, ya que los hechos históricos son producto de la experiencia, datos empíricos. Según Carr, este modo de pensamiento fue tan potente que configuró un sentido común de la historia según el cual ésta consiste simplemente en una serie de hechos verificados. "Los hechos los encuentra el historiador en los documentos, en las inscripciones, etcétera, lo mismo que los pescados sobre el mostrador de una pescadería» (Carr, 2006, p. 13). De esta manera se despliega una concepción pretendidamente aséptica de la historia que reduce la tarea historiográfica al acopio y clasificación de los datos. Asuntos importantes para un historiador serán entonces saber la datación precisa de los acontecimientos, datos que él sabe extraer de los documentos oficiales. «Pero [...] elogiar a un historiador por la precisión de sus datos es como encomiar a un arquitecto por utilizar vigas debidamente preparadas o cemento bien mezclado. Ello es condición necesaria de su obra, pero no su función esencial». (Carr, 2006, p. 15). De esta manera, en el discurso explícito de la historiografía se confunden los medios con las finalidades, lo que inevitablemente produce un ocultamiento de los verdaderos objetivos de la prédica histórica. Esta pretendida eximición se apoya en otra creencia que sostiene que los hechos "hablan por sí solos", es decir, que su contenido y valor históricos son propiedades del hecho (de los datos) en sí, no juicios o valoraciones del historiador, lo cual naturalmente ha sido ampliamente cuestionado:

Solía decirse que los hechos hablan por sí solos. Es falso, por supuesto. Los hechos sólo hablan cuando el historiador apela a ellos [lo cual] no se apoya en ninguna cualidad de los hechos mismos, sino en una decisión que formula el historiador a priori. (Carr, 2006, p. 15)

Así, el historiador es, por fuerza, selectivo y además debe comprender que lo que recibe en términos de información histórica es a su vez una suerte de compendio de selecciones producidas a lo largo del tiempo. La subjetividad en la historia aparece entonces como un componente insoslayable.

Sin embargo, nótese la influencia de este sentido común positivista en la historia de la música cuando Dahlhaus defiende la necesidad de una historia de la música "de las obras" a partir de considerar que todo sentido histórico es inmanente a ellas: la decisión metodológica por la historia de las obras [y no una historia social] está predeterminada en la cosa misma, en los hechos musicales (Dahlhaus, 1997, p. 18)

Sólo en la medida en que el historiador alcance a comprender la esencia histórica de las obras a través de su composición interna, la historiografía, a la que así se llegue, será también estéticamente sustancial, en lugar de seguir siendo una configuración ajena al arte, impuesta a las obras desde fuera. (Dahlhaus, 1997, p. 40)

Esta fe en el panteón de las obras, los hechos de la historia de la música que reemplazaban a la categoría rankeana del acontecimiento, se desplegaba, al igual que en su pariente, la historia general, a partir de una "fetichismo de los documentos". La obra es "texto", del mismo modo en que los documentos oficiales y sólo ellos podían contener los datos de los acontecimientos considerados verdaderamente históricos. "El historiador devoto llegaba ante [los documentos] con la frente humillada, y hablaba de ellos en tono reverente. Si los documentos lo dicen, será verdad.»(Carr, 2006, p. 21). He aquí el corazón del positivismo en esta fe ciega ante el material empírico, cuantificable, medible, analizable; en esta suerte de templo de los hechos, residencia de la verdad que, según Derrida, resulta ser el archivo. Compilar y acopiar documentos, clasificarlos, datarlos, adjudicarles autoría, conservarlos: tal parece ser en la concepción positivista la tarea del historiador. Esto nos devuelve a nuestra cita inicial de Joseph Kerman y la concepción cotidiana del historiador de la música como de alguien ocupado fundamentalmente con lo documental y lo analizable.

En opinión de Carr, quien a su vez se basaba en Collingwood, esto representa apenas la primera etapa de una investigación histórica, los requisitos. Luego el historiador «aparta de 
sí las fuentes, tira de los cuadernos de apuntes, y escribe el libro del principio al fin» (Carr, 2006, p. 38) Es decir, se preocupa por interpretar, generalizar y construir sentido histórico. Sin embargo, nuevamente vemos aquí un desfasaje entre la historia general y la musicología, ya que Kerman encuentra que en la historiografía musical esa "primera etapa" es en realidad la única:

Leer sobre musicología de los 50's es experimentar un salto intelectual en el tiempo. Es sorprendente que las palabras escritas por R. G. Collingwood sobre el positivismo historiográfico alemán del siglo XIX puedan aplicarse exactamente igual a la situación de la investigación musical setenta y cinco años después ${ }^{77}$ (Kerman, 1985, p. 43).

Más adelante nos volveremos a ocupar de este "salto temporal de setenta y cinco años" para adelantar alguna hipótesis acerca de sus razones. Pero antes quedémonos por ahora con este "fetichismo de los documentos" y veamos sus ramificaciones en la historiografía musical.

\subsubsection{Del fetichismo de la partitura al fetichismo de las obras.}

Para llegar a la concepción de la obra-objeto como artefacto de la historiografía musical, el despliegue metodológico del positivismo se basó en la reducción de la noción de fuente histórica a lo que pasará de aquí en más a llamarse "texto" musical: la partitura. Es un paso conveniente para este paradigma pues desde su desarrollo medieval más temprano la notación siempre pretendió detener el devenir musical para así suspender la divergencia interpretativa. Pero además, el hecho de determinar qué se anota y que no, decisión que conlleva un posicionamiento político además de estético, contribuyó a configurar una idea de música específica de Occidente basada en la consagración como eje central de la noción de forma musical y sus atributos periféricos, como estructura, equilibrio, simetría, racionalidad, entre otros (Treitler, 1991). Una construcción de otredad mediante la cual la Europa occidental medieval comienza su proceso de identificación cultural en contraste con el Oriente más desarrollado y hegemónico justamente a partir de relacionar con este último lo informe sensual, que a su vez es femenino, voluptuoso e irracional; pero sobre todo oponiendo lo improvisado frente a lo compuesto y objetivado. Si la partitura aparece como herramienta para erradicar la variación interpretativa en pos del objeto y permitir el desarrollo de la teorización de la música en tanto estructura, podemos decir entonces que en el despegue mismo de la música occidental "culta" las decisiones acerca de qué parámetros musicales son los más relevantes ocurren junto al desarrollo tecnológico que permite escribir sin ambigüedades tal relieve y centralidad, y a la construcción de una teorización que fundamenta y justifica tales opciones y tecnologías. Si en el centro de dichas decisiones descansa una concepción que hace sinónimos a música occidental con forma objeto, no debería sorprendernos que, más que un resultado metodológico, la fetichización de la partitura por parte de la musicología sea un postulado estético, mecanismo de autoafirmación del canon musical.

Esto salta a la vista, dada la precariedad, en las razones que deslizan los textos musicológicos en pos de aferrarse a la notación como única fuente. Hoppin, por ejemplo, nos regala, al comienzo de su famoso libro, una opinión que ha logrado convertirse en sentido común: «La historia de la música medieval occidental, al menos durante el primer milenio de nuestra era, debe ser necesariamente una historia de la liturgia cristiana». Y rápidamente apura la justificación a lo que, de otro modo, caería en la oprobiosa relatividad de los juicios de gusto: aunque nos dice que es probable que existiera música de varios tipos, «no se ha conservado ninguna. Sólo quedan los cantos de la Iglesia» (Hoppin, 2000, p. 45). Nadie discute tal afirmación. De hecho, los estudiantes universitarios de música

77 «To read about musicology in the 1950 s is to experience an intellectual time-warp. It is remarkable how closely words written by R. G. Collingwood about German positivistic historiography in the nineteenth century fit the musical situation seventy-five years later» (Kerman, 1985, p. 43) [traducción del autor] 
creen, sin que les resulte problemático, que durante los mil años medievales sólo existió "canto gregoriano". Afirmación que cuando es analizada con una mínima criticidad se manifiesta absurda por donde se la mire. Los estudiantes ríen al descubrir la dimensión de este ridículo histórico. Pero llamados a repoblar ese mileno con otras manifestaciones sonoras, callan. Y es que nuestra cultura general no posee alternativas para ofrecernos, ya que fue construida para que creamos que la evolución de "nuestra" música solo es posible si partimos de un inicio aburrido, tosco, plano y simple -aunque cargado de potencialidades embrionarias, como la notación y la teoría- para desplegar desde allí el magnífico edificio de la historia musical occidental. Criterio que, con bochornosa obviedad, es otro rasgo fundamental del positivismo musicológico.

Pero volvamos, como sentencia nuestra tradición interpretativa, "a la partitura". Unos capítulos más adelante Hoppin nos ofrece un muy breve atisbo de lo que podrían haber sido esos otros varios tipos de música que, si es que han existido, fueron producidos por sujetos que claramente no forman parte del canon de la cultura musical occidental: «Incultos por lo general y ni poetas ni compositores, los juglares eran cantores de canciones de otros hombres» (Hoppin, 2000, p. 280). No podemos saber nada de ellos, lo cual nos impide incorporarlos al canon musical occidental. Y esto porque su falta de cultura les impidió anotar su música. ¿O es que al no ser compositores no pudieron hacerlo? Pobres gentes cuya doble falta los condena a cantar esas canciones de otros hombres. Cantos que tampoco podemos saber cuáles eran, ya que no sobrevivieron, aun cuando la vida vagabunda de los juglares «dio a aquellas canciones la mayor difusión posible» (Hoppin, 2000 , p. 280). Lamentablemente entonces, nos da a entender Hoppin, sólo podremos hacer historia de la música menos difundida, la de los sectores "cultos" minoritarios. Una mera fatalidad histórica, accidental, que no se relaciona en nada con la posición que ocupan las nociones de compositor, obra y partitura en la tradición musical occidental, como valores centrales de su teoría y como rasgos exclusivos de la música de la cultura "legítima". Estética producida, por casualidad, justamente por esas minorías cultas, las cuales además, por mera coincidencia, son las élites dominantes de la sociedad a lo largo de su historia.

Sin embargo, un simple análisis de esas preciadas fuentes, las partituras medievales, nos arrojan otra sensación en torno a la fortaleza de los argumentos de historiadores como Hoppin.

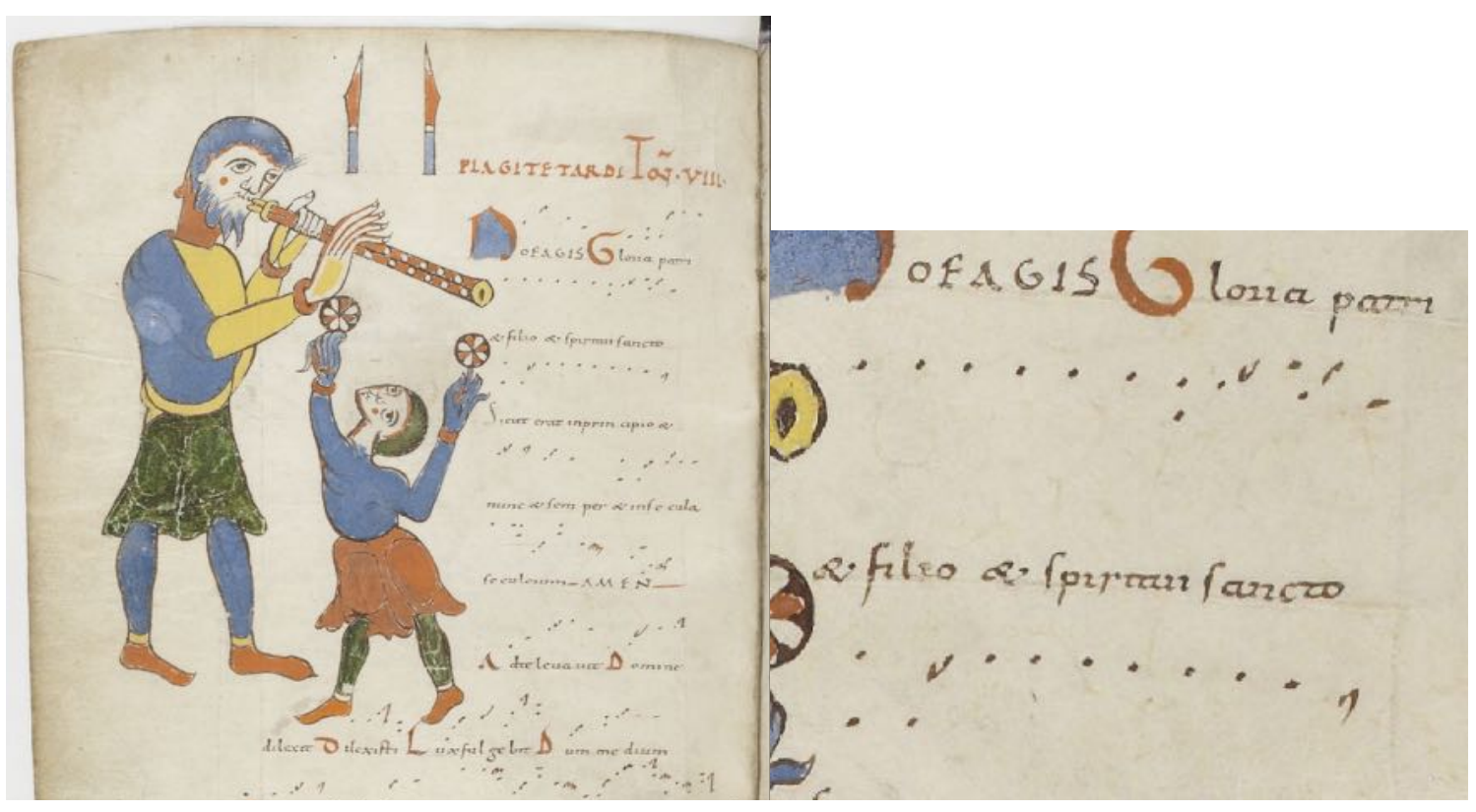


La página corresponde a un libro de cantos litúrgicos del siglo X. ${ }^{78} \mathrm{~A}$ la derecha podemos ver un detalle de la "partitura". Lo que está escrito es una parte de la Misa, anotada con signos que representan una única línea melódica, sin pautas, por lo cual las alturas son relativas. No contiene tampoco indicación alguna sobre la duración de los sonidos, su timbre, emisión, velocidad, entre muchos otros "detalles". Es decir, si confiamos únicamente en lo que vemos y lo elevamos al orden de registro absoluto, lo que estaríamos leyendo sería claramente una monodia, y cantada, dado que debajo de las notas está el texto del Gloria. Sin embargo, en el margen, podemos ver cómo están representados en gran tamaño unos músicos, a la sazón instrumentistas que, además, y sobre todo en el caso del más pequeño de ellos, parecerían estar moviéndose explícitamente, tal vez danzando (a menos que confiemos que las poses rígidas y antinaturales formaban parte del repertorio corporal cotidiano medieval). ¿Cuál es la razón de la presencia de estos personajes en la partitura? ¿Nos dicen algo de la producción musical o son simples delirios imaginativos de algún copista monástico? Si optamos por la primera opción, nos llevaría a hacerlos compatibles con la única música medieval, el canto gregoriano ¿Cómo pueden tocar entonces una música que no se toca, sino que sólo se canta? ¿Cómo pueden danzar una música que no está hecha para danzar y no tiene pulso regular? Si además aceptamos que el texto se canta ¿Estarían estos músicos acompañando el canto? Si lo hacían ¿duplicarían únicamente la melodía escrita? ¿Realmente podemos sostener que ni a éstos ni a otros músicos se les habría de ocurrir un acompañamiento diferente hasta que 400 años más tarde se comience a escribir varias melodías simultáneas, o hasta que tras otros 200 se escriba para instrumentos?

Bajo la mirada positivista, estos datos que encontramos en el mismo folio de un manuscrito son contradictorios. Y por ello se omitirá la parte del registro que no se pueda asimilar al esquema estético "culto" de Occidente. Pues resolver la contradicción aparente implicará tomar otras fuentes históricas como poseedoras de información (Martínez y otros, 2010) y, lo que es mucho peor, ellas nos llevarán a la afirmación de la existencia de músicas muy complejas y diversas en el pasado remoto, muchas de ellas por fuera de la música culta de la iglesia, fundamentalmente en la música popular: danzable, instrumental, relacionada con el carnaval y la fiesta (Bajtín, 2005); incluso subversiva (Attali, 2011) o contrahegemónica (Hall, 1984). Tal cual como expresa el temor de Hoppin, las músicas de mayor difusión. La expulsión de las músicas populares de la historia es un componente esencial de la musicología histórica de cuño positivista, orientada antes por el juicio esteticista que por razones de método.

De hecho, parte de la afirmatividad de la musicología histórica descansa en ocultar esas valoraciones y juicios, opacándolos mediante capas que aparentan rigor científico aunque no tienen fundamento alguno en metodologías o fuentes. Los presupuestos que resultan de esto, que en realidad son falacias históricas, se suelen reproducir en textos mucho más recientes, posteriores a la revuelta de Kerman y sus colegas. Podemos volver a nuestro caso paradigmático del himno procesional jacobeo, el Dum Pater Familias. En el comentario sobre un sermón que aparece en el mismísimo Códice Calixtino, en el cual se describe a esos coros de peregrinos de las escenas imaginadas por Calahorra y Fassler, ahora ante el altar de Santiago de Compostela cantando con «cítaras, liras, tímpanos, flautas, caramillos, trompetas, arpas, violas, rotas británicas o galas, o con salterios», la autora de un texto sobre la historia musical de la España medieval concluye que «lo más probable es que la presencia de una importante variedad de instrumentos musicales sonando en el interior del templo de Santiago, como parece deducirse del sermón del papa Calixto, sea más retórica que real» (Gómez, 2009, p. 206). No sólo no le alcanza el testimonio del Códice, sino que tampoco parece aportar el relieve que corona el pórtico de la gloria en la misma Catedral de

78 "Paris, Bibliothèque Nationale, fonds lat., Ms. 1118, fol. 104-113". Tonaire, tropaire, séquentiaire d'Auch (ca. 987-96). 
Compostela, concluido unos pocos años después que el Códice, y que ofrece con pétrea realidad nada menos que a 24 instrumentistas que circundan al Cristo Salvador. Podrá argumentarse que es una visión de la Ciudad Celeste del Apocalipsis. Pero aun así, ¿de dónde habrán sacado inspiración los escultores para representar tal variedad de instrumentos? ¿No es menos verosímil considerar que las referencias de Calixto y de los escultores son productos de su imaginación abstracta, antes que reconocer la existencia de una práctica instrumental viva y de relevancia, lo cual tornaría inverosímil a su vez la calificación de "incultos" asociada a los instrumentistas?

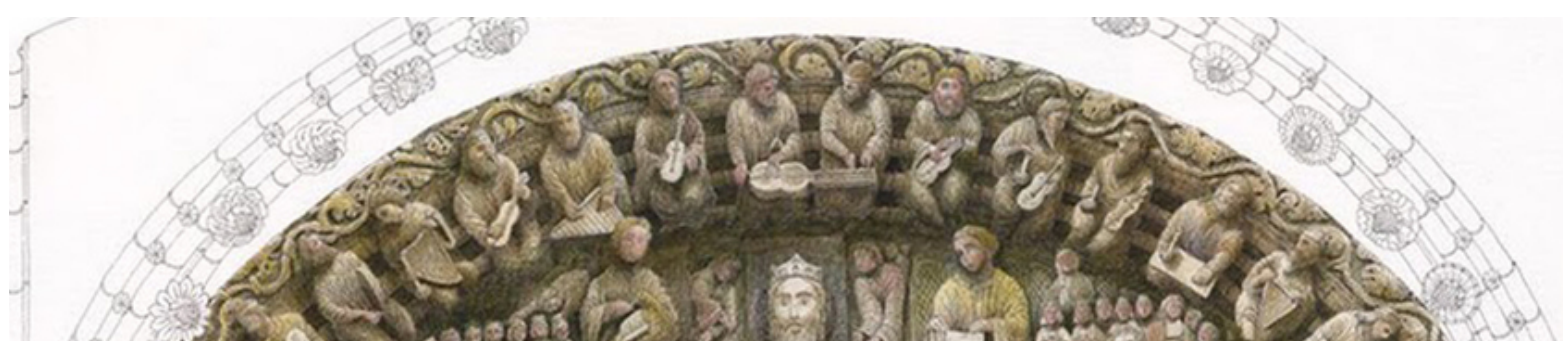

Detalle de las esculturas de los instrumentistas en el Pórtico de la Gloria de la Catedral de Santiago de Compostela

Reconocer en la escritura musical a la única posibilidad de existencia para la música es sancionar a las alturas fijas como el elemento central de la organización sonora, hayan sido o no centrales en los momentos históricos a los que se le adscriben. Conformamos una historia a la medida de los valores estéticos de la modernidad occidental, dentro de los cuales la armonía funcional es el concepto central, imaginando un pasado anhelado y convirtiéndolo en historia (Treitler, 1991). «La base de toda la música occidental desde el canto gregoriano la constituye la cadencia que, a su vez, implica que las formas están "cerradas" dispuestas dentro de un marco, y aisladas» (Rosen, 1986, p. 30) De allí que entonces la armonía sea el núcleo de la concepción musical occidental y no otros aspectos como el ritmo, o el timbre, tan prominentes en la música popular o en muchas culturas no europeas. La ausencia de conceptos explicativos para fenómenos musicales que no se condicen con este modelo es tan notoria como despectivos han sido los juicios comparativos basados en el manejo de las alturas y la armonía entre la música culta europea y el resto del mundo musical. Pero tal discriminación no es una evolución histórica natural. Es una decisión que se construye retrospectivamente decidiendo qué elementos del pasado son estudiables o no, con el fin de valorar los rasgos pretendidamente ancestrales de las músicas que en la actualidad colocamos en el centro de nuestro paradigma estético. Así Robert Stevenson podía conjugar en una misma frase la idea rankeana que colocaba como objetivo historiográfico la "satisfacción de establecer la verdad» al mismo tiempo que «mostrar las bellezas que producían nuestros propios antecesores» (Claro Valdés,1967, p. 8)

Todo a lo largo de la producción historiográfica musical nos encontramos con estas alabanzas a las bellezas de nuestros antecesores, aunque las afirmaciones que así las valoran no argumenten por qué deberíamos creer que son la verdad histórica. Un ejemplo clásico es la sobreestimación de los desarrollos polifónicos tardomedievales que, bajo el positivismo musicológico, son evaluados como origen o nacimiento de la polifonía, adjudicándose así un carácter de exclusividad o marca identitaria del manejo armónico en la cultura musical occidental. La excusa nuevamente es la detección, en las partituras manuscritas, de las primeras notaciones que incluyen más de una melodía, olvidando el carácter performático del canto a varias voces presente en numerosas culturas extraeuropeas y en la música popular occidental. Como ya escuchamos en los himnos, la polifonía es una práctica antiquísima presente en multitud de culturas a lo largo y ancho del globo. No sólo no es patrimonio de Occidente sino que, muy probablemente, su introducción en las músicas europeas, cultas y populares sea producto de migraciones provenientes de 
Oriente o incluso de África. Es una práctica mestiza, transcultural, imposible de asociar con una cultura, una región o, como parecieran haber deseado algunos musicólogos, una raza. La escritura de la polifonía, que sí es una particularidad de Occidente, no señala la invención del procedimiento sino su regulación, su disciplinamiento, así como el de aquellos que la cantan o tocan. El control y dominio de la naturaleza sonora (Small, 1989, p. 67) es en todo caso parte del proyecto hegemónico y colonial de la modernidad europea. Y las afirmaciones sobre la exclusividad occidental de la simultaneidad sonora son un recurso para cumplimentar ese proyecto.

Podemos ver que la musicología afirmativa de cuño positivista, antes que desarrollar una base metodológica sólida a partir de la reflexión sobre su episteme -cosa que como vimos no sucede-, se organiza para dar fundamento a las decisiones estéticas, al clivaje y la estratificación que configuran el paradigma de la música culta occidental, argumentando en una especie de pseudo ciencia que no hay música más allá de la partitura y por lo tanto, de la cultura de élite. Y ese fundamento sólo será posible mediante la construcción de un objeto de estudio basado en la consideración excluyente de los elementos técnico-formales y el prejuicio idealista de la gran obra de arte como valor en sí mismo, refractario a los condicionamientos de la sociedad (Lanza, 1986, p. 33). Una hipoteca científica que hace posible el estudio histórico de la música si la apartamos de la historia. Curiosa forma paradojal de historiografía, construyendo objetos fijos intemporales mediante el destierro de las prácticas efímeras, contingentes y situadas.

Hacer perdurar es también cristalizar, objetivar, reificar. "Un sistema de notación tan desarrollado como el nuestro permite que lleguen a generarse clásicos, obras musicales que sobreviven a sus creadores para convertirse en rasgos aparentemente permanentes del paisaje musical» (Small, 1991, p. 40). Obras musicales que sobreviven, para lo cual no solo hay que desarrollar un medio de conservación, sino hacer de él un fin. "El concepto de obra, en apariencia la sustancia más firme de la historia de la música, se diluye en la fuente, el texto auténtico» (Dahlhaus, 1997, p. 47). La obra es la partitura, ya que anotando la música podemos transformar el musicar (Small, 1998) en objeto, pero fundamentalmente, porque si creemos que la música es un objeto, podemos desplegar alrededor de ella todas las relaciones que el capitalismo impone al mundo de las personas y las cosas. En particular, la conversión del hecho musical en valor de cambio. Como ocurre en el caso de cualquier otra mercancía, es la fetichización de la obra musical (Bermúdez, 1982, p. 6) la que imprime el sesgo esteticista en la historiografía musical, para lo cual es fundamental quitarle su componente histórico o lo que, según Marx, son los procesos de producción mediante los cuales la sociedad le asignan un valor a la mercancía.

El mercado de los objetos imaginarios musicales, las obras, necesita del desarrollo de una teoría, una ciencia que fije pautas de valor que aprecien ${ }^{79}$, que pongan precio a esos objetos a la venta. "Finalmente, la existencia de un sistema de notación permite el nacimiento y el cultivo de la musicología, esa hija bastarda de la música y la ciencia, que está al servicio de nuestra pasión por la "autenticidad" en la ejecución» (Small, 1991, p. 41)

\subsubsection{La obra-objeto reemplaza al acontecimiento}

"Arte vs. Historia». Así comienza Jim Samson su exposición acerca de qué es la historia de la música en el compendio que Cambridge publicó en 2009 acerca de las disciplinas que estudian a la música. Y a continuación se pregunta: «¿Cómo podemos ser históricamente justos frente a las obras musicales, dado que son parte de nuestro presente?» ${ }^{80}$ (Samson,

\footnotetext{
79 ¿Es también una extraña casualidad que los cursos introductorios a la historia de la música en nuestras facultades y conservatorios se llamen "Apreciación musical"?

80 «How can we do historical justice to works of music, given that they are part of our present?» (Samson, 2009, p. 7) [traducción del autor]
} 
2009 , p. 7). Por lo que se ve, se trata de un asunto de justicia. De hecho el modelo judicial burgués posee relaciones estrechas con el positivismo historiográfico. Lord Acton por ejemplo consideraba que se haría justicia sobre Waterloo si «resultaba satisfactorio para franceses e ingleses, holandeses y alemanes por igual» (Carr, 2006, p. 84). La manera de lograr esto era mediante «la valoración imparcial de pruebas y testimonios» tal cual lo haría un juez (Ginzburg, 1993, p. 19) Así, la historiografía, cuando está basada en documentos, puede levantarse por encima de los acontecimientos y convertirse en un tribunal reconocido por todos.

El modelo judicial tuvo dos efectos interdependientes sobre los historiadores. Por una parte les indujo a centrarse en los acontecimientos [...] que en cuanto tales podían ser atribuidos sin demasiadas dificultades a las acciones de uno o más individuos; por otra a descuidar los fenómenos que no encajaban en esta pauta explicativa. Reconocemos como en un negativo fotográfico lleno de rayaduras, los lemas en torno a los cuales se constituyó la revista Annales d'histoire économique et sociale. (Ginzburg, 1993, p. 20).

El problema es que para la musicología positivista la música no debía ser considerada fenómeno, sino objeto. Por lo tanto, todo aquello que resalte su carácter de producto de circunstancias históricas y sociales atenta, en esta perspectiva, contra la integridad estética. Puede parecer extraño que la propia música, entendida como fenómeno histórico, atente contra la música/objeto. Pero como si se tratara de un malviviente o delincuente que pone en vilo a la sociedad, desde esta concepción, la historia, convertida en devenir que aleja a la música de su reproducción en el presente, atenta contra la integridad de la música, es su rival, su enemigo. Hay una sensación por parte de los autores de no quedarse de brazos cruzados y salir en auxilio del preciado arte de los sonidos, amenazado, agredido, ofendido por la historia y sus efectos colaterales: la economía, la sociedad, la política. Incluso la cultura. "Pensemos un momento acerca de las diferencias entre la historia de la música y la historia general»81 (Samson, 2009, p. 7). El juego de las diferencias es un mantra que se repite entre los musicólogos: "La historia del lenguaje "artístico" no puede comprenderse del mismo modo que la historia del lenguaje que se utiliza en la comunicación diaria [en la cual] el discurso de cada individuo vale tanto como el de los demás» (Rosen, 1986, p. 26) lo cual, para la musicología positivista es inaceptable en función de su programa de individuación de la obra/objeto y el compositor/héroe. Como vemos, se trata de una justicia bastante aristocrática. Esto lleva a que la historia de la música se describa como una disciplina en la que

el acento recae sobre la comprensión de las obras, las cuales -en contraste con los relictos de la historia política- representan la meta y no el simple punto de partida de la investigación histórica. El concepto de obra y no el de acontecimiento constituye la categoría central de la historia de la música, cuyo objeto es la poiesis, la creación de obras, y no la praxis, la acción social. (Dahlhaus, 1997, p. 13).

De esta última cita podemos deducir dos aspectos con claridad: por un lado, la musicología tiene conciencia de que el positivismo acontecimental existe. Vale decir que la supuesta tardanza en abrazar su método no es producto del desconocimiento o del encierro disciplinar. Pero además y con mucho énfasis se busca, de forma intencional y volitiva, apartar a la música de la realidad social, preservar la poiesis frente a la amenaza de la praxis. Todo un manifiesto ideológico que justamente hace pie en el artefacto por excelencia de la concepción musical moderna que también es, hay que recordarlo, capitalista: la obra musical.

81 «Think about the differences between a history of music and a general history» (Samson, 2009, p. 7) [traducción del autor]. 
Citando la máxima de Droysen, ${ }^{82}$ según la cual en historia «aquello que fue no nos interesa porque fue sino porque, en cierto sentido, sigue siendo, dado que aún produce efecto", Dahlhaus insiste en aquello que de especial o singular tiene la historia de la música, que como vimos se ocupa de las "obras", en la medida, pues, en que la presencia estética de dichas obras incide en la exposición del pasado histórico "como criterio de selección» (Dahlhaus, 1997, p. 12). Queda claro que la historia procede a partir de una selección de músicas que, según el historiador, poseen "presencia estética" e importancia para el presente. Toda una apuesta por la arbitrariedad y el relativismo del gusto que no hace otra cosa que oponer la historicidad al "carácter artístico" con el fin de preservar este último (Dahlhaus, 1997, p. 29). Según Bermúdez (1982), este tipo de pensamiento presente en la historiografía musical tradicional revela un "estetismo ingenuo", componente fundamental en la configuración de la musicología como disciplina:

basta recordar que para uno de sus pioneros, Guido Adler, el foco de la nueva disciplina debía ser: "la obra de arte en si misma y que el objeto central de toda investigación musical era el de dilucidar los principios teóricos y estéticos del arte en los diversos períodos de su historia." (Claro Valdés, 1967, p. 10).

Ahora bien, los justicieros de la musicología como Dahlhaus o Samson, al ser simultáneamente adalides del positivismo, encuentran un obstáculo en la propia definición de la categoría de obra musical.

Parece como si la obra misma sólo existiera como una idea en la mente del compositor, del ejecutante (que la toca lo mejor que se lo permite su capacidad, pero no deja de tener dolorosa conciencia de la brecha abierta entre su concepto y los sonidos reales que produce) y del oyente (que en una ejecución está atento a aquellos sonidos que concuerden lo más estrechamente que sea posible con la idea que tiene de la obra); es una abstracción que quizá nunca se pueda concretar perfectamente en sonidos reales. (Small, 1991, p. 37)

Aunque trabajar con abstracciones sea parte del sistema científico del historicismo, tampoco en este caso es tan sencillo ya que, como señala Lydia Goehr, la obra musical posee una ontología cuanto menos opaca, dado que no tiene existencia física, mental o ideal como objeto. "Las obras no existen como objetos concretos, físicos; no tienen entidad como ideas privadas existentes en la mente de un compositor, un intérprete o un oyente; tampoco existen en algún mundo intemporal de formas ideales e increadas» ${ }^{83}$ (Goehr, 1992, p. 3). Por no mencionar los problemas que conlleva la actualización de una de estas obras mediante las instanciaciones que significan las sucesivas ejecuciones o performances. Cada una de éstas diferente de las otras, a sabiendas que a su vez ninguna es idéntica a la obra original, «por más eminente que sea el intérprete, no abarca más que parcialmente la esencia de la obra» (Small,1991, p. 37) que, de todos modos, nos es muy difícil (sino imposible) poder ubicar o definir. Además, en la ejecución, las secciones musicales se suceden unas a otras mientras que en la "obra" existen simultáneamente, cristalizadas y detenidas en el concepto. Las obras musicales son "mutantes ontológicos" (Goehr, 1992, p. 3). En este universo de indeterminación, la música es, para el análisis, un inefable, un fenómeno escurridizo sobre el cual es necesario operar con el fin de transformar su condición y volverlo accesible a la razón.

Para que la obra musical se pueda convertir en el concepto regulatorio (Goehr, 1992, p. 102) de todo el pensamiento musical $y$, por ende, de la historiografía positivista, es necesario dar un paso decisivo que transforme esta noción ambigua en objeto, ente que a

82 Viene a cuento recordar que Droysen es el responsable de acuñar la noción de "helenismo" que pretende la derivación de la cultura europea de los venerables antepasados griegos, y de fundamentar históricamente la supremacía de Prusia en la reunificación alemana. También fue un activo diputado de centro-derecha.

83 «They do not exist as concrete, physical objects; they do not exist as private ideas existing in the mind of a composer, a performer, or a listener; neither do they exist in the eternally existing world of ideal, uncreated forms» (Goehr, 1992, p. 3) [Traducción del autor] 
su vez poseerá un doble sentido: ser objeto inteligible, racionalizable y por ende pasible de análisis lógico; y estar disponible como objeto de consumo, serializable y capaz de poseer un valor de cambio. En este proceso las condiciones de producción, es decir las cualidades realmente "históricas", son irrelevantes e incluso podrán considerarse contradictorias con tal objetivo. Por lo tanto serán dejadas de lado, transformadas en "contexto", información opcional de índole más bien filantrópica que acompaña la experiencia de consumo del diletante.

Por mucho que nos interesen las situaciones que nos ayudan a explicar el carácter de un edificio o de una pintura, hemos de reconocer que nuestro interés procede del valor que atribuimos a la obra particular. Si fuera cínico, diría que ese valor puede expresarse en términos monetarios. Pero no soy cínico (Gombrich, 2004, p. 114)

Una propuesta para transformar la música en objeto y así serializar tanto su producción como su percepción, la encontramos desde las múltiples teorizaciones que hunden sus raíces en el empirismo, analizando las "respuestas" frente al "estímulo" musical y deduciendo las pautas comunes que pueden considerarse leyes: el concepto de obra se forma por este proceso inductivo que a todas luces es un traslado del modelo de las ciencias naturales. Leonard Meyer, por ejemplo, entiende a la obra como una cadena de estímulos que parten de la ambigüedad y la indeterminación para progresivamente ir presentando tendencias de cierre que producen expectativas perceptuales que son satisfechas también de forma progresiva hasta llegar al final de la música, mediante la resolución de las tendencias ambiguas. Un "círculo estímulo crisis-tendencia que originasatisfacción que se produce-restablecimiento de un orden" (Eco, 2002, p. 170). De esta forma «en la música el mismo estímulo, la música, activa las tendencias, las inhibe y halla para ellas soluciones significantes» (Meyer, 1956, p. 32). Reducir la música a una estructura, detener su ambigüedad para transformarla en un principio de acción y reacción, nos devolvería el secreto de la emoción estética que habita en la música. La música se explica a sí misma mediante su lógica interna. El análisis de la obra, por tanto, no traduce directamente lo inefable sino que, a través de la definición de la emoción estética que habita en la estructura, accedemos a un atisbo de aquél. La explicación -es decir el análisis de la obra- es producida para volver cognoscible al inefable, develar esa lógica que reside en la obra. Pero justamente en la producción de esa explicación se destruye -se consume- el proceso musical, de cuya muerte depende el éxito del programa analítico. De esta forma la definición de la obra musical no revela su esencia, «porque la esencia de esta definición se transfiere al proceso de ajuste en virtud del cual partiendo del esquema -consumido- se engendra a través de la respuesta del consumidor el sentido de inefabilidad, el halo emotivo» (Eco, 2002, p. 167).

Me permití esta digresión filosófica sobre la obra musical ya que justamente es esta operación de su definición por transformación, tan compleja y abstracta, la que habita el centro ideológico del programa historiográfico del positivismo. Como señala Terry Eagleton podemos pensar que todo el despliegue de la estética moderna, desde Baumgarten y Kant en adelante, es parte nuclear de la construcción de la hegemonía ideológica del capitalismo.

\begin{abstract}
Mi tesis, en términos generales, es que si la categoría de lo estético asume la importancia que tiene en la Europa moderna es porque al hablar de arte habla también de todas estas cuestiones que constituyeron el meollo de la lucha de la clase media por alcanzar la hegemonía política. [...] Es este fenómeno -y no tanto el hecho de que los hombres y las mujeres descubrieran súbitamente el supremo valor que supone el hecho de pintar o escribir poesía- el que provoca que lo estético desempeñe una función tan singular dentro de la herencia cultural de nuestro presente (Eagleton, 2006, p. 53).
\end{abstract}

Función que asumen magistralmente los artefactos de la música tonal moderna -culta y pronto "clásica"- recontextualizando el ritual en la sala de conciertos y transformando el sacrificio en representación. Todo el programa estético musical de las élites del siglo XVII a 
XIX puede entenderse como procedimiento para «hacer creer en el orden mediante la representación, poner en escena la pirámide social enmascarando lo que ella significa de alienante, para no conservar sino su necesidad, tal es todo el proyecto de la economía política de esos dos siglos» (Attali, 2011, p. 94). Allí la musicología entra en escena, describiendo y explicando la "música artificial" producida por especialistas, enclaustrada y apartada del orden cotidiano y de las dimensiones de los sectores populares. "La estética de la representación no puede ya hacerse aceptar como naturalidad. Se disfraza como ciencia, como ley universal» (Attali, 2011, p. 94).

Veamos cómo mediante una ligera recontextualización de términos similares a los usados por Meyer, podemos entender a ese proceso de abstracción del fenómeno musical y su transformación en estructura -obra musical- como medio que posibilita la reificación y su inscripción en valor de cambio, requisitos del capitalismo moderno:

una obra es una forma abstracta [...] el compositor produce un programa, una matriz, un algoritmo abstracto. La partitura que escribe es un orden descrito a un operador-intérprete. A continuación, el intérprete crea un orden en el espacio sonoro con su instrumento, máquina para traducir la partitura, para descifrar el pensamiento codificado del autor. La forma de la música es siempre recreada por el transmisor y los medios. Por último, el objeto es producido, vendido, consumido, destruido, usado. Para ello, interviene todo un conjunto de producciones comerciales, desde la partitura hasta el disco. Veremos que la propia demanda se convierte en un trabajo, y deberá ser producida socialmente (Attali, 2011, p. 59).

El compositor, el matricero, es un especialista, y la idea moderna de música aliena la producción musical de la vida cotidiana para colocarla en manos del especialista, transformando a los no-músicos en consumidores (Small, 1991, p. 97). Eso es también parte de la definición de la música tonal. Por eso Meyer habla, en su modelo, de tensiones y estímulos que necesitan resolverse, ya que su esquema solo cierra en la música de la "práctica común", la que conforma el canon musicológico de la historia positivista. Como ya dijimos, es la música tonal funcional la que establece la propia posibilidad de la obra/objeto, producida y consumida en el mundo del capitalismo posrenacentista. El resto de las músicas serán antecedentes o conformarán estudios "opcionales", aún en textos muy actuales «El énfasis principal de Listen recae sobre el repertorio de la práctica común, con una cuidada selección de materiales más modernos y una unidad opcional aunque generosa sobre la música anterior al siglo XVIII» (Kerman \& Tomlinson, 2015, p. ix). ${ }^{84}$ Dentro de este universo es imprescindible contar con la posibilidad de racionalizar la producción de los objetos, volver cognoscible lo que según la estética es inefable.

La lógica y las relaciones lógicas son, de hecho, conceptos claves del arte occidental. La obra de arte es explicable lógicamente, y en última instancia, cognoscible; en las relaciones que contiene nada puede quedar oscuro ni resistirse al análisis. Cada elemento se relaciona lógicamente con cada uno de los otros, y con la estructura principal de la obra. Quien escucha la música puede «abrirse paso oyendo» entre los sonidos, y entender los procesos que están en juego, aun cuando no pueda darles nombre (Small,1991, p. 23).

Esa ausencia de conocimiento especializado del oyente, alienación en el consumo, es vital para comprender el desarrollo histórico de una sintaxis del objeto musical. «La música flota, como una lengua cuyos hablantes hubieran olvidado el significado aunque no la sintaxis [...] La música se ha convertido en una mercancía, un medio de producir dinero. Es vendida y consumida. Es analizada» (Attali, 2011, p. 58).

El capitalismo moderno necesita distinguir el valor de la obra del de su interpretación fenoménica, efímera y contingente, para que así adquiera un valor de cambio, diferenciando

84 «The main emphasis of Listen is on the common-practice repertory, with a careful selection of more modern material and an optional but generous unit on pre-eighteenth-century music» (Kerman \& Tomlinson, 2015, p. ix) [traducción del autor] 
el valor del "programa" -que es la mercancía- del de su "uso", es decir la música en tanto fenómeno sonoro. Así la obra se vuelve autónoma y se cristaliza. «Ella se construye sobre la existencia concreta de una valorización comercial posible en un objeto, la partitura, y en su uso, la representación» (Attali, 2011, p. 79) y sobre un modo particular de consumo. Modalidad en la cual se esconden las condiciones del proceso de producción y se distribuyen los roles -matricero, operario, consumidor- en torno del objeto racionalizado: la obra. Objeto que cuenta con su explicación musico-lógica que además elimina la naturaleza construida de sus objetos para consolidar una identidad estable de sus practicantes. (Korsyn, 2005, p. 6)

La construcción de la noción moderna de artefacto estético no se puede por tanto desligar de la construcción de las formas ideológicas dominantes de la sociedad de clases moderna, así como, en realidad, de toda una nueva forma de subjetividad humana apropiada a ese orden social. (Eagleton, 2006, p. 53)

Es la sociedad de clases moderna la que necesita transformar la música en objeto, hacer del musicar una cosa: mercancía, valor de cambio. Y lo logra confundiendo la música con la partitura, objeto además vendible entre la clase media durante todo el capitalismo prefonográfico. Aprender la lectoescritura musical es aprender "por música" y, en ese aprendizaje, a lo que más hay que prestar atención es a las notas. Es lo que un aficionado inglés del siglo XVI debía aprender para tocar con su laúd en casa, del mismo modo que hoy un adolescente hace con su guitarra eléctrica en la academia del barrio. Las notas son lo que importa, lo que obtiene relieve en el paso de la música/proceso a la música/objeto, lo cual incluso se da antes de que se comience a utilizar el término "obra" dentro del otro gran dispositivo del mercado musical capitalista: la sala de conciertos, que encierra, enclaustra al fenómeno musical en un recinto específico para así poder cobrar por su audición. La forma se cierra al mismo tiempo que se aloja en un recinto cerrado. Es en esas salas donde ocurre el espectáculo burgués moderno por excelencia, la ópera, término que es también plural de opus, trabajo, obra. En la sala pública es donde las emociones se cosifican, se transforman en "afectos", se tornan fórmulas retóricas y se reducen a efectos de las arie. La ópera es estructura lógica, racionalizable, explicable cuantitativamente, analizable: requisitos para ser transformada en valor de cambio. Por eso necesita del desarrollo del sistema tonal funcional, que le es estrictamente contemporáneo, relación en la cual la armonía y el melodrama se implican mutuamente (Fubini, 2005, p. 171), transformación técnica imprescindible ante el advenimiento del capitalismo moderno, ya que «en la música, como en el resto de la economía, la lógica de sucesión de los códigos musicales sigue la lógica de la producción de valor» (Attali, 2011, p. 65). El artefacto estético será así fetiche del orden social hegemónico: «el artista nace cuando su obra es puesta a la venta» (Attali, 2011, p. 73) mientras que la musicología no eclosiona hasta tanto el liberalismo burgués se consolide como poder dominante -en el paso del siglo XVIII al XIX- y despliegue como urdimbre de su ideología la concepción de la obra de arte autónoma y su contemplación desinteresada (Eagleton, 2006, p. 55). En este escenario, la tan vilipendiada reproductibilidad tecnológica de la obra y el advenimiento de la grabación y la fonografía no son más que etapas ulteriores de sofisticación del fetichismo de la obra. En todo caso, amplían la circulación de la música/cosa. Tal vez la democratizan y por eso son condenadas. Pero era una posibilidad que ya estaba disponible al reificar la música e historificarla 85 en tanto obra. El "aura" ya estaba perdida mucho antes de que tuviésemos conciencia de ella. Antes incluso de que advirtiéramos que la obra/objeto es la unidad de sentido estético del arte moderno ya que es la historiografía musical quien perpetúa esa

85 Lo que se pretende con el uso terminológico es diferenciar la idea de 〈historiar〉 o 〈historizar〉 un fenómeno o concepto (que implica desnaturalizarlo y restituir justamente su condición «histórica〉) de 〈historificar» mediante la construcción de un artefacto historiográfico, es decir transformar por cosificación un asunto en tradición histórica para aumentar su valor, en el sentido de ‘canon` y también del concepto de "tradiciones inventadas" propuesto por Hobsbawm (2015). 
falta de conciencia, mediante la fetichización del artefacto musical. Porque oculta que es el mercado musical el medio socioeconómico en donde (y gracias al cual) se desarrolla la idea moderna de arte, ese ideal que como citamos antes es para Dahlhaus el fundamento en el cual se basa la "historia de la obras" que él defiende ante sus detractores ideologizados. «En tanto que consideremos que el elemento esencial del arte es el objeto creado y no el proceso creativo, estaremos atados a la preservación de todo lo que ha producido el pasado» (Small, 1991, p. 99).

\subsubsection{El estilo como concepto normativo de la historiografía afirmativa}

¿Cómo hacer una historia sin historia? ¿Qué características debe tener un relato diacrónico que rechace el devenir, el carácter fenoménico y permanentemente mutable de la práctica musical a través del tiempo? ¿No es más viable un "museo" de las obras (Goehr, 1992) -o si se quiere un supermercado- que su historiografía?

La historia puede pensarse aquí como periferia de un canon de obras, información que puede hacernos apreciar con mayor profundidad de criterio la selección -estética pero además comercial- de los artefactos, que como ya vimos depende de criterios internos y juicios de gusto. Así, estudiar las condiciones en que apareció una obra ayuda a que la "entendamos mejor" (Dahlhaus, 1997, p. 12), pero no es imprescindible en absoluto. Este es otro punto en el cual la musicología se aparta conscientemente del historicismo positivista, ya que «la máxima según la cual es preciso conocer el origen de una cosa para llegar a su esencia, dista mucho de ser acatada con la unanimidad con que todavía se aceptaba en el siglo XIX» (Dahlhaus, 1997, p. 11). Los orígenes en términos de condiciones históricas pueden ser un tema lateral de estudio en la historia de la música positivista, pero la esencia de las obras no depende de que conozcamos aquéllos. Es aquí donde esta vertiente de la historiografía musical desarrolla otro de sus conceptos nucleares clave y lo hace tomando como referencia cierta categoría particular de la historia del arte: el estilo.

Como ya señalamos antes, son Guido Adler o Charles Parry quiénes por separado, pero en el mismo año de 1911, inscriben a la historia de la música en la categoría del estilo, profundizando la autonomía y el armonicocentrismo del idealismo estético decimonónico. Pero todos estos elementos se desarrollarán más tarde, en concordancia con el momento del positivismo musicológico, que es coincidente con la historiografía del estilo. Haciéndose eco de los presupuestos autonomistas que ya vimos en Dahlhaus o en Kerman, Charles Rosen suscribe que mientras «es la obra musical la que determina sus términos [es el] establecimiento de estos términos y la forma en que cada obra configura el contexto que envuelve al drama que se representa» lo que constituye el estilo. (Rosen, 1986, p. 11) Como los términos de la obra/objeto se dan a partir de la racionalización de la música, su abstracción y objetivación, es necesario un esquema clasificador igualmente racional, autónomo y producido mediante la lógica interna de la sintaxis musical y su valor estético, lo que recordemos equivale a apartarlo del sentido histórico. Por eso «El concepto de estilo es necesario para comprender la historia de la música» (Rosen, 1986, p. 12)

El concepto de estilo no se adscribe a un hecho histórico, sino que responde a una necesidad: crear una forma de entendimiento [...] Esta necesidad [...] no pertenece a la historia de la música, sino a la historia del gusto y la percepción musicales (Rosen, 1986, p. 24)

El concepto de estilo habita el "mundo 3" popperiano, mundo de las soluciones objetivas a los problemas (Gombrich, 2004, p. 113), distinto del mundo de la materia y del mundo subjetivo de las experiencias. Al menos se emparenta con ese idealismo de la renuncia que Marcuse ubicaba en el centro de la operación de la afirmatividad. Materia sonora y experiencia, es decir los atributos nodales de lo que podemos entender como fenómeno artístico, son dejados de lado, arrojados fuera del mundo de las explicaciones. Por eso el mundo de los estilos está poblado de obras/objeto. Debemos recordar que desde su 
concepción en el siglo XIX, «en el positivismo la ciencia negaba la importancia de la historia en nombre de la actuación inmutable de las leyes de la naturaleza» (Mosse, 1997, p. 235). Si como creía Comte, las leyes de la sociedad eran por completo análogas a las leyes físicas, para explicar el desarrollo musical bastaba con agrupar y clasificar las obras/objeto obtenidas a partir de la racionalización de su estructura, ya que «la observación constante de estos fenómenos individuales revelaría similitudes que, una vez cotejadas, se convertirían en leyes naturales» (Mosse, 1997, p. 236). Mediante la articulación con las ideas de Spencer, el positivismo historiográfico de la musicología ingresaría al siglo XX coordinando estos estilos en forma de evolución, considerada ésta una ley también vinculante y que podía transferirse del mundo de los fenómenos naturales al de la sociedad. La evolución "era también una verdad a la que se había llegado a través del análisis de datos, de hechos observables y no a través de ideas metafísicas» (Mosse, 1997, p. 238). La historia de los estilos se propone entonces como superadora de la idea de Zeitgeist del historicismo hegeliano. Y construye retrospectivamente una progresión evolutiva del estilo musical centrado, como ya vimos, en la organización de las alturas, eliminando o subordinado datos contradictorios con este principio rector y erigiendo una imagen histórica que va de la línea melódica tosca en el vacío a las complejidades armónicas del postromanticismo.

El carácter arbitrario de la selección que integra un estilo, así como de los parámetros que se utilizan para describirlo, casi no se esconde:

Para el historiador un estilo es un concepto ordenador y de distinción, que se conforma mediante generalizaciones a la vez que se las denota: el o la historiador/a agrupa ejemplos musicales de acuerdo con las similitudes que encuentra entre ellos ${ }^{86}$ (Pascall, 2001)

Por lo tanto los estilos, que acaban reemplazando nada menos que a la herramienta historiográfica de la periodización, son agrupamientos retrospectivos construidos en base a la abstracción de algunas características pretendidamente comunes que se obtienen por un proceso de inducción en base a la regularidad presente en la utilización del lenguaje musical desplegado por ciertos compositores en la escritura de su música. Es decir, Barroco, por ejemplo, es un estilo musical cuyos límites temporales se determinan con base en momento en que en la música comienza a estar presente, por ejemplo, el bajo continuo, el contraste dinámico, la distinción entre género instrumental y vocal o la polaridad de las voces extremas, entre otros rasgos. A su vez, Barroco concluirá cuando estas características y procedimientos sean abandonados y reemplazados por otros diferentes. Pero en su interior el Barroco debe ser consistente dado que de esa forma obtiene su identidad. $Y$ aquí es donde advertimos con mucha claridad en qué forma el positivismo se propone continuador del personalismo, ya que las diferencias ocurren entre los compositores que pertenecen a un estilo, las cuales suelen ser vistas en términos evolutivos y por lo tanto colocan en los extremos a los personajes más ilustres. Para Bukofzer ([1947]1986) o Soler (1987), por ejemplo, el Barroco se abre con Monteverdi, quien clausura y modifica para siempre los rasgos más importantes del renacimiento, y se cierra con Bach, que madura y sintetiza todas y cada una de las características del Barroco, incluyendo los aportes de Monteverdi. ${ }^{87}$ Pero también el estilo recupera cierto programa de la estética romántica, que el positivismo musicológico nunca abandona ni desecha en su afán y necesidad por el culto a la personalidad artística. En este sentido, el estilo es una especie de presencia inmanente y así el

\footnotetext{
86 «For the historian a style is a distinguishing and ordering concept, both consistent of and denoting generalities; he or she groups examples of music according to similarities between them».

87 Un buen ejemplo es el subtítulo del libro de Manfred Bukofzer sobre el Bbarroco, el cual reza precisamente «de Monteverdi a Bach» (Bukofzer, [1947] 1986)
} 
estilo, un estilo o los estilos pueden ser vistos como presencia en un acorde, frase, sección, movimiento, obra, grupo de obras, género, la obra -producción- de un compositor, un periodo (de cualquier dimensión) y una cultura. El estilo se manifiesta a través del uso característico de la forma, la armonía, la textura, la melodía, el ritmo y el ethos"88 (Pascall, 2001).

Es por este motivo que las razones estéticas, más vinculadas a la crítica musical que a la ciencia y la historia, son explícitamente - ¿orgullosamente?- esgrimidas: "Se trata al estilo como si fuera una obra de arte y se le juzga igual que se juzga la obra de un artista y con arreglo a los mismos cánones» (Rosen,1986, p. 25). En cualquier caso queda claro además que estilo y cultura son conceptos -y enfoques- divergentes y contrastantes (Kerman \& Tomlinson, 2015, p. xi).

Veamos algunos ejemplos, en los libros de texto ya mencionados, de cómo se utiliza la categoría de estilo y su insoslayable subestimación de los aspectos históricos. En el libro paradigmático de los estudios sobre el estilo Barroco (el cual es a su vez paradigmático de las concepciones de estilo) Manfred Bukofzer adelanta una definición precisa del término, invocando la autoridad a un musicólogo anterior muy representativo del positivismo «La época barroca comienza y acaba de manera casi exacta con la época del bajo continuo. Por ello, Riemann no dudó en llamar a la era barroca Generalbass-Zeitalter ("la era del bajo continuo")» (Bukofzer,[1947]1986, p. 26). Grout refuta esta posición, en lo que aparentemente sería una reivindicación de la historicidad «Designaciones tales como período del bajo continuo- o -período del estilo concertato- solo se refieren a aspectos técnicos de la música, sin dar cuenta de sus importantes vinculaciones con otros aspectos de la cultura de esa época». Sin embargo no debemos confundirnos, ya que enseguida nos aclara de qué naturaleza son esos "aspectos de la cultura" con los cuales hay que vincular a la música: «El empleo del término barroco para calificar a la música de 1600-1750 sugiere que los historiadores creen que sus atributos se asemejan, en cierto modo, a los de la arquitectura, la pintura y la literatura contemporáneas» (Grout,[1960]1984, p. 319). En tanto el concepto de barroco como categoría de estilo es importado de la historia del arte, se nos pide que busquemos las conexiones entre «las restantes actividades creadoras del hombre» y la música. Partimos de una consideración estilística (barroca) de las artes visuales para construir la clasificación estilística (también barroca) de la música. Recordemos además que en el caso de Grout los capítulos sobre el Barroco se articulan en base a personalidades, aunque se proponga constituirse en modelo de la historia sin nombres del positivismo. Ninguna exploración de las relaciones con aspectos culturales en un sentido amplio, en cuanto a las relaciones humanas, jerárquicas, las instituciones musicales, las cosmovisiones, los sistemas de producción, la tecnología, entran en la propuesta de estos historiadores. Por este motivo Bukofzer incluye en su texto un último capítulo en el cual resume y comprime una serie de datos históricos y sociales, dejando la vinculación de éstos librada al lector. Igual procedimiento realiza Grout, mediante una cronología al final del texto, la cual

tiene como finalidad reflejar los antecedentes y circunstancias que rodean la historia de la música en general o un determinado periodo de ella y a la vez permitir que el lector pueda ver las obras y los compositores individuales en relación con los acontecimientos más destacados (Grout,[1960]1984, p. 849)

Pero esas relaciones no se explicitan, ni se sugiere o indica cuál sería la naturaleza de dichas relaciones ni por qué, si al fin y al cabo solo rodean a las obras, hay que incluirlas en primera instancia. Dahlhaus, con menos demagogia, no duda en cuestionar la existencia de estos apartados «lo que no se sabe muy bien es qué se pretende demostrar al lector ¿La

88 «Style, a style or styles may be seen as present in a chord, phrase, section, movement, work, group of works, genre, life's work, period (of any size) and culture. Style manifests itself in characteristic usages of form, texture, harmony, melody, rhythm and ethos» (Pascall, 2001) [traducción del autor] 
analogía oculta entre la obra de Wagner y la de Kierkegaard? ¿O, por el contrario, la falta de contemporaneidad interna de obras contemporáneas?» (Dahlhaus, 1997, p. 29)

El carácter arbitrario y retrospectivo, sumado a la selectividad basada en el juicio estético, son los que evidencian los aspectos más reduccionistas de la aplicación del estilo a la historiografía musical. En el Atlas de la Música, la definición del Barroco recupera la ya mencionada de Bukofzer pero la vuelve más esquemática aún: «El período comprendido aproximadamente entre 1600 y 1750 constituye en la historia de la música una época estilística homogénea, el Barroco (término recogido del aplicado en la historia del arte), la era del bajo continuo (Riemann)» (Michels, [1985]1992, p. 301). El mismo carácter ecuménico y reductivo lo encontramos en Kerman «Un nuevo estilo, el estilo del periodo Barroco temprano, se impuso todo a lo largo de Italia y en la mayor parte del resto de Europa» 89 (Kerman \& Tomlinson, 2015, p. 83)

Es particularmente notable, por lo tanto, el estatismo que generan estos estilos en cuanto a su condición de herramienta de la musicología. Lo cual no es casual sino que obedece al carácter esteticista, a-histórico que, como vimos, es parte integral de la concepción moderna de la música. El estilo permite preservar a los clásicos sin caer en la disolución de su valor estético producto de una idea apresurada de progreso o evolución que haría de la música actual algo más desarrollado y complejo. Como resultado de esto, la historia de la música, asentada en las obras y su agrupamiento en estilos, adquiere un carácter regulatorio de la práctica musical (Goehr, 1992) y no puede ser otra cosa que un auxiliar del sistema económico de la representación musical (Attali, 2011) basado en la sala de conciertos (Small, 1989). Su utilidad es, por un lado, indicar a los músicos qué repertorio del pasado vale la pena recuperar -es decir cuál es más rentable- y qué aspectos técnicos priorizar al hacerlo y, por otro, divulgar al gran público un catálogo ordenado de los autores pretéritos y sus obras, suministrando algunas claves que ayuden a apreciarlos como se merecen. En definitiva, sea para los músicos profesionales o para los consumidores de la música, se trata de crear un canon de músicas y músicos del pasado, un catálogo de lo que vale la pena escuchar porque es de calidad y valor. Lo cual justifica que paguemos por ello.

Sin embargo no son pocos los problemas, sobre todo si se quiere preservar el carácter científico -y no de juicio estético- de la empresa historiográfica, lo cual es bastante evidente cuando se debe dar cuenta de repertorios musicales que, como en el caso de las músicas del siglo XVII, son heterogéneas desde una perspectiva histórica. Tim Carter (1993), por ejemplo, ha demostrado que en simultáneo con el desarrollo del bajo continuo -que como vimos es el indicador además de marcar el inicio del estilo barroco- durante las primeras tres décadas del siglo XVII ocurre un "boom" editorial del madrigal -que pertenece al otro estilo, el Renacimiento -o incluso el Manierismo- que según Bukofzer ([1947]1986, p. 19) «cayó en el olvido [mientras] el nuevo estilo ocupó su lugar». Lo cual coincide con la descripción de Taruskin que, al enfocarse en lo histórico -como el carácter social del madrigal y la monodia, y por ende de las ideologías de las que eran vehículos- puede desarticular el atributo de vanguardia que aparece en los comienzos de cada estilo/periodo de la historiografía positivista: «la "revolución monódica" del temprano siglo XVII que, como veremos, inaugura la "era barroca", no fue ninguna revolución, mientras que los estilos de canto "barrocos" [...] ya estaban perfectamente disponibles y eran familiares para los músicos "renacentistas"»"90 (Taruskin, 2005a, p. 691). También en Inglaterra o en Francia aparecen repertorios "nuevos", como el aire, que coinciden en casi todo con la monodia que

\footnotetext{
89 «A new style, the style of the early Baroque period, took hold all over Italy and in most of the rest of Europe».

90 "the "monodic revolution" of the early seventeenth century that, as we shall soon see, ushered in the "Baroque era" was no revolution at all, and that "Baroque" singing styles_-improvised" ornaments and all—were perfectly familiar and available to "Renaissance" musicians» (Taruskin, 2005a, p. 691) [traducción del autor]
} 
inaugura el Barroco, salvo en el uso del bajo continuo. Por lo tanto es tradición de la musicología colocar al aire y el madrigal dentro del Renacimiento y no del Barroco, a pesar de que el madrigal es aristocrático y vinculado a una cultura en todo lo demás muy renacentista, mientras el aire es una música para las clases medias urbanas, símbolo del capitalismo pujante. Para complicar aún más la cosa, podemos considerar los motetes policorales y el auge de los organistas católicos italianos (como Frescobaldi) o protestantes (como Sweelinck) entre 1580 y 1630, que el relato tradicional asocia con el llamado barroco veneciano, pero que en ningún caso contiene las características aludidas. Tampoco lo que según Kerman y Tomlinson (2015, p. 86) son los otros dos features del estilo barroco: la armonía funcional y el ritmo regular y métrico. Pero aún si consideramos las músicas que reúnen estas características de estilo ¿cómo explicamos las divergencias sonoras entre las óperas del floreciente mercado burgués, plagadas de arias virtuosas a cargo de los castrati, y los dramas musicales de la aristocracia, recitados al punto de la declamación, sin contrastes ni clímax con la sprezzatura que comporta la sutil profundidad emocional de la poesía áulica? ¿Es todo eso barroco, al igual que las músicas de los territorios latinoamericanos colonizados por las potencias europeas, a las que se le adjudica el término de Barroco americano, pálido reflejo degradado del original metropolitano? ¿Y la música de las bandas municipales, presentes en cada ciudad europea del siglo XVII? ¿Es barroca la música de las tabernas y las baladas vendidas en pliegos sueltos por los buhoneros en plena calle? ¿Las músicas mulatas producto del tráfico esclavista presente en América desde el siglo XVI, son barrocas también?

Compárese la narrativa estilística con el enfoque que esgrime Richard Taruskin, en una perspectiva muy particular dentro de la musicología anglonorteamericana, al cerrar el prefacio del libro que se ocupa -sin nombrarlo así- del Barroco:

el paso crucial de dejar de ser personal de servicio para convertirse en un agente autónomo, toma lugar en el transcurso de la presente narrativa y fue la transformación social más grande en la historia de la música culta. Sin ella, este libro nunca hubiera existido91 (Taruskin, 2005b, p. 5).

Al restituir la historicidad a la historia de la música, nos encontramos en la necesidad de develar y explicar ese "paso crucial" que, como ya vimos, generó al objeto/obra, el compositor matricero, el intérprete especialista y el oyente consumidor. $Y$ al texto científico explicativo para normalizar el mercado y generar demanda. El estilo es entonces una categoría de mercado que, al mismo tiempo, permite hacer una historia de las obras, la historia sin historia, en base a criterios clasificatorios y regulatorios basados en el fetichismo de las obras, en lugar de periodizaciones históricas. El mercado de la música organiza su despliegue en base al estilo, concepto regulatorio y normativo de la interpretación, hecho a la medida de nuestros cánones artísticos anhelados: «El término clásico implica un estilo que es paradigmático y normativo [...] la música del período clásico proporciona una norma con la que poder juzgar el resto de nuestra experiencia estética». (Rosen, 1986, p. 12)

En base a la autoridad -o autoritarismo (Cook, 2001)- que emana de la interpretación regulada por el estilo, las audiencias clasifican sus gustos en base a esta categoría y así se normaliza la escucha. Por ello los estilos son categorías en torno a las cuales se organizan la reproducción y el consumo musical.

"música barroca" se ha convertido en una marca de fábrica tan efectiva en su campo cultural como Nike o Adidas en el de la ropa deportiva. La etiqueta en las bateas de discos, en los anuncios de conciertos, en los títulos de festivales funciona como un rótulo que, por una parte,

91 «the crucial move from service personnel to autonomous agent takes place in the course of our present narrative, and it was the biggest social transformation in the history of music as a fine art. Without it, this book would have had no call to exist» (Taruskin, 2005b, p. 5) [traducción del autor] 
identifica claramente a un sector de la mercancía musical que responde a la demanda de un sector consumidor; por otra parte, marca con una diferencia a estos consumidores confiriéndoles un cierto prestigio, al menos ante sus propios ojos (Waisman, 2012, p. 1)

Como el propio concepto es producto de una historiografía -y una ciencia- que oculta en la fetichización las condiciones de producción de las obras, expulsando todo rastro vinculado a la sociedad y la cultura en torno a la música y privilegiando la inmanencia estética, el concepto de estilo, entonces, es contrario a la historia. Tal vez por eso en un libro de historia de la música, tensando el análisis todavía más que Leonardo Waisman, Richard Taruskin formula una propuesta radical:

\begin{abstract}
"Barroco" es un término que los músicos no necesitan. Tratar de justificar su existencia en términos que realmente se relacionen con la música del periodo al que se aplica, resultó en nada más que sutilezas, sofisticación, argucias y tergiversación. Hoy no es más que una etiqueta comercial para un tipo de "música clásica" que las radios y las discográficas comercializan como empapelados sonoros. Tratemos de olvidarlo.92 (Taruskin, 2005a, p. 797)
\end{abstract}

\title{
1.2.5 El carácter ideológico de la persistencia del positivismo.
}

Hasta qué punto están relacionados el personalismo, la autonomía estética, la obsesión positivista por las partituras en tanto fuente, la creación de la categoría obra/objeto y su regulación mediante el concepto de estilo, puede inferirse del hecho de que ninguna de estas cuestiones responde a formulaciones inocentes. Ya vimos que el marco de todo este despliegue epistemológico es el desarrollo de la civilización moderna de la burguesía, el capitalismo y la cúspide del imperialismo europeo. Hasta aquí, no hay nada demasiado sorprendente, más allá de la astucia con que la musicología pudo hacer pervivir un esquema de fetichización que en otras áreas de las ciencias y las ideas hace mucho ha sido desnaturalizado. El factor evolucionista, fundamentalmente, que coloca a la cultura europea occidental en el centro de toda la historia musical, podría considerarse parte de estos exabruptos eurocéntricos. Veamos un caso basado en las categorizaciones de estilo y en el cual nuestro ejemplo del Barroco cumple una función evolutiva:

\begin{abstract}
En general se atribuye una importancia sobresaliente en materia musical a los años del 1600 , aproximadamente, como el momento en que nació la concepción moderna de la música. Desde el punto de vista histórico esto es cierto, puesto que el período es de gran importancia. Todo el siglo XVII tiene valor, ya que vio la evolución de las nuevas formas de la construcción, nuevos medios de expresión y nuevas máximas estáticas que, en conjunto, han creado la música en sentido moderno. Sin embargo, desde el punto de vista del importante progreso artístico que trae aparejado el siglo XVIII, es más notable aún. Si el siglo XVII puede ser llamado niñez y juventud de la nueva música, el XVIII representa la primera madurez, la actividad vigorosa, joven aún y madurándose, sin embargo, del nuevo espíritu. Si añadimos los progresos musicales del siglo XIX, puede decirse con justicia que entre 1700 y 1900 el arte de la música alcanza su plena magnitud, el máximo de sus fuerzas y posibilidades, la innegable culminación de su historia de dos mil años (Leichtentritt, 1945).
\end{abstract}

Este aspecto afirmativo de la cultura musical europea, que ubica a los desarrollos de la música tonal funcional como cima de una evolución, es claramente una función de la musicología histórica, que se ha ido nutrie ndo a lo largo del siglo XIX construyendo un canon que entroniza a la música culta. Es fácil rebatir sus argumentos $\mathrm{y}$, de hecho, esto ha sucedido durante buena parte del siglo XX, particularmente desde la etnomusicología que, al ofrecer estudios de músicas extraeuropeas, hizo suyos los postulados del estructuralismo

92 "Baroque" is a term that musicians do not need. Trying to justify it in any terms that actually relate to the music of the period has never led to anything but quibbling, sophistry, and tergiversation. All it is now is a commercial logo for a kind of "classical music" that record companies and radio stations market as sonic wallpaper. Let's try to forget it» (Taruskin, 2005a, p. 797) [traducción del autor] 
antropológico, lo que derivó en un multiculturalismo relativista. Pero hay algo más, que permanece a buen resguardo de este tipo de críticas y se reproduce a pesar de la globalización y el "respeto por la diversidad". Un aspecto que se consolida cuando el positivismo musicológico realmente cristaliza, homogeneizando la práctica historiográfica de Occidente. Y que parte de ese proceso de ocultamiento de las condiciones de producción de la música que observamos en torno al desarrollo de la noción de obra/objeto musical.

Ya habíamos llamado la atención sobre el "atraso" disciplinar evidenciado por la tardía crisis del positivismo. Si ensayamos una rápida cronología, podríamos pensar que la historiografía musical durante el siglo XIX permanece bajo el signo del idealismo, la afirmatividad eurocéntrica y el personalismo del culto al compositor. Hacia los años de entreguerras aparece una tendencia sociológica en la musicología, influenciada por los trabajos de Durkheim y sobre todo de Max Weber. Pero es a partir de los años '40 y fundamentalmente en la posguerra que la historiografía positivista, de los estilos (Samson, 2009), basada en la obra/objeto se vuelve hegemónica. De allí que el capítulo de Kerman dedicado al positivismo lleve el subtítulo The Postwar Years.

En ese contexto, es muy sugerente encontrar en la defensa de esa historia de las obras o de los estilos una fuerte contrastación con todo lo que se presente como "ideológico" y pueda entrometerse en la narración estilística. No pretendemos sostener aquí una mecánica causal entre musicología positivista y antimarxismo. Sólo preguntar si no existe una relación bastante más profunda de lo que podría entreverse a simple vista. Más cuando es identitario del positivismo el presentarse como ajeno a todo sesgo ideológico, aspecto que ocupa el centro de las críticas que el posmodernismo le ha dirigido.

Retomemos a Gombrich y su defensa de Popper, la "sociedad abierta" y la historia del arte desligada del "determinismo social" marxista: "La palabra mágica para mantener a raya esas ideas subversivas es el término "estilo"» (Gombrich, 2004, p. 117). En la misma línea encontramos que

[la] historia de los estilos autónoma proveyó una alternativa segura [...] frente a las metodologías marxistas de Alemania Oriental y el bloque socialista que convertían en sospechoso todo tipo de teoría cultural y hermenéutica. Es en este contexto intelectual que se lanzaron los grandes proyectos filológico-positivistas de los años de posguerra [...] todo a lo largo de Europa Occidental [...] En EEUU y Canadá los musicólogos emigrados compartían las perspectivas de sus colegas europeos [...] también proveyó refugio a los historiadores nomarxistas del bloque soviético que se concentraron en esas áreas [el estilo] en lugar de perseguir tópicos políticamente sensibles como el sentido histórico y la causalidad"93 (Stanley, 2001).

Lo que escasea como reflexión metodológica pareciera abundar en cuanto a manifiesto político. Si consideramos, como dice Stanley, que en la Alemania Occidental hay un escenario germinal del proyecto cultural antimarxista, hallaremos sobre todo en Dahlhaus un tono militante y "bajo amenaza", más si consideramos que su posición académica en Berlín Occidental tal vez lo hizo creer que estaba en un puesto de avanzada en la lucha ideológica que requería defender los conceptos historiográficos "occidentales" a ultranza:

el concepto de obra es la categoría central de la música -por lo tanto también de la historiografía musical [...] se ve expuesta a crecientes dudas que surgen [...] por una difundida

\footnotetext{
93 «autonomous style history provided a safe alternative [...] to the Marxist methodologies of East Germany and the socialist bloc that made any kind of cultural theory and hermeneutics suspect. In this intellectual context the grandly conceived philological-positivistic projects of the postwar were launched [...] throughout Western Europe [...] In the USA and Canada [...] émigré musicologists shared the perspectives of their european colleagues [...] It also provided a haven to non-Marxist Soviet-bloc musicologists who concentrated on such areas rather than pursuing politically sensitive topics such as meaning and historical causality» (Stanley, 2001) [traducción del autor]
} 
tendencia a la crítica ideológica [...] desconfianza respecto de los fenómenos de cosificación y alienación, convergen en el concepto de que, en la música, la "letra escrita", pasible de ser transmitida, es menos importante que el proceso musical en sí (Dahlhaus, 1997, p. 14).

Nuevamente, mediante el modelo judicial de la historiografía positivista y como si se desempeñara en un tribunal, el abogado Dahlhaus condena la crítica ideológica que amenaza el corazón de la cultura occidental: la obra musical. Aquí no hay dudas, Dahlhaus no abraza la historiografía de los estilos porque no tiene otro remedio, porque no hay otra forma (tópicos que como vimos son habituales en la mayoría de los musicólogos que adoptan dicha metodología). Al contrario, «Dahlhaus desarrolló su propio método histórico el más conscientemente articulado de la posguerra- en buena medida como respuesta a las críticas marxistas hacia los procesos históricos autónomos y el análisis morfológico de la obra»94 (Stanley, 2001)

Sobre todo a partir de la década del '60, en la historiografía general las epistemologías tradicionales estaban siendo muy cuestionadas en Occidente y los enfoques marxistas resultaban atractivos, en particular al ofrecer una alternativa explícita frente al positivismo. A diferencia de los estudios musicales occidentales, este cambio paradigmático sí se trasladó a la historiografía musical de los países del este de Europa, dentro del bloque soviético, que hicieron foco en comprender la música como práctica social y no como objeto de cambio. En algún sentido los musicólogos marxistas "anticipan algunos de las tesis de la "nueva" musicología (o musicología crítica) » ${ }^{95}$ (Shreffler, 2003, p. 500). Y es precisamente en contra de esta matriz de renovación epistemológica que Dahlhaus construye su programa. Él «escribía en contra de la prolífica y cada vez más sofisticada musicología marxista que emanaba desde el otro lado de la ciudad, Berlín Oriental, tan sólo a una milla de distancia» ${ }^{96}$ (Shreffler, 2003, p. 500). Del otro lado del muro, los musicólogos de la DDR como Georg Knepler ya escribían sobre la música en términos de actividad humana y social, es decir de musicar. Y además no sólo incluían a la música popular, sino que se atrevían a pensar que algunas músicas de élite, como los organa de Pérotin del siglo XIII, estaban influenciados por la música danzable del pueblo. Que el positivismo musicológico, signo de Occidente, perpetuara la expulsión de la historia de la música popular no puede seguir apareciéndonos como un error o una mera cuestión de gusto. Existe una continuidad muy fuerte de la afirmatividad que, recordemos una vez más, tiene como principal objetivo restablecer la estratificación musical que, despreciando la cultura popular, legitima a su vez el orden social de la burguesía.

En palabras de James Hepokoski las teorías de Dahlhaus -que, recordemos, son paradigmáticas y muy influyentes dentro de la musicología occidental- «se pueden leer como una polémica anti-marxista» (Hepokoski, 1991, p. 227). La escritura musical que epitomiza Dahlhaus, que es la historiografía hegemónica de la música, es entonces, ante todo, un asunto del presente, de resguardar lo que de musical posee la sociedad occidental del capitalismo de posguerra, el «signo de carácter especial de la historiografía de la música. En la medida en que el tema principal [...] esté constituido por obras importantes que han perdurado en la cultura musical del presente» (Dahlhaus, 1997, p. 12). Este "tema principal", pensado así, mediante los conceptos del positivismo, no puede sino hacernos

94 «Dahlhaus [..] developed his own historical method -the most self-consciously articulated one in the post-war era (Grundlagen der Musikgeschichte, 1977)- in significant degree as a response to Marxist (including Adornoesque) critiques of autonomous historical process and formal work analysis» (Stanley, 2001) [traducción del autor].

95 «anticipates some of the main tenets of the "new"(or critical) musicology» (Shreffler, 2003, p. 500) [traducción del autor].

96 «He was writing against: the prolific and increasingly sophisticated Marxist musicology emanating from the other side of the divided city, East Berlin, only a mile or two away» (Shreffler, 2003, p. 500) [traducción del autor] 
concluir que la música popular es trivial, anecdótica, vaciada de presencia estética. Y comercial, novedad de la sociedad de la posguerra que, ahora sí, y con cabecera en el mundo anglosajón, que es el nuevo polo de la hegemonía mundial, consigue generar un mercado específico de lo popular sin que esto perturbe el equilibrio histórico de la musicología.

Por eso, el programa del positivismo de la posguerra no se asume a partir de articular la relación entre el modo de producción del mercado y las músicas sino, como en toda fetichización, ocultándolo, porque forma parte del artilugio por medio del cual los hombres pueden sentirse felices aunque en realidad no lo sean (Marcuse 1967, p. 70)

Que la industria automotriz se empeñe en vender automóviles nos parece tan obvio como que la textil promueva prendas de vestir [...] Por el contrario, que se comercialicen las canciones que escuchamos en nuestros ratos de esparcimiento o en nuestras horas de congoja parece topar con resistencias mayores ¿Por qué nos disgusta la música como mercancía? [...] La idea de que la música es un bien primordialmente espiritual es de corta data (Mendívil, 2016, p. 130)

A partir del despliegue idealista de la narrativa historiográfica musical, anclada en el siglo XIX, el positivismo recupera su proclama y la consolida en la historia de los estilos, en la posguerra. Se necesita otro tipo de análisis para develar lo que hay por debajo del programa esteticista, aunque puedan producir explicaciones muy sencillas y altamente verosímiles como la siguiente

Si tomamos sonido como mercancía, en el sentido del consumo, es un objeto más entre los que dispone la humanidad. Se diseña, se pone de moda, envejece igual que una heladera o un pulóver; hay un "sonido de los '60" y otro "de los '90". Cada músico persigue su sonido particular, como una marca en el orillo. Los profesionales se dedican a inventar y vender sonidos (efectos de sonido, timbres para los teclados) que se compran en CD o se descargan desde Internet (Belinche y Larregle, 2006, p. 44).

Observamos entonces que la armonía funcional descansa en el núcleo racionalizado de la música para convertir a ésta en obra/objeto; a su vez ésta se coloca en el centro de la narrativa musicológica para convertirse en concepto normativo y regulatorio de la interpretación y el consumo musicales; y que sólo rechazando el aspecto experiencial la musicología "de las obras" puede construir una historia de los estilos, clasificando tales objetos mediante su lógica interna, es decir armónico-funcional, abstrayendo la música de sus condiciones sociales y culturales, es decir históricas. Encontramos en esta circularidad una estrategia que consolida aquellos aspectos que son centrales para la concepción que el capitalismo atribuye a la música para convertirla en mercancía, que a su vez impide la consideración conceptual de las músicas que permanecen en el orden de lo performático: las músicas populares. Insistimos aquí en el hecho de que todos los desarrollos vinculados a la economía de la música, ya sea en términos de sujetos (las vedettes), los objetos (las "obras", los "álbumes", etc.) y los dispositivos (salas, partituras, grabación) fueron utilizados siempre primero para la música culta y, una vez comprobada su eficacia, ampliados para probar suerte con la música popular. Por eso ésta última debe incorporar las lógicas de la música de élite para ingresar en el cambio, volverse mercancía y obtener un valor abstracto. Debe perder en parte su identidad, pues las categorías de la modernidad musical no la contienen. Justamente de esa compresión se encargarán, entre otros, el folklore y los Popular Music Studies, trabajando en los vacíos dejados por la musicología histórica, en su afirmación de que la música, en tanto arte, no puede ser popular. El campo está marcado por esta segregación que, como vimos, aparece en la propia fundación de la disciplina musicológica. En la medida en que los estudios sobre música popular sigan estos surcos, no habrá alternativas para la compresión y la exclusión historiográfica de la música popular, pues es en el mismo trazado conceptual del territorio que está inscripta la estratificación. 
Esta relación estrecha entre la economía, la política y la estética musical de la modernidad nos permite sostener que más que un debate meramente metodológico, la firme resistencia y reproducción del positivismo musicológico en la escritura de las historias de la música se corresponde con un modelo hegemónico de sociedad transformado en globalizado tras la derrota del bloque soviético a fines del siglo XX. Una victoria a la que al menos simbólicamente, contribuyó la musicología histórica. 


\title{
Capítulo 2
}

\section{La segunda vida del pueblo97}

\author{
"Si no hubiera existido el trovador nunca hubiera podido constituirse la \\ doxa, el paradigma transmisible, enseñable, archivo y base de todos los \\ saberes que hay y que podría haber. \\ El juglar aporta la violencia de colisión, aquello que nunca había o una vez \\ sí pero fue excluido, olvidado, censurado, negado» \\ Marta Zátonyi (2011)
}

«No sabe cantar quien no dice la tonada, ni trovar versos quien no compone palabras, ni sabe qué cosa sea la rima si él mismo no entiende el sentido» Jaufré Rudel, trovador del siglo XII

"Las masas populares luchan por entrar en la historia, para invertir el orden que las mantiene subalternas»

Ernesto de Martino (2008)

\subsection{El Pathos de la distancia o "pues de este modo todos seríamos iguales"}

Cuando a los estudiantes de música se les pregunta por las primeras músicas ${ }^{98}$ de la historia que recuerdan, por regla general y en abrumadora mayoría las respuestas que se obtienen resultan en un género musical y un "periodo histórico": el canto gregoriano y la Edad Media, respectivamente. Antes de ese tiempo no habría música, si bien todos conocen sobre el Imperio Romano, la Grecia Clásica o el Egipto faraónico. Mucho más desde que la industria del cine y la televisión se interesaron progresivamente en estas culturas. Sin embargo, se las intuye mudas, silentes. O con música incidental y "épica" del siglo XX. Como en las películas.

Otro tanto ocurre con el repertorio musical medieval. El gregoriano es, para ellos, el primero de la historia; pero eso no quiere decir que los estudiantes lo asocien con algo bello, interesante o emocionante. Al contrario, les resulta en general aburrido. Sus respuestas están vinculadas con la creencia extendida de que es el único tipo de música del cual existen registros históricos. Lo cual, además de falso, no deja de ser una creencia un tanto mágica. Esto podría relacionarse con el sentido común informado por la reproducción de la historiografía tradicional, que generó un esquema evolucionista de la música y entonces colocó en el inicio las músicas más simples y poco desarrolladas (Cook, 2001). Pero lo que es más interesante es que esta respuesta homogénea de los estudiantes implicaría que durante los casi mil años del medioevo toda la sociedad medieval, en todo

\footnotetext{
$97 \mathrm{Si}$ bien este capítulo fue escrito con anterioridad, algunos fragmentos aparecen como partes del capítulo 4 "Saber trobar" (de mi autoría) en el volumen colectivo Sánchez, D. y Eckmeyer, M. "Historia del arte y la música medieval: nuevas perspectivas y enfoques" (Sánchez y Eckmeyer, 2019)

98 Desde hace diez años planteamos al comienzo del año académico esta pregunta en la cátedra de Historia de la Música I de la Facultad de Bellas Artes, Universidad Nacional de La Plata. La matrícula promedio es de 500 estudiantes al año.
} 
momento, practicaba y escuchaba únicamente canto gregoriano. Desde el pobre más pobre, hasta el rico más rico, en fiestas, bodas, cacerías, festivales, para bailar o para entretenerse, fuesen más o menos creyentes, la banda sonora sería la misma: ese repertorio legendario que además describen como monódico, lo cual entienden como sin armonía ni textura y además sin ritmo (sic). Estático, cantado sólo por hombres, sin instrumentos musicales. Y cuya memoria sonora, al estar construida fundamentalmente en base al éxito y difusión de las grabaciones del coro de la abadía de Santo Domingo de Silos, se emparenta con esa emisión cansina, de voces añejas. Un verdadero primor de espanto sonoro. Los que intentan justificar su respuesta una vez realizada esta contrastación, hablan de una cuasi dictadura eclesiástica que obligaba a todos a cantar eso, mientras reprimía todo lo demás. Razón por la cual no podemos saber históricamente qué era ese demás, ya que fue todo destruido. Algo así como "gregoriano o la hoguera". Los demás estudiantes simplemente celebran ante estas imágenes el no haber nacido en tan oscura etapa de la historia.

Podríamos detenernos en rectificar estas concepciones. ${ }^{99}$ También en indagar en los mecanismos por los cuales tanta gente responde lo mismo sobre una música que rara vez escucharon y francamente no les interesa. 100 Pero lo que nos importa aquí es otra cosa: el esquema histórico general sobre la música que resulta de esta clase de estereotipos informa una noción implícita según la cual la música "culta" o "académica" o "de tradición escrita" precede y orienta a la música popular. Esto ha sido generalmente aceptado por teóricos y musicólogos hasta no hace mucho:

El Pueblo no 'inventa' nada en sus canciones, sino que se limita a recoger, asimilar, transformar y conservar ciertos elementos de la música culta, cuyo contacto experimenta muchas veces a través de largos siglos (Mayer-Serra, 1984, p. 67)

Sin embargo la relación entre lo culto y lo popular puede pensarse en términos de reciprocidad o retroalimentación, y eso es lo que hace Marta Zátonyi en su ensayo Juglares y Trovadores (2011). La autora ya había definido a ambos personajes, relativos a la música medieval secular, no eclesiástica, en un texto anterior.

\begin{abstract}
El juglar es la figura que sabe sobre el gusto y la necesidad de la gente común y quien, al mismo tiempo, lleva noticias de un pueblo a otro, de una ciudad a otra; sin su actividad, sin sus relatos, la parte alta de la sociedad no se hubiera enterado de la vida cotidiana y de la mirada de la clase baja. [...] Cercano al caballero, el trovador busca los grandes ideales, lleva la palabra culta y elevada a su público [...] El trovador se dirige, pues, a la parte hegemónica de la sociedad aristocrática y, mientras lo hace, glorificando sus valores y sus amores. El juglar se ubica en el segmento opuesto (Zátonyi, 2007, p. 31)
\end{abstract}

Según la autora, «existe una necesidad recíproca y una oferta mutua entre los dos» (Zátonyi, 2011, p. 29). Una suerte de relación dialéctica mediante la cual el trovador establece la doxa, la convención, el archivo, y el juglar se pronuncia de manera provocativa, como colisión, en contra de ese sentido estético establecido. En este nuevo marco es el juglar, el artista popular, quién posee la propiedad de la invención, atravesando las convenciones, inventando. Relación que aparece en la transgresión que su propia figura impone con su nomadismo al estatismo de la sociedad medieval, lo cual hace que su propio modo de vida sea en sí una invención. «El juglar carece de empleo fijo; se desplaza para proponer sus servicios a domicilio. El "es" la música y el espectáculo del cuerpo. Él la crea, la porta y organiza, él solo, toda su circulación en la sociedad» (Attali, 2011, p. 27).

\footnotetext{
99 De hecho es lo que hacemos durante el dictado de la cátedra antes mencionada, para lo cual esta actividad es un diagnóstico. Para profundizar en esto puede verse Attali (2011), Raynor (1986) o Treitler (1990).

100 Pueden consultarse al respecto el ya mencionado trabajo de Cook (2001), Treitler (1990) o Small (1989).
} 
De todas maneras la historiografía afirmativa insistirá con la pregunta acerca de lo originario y hará parecer que ahora solo cambia la actitud de los sectores populares: en lugar de imitar lo establecido de forma desfasada, arremeten ahora contra la doxa, creativamente. Sigue el pueblo estando a la saga de los sectores hegemónicos y pareciera no ser capaz de generar cultura. Ésta es emanación privativa de las clases dominantes y sólo resta al pueblo posicionarse frente a ella mediante la imitación o la transgresión. En el siguiente fragmento podemos ver un debate -algo infrecuente- entre los musicólogos Norbert Dufourcq y Radamés Giro, en ocasión de que el segundo traduce al español y comenta la obra del primero, para su edición cubana de la editorial Pueblo y Educación:

Paralela al canto monódico de la Iglesia existió una música profana. Varía de forma y de fondo según se dirija al pueblo o a los grandes señores. Pero el origen de una y de otra parece ser el mismo: abrevaron del canto gregoriano... El canto popular surgió de la Iglesia". [Todo lo contrario. La canción popular tuvo sus raíces en el pueblo mismo y muchas de sus modalidades se incorporaron luego al repertorio litúrgico (N. de T.)]. (Dufourcq, 1963, p. 29)

Como hemos visto anteriormente al analizar los rasgos principales de la musicología afirmativa, la preocupación por los orígenes sólo es funcional a un esquema evolutivo y unilineal, razón por la cual no mejoraríamos demasiado nuestra comprensión histórico musical si reemplazamos simplemente un elemento por otro. No se trata de encontrar el repertorio "originario" sino en todo caso, y en función de nuestra consideración mestiza de la historia musical, comprender las relaciones entre los factores que disputan el campo musical, su correlación de fuerzas, las disputas, los préstamos, sátiras, apropiaciones e imposiciones que se suceden en función de cambios en la matriz histórico social.

Para comprender la fuerte presencia de la cultura popular en el mundo medieval, su influencia y aparición en ámbitos muy diversos, Mijail Bajtín (2005, p. 74) propone una especie de periodización, según la cual debemos considerar el carácter en formación, es decir, dinámico, tanto de la cultura de la risa como de la cultura oficial o hegemónica. Mientras el régimen feudal es todavía débil y no está consolidado (antes del siglo IX) la cultura popular heredera de la Antigüedad tardía mantenía un alto grado de influencia, incluso en los ámbitos cortesanos - «las tradiciones de las saturnales romanas y de otras formas cómicas populares legalizadas en Roma, no habían perdido su vitalidad» (Bajtín, 2005 , p. 73)-. Este es el sentido de los comentarios de Zátonyi y Attali que citamos previamente, que hablan de la circulación de los músicos populares y sus prácticas entre el espacio popular y el cortesano. De hecho, todo el período que va de la temprana Edad Media hasta la consolidación del feudalismo es el momento en el que se configuran las tradiciones de fiestas populares asociadas al calendario cristiano, en base a fechas importantes como la Navidad o la Pascua -el Carnaval y la Cuaresma- o al extenso santoral. En ambos casos la Iglesia se esfuerza por hacer coincidir estas celebraciones con un gran número de fiestas vinculadas a creencias locales (como el culto a lo arbóreo y los ciclos de los cultivos) o del politeísmo pagano (las bacanales, saturnales, lupercales, etc.). Por supuesto que el objetivo de todo esto es integrar en el proceso de la cristianización y la conformación política de los reinos occidentales las pautas y prácticas culturales del pueblo. Pero entonces podemos pensar en una primera fase de apropiación en la cual la cultura popular es relativamente tenida en cuenta e integrada en el seno de la cultura hegemónica, a la que prestará su influencia y entregará buena parte de los procedimientos y recursos formales. La música no escapa a esta tendencia, razón por la cual debemos considerar un alto grado de interinfluencia entre las prácticas de la cultura de élite y la cultura popular durante esta primera fase. Mientras «el nuevo régimen feudal era aun relativamente progresista y, en consecuencia, relativamente popular» (Bajtín, 2005, p. 74), a la música popular se le abren las puertas del palacio y, si bien el arte que desarrollan los juglares no es el mismo que el que dirigen a la plaza pública, desde los sectores hegemónicos no hay 
ninguna intencionalidad de ocultar la estrecha relación que liga la música popular con la poesía, las canciones y cantares con que se entretiene la aristocracia occidental.

Esta consideración es la que cambiará una vez que ese régimen feudal se vuelva conservador, cuando la reactivación del tráfico comercial genere una fuerte escisión entre las cortes ricas de los grandes terratenientes que participan en el mundo mercantil en alianza con los mercaderes y artesanos, y aquellos pequeños señoríos que se verán rápidamente empobrecidos (Elías, 2012, p. 312). De hecho, muy pronto el mismo carácter centrífugo de las relaciones feudales propiciará la aparición de una clase caballeresca enteramente desposeída. Este es el momento, hacia el siglo XI, en el cual van a aparecer los trovadores, quienes van a producir una estratificación que escindirá las prácticas musicales populares de un repertorio alto, distinguido, que enmarque desde la cultura sonora aquello que la riqueza y el poder territorial ya no pueden señalar: la condición aristocrática. Es este cambio de autopercepción de la nobleza, este giro político el que introduce la necesidad del trobar. Antes, sencillamente, nadie necesitaba a los trovadores. La relación entre juglares y trovadores, entre cultura popular y repertorio cortesano, se construirá a partir de este momento histórico en términos de apropiación por parte de los segundos de buena parte de la cultura popular que expresaran los primeros (Lengwinat, 2006 , p. 34), a condición de ocultar esta procedencia. Con lo cual, si consideramos este momento aislado como fundacional de toda estratificación de los valores musicales en Occidente, el esquema musicológico parece invertirse por completo. Analizaremos entonces la relación entre la música de los juglares y la de los trovadores con la intención de indagar en la siguiente hipótesis: existe una música popular que antecede a la música culta que se autopercibe como tal y produce la escala de distinción (Bourdieu, 2002); y ésta se forma a partir del rechazo explícito a la anterior, lo cual implica una apropiación de algunas de sus cualidades y su posterior estilización, con el fin de ocultar su procedencia popular y posibilitar una representación social de clase a través de lo sonoro.

En 1170 está fechado un duelo poético entre dos trovadores. Esta práctica, muy habitual, se denominaba tensó y, si bien todavía no hay acuerdo en si los trovadores eran realmente quienes actuaban sus poemas o no, es una muestra de una tradición muy temprana que además de involucrar el nombre del adversario entre los versos que se componían, solía presentar opiniones muy contundentes sobre el arte de la poesía y la música. Los adversarios en este caso son Raimbaut d'Aurenga y Giraut de Bornelh. El primero era apodado Linh'aure, que algunos entienden como "linaje de oro". Si se traduce su nombre del occitano antiguo al francés se lee Raimbaut d'Orange, lo cual nos conduce a una filiación muy aristocrática que le otorga sentido a su apodo. Justamente por doble herencia del padre y de la madre Raimbaut era el señor de los territorios provenzales de Orange y Aumelas. Un miembro paradigmático de la aristocracia feudal terrateniente. $Y$ de lo que representaba ser un trovador. 101

Giraut de Bornelh, en cambio, había nacido de una familia humilde y representa la excepcionalidad del mundo poético musical (y también general) que significaba un ascenso de clase en la Edad Media. Por medio de su destreza en el arte trovadoresco, particularmente en hacer los versos (¿y la música?) más accesibles para el auditorio, ${ }^{102}$ Giraut fue aceptado en los círculos caballerescos (Taruskin, 2005a, p. 155). Tal fue su fama que mucho tiempo después su memoria continuaba vigente, siendo mencionado por Dante

101 Podemos ver el carácter eminentemente aristocrático por el origen de los trovadores: «reyes y nobles de los grandes linajes, príncipes, duques, condes (Guillermo de Poitiers, Alfonso II de Aragón, Dalfin d'Alvernha, Ricardo Corazón de León), señores y barones vasallos de los precedentes (Gui d'Ussel, Bertran de Born, Raimbaut de Aurenga), pequeña nobleza urbana o terrateniente, caballeros pobres (Raimon de Miraval), pequeña burguesía (Peire Vidal) o incluso obispos (Folquet de Marsella), clérigos, músicos ambulantes (Gaucelm Faidit) y trovadoras (la condesa de Dia)» (Cullin, 2005, p. 116).

102 Este tipo de arte se denomina trobar clar en alusión a la claridad en la composición de los versos. 
y por Petrarca, quien lo recordó como "maestro de los trovadores". Pero veamos qué se decían estos dos adversarios (que representan también dos situaciones sociales diferentes) en aquel famoso tensó:

Raimbaut d'Aurenga: Giraut de Bornelh, me gusta saber, ahora, por qué vais criticando el trobar clus ${ }^{103}$ y con qué criterio. Decidme si apreciáis tanto lo que a todos es común, pues de este modo todos serán iguales.

Giraut de Bornelh: Señor Linhaure, no me quejo si cada cual trova a su gusto; pero juzgo por mí mismo que es más estimado y apreciado el canto si alguien lo hace ligero y humilde, y vos no me lo toméis a mal.

R. A.: [mi trovar] Por los necios nunca será alabado porque no distinguen, ni falta que les hace, lo que es más precioso y más vale.

G. B.: ¿Por qué trováis si no os place que en seguida lo sepan tal y cual? Porque el canto no aporta otra remuneración.

R. A.: no me preocupa si se divulga tanto, pues nunca lo muy vulgar fue cosa digna. Por eso se aprecia más el oro que la sal, y con el canto ocurre lo mismo. ${ }^{104}$

¿Quiénes son estos señores que están tan preocupados por la recepción de su poesía y música? ¿Cuál es la actitud estética que los lleva a debatir sobre el valor de lo accesible o lo complicado? Podemos tomar a estos dos personajes como paradigmáticos de posiciones contrastantes vinculadas a los sectores con que se relacionan y su actitud hacia el origen de clase que cada uno porta. Como señala Arnold Hauser (1992) los trovadores son la expresión de un movimiento de clase ascendente dentro de la propia nobleza que irrumpe en un momento en que los nuevos nobles, por descendencia o por acceso a la condición de la caballería, llegan tarde al reparto de las tierras. En esto coincide Norbert Elías

Los excluidos de la otra clase, de la clase guerrera o, dicho más vulgarmente, los «segundones», aquéllos cuya herencia es demasiado pequeña, ya con relación a sus aspiraciones, ya para poder alimentarse, esto es, los «desposeídos» entre los caballeros (Elias, 2012, p. 289)

Esta estratificación de las cortes ocurre en simultáneo con la revitalización y el auge del comercio y el crecimiento de las ciudades. Las grandes cortes se benefician de la monetarización pues allí vuelcan el excedente de producción de sus feudos y los impuestos que recaudan. Las cortes pequeñas, de donde provienen la mayoría de los trovadores nobles, no participan de esto y se empobrecen (Elias, 2012, p. 312). Estos intentan entonces ingresar a las grandes cortes y asegurarse el sustento como cortesanos, es decir, como trovadores, a través de prebendas o una renta que les permita mantener su condición. Lo mismo, aunque en sentido contrario, ocurre con los músicos del pueblo "ascendidos" de juglares a trovadores, como el caso de Bornelh.

Hay tres tipos de vidas caballerescas que se contraponen en los siglos XI y XII, con formas intermedias. En primer lugar contamos con los caballeros menores, señores de algunas posesiones no muy amplias; en segundo lugar son los caballeros más poderosos y más ricos, en cantidad escasa en comparación con los primeros $y$, finalmente, los caballeros sin posesiones o que disponen de muy poca tierra, que se encuentran al servicio y bajo la dependencia de los caballeros más importantes. Los trovadores caballerescos y nobles proceden principalmente, aunque no exclusivamente, de este tercer grupo [...] En esta clase

103 El trobar clus es el opuesto al trobar clar. Es decir un estilo «hermético y afiligranado» (Riquer y Codech, 2013, p. 124) y evidentemente por lo que dice Raimbaut, no apto para cualquiera. Ver Taruskin, 2005a, p. 159.

104 Fragmentos de la traducción del occitano publicado en Riquer y Codech (2013). 
hay muchos que se dan por contentos cuando [...] encuentran alguna forma de acomodo, vestimenta y manutención. $Y$ a veces, en casos muy extraordinarios y por una gracia especial de algún gran señor, reciben un trozo de tierra, un feudo (Elías, 2012, p. 313-320).

Tenemos entonces un nutrido grupo de nuevos o viejos aristócratas pobres, que justamente no poseen aquello que significa poder y riqueza en el mundo feudal: la posesión de la tierra. Además muchos son guerreros, ennoblecidos a partir de hazañas que hacia el siglo XII ya no son necesarias, como la protección frente a las invasiones nórdicas o musulmanas. Por lo tanto en un tiempo de paz y prosperidad, tenemos a todos estos bravos caballeros que no pueden pelear ni aprovecharse de la abundancia de los campos. Por un lado el ocio, tanto de la vieja nobleza terrateniente como de estos recién llegados al mundo de la corte, va a exigir un arte más elaborado. Pero existe también otra fuente que impulsará al canto de los trovadores, y que se relaciona con esta pequeña caballería desposeída, difícilmente discernible del artesanado y otros sectores populares ¿Cómo hacer notoria la diferencia de clase en ausencia de proezas y riquezas? ¿De qué modo volver explícitas esas diferencias para que principalmente la vieja nobleza las perciba? En definitiva ¿cómo articular una expresión sonora de la distancia social? He ahí un móvil para la multiplicación de los trovadores en Occitania, territorio que a los elementos anteriores debemos sumar la particularidad del reparto de las herencias entre todos los herederos, razón por la cual éstos se empobrecían sucesivamente sin remedio (Cullin, 2005).

Pero antes de hacer notoria la diferencia, los trovadores debían hacer algo más. Como estamos verdaderamente en los inicios de la estratificación musical de Occidente, esta caballería cortesana necesita crear las variables y los valores en base a los cuales se evaluarán a posteriori las posiciones culturales y sociales. Para comprender esta autopercepción de clase y la búsqueda de poner en canciones sus intereses, hacer audible el orden cortesano (Attali, 2011), nos resultará útil acudir a Nietzsche y su descripción de la caballería medieval o, en sus palabras, la bestia rubia:

«¿En qué condiciones se inventó el hombre esos juicios de valor que son las palabras bueno y malvado? ¿Y qué valor tienen ellos mismos?»... Nietzsche no demora en decir quiénes son los creadores de valores, los creadores de lo bueno. Los creadores de «lo bueno» son «los buenos». "Los buenos» son un tipo de hombre. Un tipo de hombre capaz de crear valores desde sí, a partir de sí. "Antes bien, fueron "los buenos" mismos, es decir, los nobles, los poderosos, los hombres de posición superior y elevados sentimientos quienes se sintieron y se valoraron a sí mismos y a su obrar como buenos; o sea, como algo de primer rango, en contraposición a todo lo bajo, abyecto, vulgar y plebeyo.» (Feinmann, 2010, p. 210)

Crear los valores para posicionarse en el lugar adecuado de la escala. Esa es la operación de la nobleza empobrecida de los trovadores que se manifiesta a partir de una magnitud: "Partiendo de ese pathos de la distancia es como se arrogaron el derecho de crear valores, de acuñar nombres de valores» (Nietzsche, 2001, p. 37). Ese Pathos es una condición cuasi fisiológica, un arrebato de repudio frente a aquello ante lo que se pretende establecer una distancia y consecuentemente adquirir distinción de la posición social (Bourdieu, 2002). Una verdadera patología que conmueve y aterra con la sola posibilidad de que lo que se ha logrado desaparezca en la confusión de clase social.

El pathos de la nobleza y de la distancia [es] el duradero y dominante sentimiento total y radical de una especie superior dominadora en su relación con una especie inferior, con un «abajo» -éste es el origen de la antítesis «bueno» y «malo» [...] El aristócrata tiene el sentimiento íntimo de que él mismo determina los valores morales (...) Lo que me es perjudicial, es perjudicial en sí mismo. (Nietzsche, 2001, p. 38).

En este contexto debemos apreciar la verdadera dimensión de ese rechazo a que "todos sean iguales" del que habla Raimbaut en el tensó. Esta sí es una actitud conservadora y 
reaccionaria y, como se comprueba, en nada vinculada con el arte popular. Los trovadores dan nombre a las cosas, «imprimen a cada cosa y a cada acontecimiento el sello de un sonido y con esto se lo apropian» (Nietzsche, 2001, p. 38). Sonido que no por casualidad es cantado. Y en esa operación, se las apropian. ¿Qué es lo que se apropian los trovadores? Además de las palabras y su sentido, se apropian de la música popular, que ya existe, para depurarla, recontextualizarla y servirse de ella como de un material. Y de los músicos populares también, a quienes domestican (Raynor, 1986) y recluyen en la corte, despojándolos de su condición nómada.

La canción cortesana se convierte entonces en atributo y escala de valores a partir de la cual establecer jerarquías que señalen con claridad la condición de los poderosos. Esa es la razón por la cual las grandes cortes desarrollaron la poesía y el canto trovadoresco (Cullin, 2005). De ello se beneficiaron por una parte los grandes señores, añadiendo esplendor a sus cortes; los mismos trovadores, reteniendo su condición y asegurando su sustento; y también los músicos provenientes de sectores subalternos, a través del servicio que prestaban a los trovadores. A éstos últimos se los llamará ministriles en alusión a ministeriales, es decir, quienes son siervos especializados ya que dominan un oficio. Todo trovador tiene su ministril compañero, que en verdad es un ex-juglar. Ese es el lugar del que parte el mensaje de Bornelh, representante de esa otra vertiente, la nueva caballería, que busca a toda costa insertarse en el mundo de la corte. No obstante su apología por un lenguaje más "abierto" no debe confundirnos. Pues los ministriles y trovadores "ascendidos" tampoco pretenden la igualdad de clases. Muy por el contrario, abogan por un lenguaje claro que exprese, sin lugar a dudas, el pathos de la aristocracia al que ellos ya pertenecen.

Aplicado a otro momento histórico, Edward E. Thompson nos recuerda este vínculo estrecho entre la generación de la distinción y la distancia social, y el origen de los términos para valorar la magnitud de la distancia y la relación entre aquellos que se ubican en los extremos de la escala:

tanto «gentlemen» como «los pobres» son «expresiones acuñadas por la gentry»105 y ambas llevan una carga normativa que los historiadores pueden adaptar sin espíritu crítico. Nos dicen (por ejemplo) que «el honor, la dignidad, la integridad, la consideración, la cortesía y la caballerosidad eran virtudes esenciales para el carácter de un gentleman, y todas ellas se derivaban en parte de la naturaleza de la vida rural» [...] En cuanto a «los pobres», esta expresión totalmente indiscriminada lleva consigo la sugerencia de que el grueso de la población trabajadora merecía la condescendencia de la gentry y quizá su caridad (Thompson, 2000, p. 30).

También Marta Zátonyi relaciona con la dialéctica de juglares y trovadores términos mucho más actuales sobre la estratificación socio cultural

En los últimos años emergen dos palabras, aunque siempre en textos profesionales [...] mainstream y lowbrow. La primera, mainstream, alude a la cultura principal, legitimada, paradigmática e incorporada ya en el discurso del poder, o si se quiere, en el canto del trovador. La otra, lowbrow, refiere a las expresiones que surgen de campos de expresión que hasta ahora no se han considerado arte [...] como el canto del juglar. A pesar de que la palabra tiene un connotado peyorativo sabemos que el arte docto, culto y elegido por el gusto dominante necesita de estas expresiones y renovaciones, ahora y en el futuro, así como siempre contó en el pasado con su aporte, su energía, su fuerza (Zátonyi, 2011, p. 41)

105 Según el Oxford English Dictionary este término designa a «personas de buena posición social, específicamente la clase justo por debajo de la alta nobleza». El diccionario de la Universidad de Granada, España, define al término como «pequeña nobleza, la». Es difícil pensar en mejores definiciones sobre el estatus social de los trovadores. 
El pathos de la distancia provoca la articulación simbólica bajo la forma de magnitud de la distinción, de la diferencia entre lo que, en un momento dado, cuenta como actividad cultural o atributo de élite y aquello que no cuenta como tal. Esto último es tal vez lo más importante a dejar en claro (Hall, 1984, p. 7). Las categorías de lo "bueno" y lo "malo", de lo "bello" y lo "desagradable", de lo "civilizado" y lo "bárbaro" permanecen a lo largo de la historia cultural de Occidente, más allá que el repertorio de atributos específicos se modifique de acuerdo a los patrones de gusto y las necesidades específicas de cada época. Pero todas las instituciones de la cultura de élite trabajarán permanentemente para sostener esa diferencia. La corte medieval -y en menor medida el monasterio- es una primera inscripción histórica de estas instituciones. Así debemos comprenderla, como una red institucional de intercambios y de distribución para «la difusión de la lírica cortés. El mundo feudal cristaliza en torno a los centros de poder [...] La cortesía es un valor que une a estas cortes distintas bajo un mismo ideal» (Cullin, 2005, p. 115).

\subsection{El universo subalterno de los ruidos: de la proscripción a la domesticación}

Como los trovadores "dan nombre" a las cosas, entre ellas nombran al ministril y también al juglar. Pero no hay que pensar que todos ellos nacen simultáneamente en la Baja Edad Media (Zátonyi, 2011, p. 26). Los músicos populares y sus músicas ya existían, con multiplicidad de nombres que muestran la superposición de disciplinas que llevan a cabo y las tradiciones muy antiguas en las que se inscriben. En un artículo que se concentra en los juglares profesionales anteriores al año 1100, podemos leer que

La temprana Edad Media dio muchos nombres a sus artistas: mimi, histriones (a menudo istriones), scenici, poetae, tragoedi, comoedi, comici, scurrae, joculares, jocistae, joculatores, corauli, thymelici, musici, y cytharistae. Y debió haber unos cuantos nombres más. (Ogilvy, 1963, p. 604)

Para tan extensa lista el texto se basa en fuentes directas, como los escritos de Casiodoro (s.VI), Gregorio de Tours (s.VI) San Isidoro de Sevilla (s.VII), y documentos oficiales de la Alta Edad Media, como los cánones emanados de los Concilios de Clovesho (s. VIII-IX), o una capitular de Carlomagno, la Admonitio generalis de 789. En estas últimas, por ejemplo, puede leerse que se prohíbe al clero dar cobijo y sustento a los joculatores (Ogilvy, 1963, p. 608).

Volvamos a ver esas mismas partituras de canto eclesiástico del manuscrito francés, en las que encontramos representados también a los músicos populares. Aparecen por ejemplo tocando sus instrumentos y danzando mientras hacen malabares, y recordemos que es un documento de fines del siglo $X$-es decir por lo menos un siglo antes de los trovadores- en el cual se encuentra el siguiente folio, cuyo texto y neumas corresponden a un Gloria, es decir, parte del ritual litúrgico de la misa y por lo tanto musicalmente desvinculado -tal vez para señalar el contraste- de las ilustraciones que lo acompañan. 


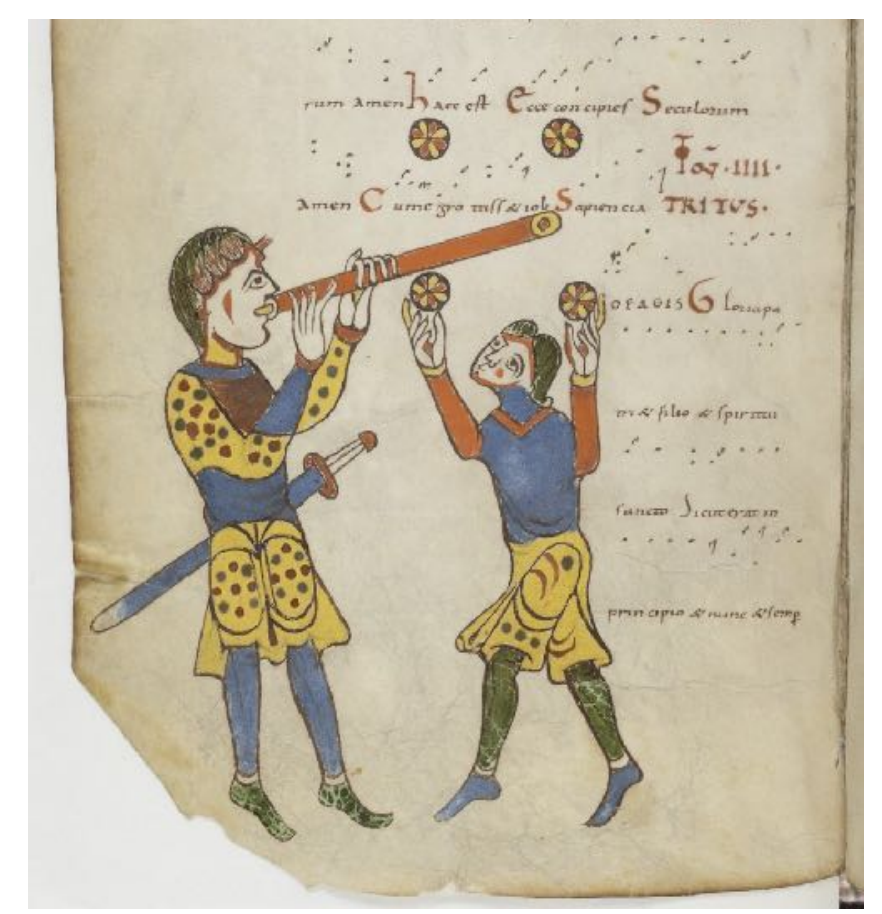

Paris, Bibliothèque Nationale, fonds lat., Ms. 1118, fol. 104-113.

Tonaire, tropaire, séquentiaire d'Auch (ca. 987-96).

También en el De Universo del intelectual alemán Rabanus Maurus, escrito todavía un siglo antes (ca. 845), encontramos una ilustración de estos músicos populares junto a su descripción. Este tratado se inspira en las confesiones de Isidoro de Sevilla a las que ya nos referimos. Además, el hecho de que Rabano fuese discípulo de Alcuino de York, el principal intelectual de la corte de Carlomagno y seguro colaborador de las "capitulares", puede servirnos de vínculo con la lista de denominaciones hacia los músicos y artistas populares compilada por Ogilvy, que citamos antes.

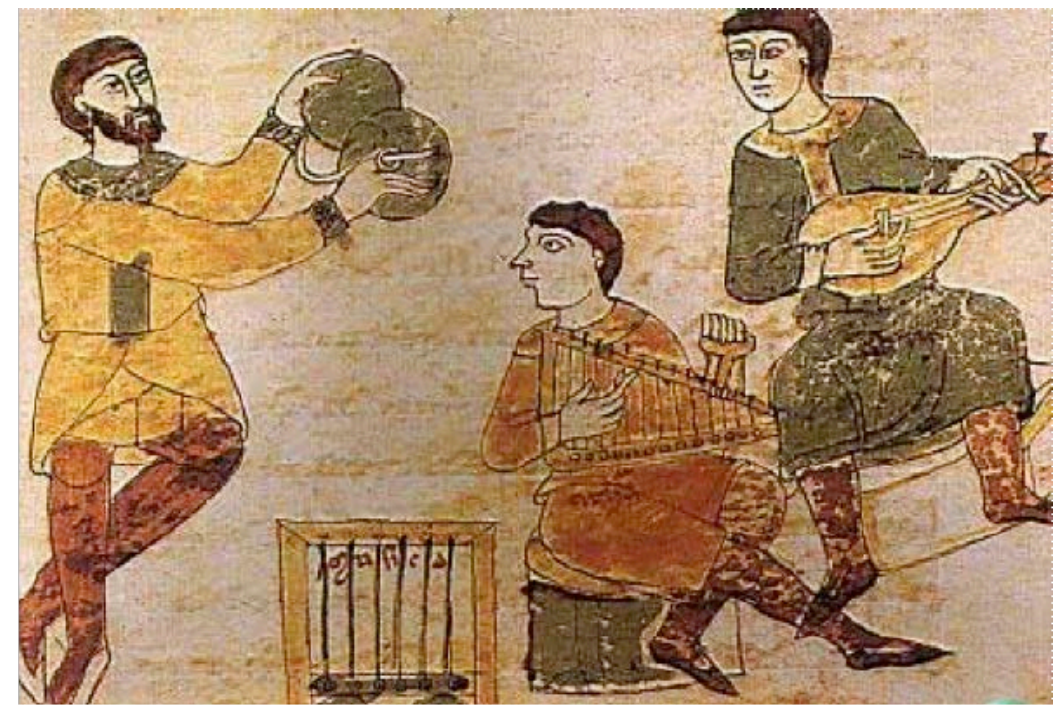

Magnentius Hrabanus Maurus (Rabano Mauro) "De Universo libri XXII", Alemania c. 842-847

Los músicos de la imagen bailan a la vez que tocan. Sus posturas y contorsiones no presentan ambigüedad al respecto. Es dable suponer que además debían incentivar a danzar a quiénes los estuvieran escuchando. Junto a esto narraban, hacían trucos de magia, acrobacias y domaban fieras. El músico popular medieval es un artista de variedades: 
el juglar debía saber inventar, hacer versos, defenderse como espadachín; saber tocar bien el tambor, el címbalo y el Bauernleier (la zanfonía); saber arrojar manza-nas al aire y atraparlas con la punta de un cuchillo; imitar los cantos de los pájaros, hacer trucos con cartas y saltar a través de aros; tocar la cítara y la mandolina, manejar la guitarra, pulsar el laúd de siete cuerdas, acompañar bien con el violín, hablar y cantar agradablemente [...] como un artista ambulante, para ganarse la vida, debía ser narrador, cantante, instrumentista, acróbata, malabarista y todo lo que pudiera realizar con convicción (Raynor, 1986, p. 58)

También Gustave Reese recupera una caracterización similar, en la que hombres y mujeres, juglares y juglaresas, desarrollan una variada gama de funciones y destrezas, aunque paulatinamente focalizado en la práctica musical:

Tal como lo demuestran los testimonios escritos y pictóricos, entre lo logros de los juglares solía incluirse la habilidad para tocar un instrumento, incluso probablemente uno de arco, como la viéle, o, por otra parte el arpa, el laúd, el salterio o un órgano pequeño (portátil o portativo) (Reese, 1989, p. 247)

Pero el comentario de este autor es quizás más importante ya que considera estas funciones y habilidades como derivación de prácticas que hundían sus raíces en la profesión del mimo latino (Reese, 1989, p. 247), lo cual nos remite nuevamente a la vigencia de una tradición popular de la Antigüedad y su relación con las creencias paganas en pleno mundo medieval. Como veremos, mucho del sentido de la cultura popular medieval se inscribe precisamente en el carácter de las fiestas de la Antigüedad y sus rituales.

Por otro lado, es muy interesante la aparición de ciertos instrumentos ligados a la profesión del juglar, fundamentalmente los de cuerda pulsada que, como sabemos, tienen una estrecha relación con los flujos culturales que durante el medioevo atraviesan la península ibérica y los pirineos, uniendo la tierra de los trovadores, el lemosín, con la cultura de ese gran otro que había construido la cristiandad: el Oriente musulmán, que por aquellos siglos en realidad rodeaba el universo cristiano y se encontraba más cerca al oeste, en el Al andaluz, que hacia el este. Es preciso recordar aquí algunas de las teorías que atribuyen a la música cortesana de los omeyas, los almorávides y los almohades uno de los principales factores de influencia en el desarrollo del arte de los trovadores (Hoppin, 2000, p. 284) Pero más importante aún es considerar la afluencia de juglares y juglaresas moros que se desempeñan como profesionales en los reinos cristianos, por lo menos desde el siglo XI. Esta presencia de juglares moros en el mundo cristiano irá incrementándose a medida que avance el proceso denominado por los españoles como "reconquista" y se mantengan los lazos, incluso de parentesco, entre las cortes a un lado y al otro de los Pirineos. "En Castilla, la presencia de juglares moros llegó a ser tan habitual que el Concilio de Valladolid de 1322 tuvo que impedir que tocasen y cantasen» (Gómez, 2009, p. 137). Está ampliamente documentada también la disputa entre diferentes cortes y los préstamos de juglares moros y la presencia muy apreciada de bailadoras moriscas (Gómez, 2009, p. 138). $\mathrm{Si}$ a este panorama añadimos la rica iconografía que nos muestra a instrumentistas moros practicando con sus instrumentos al lado de sus pares cristianos, la influencia y el mestizaje transcultural de las prácticas musicales se convierte en un elemento que debe adquirir la mayor centralidad en nuestro análisis, desplazando toda pretensión esencialista y clausurando cualquier resto de discusión sobre los orígenes de los repertorios musicales históricos. 


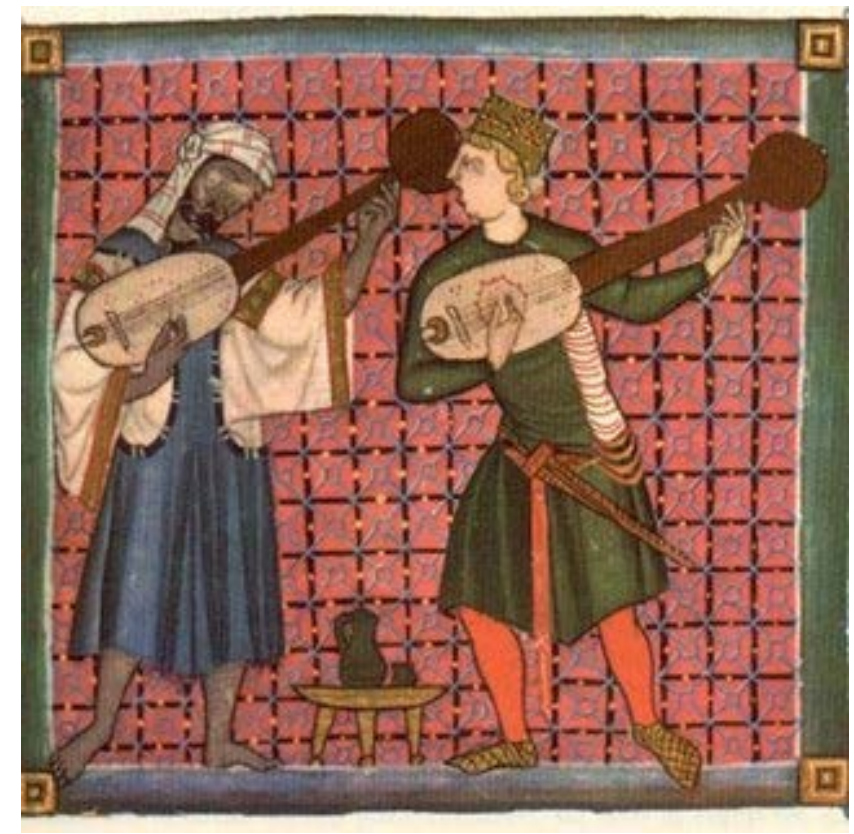

Un juglar moro tocando el Al-oúd junto a un músico cristiano y su laúd.

Extraído de las Cantigas de Santa María en el Manuscrito del Escorial

Siempre que creamos arribar a un momento cero, uno de esos "big bangs" (Goodall, 2001) tan caros a la historiografía afirmativa sus pretensiones fundacionales para Occidente, nos encontraremos con un continuo de apropiaciones y mestizajes. Si queremos proseguir con las metáforas de la astrofísica, podríamos pensar que en música siempre nos encontramos con un "tiempo de Planck", una dimensión que nos separa de ese imaginario estallido primigenio; dimensión que no es otra cosa más que la transculturación, un fenómeno que representa las antípodas del esencialismo del folklore y la musicología y hace obsoletas las pretensiones positivistas de la búsqueda de los orígenes. Es que si consideramos la producción sonora histórica en términos de musicar accedemos a considerar un fenómeno de flujo y reflujo (Zátonyi, 2007), una marea constante de interinfluencias, préstamos, litigios y resistencias en torno a las músicas, que es herencia de una situación mundial en la cual Europa era la periferia más periferia, un territorio marginal frente al centro del mundo que, al menos hasta el siglo XVI, representó el universo musulmán y su articulación profunda con la ruta de la seda, que hacía confluir en una rica red transcultural las importantísimas culturas túrquicas y mongolas del Asia Central, las poderosas India y China, todo el mundo árabe, buena parte de África oriental y occidental, e incluso el sudeste asiático y una considerable porción de Europa oriental. En los momentos en que Europa occidental participaba, lo hacía con las porciones que la afirmatividad históricamente siempre desprecia: el sur, sospechoso de parecerse demasiado a ese vasto y poderoso Oriente y su gusto por la improvisación, la consideración momentánea del musicar, la valoración de las sonoridades en tanto tales, el regodeo en la sensualidad del sonido como materia. En síntesis, un modelo estético en donde lo accesorio y secundario son justamente la forma, el equilibrio, la simetría, las relaciones lógicas y abstractas, la estricta separación de roles entre los participantes; todo aquello que tal cual vimos antes funciona en la musicología histórica como cualificador y fundamento de la idea (culta) de música en la cultura occidental de la modernidad. 


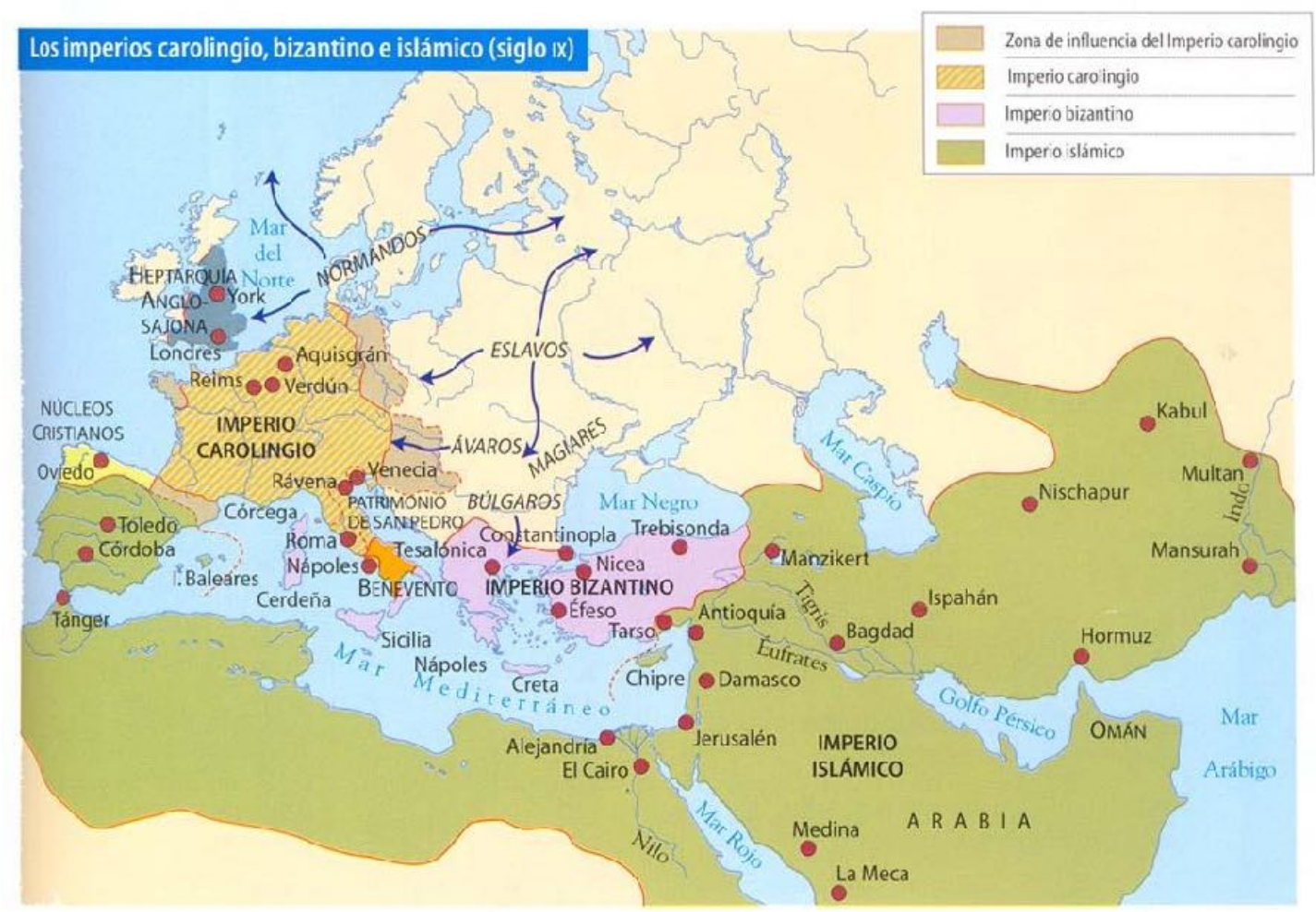

Mapa de la cuenca del Mediterráneo en el siglo IX (momento del primer Big Bang de Howard Goodall). No sólo la Europa cristiana es una periferia pobre (económica y culturalmente), sino que podemos ver hasta cuánto se expande y desarrolla (también musicalmente) el "Oriente" al punto de quedar "al oeste" de los carolingios. Fuente: Kinder y otros, 2007.

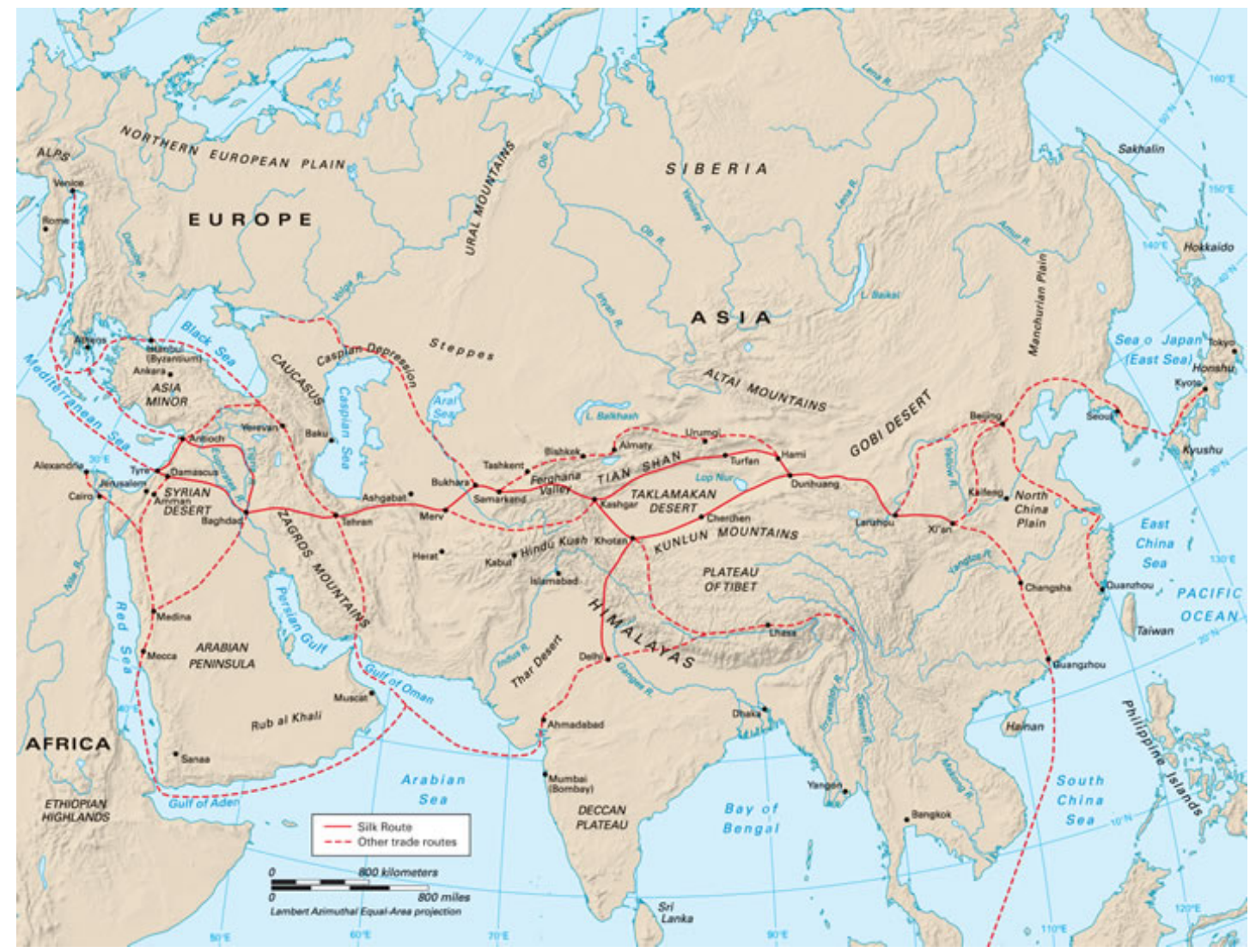

La Ruta de la Seda en una de sus configuraciones de mayor extensión, entre los siglos X y XV. Nótese la situación marginal de Europa occidental. Las muy diversas y sofisticadas culturas musicales que forman 
parte del intercambio y la dinámica de toda esta zona representan una contundente ilustración de la más absoluta falta de influencia y repercusión para la música mundial del supuesto big bang que representa la notación franca y la teoría musical guidoniana que analizamos en la sección anterior. Fuente: Bregel, 2003.

Ajena al movimiento de casi todo el mundo, sustraída de la dinámica comercial, étnica, cultural y musical, la Europa occidental medieval hará un culto del estatismo, de la fijación. Eso representa también el canto gregoriano frente las músicas procesionales, y el desarrollo mismo de la notación no tiene otro propósito más que reducir la dinámica, la vibración de la música entendida como performance, ocasión o arte presentacional (Langer, 1966). Disminuir la variabilidad entre las versiones, he ahí la piedra angular del desarrollo de la escritura musical europea. Congruente y hasta dependiente de una visión del poder que se piensa a partir de la concentración, en términos centrípetos (Elías, 2012) reunido, concentrado en una sede, sea ésta Roma, Aquisgrán, París, Innsbruck, etc. Si observamos los mundos musulmán y asiático, la perspectiva no puede ser más diferente: existe una permanente movimiento, una dinámica incesante de pueblos, gobernantes e imperios que se solapan, litigan, confluyen, chocan, establecen alianzas y vuelven a correr sus límites y recomenzar el ciclo ¿Por qué razón estos mundos móviles, que hacen de la transformación su razón de vida pensarían a la música como objeto cristalizado, o reducirían voluntariamente la riqueza de las ocasiones siempre presentes del musicar por medio del desarrollo de signos gráficos que obliguen a una lectura fija? ¿Qué haría que cualquiera de estas culturas musicales, desde Bali hasta la China de los Tang, pasando por los bereberes, kazakos, georgianos o el Magreb, culturas musicales por todo lo demás muy diversas y contrastantes, quisieran prescribir mediante instrucciones la operatividad de los músicos? Y todavía más, ¿por qué razón verían como un signo de progreso y desarrollo cultural la creciente prescriptividad de la notación musical, construida a partir de la reducción progresiva de la ambivalencia y la ambigüedad de los símbolos gráficos? Existen múltiples respuestas posibles a la profunda divergencia de concepción musical entre las culturas hegemónicas europeas que se consolidarán a partir de la modernidad y cualquiera de estas culturas "orientales". Pero tal vez un vector común y tal vez básico que explica esta diferencia es lo que Christopher Small va a denominar como rasgo de la cultura europea «el dominio de la naturaleza« (Small, 1989). Esto es también uno de los indicadores, basado en el dualismo cartesiano, que los autores del colectivo modernidad/colonialidad utilizan para referirse a la colonialidad del poder y del saber de la modernidad europea (Grosfoguel, 2014). Justamente esta consideración de la naturaleza como algo ajeno, separado e inferior frente al hombre ${ }^{106}$ posibilitará transformar el musicar en música, es decir, en objeto que será también valor de cambio. La notación musical permitirá no sólo la primera reproductibilidad técnica de los productos musicales y el desarrollo del primigenio mercado musical en el siglo XVI (Frith, 2006), sino que posibilitará la industria de la reproducción en serie de la performance, sellando la repetición al convertir al intérprete en operario (Attali, 2011) que reproduce una y otra vez los imaginado por otro, el compositor. Esta es la razón de que la repetición y la representación sean dos modalidades complementarias de la modernidad musical, ya se desplieguen en torno a la ópera, la sinfonía, el rock o el folclore argentino. Para todo esto, para el desarrollo de la industria discográfica, las giras de Clara Wieck, las peregrinaciones a Bayreuth, las mil y una puestas en escena de The Wall o los fenómenos de ventas de Caruso o Michael Jackson, fue necesario, históricamente, fijar la variabilidad, reducir el factor de cambio, detener la dinámica. En el mundo popular subalterno compartido por los sectores populares occidentales y las culturas que

106 La expresión "el hombre y la naturaleza", así, en masculino singular, recoge toda la potencia de la colonialidad moderna, con sus sesgos de género, la objetualidad de la naturaleza y su etnocentrismo declarado. Esta manera de nombrar se convertirá en apotegma en el positivismo, y así aparecerán sucesivas denominaciones que desembocarán en colecciones historiográficas como El arte y el hombre (Huyghe, 1967), Man and music (McKinnon, Sadie \& Fenlon, 1989), etc, reafirmando de manera invisible todas estas concepciones al núcleo de su narrativa y reforzando la afirmatividad historiográfica. 
sucesivamente serán dominadas por la modernidad; en todo ese mundo pre-moderno que deberíamos llamar transmoderno, existió un desarrollo consciente y buscado del cambio, una propuesta basada en la dinámica que podría vincularse al carácter dinamogénico que representa uno de los atributos posibles de la música popular (De Andrade, 1972). Se trata de convertir a la transformación en valor musical, hacer de la variante una búsqueda y no como desvío ni corrupción de la idea. ${ }^{107}$ Una música en tiempo presente, que no se dedica a repetir el pasado en el presente, sino en colocarse en el centro del flujo de una marea dinámica que posee una historia milenaria, mestiza y transcultural. Como puede observarse, cuando evidenciamos dos concepciones divergentes de la música, una objetual frente otra presentacional o performativa, el resultado nos lleva necesariamente a construir una concepción divergente de la historia ante los límites y silencios de la musicología histórica. $Y$ viceversa.

Por esta condición esquiva a los útiles de conocimiento de la modernidad, una de las categorías de la música subalterna que generará más dificultades historiográficas es la del sujeto, en torno a la cual será imposible desplegar el personalismo que como vimos es parte estructural del modelo musicológico. Esto se debe a que, más allá de las descripciones como las que citamos más arriba, la enumeración de sus habilidades e incluso la misma acuñación de los nombres de la profesión, el músico popular premoderno detenta una particularidad que se da de plano con los valores de la cultura oficial, y muy especialmente la que emergerá de la estética burguesa moderna: su condición de nomadismo.

El juglar ambulante es el único personaje que podemos llamar libre dentro del mundo medieval. No forma parte de las relaciones que atan a las personas a la tierra, y por ello se puede mover, no sin recibir a cambio el más violento de los rechazos sociales. Justamente por esa condición que escapa a los estamentos medievales y al vínculo feudo-vasallático, el juglar es un proscrito y un perseguido, está fuera de la sociedad, confundido con los maleantes y salteadores de caminos (Attali, 2011, p. 26), con los cuales es muy probable que tuviese relación y hasta que fuese uno de ellos. Este in-quieto juglar es también un lastimoso clown que apunta su gorda nariz roja hacia cuestiones tradicionalmente atribuidas a lo político, y este rasgo sedicioso lo hace rebelde a toda uniformización del mundo y toda asignación de categorías (Laplantine y Nouss, 2007, p. 200). Desde esa libertad vilipendiada que atropella la lógica histórica y produce un desorden de las categorías, el músico popular ridiculiza el orden del mundo a través de su presentación, de su performance. Es decir que sin discursos preparados ni pretenciosos, con un caldero como sombrero y unas ropas que desafían las normas del tamaño, sin asumir un discurso revolucionario, puede poner en crisis todo el esquema clasificatorio de la cultura oficial, por ejemplo, el que emana del pathos de la distancia. Es un sentido crítico que se manifiesta en la simple condición incontrolada del juglar. Lo que está fuera de control interpela con urgencia a los poderes morales, legales y también estéticos, que persiguen constantemente subordinar y disciplinar.

Los signos de la falta de control de lo subordinada aterrorizan a las fuerzas del orden (ya sean morales, legales o estéticas), dado que constituyen un recordatorio permanente de cuán frágil es el control social y hasta qué punto es aceptado a regañadientes; demuestran que el escapar al control social, aún momentáneamente, produce un sentido de libertad. Que esa

107 En este divorcio conceptual entre lo presentacional/performativo y la idea como ideal de obra/composición, radica la sustancial diferencia en el uso del término musicar entre Christopher Small y Carlos Vega. Para este último, musicar significa idea musical, pensamiento en sonidos, lo cual explicaría la génesis de la composición que deriva en la obra. Por eso en esta concepción el musicar está afuera de la música, es pensamiento específicamente musical, o como lo dice su autor, es «un suceso psíquico que trasciende la Música sin una palabra especial que lo designe» (Vega, 1941, p. 12). Nada más contrastante con la noción actancial, práxica, de Small. 
libertad se exprese a menudo por medio de una conducta excesiva, "irresponsable" (disruptiva o desordenada -los adjetivos son significativos) evidencia tanto la vitalidad de esas fuerzas populares disruptivas como la intensidad con que son reprimidas en la vida cotidiana108 (Fiske, 2009, p. 67)

La condena al juglar, aún de parte de aquellos que demandan sus servicios, no será modesta. La libertad y falta de ataduras tienen un precio altísimo, como bien sabe la memoria de la cultura popular. Por eso la música, junto a las demás artes performáticas, quedarán del lado malo de las jerarquías, como nos muestran tantas imágenes contemporáneas a la transición histórica entre ese mundo nómada y la fijación que muchos músicos y artistas se sentirán llamados a transitar. El ejemplo máximo sea tal vez la iconografía, tan sugestiva, de Pieter Brueghel "el viejo". No por casualidad Attali (2011) y Edward Muir (2001) basan sus análisis sobre la cultura popular en la pintura El combate entre don Carnal y doña Cuaresma, de 1553. En esa pintura el músico, que toca una suerte de guitarra, está del lado de los vicios, el exceso, la falta de contención, lo impío: todos aquellos valores construidos como atributo del bien por la caballería cortesana. Cuando sobre el final de la Edad Media los músicos ambulantes busquen establecerse en las ciudades, su principal preocupación al agremiarse será recuperar la honra de la profesión. Y lo conseguirán, a costa de domesticarse y servir en las ciudades a la burguesía en ascenso (Raynor, 1986, p. 59), lo cual no impedirá que perpetúen su repertorio popular y lo hagan entonces urbano.

Frente a la necesidad de la cultura oficial de fijar, de legislar en términos culturales lo que está bien y lo que no, el juglar nómada propone una estrategia que será habitual en la cultura popular: más que el enfrentamiento directo, en términos de una contraofensiva cargada de una idea igualmente monolítica y afirmativa de la cultura, el recurso será la ambigüedad, actitud de rodeo y evasión, profundamente mestiza (Laplantine y Nouss, 2007, p. 78) que representa un verdadero fuera de juego para toda la construcción clasificatoria de la racionalidad moderna. Esta es una buena razón por la cual los placeres de la evasión tienden a concentrarse en la parte baja del cuerpo, es decir, en aquellos lugares vinculados a los excesos de la comida, la violencia y la sexualidad que representan la «producción de las significaciones contrarias a las de la mente»109 (Fiske, 2009, p. 67). No estamos hablando aquí de un ornamento ni un artilugio de disimulo, sino de un factor intrínseco a la dinámica: la ambigüedad, a diferencia de la ambivalencia, rechaza la conciliación, es decir, el pensamiento consensual, que es tan importante para la estética moderna y el establecimiento del canon musicológico. Al hacer esto, lo ambiguo-popular se revela en un rechazo a esa fijación de valores y atributos que vimos es esencial en la cultura cortesana y que heredará luego la burguesía. En el mundo de la ambigüedad, que es un universo heterogéneo, diverso e intransitivo, el signo de un gesto, de una palabra, de una melodía, puede mutar una y otra vez: no es ni verdadero ni falso, ni bueno ni malo, ni blanco ni negro. Es el mundo del doble sentido, la ironía, la relativización por negación de la afirmación.

Pero reservándose la libertad de volverse esto o aquello, negro o blanco, día o noche, en diacronía, gracias al principio de alternancia. Ningún naturalismo o escencialismo resiste el

108 «Anything out of control is always a potential threat, and always calls up moral, legal, and aesthetic powers to discipline it. The signs of the subordinate out of control terrify the forces of order (whether moral, legal, or aesthetic), for they constitute a constant reminder of both how fragile social control is and how it is resented; they demonstrate how escaping social control, even momentarily, produces a sense of freedom. That this freedom is often expressed in excessive, "irresponsible" (i.e., disruptive or disorderly -the adjectives are significant) behavior is evidence both of the vitality of these disruptive popular forces and the extent of their repression in everyday life» (Fiske, 2009, p. 67) [traducción del autor]

109 «The pleasures of evasion tend to center on the body; those of the production of contrary meanings center on the mind» (Fiske, 2009, p. 67) [traducción del autor] 
principio de alternancia, porque arruina la la fijeza de los seres o los entres y pone a prueba constantemente el devenir (Laplantine y Nouss, 2007, p. 79)

Esta ambigüedad requiere sostener la dinámica, que hará que las prácticas musicales, la filiación de los sujetos y la situación de los eventuales destinatarios de la música sean cambiantes. Por eso no es ambivalencia, síntesis, hibridación, conciliación de los contrarios en lo que se autoproclama superador. La ambigüedad, como el mestizaje, no busca resolver el litigio o la tensión. He ahí la clave de esa «circulación por toda la sociedad» de músicas y músicos populares de las que habla Attali y a la que ya nos referimos. Es que los consumidores de los servicios del juglar pueden pertenecer a cualquier clase social, lo cual no implica que las prácticas sean las mismas ni que el musicar se produzca indistintamente. Al obtener su -magro- sustento de sus actuaciones, y a diferencia de la gran mayoría del mundo subalterno medieval, los juglares y juglaresas son profesionales (Lengwinat, 2006). Como la ambigüedad también reside en el carácter de su profesión, pueden actuar en bodas campesinas y en las fiestas cíclicas (de las que hablaremos más adelante) y demás ocasiones cívicas, junto a otros artesanos, cofradías y gremios, y luego, sin por ello inmutarse ni considerar traicionados sus valores, presentarse en los banquetes de la aristocracia más encumbrada, buscando prebendas y rédito. Un juglar o juglaresa puede entonces, y allí reside su ambigüedad, actuar «para una boda aldeana y la siguiente noche en un castillo, en donde come y duerme con los sirvientes» (Attali, 2011, p. 27). Y por esto mismo las tonadas, melodías y aires circulan, se mezclan y reinventan en base a la misma ambigüedad. Son danzas y canciones que pueden tener remotos antepasados de Medio Oriente, así como cargar una historia "bárbara", romana o celta. Quién puede saberlo. Pero, justamente, ¿qué importancia tendría saber eso? A los juglares, a la cultura popular, no le interesan los orígenes en términos de filiación exclusiva y excluyente. Por eso son músicas ambiguas, melodías que deben tocarse de memoria, aprenderse de oído, y por lo tanto, transformarse, reinventarse, modificarse. Como insiste Attali (2011, p. 27), cuando una melodía o tonada se hace conocida y encuentra buena recepción, se la reutiliza una y otra vez, inventando para ella numerosas letras, multiplicando los arreglos, suavizando la instrumentación o explotando el ritmo y la sonoridad de las texturas, volviendo una y otra vez sobre las mismas estructuras que son ellas mismas, a su vez, como toda sonoridad modal, ambiguas, reversibles, nómadas, mestizas.

La ambigüedad introduce también un sentido muy perturbador para la cultura musical hegemónica, que se aprecia fundamentalmente en las formas alternativas de la música popular en relación con el uso de las alturas o "notas", concepción que puede describirse a partir de pensarla como "ordenamientos sonoros basados en aglomeraciones de componentes armónicos» (Prudencio, 2001) en lugar de en escalas. Es decir que en lugar de una segmentación discreta del continuo sonoro del espectro de frecuencias en puntos fijos -esto es lo que producen las escalas- se privilegian configuraciones más complejas y diversas en las cuales, incluso dentro de una melodía, conviven varias versiones de una misma nota, que poseen no sólo afinaciones discrepantes entre sí, sino también variabilidad en lo tímbrico, las articulaciones, el ajuste temporal, etc. En este sentido es muy significativo que uno de los rasgos que distinguen al Oúd árabe del Laúd occidental sea que este último es el que tiene trastes, produciendo la segmentación del continuo sonoro que el instrumento musulmán evita conscientemente. 110

Como vimos en el primer capítulo, la musicología desprecia todo aquello que se aparta de una fijación muy estricta de las alturas, seguidas de una disposición para conducirlas, es

110 Es muy curioso cómo cambia la naturaleza sonora de los instrumentos occidentales cuando se los acerca a los del mundo musulmán, ya sea por el modo de tocarlos o al quitar los trastes. Puede verse en el siguiente video el resultado de esto último en una mandolina europea, por parte de un músico de tradición musulmana, y hasta qué punto el sonido resultante se acerca al del Oud sirio (min 5:15) https://www.youtube.com/watch? $\mathrm{v}=\mathrm{R} 9 \mathrm{St}-\mathrm{A} 36 \mathrm{mes}$ 
decir, administrarlas racionalmente en base a un plan lógico, el cual será todavía más celebrado si recibe los atributos de la direccionalidad resolutiva y la búsqueda del equilibrio formal. En contraste, toda otra música será un resabio lujurioso, sin plan, indisciplinado, irregular, voluptuoso, de irracionalidad (Treitler, 1991, p. 286). Decimos toda otra música y, precisamente, estos son algunos de los epítetos que han recibido las manifestaciones del mundo popular subalterno, en el cual los cruces y empatías se dan también en la circularidad que producen las adjetivaciones: la música oriental será, porque irracional, bárbara, es decir, inculta, rústica, informe y carente de todo sentido de la armonía, justamente como se designa a lo popular; que a su vez y del mismo modo que el Oriente, será, por irracional también, caracterizado de enfermizo e inmoral y, a través de esto, como femenino. Este es un aspecto interesante de nominación en medio del silencio de las descripciones oficiales, que nos revela la potencia de las nociones como sur global o mundo popular subalterno, en términos del "colectivo mundial de los oprimidos» (Dussel, 1994) o de la "posición asimétrica de ciertos sectores con relación a otros» (Escobar, 1991, p. 88). En la música y la musicología modernas, la estigmatización hace uno de lo extraeuropeo, las mujeres y el pueblo.

Las maneras melódicas de lo popular son justamente nómadas, ambiguas, mestizas. Emergen de un proceso permanente de reciclaje, de una latencia constante de posibilidades, que se podría resumir en la idea del "puede ser", como presencia espectral que dibuja toda la gama, toda la escala de las posibilidades (Laplantine y Nouss, 2007, p. 624). En los instrumentos de los juglares y juglaresas podemos encontrar toda una gama de indeterminación de las alturas, un universo acústico en el que predominan los ruidos, los ataques, los roces y crujidos. Por ejemplo en las gaitas, instrumento muy popular de amplia difusión en la Europa medieval. Del mismo modo que muchas de las antiguas fiestas de raigambre latina, germana, helénica o celta, perviven mestizadas y se hacen netamente populares resistiendo durante toda la Edad Media, la gaita es un instrumento también muy antiguo, con presencia desde la India hasta Irlanda, que sobrevive y se populariza con mucha intensidad en la época medieval (Partridge, 2008, p. 640). Podríamos incluso pensar que la gaita es una evidencia muy tangible y concreta de la cultura popular de este período, una suerte de indicador de la presencia de la música popular por todo el territorio europeo en fechas muy tempranas. Además, es interesante encontrar que gran parte de las investigaciones concluyen que mientras la gaita se populariza en algunas regiones de Europa en las que será luego icónica, como Gran Bretaña o Francia, tiene una gran presencia en la Ruta de Santiago de Compostela que analizamos en el primer capítulo a partir del nomadismo de los juglares, quienes parecen ser en parte responsables de introducirla allí y contribuir a la muy próspera tradición de la gaita gallega y asturiana (Mariño Pego y Salgado López, 2005). 


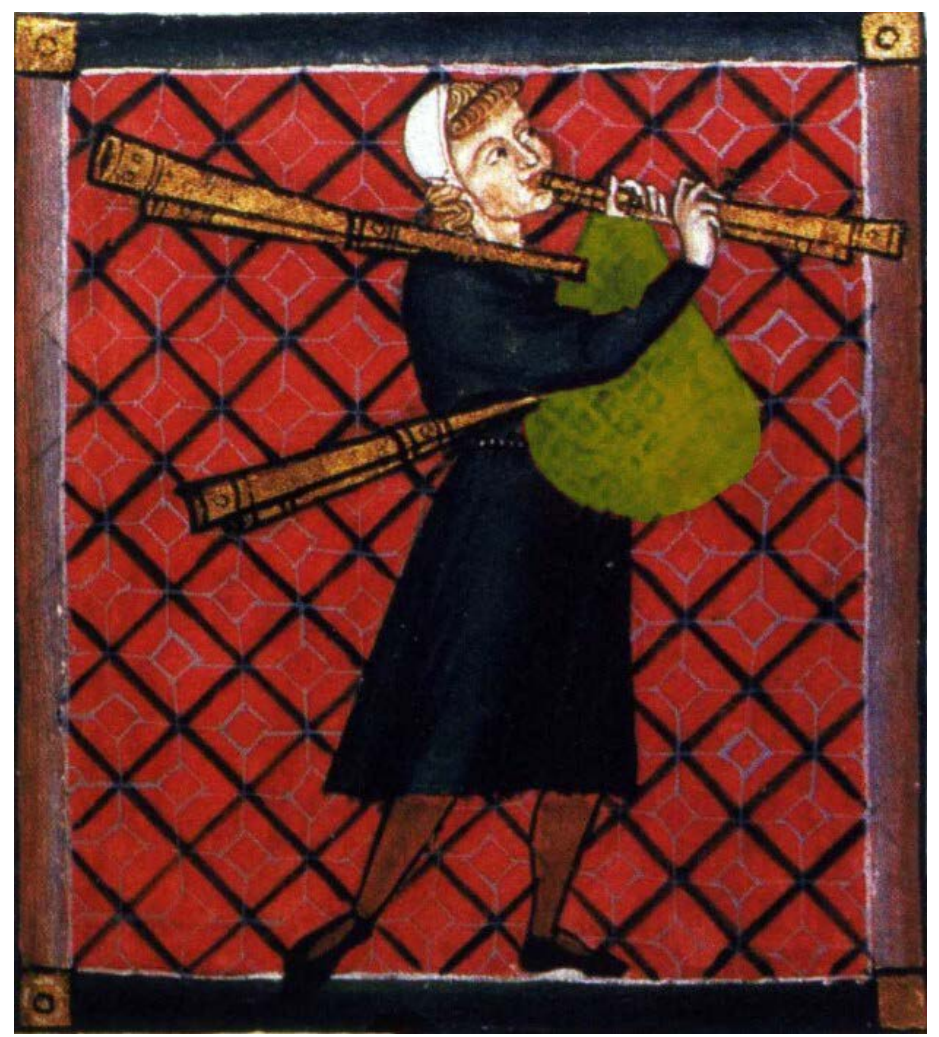

Un juglar tocando la gaita en el manuscrito de las Cantigas de Santa María, del siglo XIII

Como se sabe, el funcionamiento de la gaita supone la superposición de uno o más roncones, tubos que producen sonidos tenidos o pedales, sobre lo cual "canta" una melodía de mayor movimiento, que se toca en otro tubo con agujeros llamado puntero (Cocks, Baines y Cannon, 2001). Esto ya echa por tierra toda pretensión erudita y eclesiástica de la invención de la polifonía, presente en este instrumento desde por lo menos el antiguo Egipto. Pero además es muy interesante que la gaita recibe su identidad sonora a partir de un aspecto de su funcionamiento que va en contra de lo que en los instrumentos de viento madera es una característica buscada progresivamente en su desarrollo tecnológico: la posibilidad de controlar con la mayor precisión los campos armónicos del instrumento (Prudencio, 2001). Lo que oboístas, clarinetistas o fagotistas aprenden primero es a controlar con la boca, con los labios, los componentes armónicos del sonido que se considera óptimo o "limpio" en el instrumento, en lo referido a la afinación, los registros, y las componentes espectrales que hacen a cada nota. Todo está centrado en privilegiar la pureza de las notas, un aspecto nodal que subordina cuestiones de ritmo, de complejidad tímbrica, de posibilidades texturales y de una gama de sonidos aleatorios muy amplia, como es por ejemplo el caso de los multifónicos o los distintos golpes de boca que la música de vanguardia "descubrirá" en todos estos instrumentos durante el siglo XX. Es decir que podemos pensar a todo el desarrollo histórico de los instrumentos de viento de la orquesta moderna, tanto en la tecnología de fabricación como en la técnica instrumental, como la historia de la conquista del control armónico de los tubos y las columnas de aire. Muy por el contrario, en la gaita, al igual que en otros instrumentos de juglares como la rauschpfeife, lo interesante está en la rugosidad del espectro sonoro, que proviene de la relativa ausencia de control del instrumentista sobre la lengüeta o embocadura debido al modo de insuflación del aire: se trata de un sistema indirecto, ya que se sopla en una cápsula o, como en la gaita, en un soplador que llena un reservorio o bolsa de aire, que luego a su vez pasa el aire hacia las lengüetas. Si bien el gaitero tiene un relativo control sobre la presión del aire, presionando con su brazo la bolsa e intentando mantener una presión de aire constante y pareja, no hay posibilidad de incidir directamente sobre la embocadura, ni con la boca ni 
con las manos. Uno de los aspectos más difíciles de controlar para los aprendices de gaita, y de lo que más practican, es justamente el control de la presión de aire, porque es el responsable de la afinación y la fijeza de las notas (Gordon, 2014). Pero aún dominado con la maestría que detentan numerosísimos intérpretes de todo el mundo, este sello distintivo del sonido de la gaita siempre conserva un resabio de aleatoriedad en la producción de las notas, especialmente en sus componentes armónicas. Lo cual se suma a su vez a otras formas de "ruido" ya presentes de por sí en el funcionamiento de todos los instrumentos antiguos de lengüetas dobles, como por ejemplo la chirimía o la bombarda. De tal suerte que el resultado es una armonía ruidosa, una aglomeración sonora (Prudencio, 2001), especie de banda espectral ancha en donde conviven notas que se parecen mucho pero no son las mismas y suelen darse paralelismos aproximados entre melodías que tienden a una misma direccionalidad, pero jamás se copian de forma exacta. Este ordenamiento sonoro no es un error. Es parte de la multitud de modos de organización de las alturas que evitan la fijación exacta y persiguen un resultado tímbrico, ocupado en la materialidad y la sensualidad del sonido por sí mismo, antes que una melodía "precisa" enmarcada en base a una concepción de la armonía lógica y proporcional. Un buen ejemplo de este uso de las gaitas por parte de instrumentistas muy consagrados, es la danza Omnis caro ${ }^{111}$, una versión del grupo The Dufay Collective (1995) de una canción secular medieval sobre el diluvio universal, hallada en una fuente manuscrita inglesa. Son dos gaitas las que suenan y puede percibirse tanto la destreza instrumental requerida para tocar esta música, como esa rugosidad del ordenamiento sonoro. Al comienzo, mientras suena sólo una gaita, aparecen muy claramente las discrepancias entre la nota pedal del roncón y la melodía y, como la música es lenta y son frecuentes las notas largas, se escucha otro rasgo característico, que son las oscilaciones de altura por la variación de presión del aire. En la segunda estrofa de la canción, en donde la melodía rápidamente va a la octava superior, se percibe con claridad la nula capacidad para controlar los pasajes registrales en el instrumento, lo que resulta en una alta heterogeneidad del sonido que atenta también con que percibamos la ejecución "afinada". También al ser una melodía lenta se presta para que observemos de forma muy pregnante otra característica de esta "falta de control" sobre las notas: como en la gaita el aire sale todo el tiempo, sin que se pueda interrumpir el flujo de forma abrupta y precisa, los instrumentistas se ven impedidos de articular silencios y obligados a introducir apoyaturas y otros adornos para poder atacar más de una vez la misma nota, lo que resulta en esos sonidos muy típicos del instrumento, producto de levantar y tapar los agujeros rápidamente mientras todo sigue sonando (Cocks, Baines y Cannon, 2001). Es un rasgo que privilegia la continuidad del sonido por sobre su segmentación discreta y los portamentos que resultan de la técnica de ejecución dan la sensación de que la escala tiene muchos más sonidos que los de las notas que corresponden a los agujeros del puntero. Es especialmente notable la amplificación de todos estos rasgos cuando ingresa la segunda gaita, promediando la canción. Todo aumenta: la presencia y el cruce de las componentes no armónicas de los ataques y articulaciones, el zumbido de los roncones, la heterogeneidad tímbrica cuando se cruzan los registros. Las aglomeraciones sonoras son particularmente notorias en lo que debieran ser unísonos, que aún cuando están tocados con maestría en instrumentos muy bien preparados, resultan sin embargo en una suerte de ensanchamiento del sonido general. Un efecto de "coro" que se da justamente a partir de las desafinaciones y las discrepancias que aumentan a medida que transcurre la danza cuando una de las gaitas "ornamenta" y realiza ondulaciones y portamentos sobre la melodía que continúa la otra. Nuevamente, lo significativo de la música son la textura y el sonido, producto de las discrepancias participatorias. Las notas y la armonía son muy sencillas y repetitivas como para tener alguna importancia. Los ejemplos de todos estos rasgos se multiplican en otros conjuntos y versiones, pero es especialmente notorio en el grupo Corvus Corax que, un tanto alejado de la ortodoxia de la música antigua, fabrica sus

$111 \mathrm{El}$ ejemplo 10 puede escucharse aquí https://youtu.be/sjD5FZNmi2E 
propios instrumentos y monta shows que no pretenden reproducir un ambiente medieval, sino más bien fantástico. De todas formas en sus primeros discos prevalecen las versiones de músicas medievales populares, como el caso del Saltarello Venusti112 del fonograma Tritonus (1995), en cuyo comienzo puede escucharse el "glissando" que supone al poner en funcionamiento la gaita, a lo cual le sucede una muestra de todos los recursos tímbricos y sonoros que describimos: la discrepancia entre el roncón y la melodía, los portamentos y ornamentaciones constantes, la oscilación de las notas largas producto de la variabilidad del aire, etc. Pero más aún se explicitan en la versión del Lamento di Tristano113 del CD Ante Casu Peccati (1989). Aquí la gaita se combina con otros instrumentos igualmente ruidosos, como el rabel o violín medieval, varios instrumentos de percusión entre los que aparece una quijada de burro y otros zumbadores y una cítola, especie de guitarra medieval, que es utilizada para marcar el ritmo antes que la armonía. El resultado es una masa sonora que privilegia los ataques, las transiciones, una fuerte heterogeneidad sonora montada para celebrar un ritmo frenético pensado para mover a una danza que se va haciendo progresivamente más rápida y en la cual lo corporal adquiere un carácter central. Nuevamente, la melodía es una excusa, un esquema repetitivo y sencillo sobre el cual emerge lo importante: las texturas, la velocidad y la repetición, que nunca es exacta y se va intensificando.

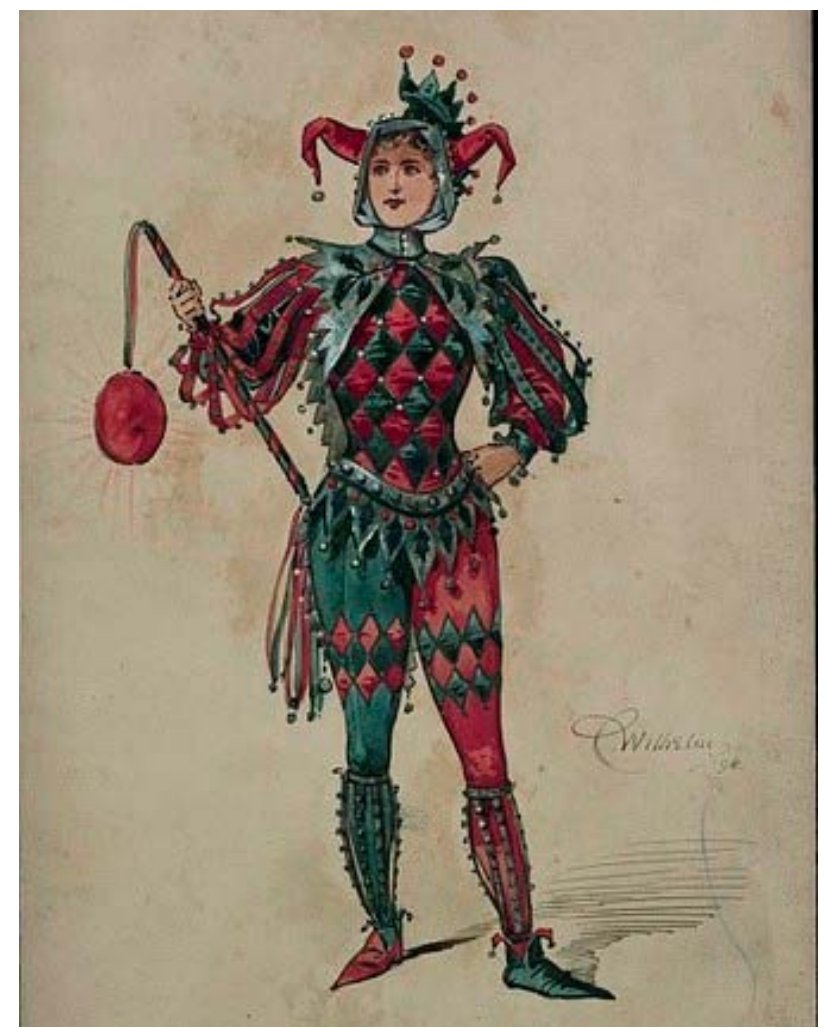

Un juglar carnavalesco con su cetro de vejiga de cerdo o cordero, muy similar al odre o bolsa de la gaita

Otro instrumento relacionado con la gaita, probablemente muy antiguo también, es el llamado odrecillo, en realidad una gaita más simple, sin roncones y en el cual el músico sopla por un pico directamente en el odre, que queda así frente a su boca, tocando luego en un puntero la digitación. De esta forma la posición del instrumentista se asemeja más a la de un oboe o clarinete aunque, al igual que en la gaita, no hay control directo sobre la embocadura de doble lengüeta. Pero hay un aspecto particularmente interesante en el

112 El ejemplo 11 puede escucharse aquí https://youtu.be/P1tHmQa5IRI

113 El ejemplo 12 puede escucharse aquí https://youtu.be/hdvCqlkTx-U 
odrecillo y es que el reservorio de aire está hecho en este caso con una vejiga de cerdo, de allí el nombre del instrumento en inglés, bladder pipe (Mayer Brown y Boydell, 2001). Aquí se nos abre un fecundo campo de simbolismos, ya que como se sabe el cerdo es el animal fundamentalmente relacionado con la zona baja del cuerpo, lo carnal, los excesos, entre otros atributos vinculados a la fiesta, es decir, a la cultura popular. Por ejemplo la lascivia.

La vejiga que llevaba un bufón, por ejemplo, reproducía distintos significados; era una vejiga y por lo tanto estaba asociada con los órganos sexuales; procedía del cerdo, el animal carnavalesco par excellence, y la llevaba un tonto, cuya «necedad» era simbolizada por la vejiga vacía (Burke, 2014, p. 274)

En función de todo esto, la vejiga del cerdo se transforma en símbolo de lo que Bajtín (2005, p. 286) denomina el cuerpo grotesco, un principio que procede por hiperbolización de ciertas partes o zonas del cuerpo, fundamentalmente las aperturas y orificios, por un lado, y las prolongaciones por otro. El grotesco se demora en los pasajes, en lo que entra y sale del cuerpo, en aquello que lo vincula con el afuera, con la comunidad. De allí que nos remita a las entrañas, los genitales, los esfínteres, y partes del cuerpo como el vientre, la nariz, el falo, la boca o el ano. Es muy importante aquí el sentido de ambigüedad y de incompletud, ideas fuertemente relacionadas con una concepción centrada en los procesos del cuerpo, en sus transformaciones y cambios, en todo aquello que lo desborda. Porque son ellas las que guardan un sentido cómico del cuerpo, además de un simbolismo en cuanto a los ritmos de creación y destrucción de la vida. De hecho la cultura popular contiene como sentido de sus rituales a los ciclos de renovación y renacimiento, a partir de la destrucción que supone la profanación de los símbolos oficiales. La vejiga de cerdo es entonces un objeto paradigmático que reúne varias de estas connotaciones: los fluidos corporales, las excrecencias, el exceso en la bebida, la zona baja y sexual del cuerpo. Pero también es un símbolo político del cuerpo indisciplinado que le genera ruidos a la doxa de la cultura hegemónica. 


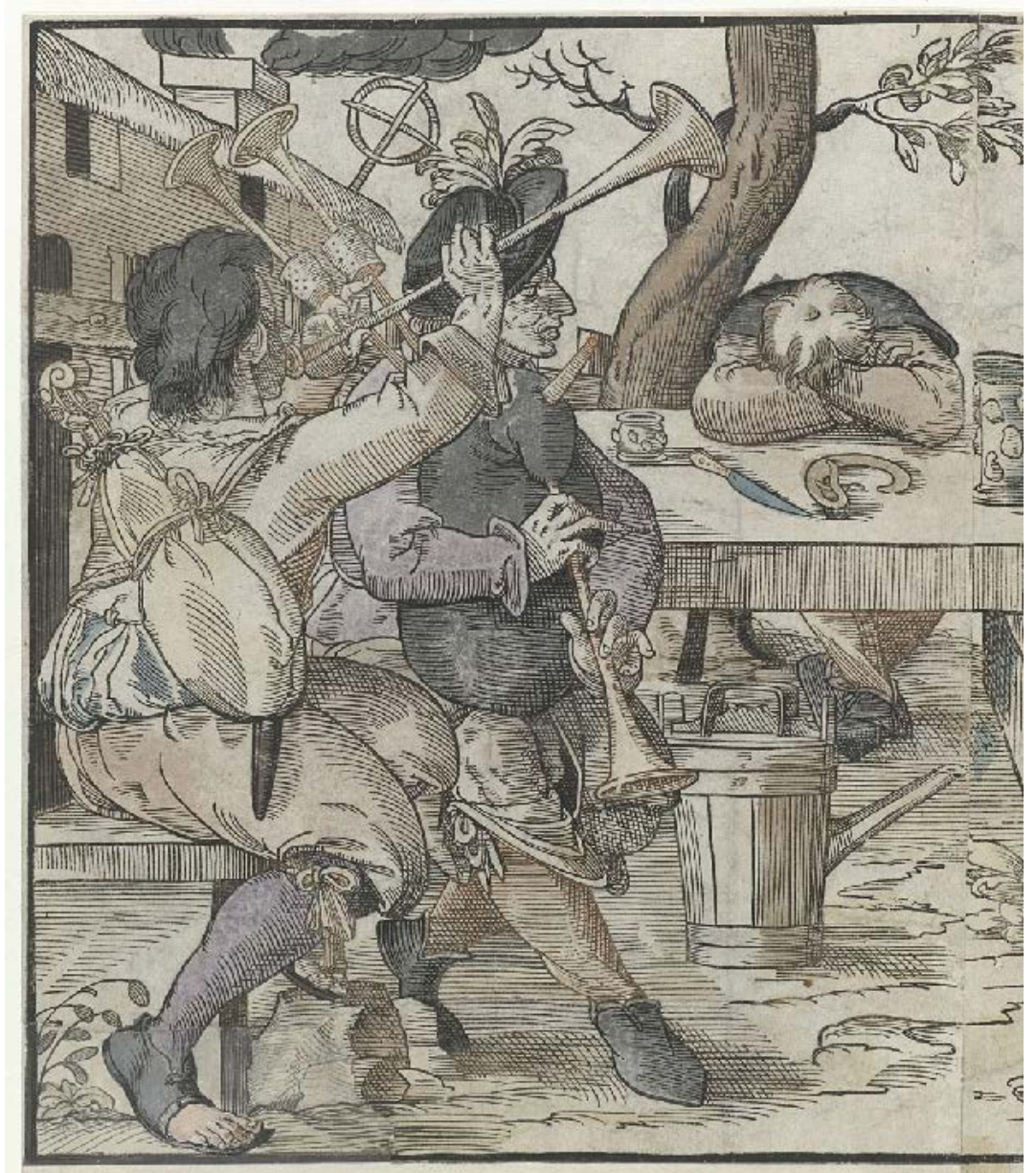

Grabado anónimo de 1590 en el cual se muestra un juglar tocando un odrecillo, platerspiel o bladder pipe, hecho con vejiga de cerdo

El lenguaje de la cultura popular medieval, que es un lenguaje específico de la plaza pública (Bajtín, 2005, p. 9), se basa entonces en el vocabulario del cuerpo humano y de sus procesos (Muir, 2001, p. 101), lo cual se despliega en las temáticas de la comida incluyendo el canibalismo- el sexo, la violencia (Burke, 2014, p. 265) y la risa popular (Bajtín, 2005, p. 10). Estos temas claramente codifican cierta emocionalidad colectiva, incluidos deseos, venganzas y protestas, siempre en relación con generar ambigüedad en los límites, los bordes del cuerpo. «El acto de comer y el acto sexual se pueden entender como funciones corporales, formas en que se traspasan las fronteras del cuerpo humano» (Muir, 2001, p. 96). De allí la profusión de alegorías y simbolismos vinculados a los placeres del vientre y los genitales: la nariz larga de las máscaras, las "metáforas" vinculadas a los clavos, salchichas, troncos y cuchillos, que penden entre las piernas, la hiperbolización de bocas y vientres, etc. Lo grotesco entonces se interesa por lo que desborda el cuerpo, lo que sale, escapa o brota de él, pero también todo lo que ingresa y se introduce, ya que el cuerpo es al mismo tiempo un abismo corporal abierto y engullente. También el cuerpo grotesco es nómada, cuerpo en movimiento, en construcción, inacabado. Recreación continua. Es ambiguo física y sexualmente, y heteróclito, conteniendo a la vez las funciones de ambos géneros, a la vida y a la muerte. El cuerpo grotesco es finalmente un cuerpo mestizo.

Después del vientre y del miembro viril, es la boca la que desempeña el papel más importante en el cuerpo grotesco, pues ella engulle al mundo; y, en seguida, el trasero. Todas estas excrecencias y orificios están caracterizados por el hecho de que son el lugar donde se superan las fronteras entre dos cuerpos y entre el cuerpo y el mundo, donde se efectúan los cambios y las orientaciones recíprocas [...] la imagen grotesca que se pretende lograr [...] está 
formada de huecos y excrecencias que constituyen el nuevo cuerpo empezado; en cierto sentido, es el pasaje de doble salida de la vida en perpetua renovación" (Bajtín, 2005, p. 286)

El cuerpo grotesco es encarnado, cual especie de metáfora viva, en el personaje del juglar, cuyos rasgos y prácticas se acoplan por medio de una fuerte identidad con todas las características que venimos listando: nomadismo, ambigüedad, mestizaje, recreación, incompletud, indisciplina. Los elementos del cuerpo grotesco, como los del juglar y su práctica musical, todos ellos marcados por la impureza, imponen sus necesidades a las de la razón y el espíritu, atributos predilectos de la cultura oficial. Y de modo análogo la relación se traslada a los instrumentos sonoros del músico popular, de entre los cuales la gaita y el odrecillo son el símbolo directo del cuerpo grotesco: el saco como vientre, los roncones y punteros miembros que se introducen mediante orificios que "respiran", engullen y devoran al mismo tiempo que expulsan y derraman de manera descontrolada el contenido del cuerpo, que en sus sonidos organiza una gama analógica de los ruidos más grotescos del cuerpo humano. Ruidos que debemos leer también en términos políticos: ya que los placeres populares funcionan y son experienciados únicamente a través del cuerpo, el control sobre los comportamientos y sentidos de lo corporal será posteriormente preocupación de la cultura afirmativa, de lo cual una primera inscripción lo constituye la descorporeización de la música cortesana de los trovadores. El cuerpo será un territorio de disputa de significación entre el poder y la evasión, el disciplinamiento y la liberación: el cuerpo racial, social, de clase y de género. El cuerpo del juglar, mestizo, indiciplinado, nómada, desclasado, pone en crisis por su propia existencia esta voluntad de control en todas estas dimensiones

Los placeres y excesos del cuerpo -la borrachera, la sexualidad, la holgazanería, el vandalismo- eran vistos como peligrosos para el orden social [...] Los placeres del exceso siempre han amenazado al control social, pero cuando estos placeres pertenecen a los grupos subordinados (ya sea una subordinación de clase, género, raza u otra) la amenaza es particularmente aterradora y la acción disciplinaria, sino represiva, se hace prácticamente inevitable ${ }^{114}$ (Fiske, 2009, p. 75)

Hay todavía otro de los instrumentos icónicos de los juglares medievales en el que encontramos estos rasgos vinculados al ruido, lo ambiguo y lo grotesco: la pintoresca zanfona o viola de rueda. Se trata de un instrumento muy llamativo por su mecanismo increíblemente complejo para la época115: el sonido se produce por el rozamiento de una rueda que se acciona mediante una manivela, que incide sobre una o más cuerdas dispuestas sobre un diapasón. Hasta aquí es una especie de violín automático, que reemplaza el arco por la rueda. Sin embargo, para modificar las alturas en lugar de presionar las cuerdas con los dedos en el diapasón, la zanfona posee una caja de teclado, una tapa sobre el diapasón dentro de la cual hay una serie de pequeñas palancas que son las que presionan las cuerdas. Para mover esas palancas el músico presiona una suerte de teclas o botones por fuera de la caja de teclado. Como en la gaita, vemos que la acción instrumental es indirecta en los dos lugares clave: el roce sobre las cuerdas y la pulsación de las diferentes alturas. Y más allá de lo sofisticado del mecanismo, su componente artesanal hace que las palancas tengan algo de movimiento, por lo cual siempre existen corrimientos en la afinación de las notas. Del mismo modo en que en la gaita el instrumentista no controla con la boca la afinación, aquí no se puede cambiar la afinación moviendo el dedo milimétricamente, como hacen los violinistas. Como en el caso de la

\footnotetext{
114 «the pleasures and excesses of the body -drunkenness, sexuality, idleness, rowdiness- were seen as threats to the social order [...] Excessive pleasures always threaten social control, but when these pleasures are those of subordinated groups (whether the subordination is by class, gender, race, or whatever) the threat is particularly stark, and disciplinary, if not repressive, action is almost inevitable» (Fiske, 2009, p. 75) [traducción del autor]

115 Una muy ilustrativa descripción del instrumento y su funcionamiento por parte de una aficionada puede verse aquí https://www. youtube.com/watch?v=qYd0G4sRrw0
} 
gaita, también en la zanfona además de la cuerda o cuerdas que "cantan" y son modificadas por las palancas de la caja de teclado, existen cuerdas bordonas y armónicas, que producen una nota pedal permanente. Por lo demás, la rueda tienen un comportamiento parecido al de la bolsa u odre de la gaita: debe girar constantemente y además produce oscilaciones por el cambio de presión que supone el paso de la manivela de arriba a abajo, ya que es muy difícil hacerla girar de forma pareja y homogénea. Pero no debemos pensar que estos son "defectos" del instrumento. Un rasgo que nos demuestra lo buscado y ex profeso de estos rasgos sonoros lo constituye una pequeña piecita de madera que recibe el nombre de "perro" o "mosca". Se trata de un accesorio de presión variable que se coloca sobre una de las cuerdas bordonas y sirve para producir diferentes chasquidos, crujidos y zumbidos mediante golpes de presión en la rueda, añadiendo voluntariamente ruido a la sonoridad general. Y es que, de hecho, frente a otros instrumentos de cuerda, la zanfona es un instrumento mucho más ruidoso, en el cual de por sí el roce de la rueda es muchísimo más áspero y rudo que el de un arco de cerda.

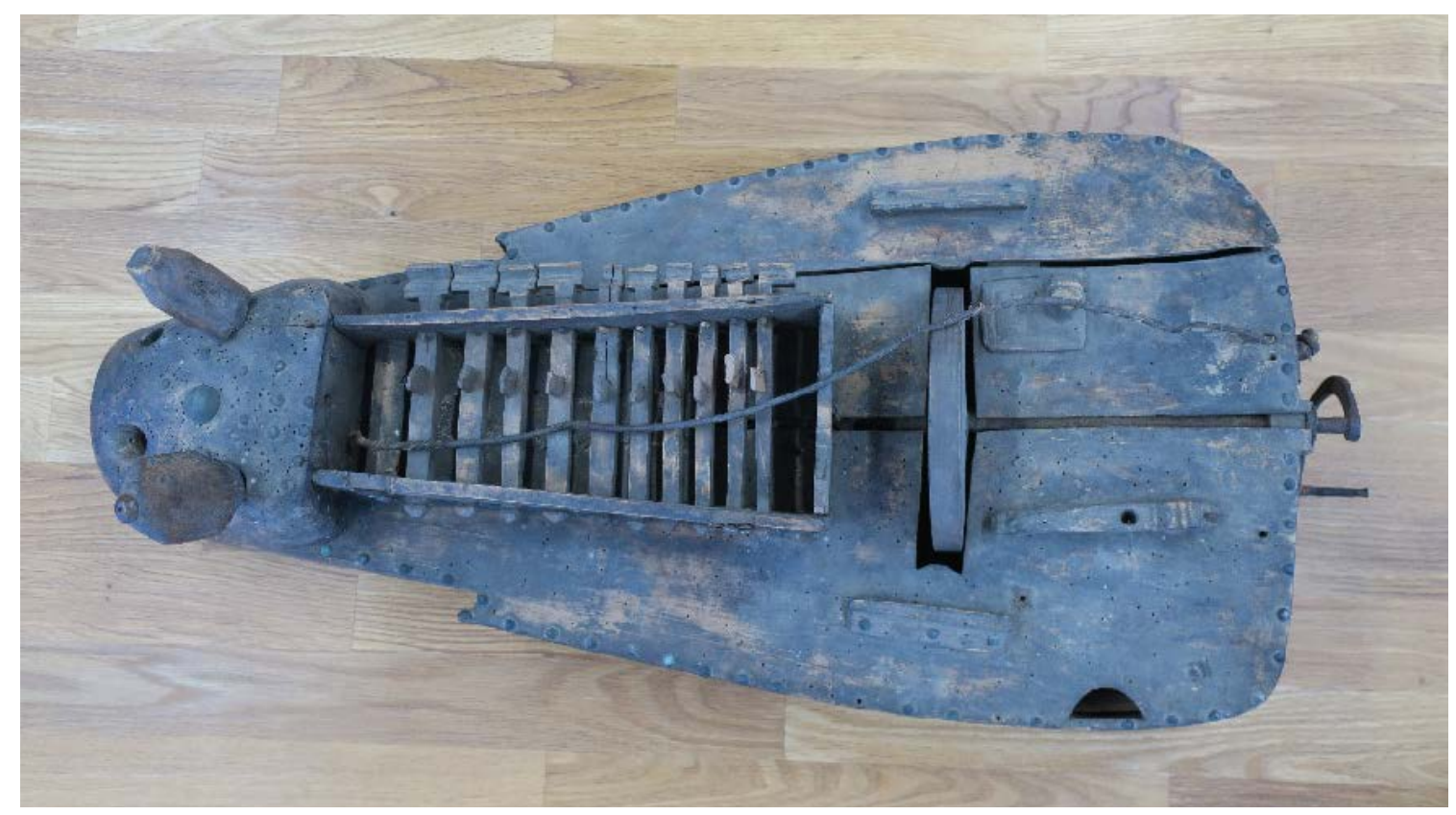

Un organistrum o zanfona medieval, ca. 1400. Según se publicó recientemente ${ }^{116}$ se trataría del ejemplar más antiguo conservado al día de hoy, aunque como puede verse se encuentra en muy mal estado.

116 La publicación todavía puede encontrarse en E-Bay: https://www.ebay.co.uk/itm/ca-Anno-1400-SENSATIONoldest-hurdy-gurdy-in-the - World-now-on-E B a y-/253921417571? nma=true\&si=jeJ5NMJiktHO5ra1KW0YMZePI\%252BM\%253D\&orig_cvip=true\&nordt=true\&rt=nc\& trksid=p2047 $\underline{675.12557}$ 


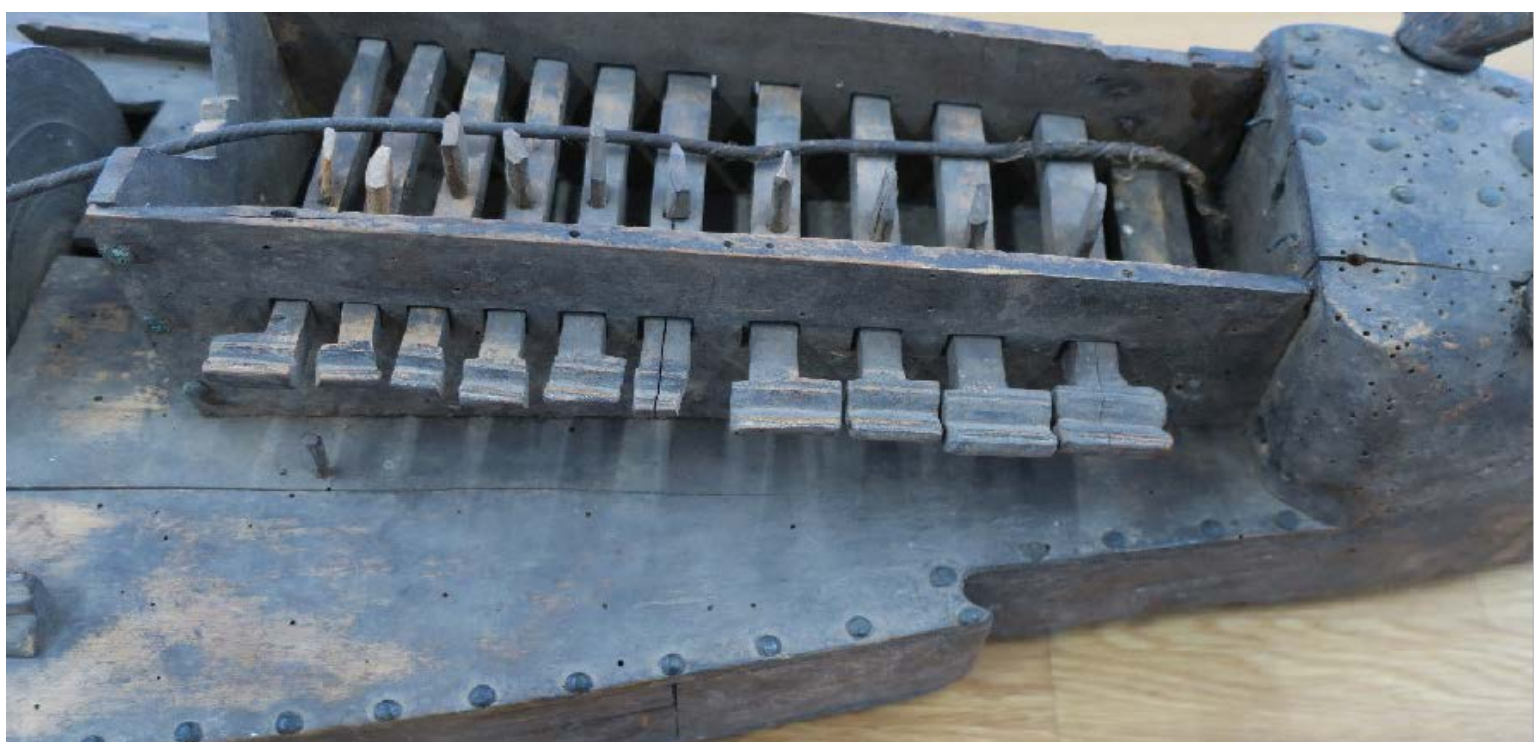

Detalle de la caja de teclado (sin tapa y abierta en este caso) que descubre el mecanismo de palancas para "pisar" las cuerdas. Por fuera de la caja y en primer plano se observan los botones o teclas que presiona el ejecutante.

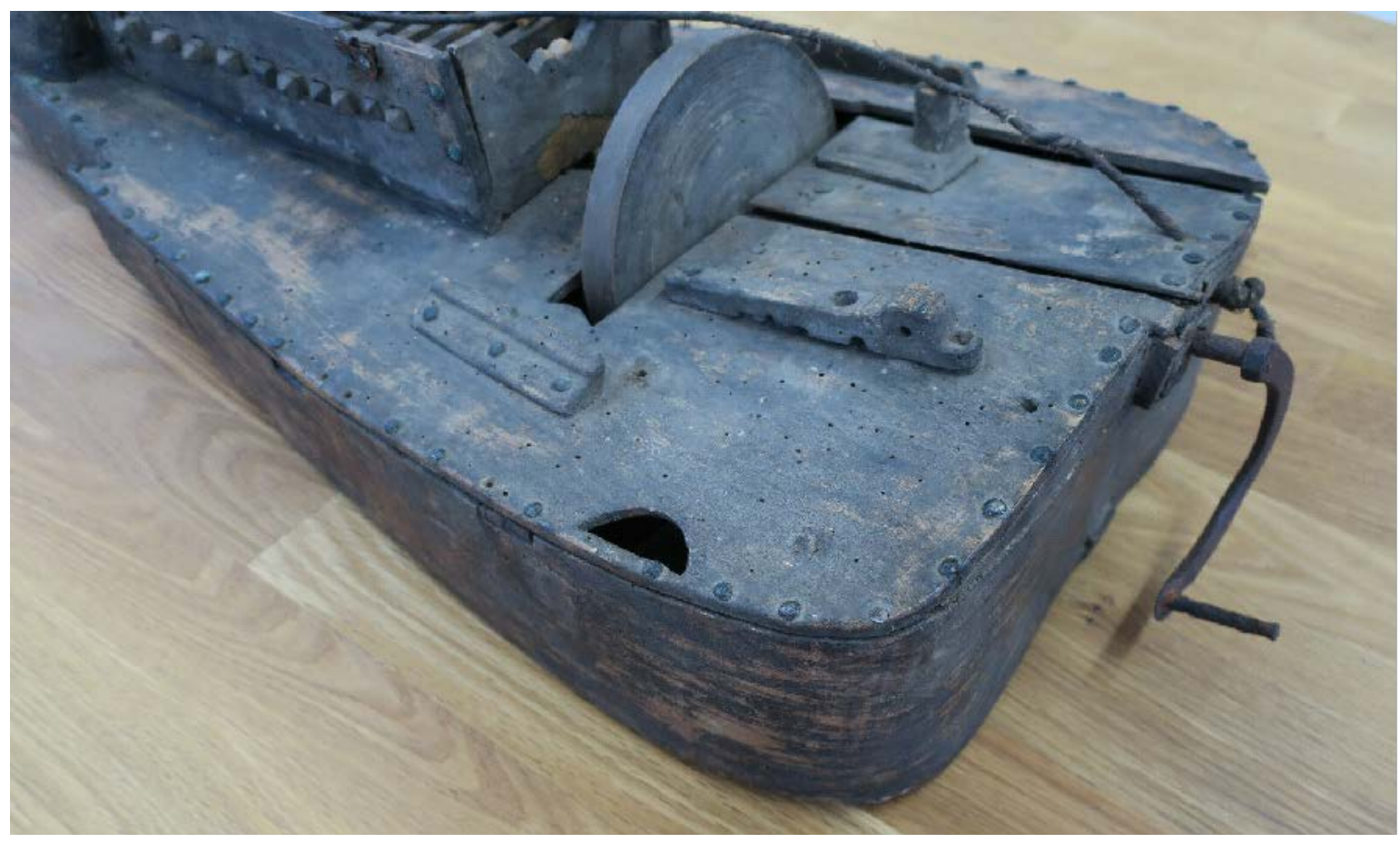

Detalle de la manivela y la rueda de madera enresinada que fricciona las cuerdas. En primer plano puede verse una pieza de madera con varias muescas, unida a la caja de resonancia, que muy bien puede tratarse de la "mosca" o "perro".

Un buen ejemplo de la sonoridad de este instrumento aparece en la danza medieval Saltarello La Regina ${ }^{117}$ en la versión del músico húngaro Arany Zoltán, registrado en el CD The last of the Troubadours (2010). En esta música, sobre todo en la primera estrofa en que la zanfona suena en solitario, pueden escucharse numerosas discrepancias entre las notas que se pulsan con la caja de teclado y los bordones, que tienen muchísimas oscilaciones producto de la mecánica de la rueda. Además el transcurrir de la melodía es poco fluido, lo

117 El ejemplo 13 puede escucharse aquí https://youtu.be/ggZp9DoW3CY 
que evidencia la distancia entre los movimientos del músico y la incidencia de estos en la articulación efectiva de las notas. Pero nada de esto es un problema. Nuevamente, el sentido de la música está en la danza, que también procede por repetición y su intensificación progresiva, que lleva a un aumento de la intensidad y la velocidad en conjunción con el movimiento de los danzantes. Todo esto se acentúa cuando ingresan los instrumentos de percusión, un salterio (que aumenta la presencia de ataques brillantes) y un rabel que duplica la melodía, con unísonos discrepantes. En ese marco lo que importa realmente es el marco sonoro, de un brillo iridiscente, un tintineo que da marco y voluptuosidad a los movimientos. Las notas, otra vez, funcionan como esquema, esqueleto sobre el cual se despliega la materialidad del sonido (o del ruido deberíamos decir).

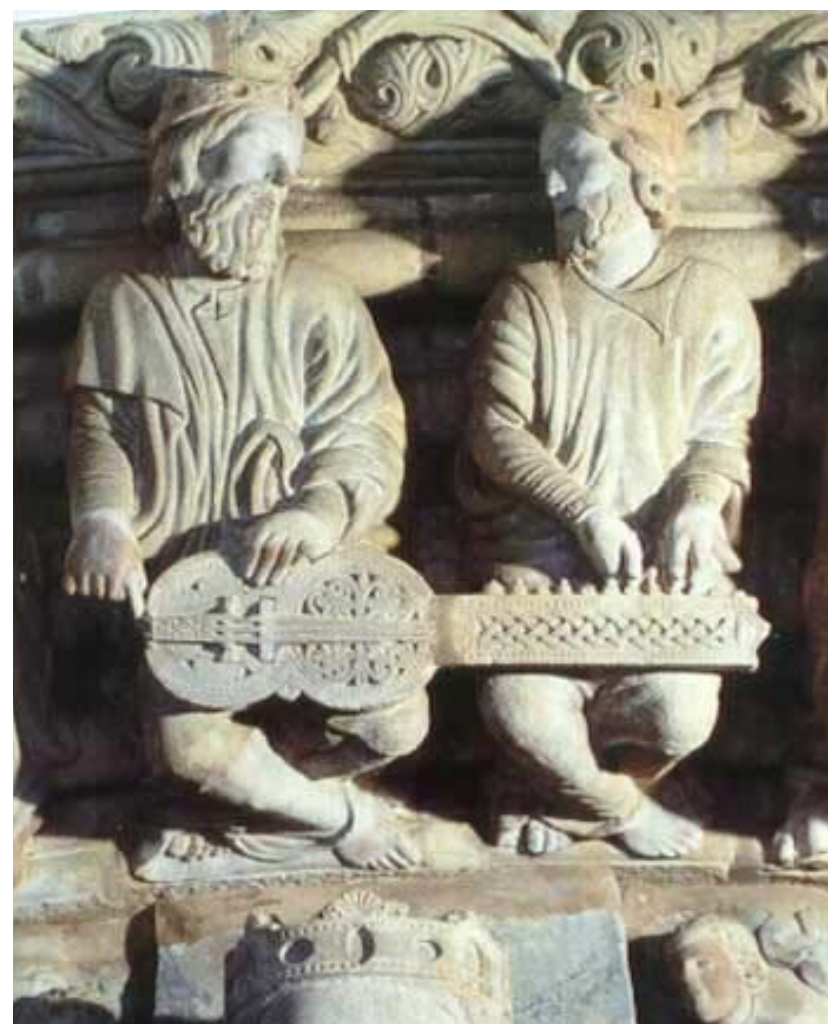

Dos músicos tocan el organistrum. Detalle del relieve medieval del Pórtico de la Gloria de la catedral de Santiago de Compostela, que ya mostramos en la sección anterior

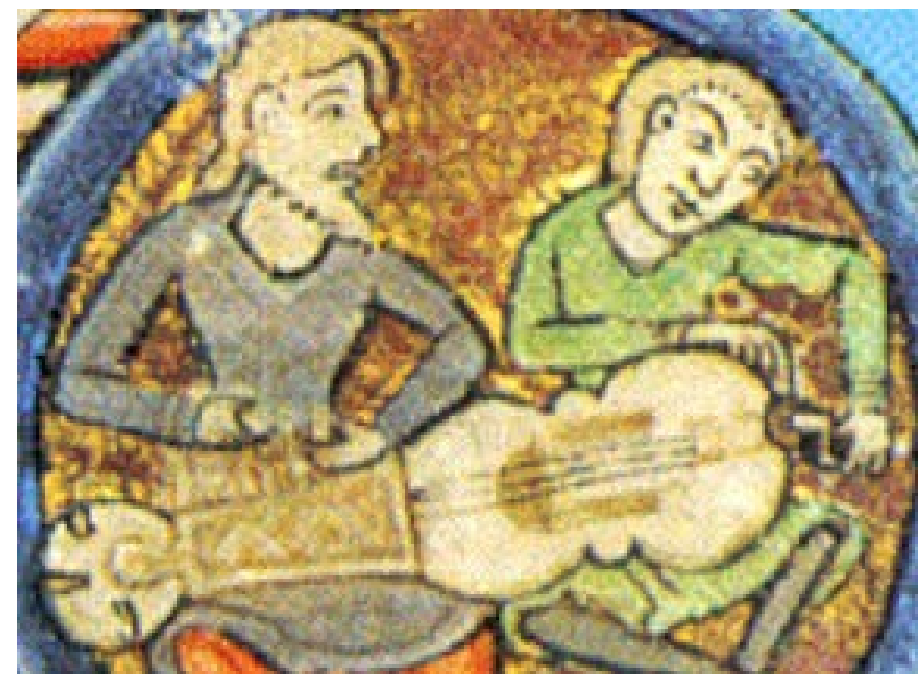

Ilustración en un salterio inglés, conservado en la biblioteca de la Universidad de Glasgow. Como en el caso anterior, las miniaturas hasta el siglo XII presentan la versión "larga" del organistrum tocada por dos juglares. 


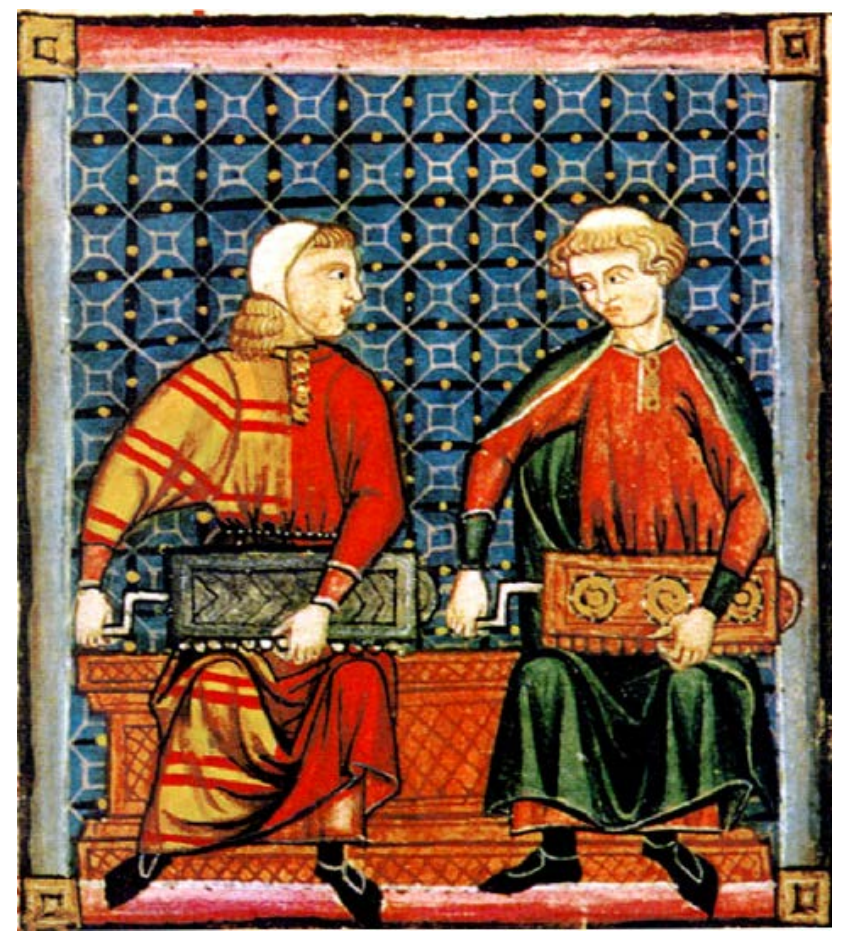

Ya en el siglo XIII los registros muestran que el organistrum es un instrumento individual y más pequeño. Miniatura de las Cantigas de Santa María.

En resumen, podemos pensar que lo oscilante, lo heterogéneo, lo que discrepa y es ambiguo, es decir, lo que se resiste a ser domesticado y disciplinado, forman parte no solo del discurso superficial de la figura del juglar: es la propia materialidad del sonido, de su música, la que expresa estos valores que se erigen como contrahegemónicos, aún cuando no se muestran abiertamente confrontativos. En el cuerpo nómada del juglar, en los sonidos indisciplinados de sus instrumentos, en las notas móviles y fluctuantes de sus melodías, en la reinvención permanente que no reconoce autores: allí está la clave de la música medieval en los albores de la cultura occidental. Y como justamente sus rasgos están en los cuerpos, en la materialidad sonora, en lo que la modernidad reservará para la interpretación musical, sacándolo de la "obra", la musicología histórica y sus esquemas analíticos se revelan pobres e impotentes para dar cuenta de esta realidad musical. No es solo desprecio esteticista, sino que es imposibilidad analítica producto de que la música popular medieval pone de cabeza todo el esquema musicológico de la modernidad europea. Precisamente, el tema de la inversión, el poner la realidad "patas arriba", será el tema privilegiado de toda la cultura popular occidental, fundamentalmente en sus primeras inscripciones durante la Edad Media y la modernidad temprana. Analizaremos a continuación las relaciones entre esta pauta cultural y su incidencia en la música.

\subsubsection{Lo carnavalesco y la carnivalización del musicar}

Para ensayar una hipótesis descriptiva de estas músicas es hora de regresar a nuestra escena en la aldea medieval del film de Ingmar Bergman ${ }^{118}$, en el momento inmediatamente anterior a la secuencia que ya comentamos en la sección previa. Para Marta Zátonyi (2007, p. 31) la película construye dos personajes simétricamente contrastantes: el noble o caballero, que en lo que estamos desarrollando coincide con el trovador; y el juglar o comediante. Éste sabe del gusto popular pero también, en lo cual coincidimos con Attali (2011, p. 27), conoce el modo cultural de la corte. Por lo tanto los destinatarios de las prácticas de juglares y juglaresas pueden tener pertenencias sociales distintas. Esto

118 El ejemplo 14 puede verse aquí https://youtu.be/rAaTIdFRIQ8 
aparece en la película, y lo que si atestiguamos es la diferente recepción que los distintos sectores hacen de las canciones, pantomimas y danzas. El caballero, personificado magistralmente por Max von Sydow, contempla la escena impasible junto a su escudero. Está en cierto sentido afuera de la ocasión musical. Esto es algo que según Burke (2014) es típico de la actitud aristocrática premoderna, en la cual las clases hegemónicas a lo más participan de la cultura popular pero rechazan intervenir en ella. La modernidad requerirá que tanto la aristocracia como la burguesía ordenen y regulen el desarrollo de la cultura popular y su música. O al menos que lo intenten.

En contraste con esa actitud noble y distante, toda una metáfora del pathos de la distancia, la soldadesca, los campesinos, artesanos y demás participantes tienen un rol más activo, incluso arrojando objetos al escenario o abucheando a los juglares. La actitud popular llega a la máxima intensidad en el accionar del personaje de la mujer del herrero, quien detrás del rudimentario tablado mantiene una escena sexual abiertamente adúltera con uno de los juglares mientras continúa el espectáculo. Todo esto es parte de la cultura de la risa, el accionar de los músicos ambulantes y su interacción con el mundo de la cultura popular. En este mundo «al caballero no lo entienden, al juglar sí y lo pueden aplaudir o maltratar» (Zátonyi, 2007, p. 31)

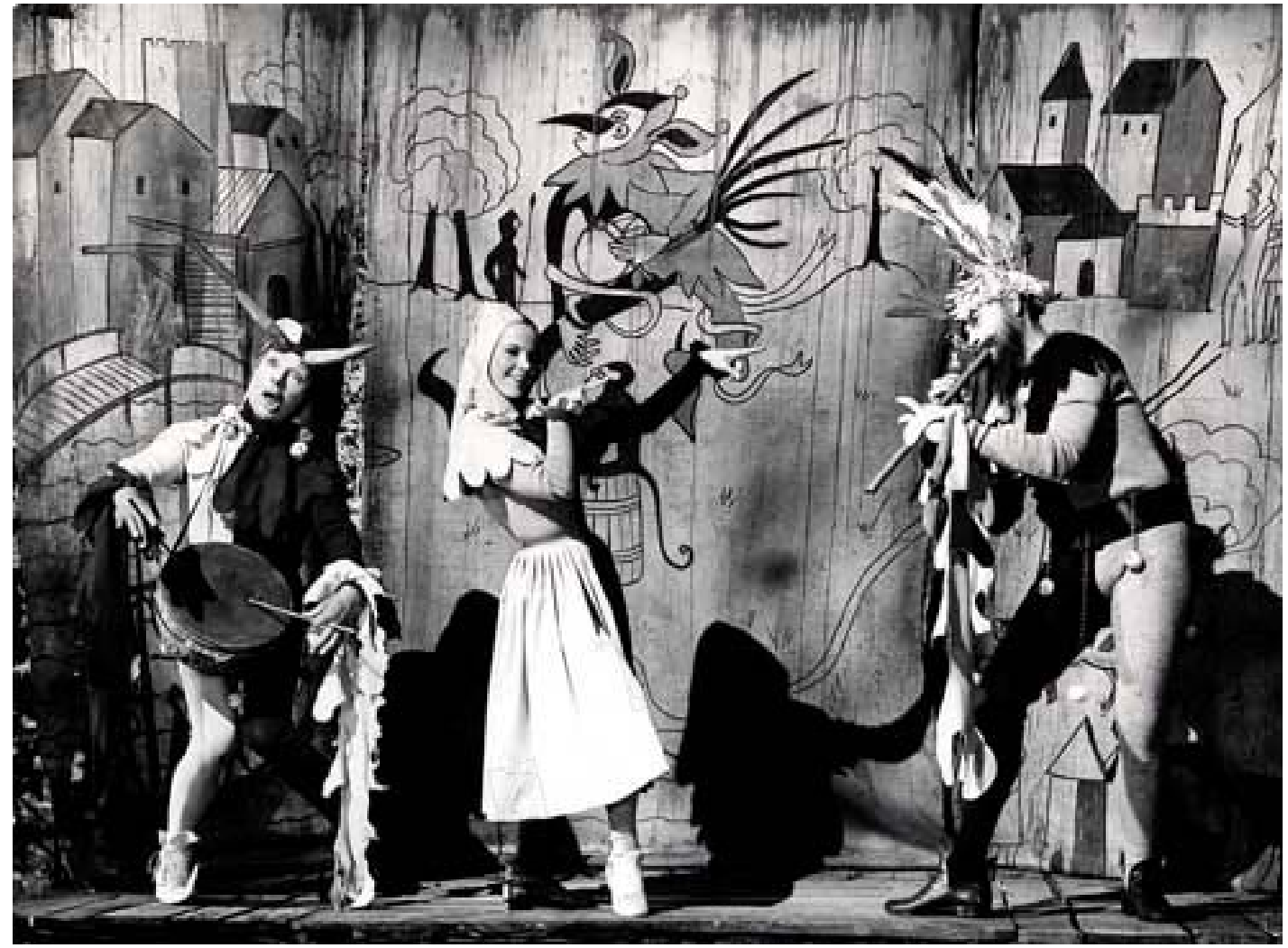

Fotograma del film El séptimo sello, de Ingmar Bergman, donde vemos la actuación de los juglares.

El momento más extenso de la escena de juglares lo constituye una canción, que no es una pieza de repertorio sino una creación del compositor de la banda sonora del film, Erik Nordgren. De todos modos la intención de éste es recrear la música de los juglares medievales así que, provisoriamente, la consideraremos una aproximación interpretativa a esta música ¿Cuáles son los rasgos que toma Nordgren para justificar el carácter histórico de la canción? En primer término se trata de una música pulsada y, aunque el tempo fluctúa, podríamos decir que su ritmo es regular. En todo caso, como ya vimos en relación con los himnos medievales, dicha regularidad se debe a una consideración de la dimensión corporal, del movimiento, antes que a una racionalización metronómica. Por lo tanto 
podríamos llamar ritmo o pulsación orgánica a este tipo de configuraciones. Sin embargo existen aquí también las discrepancias de Keil (2001) que ya referimos. Hay un sentido de la acción que acompaña además una narrativa presente en el texto y una suerte de escenificación sonora de su contenido, que genera desvíos entre los cantantes y los instrumentos que tocan. Un desajuste en el cual reside parte del valor de esta canción, en particular si consideramos las fluctuaciones rítmicas. Podríamos plantearlo mejor como una pregunta ¿Cuál es el sentido de un canto al unísono (en realidad a la octava) entre dos personas y la presencia de un tambor que bate el pulso, en el contexto de una melodía que todo el tiempo acelera y desacelera? Si se buscase una ejecución "exacta", estos no son los recursos para poner en acto y mucho más efectivo sería hacer descansar en un solo cantante la melodía y minimizar las fluctuaciones del pulso. Pero no es lo que sucede, razón por la cual debemos considerar que las dos voces y los dos instrumentos (uno armónico y otro percusivo) están presentes porque nos interesan los desajustes que producen al sonar juntos. $Y$ de eso se trata uno de los posibles sentidos de la canción: escuchar cómo participan en el musicar estos instrumentos y estas voces, como si fuesen individuos dentro de un colectivo. Es decir que existen dos niveles de sentido, uno que reside a nivel de cada fuente, que podemos seguir en el despliegue de cada voz o en los acordes o el batir del tambor; y otro que resulta de todo este conjunto heteróclito que busca tensionar las similitudes para profundizar el carácter transicional de la mezcla sonora. En esto la canción logra, a nuestro criterio, el propósito histórico que se propone. Tal vez existan algunos datos controversiales, como la presencia de un instrumento como el laúd entre los juglares, de lo cual no existen suficientes evidencias históricas. Un rabel o una zanfona podrían presentar un rasgo un poco más sólido. Pero sabemos que los ministriles al servicio de los trovadores tocaban instrumentos armónicos, como el salterio, el arpa medieval e incluso también el laúd. Así que en el terreno de las hipótesis no deberíamos descartar la versión sonora de Nordgren, como hace muy rápidamente Marcos Azzam Gómez (2014, p. 297), reproduciendo todo el rosario positivista de la musicología afirmativa y entendiendo que la canción debería ser "monofónica", como las de trovadores. Este es también un claro ejemplo de compresión conceptual. Sabemos por todas las evidencias iconográficas que ya referimos y mostramos que los juglares y juglaresas tocaban instrumentos y también cantaban, por lo cual se sigue que la melodía con acompañamiento debe haber sido la configuración textural más habitual en las canciones y danzas instrumentales. Sería una verdadera excentricidad que una actuación al aire libre, con las necesidades sonoras para sobreponerse al ruido circundante (incluso en la silenciosa campiña medieval) prescindiera de los instrumentos y propusiera una cantilena a capella y monofónica, del mismo modo que sería un sinsentido excluir los instrumentos de percusión cuando existe un correlato tan estrecho entre música y danza, sumado al componente popular de exacerbación de lo corporal y lo sexual. Incluso si se especulase con una duplicación de la melodía vocal por los instrumentos, hipótesis relativamente frecuente, todavía sería una compresión considerar al resultado una "monodia": este concepto es exactamente todo lo contrario al de "discrepancias participatorias", ya que es imposible abstraer el sentido de estas músicas en una serie de alturas fijas por fuera de la performance, que introduce a propósito los desvíos referidos vinculados precisamente a la afinación, el tempo y la textura. Cualquier estudiante inicial de instrumentación sabe que debe evitarse la duplicación de una melodía por menos de tres instrumentos, justamente porque se hace muy difícil a los instrumentistas ocultar estas discrepancias, que en la música culta son un problema, un ruido en el sentido musical ¿Por qué razón entonces los músicos populares medievales habrían violado esta regla de oro si su concepción de la música hubiese sido "monódica"? La musicología rechaza todos estos argumentos y establece una riña con el sentido común más corriente, en pos de custodiar el sitial de la notación musical, única pauta -y cuán parcial e incompleta- que le permite sostener que la música medieval es monofónica. Se recurrirá entonces a la estigmatización de los juglares para sortear estas contradicciones: «lncultos por lo general y ni poetas ni compositores, los juglares eran cantores de canciones de otros 
hombres» (Hoppin, 2000, p. 280). Se pretende con suficiencia señalar que el juglar no sabe de composición ni de instrumentación. No le podemos pedir al bárbaro que utilice correctamente los recursos del civilizado. Mucho menos podremos imaginar que posea ideas propias en función de una propuesta musical alternativa que, casualmente, pone en crisis la concepción hegemónica sobre la música.

En este ejemplo podemos ver con mucha claridad lo que implica la utilización de la idea de musicar: considerar el hecho musical desde la perfomance y ya no desde la estructura modifica diametralmente el sentido que emerge del análisis, haciendo que aquello que es central para una concepción objetual de la música -fundamentalmente las relaciones de alturas- sea accesorio y lo que suele considerarse un problema -las discrepancias- pasen a configurar el centro de interés. Esto implica abandonar la idea de objeto u obra musical: un cambio radical de sentido. Por eso, a los fines del análisis, deberemos recurrir a la propia performance, a grabaciones o incluso recreaciones como la del film de Bergman. Aún a sabiendas de que son versiones "contemporáneas" y no piezas arqueológicas. La referencia documental, la partitura si es que existe, es en el mejor de los casos un auxiliar secundario. Y no sólo porque debemos hacer una crítica de fuentes, señalado el hecho que por regla general siempre la música popular será transcripta por músicos de la cultura oficial, con todos los sesgos que eso implica; es el propio sistema notacional, como heredero de la filosofía musical guidoniana, el que está sesgado para ofrecernos un registro de la estructura relacional de alturas, descartando absolutamente todo indicio sobre los rasgos texturales, sonoros y rítmicos derivados del musicar y las discrepancias de la performance. Es necesario recordar que el sistema de notación occidental fue creado específicamente para neutralizar estas discrepancias, cuando los carolingios consideraron que la consolidación de su poder político descansaba en la unificación de la liturgia en todo el territorio imperial, para lo cual era vital que la música del rito eclesiástico fuese exactamente la misma en cada iglesia y parroquia europeas (Treitler, 1991; Taruskin, 2005a). Esta es una huella que se mantiene y profundiza en la industria de la interpretación musical culta de la modernidad, especialmente a partir de la consolidación del mercado burgués de la representación (Attali, 2011, p. 116) y el modelo de la autoridad del compositor, que se materializa precisamente por medio de las instrucciones de la partitura (Cook, 2001, p. 40).

En el orden de su discurrir temporal la canción de los juglares del film de Bergman es estrófica, tal cual lo que vimos para los himnos medievales, lo cual refuerza el criterio de considerarlos a ambos como emergentes del mundo popular subalterno. Son las diferencias en el texto de cada estrofa lo que lleva a que aparezcan las fluctuaciones de velocidad y que hacen tan interesante la performance, que añade a la letra onomatopeyas con el sonido de animales. El texto de la canción es una especie de conjuro contra la muerte, que es uno de los personajes centrales de la película. Pero a diferencia de lo que elaboran la cultura cortesana o eclesiástica en torno al tema, el recurso de la canción parece salir textualmente de la descripción de Bajtín sobre la cultura popular medieval: es una inversión carnavalesca del mundo, en el cual todo el orden que podríamos considerar natural -o en la época divinoes puesto de cabeza. Es por ello la inclusión de los animales, de modo tal que «El caballo se sienta en el árbol y cacarea», "La gallina maúlla» o "La serpiente revolotea en las alturas». Pero también, siguiendo la misma actitud poética, cuyo objetivo es tensionar de forma contenciosa (Cusicanqui, 2014, p. 70) el orden social y la propia "realidad", los personajes clave del mundo popular medieval también aparecen en actitudes invertidas, como «la Virgen que está pálida» o todavía más, e incorporando las groserías del "lenguaje familiar de la plaza pública" (Bajtín, 2005, p. 21), la ridiculización de la muerte misma: «El negro se tira un pedo en la playa», reintroduciendo el tema del cuerpo grotesco.

El mundo carnavalesco es un universo de litigiosidad, de oposición entre el mundo cotidiano, el de la vida oficial y administrado por la cultura hegemónica, frente al mundo al 
revés, en el que la inversión puede ser física, de las relaciones sociales e interpersonales, o de los roles de género, las jerarquías, e incluso el orden natural o lógico del mundo (Burke, 2014 , p. 271). Este sentido del carnaval se abre a un rico universo de imágenes que pueblan ese segundo mundo invertido, también llamado tierra de Cucaña, Die verkehrte Welt, le monde renversé, il mondo alia rovescia: las personas caminando de cabeza, los jinetes que cabalgan hacia atrás, los tontos enseñando a los sabios, los sirvientes ejerciendo el poder, los mendigos dando limosna, los peces volando, la luna rodando sobre la tierra, el buey faenando a un hombre, campesinos imitando a reyes, artesanos vestidos de obispos, entre muchos otros (Muir, 2001, p. 106). Las canciones, los textos, los sonidos de los instrumentos, junto a muchos otros elementos producen el lenguaje musical, teatral y dancístico de los juglares, que se organiza en torno a estas imágenes de la inversión, el mundo al revés.

Se puede decir (con ciertas reservas, por supuesto) que el hombre medieval vivía dos vidas: una era oficial, monolíticamente seria y sombría, subordinada a un estricto orden jerárquico, llena de miedo, dogmatismo, veneración y piedad, y otra era la de plaza carnavalesca, una vida libre, plena de risa ambivalente, de sacrilegios, de profanaciones de todo lo sagrado, de rebajamientos y obscenidades que provienen del contacto familiar con todo y con todos. $Y$ ambas vidas eran legítimas, pero separadas por estrictos límites temporales." (Bajtín, 2003, p. 189)

Tal vez la más importante de estas oposiciones y profanaciones que introduce el sentido carnavalesco de la cultura popular sea la eliminación de toda distancia entre las personas (Bajtín, 2003, p. 179), lo que da lugar a una categoría carnavalesca de las relaciones que promueve el contacto libre y familiar entre las personas. La máscara, la posible participación indiscriminada y anónima de todos y todas, independientemente de su condición, sin requisitos ni privilegios, aunque también sin garantías, se opone diametralmente al pathos de la distancia, al ritual oficial, generado específicamente, como ya vimos, para marcar y afirmar las diferencias.

Este sentido político de la cultura de la inversión de la plaza pública lo recupera Jesús Martín-Barbero (2002, p. 52) cuando en sus lecturas de Gramsci entiende que la concepción carnavalesca del mundo constituye, en su sentido más fuerte, una contraposición a las concepciones oficiales de los sectores cultos. Es un enfrentamiento cuya profundidad se expresa en la metáfora del carnaval y la cuaresma. El motivo de la inversión no es caprichoso ni casual, ya que si los sectores populares luchan por entrar en la historia, es precisamente "para invertir el orden que las mantiene subalternas» (De Martino, 2008, p. 86). Esto hace que la cultura popular sea específica de la plaza pública, en el sentido de que es universal, es decir, que todos deben participar. Es un espacio abierto, en el que no hay barreras para ingresar -aunque tal vez no haya garantías de cómo salir. Lo cual genera, además de una igualdad social entre los participantes, una horizontalidad en términos artísticos, ya que el lenguaje del carnaval y la fiesta popular no distingue escenarios ni concibe un público ausente de participación, afuera de la música (Small, 1989). La plaza además es ambivalente, ambigua, biplana (Bajtín, 2003, p. 187) como nos enseña también la secuencia fílmica de Bergman, ya que vemos una escena completamente diferente de un lado y del otro del carromato: delante los juglares actuando, y detrás el otro juglar, el ofendido, que se entrega a una relación de la mayor familiaridad con la esposa del herrero. La plaza, además, es el espacio en donde las personas vivían su vida comunitaria (Muir, 2001, p. 96), celebrando acuerdos, haciendo amigos y enemigos, discutiendo, flirteando. Es importante considerar aquí que la plaza del carnaval no conoce el escenario en un sentido representacional, dramático del término. No son propias de su ritual las candilejas del teatro. $Y$ aquí aparece también un rasgo propio del juglar, ya que no es artista teatral, figura prominente o celebridad. Los juglares no son actores sobre el escenario, sino que asumían la vida de juglar en todas las circunstancias de su vida. Ser 
juglar o juglaresa es una condición, no la representación de un papel. «Encarnaban una forma especial de la vida, a la vez real e ideal [...] en la frontera entre la vida y el arte (en una esfera intermedia)» (Bajtín, 2005, p. 13). Por lo tanto, representan una figura también ambigua en cuanto a su condición social: son profesionales, y por tal razón detentan un saber específico por el cual consiguen remuneración pero, al mismo tiempo, pertenecen a una de las formas más comunitarias de producción cultural, como es el carnaval. En tanto fenómeno sonoro de la plaza pública, la música popular de los juglares, por su aspecto colectivo, de ocasión y fenómeno social, encarna también el simbolismo del cuerpo grotesco; y al hacerlo converge en ese proceso mediante el cual se diluyen las fronteras del cuerpo y la corporeidad de cada persona abandona lo individual para fundirse en lo comunitario. Lo cual reenvía la música popular a la idea bajtiniana según la cual el carnaval no se observa, sino que se vive, complejizando y densificando la condición del músico profesional. Como la diferenciación y regulación de los cuerpos, tan cara a la modernidad y al capitalismo, no tiene aquí ningún lugar, el estatuto musicológico del profesional como personalidad apartada del colectivo pierde todo sentido. Lo cual nos empuja a reconfigurar la categoría misma del músico profesional.

En esta clave de lectura podemos interpretar todos los elementos que habitan la canción y la performance de los juglares (presencia de lo corporal grotesco y sexual, las discrepancias participatorias, los ordenamientos sonoros del ruido, la organización en función del "mundo al revés") como rasgos de ese segundo mundo y esa segunda vida (Bajtín, 2005, p. 11) de la que participan los hombres y mujeres del pueblo medieval, quizás con mayor frecuencia de lo que participan del mundo oficial y hegemónico. Es una cultura plebeya que sirve a los intereses del propio pueblo (Thompson, 2000, p. 25) que, aún fragmentaria y heteróclita, es articulada mediante estos sentidos que promueven una concepción popular del mundo. $Y$ dentro de este mundo popular subalterno el músico popular precapitalista posee un rol protagónico al generar mediante el sonido esa tensión frente a la visión consensual del mundo, incorporando al ruido, es decir al timbre y la materialidad sonora, como proceso social subversivo.

como imagen invertida de [la] canalización política, subterránea y hostigada, una música subversiva se ha mantenido siempre; una música popular, instrumento de culto extático, superación de la violencia no censurada [...] La música es el lugar de la subversión, trascendencia del cuerpo. En ruptura con las religiones y los poderes oficiales, esos ritos reagrupan [...] a los marginados: mujeres, esclavos emigrados. [...] Actividad de masas por excelencia, la música es, con la locura, a la vez amenazante y fuente necesaria de legitimidad (Attali, 2011, p. 26)

\subsubsection{Una música de incultos, para los locos y los tontos}

Numerosas son las fiestas en las que habita muy especialmente el sentido carnavalesco de la cultura, pertenezcan o no al calendario específico del carnaval. Son fiestas en las que aparecen y se reproducen las funciones y características del carnaval (Burke, 2014. p. 275) y en las cuales florece el realismo grotesco del mundo al revés. De tal suerte que podemos hablar de lo carnavalesco (Fiske, 2009, p. 82), o las carnavaladas (Muir, 2001, p. 111), e incluso pensar la transposición del carnaval a toda la música popular en términos de carnivalización (Bajtín, 2003, p. 179). Una de estas fiestas que podemos considerar aquí es la Fiesta de los Tontos, o de los Locos, o de los Bobos. Que también se confunde en algunas regiones con la Fiesta del Asno. Esta ambigüedad de la denominación (asinaria festa, festum stultorum, festum follorum, festum baculi, Fête de l'âne) es justamente un indicio de la carnivalización. Se trata de una celebración que se daba en un periodo de mucha intensidad carnavalesca, como es el tiempo entre la Navidad y el Carnaval propiamente dicho, y que en el calendario cristiano se hacía coincidir con el día de los Santos Inocentes, aunque podía fluctuar acercándose al Año Nuevo o incluso prolongarse 
hasta pasada la fiesta de Epifanía, de acuerdo con variantes regionales que también incluían la celebración de la huida a Egipto de la Sagrada Familia o la investidura del "obispillo" o del niño obispo. En todos estos casos, lo que aparece como fundamento es un sincretismo (Caro Baroja, 1984)119, es decir un mestizaje basado en la recuperación y el reciclaje (Laplantine y Nouss, 2007), que reúne varias tradiciones que confluyen en el mundo popular medieval. Por un lado, estas fiestas son reliquias de los rituales en torno a los ciclos de renovación y renacimiento presentes en culturas muy antiguas (Clemencic, 1980, p, 9; Pickett, 1992, p. 8). Pero también la Fiesta de los Tontos organiza un "mundo al revés", una inversión de los valores sociales, que tienen como antecedente festivales paganos como las Saturnales (Hayward, 1988, p. 5) y las Kalendas de enero de la Roma antigua, ya que esta última plantea el simbolismo en torno al Cervulus, un dios con cuernos, que podría haber derivado en el asno. Aunque también se vincula la figura del asno con el culto a la diosa Epona (o Hipona) por parte de los celtas, sobre todo en Galia, y cuya fecha en diciembre coincide también con la Saturnalia y el día de Inocentes. Habría que considerar estas fiestas penetradas también por la influencia oriental (Bajtín, 2005, pp. 72-73). Por su parte el cristianismo, siempre presto a resignificar los cultos y el ornato antiguo, justificaron la presencia del asno con la imagen de la llegada a Belén, el pesebre y la huida a Egipto. Aunque habría que considerar todo un ejemplo espectacular de mundo al revés la misma cuestión del nacimiento del hijo de Dios en un pesebre (Burke, 2014, p. 276). En cualquier caso «la respuesta parece residir en una mixtura de las tradiciones celtas, romanas y cristianas, ya que el asno es simultáneamente una reliquia de antiguos cultos mágicos, un símbolo de fertilidad o de fuerza, y el epítome de la estupidez»120 (Pickett, 1992, p. 9). En la Saturnalia, fiesta que paulatinamente se extendió hasta el 25 de diciembre y terminó confluyendo con el Año Nuevo, la inversión se concretaba en que los esclavos adoptaban poses de señores y se hacían servir por éstos (Petzoldt, 1993, p. 157). Esta similitud con el sentido del carnaval y las carnavaladas hizo pensar a James Frazer que el vínculo de las saturnales con la Fiesta de los Tontos era directamente una relación de identidad (1922). Y es que efectivamente existía, durante la fiesta, una eliminación de la diferenciación social entre esclavos y libres y los primeros, coronados reyes de una república burlesca, podían pedir a sus amos las cosas más obscenas, ridículas y grotescas (Bringmann, 1993, p. 73). Existía además ya una recuperación y reciclaje por parte de la cultura urbana de Roma de tradiciones campesinas, vinculadas a la época de descanso de las tareas rurales, por lo cual las Saturnales eran experimentadas como un retorno efectivo y completo (aunque provisorio) al país de la edad de oro (Bajtín, 2005, p. 13). Como la fiesta era en realidad una conmemoración del reinado de Saturno, el dios de la semilla sembrada y de la germinante, época de abundancia y paz, esto favoreció sin dudas el sincretismo con el culto a lo arbóreo presente en otras tradiciones antiguas de Europa (Frazer, 1922, p. 1664). Y a esto hay que agregar la difusión por toda Europa de la fiesta por parte de las tropas romanas y de los comerciantes (Petzoldt, 1993, p. 157), quienes celebraban la Saturnalia incluso en las fronteras (Frazer, 1922, 1658). Nos demoramos en todo este asunto del sincretismo de las fiestas populares medievales ya que nos permite observar el grado de mestizamiento y difusión de la cultura popular en toda la Europa

119 Es muy interesante la crítica que hace Julio Caro Baroja a lo que, como veremos, será el fundamento de la doctrina burguesa del folklore, basada en el concepto de "supervivencias", que no es otra cosa que una faceta complementaria de la obsesión con los orígenes del positivismo. Es lo opuesto a una concepción mestiza de la cultura: "hablar de "supervivencias" y no de fenómenos de sincretismo, de fusión, de transformación o de cambios, de significación en el orden temporal, no referirse a expresiones colectivas o individuales de deseos, emociones y pasiones en otro orden, para buscar la raíz de todo en un "culto prehistórico" en una "cultura" antiquísima reconstruida y caracterizada con arreglo a lo que uno cree la mayor expresión de primitivismo, es darle al hombre menos capacidades que las que en realidad tiene y erigirse en "calificador", si no del Santo Oficio, sí del Santo Progreso» (Caro Baroja, 1984, p. 21).

120 «The answer is more likely to lie in a mixture of Celtic, Roman and Christian traditions, for the ass is at once a relic of ancient magical cults, a fertility symbol, a symbol of strength and the epitome of stupidity» (Pickett, 1992, p. 9) [Traducción del autor] 
medieval (difusión que es paralela a lo que como vimos antes sucedía en el plano sonoro con los instrumentos musicales) y la aparta del concepto de "regional" o "local" que le asigna, retrospectivamente, el folklore en la modernidad. Lo cual no hace más que expresar el carácter burgués y hegemónico de este último.

Todas estas fiestas que confluyen en el corazón de la cultura popular o de la risa en la Edad Media, presentan como característica común la idea de inversión, fundamento de la ambigüedad carnavalesca. "La idea central de la fiesta era la inversión del estatus y la ejecución por parte del clero inferior de funciones normalmente llevadas a cabo por sus superiores» ${ }^{121}$ (Pickett, 1992, p. 8), y en todas sus versiones se instala como cúspide de la autoridad a un representante de los marginados y expulsados de la sociedad: los niños, los jóvenes, los discapacitados, los locos o las mujeres. A todos estos colectivos se los emparenta con los animales y sobre todo con los más carnavalescos, como el cerdo o el asno. Todos ellos son representaciones de lo más humilde $\mathrm{y}$, simultáneamente, de la inocencia, sobre todo frente a los poderosos (Caro Baroja, 1984, p. 314). También, con los bobos o tontos se asocia el país de la Cucaña o Jauja, también conocido como «país de los necios» (Burke, 2014, p. 272), es decir, la tierra del Arcipreste Juan, símbolo de la abundancia también por inversión, ya que en este extraño territorio celebrado por el pueblo los arroyos son de leche, los árboles dan tartas y los cerdos corren ya cocidos y con un cuchillo a la espera de que los coma hasta el más desprevenido. De los marginales, lo más bajo de la sociedad, provienen entonces quiénes estarán a cargo, durante la fiesta, de establecer la doxa, de impartir la autoridad también en los rituales. En todas esas fiestas, que utilizan el disfraz, la máscara y la sátira, muestran específicamente los elementos característicos del cambio de funciones, el "mundo al revés" (Petzoldt, 1993, p. 158). Aquí la figura del juglar está en el centro de la fiesta, de ahí sus atributos de rey de los tontos, que es también el rey del carnaval (Muir, 2001, p. 97) y la necesidad de un cetro juglaresco de vejiga, parodia del poder oficial. Precisamente el juglar es llamado también "bobo" en inglés o francés, dando lugar a la denominación de esta fiesta como Feast of Fools o Fête des Fous. De esta manera podemos pensar al juglar como representante o figura emblemática, incluso alegórica, de aquellos más subalternos dentro del mundo popular subalterno, que mediante la inversión carnavalesca pasan a formar parte de de un poder festivo basado en la ambigüedad, el grotesco y la risa, mientras dura la fiesta.

En el caso particular de la Fiesta de los Tontos, según cuentan algunas crónicas de finales del período medieval, el lenguaje festivo podía incluir las obscenidades más lascivas aún dentro del marco del clero, ya que la fiesta era fomentada y conducida sobre todo por los clérigos inferiores y menos instruidos. Aunque esto no debe llevarnos a creer que era una celebración exclusiva de los novicios ni de los religiosos en general. Como señala Julio Caro Baroja (1984, p. 308) la Fiesta de los Tontos o del obispillo introducía una tensión permanente en el seno de la sociedad en su conjunto y, por lo tanto, lejos de quedar restringida a un entremés eclesiástico, circulaba por las calles atravesando todos los sectores. Debemos comprender entonces que toda la comunidad participaba activamente en ella (Hayward, 1988, p. 9). En una de las descripciones que recupera Petzoldt (1993, p. 159) se nos cuenta que eran los mismos sacerdotes quienes elegían un «obispo de los bufones», a quién conducían en procesión hacia la Iglesia y coronaban en el trono episcopal. Luego comenzaba la misa cantada, en la cual los clérigos realizaban parodias satíricas de los cantos eclesiásticos usando máscaras grotescas y ridículas o pintándose la cara de negro. Además, durante la misa y sobre el altar, otros danzaban disfrazados de hombres salvajes o de mujeres, mientras continuaban las canciones procaces. También se comía en abundancia carne y fundamentalmente salchichas, todo en el altar, parodiando los

121 «The ruling idea of the Feast was the inversion of status and the performance by the inferior clergy of functions normally carried out by their betters» (Pickett, 1992, p. 8) [Traducción del autor] 
sacramentos, para cuyo ritual se utilizaba el incensario en el que quemaban trapos viejos, suelas de zapatos o excrementos humanos o animales. Por último, otro grupo de "celebrantes" se abocaba a los juegos de azar vinculados a las apuestas, como los dados o naipes.

Durante toda esta celebración invertida la música era constante, como en la misa oficial, y los cantos, que incluían también partes instrumentales, se recreaban con los mismos procedimientos de la música carnavalesca, a partir de la sátira y la deformación del ritual oficial mezclándolo -o mestizándolo- con las danzas y canciones populares presentes en otros contextos festivos. Analizaremos brevemente a continuación tres versiones de una de las canciones más emblemáticas de esta primera parte de la Fiesta de los Tontos, titulada Orientis Partibus, es decir, "partiendo del este" y se la conoce también como Canción del asno. El texto y el título hacen referencia, aunque lateralmente, al burro de la huida a Egipto, pero es solo una excusa. El tema central de esta fiesta no son el niño Jesús ni María, ni tampoco los pesares del pueblo oprimido obligado al exilio. Todo sirve de marco para caracterizar al protagonista de la fiesta, el burro, uno de los símbolos más antiguos y vivos de lo inferior material y corporal. A partir de este curioso patrono se desplegaba todo el repertorio de ruidos, torpezas, groserías y brutalidades asociadas con el animal. El ritual se trastoca entonces en una Misa del burro en la cual el sacerdote bendice rebuznando y los feligreses, en lugar de contestar amén, profieren a coro una profusión repetitiva de «hi ha!» (Bajtín, 2005, p. 75).
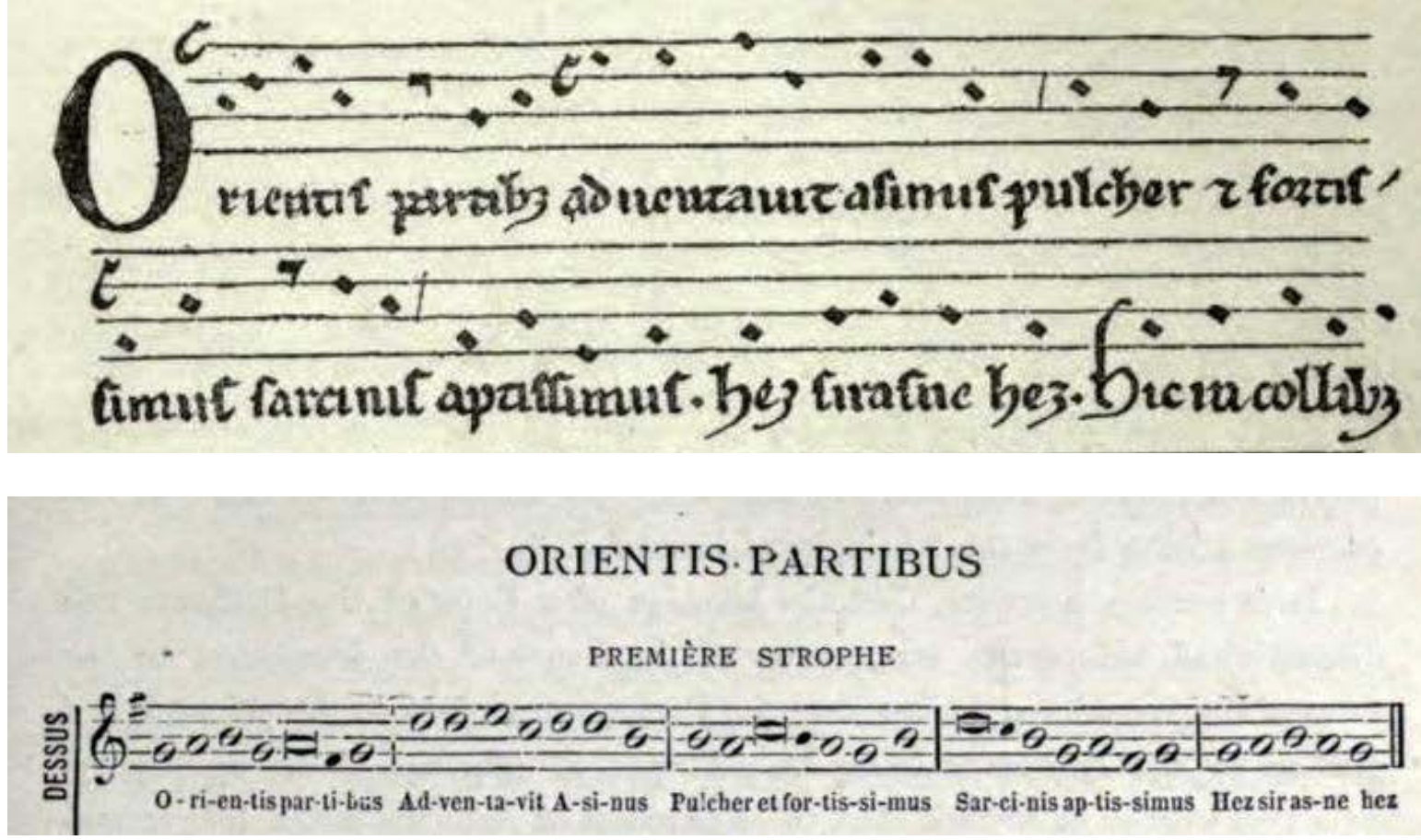

Arriba: Facsímil conteniendo la primera estrofa del registro de Orientis Partibus, o "prosa del asno", en el manuscrito de la biblioteca de Sens, fechado en el siglo XIII. Debajo: Transcripción moderna de la primera estrofa y estribillo.

Las versiones de Orientis Partibus que tomamos son de conjuntos especializados de amplia trayectoria y reconocimiento, provenientes de tres grabaciones clásicas de la Fiesta de los Tontos o del asno. En los tres casos, las principales fuentes utilizadas por los músicos actuales para recrear la música de estas ocasiones festivas proviene de registros ocasionales en manuscritos, comúnmente bastante tardíos, en los cuales se anotaba y describía este tipo de fiestas de larga trayectoria en el mundo popular. El objetivo de plasmarla con tanto detalle obedecía, en general, a la necesidad de pronunciarse a favor o 
en contra en el marco de la permanente polémica que este tipo de celebraciones generaba en el interior de la cultura oficial. Los manuscritos más consultados sobre la Fiesta de los Tontos son el misal "de los tontos" de Sens y el Officium Circumcisionis de Beauvais, ambos franceses y del compilados aparentemente entre los siglos XII y XIII (Pickett, 1992, p. 9; Hayward, 1988, p. 9). Los dos registros poseen apenas algunos datos sobre las alturas de la melodía de la canción, razón por la cual ya desde su concepción son muy incompletos, más allá de las limitaciones tecnológicas de la notación medieval. Por lo tanto debemos considerar que en las reconstrucciones musicales que vamos a considerar existe un alto grado de interpretación en el cual convergen otros saberes históricos, derivados del análisis de fuentes alternativas como la iconografía, las crónicas, tratados teóricos y científicos, documentos de prohibición y censura hacia la fiesta, etc. Queremos resaltar que en todos los casos que consideraremos existe un fuerte trabajo historiográfico por parte de los músicos, de gran profundidad y seriedad, independientemente de cómo evaluemos sus resultados. Es decir que, más allá de que la imaginación interpretativa habite en las reconstrucciones, las versiones parten de intentos serios por estudiar los modos de producción musical medievales.

La primera versión ${ }^{122}$ de la canción seleccionada es del conjunto Clemencic Consort, dirigido por René Clemencic, y forma parte del fonograma La Fete de l'Ane en la cual se propone una recreación sonora completa de la Fiesta de los Tontos, combinando elementos de las distintas festividades carnavalescas que mencionamos antes (Clemencic, 1980). Dentro del introito apócrifo de la misa de los tontos, aparece la mencionada canción del asno, como tercer número. Este conjunto decide comenzar con uno de los instrumentos juglarescos por antonomasia que describimos antes, la zanfona u organistrum, con lo cual lo ruidoso de la fiesta y de la figura del asno irrumpen desde el primer sonido. La primera estrofa está realizada por este instrumento, acompañado por unas sonajas que acentúan la pulsación, puesto que la canción está construida sobre un marco rítmico bastante ágil y danzable. Esta primera frase instrumental, en la cual se perciben numerosos golpes de rueda que añaden aspereza al sonido de la zanfona, continúa hasta una suerte de estribillo en el que lo que se busca es imitar los rebuznos. Los ruidos se multiplican al comienzo de la segunda estrofa cuando, simultáneamente con el inicio del canto por parte de una voz masculina solista, aparece otro instrumento profusamente ruidoso: la tromba marina, una especie de contrabajo antiguo con caja piramidal, en el que se buscaba excitar diferentes armónicos de la cuerda a partir de una acción de máxima presión del arco sobre la única cuerda. El resultado es una suerte de zumbido muy particular en el cual las componentes transitorias son mucho más relevantes que el sonido tonal, si es que éste llega incluso a percibirse. Podría pensarse que el arreglo amplifica la acción del "perro" o "mosca" de la zanfona, esa pieza añadida para que vibrase contra la tapa y produjera un zumbido. A partir de la repetición del estribillo ingresan más voces -son cuatro en total, una femenina- que se alternarán en las sucesivas estrofas, uniéndose en los estribillos y en la séptima y última estrofa, que a su vez modifica y extiende levemente el estribillo en el cual aumentan los efectos vocales que imitan las exclamaciones y rebuznes. En todo momento las voces se mueven priorizando la sonoridad satírica, con una emisión muy nasal que remite a los quejidos del burro, en una zona ambigua entre el canto y el recitado más teatral, de forma tal que las alturas quedan en todo momento muy desdibujadas, aunque se comprende la curva general de la melodía. Los efectos como los arrastres, portamentos y glissandi son de uso constante, lo que añade todavía más heterogeneidad entre las voces y dificulta concebirlas como armoniosas, fundamentalmente porque la afinación se resiente en todo momento en función de esta concepción más escénica o representativa del canto. Por lo demás, la base de los instrumentos permanece durante todas las estrofas, incrementando leve y gradualmente la intensidad hacia el estribillo final. En cuanto a lo rítmico, más allá de

122 El ejemplo 15 puede escucharse aquí https://youtu.be/3xLViswe62g?t=137 
lo mencionado anteriormente, en ningún momento la versión incorpora otros elementos sonoros que inviten al movimiento, motivo por el cual la percepción tiende a encontrar el pulso en la mitad del valor que se adivinaba al comienzo, agrupando las frases en torno a una periodicidad más amplia, en torno a una cifra de $d=63$ (en lugar de los 120 que pareciera ser el pulso "real" de la canción). En base a esto podríamos interpretar que existe una fuerte ambigüedad, muy carnavalesca, en el arreglo: por un lado percibimos el pulso y la configuración rítmica que nos impele a la danza $(d=120)$, pero al mismo tiempo se genera una temporalidad mucho más lenta, casi estática.

O tal vez, en virtud de la ocasión musical en que se enmarca la canción, debiéramos decir extática. Es importante comprender que el componente ritual presente en la Fiesta de los Tontos y la demás celebraciones carnavalescas es muy relevante y que, si bien está enmarcado en la cultura de la risa, se lo toma muy en serio: "esta risa es ambivalente: alegre y llena de alborozo, pero al mismo tiempo burlona y sarcástica, niega y afirma, amortaja y resucita a la vez» (Bajtín, 2005, p. 17), Fundamentalmente en virtud de que las ocasiones carnavalescas poseen herencias transculturales muy antiguas asociadas a los rituales de renovación y renacimiento, en los cuales se funden concepciones que provienen de las cultura celtas, germánicas y el imperio romano occidental. Lo cual va a ser a su tiempo asimilado y resignificado parcialmente dentro del calendario cristiano, de ahí la aparición del tiempo de carnaval, como parte de una conflictiva negociación cultural dentro de la Europa medieval. Todo esto nos vuelve a remitir al carácter ambiguo de la cultura popular en general, y de la música de estas fiestas carnavalescas en particular. Por estos motivos no deberíamos dejar de lado el componente de éxtasis o trance dentro de estas festividades, y la acción que se requiere de la música para provocar estados de enajenación. Es muy curioso que Berry Hayward (1988) cite el libro Music and trance de Gilbert Rouget, en donde se dice que los que participan de la Fiesta de los Tontos están poseídos en un tipo de trance, contrario a las formas cultivadas del ritual que reprueban la posesión (1985, p. 154), como el ceremonial cortesano o el ornato eclesiástico oficial. Pero también Ángel Quintero Rivera cita el mismo texto de Rouget ${ }^{123}$ para ubicar los temas del éxtasis y la posesión como una de las características específicas de las músicas afrodescendientes en América Latina (2009, p. 97) en donde liga además el carácter popular con la dimensión de la performance musical y la abolición del control racional sobre el sonido y sobre los cuerpos danzantes. Un descentramiento de la organización musical (Quintero Rivera, 2009, p. 82). Y todavía deberíamos reconocer algunos ecos de todo esto en cierta paradoja rítmica, ambigua entre lo dinámico y lo estático, muy característica de cierta música electrónica de baile, que llamamos trance. Una característica que Simon Reynolds (2010, p. 175) asocia con el carácter físico, sónico, localizado de la música y su necesaria asociación con los alucinógenos. Es muy significativo que en los tres casos, en la música popular medieval, la música popular afroamericana y la música trance, se suspendan las dualidades entre sujeto/naturaleza y cuerpo/mente -ambos inventos de la modernidad burguesa (Reynolds, 2010, p. 180; Quintero Rivera, 2009, p. 88), y que además el componente tímbrico y textural desplacen a la racionalidad armónica del centro de la organización musical (Quintero Rivera, 2009, p. 101; Reynolds, 2010, p. 179). Por supuesto que en todas estas músicas son igualmente extraños los conceptos de obra, compositor (como individuo) o autonomía estética, como también la necesidad de codificar la performance musical mediante un sistema teórico y notacional para obtener repeticiones de la misma a futuro. Frases como composición dialógica, muerte del autor, contra la interpretación o el colectivo manda y el individuo florea, atraviesen los textos de Reynolds y Quintero Rivera en un derrotero por momentos curiosamente paralelo. Podríamos pensar que existe un antecedente común entre ambas experiencias musicales. De hecho Quintero

123 Todavía más curioso es que a párrafo seguido Quintero Rivera cita a Bajtín, Burke, Muir y Thompson, entre otros autores que venimos referenciando en cuanto estudiosos de la cultura popular medieval. 
habla de «raíces compartidas» (2009, p. 72), aunque el aporte europeo se restringiría justamente a la organización armónica de las alturas proveniente de la música culta. Sin embargo tal vez sea demasiado aventurarse por ese territorio. Lo que sí podemos afirmar, más allá de los evidentes ecos que las músicas carnavalescas presentan en la música popular latinoamericana y afronorteamericana, es que todas ellas nos demuestran de forma contundente y sonora que la organización armonicocéntrica y dramática, con todos sus atributos y auxiliares formales, la concepción moderna de la obra y la idolatría por el compositor individual, son particularismos, excepcionalidades acotadas y reducidas a un repertorio muy específico. Una rareza o anomalía dentro de la marea general y extremadamente heterogénea de las músicas del mundo. Fundamentalmente en comparación con las músicas del mundo popular subalterno. En contraste con ellas, el paradigma musical de la modernidad no tiene nada de natural ni de universal, como la historiografía musical afirmativa nos incita a creer.

Pasemos a una segunda versión ${ }^{124}$ de nuestra canción Orientis Partibus, en este caso por el consort de Berry Hayward, para el fonograma La messe des fous (1988). En este caso se mantiene la configuración rítmica en base a un pulsar, que aquí es un poco más ágil, en torno a $d=140$. Pero, a diferencia del anterior, el arreglo no es sumativo sino que todos los instrumentos y las voces ingresan en simultáneo y con mayor intensidad, confiriéndole un carácter mucho más eufórico y ruidoso a la canción. Los instrumentos son diferentes al grupo anterior pero aparecen varios que son de uso frecuente entre los juglares y podemos apreciar en numerosas iluminaciones medievales, como el salterio y el rabel (cuyos antecedentes orientales ya comentamos), más flautas de pico e instrumentos de percusión variados. Uno de los aspectos particulares de la versión lo presenta también el ritmo, en especial en el cierre de los estribillos, donde aparece una alternancia rítmica parecida a una hemiola, aunque con un alto grado de síncopa. De hecho se configura una especie de compás aditivo, aunque no consideramos pertinente en este caso asociar esta particularidad con un dato cultural exótico. En todo caso deberíamos considerarlo una expresión más de la inversión, del mundo al revés y la alegoría a la locura, lo irracional, un pulsar que se escapa del tiempo organizado. El propio Hayward da pistas sobre este carácter presente en su interpretación, mencionando incluso los estudios sobre la locura de Foucault como marco conceptual (Hayward, 1988, p. 9)

En todo caso, estos recursos derivan en un incremento general del frenesí y la intensidad de la canción, que también se da mediante la instrumentación. Lo cual es coherente con el añadido que estos intérpretes hacen en el fonograma de una sección (pista 19) que aparece rotulada como charivari, y que no es otra cosa que una cencerrada, otra variante de lo carnavalesco. Junto a otros formatos equivalentes (rough-music en Inglaterra, charivari en Francia, Katzenmusik o Haberfeld-treiben en Alemania, Ketelmusick en Holanda, scampanate en Italia, etc.) la cencerrada era una forma ritual de justicia popular (Petzoldt, 1993 , p. 152) en donde la música tenía un rol central, configurando una suerte de antiserenata o serenata paródica o fingida (Burke, 2014, p. 283). De hecho en la versión italiana, las cencerradas se emparentaban con la mattinata, la serenata que los enamorados ofrecían a su amada ${ }^{125}$, pero transformándose en una parodia, las cantilene, canciones pobladas de doble sentido y palabras obscenas. Nuevamente se presenta ante nosotros la ambigüedad de las formas de la música popular medieval: «la mattinata honraba a una joven hermosa y a su familia, pero otras veces esta misma forma ritual daba lugar a una cantilena abusiva que ponía en un aprieto y avergonzaba a toda la familia, llevando hasta los tribunales casos y represalias violentos» (Muir, 2001, p. 122). En otros casos

124 El ejemplo 16 puede escucharse aquí https://youtu.be/sxoMjR-gFcg?t=111

125 Por ejemplo la que vemos en la escena del balcón de Romeo y Julieta de Shakespeare 
poseía un ritual más elaborado, siempre sobre la base del lenguaje de la risa festiva de la plaza pública, convirtiéndose en un desfile carnavalesco o mejor, una antiprocesión "en el sentido en que jinetes, tambores, pancartas, portadores de faroles, efigies en carros, etc., se mofan, en una especie de antífona consciente, del ceremonial de las procesiones del Estado, de la ley [...] y de la Iglesia» (Thompson, 2000, p. 532). En cualquier caso el objetivo de esta costumbre popular era canalizar los ruidos de la violencia social, por medio de un simulacro en forma de sacrificio pagano, que es una manera de entender la Fiesta y «el cortejo de las máscaras de carnaval» (Attali, 2011, p. 39). Justamente otro de los nombres alternativos de la cencerrada es «tribunal de máscaras» (Petzoldt, 1993, p. 152). Es decir que, ante la conducta reprochable de ciertos miembros de la comunidad, y más allá de que la justicia oficial interviniera o no en el caso, el pueblo se convierte en tribunal y mediante el "ruido" grotesco realiza su propia concepción de la justicia

la cencerrada es un rito de juicio popular utilizado en aquellos casos que implican una aparente trasgresión de las normas de la comunidad en cuanto a comportamiento matrimonial o sexual. En su forma más simple supone la difamación pública de una pareja o un individuo por medio de canciones burlescas y ruidos provocados golpeando cacerolas y cazuelas [...] los bromistas formaban una procesión, a veces con disfraces o máscaras, y sometían a sus víctimas a un remojón, a una serenata humillante o a un desfile en el que le hacían participar montado del revés en un burro. El ambiente era, generalmente, carnavalesco, con muchas risas y parodias burdas $y$, si todo se atenía al guion ritual típico, la cencerrada terminaba con un pago que hacía la víctima, una ronda de copas y una noche de jarana. Si el ritual tomaba un rumbo diferente, podía terminar en disputas, en peleas a puñetazos e incluso en asesinato (Muir, 2001, p. 119).

Esta descripción es muy congruente con la segunda parte de la Fiesta de los Tontos, lo que hace probable que en la interpretación de Hayward aparezca la cencerrada. Es el momento más colectivo del festejo, en el cual el ritual se abre a la participación de toda la comunidad, los que producen nuevas "extravagancias e impiedades" junto a todo tipo de "insensateces y excesos", como comentan las crónicas medievales más escandalizadas. Terminada la misa sarcástica y luego de danzar frenéticamente al son de una música sonora y rítmica en el altar y por los pasillos de la iglesia, toda la comunidad, hombres y mujeres, sacerdotes y novicios, salían corriendo por las calles, muchos de ellos completamente desnudos, otros enmascarados. Algunos se subían a carromatos cargados de basura que arrojaban sobre la gente, que a su vez les contestaba con más residuos y excrementos, en una sátira de guerra, verdadera encarnación de lo grotesco. Y aquí viene lo que más nos puede interesar:

De trecho en trecho se detenían ante escenarios erigidos especialmente para exhibir sus extravagancias y comenzaban a representar de nuevo sus bufonadas delante de la multitud. Las personas más licenciosamente mundanas se mezclaban con el clero y disfrazadas de monjes o monjas hacían gestos obscenos y adoptaban todas las posturas del placer más lascivo. En estas circunstancias se cantaban continuamente canciones groseras e impías (citado en Petzoldt, 1993, p. 159)

Como vemos, tanto en la cencerrada como en la Fiesta de los Tontos la presencia de canciones y danzas es central, ya que el sentido ritual del ruido y de su organización en música es profundamente simbólico de la violencia y la protesta que se pretende canalizar. Los ruidos son exigencias de autonomía cultural, reivindicaciones de diferencias o de marginalidad (Attali, 2011, p. 17). No es casual que la versión de la cencerrada de Hayward contenga como único texto, antes de la cacofonía sonora, la frase exaudi populum, es decir, «escucha (o escuchen) al pueblo», frase recurrente además en los repertorios de canciones 
de los peregrinos de Santiago y de Montserrat ${ }^{126}$ que discutimos en la sección anterior. Este ruido satírico siempre está presente formando parte de una expresión ritualizada de hostilidad, aunque atenuada (Thompson, 2000, p. 522), sublimado en la música popular que de la ocasión emerge.

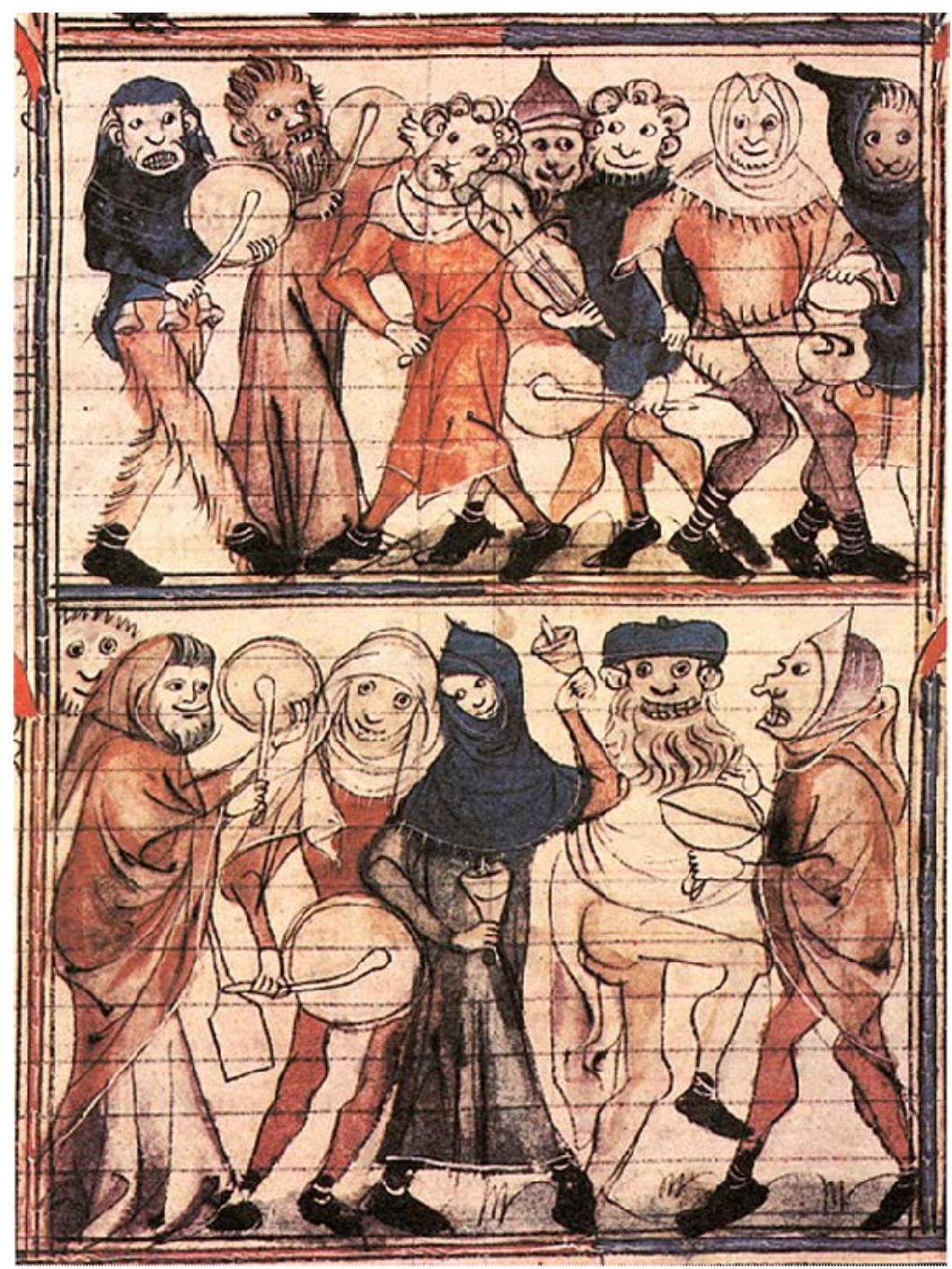

Ilustración de una cencerrada, con profusión de instrumentos musicales, en uno de los manuscritos del Roman de Fauvel (BN fr. 146), verdadero poema carnavalesco del siglo XIV en el cual la fortuna corona como rey a un burro, cuyo nombre es Fauvel.

Y es allí que debemos buscar la figura de juglares y juglaresas, en este aspecto sonoro, mediante el manejo hábil de los instrumentos, el conocimiento de las canciones y los procedimientos para recrearlas y adaptarlas a la ocasión. Pero también a partir de que uno de los elementos fundamentales del lenguaje carnavalesco, de la cencerrada y de la Fiesta de los Tontos es su carácter presentacional, nunca de objeto u obra. Habitan ineludiblemente en la performance, eso que Bajtín llama «diversas formas y rituales del espectáculo» (2003, p. 10) y Thompson identifica como «formas dramáticas [...] especie de teatro callejero» (2000, p. 531). Por lo tanto siempre veremos aparecer en las descripciones

126 Un ejemplo muy conocido donde aparece esta frase es la canción Stella Splendens, presente en el manuscrito del Llibre Vermell de Montserrat, santuario mariano de Cataluña de intensa peregrinación medieval. En el texto de la canción se equiparan, mediante su idéntica situación en la peregrinación y la búsqueda del perdón, a "príncipes y magnates", "prelados y barones", "campesinos, labradores" y "abogados y escultores". Como en el carnaval, la peregrinación suspende todas las diferencias. Una razón más para reconocer la pertenencia de los himnos peregrinos en el universo del mundo popular subalterno. 
la referencia a los músicos y actores profesionales, aunque por regla general no se los identifique ni sepamos sus nombres. El carnaval y lo carnavalesco son populares y universales, en la medida en que todos deben participar, y en tanto fiestas o rituales no se perciben como obras de arte, sino que se viven (Bajtín, 2003, p. 187). Pues bien, tal vez el personaje vital por excelencia de lo carnavalesco sea el juglar, ya que «él es la música y el espectáculo del cuerpo. Él la crea, la porta y organiza, él solo, toda su circulación» (Attali, 2011, p. 26). Por eso se puede decir que «no existe clown sin público, sin escena, sin espectáculo» (Laplantine y Nouss, 2007, p. 199), aunque es una escena popular, que «no conoce las candilejas del teatro» (Bajtín, 2003, p. 187), es decir, no forma parte de ese claustro que es el teatro moderno, que dividirá para siempre el espacio de los artistas (escenario, camarines) de las localidades destinadas a un público pasivo y transformado en espectador. La escena del carnaval es el propio cuerpo de los participantes, y en especial, el cuerpo del juglar, que presenta el sentido último del carnaval y lo carnavalesco. Su propia figura se caracteriza por la deformidad y la irregularidad. Como es un perfomer todo el tiempo se sale de la forma, la desborda. O mejor, «no guarda las formas», en todo el sentido moral pero también estético que la frase puede contener. Su disfraz tosco, con ropajes raídos y fuera de las dimensiones "normales", su andar estrambótico, sus ademanes excesivos. Todo es un atropello a la lógica y por lo tanto, a los conformismos. Esas aparentes payasadas lo que hacen en realidad es contrariar los usos y costumbres de la sociedad, ya que la propia torpeza de sus movimientos y conducta se regodea en señalar lo que está mal hecho. Como es ridículo, el juglar es quien está en mejor posición para ridiculizar al mundo y señalar con un gran dedo grotesco lo ridículo del ritual oficial. Pero al mismo tiempo que pone cuerpo al sentido grotesco y lo arroja en la cara de la visión oficial del mundo, es el personaje más infinitamente sensible de la comunidad. Por eso se relaciona con el mundo marginal de los tullidos, los locos y los tontos. Y también con los niños (Laplantine y Nouss, 2007, 199)

Una tercera versión ${ }^{127}$ de la canción Orientis Partibus la tomamos del fonograma The Feast of Fools del New London Consort dirigido por Philip Pickett (1992). En este caso el ritmo aparece mucho más vinculado con el movimiento y la danza, si bien tiene una cifra metronómica inferior al anterior (ca. $d=112$ ). Esto se debe quizás a que desde el comienzo y durante toda la canción aparece la división del pulso realizada por múltiples instrumentos de percusión que generan una célula rítmica muy pregnante con variedad tímbrica. Es interesante que la división muta de binaria, en las estrofas cantadas, a ternaria para las estrofas instrumentales, que se alternan durante toda la canción a partir de la segunda estrofa lo cual, más que a la hemiola del caso anterior, remite a las canciones configuradas a partir de alternancias entre fragmentos de canciones conocidas, transmitidas de forma oral. Casos muy habituales de esto son la ensalada española o el quodlibet, lo cual nos remite nuevamente al carácter dialógico de la creación musical, es decir, el recrear canciones ya conocidas de las cuales no se sabe ni interesa identificar al "autor", en una nueva versión de acuerdo a la ocasión musical. Recreación que puede alterar la melodía, el ritmo o el texto, o todo esto al mismo tiempo. Y sin dudas propone un nuevo formato de instrumentación y textura. Cuando las relaciones del capitalismo moderno conviertan a la música en objeto de cambio, estas canciones pasarán a considerarse anónimas pues, como ya dijimos, se volverá importante identificar la autoridad del autor. Pero como en estos casos es imposible establecer paralelismos entre las formas y la personalidad artística, el folklore transformará estas canciones en tradicionales y por lo tanto, voz de un pueblo que paulatinamente será pensado como masa, para el cual se inventa una tradición (Hobsbawm, 2015). En ese proceso histórico del pensar sobre la música los juglares, que en ese sentido representan el concepto opuesto al de compositor, no tienen ningún lugar y precisamente por esto, por esta suerte de nomadismo estético que se resiste al juego de la

127 El ejemplo 17 puede escucharse aquí https://youtu.be/n s-90TW Ds 
obra y el autor, su figura es silenciada hasta prácticamente desaparecer de la narrativa historiográfica de la música.

El coro es otro elemento a destacar de la versión de Pickett de Orientis Partibus, ya que ingresa por completo en el comienzo y se mantiene así en todas las estrofas cantadas/ binarias. En la concepción del sonido de las voces podemos percibir una cohesión tímbrica mucho mayor que en los casos anteriores. Aquí evidentemente se ha privilegiado un criterio tendiente a la homogeneidad, probablemente a partir de considerar la ligazón con las instituciones eclesiásticas de parte de los practicantes de la Fiesta de los Tontos medieval sobre todo de los que cantarían en la fiesta, los novicios y monjes. Esto tal vez haya hecho pensar aquí en una emisión vocal más vinculada con el canto cristiano oficial, dejando en manos de los instrumentos los aspectos discrepantes más ligados a una sonoridad festiva y popular. Esta hipótesis se refuerza por lo más significativo de esta versión, que es el ingreso a partir de la segunda estrofa -y continuando en todas las instrumentales y ternarias- del otro instrumento que comentamos en extenso anteriormente a propósito de su carácter ambiguo, grotesco y ruidoso: la gaita. Este es el instrumento que se destaca en las estrofas ternarias y les otorga una sonoridad mucho más llena, potente y rica en cuanto a lo espectral, que nos lleva a relacionarla muy fuertemente con la danza. De esta manera se revelan con mucha más claridad las decisiones interpretativas del cambio de división, jugando con una alternancia que potencia lo ambiguo de la fiesta: de un lado, una sonoridad más homogénea vinculada con los himnos cristianos, las procesiones, satirizando lo solemne; del otro, el frenesí de la danza, el ruido del movimiento.

Como podemos ver con la Fiesta de los Tontos, el carácter carnavalesco no se restringe en ningún caso a las fechas estrictas del carnaval. Pero incluso la carnivalización de la cultura está presente por fuera de la gran temporada carnavalesca que inicia en el tiempo del invierno del hemisferio norte. Mucho se ha discutido acerca del por qué de la existencia, o mejor de la permisibilidad hacia lo carnavalesco por parte de las autoridades y los sectores hegemónicos. ¿Puede entenderse al carnaval como espacio utópico o deberíamos considerarlo un dispositivo de control social? (Storey, 2002, p. 176). Una hipótesis bastante extendida considera al carnaval como una especie de válvula de seguridad dentro de la sociedad, una forma de atenuar las tensiones dentro de una sociedad muy injusta y jerarquizada. El carnaval sería un respiro, una pausa o interludio entretenido dentro de la continuidad de una vida de opresión, que cumple la función de liberar tensiones (Muir, 2001, p. 107). Pero no debemos menospreciar lo que la cultura carnavalesca representaba en términos de oportunidades de expresión. «Las fiestas, sobre todo el Carnaval, ofrecían la oportunidad de celebrar encuentros públicos y proporcionaban un vocabulario y una sintaxis rituales para comunicar ideas» (Muir, 2001, p. 100). En la fiesta se ganaba el derecho a tener voz, la posibilidad de decir en la cara de los poderosos aquello que se callaba el resto del tiempo. Costumbre que también provenía de la Saturnalia en donde se «daba vuelta la tortilla» y los esclavos podían decir a su señor las verdades incómodas (Bringmann, 1993, p. 73). Por lo tanto la fiesta es un derecho a la palabra, a la manifestación. Una oportunidad de criticar el orden dominante (Muir, 2001, p. 109) ya que «los rituales de la revuelta coexistían con un cuestionamiento profundo del orden social, político y religioso [...] Todas estas fiestas permitían que los campesinos fuesen a la ciudad y que todos juntos tomasen las calles» (Burke, 2014, p. 288). Como buena parte del sentido popular de la fiesta reside en la ambigüedad que comentamos antes, muchas veces es esquivo asignar un sentido unívoco de resistencia a los rituales de la cultura popular. Es más sencillo analizar e interpretar la actitud de las clases dominantes hacia lo carnavalesco, ya que los sectores hegemónicos siempre intentan, aún cuando son meros observadores, introducir al fenómeno de la fiesta en el orden (Burke, 2014, p. 271). Por el contrario, y esto es parte del sentido de resistencia de la cultura popular, 
la dimensión política de la resistencia popular solamente es legible en la experiencia cultural de clase en que se basa. Pues los modos de lucha de la plebe -el motín y la revuelta, las procesiones bufas, las canciones obscenas y las anónimas cartas blasfemas- inscriben su sentido en los antagonismos que dialectiza y expresa su cultura (Martín-Barbero, 2002, p. 51)

Por lo tanto son muchas las formas que puede adoptar la resistencia a la dominación, muchas de las cuales no son explícitamente confrontativas, desde un discurso proposicional y articulado. Por ser símbolos de lo subordinado, hechos por y para los subordinados, adquieren por su sola presencia un sentido de oposición frente a los valores promocionados por el bloque de poder (Fiske, 2009, p. 67). Por eso, como venimos ejemplificando, es en la performance, en lo presentacional donde hay que buscar estos sentidos.

Pero incluso si considerásemos a lo carnavalesco como un hiato, una especie de recreo, quedaría sin resolver otro problema: la presencia de la actitud de inversión, de la cultura de la risa y lo grotesco, en multitud de fiestas y celebraciones que se extendían prácticamente durante todo el año. Es decir que, si buscamos considerar un lapso del calendario anual como interrupción de lo común o cotidiano, deberíamos pensar en todo caso en la cuaresma antes que en el carnaval. $Y$ es que la profusión de celebraciones burlescas, satíricas o grotescas continuaba con renovado ímpetu una vez concluido el tiempo cuaresmal. Una primera manifestación de esto, muy significativa, lo constituía la costumbre de la risa pascual o risus paschalis, que consagraba las burlas y la risa al interior de la celebración eclesiástica de la resurrección, en la cual los sacerdotes se permitían todo tipo de licencias para despertar la risa de su feligresía. Las mismas podían incluir desde bromas obscenas y gestos considerados indecorosos, hasta la exhibición de los genitales y la masturbación pública en el púlpito (Jacobelli, 1991). Y por supuesto, la aparición de canciones populares que de otro modo estaban totalmente prohibidas en los altares. De modo tal que podríamos considerar que el carnaval y la risa pascual se transformaban en los límites de la cuaresma, que quedaba confinado como período excepcional, y no a la inversa.

En la Edad Media, en realidad, casi cualquier festividad tenía su aspecto de plaza carnavalesca (sobre todo fiestas como la del Corpus). [...] La atmósfera de carnaval dominaba en los días de feria, durante la vendimia, en las representaciones de los miracles, misterios, sauties, etc., todos los espectáculos teatrales del Medievo eran de carácter carnavalesco (Bajtín, 2003, p. 188)

Sobresalen dentro de estas celebraciones las fiestas del $1^{\circ}$ de mayo, o fiestas mayas. Su carácter está asociado con la adoración muy antigua de los elementos de la naturaleza y en general tienen un sentido de celebración del cambio estacional, del inicio de la temporada de cosecha y abundancia. Por eso participan del carácter carnavalesco, fundamentalmente por dos aspectos: lo relativo a los rituales de renovación y renacimiento, es decir, el culto a la fertilidad, con toda su carga sincrética y mestiza; y el vínculo con el cuerpo grotesco y sus significaciones en torno a la comida, la abundancia y el placer sexual (Burke, 2014, p. 277).

En general la fiesta de mayo consiste en la participación de toda la comunidad para la selección de lo que pasa a ser el símbolo del inicio de la estación de la prosperidad, de un nuevo ciclo de fertilidad, como es el árbol o palo de mayo. Uno de sus objetivos es el de atraer al espíritu fructificante de la vegetación (Frazer, 1922, p. 362). Además de tener connotaciones con los ritos de veneración de lo arbóreo, muy antiguos (Fraser, 1922) el árbol participa de la veneración religiosa de la fertilidad (Muir, 2001, p. 111) y por lo tanto, como está claro, es nuevamente un símbolo fálico como los que encontramos en numerosos objetos y disfraces de lo carnavalesco. Por lo común se trata de un olmo, un abeto u otro árbol muy largo que se corta en algún bosque cercano especialmente para la celebración y luego se traslada en procesión hasta el centro de la aldea, la iglesia parroquial, la plaza o la era donde se acarreaban las mieses (Baroja, 1984, p. 26). Existen 
numerosas crónicas en las cuales el carácter explícito de la relación grotesca con el árbol queda muy en evidencia, como la de un carnaval napolitano en que las mujeres fueron obligadas a que viesen un falo de madera «del tamaño de un caballo, que era transportado por las calles» (citado en Burke, 2014, p. 268). La comunidad entera aportaban el dinero para transportar y engalanar el árbol y en numerosas ocasiones se contrataba especialmente a los juglares para tocaran música acompañando la procesión del palo. (Muir, 2001, p. 112). Una vez emplazado el árbol, comenzaba una ceremonia, en la que no faltaban las canciones y las danzas, en la cual se erigía el árbol (Frazer subraya el término "erección") lo cual demandaba la participación de buena parte de la comunidad y el desarrollo de un sistema de sostén bastante sofisticado. El árbol era además despuntado casi en su totalidad, dejando solo en la punta algunas ramas. Además se le añadían cintas y emblemas que con el tiempo se realizan con los colores de la villa o pueblo. Los palos de mayo también se denominan "árboles de la cucaña», un evidente lazo con el carnaval (Burke, 2014, p. 278) que remitía al mentado país de la abundancia y la inversión. Incluso en algunas variantes de la fiesta se colocan salchichas, tartas y otros manjares en la punta del árbol -o en un anillo que se le adosa en la punta- y se practica un juego que consiste en intentar subir para quedarse con el botín (Frazer, 1922, p. 362).

De esta manera la fiesta adquiere un carácter de tipo totémico, que refuerza el sincretismo de tradiciones muy antiguas con las sucesivas culturas que van tomando forma en Europa occidental. «Esta idea de la abundancia, asociada con la prosperidad colectiva de la buena temporada, desempeñaba un papel principal en la cultura de la vida cotidiana compartida por todas las clases» (Muir, 2001, p. 98). Para Bajtín la esencia misma del carnaval y lo carnavalesco reside en este estado peculiar del mundo atravesado por la renovación y el renacer (2005, p. 13), razón por la cual los rituales son caracterizados como de coronación y destronamiento. En todos los rituales carnavalescos se corona a un rey que preside la inversión, que será ejecutado al final de la fiesta. Puede ser el rey de lo locos, el obispo niño, el mismísimo carnaval, o como en este caso, el árbol. Todos serán destronados al finalizar el tiempo de fiesta. Incluso en las Saturnales romanas y durante buena parte de la Edad Media, el rey de la inversión era realmente ejecutado (Petzoldt, 1993, p. 157). Del simulacro ritual de estos sacrificios proviene el ritual del entierro del carnaval, al final del martes graso, así como también la quema de los árboles o de muñecos que simbolizan diferentes rasgos de lo viejo o decadente (Frazer, 1922, p. 854). Por eso, en cualquier temporada y ocasión, la acción carnavalesca principal es la coronación burlesca y el subsiguiente destronamiento del símbolo que oficia como rey del carnaval (Bajtín, 2003, p. 181). Reside aquí una profundidad muy interesante que da un sentido vital a lo carnavalesco y resignifica la potencia de esta cultura de la risa y la bufonería. No hay nada de superficial en la cultura de la plaza pública, ya que es la vida lo que se está jugando en el ritual. La vida comunitaria, no sólo individual. La concepción estrecha del folklore no penetra generalmente en esta dimensión (Bajtín, 2005, p. 9), trastocando el sentido de la cultura popular, banalizándola u horrorizándose ante los sacrificios humanos sin poder despojarse del antifaz moderno y burgués. Frazer, en cambio, ensaya una interesantísima interpretación sobre estos sacrificios, muy interesantes en la medida en que recordemos su sentido en relación con la idea de la renovación de la vida

¿Por qué les matan? [...] La vida divina, encarnada en un cuerpo material y mortal, está sujeta a mancillarse y corromperse por la debilidad del frágil instrumento en el que está temporalmente enclaustrada; y si ha de salvarse del creciente debilitamiento del que debe participar en su encarnación humana según avanza en años, deberá ser separada antes de que la persona muestre signos de decadencia [...] La muerte del dios, esto es, de su encarnación humana, es, por esto, un paso necesario para su revivificación o resurrección en una forma mejor. Lejos de ser una extinción del espíritu divino, sólo es el comienzo de una manifestación más pura y vigorosa de él. Si esta explicación vale para la costumbre de matar a 
los reyes divinos y sacerdotes en general, es todavía más evidente su aplicación a la costumbre de matar anualmente al representante del espíritu del árbol (Frazer, 1922, p. 860)

Es decir que para prevenir que el espíritu -de la comunidad, de la naturaleza, de la vida, etc.- se haga viejo y se extinga, es necesario detener la corrupción que el tiempo produce en los cuerpos, para así transferir a un nuevo cuerpo, joven y vigoroso, la nueva encarnación del espíritu, que así se renueva, renace. La muerte es un medio para promover el nacimiento, el crecimiento y la abundancia. Es un espíritu fertilizador el que se hace renacer, y por lo tanto su poder se extiende a las mieses y el ganado, entre otras formas de abundancia económica, pero también a la fertilidad humana. De hecho muchos jóvenes plantaban un pequeño mayo en la puerta de la casa de su enamorado y también se utilizaba como símbolo en las bodas. Uno de los aspectos más comunes del ritual asociado a las fiestas de mayo será entonces favorecer el encuentro sexual entre los miembros de la comunidad, fomentado por el sentido de la fertilidad y la renovación. Los estudios más recientes de demografía histórica están comenzando a notar que en los meses de mayo y junio se producían más concepciones que en cualquier otra época del año. De ahí que durante la fiesta de mayo «muchas parejas jóvenes "se perdían" por la noche en los bosques para practicar un amor semiclandestino» (Muir, 2001, p. 112) o que se notara que «todos los jóvenes y muchachas, viejos y casados, corretean por la noche en los bosques, umbrías, lomas y montañas, donde pasan toda la velada en alegres pasatiempos» (Frazer, 1922, p. 360). Las crónicas hablan también, siempre con la voz de la indignación de la cultura hegemónica, de danzas frenéticas y licenciosas alrededor del árbol, en las que todos «bailan como paganos» y en las que evidentemente toda distinción y barrera social se disuelve o suspende. De aquí la relación con historias o costumbres muy arraigadas en la cultura popular, como la danza de la muerte, y anécdotas históricas como la "epidemia de baile" o coreomanía de Estrasburgo en 1518, según la cual casi todo el pueblo no podía parar de bailar frenéticamente hasta que terminaron muriendo de agotamiento. Más allá de que esto pueda ser o no un caso verídico de histeria colectiva, existe indudablemente una visión despectiva en torno a la danza popular y sus connotaciones sexuales, de tal suerte que podemos encontrar crónicas que dicen certificar que «de cuarenta, sesenta o un centenar de doncellas que van al bosque [en la noche de mayo], escasamente la tercera parte de ellas vuelven inmaculadas a sus casas» (citado en Frazer, 1922, p. 360).

Todos estos contenidos acerca de la fertilidad, la renovación y el contacto sexual entre los miembros de la comunidad, aparecen en una canción medieval muy conocida titulada $A$ l'entrada del tens clar, anotada -como registro- tardíamente en el siglo XIII, situación que no obsta para que exista bastante polémica en torno a poder fecharla con precisión y adscribirla a algún espacio social específico y sus significaciones. En principio, podemos citar dos teorías contrapuestas: por un lado se relaciona esta música con el arte itinerante de los juglares, transmitido oralmente y siempre en transformación dinámica, que en este caso estaría relacionado además con la supervivencia en los rituales y fiestas de mayo de creencias paganas precristianas. En ese contexto, las canciones y danzas de este tipo estarían vinculadas con la diversión, el baile y fundamentalmente con el amor. Aunque aquí hay que hacer una aclaración, ya que este tipo de amor difiere del que será el tema por excelencia de los trovadores, el fin amors o amor cortés, especie de amor platónico asexuado. Muy por el contrario, el amor de mayo, primaveral, promueve el contacto de los cuerpos y se demora en las connotaciones sexuales. Es un amor muy relacionado con esta idea dinámica de la naturaleza, de renacimiento y renovación, a quien se dedican las celebraciones sobre sus ciclos y fertilidad. Los temas de estas danzas «son siempre de carácter descriptivo e inspirados por temáticas populares [...] En esto difieren muy claramente con el repertorio cortesano, que es generalmente introspectivo y dedicado a los sentimientos» (Robert, 1999, p. 5). El texto de A l'entrada del tens clar presenta este contraste de forma explícita, a la vez que recupera muy claramente los temas de la fiesta de 
mayo y la renovación, además de lo carnavalesco asociado fundamentalmente al carácter sexual y la eliminación de la distancia social:

\begin{abstract}
A l'entrada del tens clar, eya per joia recomençar, eya e per jelos irritar, eya vol la regina mostrar qu' e' es si amorosa.
\end{abstract}

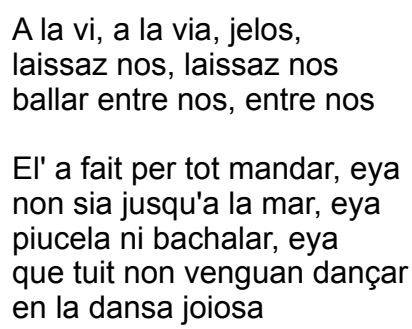

A la vi, a la via, jelos...

Lo reis i ven d'autra part, eya per la dansa destorbar, eya que el es en cremetar, eya que om no li vólh' emblar la regin' aurilhoza

A la vi, a la via, jelos...
Al inicio de la primavera - jeya! Para renovar nuestra alegría - jeya! Y para irritar a todos los maridos celosos - jeya! ¡Nuestra Reina desea mostrar que está Ilena de amor!

¿Váyanse, váyanse, todos los celosos!
Déjennos, sí déjennos
Bailar juntos, juntos

Ella ha proclamado por todos lados - jeya! Hasta el borde del mar - jeya! Que cada soltero y cada doncella - jeya! ¡Deben unirse y bailar con nosotros nuestro baile de alegría!

¡Váyanse, váyanse, todos los celosos!...

El Rey viene desde otro lugar - ¡eya! Para intentar arruinar nuestro baile - jeya! Porque está muy asustado - jeya!

¡De que alguien quiera arrebatarle su Reina de Abril!

¡Váyanse, váyanse, todos los celosos!...

La canción nos deja en claro que todas las muchachas y los solteros deben estar juntos en esta ocasión, pues lo dice la reina del amor, que es carnavalesca y aparece asociada con los atributos de la renovación y la risa (alegría). Por si esto fuera poco, el rey, la autoridad de la cultura oficial que está afuera y viene de lejos, no consigue censurar la fiesta, sino que debe desistir transformándose en objeto de burlas, como rey de los cornudos. El vínculo con el carácter de las fiestas de mayo y de la cultura de la risa es muy explícito y no arroja duda alguna sobre la condición fuertemente popular de la canción. Pero debemos mencionar que también hay otra teoría, que sostiene que en el ambiente trovadoresco, y específicamente en torno al género de la pastorella (al cual esta canción no pertenece) se desarrolla un movimiento de burla o parodia de los sectores populares (Taruskin, 2005a, p. 155), razón por la cual se copia parte del lenguaje, la música y las connotaciones propias de la cultura de los sectores populares. Es realmente muy difícil verificar esta hipótesis, y en base a las descripciones que citamos de las fiestas populares, es altamente inverosímil. Pero aunque aun así creyéramos que $A$ l'entrada del tens clar es una creación de los trovadores por imitación burlesca de la tradición popular, lo que deberíamos hacer es identificarla como parte de un proceso de estilización y apropiación operado por los sectores hegemónicos, que será recurrente en la historia: ocurre en el manierismo de finales del siglo XVI, en las danzas "para escuchar" de la Suite del siglo XVII, en los personajes cómicos de la ópera del siglo XVIII, en el folklore y el nacionalismo del siglo XIX (Hauser, 1974), etc.

En el próximo apartado reconstruiremos este camino hipotético de la estilización, observando varios pasos progresivos. Por el momento, tomaremos la canción vinculada con la fiesta de mayo como manifestación de la cultura popular y el carácter carnavalesco, asociado más con lo que escuchamos de la Fiesta de los Tontos que con el arte trovadoresco. A l'entrada del tens clar será nuestro punto de partida para luego considerar las modificaciones que la estilización producirá históricamente. 


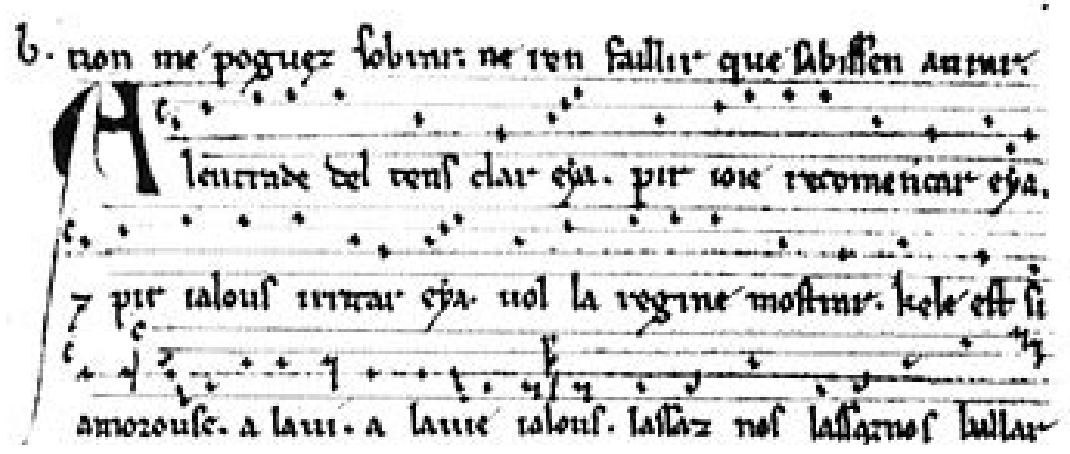

A l'entrada del tens clar. Facsímil del manuscrito PC 418

París, Biblioteca Nacional fr 20050

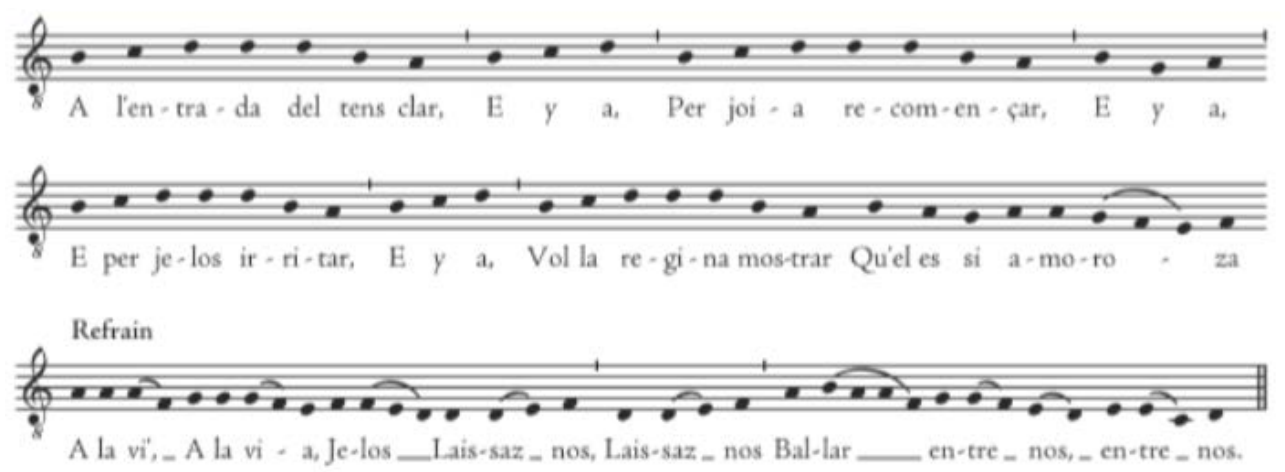

A l'entrada del tens clar. Transcripción en notación moderna

Para el análisis sonoro de esta canción-danza tomaremos las siguientes versiones fonográficas, todas realizadas a partir del mismo manuscrito ${ }^{128}$ del siglo XIII que ya mencionamos: 1) Perceval ([1996] 2008); 2) Studio der Frühen Musik ([1970] 1985); 3) Micrologus (1999); 4) Clemencic Consort ([1977] 1998); y 5) Martin Best Consort (1995).

Todas ellas comportan características muy similares en cuanto al ritmo: poseen un tempo rápido y muy ajustado al pulso, que varía entre $d=120$ y 160 . El esquema métrico es ternario y reproduciendo el patrón largo-corto, como un batir permanente. Estos factores son inconfundiblemente rasgos que evidencian el compromiso con la danza, que además debiera ser ágil. En cuanto al carácter, con excepción de la segunda versión, todos los demás intentan otorgar una connotación festiva y cómica a la interpretación, a través de formas de emisión vocal nasales, que buscan incorporar ruido y connotaciones obscenas, burlas y sátira hacia los personajes mencionados en el texto, y sobre todo a lo referido a la cultura oficial y la autoridad. En esto se acerca bastante a lo que ya escuchamos en la canción Orientis Partibus y los sonidos del "asno".

La primera versión, ${ }^{129}$ del grupo Perceval, es interesante pues, aunque es prácticamente a capella y sólo se incorpora un instrumento de percusión en los estribillos, no por ello pierde su carácter festivo y nos introduce en la hipótesis de que las músicas populares y festivas podían producirse con escasez de recursos instrumentales sin por ello perder efectividad ni vínculo con lo carnavalesco. Además prevalecen las voces femeninas y esto debe servirnos de recordatorio hacia los conjuntos de juglaresas y la participación activa y muy frecuente de las mujeres en la música popular medieval. También aparece en los estribillos, cuando se canta a más de una voz, alguna armonización que claramente está

128 PC 418, París, Biblioteca Nacional fr 20, 050.

129 El ejemplo 18 puede escucharse aquí https://youtu.be/5AyZz4IPhus 
construida de forma improvisatoria, haciendo una "segunda voz" sobre la melodía transmitida y aprendida de forma oral. Esto nuevamente nos habla de la recreación que pivota entre la composición y el arreglo y en las capacidades de los juglares y juglaresas para hacer polifonía. Sobre todo de esta forma, improvisando sobre una melodía conocida. También en este caso, por estar las voces tan expuestas, se aprecia con claridad la heterogeneidad sonora con que se piensa la conjunción de las diversas fuentes, evitando por completo los ideales estéticos modernos vinculados al empaste tímbrico. Desconocemos cuál es la razón de la incorporación en esta versión de sonidos de la naturaleza en la versión, como el piar de los pájaros emulados por instrumentos y accesorios, pero en el contexto de nuestra argumentación son interesantes para relacionar estas canciones con el culto a lo arbóreo y a la exuberancia de lo vegetal, en directo vínculo con las ideas de renovación, renacimiento y abundancia. Podemos imaginar que esta canción acompañara a la comunidad en la búsqueda del palo de mayo en el bosque y en su posterior traslado procesional hacia el pueblo.

La segunda versión, ${ }^{130}$ del Studio der Frühen Musik de Thomas Binkley, es la que más se aparta del resto y pareciera atenuar el carácter festivo. Es una recreación en la cual se introducen varios instrumentos (viola medieval, flauta de pico, chirimía, laúd, percusión) y conserva el carácter de alternancia entre estrofas de una sola voz a capella frente al estribillo a coro y con los instrumentos. Pero a diferencia de la versión de Perceval aquí predomina la homogeneidad tímbrica y se nota una permanente preocupación por conseguir claridad y afinación en las alturas, lo cual aparta este caso de la idea de proliferación tímbrica y las discrepancias participatorias. Estas últimas tampoco se dan en el ritmo y por lo tanto la canción termina sonando estática debido a una organización rítmica demasiado rigurosa e invariable. Es también la versión que posee el tempo más lento y todos estos elementos tienden a apartar lo que suena de la relación con lo corporal, mucho menos con lo grotesco y lo sexual, anulando prácticamente el carácter danzable y festivo. Sobre esta base, podría pensarse que este caso es un primer acercamiento a la reconstrucción de los procesos de estilización que protagonizaron los músicos al comenzar a servir en las cortes como ministriles domésticos. De hecho este grupo musical dedicó varios fonogramas a los ministriles domésticos, incluso de la corte imperial del Sacro Imperio Germánico.

La versión número tres ${ }^{131}$ es tal vez la que mejor nos introduce en la idea de lo carnavalesco. Además,en el fonograma, A l'entrada del tens clar viene a continuación de una danza de trovadores, subrayando el contraste entre la cultura oficial y la popular y sus relaciones contenciosas. El disco es a su vez un registro de la ocasión en vivo dentro del marco de la fiesta de mayo, es decir que está actuada en contexto y no como espectáculo en un escenario, reconstruyendo las condiciones de la cultura de la plaza pública que, como mencionamos antes, enumera Bajtín. En lo estrictamente sonoro, la versión de Micrologus incorpora desde el comienzo de la canción un sonido pedal realizado por una zanfona con un alto grado de ruido en la fricción de la rueda. Si bien el arreglo continúa con el criterio de alternar la estrofa por una voz solista y el estribillo con el coro, tiene también un criterio sumativo en lo instrumental, de forma tal que a partir de la segunda estrofa se incorporan sucesivamente más instrumentos en cada vuelta. Éstos son, además de la zanfona, un rabel (también con la fricción del arco en primer plano), una flauta de pico, percusiones, y un instrumento de cuerda pulsado, probablemente una guiterna. Esta versión, además, introduce estrofas completamente instrumentales y en ellas, como en las cantadas, algunos de los instrumentos hacen segundas voces y contracantos, también de carácter improvisatorio. Pero con claridad el carácter festivo se exhibe a partir del aumento

130 El ejemplo 19 puede escucharse aquí https://youtu.be/oGwVEARzrJ0

131 El ejemplo 20 puede escucharse aquí https://youtu.be/IU73 gcmH8Y 
constante de la intensidad y el ruido, la deformación de la fonación en virtud del carácter grotesco y satírico y en especial, por el ritmo. Aquí pareciera que los instrumentistas se han olvidado del patrón métrico y las frases se deslizan sobre el batir de las percusiones. Hay corrimientos pequeños y desvíos en el fraseo, pero lo más importante es que se nota que es un ritmo que se concibe desde lo corporal, para ser bailado, y que la ciclicidad proviene del movimiento, no de la medida ni de la cuenta del tiempo. Nos parece un buen ejemplo de discrepancias participatorias en torno a lo rítmico y de hasta qué punto esto puede afectar la efectividad en la incitación a la danza, el refuerzo del carácter grotesco y la temática de la fiesta popular.

La cuarta versión, ${ }^{132}$ del conjunto de René Clemencic, hace constante en este caso la sonoridad de la percusión, con un ritmo muy ágil y marcado. Es además un plano rico tímbricamente, con varios parches golpeados con la mano y con palos, campanillas y accesorios que agregan más ruido: cascabeles, matracas, sonajas, etc. Este conjunto suena en toda la canción, generando un piso de sonido muy alto y pregnante. A esto se incorporan otros instrumentos: un laúd que hace un rasgueo muy rítmico, en el que casi no se escuchan las notas; y un rabel, muy ágil y hasta virtuoso que, una vez que ingresa, se mantiene haciendo contracantos y ornamentaciones que bordean a las voces hasta que, al promediar la cuarta estrofa, parece sumarse más a la percusión exagerando la presión del arco y realizando un esquema rítmico complementario al de los parches. Las voces modifican el criterio de las versiones que escuchamos antes, ya que el arreglo está pensado de forma dialógica entre dos cantantes que se reparten alternativamente las estrofas y se unen en los estribillos. Nuevamente la emisión vocal, al igual que la producción del sonido en los instrumentos, es fuertemente heterogénea y discrepante y en todo momento nos damos cuenta de quién está cantando a pesar que ambas voces se mueven en la misma tesitura y el registro de los cantantes es el mismo. A esto se suman otras voces que profieren gritos y arengas sobre el eya del estribillo. Podemos imaginar a partir de esta versión a los músicos tocando y cantando al pie del árbol de mayo, ya erigido, con la multitud danzando en derredor y acompañando con exclamaciones cada aparición del estribillo. Por último, en este caso, como en el anterior de Micrologus, la repetición de las estrofas se plantea con un criterio de intensificación mediante el cual, a medida que transcurre la canción, se incrementa la tensión, el ritmo acelera levemente y el sonido se vuelve más estridente, todo lo cual confluye en el final del último estribillo con profusión de vítores y redobles. Es un rasgo que comparten muchas músicas populares y que retomaremos en el análisis de las músicas de este lado del Atlántico.

Finalmente la versión de Martin Best y su consort, 133 directamente inicia con un redoble en un instrumento de parche, casi dándonos la sensación de continuar donde dejó el arreglo anterior. También aquí los instrumentos están presentes durante toda la canción: laúd, rabel y parches, todos los cuales exponen su costado más ruidoso mediante los rasguidos, pasajes rápidos, golpes de arco y redobles. En ningún momento las alturas -y sobre todos los acordes- aparecen como importantes. Por cierto, son frecuentes los fragmentos en donde el laúd se queda repitiendo un mismo acorde que, de hecho, es prácticamente el único en toda la canción, casi con obstinación, como si fuese un marco o una excusa para tocar un rasgueo y experimentar todas las posibilidades tímbricas, rítmicas y de articulación que el instrumento permite. Casi podrían haber sido las cuerdas al aire, como si no importara qué lugares de la cuerda se pisan. A esto ayudan las voces -una masculina y una femenina- forzando la tonicidad, como en las versiones anteriores, mediante una emisión burlesca y muy nasal, efectos de recitado y exclamaciones.

132 El ejemplo 21 puede escucharse aquí https://youtu.be/UX34UsrglA4

133 El ejemplo 22 puede escucharse aquí https://youtu.be/UoCcePiYvCU 
En conclusión, A l'entrada del tens clar es una danza ágil y "sin aliento" (Wright, 1981, p. 135), estrófica (esquema del cual surgirá la balada o ballata), muy probablemente vinculada con las festividades colectivas en torno a las fiestas de mayo, en la cual se despliegan con mucha claridad prácticamente en todas las versiones las temáticas de inversión y los elementos de la risa carnavalesca y la cultura de la plaza pública.

\subsection{El Pathos de la transformación o la inversión carnavalesca del paradigma musicológico}

¿Por qué nos interesa trabajar con tantas versiones? lo hemos hecho hasta aquí con Orientis Partibus y con A l'entrada del tens clar, pero antes también con el himno peregrino Dum pater familias. Lo que nos anima en esto no es el gusto, aunque confesamos que la audición de todas estas músicas es una experiencia estéticamente muy valiosa y grata. Tampoco hay la pedantería positivista en la acumulación de catálogo, seguramente relacionada con el "mal de archivo" derridiano. Aunque esa sería una objeción superficial. Más importante es resaltar que tampoco nos demoramos en buscar una misma canción para encontrar lo que permanece igual, el denominador común. Porque en todos estos repertorios no existe la canción originaria que debamos recuperar a través de una especie de depuración de los elementos presentes en las versiones que inevitablemente le añaden sus "impurezas", que serían un subproducto de la insuficiencia del registro histórico. Lo "puro" y lo "impuro" son términos que aquí no tienen ninguna relevancia. Como señala el músico Raúl Rodríguez cuando habla del cante, son fotos o momentos dentro de una recreación y re-actualización continua, que es la gran responsabilidad que cae sobre quien decide tomar una canción de tradición oral, aprenderla y devolverla recreada, modificada (Rodríguez, 2019). No hay canción auténtica, ni autoridad compositiva, ni versiones autorizadas; y no hay manera de que hubiese existido un registro gráfico más completo. Porque lo que estas músicas tienen de identitario, lo que es importante en ellas, el sistema notacional no lo registra. Sencillamente porque estuvo diseñado para escribir otra cosa. Esto ya debería ser suficiente para que consideremos a estas canciones como música popular: las hace estar bien afuera del modelo estético hegemónico. La música de los juglares no incorporó la escritura en sus modos de hacer, simplemente porque no era necesario. No podía serlo.

Uno de los rasgos distintivos de las músicas transmitidas a partir de la oralidad es el carácter de auto re-creación continua. Cada vez que la obra es interpretada, es reconstruida, proceso que es inherente a estas prácticas, ya que la obra reside en la memoria de cada juglar. Cada uno tendrá su versión y la cambiará en función de sus necesidades y capacidad de memorizar. Este rasgo particular hace de estas obras una materia en constante cambio, una materia efímera y fluida, características diametralmente opuestas a las de fijación y delimitación de lo escrito (Martínez y otros, 2010, p. 5).

Por lo tanto analizamos las versiones porque nos interesa explorar lo que todas ellas proponen como diferente, o si se quiere hasta divergente. Aquello que las hace sonar tan distinto: las acciones instrumentales, la expresividad de la emisión vocal, las discrepancias, la concepción del tiempo y el movimiento del ritmo; y sobre todo los ruidos, eso que la acústica clásica definió -en complemento con la estética idealista- como transitorias que, más allá de su naturaleza física, se espera que pasen desapercibidas y se estabilicen lo antes posible. Por eso decimos que estas músicas se demoran en los pasajes, en lo transicional; allí se revelan los modos en que se concibe el musicar en relación con la ocasión social. Las partituras son mudas en torno a todo esto. Pensamos que de lo expuesto emerge un indicador que define a la música popular: el cambio, la recreación, la transformación. Una acción que produce una música mestiza, ambigua, de cambio y renovación. Habita en la música popular un sentido opuesto al de la cultura hegemónica: un pathos de cambios y transformaciones (Bajtín, 2003, p. 181). Un pathos de la risa, contrario 
a la solemnidad de la cultura oficial, una alegre relatividad «que no permite que el pensamiento se detenga y se petrifique en una seriedad unilateral, en el determinismo irresoluble y en el monismo» (Bajtín, 2003, p. 193). Incluso esto podría llevarnos a decir que, en sentido estricto, la música popular no consiste en "tradiciones"; asunto que discutiremos en la sección siguiente dedicada al folklore. En todo caso, recuperando la noción de un campo de disputa, deberíamos considerar junto con Stuart Hall (1984, p. 2) que es «el terreno sobre el que se elaboran las transformaciones», en el cual pueden aparecer otros sentidos igualmente populares como la resistencia, la contención, diferentes grados de aceptación o incluso la indiferencia (Grignon y Passeron, 1992, p. 108-109). Todos son parte de la litigiosidad, la ambigüedad, la condición heteróclita que reside en la música popular.

De esta manera podríamos pensar que el carácter popular carnivaliza las nociones de la musicología histórica al invertir su paradigma, puesto que la lógica de la relatividad de las verdades y las autoridades dominantes es también la lógica de lo que está "al revés" y se revela contradictorio. Insistimos en que esto no debería desvalorizar el sentido político de la cultura popular; muy por el contrario es desde la risa, desde la performance misma, que se producen de forma presentacional, práxica, las parodias y degradaciones, la inversión de lo bajo y lo alto, las profanaciones, etc. Hay cierta excentricidad en las formas de producción de la música popular, que podríamos pensar relacionadas con una liberación de cualquier tipo de situación jerárquica que, como vimos, determina el pathos de la distancia y, por ende, pasa a regular la práctica en la música oficial: quién está en condiciones de decir qué cosa, cuándo es oportuno hacerlo, hasta qué punto se puede o no se puede decir esto, etc. Todo esto con relación a la autoridad que se fundamenta en la cualidad del origen, sea ésta dada por la personalidad del compositor o por la tradición a la que se recurre como fuente de autenticidad. Así como en lo carnavalesco «el comportamiento, el gesto y la palabra del hombre se liberan del poder de toda situación jerárquica» (Bajtín, 2003, p. 180), en la performance de la música popular la regulación que emana de una concepción objetual/ personalista se suspende. Es importante señalar que esto no anula la posibilidad de creación individual. Son personas las que hacen las músicas populares, que las crean cuando recuperan y recrean una canción (Rodríguez, 2019). El príncipe deja de serlo cuando participa del carnaval, debajo de su máscara, situación que lo libera del orden cotidiano de la cultura oficial; del mismo modo el campesino, el artesano o una comerciante abandonan su condición social mientras viven la vida festiva, el segundo mundo que propone la cultura popular. Pero ninguno de ellos deja de ser persona, de percibir el mundo y exponer sus deseos y miserias en la manifestación vívida de la fiesta. Por el contrario, en el contexto de la fiesta, el sujeto individual puede -y hasta debe- eludir la abstracción y producir «pensamientos sensoriales concretos» (Bajtín, 2003, p. 180) que refuerzan y amplifican sus posibilidades de expresión individual. Una expresión que habita en la materialidad del sonido, que vehiculiza sus contenidos de modo presentacional. Podemos relacionar esto con la propuesta de Gramsci de que lo popular reside mucho más en los usos y las relaciones, no en el origen o las esencias.

Una cultura conformada más por las prácticas y los usos que por los objetos [...] una estética popular basada (nietzscheanamente) más en la experiencia que en las obras, en la voz colectiva que en la expresión individual, en la continuidad del arte con la vida, y de la técnica con el arte, en un arte-acción radicalmente antiautoritano (Martín Barbero, 2002, p. 50)

¿Existe entonces algo que todavía nos impida comprender a los juglares y juglaresas como músicos populares históricos? Por lo pronto vimos que encarnan, al menos lo suficiente, todos los rasgos de la cultura de la risa que formula Bajtín y que se integran al concepto de «mundo popular subalterno» de Ernesto de Martino. Y sin embargo estos actuantes, que figuran en las historias del teatro, de la danza o de la cultura, no aparecen en las historias de la música. Recordemos que para Donald Grout representan un repertorio 
que literalmente no le interesaba, aunque hubiese dedicado algún tiempo a estudiar todas las evidencias que aquí presentamos. También existe cierto pathos de la distancia en Dahlhaus, nada más al imaginar lo que podría suceder de incorporarse al corpus de la historia de la música estas manifestaciones de la trivial musik. Pero aunque sus palabras altivas nos resulten dolorosas, insistimos en que esa es todavía la superficie del problema. Hay algo mucho más profundo que se revela en nuestras propias limitaciones musicológicas para el análisis historiográfico, acercándonos a un dominomorfismo ${ }^{134}$ (Grignon y Passeron, 1992, p. 139) tan cuestionable como el etnocentrismo presente en los comentarios despectivos de estos autores. Porque todas y cada una de las características y rasgos de las músicas populares históricas, que en nuestros análisis hicimos emerger de las ocasiones musicales de los juglares, invierten por su sola existencia el paradigma de la musicología histórica.

Por un lado, el problema aparece a partir de la despreocupación de estas prácticas musicales por afirmar los nombres de juglares y juglaresas que, incluso cuando aparecen en fuentes indirectas, no permiten construir lo que llamaríamos una personalidad artística. Sencillamente porque, a diferencia de los trovadores, no se erigen como autores sino que se integran en el musicar, en la ocasión social; viven la vida carnavalesca generando y regenerando sonoridades que no pueden reclamarse como propiedad intelectual. De hecho, son completamente ajenas a todo concepto de propiedad, razón por la cual algunos términos de la musicología y el folklore quedan por completo obsoletos, como "herencia", "apropiación", e incluso tradición, ejecución o interpretación. Sencillamente porque la operatoria del musicar popular no coincide con actitudes que requieren que se reconozca la propiedad y la autoría de las prácticas musicales. Justamente por esto, y como segundo asunto, lo que hacen los juglares no son "obras". Aquí se despliegan con mucha precisión todos los rasgos que podemos asociar con el mentado concepto de musicar: se trata de un hacer, de un fenómeno presente en la performance y por lo tanto de índole presentacional (Langer, 1966), que tiene valor mientras ocurre y es sostenido por los practicantes, dentro de los cuáles está incluido lo que Ilamaríamos "público". Pero que no es tal, ya que la noción de "publicidad", inherente a la concepción del espectáculo musical, es un concepto creado para la estética moderna del capitalismo (Bianconi, 1986). Situación histórica de la que surge específicamente el término de "obra", derivado como sabemos de "ópera", un formato pionero para vehiculizar la necesidad de poner a la venta, con valor de cambio, la puesta en escena de la representación musical -que será representación a su vez del orden social. Esquema que sí se apropiará de las prácticas de la cultura popular, ya que «la representación en una sala de conciertos toma el lugar de la plaza de la fiesta popular» (Attali, 2011, p. 73). En contraste, no hay nada de todo esto en la performance premoderna y precapitalista de los juglares y juglaresas. Incluso este simple asunto de que hombres y mujeres actúen libremente y en pie de igualdad perturba lo ya inasible de este mundo musical popular. Al no poder aplicarse aquí la categoría de obra, toda la discusión sobre las fuentes y los registros en partitura desaparece. No podemos convalidar una metodología musicológica en repertorios que hacen de lo instantáneo, repentista o efímero, valores artísticos. No puede haber un interés por registrar la música y pretender transmitirla "inalterada" en estos artistas de la performance. Como vemos, nada parece coincidir con los conceptos nucleares del paradigma de la musicología histórica; y entonces, rendida en absoluto ante un fenómeno al que sus útiles no pueden acceder, ensaya como último recurso la disculpa positivista de la "carencia de fuentes".

\footnotetext{
134 «la descripción del modo de vida y del ethos de las clases dominadas que permite la transposición a estas clases de esquemas y de conceptos forjados para el estudio de las clases de la cultura dominante permanece inevitablemente impregnada de dominomorfismo» (Grignon y Passeron, 1992, p. 165)
} 
La carencia de datos positivos sobre la música profana obliga al historiador a limitar el examen de las manifestaciones musicales en los primeros siglos cristianos al de la música eclesiástica, la sola que permite fundar la investigación en documentos de la época (Leuchter, 1946, p. 13)

Las coordenadas de un musicar transcultural que emerge de las prácticas de los juglares presentan problemas para la historiografía afirmativa, precisamente porque sus disciplinas pertenecen a la modernidad europea. No sólo la musicología, sino que tampoco el folklore, como veremos, podrán asir una praxis itinerante y profesional, pues el nomadismo choca con la necesidad de territorializar lo musical y convertirlo en regional. Por si fuese poco, los juglares y juglaresas no son campesinos, es decir, no son el Volk, el pueblo atrasado, conservador e ignorante, consentido por el paternalismo del folklore. Muy por el contrario y aproximándose al insolente Pöebel herderiano, los músicos del carnaval no pertenecen a la casta de los campesinos (Lengwinat, 2006, p. 33) porque sencillamente no están integrados a la sociedad. No son rurales ni urbanos. En cierto sentido no son, porque los atraviesa una de las condiciones que más ha perturbado a la cultura occidental a lo largo de su historia: son nómadas trashumantes. Parte del periplo de estos artistas -que además son profesionales porque se ganan la vida mediante esta práctica- consiste, remarcamos, en conectar el mundo rural con el urbano incluso durante la Alta Edad Media. Por esta razón no son portadores de ningún folklore, si es que vamos a creer que tal cosa existe. Por último, deberíamos añadir que, si como analizamos la producción sonora de la fiesta popular se basa en el ruido, lo transitorio y heterogéneo, los conceptos derivados de una muy sofisticada teorización armonicocéntrica de la historiografía musical, pierden todo poder. Sólo se puede hablar de lo que no es: no es afinado, ni armónico, ni regulado, ni conducido, ni contrapuntístico, etc. Y si no es, como no son los juglares, entonces lógicamente no es necesario contar su historia.

Sin embargo, esto no es un asunto exclusivo de la modernidad y su historiografía musical. Porque la música de la fiesta y carnaval popular no podía, sin más, servir de banda sonora de los ideales cortesanos de la propia Edad Media. Como ya dijimos, cuando se funda el ideal caballeresco del Pathos de la distancia, los juglares son domesticados en las cortes. Pero aún más, será necesario modificar la música que estos artistas portan, ocultar su origen, domesticarla a ella también y permitir así que esos sonidos trastocados y mutilados expresen ese "punto de vista" de la aristocracia feudal. De esta estratificación musical operada desde arriba provendrá, por un lado, el ocultamiento de la música popular. Eso significa ni más ni menos la estilización, el procedimiento predilecto de los trovadores y sus sirvientes, los ministriles cortesanos domésticos. Pero debemos comprender que, por otro lado, es también mediante este gesto de distancia, o mejor, de distinción (Bourdieu, 2002) que la propia música popular es nombrada y, por lo tanto, creada en su especificidad. Como proponen todos los autores sobre los que nos apoyamos para pensar la cultura popular, de Bajtín a Martín-Barbero, no podemos pensar la música popular por fuera de la estratificación que la contiene, incluso como anti-valor. Por eso, una vez más, insistimos en una definición operativa de la música -y la cultura popular- como campo de disputa y oposición, en el cual litigan la cultura hegemónica y la inversión del carnaval que propone el mundo popular subalterno. Ni el término cultura ni el de música nos deben distraer con su «agradable invocación de consenso» (Thompson, 2000, p. 19). Existe desde la propia fundación de la cultura occidental una lucha cultural, una batalla constante de sentidos, análoga a la que vimos pintada en el Carnaval y Cuaresma de Brueghel. Pero debemos añadir que es una lucha desigual, en la cual la cultura dominante redobla sus esfuerzos para regular y organizar no sólo su propia cultura de clase sino fundamentalmente la cultura de los sectores subalternos. Así, la cultura popular puede ser al mismo tiempo el escenario de la resistencia ante el poder, el despliegue por inversión de una contracultura; pero también es en parte el sitio donde la hegemonía surge y se afianza (Hall, 1984, p. 11). La modernidad cumplirá, al menos parcialmente, con su propósito de regular y articular la 
cultura de los sectores populares; la musicología histórica y sobre todo el folklore, serán productos de su eficacia cultural. Es lo que Burke denomina "el triunfo de la cuaresma»135 (2014, p. 295). En ese proceso podemos considerar que un paso importante es el que ocurre durante la apropiación de los músicos y las músicas populares que hacen las cortes feudales en busca de transformar la presentación carnavalesca en un arte de representación social.

\subsection{Representación por estilización}

Si la suerte del juglar está definida por su condición de proscrito, con todo el desprecio social que esto conlleva tanto para su condición personal como para la profesión de músico en general, un destino completamente diferente será el del ministril doméstico a partir de su entrada a las cortes feudales del siglo XII. Ganará en la seguridad del puesto fijo, en la posibilidad ahora de especializarse en la técnica musical y tener para sí un grado aceptable de respetabilidad. Ya no deberá vivir como proscrito, manejando sin dominar una gran diversidad de entretenimientos y acrobacias. Pero esto comportará también una grave pérdida: "Hasta entonces era un artesano libre, confundido con el pueblo y que trabajaba indiferentemente para las fiestas populares [...] Desde ahora tendrá que venderse por completo y en exclusiva a una clase social única» (Attali, 2011, p. 29). Y en esa "venta", en ese servicio en exclusividad, el ministril ofrecerá al trovador el arte musical popular como ofrenda, ya que serán los ministriles quienes canten y toquen las canciones trovadorescas

¿Suministraban los cantantes aristocráticos normalmente la música para sus propios poemas? ¿Quiénes se la suministraban si no? [...] fueron ellos quienes introdujeron la voz «minstrel» como el término preciso para definir a un músico que era cantante y actor [...] que les «suministraba» música y les servía como ayudante para acompañar sus canciones. En las ilustraciones medievales, el trovador y el juglar aparecen juntos, y el segundo lleva una viella, primitivo instrumento semejante al violín que se hizo tan común [...] que en épocas posteriores «vielle» y «jongleur» se convirtieron en palabras intercambiables." (Raynor, 1986, p. 59)

Las "escuelas de juglares", verdaderos congresos que reunían a los ministriles de prácticamente toda Europa occidental, dan cuenta de la profesionalización de estos músicos, pero además de su rol como arregladores y musicalizadores. «A veces los juglares [ministriles] ayudaban a los trovadores» (Reese, 1989, p. 248). Es decir, es altamente probable que muchos trovadores hayan sido ante todo poetas, y los ministriles, ex-juglares, quienes hayan realizado la música y transformaran en canción esos versos. ¿Qué música serviría como punto de partida a los ministriles? Evidentemente la que ellos tradicionalmente dominaban con fluidez y había sido transmitida de forma oral durante cientos de años: la música popular.

Será entonces en las cortes feudales de fecha tan tardía como el siglo XII, y a partir de su coyuntura socio política particular que ya mencionamos, cuando convertir al príncipe en alguien que brille por su cultura se vuelva una virtud primordial. En ese marco, la música, tanto en su realidad práctica como en su encarnación estética, deberá dar cuenta de su magnificencia. Necesidad política en tiempos turbios y afirmación del poder, esta suntuosidad no persigue el prestigio del individuo como productor, sino que su eficacia es ante todo simbólica.

De las cortes condales del sur de Francia, en el siglo XII, a las cortes principescas o episcopales del siglo XIV, la música desempeña un papel capital en la organización social de

135 La actitud del folklore aparece con mucha claridad en esta definición de la reforma de la cultura popular en la modernidad: «los intentos que de forma sistemática llevaron a cabo algunas personas procedentes de las clases cultas para intentar cambiar las actitudes y los valores del resto de la población, o como decían los victorianos, para "perfeccionarlos"» (Burke, 2014, p. 296) 
la sociedad medieval. La música, expresión del ideal corles, y luego su figuración, se transforma de un arte de diversión en un arte de representación, verdadera encarnación del poder y las virtudes del mecenas [...] el trovador expresa de manera consensual en la cansó los valores unificadores de la cortesía: mesura, sabiduría, refinamiento, códigos de valores y de honor, servicio de amor y perfección moral (Cullin, 2005, p. 113-116)

Estos valores de los que habla Cullin son los perfectos opuestos de lo que Bajtín propone en relación con la fiesta popular y «la cultura específica de la plaza pública», que en ese campo de batalla cultural aparecen en oposición al ceremonial culto

El mundo infinito de las formas y manifestaciones de la risa se oponía a la cultura oficial, al tono serio, religioso y feudal de la época [...] Todos estos ritos y espectáculos organizados a la manera cómica, presentaban una diferencia notable, una diferencia de principio, podríamos decir, con las formas del culto y las ceremonias oficiales serias de la Iglesia o del Estado feudal (Bajtín, 2005, p. 10)

El proceso que va de la cultura de la risa popular al ceremonial serio y específicamente representativo de los valores cortesanos es paralelo a la domesticación de los juglares, al paso del músico vagabundo al sirviente cortesano. La modificación en la sonoridad musical que esto requiere puede inferirse de algunas músicas paradigmáticas de las sucesivas etapas de este proceso. A continuación tomaremos algunos casos seleccionados entre los más notables y estudiados que, como han podido datarse con alguna precisión, pueden constituirse, para nuestro objetivo analítico, en una suerte de línea temporal del proceso de estilización cortesano. Partiremos de una música tal vez más similar a las que analizamos antes, producto de músicos que sabemos fueron también juglares, y terminaremos con una canción de nuestro conocido Raimbaut d'Aurenga, como vimos, uno de los mayores representantes del aristócrata-trovador y sus valores cortesanos. Al igual que en el caso de las músicas de los juglares antes analizadas, todas estas canciones se han transcrito y anotado bastante tiempo después de su praxis viva y la notación con la cual se registraron posee nuevamente muy poca información: sólo muestran las alturas, sin indicaciones acerca del ritmo o el acompañamiento, entre otros factores esenciales. Por más que en estas músicas cortesanas aparezca una mayor centralidad de la organización horizontal y vertical de las alturas, todavía deberíamos pensar en un arte mucho más vinculado a la performance que a la noción de "obra". Por estas razones, nos basaremos para nuestro análisis también aquí en las propuestas interpretativas que de estos manuscritos han sido realizadas por diversos músicos de gran reconocimiento mundial, especializados en el repertorio e históricamente informados. Sin embargo, como nuestro interés es presentar el proceso de estilización y no un marco teórico de las músicas trovadorescas, los análisis serán mucho más escuetos que en los casos anteriores, concentrándose en los indicadores del proceso de apropiación cortesana.

Nuestro primer caso de análisis en este camino de la estilización es la pastorela del ministril-trovador conocido como Marcabrú, titulada L'autre jost'una sebissa. Si tomáramos como cierta la hipótesis de Taruskin de la sátira de los sectores populares por parte de la aristocracia, aquí nos encontraríamos con un caso completamente opuesto y por ende más cercano al carácter del carnaval; ya que se trata de un poema muy irónico hacia la aristocracia que satiriza el intento de un caballero de aprovecharse de la inocencia de una joven campesina. De hecho Riquer y otros autores (Palao Gómez, 2008) interpretan que este poema de Marcabrú satiriza la cultura trovadoresca de la generación anterior, específicamente la de la corte de Guillermo IX de Aquitania. Pero es especialmente interesante para nuestro análisis que la campesina, que claramente simboliza a los sectores populares abusados por la clase terrateniente, sea una mestiza. En opinión del citado Palao Gómez esto refleja la situación transcultural de toda una región que comprende no sólo la península ibérica, como ya vimos, sino también el sur de la actual Francia, potenciando las 
hipótesis de la presencia de moros -entre ellos músicos- en las cortes de amor de los trovadores aquitanos. Que el símbolo del carácter popular sea lo mestizo no deja de plantearnos la perspectiva que nos permite considerar todo esencialismo y pureza asociadas a la música como producto del arte y la teoría de los sectores hegemónicos. Volviendo a la canción, en el texto se contrasta la torpeza y falta de inteligencia del noble con la rapidez de reflejos y sentido de la moralidad de la muchacha. Reproducimos cuatro de las diez estrofas.

L'autrier jost' una sebissa

Trobei pastora mestissa,

De joi e de sen massissa,

Si cum filla de vilana,

Cap' e gonel' e pelissa

Vest e camiza treslissa

Sotlars e causas de lana.

Ves lieis vinc per la planissa.

Toza, fi·m ieu, res faitissa,

Dol ai car lo freitz vos fissa.

-Seigner, so $m$ dis la vilana,

Merce Dieu e ma noirissa,

Pauc m'o pretz si $\cdot$ I vens m'erissa,

Qu'alegreta sui e sana.

Don, tot mon ling e mon aire

Vei revertir e retraire

Al vezoig et a l'araire,

Seigner, so $m$ dis la vilana!

Mas tals se fai cavalgaire

C'atrestal deuria faire

Los seis jorns de la setmana.

Don, hom coitatz de follatge

Jur' e pliu e promet gatge:

$\mathrm{Si} \cdot \mathrm{m}$ fariatz homenatge,

Seigner, so $m$ dis la vilana!

Mas ieu, per un pauc d'intratge,

Non vuoil ges mon piucellatge,

Camjar per nom de putana.
El otro día, entre unos arbustos, encontré una pastora mestiza,

llena de alegría y entendimiento.

Como hija de villana,

capa y sayón forrado

vestía, y camisa de malla,

zapatos y medias de lana.

Me acerqué por la planicie:

"Moza," dije, "ser encantador,

me temo que paséis frío."

"Señor", dijo la villana,

"gracias a Dios y a mi nodriza,

poco me importa el viento,

pues soy chica sana y alegre."

"Señor, mi linaje y familia

se remontan, que yo sepa, a la pala y al arado."

"Señor," me dijo la villana,

"pero algunos que se llaman caballeros

deberían hacer lo mismo

los seis días de la semana."

"Señor, el hombre acuciado por la locura

jura, suplica y promete:

Así me haríais homenaje,

Señor," ¡dice así la villana!

¡Pero yo, por semejante peaje,

no quiero cambiar mi doncellez,

por el nombre de puta."

Marcabrú (c.1150) fue un gascón nacido de cuna muy humilde. Se conoce muy poco de su vida. Por este motivo se cree que en sus inicios era un juglar. Una cosa bastante segura es que fue músico y poeta profesional, itinerante, que luego pasó a trabajar en las cortes, del mismo modo que su contemporáneo Cercamon (Hoppin, 2000). Mediante estos datos es dable suponer que estamos en presencia de un ministril, uno de los juglares domesticados de Raynor, al servicio del poderoso trovador Guillermo X de Poitiers, hijo del famoso iniciador de la dinastía trovadoresca. Como los poemas de Marcabru se anotaron, en general se lo considera un trovador, pero no hay noticias de que recibiera tal condición o mucho menos que fuese nombrado caballero.

Para el análisis de este caso nos basaremos en las siguientes grabaciones fonográficas: 1) Gérard Zuchetto136 (S/F); 2) La reverdie ${ }^{137}$ (1991); 3) Micrologus ${ }^{138}$ (1999). Si tomamos esta canción como paradigma de una segunda marca en nuestra escala de apropiación y estilización, algunos de los rasgos sonoros encontrados en estas interpretaciones son muy sugerentes:

\footnotetext{
136 El ejemplo 23 puede escucharse aquí https://youtu.be/JC_DguBmh14

137 El ejemplo 24 puede escucharse aquí https://youtu.be/ozJ6I3mKsVo

$138 \mathrm{El}$ ejemplo 25 puede escucharse aquí https://youtu.be/mUTCKcifZNQ
} 
En las tres versiones hay un aligeramiento de la textura muy notorio durante las estrofas, en marcado contraste con los interludios instrumentales. Esto pareciera indicar una voluntad de dejar espacio al texto, que subordina así completamente a la música. En la versión 1 esto se da mediante el uso de notas pedales, criterio que seguramente procede de la consabida familiaridad entre los recursos de la música eclesiástica y la cortesana. En los otros dos casos, utiliza acordes plaqué o arpegios en instrumentos de cuerda pulsada: laúd y salterio respectivamente. En los tres casos también es notoria la ausencia de percusión, salvo unas campanillas en 3. Esto parece estar en concordancia con el muy flexible tratamiento del ritmo, que tal vez sea lo más notorio como contraste entre esta pastorella y las canciones populares que analizamos anteriormente: por un lado la melodía -y también el acompañamiento instrumental- no se adaptan al pulso sino que fluctúan permanentemente en una especie de rubato constante. De hecho, la versión 1 directamente no presenta pulso discernible y se trata más bien de un parlato o recitar que pareciera estar construido en base a criterios retóricos y la concepción medieval de rythmus (Cullin, 2005). Esto es curioso, ya que el manuscrito es uno de los pocos que presenta una incipiente notación mensural (Haynes, 2001) que comporta la alternancia entre largas y breves, esquema similar al que sí aparece en el caso analizado anteriormente. Otro aspecto que también sobresale es el marcado descenso del tempo: las dos versiones con pulso distinguible rondan cifras metronómicas entre 50 y 68. Todo esto hace muy notoria la ausencia de una conexión con lo corporal y la danza.

Estos elementos hacen que este caso presente ya rasgos muy distintivos de la canción cortesana, aún con su estructura estrófica. «Aunque algunas piezas cortesanas son similares a las danzables, esto solamente responde a que la naturaleza de su poesía hizo necesario que adopataran esa forma. Este tipo de piezas [...] nunca tuvieron como fin el ser bailadas» (Robert, 1999, p. 5).

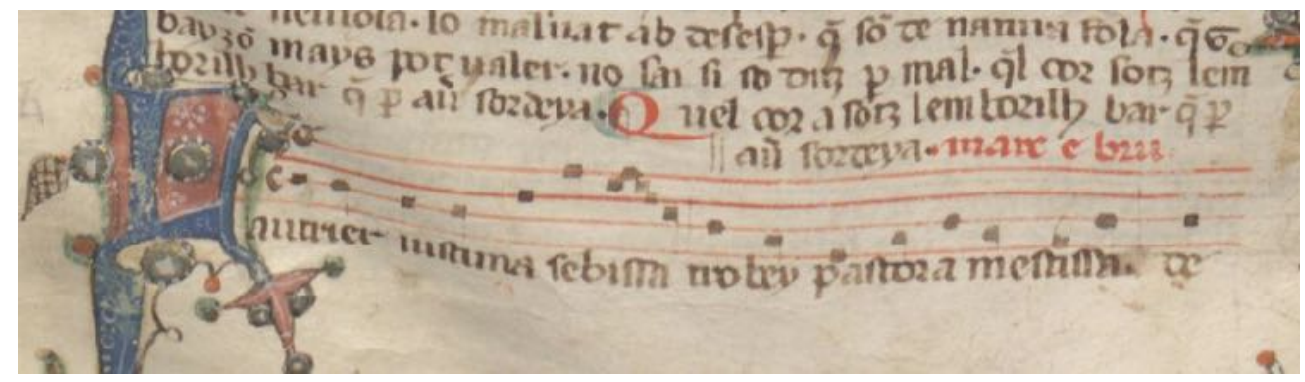

Manuscrito de L'autre jost'una sebissa.

París, Biblioteque Nationale f.frcs. 22543 (manuscrito R) Línea 1

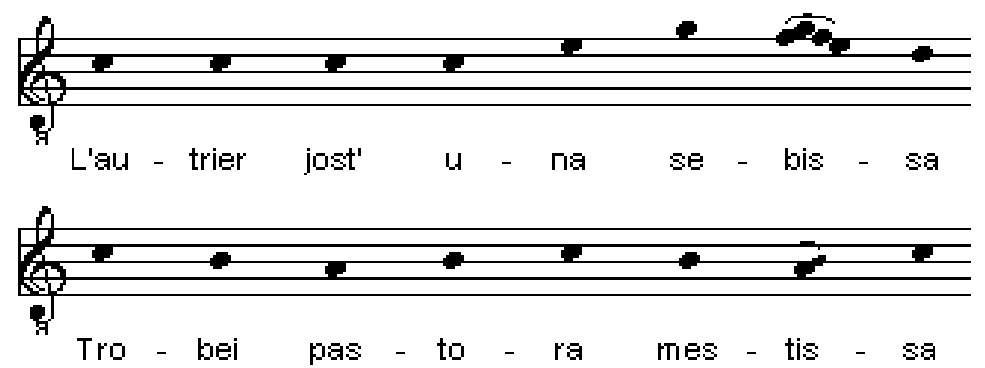

Transcripción a notación moderna de la primera línea de L'autre jost'una sebissa.

Una segunda música que ya representa una etapa muy superior de la estilización es la canción Can vei la lauzeta mover, del trovador Bernart de Ventadorn, quien es "generalmente considerado el mejor de los trovadores y uno de los más altos poetas amorosos de todos los tiempos» (Riquer, 1983, p. 346). Sirviente -¿ministril? ¿discípulo?- 
del vizconde trovador Ebles II de Ventadorn; trovador predilecto de Leonor de Aquitania, la «reina de los trovadores», a quien siguió hasta que ella se convirtió en reina de Inglaterra; cortesano del conde y cruzado Raimon $V$ de Toulouse. A pesar de haber sido el hijo de un sirviente de palacio y una panadera, Bernart de Ventadorn (c.1140-c.1190) sí consiguió transformarse en trovador, acceder al círculo íntimo de la caballería cortesana, hasta llegar al palacio de reyes y reinas.

La cansó de Bernart contiene un texto que es mucho más elaborado y metafórico que los vistos hasta ahora. El simbolismo y el grado de sutileza para referirse al cortejo de la amada lo hacen paradigmático del ideal del fin amors: la palidez y el enmudecimiento del enamorado, su resignación ante el desdén «de aquella de quien nunca obtendré ventaja», el robo del corazón por parte de la enamorada. De todas formas esto no debe confundirnos en pensar que es un tipo poético hermético. Bernart es "partidario del trobar leu» (Riquer, 1983 , p. 346) es decir lo contrario al trobar clus, lo cual lo convierte en el principal representante de la escuela idealista entre la segunda generación de trovadores (Falck y Haines, 2001). Transcribimos a continuación las estrofas 1, 2, 3 y 7 de Can vei la lauzeta mover.

Can vei la lauzeta mover de joi sas alas contra.l rai, que s'oblid'e.s laissa chazer per la doussor c'al cor li vai, ai! tan grans enveya m'en ve de cui qu'eu veya jauzion, meravilhas ai, car desse lo cor de dezirer no $m$ fon.

$A i$, las! tan cuidava saber d'amor, e tan petit en sai! car eu d'amar no.m posc tener celeis don ja pro non aurai. Tout m'a mo cor, e tout m'a me, e se mezeis'e tot lo mon; e can se. $m$ tolc, no.m laisset re mas dezirer e cor volon.

Anc non agui de me poder ni no fui meus de l'or'en sai que $m$ laisset en sos olhs vezer en un miralh que mout me plai. Miralhs, pus me mirei en te, m'an mort li sospir de preon, c'aissi.m perdei com perdet se lo bels Narcisus en la fon.

Pus ab midons no.m pot valer precs ni merces ni.l dreihz qu'eu ai, ni a leis no ven a plazer qu'eu l'am, ja mais no.lh o dirai. Aissi.m part de leis e.m recre; mort m'a, e per mort li respon, e vau m'en, pus ilh no.m rete, chaitius, en issilh, no sai on.
Cuando veo la alondra mover sus alas de alegría contra el rayo [del sol] y que se desvanece y se deja caer por la dulzura que le llega al corazón, jay!, me entra una envidia tan grande de cualquiera que vea gozoso, [que] me maravillo de que al momento el corazón no se me funda de deseo.

¡Ay de mí! Creía saber mucho de amor, iy sé tan poco!, pues no me puedo abstener de amar a aquella de quien nunca obtendré ventaja. Me ha robado el corazón, me ha robado a mí, y a sí misma y a todo el mundo; y cuando me privó de ella no me dejó nada más que deseo y corazón anheloso

Nunca más tuve poder sobre mí, ni fui mío desde aquel momento en que me dejó mirar en sus ojos, en un espejo que me place mucho. Espejo: desde que me miré en ti, me han muerto los suspiros de lo profundo, porque me perdí de la misma manera que se perdió el hermoso Narciso en la fuente.

Ya que con mi señora no me pueden valer ruegos ni piedad ni el derecho que tengo, y a ella no le viene en gana que yo la ame, no se lo diré nunca más. Así pues, me alejo de ella y desisto; me ha muerto y como muerto le respondo, y me voy, ya que no me retiene, desgraciado, al destierro, no sé a dónde. 
De entre los cientos de versiones existentes, tomaremos como referencia para el análisis las siguientes: 1) Studio der Frühen Musik ${ }^{139}$ ([1970] 1985); 2) Gothic Voices ${ }^{140}$ (1990); 3) Micrologus $^{141}$ (1999); 4) Alla Francesca142 (1996); 5) Evelyn Tubb143 (1982).

Todas las versiones acentúan aún más los rasgos que veíamos en el caso anterior y que conducen a una contemplación atenta y pasiva de la música, una subordinación total de lo musical al texto poético y una ausencia de elementos que tiendan al baile, el movimiento o las referencias corporales. Del mismo modo que la poesía nos habla de un amor que no se consumará jamás en el acto sexual, la música de estas interpretaciones aleja todo lo posible la presencia de lo corpóreo y su relación con lo sonoro.

El tempo ha descendido al mínimo, rondando la cifra 40, en los casos en que existe pulso perceptible. Los casos 2, 3 y 4 directamente se manejan por fuera de toda pulsación y dado que la versión 2 es a capella, la sonoridad nos recuerda al canto llano y su preocupación por minimizar toda connotación corporal. El mismo recurso de no presentar acompañamiento lo utiliza la versión 1 , aunque en este caso se percibe un pulsar que de todas formas es constantemente eludido por la melodía. Las versiones 3, 4 y 5 sí poseen instrumentos acompañantes, pero el protagonismo de estos es reducido al mínimo: notas pedales con algún glissando y arpegios de poca densidad cronométrica. Todos los instrumentos son de cuerda pulsada o frotada y de poco caudal sonoro: viellas, laúdes, arpas. Anticipan el carácter cortesano que será tipificado en el Renacimiento dando a estos instrumentos la clasificación de bajos.

No sorprenderá entonces que esta música tenga una gran cantidad de contrafacta, algunas de las más notables atribuidas a Felipe el Canciller. Incluso Dante la parafrasea en el canto XX del Paradiso en La Divina Comedia.

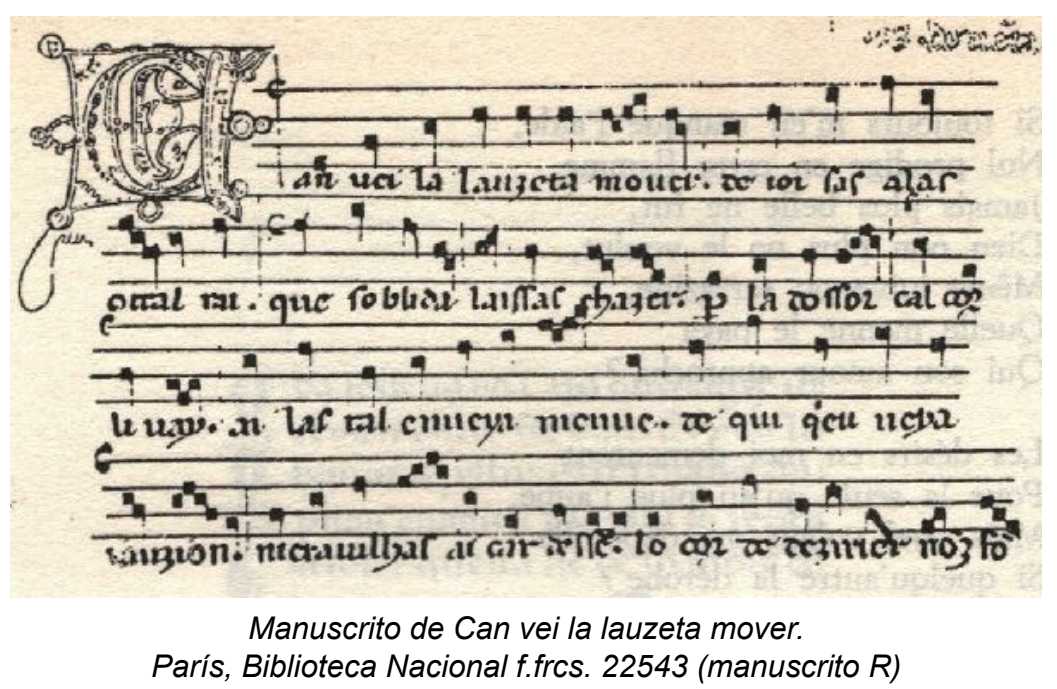

\footnotetext{
139 El ejemplo 26 puede escucharse aquí https://youtu.be/2I-H6eG2SsY

140 El ejemplo 27 puede escucharse aquí https://youtu.be/gjR32YolFcg

141 El ejemplo 28 puede escucharse aquí https://youtu.be/Y40cH2zJwfU

142 El ejemplo 29 puede escucharse aquí https://youtu.be/jkp2GHBRUiQ

143 El ejemplo 30 puede escucharse aquí https://youtu.be/A35laRguNIU
} 


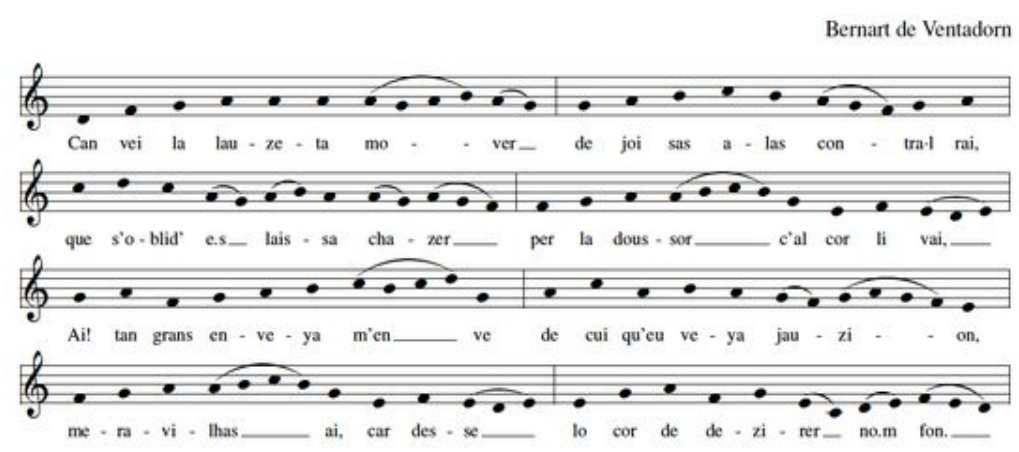

Transcripción moderna de Can vei la lauzeta mover.

Como adelantamos, el último caso es una cansó de Raimbaut d'Aurenga, titulada Pois tals saber. Si bien Marcabrú y Bernart son de los trovadores más conocidos, su condición es claramente profesional y, antes que nada, están al servicio de otro señor o señora, trovador o no. Por lo tanto, para completar nuestra escala necesitamos algún caso atribuido a un trovador aristócrata. Como no podemos analizar la música del tensó que comentamos antes, elegimos directamente una canción de Raimbaut d'Aurenga, el poderoso Conde de Orange y promotor militante del trobar clus, paradigmático del extremo cortesano del recorrido de apropiación que estamos proponiendo.

Transcribimos las primeras tres estrofas:

Pois tals saber mi sortz e $\cdot \mathrm{m}$ creis Que trobar sai - et ieu o dic! Mal estara si non pareis Et er mi blasmat si m'en gic; Car so qu'om van'ab la lenga Taing ben que en pes lo tenga, Car non pot aver pejor dec

Qui ditz so que no s'avenga.

Er ai gaug car sebram dels freis E remanon sol li abric;

Li auzellet - et es lor leis

Qe negus de chantar no:is gic -

Us quecs s'alegr'en sa lenga

Pel novel temps que $\cdot$ il sovenga;

$E$ dels arbres qu'eron tuit sec

Lo foils pels branquils s'arenga.

E qui anc jorn d'amar si feis Non taing q'era s'en desrazic C'ab lo novel temps que s'espreis Deu quecs aver son cor plus ric; $E$ qui non sap ab la lenga Dir so que $\cdot$ il coven, aprenga Consi ab novel joi s'esplec: C'aisi vol Pretz que·s captenga.
Dado que tal habilidad brota y crece en mí, que puedo escribir poesía, iy lo afirmo! se verá mal si no la muestro y me culparán si me rindo; ya que eso de lo que se jacta uno con su lengua debería pesar mucho en su mente, ya que no hay peor culpa que reclamar algo que no sucede.

Ahora disfruto que nos separemos del frío y que los refugios permanezcan sin usarse; pajaritos: sus leyes imponen que nadie salga sin cantar -

cada uno se regocija en su propio idioma por Primavera, que es a quien llama; y las ramas de los árboles, que estaban todas secas,

están llenas de follaje.

Y quienquiera que se haya dedicado a amar no debería desviarse ahora

porque, con el despertar de la primavera, cada uno debería tener su corazón enriquecido; y el que no sabe cómo expresar con su lengua lo que le incumbe, que aprenda cómo lograr su objetivo con una alegría nueva: porque Valor quiere que cada uno pueda realizarse 
Consideraremos una sola versión, ${ }^{144}$ del fonograma Vox Humana del Studio der Frühen Musik (EMI, Cologne, [1976] 2000). Con mucha claridad pueden evidenciarse en este caso los rasgos que aparecían en la interpretación de la canción de Bernart, ahora profundizados: la ausencia de pulso, las notas pedales, arpegios, glissandi. Una resultante temporal muy lenta y estática de la cual emerge el canto, muy suave, íntimo, en absoluto primer plano. Casi un susurro, un poema declamado en nuestros oídos, con muy pocas alturas. Prácticamente un parlato, para demostrar esa «habilidad que brota y crece», que distingue al trovador.

Aquí la canción de Raimbaut es ya directamente una banda sonora de la cultura oficial del mundo feudal:

La fiesta oficial era el triunfo de la verdad prefabricada, victoriosa, dominante, que asumía la apariencia de una verdad eterna, inmutable y perentoria. Por eso el tono de la fiesta oficial traicionaba la verdadera naturaleza de la fiesta humana y la desfiguraba. (Bajtín, 2005, p. 15)

En nuestra hipótesis, el vector de todo este recorrido de cuatro pasos -que va de la música popular y la cultura de la risa, a la música y la cultura de la representación cortesana- es lo que llamaremos estilización. De forma contundente, el diccionario de la Real Academia Española define estilizar exactamente como «someter a una nueva elaboración refinada una obra popular» y también «interpretar convencionalmente la forma de un objeto», es decir, aplicar la convención a las prácticas, elaborar la doxa. También el diccionario enciclopédico VOX posee una definición interesante: "Representar artísticamente algo de manera que destaquen sólo sus elementos característicos o los que más responden a la idea que el artista quiere transmitin. Como estamos en el momento en que se crean las reglas y convenciones, en que se elabora la doxa que señala cuáles son los «elementos característicos», podemos interpretar que tal reducción no es otra cosa que una limpieza: eliminar los aspectos que no marcan ese pathos de la distancia, desechar lo que exprese la fiesta y la cultura cómica popular. Ocultar el origen, que es vergonzante, a partir de la creación de una nueva concepción de lo que es un elemento estructural y característico. Lo que nos conduce a una última entrada del diccionario: "Hacer que algo parezca más delgado de lo que es».

La estilización, entonces, es el proceso de estratificación producido por la música trovadoresca a partir de la popular, tras la apropiación de su acervo musical, y cuyo agente es el ministril al musicalizar y/o acompañar los poemas de trovadores, con el fin de adaptar los procedimientos y criterios musicales a la doxa de la representación cortesana de los valores que menciona Cullin. Como dirección general podemos señalar que la intención será diluir los componentes sonoros que referencien a lo vulgar, lo corporal, la danza y lo sexual, así como también lo directo y carente de ambigüedades. La atención hacia el texto y la concentración en la contemplación serán también objetivos a alcanzar, rechazando todo lo que pueda connotar la participación activa del auditorio. Todos los dominios del lenguaje musical se verán modificados en la estilización, aunque el ritmo y la textura son los que sufrirán un mayor grado de transformación.

¿Se puede hablar de dominación cultural a partir de estos procesos de apropiación que ocurren en la fundación misma de la cultura occidental? Con todas las precauciones del caso creemos que sí, en la medida en que concedamos que estamos ante una relación dialéctica que se expresa en un gradiente y no en posiciones absolutas y fijas, que reproducirían justamente esos valores de "bien" y "mal" fabricados por las clases dominantes. Es necesario escapar a estos dualismos si queremos restaurar al arte popular

144 El ejemplo 31 puede escucharse aquí https://youtu.be/Bu8Y7IDe00Q 
su agencia creativa, su carácter emergente (Williams, 2015, p. 189) y su lugar dentro de la cultura.

Siguiendo el movimiento de la estructura de poder, podemos entonces afirmar que éste no es un conjunto acotado de instituciones o personalidades sino que es un complejo entretejido de todos los que participan en su discurso, tanto quien impone, como quien lo reproduce, pero también, aunque contradictoriamente, aquél que introduce cambio en ello. Sólo quien elimina, destruye, se margina o es marginado, queda fuera del poder (Zátonyi, 2002, p. 30)

Los juglares, proscritos y expulsados de la sociedad, no participan del esquema de la cultura dominante y por eso su arte introduce lo que para el poder será ruido (Attali, 2011). Pero no hay que extender el concepto de resistencia popular indiscriminadamente, pues implicará un reduccionismo que. a la larga. impedirá una comprensión de las variadísimas actitudes que residen en la cultura popular. De eso nos advierte Bajtín con la enunciación de la cultura de la risa, que es también hacer de la dominación, mediante la ironía y las burlas, un objeto simbólico que transforme y neutralice en parte su opresión, que ponga de cabeza el registro representativo de la cultura dominante. "Nos encontramos aquí muy cerca de un mecanismo de producción simbólica particularmente revelador de la heteronomía de las culturas dominadas» (Grignon y Passeron, 1992, p. 109). Éstas, además, no adoptan noche y día una posición permanente de contraataque y lucha abierta frente a la cultura dominante y sus mecanismos de legitimación. "Funcionan también en posición de descanso» (Grignon y Passeron, 1992, p. 108).

Habitualmente se suele pensar en la dominación cultural concentrando en el polo superior, es decir el hegemónico, la mayor densidad conceptual. Ya sea que exista un aparato dedicado a producir mensajes destinados a que las clases subalternas acepten su condición, o que la aparente sofisticación del arte culto demande el mayor porcentaje de desarrollo teórico, las descripciones y explicaciones sobre los que están en el extremo inferior de la ecuación son escasas e indiferenciadas. Esto «engendra la ilusión de homogeneidad de las clases y las culturas dominadas» y lo que es mucho peor, la imagen de «la cultura del pobre como cultura más pobre» a quienes lo único que les queda es la privación de cultura (Grignon y Passeron, 1992, p. 140).

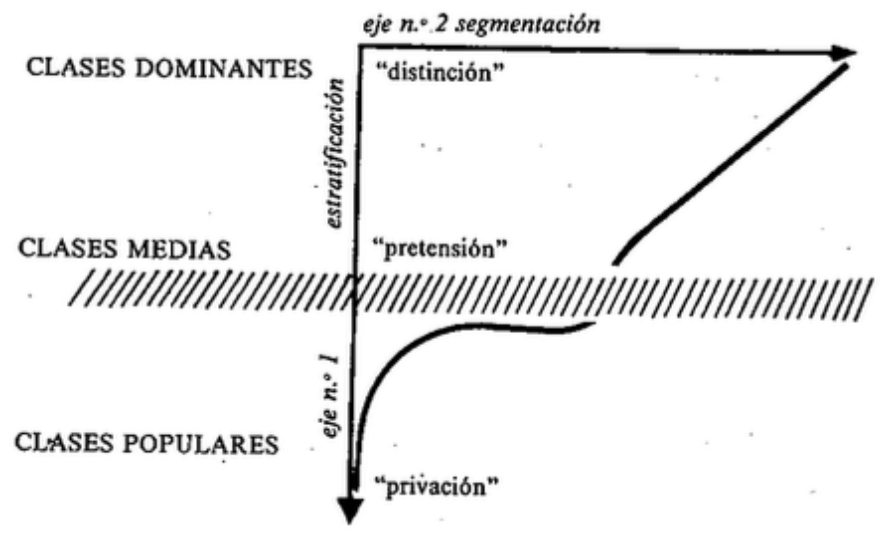

Gráfico extraído de Grignon y Passeron, 1992.

Grignon y Passeron llaman a este esquema de pensamiento sobre la cultura popular dominocentrismo, y si bien puede responder a la intención de desenmascarar los mecanismos de poder que encierra el aparato simbólico de una cultura dada, perpetúa el vacío de contenido que subyace en los estereotipos de la cultura y el arte populares. $\mathrm{O}$ formulado como pregunta, ¿hasta qué punto este esquema expresa como fórmula aquella creencia de que «el pueblo no inventa nada»? 
La idea de apropiación cultural por parte de las clases dominantes añade al esquema una flecha ascendente, cuyo trayecto parte de la riqueza de la cultura popular, condición existente al momento de iniciarse el proceso. De hecho, las proporciones del esquema debieran invertirse y así mostrar un mayor grosor de la cultura popular frente a un área más reducida que es la cultura dominante.

Esa segunda flecha señala el vector de la distinción social a través de la producción

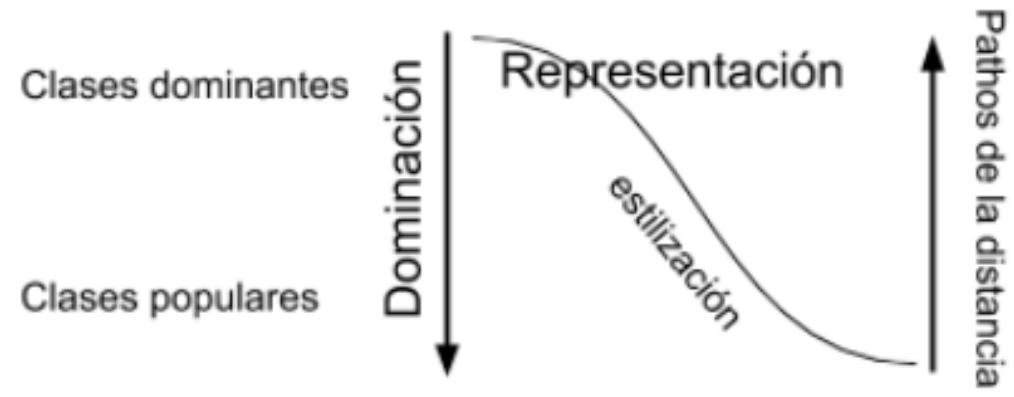

cultural, pero como un vector de disputa que recorre todo el campo y no una posición fija como en el esquema. Esa disputa se da en el proceso que llamamos representación social, y expresa como magnitud al pathos de la distancia. Podríamos pensar a éste como una fuerza que intenta precisamente detener, desarticular o desactivar el Pathos de la transformación. Para ello, el procedimiento principal es la estilización. Pero esa flecha no expresa únicamente la situación de los que están en la cima del esquema. Refleja la condición de todos aquellos que se pretenden ver en él, qué creen en él. De ahí su aceptación y la participación activa en el esquema también de los sectores populares que encuentran en el ministril a su representante.

Zatonyi dice que la doxa que formula el trovador es el paradigma enseñable. Esto supondría que toda educación implica una estilización, una compresión de la dinámica del arte popular y su transformación en convención académica. Está claro entonces que el desafío de enseñar música popular implica construir un nuevo paradigma que evite tal compresión. $Y$ también la estigmatización historiográfica que propone al arte popular como a-histórico, en su versión únicamente actual, o en la tradicional e inmutable. Pero siempre copia menor, rebajada, hecha más simple que su modelo culto e histórico.

lo importante, pues, no es un mero inventario descriptivo -que puede surtir el efecto negativo de congelar la cultura popular en algún molde descriptivo intemporal-, sino que son las relaciones de poder que constantemente puntúan y dividen el dominio de la cultura en sus categorías preferidas y residuales. [...] trazar la línea divisoria, siempre, en cada período, en un lugar distinto, entre lo que se debe y lo que no se debe incorporar a «la gran tradición». Las instituciones docentes y culturales, junto con las muchas cosas positivas que llevan a cabo, también ayudan a disciplinar y vigilar esta frontera (Hall, 1984, p. 9).

Como pudimos ver, ya sea que tomemos en cuenta las imágenes de los manuscritos, las fuentes escritas que los describen o que consideremos las estrategias actuales de interpretación musical sobre la música medieval, los juglares anteceden históricamente a los trovadores. Exactamente al revés de lo que, como veremos, propone la musicología de Carlos Vega y otros ilustres investigadores. La confusión puede derivar del positivismo musicológico, según el cual solo valen como documento las partituras. Como vimos, las hay únicamente de los trovadores pero además, el propio sistema, de considerarse aisladamente, nos devolverá una apariencia en la cual la escritura se convierte en el origen 
de todas las músicas. Así, mediante estos sesgos conceptuales, se fueron generando profundas estigmatizaciones en la historia de la música hacia los músicos populares. Es una historia que ubica en el centro los nombres. Los trovadores son de los primeros agentes hegemónicos de la música que hacen del nombre un culto y por eso existen prolijamente redactadas en manuscrito sus biografías o "vidas". Desde ya que, entre las cosas que nombran los trovadores, se nombran a sí mismos y eligen para sí el mote de compositor, pues eso quiere decir el trobar occitano o el tropare latino: componer. En ese gesto, sellan un destino histórico de la música de Occidente por medio del cual el intérpreteministril, y sobre todo el juglar-popular y sus herederos, quedan fuera de la historia que, a partir de aquí, será una historia de los compositores. "La derivación de la palabra juglar del inglés "juggler" debería ser suficiente para despejar las dudas sobre la connotación subartística del término» ${ }^{145}$ (Taruskin, 2005a, p. 155).

La musicología histórica se construyó en torno a la doxa del mundo cortesano y monástico y será ante todo narración de autores, historia de los nombres que son a su vez quienes definieron y definen -al tiempo que se definen como- los valores del "bien" y de lo "bello": dimensión del pathos de la distancia. En la construcción afirmativa de la historiografía musical, lo que arroja esta proyección de identidad entre el pasado y el presente es pura ganancia para el academicismo de los sectores dominantes.

¿Cuál es la importancia de estudiar a los juglares y trovadores en nuestra contemporaneidad latinoamericana? Como parte del mundo popular subalterno, dentro del Sur Global, tanto las teorías musicológicas como las valoraciones hacia las prácticas musicales tienen en Latinoamérica una doble dependencia: por un lado, en tanto periféricas, se han construido a partir del cotejo permanente con el modelo de ultramar, metropolitano (Aharonián, 1994). Así los estudios de la música popular han no sólo derivado de los marcos teóricos de la música culta, sino además de la música Europea, sobre todo sosteniendo sus marcos teóricos en el difusionismo y el evolucionismo (Reynoso, 2006), entre otras teorías profundamente occidentalocéntricas.

Las danzas de los soldados y de los colonos, esto es, las folklóricas españolas, inseparables de su patrimonio espiritual en marcha, murieron en América con ellos o con sus hijos. [...] América folklórica no es España folklórica sino España culta, Europa culta. América folklórica es una retardada selección de la Europa superior (Vega, 1977a, p. 10)

Así volvemos nuevamente al dominocentrismo según el cual sólo es posible estudiar el arte de los sectores dominantes y "cultos" y, todavía más, es deseable hacerlo ya que todo arte popular es una emanación tardía de aquél. Pero además y para peor, según este modelo la música popular de Latinoamérica ni siquiera es una copia de la música popular española (lo cual sería de todos modos una aculturación) sino que es copia "retardada" de la música culta de otras naciones más distinguidas de Europa: Francia, Italia, Alemania. Restituir la existencia histórica de la música popular y su condición creativa y pionera nos emancipa de tener que creer que solo a través de dominar a la perfección los códigos del "dueño" podremos hacer una música que se pueda llamar arte. Eso es lo que el dominocentrismo hereda con mucha fuerza del etnocentrismo más rancio. Pero antes de profundizar en el carácter emergente de las músicas populares de la modernidad temprana, debemos revisar críticamente las teorías que produjeron la estratificación y jerarquización de las músicas, oponiendo la historia al pueblo. Su magnitud fue caracterizada por Vega como «el ritmo del descenso». Todo un manifiesto, no sólo estético, sino también político. En esa clave comenzaremos nuestro derrotero por los laberintos conceptuales del folklore, en tanto disciplina de conocimiento musical.

145 «the derivation of our English word "juggler" from joglar should leave no doubt about its subartistic connotation» (Taruskin, 2005a, p. 155) [nuestra traducción] 


\section{Capítulo 3 \\ El ritmo del descenso}

«América folklórica es una retardada selección de la Europa superior»

Carlos Vega (1977)

A partir del análisis que llevamos a cabo en el capítulo anterior, se desprende un derrotero histórico que contempla al menos dos variables importantes: 1) es a partir de las formas de producción de los músicos populares que la cultura aristocrática de las cortes feudales reorganiza la música en función del pathos de la distancia y la necesidad de representación social; 2) en la propia materialidad musical está inscripta la estilización que filtra los aspectos tensionantes y discrepantes de la ocasión musical popular (inscriptos en el sonido-textura y el ritmo) y decanta el lenguaje musical hacia una preeminencia de la combinatoria armónica, la depuración de los timbres y la variación melódica.

Esto produce hacia el siglo XI que los juglares, de trashumancia entre las cortes y el pueblo, que hasta ese momento «organizan una circulación permanente entre música popular y música de corte» (Attali, 2011, p. 27), sean paulatinamente proscritos y rechazados de los círculos hegemónicos; rechazo y censura que puede leerse en las prohibiciones y detalladas descripciones por parte de las autoridades. Es decir que al conjunto de músicos-artistas que circulaban en la sociedad medieval, el proceso de representación musical lo segmentará en función de las especialidades y el valor social que se le asocia a cada quién: juglar, ministril, trovador, etc. Los círculos de acción de la música se cierran sobre sí mismos y esto se acentúa en la alta aristocracia. Recién, como señala Burke (2014), en la modernidad temprana y fundamentalmente con el advenimiento de las monarquías los sectores aristocráticos pretenderán intervenir directamente en la cultura popular. Hasta ese momento, prima el rechazo, el silencio y la negación del pueblo.

Pero el esquema historiográfico de la musicología histórica es otro completamente diferente. Como vimos, pretende crear un esquema histórico lineal evolutivo que, preocupado por encontrar los orígenes de los estilos (Gelbart, 2007) y montado sobre el exclusivismo de la notación musical, nos muestra a la música culta surgiendo del vacío, en un tiempo en que la música no es popular, y cuando consiente admitir a la música popular en su esquema, ésta siempre va a la zaga, atrasada respecto a la música culta. Cuando se trata de las músicas de las mayorías históricas en contraste con la producción sonora de las élites, este esquema supone una creencia que desafía el sentido común y las vivencias contemporáneas de historiadores, musicólogos y melómanos.

\footnotetext{
El pueblo no crea y, sin embargo, la música tradicional, andando el tiempo, deriva y se transforma. Hay que averiguar, entonces, cómo la masa rural, es decir, sus músicos, llegan a resultados semejantes a los del compositor culto, verdadero creador [...] No hay creación pura en los dominios de las clases populares [...] El pueblo, a lo largo del tiempo y a través de varias generaciones [...e]s un creador culto con ralentisseur. (Vega, 1944, p. 85) [el resaltado es nuestro]
}

Términos que podemos encontrar en autores de menor renombre pero mucho más actuales: «el esclavo ... imitaba la música de su patrón, ... Copió el estilo de la música de su dueño, ... Copió la sonoridad de la música del dueño» (Guerrero, citado en Lengwinat, 2006, p. 26).

Este tipo de ideas responden al marco del difusionismo antropológico, de mucho auge a principios del siglo $X X$, pero que ya ha sido muy refutado en los ámbitos académicos. Sin 
embargo vemos que ha logrado instalarse muy fuertemente en las concepciones sobre la música popular y el folklore que circulan no solo en libros actuales sino también en los imaginarios sociales. En ocasiones adquieren posiciones paternalistas (Grignon y Passeron, 1992) que persiguen una revalorización del arte popular pero que terminan, voluntariamente o no, identificándolo con un carácter irremediablemente marginal. Lo cual supuestamente redunda en un refugio rural y anónimo en el cual se preservaron las expresiones del pueblo. De allí su condición tradicional y pretérita, folklórica.

El arte rural es un fenómeno histórico [...] un principio consagrado, tradicional e inflexible [La cultura popular] se muestra en su arte también más conservadora, tradicional y convencional que un grupo cultural más elevado (Hauser, 1979 en Zátonyi, 2011, p. 22).

Lo cual lleva a pensar que el arte popular, para preservarse de esos desprendimientos transitorios e indiferentes, para convertirse en esa "resistencia anónima», además de rural debe ser "esencialmente reaccionario» (Zátonyi, 2011, p. 24). Si el tempo del descenso es demasiado rápido, si entra mucha agua a esa pileta en que Vega ha transformado la cultura popular -un líquido sucio, podemos presumir- el pueblo deberá reforzar la tradición, y ese será un acto de defensa.

Los sectores populares, intérpretes a destiempo, no hacen "la escritura de la música", que como se ve, es letrada, culta, en partitura. Sino que los músicos del folk transmiten, externan supervivencias de creaciones de otros [...] son actos que importan modificaciones, pero modificaciones mínimas, insuficientes para trastornar las anchas formas y normas de que hablamos [...] Desde este punto de vista, las modificaciones mínimas equivalen a la conservación (Vega, 1944, p. 87)

Estas asunciones nos darán a cambio una realidad paradójica como propiedad de las producciones de las clases subalternas: son por un lado altamente conservadoras, pero sirven en cada etapa histórica como manifestación de ruptura y cuestionamiento a los poderes establecidos: las rebeliones campesinas de la Baja Edad Media tuvieron sus canciones; la lucha de los poderes seculares en el Renacimiento se aprovechó de los cantos populares para cohesionar a las poblaciones de las ciudades burguesas; la reforma protestante pudo abrirse paso a través de la actualización de canciones populares que le garantizaron difusión entre la población analfabeta; la Marsellesa es una recreación de una canción callejera de buhoneros; la identidad nacional en las luchas contra el imperio napoleónico se manifestó en base al arte popular. Y ni hablar de la relación entre música y luchas por derechos sociales, políticos, étnicos y sexuales a lo largo del siglo XX ¡Qué difícil es ser conservador y revolucionario al mismo tiempo, si asumimos los términos del paternalismo estético sobre el arte popular!

La tradición es un elemento vital de la cultura; pero tiene poco que ver con la mera persistencia de formas antiguas. Tiene mucho más que ver con la forma en que se han vinculado o articulado los elementos unos con otros. Estas combinaciones en una cultura nacional-popular no tienen una posición fija o inscrita y, ciertamente, ningún significado al que arrastre, por decirlo así, la corriente de la tradición histórica, sin sufrir ningún cambio. [...] Las tradiciones no son fijas para siempre: ciertamente no lo son en ninguna posición universal en relación con una sola clase [...] Esto es el terreno de la cultura nacional-popular y la tradición como campo de batalla (Hall, 1984, p. 9).

Justamente, las teorías que contemplaron las músicas populares antiguas buscan construir una noción de tradición que es universal y obligatoria y, por ende, afirmativa, que niega la dinámica de transformación permanente que señala Hall y que se instalará como patrón de garantía de la autenticidad. Estas tradiciones serán fuertemente segregadoras de prácticas y ocasiones populares históricas, ya que al otorgar a la cultura popular un carácter intrínsecamente conservador genera una parcialidad que excluye a la música y el arte 
popular urbano. Como también los sectores oprimidos "rurales" han sido perseguidos, estigmatizados y expulsados de la historia en múltiples ocasiones. Lo fueron (y lo son) y en ocasiones por medio de gran violencia y crueldad. Pero en verdad, la dedicación diferenciada y específica en silenciarlos y perseguirlos por parte de los sectores dominantes a lo largo de la historia hace de su presencia en todos los ámbitos de la sociedad occidental una realidad constante. No hay momento histórico sin arte popular urbano, ni siquiera en la Edad Media, cuyo estereotipo es predominantemente rural. De hecho, podemos pensar que la música popular en los inicios de Occidente aparece, efectivamente, en la aldea, el precario núcleo social que interrumpe el océano bucólico de los cultivos. Sin embargo, y casi sin darnos cuenta - ¿o sí?- aceptamos con total naturalidad que el sector hegemónico o dominante de la población, el que además detenta el poder sobre los medios de producción, tiene el monopolio de la creación artística, de la innovación, porque «es el único que tiene acceso a los conocimientos teóricos y técnicos» (Lengwinat, 2006, p. 25). Cuando en realidad estamos consagrando como únicos conocimientos y tecnologías válidas a aquellas que emanan de la producción musical hegemónica, movida por la distancia y la necesidad de representación. Como es fácil advertir, este es un claro ejemplo de los mecanismos de la cultura afirmativa, mediante los cuales aceptamos sin reparos que la innovación, y los comienzos de toda historia, son patrimonio exclusivo de los sectores dominantes.

Una disciplina que converge con la musicología histórica en la configuración conceptual de la afirmatividad historiográfica de la música es el Folklore, que completará la narrativa musicológica ensanchándola, ocupándose de la música del pueblo, pero reemplazando a éste por las nociones equivalentes de folk o volk, más allá de los matices culturales e históricos de cada una (Martín-Barbero, 1991, p. 19). Como ya mencionamos en la introducción, para el folklore el pueblo no será pueblo, sino una comunidad imaginada, una construcción bucólica y melancólica, imagen disciplinada y sometida de los sectores subalternos que finalmente terminará oponiéndose al mundo popular. Por lo tanto, la música del folklore tampoco será, en última instancia, "popular". Y podemos leer los esfuerzos teóricos del folklore como una empresa cuyo objetivo reside, precisamente, en restar agencia musical a los sectores populares. El caso que tal vez lleva esto a la exacerbación, es el del legendario musicólogo argentino Carlos Vega que desarrollará la teoría del "descenso de los bienes», es decir, un modelo conceptual mediante el que se pretende explicar científicamente el derrotero por el cual las músicas se originan en los sectores hegemónicos, o "superiores", para luego descender al pueblo, aunque lo suficientemente tarde para que se las considere músicas extintas.

La creencia en una marcha paralela de lo "popular" y lo "culto", merece abandono...Ya sabemos que en el ambiente popular hay supervivencias entre muchas otras cosas. Todas fueron alguna vez superiores... Llegué a la conclusión de que las clases populares imitan a las clases superiores... En términos generales, pues, podemos decir que los bienes hoy folklóricos, son, en gran parte, los mismos que ayer abandonaron las clases ilustradas (Vega, 1944, p. 31)

En realidad no es de Vega la invención de esta teoría de la imitación, sino que el folkmusicólogo la deduce de la sociología de sesgo darwinista del español Gabriel Tarde. Incluso la referencia como Ley de Tarde (1944, p. 50) y la complementa con formulaciones de otros autores, como en el siguiente ejemplo: «El inferior imita al superior; en la muchedumbre el pensamiento se resta y el sentimiento se suma» (Raúl A. Orgaz como se citó en Vega, 1944, p. 48).

Esos hechos antiguos se encuentran principalmente en el dominio de los grupos llamados "inferiores". Son actuales pero están grávidos de pasado; hablan de anteriores peripecias culturales del hombre. De ellos se desprenden sugestiones útiles para satisfacer circunscripta 
apetencia de conocimiento, y los especialistas, en cuanto aspiran a escrutar el pasado de la cultura humana, pertenecen a la gran familia de los historiadores. (Vega, 1944, p. 21)

Vale decir que el ámbito de lo popular está simbolizado por el atraso, el pasado, lo subdesarrollado; es una suerte de viaje en el tiempo, ya que podemos hacernos una idea del pasado histórico escuchando la música de los sectores subalternos actuales. Las primeras inscripciones de este tipo de ideología sobre lo popular tienen su punto de partida en el siglo XIX. Si bien el folklore de los hermanos Grimm o de Herder instalan la noción de creación espontánea del pueblo que cristalizará en el concepto de tradición y todos sus calificadores (anónima, oral, rural, no profesional, auténtica), el Romanticismo también propone la idea de los descensos, como forma de explicar sobre todo las relaciones entre las tradiciones, la de la cultura ("superior") y la del folk, que no es cultura. "Swift nos indica que las opiniones son como las modas que, como siempre, descienden de las personas de calidad a las de clase media y de ésta al vulgo, donde a la larga cesan y desaparecen» (Burke, 2014, p. 106). Pero es fundamentalmente en el paso del siglo XIX al XX cuando el cambio en favor de los "descensos" se consolida y hace más común. En un artículo de homenaje a Carlos Vega, el musicólogo estadounidense Gilbert Chase contextualiza las ideas del folklorista argentino haciendo referencia al también norteamericano Alexander $\mathrm{H}$. Krappe quien sostenía, sin dejar lugar a dudas, que las canciones folklóricas antiguas no eran de creación popular sino que tenían un origen literario, es decir un autor culto, del que no teníamos datos. En una argumentación que nos retrotrae al pensamiento positivista sobre las clases populares en Argentina, Krappe sostiene que el "hombre común", quiere decir el pueblo, padece de una suerte de pereza creativa o intelectual y por lo tanto prefiere adaptar lo ya hecho por los superiores que inventar algo nuevo. Lo cual estimula a Chase quien, indiferente a las connotaciones aristocráticas de Krappe, atisba un panorama futuro de la disciplina a partir de considerar lo positivo en estos antecedentes

Por lo tanto [...] la producción literaria se sumergirá, de las clases para la cual fue creada originalmente, hacia los niveles inferiores populares". Substituyamos la palabra "literaria" de la última frase por "musical" y tendremos [...] la explicación del hecho de que la música folklórica de Europa Central abunde en melodías que obviamente descienden de la música artística de ese período. ¿Es posible [...] comprobar científicamente la descendencia según las reglas de la evidencia histórica? Mi respuesta es, primero, que toda evidencia debe ser recopilada y estudiada objetivamente. El resultado dejará pocas dudas con respecto "a la constante interrelación entre las capas alta y baja y los préstamos al por mayor de los productos literarios (o musicales) por los últimos, del patrimonio de los primeros" (Krappe, 1929). Confío en que este estudio servirá para renovar el interés por un tema y un método que ofrece un fértil campo de investigación a la musicología histórica (Chase, 1967, p.48).

Por su parte, los folcloristas alemanes de comienzos del siglo XX sostenían que «la cultura de las clases bajas (Unterschicht) era una imitación anticuada de la de las clases altas (Oberschicht). Imágenes y temas, canciones e historias "penetraban" gradualmente utilizando su expresión- hasta el fondo de la escala social» (Burke, 2014, p. 106). Es esta una creencia central del método antropológico denominado histórico-cultural (Reynoso, 2006 , p. 78; Ruiz, 2015, p. 19), muy en boga a principios del siglo XX en pleno clima positivista. Si bien se promociona en confrontación con el evolucionismo antropológico, en la escuela histórico-cultural persisten múltiples nociones derivadas de las ideas de Herbert Spencer que, por ejemplo, John Rowbotham traslada, a fines del siglo XIX, al estudio de la música. Como en ese momento los descubrimientos arqueológicos comenzaban a revelar un pasado "primitivo" de los pueblos europeos, la creencia de los intelectuales y científicos, representantes del imperialismo triunfante era que la observación y el estudio de las sociedades colonizadas, consideradas por ellos "primitivas", permitiría deducir el pasado histórico europeo. Porque se creía que lo que musicaban los "primitivos" contemporáneos 
eran cosas de gran antigüedad. De hecho, Rowbotham creía que la de los primitivos actuales era exactamente la misma música que las sociedades modernas habían producido en etapas "inferiores" de desarrollo (Reynoso, 2006, p. 26). Si la música era un patrimonio universal, la diversidad sonora que los europeos encuentran cada vez en mayor proporción a medida que avanza su dominio del mundo no puede explicarse sino a través de una teoría que ubique «la circunstancia de tiempo en primer plano» (Vega, 1944, p. 24)

Los grupos superiores se definen por la posesión y el usufructo de los bienes más modernos [...] En el ambiente "inferior" subsisten numerosos hechos que el estudioso, desde su plano "superior", descubre con extrañeza, porque intuye en ellos inferioridad explayada, antigüedad sin extinción. Reconoce la inferioridad por comparación (Vega, 1944, p. 24)

Si bien en el método histórico-cultural hay posibilidad de considerar desarrollos históricos "paralelos", no aparecen en el planteo general las diversidades hechas de cosmovisiones, idiosincrasias, creencias, rituales y funciones diferentes y cambiantes a lo largo del tiempo y el espacio. De esta forma, la historia musical es una sola y los diferentes pueblos que manifiestan sonoridades distintas deben ubicarse como etapas sucesivas, nunca superpuestas, del vector histórico. Ya vimos en el primer capítulo la consideración diferencial que la musicología histórica hace de Oriente medio como un territorio que no puede salir de la Antigüedad y por lo tanto de la monofonía. Son creencias que se fundamentan en las premisas evolucionistas y etnocéntricas pero además en el estudio comparado de las músicas de Oriente y Occidente contemporáneas al momento de ser estudiadas. De esta suerte surge la atribución que le niega presente pero también historicidad a las músicas que quedan fuera de la modernidad occidental, ya que se las fija en una temporalidad cuasi mítica, en un pasado estático, del cual las culturas musicales no pueden salir. Este diferencial de evaluación etnológica de las músicas contemporáneas de sociedades distintas, es la base a partir de la cual considerar lo popular como parte del pasado, no del presente.

Hay que empezar por admitir la existencia de remotos orígenes musicales entre mamíferos no músicos. La horda se moviliza por imperio de sensaciones comunes y en el seno de la rudimentaria danza sorda la respiración jadea ruidos premusicales mientras el paso isocroniza los uniformes acentos elementales. El hombre se hace músico amasando gérmenes sonoros y rítmicos carentes de significación musical, y este período, el período de la "premúsica", debió durar mucho(s) millares de años. Una hipótesis así, más o menos variada, es lo poco que autorizan las más antiguas melodías de la humanidad, vivas aun en algunas tribus primitivas (Vega, 1985, p. 28) [Nuestro resaltado]

Lo cual se confirma en otros trabajos del mismo musicólogo: «Los comienzos de la música humana están vivos en la voz de las tribus más rezagadas» (Vega, 1977b, p. 3), en donde se nos explica además la importancia historiográfica de este procedimiento de juicio cultural, sobre todo para llenar las lagunas históricas en donde el positivismo de los documentos y las partituras no se atreve a internarse:

en los más lejanos y retardados hontanares, la ya menguada música de los primitivos se anima y conserva hasta hoy impresionantes datos inéditos sobre orígenes e itinerarios aptos para esbozar una prehistoria musical de hacia doscientos mil años rumbo a los tiempos oscuros en que el hombre, mamífero y desnudo, se hace músico haciendo música" (Vega, 1977b, p. 32) [nuestro resaltado]

Sin embargo, falta un paso más para convertir a lo primitivo en popular e incorporarlo a esa «prehistoria de doscientos mil años». El recurso aquí consistirá en la estratificación del inferior o, si se quiere, en distinguir diferentes clases o grados de inferiores o inferioridades. Mediante este procedimiento, se fragmenta la música, «toda la música de que disponen Europa occidental y sus zonas de influencia, incluso América» (Vega, 1944, p. 77) en tres: 
la música del superior, es decir la música culta que, como vimos, se distingue por su modernidad; en segundo lugar «esa música menos complicada, a base de pequeñas formas, para todos», ${ }^{146}$ que Vega ubica en la música de salón, es decir, una música ligera. Y por último, la música primitiva "siempre en las regiones que domina la cultura europea», es decir, dentro de la universalidad afirmativa y colonial. Nos ofrece incluso un esquema, por si aún tuviésemos dudas de la dirección excluyentemente vertical de todo el asunto:

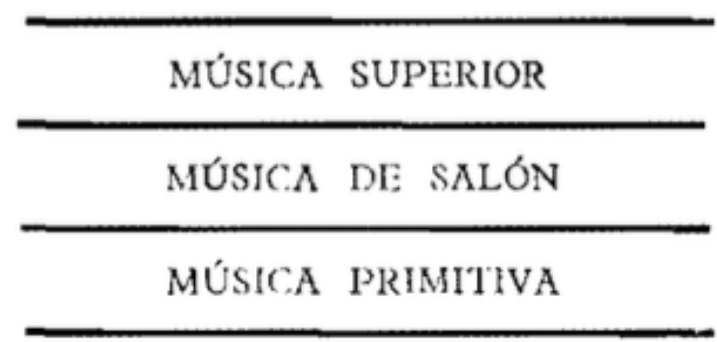

A continuación Vega nos aclara, como podrá haber detectado el lector minucioso, que la música folklórica no forma parte del esquema. Pero no debemos preocuparnos, pues la ley de imitación social nos socorre de inmediato

yo incluyo la masa principal de música folklórica en la gran corriente "universal" de la música de salón. Una y otra nos producen sensación distinta, pero no son distintas, esencialmente, genealógicamente hablando. Gran parte de la música folklórica es antigua música de los salones urbanos ya instalada y acomodada en el ambiente rural (Vega, 1944, p.77).

Para formular esta idea del origen de las músicas populares en las danzas de salón, Vega se inspira en Charles Lalo, al que llega a través de la lectura de Roger Bastide, quién en 1908 había formulado una mecánica similar mediante la cal las "danzas campesinas" eran bailes aristocráticos "pasados de moda" y lanzados a alguna lejana provincia (Citado en Pérez González, 2015, p. 45). En función de todo esto se operará la transmutación histórica de la música popular, en función de que «Un elemento musical, si no el cancionero folklórico íntegro, puede haber pertenecido al ambiente superior, cincuenta, cien, quinientos o más años antes» (Vega, 1944, p. 41). Es decir que la inclusión en la música de salón que otros autores denominan semi-popular- no significa revalorizar la música popular, aunque sea por asociación con la música "del superior". Todo lo contrario, al ser la música folklórica, que para los folkloristas es música "popular", imitación retardada de la música culta, supervivencia vigente de lo extinto en los sectores hegemónicos, es por definición, una música del atraso, la pervivencia un tanto curiosa y pintoresca de prácticas que se agotaron hace cientos de años.

Consideran que se trata de bienes culturales provenientes de una capa social superior, los cuales al ser desechados por ésta, por haber perdido vigencia y eficacia, quedan relegados y confinados a niveles inferiores. Desde el momento en que el hecho, una vez menoscabado, pasa a ser estudiado por el Folklore, le están confiriendo atributos de deterioro al fenómeno (Blache, 1981 p.37).

Así, el pueblo es testimonio presente del pasado de las clases ilustradas, es su espejo histórico que les enseña aquél estado semi-bárbaro que felizmente la sociedad moderna dejó atrás; en esos hombres desnudos, «mamíferos no músicos», en que este pensamiento convierte a las personas del pueblo en los necesarios salvajes precursores de la

146 La terminología de Vega, por momentos atemorizante, recuerda aquí muchísimo el pathos de la distancia presente en la discusión del trobar clus a la que hicimos referencia en el capítulo anterior ¿Será una coincidencia? ¿O podemos pensar, en inesperada adscripción vegiana, que los musicólogos de hoy son los aristócratas del ayer? ¿Serán los musicólogos supervivientes extintos y vigentes? 
modernidad triunfante. Es una proyección similar a la de esas personas de «origen humilde» que, una vez que triunfan en la vida, tienen la necesidad de contar y recordar a esos personajes de la niñez que testimonian el pasaje social de abajo hacia arriba de forma indiscutida. Hay una necesidad de introducir en los cuerpos las marcas de la diferencia. Por eso la terminología de Vega es tan cruda. Veremos que otros folkloristas se demoran en estas diferencias aún más, buscando en los cuerpos y sus marcas epidérmicas las "garantías" (Hall, 2010, p. 287) de la autenticidad, racializando así la cultura y el musicar.

Pero todavía más, la ley de imitación y el evolucionismo cultural de Vega hacen que el pueblo mismo sea definido por su atraso, de forma tal que podemos decir que es esa limosna cultural tardía lo que hace pueblo a los sectores subalternos. "Para la Ciencia del folklore, el pueblo es el conjunto de individuos que usufructúan las supervivencias [...] Es la posesión de las cosas folklóricas lo que convierte en pueblo a las gentes, y no a la inversa» (Vega, 1944, p. 53). Es importante prestar atención aquí al uso del término usufructo, que mediante un lenguaje "civil y comercial" nos deja en claro que, como decía Mayer-Serra, el pueblo no inventa nada. En todo caso es usuario, aprovecha, festeja o a lo sumo modifica -de forma no esencial- las cosas de otros, los bienes "del superior". En la definición de las metáforas espaciales de alto y bajo, superior e inferior, Vega intenta despegarse de sus connotaciones sociales (Vega, 1944, p. 31). Pero en el uso que hace de estas categorías se revela permanentemente que la condición de clase determina fuertemente todo el esquema de estratificación musical: el superior es directamente "la aristocracia" (Vega, 1944, p. 21-31-33). La "inferioridad" en cambio tiene relación con lo subalterno que además es sumiso, idealización del pueblo que procede del imaginario romántico del folklore, que Vega sin embargo pretendía discutir. «Las clases populares, en general, viven aspirando, esperando, imitando. Y el espíritu en sumisión, no crea» (Vega, 1944 , p. 84). Pero si bien esto basta para el folklorista como determinación de la inferioridad -aunque el factor temporal, como ya señalamos, tiene prioridad y por lo tanto, aún cuando las apariencias quieran engañarnos exhibiendo músicas demasiado complejas para ser "del inferior"- la sola posibilidad de que hayan sido descartadas por "el superior" será prueba suficiente de su inferioridad, y todavía más en consecuencia, de su antigüedad

Ya se ve cómo es posible determinar la inferioridad. Sin embargo, la inferioridad misma no nos interesa sino en cuanto implica antigüedad; y si todavía encontramos hechos que no parecen inferiores una vez analizados, su antigüedad resulta directamente, en última instancia, de que han sido eliminados del ambiente superior, como veremos más adelante (Vega, 1944, p. 25)

Los bienes que usufructúa el inferior deberían haber desaparecido, porque el modelo de Vega es fuertemente evolucionista (Ruiz, 2015, p. 18). Sin embargo parecen en una «vida póstuma», como supervivencias de lo que ayer fue culto. Los sectores populares anhelantes, acostumbrados a la espera, aguardan impacientes el derrame de las novedades del superior para imitarlas en una adopción al mismo tiempo jubilosa y melancólica. Queda claro el esquema social y la política que se desprende de este modelo conceptual sobre la música del pueblo. Como confirma el mismo autor, «superior e inferior, cada uno en su puesto y función» (Vega, 1944, p. 32). De la velocidad diferencial entre esa espera y la satisfacción del anhelo, es decir, la llegada de lo «ex-urbano/superior», dependerá el «ritmo del descenso» (Vega, 1944, p. 66). Como la velocidad de modernidad del superior, de innovación y cambio, no puede alcanzarse nunca por el pueblo, que siempre es atraso y por eso es inferior, entonces, casi naturalmente, existe «la diferencia de jerarquías en el orden cultural» (Vega, 1944, p. 34). Este diferencial del ritmo del descenso permite hacer compatible en música el evolucionismo de criterio occidentalocéntrico, básicamente ligado a la idea de armonía tonal, con el concepto de survival de la antropología difusionista. Así Vega propone un esquema de clasificación universal de las músicas que contiene ambas direcciones 


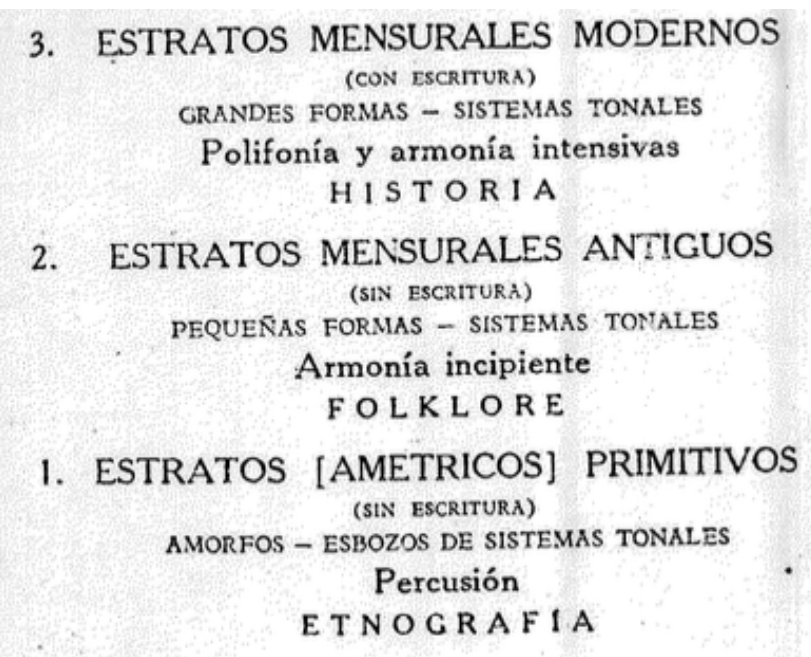

Gráfico con la clasificación universal de la música propuesta por Vega (1944, p. 92)

Como puede observarse, el esquema va del superior al más inferior, es decir el primitivo, a través de diferenciar el orden armónico, mensural y morfológico de la música. No hay ninguna mención al sonido o timbre, a las texturas, a las formas de producción sonora; de hecho la aparición del término percusión en el estrato "primitivo" no alude a la instrumentación y el sonido, sino a la ausencia de armonía, para lo cual Vega no encuentra un término más adecuado. Es un lugar común pensar que la percusión no forma parte de la música o habita en la frontera entre ésta y el ruido. Hay numerosas humoradas que incluso han llegado a publicarse (Barber, 1997). Pero Vega no está tratando de ser cómico en su esquema, sino que responde al más puro evolucionismo musical que proponía ciclos ternarios de desarrollo, y que en sus versiones más esquemáticas como la de Edward Tylor, se formula en base a tres niveles o etapas: salvajismo, barbarie, y civilización (Ruiz, 2015, p. 20; Reynoso, 2006, p. 29). Esto da lugar a teorías musicales varias que proponen matrices evolutivas también ternarias y en cuya progresión, justamente, se complejiza el ordenamiento de las alturas que va siempre del ruido no-tónico a la posibilidad de agrupar en sentido vertical varias notas en un acorde. A esto hemos dado en llamar armonicocentrismo (Eckmeyer y otros, 2017), que es una parte importante del etnocentrismo y occidentalocentrismo de la modernidad burguesa. Cuando decimos importante, queremos resaltar nuevamente que estas discusiones, si bien se dan en un campo que aparenta dedicarse al estudio de una actividad secundaria para la sociedad capitalista, reciben la atención y son testigos de debates muy apasionados y conflictivos, porque también en ellas se discute la hegemonía de la modernidad (Eagleton, 2006). El arte y la música son un argumento históricamente favorito de las clases hegemónicas para discutir la legitimidad de las distinciones (Bourdieu, 2002) y otorgar una materialidad pretendidamente incontrastable a la distancia social. Así, Rowbotham propone a fines del siglo XIX las etapas Tambor-Flauta-Lira, que comparte también con Edward MacDowell y podría traducirse en Ritmo-Melodía-Armonía. De hecho este último es exactamente el esquema que propone otro evolucionista como John Powell, añadiendo un cuarto estadío superior al que llama Sinfonía. El musicólogo británico Charles Hubert Parry, que a su vez es el primer presidente de la Folk Song Society -es decir, de la institución oficial de estudio del folklore musical- resume estas concepciones fuertemente etnocéntricas en una fórmula que ya estructura las que propone Vega: «Salvajismo, Folklore, Arte» (Reynoso, 2006, p. 29). Un paseo por el índice de su obra más conocida, The evolution of the art of music (Parry, 1896) no nos deja ninguna duda. Luego de unos "preliminares" en donde se discute la música "en lo rústico, los animales y los salvajes» sobreviene un capítulo teórico sobre las escalas, porque todo lo que vendrá en las próximas 350 páginas es la evolución del manejo armónico de las alturas: desde el folklore, que parte de «los salvajes» y es explicado en función de «características raciales», pasando por formas de «armonía 
incipiente» en la música vocal polifónica europea, hasta llegar al máximo de la evolución musical que se describe con términos como "tonal», «instrumental», «moderna», «expresiva», etc. (Parry, 1896, p. ix). En Estados Unidos otro musicólogo, Waldo Selden Pratt, en su History of Music de 1905 propone en base al evolucionismo las «divisiones naturales de la música», que representan el detalle o desagregado de las dos grandes secciones de la historia musical planteadas por este autor y que ya referimos como epígrafe del capítulo 1 (Cfr. pág. 48).

Las subdivisiones naturales son las siguientes:

A - Música No Civilizada: 1) Primitivos, entre los que figuran los que no han alcanzado el grado de organización artística; 2) Semi-civilizados, que incluye dos grupos diferentes: a) Pueblos que todavía existen, como los Chinos y los Hindúes, cuya música tiene un sistema pero no se relaciona con el nuestro. b) Pueblos antiguos, como los Egipcios, los Asirios y los Hebreos, que parecen haber tenido las mismas características de los anteriores, pero en el pasado.

B - Música civilizada: 1) Griegos y Romanos, incluyendo cualquier cosa que haya podido significar una base para el desarrollo de la música cristiana y medieval [...] 2) Medieval [...] 3) Moderna [...]

(Selden Pratt, 1905, pp. 18-19)

Como vemos el esquema básico se repite más allá de las elaboraciones más o menos detalladas de los autores. Todos convergen en estas ideas evolucionistas que centran en el desarrollo de la armonía tonal la base de su concepción histórica y del lugar que los diferentes pueblos y culturas tienen en ella; la cual, desde ya, es un producto y a la vez productora del imperialismo europeo que se extenderá hasta la posguerra.

Irma Ruiz (2015, p. 21), sintetizando varios de los esquemas presentes en los textos de Vega, propone uno en el que se lee de forma mucho más simplificada este lugar "del pueblo" que emerge de la combinatoria del evolucionismo y el difusionismo musicales.

Superiores

Pueblo ----- Folklóricos

Primitivos

Toda esta clasificación evolutiva impacta directamente entonces en la idea de antigüedad de los bienes folklóricos, que pueden ser por lo tanto supervivencias centenarias o milenarias, también en función del ritmo del descenso. Un caso de las de más larga duración, muy transitada por Vega, es la que nos ocupa directamente aquí:

Los estratos inferiores fueron antes los superiores; nada más que la aparición y presencia de un estrato superior determina la inferioridad del otro. La aristocracia de antaño se asemejaba al pueblo de hoy: el rey era analfabeto, creía en brujas, oía cuentos, comía con las manos, viajaba a caballo y aplaudía canciones como los arrullos actuales, a cuyo tipo pertenecieron las más altas expresiones de la lírica antigua. El arrorró argentino pudo haber sido obra de un rey-trovador. Sé por qué lo digo (Vega, 1944, p. 26).

\subsection{La tradición como fuente}

El método de Vega pareciera proponerse complementar al de la musicología histórica, fundamentalmente porque existe un área alternativa de gran interés para el folklorista que es, casualmente, la música de los trovadores. Gran parte del problema para la musicología, 
como hemos visto en capítulos anteriores, consiste en descifrar la notación sin mensuración alguna de lo poco que se ha escrito en partitura de las canciones del mundo feudal cortés. Testimonio de la ambigüedad de la notación son las versiones por momentos muy diferentes que hemos analizado en el capítulo anterior. Ante la tan particular situación de estos cancioneros, Vega querrá proponer un método que, imagina, clausurará la discusión, resultando así una transcripción objetiva de los manuscritos de trovadores. Más allá de cuestionar el accionar de los musicólogos que lo antecedieron en el estudio de las fuentes, señalando el carácter fragmentario de las investigaciones, la novedad metodológica de Vega emerge de la convergencia de sus dos pasiones. El estudio de las músicas de la campaña sudamericana, los bienes folklóricos en usufructo del pueblo, mientras las entendamos como supervivencias de lo extinto-superior, pueden considerarse testimonios vivos de la música de los trovadores. Si estos representaban una etapa de la Historia -por eso su estudio por la musicología histórica- el popular «es la misma etapa sobreviviente, sombra de cuerpo extinto» (Vega, 1944, p. 75). Mediante este recurso, deducido circularmente de su propia teoría del folklore, Vega piensa llenar todo aquello que falta en los manuscritos de los trovadores con los casos etnográficos recolectados en el trabajo de campo. Propondrá entonces considerar «la tradición como fuente» (Vega, 1981, p. 31). Podríamos considerar esta particular formulación historiográfica un caso de difusionismo primitivista explícito.

es tal la eficacia de la fuente folklórica, que [...] se produjeron aciertos capaces de causar estupor desde el punto de vista profesional [...] Nosotros hemos trabajado treinta años en los propios hontanares folklóricos de casi toda Sudamérica y el conocimiento de la música rural nos dio las leyes de forma que antaño obraron oralmente sobre esas notaciones medievales incompletas y muchos otros elementos de orientación. El folklore, en combinación con todas las demás fuentes históricas, contribuyó decisivamente a la lectura de los manuscritos antes ilegibles (Vega, 1981, p. 31).

Es muy evidente que aquí se transparenta una forma claramente eurocéntrica, armónicocéntrica, de pensar y escuchar la música. Es indudable que entre la recolección y clasificación de los interminables ejemplos etnográficos y el estudio de casi la totalidad de las fuentes manuscritas de los trovadores existentes en toda Europa, el sesgo del investigador comenzó a escuchar y ver analogías. Mientras el interés del trabajo sobre lo popular folklórico resida en lo melódico, en el orden de alturas, en la escalística -todas categorías de clasificación de los cancioneros populares en Vega-, intentar dar sentido por otra parte a una música cuya escritura apenas deja testimonio precisamente de las alturas y de ninguna cosa más; estando el método de trabajo atravesado por las categorías objetuales de la musicología, por la forma y la armonía; es casi lógico que comenzará a percibir similitudes, recurrencias, que en la ansiedad de la investigación fueran potencialmente las que aportaran la esperada confirmación de arriesgadas teorías. Vega habla todo el tiempo de "estilos», de "contorno estilístico», de "melodía»", relacionando todo esto con la "comparación» y el método etnológico (Vega, 1977b, p. 26). Lo que nos resulta importante resaltar entonces es que la conexión que Vega produce entre la música medieval cortesana -como hemos visto, fuertemente antipopular- con la música popular argentina y suramericana, revela el fuerte componente antipopular del folklore, que dice abocarse al estudio de la música popular. De lo cual podríamos inferir que existe una sofisticación en el folklore que potencia lo postulado por la musicología histórica, por un lado al introducir sus conceptos extraños e intrusos, anómalos (Acosta, 2006) en las músicas populares de buena parte del mundo; por otro, al crear un repertorio antipopular, superviviente, en esencia culto o superior, que toma el lugar del pueblo, lo desplaza y lo vuelve a expulsar, por segunda vez, de la historia musical.

Si lo que faltaba en los manuscritos medievales era principalmente la indicación de las duraciones, podría ser muy bien que estas normas de forma -fórmulas rítmicas fijas-, 
conservadas en Sudamérica por antiquísima práctica oral, fueran la base invisible de aquella primitiva escritura de altura sin valores (Vega, 1985, p. 5)

El sesgo eurocéntrico en el folklore de Vega es explícito, ya que en la música folklórica latinoamericana éste no ve prácticamente ningún aporte indígena, mientras que el aporte europeo representa el corpus principal de la música popular (Vega, 1944, p. 80), claro está, por descenso. Tampoco hay en las músicas populares latinoamericanas contribución alguna de las culturas africanas presentes a partir del tráfico esclavista, más allá de ciertos modos que podríamos llamar "interpretativos" y que Vega denomina "de estilo». Aquí también se le niegan al "africano"147 las dimensiones privilegiadas por la musicología europea, como la composición y el dar forma

Los negros [...] "vitalizan el ambiente americano con imponderable inyección de temperamento, de aptitudes, de maneras de hacer"... No de formas [...] No se socializó en América ningún baile cuya forma sea o haya sido híbrida de español e indio o negro (Vega, 1977, pp. 9-10)

Hay una frontal negación de todo mestizaje y transculturación. Vega de hecho utiliza el término híbrido, pero no hay que entusiasmarse fácilmente y pretender una anticipación del concepto introducido por García Canclini, ya que le otorga una significación muy diferente. Vega utiliza el concepto para describir los procesos en los que al orden temporal lógico -el descenso de los urbano superior a la campaña inferior- se le suma la confluencia de otros aportes externos, por ejemplo por contacto directo o ascenso de lo primitivo. Son confluencias de esencias culturales concebidas en tanto homogéneas. Es decir, lo contrario a la hibridez.

Lo racializado y eurocéntrico del ritmo del descenso hace que lo que se aleja de Europa sea todavía más "inferior", razón por la cual Vega intenta proponer que el folklore sea un estrato "medio", entre lo primitivo (lo no europeo) y lo "superior": "En relación con el ciclo superior, lo folklórico constituye el pasado inmediato; lo etnográfico, el pasado remoto» (Vega, 1944, p. 42). Los bienes extintos y vigentes en lo primitivo son todavía más antiguos, más demodé, más eliminados y superados que los del folklore. El atenerse con tozudez al propio marco teórico -que emerge, insistimos, de la notación y el armonicocentrismo-, el aferrarse a él hasta las últimas consecuencias e insistir en que "es ley sociológica» (Vega, 1977b, p. 24), puede quizás explicar la siguiente formulación de este autor, inverosímil para el más modesto practicante de una murga de barrio, de una milonga o de cualquier carnaval.

A lo largo de las costas del Atlántico, desde Norteamérica hasta la Argentina, vive un cancionero rural y suburbano de humilde factura, carácter penetrante y gran éxito social. Varias veces ha ascendido al plano superior de la "mesomúsica" con los nombres de ondú, modiña (binaria) ,samba, danza, entre otros muchos, y se ha colocado en los programas universales del baile con los nombres de habanera, maxixe, tango argentino, y con el de algunas danzas norteamericanas. Este cancionero -que al lado de su estilo principal admite otros y forma un grupo de estilos- tiene una sola forma de frase (la del $4 \times 8$ ), una sola forma de período y una sola especie que cambia de nombre. Le atribuyen origen africano. Se encuentran en un manuscrito español del siglo XIII varias muestras, sin duda de ascendientes o de familiares de las americanas. Como una de esas canciones progenitoras aparece escrita en notación mensural pura -prodigio no igualado en la Edad Media- no hay nada que poner en duda (Vega, 1977b, pp. 26-27).

Lo que Vega está comparando son arrullos sudamericanos con el Laudario di Cortona, un manuscrito medieval de música paralitúrigica o devocional, sacra, canciones que se llaman

147 Insistimos en que Vega, como buen positivista, nombra siempre en masculino y singular, sean condiciones sociales o "razas". 
laude, de origen popular pero luego estilizadas, como el carol inglés, el noël francés o el villancico español. Vega llega a este manuscrito pues una de las hipótesis sobre su escritura, cuyos datos ciertos se desconocen, sostiene que es obra de trovadores occitanos emigrados a Italia luego de la cruzada de los albigenses y la derrota de los nobles aquitanos a manos del rey de Francia y el Papa. Así que podemos considerar a esta música equivalente a la de los trovadores que analizamos anteriormente, con una finalidad levemente diferente como es la adoración religiosa y ya no el amor cortés. Lo cual incluso profundiza la necesidad de estilización de los aspectos sonoros populares relativos a la danza y lo corporal.
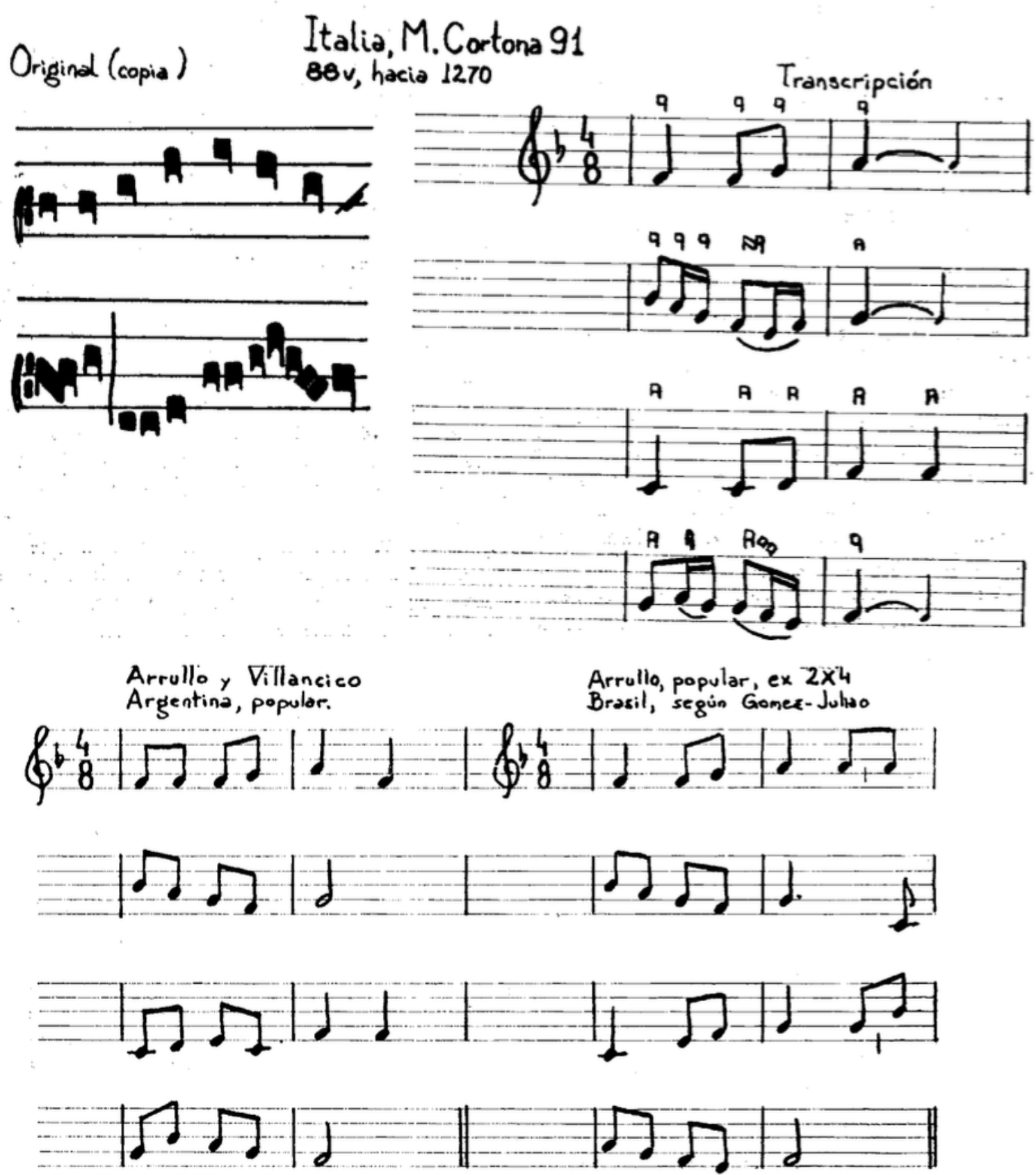

Transcripciones y gráficos en las que Carlos Vega (1977) concluye que existe una identidad por descenso entre la música trovadoresca del Laudario di Cortona y los arrullos sudamericanos, que además son compatibles con las músicas populares de la Habanera, el Tango, o el Maxixe.

Si bien a primera vista las transcripciones aportan cierta similitud del contorno melódico, no debemos entusiasmarnos demasiado, ya que lo que está jugando muy fuertemente en la 
imagen de homologación es nuestra creencia en que la notación sintetiza la identidad del fenómeno musical, creencia derivada de la musicología histórica y la inscripción moderna de la música culta como objeto anotado. Es decir que, tanto para el caso de la música medieval como el de las músicas populares latinoamericanas, lo que se pretende es analizar sus semejanzas a partir de herramientas que no pueden mostrarnos aquello que en estas músicas es central, y forma parte justamente del musicar y sus discrepancias participatorias. Hagamos un ejercicio escuchando un arrullo tradicional grabado por un equipo de extensionistas universitarios dirigidos por la Licenciada Verónica Benassi, en la Provincia de Buenos Aires. ${ }^{148}$ Es la voz de Ramona Toloza, a la que se suman una sonorización y un bombo, como arreglo realizado por alumnos de la Facultad de Bellas Artes de la UNLP. Observemos comparativamente la partitura del «arrullo popular argentino» que ofrece Vega y notaremos las enormes distancias que separan a la notación de la ocasión musical en que se canta el arrullo, si bien la "melodía" parecería coincidir. Lo que escuchamos es la voz de una madre o abuela "de barrio", que participa en la grabación para registrar las variantes en las interpretaciones de los arrullos más conocidos en la zona. Es decir, en terminología folklórica, como la de Vega, es una "informante" que garantiza la autenticidad de las "especies" muestreadas. Sin embargo nada de lo interesante que tiene el arrullo reside en esas pretensiones ni en lo que registra la partitura, si es que registra algo. Es en la sonoridad de la voz, en los arrastres, las inflexiones de la voz, las pequeñas discrepancias rítmicas, pero también en las oscilaciones de alturas que abarcan una banda de frecuencias continua, no escalar y muy amplia; en todo esto reside lo hipnótico y conmovedor de estos arrullos. Las "notas" no son lo importante, porque no son tales. El "compás" de 4x8 que para Vega es central en su comparación, casi que preferimos olvidarlo, pues da pena que se rompa el hechizo de la nana con sólo imaginar lo que la cuenta y la regularidad acentual le impondrían al canto. Hay grabaciones más famosas y hasta televisadas de cantos de cuna, como la del Arrorró Herreño ${ }^{149}$ de Canarias, grabado por la famosa Valentina Hernández, la de Sabinosa. En este, más aún, lo estremecedor se demora en las alteraciones y fluctuaciones entre las notas, que nunca están fijas como nos impone la partitura. Además lo más identitario y característico no es el motivo, que se disuelve en una red de variaciones circulares que desdibujan sus contornos e impiden pensar el "período", sino el timbre de la voz de esta anciana, rasposo y con más "ruido" que armonía. Incluso podemos ir más lejos y escuchar un arrullo de los Selk'Nam ${ }^{150}$ fueguinos registrado de boca de Lola Kiepja, una de las últimas representantes de esta nación indígena sometida a todo tipo de vejámenes y finalmente exterminada. ${ }^{151}$ En este caso directamente ya no hay "notas", nada que se pudiera anotar entre pautas de pentagrama. Sin embargo lo que suena recuerda mucho a las nanas "de barrio" que escuchamos antes, y el sonido de la voz es muy similar al de "la de Sabinosa". Y de las tres podemos hacernos una imagen que retrotrae a cualquiera que fue arrullado de niño, aunque las palabras sean diferentes o estén incluso en idiomas distintos.

Pero escuchemos ahora lo que para Vega resulta la fuente originaria de estos arrullos, que por supuesto son supervivencias-por-descenso-de-músicas-del-superior: es la canción Chi vol lo mondo despreççare, ${ }^{152}$ como dijimos, del Laudario di Cortona. La versión que

\footnotetext{
148 El ejemplo 32 puede escucharse aquí https://youtu.be/o5YxBA-mhAs

149 El ejemplo 33 puede escucharse aquí https://youtu.be/AS61fMLZFNQ

150 El ejemplo 34 puede escucharse aquí https://youtu.be/bWDYy_OPf4Y

151 Anne Chapman calcula que la población Selk'nam era de unos 5000 individuos antes de 1880. En 1900 comienza la intervención "blanca" del territorio, y la población desciende a 500. Para fines de la década de 1970, en que Chapman hace su investigación quedaba una sola mujer Selk'nam (Chapman, 1967). Este es otro tipo de "ritmo del descenso", que expone con más crudeza la modernidad burguesa que las partituras de Vega.
}

152 El ejemplo 35 puede escucharse aquí https://youtu.be/ak55sg6Ydml 
elegimos, del Ensemble Micrologus (1999) comienza con la irrupción de unas matracas, que como vimos en la secuencia de la película de Bergman, eran de uso común por parte de los grupos religiosos mendicantes y procesionales que participan del mundo popular subalterno medieval. Es un llamado para prestar atención a lo que se nos va a cantar. Se nos "despierta" a la música y se enfoca nuestra escucha, buscando máxima atención. Pasado esto, la melodía de la voz, es cuanto menos muy contrastante en la sonoridad, que en este caso sí busca ser precisa con las alturas, que a su vez son fijas, es decir son "notas". Es un sonido mucho más tenso, decidido y proyectado que cualquiera de los arrullos que escuchamos. Pareciera querer llenar el espacio en el que irrumpe, aprovechando los rebotes y reverberaciones que amplifican todavía más el canto. La emisión es nasal, muy diferente a la de un arrullo, por más que el o la cantante sea un aficionado. Sencillamente porque una emisión nasal necesita mucho caudal sonoro. El ritmo no es medido, pero se advierte cierta recurrencia como de una suerte de célula o patrón, tal vez una decisión de los intérpretes a partir del conocimiento de ciertas técnicas rítmicas de la música culta bajomedieval. No hay el mentado compás de " $4 \times 8$ " pero, si se quiere, existe una resultante perceptual que nos hace escuchar una especie de compás irregular, aunque esto es seguramente una distorsión de nuestro oído métrico contemporáneo. Más adelante, cuando aparece el coro respondiendo al solista, todavía más se nos revela una intencionalidad sonora penetrante y estridente. Porque es un canto devocional, que expresa un convencimiento, un conjunto de creencias. Un posicionamiento que no se canta a media voz.

Hay una canción de cuna que sí suena como la escrita por Vega. Pero no la canta una madre ni un padre, sino un cantante lírico, y es parte de las Cinco canciones populares argentinas opus 10 de Alberto Ginastera, compuestas en 1943. Si la escuchamos, ${ }^{153}$ efectivamente podemos comprobar que el motivo melódico coincide nota por nota con lo pautado por Vega, a pesar del fondo un tanto expresionista y atonal que, a modo de gracia armónica, escribe Ginastera para rodear de algún aura misteriosa lo que no tiene ningún misterio. Nadie puede dormir con la canción de Ginastera, pero tal vez esto es otro aspecto que la acerca al Chi vol lo mondo despreççare que busca todo el tiempo mantenernos despiertos.

Volviendo al ejemplo de Cortona, consideremos ahora el texto de algunos de los versos del comienzo, en una traducción aproximada:

La morte è fera e dura e forte, runpe mura e passa porte: ella è[ne] sì comune sorte, ke neun[o] ne pò campare/ Tutta gente cum tremore vive sempre cum gran tremore, emperciò ke son securi di passar per questo mare/ Papa collo 'nperadori, cardinali e gran signori, iusti et sancti et peccatori fa la morte ragualliare.

La muerte es feroz, brutal y fuerte/ derriba muros y abre puertas/ la muerte es un destino común para todos/ al que nadie puede escapar. Todos viven temblando de temor, porque están seguros de que cruzarán ese mar/ El Papa con el emperador, los cardenales y grandes señores, los justos, santos y pecadores; a todos la muerte los convierte en iguales

¿Por qué alquimia extraña de la racionalización de lo musical hemos terminado pensando que una canción que nos habla del temor a la muerte y el destino fatal de toda la humanidad pueda asociarse con el paradigma de la ternura y el máximo conjuro a todos los temores, como es un canto de cuna? ¿Hasta dónde nos puede llevar la fiebre por las herramientas analíticas y el núcleo conceptual de la musicología histórica, que terminamos confundiendo una horda de militantes religiosos con una madre tratando de dormir a su bebé? Pero aún más, y sobre todo si consideramos el tercer verso, podríamos dudar de si esta canción pertenece efectivamente "al superior", ya que expresa una actitud muy

153 El ejemplo 36 puede escucharse aquí https://youtu.be/PgzxnazQJEY 
compatible con las ideas en torno al carnaval y el mundo popular subalterno que comentamos previamente. Incluso si escuchamos una segunda versión, esta vez por el grupo La reverdie 154 (1994), la sonoridad general se acerca a las recreaciones de las ocasiones musicales de juglares y del mundo popular que analizamos en capítulos anteriores, con el uso de muchos instrumentos, y una pulsación rítmica incesante vinculada con una concepción orgánica del ritmo. En las notas al disco que acompañan esta grabación el conjunto especifica que sus criterios interpretativos se basan en las investigaciones de Blake Wilson (1992), las que han reorientado el estudio de las laude, acercándolas al universo que emerge en las ciudades italianas de fines de la Edad Media, las comunas, en las cuales las imbricaciones entre las clases sociales, fundamentalmente entre la burguesía y los sectores subalternos, producen numerosos préstamos y transculturaciones en diversos géneros. Uno de ellos es la lauda, canción popular más tarde tomada por las confraternidades y corporaciones burguesas, las que luego la anotan en partitura. Es un proceso que sin dudas introduce fuertes cambios en la música. Pero al menos debiera llevarnos a relativizar la filiación de la lauda con los trovadores y el ambiente cortesano feudal, que aquí no tiene ninguna injerencia. Si es cierto que algunos trovadores huyeron para asentarse en Italia, cabría preguntarse cuántos de ellos eran en realidad ministriles y en qué medida se reconvirtieron en función de las coordenadas políticas y sociales del entorno urbano italiano. Veremos en próximos capítulos que precisamente por esta época, el siglo XIII, emerge un nuevo tipo de profesión musical, heredera del mundo popular medieval y asociada con la burguesía, que será justamente la de los "ministriles urbanos" que estudiaremos en el capítulo 5.

Vega, no obstante, toma la música de la lauda en función de considerar su condición de escrita -no importa cuándo ni cómo, si es parte del proceso compositivo o si es un registro de una ocasión musical performativa- reproduciendo la dicotomía moderna y afirmativa entre la idea de "tradición escrita" frente a la de "tradición oral", que a su vez se asocian con el "superior" o la música culta y el "inferior" popular. Es tan variable históricamente la condición de la escritura musical, tan distintos sus objetivos e intereses, tan ricamente diversos sus procedimientos, que reducirlos a la creencia de que todo lo escrito responde a una unicidad estética y social "superior" es sólo comparable con la homogeneización que el folklore pretende al considerar a la cultura popular en términos de origen y pureza. Vega comete ambos reduccionismos. Un pensamiento atravesado de punta a punta por la ideología del estilo que, ya vimos, es esencialista y encierra de forma metonímica la dinámica musical.

La melodía del códice italiano de hacia 1270 reaparece en los campos del Brasil y de la Argentina a setecientos años y a cerca de 10.000 kilómetros. La semejanza de las versiones, superando los términos generales de la analogía estilística, desciende hasta la minucia particular de tal modo, que hasta nos parece una exageración, casi una falta de respeto al tiempo y al espacio (Vega, 1977b, p. 30).

¿Es realmente lógica la "lógica interna" de los estilos musicales, o en verdad su ausencia de toda lógica es la más firme evidencia de su afirmatividad, de su sinsentido, que se nos revela como tal cuando emerge a la superficie el objetivo de hacer creer en el orden consensual del mundo y en la naturalidad de la "ley sociológica" que encumbra al "superior"? Para la cultura afirmativa de la burguesía moderna, la muerte y la vida son lo mismo (de allí su despliegue de biopolítica y necropolítica). Para el mundo popular subalterno, no lo son. El carnaval, en toda su inversión, jamás superpone la vida y la muerte. La escena -y toda la película- de Bergman que continuamos referenciando lo deja muy en claro. Pero para la musicología y el folklore afirmativos es preciso neutralizar lo que de subversivo tiene, incluso, un canto de cuna en la voz de una mujer del pueblo. Tal vez

154 El ejemplo 37 puede escucharse aquí https://youtu.be/7gg3Ca-5ylo 
porque sintetiza varias capas de la opresión de la cultura moderna que también es patriarcal y es conducida por la necropolítica.

Es tan explícitamente europeo el pensamiento musicológico de Vega, tan atravesado por las categorías analíticas de la musicología afirmativa, que mediante idéntico procedimiento se propone resolver un problema planteado por el musicólogo francés Pierre Aubry en torno al jeu-parti, un género de oposición y disputa entre trovadores, similar al tensó155 (Taruskin, 2005a, p. 159) de Aurenga y Bornelh que analizamos en el capítulo 2. Aubry se preguntaba en 1910 a cuál de los trovadores que intervienen en la tensó hay que atribuirle la autoría de la música. Es una pregunta que expone frontalmente el núcleo afirmativo de la musicología, en la medida en que una de sus principales preocupaciones -sino la principal- reside justamente en instaurar de forma estable y objetiva la relación entre el personalismo del autor y la objetualización de la obra. Vega intentará saldar el problema afirmando que "ha visto" un jeu-parti y que, en virtud de ello, puede atestiguar que es el primer cantor el que propone una melodía, una especie de recitativo libre, que luego su contrincante adapta y repite. Para sumar pruebas, Vega cita a Ventura Lynch y le hace decir que también presenció un jeu-parti. Todo este flagrante anacronismo, que a simple vista recuerda algunos célebres comentarios de superficiales conductoras de televisión, es explicable únicamente por la teoría del descenso de los bienes: «En la Argentina, a diez mil kilómetros y a setecientos años de su fuente, el jeu-parti está vivo» (Vega, 1985, p. 27). Incluso, que se trata de la supervivencia de lo mismo es para el autor tan groseramente evidente, que su palpable y audible realidad -que podemos imaginar ensordecedora para Vega- produce a la disciplina folklórica. "Es esta persistencia de las cosas mentales y materiales, son estos bienes tradicionales grávidos de pasado, los que en la segunda mitad del siglo XIX reclamaron la organización de dos nuevas ciencias, la Etnología y el Folklore» (Vega, 1985, p. 27). En este sentido, el descenso de los bienes es casi una derivación de la naturaleza humana, por eso "ley sociológica", y en tal medida, la aparición del folklore académico es un gesto de abnegación epistémica, más que la construcción de estos discursos aristocráticos sobre el mundo popular subalterno. Cada palabra, cada comparación, cada analogía en Vega es un gesto de afirmatividad de la cultura burguesa moderna.

Para convencernos, el folklorista sustrae de lo que muestra la materialidad sonora, es decir, oculta las relaciones materiales que se presentan en el musicar y sus discrepancias participatorias. Por eso, como buen musicólogo, nos ofrece partituras en las cuales debemos buscar las correlaciones en las semejanzas de estructura formal y fundamentalmente motívica. De esta forma, un jeu-parti del Rey de Navarra, Teobaldo I, a la vez cuarto Conde de Champaña, más conocido en la literatura como "Thibaut" y apodado "el trovador", es el antecedente "superior" de una milonga grabada por Vega en la campaña argentina, extraída, suponemos, de las manos trémulas y la garganta ronca de algún peón rural "inferior". Veamos las partituras de Vega:

\footnotetext{
155 Si bien el Jeu-Parti es caracterizado en los tratados de la época como un debate en que específicamente un trovador da a elegir dos soluciones a su contrincante, para así repartirse los bandos de la disputa, en las fuentes documentales ambos términos (Jeu-Parti y Tensó) aparecen indistintamente. "Los trovadores y troveros no sólo usaron ambos términos de esta forma, sino que tampoco distinguieron entre ambos géneros» [Not only did the troubadours and trouvères not use the two terms as described, they also did not distinguish between the two genres] (Van Der Werf, 2001) [nuestra traducción]
} 

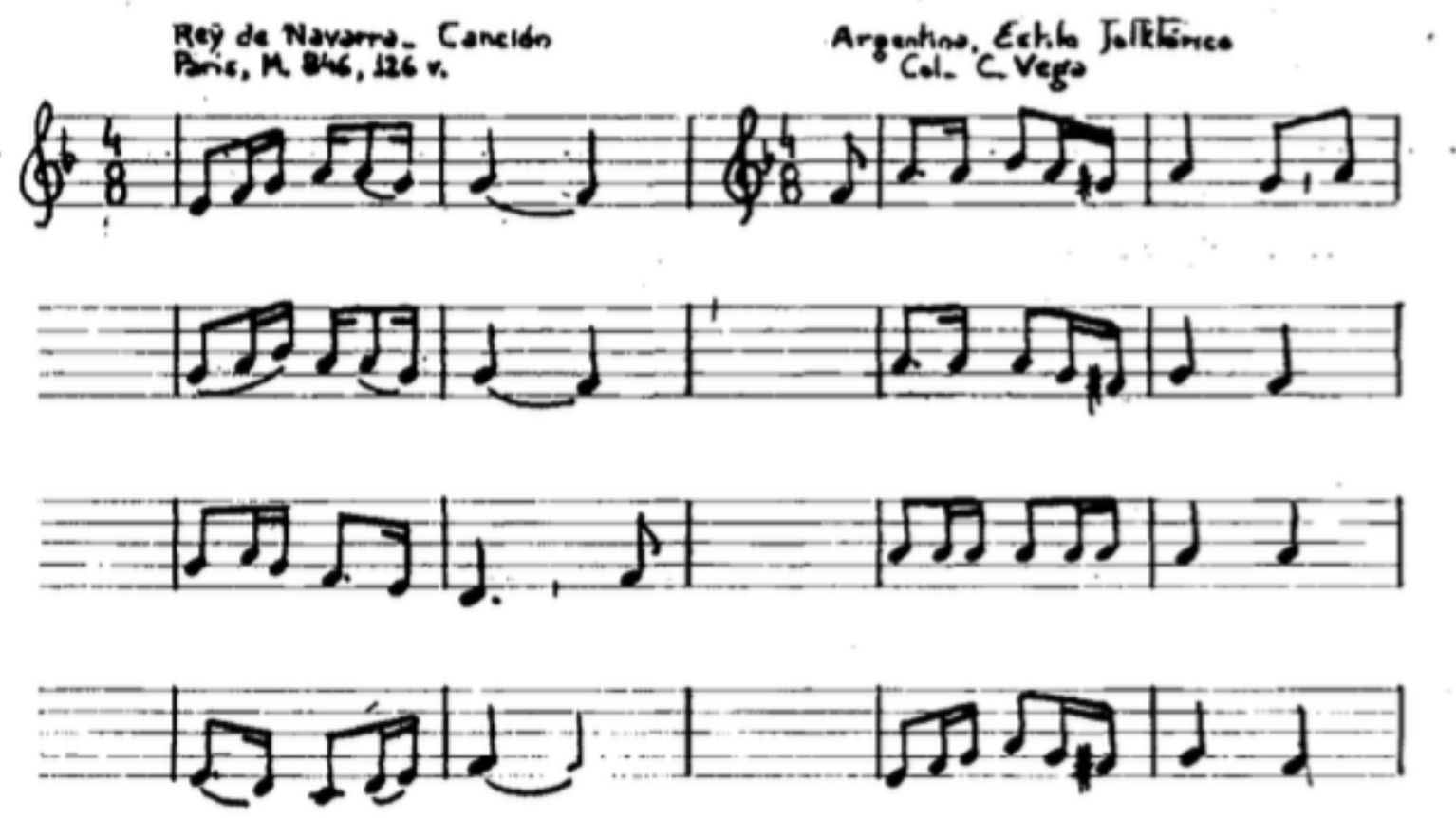

Recordemos que Vega propone una forma de interpretación del ritmo de las músicas de trovadores que intenta superar a la de los musicólogos y paleógrafos medievalistas europeos. Por lo tanto es importante que consideremos el ritmo y en parte también la presentación de las alturas como una transcripción original de Vega. Para comparar, aquí mostramos el manuscrito, que aparece en el folio 126 v. del Chansonnier Cangé, MS. Fr. Bn. 846. ${ }^{156}$

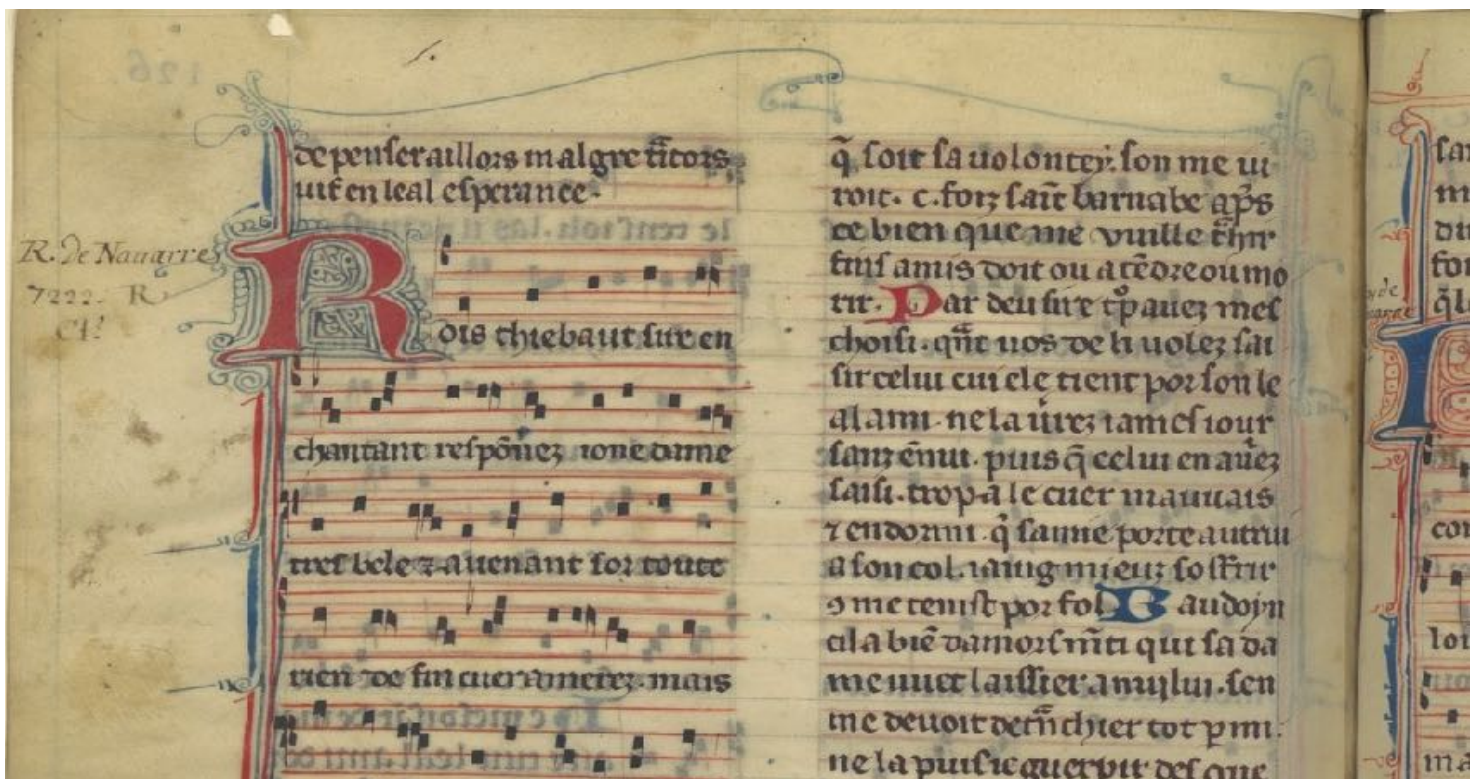

Como podemos apreciar visualmente, hay cierta literalidad en el traspaso de las notas desde el manuscrito a la transcripción, pero el ritmo es un "añadido" de Vega, si bien

156 El manuscrito completo puede consultarse aquí https://gallica.bnf.fr/ark:/12148/btv1b6000950p/f284.item 
podemos considerarlo como una interpretación muy informada históricamente, resultado del estudio de numerosísimos manuscritos y cancioneros. Es decir, no proponemos considerarlo falso, sino en todo caso, pensar que cualquier tipo de propuesta rítmica (y sonora en general) sobre el manuscrito, procede mediante el llenado de "lagunas" cuya información se obtiene de otro tipo de fuentes, históricas o no.

En el capítulo anterior, todas las versiones de juglares y trovadores que escuchamos hacían este tipo de procedimientos todo el tiempo. Lo cual no las hace falaces o, como pensarán musicólogos y folkloristas, inauténticas. Por el contrario, todo tipo de interpretación parte de la consideración de alguna información histórica o actual que guía los criterios a la hora de hacer sonar estas músicas tan antiguas. Lo que estamos considerando aquí es cuáles son los procedimientos específicamente utilizados por Vega, y cuán "objetiva" o crítica (Taruskin, 1996) pretende ser su posición interpretativa. Porque esto nos devolverá su forma de concebir la música popular, que es lo que estamos estudiando.

Pues bien, nuevamente hagamos una breve comparación, pero ahora escuchando. Esta es una versión instrumental157 de la melodía de Thibaut que cita Vega, hasta donde pudimos constatar, la única publicada en fonograma158 por Gregorio Paniagua y su Atrium Musicae de Madrid, en el LP de 1979 denominado justamente Thibaut de Champagne, reeditado en CD por Harmonia Mundi (HM 1016). Si escuchamos la música observando el manuscrito, veremos que hay muchas más "licencias" que las que aparecen en la transcripción de Vega, que podemos entender como ornamentaciones alrededor de la melodía principal, la que no obstante mantiene su contorno. Lo que sí sorprende es el desacuerdo en el ritmo entre la versión sonora y la transcripción. Sobre todo porque lo que suena es ternario y Vega propone el compás de 4x8 que, rememoremos, es su indicador de identidad para probar el descenso. Además, como en otras músicas de trovadores que ya analizamos, el ritmo es muy fluctuante y de hecho no cabría aquí tampoco hablar de compás, pues si bien existe una célula o patrón ternario estructurando el andar del ritmo, no hay regularidad acentual como para pensar en un esquema métrico. Ni que hablar si consideramos el ritmo que proponen los instrumentos de percusión y el mismo arpegio de fondo de las vihuelas.

Recordemos, sin embargo, que Vega nos propone la melodía de Thibaut para que consideremos que «sigue viva» en la campaña argentina, lo cual a su vez y utilizando «la tradición como fuente», corroboraría la transcripción rítmica del manuscrito. Es decir que Vega compara abiertamente una melodía anotada en notación cuadrada medieval con una payada, más específicamente, una payada de contrapunto, que sería el equivalente, o mejor, la supervivencia extinta vigente, del joc-parti francés. Antes que anteponer otros argumentos que emanan del sentido común, tengamos en cuenta un aspecto muy importante de la payada, cualquiera sea su tipo: es creación repentista, es decir, es una práctica improvisatoria, de recreación instantánea a partir de un repertorio de fórmulas musicales y poéticas.

La payada está basada en la creación repentista [...] la payada de contrapunto o desafío entre dos improvisadores, ocasionalmente entre tres. En el área rioplatense se canta actualmente por milonga, con acompañamiento de guitarra; también fue muy popular la cifra [...] La práctica del improviso está documentada para los siglos XVIII y XIX [...] canto masculino a solo, acompañado de guitarra, y específicamente al canto improvisado (Fornaro, 2010, p.79)

Si de comparaciones se trata, esta descripción estaría mucho más cerca de los juglares que de los trovadores, lo cual coincide con la mirada despectiva de los conquistadores:

157 El ejemplo 38 puede escucharse aquí https://youtu.be/7yO1WFuX8VQ

158 Según la base de datos del portal medieval.org consultados el 9-3-2019 
«Se hacen de una guitarrita que aprenden a tocar muy mal y a cantar desentonadamente varias coplas que estropean y muchas que sacan de su cabeza» [...] Alejandro Gillespie, prisionero durante las citadas Invasiones Inglesas, para quien «la poesía parece el genio conductor de las clases inferiores en esta parte de la América del Sur, pues al pedírsele a cualquiera que toque la guitarra, siempre la adaptará a estrofas improvisadas y convenientes, con gran facilidad» (como se citó en Fornaro, 2010, p. 80)

Como señala Fornaro, la payada, en tanto música del gaucho, se asimila a estados de barbarie y es claramente producto de las clases subalternas, que además son mestizas y reproducen todo el repertorio de lo que la modernidad europea rechaza en su proyecto civilizatorio: el nomadismo, la desobediencia del orden del tiempo y el espacio (Waisman, 2005), la falta de sujeción a las relaciones de trabajo y de propiedad. Por eso «El gaucho, producto del mestizaje entre españoles, portugueses y culturas indígenas de la región, es considerado la amenaza del proceso civilizatorio» (Fornaro, 2010, p. 80). Comentando la obra estigmatizante hacia el gaucho de Esteban Echeverría o Hilario Ascasubi, entre otros ilustres argentinos, Daniel Belinche dice que «el liberalismo argumenta la analogía entre el animal carneado y el gaucho carnicero, con cuchillo en mano, pelo revuelto, camisa, chiripá y rostro embadurnado de sangre» (Belinche, 2010, p. 7). Es que los gauchos son «todo lo horriblemente feo, inmundo y deforme de una pequeña clase proletaria peculiar del Río de la Plata» (Echeverría, 1979[1871], p. 11). Prestemos atención, puesto que luego el nacionalismo y el folklore convertirán a esta antítesis de la civilización moderna en emblema de la cultura nacional, cuando se necesite erigir alguna tradición que oponerle a las nuevas «negras rebuscotas» salvajes que provienen, a fines del siglo XIX, de las orillas europeas. Pero por el momento, los gauchos son salvajes, no puede convertirse en "pueblo", y por eso Sarmiento, entre tantos otros, sueña con exterminarlos.

En algo se parece este discurso liberal a todas las protestas e impugnaciones que la figura del juglar sufre de parte de las clases hegemónicas medievales. Y recordemos que su mayor agravio es estar fuera de la sociedad, que viene a ser la definición misma del bárbaro. Pero la música no es la misma y mucho menos podríamos pensar en hacer derivaciones estilísticas o formales como pretende Vega, y que es precisamente la razón por la cual vincula a los payadores con los trovadores, y no con los juglares. Completemos de todos modos la comparación del joc-parti de Thibaut que describimos antes, escuchando algún estilo (qué casualidad que se llame así) similar al que propone Vega para la establecer la analogía. Lamentablemente, el folklorista no especifica cuál es el estilo grabado por él en campo, por lo que no tenemos la grabación de la transcripción que copiamos más arriba. De todas formas, para establecer algunos puntos de referencia, escuchemos algunas grabaciones que Vega podría haber conocido y son aproximadamente de la misma época del estilo referido.

El primer caso es Cuando el mundo se formó, ${ }^{159}$ cantado por Wenceslao Núñez y grabado por el colega y amigo de Vega, el uruguayo Lauro Ayestarán, en la ciudad de Minas, en 1946. Es una de las conocidas como "décimas de la nada», versificaciones que remedan la creación y en cuyo relato el cantor se propone como un ser atemporal y ocupa el lugar de Dios, posición insumisa si las hay, pero que además remeda las actitudes del carnaval dentro de las cuales es frecuente que aquellos que provienen de los estamentos sociales más bajos ocupen roles dirigenciales o de gran poder en la sátira del mundo popular subalterno. Así que no debe resultarnos extraño que el gaucho bárbaro se proponga creador del mundo, pues en realidad está creando ese «segundo mundo» de Bajtín. En cuanto a lo sonoro, la grabación nos muestra nuevamente una música que rehuye a la marcación constante y mensurada del ritmo, si bien se perciben agrupamientos ternarios. Nuevamente esto contradice la idea del $4 \times 8$ de Vega y es realmente difícil

159 El ejemplo 39 puede escucharse aquí https://youtu.be/83m4piu3z2w?t=823 
encontrar un estilo en pie binario. Más allá de esto, el ritmo de la canción está muy claramente subordinado al fraseo del texto improvisado y esto hace que sus frases se alarguen o contraigan de acuerdo a lo que propone cada verso de la décima. La emisión vocal de Núñez se parece mucho más a la de las ancianas y sus canciones de cuna que a cualquier canción de trovador que podamos encontrar. Hay mucha rugosidad en el timbre de la voz y esto es compatible con las descripciones del payador en donde «su voz, su talento lírico o su capacidad como instrumentista son secundarios» (Fornaro, 2010, p. 82). Sin embargo es muy interesante lo que encontramos en el sonido de la guitarra, en donde podemos adivinar un modo de acción muy percusivo y sobre el puente, que da como resultante un timbre chillón, incisivo, con muchísimo ataque. Parece que a las cuerdas se les "arranca" el sonido, y las alturas fluctúan mucho entre el momento del ataque y el de la extinción del sonido, casi un cuarto de tono, lo que hace que el acompañamiento nuevamente se destaque como textura y sonido, antes que como armonía.

Otro caso interesante es el del payador Angel Crecencio Nieto con otra versión de «décimas de la nada», en este caso titulada Yo en el mundo no he nacido. ${ }^{160}$ Fue grabado en la provincia de La Pampa por Ercilia Moreno Chá en 1975. Aquí también encontramos, tal vez más exacerbadas, las características que describimos en el ejemplo anterior relativas al acompañamiento de guitarra y el esquema rítmico, que nuevamente es ternario en los tramos en que existe pulsación. Otra vez el timbre de las cuerdas y el entramado textural son lo importante, mientras que el ritmo está subordinado a la declamación del texto improvisado. La voz, en este caso, es más forzada, sobre todo en el registro que juega con el límite agudo de las posibilidades del cantante, que además muestra cierta fatiga en la garganta que se traduce en frecuentes carrasperas que interrumpen el canto. Esto hace que las notas de los finales de frase estén siempre "desafinadas", por lo cual la melodía exhibe una permanente fluctuación de su contorno. Pero lo significativo, como en el caso anterior, es la descripción del propio payador como ser antediluviano y ajeno a las regulaciones del orden divino. Es un individuo no-sujeto, está afuera y de hecho puede pasearse por el infierno sin que por eso se convierta en alguien moralmente rechazado, ya que en realidad toda la gradación de la moral no le afecta. Esto es ese aspecto subversivo de la música, el ruido que introduce el músico en el orden sacrificial, el carnaval contra la cuaresma y su normalización que, como ya vimos, asociaba Attali (2011) con el mundo de los músicos populares. Poner en cuestión el orden es abstraerse del mismo, demostrar que se puede vivir por fuera de esas reglas, que a quien canta no le interesan, porque está más allá de ellas.

Yo al mismo Dios conocí, antes de ser conjurado/ no tuvo mal resultado, pero no se informó de $\mathrm{mi} / \mathrm{yo}$ al cielo lo escribí antes que cielo fuera /fui sacristán de la era y fundador de la fe /con los ángeles hablé y no supieron quién era (Nieto, Décimas de la nada)

Reglas que son también las de la armonía, la forma, la "correcta" emisión y declamación, la mensuración del tiempo y la compresión del mundo sonoro en las coordenadas cartesianas y las analogías espacio temporales. En la performatividad de Nieto, en la ocasión musical en que crea de forma repentista el texto y lo articula mediante el canto, todas esas convenciones, elevadas al rango de norma estética por la musicología, se suspenden, pierden poder y se hacen relativas, ya no obligatorias. El canto del payador pone en crisis la afirmatividad precisamente por cómo canta y hace sonar su guitarra. En este carácter particular de lo subversivo que está presente en el canto popular y en la guitarra latinoamericana, hay que leer la analogía de Martí cuando se preguntaba "¿A qué leer a Homero en griego, cuando anda vivo, con la guitarra al hombro, por el desierto americano?» (citado en Acosta, 2000, p. 183). Si la comparamos con la pretensión de parentesco occitano por descenso de Vega, tal vez podamos entender la enorme diferencia

160 El ejemplo 40 puede escucharse aquí https://youtu.be/U9ADF2T8FEA 
que separa al folklore y su invención de un pueblo ficcional, de un verdadero pensamiento asuntivo (Zea, 1986) que nos exige la descolonización de la historiografía musical latinoamericana. No es el camino que siguió Vega, ni podemos proyectar un pensamiento emancipatorio a partir de sus ideas.

Una decena de "estilos" hemos hallado hasta hoy, todos en el manuscrito 846 de París; muchos centenares he grabado personalmente en la campaña argentina. No puedo ofrecer en paralelo canciones idénticas; pero una sola muestra bastará para reconocer el parentesco estilístico de las medievales con las argentinas [...] Lea el estudioso esa escritura medieval de cualquier manera, como pueda; eso que lee está en la campaña de Sudamérica" (Vega, 1977b, pp. 27-30)

Dado este marco en que el musicar de estos cantores latinoamericanos produce el ruido y sonoriza la tensión con la modernidad civilizatoria y su afirmatividad, no nos debiera sorprender que muchas de las figuras históricas de los payadores del siglo XIX y principios del XX sean mulatos, como Bartolomé Hidalgo (1788-1822), el más antiguo del que tenemos noticias. Porque ese canto y esa música son transculturales y mestizas, aspecto en el cual también reside un fuerte rechazo a las categorías folklóricas que, como veremos, son esencialistas y raciales. Por eso Gabino Ezeiza es afroargentino del mismo modo que Higinio Cazón (1866 - 1915), los cuales se midieron por primera vez en una payada de contrapunto el 30 de junio de 1896. No lo hicieron en "la campaña" ni en un rancho abandonado, sino en el teatro Doria de Buenos Aires. ${ }^{161}$ Esto demuestra que entre el siglo $\mathrm{XIX}$ y el $\mathrm{XX}$, el arte de la payada en realidad se trata de un arte urbano y de artistas profesionales. Ezeiza y Cazón, como muchos otros, forman parte del fenómeno popular, mediatizado, comercial y urbano del circo criollo. También forman parte del ambiente musical del tango. Es que no existen en las músicas populares del 1900 las distinciones genéricas (y políticas) que la academia, el nacionalismo y la diversificación del mercado les impondrán luego. La disciplina académica del folklore disciplina las músicas populares y las comprime mediante sus categorías, que proceden a su vez de la musicología histórica. E inventa las tradiciones, como la del payador blanco, ${ }^{162}$ "hispánico", campesino y de un saber elemental, todo lo cual la historia revela mera ficción.

\footnotetext{
161 El teatro Doria fue conocido como "el Colón del Oeste", ya que en general pasaban por él compañías musicales y teatrales algo modestas y populares. Una crónica de 1932 lo describe como «el teatro plebeyo por excelencia. Un teatrito de barrio, frecuentado hoy solo por compañías de verano, baratas y mal trajeadas, por poca plata pueden presenciarse asesinatos más o menos alevosos, de "Toscas" y "Traviatas"». Se demolió entre 1901 y 1903, y fue reemplazado por otro teatro, el Marconi, también popular, demolido a su vez en 1967, para ser reemplazado por la más rentable inversión de un edificio de departamentos.

162 En la película El último payador de Homero Manzi y Ralph Pappier de 1950, aparece el payador Gabino Ezeiza en una escena donde se trenza a duelo payadoril con el personaje del film, José Betinotti, hijo de inmigrantes italianos. Éste último es personificado por Hugo del Carril, lo cual, junto al modo de su canto, escenifica el estrecho vínculo entre el tango y el arte de los payadores. Además, el contrapunto ocurre en la pista de un circo criollo, y es muy interesante que Ezeiza esté personificado por el actor rosarino Marino Seré. Tal vez sea involuntario, pero coincide con el fuerte blanqueamiento de la figura del payador que se opera a partir de la intervención del nacionalismo literario en las décadas de 1920 y 30. La escena -ejemplo 41- puede verse aquí https://youtu.be/4WKyLIVOGSA
} 


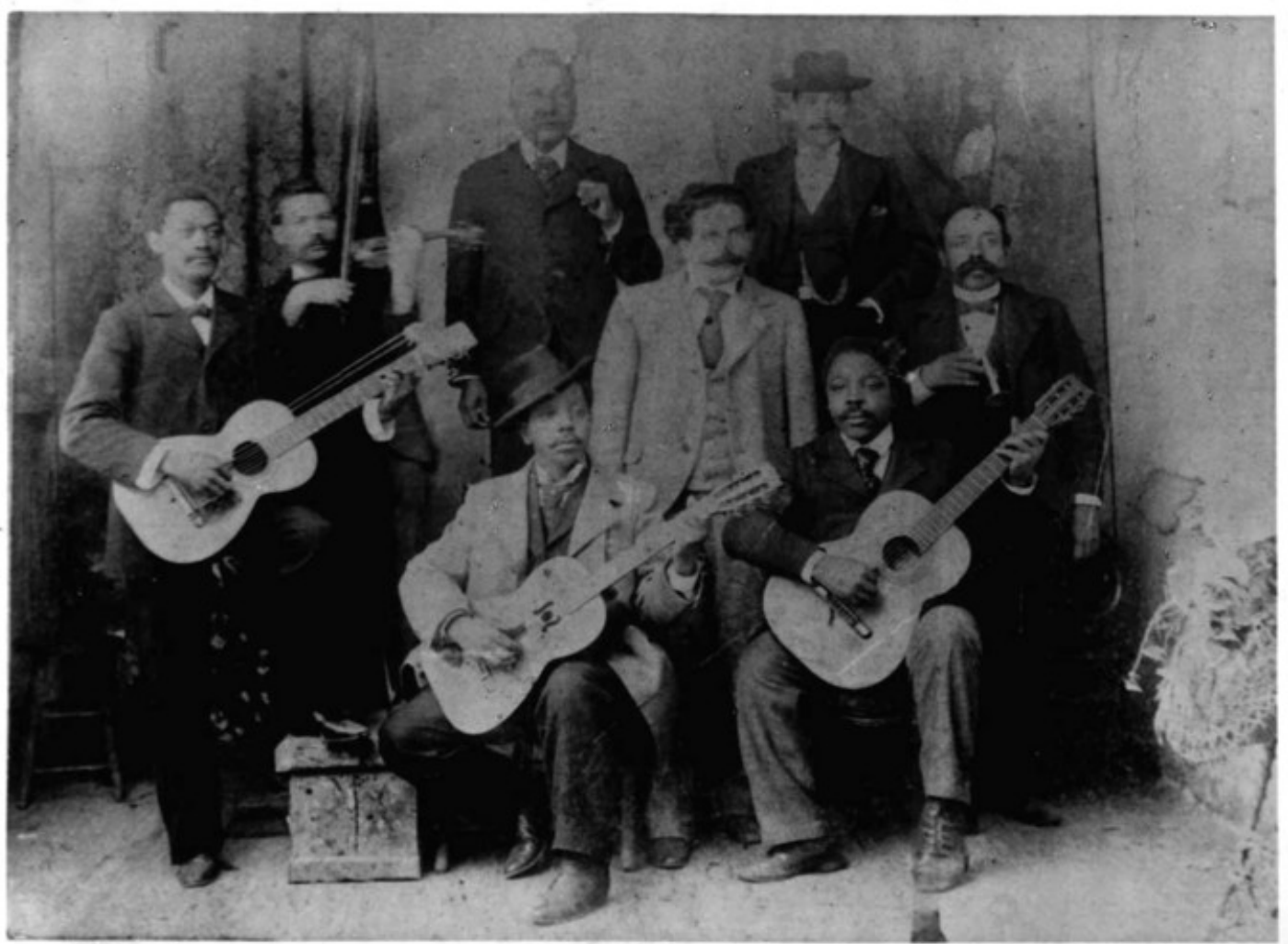

Los músicos populares afroargentinos Gabino Ezeiza (abajo centro) e Higinio Cazón (abajo a la derecha) junto a un conjunto criollo en el cual revistan otros mulatos.

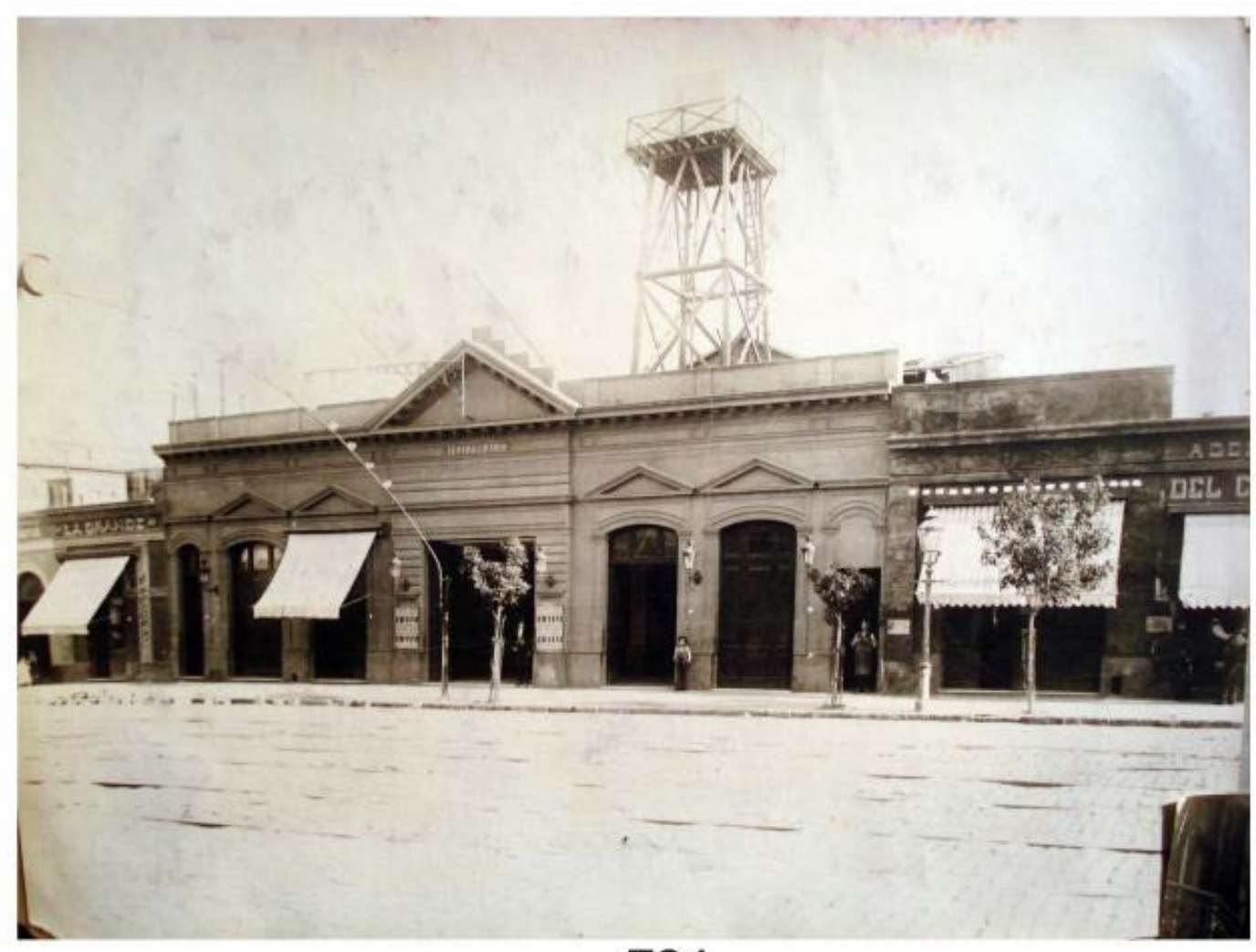

El Teatro Doria, "el Colón del oeste", Ciudad de Buenos Aires ca. 1900. 
La conversión de la música popular a folklore produce su reenvío a la antigüedad, si bien de un pasado culto y no popular que, descendido, desfigurado y devaluado, habita en el presente. Es una operación diferente a la del museo musical de las obras cultas, que gracias a su antigüedad ganan prestigio y valor y, en tanto "clásicos", producen esa ambivalencia temporal que para Dahlhaus suponía oponer el valor estético a la historia en la escritura de la historia de la música. Como la música popular, que al ser "parte del patrimonio inferior, solo puede ser música antigua, no extinta» es testimonio de un pasado perdido, sin conexiones con el presente. Por eso es «Música eliminada; música sobreviviente» (Vega, 1944, p. 63). Cabe preguntarse aquí por la ampliación del canon musicológico, que evidencia los límites del tipo de argumentación que ensaya Vega. Si en la música culta la ampliación retrospectiva del repertorio, que parte del ciclo clásico romántico para extenderse hasta la Edad Media, supone la anexión de aquellas músicas que pueden convertirse en obras musicales y prestar su antigüedad para erigir el vector temporal, histórico, que es parte fundamental del prestigio y por ende del valor de cambio de estas músicas, debe existir algo que, para las músicas populares, funcione exactamente al revés, restando valor en función de la antigüedad. La respuesta que ensaya Vega es el diferencial de la "vigencia". Se nos dirá que la música del "superior" que circula por las salas de conciertos es antigua, pero vigente. Sin embargo lo que esto demuestra es la asunción plena de las premisas de la musicología afirmativa, especialmente de la autonomía musical, que Vega efectivamente desarrollará en su propuesta analítica del folklore. Sólo despreciando las relaciones entre la música y la sociedad, la música y la economía y/o la música y la política puede pensarse que la música de Lully, de Josquin o de Monteverdi es vigente. Y si se insiste en responder que el mercado es quien les insufla vigencia -lo cual ya supone reconocer toda la economía política de la música- entonces nos sorprenderá que es el folk market (Colombres, 2004) el que produce el folklore editando la cultura popular (Harker, 1985) con fines comerciales además de políticos. Es decir que si, en el caso de la música culta, toda historia es imposible en la medida que se pretenda conservar la autonomía, en el caso del folklore, al ser todo él una acción política y comercial producida "desde arriba", la autonomía se resquebraja por todas partes, revelando la matriz afirmativa de la compresión que se produce de la música popular. Por eso no debe sorprendernos que para generar esa visión de los «bienes extintos aunque vigentes», el folklore científico de Vega, como el de muchos otros, utiliza categorías extraídas de la musicología clásica: parte de la "armonía", de la organización de las alturas como centro estructural de la "lógica musical", y se demora en observar la forma, mediante la cual se discriminarán las "especies" y "cancioneros" del folklore.

Hemos dicho antes que aquí vamos a estudiar la música, solamente la música [...] La asociación música-poesía-baile, pues, resulta de una confluencia de corrientes autónomas y es pasajera o temporal [...] No es posible tratar a un tiempo mismo la música, la coreografía y el texto, pues cualquier información que se haga cierta para el orden musical puede no serlo para el coreográfico, (Vega, 1944, p. 69-71)

Es decir que el folklore musical, en la versión de Vega y en las más convencionales, a pesar de los desacuerdos, procede aplicando la lupa conceptual desarrollada para explicar, racionalizar y poner en valor a la música culta, que hemos visto configurarse en el paradigma de la musicología histórica. Es uno de los factores que mayor responsabilidad acarrea en la compresión historiográfica del folklore, aplicando una violencia conceptual a lo que, por lo menos, no son "hechos", ni "bienes", ni "obras", sino ocasiones musicales (Camacho, 2011), rituales sociales (Small, 1999), discrepancias participatorias (Keil, 2001), o como queramos llamar al musicar. Al rehuir la música popular la condición de objeto, las categorías de la musicología traficadas por el folklore debieran perder todo sustento. Es más: debieran ser comprendidas, ellas sí, como extintas y no vigentes para el caso de la música popular. Pero el folklore no ha perdido en absoluto su poder de influencia (Gelbart, 2007) y por eso debemos dedicarnos a analizar su configuración histórica y la matriz a partir 
de la cual esta disciplina concibió la música de los sectores subalternos, a tal punto que generó un bloqueo que impide pensar la larga duración histórica de la música popular. 


\section{Segunda parte: El pueblo no es el pueblo}

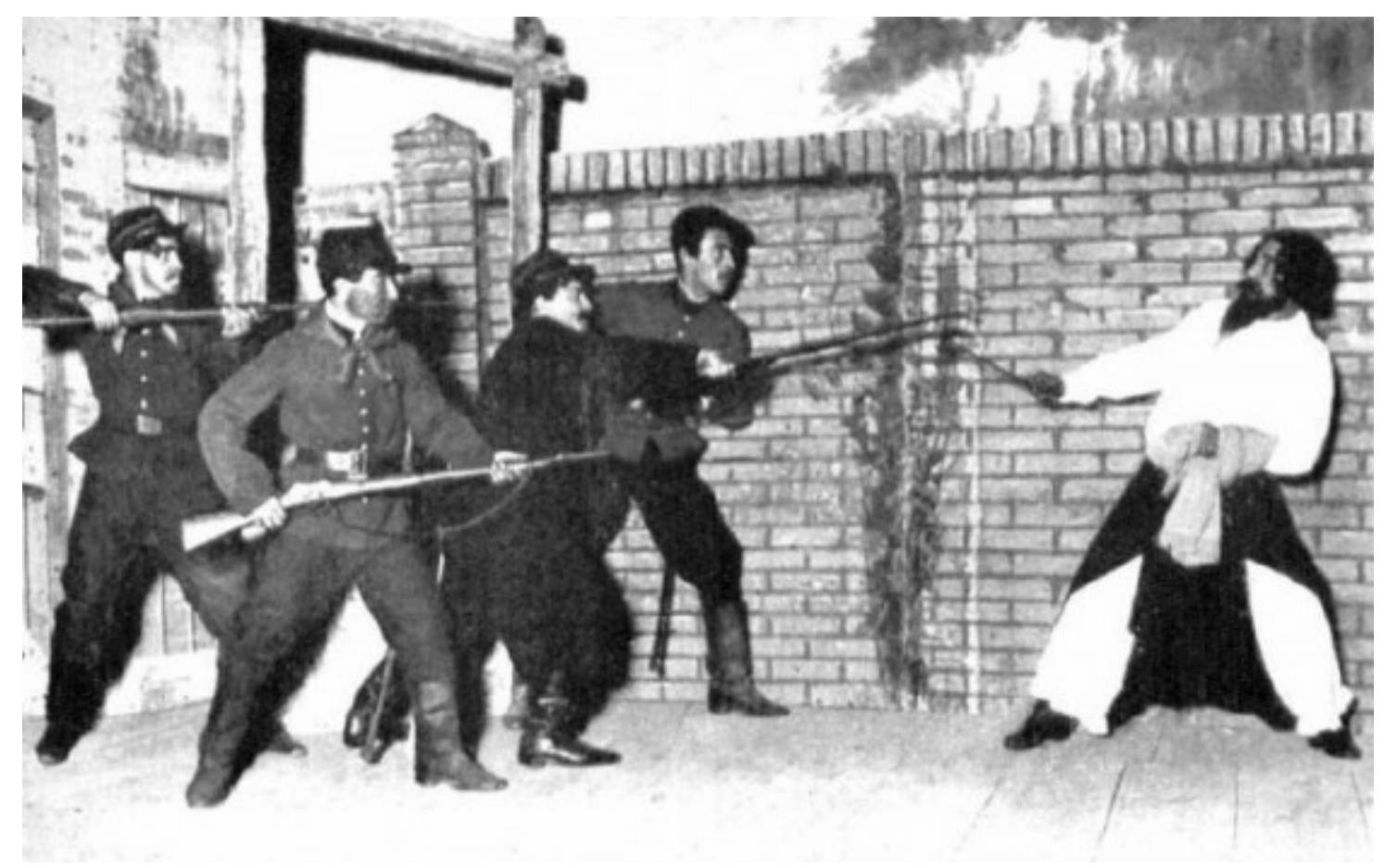

José Podestá poniendo el cuerpo a las balas como Juan Moreira, obra coescrita con Eduardo Gutiérrez y estrenada en 1886 


\title{
Capítulo 4
}

\section{De las radios a los ranchos}

\author{
«... y cuando vibrar oyeron la música de sus pagos \\ volvieron cara venciendo al ejército invasor» \\ Andrés Chazarreta, ZAMBA DE VARGAS
}

\begin{abstract}
"La muchedumbre de pronto se ha hecho visible. Antes, si existía, pasaba inadvertida, ocupaba el fondo del escenario social; ahora se ha adelantado a las baterías, es ella el personaje principal» José Ortega y Gasset (1937)

"hay que encontrar alguna forma de transformar al "folk" $y$ a los folkloristas otra vez en pueblo»
\end{abstract}

Charles Keil (1978)

Andrés Chazarreta ha pasado a la historia como un «verdadero hijo de las pampas argentinas [...] a cuya inspiración, la canción vernácula debe un sinnúmero de producciones [...] donde quedaron fielmente reflejadas las cosas y las costumbres de nuestra tierra gaucha» (Cantó, 1962). Esta sentida descripción póstuma de Chazarreta condensa varios de los cualificadores con los que suelen valorarse las músicas que pretenden identificarse con el pueblo: verdadero, reflejo fiel, vernáculo, cosas y costumbres, nuestra tierra. De esta forma, la figura del folklorista práctico -es decir el que toca, publica y graba música- es identificada con la idea de un medium, que sirve de nexo entre lo que verdaderamente es la música popular y aquellos que pretenden escucharla. Rol que puede adivinarse bastante congruente con el que la musicología le reservaba al intérprete, fundamentalmente clásico, como vimos en el primer capítulo. Claro, aquí funciona nuevamente la idea de un original fijo, un objeto que en este caso correspondería con las manifestaciones sonoras $-y$ dancísticas- del pueblo, a cuyas credenciales de origen el intermediario nada debe agregar, a riesgo de desmerecer o aún peor corromper sus cualidades verdaderas. Chazarreta, como folklorista, se erige entonces como recopilador, es decir, aquél que escucha lo realmente popular; lo recoge, clasifica y atesora, para luego darlo a conocer y, por añadidura, salvarlo de las amenazas del mundo moderno que señalan, cual campanas del destino, su segura extinción. La estampa que lo inmortaliza como patriarca del folklore argentino se vincula con la creencia en que don Andrés

recopiló los temas populares, es decir, de autor anónimo, de todos y de nadie [...] Procesó ese trabajo, hizo puestas en escena y lo transmitió con un método, lo enseñó y difundió a través de su compañía o del Instituto de Folklore que llevó su nombre y llegó a tener 72 sucursales en todo el país (Micheletto, 2010).

También y ya en tono de leyenda, se dibuja una biografía que imagina movimientos y traslados que jamás ocurrieron, como cuando se nos dice que "recorrió el país [...] y empezó a consustanciarse con la cultura de cada región y con esos ritmos criollos que describen el paisaje, las costumbres, las penas y las alegrías de la gente de campo» (Plaza, 2000). Pero en realidad, si el músico recorrió el país lo hizo de gira, presentando -y no recopilando- su espectáculo nacional a cada rincón del país. Como dice Carlos Vega en una mucho mejor documentada semblanza de Chazarreta, «don Andrés no hizo pesquisas ni viajes de colección» (Vega, 1981, p. 129).

¿Pero de qué se trata esa tan mentada verdad -término incómodo en el campo del arte si los hay- que el folklorista debe transmitir con método y que en todo caso suele identificarse con la autenticidad? 
Tal vez los esfuerzos más importantes de los folkloristas, en tanto investigadores, hayan estado concentrados en poder encontrar evidencias de esa autenticidad. En una trayectoria no exenta de fuertes debates y posturas contrastantes, el desarrollo de la disciplina está atravesado por la pregunta sobre las manifestaciones populares verdaderas, desde por lo menos el siglo XIX hasta el presente -si bien en términos académicos su auge se redujo notablemente a comienzos de la década de 1980. Desde Herder, Fichte y los hermanos Grimm, a Thomas Percy, Francis Child o Cecil Sharp, pasando por John Lomax, Juan Alfonso Carrizo, Mario de Andrade o Isabel Aretz, y llegando hasta Philip Bohlman, esos esfuerzos se han manifestado principalmente en términos de condiciones frente a las cuales se someten los análisis de las músicas para comprobar si, efectivamente, pertenecen o no al pueblo.

El caso de Andrés Chazarreta y la Zamba de Vargas / Baile nacional es quizás un buen caso para indagar en las formas que produjo la cultura afirmativa de la modernidad occidental para establecer la noción de un pueblo genuino, siempre a mano y eficaz para establecer el rol que los sectores populares deben ocupar dentro de los proyectos hegemónicos de sociedad ${ }^{163}$. Comencemos recuperando la trayectoria de Chazarreta con el fin de intentar desarmar la apelación a la autenticidad que persigue el folklore, a partir de la propia actividad musical de este músico y el carácter espectacular (en el sentido de escenificación) de su arte nativo. Apelaremos fundamentalmente al relato ya citado de Carlos Vega (1981), por un lado porque como ya dijimos abunda en detalles y fuentes, pero además porque nos permitirá penetrar, a partir de las cuantiosas valoraciones e interpretaciones, en una parte importante del pensamiento del musicólogo argentino: su cercana relación con el movimiento nacionalista, a partir de la cual su teoría folklórica puede entenderse, al menos en parte, como una fundamentación de dicho espacio ideológico y político.

\subsection{Acerca de la pureza de los manantiales y la orografía del pueblo}

Peter Burke (2014, p.58-59) resume en tres las condiciones del folklore que se gestan a fines del siglo XVIII y principios del XIX en Europa Occidental: 1) el primitivismo, que ubica las manifestaciones populares como supervivencias de un indefinido "periodo primitivo», precristiano y precapitalista, es decir y sobre todo, premoderno, que a su vez iba relacionada a la creencia en que dichas manifestaciones prácticamente no habían cambiado a lo largo de miles de años, es decir, las actuales eran prácticamente iguales a las del pasado; 2) comunalismo, que conlleva la creencia en la creación popular anónima, espontánea, comunitaria, hecho que refuerza su desinterés y apunta al grado de identificación colectiva, luego nacional, que persigue el folklore; y 3) purismo erigido como respuesta a la pregunta ¿quién es el pueblo?, a la que se pretende dar respuesta con el hallazgo de una cultura homogénea y unificada, que a partir de múltiples prejuicios vinculados al carácter iletrado, ignorante o subdesarrollado de los sectores populares, ubicaba al folk en un idílico e inocente paisaje rural, alejado y por lo tanto autónomo frente al mundo occidental culto, moderno y actual de la burguesía.

Todavía en la década de 1950 se estabilizaron definiciones del folklore que recuperaban muchas de estas nociones. Por ejemplo el International Folk Music Council (Consejo Internacional de Música Folklórica) publicaba una definición en la que puede verse muy claramente la pervivencia de la mayoría de las nociones de origen, razón por la cual hemos resaltado algunos términos

163 Quiero reconocer que fue Andrés Duarte Loza quien llamó mi atención sobre la relación de la zamba de Vargas con los escritos de Vega, especialmente en la defensa que el musicólogo desarrolló en torno al rol de Chazarreta en la difusión del folklore. Véase Duarte Loza, 2018. 
La música folklórica es el producto de una tradición musical que ha evolucionado a través de procesos de transmisión oral. Los factores que dan forma a la tradición son: (i) continuidad, que vincula el presente con el pasado; (ii) variación, que emerge del impulso creador de un individuo o de un grupo; y (iii) selección por parte de la comunidad, lo que determina la forma o formas en que la música sobrevive [...] El término puede aplicarse a música que evolucionó desde comienzos rudimentarios por parte de una comunidad no influenciada por la música culta o popular ${ }^{164}$ [International Folk Music Council, 1955)

Coincidiendo aproximadamente con Burke, y tomando la noción folklórica de los comienzos rudimentarios, Néstor García Canclini establece en el primitivismo el concepto que resume la forma en que las sociedades modernas -capitalistas e industriales-conciben a lo popular que habita en su interior. Es decir que se trata un primitivismo interno que, descripto por su transmisión oral y factura manual, se presenta como tradición (Canclini, 1992). El factor de la tradición como especificidad consolida lo que Claudio Díaz llama el «paradigma clásico» del folklore (2005, p. 158), y por eso lo encontramos como el principal fundamento de la gran mayoría de las teorías folklóricas hasta por lo menos la década de 1940. Dentro de la tradición se acomoda una variopinta seguidilla de elementos culturales, que se toman como un todo orgánico. En la definición fundacional del británico William Thoms, mediante la cual acuña el término Folk-lore, se listan «los usos, las costumbres, las ceremonias, los romances, los refranes, etcétera, de los tiempos antiguos» (citado en Vega, 1981, p. 85).

Esta es tal vez la razón por la cual el Consejo Internacional de Música Folklórica cambió su nombre en 1981 por el de International Council for Traditional Music (Consejo Internacional de Música Tradicional), lo cual evidencia un intento por salir del problema de la definición del Folk -y por ende del pueblo- para caer en un problema tal vez menor como es la ambigüedad del mismo concepto de tradición y su presencia en diversos repertorios, como por ejemplo el de la música culta (Bohlman, 1988, p. xiii). El recurso al término tradicional también permite evadir $-\mathrm{y}$ no resolver- un gran problema que revela la matriz etnocéntrica del folklore, lo que produjo que buena parte de los folkloristas rechazara incluir en sus estudios a lo que denominaron "música tribal" o "étnica", es decir, la del primitivismo externo. Carlos Vega diferenciaba ambos en base a las diferencias institucionales entre unas culturas y otras - «el régimen legal, la religión, el orden económico» (1944, p. 43)pero también, y a partir de considerar lo popular como supervivencias de lo que alguna vez fue moderno y culto, en base a «un matiz del mismo accidente temporal [...] En relación con el ciclo superior [es decir, la música culta] lo folklórico constituye el pasado inmediato; lo etnográfico, el pasado remoto» (Vega , 1944, p. 42). En el folklore es siempre evidente el occidentalocentrismo (Grosfoguel, 2014). Todo se mide desde la perspectiva de la cultura de la burguesía moderna, el ciclo superior. Como ante una primera lectura sus conceptos "causan escozor» (Ruiz, 2015, p. 18), Vega suele disculparse por su utilización y adjudicarle a los sociólogos el problema (1944, p. 23). Pero en realidad su vocabulario tiene la virtud de usar términos y construcciones muy transparentes a la hora de mostrar los sesgos clasistas y etnocéntricos, la posición moderna y exotizadora del folklore:

En América faltan casi todos los grandes estratos inmersos que -precisamente - inspiraron esta ciencia en Europa. Aquí, campos abajo, tropezamos en seguida con los ciclos que estudia la Etnografía; en Europa se tocan de inmediato los estratos folklóricos y faltan, casi, los ,ciclos etnográficos. El Folklore no se habría concebido en América; la Etnografía no habría nacido en Europa a base de hechos europeos propios. (Vega, 1944, p. 41)

164 «Folk music is the product of a musical tradition that has been evolved through the process of oral transmission. The factors that shape the tradition are: (i) continuity which links the present with the past; (ii) variation which springs from the creative impulse of the individual or the group; and (iii) selection by the community, which determines the form or forms in which the music survives... The term can be applied to music that has been evolved from rudimentary beginnings by a community uninfluenced by popular and art music» [International Folk Music Council, 1955) [Traducción y resaltados del autor] 
Si bien no es el caso de Vega, la distancia entre lo folklórico y lo "etnográfico" solía explicarse a partir de la diferencia que la civilización occidental observó entre dos tipos de barbarie musical: una cosa es no saber leer y escribir en partitura cuando se forma parte de una cultura y una zona que sí poseen música urbana, escrita y profesional (todos rasgos que los folkloristas asocian exclusivamente a Occidente). Otra cosa bien diferente es no tener esa "suerte" y formar parte directamente de una cultura ágrafa -por descarte las nooccidentales- "que no tienen una tradición musical compleja y escrita paralela» (Nettl, 1985, p. 9). Lo no-occidental es considerado entonces una barbarie dentro de la barbarie, o lo más primitivo de lo primitivo. El recurso a la denominación "música tradicional" surge entonces para intentar disimular esa evidente discriminación racializada. Pero como suele ocurrir con los eufemismos, esta maniobra tal vez profundizó los problemas.

Hay que tener en cuenta que la tradición es en realidad «una construcción discursiva cuya función consiste en legitimar aspectos estéticos, éticos o ideológicos dominantes en el presente» (Díaz, 2005, p. 160). Como el mismo autor lo reconoce, este enfoque deriva del concepto de "tradición selectiva" de Raymond Williams,

una versión intencionalmente selectiva de un pasado configurativo y de un presente preconfigurado, que resulta entonces poderosamente operativo dentro del proceso de definición e identificación cultural y social (2000, p. 137)

A esto podríamos añadir la noción de "tradición inventada" de Eric Hobsbawm (2015) que, como vimos antes, jugaba también un papel central en la construcción musicológica del artefacto primordial de la historia de la música: la obra, en tanto objeto resultante de una historia que se vuelve canon, lo cual es otra forma de decir tradición. Las ideas que en esta construcción Leo Treitler asocia a una suerte de edición histórica, de «acomodar el pasado de acuerdo al presente» 165 (1991, p. 293) convergen también en el folklore pues, como vemos, todas parten de la burguesía moderna que, mientras define su cultura y la afirma como universal, especifica por contraste qué es lo popular y le asigna un espacio categorial, un rol y un lugar, dentro de la modernidad. Esa categoría es el folklore. Es importante que tengamos presente que la construcción de hegemonía incluye en su acción mucho más que la simple ponderación de elementos culturales «dominantes» (Williams, 2000, p. 137). En la cultura afirmativa se incorporan elementos que a simple vista pueden parecer contradictorios, incluso contrahegemónicos. Pero que son puestos en nuevas formas de relación y por lo tanto resignificados por la acción hegemónica. «Estas son en sí mismas soluciones vivas -y en el sentido más amplio: resoluciones políticas- a realidades económicas específicas» (Williams, 2000, p, 137). Si bien tanto en un sentido cronológico como geológico (Martín-Barbero, 1991) lo tradicional es generalmente visto como supervivencia de un pasado más o menos remoto, más o menos definido, en el sentido de agencia cultural con que el concepto aparece en la modernidad, la tradición es una «fuerza activamente configurativa» (Williams, 2000, p. 137) que termina expresando, revelando, las intencionalidades hegemónicas de la cultura afirmativa. Recordemos que, según Herbert Marcuse, una de las operaciones más fuertes de la afirmatividad es la de situar a los sujetos en una «colectividad falsa» (1967, p. 72) que además de nociones uniformes de raza y territorio conlleva el establecimiento de una tradición, a partir de lo cual emerge la cultura en términos de (falso) "patrimonio" (Marcuse, 1967, p. 50). A esta operación responde también el canon de la musicología histórica, en tanto (falso) patrimonio universal y obligatorio.

En cambio para Carlos Vega, como buen folklorista, «tradición significa (...) continuidad [y ésta] se produce y asegura mediante la transmisión de cosas de la generación que se va a la generación que la sigue» (Vega, 1981, p. 7). Este autor utilizaba con mucha frecuencia

165 “The Tailoring of the Past as Progenitor of a Preferred Idea of the Present" (Treitler, 1991, p. 293) [Traducción del autor] 
en sus formulaciones teóricas, todavía en la década de 1960, el término hontanar, en tanto espacio rural en que residen las tradiciones y se perpetúan de forma auténtica en toda su ingenuidad popular: "sólo en hontanares silenciosos, y remotos a donde no llegó sombra de un aria, los tristes y las chacareras siguieron rodando su ternura» (Vega, 1981, p. 94). Probablemente esto sea un modismo adquirido de Ricardo Rojas, de quien fue ayudante de cátedra en la Universidad de Buenos Aires y un fiel discípulo. Si bien, como veremos, Vega rechaza con vehemencia la idea de una creación popular, sí en cambio ubica en esos hontanares la fuente de donde salen los materiales y la inspiración tanto de los compositores como de los artistas populares nacionalistas, tal el caso de Andrés Chazarreta (Vega, 1981, p. 104). El término hontanar, según la Real Academia, implica el origen más puro imaginable, en términos de manantial. Por lo tanto, se vuelve sobre la noción de purismo que mencionaba Burke. Como veremos, esto no es del todo contradictorio en Vega, si se añade aquello que alimenta al manantial. De hecho este autor utilizaba la metáfora de una piscina que se llena por un lado mientras rebalsa por otro (Chase, 1967, p. 42) y las dos agencias que sí le reconoce a los sectores populares, la recreación y la hibridación de materiales hechos por otros (Vega, 1944, p.87), realizan en todo caso una depuración de aquello que el pueblo recibe, depósito del cual brota el manantial folklórico. Es muy sugerente el ejemplo que propone el diccionario VOX en la entrada hontanar: «prehistoria española, hontanar de vuestras más limpias y claras esencias». Podría haberlo propuesto un folklorista, ya que aparece no sólo el purismo sino también la trampa cronológica de ubicar el origen de la identidad nacional en una temporalidad histórica remota e inefable. Así pensaban los románticos, tanto en Europa como en América Latina.

En el prefacio al libro El Folklore Musical Argentino de la más célebre discípula de Vega, Isabel Aretz, José Alfonso Carrizo sintetiza en tan solo cinco páginas la mayoría de los lugares comunes de los folkloristas. No sólo el folklore es tradicional, sino que habita en «nuestra campaña pampeana o montañosa» (Aretz, 2008, p. 3), es decir, en aquello que se define como rural. Es un "saber heredado» por los miembros de una colectividad, es decir que no es creado por ellos, con lo cual se acerca, aunque por otros caminos, a la formulación de Vega. En tanto el folklore es supervivencia, la tarea de la ciencia del folklore es «salvar y descubrir [...] los matices de nuestra propia personalidad, de nuestra alma» (2008, p. 4), aquello que se encuentra amenazado por la modernidad. Esto reviste a la tradición de un aspecto adicional: la transforma en conservadora, lo cual hace de las variaciones un problema y por lo tanto el folklore anhela una tradición estática. Esto es algo compartido por una amplia franja ideológica. Por ejemplo para Arnold Hauser el arte popular, que también identificaba con la cultura rural, es «tradicional e inflexible [...] esencialmente irracional [...] conservador, tradicional y convencional» (citado en Zátonyi, 2011, p. 21). Esto genera siempre un problema para los movimientos de izquierda que pretenden basarse en el folklore, ya que si por un lado la cultura folklórica es "esencialmente reaccionaria», se "refugia en el campo» y se perpetúa gracias al rechazo de hasta la más mínima innovación, «resistiendo contra todos los posibles cambios», se hace muy difícil adjudicarle simultáneamente un carácter emergente, transformador y de «rebeldía contra la injusticia». Establecer la línea divisoria que demarca una y otra actitud en la cultura popular es algo que la izquierda, desde la estética y la historiografía, encontraron como «algo difícil de establecer» (Zátonyi, 2011, pp. 23-24). Aunque parece ser más sencillo detectar cuándo la cultura popular es definida y utilizada por parte de los sectores nacionalistas y autoritarios, ellos mismos conservadores, muchos estudios recientes recuperan cierto carácter progresista del folklore, en general a través de las lecturas de Ernesto De Martino (2008) de las pocas páginas que Antonio Gramsci dedicó a la cuestión. En sus cuadernos de cárcel hay una formulación mucho más clara de esa aparente contradicción del mundo popular subalterno y su cultura, que todavía desvela al campo progresista: 
en esta esfera hay que distinguir diversos estratos: los fosilizados que reflejan condiciones de vida pasada, por consiguiente conservadores y reaccionarios, y los que son una serie de innovaciones, a menudo creativas y progresistas, determinadas espontáneamente por formas y condiciones de vida en proceso de desarrollo y que están en contradicción, o solamente son distintas, de la moral de los estratos dirigentes" (Gramsci, 2000, pp. 203-204)

En cambio, de la concepción exclusivamente conservadora de la música y la cultura popular surgirá la estrecha compatibilidad de las herramientas favoritas de los folkloristas: la transcripción a partitura y la grabación. Como vimos con respecto a la primera en su rol dentro de la musicología, se tomará a estas tecnologías como garantes, primero de la exactitud del registro que garantiza la autenticidad; en segundo término, de la conservación de los especímenes recogidos y coleccionados. El aspecto conservador de los bienes folklóricos -nótese el léxico "civil y comercial" del folklore que habla de "patrimonio", "bienes", "usufructo"- se da en Carrizo al adjudicarles unos valores que bien podrían derivar de ese carácter selectivo de la tradición que explicaba Williams: se trata de detectar -en realidad seleccionar- «las excelencias de pureza de sentimiento, de la sublimidad en el amor, de la deificación de la mujer [y] la casticidad de la poesía campesina, [...] latentes en la mente del pueblo». Todo lo contrario de el populacho que representa "la inmigración venida con afán de lucro» y la "concepción materialista de nuestra educación» (Aretz, 2008, p. 4). Hay una cultura impura -si es que todavía se puede llamar cultura- que Carrizo, como prácticamente todos los folkloristas, detecta en las ciudades, y sobre todo las más grandes y cosmopolitas. En la ciudad están los «bailes de moda importados del exterior, cuyo estilo, para no hablar sino de él, es todo lo contrario de nuestros cantos y bailes, que no rezuman sensualidad dislocada o morbosa, sino que amalgaman una casta sentimentalidad un señorío gentil y grave» (Aretz, 2008, p. 7). En la ciudad también habitan «los juglares de la urbe» y sus "composiciones modernas», cuyo fin es "el pequeño derecho», lícito tal vez, pero cuya presión no debe seguir «desalojando a la verdadera tradición» (Aretz, 2008, p. 7). En cuánto recuerdan estas descripciones, sus propios términos, a las valoraciones que vimos asociadas a la estratificación cultural de la aristocracia medieval, cuyo señorío gentil fabricaba una distancia simbólica frente a los juglares. El hispanismo de Carrizo explica tal vez esta filiación. Veremos que en Vega esto se da por otra vía, que lo acerca a las posiciones del positivismo musicológico y el análisis armonicocéntrico.

Frente a esto, Carrizo y sus colegas folkloristas oponen lo castizo, es decir, lo típico, puro o genuino de un país, que se considera en estado unificado, homogéneo, en los ambientes rurales. Es una creencia fuertemente racializada y que va a adquirir matices biologicistas de darwinismo social. Pero que desconoce, o elige desconocer, el fuerte grado de transculturación que existe en todas las poblaciones y comunidades y en particular, en la realidad histórica de América Latina. Los folkloristas creen en la pureza de sangre del pueblo rural, lo cual como sabemos derivará en el nacionalismo hacia soluciones aterradoras basadas en el Volkskunde. Lo castizo es también lo relativo a una casta, a la "buena cuna". Es decir que el establecimiento de lo puro, lo auténtico, parte de un gesto fuertemente aristocrático, que se asocia a valores conservadores, que no provienen del mundo popular subalterno sino de la cultura de la respetabilidad de la burguesía y su apropiación de valores nobiliarios (Mosse, 1997, p. 29). La autenticidad tiene entonces un rol en esa «fuerza activamente configuradora» de la hegemonía: asegura la sumisión de los sectores subalternos en nombre de lo que -según les dicen- es su propia cultura.

En Carlos Vega el folklore también se define en función del contraste con la burguesía, que este autor define como estrato superior. La cultura superior es la que posee «los bienes más modernos [...] consecuencia de los últimos inventos, de las últimas concepciones, de las últimas orientaciones» (Vega, 1944, p. 24). Tenemos que recordar aquí que, en la perspectiva de este autor, la posibilidad de invención, de creación de algo "nuevo", está restringida exclusivamente a este estrato superior. Por el contrario, dado que «las clases 
populares viven aspirando, esperando, imitando», el pueblo no es creador ya que "el espíritu en sumisión, no crea» (Vega, 1944, p. 84). Al estimar entonces lo popular "con relación al patrimonio de otros grupos» (Vega, 1944, p. 24), las definiciones siempre parten de la música culta y su esfera socio cultural «más rica en exigencias [y que posee] bienes materiales y recursos técnicos en mayor número y más eficaces» (Vega, 1944, p. 24). Estos "bienes", en cuanto musicales, son los que terminan configurando la música folklórica, por intermedio de la "circunstancia de tiempo» (Vega, 1944, p. 24). Es decir que la música popular -recordemos que así llama Vega a la folklórica- es música culta obsoleta: "como parte del patrimonio inferior, solo puede ser música antigua, no extinta [...] música eliminada, música sobreviviente» (Vega, 1944, p. 63).

El acérrimo rival académico de Vega, Augusto Raúl Cortazar (Ruiz, 2015, p. 15), suscribía en cambio a las ideas de creación folklórica espontánea y, por lo tanto, al carácter anónimo de toda la cultura popular, incluida la música, ya que la herencia común, la tradición, hace que cada intérprete de lo folklórico se sienta copartícipe, además de haber olvidado los nombres de los creadores (Cortazar, 1959, p. 20). Esto es claramente una recuperación del romanticismo alemán decimonónico. Jakob Grimm justificaba el carácter desconocido de los poemas folklóricos, ya que pertenecen al pueblo y uel pueblo crea» (Das Volk dich tet), por lo cual son comunales y se acercan a una concepción idílica de poesía de la naturaleza. «Nadie había realizado estos poemas; eran como los árboles, simplemente crecían» (Burke, 2014, p.36). Y como la tradición es continuidad, y la continuidad es transmisión, entonces también una condición de lo folklórico es para Cortazar lo oral (Cortazar, 1959, p.15).

Tal vez por las burlas de Vega hacia él (lo llamaba «tratadista» y ponía como ejemplo crítico de sus teorías el absurdo ejemplo de una "carreta oral, anónima y transferente» (Vega, 1944, p. 66)) Cortazar estuviera preocupado por delimitar con precisión qué era lo folklórico y cuál era el tipo de sociedad que debía llamarse folk, dentro del estado moderno (Chamosa, 2012, p. 156). Como en los románticos, el Folk es una capa geológica de la Nación, que reúne el núcleo de su identidad nacional. Y lo popular se define como perteneciente exclusivamente al Folk. Pero al mismo tiempo, en tanto los fenómenos folklóricos son vigentes, es decir supervivencias, sólo será Folk el sector social que cultiva una tradición escindida de las instituciones y acciones de la Nación. Fundamentalmente de la escuela, además, claro está, de los medios de comunicación impresos o radioeléctricos (Cortazar, 1959, p.12). Por eso, para este autor, los hechos folklóricos son empíricos, es decir que no están mediatizados; son espontáneos y no institucionalizados y por eso son orales. Todas estas razones hacen que sea imprescindible el trabajo de campo, el internarse en la aventura de los montes. El folklorista es tal siempre y cuando esté «en busca del pueblo» (Cortazar, 1959, p.40). Como el folklore impone correlaciones entre los fenómenos que estudia con maravillados ojos de naturalista, finalmente describe conductas:

modos de comportamiento (folkways) que resultan encantadores en el saludo y en las hospitalarias bienvenidas [mientras que] las indecibles molestias [son] superadas siempre por ese desborde de espontaneidad cordial, de solidaridad sincera [...] Tras las míseras apariencias [...] sorprenden la sobria cortesía en el teatro, el señorío hidalgo en las actitudes (Cortázar, 1959, pp. 41-43)

Como se ve, todo en el Folk es extraordinariamente agradable, bello, calmo, ameno, amable, cordial. En una palabra, inocente y por lo tanto desinteresado, justamente porque el folk no pelea por sus intereses y acepta de buen grado vivir como viven, en «una etapa retrasada, pero normal, dentro del proceso de su evolución [...] Han quedado al margen del tiempo y su propio aislamiento los ha salvado» (Cortazar, 1959, p.43). Los "retrasados" y sus manifestaciones se salvan de la extinción, como imploraba Carrizo, en la medida en que se asocie a ellos una nueva forma de autonomía que podríamos denominar cultural e 
histórica: estar al margen de la sociedad, de sus instituciones, pero también del tiempo. Este aspecto es revelador de la forma en que el folklore pone fuera de la historia la cultura popular, al mismo tiempo que proclama rescatarla y valorarla. Además es congruente con la otra autonomía, la que vimos en el primer capítulo asociada al compositor culto. Recordemos que ambos son recursos de la cultura afirmativa: el arte culto se hace universal al esconder las relaciones de clase que lo integran y sus condiciones de producción, del mismo modo que el arte popular se folkloriza y se hace visible o audible en la medida en que se esconden las condiciones de vida de los sectores subalternos y se elimina toda referencia a las disputas de poder en las manifestaciones del mundo popular subalterno.

Esta es otra herencia alemana (aquí sí hay una verdadera tradición) ya que del mismo modo Herder pensaba que el Volkslied pertenecía a una comunidad orgánica, nuevamente el Folk, «que denominamos salvajes (Wilde), pero que a menudo fueron más morales que nosotros» (Burke, 2014, p. 35). Pero Cortazar guarda una doble filiación con la otra vertiente de la teoría folklórica, la inglesa, ocupada como señalaba Martín-Barbero más en la relación de contraste/integración de lo antiguo y primitivo en lo moderno. Por eso se inscribe dentro del funcionalismo de Malinowski, que aplica un naturalismo etnológico a los sectores populares, expresión de la relación estrecha entre la explotación política de las masas populares subalternas y la consideración de su cultura.

el naturalismo de la investigación etnológica europeo-occidental refleja, en el plano de la consideración científica, la naturalidad con la que el mundo popular subalterno es tratado por la civilización burguesa en el plano práctico-político [...] el mundo popular subalterno constituye, para la sociedad burguesa, un mundo de cosas más que de personas, un mundo natural que se confunde con la naturaleza dominable y explotable (De Martino, 2008, p. 78).

En el folklore es tal la preponderancia naturalista, tan manifiesto el dualismo cartesiano que convierte la naturaleza en recurso de la modernidad, que ese «sentido prácticopolítico» finalmente determina los colectivos sociales en función de las cosas: «Es la posesión de las cosas folklóricas lo que convierte en pueblo a las gentes, y no a la inversa» (Vega, 1944, p. 53). Es decir, las cosas, las músicas populares «caen en la esfera del folklore» ${ }^{166}$ por razones ajenas al pueblo -para Vega, por ejemplo, porque el superior los abandonó. Razón por la cual para el naturalismo folklórico no existe agencia del pueblo en la constitución de los hechos folklóricos. Más adelante veremos que la transformación de esas cosas en objetos es una de las principales resultantes del impacto historiográfico del folklore. Por lo tanto, efectivamente podemos decir que el pueblo no tiene nada que ver en la configuración de la música folklórica. Pero no porque no produzca cultura, sino porque la música popular no es folklore.

Al comienzo de su Esquema del Folklore, Cortazar (1959, p. 7) elige referenciar la definición clásica de Thoms. Al hacerlo nos advierte sobre lo que supone una doble acepción: es folklore la cosa, el fenómeno popular genuino del folk; pero es también folklore la ciencia que lo estudia, el saber sobre el pueblo. Si entendemos que en esto último existe una relación de poder, que más que como normalización (Foucault 2002) elegimos explicar en términos de colonialidad del saber, entonces la doble acepción no es tal. Sólo existe como folklore lo segundo, en términos de construcción conceptual sobre el pueblo, la cual es interesada social, política y culturalmente. Una tradición tanto selectiva como inventada. Los «hechos folklóricos» no existen (Mendívil, 2016, p. 56). Los folkloristas, no "el pueblo", son quienes producen los fenómenos folklóricos. Que ya podemos dejar de pensar como anónimos, espontáneos, empíricos u orales. $\mathrm{Y}$ no porque se trate de carretas, sino en tanto

166 Recordamos nuevamente la ya referida definición del diccionario VOX en la entrada "música popular". 
son conceptos operativos que pertenecen, sí, a una tradición: la de la burguesía occidental moderna.

Los graves problemas de estos planteos resultan bastante evidentes. En todos los casos, de lo que se trata no es tanto de oponer una música folklórica a la música culta. En general, los folkloristas dan esto por supuesto o resuelven el asunto en unas pocas páginas introductorias. Lo cual es interesante, dado que los mismos términos "Culto" (o "serio", "artístico", etc.) y "Folklórico" (que en realidad se piensa como "popular") son parte de una misma clasificación que los acuña al mismo tiempo en un particular momento histórico: la consolidación de la hegemonía burguesa moderna en el ocaso del siglo XVIII y hasta por lo menos mediados del XIX (Gelbart 2007). Por el contrario, el desarrollo del folklore, en tanto esfuerzo epistemológico y disciplinar (un término que como veremos tiene resonancias muy interesantes en este caso) se concentra en contrastar la música del pueblo de aquella que, falsamente, engañosamente, se hace pasar por popular y no es otra cosa que una producción fabricada para las masas. Como ya hemos señalado, curiosamente esta última es la música que suele denominarse "popular".

Por lo tanto de lo que se trata es de separar al pueblo de lo popular, de generar (encontrar) un pueblo para contraponer a los sectores populares, o establecer qué es lo genuinamente popular a través del recurso de definir qué es el pueblo. Todo para que el pueblo aprenda quién es, lo cual produce otra regla general de los folkloristas, que es la de ocuparse de que sus hallazgos y teorías se incorporen obligatoriamente a la educación pública. Y allí aparecen no pocos problemas, dado que, como señala el título de esta sección, los sectores populares, es decir, el mundo popular subalterno (De Martino, 2008, p. 77), suelen tener una relación cuanto menos ambigua con aquello que se les presenta como folklórico: pueden aceptarlo con disfrute en la medida en que aparece como espectáculo performativo, en donde llamativamente se acerca muchísimo a esa "otra" música popular, masiva e inauténtica. Además, en el transcurso del proceso que ocurre hasta que algunos sectores populares se identifican con el folklore y lo consideran parte de "lo propio", suele mediar una experiencia de extrañamiento y hasta de exotismo, en el que es necesario afirmar dicha identidad desde afuera, es decir, mediante narrativas que provienen de la agencia académica o de los artistas, y en muchos casos de los estados o de sectores dominantes de la sociedad. Como contenido escolar, es absorbido como cosa muerta, equiparable a la clase de historia. Es decir que para que lo folklórico produzca una identificación popular, cosa que rara vez sucede en una primera escucha, es necesaria la mediación de los sectores hegemónicos. Y además, la difusión de la música estrictamente folklórica entre "el pueblo" necesita del arreglo, es decir, debe modificarse, editarse y parecerse a esa otra música, masiva, que a su vez la amenaza y corrompe. Baste pensar en la escasísima difusión de las grabaciones "etnográficas" o de campo -el verdadero folklore- en contraste con la abrumadora cantidad de partituras de música «tradicional» con arreglos armónicos y de acompañamiento. O las muchas composiciones nativistas o nacionalistas que toman «motivos folkóricos» para "elevarlos a la categoría de obra de arte» (Ponce, 1919, p. 9), es decir, transformarlos en sinfonías y oberturas. También grabaciones "para orquesta» de las "tonadas anónimas» recogidas en el campo, en las 
cuales se instrumenta y armoniza la música «verdaderamente popular», ${ }^{167}$ la cual, queda claro, necesita ser otra cosa de lo que es para ser popular, en el sentido de popularizada.

Ya vimos que para los románticos el pueblo no es "el" pueblo. Para los ilustrados y su paradigma escolar, podríamos decir que el pueblo todavía no es el pueblo, en tanto necesita aprender a ser ese soberano que la República interpela. Para el positivismo, el pueblo dejará de ser un sujeto posible de ejercer soberanía y entonces se lo cuestionará o desaparecerá como categoría para ser reemplazado por «la masa», con sus conductas que producirán abominación, que se intentarán explicar mediante la psicología social -como la que estudia en nuestro país Ramos Mejía, el mismo que también se había ocupado de narrar la historia del período federal en términos de la locura y los excesos de sus personajes. La irrupción del positivismo, entonces, luego de desarrollar un sofisticado aparato de medición y catalogación, ofrecerá las pruebas "positivas" para que, por un lado, se perpetúe la idealización de los sectores marginales y empobrecidos de la sociedad enalteciendo sus tradiciones y, por el otro, se justifique la represión y la expulsión de las masas de la escena política y cultural. Nuevamente encontramos aquí que, producto de la afirmatividad de la cultura burguesa moderna, el folklore, con sus personajes telúricos ficcionales, sus tradiciones selectivas e inventadas, produce una huida idealizada que no solo deja fértil el campo para el despliegue político del positivismo sino que complementa y justifica a éste al oponer un pueblo "bueno" a las masas, que no son el pueblo.

A mediados del siglo XIX [...] junto a los nuevos modos de control de los movimientos populares se pondrá en marcha un movimiento intelectual que desde la derecha política trata de comprender, de dotar de sentido a lo que está pasando. La teoría sobre las nuevas relaciones de las masas con la sociedad constituirá uno de los pivotes fundamentales de la racionalización con que se recompone la hegemonía y se readecua el papel de una burguesía que de revolucionaria pasa en ese momento a controlar y frenar cualquier revolución (MartínBarbero, 1991, p.31-32).

De allí que hay que ser precavidos a la hora de celebrar el "rescate" de lo popular por parte del folklore aunque desaprobemos sus postulados teóricos. La invención de la tradición selectiva es afirmativa, no un asunto que parte del desencanto romántico o una actitud "melancólica" hacia un pasado ideal como suponen Néstor García Canclini (1989, p. 194), o Richard Middleton (1990, p. 127). El problema del folklore no se trata, mucho menos, de una cuestión de métodos o de la incorrección o falta de propiedad en los términos. Es un problema político y, si se quiere, de política cultural, pero como parte de la articulación hegemónica que la burguesía hace de la totalidad social. Es una faceta crucial del programa civilizatorio/colonial de la modernidad (Grossfoguel, 2014) que interviene la cultura popular y genera versiones del pueblo a medida que la sociedad se ve atravesada por sucesivas tensiones. Los sectores populares pasan de ser los bárbaros a convertirse en el vulgo excluído por Herder; de allí se hacen turba para terminar formando la masa, el

\footnotetext{
167 Como ejemplo de todo esto baste decir que aún hoy en nuestro país es muy difícil acceder a la totalidad de las grabaciones de campo de Carlos Vega. Para escucharlas hay que concurrir al Instituto de Musicología que lleva su nombre, en la Ciudad de Buenos Aires. Es decir que, por caso un riojano, para escuchar las grabaciones de sus abuelos en las que suena una música que "se salvó" de la invasión mediática proveniente de la capital cosmopolita, debe someterse al centralismo y sacar el respectivo boleto de ómnibus y viajar un buen trecho para encontrarlas, en lugar de abrir la ventana y escuchar el paisaje musical de su "pago". Y esto sólo en el caso en que se anoticie de la existencia del archivo, cosa ya bastante poco probable y que, si ocurre, es por intermedio de alguna otra agencia no folklórica: la escuela, la industria editorial, la televisión, etc.

Sólo algunas del acervo de Vega se han agregado como CD en la reedición de su Panorama de la música popular argentina (2010). Y otras se añadieron en la reedición (Goyena y Cirio, 2015) de los únicos fonogramas que publicó en vida: la Colección de canciones y danzas argentinas de 1943, y las Danzas populares argentinas, de 1952. En ambos casos son versiones, arreglos efectuados por su esposa, la pianista Silvia Eisenstein, y arreglados para la Orquesta Argentina de Cámara y la Orquesta Argentina de Cuerdas respectivamente. Vega jamás publicó fonograma alguno de sus grabaciones etnográficas (Goyena y Cirio, 2015, p. 3). La música popular verdadera no era para el pueblo.
} 
enemigo interior que poblando las metrópolis disuelven las costumbres y erosionan la cultura. El folklore pertenece al mismo programa estético del que habla Eagleton (2006), es parte del despliegue histórico de la concepción del mundo popular subalterno que hacen los sectores hegemónicos. La historia de una mirada y una escucha que van «del miedo a la decepción y de allí al pesimismo, pero conservando el asco» (Martín-Barbero, 1991, p.31). Este proceso es, en todo caso, el que traza el "éxito triste" de lo popular del que habla Néstor García Canclini (1987).

Carlos Vega, que como Lauro Ayestarán revista sin dudas en las filas del positivismo (Fornaro, 2011; Pérez Gonzáles, 2010) problematiza justamente la idea de pueblo. Por eso, para Vega, el folklore es lo «trascendente subrepticio» (Vega, 1944, p. 29). Recordemos que subrepción es el ocultamiento de un hecho para obtener una cosa que no se conseguiría de otro modo. Todo un manifiesto de la afirmatividad y la potencia política del folklore: la burguesía moderna, para mantener alejados a los sectores populares de la escena política, para ocultarlos, concibe de forma antipopular un pueblo (falso) idealizado, y les propone a los sectores subalternos que se identifiquen con él. Charles Keil, autodenominado «ex-folklorista», resume este punto de forma magistral

\begin{abstract}
El estudio prolongado del folklore y de los folkloristas ha terminado por convencerme de que nunca existió el "folk", salvo en las mentes de la burguesía. Todo este campo es por completo un cuento de hadas de los Grimm. Mediante un acto mágico de denominación, todos los campesinos y pueblos tecnológicamente primitivos del mundo, pueden ser convertidos en el "folk". De seguro que así se los digiere mejor. Los campesinos explotados por los centros urbanos o las tribus atrapadas en los resortes de poderes imperiales más distantes, pueden hacernos sentir culpables o avergonzados si no podemos transformarlos en encantadoras fuentes de inspiración. Un mundo de miseria y placeres robados puede convertirse en la escenificación de un universo poblado de canciones, danzas y vestuarios muy coloridos [...] una fantasía, una mentira, que el mundo burgués necesita creer ${ }^{168}$ (Keil, 1978, p. 263).
\end{abstract}

Esto no ocurre sólo con la música. Como se sabe, el folklore es una disciplina que cartografía toda la cultura popular, desde las leyendas a los tejidos, pasando por la medicina "ancestral" y la cosmogonía. $Y$ en todos los casos se da esta necesidad de separar la paja del trigo. Tal vez una forma de explicarlo sea indagando en algunos aspectos que emergen como resultados -por no decir objetivos- del folklore y revelan una importante faceta política: erigir un pueblo en oposición a los sectores subalternos contemporáneos, ya sea para redimir y "despertar" a éstos y movilizarlos a la acción revolucionaria, en la medida que se los considere alienados o manipulados; o porque se necesite desmovilizarlos y controlarlos mediante la adjudicación de un lugar en la sociedad, el cual suele identificarse con un pasado idealizado de sumisión y armonía entre las clases.

\title{
4.1.1 Cuchillos de palo
}

Como es sabido, Chazarreta tuvo que esperar a triunfar en la nada vernácula Buenos Aires para que sus músicas nativas se convirtieran en nacionales, aún para sus coterráneos de Santiago del Estero (Reder Carlson, 2013, p.130). El proyecto es, desde el inicio, de índole comercial, cosa que revela la faceta de empresario de Chazarreta, modo en el que lo define Carlos Vega (1981, p. 105). De esto da cuenta su primera acción como músico: la de

\footnotetext{
168 «Long study of folklore and folklorists has convinced me that there never were any "folk", except in the minds of the bourgeoisie. The entire field is a grim fairy tale. By an act of magical naming, all the peasantries and technologically primitive peoples of the world can be turned into "folk." They are certainly more palatable that way. The peasants exploited by near by urban centers or the tribes trapped in the coils of more distant imperial powers might make us feel guilty or ashamed if we could not transform them into charming sources of inspiration. A world of misery and stolen pleasures can become a staged world of song and dance and ever so colorful costumes [...] a fantasy, a lie, that the bourgeois world needs to believe» (Keil, 1978, p. 263) [traducción del autor]
} 
publicar la partitura de la Zamba de Vargas en 1908, lo cual hace también, llamativamente, bajo la casa editora Medina, de Buenos Aires. De hecho, además de su tarea de maestro e inspector educativo, Chazarreta es un músico profesional. Participa de conjuntos y orquestas que actúan en los "bailes de sociedad", cuyo repertorio era fundamentalmente el de las danzas europeas (polca, vals, mazurca) que son muy valoradas en términos artísticos por las élites provincianas y sus músicos. Esto es muy congruente con el proceso de «rejuego de identidades» que describe Alejo Carpentier, presente en la instauración de las repúblicas latinoamericanas, que implicó como momento fundacional de la cultura nacional la incorporación de las corrientes "universales" de la cultura, lo cual conllevó una necesaria "subestimación de los valores nacionales [...] unida al deseo de aplicar nuevos métodos, de estar up to date, de barrer con todo lo que pueda parecer un lastre de provincialismo o de coloniaje» (2004, p. 248). Esta era la música de las provincias, del "interior", a fines del siglo XIX y principios del XX. Dentro de estos bailes y ocasiones sociales, sin embargo, se acostumbraba incorporar, al final y como una suerte de gracia condescendiente hacia ese pasado colonial y atrasado, algunas de las danzas que habían circulado en toda la zona del virreinato del Perú, especialmente la zamacueca. No abordaremos aquí los debates en torno a su adscripción, como los de Vicuña Mackena o el mismo Carlos Vega, ya que justamente lo que tratan de establecer es su origen en términos incontrastables. Lo cual en general está atravesado por cuestiones etnológicas (si es un «baile de negros» o música «indígena») o etnocéntricas (cuando se la considera un "descenso» de danzas europeas antiguas). Sí queremos resaltar en cambio la actividad de músicos profesionales populares en el ámbito colonial. Si bien lo desarrollaremos específicamente en el próximo capítulo, baste decir aquí que el mundo colonial andino estuvo poblado de prácticas musicales de una fuerte transculturación, en la cual confluyen múltiples matrices: las castas profesionales del mundo incaico, los músicos profesionales provenientes de los esclavos africanos o afrodescendientes, los maestros e instrumentistas españoles, portugueses, franceses o flamencos, entre los cuales también existían músicos callejeros. La tensión que habitan las danzas populares en el mundo colonial y su puesta en crisis del orden colonial, hacen irrelevante su origen, ya que se trata de ocasiones musicales (Camacho 2011), es decir, de realidades que surgen de la praxis musical. Que en este caso, además, es profundamente mestiza, como mestizas son las matrices culturales, variadísimas, que confluyen en esas ocasiones: lo "europeo" no es una sola cosa, así como tampoco lo "africano" o lo "indígena", todas categorizaciones provenientes de un horizonte clasificatorio y homogeneizador. Por lo tanto, interesa aquí que la zamacueca, en cualquiera de sus múltiples variedades y versiones, no era en tiempos de Chazarreta expresión de ningún pueblo homogéneo, tradicional ni regional, ni de ninguna "tierra". Era en todo caso el producto, el registro sonoro, la banda audible (Attali, 2011) de varios siglos de tensiones en el mundo andino y su periferia, dentro de la cual Santiago del Estero era un punto cardinal. Y además había circulado por los cuerpos y los instrumentos de músicos profesionales, que no solo eran especialistas sino que se ganaban el sustento mediante la práctica de su oficio. Como el mismo don Andrés hacía en aquellos bailes de sociedad. De esos conjuntos saldrían también los músicos, arpistas, violinistas, bandoneonistas, que lo secundaron en su orquesta nativa.

En cierto sentido esto explica la sorpresa, el extrañamiento que los santiagueños experimentaron en el debut de la compañía de Chazarreta en 1911, que en ningún caso, gustando o despreciando del espectáculo, se identificaron con esas músicas y danzas nativas en tanto santiagueñas. Días antes, los periódicos locales como El Liberal y La Mañana dan cuenta del artificio del espectáculo, promocionando a Chazarreta como compositor de "canciones criollas», las cuales si bien se asimilan con los espectáculos del circo, también son tachadas de "antiguallas pobres" o «bailes de nuestros mayores» (Vega, 1981, p. 113). La gobernación le niega la solicitud para utilizar el Teatro 25 de Mayo ya que sólo está disponible, dicen, para «compañías de primer orden». Lo cual no impide que el 15 
de julio, en un más modesto teatro Pasatiempo del Águila, «el empresario señor Chazarreta» debute junto a «su troupe», según consigna el diario El Liberal de ese día. El cronista de ese mismo diario comenta que el Bailecito ejecutado por la compañía era «un número de baile verdaderamente novedoso, pues no es aventurado decir que entre todo el público no había cinco personas que lo conocieran». El diario El Porvenir comenta en igual sentido que "el baile que más gustó fue la Media Caña, por su originalidad». Todo lo contrario resulta la recepción del momento central de la función, que consistía en un concierto de guitarra del propio Chazarreta en el cual ejecutaba un fragmento del II Trovatore. Esta sección, en contraste con las "nativas", lejos de producir sorpresa o resultar extemporánea, es relatada por la crítica como algo esperable, que si se critica es en todo caso por la calidad de la ejecución o la acústica de la sala del teatro.

Todo esto, según Vega es producto del «ambiente europeizado de las ciudades provinciales» (1981, p. 119), pero no de la verdadera invención que esas músicas significaban ni de la escasez de tales aires entre el pueblo santiagueño. Es seguro que las élites de provincia estuvieran fuertemente representadas por la cultura occidental y sabemos hasta qué punto se ocupaban de estar al día de las novedades musicales, sobre todo en cuanto a la ópera que funcionaba como su «espejo idealizado» (Miranda, 2011, p. 71). Pero aún así, es inverosímil que la presión hegemónica de una cultura impuesta desde arriba hiciera que los sectores populares desconocieran casi por completo su "auténtica" tradición y hace nada probable la afirmación de que «el malambo haya sido recordado hasta entonces en los suburbios de Santiago» (Vega, 1981, p. 129)

No parecen perturbar la semblanza de Chazarreta como recopilador que hace Vega, argumentaciones tales como las que señalan que «fuentes importantes para Chazarreta fueron los aludidos músicos de sus orquestas» aunque «ninguno poseía un gran repertorio de bailes tradicionales». Recordemos que esos músicos, profesionales de bandas de salón y nada campesinos, habitualmente tocaban habaneras, valses, polcas, chotis. Si sabían algo más telúrico eran generalmente bailes criollos no precisamente norteños, como el Minué federal o el Cuando. Tampoco impacta aventurar que la Firmeza proviniera de una publicación, nada menos que del porteño y nada paisano Ventura Robustiano Lynch. La música, dice Vega, «parece local» (1981, p. 129).

En las impresiones recogidas por la prensa que se hacen eco de la recepción del público, aparece una y otra vez la mención de que lo visto sobre el escenario no corresponde a la actualidad, ni siquiera la de las áreas rurales. Lo que se muestra es «una costumbre que ya no existe» dice el diario El Siglo el 17 de julio de 1911, y continúa celebrando que lo característico «de la época», es decir lo antiguo, se presente "con brillo, con lujo [...] para no chocar con el adelante estético que vivimos». En Tucumán, La Razón del 2 de agosto cuestiona en cambio que en el teatro Belgrano de San Miguel (donde se presenta durante el mismo 1911 la compañía de arte nativo) se muestren «costumbres criollas del pueblo de la campaña con la indumentaria de aquella época» ya que el teatro «es escuela de cultura y de educación artística y del buen gusto» (Vega, 1981, p. 123). Está claro que para la prensa, y aparentemente también para el público de las ciudades del noroeste argentino, escuchar esa música nativa era traer al presente la historia, actualizar mediante la interpretación una música antigua. Algo que acostumbramos encontrar en los teatros, sólo que vinculado a otros repertorio, el de la música culta "antigua". Con el folklore en cambio nuestra sociedad pretende encontrar algo "vivo", anclado en el pasado, sí, pero no "extinto". No se trata de una percepción histórica, sino de una tradición permanente e ininterrumpida que, inalterada, llegaría hasta nosotros, aún vigente. «El terreno popular es un bisabuelo; de aspecto desconocido, puede ser, pero de nuestra propia sangre. Un bisabuelo que se internó en la campaña, y vive todavía» (Vega, 1944, p. 75). Pero a partir de los testimonios de la época queda claro que a principios del siglo XX tal percepción no 
existía en el público del noroeste de nuestro país. Todavía necesitaba del impulso del nacionalismo porteño y que el folklore espectáculo triunfara en Buenos Aires.

Si bien Vega, como dijimos, admite que Chazarreta no hace trabajo de campo, al ser el musicólogo heredero de esa misma generación del centenario y su ideología nacionalista, atribuye a la memoria popular y no a la muy probable influencia del propio Chazarreta, su éxito nacional y su enorme difusión por toda clase de medios, que «cuarenta años después» los ancianos tocaran unas danzas muy similares ante su aparato grabador (Vega, 1981, p. 130). Este es una de las creencias más frecuentes en la mentalidad del folklore: sostener mediante algún artículo de fe que la continuidad y la tradición oral que habitan en los pretendidos hontanares de la tradición -todos elementos absolutamente reacios a cualquier tipo de corroboración- son más fidedignos que la penetración de los medios de difusión. Más adelante documentaremos el carácter explícitamente selectivo de los folkloristas que, mientras buscaban genuinas piezas de tradición oral, tenían que descartar de a montones las que resultaban ser músicas alguna vez cantadas por juglares en las ferias, publicadas en la imprenta, grabadas en disco o radiodifundidas, y aprendidas de memoria por un público transformado, por el folklorista, en informante. En ocasiones, el largo proceso se resumía en una sola persona, que componía alguna música que tal vez tomara un gesto, algún material melódico o rasgo de alguna ocasión musical determinada. Chazarreta es tal vez un buen ejemplo de esto último. Por eso, el padre de la musicología argentina es tal vez más sincero cuando escribe «este es el momento de decir que ambos, el promotor [Chazarreta] y su primer bailarín, tocaron y retocaron casi todos los bailes poco o mucho» (Vega 1981, p. 129).

Antes del debut, Chazarreta como buen empresario, da a publicidad lo que está preparando y manifiesta también sus pretensiones. «Después de ofrecer varios espectáculos entre nosotros, el señor Chazarreta irá a hacer igual cosa en Tucumán, Salta, Córdoba, Rosario, Buenos Aires y quizá Montevideo» dice el diario El Liberal de Santiago el 20 de junio de 1911. Si bien en la capital santiagueña el espectáculo tiene una buena recepción y se hacen tres funciones a sala llena, al emprender la gira por provincias vecinas la suerte comienza a abandonarlo. En Tucumán realiza una función y luego el intendente decide suspender las siguientes, por considerar al espectáculo un resabio de barbarie. De allí pasan a Jujuy donde en las tres funciones pactadas hay escasa concurrencia de público. Ante ese panorama las pretensiones de ir a Salta o Córdoba y ni qué decir Buenos Aires o Montevideo, quedan sólo como un sueño. Ante este fracaso, en que la música que debería ser popular no es apreciada por el pueblo «Chazarreta disuelve la compañía, triunfante y desalentado» (1981, p. 132). Pareciera entonces, a todas luces, que los públicos de las provincias del noroeste no se identifican con esos bailes y músicas, que en todo caso no serían tan nativos como Chazarreta pretende, sino invenciones, creaciones más o menos originales, tal vez basadas en tradiciones antiguas que no se circunscriben en absoluto a "la provincia" ni mucho menos a "la nación" como se pretende hacer creer desde la mirada localista -y nacionalista- del folklore. Las impresiones populares que registra la prensa atestiguan la sorpresa y el extrañamiento del público frente a ese espectáculo novedoso y claramente artificioso, «que no apunta al naturalismo sino, justamente, a la representación [...] que más tarde quedaría fijada, a su vez, como una idea acabada de "lo gauchesco"» (Micheletto, 2010).

\subsubsection{Gauchos porteños}

Durante la década que separa el debut norteño del desembarco en Buenos Aires, don Andrés continuará publicando partituras para piano de sus piezas criollas, emprenderá la formación de un conjunto infantil y mantendrá la compañía de arte nativo, dando alguna función anual en Santiago. En el marco de unas actuaciones en el interior de la provincia, 
conocerá al empresario que lo financiará para su debut en Buenos Aires, el mecenas «destinado a realizar todos los sueños del maestro santiagueño» (Vega, 1981, p.137). Es, paradójicamente un inmigrante italiano, Antonio Mauri. ¿Por qué señalamos esto?

La década que separa esas fechas clave de 1911 y 1921 es testigo también del vínculo entre Chazarreta y varios de los más notables intelectuales de la generación del Centenario: Leopoldo Lugones y Ricardo Rojas, así como también del hacendado e intelectual tucumano Ernesto Padilla. En 1917, Rojas hace una primera tentativa para llevar a los escenarios porteños el espectáculo nativo, pero fracasa. Vega opina:

los empresarios no percibieron el "mensaje". Acostumbrados a valorar técnicas y a medir por números, se encontraron entonces con las voces menos adulteradas de la República y no contaron con la masa de tradicionalistas sobrevivientes ni con la fuerte presión de los nacionalismos musicales europeos que desde los más altos niveles del arte movían los espíritus hacia los hontanares del pueblo. Ni se acordaron de los intelectuales tradicionalistas que, a su tiempo, acudirían a disimular la humildad del espectáculo, a exaltar sus altas notas de carácter, a proclamar sus posibilidades artísticas y a encarecer sus valores extraestéticos patria, nacionalidad, unidad espiritual, etcétera-. En conclusión, todos los empresarios le contestaron a Chazarreta que no tenían interés en su espectáculo (1981, p 135).

Como ya vimos, en la hipótesis de Vega -que es también un imaginario común sobre lo folklórico que se popularizó en el siglo XX- la falta de sensibilidad de empresarios, autoridades y funcionarios hacia el lanzamiento del arte nativo es siempre resabio de la moda cosmopolita y "lo eurocéntrico". Lo cual no obsta para que festeje la publicación en París, por Lugones, y en francés, de las partituras de Chazarreta. Tampoco para que cuando lo contrate Padilla -que luego financiará a Aretz y al mismo Vega- éste deje de ser parte de «la masa de familias extranjeras en el poder» (Vega, 1981, p. 123) extraños a nuestras tradiciones y culpables de los infortunios y la incomprensión de don Andrés. Padilla, parte indiscutida del poder de Tucumán al ser propietario de tres ingenios azucareros y cuyo primo Miguel era senador nacional, desde ya que formaba parte de esas "familias en el poder". Pero distaban mucho de pensarse como "extranjeras", al igual que los «Rougés, Nougés, Salvatierra, Avellaneda, Terán, Etchecopar, Cosio y Padrós» (Chamosa, 2012, p.65) que militaban, todos, en el movimiento tradicionalista y conservador. Al contrario de lo que intenta defender Vega, esta es la oligarquía terrateniente nacionalista que, en crisis económica en tiempos del centenario y enfrentada con Buenos Aires y la Unión Cívica Radical, impulsará en el Congreso Nacional la creación de una ley para sancionar a la industria azucarera como "industria blanca", en el sentido de no poseer trabajadores mestizos o indígenas, a imagen de la industria Australiana del azúcar y en contraste con Brasil, Cuba y Java, que ofrecían para la importación el mismo producto a precios considerablemente menores. El argumento principal era que no se podía «comparar a un país de negros, como Java, con un país de blancos, como Tucumán», de acuerdo al encendido discurso del diputado azucarero Camaño en recinto, durante una sesión de 1917. Como el azúcar de Java, Brasil y Cuba era producido por "razas inferiores", entonces lógicamente era más barata. Por eso, el país de blancos, la Argentina que, según el censo de 1914, carecía de "razas inferiores" en su territorio, debía impulsar una política proteccionista que resguardara a los ingenios del Noroeste. Finalmente el presidente Alvear, para solucionar un conflicto entre ingenios y cañeros, declarará la mentada "industria blanca" (Chamosa, 2012, p.76-77). Que el conflicto entre Buenos Aires y la oligarquía del Noroeste haya obrado como base del movimiento tradicionalista, que por supuesto deriva en el éxito final de Andrés Chazarreta y su "música nativa", salta a la vista. Lo que es menos lógico es que Vega, el científico del folklore, haga descansar en el nacionalismo romántico de Rojas y en "la figura eminente" de Padilla el resguardo de las verdaderas tradiciones de los "hontanares" del pueblo, mientras esa misma élite azucarera se esforzaba con denuedo por blanquear al Tucumán y su cultura. 
Más allá de la aparente contradicción, Vega no oculta su simpatía por Mauri ya que, a diferencia de los dueños de los teatros porteños, "comprendió y sintió muy pronto las expresiones folklóricas "locales" lo cual hacía que no fuese «un hombre de negocios calculador y frío» (Vega, 1981, p.137). Es decir que para el investigador las clases hegemónicas son "extranjeras" o "nacionales" en función de su sensibilidad y su sentido del folklore -incluso cuando no haya un explícito rechazo a lo europeo, que por otro lado ni siquiera Vega se hubiese permitido- lo cual casi las transforma en contra hegemónicas. Es más, una vez transformado en mecenas, "Mauri estaba en esta empresa menos como hombre de negocios que como provinciano cautivado por sus tradiciones» (1981, p. 138). Lo que no queda claro es si las mentadas tradiciones provincianas son de Tucumán o de alguna región de Italia. O si es esto indistinto, lo cual no sería raro en Vega dado su afán por universalizar ciertos procesos histórico culturales asociados a la música, como en la mentada tesis de los trovadores. ¿Tal vez la lauda, muy estudiada por el musicólogo, tendría resonancias en las tradiciones inferiores del noroeste argentino? Don Carlos, por lo pronto, nunca lo especificó.

Gracias a la sociedad con Mauri y luego del virtual fracaso en el noroeste argentino, es en la cosmopolita Buenos Aires donde se consagra y convierte en nacional la música de Chazarreta. Con la bendición del movimiento nacionalista y los intelectuales del centenario, aunque con la financiación de un inmigrante, el éxito y la transformación en símbolo de argentinidad se dan en 1921, haciendo que las tres funciones programadas inicialmente se transformaran en casi un centenar. ¿Qué era lo que festejaba la capital de la Nación que al interior del país le resultaba bastante indiferente?

Festejaba una imagen, que cuajaba perfectamente en la búsqueda de un arte claramente nacional, cuya ausencia tanta decepción había generado en los festejos del Centenario (Pujol, 2013). La imagen que Chazarreta ofrecía era una idealización de lo "rural", universo en el cual habitaban todos los arquetipos esenciales de los que hablaba la literatura culta de los nacionalistas, fundamentalmente los payadores de Lugones o los gauchos de Güiraldes, y que hubieran colmado la nostalgia de Miguel Cané, que soñaba con la paisanada sumisa que como un sueño idílico lo asaltaba mediante los recuerdos de su infancia. Como dice el historiador Gabriel Di Meglio «ese otro, que Cané idealizaba, estaba representado por su hogar familiar. Allí, las clases propietarias se habían relacionado vertical y armónicamente con los fieles servidores provenientes de las clases populares» (Mignona, 2010a, 12:53). De esta manera, el mundo rural implicaba un reservorio de valores y virtudes "que se habían perdido" a causa de la modernización, y en estricta asociación con la concepción localista del folklore, ese universo perdido se ubica en el espacio que pasa a denominarse el pago, poblado por «el personaje prototípico, también idealizado: el paisano, el provinciano, el hombre del interior. Y de un modo más fuertemente simbólico, el gaucho» (Díaz, 2005, p. 163).

Ahora bien, ese gaucho y ese pago rural cumplen, en términos temporales, un doble papel, y esto es importante para el panorama sobre la construcción de la doctrina del folklore que aquí estamos trazando: si, como vimos a partir de las crónicas del debut santiagueño y provinciano, lo que el espectáculo de Chazarreta ponía en escena ante los ojos del público del interior era el pasado, diez años después para los espectadores de Buenos Aires significaba una visión alternativa -y hasta utópica- del presente. Claudio Díaz, a continuación del párrafo que referimos antes, cita algunas líneas del eufórico comentario que Ricardo Rojas publica en el diario La Nación dos días después del célebre debut porteño de la Compañía de Arte Nativo del Norte Argentino. En estos y otros fragmentos del texto de Rojas puede verse cómo la percepción es la de estar ante una representación de los "usos regionales", es decir, de cuáles son las costumbres y las maneras vigentes en el interior del país, ya que la presentación de Chazarreta había 
cumplido la función de «ofrecer a la Ciudad Cosmopolita la sensación auténtica del arte popular argentino». Lo que es actual en "aquella selva dulcísima» lo exhibe el espectáculo mediante la propia corporalidad de los bailarines, que son imaginados «jornaleros del pago», es decir aficionados subidos al escenario de la capital que "venían trajeados como para un domingo, según la usanza regional». También por los músicos, que aunque son "gente más civil» y por eso visten «traje urbano», portaban los «típicos instrumentos» (recordemos la presencia del bandoneón, el violín y las arpas, junto a la guitarra de don Andrés, para evaluar la impresión de tipicidad que asalta a Rojas). Pero nada describe mejor la impresión de ser testigo de un traslado meramente geográfico de una porción del territorio "salvaje" del país que la siguiente frase:

Cuando se descorrió el telón apareció en el fondo un paisaje de la tierra nativa. El tablado fingía un antepatio de los ranchos donde suelen realizarse las fiestas del pueblo, y a su vera se alzaba la choza de quincha en donde habita el gaucho del bosque (Rojas, 1921).

Esta noción transformaba en vigentes las pautas culturales que el propio interior entendía como antiguas y obsoletas. Era una herencia del positivismo de finales del siglo XIX que la generación del Centenario potenciaría. De esta forma, el noroeste argentino se exotiza, se vuelve objeto etnológico y se convierte en reservorio de la tradición. Autores como Joaquín V. González o los peritos y exploradores, como Holmberg o Ambrosetti, son los que crearán «la noción de que las antiguas tradiciones argentinas estaban aún vivas en los aislados valles subandinos» (Chamosa, 2012, p. 32). Este aspecto temporal es fundamental para la cristalización de la concepción folklórica de la música y será sancionada en términos científicos por los folkloristas académicos. Vega, por ejemplo, ve en Ambrosetti al pionero de los estudios folklóricos en Argentina, ya que considera que sus Apuntes para el estudio del folk-lore misionero y "Apuntes para un folk-lore argentino (gaucho)" son los primeros artículos sobre el tema. Ambos textos aparecen en 1893 y resulta lógico para aquel ambiente etnológico que se publiquen en la Revista del Jardín Zoológico de Buenos Ayres. Es cierto que, a diferencia de las exposiciones universales, ese predio porteño nunca tuvo jaulas para ejemplares humanos, como podrían haber sido los gauchos del bosque de Rojas. Pero debemos recordar que otro ícono del positivismo argentino, el Museo de Ciencias Naturales de la ciudad de La Plata, exhibía hasta hace no mucho ejemplares humanos embalsamados de lo que sí había podido conservarse: los cuerpos indígenas de los pueblos exterminados por el ejército de la campaña al "desierto", brazo armado del mismo movimiento cultural. El Museo de La Plata fue fundado en 1884, y en esa acción concretada por el famoso Perito Francisco Moreno, el historiador Javier Trímboli ve uno de los hechos fundacionales de la generación del ' 80

\footnotetext{
Porque en ese museo, entre otras cosas, los que pasan a exhibirse son esas culturas premodernas que el nuevo estado nacional y esta generación del 80 victoriosa, había finalmente doblegado [en la conquista del desierto] [...] rápidamente empezó a llenarse de restos de cultura indígena, entre otras cosas de personas que pasaron a ser parte del muestrario de ese museo en el cual lo que se celebraba era el triunfo de una generación que se suponía altamente moderna, finalmente sobre todo aquello que había sido la barbarie (Mignona, 2010a, 10:47).
}

Vega ve en el tradicionalismo del movimiento nacionalista del Centenario el impulso de mayor valor que auxilia a la génesis de la ciencia del folklore y establece como momento significativo del comienzo del rescate de la cultura nacional aquel en que «el arqueólogo [Ambrosetti] abandona las fecundas piedras de la zona andina y desciende a las llanuras del gaucho para enfocar al personaje resurrecto desde el nuevo punto de vista» (Vega, 1981, p.88). En todo el libro, nos referimos a los Apuntes para una historia del movimiento tradicionalista argentino, Vega celebra en un sentido ideológico e incluso estético a escritores como J. V. González, Lugones y Rojas y músicos como Chazarreta, 
fundamentalmente por poner a buen resguardo el sentimiento nacional, verdadero "espíritu de la patria", protegiéndolo de las amenazas extranjeras. Éstas son la inmigración, leída en clave de invasión extranjera, y el cosmopolitismo que amenaza mediante la implantación de ideas foráneas, entre las que hace figurar al marxismo y el socialismo, junto al liberalismo y en alguna cita de Rojas, el capitalismo. Por el contrario y de forma muy inconsistente, el romanticismo, el nacionalismo y el positivismo cientificista son celebrados por Vega, sin ningún resguardo situacional ni asuntivo. Como muestra, la siguiente cita, en donde aparecen todos los tópicos de esa acriticidad frente a Europa como centro neurálgico del saber:

El nuevo año se inicia con la aparición de una figura excepcional: la del sabio Roberto Lehmann Nitsche, alemán de origen, benemérito de nuestro país, a cuya cultura científica consagró largas décadas de su vida. Su ensayo titulado Indagaciones sobre el Caballo "Retajo" se publica en los Anales de la Sociedad Rural Argentina y es de 1900. En 1906 recogió fonográficamente, por vez primera en la Argentina, música aborigen y criolla. La aborigen, de los araucanos, fue enviada por el colector a Berlín y, notada allá, se publicó complementando la nota Patagonische Gesánge und Musikbogen, del propio Lehmann Nitsche, y la criolla, de los gauchos bonaerenses que alcanzaba a seiscientos cilindros primitivos- fue remitida por él al Museo fonográfico de Berlín. El autor de estas líneas alcanzó a conocer al sabio alemán allá por el año 1930. Le aclaró el sabio que había mandado las grabaciones a Alemania porque "no había en el país ningún musicólogo". Ese tesoro se ha perdido para nosotros; apenas podemos conformarnos, en parte, con la información de que, mucho después, hacia 1950, nosotros conseguimos sobrepasar ese número de grabaciones durante nuestros viajes de estudio a las llanuras bonaerenses. Muchas cosas desaparecieron en esos cuarenta y cinco años (Vega, 1981, p.89).

Nótese que el primer trabajo de Lehmann Nitsche es también zoológico. De modo tal que en la producción de la nueva ciencia se entremezclan los caballos, los gauchos y los araucanos. Total normalidad en el país de los ingenios tucumanos, que no posee razas inferiores. Tal vez su problema es la abundancia de inmigrantes que deberían haber sido "superiores" y resultaron inferiores.

El impacto de la música y el espectáculo integral nativo que presenta Chazarreta en 1921 no se trata, por lo tanto, de la aceptación por parte de las clases hegemónicas porteñas de un clamor popular construido desde abajo, que como una avalancha hubiese bajado imparable desde el norte trayendo las costumbres y sonoridades de las clases subalternas del interior, «llevando el género a ámbitos que hasta entonces le estaban vedados» (Micheletto, 2010). Por el contrario, el proceso se da a la inversa. Las clases populares norteñas son incorporadas al proyecto nacional a partir de su aceptación del espectáculo que irradia, una vez más, desde Buenos Aires, sus teatros, radios y casas discográficas, y que construye, en el mejor de los casos, una caricatura de ese pueblo. La ocasión del debut porteño de la Compañía de arte nativo del norte argentino aparece en el momento perfecto y ocupa el lugar del monumento de reivindicación de la cultura nacional frente a la chusma ultramarina. Chazarreta es el actor protagónico de esa puesta en escena que sintetiza todo el derrotero de la construcción hegemónica de las élites, desde el romanticismo de la generación del 37 , pasando por el positivismo de los 80 , hasta acabar con el nacionalismo etnologizado de la generación del Centenario y su alianza con la oligarquía. ¿Qué otros elementos necesitaríamos para comprender que estamos en presencia de una construcción del pueblo desde arriba, en contra de los sectores populares movilizados y que disputan la política del país, y absolutamente ajeno a las manifestaciones musicales populares? El salto que Oscar Chamosa denomina «de los ranchos a las radios» habría que pensarlo en sentido inverso, al menos como dialéctica en un doble recorrido que 
implica necesariamente la apropiación y estilización por parte de la cultura hegemónica de, quizás, algunos rasgos aislados presentes en las prácticas vigentes de las clases subalternas.

\subsubsection{El Pozo de Vargas se convierte en manantial del folklore}

La batalla de Pozo de Vargas, ocurrida el 9 de abril de 1867, es uno de los hechos más controvertidos de la historia argentina, ya que se ubica en el centro de las disputas en torno a los proyectos de país que hasta el día de hoy están en discusión. Se la puede entender como el último combate de las llamadas guerras civiles que enfrentaron a unitarios y federales, pero también, si se amplía la mirada por fuera de las fronteras nacionales, como un momento culminante de las disputas entre un americanismo asuntivo y emancipatorio enfrentado a los planes foráneos de dominación del continente, operados sobre todo por Gran Bretaña (Ortega Peña y Duhalde, 1966). Lo que se enfrenta en batalla son dos formas diferentes de organización que se surgen del ciclo de las independencias latinoamericanas, razón por la cual lo que es propio de toda historia que, depende de quién la cuente, se hace en este caso muy evidente. Si, como decía Benjamin, el "historiador historicista" entra en empatía con el vencedor, los sesgos en la narrativa sobre la batalla de Vargas aparecen con claridad. Como Waterloo para Lord Acton, éste es uno de esos casos que pone nerviosos a los positivistas. Esto tal vez explique el alto grado de connivencia entre el historicismo y el desarrollo de una frondosa mitología para dar cuenta de los sucesos de Vargas y convertirlo en un episodio histórico que define el rumbo de la nación, proceso en el cual el folklore musical cumplió un rol protagónico.

El propio proceso histórico que iría a confluir en este episodio revela algunas de las percepciones y valoraciones que la clase dirigente tenía de los sectores populares, a partir de concluido el ciclo estrictamente emancipatorio. En términos generales puede pensarse y esto válido también para el caso europeo más o menos por las mismas fechas- que la preocupación de las clases hegemónicas una vez terminada la revolución es desmovilizar al pueblo. Para destacar esto, el historiador Fabio Wasserman (2016) llama la atención sobre un bando del Congreso de Tucumán, que se dicta a menos de un mes de firmada la Declaración de la Independencia, el $1^{\circ}$ de agosto de 1816 . Lleva por título Fin de la revolución, principio del Orden. Es decir que, para aquellos mismos patriotas que proclaman la independencia, el nuevo país liberado del yugo colonial sólo puede configurarse una vez finalizado el proceso revolucionario, que para los patriotas puestos a conducir los destinos de la patria, como José Ignacio Gorriti, se ha vuelto ya «intolerable». En el bando se discute acerca del "estado de disolución» en que se encuentran las Provincias del Plata, lo cual suele asociarse con la "anarquía», término que a su vez la historiografía mitrista ha utilizado para caracterizar a todo el período que media, justamente, entre la declaración del 16 -el «fin de la revolución»- y lo que se considerará como principio del orden: la etapa de los líderes, o caudillos federales, que culmina en el acontecimiento que marca otra batalla, la de Pavón. Pero, más allá de la puja política, ¿qué era lo intolerable del estado efervescente y revolucionario que el federalismo prolonga, o al menos no es capaz de finalizar?

es la movilización de los sectores populares que ponían en cuestión el orden social. La revolución y las guerras habían provocado también un proceso de movilización de las clases subalternas, de los sectores populares [...] que ponían en cuestión no solamente determinadas características de la organización política sino del orden social (Wasserman, 2016).

Por lo tanto, el problema -que terminará desembocando en Vargas- no es tanto un asunto de luchas facciosas y regionales sino algo que, incluso después, se denominaría la guerra social. Hay entonces una relación muy estrecha entre la forma en que la élite valora 
el accionar de los sectores populares -oscilante aunque siempre "desde arriba" y en la cual el folklore es protagonista- y la construcción del orden social y político del Estado Nación. Un símbolo de ese orden que se impone tras la derrota de los caudillos -uno de los últimos es Varela- es el famoso lema Paz y Administración del gobierno de Julio Argentino Roca. En la apertura de sesiones del Congreso Nacional de 1884, durante su primera presidencia, Roca cita la proclama de Tucumán al dar cuenta de que esos problemas del pasado reciente -la revolución- han finalizado. Habían pasado 17 años de la batalla del Pozo de Vargas.

Un mal gobierno pasa, y si viene otro malo enseguida pasa también, pero las revoluciones son como el incendio, abrasan la heredad, devoran la simiente y agotan la savia por muchas generaciones, cuando no esterilizan el suelo por siglos. Vosotros os congregáis de todos los puntos de la República, y podéis comunicaros vuestras impresiones de lo que habéis visto y notado en vuestras propias provincias y en el trayecto recorrido, con la realización del voto de aquella asamblea patria, que aconsejaba hace sesenta años a los pueblos, dar fin a la revolución y principio al orden (Honorable Cámara de Diputados de la Nación, 1884, p. 6).

La consideración por parte de las élites del pueblo como sujeto es un problema constitutivo de los regímenes burgueses que emergen de los procesos revolucionarios a principios del siglo XIX, en tanto la República se sustenta en la idea de soberanía popular. Simultáneamente "el pueblo" es una categoría que requiere de una definición ya que, en función de su carácter estructurado (Gramsci, 2011), emerge del proceso de estratificación y no es un sentido social o cultural dado, ni natural, ni espontáneo. Por lo tanto la construcción del sujeto "pueblo" representa un escenario de tensiones y disputas en el que convergen las consideraciones, prejuicios y hasta la fascinación que las élites tienen acerca del mundo popular subalterno. Como el ideal republicano de orden social y político postula al pueblo como depositario de la soberanía, la presencia de los sectores populares en la vida pública no puede ser negada sin más trámite, cuestión más habitual en la aristocracia, aunque nunca por completo, como vimos incluso en el mundo medieval. La propia idea de pueblo que luego la burguesía transformará en soberano, aparece como tercer estado dentro de la monarquía. De esa necesidad de consideración y definición de los sectores subalternos, de su naturaleza y de su rol ideal dentro del nuevo orden moderno, en pocas palabras, de lo que esperan los sectores dominantes que sea el pueblo, surge históricamente, para dar respuestas a esas disputas, la disciplina del folklore. Los sectores populares, más que sujetos sociales, se constituyen entonces en objetos: objeto de discurso, objeto de disciplina, objeto de conocimiento, de recolección, y hasta de exhibición. Si «por lo tanto su subordinación requeriría diseñar dispositivos, ya sean de carácter coercitivo o consensual [y entonces] aparecería la represión, la exclusión, la pedagogía» (Wasserman, 2016), podemos añadir al final de esa lista el tradicionalismo, el arte nativo, el nacionalismo musical y el folklore.

Una vez que las burguesías nacionales tomaron el poder y las fronteras político administrativas fueron delimitadas por los países independientes, se fortaleció aún más la división entre las elites dominantes y los sectores populares. A partir de entonces hubo una mayor diferenciación entre la llamada "música culta" y "la popular" (Eli, 2010, p. 97).

Si durante el proceso histórico, que con no pocas dificultades y conflictos internos en Argentina va a extenderse al menos hasta la década de 1930, "el pueblo" va a ser considerado fundamentalmente en base a sus tradiciones -que no son populares sino "inventadas" y "selectivas"- es natural que una arista importante para afirmar este orden que surge de las exequias de la revolución sean las manifestaciones de ese pueblo nacional. Por eso la música, entre otras producciones, recibirá mucha más atención en términos de su rol configurador del alma nacional. El folklore, sobre todo en pioneros de la disciplina como José Alfonso Carrizo, adquiere un tono de gesta patriótica 
Catamarca contribuía con la bravura de sus hijos para la independencia del suelo patrio; pero no era la libertad del país lo que más conturbaría aquella vida sosegada, fueron la anarquía primero, la tiranía después y las montoneras por último las que sacudieron aquel pueblo montañés [...] Las intervenciones nacionales intentaban en vano volver a su quicio a las instituciones provinciales (Carrizo, 1926, p. 6)

Vega también celebra «la ola de progreso [...] fecunda como rumbo, engrandecedora y enriquecedora en la realización» que siguió a la caída de Rosas, aunque la denominará como un "padecer» en función de la destrucción -por supuesto involuntaria- de las «tradiciones locales» del interior. Para el folklorista, es una pena que la primera versión del orden nacional que emerge al finalizar la revolución no le haya concedido la importancia que tenían y tienen las tradiciones para la consolidación espiritual de la nacionalidad (Vega, 1981, p. 93). Esta es la exigencia que los nacionalistas del Centenario le demandarán a los creadores de la paz y la administración. Es decir que los intelectuales ligados al tradicionalismo que Vega reverencia, como Rojas o Lugones, celebran también la derrota federal y la desmovilización popular, sólo que consideran a éstas condiciones necesarias aunque no suficientes para la constitución de la Nación.

El traslado del pueblo de sujeto a objeto, que ya vimos antes -por ejemplo en Cortazares idealizado y, como veremos más adelante, es a su vez etnologizado: implica que la distancia, ese pathos nietzscheano que nos ayudó a comprender la estratificación de los trovadores, se mantiene cuando las élites toman en consideración a los sectores populares. Incluso podríamos decir que se sofistica, ya que toda la discusión cultural y el preciosismo de las descripciones que el positivismo lleva a límites inauditos, no hace otra cosa que otorgar entidad a esa distancia social prácticamente en términos naturales. Recordemos que Nietzsche piensa ese pathos de la distancia teniendo en mente a los «lectores de periódicos» a quienes desprecia y, justamente, son estas distinciones entre lo ligero y lo profundo, lo superficial y lo serio, lo alto y lo bajo, o lo culto y lo folklórico, las que señalan el grado de detalle que presenta esa preocupación clasificatoria de la burguesía moderna, tanto en sus formulaciones estéticas como políticas, sociales o antropológicas. Además es importante recordar el carácter de hipótesis cultural, destinada a explicar los elementos en proceso, lo inasible -y qué es sino la movilización de los sectores populares para la éliteque reviste todo esto en términos de ser una «estructura de sentimiento» (Williams, 2000, p. 155).

Pero volvamos a nuestro episodio legendario de la batalla de Pozo de Vargas. No nos extenderemos aquí en los detalles que enmarcan la contienda. Baste señalar que, en función de las respectivas bases de operaciones, los bandos que se enfrentan en batalla se identifican con las provincias argentinas de Santiago del Estero y La Rioja. La primera facción está al mando del comandante Antonio Taboada, que recibe órdenes de Buenos Aires, de un gobierno central; mientras la otra responde al legendario Felipe Varela, cuya gesta es americanista y está fuertemente ligada al período inmediatamente anterior del país. A partir de allí la historia nacional, mitrista, a veces llamada oficial, ubica la contienda como una batalla en que la Nación se defiende de "los invasores". El ejército patrio no es santiagueño, sino nacional. Enfrente están los extranjeros, que ya no serán tan riojanos sino chilenos y, por si fuera poco, unos bárbaros asesinos a las órdenes de un salteador, «un caudillo alzado en armas contra la Nación» (Vega, 1981, p. 105). Del otro lado de la trinchera académica, los verdaderos patriotas son los varelistas, las fuerzas revolucionarias que no sólo luchan para liberar a la Patria de la opresión del estado porteño oligárquico y vengar así a los caudillos federales como el "Chacho" Peñaloza. La "dimensión americana" de lo que desata Varela y sus montoneras es también la resistencia que se interpone al imperialismo británico y su expresión más tangible e injusta: la guerra del Paraguay. 
La batalla en sí no es un hecho decisivo y, si bien se debate su resultado (Ortega Peña y Duhalde, 1967, p. 35), el conflicto que la origina, sea cual sea nuestra interpretación del mismo, claramente la excede. Pero alrededor de ella, y por parte de ambos "bandos" -si bien pareciera que el mitrismo es pionero- se construye una mitología alrededor de la batalla que está atravesada en su núcleo por la música. En el caso de los revisionistas, se señala que en las montoneras existían bandas populares tocando en las chinganas, en cuyas canciones se solía narrar entre otras cosas la gesta vareliana. Estas músicas y bailes podían llamarse zamacuecas, o "zambacuecas» (Ortega Peña y Duhalde, 1967, p. 35) o «zamuecas» (Alen Lascano, 1972, p. 35). Todo lo cual es parte de músicas que luego se particularizan y el folklore, mediado por los nacionalismos, "reparte" en las naciones o provincias: la cueca será chilena o cuyana, la marinera peruana, etc.

De allí surgieron canciones como Viva el General Varela: «iViva el General Varela! Por ser un hombre de honor, ¡Que vivan sus oficiales! Viva la Federación». En esta canción podemos ya atisbar cómo queda al descubierto la vinculación de la "ciencia del folklore" con la historia política, "sus supuestos ideológicos y la encubierta politización antipopular que encierra, tras su corteza aparente de abstracción y universalidad» (Ortega Peña y Duhalde, 1967, p. 10). El folklorista que "recopila" la canción no es otro que Juan Alfonso Carrizo. Y la publica en su célebre Cancionero de Catamarca. Allí, como es costumbre en los folkloristas, los textos (porque Carrizo no publica música) están acompañados de comentarios que, más que en descripciones y análisis, consisten en impresiones o juicios personales y en este caso son más políticas que estéticas:

En 1866 pasaba la cordillera con rumbo a nuestro país [...] Felipe Varela [...] Este caudillo de las montoneras federales de tan ingrata memoria, traía algunos milicianos enganchados, parte en Chile y parte de las provincias de Catamarca y La Rioja. Venía titulándose jefe de una cruzada libertadora [...] Dicen que pensaba también reunir Chile. Bolivia, Perú y parte de la República Argentina en una gran Confederación. Estos y otros embustes por el estilo propalaba para hacerse de prestigios y justificar sus atropellos (Carrizo, 1926, p. 50).

Incluso este autor argumenta que no se trataría de una canción genuinamente popular. Como ya vimos, para alcanzar este mérito debería ser parte de la creación espontánea y colectiva, no una obra de «juglares de la urbe». Pues bien, don Juan Alfonso nos dice que la canción tiene un autor e incluso un datación precisa: 1866. La anécdota, que vuelve las coplas un mero artificio, cuenta que Varela, a su paso por Catamarca, habría encarcelado al poeta Abraham Aguilar y éste, para obtener su libertad aunque a regañadientes, le habría compuesto la canción laudatoria. Todo un embuste inauténtico, que solo su posterior colectivización, es decir, su caída en el folklore, su descenso (para usar la terminología de Vega) podrían redimir depurando la contaminación en los hontanares comunales de la tradición oral que hicieron posible que "llegara" al folklorista. Así, orgulloso, Carrizo cierra el comentario a la canción diciendo que «fue tomada del pueblo».

Pero no es Viva el General Varela la música legendaria de la batalla de Pozo de Vargas. Porque a esas cuecas chilenas, a esa música tan extranjera como el ejército invasor, la historiografía mitrista y el folklore le van a oponer la Zamba de Vargas. Esto es de la máxima importancia, ya que según el mito-histórico es gracias a esa música que ganaron los "leales", como llama Vega al bando de Taboada. La leyenda dice más o menos así: las tropas de Varela sueltan un cañonazo en señal de combate; Taboada ordena repeler el ataque y entonces el mayor Brizuela, al mando de una compañía catamarqueña y viendo la desazón en los rostros de sus soldados da la orden de... jejecutar una zamba! Casi cuarenta años después, un testigo de los hechos, el capitán Salvatierra, describe lo que produjo la música en la tropa: 
El efecto fue extraordinario: las tropas, electrizadas con los acentos del baile nacional, prorrumpieron en gritos, en vivas al general (Taboada) y en mueras al enemigo. Todos los soldados comenzaron a bailar, arremangándose el chiripá y tomando el fusil por el medio (citado en Vega, 1981, p. 106; y en Alen Lascano, 1972, p.34).

Esta increíble descripción se transforma en leyenda fundamentalmente de la mano del tradicionalismo nacionalista y el folklore. Si bien seis años más tarde y en otro diario de Santiago el capitán Salvatierra se desdice de este relato y cuenta que los primeros que tocan son los de Varela, y que los taboadistas contestan con una chacarera (Ortega Peña y Duhalde, 1967, p. 37) o un gato (Goyochea, 2009), con pocas objeciones Carlos Vega le da estatuto científico a la leyenda: «la versión más lógica y exacta es la primera de las dos o tres que dio el capitán Salvatierra [...] Esto es claro y sensato» (Vega, 1981, p. 106). ¿Cuál es la razón para que el folklorista se incline por la primera versión, la que habla de una zamba en términos de baile nacional? ¿Qué fundamentos tiene, aparte de sus simpatías ideológicas, para corroborar sin evidencias los dichos de un hombre mayor, probablemente senil, que testimonia de forma muy variable un recuerdo de cuatro décadas? Según Vega el problema es de escala: "¿Se ve? Salvatierra habla de su cuerpo de infantes santiagueños, que estaba próximo a la banda [...] Todo es cierto y todo bellísimo si lo imaginamos en pequeño, ahí, entre un par de compañías vecinas, duración muy corta» (Vega, 1981, p. 107). Nada respalda esta conjetura salida de su imaginación. Otros historiadores han intentado basarse en los planos de la batalla (Noriega, como se citó en Ortega Peña y Duhalde, 1967), en las migraciones de las músicas (Alen Lascano, 1972) o en la configuración de las fuerzas y su armamento (Turone, 2015).

Cualquier análisis histórico debería considerar que las tropas de Taboada -entre quienes existían veteranos del Paraguay y provincianos reclutados a la fuerza, como el "batallón catamarqueño"- habrían huido si las "montoneras bárbaras" eran todo lo potentes y asesinas que la historiografía mitrista cuenta. Aunque oyeran una zamba, una chacarera o un vals vienés. En cambio, lo que inclinó la batalla fue la desigualdad, no de número ni de estilos musicales, sino de condiciones, muy desiguales en ambos ejércitos: por un error militar, los de Varela venían cabalgando hacía días y sin provisión de agua; él y sus montoneras no iban a Santiago sino a Salta, y Taboada lo obliga a retroceder a La Rioja; de ahí la premura de Varela y el descuido del agua; Taboada arma sus trincheras tiempo antes de la batalla, en el único pozo que había dejado disponible -el de Vargas- para atraer allí a su contrincante; pero sobre todo, las técnicas de combate representan casi dos épocas históricas: las montoneras de Varela eran gauchos montando al pelo y con tacuara, frente a los fusiles Sharp de los taboadistas, que los ingleses le habían dado al gobierno de Mitre para la guerra contra Paraguay. De allí se explica que los "rebeldes" fueran diezmados y los nacionales tuvieran muy pocas bajas, estimándose los caídos en 1200 frente a sólo 200, respectivamente. «Lanzas contra fusiles» Ilama a esta batalla José María Rosa (2011). Una imagen que no busca la metáfora.

Es evidente, en cambio, que Vega construye una inferencia, un verosímil, para dar algún crédito y salvar las increíbles incongruencias de la versión legendaria. Si de imaginación se trata, imaginemos entonces una escena como las de esas películas del Lejano Oeste en donde un gran malón de indios desfila, para morir, delante de las ametralladoras que no dan cuartel. La cultura popular del cine y de los espectáculos musicales es mucho más potente que la ciencia del folklore para fijar una creencia mítica sobre los sucesos históricos. Y por eso aquí hacemos entrar en escena a nuestro juglar, Andrés Chazarreta. Porque es él quien logra fijar la leyenda de la batalla, a través de su Zamba de Vargas. Existe tanto debate acerca de esta zamba como versiones históricas de la batalla. Y si bien, como vimos, se ha cuestionado mucho que esa zamba se tocara efectivamente en el campo aquél 10 de abril, se ha discutido mucho menos sobre la naturaleza de esa canción de Chazarreta. 
Comencemos teniendo presente que existe un consenso en que Chazarreta es recopilador, es decir, él toma la música del pueblo, la transcribe y atesora (como vimos decía Carrizo). Como también es músico, a lo sumo la arregla, es decir, le añade algunos acordes, probablemente la instrumenta. Pero para usar la terminología de Vega, Chazarreta "usufructúa» bienes musicales folklóricos. Por eso el folklorista dice de don Andrés que «desconoce la ciencia del folklore y no se siente folklorista; actúa entonces como tradicionalista, costumbrista y hombre de empresa» (1981, p. 105). No importa que los derechos de autor -sí, de autor- de la Zamba de Vargas estén registrados a nombre Chazarreta, o que incluso el músico haya tenido que atravesar $-y$ perder- un juicio por plagio merced a otra leyenda del folklore, como es la zamba La López Pereyra (Ortega Peña y Duhalde, 1967, p. 46). Incluso para los historiadores abiertamente enfrentados con la visión "mitrista" que cuenta la Zamba de Vargas, Chazarreta no hace más que transmitir una música que obtiene del pueblo

Quien descubrió la Zamba de Vargas fue el eximio compilador don Andrés Chazarreta, cuyo entusiasmo por las cosas nuestras lo llevó a levantar una primera versión de la pieza de boca de dos ex combatientes de Pozo de Vargas (Turone, 2015)

Incluso hasta se lo puede censurar por falsear la verdad histórica, pero no a costa de renunciar a la idea folklórica de que existe una versión original de la zamba en algún puro hontanar popular,

Andrés Chazarreta realiza una gira por la campaña de Santiago del Estero. [...] Poco tiempo después trae una versión de la Zamba a Buenos Aires [...] Pero lo cierto es que este Mitre del pentagrama [...] ni es autor ni recoge una versión auténtica (Ortega Peña y Duhalde, 1967, p. 40)

De forma similar a lo que veíamos antes, en que muchos movimientos progresistas y de izquierda generaban una explicación para justificar la creencia del carácter conservador del pueblo, sin poner en cuestión que lo conservador no es la cultura popular sino el "folklore" mediante cuyos conceptos se comprime el arte y la música populares, aquí vemos también que lo que se discute son los resultados de la folklorización, no el folklore y sus conceptos en sí. Esto es evidente en la interpretación de todas las coplas y canciones del "ciclo Vareliano" que analizan, con las mejores intenciones, Rodolfo Ortega Peña y Eduardo Luis Duhalde en el texto ya referido.

Pero vamos a la versión del propio don Andrés, que recoge su hijo en el libro-homenaje El eterno juglar (Chazarreta, 1965). En ella, el músico cuenta cómo, en el patio perfumado de azahares y madreselvas de una casona de Santiago, su abuela-madre Agustina, mientras rezaba el rosario y cebaba mate, le transmite la Zamba de Vargas, emocionada, quebrada la voz, recordando además la ausencia de su hijo Manuel Antonio, combatiente de la legendaria batalla, que nunca más volvió de otras aventuras posteriores.

Chazarreta: Al año, cuando organicemos la comparsa para el Carnaval la tocaremos para usted aquí, en este mismo patio.

Abuela Agustina: Si Dios me presta licencia, hasta entonces gozaré al escucharla. Las taboadístas mantenemos rico el recuerdo de esa zamba.

Chazarreta: Cuénteme mama una vez más... cuénteme lo que sabían recordar mi tío Manuel Antonio, don Ambrosio Salvatierra, el Negro Chagaray y los otros.

[...]

Chazarreta: ¿Ese fue mama, el bautismo de la zamba?

Abuela Agustina: "La zamba de Vargas", hijo!, allí fue bautizada en el campo de batalla. (Chazarreta, 1965) 
A partir de esta hermosa anécdota dice Vega que "Chazarreta ha pasado al pentagrama una zamba tradicional, ha hecho un arreglo para su instrumento y lo ha ejecutado en público» (1981, p.107). Nuevamente corre en auxilio del folklorista el término tradición, que ya analizamos previamente. Recordemos el carácter "selectivo" e "inventado" de las tradiciones, y podríamos agregar construido o configurado. Tal vez, por qué no, compuesto. Es importante para comprender la dimensión de lo que hace Chazarreta con Vargas. Componer una zamba a partir de un suceso, la batalla, configurado en la memoria popular de un modo específico que en ese momento se estaba consolidando. "Tomando nota de la música santiagueña, Chazarreta compuso canciones que luego interpretaría en los escenarios con su conjunto» (Chamosa, 2012, p. 73). Estamos en 1906, y el 10 de abril se publica el relato de Salvatierra, esto es la primera versión sobre lo ocurrido en la batalla, que es la que coincide con la versión musical de Chazarreta. Poco después, el 22 de agosto (Vega, 1981, p. 107) o el 25 de ese mes (Alen Lascano, 1972, p. 32) Chazarreta estrena en público su "arreglo" de la zamba, en un evento a beneficio, en el teatro Cervantes de Santiago. Pero es una versión instrumental, es decir, que no toma las coplas escuchadas en el patio de la casona. La letra de la Zamba de Vargas tiene un recorrido diferente y, más allá de las versiones que también le adjudican un origen tradicional y folklórico, es aún posterior y quien rubrica el texto en "versión taboadista", es el poeta Antonio Lombardi que escribe el texto -o le «da forma a la tradición»-a pedido de Chazarreta.

Es decir que el recuerdo de la ocasión histórica, la publicación de la leyenda musical de la batalla, la recopilación de la zamba y el canto de la abuelita Agustina, todo ocurre aproximadamente al mismo tiempo. Un momento en que, como veremos, las clases dominantes del noroeste argentino comienzan una fuerte acción política para mantener sus privilegios, para lo cual se pondrán el folklore a cuestas. Son los hacendados tucumanos quienes financian e instruyen a José Alfonso Carrizo para que «tome del pueblo» el folklore, trabajo a partir del cual Bartolomé Peralta Luna (re)construirá la otra versión, «riojana y federal», de la Zamba de Vargas (Carrizo, 1934) Lo harán en pos de encontrar una voz del interior nacional que pueda confrontar el proyecto cosmopolita porteño, poblado de ideas extrañas y de inmigrantes, pero sobre todo de una apertura comercial desfavorable para los ingenios azucareros. $Y$ todavía luego, continuarán su tarea patrocinando a Vega e Isabel Aretz (Chamosa, 2012).

Todo esto hace muy difícil que la Zamba de Vargas fuese en el comienzo del siglo XX «la música más fácil de recoger en Santiago: la interpretaban en cuanto acontecimiento popular requería un tema folklórico» (Alen Lascano, 1972, p. 34). Sobre todo porque, como incluso el mismo Vega hace dando crédito a la leyenda de Salvatierra, la de Vargas sería «la primera zamba». La malograda música que exaltó la moral de los combatientes en batalla «significa que en el año 1867, la Zamba había echado profundas raíces en el espíritu del pueblo» (Vega, 1952 , p. 25). Es decir, y porque «una tradición provincial muy difundida [...] lo confirma», la acción militar de la zamba en el campo de Pozo de Vargas marcaría su origen como género o especie musical, emancipándola de la zamacueca. Más allá de esta fantástica creencia, está claro que antes de la época de Vargas, no hay "zambas", sino, en todo caso, zamacuecas, o chacareras, o músicas cuya denominación es variable y no responde a la taxonomía positivista del folklore. Unas músicas que tocaban las bandas de ambos ejércitos que, recordemos, eran todos básicamente habitantes de la Precordillera y los valles y que, seguramente, lo hacían mucho menos en batalla que en bailes y chinganas. Porque todos formaban parte del mismo mundo popular subalterno, mestizo y transcultural. «Es decir, la zamacueca primero se santiagueñizó, y transformada en zamba cobró después ciudadanía nacional» (Alén Lascano, 1971, p. 36). Es muy probable que el proceso histórico responda a este derrotero. Pero notemos el agenciamiento que se le adjudica a "la cosa", casi propia de un pensamiento animista sobre la música. Esto es muy característico del folklore en tanto pretende trabajar con fenómenos comunales y anónimos 
en los cuales el sujeto siempre es un problema. Como vimos en el caso de los juglares, esto redunda además en una jerarquización siempre desfavorable para la música popular. Por lo cual proponemos salir de esa falsa dicotomía, pues no tiene ningún sentido preguntarse si la Zamba de Vargas es "la primera zamba", o mucho menos si Chazarreta "inventó" la Zamba en tanto tal, o si "santiagueñizó" la zamacueca. Son todas formas discursivas de la afirmatividad moderna que ya vimos, están íntimamente asociadas al personalismo de la cultura burguesa, al escencialismo y a la estratificación, ya que configuran sus categorías de distinción. Chazarreta se formó a partir de las músicas con las que tuvo ocasión de tomar contacto, al mismo tiempo que participó en su configuración. $Y$ en su caso son muchas, desde la ópera alla italiana, a las canciones de las calles y los carnavales santiagueños. Como cualquiera de sus amigos o vecinos, músicos o no, tuvo simpatías políticas, y la influencia de su familia taboadista o su paso como director de la Escuela Militar del Regimiento 19 de Infantería, seguramente lo marcaron profundamente e hicieron que sus inclinaciones fuesen algo notorio y presente. Con todo eso, cuando tuvo la oportunidad -en un sentido de producción y no de inspiración- hizo una canción, como un juglar, articulando las sonoridades y características de las ocasiones musicales del mundo popular subalterno de su entorno provinciano, al que pertenecía y que no era "rural" o de la "campaña", además de pertenecer plenamente al 1900. De lo que podemos estar seguros es que su Zamba de Vargas es la primera que lleva esa denominación como objeto de cambio: su publicación en partitura en 1908 lo confirma y no revela que si todavía queremos preguntarnos por el origen de la zamba, este hay que buscarlo entre el olor a tinta y el ruido de la tipográfica de la imprenta Medina, Buenos Aires, Capital Federal.

La etnologización tan habitual en la historiografía nacionalista, de la cual el folklore junto a la antropología ha sido un gran auxiliar, hace parecer que unas músicas son santiagueñas y otros riojanas, o argentinas y chilenas, en virtud de un esencialismo que se sirve conceptualmente de la tradición y su fuerza configurativa, de modo tal que parecen remontarse a un pasado idílico y naturalizado, pero que simultáneamente es previo a la Nación, por lo cual todas esas categorías pierden automáticamente su sentido. Es un modo de pensamiento segregacionista que implica un radio de acción mucho más amplio que el de la música, a cuya gestación en la primera mitad del siglo XX ayudará mucho el folklore (Miller, 2010).

El mismo Alan Lascano, con pocos párrafos de diferencia, aporta una nueva hipótesis que contradice totalmente su afirmación acerca de la popularidad comunal de la zamba: José María Gauna, que además de ser otro sobreviviente de la batalla de Vargas era músico, le habría "transmitido los acordes musicales» a don Andrés. Gauna era músico culto -por ejemplo escribe un oratorio- y enseñaba la "zamba" de Vargas a ejecutantes locales. Como era vecino de Chazarreta, éste la habría oído frecuentemente en su juventud y así la habría aprendido, "siendo dable pensar que es la suya» [de Gauna], con ligeras variantes, la versión recopilada por Chazarreta ¿Es decir que sería una recopilación de una versión de un músico culto, un "juglar de la urbe"? También agrega Alen Lascano, que hacia 1905 Chazarreta, comenzó a sentir «la necesidad de pasar al pentagrama la música de tantos cantos y bailes que en cada punto oía con sorpresa ejecutar a gente aborigen, con toda alma y sentimiento» (1972, p. 27). Vega también menciona esto, y en ambos autores se transforma en explicación [para Lascano ya es la tercera hipótesis] del hontanar popular de donde saca Chazarreta la Zamba de Vargas. Acuerdo que no surge de sendas y profundas deducciones, sino porque citan la misma fuente: una autobiografía del mismo don Andrés. Sólo que en Vega se traspapela una ligera modificación al testimonio. Según el folklorista, Chazarreta siente la necesidad de escribir música (Vega, 1981, p. 105). La polisemia del término transparenta algo que se parece mucho más al acto de la composición. 
De modo que por parte de la abuela y el tío, Chazarreta conoce la letra de la zamba que en realidad escribirá mucho después un poeta; también la melodía o tonada, que a su vez aprende de «cuanto acontecimiento popular» participa en Santiago y al mismo tiempo de la campaña, de mano de los «aborígenes»; a lo cual se añaden «los acordes» que don Gauna le transmite por encima del tapial. Pareciera que de acuerdo al elemento musical que enfoquemos, el "hontanar" cambia o, en todo caso, se enturbia hasta que lo que finalmente obtenemos se parece más al agua envasada de los supermercados. Elementos en los que sobresalen siempre las alturas, en sucesión o armonía vertical. Las bases del estilo de los objetos de la musicología histórica.

Baile nacional. Así denominaba en su propia introducción don Andrés Chazarreta a la que es quizás una de las más insignes piezas del folklore argentino, o criollo... o música nativa como él mismo llamaba al género musical. Tal vez en esa denominación, muy vinculada a la visión mitrista de los hechos, aparezca un verdadero sentido histórico de esta zamba, que consolidó a nivel popular una forma de comprender la historia de nuestro país, desde una concepción afirmativa, hegemónica: la de las élites gobernantes. Esto es lo que le valió a Chazarreta el epíteto de ser un Mitre del pentagrama (Ortega peña y Duhalde, 1967, p. 40) a propósito de la creación de la Zamba de Vargas. Tal vez, como dice Alen Lascano (1972 p. 36), sea un tanto injusta o exagerada, en función de que don Andrés no era un falso taboadista, sino un nacionalista convencido, conocedor de los textos de los intelectuales del movimiento tradicionalista como Rojas o Leguizamón (Vega, 1981, p. 105). Es mucho más inverosímil la creencia de Lascano en que Chazarreta creía «con ingenua sinceridad» en la historia fantástica de la batalla. El empresario que describe Vega de seguro no era tan ingenuo y sí, en cambio, estaba indudablemente en condiciones de comprender el potencial que tenía la leyenda del Pozo de Vargas como base de un espectáculo artístico de danzas y músicas nativas. Sobre todo si declaraba que esas músicas no eran de él, sino del pueblo. Se trata sin dudas de música popular, creación de uno de esos "juglares de la urbe". Un juglar de derecha, en todo caso. Podemos recuperar una frase de Vega que ya usamos y aplicarla en este nuevo contexto para darle un sentido totalmente distinto, definiendo provisionalmente al folklore: «todo es cierto y todo bellísimo, si lo imaginamos» (Vega, 1981, p. 107).

\subsubsection{El sonido de Vargas}

¿Qué podemos saber de las sonoridades de ésta música en términos de lo que presentó Chazarreta como Zamba? Es muy probable que estas canciones y danzas que están presentes entre los sectores populares de la época de la batalla de Vargas se basaran en derivaciones de la zamacueca, es decir, músicas mestizas devenidas del proceso histórico colonial. En este caso, fundamentalmente de la relación entre la transculturación musical popular o no- del Virreinato del Perú y sus zonas de influencia en el siglo XVIII, los resabios de la música de las reducciones jesuíticas y otras músicas, como el gato, que probablemente estuvieran más presentes en la región pampeana. (Vega, 1948, p. 7). En su materialidad sonora, la zamacueca y el resto de las músicas populares mestizas priorizan el sonido (timbre) y la textura como elementos estructurantes, de tal suerte que en los instrumentos más habitualmente utilizados, la guitarra y la percusión, sobresalen las sonoridades no puntuales, es decir, las que no determinan el factor de alturas o "notas". El campanilleo de los rasguidos y chasquidos, sumado a sonajas, bombos y el estruendo de las palmas de los bailarines, genera una banda inarmónica que sobrepasa en lo acústico cualquier articulación de acordes y notas. Es un "ruido" en los términos que utiliza Attali (2011), como subversión del orden armónico, pero no porque sea una protesta, sino en cuanto a que aquí lo tímbrico y lo textural son la estructura de la música, que no se deja reducir a términos de abstracción lógica. Todavía puede escucharse esto en las 
reconstrucciones que los tradicionalistas hacen de las sonoridades populares del primer siglo de los países de la región. ${ }^{169}$

Junto a estos factores está el de los ritmos -que, como se sabe, en música popular suelen transformarse en índice identificador del género. Aquí debemos hablar de configuraciones desvinculadas del orden métrico y articuladas, en cambio, a partir de la convivencia o reunión heteróclita -es decir no sintética- de más de un estrato temporal. Pero explicar esto en general es difícil desde la caja de herramientas analítica configurada para describir la obra musical culta occidental. Lo cual conlleva soluciones teóricas que poco ayudan a comprender lo que de particular hay en estas manifestaciones musicales. No tanto por lo "extra-europeo", ya que algo de Occidente hay en todas estas músicas; más bien lo que tienen de popular, que se aparta del formato de pensamiento de la modernidad europea, de la obra musical, e incluso en ocasiones lo pone en crisis abiertamente. Eso quiere decir «no-métrico» o «ritmo orgánico», «clave» (Quintero Rivera, 2009). Son formas de organización del ritmo que, a diferencia de Occidente, rehúsan partir de la abstracción lógica y la descomposición proporcional de la unidad, entendida como totalidad intemporal. El fraccionamiento, que da lugar al "contar" propio del ritmo moderno europeo, no tiene relación con la música popular. Y la trampa de la teoría musicológica es que, al conservar para sí la mayoría de los nombres y conceptos, pareciera que lo anómalo es pensar el ritmo por fuera del modelo lógico moderno, cuando en realidad es al revés: la excepción es rechazar los ritmos que parten del movimiento corporal, de los ciclos y cambios naturales, del fluir de la sangre ${ }^{170}$ o el soplar del viento. Esta es una de las formas más crudas del dominocentrismo (Grignon y Passeron, 1992) que revela una faceta de producción de la colonialidad del saber (Lander, 2000). Se cruzan en este aspecto el hacer del arte del pobre algo más pobre, con el primitivismo que reserva un lugar de simpleza extravagante y pintoresca a las culturas periféricas a la modernidad. Históricamente, la cuantificación y mensuración del ritmo y su apartamiento de la articulación verbal en el canto, ocurre precisamente cuando se dan los primeros signos del desarrollo de la modernidad occidental: es un asunto de las ciudades europeas del siglo XIII, de las instituciones académicas como las universidades, en el marco de lo que rodea a la emergencia de la burguesía como clase y su preocupación incipiente por fragmentar y contabilizar. Hasta ese momento, incluso en el ambiente intelectual de la Iglesia, el ritmo era lo opuesto a lo métrico (Cullin, 2005, p. 75) y, más que con contar, tenía que ver con modular el lenguaje sonoro en función del contexto de significación de cada frase y de las necesidades de persuasión que también cambiaban en función de los circunstanciales auditorios. Otro aspecto que, como es evidente, nos revela su imposibilidad de transcripción a la partitura y nos ofrece un panorama en el cual el aprendizaje de oído era imprescindible para adquirir justamente esas técnicas más vinculadas con la improvisación que con la idea de obra cristalizada. Todo esto cambia en los prolegómenos de la modernidad, en que el ritmo se hace "medido" y para ello, lo cual no es ninguna casualidad, se desarrolla un sistema de notación mensural del cual carecían hasta el momento, por no necesitarlo, las partituras. Escribir y contar el ritmo son dos metáforas del control de la naturaleza que será el signo de la modernidad (Small, 1989, p. 67). Además representan una circunstancia que podría constituir un nuevo

\footnotetext{
169 Puede escucharse un ejemplo en las reconstrucciones que se hacen en Chile de las "chinganas", ocasiones musicales del tipo que producían los sectores populares de un lado y otro de la cordillera en tiempos de la batalla de Vargas, tocando cuecas (que son derivaciones de la zamacueca y muy similares a lo que probablemente se escuchara entre las tropas de ambos bandos). Estos fenómenos de reconstrucción, con toda su carga especulativa y de hipótesis, fueron muy habituales en momentos de los bicentenarios. Por ejemplo puede verse el ejemplo 42 en https://youtu.be/uTbf4ztus/Y

170 Pensemos qué tan lejos llega la modernidad occidental en su apartamiento de la naturaleza, que John Cage tuvo que meterse en la famosa cámara anecoica para "descubrir" que el paso de la sangre por los vasos cercanos a los oídos tenía un ritmo y una sonoridad que hacían imposible el silencio. Pareciera que sólo en un espacio imposible podemos acceder a lo que de otra forma, en otro marco cultural, es tal vez lo más evidente.
} 
ejemplo del carácter profético de la música en términos históricos, como insistía en señalar Attali (2011).

Para Carlos Vega, la zamacueca, el gato y las demás músicas que podrían vincularse al ciclo de Vargas, son parte de lo que llamó «ternario colonial» (Vega, 1944, p. 156). Como es natural, el folklorista no se refiere ni a la textura ni al sonido en sus análisis y, de hecho, algo que vimos en el capítulo uno emparentado con la polifonía performativa popular es para él no solo una característica del "sistema tonal" (es decir de la organización de las alturas)de la zamacueca, sino prueba de su teoría de la supervivencia

El antiguo cantus gemellus, gymel, reducido a la marcha de las dos voces exclusivamente en terceras paralelas, está vivo en el campo folklórico de América española y es típico del cancionero ternario colonial (Vega, 1944, p. 159)

Es decir que las montoneras de Varela y los compungidos reservistas de Taboada practicaban un arte medieval fuera de moda, unos mil años después, cuyo nombre además es producto de los cronistas medievales de la élite -vanguardia de folkloristas-, testigos de prácticas que les resultaban sorprendentes en el pueblo y que denominaban en latín. Si los sectores populares de la Inglaterra o Gales medieval no se reconocía en la categoría del cantus gemellus (Bukofzer, 1940) qué podríamos esperar de los paisanos riojanos y santiagueños. Este es un ejemplo paradigmático de la violencia interpretativa de los útiles de análisis que la modernidad aplica a las músicas populares, de aquí y de allá.

Pero «ternario colonial» es una tipificación que parte de la consideración del ritmo en tanto configurador de lo que para Vega son los «estratos mensurales», que caracterizan a lo folklórico frente a lo "histórico" es decir la música culta, por no ser «escritos», sino orales, y estar relacionados a "pequeñas formas» y una armonía «incipiente» (Vega, 1944, p. 92). Esto se corresponde a las valoraciones de una «rítmica melódica pobre en elementos» (1944, p. 164), mientras que la «riqueza» del ternario colonial se presenta en la combinación de «períodos». Esto lleva al folklorista a afirmar que el ritmo de estas músicas es exclusivamente de métrica ternaria, aunque «el colector cuidadoso se ve obligado a anotar con gran frecuencia el dosillo» (1944, p. 165). Es decir que los dos órdenes rítmicos, no métricos sino orgánicos y que parten de la unidad en lugar de subdividirla, no son tales, sino que existe una suerte de desvío permanente en la estructura métrica derivado de un «dosillo por deformación» (1944, p. 165). Lo que sigue en el análisis, las «frases», recupera de forma notable los términos exactos que los intelectuales protomodernos de las universidades medievales acuñaron para transformar al ritmo en métrica: las frases rítmicas son «perfectas» o «imperfectas», «anacrúsicas» o «téticas», etc. (1944, pp. 166-167). Por último, en lo que ya representa un lugar común de la literatura musicológica sobre estos temas, aparece la «síncopa» para explicar lo inexplicable: esa crisis contradictoria pero convivencial, heteróclita y no sintética, de configuraciones rítmicas superpuestas que pueden habitar sin excluirse una misma temporalidad musical. Por lo cual no son "desvíos", y por lo tanto, tampoco "síncopas". El «ternario colonial», como explicación y conceptualización, comprime las configuraciones rítmicas de la música popular latinoamericana, las reduce a abstracciones lógicas que no permiten la coexistencia de lo diverso sino como anomalía frente a la norma y pretenden encerrar en una grilla de posibilidades acuñada en la Baja Edad Media francesa una naturaleza divergente que desafía todo esquema. El ternario colonial no es ternario. Sí, en cambio, es profundamente colonial el modelo de análisis de Vega, para el cual todo deriva de Europa y de su cultura erudita.

Podríamos pensar que Chazarreta, en su Zamba de Vargas, estaría más cerca de este tipo de explicaciones. Su carácter tradicionalista, la lectura de los escritores e intelectuales nacionalistas, lo habrían acercado a un tipo de pensamiento congruente con el de Vega. 
Algo de esto hay, sin duda, ya que su propia formación como músico culto de solfeos y armonías hace que prontamente se vea interesado, como dijimos, en publicar la partitura de la Zamba, con todo lo que implica la reducción a la notación de la música. Sin embargo no es un músico especulativo y la composición de Vargas es mucho más probable que ocurriese "rasgando la guitarra", como lo escuchaba hacer, según la leyenda, su abuelita Agustina desde el patio. La primera grabación de la zamba por Chazarreta es instrumental, sólo con su guitarra, ${ }^{171}$ a principios de los años 30, para la Radio Corporation of America Victor Talking Machine Company, es decir, la RCA-Víctor. Pero la versión más difundida es la que grabó con su conjunto nativo, una de 1929 y otra editada en 1962, en el disco sencillo que ya referimos. Tomaremos esta última como versión para analizar, ${ }^{172}$ ya que presenta una conformación instrumental similar a la de la presentación de Chazarreta en Buenos Aires en 1921, y además es cantada con el texto de Lombardi.

Antes de empezar la música se escucha el vozarrón de don Andrés, que exclama « ¡Zamba de Vargas, baile nacional!», como para no dejar dudas del carácter extensivo de la historia y de los sonidos que vamos a escuchar. Argentina es la zamba y es el resultado de la resistencia santiagueña en Pozo de Vargas. Esto se refuerza con el relator, Alberto González, que a su vez es uno de los cantantes, que refuerza el sentido patriótico de la canción al decir un recitado, en un tono que recuerda la declamación que la escuela normalista tenía como uno de sus contenidos universales y obligatorios a enseñar a todos los niños y niñas de la República. Es decir que no se trata de un hablar provinciano ni telúrico, tampoco un remedo del decir popular ni esas formas narrativas que, como buen folklore, son tradición oral. Lo performático aquí nos introduce en una idealización de lo que se espera que sea el pueblo argentino, como resultado de su alfabetización y paso por el sistema educativo obligatorio. Para decir que «cuentan los paisanos que al son de Zamba triunfaron, santiagueños que pelearon allá en los campos riojanos», se elige una sonoridad vocal y una forma de pronunciación que, salvo algún pequeño arrastre de la $r$, no se parece en nada desde un punto de vista etnográfico a las formas populares del hablar santiagueño. Para decir sus "verdades" esos paisanos deben ser hablados con otro lenguaje, más correcto y elegante. El de los que saben mejor que los gauchos lo que de auténtico tiene el relato. Este es otro buen ejemplo, en sonidos, de la invención y selección -a esta altura es mejor que usemos el término edición- de la tradición a la que ya nos referimos.

Inmediatamente después del recitado, da comienzo la música. En la introducción, los instrumentos de estos músicos profesionales, de trayectoria en bailes y escenarios, suenan, ahora sí, de una forma inusitadamente "desprolija". Si el recitado es todo lo que una maestra normal hubiera anhelado de uno de sus queridos ex alumnos, la introducción instrumental suena rústica, primitiva. Se trata de la combinatoria de unos acordes desplegados por el bandoneón con el contracanto de violines y la flauta traversa, sobre un plano de fondo del rasguido de las guitarras y el apoyo armónico del piano. Si la consideramos desde un punto de vista "formal", como haría Vega, se trata de la alternancia de dos acordes arpegiados, rematados por una fórmula cadencial que conduce a la primera estrofa. Lo cual no nos dice nada de la zamba, a excepción de que evidentemente no se trata de una música recopilada en la campaña, por su alto grado de elaboración y complejidad del arreglo, únicamente posible en el marco de un conjunto profesional. Esto no quiere decir que no sea popular, todo lo contrario, ya que como veremos en el próximo capítulo la existencia de un alto nivel instrumental en músicos populares criollos, indígenas e incluso africanos, era norma ya desde época colonial. Eso sí, esta introducción a la

\footnotetext{
171 Puede escucharse aquí una grabación posterior (de 1947) similar en solo de guitarra por Chazarreta, que incluye una muy ilustrativa locución introductoria del músico contando la historia de la batalla y la leyenda de su "recopilación". Ejemplo 43: https://youtu.be/bG41wNB0K7M
}

172 El ejemplo 44 puede escucharse aquí https://youtu.be/Lin9hpJQvWM 
Zamba de Vargas de tradicional no tiene absolutamente nada sino que es sorprendentemente contemporánea con otras músicas, como el tango de la primeras décadas del siglo XX, aspecto que desarrollaremos más adelante. Si por contraste elegimos describir lo performativo, es decir el aspecto del relieve sonoro y ya no su estructura, aparecen elementos que sí podrían vincularse con formas de producción musical que respondan a las coordenadas históricas de la zamacueca y demás géneros que mencionamos antes. En este caso llama la atención la forma de tocar el violín, que luego será prototípica del género discográfico "folclórico", en donde la presión del arco y la proximidad con el puente del instrumento hacen que se escuche más la fricción, el "ruido", que las notas, las cuales a su vez y sobre todo en la cadencia, son muy oscilantes y hasta algo "desafinadas". Este plano, el de los violines y la flauta, permanece en las estrofas, llevando a cabo lo que, desde la partitura diríamos es una "duplicación" de la melodía cantada, aunque más que duplicarla, la desafía. Ésta, que efectivamente se compone de dos voces cantando a terceras paralelas (el malogrado gymel de Vega), como en la declamatoria introducción, es realizada por voces masculinas cubiertas y con una sonoridad "de pecho". Detrás de lo cual, y por sobre el rasguido "típico" de guitarras y bombo que, como dijimos, es más percusión que armonía, el estrato violines/flauta traza una banda oscilante que desdibuja la melodía y se entretiene en los pasajes más que en las notas que debería articular. Su interés está en la sonoridad, un espectro de frecuencias amplio y variable, destellante, que además otorga variación a una melodía que por lo demás sería demasiado sencilla. El conflicto entre ambos planos, estrictamente performativo e imperceptible en la partitura de la composición, estructura la totalidad de la Zamba de Vargas, convirtiéndose en el rasgo preponderante. Cuando la tocan otros conjuntos, como los Quilla Huasi o los Chalchaleros, que ya usan una configuración "clásica" del folclor ${ }^{173}$ discográfico -el trío de guitarras y bombo- la canción de Vargas ya es otra cosa totalmente distinta. Los derechos de autor se aplican, pero el oído civil y comercial, que tanto se parece al de los folkloristas, es sordo ante la música popular.

Deberíamos encontrar alguna explicación histórica para esta característica notable de la zamba de Chazarreta, atravesada por esta forma tan singular de tocar unos instrumentos que para la tradición moderna culta vienen a ser algo así como la materialización en tripa y madera del ideal armónico. En el próximo capítulo intentaremos ensayar algunas hipótesis sobre esto, pero baste decir ahora que no es un caso atípico el que emerge en la sonoridad de la orquesta de Chazarreta sino que puede estar vinculado con una tradición de ejecución instrumental que hunde sus raíces en la época virreinal, como emergente del mestizaje y la transculturación que proceden del carácter contencioso del proceso histórico colonial. En toda una gran zona que coincide con las fronteras orientales del virreinato del Perú, y que se yuxtaponen con el noroeste "folklórico" argentino, existen aún hoy músicos que presentan prácticas musicales que acarrean en la materialidad sonora estos conflictos entre formas de comprensión del universo sonoro muy diferentes. Los violinistas religiosos de la zona del Beni en Bolivia, ${ }^{174}$ del mismo modo que las comunidades de la zona periférica de la ciudad de La Paz, ya en el Altiplano, poseen una forma de tratamiento de las alturas y sobre todo de los intervalos que Cergio Prudencio denomina «ordenamientos sonoros» (2001), cuya característica principal es el rehusar al determinismo y la vocación de control que implica el fijar las alturas de forma puntual y unívoca, lo cual es típico del pensamiento musical occidental, desde la escala hasta el temperamento. A esto se suma otra noción, la de «aglomeración de los campos armónicos», concepción sonora justamente indiferenciada que no discrimina el componente tímbrico de la altura sino que lo concibe como una integralidad. Prudencio lo ilustra en comparación con la noción occidental del

173 Reservamos el término folclor para el género discográfico de música popular, diferenciándolo así del folklore como disciplina histórico musical.

174 En el capítulo siguiente desarrollamos un análisis en extenso sobre estos músicos. Cfr, p. 379 y ss. 
multifónico para los instrumentos de viento madera, "una amalgama audible de todos los campos armónicos que fueran posibles» (Prudencio, 2001). Volveremos sobre estos conceptos al abordar en profundidad el repertorio de los músicos de la época colonial en el próximo capítulo.

Para ilustrar por el momento estas discrepancias y el carácter contencioso y mestizo de estas músicas, un excelente ejemplo es el de la práctica musical en las comunidades MbyáGuaraní que habitan justamente muy cerca de lo que fuera San Ignacio Miní, una reducción indígena. En la canciones Jaguota Javy175 y Peime'ê Jevý desarrollan un uso del instrumental musical evidentemente introducido por los españoles tras la conquista, que es absolutamente divergente y cuya mayor discrepancia procede muy claramente de esta concepción sonora alternativa. Los dos instrumentos más relevantes que acompañan el canto son un violín y una guitarra que, para la música occidental, representan respectivamente el ideal de la melodía y la armonía. Sin embargo los Mbyá los utilizan en función de su sonoridad integral, eludiendo esos ejes: la guitarra es tocada únicamente con un rasgueo, prescindiendo totalmente de pisar las cuerdas sobre la tastiera; de hecho en ambos ejemplos, la mano izquierda cumple la mera función de sostener el instrumento. Por lo tanto se asemeja más a la función de un instrumento rítmico, como las maracas o los palillos que también intervienen en esta música. Los Mbyá desarrollan así un instrumento que debiéramos llamar tímbrico-rítmico o textural-rítmico; con el violín las cosas no son muy diferentes. Por un lado el instrumento se toma sobre el brazo, con la tastiera mirando de frente al instrumentista, de una forma análoga a la viola da braccio renacentista. Pero una vez más, aquí termina toda analogía; los sonidos que sacan ambos instrumentistas están llenos de arrastres, ruidos, crujidos y sobre todo, discrepancias rítmicas y de alturas con la voz cantada, en un acompañamiento en el que es muy difícil determinar si intentan duplicar la melodía, hacer un contracanto o directamente establecer un esquema repetitivo de acompañamiento: porque en realidad hacen esas tres cosas al mismo tiempo, lo cual es un buen ejemplo también de una concepción que puede convivir con la contradicción de los opuestos, que se plantea en una lógica trivalente que no reduce el mundo a un dualismo irreductible como traza el pensamiento cartesiano de la modernidad. No se trata de que estas "desafinaciones" o mejor dicho, discrepancias que recurren en el violín de la zamba de Chazarreta, sean un rasgo "indígena". Está claro que forman parte del mundo sonoro producido por la conquista y la colonización. Pero conservan ese elemento contencioso, mezclado, litigante, en donde estas maneras de pensar y sentir lo musical no terminan de confluir ni de asociarse del todo. Algo que para las autoridades coloniales podría haber sido funcional para mantener la dominación y justificar una evangelización permanente (Estenssoro, 2001), estas discrepancias serán totalmente inaceptables para la modernidad y sus instituciones del conocimiento, lo cual es coherente con el proceso de blanqueamiento de los estados nación y la aparición del folklore.

Isabel Aretz en su libro El folklore musical argentino elige como hontanar de las músicas del noroeste argentino justamente al establecimiento de las "misiones", como ella las llama, y a los inicios de la enseñanza musical impartida por los religiosos europeos a los indígenas (Aretz, 2008, p. 17). Pero, y aquí se revela uno de los rasgos principales del pensamiento folklorizante, concibe el resultado no como un mundo contencioso y mestizo sino fundado a partir del reemplazo de las prácticas musicales, por una aculturación neta. Desde su perspectiva, el folklore argentino es hispánico en esencia, traído por los músicos eclesiásticos europeos. La música tradicional argentina es música europea en una geografía extraña. Música trasplantada. La tradición oral a partir de la conquista, proceso en el que se suman otras músicas europeas ya no hispánicas, son responsables de las variaciones que dan como resultado las supervivencias del folklore que Chazarreta llevó a

175 El ejemplo 45 puede escucharse aquí https://youtu.be/Nd5s0p8LDu8 
escena y la investigadora grabó "en el campo" a mediados del siglo XX. Recordemos que quiénes patrocinan y financian a Aretz en sus viajes de campaña y publican sus primeros libros son los mismos industriales azucareros, los Padilla y Rougés, que promueven ese imaginario de la industria blanca de la zafra tucumana que mencionamos anteriormente. El folklore que emerge de esa reunión de empresarios, hacendados, políticos e investigadores se piensa como un eco lejano y algo distorsionado, aclimatado, de la música europea antigua. Esta hipótesis del folklore sudamericano contrasta con otra muy difundida, que recoge el artículo de Wikipedia Historia de la música folklórica de Argentina, ${ }^{176}$ en donde se ensaya una explicación, derivada de concepciones americanistas o nativistas, según la cual las raíces del folklore se derivan de las múltiples culturas indígenas originarias (Locatelli, 2007, p. 39; Alvarenga, 1984, p. 241; Bolaños, 2007). Esta última perspectiva no es habitual en los folkloristas argentinos, que relegan lo indígena al campo de lo etnográfico y no a lo folklórico, criterio que comparten Cortazar, Aretz y Vega, entre otros y es coincidente con el patrón cultural de "Argentina blanca" de quienes posibilitaron financiera y logísticamente sus investigaciones. Vega es muy estricto en esta demarcación entre lo folklórico y lo indígena (o según él lo "primitivo") en su ensayo La Ciencia del Folklore y en el capítulo "La clasificación de la música», ambos publicados en el Panorama... (Vega, 1944). De todas formas, como apunta Irma Ruiz (2015, p. 32), esto lo lleva a no pocas contradicciones muy evidentes dentro de su modelo teórico. Si para Vega la música folklórica es un descenso retrasado en el tiempo de la música culta (europea), no hay posibilidades de influencia alguna por parte de lo indígena. Esto hace que en sus clasificaciones los cancioneros «tritónico» y "pentatónico», que preceden al ternario colonial al que ya nos referimos, queden en evidencia al poseer mayoría de elementos indígenas, incluidas las supervivencias como la baguala, la tonada, etc. El intento de subsanar este problema lleva a que el folklorista, según Ruiz, incorpore como parte del estrato superior (culto) a las «altas culturas precolombinas» para que sean «urbanas», es decir, a los Incas, y por lo tanto hacer compatible su teoría con la existencia de manifestaciones que, por consenso más que por investigación histórica, se suelen comprender como "indígenas". Un buen ejemplo de esto último es la construcción del ideal de canto vallisto derivado de las publicaciones de Leda Valladares (1970). Finalmente hay un gesto conciliador en Vega y para morigerar sus contradicciones, se apoya ahora en sus contrincantes académicos

El folklore, suma de estratos medios, conserva lo que subsiste de los primitivos y lo que desciende de los superiores. Los tratadistas enfocaron principalmente la subsistencia de lo primitivo; nosotros completamos la visión de lo folklórico al reconocer la pervivencia de lo ex superior (Vega, 1944, p. 338)

A pesar de estas discusiones que alternativamente incorporan o excluyen de nuestra cultura a los indígenas, ambas narrativas coexisten en los imaginarios de los argentinos acerca de sus aspectos identitarios. El antropólogo Alejandro Grimson (2012) ha trabajado extensamente estas auto-imágenes sociales o mitomanías como él las llama, en las cuales, junto a un linaje derivado de lo indígena que nos conecta con "la tierra", se amontonan las explicaciones según las que somos todos "hijos de los barcos" en un país "sin negros" y "sin indios", asunto que no solamente es permanentemente desmentido por los estudios poblacionales, históricos y censales, sino por otra mitología según la cual este «país de mierda» en el que "no hay racismo porque no hay negros» está poblado por «cabecitas negras» (Grimson, 2012, pp. 65-92). Toda esta yuxtaposición etnográfica que habita nuestros imaginarios se explica porque «en el mundo del mito sobra espacio para las contradicciones» (Grimson, 2012, p. 41). Pero deberíamos advertir, ya que estamos estudiando la cultura popular y su música, que hay que diferenciar entre los mitos populares, lecturas poéticas y parabólicas de la realidad, explicaciones dúctiles y dialécticas que funcionan como "motor de la historia", de aquellas construcciones que no cumplen esa

176 https://es.wikipedia.org/wiki/Historia_de_la_música_folklórica_de_Argentina 
función articuladora propia del mundo popular subalterno, sino que son definiciones afirmativas de la hegemonía mediante las cuales "la historia se evapora» (Colombres, 2007 , p. 142). Éstos últimos son prejuicios que, lanzados "desde arriba", tienen como objetivo central la creación de imaginarios inclusivos que posibiliten la hegemonía. Así debemos leer la frase con la que Grimson sintetiza el blanqueamiento indígena del imaginario nacional: «No quedaron indios por aquí. ¡Pobres!, a pesar del valor que representan en nuestro patrimonio histórico, no tuvieron lugar en la Argentina que intentaba modernizarse» (Grimson, 2012, p. 92). Esto es claramente una idea folklorizante en la cual, como vimos, aparece una acción política que pretende revalorizar a posteriori aquellos colectivos derrotados e incluso víctimas de genocidio, ocultando las formas de producción de esa desaparición, ya que el sujeto está ausente en la oración: los indígenas «no quedaron», como si se tratara de un producto sin reposición en una estantería del supermercado. "¡Pobres!», quién habrá sido. Había algo en ellos, su incapacidad para «modernizarse». Así operan la selectividad y la invención de las tradiciones. Son parte constituyente de la afirmatividad. Lo que tienen en común las narrativas de Aretz o Carrizo con las de Bolaños o Valladares, es que ambas buscan ese hontanar de la autenticidad que, como fuente primigenia, garantice una marca identitaria, es decir que obture toda futura discusión. Son perspectivas esencialistas que buscan rasgos en función de la creencia en que una cultura es una unidad homogénea íntegramente compartida por sus practicantes y que, en tanto rural es conservadora, no cambia -o mejor no debe cambiarcon el tiempo. Esto explica afirmaciones que, sacadas del contexto esencialista y afirmativo de las narraciones que las contienen, se revisten de un carácter francamente absurdo:

las recopilaciones de cantos religiosos que sabe nuestro pueblo por tradición oral [...] muestran la pervivencia de varias corrientes musicales antiguas. Por una parte existen muestras evidentes de antigua música gregoriana [...] Ya en épocas de la Independencia, cuando nos frecuentaban viajeros europeos aparecen documentados los nombres de algunas especies musicales que registramos todavía [...] El carácter arcaico de ciertas melodías folklóricas nos permite suponer que se trata de una misma corriente musical (Aretz, 2008, pp 21-23)

La apelación a la tradición en nombre de una supuesta fidelidad a lo propio no hace más que negar historicidad a la cultura popular. El problema no pasa por precisar si la herencia es europea o indígena o africana o asiática, sino que se encuentra en los términos mismos en que se plantea la pregunta. Buscar atributos que indiquen la esencia, el espíritu del pueblo; preguntar por los orígenes de las músicas y demás manifestaciones; todo esto tan presente en el folklore, precisan que todo abordaje histórico se encuentre lo más lejos posible. Historia y folklore se vuelven términos contradictorios (Eckmeyer y otros, 2018). Y por lo tanto, si lo que queremos es indagar en la historia de la música popular, el folklore, lejos de ayudarnos, nos pondrá permanentemente obstáculos que, en tanto surgen del carácter afirmativo de la disciplina y su convergencia con la musicología histórica, impiden tomar dimensión de los procesos que en el tiempo transforman las culturas populares y sus particulares formas de musicar. Como venimos diciendo en todo este trabajo, el musicar es un entramado integral de dimensiones estéticas, sociales, políticas y económicas. Por lo tanto ocultar expresamente los procesos productivos y políticos, es decir producir la afirmatividad, impide penetrar en la historia musical del mundo popular subalterno.

Está claro que la música Mbyá que escuchamos antes está también producida, aunque no llega a ser una de esas músicas que saca tarjeta de identidad, como decía Carpentier (1984), si bien refuerza cierto pintoresquismo. Pero su materialidad sonora se aparta del carácter afirmativo folklorizante. Casi a riesgo de sacrificar ese valor estético, el carácter artístico que Dahlhaus y los musicólogos del estilo ponen por delante de todo valor histórico. Por el contrario, lo más interesante aquí es relacionar esas formas de tocar con lo que se escucha en los músicos populares del siglo $\mathrm{XX}$, como son los de la orquesta de Chazarreta. Y más que en la superficie, pensar el vínculo en términos de performance, es 
decir, en esa convivencia crítica entre dos órdenes que no parecen ser compatibles. En el caso de la Zamba de Vargas, además del conflicto entre la declamación y el primitivismo de lo que suena, el plano intermedio de los instrumentos nunca se funde con la melodía, siempre renueva la tensión. En la música europea eso es algo que, después del siglo XVI, quedó descartado del modelo estético musical. En América Latina, por el contrario, es un componente central de la configuración musical, más a nivel performático que compositivo, y por lo tanto, más lejos del ideal moderno, o más cerca de la cultura popular. Las canciones de Chazarreta, en este sentido, tampoco son "de él". Porque lo que las identifica aparece cuando se las toca y depende de quién lo hace y en cuál ocasión. Por lo cual, aunque la partitura de la Zamba de Vargas esté registrada a su nombre -y este es un buen indicio de que es música popular del siglo $X X$ también- es menos una composición que un acto performativo, un musicar. Preguntar por el autor pierde aquí todo sentido.

Lo que sí nos puede aportar el considerar la variabilidad de las músicas de la conquista y las tensiones en torno a las reducciones y el plan civilizatorio colonial, es que nos introducen en una de las categorías que vamos a proponer como dimensiones de la música popular: la transculturación. Es evidente que en el folclor discográfico de Chazarreta, existe ese "ser y no ser" Occidente que aplica Ángel Quintero Rivera en sus análisis. Pero al mismo tiempo, y ahí se revela el sesgo occidental del folklore, preguntarse por las proporciones, por los orígenes precisos de cada componente o detalle, inquirir acerca de nacionalidades, continentes o "pueblos"; todo se revela un gesto vacío, un sinsentido que lo único que nos deja como resultante es la compresión de la variabilidad y la dinámica popular a categorías que han producido algunos de los episodios más trágicos de nuestra historia. Preguntar por el origen, la región y el pueblo es aplicar una escucha racializada que inmediatamente compara con lo moderno y por lo tanto, racializa todo aquello sobre lo que se posa. Debemos pues considerar los aspectos del folklore vinculados a la racialización, antes de volver sobre la transculturación y continuar el análisis de la música de Chazarreta, entendida ya no como folklore ni recopilación, sino como musicar popular y transcultural.

\subsection{Patria, raza y autenticidad. Del escenario a la academia}

Hay varios accidentes relativos a los inicios de la aventura folklórica de Chazarreta que deberían llamarnos la atención acerca de las relaciones entre los imaginarios del folklore y la noción de autenticidad. Por ejemplo, en la cronología que propone Vega como etapas de su vida profesional, aparecen dos aspectos relevantes: por un lado queda claro que Chazarreta, que además de ser músico era inspector de escuelas, al estudiar guitarra de forma sistemática, «prefiere la música clásica» (1981, p. 98). Es decir, don Andrés, casi al mismo tiempo que compone la primera versión de la Zamba de Vargas, tiene en la más alta valoración estética a la música culta, no a la "popular" o criolla. Por otro lado, una influencia evidente en la decisión de Chazarreta de lanzarse a la escena con un espectáculo nativo no provendría del entorno sonoro de Santiago del Estero, sino de los escritores de la generación del Centenario ya que justamente en los años inmediatamente previos al debut del espectáculo «los libros iniciales del movimiento tradicionalista son ávidamente absorbidos por Chazarreta y lo lanzan a su durable empresa nacionalista» (Vega, 1981, p. 98). A esto hay que agregar las restantes influencias que proveen las ideas germinales y catalizan los inicios de la compañía: las frecuentes giras por la ciudad de Santiago de las compañías de circo criollo y sus espectáculos tradicionalistas. El contenido de los mismos, como se sabe, era el relativo a la literatura del movimiento criollista, fundamentalmente atravesado por el Martín Fierro de Hernández y las novelas de Eduardo Gutiérrez, como Juan Moreira o Santos Vega. Es un arte urbano, muy popular, pero claramente alejado de toda pretensión telúrica. Más bien corresponde con el impulso homogeneizador de la cultura que forma parte del proyecto nacional de la generación del '80. El sujeto de estos 
espectáculos era un gaucho fuertemente estilizado, convertido en monumento, una vez que los gauchos "vivos" habían sido exterminados o sometidos, ya que fundamentalmente habían participado de las montoneras federales y representaban el atraso y la barbarie para las élites nacionalistas, tanto porteñas como del interior.

En este sentido el «criollismo en el campo del espectáculo» (Chamosa, 2012, p. 21) que entre el ' 80 y el Centenario incluía al circo, es muy similar al fenómeno del Blackface Minstrel Show de Estados Unidos, del cual es contemporáneo. Contexto internacional que también explicaría otra experiencia que marcó profundamente a un joven Chazarreta: la presentación en el teatro de Santiago de una compañía mexicana con un espectáculo de danzas típicas (Vega, 1981, p.110). Todas estas manifestaciones son urbanas, populares, existen plenamente en el mercado y podrían reunirse dentro de la denominación de espectáculo de variedades, junto al vodevil y el music-hall, entre otros formatos. Su base de irradiación son generalmente las capitales o ciudades importantes ${ }^{177}$ (Buenos Aires, New York) y entre sus practicantes y promotores destacan los inmigrantes, como es el caso del ícono del circo criollo, José "Pepe" Podestá, hijo de genoveses radicados en Uruguay). Según estos rasgos sería impensado asociar al circo criollo o al minstrel show con una noción de música genuina de una región o territorio, que es lo que generalmente viene a nuestra mente cuando pensamos en lo folklórico, lo nativo o lo criollo. Vega lo confirma, aunque parece no perturbar su fe en la autenticidad folklórica de Chazarreta: «con los circos llegan los cantos y los bailes nativos. Del teatro y de los circos porteños recibe Chazarreta la gran lección del espectáculos nativo» (Vega, 1981, p. 109). Es que, como sugiere Karl Miller (2010, p. 5) para el caso del minstrel norteamericano, la cuestión de lo auténtico en estos espectáculos descansa en torno a lo performativo, en el show de las apariencias, en lo que de antemano se sabe ficticio. Las caras teñidas con corcho para contar con cuerpos blancos al pueblo "negro" afroamericano, para construirlo a la medida de las necesidades de la hegemonía "blanca", son el equivalente de los rostros "gauchescos" maquillados de un blanco níveo del circo criollo. El contraste de colores no debe opacar el componente etnologizado y racial que acompaña la puesta en escena de estos espectáculos ni la ideología y la relación con los proyectos de nación de los cuales son punta de lanza: en el caso de EEUU, el lugar que la sociedad de principios del siglo XX le reservará a la comunidad afroamericana mediante las leyes de segregación, requería de una etiqueta clara y efectiva de "lo negro"; en el caso argentino, y también a posteriori de la guerra civil y la virtual extinción de los gauchos montoneros, el prototipo del gaucho devenido performer del ser nacional, coincide con ese país de blancos que promueven las clases hegemónicas, tanto del interior como de las provincias. $Y$ es un modelo que se introduce desde la capital hacia las provincias, mediante diversos medios entre los cuáles también está el espectáculo criollo.

\footnotetext{
177 Justamente Buenos Aires y Nueva York, sedes respectivas del circo criollo y el minstrel show, son muy buenos ejemplos, ya que en las dos primeras décadas del siglo XX se las considera las ciudades más importantes del continente, una al norte y la otra al sur.
} 


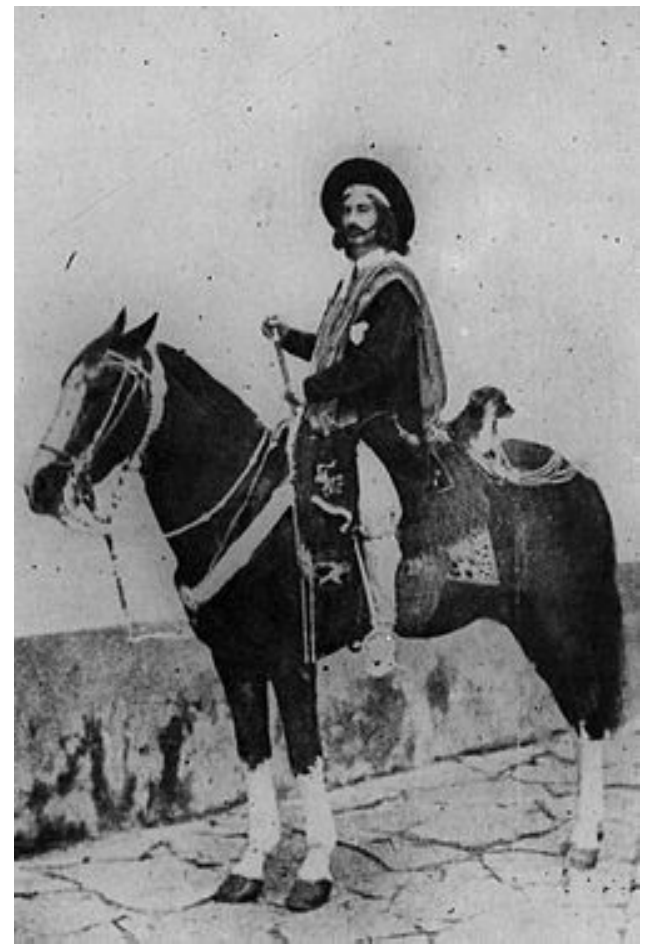

José "Pepe" Podestá en su caracterización del gaucho Juan Moreira

Como analiza Natalia Di Sarli (2013 p. 108), el circo criollo de los Podestá se basaba en

un sistema teatral a partir de la creación de un personaje arquetípico, del uso de una lengua literaria característica (la del poema gauchesco) [...] de una estética surgida a partir de un realismo ingenuo en su conceptualización, cuyo fin es conmover a partir de la identificación directa entre personaje y público $(2013$, p. 108).

Pues bien, tengamos en cuenta que esa "identificación" que opera se da por parte de un público porteño y platense, objeto del análisis de la autora. Es decir, los que se identifican no son los campesinos del interior sino los sectores urbanos que pasan a percibir su ser nacional en el gaucho construido escénicamente. Esto se profundiza cuando las temáticas del teatro derivan hacia el nativismo, más acorde con el nacionalismo del período del Centenario, en donde lo que se busca es "Una reconstrucción de "lo nuestro" y de la idea de Nación en lo rural, lejos de las ciudades donde el "otro" inmigrante personifica la pérdida de la identidad [...] lo cual propone como núcleo estético la domesticación del gaucho» (Di Sarli, 2013, p. 109). Al ser un espectáculo que parte de las clases hegemónicas urbanas, el modelo de blanqueamiento y construcción del ser nacional ocurre desde la capital hacia las provincias. De forma tal que la recepción en el interior, antes que hacer pie en la autoimagen de los provincianos, comunica una efigie que se propone como emblema de lo nacional. Por ejemplo, al recoger testimonios del paso de la compañía de los Podestá por Tucumán hacia 1896, todavía puede leerse que «Esa famosa troupe (...) puso los cimientos del teatro nacional con una temática incuestionablemente nuestra» (La Gaceta de Tucumán, 2006). La construcción escénica de una expresión nacional "auténtica" alcanza así su objetivo.

Karl Hagstrom Miller (2010) propone que esta autenticidad (que se da también en el blackface minstrel show) se basa en el trazado de una línea racial, que a su vez se erige en indicador de la particularidad de una música, a partir de lo cual puede inequívocamente atribuírsele a un sector socio cultural o a la imagen que de él se tiene, emergiendo de todo este proceso una garantía de la identidad de dicho sector o subcultura (Hall, 2010). Es decir, en el ejemplo que utiliza este autor, bastaba con que los actores "blancos" se pintaran 
la cara de negro para que el público identificara las músicas del show con el pueblo afroamericano del sur estadounidense o lo que creían saber de él. Pueblo que, a su vez, y como resultado del contenido y la performance de los espectáculos, era definido de manera unificada, homogénea y dotado de una serie de rasgos identificables como conductas: menor inteligencia, mayor expresividad -fundamentalmente en lo corporal-, una predisposición hacia el crimen, menor tendencia a la higiene, etc., todos rasgos que serán el fundamento de las leyes de segregación.

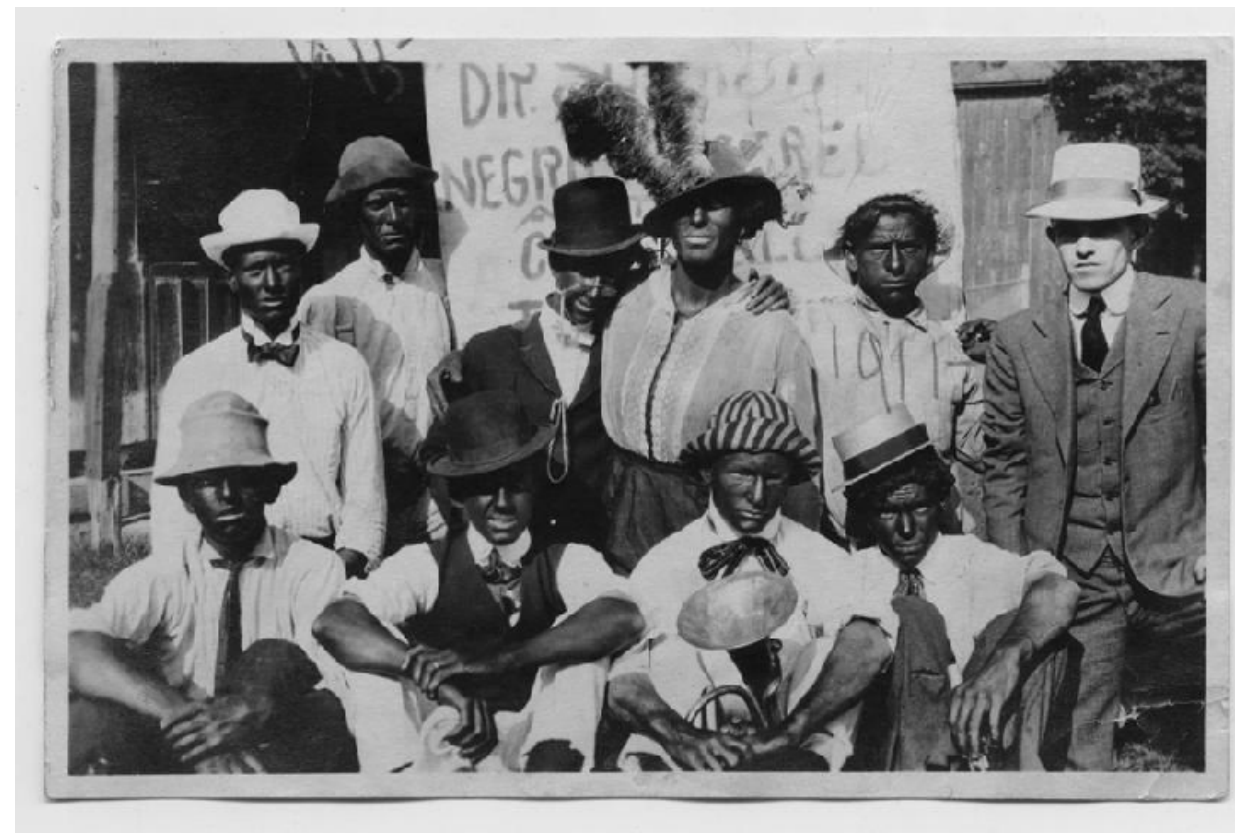

Una troupe de Blackface minstrelsy de gira por el sur de EEUU, circa 1915.

En Argentina, y en torno a la figura del gaucho, la vinculación entre una concepción racializada $-\mathrm{y}$ por tanto homogénea de los diferentes colectivos culturales- y la actividad política concreta dirigida a neutralizar a los sectores conflictivos contiene numerosas analogías con el caso norteamericano. Basta mencionar que nos referimos al período que va de la Ley de Residencia, producto que sintetiza la producción del positivismo argentino, al discurso de Lugones de 1924 en Lima, que se constituyó en el fundamento filosófico del golpe de estado de 1930, protagonizado por una derecha que, además de clerical y nacionalista, era antisemita. En todo este lapso que incluye lo que se conoce como positivismo ideológico, modernismo y restauración nacionalista, se consolida la pauta ideológica que evalúa, a partir de consideraciones raciales y biologicistas, que las manifestaciones populares del presente son resabio vigente, aunque anacrónico, del pasado superado por la civilización. Lo cual no obsta para que sean a su vez reconocidas como indicadores de nacionalidad, en la medida en que son inofensivos al modelo hegemónico de país.

Por ejemplo, Oscar Chamosa (2012, p.35) recupera las descripciones en que J. V. González habla de una «religión prehispánica que se desarrolla en los ranchos de las orillas, entre la gente más torpe», lo cual formaba parte de un «festival indio». O Juan Bautista Ambrosetti, cuando señala que en tales ámbitos el amor de la «gente civilizada» es reemplazado por el «instinto animal» (lo cual tal vez explica aquel asunto de que publicara sus trabajos de folklore en la revista del zoológico). Los censos nacionales de 1869 y 1895 clasifican a la población contando y descontando alternativamente a los indígenas, a los que no se considera ni argentinos ni extranjeros. Estos últimos, a su vez, se contabilizan aparte y ya con cierto recelo. Ciertos parentescos históricos parecen adaptarse a este 
rejuego ideológico que pivotea entre nacionalismo y positivismo. El segundo censo nacional de 1895 fue encargado por José Evaristo Uriburu, presidente de la nación, que a su vez era hijo de Evaristo Uriburu, un militar que había luchado contra las montoneras de Varela en batallas posteriores a la de Pozo de Vargas inmortalizada por Chazarreta. A su vez, el nieto de este último y sobrino del censista, José Félix Uriburu, es, como se sabe, quien realiza el primer golpe de estado e inaugura la sórdida tradición de interrupciones a gobiernos democráticos que caracterizará al siglo $X X$ argentino. Uno de los principales intelectuales que lo apoyan es, justamente, Leopoldo Lugones.

Pero en el debut folklórico de Chazarreta del Politeama de 1921 -anterior sólo en tres años a La hora de la espada de Lugones-, el rostro pintado de blanco y la pulcritud gauchesca a la usanza del circo criollo ya no podía disimular, de todas formas, la corporeidad de los bailarines. Es esta fase la que justamente Miller (2010, p.217) define como el paso de una autenticidad performativa a una folklórica ya que, a diferencia de los espectáculos escénicos del minstrel -o el circo en nuestro caso- que ficcionalizan estereotipos raciales, el folklore relaciona directamente la autenticidad de los sonidos con una pretendida etnicidad naturalista de los cuerpos. Este es el proceso que hace subir a escena a los músicos "negros" del blues o el que legitima como auténticas las grabaciones de campo de Bartok y Kodaly con el auxilio de la fotografía que congela los rostros adustos y avejentados de los campesinos de la periferia europea. Alan Lomax se erigirá como una figura de este nuevo paradigma. En nuestro medio, Carlos Vega, Isabel Artez, Lauro Ayestarán, entre muchos otros, seguirán esa trayectoria. Basta ver que los respectivos archivos documentales de estos investigadores, valiosos acervos que hoy integran estados o fundaciones, las fototecas son tan celosamente custodiadas como las grabaciones.

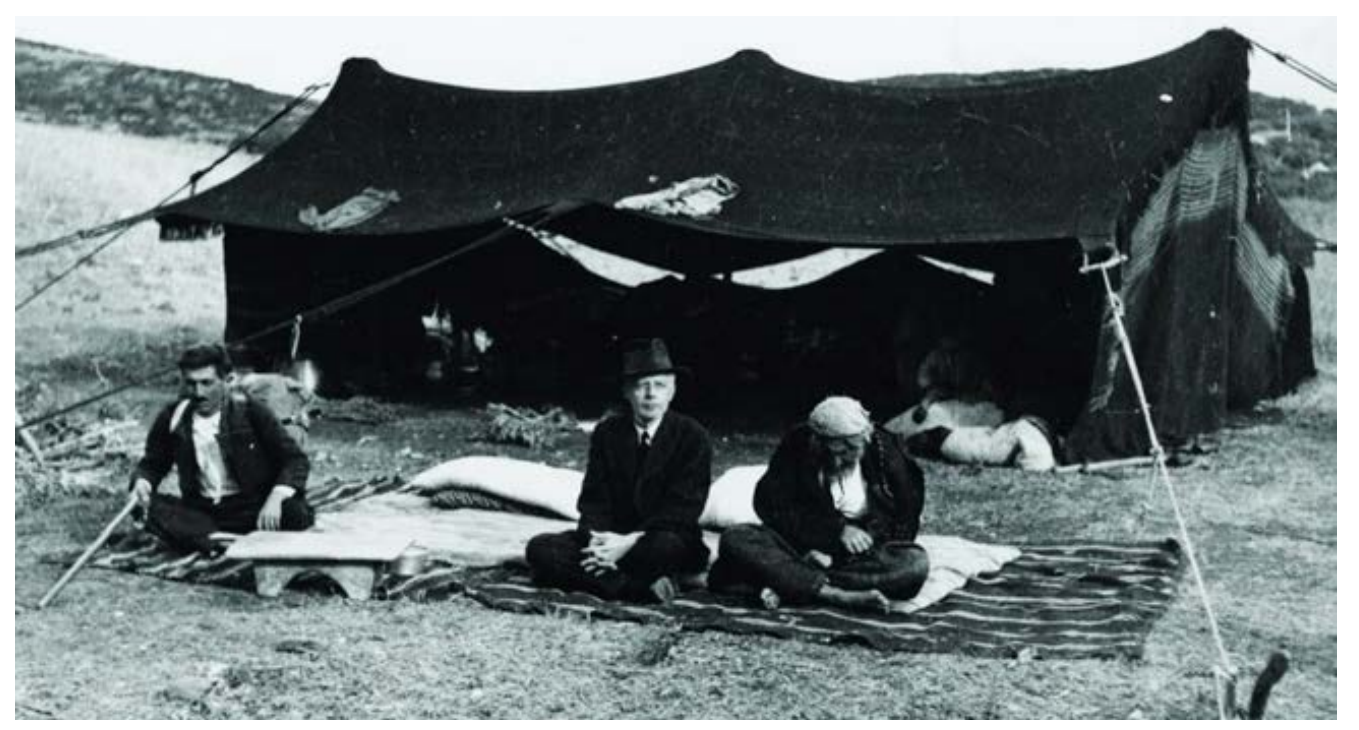

Bela Bartok (al centro) entre campesinos nómadas de las estepas de Turquía. 


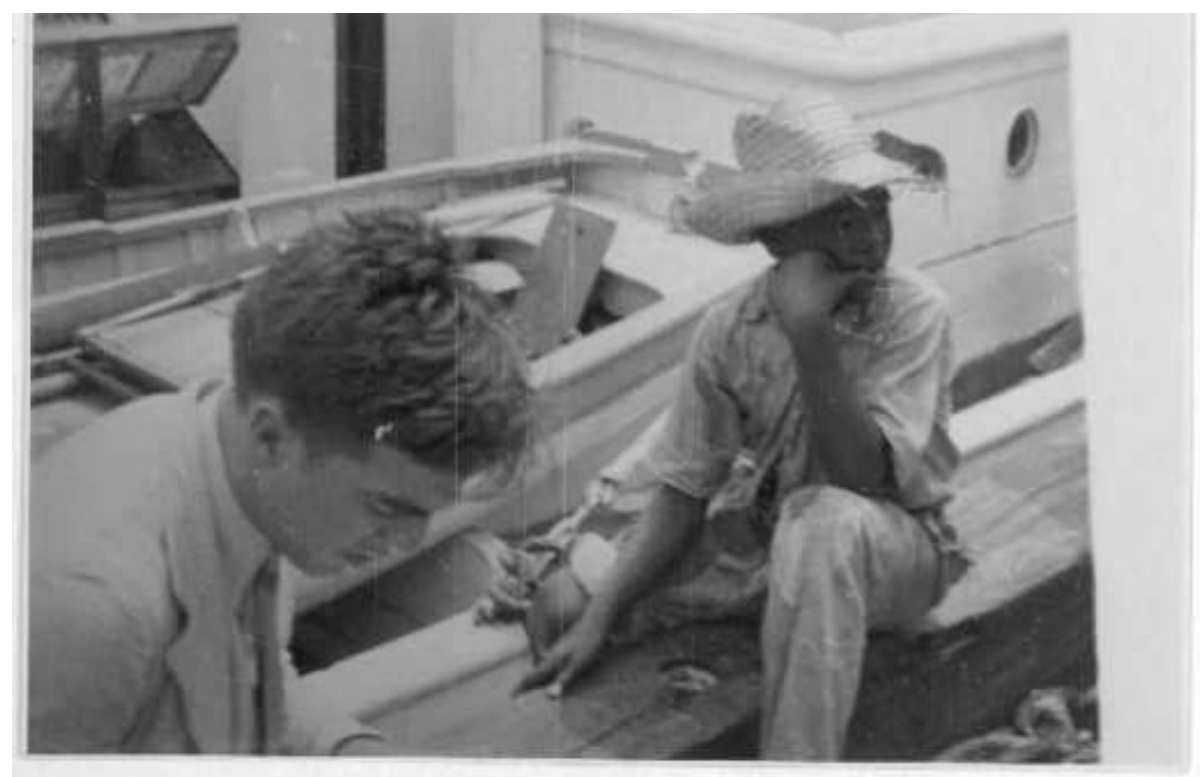

Alan Lomax (a la derecha) en sus recorridos por el sur estadounidense

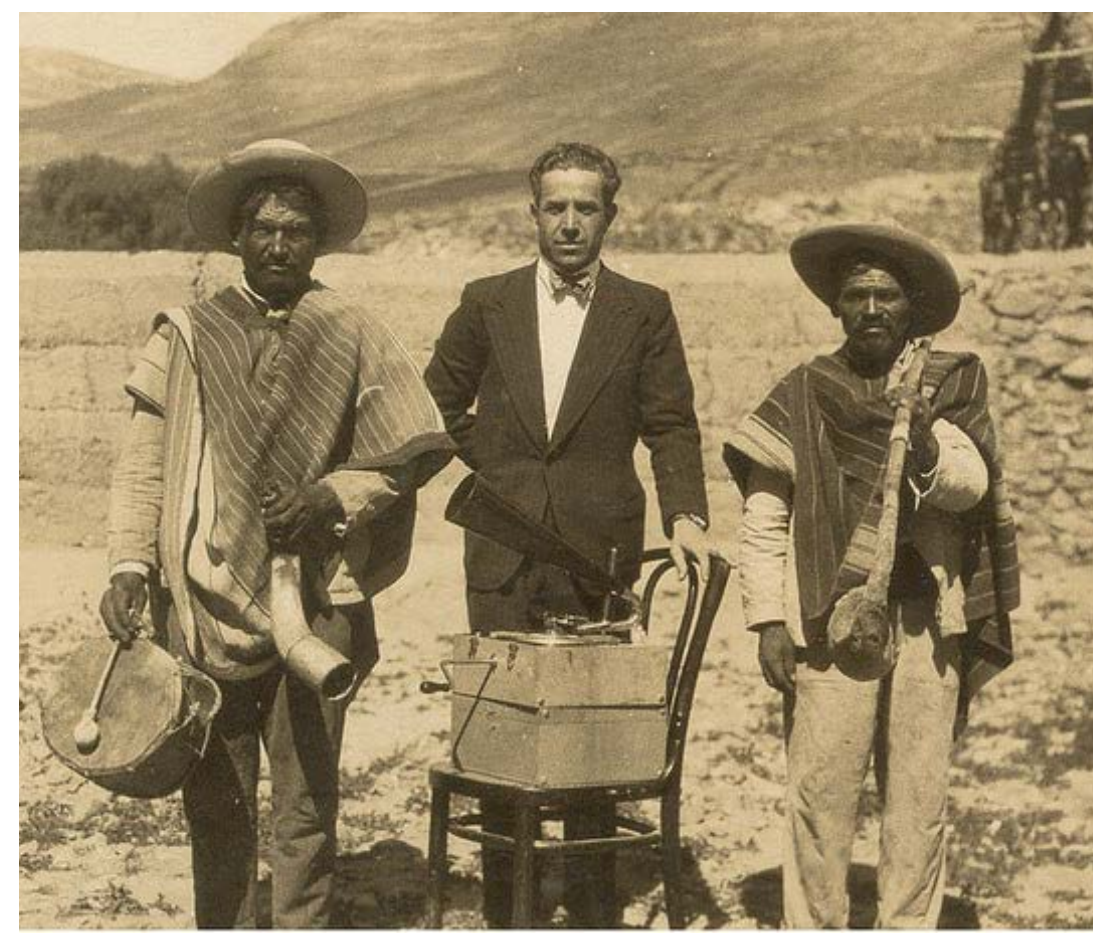

Carlos Vega y su grabador, en el centro de la imagen 


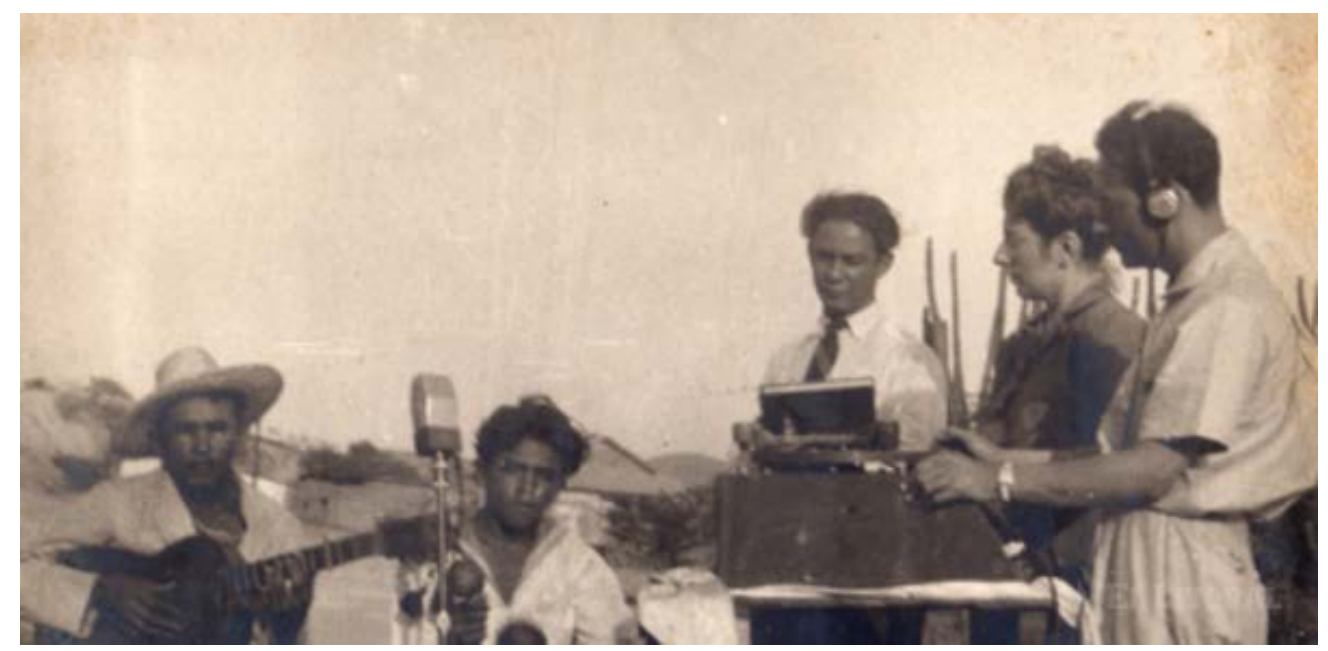

Isabel Aretz, segunda desde la derecha, en uno de sus viajes de recolección.

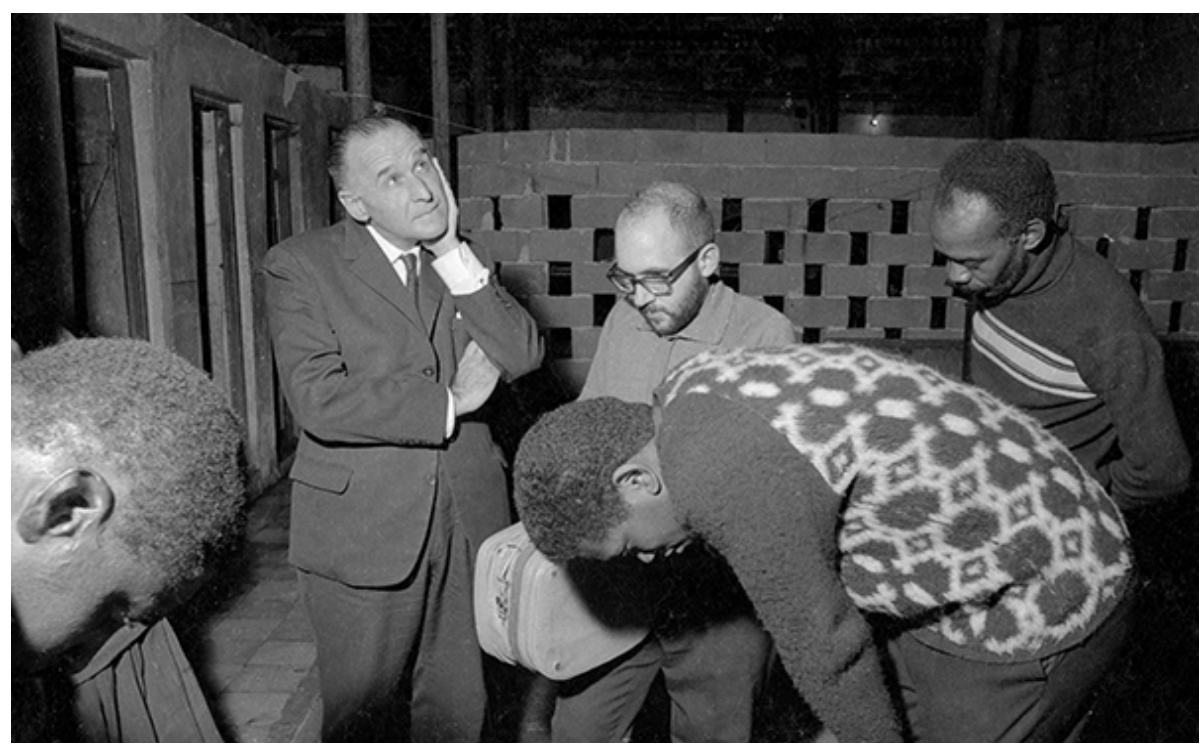

Lauro Ayestarán (segundo desde la izquierda) junto a un joven Coriún Aharonián (centro) grabando en el terreno a músicos afrouruguayos.

Este cambio de paradigma se refuerza con la condición de comunalidad del folklore que, basándose en la máxima de los hermanos Grimm de que las canciones folklóricas se componen en sí mismas, y por lo tanto son anónimas y espontáneas, los músicos racializados, como Chazarreta y su troupe, no expresan su subjetividad interna, sino en última instancia la de la Nación, que se concibe como un organismo. Esta creencia en la creación comunal del pueblo (base de la noción de "música tradicional" central en la definición del folklore) contradice frontalmente la popularización de la literatura popular de autor que hacía el circo criollo (por ejemplo, Podestá poniendo en escena las novelas de Gutiérrez) o para el caso norteamericano, la condición del Blackface Minstrel Show de ser creaciones de compositores vinculados a Tin Pan Alley y su industria cultural. Para cantar la Nación de forma pura y auténtica, es decir inobjetable, «el creador de la música popular debe ser un representante no individualizable del pueblo, él mismo un producto folklórico» (Krehbiel, como se citó en Miller, 2010, p.93). ${ }^{178}$

178 «The creator of the folksong is an unindividualized representative of his people, himself a folk- product [...] His potentiality is racial or national, not personal» (Krehbiel como se citó en Miller, 2010, p.93) [Traducción del autor] 


\subsubsection{El naturalismo musical de los cuerpos}

Así, merced a esta línea racial, se percibe la presentación porteña de Chazarreta, que genera ejemplares comentarios como el siguiente: «los tipos eran todos morenos, con el atávico resabio de las razas indígenas, como si nos dieran con orgullo a descifrar en sus rostros el misterio profundo de sus almas, el secreto de la rara belleza que venían a enseñar» (Rojas, 1921). Al ver las imágenes de la compañía de Chazarreta nos cuesta encontrar ese grado de naturalismo que encandiló a Ricardo Rojas.

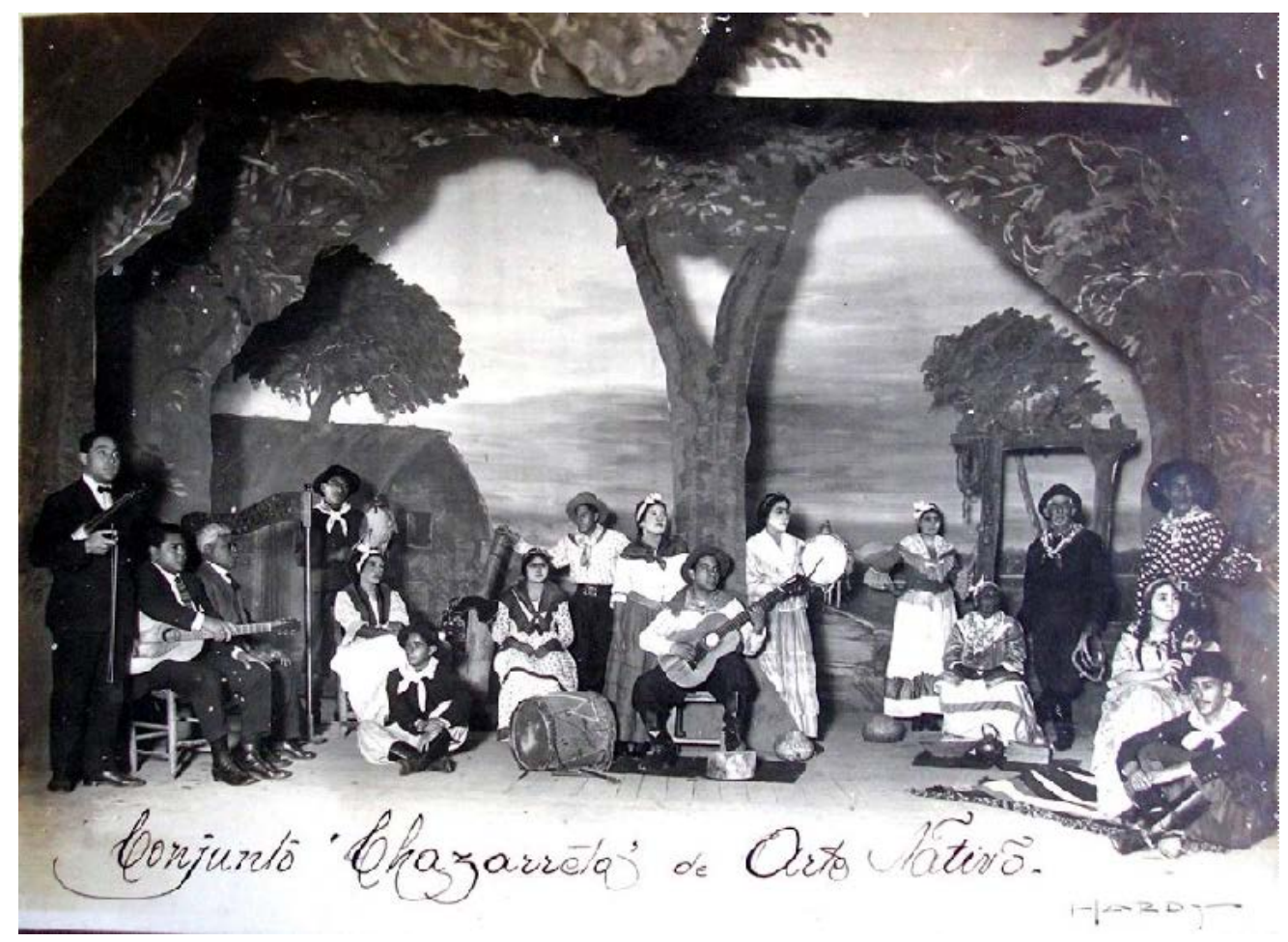

La Compañía de Arte nativo de Chazarreta en escena

Sobre el escenario del espectáculo nativo convivían diversos personajes, algunos ataviados como indios, otros como paisanos, que indiscriminadamente podían mantener la tez trigueña o como ya vimos para el caso de los espectáculos criollos, estar maquillados de blanco. Aparte, en un contraste que escenifica la polarización urbano/rural característica de la disciplina folklórica, pero no de la música popular latinoamericana, los músicos vestían de traje y corbata, como las orquestas clásicas o de tango (éstas últimas fundamentalmente en el ámbito local más que el internacional), y la instrumentación, incluyendo arpas o bandoneón, no presentaba lo que pasaría a conformar un conjunto "típico" del folklore décadas más tarde, sobre todo el cuarteto de guitarras y bombo. 


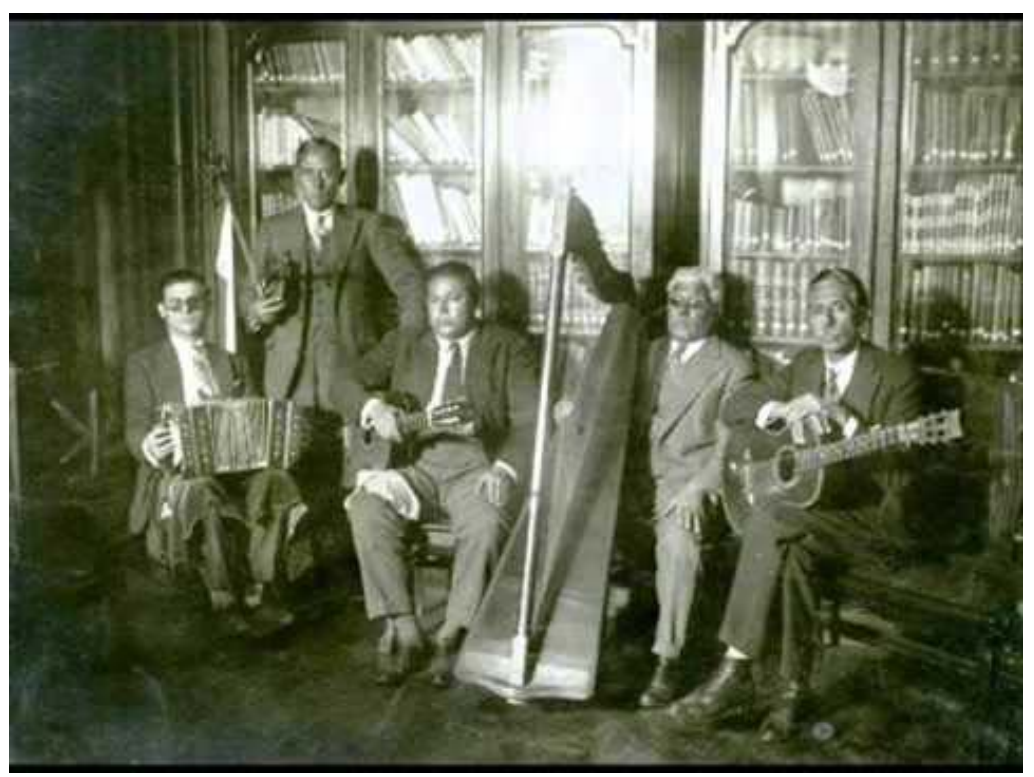

Conjunto nativo de Andrés Chazarreta, con bandoneón y arpa

Más allá del inverosímil de la puesta, existe en el comentario de Rojas una euforia mesticista producida por la caracterización de los bailarines, que pareciera contravenir la concepción racista de la generación del '80, representada en el blanqueamiento del vestuario, la actitud y hasta los instrumentos de los músicos. Pero interesa aquí que ambas perspectivas consideraban lo criollo y mestizo como una fase de un proceso de genética, fantasía al final del cual se impondría, para bien o para mal, la "raza" europea. Lo cual es compatible con el blanqueamiento del gaucho operado por el positivismo argentino. Por más que Rojas celebra la cultura popular santiagueña -y por extensión la identifique con la nacional- «no obstante, asumía Rojas, este cándido campesinado mestizo de origen colonial pronto dejaría paso a otros sujetos sociales» (Farberman, 2010, p.71). Esto explicaría, por ejemplo, la idealización del mundo campesino pronto a desaparecer en la figura del Zupay, personaje mítico que en la obra de Rojas es amenazado por el desmonte, y no un "contrabalanceo" de esa idealización, como pretende leer Chamosa (2012, p. 45). Es decir, lo que compone Rojas, y allí se revela su faceta de folklorista, es un cuadro nostálgico de un cadáver en descomposición, de un universo simbólico y físico a punto de morir a manos de los hacheros. Las armas del desmonte no las blanden otros mestizos, como el hacherito Maturana del Cuchi Leguizamón, sino la inmigración extranjera, que de forma inexorable llegará, también, al noroeste argentino. No se trata entonces de una denuncia, sino de la afirmación de un proyecto político que parte de la élite hegemónica.

Torcuato Di Tella señala que los intelectuales de la restauración nacionalista continúan y actualizan «lo que se había pensado en el '80» (Mignona, 2010b, min 5:00). También Oscar Chamosa señala este recorrido del folklore argentino, que va del positivismo al nacionalismo (2012, p. 21), movimiento político y cultural cuya emergencia está íntimamente ligada con el «descubrimiento del pueblo» operado por el folklore (Burke, 2014, p.47). En el caso europeo, desde mediados del siglo XIX aparecen, en el pensamiento acerca del pueblo, las oscilaciones entre nacionalismo y positivismo, por ejemplo en los famosos folkloristas finlandeses que, mientras buscan en la poesía oral el indicador del "alma del pueblo" profesan un lema de positivismo explícito: «dejémonos de teoría. Lo importante es coleccionar» (Canclini, 1989, p. 198), lo que liga íntimamente al folklore con la museificación de la cultura popular. Para el caso argentino, Gabriel Di Meglio contribuye a describir este panorama, en el que ve en los intelectuales de la élite una «ambigüedad frente a la transformación» que simultáneamente ellos mismos impulsaban, como parte de la construcción de hegemonía que estaba produciendo su clase (Mignona, 2010a, 12:53). 
Fundamentalmente frente a aquello en lo que se convierte la gran ciudad, cosmopolita, próspera, poderosa e ilustrada, pero al mismo tiempo democrática, muestrario ineludible de las profundas inequidades sociales y de los conflictos políticos que consecuentemente irrumpen con fuerza.

Algo similar ocurre entre los formatos musicales y escénicos, que no deben leerse como antagónicos sino como diferentes síntesis de las lecturas idealizadas e interesadas que se hacen de los sectores populares. Así como Chazarreta evidencia la influencia del circo criollo y su autenticidad performativa en su despertar nativo, del mismo modo tenemos que considerar que el paradigma folklórico se consolida, al menos parcialmente, heredando y perpetuando esa autenticidad de los espectáculos y sus estereotipos raciales, a los que inviste con autoridad científica, generando mezclas en las cuales las ficciones escénicas se convierten en verdades folklóricas (Miller, 2010, p. 6). ${ }^{179}$ Es una curiosa ambigüedad, que nuevamente sintetiza romanticismo y positivismo como intensidades diferenciales que, a su vez, estructuran el núcleo epistémico del folklore -cosa no tan singular ya que, como estamos proponiendo, también esto ocurre con la musicología histórica. Un buen resumen de esta peculiar configuración teórica podemos encontrarlo en otro "padre fundador" de la disciplina en Argentina: Juan Alfonso Carrizo. En una de sus recopilaciones más célebres, el Cancionero de Catamarca, se encuentra una descripción etnográfica que explica ese atávico resabio detectado por Rojas sobre el escenario del Politeama

el nativo es vencido, relegado a segundo orden y que al fin concluye por desaparecer, en que el conquistador impone sus costumbres, su civilización, sus vicios y virtudes, sin que perturbación social alguna interrumpa su vida patriarcal, esa calma y quietud paradisíacas [...] El tipo del indio de raza ha desaparecido por completo en el Valle de Catamarca y se va extinguiendo paulatinamente en toda la provincia. El paisano de hoy debe tener un $70 \%$ de sangre española [...] La conquista fué una empresa heroica y la acción constructiva de la colonia, la obra más grande de los tiempos modernos. España cumplió una misión providencial al civilizar estas tierras (Carrizo, 1926, pp. 6-7)

A través de esta franca oda al hispanismo de Carrizo se comprende mejor el carácter de ese "mesticismo" (muy diferente a lo que llamamos mestizaje musical), que en realidad está subordinado al rastreo de las fuentes de la cultura criolla en la España de los Habsburgo (Chamosa, 2012, p. 50). Un anhelo del nacionalismo católico conservador que, después de la Semana Trágica de enero de 1919, adoptará un fuerte sesgo antisemita. Leopoldo Lugones es uno de tantos que se inscriben en este giro ideológico en el que los gauchos son lanzados como defensa contra los inmigrantes y, sobre todo, contra sus ideas políticas.

Pero además, es racial el indicador que se utiliza para hacer del criollo el prototipo de Nación, aquello que animará la particularidad de la voz del payador de Lugones y podrá así expresar de la mejor forma el alma de ese ser vivo que es la Patria. En Rojas también se da una identificación del nativo (que no es el indígena sino el gaucho) con la tierra, lo cual se hace derivar de leyes biológicas y universales (Chamosa, 2012, p. 42). Como se ve, más que frente a su epistemología positivista, lo que el nacionalismo del Centenario cuestiona de la generación del '80 es una consecuencia residual de su actuación política. Hoy diríamos una "mala gestión". Ponen en crisis lo que sobrevino luego del genocidio indígena y la integración sumisa del gaucho a capa y espada, pero no esos procesos en sí mismos ni su fundamentación. El tradicionalismo nacionalista lamenta que el cosmopolitismo y el liberalismo hayan generado ese estado de cosas según el cual la Argentina se convirtió en un país de extranjeros. Pero esto no lo vuelve menos eurocéntrico ni lo hace más popular.

179 «The folkloric paradigm ascended, in part, by inheriting and perpetuating some of the qualities of minstrel authenticity: folklorists invested minstrel and hillbilly stereotypes with scientific authority [...] thinkers combined the two notions of authenticity into a series of mongrels that often tendered authentic minstrel deceits as authentic folkloric truths» (Miller, 2010, p. 6) [Traducción del autor] 
El «gaucho del bosque» de Rojas-Chazarreta es un gaucho falso, un gaucho de utilería, un estereotipo que de todas formas se monta sobre los gauchos muertos, esos sí revoltosos y montoneros. Solo cuando éstos dejan de ser un peligro, y por eso en las provincias los asocian al pasado, en el proyecto irradiado de Buenos Aires puede volver a emerger y ser presentado como presente alternativo de la ciudad cosmopolita. Un continuador de la obra de Rojas, como es Oreste Di Lullo, confirmará tiempo después esta visión al señalar que «folklore es el estudio de las distintas formas culturales tradicionales que son patrimonio de la clase subdesarrollada de la sociedad actual» (citado en Lascano, 1972, p. 7). La misma terminología desnuda la mirada moderna y burguesa de estos sectores, aún cuando se pretende vindicarlos, como es el caso de ambos autores.

Como señala Adolfo Colombres «El racismo y la discriminación social se alimentan no solo de intereses económicos y políticos concretos, sino también de estereotipos, de ideas adquiridas que la gente no revisa hasta que se enfrenta a hechos que desnudan su inconsistencia» (2007, p. 157). Los nacionalistas que impulsan el folklore participan de igual modo del modelo etnocéntrico y eurocéntrico como los liberales que pretendían criticar. Tal vez difieren en qué parte de Europa considerar su fuente de inspiración: para unos será España, aunque más la del Siglo de Oro que la del 1900, encaminada a una república de la mano del anarquismo y el comunismo; para los otros seguían siendo Francia e Inglaterra. Pero en lo que ambos sectores convergen, sin lugar a dudas, es en cierto ideario que expulsa de su proyecto a las "razas inferiores», por un lado, y a la "chusma ultramarina» por otro. Como sabemos, todos ellos, antes o después, son blanco tanto de sus fusiles como de sus escritos, unión que resume de forma magistral la tristemente célebre "hora de la espada" de Lugones.

No queremos confundir con esto y amontonar lo diferente, asunto delicado ya que algunas posiciones derivan en actitudes racistas que, llevadas a la práctica por la ultraderecha, constituyeron parte de tragedias históricas que están muy lejos de la posición de los nacionalistas argentinos agrupados en torno al nacionalismo. Por más que algunos, como Lugones, comulgaran con Uriburu y los fascistas del 30. Más bien puede pensarse que durante el cambio de siglo «el espacio intelectual está ocupado en términos filosóficos por el positivismo y en términos estético-literarios por el modernismo cultural» (Terán, 2008, p. 137). Este último no es otro que el nacionalismo que Chamosa llama "romántico», adjetivación consistente con el planteo de Terán ya que, según los intelectuales del Centenario, «es portador de una verdad diferente e, incluso, superior a la verdad del discurso racional o científico: la verdad de la fantasía o de la imaginación que persigue el ideal de la belleza» (Terán, 2008, p. 137). La apelación de la naturaleza que el nacionalismo romántico convierte en paisajismo, tiene raíces biologicistas que proceden del positivismo y son adoptadas por el folklore, lo que le permite unir un determinado "espíritu" con "la tierra" sin que por ello se tenga que renunciar, en lo más mínimo, al eurocentrismo:

Con este ligero vistazo dado a la historia de Catamarca, fácil cosa será comprender que en sus valles, en los pueblitos de sus sierras, se conserva muy puro el espíritu que animó a sus mayores y como el perfume de sus flores silvestres, del corpus y de la flor del aire, se conservan las virtudes de la familia hidalga que en un instante de su vida, generoso y noble, dejó su aldea castellana y vino a las faldas de los Andes trayendo con su fe antigua el alma lírica de la vieja raza. (Carrizo, 1926, pp. 6-7)

Esa es la ambigüedad de la que hablamos, ya que se advierte aquí la divergencia entre una posición y la otra, que hace plausible considerar que entre ellas media un «cambio de actitud», un «dramático giro conceptual» (Chamosa, 2012, p. 41). Pero ello no obsta a que podamos considerarlas versiones internas, intensidades diferenciales de la élite argentina y de su pensamiento programático en torno al pueblo, su identidad y su lugar en el proyecto de nación. Para el positivismo los segmentos "inferiores" de la población estaban condenados a desaparecer. José Ingenieros por ejemplo, sostenía que los futuros 
"euroargentinos" solo sabrían de indios y gauchos al leer cuentos infantiles para irse a la cama (Ingenieros, 1957, p. 318), tal vez porque él mismo era un inmigrante italiano, como los padres de los Podestá o Mauri, el mecenas de Chazarreta. Para el nacionalismo del Centenario, en cambio, la inmigración, en toda su frustrante realidad y desencanto, ya no será un valor sino negativo. De ahí que al constatar la tenaz persistencia de los viejos sectores subalternos que contra el anhelo positivista se resistían a desaparecer, estos pasan a ser, ya domesticados, "el pueblo", el índice seguro de la argentinidad. ¿En qué reside ese "giro dramático»? En que lo subalterno, lo contrahegemónico, cambia: ya no son los gauchos montoneros ni la indiada, pesadilla de los liberales y protagonistas de las pulsiones etnicidas de los positivistas; ahora son los socialistas y anarquistas inmigrantes los que ponen en crisis la continuidad hegemónica de la oligarquía. Pero que sigue pensando un país minoritario: lo modernista de la generación del Centenario reside en «una propuesta para pocos [...] para una minoría de la belleza [...] un elitismo esteticista» (Terán, 2008, 142). Por eso se genera un lugar diferencial para los sectores populares. Y el resultado de este proceso, que a su vez permite nombrar ese territorio que queda fuera de la cultura de la belleza, es el folklore.

La discusión sobre las "verdades" hace entonces que estas puedan ser científicas o espirituales; incluso estéticas. Pero todas son, a la postre, posiciones raciales. Así, tanto el positivismo de Ingenieros, como el hispanismo de Carrizo y el criollismo de Rojas, parten de un pensamiento etnologizado que puede adoptar posiciones de blanqueamiento o de mesticismo. $Y$ que en otras latitudes adoptaron perfiles más dramáticos, como el integracionismo por mestizaje en México, el segregacionismo de EEUU o el antisemitismo genocida en Europa central.

\subsubsection{La raza como garantía de autenticidad}

Ya sea a favor o en contra de los cuerpos racializados, la raza se toma como el índice seguro que demuestra una autenticidad, es decir, un conjunto de valores, en gran medida arbitrarios, que se adjudican a las manifestaciones que son consideradas "desde arriba" expresión cultural de un sector social en cuestión. De este modo la raza

es la categoría organizadora de aquellas maneras de hablar, de aquellos sistemas de representación y de las prácticas sociales (discursos) que utilizan un conjunto suelto y a menudo no-específico de diferencias en las características físicas -el color de la piel, la textura del pelo, los rasgos físicos y corporales, etc.- como marcas simbólicas a fin de diferenciar un grupo de otro en lo social (Hall, 2010, p. 386)

La conceptualización racializada está inextricablemente asociada con los proyectos nacionales que analizamos anteriormente, de forma tal que la raza pasa a ser un parámetro que permite pensar a la Nación como una cultura homogénea y unificada, sobre todo en comparación con otras. Aunque parezca evidente lo inverosímil de este argumento que pretende diferenciar entre alemanes y franceses o argentinos y chilenos [o para el caso cualquier combinación de esos cuatro términos], ${ }^{180}$ la historia contemporánea de Europa y de América Latina están atravesadas por discursos racializados y todavía «las identidades nacionales siguen siendo representadas como unificadas [...aún cuando un] breve examen [histórico cultural] mina la idea de la nación como una identidad cultural unificada» (Hall, 2010 , p. 387). Esto reside en la potencia que tiene la raza como concepto y en su capacidad para organizar la diferencia al interior y entre las sociedades (Hall, 2015).

\footnotetext{
180 ¿Qué son las comunidades "latinas" de París o Berlín sino europeas? ¿Son o no son argentinos los habitantes de Häsenkamp [Entre Ríos] y Belleville [Córdoba]? Por más que los chilenos bromean acerca de que los "alemanes de Valdivia" tienen una pureza germánica mayor que sus parientes europeos, esas filiaciones nominales sólo sirven hoy para sacar una tarjeta de inmigración al primer mundo. Perfecto reverso de la época que estamos analizando, aunque no por eso menos racializada.
} 
Cuando se percibe en su aspecto inmediato el contexto colonial, es evidente que lo que divide al mundo es primero el hecho de pertenecer o no a tal especie, a tal raza. En las colonias, la infraestructura es igualmente una superestructura. La causa es consecuencia: se es rico porque se es blanco, se es blanco porque se es rico (Fanon, 1963, p.29).

Esta referencia a las relaciones de poder que tan bien analizó Fanon nos lleva a recuperar la filiación de la categoría de raza con todo el ordenamiento de la modernidad, que comienza a gestarse con la colonización paulatina del resto del mundo por parte de Europa. Por eso para Aníbal Quijano (2014) la raza, que es una categoría mental, se origina en América a partir de la conquista y se traslada luego como vector de justificación del proceso de control del resto del mundo progresivamente colonizado, fundamento de la especificidad de las relaciones de poder en todo el mundo hasta el presente (Quijano, 2014, p. 83). De forma similar al planteo de Hall, la raza no se reduce meramente a una diferencia en términos epidérmicos de etnicidad. Es una forma afirmativa de las relaciones de poder ya que éstas se basan, no en una arbitrariedad simple, sino en el desarrollo de una noción que define a los colonizados no únicamente "diferentes" de los europeos, sino fundamentalmente miembros de un nivel "inferior" (Quijano, 2014, p. 84). Basar las diferencias culturales $-\mathrm{y}$ los valores que se hacen en torno a ellas- a partir de las variaciones biológicas implica sustraer el carácter histórico de las relaciones de desigualdad, al mismo tiempo que se impide su transformación. A partir de este mecanismo se construye un complejo cultural que se puebla de imágenes, valores y actitudes, y despliega no sólo correlaciones entre etnicidad y cultura, sino también las explicaciones acerca de las diferencias. Esto justifica que, superado el momento estrictamente colonial, las identidades racializadas permanezcan como forma de dar cuenta de las relaciones diferenciales entre los grupos sociales. Muy por el contrario, todo el sistema de pensamiento racializado se vuelve más sofisticado hasta alcanzar su apogeo, como analizamos anteriormente, en el positivismo. La aparición de la antropología y los estudios comparados son un indicador de este proceso de sofisticación que devuelve como resultado la creación de identidades racializadas. «(...) en esas nuevas identidades quedó fijada, igualmente, la idea de su desigualdad, concretamente inferioridad, cultural, si se quiere "étnica"». (Quijano, 2014, p.85). En esta permanencia de la categoría de raza como criterio de valoración cultural diferencial en los procesos nacionales de América Latina, Fanon observa también un mecanismo de legitimación de las élites criollas que, como vimos, sirve para desmovilizar y hacerle un lugar a los sectores populares en el proyecto nacional. Por eso «el racismo de la joven burguesía nacional es un racismo defensivo, un racismo basado en el miedo» (Fanon, 1963, p.130).

Siguiendo a Fanon y a Cedric Robinson, Ramón Grosfoguel ve en el racismo un principio organizador de la modernidad. Además de estructura de poder, autoridad moral, o economía de justicia y comercio, la raza se vuelve epistemología (Cedric, como se citó en Grosfoguel, 2018, p. 14). Esto produce que la modernidad en su conjunto deba ser considerada como racial desde su primer momento. Es decir, la racialización no es un procedimiento que se agrega sobre las ideas de la modernidad, como podrían ser el progreso, la acumulación del capital o la estética clásica. Por el contrario, ellos mismos son posibles de pensarse y de representar el proyecto moderno a partir de que obtienen su fundamento en la categoría de raza y sus clasificaciones, ya que la modernidad no puede pensarse si no es en expansión y apropiándose ya sea de la naturaleza o de otras culturas.

el proyecto de expansión colonial europea, a partir de 1492, no fue solamente la expansión de un sistema económico, sino la expansión de una civilización que se hizo planetaria por medio de la destrucción de todas las otras civilizaciones existentes y la interiorización racial de sus sobrevivientes. Para Césaire, como para muchos intelectuales afros e indígenas, la modernidad constituye una civilización de muerte (Grosfoguel, 2018, p. 19). 
En la actualidad, este asunto se ha vuelto urgente al comprobarse justamente que esa relación entre desarrollo y expansión ya no es posible, dado que hemos ingresado en una fase en la que las potencialidades planetarias van agotándose vertiginosamente. Y así, como el extractivismo es perpetrado por aquellos que promueven una ecología de élite, la burguesía occidental, que además de moderna es fundamentalmente racista, "consigue casi siempre disfrazar ese racismo multiplicando los matices, lo que le permite conservar intacta su proclamación de la eminente dignidad humana» (Fanon, 1963, p. 130).

Grosfoguel también asocia el pensamiento de Stuart Hall con el de los marxistas negros, al recordar que, para el autor británico, la raza funciona como «principio estructurante» de la economía, las clases sociales y la organización de las sociedades (Grosfoguel, 2018, p. 16). De hecho, Hall sostiene que la forma en funciona la categoría de raza «está más próximo al funcionamiento de un lenguaje que al funcionamiento de nuestra biología o de nuestras fisiologías» (Hall, 2015, p. 7). Esta idea fue concebida al calor del clima intelectual de la década de 1990, y se nota. Sin embargo, nos permitiremos forzar el argumento fuera de ese marco para utilizarlo en este contexto y trazar así una analogía: el lenguaje de la raza es al folklore lo que el lenguaje armonicocéntrico de los estilos es a la musicología. Entendida la raza como categoría clasificatoria basada en la desigualdad que permite adjudicar una identidad cultural a un determinado sector popular, se convierte entonces en equivalente del estilo, en tanto conjunto de rasgos y por tanto índice del valor estético de la obra-objeto musical, el que a su vez permite adjudicarle una dimensión temporal o histórica. El célebre folklorista del siglo XX Alan Lomax utilizará en su proyecto de normalización de las músicas del mundo -conocido como cantométrica- el término estilo, y lo definirá como hábito conductual social determinante de la particularidad musical de una cultura, que continúa pensándose como homogénea y unificada. "Al ser el estilo el producto final de un patrón de conducta, puede ser descompuesto en elementos aislados y descripto» ${ }^{181}$ (Lomax, 1959, p. 929).

El estilo folklórico emerge como valor de la relación entre una música "nativa" (Grauer, 2005) y la cultura a la cual se la asocia. Es la magnitud de la autenticidad. Es un valor cuantificable, como lo es cuando el estilo en la musicología histórica representa la magnitud de la autonomía, donde funciona como otro patrón de conducta, en tanto conjunto de rasgos de la escritura de un compositor individualizado, socialmente aislado de las relaciones de producción.

En ambos casos, el estilo es "garantía" de origen, en tanto que certifica o bien la autenticidad étnica de la cultura o la autonomía de la personalidad artística, respectivamente. Por los mismos términos en que se piensan y formulan, es evidente su procedencia del conductismo y el positivismo, cuyo método busca encontrar estas garantías mediante la correlación y comparación. Un modelo pensado para detectar, discriminar y clasificar la colección. «El modelo no explica la correlación; sólo da cuenta de ella, o la establece» (Reynoso, 2006, Vol II p. 60). En otras palabras, es una pieza fundamental del carácter afirmativo de la cultura moderna. Así, pretender que una sociedad tenga un único tipo musical auténtico -búsqueda obsesiva del nacionalismo- es un gesto epistémico de una afirmatividad equivalente a la de pretender que un único compositor (o tres o veinte) sintetice la música de toda una época histórica del mundo. Esto revela la intrincada convergencia de los sectores que desarrollan tanto la musicología histórica como el folklore, y la estrecha complementariedad de ambos enfoques.

181 «since a style is the end-product of a pattern of behavior, it can be broken down into its separate elements and described» (Lomax, 1959, p 929) [Traducción del autor]. 


\subsubsection{Cartografías del extractivismo epistémico}

Una forma de concebir la homogeneidad o unicidad de una cultura que complementa y refuerza la garantía construida por la racialización de los cuerpos, es el recurso al territorio. Decía Cortazar que «todo fenómeno folklórico es geográficamente localizado, es decir, tiene expresión regional [...] es lugareño y típico» (1959, p. 21-22). Este recurso al lugar, que mediante cierta imaginación ambientalista funciona también como casuística de la tipicidad del pueblo y sus manifestaciones, comprende un procedimiento recurrente de la modernidad como es la producción del espacio (Santos, 2000). En términos culturales esto puede entenderse en términos de una territorialización y sus procesos derivados, desterritorialización y reterritorialización

Con esto me refiero a dos procesos: la pérdida de la relación "natural" de la cultura con los territorios geográficos y sociales, $\mathrm{y}$, al mismo tiempo, ciertas relocalizaciones territoriales relativas, parciales, de las viejas y nuevas producciones simbólicas que se relacionan con la cultura (García Canclini, 1989, p. 278).

Para García Canclini, sin embargo, los procesos de desterritorialización y reterritorialización operan en términos secuenciales, a posteriori de una época de mayor unicidad y homogeneidad socio cultural, que la posmodernidad y la globalización desplazan. Por lo tanto a una supuesta época del folklore y el nacionalismo, y sus categorías, le sucede otra en la que irrumpen factores que no permiten reproducir oposiciones binarias -como imperialismo/dependencia- que ya no pueden dar cuenta, por ejemplo, de las migraciones masivas, la transnacionalización o la emergencia económica de países en vías de desarrollo. «El maniqueísmo de aquellas oposiciones se vuelve aún menos verosímil en los ochenta y noventa» (García Canclini, 1989, p. 289).

Pero también debemos pensar que la modernidad produce el territorio, es decir que el mismo concepto de espacio es portador de una intencionalidad, un horizonte de productividad expresado por el conjunto de funciones que la sociedad elige ver en una configuración territorial determinada. Así se da la transformación del lugar en recurso, lo cual hace a su vez de las cosas, objetos. Es un proceso que despega en la modernidad temprana, a partir de la escisión fundamental entre el hombre y la naturaleza que parte de las ideas de Descartes, Bacon o Galileo Galilei. A esto sigue una interrogación de la naturaleza "objetificada", es decir, la producción científica moderna que se funda en dicha escisión con fines de control y dominio que, su vez, implican el antagonismo culturanaturaleza que las iglesias cristianas producen mediante su condena a la "idolatría" de lo natural (Small, 1989, p. 68). Territorializar es uno de los ejes de la dominación de la naturaleza por parte de la modernidad, que sólo puede pensar su propia existencia a partir de su expansión permanente (Grosfoguel, 2014), la cual es fundamentalmente una expansión territorial. Y que, como parte de la configuraciones territoriales que encuentra al paso de su expansión, somete también a los seres y sus creaciones. La noción de producción del espacio del gran geógrafo brasileño Milton Santos puede ayudarnos aquí a comprender su valor estratégico como condición de la modernidad a la vez que es un factor de su desarrollo. Desde su perspectiva, el espacio se construye a partir de las condiciones que ofrece para la vida social y cultural (Santos, 2000, p. 48), la cual queda incluida en el espacio, que es a la vez productor y producto de todas las dimensiones de la sociedad. En la producción del espacio por la modernidad juega un rol crucial la interpretación de los componentes de la configuración territorial (los seres vivos, las manifestaciones culturales, los yacimientos minerales, etc.) a los cuales la razón moderna recurre, es decir, los transforma en recursos

Los recursos del mundo constituyen, juntos, una totalidad. Entendamos aquí por recurso toda posibilidad, material o no, de acción ofrecida a los hombres [...] Recursos son cosas, naturales 
o artificiales, relaciones compulsivas o espontáneas, ideas, sentimientos, valores. A partir de la distribución de esos datos, los hombres van cambiándose a sí mismos y a su entorno. Gracias a esa acción transformadora, siempre presente, en cada momento los recursos son otros, es decir, se renuevan, creando otra constelación de datos, otra totalidad (Santos, 2000, p. 111)

El espacio está formado por objetos, que están determinados por la acción de quienes producen el espacio, a partir de la aplicación de una lógica, una técnica y una agencia a los componentes del territorio. Es decir que aquello que a los ojos de la modernidad está dado, lo que entiende como mundo natural e incluye tanto a las culturas "exóticas" como a los sectores populares "internos", al aplicársele una intencionalidad que se basa en el provecho y la extracción, pasa a conformar una colección de objetos. "Así, la naturaleza se transforma en un verdadero sistema de objetos y ya no de cosas» (Santos, 2000, p. 56). A las cosas que ofrece el territorio ante la mirada moderna, se las transforma en objetos, los cuales serán a su vez abstracciones, signos de una profunda repercusión en la definición de la sociedad y el espacio. Signos abstractos que pasan también a conformar un sistema de valores, en tanto se los entiende como valor de cambio al hacerlos ingresar a la lógica del capitalismo.

La consideración del espacio es tan importante aquí en función de que dicho valor es especialmente dependiente del lugar en que se los puede ubicar. Fuera de esa coordenada se comoditizan, ${ }^{182}$ es decir pierden su especificidad, como ocurre con las commodities, cuyo valor de mercado es independiente del sitio de extracción o producción. Aquí entra en juego otra acción, la localización que concretiza una serie de rasgos presentes en los fenómenos de un lugar y crea la diferenciación necesaria para que obtengan valor. Como «la localización es un haz de fuerzas sociales ejerciéndose en un lugar» (Santos, 1986), la definición de un objeto folklórico dependerá, por lo tanto, de una localización determinada, la cual, como parte de la construcción misma de los "hechos folklóricos" es producida por el folklore (disciplina).

A partir de estas consideraciones acerca de la producción del espacio cultural y sus objetos etnologizados, queremos proponer a los procesos de territorialización como un componente estructural de la modernidad, no de su disolución aparente; y que estos procesos se dan específicamente en la generación de los repertorios musicales, es decir en la fragmentación de las manifestaciones sonoras en lo culto, lo folklórico y lo popular, ya que la producción del territorio es parte estructural de la modernidad. Por lo tanto asignar valor a las músicas, introducirlas en una colección y repertorio, producirlas como objeto de mercado, implica considerarlas en función de un lugar, es decir localizarlas.

En las propias formulaciones de la disciplina del folklore aparece el proceso de conversión de las cosas de una configuración territorial, de un paisaje, en objetos particulares asociados a un espacio, lo cual permitirá luego la conversión de los fenómenos populares presentes en diferentes configuraciones culturales en productos. Los cuales a su vez terminan por definir al pueblo

el pueblo que interesa al Folklore se define por la posesión de los hechos folklóricos, esto es, de las supervivencias. Es la posesión de las cosas folklóricas lo que convierte en pueblo a las gentes, y no a la inversa (Vega, 1944, p. 53)

Territorializar es construir o configurar un espacio para la apropiación extractiva de sus cosas, las cuales, por la acción folklórica, se convierten en objetos.

182 Hay que diferenciar el concepto de comoditización del de comodificación, que implica no la equivalencia o intercambiabilidad de productos de diferente origen -en todo caso más cercano a la música "clásica" que al folklore- sino la transformación de los fenómenos culturales en bienes u objetos de mercado. 
¿qué nos importa el pueblo por sí mismo en cuanto implica un grupo de individuos físicos? [...] sí, en cambio, productos que, aún considerados independientemente, suponen las gentes que los poseen y vitalizan. Ciencia de productos es el Folklore (Vega, 1944, p. 54)

El folklore es una ciencia de las cosas, encontradas y cartografiadas, traficadas luego en objetos. No es una ciencia del pueblo. Esta especificación de Vega, central en el modelo folklórico del positivismo de mediados de siglo $\mathrm{XX}$, hace ingresar a la música popular en la noción de recurso, es decir que es parte del proceso por el cual la modernidad produce el ingreso de la música en el cambio (Attali, 2011). Todo lo que vimos hasta aquí, la creación de un ideal de lo popular como procedimiento político y la exotización del pueblo basada en la etnologización, puede entenderse también a partir de que confluyen en su conversión en objetos de mercado. De ahí la importancia de considerar lo regional, es decir de localizar los "bienes" folklóricos, a partir de lo cual emerge su valor en tanto objetos locales.

En la introducción de su libro Victorian Song Hunters (Los Cazadores de Canciones Victorianos), David Gregory introduce la imagen de la expansión colonial europea como metáfora de la actividad de los folkloristas

Cuando hablamos del descubrimiento (o recuperación) de las canciones folklóricas no queremos decir que estaban perdidas en un sentido específico. Queremos señalar simplemente que no habían sido registradas de una forma que las hiciera más accesibles al público en general. De esta forma, los recolectores victorianos y sus precursores georgianos descubrieron (o mejor, redescubrieron) las canciones folklóricas de un modo análogo a como los europeos descubrieron el Nuevo Mundo. Si quisiéramos ser cínicos, diríamos que produjeron la accesibilidad de esas canciones de un modo no muy diferente a como los colonizadores europeos abrieron el Nuevo Mundo a la explotación. Pero quizás eso sea llevar la analogía demasiado lejos ${ }^{183}$ (Gregory, 2006, p. 3).

Para Gregory, la comparación es exagerada. Tal vez en función de que está describiendo específicamente a los folkloristas ingleses que coleccionaron las canciones británicas. Pero a riesgo de ser cínicos, si ampliamos el concepto de extractivismo asociándolo con el saqueo de los "bienes" culturales, además de los recursos naturales, la metáfora se transforme en algo más concreto. Pensemos en Claude Debussy y su maravilla frente a la orquesta javanesa -en la época dirían de Cochinchina- que formaba parte de la Exposición Universal de París de 1889. Esa misma exposición exhibía en recintos análogos a los de los animales salvajes de Asia y África, a los pobladores nativos de las regiones en poder de los imperios, como atractivo exótico. Una escenificación del dominio de la naturaleza, que incluía también a las culturas localizadas.

\footnotetext{
183 «When we talk of the discovery (or recovery) of folksongs, then, we do not mean to imply that they were lost in any absolute sense. We mean merely that they had not previously been recorded in a way that made them more widely accessible to a general public. The Victorian collectors and their Georgian precursors thus discovered (or, better, recovered) folksongs in a way analogous to the European discovery of the New World. If one was inclined to be cynical one might even say that they opened up those songs for exploitation in a manner not unlike the way in which European colonists opened the New World for exploitation. But that, perhaps, is to take the analogy too far» (Gregory, 2006, p. 3) [Traducción del autor]
} 


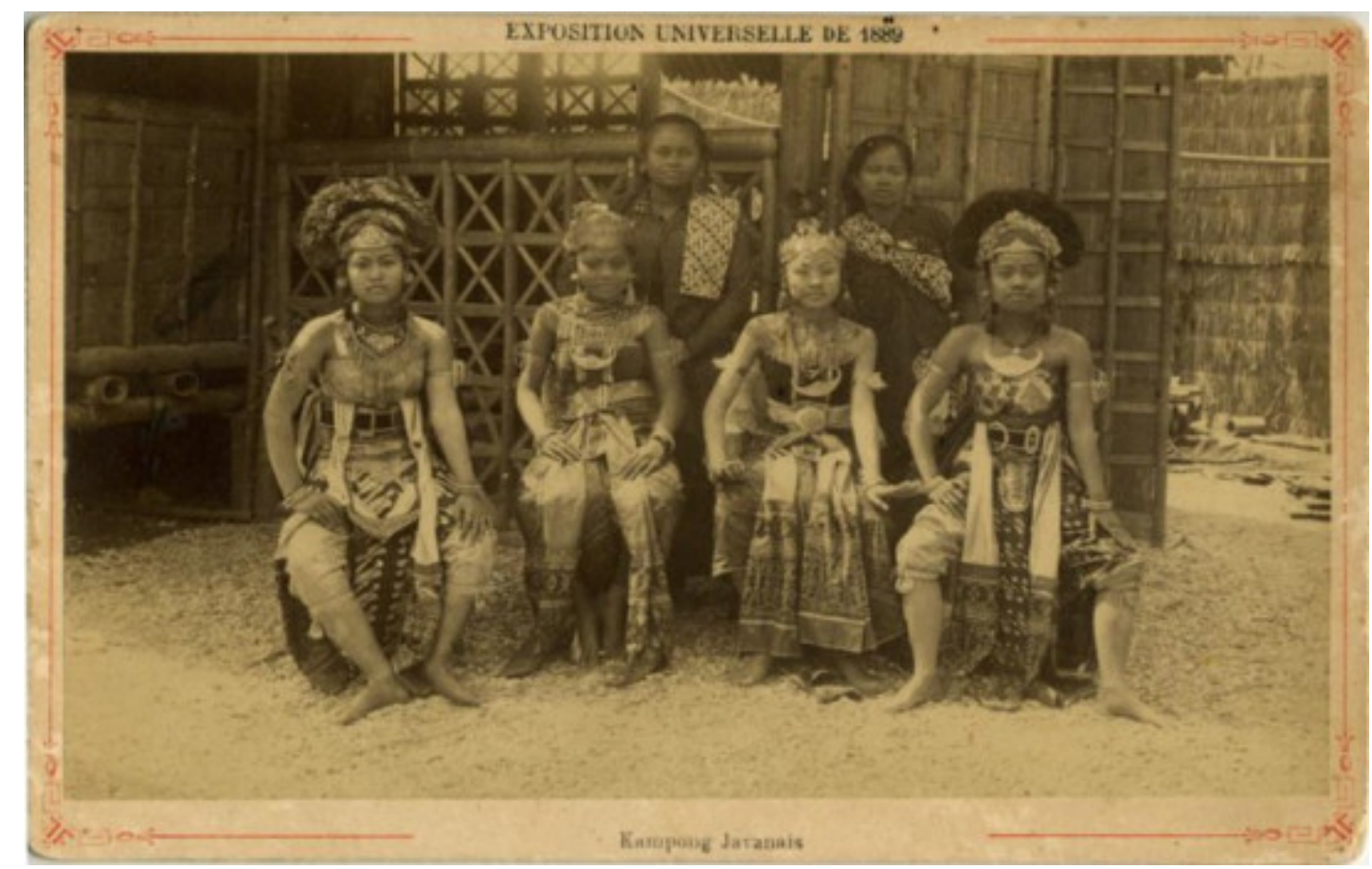

Bailarinas de Java en la Exposición Universal de 1889, parte de la compañía que ejerció fascinación en Debussy

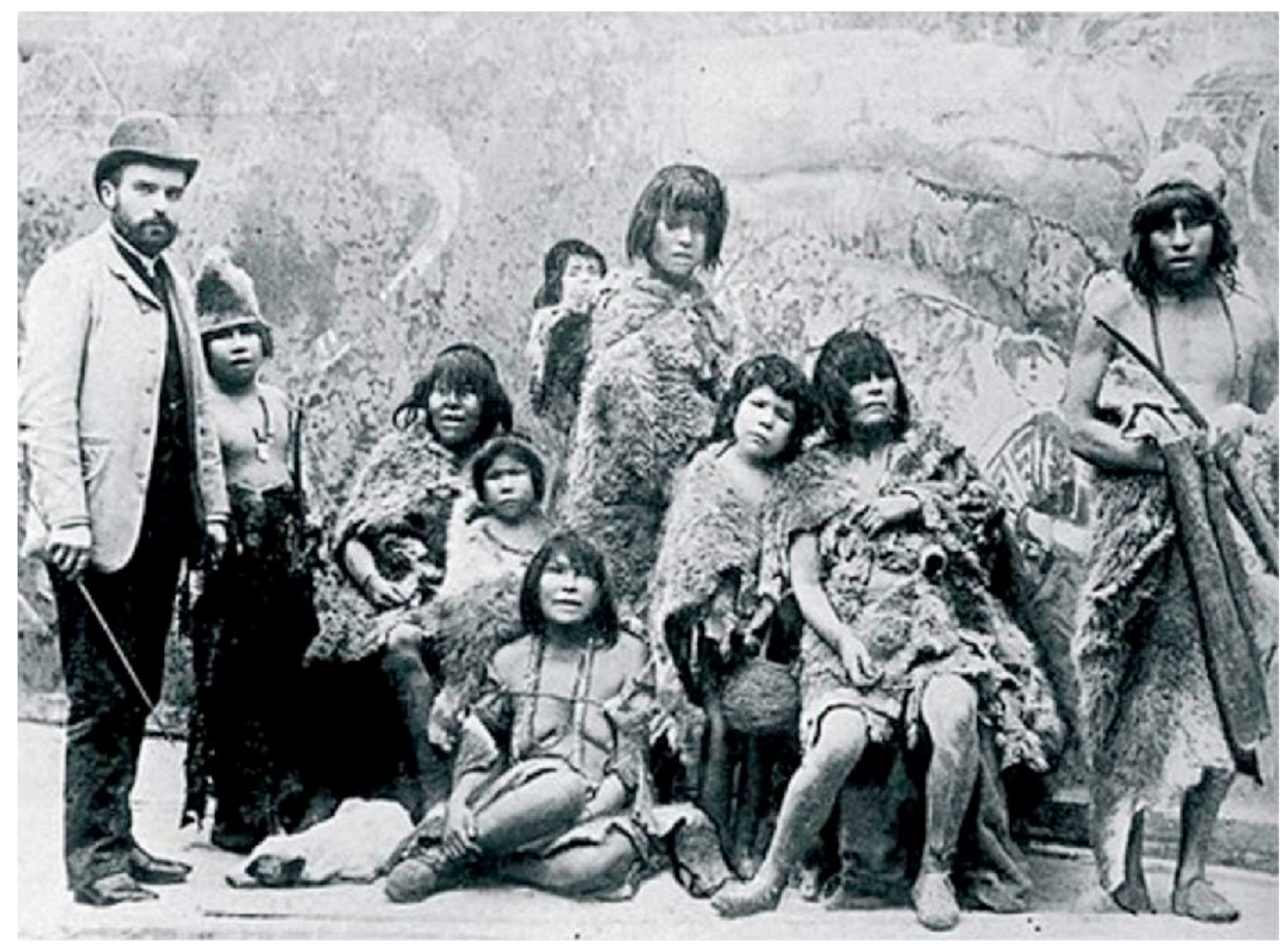

Familia Selk'nam secuestrada de Tierra del Fuego, exhibida en la Exposición Universal de 1889 junto a su captor, el empresario Maurice Maitre. Durante la exhibición se los presentó como caníbales y se los alimentaba con carne cruda. De los once fueguinos sólo seis pudieron regresar a su lugar de origen, luego de atravesar los más inconcebibles horrores.

Con la expansión colonial surge una particular "tecnología", los mapas, que al igual que la notación musical que se utilizaba para registrar los cantos folklóricos y primitivos, organiza en el plano lo de "arriba" y lo de "abajo", lo "grande" y lo "pequeño", lo "central" y lo 
"periférico". Recordemos al ilustre Mercator, el cartógrafo flamenco del siglo XVI que produjo el célebre planisferio que habita en nuestra imagen del mundo que, como sabe hasta la industria audiovisual de Hollywood o los gigantes de Big Data, ${ }^{184}$ posee una cantidad considerable de distorsiones en su forma de presentar los continentes, sobre todo en su tamaño. Hay una enorme controversia alrededor de este mapa que acompaña de forma universal la formación de millones de niños alrededor del mundo. Muchos se quejan del mapa por inexacto, lo cual es cierto, a la vez que señalan que una proyección bidimensional correcta del globo no es posible. $Y$ quienes buscan contextualizar su trazado dicen que el holandés no lo hizo así por maldad, sino porque buscaba representar el mundo de forma tal que pudieran trazarse las rutas de navegación en forma rectilínea. Lo cual también es correcto, ya que el mapa funciona así. Lo que se discute menos, aunque se ha escrito sobre ello (Saarinen, 1987; Monmonier, 2010) es el carácter ideológico y colonial que expresa el mapa, en el cual Mercator colocó a Europa -su mundo- en el centro del plano, de cuya superficie el hemisferio norte -el de Mercator- ocupa casi el sesenta por ciento. Es decir, el Ecuador no parte el mundo en dos, sino que cumple una función un tanto más secundaria. Casi es un trópico. Poder calcular la navegación sobre el mapa en línea recta, además, no era un asunto de turistas para Mercator y sus compañeros, sino que esa precisión, velocidad y economía de los viajes garantizaba una explotación eficiente del mundo sometido. Además, como no se cansa de enseñarnos Enrique Dussel (2007), el mapa de Mercator hace que sea muy difícil visualizar o imaginar las conexiones históricas entre diferentes culturas y civilizaciones de los que De Sousa Santos (2014) llama el sur global, esto es, los territorios que han sido sometidos por el eurocentrismo. Del mapa que todos calcamos y contorneamos alguna vez se desprende, casi naturalmente, una concepción histórica occientalocéntrica en la cual el continente americano, convenientemente "solo" y a la izquierda, no puede relacionarse con Asia, Oceanía o África, si no es a través del descubrimiento que de él hace Europa. Descubrimiento que inicia la expansión, es decir, la modernidad. Mercator era matemático y astrónomo, además de cartógrafo. Pero no había nacido con ese nombre, sino que lo habían bautizado Gerard Kremer. Eligió latinizar su nombre para firmar sus textos que, como era costumbre, se escribían en latín. Podría haber elegido como apodo Geographus o Geographicus, o también Physicus (científico); Tabulator, es decir el "que cuenta cosas" o hace una "tabula", que es una forma de decir "mapa" en latín. También y dada la función de su cartografía, podría haber sido conocido como Nauta o Navigator, que también se dice Gubernator, o Sapiens o Sensatus, es decir "Sabio". Pero no, nada de eso. Gerard eligió llamarse por el nada distinguido, honorable ni grácil apodo de "comerciante". Porque después de todo, para qué servía su mapa si no era para convertir en recurso, en territorio, producir el espacio para el extractivismo de la periferia destinado a hacer progresar a ese centro europeo que su proyección validaba en lo visible. Poniendo a Europa en el centro, Mercator construye inmediatamente, sin controversias y cerrando la discusión, la distancia centro-periferia, metrópoli-colonia. El mapa es garantía física, espacial, del occidentalocentrismo. Como ocurre con la raza, el factor territorial es el factor epidérmico que puede leerse en la piel del mapa.

Casualmente o no tanto, al folklore y a los folkloristas les encantan los mapas. De hecho sus textos, así como los discos grabados por el folklore artístico, suelen denominarse "mapa musical" o "panorama".

\footnotetext{
184 La serie televisiva The West Wing [El ala oeste] (Sorkin, 1999), que cuenta los entretelones de los hombres y mujeres del gobierno estadounidense en los pasillos de la Casa Blanca, muestra en una conocida escena la presentación de unos geógrafos que explican con lujo de detalles el sesgo imperialista del planisferio de Mercator, al que proponen reemplazar por la proyección de Gall-Peters. A pesar de las implicancias políticas de la cartografía -o tal vez justamente por ellas- la propuesta nunca prospera, extraviada en los vericuetos de la burocracia estatal. Puede verse aquí https://youtu.be/i8iHj_O_ZNk (ejemplo 46) la escena que corresponde al capítulo 16 de la segunda temporada de la serie. Por su parte la aplicación Google Maps abandonó en agosto de 2018 la proyección de Mercator por considerarla errónea
} 


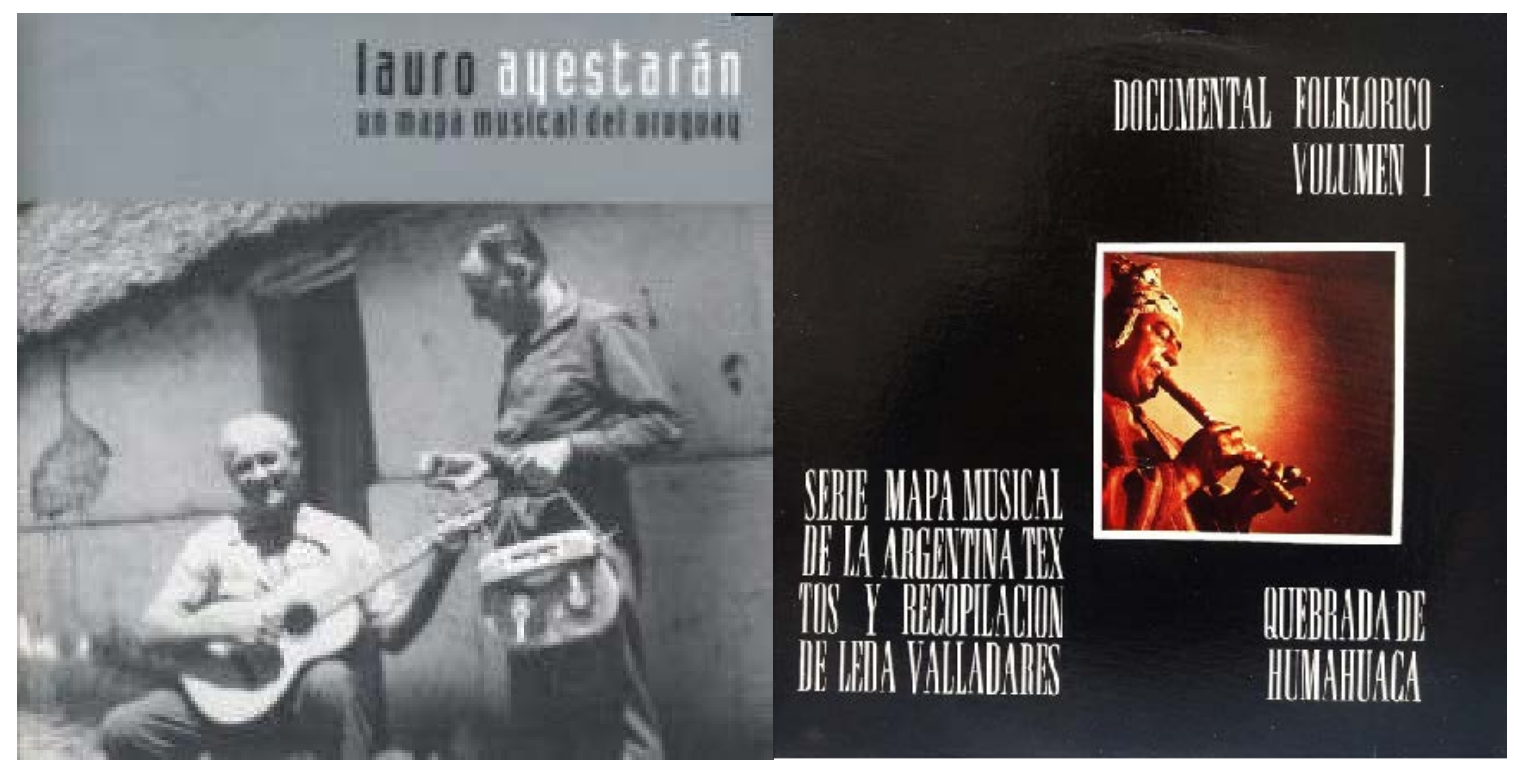

Portadas territorializantes: a la izquierda el CD "Lauro Ayestarán. Un mapa musical el Uruguay", que contiene grabaciones de campo del legendario musicólogo y folklorista oriental. (Ayuí/Tacuabé. A/M38CD); derecha, el LP volumen I del Documental Folklórico- Serie Mapa Musical de la Argentina, con recopilaciones de Leda Valladares. Disc Jockey, LD-15136

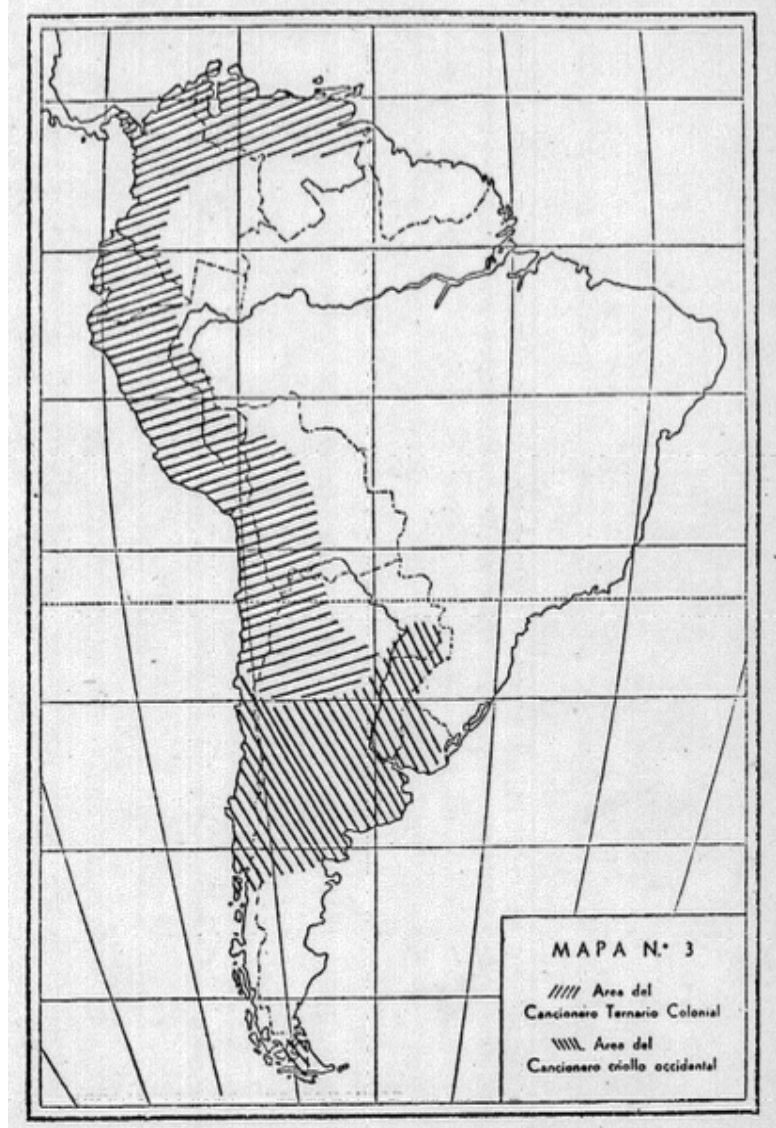

Tercer mapa de una serie de seis, mostrando el "área de difusión" de los cancioneros "ternario colonial" y "criollo occidental". Página 157 del Panorama de la Música Popular argentina, de Carlos Vega (1944)

Con los mapas, el contenido de las investigaciones del folklore aparenta clasificarse solo, casi espontáneamente, como la creación comunal que el folklore colecciona. Los mapas son imprescindibles para generar la colección y localizar las músicas, lo que, como dijimos, 
significa producir los objetos del folklore. En el caso de Carlos Vega o Lauro Ayestarán, que adoptan el difusionismo de la escuela antropológica histórico-cultural, el mapa es a la vez la explicación del origen y posterior circulación de las músicas. Por eso en el texto de Vega de 1944 se corresponde un mapa por cada "cancionero", es decir, por cada unidad del repertorio de música folklórica de Argentina.

Esta cartografía musical produce entonces series o colecciones que se articulan a su vez con las resultantes del procedimiento de creación de identidades etnologizadas que analizamos previamente. No es posible evadir el carácter colonial y marcadamente capitalista de estos procedimientos

La formación del mundo colonial del capitalismo, dio lugar a una estructura de poder cuyos elementos cruciales fueron, sobre todo en su combinación, una novedad histórica. De un lado, la articulación de diversas relaciones de explotación y de trabajo -esclavitud, servidumbre, reciprocidad, salariado, pequeña producción mercantil- en torno del capital y de su mercado. Del otro lado, la producción de nuevas identidades históricas, "indio", "negro", "blanco" y "mestizo", impuestas después como las categorías básicas de las relaciones de dominación y como fundamento de una cultura de racismo y etnicismo (Quijano, 2014, p. 83)

En el ensayo Folk Song Style de Alan Lomax (1959) aparece con mucha claridad una serie que parece copiada de la que exhibe Quijano en toda su crudeza. Para Lomax, el canto «tradicional» a nivel mundial puede clasificarse en diez categorías o «familias estilísticas», que describe como Indoamericana, Pigmoide, Africana, Australiana, Melanesia, Polinesia, Euroasiática, Europea antigua, y Europea moderna. A través de estas categorías Lomax clasifica toda la música del mundo a la que, a su vez, somete a un complejo método de análisis, la "cantométrica», que supone la herramienta para establecer correlaciones desprejuiciadas entre la organización social y los rasgos sonoros de las culturas. Pero si observamos los nombres de las familias estilísticas, sin discutir siquiera el contenido de lo que se pretende clasificar, encontramos varios prejuicios: a la evidente diversidad de las músicas de Oceanía se opone una monolítica cultura musical "africana", que no incluye a las culturas denominadas "pigmeas" (denominación racializada europea) ni tampoco a todo el área del magreb (racializada como "blanca") que es casi la mitad del continente africano. Esto reproduce el estereotipo de una música africana "negra", lo cual es coherente con el grado de segregación musical que Lomax contribuyó a crear en torno a la música "negra" del sur de Estados Unidos (Miller, 2010). Además, en la clasificación estilística, la única cultura musical que se descompone en dos momentos es decir en términos históricos, es casualmente la europea. Aunque los repertorios de Lomax son folklóricos, la historicidad exclusiva de Europa coincide con el prejuicio que encontramos en la base del paradigma de la musicología histórica y su repertorio musical "culto".

Para ilustrar estas familias, Lomax presenta un gráfico de un mapa 


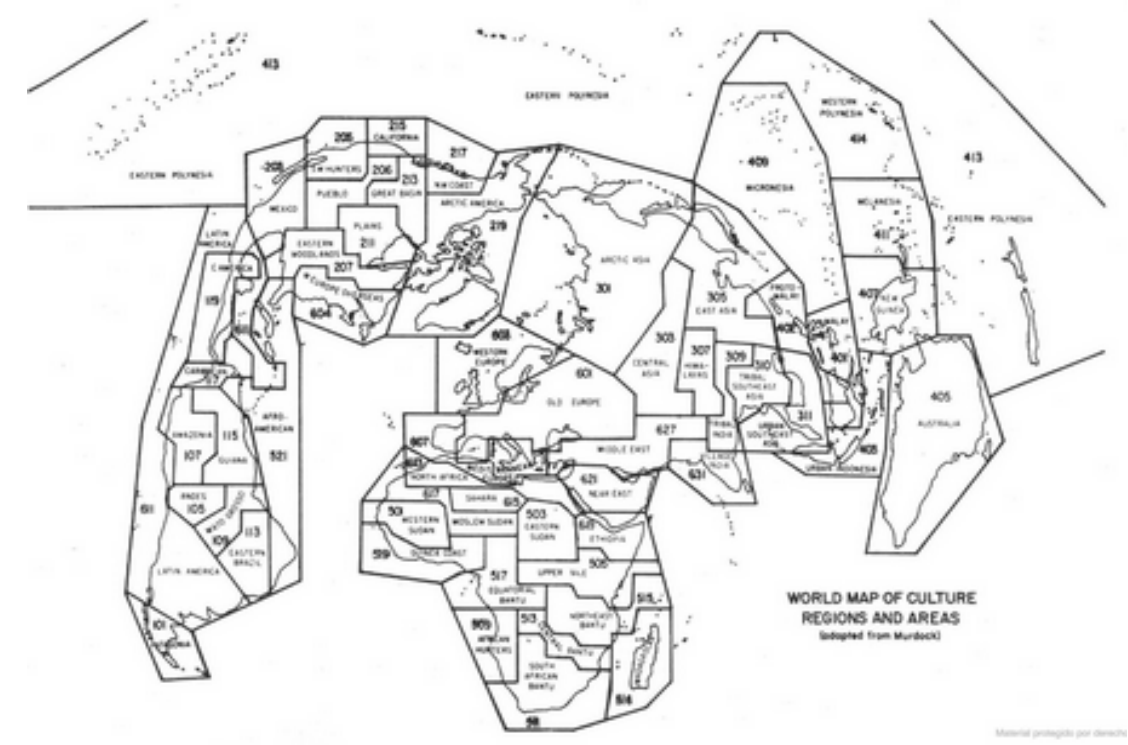

Mapa mundial de las regiones y áreas culturales (Lomax, 1968, p. 10)

También el sitio web donde se encuentra alojado el material clasificado y analizado por el método cantométrico de Lomax está organizado, justamente, como un gran mapa.

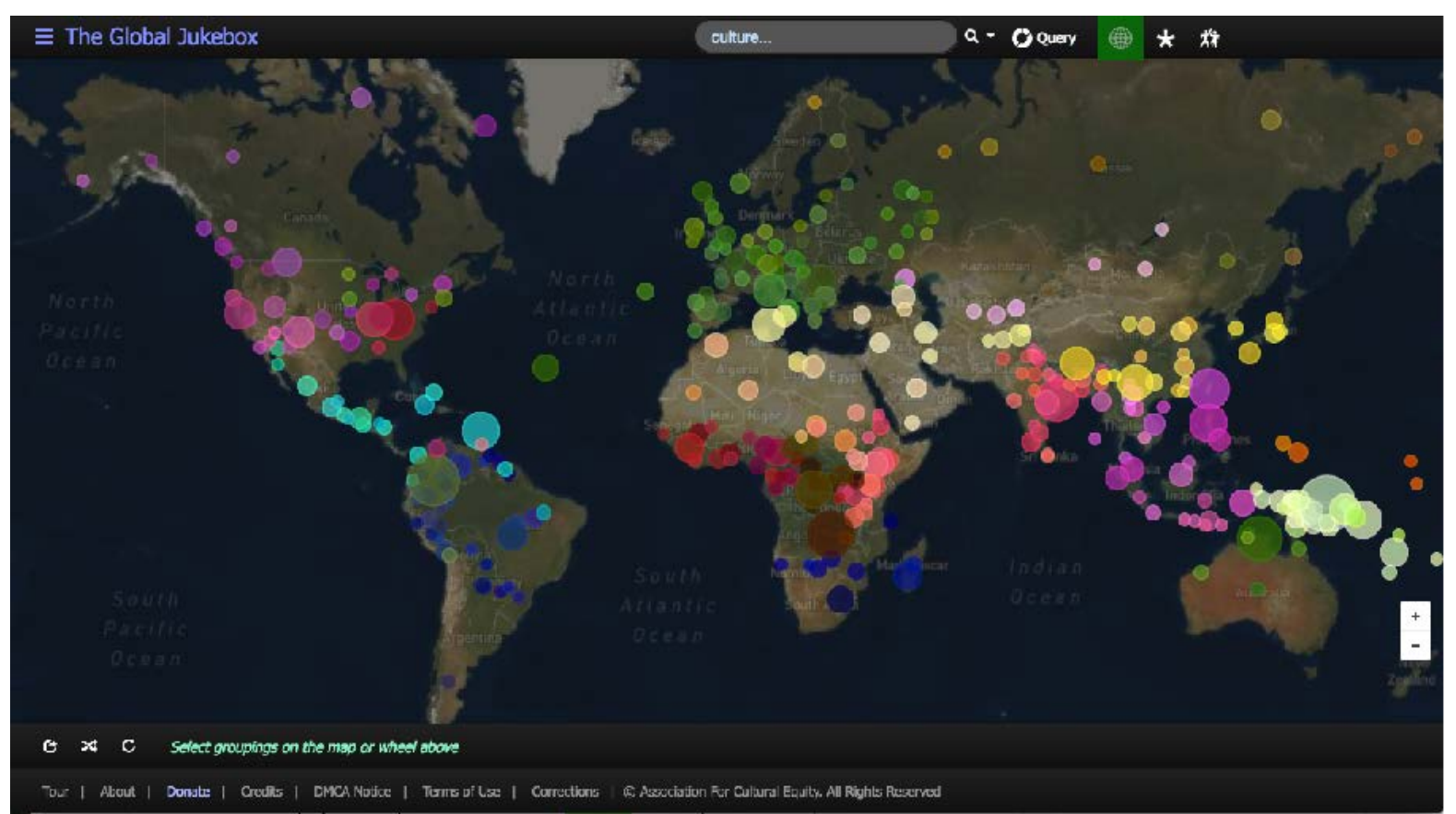

Captura web del sitio theglobaljukebox.org, que permite navegar el mapa musical del folklore organizado por Alan Lomax. 


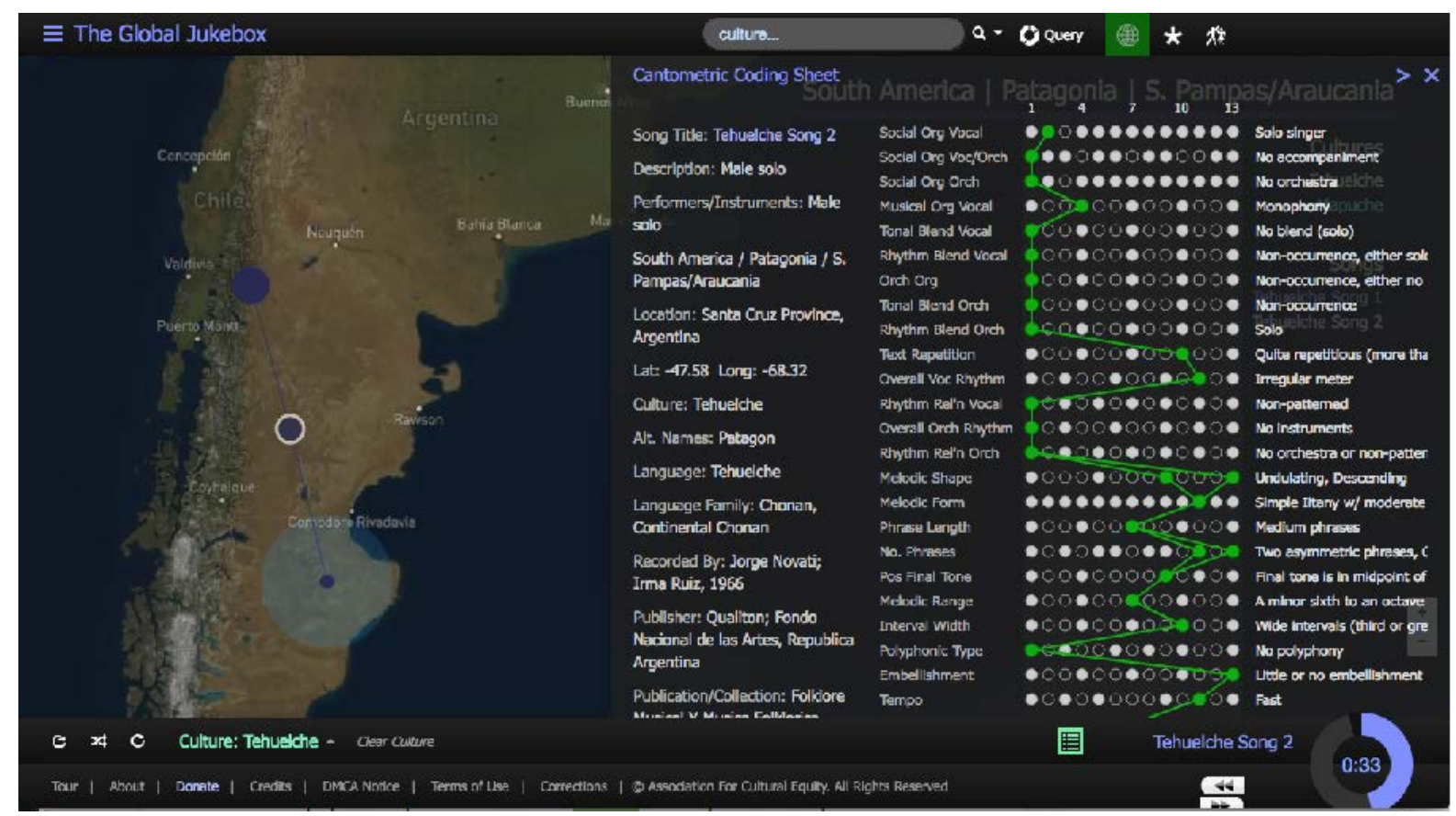

Captura web del sitio theglobaljukebox.org, mostrando el mapa correspondiente a la "canción tehuelche 2" y el gráfico de su análisis cantométrico. El registro de audio fue tomado por los musicólogos argentinos Irma Ruiz y Jorge Novati, con financiación del Fondo Nacional de las Artes, editado por el sello Qualiton como parte de seis LP que presentan un mapa musical de la música folklórica y el folklore musical argentino.

El sitio web que contiene el trabajo clasificatorio y analítico de Lomax se llama Global Jukebox, es decir la máquina de discos global, la "rocola", tal vez el artefacto que mejor simboliza la mercantilización de la música a través de la industria fonográfica. La música que sí es denominada por la academia "música popular", pero que, como vimos, los folkloristas despegaban del pueblo, cuando no la condenaban abiertamente. El mismo Lomax lamentaba los estragos que la radiofonía y la industria del disco causaban en las músicas tradicionales. Así que es muy probable que la denominación del sitio web tenga un dejo de ironía. Pero también Lomax utilizaba la denominación world collection [colección del mundo] (Cohen, 2003, p.123), world library [biblioteca del mundo] (Cohen, 2003, p. 179), world folk song style [estilo de la canción folklórica del mundo] (Lomax, 1956, p. 48) que además se organiza en un world song style map [mapa estilístico de la canción del mundo] (Lomax, 1968, p. 100). De ahí que Andrew Kaye y Matthew Barton describen la etapa en que Lomax sale a recorrer el mundo luego de sus primeros años en el sur estadounidense, como world-music [música del mundo] (Cohen, 2003, p. 99). Esto es cuanto menos llamativo porque, como sabemos, "músicas del mundo" o World music es una de las categorías más explícitamente comerciales del mercado musical que, justamente en la fase pretendidamente "poscolonial" del Occidente capitalista, a partir de la década de 1980, distribuye músicas etiquetadas como étnicas, tradicionales o "de raíz". Es decir, sonoridades clasificadas exactamente con los mismos términos del folklore,

las músicas del mundo constituyen una afirmación de los lugares. Implica la reterritorialización del repertorio [...] Los artistas se seleccionan del repertorio «nacional» de lugares específicos (Bulgaria, África occidental, América del Sur) y se les da una nueva presentación [...] Es evidente que las músicas del mundo no son músicas «del mundo», sino una limitada selección de sonidos de otros sitios del mundo. En algunos casos implican una redefinición de artistas nacionales como músicas del mundo en el mismo territorio nacional” (Negus, 2005, p.280)

Como objetos de mercado, recursos extraídos de ese mundo subalterno cartografiado, territorializado, las músicas del mundo son racializadas a partir de acentos, lenguas y 
sonidos que puedan ubicarse con seguridad, aunque su localización sea falsa. Los rasgos sonoros, algún componente de la instrumentación, ciertas palabras que se cantan, más que informarnos acerca de una práctica cultural específica, nos «transmiten una sensación de lugar geográfico» (Negus, 2005, p.281). La promoción de los músicos y sus discos es ilustrada mediante su localización y la racialización, como hemos visto que se hacía con los gauchos del bosque de Chazarreta. Keith Negus en su análisis utiliza como ejemplo el cantante maliense Salif Keita, el cual es "ambientado" en las carátulas de los LP mediante trajes típicos y montajes fotográficos en "paisajes naturales" que remiten a "prácticas ancestrales". Toda una puesta en escena para una música que combina textos en malí sobre una base pop de sintetizadores, bajo y batería para nada local, condimentada por algunos instrumentos de percusión de la región. Citando a Rick Glanville y Paul Gilroy, Negus interpreta estas estrategias de la industria como una continuación del predominio de las ideas románticas acerca de la inocencia precapitalista, es decir lo comunal y espontáneo de la música tradicional, que a su vez se traduce en una reminiscencia de los esquemas comerciales coloniales en los cuáles la música de África, América Latina o Asia se explotan como materias primas. Todo lo cual depende de una lógica de la autenticidad, una idealización de las músicas de "otros lugares". Es decir, un exotismo (Negus, 2005, p. 283) Es muy interesante que la etiqueta world music naciera por consenso entre ejecutivos de varios sellos discográficos en una reunión en Londres. Veremos a continuación que Inglaterra es históricamente cuna de una forma consensual y ahistórica de definición de las músicas exóticas.

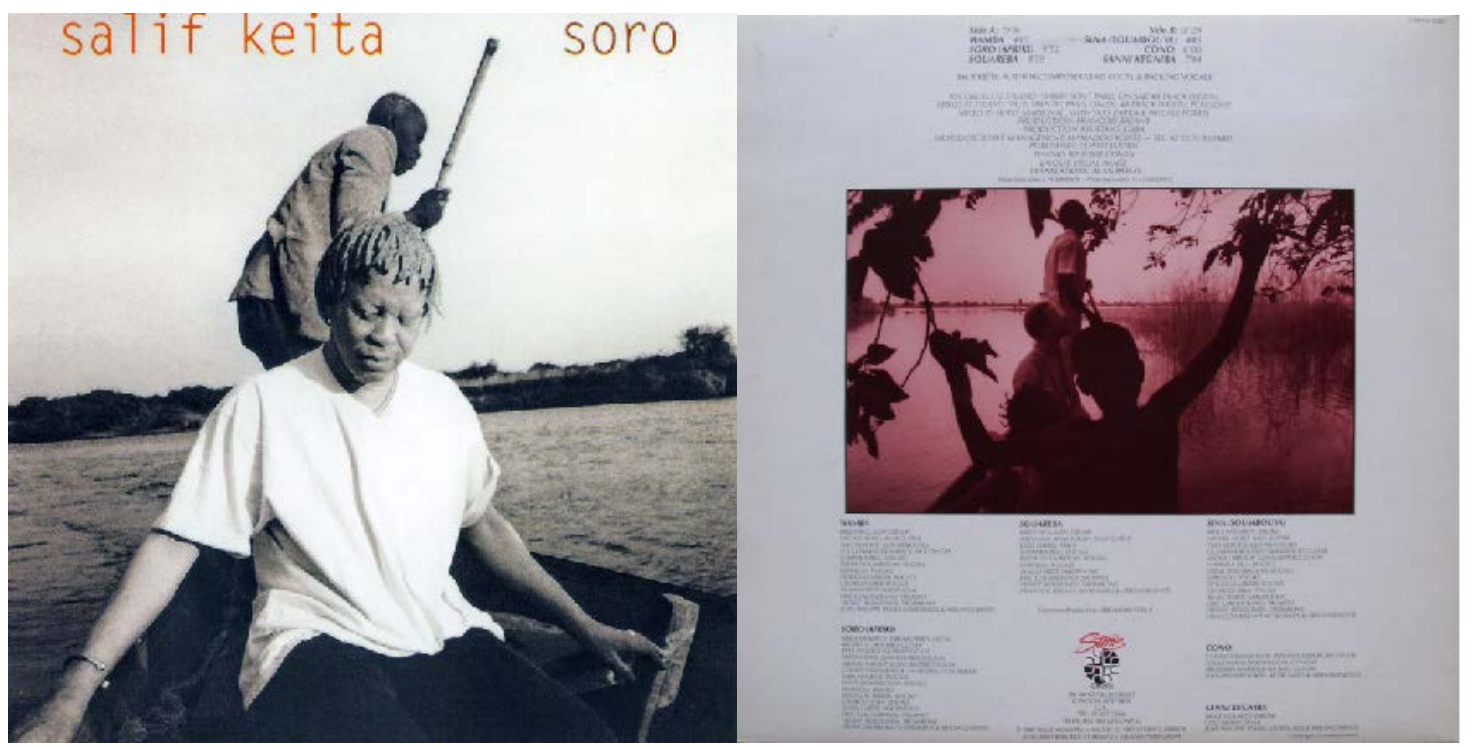




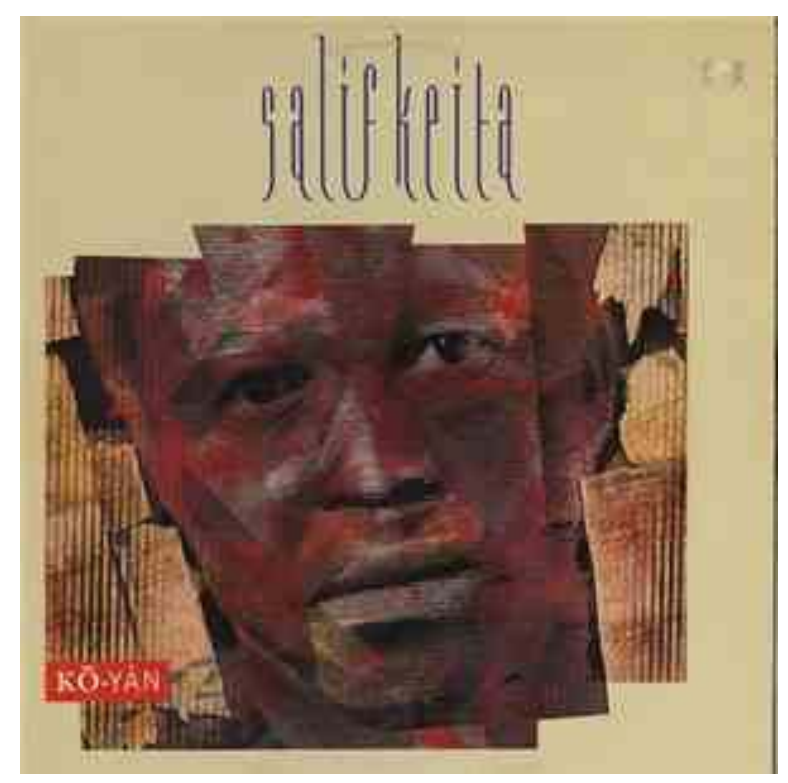

Carátulas de Discos LP del artista maliense Salif Keita

Antes nos referimos a como el Folk Music Council pasó a llamarse Traditional Music Council, una vez que el término Folklore comenzó a considerarse de forma crítica. Ese momento antecede por muy poco al despegue de la World Music (entre mediados y finales de la década de 1980), por lo cual es posible pensar que existe cierta relación entre ambos asuntos, el académico y el comercial, que reorientan sus términos y objetivos. Por esa época, en 1984, aparece en Inglaterra una revista musical de proyección internacional a la que se considera estar especializada en World Music (Myers y Wilton, 2008, p. 1010). Es una publicación principalmente dirigida a melómanos y consumidores de música, que complementa los artículos y críticas con ediciones musicales en CD y DVD. Se llamaba Folk Roots (Raíces Folklóricas), pero al poco tiempo abrevió su nombre, ocultando la primera palabra, constatando que para fines de siglo era un término poco conveniente y cuanto menos demodé. La publicación se llama hoy fRoots, y si bien eliminó al "folklore" de la portada y lo reemplazó por una modesta "f" en minúscula e itálica, que casi está cayéndose, los problemas en torno a la racialización y la invención selectiva de las tradiciones persisten e incluso, como en la world music de las discográficas, se acentúan. En su presentación puede leerse que su especialidad es «la música moderna y tradicional con raíces de todas partes del globo».185 Un poco más abajo aparece la explicación de a qué se refieren con "raíces". Luego de contabilizar algunos de sus principales premios y distinciones, argumenta que "fRoots posee este excepcional estatus en función de que se ocupa de una mezcla única que va desde el Anglo-trad ${ }^{186}$ al Pop de Zanzíbar, de las últimas fusiones a lo más étnico».187 Toda una declaración de principios y una confesión que quizás los folkloristas académicos no se hubieran permitido, pero que evidencia el vínculo entre industria y folklore y el rol que la etnologización racializada, heredera del nacionalismo, aún conserva. Para reforzar esta manifiesta dependencia histórica entre la disciplina folklórica y el mercado musical, los editores de fRoots señalan con orgullo que «durante cuarenta años

185 «covering modern and traditional music with roots from around the globe» (fRoots, 2019) [Traducción del autor]

186 Anglo-trad o Anglo-irish son nomenclaturas de la industria fonográfica y del espectáculo para referirse a lo que con anterioridad se denominaba folklore celta o irlandés por los folkloristas.

187 «fRoots has its exceptional status because it deals with this unique mix, from Anglo-trad to Zanzibar pop, from the latest fusions to the very ethnic» (fRoots, 2019) [Traducción del autor] 
hemos estado siempre en la primera línea de la escena musical "folk", "de raíz" y "world music"»188 (fRoots, 2019).

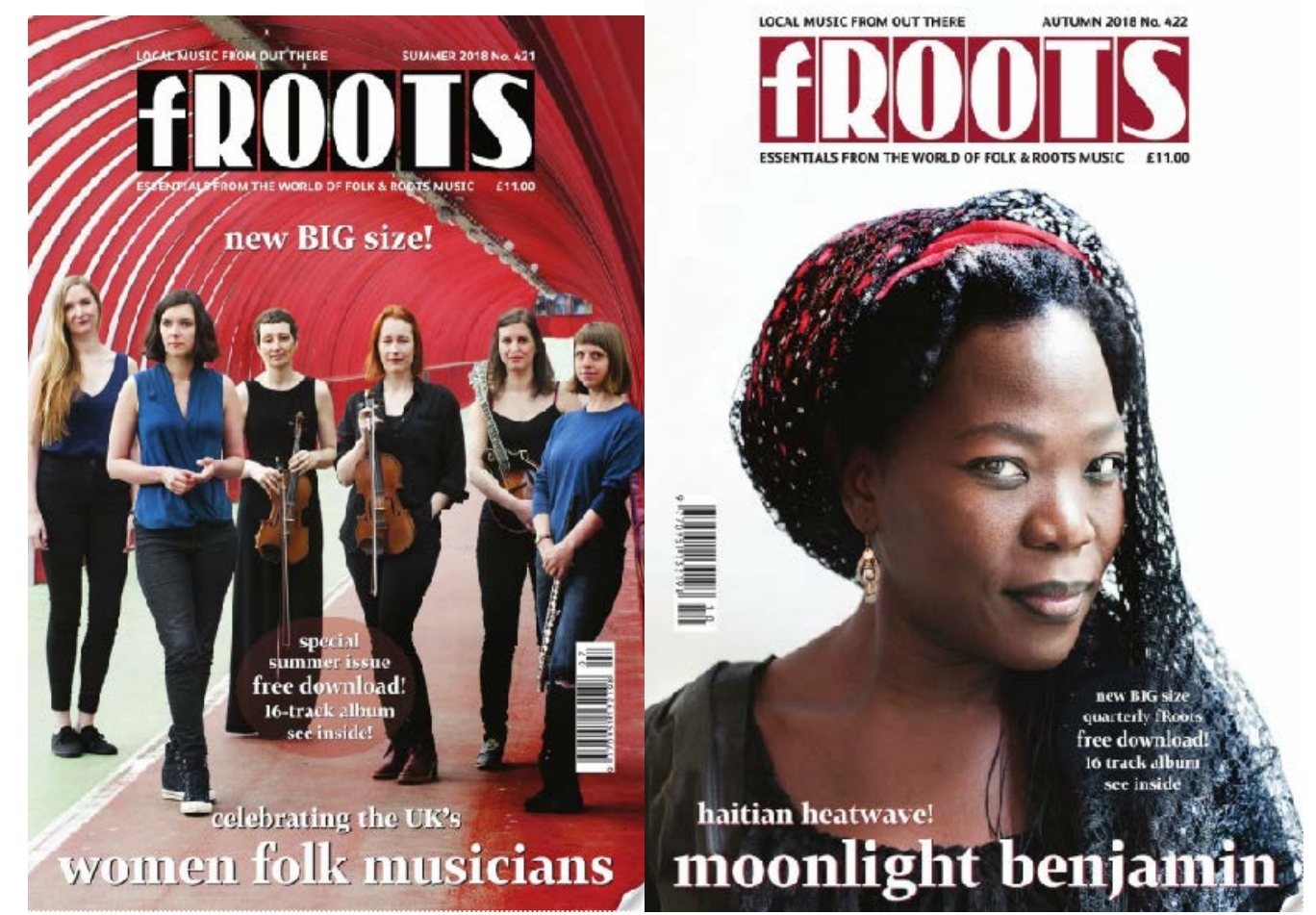

Las dos portadas de la revista fRoots del año 2018, mostrando respectivamente un conjunto folklórico británico y una artista de "música étnica" de Haití. El Folklore y la World Music representan la continuidad de un modelo basado en la etnologización

Antes que la World Music es el folklore, de la cual es al menos su antecedente si no su disciplina marco, quien realiza las categorías, las clasificaciones, las colecciones y repertorios necesarios para el ingreso de la música popular -traficada como tradicional- en el mercado de los objetos. Lo hace en convergencia consciente con la industria del espectáculo, la fonografía y sobre todo la industria editorial de la música, que acompaña todo el desarrollo de la modernidad desde fines del siglo XVI, erigiendo un mercado específico y nichos socialmente dirigidos. Tal vez sea más sutil que la World Music, o pertenezca a la etapa en que la afirmatividad exigía un ocultamiento mayor del procedimiento. La comodificación, es decir la transformación del musicar popular en objeto etnologizado y valor de cambio, opera a partir de transfigurar lo común en exótico, y funcionalizarlo, localizarlo, produciendo lo típico. Es una tipicidad que, sin embargo, posee un doble pathos: por un lado, persisten el miedo, la decepción y el asco que acumula secuencialmente Martín-Barbero en su comentario ya citado (1991, p. 31). Es decir, el pathos de la distancia se reproduce, pero con la particularidad moderna de transformarse en vocación de control del mundo popular subalterno. Ya no es el simple rechazo estigmatizante del trobar clus medieval. Pero al mismo tiempo, la propia exotización mercantilista revela una fascinación de parte de los sectores hegemónicos por el pueblo.

La apropiación musical canta una doble línea mediante una única voz. Es una melodía de admiración, incluso de respetuoso homenaje; una fuente de conexión, creatividad e innovación fundamental. Esto lo ubicamos en el discurso sobre "las raíces" que reproducen y expanden "la tradición". Pero sin embargo esta voz está armonizada por una contramelodía de poder, incluso de control y dominación; una fuente fundamental para mantener las asimetrías que

188 «We have been at the sharp end of the folk/roots/world music scene for 40 years» (fRoots, 2019) [Traducción del autor] 
rodean la propiedad y comodificación de la obra musical. A esto lo ubicamos en un discurso de la estafa y reproducción de la hegemonía189 (Feld, 1994, p. 238).

El folklore, en tanto ciencia de los objetos localizados a partir de la producción del espacio, de su cartografía en el marco de la modernidad/colonialidad, puede comprenderse entonces como esa estructura de sentimiento que, sin poder capturar lo popular en suspensión, intenta comprimirlo en sus categorías racionales y racializadas para ponerlo a la venta.

\subsection{Del Típico exótico al objeto etnológico como estilo}

El vector racializado del folklore tiene una doble función: por un lado contribuye a particularizar a ciertos sectores sociales y a endilgarles, luego de homogeneizarlos, un estatus específico basado en rasgos raciales. Por lo tanto, con puntos de partida muy diferentes y construyendo valores específicos, la raza, el vector etnológico, funciona con el mismo grado de reducción ahistórica que presenta la musicología histórica en su periodización. Podríamos decir que la raza es al folklore lo que el estilo a la historia de la música afirmativa. Así, comprender que las manifestaciones folklóricas son supervivencias en el presente del pasado no solo estigmatiza a los sectores populares en términos de atraso o barbarie, sino que reafirma la modernidad histórica de la burguesía, al mismo tiempo que oculta las relaciones de explotación que producen el subdesarrollo. El "método comparativo" etnológico de la antropología de raíz darwinista de Tylor es un buen ejemplo de esto, en la medida en que constituye una extensión del evolucionismo biologicista al terreno de la cultura. De lo que se trataba era de reconstruir la historia de la "cultura civilizada", es decir la del mundo occidental desarrollado, comparándola con las de otras culturas que, si bien eran contemporáneas, se entendía que suponían etapas anteriores del desarrollo cultural evolutivo. Tylor sostenía que las variaciones en términos de civilización entre europeos y africanos podía deducirse del estudio de las características morfológicas del cerebro de unos y otros, lo cual era a su vez abstraído en términos de leyes universales de evolución biológica y cultural (Miller, 2010, p. 94). En los casos más extremos, como en los de cierto positivismo antropológico asociado a las realidades coloniales, este diferencial de civilización pretende expresar una disimilitud insalvable entre las sociedades, justamente porque se deduce de la raza, de aquello que no puede modificarse. Así, el primitivismo es una condición social que no puede evolucionar, es un vector evolutivo diferente al de la cultura europea "blanca", lo cual hará que se justifiquen las condiciones inhumanas de la vida colonial en función de considerarla una forma vital constitutivamente diferente a la europea: "ellos" viven así, son "sus costumbres". A partir de aquí se abre toda una compleja búsqueda de una ciencia que valide la diferencia y en donde el papel central se deduce de variantes morfológicas que se agrupan arbitrariamente en el valor "raza". Lo cual produce conclusiones como la siguiente:

[EI] primitivismo no es sólo una manera resultante de una educación especial, tiene cimientos mucho más profundos y hasta pensamos que pueda tener su sustrato en una disposición particular de la arquitectónica, al menos de la jerarquización dinámica de los centros nerviosos (Porot, como se citó en Fanon, 1963, p. 245)

\footnotetext{
189 «Musical appropriation sings a double line with one voice. It is a melody of admiration, even homage and respect; a fundamental source of connectedness, creativity, and innovation. This we locate in a discourse of 'roots', of reproducing and expanding 'the tradition.' Yet this voice is harmonized by a counter-melody of power, even control and domination; a fundamental source of maintaining asymmetries in ownership and commodification of musical works. This we locate in a discourse of 'rip-offs,' of reproducing 'the hegemonic'» (Feld, 1994, p. 238) [Traducción del autor]
} 
Esta es una descripción que Franz Fanon toma de un estudio de la década de 1940 (es la época de Vega y de la musicología histórica positivista) que los científicos franceses realizan para justificar la inferioridad de los norafricanos, en particular de los argelinos: «para el profesor Porot, la vida del indígena norafricano está dominada por las instancias diencefálicas. Esto equivale a decir que el indígena norafricano está, en cierto sentido, privado de corteza cerebral» (Fanon, 1963, p. 245). Todas las tendencias irracionales del colonizado [el positivismo siempre nombra así, en masculino singular], su pulsión criminal, su incapacidad para el lucro y el emprendedurismo, sus modos de vida bárbaros «que no quiere modificar», se explican porque no tiene un verdadero cerebro sino un aparato nervioso más parecido al de los vertebrados inferiores. "La reticencia del colonizador para confiar una responsabilidad al indígena no es racismo ni paternalismo, sino simplemente una apreciación científica de las posibilidades biológicamente limitadas del colonizado» (Fanon, 1963, p.245).

La circularidad de este tipo de pensamientos desnuda su carácter apriorístico, ya que lo biológico es garantía de lo cultural al mismo tiempo que las diferencias en lo cultural son tomadas como argumento e indicador que discretiza la diversidad continua en lo biológico que impide pensar la categoría de raza. Justamente una de las variantes del folklore que exhibirá una mayor intensidad positivista será la musicología comparada, cuyo auge se da entre 1885 y la posguerra, hasta que las críticas de Merriam y Blacking, entre otros, al etnocentrismo manifiesto de la "comparación" hagan que cambie de nombre y se transforme en la etnomusicología. Analizando las primeras definiciones de la musicología comparada por Guido Adler o las últimas como las de Glen Haydon, se advierte que es una disciplina creada para estudiar la música de los "otros", los que no pertenecen a la cultura moderna europea, de cuya música ya se ocupaba la musicología histórica. Decir los otros en el paso del siglo XIX al XX significaba referirse al conjunto de culturas y sociedades sometidos por el imperialismo europeo, en una escala global. Eran otros-inferiores, otros-primitivos, otros, fundamentalmente, exóticos. Los cuales se homologaron con ese otro-interior que era el pueblo. Es decir, la musicología comparada tenía como objeto de estudio las músicas «no europeas y del pueblo» (Merriam, 2001[1977] p. 63). Prácticamente una confesión de la posición de clase y el etnocentrismo subyacente a la perspectiva de las dos musicologías. De ahí que para representar una cultura en términos homogéneos y unificados sea la Etnicidad «el término que damos a los rasgos culturales -lenguaje, religión, costumbre, tradición, sentimiento "de lugar"- que son compartidos por un pueblo» (Hall, 2010, p.385).

Por lo tanto si consideramos que desde la perspectiva de la musicología (comparada o histórica) las músicas de otras culturas eran caracterizadas como "inhabituales" y "exóticas" (Hornbostel, 2001[1905], p. 43), es fácil comprender que se tenía en idéntico concepto a la música de los sectores subalternos existentes en el mismo terruño del investigador. Peter Burke (2014) repara en el hecho de que ya no se buscan las ruinas o los restos arqueológicos sino las costumbres de la gente "simple". De ahí que, como señala este autor, los investigadores pudiesen ubicar al pueblo en términos temporales -es decir en algún tipo de pasado- y adjudicarle valores, como la simpleza, la honestidad o la inocencia, que, ya vimos, era patrimonio de los "gauchos del bosque». Esto se hacía justamente a partir del método comparativo, mediante el cual podían establecerse relaciones firmes de semejanza entre los morlacos de los Balcanes y los khoikhoi africanos, ubicándolos en una "etapa" similar en términos de "evolución" o "civilización". Todo lo cual, necesariamente, se triangulaba con la posición de referencia que significaba la cultura europea, máximo índice de evolución.

Samuel Johnson y James Boswell recorrieron las islas occidentales de Escocia "para especular" en palabras de Johnson, "sobre los vestigios de la vida pastoril", para buscar las "costumbres primitivas", para entrar en las cabañas de los pastores, escuchar las gaitas, encontrar a personas que no hablen inglés y que todavía usen los tradicionales vestidos 
escoceses. En Auchnasheal, Boswell indica al doctor Johnson que "era exactamente encontrarse en una tribu de indios", ya que sus pobladores "tenían una apariencia tan negra y salvaje como la que mostraban los indígenas americanos" (Burke, 2014, p.42)

Al igual que la musicología histórica, el folklore construirá objetos. Pero en este caso serán objetos exotizados, objetos etnológicos. Su particularidad, cuestión que adquirirá la máxima importancia en su circulación en el mercado, radica justamente en esa diferencia comparativa que, como sabemos, constituye el tronco de la etnología y aquello que la aleja de la historia (Lévi-Strauss, 1987, p. 51). Lo étnico constituye aquello que permite considerar a una cultura como homogénea y particular, cuyo conjunto de rasgos se asume en contraste con otras culturas, fundamentalmente y en desventaja permanente con la cultura europea occidental, establecida como modelo perfecto (Paraskevaídis, 1999, p. 2). Esto es lo que, en referencia con la historiografía musical hispanoamericana de la cual sería un componente específico, Juliana Pérez González (2010) denomina el cotejo entre lo europeo y lo americano, basado evidentemente en el rejuego de Alejo Carpentier (2004) al que ya nos referimos, ese «permanente cotejo entre lo propio y lo ajeno». Este es un elemento estructural de toda escucha etnologizada y por eso no sorprende que la etnomusicología derive, como disciplina, de la "musicología comparada" cuyo esplendor ocurre, justamente, en el primer tercio del siglo XX.

Ahora bien, si volvemos a la definición germinal de estilo que, recordemos, acuña Wölfflin (2007 [1915]), éste se ofrece como atravesado por múltiples dimensiones, ya que «junto al estilo personal aparece el de escuela, país y raza» (p. 29) que luego resume en "estilo de individuos, épocas y pueblos» (p. 33). La ligazón entre pueblo y raza queda entonces comprendida en el concepto de estilo que, como vimos en referencia a la musicología, consagra el índice de especificidad del objeto musical y garantiza su ingreso en el cambio, en el mundo mercantil moderno de la burguesía. Al considerar la convergencia entre musicología y folklore -y al encontrar a ambas disciplinas como facetas de la modernidad burguesa, productora de objetos de mercado como la "obra musical" o "la especie folklórica"- se comprende que lo que para el primer caso es el estilo, en el segundo lo representa la raza. Y de ahí que para que funcione el artificio del folklore, tanto en el proyecto político como en el mercado del espectáculo, deba ocurrir un extrañamiento, una exotización ${ }^{190}$ que, referida a los sectores populares, se transforma en una «exotización de lo propio» (Garramuño, 2007, p. 81).

Repasemos, aunque parezca obvio, que lo exótico implica la procedencia desde una geografía localizada como lejana, de la que emerge una cultura que se percibe extraña y desconocida. Generar de lo local un "exótico", podríamos decir "hacia adentro", implica una importante construcción de sentido que parte de la asunción de una posición universalista, es decir, eurocéntrica. $Y$ esto es precisamente lo que caracteriza a las élites latinoamericanas vinculadas con el nacionalismo y el modernismo de principios del siglo XX, herederas de las prácticas culturales de sus antecesores que se habían reflejado en el espejo idealizado de la ópera «el ámbito donde las sociedades latinoamericanas del siglo

190 Es muy curioso a propósito de las formas clasificatorias del folklore y sobre todo en relación con el positivismo de Carlos Vega, que la entrada "exótico" de la Wikipedia refiere a la terminología utilizada por la Unión Internacional para la Conservación de la Naturaleza, que distingue «especie, subespecie o taxón inferior, de flora o fauna que existe fuera de su área de distribución natural», es decir cuando cualquiera de esas tipologías no puede existir «sin introducción directa o cuidado por parte del hombre», de lo cual surge una nomenclatura que clasifica entre especies foráneas, introducidas, no nativas o naturalizadas. Esto es casi una cita de la metodología y la terminología que aplica Vega, a partir del modelo difusionista que representa la estructura principal de su perspectiva. Los términos "especie", "inferior", "área de distribución" son de lo más recurrentes en sus textos y de fuerte raíz positivista, específicamente de diferentes versiones de darwinismo social que hereda de su adopción de autores como Tylor, Spencer y sobre todo Gabriel Tarde (Ruiz, 2015, p. 18; Reynoso, 2006, p. 102). En función de esta visión naturalista de la cultura, no es ninguna sorpresa que el mencionado artículo de Wikipedia continúe así: «El término es utilizado con igual sentido en la cultura humana, cuando hablamos de música exótica» Véase: https://es.wikipedia.org/wiki/Exótico 
XIX quisieron retratarse y en el que se cifraron las aspiraciones civilizadoras de las jóvenes naciones del continente» (Miranda, 2011, p. 71). Justamente en el ámbito decimonónico de la escena operística latinoamericana, que dará lugar a la construcción de esos monumentos musicales de la modernidad y la civilización que son los teatros líricos, ${ }^{191}$ pueden rastrearse los primeros atisbos de esta estética de la exotización en el curioso movimiento llamado nativismo. Como intento de resolver el problema pendiente de la identidad, aparecen hacia la década del 1860 los discursos nativistas y su programa cultural y artístico, el indianismo, cada uno de los cuales «intentó desarrollar un sentido de pertenencia basado en el territorio compartido, un discurso en el que la noción de identidad comenzó a construirse en relación al "otro" europeo» (Madrid, 2010, p. 227) Se abre así la discusión sobre cuáles deberán ser los sonidos de la Nación (Madrid, 2010 - Pujol, 2013). En el marco de producir ahora políticas tendientes a incluir en el proceso civilizatorio a sectores de la población antes ignorados, el indianismo traslada el fenómeno del exotismo, de amplia presencia en la Europa decimonónica, al ámbito de la propia geografía. De esta suerte se buscan, rescatan o directamente inventan temáticas, personajes o geografías de -dudosa- relación con poblaciones indígenas o comunidades afrodescendientes, manifestadas por medio de leyendas, historias o mitos. Esta "materia prima" local era luego utilizada para crear obras cuyo lenguaje musical continuaba siendo completamente europeo y, en el caso del teatro lírico, todavía en italiano. La asimetría de poder desde la cual se despliegan los proyectos nativistas les imprime un carácter neocolonial, ya que «tienden a despojar de su capital cultural a las comunidades social y étnicamente más marginadas, en aras del espejismo de un pacto hegemónico supuestamente incluyente» (Madrid, 2010, p. 228).

El máximo ejemplo musical de este movimiento lo constituye el compositor brasileño de ópera Antônio Carlos Gomes, figura central de la música latinoamericana del tercer cuarto del siglo XIX. Gomes es un compositor formado en Europa luego de dar sus primeros pasos en el propio país, pero que triunfa en el Viejo Mundo, y vuelve a Brasil de gira, en los términos de un artista de fama internacional. A tal punto es exitoso que el propio Verdi le dirige elogios y lo considera "un verdadero genio musical» (Miranda, 2011, p. 69) luego de presenciar el estreno de su obra más importante. Es ésta // Guarany, ópera ambientada en "la floresta" de Brasil y cuyo protagonista es Peri, hijo del jefe tribal guaraní enamorado de Cecilia, una muchacha portuguesa, hija de familia de conquistadores. El personaje principal está caracterizado con vincha de plumas, el torso desnudo y taparrabos. Y no es un problema que el tenor que lo encarne sea un poco rubio y tenga barba y bigote. Porque además Peri, como el resto del elenco, canta en italiano, y toda la obra está planteada de acuerdo con las convenciones del lenguaje musical del bel canto. No era para menos en una ópera estrenada en 1870 en el mítico teatro alla Scala de Milán.

\footnotetext{
191 Las élites latinoamericanas construyen presurosas los teatros de ópera, incluso cuando en los países está en discusión la configuración nacional y el orden constitucional: el Real Theatro de São João de Río de Janeiro en 1813, el Gran Teatro Nacional de México (DF) en 1844, el Teatro Caracas de 1854, el Teatro Solís de Montevideo en 1856, el Teatro Colón de Bogotá en 1885, el teatro Amazonas de Manaos en 1896. El primigenio Teatro Colón de Buenos Aires se inaugura en 1857, tan solo cinco años después de la batalla de caseros y cuatro después de la sanción de la constitución nacional. Aunque diez años antes de la batalla del Pozo de Vargas.
} 


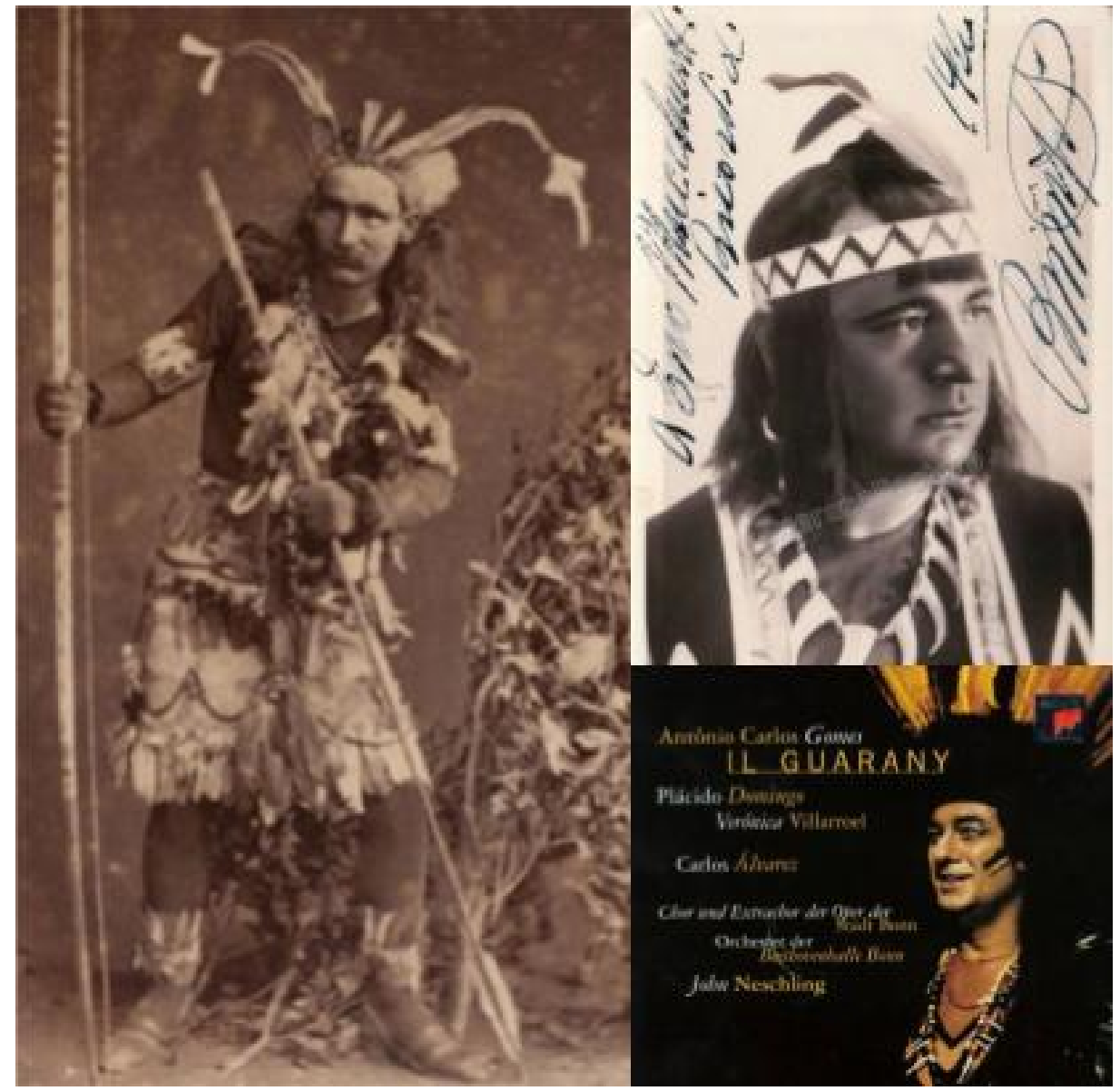

Tres modelos del guaraní de Carlos Gomes. A la izquierda, el tenor Ludovico Giraud como Peri en 1880; arriba a la derecha, el también italiano Beniamino Gigli, en una puesta de 1930; y debajo el español Plácido Domingo en el mismo papel en 1994.

Del mismo modo que los incas y turcos de Rameau cantaban en francés o los egipcios y suecos de Verdi lo hacían en italiano, lo que propone Gomes no es más que nutrir al repertorio internacional de la música culta con el colorido exótico de lo brasileño. Pareciera -pero sólo eso- que de casualidad se trata de su propio país. Está claro entonces que el Peri de Gomes no es el indio vivo, de carne y hueso que negocia su identidad y se resiste como puede dentro de la crueldad del imperio brasileño. En consonancia con lo que ya postulaba el folklore en Europa que hacia fines del siglo XIX arribará a Latinoamérica en medio de una nueva importación de concepciones culturales, el guaraní es una figura distante, mitológica, que solo pervive en la memoria del pueblo anónimo. Como vimos con el caso de los gauchos, es un pasado ya derrotado por el cambio y el orden de la civilización occidental. Los indios y mestizos de la calle, que nunca se enterarán siquiera de que existen óperas en italiano, son despreciados, perseguidos y marginados. Sometidos a un segundo movimiento de conquista, esta vez en el marco de la importación del modelo colonial anglosajón implantado en EEUU, 192 los indígenas de Brasil, de Argentina, de Chile serán expulsados de sus territorios, reducidos y también exterminados. Si se los conserva vivos, como en el caso de México o Perú, se deberán acomodar al orden civilizatorio,

192 La militancia de Sarmiento en este aspecto es indudable: «¿en qué se distingue la colonización del Norte de América? En que los anglosajones no admitieron a las razas indígenas ni como socios ni como siervos en su constitución social. ¿En qué se distingue la colonización española? En que hizo un monopolio de su propia raza, que no salía de la Edad Media al trasladarse a América, y que absorbió en su sangre una raza prehistórica y servil» (Sarmiento, 1915, p. 449). 
relegando su cultura como prenda de un origen mítico - de la Nación- y renunciando a toda reivindicación que discuta el presente.

Ahora bien, no sólo es exótico -aún para los brasileños- el tema y los personajes de II Guarany de Gomes. El mismo compositor, aún laureado en Europa y felicitado por Verdi, será calificado de manera racial, siendo "aborigen americano", "negro", o "salvaje" (Zárate Toscano y Gruzinski, 2008, p. 831) para sus "fans" del Viejo Mundo y para un sector de la propia élite "carioca". Pero esto, lejos de ser meramente denigrante para Gomes, es un indicador para transformar ese exotismo en mercancía. Para el compositor «música é comércio» (Zárate Toscano y Gruzinski, 2008, p. 845), lo que nos recuerda la frase de Attali «el artista nace cuando su obra es puesta a la venta» (2011, p. 73). En este caso, como en el caso de las músicas latinoamericanas que se subirán a la escena internacional en el cambio del siglo XIX al XX, ese poner a la venta implicaba exotizar lo propio. Pero a su vez, y esto es particularmente importante porque ocurre en la inscripción de las músicas en el cambio, los rasgos que hacen posible la exotización aparecen como objetos, no como experiencias compartidas, ya que quien exotiza está en realidad mirando a un inferior, señalando una otredad (Garramuño, 2007, p. 80). Por lo tanto, es en el objeto etnologizado que reside la transformación de lo local en bien de cambio compatible con la internacionalización que la cultura moderna imprime entre fines del XIX y principios del XX. Es una conversión en la cual se cambia el signo de la racialización, a instancias de poder poner el objeto etnológico a la venta. $Y$ esta posibilidad reside justamente en la valoración negativa, estigmatizante, denigrante que se hace del otro, al que se comodifica precisamente por primitivo, inferior, bárbaro. No hay que considerar aquí ningún tipo de valoración positiva en términos de igualdad o equidad, pues es la negatividad de la consideración de lo primitivo lo que fascina y permite la elaboración del exótico local. La consideración negativa se complementa con una «hipótesis productiva» (Garramuño, 2007, p. 79) mediante la cual, aquello que se abomina y rechaza es también lo que documenta con claridad incontestable e irresistible la visión típica de las regiones periféricas, que convergen como contenido de la música.

El exótico-local se transforma así, mediante su puesta a la venta, en lo que Garramuño denomina el «típico-exótico», lo cual no supone otra cosa que el traslado del exotismo presente en todo el arte y la cultura de la modernidad burguesa de Europa a las élites y empresarios del espectáculo, compositores y artistas de renombre de América Latina, que recurrirán a sus propios territorios y transformarán el atraso y la barbarie, las cosas en objetos, cartografía en función de la cual se erigirá también la cultura nacional. Garramuño no habla específicamente de la música nativa de Chazarreta, aunque aborda la literatura de Güiraldes y la conversión exótica del gaucho como típico. Pero sí señala que otras músicas presentes en la época, el Tango y el Samba, «ejercen una fascinación particular, que oscila entre un rechazo y una especial atracción. O mejor: que en su rechazo exhibe el hechizo que ejerce aquello que busca reprimirse o prohibirse» (Garramuño, 2007, p. 80)

Si observamos las fotografías de las orquestas de tango que se embarcan en la empresa que describe la autora, es decir la exportación del tango a Europa y especialmente a París, en la década del 1920, encontramos que tanto los atuendos de los músicos como sus instrumentos nos recuerdan a la conformación del conjunto nativo de Chazarreta y al vestuario de sus bailarines que suben a la escena exotizada del escenario del Politeama, también recordemos, en 1921. Los géneros musicales son evidentemente diferentes y además las orquestas de tango de exportación abandonan el formato instrumental característico de la "Guardia Vieja", más parecido en sonoridad al conjunto nativo chazarretiano, en pos de la configuración de orquesta típica "a la" De Caro. Pero de todos modos, salvando estas distancias, la exotización que producen estos géneros "criollo" y "nativos" está impulsada por los mismos criterios. 


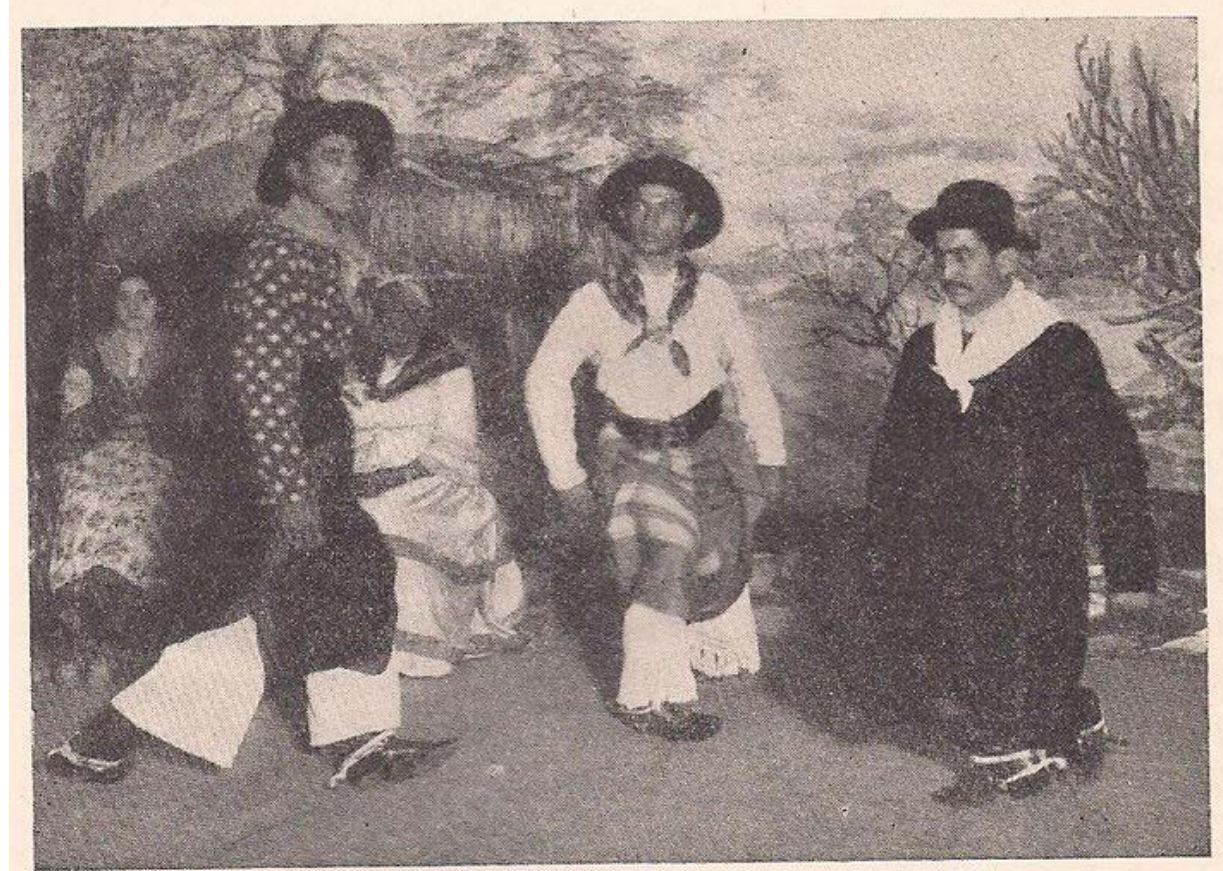

Zapateadores santiagueños, Nicolás Juárez, Pedro Giménez y Enrique Suárez, aก̃o 1921.

Los bailarines de la Orquesta Nativa de Chazarreta, en pose de zapateo y posando con su vestuario típico sobre el fondo pintado de la selva Santiagueña.

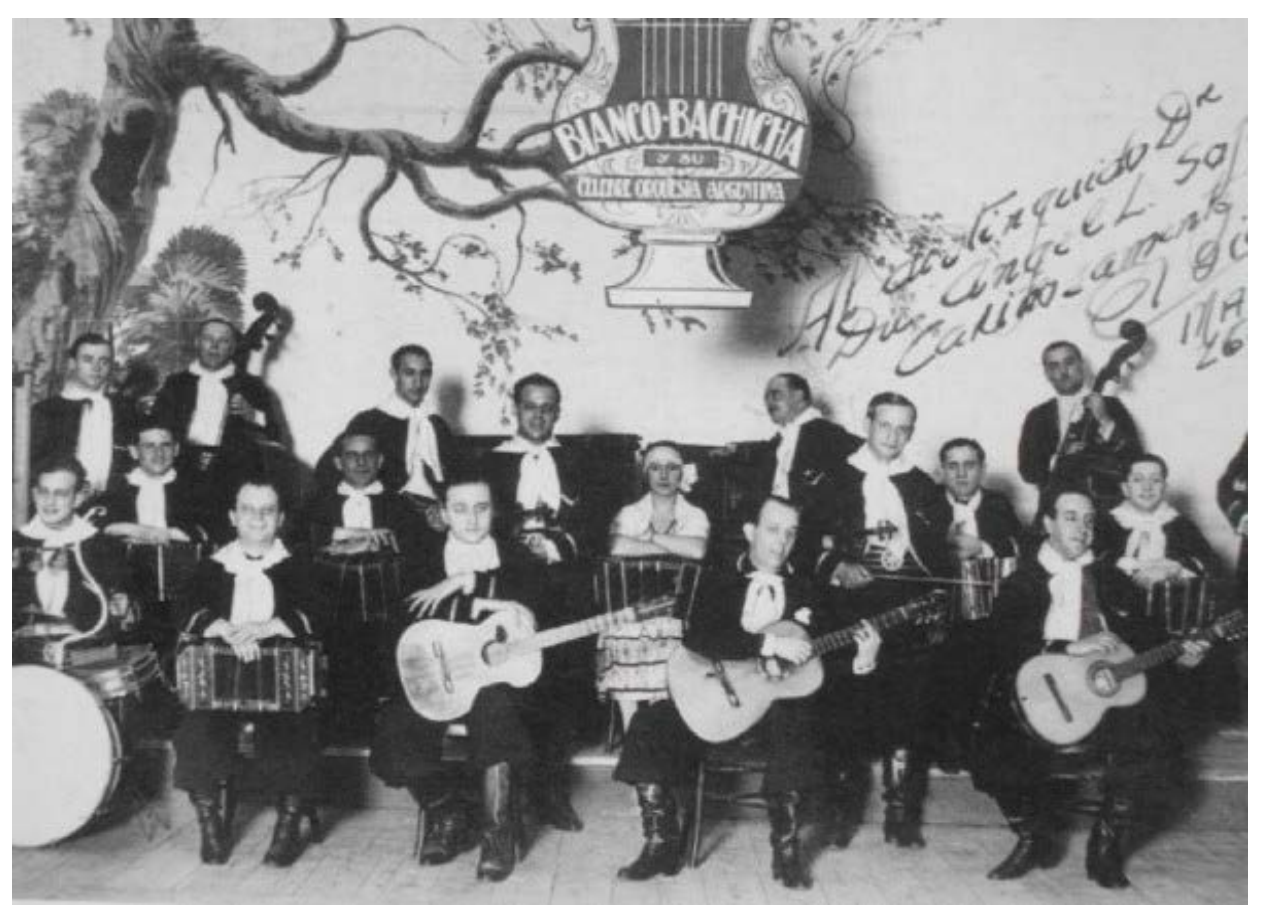

Orquesta de tango Bianco y Bachicha, en París en los años '20, también sobre un fondo escenográfico con árboles pintados y botas gauchas de media caña 


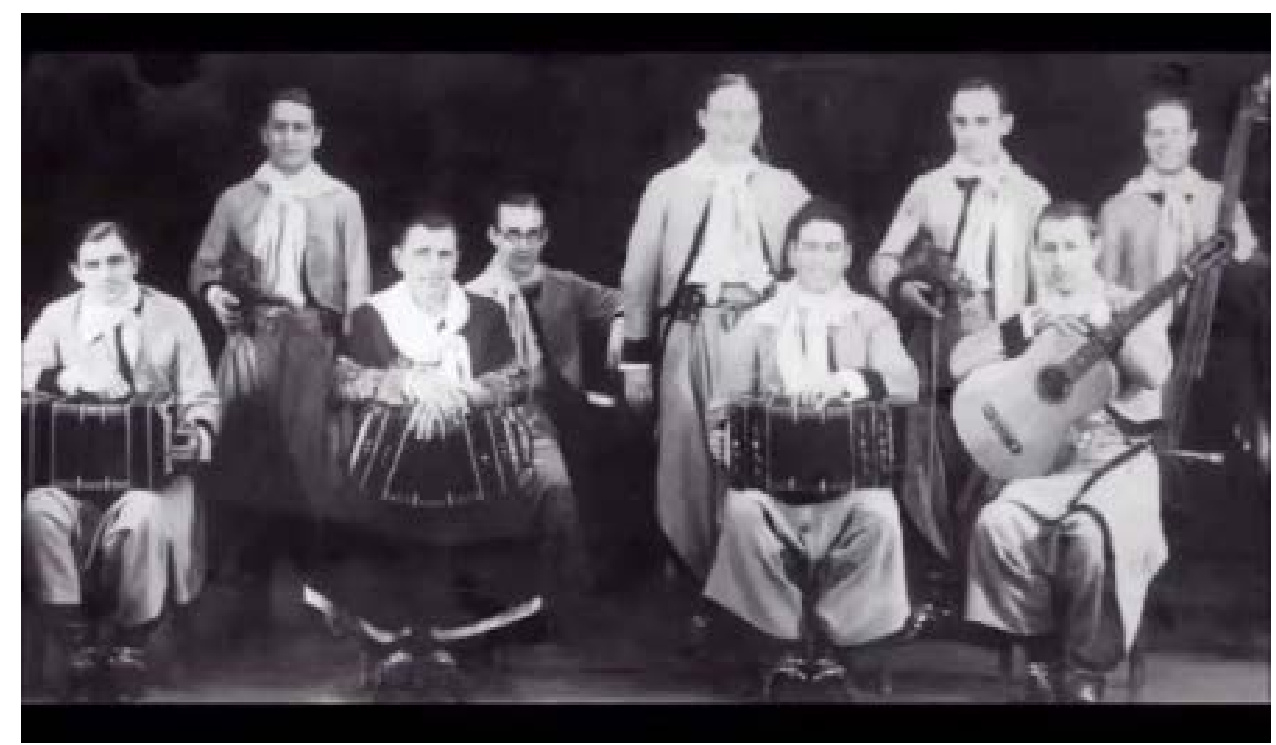

Orquesta de Tango de Manuel Pizarro, también en París en la década de 1920, con una configuración instrumental que recuerda en parte a la orquesta nativa de Chazarreta, además de la similitud de las vestimentas.

En el caso del Brasil, el samba dará un tratamiento muy distinto al mestizaje, transformando en sonido nacional la música basada en lo más pobre y lo más negro del vasto territorio del país, que confluye en las periferias de Río de Janeiro. El tango argentino presentará migraciones más recientes y presentes en el panorama porteño (Garramuño, 2007). Pero en todos estos casos lo marginado y oculto se vuelve prenda de orgullo, cultura nacional, producto de exportación, rasgo identitario indiscutible. $Y$ en base al impulso del modernismo, se inmiscuye también en los sectores progresistas y por último en las clases acomodadas. $Y$ de todos modos la tensión entre lo primitivo y lo moderno, como en el mestizaje -o porque esto es el mestizaje- nunca será resuelta ni podrá reducirse completamente en las categorías del folklore.

Este tipo de similitudes que forman parte del clima cultural y político en que emergen todas estas músicas, lleva a que Julius Reder Carlson relacione específicamente el accionar de Chazarreta con el movimiento estético-político del nativismo y las ideas de Garramuño en torno a la exotización de la Nación. Particularmente al modo en que «la música folklórica de Chazarreta puede ser vista como un intento de establecer un imaginario argentino moderno basado en formas culturales primitivas» (2013, p. 128). Pero más allá de este programa, que como hemos visto partía de los intentos de la intelligentsia modernista y de la restauración nacionalista del Centenario, el accionar de Chazarreta y su compañía es visto por este autor específicamente en relación con la industria discográfica y el sistema de radiodifusión, a lo que debiéramos agregar la industria del espectáculo escénico, todos responsables de la «popularización y reificación de su estilo particular de tradición argentina» (Reder Carlson, 2013, p. 128). Citando publicaciones de los periódicos de ese momento, del estilo que ya hemos referido en secciones anteriores, Reder Carlson testimonia una recepción del conjunto de Chazarreta que es característica de la exotización de lo primitivo en el mercado de la época.

Los veinte temas musicales ejecutados por la Compañía de Arte Nativo en sus actuaciones fueron tan genéricos como el paisaje escenográfico en el cual se realizaron. En la "Vidala," por ejemplo, la diva femenina del ensamble (Patrocinio Díaz y, posteriormente, Juanita Gilardi) cantó canciones melancólicas parecidas a las de una Zarzuela. En la "Pala Pala," mientras tanto, una vieja indígena (La "Vieja" Narcisa) bailó y cantó "de la persecución y la nostalgia de la raza espléndida que trabajó pacíficamente en las minas del alto Perú" (El Telégrafo, 8 Diciembre, 1921). Pero las canciones más populares del conjunto fueron las chacareras, gatos, malambos y escondidos, bailes que, según un crítico de 1922, "no desmerecen en nada a los que vemos realizar por los negros yankees, y en cuanto a la agilidad de 
rodillas podrían competir con los danzarines rusos sin perder un ápice en el parangón" (El Pueblo, 8 Febrero, 1922) (Reder Carlson, 2013, p. 130).

Estos comentarios no distan mucho de la descripción periodística de Ricardo Rojas que comentamos antes, sobre el espectáculo de la Compañía de Arte Nativo ofrecido en Buenos Aires; éste decía ser la presentación de las melodías y danzas populares del monte Santiagueño, recopiladas por Chazarreta en una suerte de trabajo de campo pionero aunque intuitivo, a partir del testimonio de las fuentes originales. Sin embargo, lo que maravilla en esto es que todas esas cosas recopiladas del pueblo auténtico, que además expresaban la Patria y el solaz de la raza americana, eran completamente desconocidas, no sólo para el público porteño, sino también, como ya vimos, para los santiagueños. Esto, y no el inverosímil del rancho de cartón, las caras maquilladas de blanco o el telón pintado del fondo, es lo que señala la presencia del exótico. Esos bailarines, esas danzas, eran percibidos como de otra parte, lo que además, se transforma automáticamente, por la diferencia que introduce el evolucionismo racializado, de otro tiempo. De hecho Reder Carlson desafía la tradición epistémica del folklore cuando sugiere que el espectáculo de Chazarreta no sólo no está inspirado en los bienes folklóricos santiagueños sino que ni siquiera en la influencia documentada de la obra de Rojas sobre don Andrés: para el autor son tanto o más importantes las influencias del circo criollo y "de los ballets russes» (Reder Carlson, 2013, p. 130). Todos ejemplo claros del culto a lo exótico propio del modernismo de principios de siglo. El espectáculo exótico implica el traslado en ambas dimensiones. Eso percibía el público de ópera cuando asistía a los dramas en que los príncipes egipcios y las geishas del Japón cantaban sus desventuras en el lenguaje tonal de la civilización moderna. Esas historias, además de transcurrir en lugares distantes y extraños, tenían una temporalidad que oscilaba entre lo mítico y lo histórico, pero siempre de un tiempo muy antiguo. Todavía persisten esos estereotipos en torno a ciertos países, a los que pareciera les está vedado el ser contemporáneos: Grecia siempre vivirá en el siglo de Pericles, o lo suyo será una catástrofe donde las llamas llegarán al Partenón; el Medio Oriente está condenado a vivir "en la Edad Media". Estas nociones, como parte de la historiografía, son siempre construcciones retrospectivas. Del mismo modo funcionan las tradiciones selectivas que el folklore despliega para generar una memoria histórica nacional. Así el cancionero nativo de Chazarreta funciona como parte central en «la construcción de concepciones premodernas de la Argentinidad» (Reder Carlson, 2013, p. 134)

En una de las formulaciones fundacionales de la musicología comparada, la de Guido Adler de 1885 , el estudio de las músicas de «los variados pueblos de la tierra» tenía propósitos «etnográficos y clasificatorios» (Merriam, 2001 [1977], p. 62). Es decir que cuando estas músicas exotizadas son inscriptas en el cambio, son puestas a la venta, la diferencia racializada devenida concepto en el folklore y la musicología comparada, se convierte en clasificación. Para Vega, la Ciencia del Folklore se distingue del tradicionalismo porque aparece 0171discriminando, definiendo, aclarando» (1981, p. 16) las "cosas" rurales, es decir, clasificando las supervivencias.

Si el pueblo folklórico es, al fin, (...) parte de un patrimonio en usufructo, conviene que nos quedemos a solas con esa parte, con las supervivencias, y que nos desentendamos del hombre físico a quien se las tomamos para formar nuestro repertorio de hechos (Vega, 1944, p. 54 - Itálicas nuestras)

De lo que se trata es de consagrar el poder clasificatorio para establecer los criterios de la colección, es decir, el repertorio, que no sólo tiene un valor retrospectivo y de archivo en disponibilidad para intérpretes y público. La colección, su orden racionalizado posible mediante las categorías de la musicología histórica y el folklore, es la serie diferenciada que se ofrece en el mercado, la escala que permite la abstracción de su valor y su conversión monetaria. Lo cual converge en el positivismo, además, con la manía del museo y el archivo 
y la cuasi identificación disciplinaria con el acto de coleccionar. «Se reúnen pues todos los requisitos para la recolección de ejemplos musicales y lingüísticos a gran escala y para su conservación en los museos fonográficos o archivos» (Hornbostel, 2001 [1905], p.42). Del mismo modo, entonces, en que las categorías de estilo armonicocéntricas, sus términos específicos, sus nombres, constituyen los criterios para serializar y clasificar la colección de música culta puesta a la venta, el folklore, al racializar, localizar y exotizar, permite que las músicas del mundo popular subalterno ingresen en el cambio. Incluso las produce; deberíamos decir que las reescribe, pero en función de la naturaleza política y de las metodologías de la disciplina, en realidad las construye porque las escribe. Y esto se reproduce, generando un valor aún mayor, en la exotización de las culturas populares de las periferias.

Proponemos ampliar el concepto de Garramuño y que entonces el típico-exótico incluya a las músicas del folklore. No sólo por lo inverosímil de la empresa del folklore espectáculo en tanto búsqueda de autenticidad, o por la convergencia de los medios técnicos "modernos" en el folklore espectáculo, como sugiere Reder Carlson (2013). Sino porque el mismo concepto de folklore participa de una clasificación para consagrar como genuinas unas músicas que tanto la Nación como el mercado capitalista internacional necesitan, aunque sus élites oscilen entre el rechazo -o el asco- y la fascinación (lo cual marca un rebote en la dirección de la secuencia de Martín-Barbero). Podemos ver a través de esta lente de la economía política de la música popular cómo el mercado que emerge entre el siglo XIX y el XX se abre paso gracias a la colección del folklore, a sus clasificaciones y condiciones que garantizan la autenticidad, del mismo modo que el paso de lo performático a lo disciplinario no objeta sino que reafirma la creación de estereotipos racializados y políticos del pueblo.

Tiempo después, cuando las naciones ya no sean las unidades de consolidación del poder de las hegemonías, cuando el nacionalismo sea demodé y se lo estigmatice en la época de la guerra fría, el folklore se transformará en afirmación rebelde de los pueblos que luchan por su libertad. $Y$ así se creará otro mercado, también internacional y de la folksong auténtica: la del cantautor que cambia el fusil por la guitarra. Pete Seeger, Joan Báez, Víctor Jara, Daniel Viglietti y tantos otros participaron de un movimiento que sólo pudo ser internacional a través de la combinatoria entre la colección de músicas folklóricas nacionales y su puesta en circulación mediatizada. Paula Cannova (2016) o Ernesto Donas (2004), entre otros, han estudiado el estrecho vínculo entre el movimiento de la canción testimonial latinoamericana y la industria cultural, fonográfica y de música en vivo, durante los años 1970 y 1980, al punto de que no hubiera existido el fenómeno en tanto continental sin esa mediación explícita, que en algunos casos estuvo conducida por el Estado Revolucionario (Cuba, Chile, Nicaragua). Es justamente en esta época cuando sobresalen los folkloristas "de izquierda", como Bert Loyd o Alan Lomax, o cuando Fernando Ortega Peña y Eduardo Luis Duhalde escriben el revisionismo histórico de la Zamba de Vargas. Aunque la consigna sea ahora "a desalambrar", la música sigue estando "en la tierra" y en tanto tal, es expresión del volk rural, aunque se lo sueñe revolucionario. Lo cual no le quita valor a que se discuta la posesión de esa tierra y el latifundio.

Como ya hemos analizado, cuando todavía después estos movimientos pierdan intensidad y la polarización del mundo aparente diluirse en un imaginario consenso liberal, el poder de la colección folklórica se reinventará en toda su crudeza en la World Music. En todos los casos se despliega la modernidad, montada a horcajadas sobre lo "primitivo", extendiendo una mirada desde arriba, movida por la fascinación emancipadora o buscando el disciplinamiento del pueblo. Porque es la modernidad la que crea una idea de cultura unificada exotizando rasgos y elementos del mundo popular subalterno. Finalmente, se produce la compresión, se hace ingresar en el cambio a ese universo popular, disciplinado y 
comodificado mediante las categorías de la racionalización musical moderna. La fricción entre lo típico y lo exótico que habita en el núcleo del folklore, que es además de racional un pathos moral acerca del pueblo, permite la localización de lo popular y su conversión en objeto etnologizado, clasificado y por ende comercial.

\subsubsection{A fakesong folk-market o una "saladita193 de canciones de dudosa procedencia"}

A estas alturas ya podemos darnos una idea de que la tríada de intencionalidades que atraviesan y determinan el campo del folklore (nacionalismo político, racialización cultural y comodificación artística) se inscriben en el núcleo ideológico y procedimental del proyecto europeo occidental, es decir en la modernidad. Nuevamente insistimos en que estas consideraciones acerca de lo popular juegan una centralidad que es incompatible con la presentación del folklore en términos de la filantropía de unos seres sensibles preocupados por las condiciones de los sectores subalternos y emocionados por su ingenua expresividad. La propia terminología posee una marca "en el orillo" que revela el esquema colonial de la disciplina y es sintomático que si bien el núcleo ideológico más sofisticado procede de la concepción del volkskunde por parte del romanticismo alemán, es a partir del desarrollo y las emanaciones inglesas y luego estadounidenses del folk-lore que este campo se hace universal.

En el folklore estamos, culturalmente, siendo hablados por otros, lo cual es una insalvable paradoja de esta ciencia de lo local. No debe por lo tanto llamarnos la atención que permanentemente se tenga que recurrir a vocablos extraños al español, porque estamos hablando la lengua de la colonialidad, lo cual revela el ejercicio vano de pretender tranquilizar nuestra conciencia nacional usando la "c" en folclore, ya que incluso si "folk" existiera en nuestra lengua, el "lenguaje conceptual" del folklore permanecería en la posición colonial y "desde arriba", porque es una disciplina pensada así y con el propósito de disciplinar al mundo popular subalterno. Esto es lo que Dave Harker (1985) y el ya citado Charles Keil (1978) quieren aportar cuando nos proponen desprendernos de los mismos conceptos de folk y folksong, que a nosotros en la traducción nos genera todavía más problemas (¿es folksong "canción folklórica", "música folklórica" o directamente "folk(c)lore"?). Para Harker, todos estos términos son "escombro intelectual [...] basura conceptual, y deben desecharse» ${ }^{194}$ (1985, p, xii).

Si todavía folksong y ballad, en tanto conceptos, mantienen algún tipo de poder explicativo, lo hacen en relación con la cultura burguesa. Relacionados con la cultura de los trabajadores son lisa y llanamente un problema, y no puedo ofrecer esperanza alguna de que podamos rehabilitarlos ${ }^{195}$ (Harker, 1985, p.254)

\footnotetext{
193 Con la crisis económica, política e institucional que asoló entre 2001-2002 a la Argentina, proliferaron el conurbano que rodea la Ciudad de Buenos Aires ferias en las que se vende principalmente indumentaria de marcas falsificadas o "truchas". En honor de la más famosa de ellas, conocida como "la Salada", estas ferias suelen recibir el nombre de "saladitas". Es lo más parecido a una feria popular en sentido clásico, incluso por su condición fronteriza con la legalidad que las hace participar de la fascinación y rechazo de las clases medias, en cuyo discurso se las condena fuertemente, mientras que se las visita para comprar multitud de productos y ahorrar así unos pesos. Durante muchos años uno de los artículos de mayor circulación en las ferias fueron los CDs musicales piratas. La duplicación en serie de música y películas para este fin comercial puede verse en el documental más conocido sobre la Salada, "Hacerme Feriante" (d'Angiolillo, 2010).

194 «intellectual rubble [...] conceptual lumber, and they have to go» (Harker, 1985, p, xii) [traducción del autor]

195 «In so far as 'folksong' and 'ballad' retain any explanatory power, as concepts, they do so in relation to bourgeois culture. In relation to workers' culture, they are simply a problem, and I can offer no hope of rehabilitating them» (Harker, 1985, p.254) [nuestra traducción]
} 
Keil es todavía más intransigente (su artículo se llama ¿Quién necesita al "folk"?), y su alegato exhibe también, como en Harker, lo inevitable del carácter construido y comercial de toda la empresa folklórica, aún cuando (algunos de) sus practicantes no la hayan pensado con esos propósitos. Para ambos autores los términos folklore y folk no pueden reconvertirse o resignificarse.

¿No podemos preservar el concepto de "folk" y redimirlo? ¡No, no y otra vez no! No podemos, porque se han fabricado demasiados Volkswagen, se han aplaudido incontables ballets folklóricos, se han vendido incontables canciones folklóricas. Demasiada ayuda y comodidad se le ha otorgado al enemigo. A diferencia de "primitivo", el término "folk" solo tiene una significación positiva, amigable. El folk no es el colectivo de oprimidos cuya revolución es tan necesaria, sino lo típico-diferente, los campesinos agradables, esos que son comunes, "casi como vos y yo", para ser consumida en nuestro tiempo libre. La gente del folk no son algo neutral por lo cual luchar por izquierda y derecha. El folk pertenece a la burguesía196 (Keil, 1978, p. 265).

Dado entonces que en la disciplina folklórica y en su nomenclatura habita la colonialidad, consideremos la posibilidad de tomar como ejercicio crítico algunos términos también en inglés, como forma de evidenciar su marca constitutiva y ensayar una posible deconstrucción: tomaremos las ideas de folk-market y fake-song.

El Folk-market es una producción en serie inmersa en la cultura de masas (Colombres, 2007, p. 161), que demanda de los sectores subalternos, para su extracción y posterior reelaboración, temas, elementos y valores de su visión del mundo. Es decir que al introducir a los sectores populares en el cambio, al comprimir la dinámica de la cultura popular mediante la autenticidad y tipicidad, que son categorías de mercado, se introducen los temas y valores en el mundo popular subalterno. La homogeneización por tipicidad de la cultura popular produce estereotipos que los sectores populares identificados como folklóricos por los sectores dominantes deben reproducir si pretenden incorporarse a la sociedad. Se aprecia aquí finalmente un proceso del todo contrario al que denunciaban prematuramente los apocalípticos frankfurtianos de Umberto Eco (1976) cuando creían que la alienación del capital simbólico popular lo producirían las manifestaciones de los medios técnicos. Por el contrario es el folklore el que fuerza no solo una identificación afirmativa en tanto comunidad y nación, sino también una producción que se corresponda con esa afirmación identitaria. "La cultura subalterna tiene que producir no lo que la representa de verdad, sino lo que el mercado necesita [...] para resultar visible [...] debe estereotiparse al máximo» (Colombres, 2007, p. 162). En el mercado de las artesanías puede verse cómo este mecanismo llega al paroxismo, cuando las supuestas formas típicas de los pueblos "auténticos" son aplicadas a objetos de un utilitarismo exclusivamente urbano y burgués, e incluso, globalizado: no solo ceniceros y destapadores producen las comunidades "rurales" para intentar subsistir, sino también soportes para sahumerios de asiáticas fragancias y contenedores para bolsas de plástico de los supermercados transnacionales. Pero más allá de estos disparates, es interesante notar que muchos de estos artesanos, copleros o músicos que hacen las delicias del turismo internacional a cambio de algunas migajas de subsistencia, se dedicarían a otras tareas si el folklore y su market burgués no existieran. $Y$ si no hubiesen sido -como todavía son-, a partir del indicador colonial de raza, violentamente explotados y arrojados a una vida de miseria. «Si esas sociedades tuvieran

196 "Can't we keep "the folk" concept and redeem it? No! and no! again. You can't, because too many Volkswagens have been built, too many folk ballets applauded, too many folksongs sold, too much aid and comfort given to the enemy. Unlike "primitive,"folk" has only a positive, friendly meaning. The folk are not the oppressed whose revolution is long overdue, but the Quaint-not-quite-like-us, the Pleasant peasants, the Almostlike-me-and-you, to be consumed at leisure. The folk are not neutrals to be fought over by left and right. They belong to the bourgeoisie» (Keil, 1978, p. 265) 
otros medios de vida, el número de artesanos disminuiría enormemente» (Colombres, 2007, p. 156)

En lo que elabora Colombres como noción de Folk-market, hábitat del típico-exótico en que se ha trocado lo popular, pueden deducirse entonces dos procedimientos concurrentes: 1) la creación de las categorías mismas que separan lo culto de lo que es propio del folk, es decir de las clases populares idealizadas. Son etiquetas afirmativas en un sentido de clase (la cultura de la respetabilidad burguesa vs. la tradición popular). Pero también y al mismo tiempo son categorías de mercado, colecciones, repertorios específicos que obtienen valor de cambio al adquirir cada uno, respectivamente, sus términos estilísticos particulares; la primera desde la musicología histórica -la obra, la personalidad autoral, el estilo formal/ tonal-; la segunda con el folklore -el objeto etnológico, la comunidad folk, el estilo racializado; valores que a su vez se contabilizan en virtud de la autonomía o de la autenticidad. 2) la condición producida del folk y de lo folklórico, es decir, la promoción y el incentivo para que algunos sectores del mundo popular subalterno realicen lo que se espera que produzcan. En la trama artificiosa de la creación del ideal popular moderno, la promesa de la inclusión que se lanza a los sectores subalternos contiene en su interior la cláusula de obligatoriedad de la conversión del pueblo en folk, al mismo tiempo que la aceptación de la cultura universal que se provee "desde arriba". Por un lado el folklorista que "rescata y atesora" la tradición popular selecciona y edita aquello que de antemano dictamina como auténtico, desde una elaboración apriorística del folk. Buscará en algunos lugares y no en otros, y establecerá una red para encontrar lo que sabe está ahí, en el monte o en el desierto, esperando ser descubierto. Pero también podemos decir, hay muchas evidencias de esto, que el informante del folklorista canta aquello que sabe están esperando que cante, superponiendo el artificio, es decir lo "trucho", con el momento etnográfico por antonomasia.

Es desde esta sofisticación del mecanismo de la afirmatividad burguesa y su expresión mercantil que puede pensarse, sin riesgo de pronunciar una denuncia vacía de sentido, que «desde el dorado reducto del folklore, la burguesía ejerce así el control de la producción simbólica popular» (Colombres, 2007, p. 155). Para que esto suceda, la cultura moderna, consolida a principios del siglo XIX lo que de forma incipiente comienza a partir del 1600: la intervención efectiva de los sectores hegemónicos en la cultura popular (Burke, 2014). Y esta intervención se da no sólo en la academia, en la teoría, sino también y con mucha fuerza en el mercado. Como ambas esferas son concurrentes, es en un mismo momento histórico que emergen las nomenclaturas académico/mercantiles que se destinan a diferenciar las colecciones, los repertorios: la música artística, culta, seria; y la música popular, que en ese momento se entiende como folklórica. A esta dupla, que es la estructural, se añade una tercera categoría que irá consolidándose durante el siglo, primero como desprendimiento de la música orquestal y luego en función de la diferenciación entre la sala de conciertos y su significación histórico cultural (Small, 1989) y el local musical (music-hall, café concert, etc.). Esta será primero música ligera [Leichtemusik (Dahlhaus, 1997)] para convertirse luego en música popular. Tengamos en cuenta que es un repertorio anterior a la creación del fonógrafo, factor técnico que será para los Popular Music Studies definitorio de la música popular. Más allá de la mudanza de nombres, a mediados del siglo XIX los tres repertorios están en funcionamiento, con sus circuitos comerciales, categorías clasificatorias y profesionales especializados. Pero los que organizan la dicotomía alto/bajo son la música culta y el folklore (llamado entonces, repetimos, "música popular"). Es decir que con la emergencia de la burguesía como clase hegemónica,

las instituciones musicales comerciales se estaban transformando de forma concurrente. El concert hall (sala de conciertos) cambia gradualmente y pasa de ser un fenómeno provincial en parte asociado a la clase trabajadora, a convertirse en nacional y de la pequeña burguesía; y estos desarrollos otorgaron un estímulo adicional a la burguesía para definir su cultura 
musical como se hizo, en contra de la cultura que consideraba perteneciente a una clase diferente de personas (una clase inferior) ${ }^{197}$ (Harker 1985, p.146).

La burguesía elabora las categorías ante la pregunta «¿De qué tipo es la cultura popular? ¿Quién es el pueblo? [...] El pueblo eran los incultos, como lo indicaba Herder al distinguir entre Kultur der Gelehrten y Kultur des Volkes» (Burke, 2014, p.58-59). Para hacer de los incultos el pueblo de la sociedad moderna y a su vez convertirlos en objeto, comoditizarlos como bien de cambio, la cultura afirmativa genera categorías más sofisticadas que se basan en estas de Herder al permitirse pensar, cosa que la aristocracia no hacía, que lo del pueblo (idealizado o no) podía ser considerado también "cultura". Es importante que no perdamos de vista que este gesto es burgués, lo cual equivale a decir que además de una aparente valorización de lo popular, esta conversión de lo proscrito en cultura es la condición necesaria que permite su ingreso en el cambio, su transformación en valor de mercado. Recordemos la diferencia categorial observada por Edward P. Thompson (2000, p. 30) entre la "gentry" y "los pobres", su formulación por parte de las clases hegemónicas y, todavía más importante, su utilización absolutamente acrítica por parte de la historiografía. También Charles Keil insiste en que los términos culto/folklórico representan una dialéctica que está contenida casi exclusivamente en la ideología burguesa. "Una requiere de la otra para una mutuamente satisfactoria autodefinición» 198 (1978, p. 263).

Quién ha estudiado este proceso histórico de complementación en el que ambos repertorios producen sus categorías clasificatorias y consagran sus repertorios estableciendo un canon, es Matthew Gelbart (2007), quien puntualiza el modo en que la concepción burguesa de la música, íntimamente relacionada con el capitalismo y por ende con el mercado (también musical), realiza a comienzos del siglo XIX un traslado de los criterios de clasificación musical, que ya no estarían tan ligados a la función, sino que serían reemplazados por los orígenes (Gelbart, 2007, p. 15). Este cambio, que buscará una nueva fundamentación para la calidad diferencial de las músicas, estará atravesado por los objetivos concurrentes en términos políticos que analizamos en apartados anteriores, y que Gelbart vincula con las ideas de progreso y civilización (p. 50) tanto como con el nacionalismo (p. 98) y el organicismo romántico (p. 191). Pero el recurso a los orígenes posibilitará la articulación de los términos conceptuales centrales que hemos analizado tanto para la música culta como para el folklore: en el culto al origen se encuentran tanto el genio romántico del compositor, en cuya subjetividad inmanente residen los secretos sensibles del universo, como el hontanar de la comunidad imaginada del pueblo auténtico. El análisis de Gelbart es histórico, y esto precisamente es lo que expone a todas las categorías de la historiografía musical, musicológicas y folklóricas, revelando la trama de su afirmatividad, esto es, exponiendo las coordenadas históricas y los intereses políticos y económicos que subyacen en ellas y por los cuales fueron creadas. Creación que ya llevaba inscripta la reciprocidad y complementación de ambos conjuntos categoriales.

Música folklórica y música culta son construcciones recientes que se han presentado a sí mismas como categorías intemporales, y se emparentan con la idea de "tradiciones inventadas". Creadas para cumplir propósitos sociales específicos cuando eran nuevas, tienen también el poder de adaptarse. De hecho estos términos tienen que seguir siendo necesarios, o no tendrían un poder tan duradero [...] tenemos que observar además algo que no se ha considerado demasiado en la literatura sobre el tema: la específica interdependencia histórica 197 «Commercial musical institutions were being transformed concurrendy. The concert hall gradually changed
from being a partly working-class and provincial phenomenon into a predominantly petty-bourgeois and national
one; and these developments gave a further stimulus to the bourgeoisie to define their musical culture, as it
were, against the culture perceived to belong to different (and lower) class of people» (Harker 1985, p.146)
[traducción del autor]

198 «One requires the other for mutually satisfactory self-definitions» (Keil, 1978, p. 263) [traducción del autor] 
de "folk" y "culto" como par binario y dialéctico. Estos significantes han obtenido sus referentes a partir del contraste y la oposición entre uno y otro: a través de su historia, el hecho de que "música folklórica" y "música culta" hayan funcionado en diálogo mutuo ha producido que su potencia sea excluyente antes que inclusiva ${ }^{199}$ (Gelbart, 2007, pp.6-7)

Estas categorías, efectivamente, se configuran a partir del rechazo de aquello que dicen no ser. Esto es lo que pretendemos desde el comienzo de este trabajo con la articulación de los títulos y apartados: la música culta no se llama a sí misma culta, sino que se define en tanto "música", a secas, en la medida en que no es popular; el folklore, la tradición musical del folk, se define en tanto no es cultura ni arte, sino folk-lore. Pero además las obras musicales no son el efímero sonar sino el objeto escrito, al que también se llama música, a secas; mientras que se nos deja claro que el folk no es el pueblo, ya sea porque todavía no lo es o porque nunca podrá serlo. $Y$ es que «las categorías estéticas son inherentemente instrumentos socio políticos» 200 (Gelbart, 2007, p. 6).

Pero sumemos a estos señalamientos vinculados a la política de la burguesía y su visión racializada de las culturas, o mejor de "la" cultura y el folk en sus diversas afloraciones nacionales, una segunda interdependencia histórica. Según Derek Scott (2014) en el siglo XIX el término "música seria" (o "culta") se origina también como contrapartida a "música ligera", conceptos que se piensan primero en alemán: leichte Musik y ernste Musik. Con el tiempo estas categorías se abreviarán como E-Musik (ernste) y U-Musik, esta vez no por "ligera" sino por Unterhaltungs, que literalmente significa "entretenimiento", pero incluyendo en su sentido la idea de "pasarla bien", que es concurrente con esa idea de ligereza. Recordemos que Carl Dahlhaus, en sus definiciones acerca del carácter artístico o estético, requisito para formar el canon de obras que merecían estudiarse por la historia de la música, opone claramente como aquello que no se debe estudiar a la Trivial Musik, es decir la música trivial (Dahlhaus, 1997). A esta altura podemos imaginarnos que "entretenimiento" y "ligero" son términos que remiten a lo que posteriormente se llamará "comercial", en tanto faceta económica pero también como vacío de contenido estético o artístico. Y justamente, es la sociedad de derechos de autor de Alemania, la Verwertungsgesellschaft, la que define con precisión los términos con el fin de regular correctamente la comercialización de la música, especialmente en su representación pública, y posteriormente en su circulación fonográfica y radiodifusión. Es decir que unos términos que se venían utilizando de forma esporádica y con diversos matices de sentido en función de la ocasión en que se utilizaba y por quiénes lo hacían, se establecen como categorías fijas a partir de la institucionalización del control sobre el mercado de la sociedad moderna. Los conceptos de música ligera, música seria, música culta y folklore se inventan a partir de que se detecta la necesidad de filtrar los diferentes repertorios, en función de la estratificación cultural. Según Scott, es el interés por filtrar lo trivial dentro del mundo industrial lo que produce la etiqueta de leichte Musik y en consecuencia, necesita de su opuesto, la música seria o culta. Es una oposición binaria desbalanceada, ya que no es simplemente

lo ligero vs. lo pesado, o lo fácil vs. lo difícil: «serio» es el término que regula y domina y «ligero» existe únicamente como forma negativa e inferior en relación con el primero. La

\footnotetext{
199 «Folk music and art music, being recent constructions that have portrayed themselves as timeless categories, share much with the idea of "invented traditions". Forged to fulfill specific social purposes when they were new, they also have the power to adapt. Indeed, these terms must still be necessary in the contemporary world, or they would not have such lasting power. [...] we must also realize something that has not been considered much in the existing literature: the specific historical interdependence of "folk" and "art" as a binary, dialectical pairing. These signifiers have gained their referents through contrast and opposition to each other: throughout their history, the fact that "folk music" and "art music" have functioned in dialogue with each other has rendered their force exclusive rather than inclusive» (Gelbart, 2007, pp. 6-7) [traducción del autor]
}

200 «aesthetic categories are inherently socio-political instruments» (Gelbart, 2007, p. 6) [traducción del autor] 
música seria no tiene por qué ser difícil, pero la música ligera no puede ser nunca seria"201 (Scott, 2014, p. 43).

Esta última categoría siempre será estigmatizada: «el objetivo de la música ligera es atraer lo más rápidamente posible al mayor número de oyentes. En cuanto a su valor, uno puede decir: Dame tiempo y veremos lo que sobrevive» (Harrison, 2005, p. 75).

Ahora bien, el folklore también surge como rechazo a la música ligera. Si el pueblo folk no es el pueblo de la calle, que justamente es quien se entretiene con las baratijas y fetiches de la U-Musik, el adversario estético de los folkloristas es esa música trivial, que no solo es de mala calidad y habrá que ver qué sobrevive de ella, sino que contamina y corrompe las tradiciones del folk. $\mathrm{Y}$ es importante tener presente también que estas acusaciones se producen dentro del mercado. Así la música popular impresa será demonizada por las publicaciones (comerciales) de los folkloristas; el music-hall, el minstrel show y el circo criollo serán enfrentados con la puesta en escena de los cuerpos folklóricos; dentro de la industria cultural del disco aparecerán los fonogramas que registren lo auténtico, aún para transformarlo luego en World Music. La sociedad alemana de derechos de autor define por escrito la U-Musik y la E-Musik en 1904; Cecil Sharp, el más importante folklorista inglés, establece la definición de canción folklórica en 1905; y Andrés Chazarreta inventa las categorías Zamba y Música nativa con la publicación comercial de Vargas en 1906. Demasiadas simultaneidades para que sean casuales, sobre todo porque en todos los casos existía la preocupación de que para las "mentes simples" bombardeadas por la música ligera «la música culta era demasiado erudita, mientras que la nueva categoría del folklore [o música nativa para el caso] ofrecía un medio para designar un tipo de música que era sencilla (easy listening), que podía apelar a lo acrítico, pero no estaba contaminada con la banalidad. No podía considerarse trivial, porque sólo la música escrita para vender era percibida así»202 (Scott, 2014, p. 43).

Una evidencia muy clara de la convergencia entre musicólogos y folkloristas, además de las que tienen que ver con su común pertenencia a las clases hegemónicas, es la participación de numerosos compositores e historiadores de la música en la fundación de la Folk Song Society (sociedad de la canción folklórica) británica, en 1898 (muy cerca de las fechas que acabamos de mencionar). Algunos eran muy célebres, como Edward Elgar, Grieg o Dvorak. El discurso de inauguración estuvo a cargo de un musicólogo que ya conocimos en capítulos anteriores: Sir Hubert Parry, el paladín (Junto a Waldo Selden Prat) de la teoría darwinista de la evolución musical que, como vimos ${ }^{203}$ concebía un prístino orden que iba desde lo muy primitivo a lo "semi-civilizado" de Oriente, llegando por supuesto a la cumbre de la música europea del Romanticismo. Desde el púlpito de la Folk Song Society, Parry «arremetió contra el "público degenerado" y su afición por las "canciones populares del momento", esos productos de chapuceros y parte de las "regiones ilimitadas del engaño" que él y los de su clase percibían cuando miraban hacia la periferia

201 «this is not a balanced binary opposition: it is not light and heavy, or easy and difficult; the "serious" is the ruling term, and "light" exists only in a negative and inferior relation to it. Serious music does not have to be difficult, but light music can never be serious» (Scott, 2014, p. 43) [traducción del autor]

202 «Classical music was thought too erudite for such minds, but the newly invented category of folk music offered a means of designating a type of music that was easy, that had the power to appeal to "the uncritical" (ibid.: 137), but was not contaminated by triteness [trivial, banal]. It could not be considered trite, because only music written for sale was perceived as trite» (Scott, 2014, p.43) [traducción del autor]

203 Cfr. pág. 191 
de "nuestras terriblemente superpobladas ciudades"» ${ }^{204(H a r k e r, ~ 1985, ~ p . ~ 170) . ~ E l ~ c a m i n o ~}$ evolutivo musical de Parry iba de las melodías folklóricas hasta la sinfonía. Es decir que lo que no podía calificarse de folklore ni de música culta (en ese orden) simplemente no era música. Una definición que acarreaba intencionalidades políticas y morales, además de servir a la preservación material a la que pertenecían Parry, Sharp y sus colegas de la música y la musicología.

Debemos considerar entonces el accionar articulado de los conceptos de la musicología histórica y el folklore, vínculo que se da también en el mercado y en relación con la regulación de la propiedad intelectual, con el fin de asignar un grado de profundidad y sofisticación a la concepción del folklore como algo construido. No se trata de una simple invención bucólica lanzada a su suerte o impuesta mediante la simple coerción. Es mucho más que eso. Y precisamente de la articulación de diversas capas, aparentemente confrontadas en una dialéctica discusión, puede entreverse un revés de la trama de producción de los repertorios, en este caso del folklórico. Tiremos de la hilacha volviendo a nuestro ejemplo paradigmático para luego aportar otros casos célebres de producción del falso/fake popular.

Entre las zambas popularizadas por Chazarreta aparece otra muy famosa, también de principios de siglo XX, cuyo título más conocido es el de La López Pereyra. ${ }^{205}$ Alrededor de esta canción, que en realidad no fue pensada como zamba sino como zamacueca (recordemos el carácter nacionalista y racializado del término zamba), cosa que incluso se puede escuchar en la grabación del conjunto nativo, interpretación en la cual el tempo es muy ágil y se acerca al que luego tendería a emparentarse con la cueca. Tampoco el ritmo del acompañamiento, sobre todo el rasguido de guitarra, es el estereotipo que pasará a asociarse a la zamba. De hecho, si se la compara con otra versión icónica, la de los Chalchaleros en una de sus tantas presentaciones en vivo, ${ }^{206}$ parecieran no sólo dos canciones distintas, sino dos géneros musicales diferentes. Para Vega serían dos especies con caminos evolutivos distintos. Por lo pronto, además de una instrumentación muy diferente que en el segundo caso conforma el cuadro típico de las tres guitarras y bombo, poncho salteño al hombro, y la emisión vocal grave e impostada, el ritmo es otro, con la velocidad de la canción que baja notablemente. Si en la versión de Chazarreta el tempo es ca. 102, en la de los Chalchaleros es de ca. 68, prácticamente la mitad. El bombo de "Polo" Román marca el característico batido lento, en tres tiempos, acentuando el último y omitiendo el primero, lo cual refuerza la sensación de estatismo en la zamba típica. Nada de esto suena en la versión de Chazarreta, probablemente similar a la que se escuchó en las funciones del Politeama donde, se sabe, fue puesta en escena.

Pero La López Pereyra tiene otro condimento célebre, que es el de haber conducido a don Andrés a los tribunales, acusado de plagio por los familiares del autor de la música, Artidorio Cresseri. El malogrado compositor, que no pudo ver en vida como era asociado nuevamente su nombre al de la canción, era salteño. De hecho, se conoce popularmente a La López Pereyra como el "himno a Salta", lo cual no hace más que confundir nuevamente la territorialización de la Zamba -si es del noroeste, o es santiagueña o salteña (como eran los Chalchaleros)- confusión que, en definitiva, es funcional a que la zamba sea argentina,

\footnotetext{
204 «lambasted an "unregenerate public" and their fondness for the "common popular songs of the day", those products of the cultural "jerry-builder" and part of the"'boundless regions of sham" which he and his kind perceived when they looked at the outskirts of "our terribly overgrown towns"» (Harker, 1985, p. 170) [traducción del autor]

205 Puede escucharse aquí la grabación de Chazarreta y su conjunto nativo de 1932, publicada en un disco simple para Víctor https://youtu.be/NAOCh1NPMd8 (ejemplo 47)
}

206 Por ejemplo esta de 1996 en un estudio de televisión https://youtu.be/URahvztij5Q (ejemplo 48) 
solución facilista pero congruente con las motivaciones del nacionalismo y el folk-market local, a los cuales nunca les interesaron demasiado las identidades federales. Para complicar aún más el asunto, parece que Cresseri no concibió la canción como zamba, sino como chilena, que era uno de los nombres que se le daban a la zamacueca en el cambio de siglo (Vega, 1977a) y con el cual, entre otros, participó del ciclo vareliano y de las versiones sobre la batalla de Vargas, como ya hemos discutido.

Pero Chazarreta, que la edita como zamba en partitura en la década de 1920, no duda en adjudicarse la canción, tanto la letra como la música, lo que de igual forma hizo, desde un primer momento, con la "anónima" Zamba de Vargas.

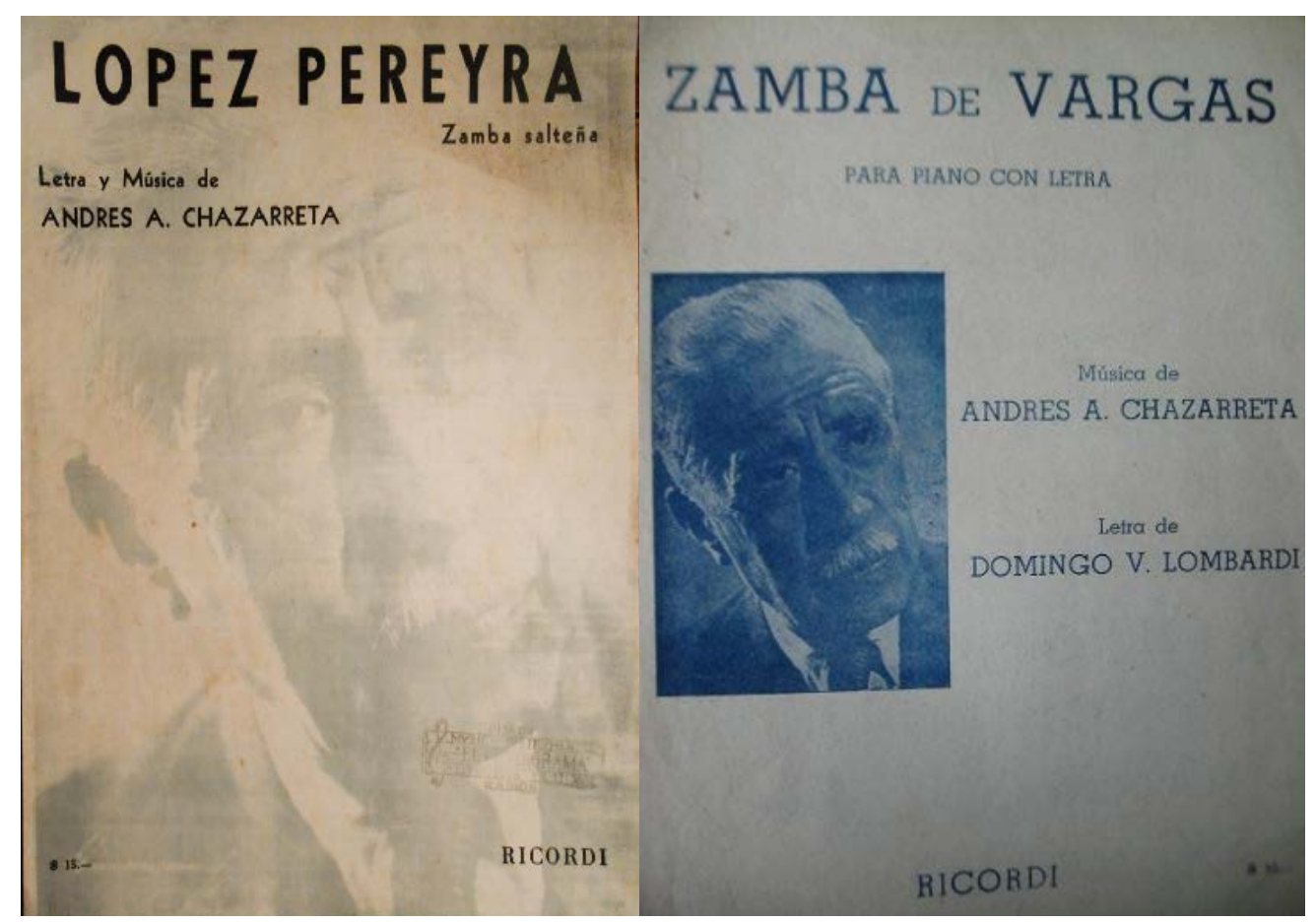

Carátulas de las ediciones de "La López Pereyra" y la "Zamba de Vargas", en las que puede leerse claramente la adscripción autoral de Andrés Chazarreta

Chazarreta perdió el juicio contra los herederos de Cresseri. Pero eso no es lo importante, puesto que podría haber sido al revés. Lo que queremos resaltar aquí es una serie de convergencias o simultaneidades que son muy importantes a la hora de despejar las mitomanías acerca de la ligazón del folklore con las nociones nacionalistas, racializadas y exotizadas de la unicidad de la cultura popular. Que Chazarreta se adjudicara las piezas que decía recolectar y se inscribiera como autor para percibir los derechos de interpretación y radiodifusión no es una picardía de don Andrés. Muy por el contrario, es una práctica, casi nos vemos tentados a decir un modus operandi, muy frecuente entre los folkloristas o "mediadores" (como la musicología los llama), especialmente antes de la década de 1940, momento en el cual las grabaciones de tipo etnográfico "de campo" producen el surgimiento del despertar naturalista del positivismo folklórico que vimos, por ejemplo, en Vega, Ayestarán o Lomax y sus colecciones. Aunque de todas formas, los arreglos para orquesta de la esposa de Vega de los "bienes folkóricos" que ya mencionamos, o los músicos del blues que hace ingresar Lomax al mercado fonográfico de la repetición (Attali, 2011), transformándolos en "grandes nombres" de la música "negra" estadounidense (como Leadbelly o Muddy Waters), relativizan el contraste que ambos construyeron frente a sus muy criticados- predecesores de libreta pentagramada. En otras ocasiones directamente hay un reconocimiento y valoración por los precursores. 
Hemos explicado que los tradicionalistas son ciudadanos sensibles que vuelcan su afecto de modo espontáneo sobre las cosas de sus mayores y suyas propias. Son propensos, y se exaltan cuando notan que las pierden. Los tradicionalistas proceden por intuición como de propietarios, y distinguen los bienes folkóricos antes que la Ciencia del folklore aparezca discriminando, definiendo y aclarando (Vega, 1981, p. 16) [el resaltado es nuestro].

Está claro que el folklorista no solo aprueba la acción de los tradicionalistas, entre los cuales Chazarreta es una figura principal, aunque se haya apropiado de las músicas ajenas. Vega incluso atisba la posible complementación y solidaridad entre el trabajo de éstos y los auténticos folkloristas "científicos". Pero hay además una similitud de "sensibilidad" que es típica de la exaltación burguesa, como vimos en el primer capítulo con Joseph Kerman y su descripción de los «europeos polifonistas» y su «natural predisposición» a la armonía. Esto evidencia un componente de comunidad de clase que reúne, en virtud de valores estéticos, espirituales e ideológicos, a musicólogos, folkloristas y "mediadores". Un gesto afirmativo de la cultura moderna por antonomasia, que Vega exuda en la descripción que hace de los "propietarios". Podemos imaginarnos a los mediadores tradicionalistas como patrones de estancia, a caballo entre la peonada, seleccionando los ejemplares más robustos de la especie que representen, con su marca a fuego, la calidad del establecimiento y de la familia a quién pertenece. Como las "vaquitas" que según el adagio folklórico "son ajenas", las canciones también se escurren de las bocas y las manos de los sectores populares, «distinguidas como bienes folklóricos» por los patrones de la tradición que, dicen, las están perdiendo. ¿Cómo atreverse a hablar de apropiación frente a estos varones que, como los trovadores, tienen la deferencia de posar su atención auditiva sobre lo rústico? ¿Con qué derecho puede alguien siquiera imaginar en su mente la palabra plagio?

El tráfico de canciones apropiadas como material tradicional bajo la coartada de lo popular y la generación del "peligro de extinción", está íntimamente ligado con el desarrollo mismo del folklore y la emergencia de los folkloristas, su ideología y su necesidad de construir una música auténtica que se diferencie de aquella que circula entre el pueblo. Parece un contrasentido que la autenticidad resida en el simple robo de tonadas y poesías que, se sabía, eran producto de profesionales, presentes en publicaciones centenarias obsoletas o en fragmentos de obras, incluso cultas, que ya todos habían olvidado. Pero las necesidades políticas y económicas de generar esa tradición editada, selectiva, hicieron incluso que parte del edificio teórico del folklore científico prestara ayuda para legitimar el procedimiento extractivo. Esto ocurre por ejemplo con la teoría del «descenso de los bienes» de Vega, que ya explicamos en el capítulo anterior. No sólo la utilización recurrente de la idea de usufructo, cuando las canciones están en boca de los "informantes", del folk, sino la idea misma de que todo lo folklórico fue hecho por "el superior", a partir de lo que Vega llamará "musicar", que no tiene nada que ver con el planteo que aquí estamos tomando de Small $(1999 ; 2010)$, sino con lo que para el folklorista es «un pensamiento musical» asociado a la creación (Vega, 1941). La tradición es quién se encarga de borrar las huellas de la autoría, que sólo el investigador atento, poseedor de las teorías y los útiles de conocimiento "correctos", como él mismo, podrá develar y reconstruir. En eso reside gran parte de la polémica que enfrenta a Vega con Cortazar y otros folkloristas, que creían en la creación espontánea popular. Para Vega, el pueblo no crea, y entonces, como es lógico, nada tiene que ver con los derechos de autor, pues usufructúa lo que hizo otro, a quien, como no conoce, tampoco reconoce en su creatividad. Esto hace que, ante la necesidad de registrar los fonogramas y partituras, los tradicionalistas y folkloristas tengan el campo despejado. El que le roba a un ladrón...

Pero la coartada también funciona cuando los folkloristas no promueven el paradigma del «descenso de los bienes» y en cambio apoyan las teorías románticas de la comunalidad creativa, ya que 
como es espontánea, o sea, no consciente, desprovista de sentido crítico, lo que hace preciso que otras personas la estudien, la objetiven, y esas personas provienen por cierto de las clases dominantes, las que toman así el control de su mundo simbólico (Colombres, 2007, p. 151).

Ya vimos que así opera la modernidad sobre la naturaleza, transformándola en recurso, localizándola, y así, del mismo modo en que las commodities llevan el nombre del empresario que las extrae, las músicas de la "tradición oral" se registran en las sociedades de derechos de autor bajo el santo de su "recolector". El temprano extractivismo musical es precisamente el contenido principal de las importantes críticas al folklore producidas por dos autores ya citados, que desde los títulos de sus libros evidencian el carácter falaz y editado de la tradición folklórica: el de Dave Harker (1985) se llama nada menos que Fakesong, en el cual el término del título se opone rotundamente a la noción de folksong como "canción del pueblo"; el otro es The invention of Art Music and Folk Music [La invención de la música de arte y el folklore musical] de Matthew Gelbart (2007), en el que se hace explícita la invención de las categorías del pensamiento musical burgués moderno.

Una figura importante para el paradigma de autenticidad del folklore es la del informante, es decir, aquella persona o grupo que realiza la performance musical frente al recolector, que también es llamado mediador. Es decir, el folklorista. Tomar la música de los mismos labios del informante es parte de la consecución de lo auténtico y en el imaginario del folklore que ilustramos más arriba con varias fotografías, vemos siempre al mediador, libreta en mano $u$ operando un aparato grabador, frente a quienes hacen la música: el pueblo. Es muy importante para el éxito de la empresa que el o los informante/s no sean percibidos como autores ni como profesionales. De ello depende que sean la voz del pueblo, porque como ya dijimos, la comunalidad, ya sea en la creación como en el usufructo, es crucial para que estos registros puedan convertirse, mediante esa «magia designativa» de la que hablaba Keil, en folkore. Del mismo modo, el mercado de partituras y mucho más el de grabaciones de pretensión etnográfica, depende de este factor crucial que produce el anonimato de los músicos populares. Notemos una vez más la complementariedad con el repertorio culto: si en éste lo auténtico es la expresión individual, en el folklore ésta está terminantemente prohibida. Todo sea por evitar las confusiones de desprevenidos consumidores. Si bien la grabación pareciera superficialmente ser más fidedigna que una partitura, pensemos en que la posibilidad de la performance amateur que brinda esta última hace de la autenticidad un valor participativo por parte del consumidor. Tocar uno mismo la Zamba de Vargas, acción en la cual Chazarreta claramente es mediador y no compositor, es, a los fines de fundirse con el "ser nacional", una operación muchísimo más auténtica que escuchar la grabación de la orquesta nativa, incluso remasterizada. Pero además tenemos que considerar la situación de registro como un aspecto importante, que está íntimamente ligado con la creación por parte de los folkloristas mediadores de la figura misma del informante. Es decir, quiénes son los informantes y en qué situaciones se los graba son factores que están absolutamente bajo el control del mediador e inciden de manera definitoria en el resultado de la recolección.

Por ejemplo, veamos como Augusto Cortazar advertía a noveles folkloristas acerca de qué debían tener en cuenta a la hora de identificar los mejores mediadores en su tarea de campo.

Informantes. En términos generales, el sujeto ideal sería un individuo de edad avanzada, que conservara el pleno goce de sus facultades mentales y en especial la memoria, nativo del lugar y residente en él durante largo tiempo, y bien impuesto de lo que se trasmite por tradición oral. Todo esto no sólo refuerza la autenticidad de la información, sino que demuestra hasta qué punto, y en virtud de qué circunstancias, el colaborador ocasional puede ser tomado como representante del grupo humano con el cual convive, como intérprete del sentir de la comunidad y fiel conservador del legado tradicional. En este sentido los ancianos, y 
especialmente las mujeres, son informantes preferidos por los folklorólogos, pues los consideran nexos vivos entre el presente y el ayer. En los testimonios de los ancianos, el técnico deberá distinguir lo que corresponde al folklore vigente, por coincidir con otros datos actuales, y aquello que ha pasado a ser folklore histórico (Cortázar, 1959, p.44).

Esta definición es muy transparente del sentido producido de la recolección folklórica, aún cuando está esbozada de forma general. Además, si la comparamos con la definición de folk del mismo Cortazar que citamos anteriormente, se podrá deducir el grado de coherencia entre lo que se concibe teóricamente como pueblo y la manera en que se lo busca hasta encontrarlo. En el folk que emerge de este procedimiento, los jóvenes no tienen nada que decir, las mujeres están condenadas a representar el estereotipo de la conservación -de la tradición como de la especie- y en la voz de un personaje se condensará la totalidad cultural e histórica de una sociedad, aunque quién es esa persona no nos interese y sus ideas y sentires personales nos estorben. Curiosa forma de metonimia analítica, más sofisticada aún que la analizada en la construcción del estilo histórico musicológico.

Aunque para Cortazar el folklore era localizado, el mismo recurso podemos encontrarlo en la selección de informantes en el sur estadounidense de Alan Lomax, aproximadamente en la misma época en que Cortazar escribía el texto citado. Como sabemos, Lomax junto a su padre John, estaban buscando registrar la música más auténticamente negra de la región. Los folkloristas, en su búsqueda esencialista del vector puro de la cultura, en la pesquisa para encontrar la garantía de la autenticidad, luchan siempre, en inferioridad de condiciones, contra un enemigo implacable: los medios de comunicación y la cultura que de ellos emana, que elimina, casi como una peste, todo tipo de cultura tradicional. Es un poder enorme, pues como pensaba Lomax y prácticamente todos los folkloristas, algo como la radiodifusión podía exterminar en cuestión de semanas las tradiciones musicales que, como resistencia consciente a la opresión, la explotación y hasta la esclavitud, se habían conformado en el transcurso de varios siglos. De ahí la ansiedad y la preocupación de los folkloristas, que siempre dan esa sensación de estar en la cubierta de un barco a punto de hundirse. La cultura es algo que a los folkloristas siempre se les está escapando de las manos. El punto es que son ellos mismos quienes fabrican la arena. Volviendo a Lomax, su problema entonces para hallar a los informantes correctos era que casi todos los miembros de las comunidades negras ya estaban "contaminados" por el virus de la radio, el teatro de Tin Pan Alley y el Minstrel Show. Parecía que ya no quedaban negros verdaderamente "negros". Salvo en un lugar, convenientemente aislado, es decir, autónomo de esas influencias culturales nocivas para la cultura de los negros, que no se daban cuenta que estaban dejando de ser "negros". Ese lugar, impresionante clarividencia de los Lomax mediante, era la cárcel. En el sur estadounidense extremadamente racializado de la década de 1940, con sus leyes de segregación y su violencia racista explícita, los negros más negros estaban presos. Por alguna fechoría, tal vez. Pero seguro, por ser negros. Y esa era la certeza de lo auténtico que los folkloristas estaban buscando y hacia allí se dirigieron, con sus aparatos grabadores. El argumento de Lomax era que el encierro de la cárcel, en donde no había prisioneros blancos, neutralizaba por aislamiento la influencia de la cultura blanca. «Un convicto negro recluido por mucho tiempo [...] se deshace del idioma blanco que alguna vez utilizó en su propio lenguaje, y vuelve cada vez más a su propio idioma, el de la gente común negra»207 (Lomax, citado en Miller, 2010, p. 260). Afuera de la prisión, la comunidad afroamericana libre no quería cantar ante el micrófono de Lomax, según él porque desconfiaban de un blanco, pero podemos suponer que no querían realizarse, como el folklorista les proponía. Las personas a las que Lomax y su padre se acercaban, a

207 «[A] long-time Negro convict [...] slough off the white idiom they may once have employed in their speech and revert more and more to the idiom of the Negro common people»' (Lomax, citado en Miller, 2010, p. 260) [traducción del autor] 
menudo se mostraban reticentes a mostrar su cultura ante un extraño con una máquina de grabación en búsqueda de la auténtica negritud. Pero cuando los Lomax pudieron obtener la cooperación los directores de las prisiones estatales, los sujetos podían ser coaccionados y convertidos en informantes.

Pronto apareció en el cuarto el enorme hombre negro, asustado pero sonriendo condescendientemente. El director dijo "Black Sampson, párate delante del micrófono y canta lo que sea que este señor blanco te pida". Black Sampson se arrastró vacilante hacia el micrófono... y comenzó a rezar: "Oh Señó, ve' en qué lío está tu poble hombre negro. Aquí está en este mundo donde tiene que hacé todo lo que el hombre branco le diga. Pero oh Señó, espero que comprenda y perdone a mí por lo pecado que estoy por cometé y no castigue al pobre negro que no puede defenderse. Por Cristo nuestro Señó, Amén", tras lo cual se puso a cantar una hermosa canción de trabajo. Mientras, nuestra máquina había grabado tanto la oración como el canto208 (Lomax, citado en Miller, 2010, p. 262).

¿Qué puede esperarse de esa situación en términos de autenticidad? ¿A qué crueldades hay que someter al "folk" para extraer pura su esencia cultural incontaminada? Existiendo tal grado de conciencia de la opresión en el "informante" ¿cómo invisibilizarlo como sujeto y considerarlo una muestra del colectivo "pueblo"? ¿Seguiremos confiando en la grabación como registro fiel e inalterado de la expresión popular? $\mathrm{O}$ en todo caso, ¿puede sostenerse todavía que si Lomax hubiera tenido una libreta en lugar de un grabador, su registro hubiese sido menos fiel?

De hecho la manipulación de la situación en la cual se toma del intermediario el registro atraviesa la totalidad de la empresa folklórica, desde sus inicios. Tengamos en cuenta aquí nuevamente la noción de musicar, en términos de ocasión musical o como prefería Small (1999) «ritual en el espacio social». Sea en el extremo de las prisiones para afroamericanos de Estado Unidos o en la tranquilidad de la campiña, la manipulación de la situación mediante la selección de los informantes y de la interpelación que hacia ellos hace el folklorista, solicitando cierto repertorio, pidiendo moderación en los temas y sonoridades subversivos, exigiendo prácticamente que sean auténticos; todo eso modifica significativa e irreversiblemente el musicar. En un pequeño metraje fílmico en que puede verse a John Lomax conversando con Leadbelly (HuntleyFilmArchives, 2013) para arreglar su salida de prisión y permitir lo que sería el lanzamiento de su carrera musical, puede verse el servilismo y la auto personificación como "negro" que hace el exconvicto frente a quien ve como su salvador: «¡Por favor Jefe, lléveme con usted!». Además y tal vez más importante, se constata que esa aparente autonomía de los afroamericanos encarcelados frente a la cultura de los blancos es pura ilusión, ya que no solo su repertorio "negro" era en realidad transcultural e influenciado durante al menos un siglo por los espectáculos "comerciales" (Miller, 2010), sino que también es el propio Lomax el "blanco" que influye en Leadbelly exigiendo como parte de la negociación que sea un auténtico negro, quien ante la aceptación de Lomax exclama «¡Gracias Jefe, yo cantaré todas las canciones para usted!».

Si recuperamos la analogía legal que discutimos junto a Carlo Ginzburg en el capítulo 1, podemos ensayar aquí otra comparación similar: el mediador, el folklorista, contamina la escena y las pruebas en el acto mismo de la recolección. Y esto no tanto por su presencia o porque observe con la lente de sus propias ideas (la conocida dialéctica etic/emic de la antropología que luego permeó en la etnomusicología y que ha despertado múltiples

208 Soon the big black man, frightened but smiling ingratiatingly, came into the room. "Black Sampson," said the Warden, "stand up before the microphone and sing whatever this white man tells you." Black Sampson shambled up to the microphone . . . He prayed: "Oh Lawd, you see what a fix yo po black man is in. Heah he is down in do world where he has to do ev'ything this white man tells him to, But Oh Lawd, I hope you will understand and forgive me for de sin I is about to commit and not charge it up against a po negro who caint hep hissef. For jesus' sake, Amen," and then he sang some beautiful work song. Meanwhile our machine had recorded both the prayer and the songs. (Lomax, citado en Miller, 2010, p. 262) [traducción del autor] 
soluciones posteriores a estos problemas). Es la misma exigencia de autenticidad en el marco de una fuerte relación de poder, que interpela y presiona al intermediario escogido, el cual no puede más que sentirse "subalterno" e "inferior". No es posible que convengamos que en la situación de campo de los folkloristas se mantenga la ocasión del musicar. Y ya esto sólo anula las posibilidades de que consideremos a estas grabaciones o registros música popular. Las performances urbanas de Leadbelly y sus colegas contemporáneos y posteriores de la escena comercial del Blues son mucho más "música popular" que lo que puede haberse grabado en la cárcel a punta de pistola y arrastrando los grilletes. Por supuesto que no por su mediación técnica "moderna", y más allá del fuerte contraste en las condiciones de libertad y humanidad. La escena "comercial" del blues construye una nueva ocasión social, una nueva realidad cultural; un musicar transcultural que reenvía el carácter tensionante y en suspensión de esta música al terreno del mundo popular subalterno.

La presencia de la huella del folklorista se observa en la definición que de "mediación" hace Harker, al inicio de su libro, mientras nos deja muy en claro que tenemos que ser conscientes de que todo folklorista tienen siempre un objetivo intelectual, a la vez que material e ideológico.

Por mediación entiendo no sólo el hecho de que algunas personas particulares transmitieron canciones que obtuvieron de algunas fuentes, desde manuscritos o la imprenta; sino que en ese mismo proceso lo que buscaron, aceptaron y rechazaron estuvo significativamente determinado por sus prejuicios, actitudes, gustos y disgustos. Y no solo eso, porque también entran en juego el sólo hecho del acceso de estas personas a las fuentes, y que tuvieran el tiempo, la oportunidad, los motivos y los medios para hacer la recolección, junto a otro conjunto de factores materiales. Por supuesto que los factores materiales e ideológicos no discurren de forma separada en este proceso, Por lo tanto, si bien no podemos 'leer' lo que una persona hizo con las canciones a partir de, por ejemplo, su posición de clase, es posible afirmar todavía que sus orígenes sociales, su educación, ocupación (o falta de ella), entre otros, son factores obviamente conectados a como sentía, pensaba y hacía en relación con las canciones y a todo lo demás. Aunque estos procesos no se daban de una forma mecánica e inevitable, de todas formas estaban vinculados ${ }^{209}$ (Harker, 1985, p. xiii)

Todos los folkloristas, de los ilustrados y románticos a los positivistas, de los que usaron éstos o aquellos medios técnicos, de tendencia progresista o conservadora, europeos o americanos; todos por igual al poner delante del carro la zanahoria de la autenticidad necesitan de la edición. Por "edición" estamos aquí entendiendo de forma integral el conjunto de procedimientos que despliega la tarea del folklore en función de sus objetivos: la selección (de sonoridades, técnicas, temas, lugares y personas); la manipulación (de las ocasiones sociales de las músicas y también la modificación de las muestras registradas); la reorganización de las muestras para su circulación y exhibición, fundamentalmente comercial pero también académica (desde las colecciones a la composición lisa y llana, pasando por las ediciones para el público en general, de partituras y de fonogramas).

Todo este trabajo es necesario para producir un sentido afirmativo de lo popular (desmovilizador, nacional, racializado y subalterno) generando al mismo tiempo la negación del mundo popular subalterno. Como éste es, incluso en la Europa moderna un espacio en

209 «By mediation I understand not simply the fact that particular people passed on songs they had taken from other sources, in the form of manuscript or of print, but that in the very process of so doing their own assumptions, attitudes, likes and dislikes may well have significantly determined what they looked for, accepted and rejected. Not only that, but these people's access to sources of songs, the fact that they had the time, opportunity, motive and facilities for collecting, and a whole range of other material factors will have come into play. Ideological and material factors in this process did not occur separately, of course. So, while we cannot 'read off' what a person did with songs from, say, their class position, it is still the case that their social origins, education, occupation (or lack of it) and so on were obviously connected with how they felt, thought and acted, in relation to songs as to everything else. These things happened, not in a mechanical or an inevitable way, but they were linked all the same» (Harker, 1985, p. xiii). [traducción del autor] 
el cual «lo escrito y lo oral, la ciudad y el campo, la pequeña y la gran tradición, coexistían y se influían mutuamente» (Burke, 2014, p.125), a lo cual podríamos añadir el vector de lo transcultural y mestizo; el folklore debe entonces buscar las diferencias para producir al folk y su unicidad cultural, haciendo que lo popular participe de la cultura afirmativa.

Ya desde el siglo XVII vemos ponerse en marcha una producción de cultura cuyo destinatario son las clases populares. A través de una "industria" de relatos e imágenes se va a ir configurando una producción cultural que a la vez media entre y separa las clases. Pues la construcción de la hegemonía implicaba que el pueblo fuera teniendo acceso a los lenguajes en que aquélla se articula. Pero nombrando al mismo tiempo la diferencia, y la distancia entre lo noble y lo vulgar primero, entre lo culto y lo popular más tarde. No hay hegemonía -ni contrahegemonía- sin circulación cultural. No es posible un desde arriba que no implique algún modo de asunción de lo de abajo [...] para decirse culturalmente la clase hegemónica no tuvo más remedio que nombrar a la otra y su cultura. (Martín-Barbero, 1991, p.110)

Pero las manifestaciones del mundo popular subalterno, con su demora en los pasajes y su permanente carácter transicional, emergen siempre complicando el proceso. Porque la presión sobre los informantes populares produce efectos contrarios a lo que se busca

[En Catamarca] recorrí casa por casa, preguntando por los cantos antiguos que se conservan en la tradición oral y que vienen de padres a hijos desde tiempos inmemoriales. Unos sabían algo, otros no recordaban nada; buscaba a los viejos, a las viejas, a la gente joven, a los niños, a los guitarreros de profesión, a los cantores, a la gente trabajadora, a la casera y a todo el mundo. Algunos recordaban el principio de algún cantar, otros el fin y hasta hubo quien solo me dictara dos versitos. En más del $60 \%$ de los casos el pueblo no sabía nada. Ocurría a veces que después de una semana de investigaciones diarias, no anotaba sino coplas. Una vez me dictaron el Inválido de Mitre y otra, unas rimas de Bécquer. Algo sacaba, sin embargo, y eran las noticias de que antes hubieron cantores que sabían versos muy bonitos... (Carrizo, 1926, p.7)

También Chamosa (2012) recuerda que en aquel ejercicio tan interesante y ambicioso como fue la Encuesta Nacional del Folklore de 1921 en Argentina, cuyo resultado todavía habría que seguir analizando, la recolección de leyendas, mitos, poesías y canciones relevadas por los maestros en todas las escuelas del país, daban resultados contrarios a lo buscado por el gobierno nacional. Así, las fábulas y leyendas que, se suponía, eran de tradición oral y folklórica, eran tenidas por típicas y locales tanto en el noroeste del país como en el conurbano bonaerense; en los valles de Salta y Tucumán las milongas de Gardel eran lo que cantaba el folk, y «la maestra Palmira Rivas describe chacarera, gato, cueca y zamba como danzas locales de Villa Domínico» (Chamosa, 2012, p. 57), una localidad situada a unos catorce kilómetros de la Capital Federal pero a más de mil de Santiago del Estero, la provincia de Chazarreta.

Es cierto que los instrumentos de recolección de la Encuesta de 1921 tenían no pocos problemas y en algunos casos eran tan estrictos en la tipificación de lo que se buscaba que muchos maestros terminaron citando como material folklórico los manuales del Consejo de Educación (Ministerio Nacional) al no encontrar nada parecido "en el campo". Es un caso bastante extremo, pero nos muestra con crudeza los problemas que pueden surgir del folklore y su objeto de estudio, que es muy estrecho ya en su propia concepción teórica. Estos problemas no son algo que se produce en la periferia, o simplemente por el mal diseño de los útiles de investigación. Podemos encontrar problemas muy similares a lo largo de la historia de la disciplina y asociados al trabajo de los representantes más ilustres del campo. E incluso tenemos el mismo testimonio de Andrés Chazarreta sobre su "método" de recopilación, sobre el cual ya discutimos a propósito del "origen" de la Zamba de Vargas.

Viene alguien o sé yo de alguno que conoce algún baile o canto que oyó a sus padres o cuando era chico. Me lo cuenta y yo lo transcribo al pentagrama, puliéndolo, limándolo, pero 
siempre conservando el tema y el ritmo del original. Lo que más me cuesta es, muchas veces, la introducción que generalmente es obra mía y que tiene que ser como de una sola pieza con el resto. Así he arreglado, transcripto o compuesto más de trecientos cincuenta piezas... (Chazarreta, como se citó en Reder Carlson, 2013, p. 129).

Al historizar la trayectoria del folklore en Gran Bretaña, Dave Harker describe con mucho detalle la forma en que algunas figuras precursoras muy emblemáticas, como Walter Scott, William Motherwell o Francis James Child o Motherwell, anteponían sus concepciones por delante de los datos que les devolvía la recolección, manipulando permanentemente los resultados en aras de un sentido particular del folklorista. Esto tiene muchas resonancias con las ideas acerca del gusto presentes en la estética del lluminismo pero también con la figura emergente del crítico de arte que, en muchos casos, se superpone a la del historiador y también al folklorista en el temprano siglo XIX. Child, por ejemplo, alardeaba de su talento para saber si una balada era original y popular, o no, alegando que poseía un sentido de la percepción de aquello que había sido "corrompido", generalmente por la acción de la imprenta de cancioneros de pliegos sueltos (broadsides) o libros de cordel (garlands), que incluían canciones. "Podía reconocer cuando un "lugar común" era "familiar" o no, y cuando un texto era anciano o de factura reciente» 210 (Harker, 1985, p. 58). Para Child la poesía y el canto popular eran productos espontáneos de la naturaleza y este aspecto las diferenciaba de lo inauténtico, producido por músicos profesionales que, aunque no carentes de gracia en su totalidad, pertenecen a "la literatura artificial" (Harker, 1985, p. 60), es decir, lo inauténtico.

Un grupo de folkloristas ingleses activos alrededor de 1900, como Baring-Gould, Kidson y Broadwood, revelan las incoherencias entre la idealización folklórica y las manifestaciones recolectadas. Por ejemplo, si bien casi todos los folkloristas consideraban que el folk ideal estaba formado por trabajadores rurales, los informantes del hacendado y presbítero Sabine Baring-Gould son, en su mayoría, artesanos, profesionales urbanos o directamente indigentes desempleados que cantaban en las calles. Sin embargo el folklorista continuaba hablando de las canciones del campesinado («peasantry») (Harker, 1985, p. 162). Incluso cuando se encuentra con un personaje que cuadra en su "tipo ideal", como le ocurre con un informante llamado Roger Luxton, omite toda referencia a su historia. El problema no es solo que refuerza el prejuicio de lo comunal al aislar a su fuente del contenido registrado, dando continuidad así a su creencia romántica de que las canciones brotaban espontáneamente de los corazones tristes o alegres del pueblo. El problema es que Luxton era un cantante profesional caído en desgracia que tiempo antes había sido empleado para amenizar las reuniones de los hacendados y terratenientes, moda que al pasar lo había forzado a ser un campesino (Harker, 1985, p. 151). De hecho, sus canciones provenían de ediciones antiguas de baladas y tonadas de la imprenta, es decir, del circuito comercial urbano. Las artificiosas y falsas baladas según Child.

Frank Kidson, por su parte, dejaba descansar en su gusto personal la selección de las melodías que buscaba proteger de los embates de la imprenta, los cantantes profesionales y el music-hall, que rápidamente se difundían, como vimos en el caso argentino, por medio del ferrocarril. Consideraba que había que distinguir entre las canciones de estos espectáculos, que eran agradables aunque tontas, de las verdaderas canciones folklóricas, las cuales se detectaban porque sus tonadas eran juzgadas "bellas" y nos mostraban la auténtica tradición (Harker, 1985, p. 155). Aunque Kidson no tenía ni la más remota idea de cómo era la música antes del ferrocarril, del music-hall ni de la imprenta. Lo cual no le impidió publicar comercialmente, por medio de suscripciones, sus Traditional Tunes de 1891, adaptadas al gusto de las clases medias de Oxford.

210 "He recognized when a "commonplace" was "familiar" or not, and when a text was or was not “ancient”» (Harker, 1985, p. 58) [traducción del autor] 
El caso de Lucy Broadwood es tal vez el más revelador ya que, al tratarse de una mujer, la situación de recolección debía producirse con muchísimo más detalle y cuidado, en medio de una sociedad victoriana fuertemente moralista. Esto habla por un lado de la enorme valentía de Broadwood, quien como legado familiar era propietaria de una modesta industria editorial para la cual buscaba las canciones a publicar. Lo cual no quita que tuviese también un interés académico, además de ideológico. Por ser mujer, no estaba bien visto que se la viera mezclándose con el vulgo de la clase trabajadora, en tabernas, cobertizos o graneros. Por lo tanto Lucy tenía que hacer que los informantes vinieran a ella, invitándolos por medio de terceros a su casa o la de algún amigo, para allí registrar las canciones a partir de las performances. Para garantizar que los informantes fueran los adecuados, enviaba una lista de canciones que, en caso de saberlas, operaban como factor de validación de los cantantes. A su vez, para confeccionar las listas, Broadwood se basaba en cancioneros anteriores recopilados por otros músicos y folkloristas, algunos de los cuales solicitaba por correo y en no pocas ocasiones se generaron confusiones y Lucy terminó recibiendo cancioneros equivocados que presentaban baladas impresas, comerciales, en lugar de folklóricas. En paralelo, los agentes que buscaban a los cantantes malinterpretaron las guías de Broadwood sobre el tipo ideal de informante, que eran semejantes a las descripciones que vimos antes por Cortazar, por ejemplo. En la acción de seleccionar a los sujetos para las recopilaciones, afloraron entonces todos los prejuicios que la burguesía podía tener sobre la clase trabajadora, urbana o rural. Por ejemplo, Samuel Willet, un asistente de Broadwood, usaba como criterio la "rusticidad" de las personas. Este cuasi desopilante mecanismo de búsqueda de lo auténtico por control remoto produjo que «entre las prohibiciones y el criterio subjetivo, queda claro que Broadwood estuvo en el negocio de prescribir qué era una "canción folklórica" y qué no»²11 (Harker, 1985, p. 165). Por si fuera poco, a la hora de editar las canciones, y apuntando a un mercado de clase media, Broadwood seleccionaba las melodías que presentaran escalas modales, a las que consideraba marca de antigüedad, descartando por inauténticas las que sonaban en base a una escala mayor convencional. Es decir que si los cantantes y ayudantes de Broadwood no podían discriminar suficientemente bien lo auténtico de lo inauténtico, ella como editora y mediadora podía hacerlo por ellos. De igual modo recortaba y adulteraba los textos, para limpiarlos de términos o modismos vulgares e indecentes desde el punto de vista burgués. Lo cual nos muestra con mucha claridad hasta qué punto existía una edición profunda del pueblo, al punto de recortar lo que como vimos era parte estructural de la cultura del mundo popular subalterno. A lo cual hay que añadir, en el caso de Lucy Broadwood, un proceso de autocensura de los propios informantes, que evitaban cantar ante la dama canciones tan rudas que no correspondía cantarlas ni siquiera ante un caballero (Harker, 1985, p. 168), lo cual nos recuerda la coerción y lo extraño de la situación para los informantes, como ocurría con los presos de Lomax.

211 «Between prohibitions and subjective criteria, it is clear that Broadwood was in the business of prescribing what a "folk song" was and was not» (Harker, 1985, p. 165) [traducción del autor] 


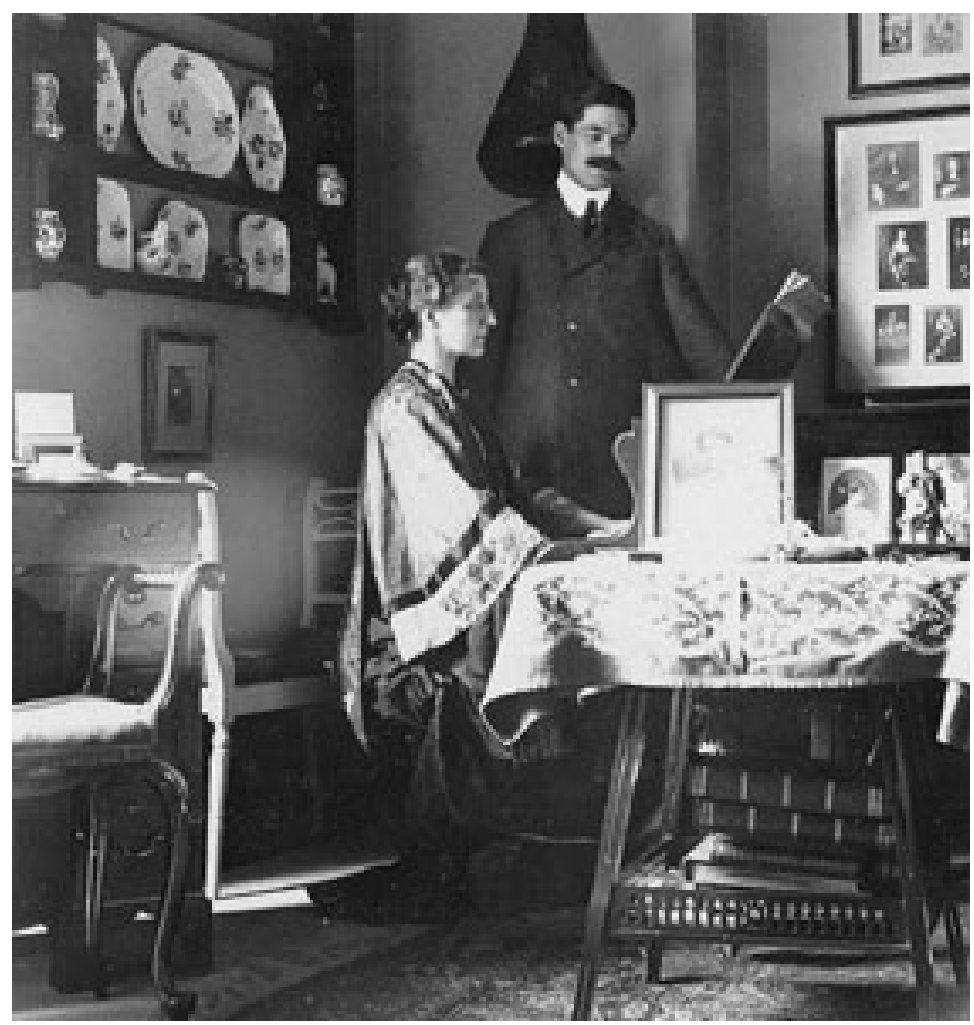

Lucy Broadwood al piano, en su casa, a principios del siglo XX

Sobre estos tres importantes folkloristas, figuras epigonales para la fundación en 1898 de la Folk Song Society de Londres, Harker escribe un apartado que denomina Their editing (Sus formas de edición) a lo largo del cual aparecen repetidamente alguna palabras muy significativas: sifted (seleccionadas-clasificadas), altered (alteradas-modificadas), choose (elegidas), preferred (preferidas), adapted (adaptadas) a las cuáles se suman las frases expunged erotic (expurgaba el erotismo) y excluded songs dealing with drink (excluian las canciones que trataban sobre la bebida). El grado de manipulación y edición es enorme y no puede dejar de relacionarse a la condición social de cada uno de los tres: Bearing-Gould era presbítero protestante además de propietario, es decir, terrateniente, y Broadwood una mujer de la burguesía, de la respetabilidad. Kidson por su parte era un anticuario y librero, hijo de un oficial de impuestos. Todo un representante de la respetabilidad burguesa.

Sin ponerse necesariamente de acuerdo, sino como una derivación de su pertenencia común a la burguesía, «extirparon toda pieza que tuviera alguna pizca de lucha obrera, subestimando en todo momento a los músicos de la clase trabajadora, y por lo general reconstruyeron una cultura musical desde una perspectiva ideológica muy obvia, para beneficio del Duque, los miembros de la Sociedad de Antigüedades, cualquier anticuario musical del país, y todas las conexiones que estas personas tenían dentro de los ambientes cultivados» ${ }^{212}$ (Harker, 1985, p. 166). Pero también es importante tener presente que, además de construir una idealización refinada de la música popular, Baring-Gould, Kidson y Broadwood fueron de los primeros que tomaron el control del folk-market de estos bienes muebles que eran las canciones folklóricas, situación que les permitió acaparar el mercado editorial de la música popular genuina. Pudieron, de este modo, combinar su liderazgo en las ventas dentro del mercado musical, como también la capacidad de intervenir

212 «They excised any piece which smacked of working-class struggle, downgraded worker-musicians at every opportunity and generally reconstructed a musical culture [...] from a very obviously ideological perspective, for the benefit of the Duke, members of the Society of Antiquaries, musical antiquarians elsewhere in the country, and all these people's connections in polite society» (Harker, 1985, p. 166) [traducción del autor] 
ideológicamente en su propia cultura, la de la burguesía, y por extensión, en la cultura de la clase trabajadora (Harker, 1985, p. 165)

Esta simultaneidad, que expresa una modelización del pueblo acompañada con el desarrollo de un producto a tono con el gusto de la burguesía y las clases medias, se completa con la "mejora" de las músicas recolectadas de manera selectiva e interesada. Como ya referimos para los casos de Vega y sus versiones para orquesta, o de Chazarreta y sus partituras de Zamba para piano, la producción de los folkloristas ingleses solía comercializarse en forma de arreglos, en general para piano, los cuales por lo menos incorporan una armonización tonal y alguna configuración de acompañamiento al estilo de la música de salón, que era un repertorio culto destinado a la práctica amateur y doméstica de las clases medias. En esta línea, Sabine Baring-Gould se asoció con un músico profesional, H. Fleetwood Sheppard, que aunque se había formado en la Iglesia «podía comprometerse personalmente en la melodía de una balada, hacerla suya y rodearla con un torrente de exquisita armonía» además de tener el talento para "escribir un acompañamiento científicamente correcto» (Baring-Gould, como se citó en Harker, 1985, p. 166). Para el folklorista había también que insertar versos nuevos que para reemplazar gran parte de las palabras obscenas y poco delicadas. De modo tal que la censura poética sumada a la armonización y al acompañamiento al estilo de la música culta, permitía hacer que estas canciones «sean aptas para cantarse en el salón de una casa [...] haciendo de los textos algo tolerable para hombres y mujeres de cultura [...] salvando las exquisitas melodías de ser asesinadas por las palabras con que están enlazadas [en conjunción con un] acompañamiento simpático que realza enormemente su encanto» (Baring-Gould, como se citó en Harker, 1985, p.166). La manipulación, por lo tanto, revestía una importancia crucial para poder insertar las canciones populares en el mercado, dominado por el gusto burgués. Como dice Harker, Baring-Gould y sus colegas estaban reescribiendo la cultura (1985, p. 166).

Las manipulaciones más o menos explícitas en el trabajo de recolección no eran para nada nuevas a comienzos del siglo XX. Peter Burke cita como el editor del siglo XVIII Thomas Percy (ique había cambiado su nombre de Pearcy para parecer más noble!) declara que "Con pocas y leves correcciones y adiciones se ha conseguido dotar [a las canciones] de un sentido más bello e interesante» (Burke, 2014. p.55)

\footnotetext{
Este autor también cita una famosa anécdota vinculada a Cecil Sharp, el más eminente de los folkloristas británicos, que recopiló muchas canciones de una señora llamada Brown. Mientras Sharp creía -o deseaba creer- que ella era campesina, la verdad es que era la hija de un profesor de música versado en las tradiciones populares y sobre todo en las colecciones impresas de Percy y de otros antiguos compositores de música popular, como Ossian. Más allá de la naturaleza particular de cada canción que Brown cantó ante Sharp, "es probable que estos conocimientos afectasen a sus versiones $y$, en cualquier caso, su interés por lo sobrenatural, su sentimentalismo y su rechazo de todo lo erótico, reflejaban las actitudes de las clases medias de finales del siglo XVIII. Ella era, sin duda, un intermediario" (Burke, 2014, p.125)
}

Es muy clara la encerrona conceptual en la que intenta introducirnos la disciplina del folklore, al hacernos participar de un juego del huevo y la gallina que no tienen ningún sentido. Incluso Burke recuerda que los famosos hermanos Grimm basaron sus célebres colecciones en la información que les proveyó una mujer ("Die Frau Viehmännin") que era descendiente de franceses exiliados por cuestiones religiosas. «¿Conocía la colección de Perrault? ¿Son algunas de las coincidencias entre ésta y la de los hermanos Grimm el resultado de una dependencia accidental con un informador particular?» (Burke, 2014, p. 125). El problema es entonces la concepción esencialista y homogeneizante de la cultura que plantea el folklore. No hay hontanares ni orígenes que buscar, ni certificados de 
autenticidad. El tráfico y la circulación de las músicas entre diferentes sectores sociales, así como entre vertientes culturales con historias divergentes y cosmovisiones contrastantes, es una característica de lo que podemos llamar cultura popular. Como vimos, y podríamos seguir buscando ejemplos, todos los informantes y también los mediadores o folkloristas, estuvieron siempre relacionados e influenciados por el mercado musical, fuese este performativo, impreso o fonográfico, dependiendo de las transformaciones tecnológicas. En todos los casos que analizamos, detrás de un informante, a la vuelta de la esquina, siempre hay algún músico profesional, algún cancionero impreso, el manual estatal de música, o incluso grandes obras de la música universal. A su vez, la industria musical, el mercado sonoro, por lo menos desde el siglo XVI en adelante, se ve influenciado permanentemente por la producción aficionada y la participación de todo tipo en el musicar, eso que el folklore malinterpretó -es decir, quiso malinterpretar- como "espontáneo" y de "tradición oral". La cultura y la música del mundo popular subalterno es una interacción permanente entre todas estas vertientes, intereses, tradiciones y anhelos. Parafraseando a García Canclini (1989, p. 17) podríamos decir que en música popular debemos preocuparnos por estudiar cómo es que se dan las transformaciones y procesos de mixtura en la historia, más que por destilar las supuestas contaminaciones perpetradas en detrimento de esos manantiales puros de un pueblo ficcional.

\subsubsection{El consenso de la Zamba: Recuerdos del porvenir que también evocan grandes éxitos}

Como vemos, la autenticidad del folklore parte de formatos que habitan el corazón del mercado del espectáculo, los cuales, como también pasaba con Chazarreta y su compañía, cumplen un rol temprano en el proceso de crear una tradición nacional. Pero como este factor mercantil no sólo suele estar oculto, sino que se lo niega explícitamente, es importante remarcar que, en todos los casos que venimos analizando, la apelación a la autenticidad y a lo telúrico «no estaba enraizada en la historia, el patrimonio o la memoria colectiva. Se basaba en el consenso» (Miller, 2010, p.5). ${ }^{213}$

Por ejemplo, dos momentos fundamentales del desarrollo de la disciplina folklórica en Gran Bretaña son los que Harker denomina el «consenso de la balada» (1985, p. 121) y el «consenso de la canción folklórica (folksong)» (1985, p. 198), los cuales a su vez están relacionados a los folkloristas Francis James Child y Cecil Sharp, respectivamente. ¿A qué se refiere Harker con el término consenso? En primer lugar, a la producción de definiciones acerca de la música y la poesía popular configuradas en torno a los conceptos centrales del folklore que venimos analizando críticamente (lo oral, lo rural, la tradición, lo anónimo, lo comunal, la nación, la raza, etc.). Las categorías que surgen son, por lo tanto, cristalizaciones en las cuales se hacen coincidir de manera dirigida los tópicos y conceptos con la manipulación y edición de los casos. Como hemos visto que surge del trabajo de los folkloristas, se busca lo que se quiere encontrar y se acomoda lo encontrado, para que coincida con las premisas de partida que obedecen a valores estéticos e ideológicos de la burguesía. Al partir de supuestos apriorísticos, los folkloristas

tenían que avanzar y deducir algo parecido a una psicología social de las comunidades históricas [es lo que vimos que hace el positivismo] y una historia cultural que coincidiera. Los "elementos" de las baladas y las ideas acerca del "folk" que acuñaron o por lo menos ayudaron

213 «authenticity was not rooted in history, heritage, or collective memory. It was founded on consensus» (Miller, 2010, p.5) [traducción del autor] 
a propagar, se integraron a lo que es en esencia un análisis estético basado en valores académico-literarios contemporáneos ${ }^{214}$ (Harker, 1985, p. 125).

Un procedimiento por lo demás, muy similar al de la musicología histórica, que extendía su paradigma estético hacia atrás en la línea de tiempo buscando las "obras" que pudiesen coincidir con ese modelo y pasar a formar parte del canon. Por eso Harker denomina al consenso «un proceso teorético incestuoso» 215 (Harker, 1981, p. 146) en la medida en que las asunciones y prejuicios son convertidos en deducciones y leyes a partir de la manipulación y edición de los datos. Es interesante observar que Jacques Attali ubica como objetivo del proceso que se abre con la "representación", es decir la comercialización de la música escénica e impresa y la instalación del sistema tonal y la combinatoria armónica, «hacer creer en una representación consensual del mundo» (Attali, 2011, p. 72). Es decir, la música de la modernidad se basa en el consenso. Como venimos diciendo, esto es la afirmatividad que no sólo esconde y disimula tras bambalinas las formas de producción, la inequidad y la injusticia que hacen posible la puesta en escena del orden, sino que transforman a ésta en obligatoria y por lo tanto la presentan como emergente de un acuerdo que disuelve las tensiones, que olvida la lucha y los intereses de las clases sociales. John Storey, tomando las ideas de Harker, interpreta el discurso de Parry al que ya nos referimos antes como un alegato en favor de "un consenso nuevo en el cual las divisiones de clase perderían sus cualidades antagónicas y pudieran existir solo como diferencias entre personas que comparten una anglicidad esencial» 216 (Storey, 2016, p. 208). En el consenso se articulan entonces varios, sino todos, los presupuestos de la afirmatividad moderna acerca de la música y, en particular, de la música popular definida como folk. Como es una articulación de aspectos políticos, nacionales, étnicos y estéticos, las manifestaciones -que se aceptan como populares "del folk" y que serán puestas a circular comprimidas en el folkmarket- y sus definiciones se desentienden de los aspectos históricos, los niegan o minimizan en favor de los esencialismos de la patria, la raza, la tradición y la comunidad. Sólo así, negando la historia, la memoria colectiva, la dinámica inestable, transcultural y en suspensión del mundo popular subalterno; sólo así, mediante un consenso impuesto, arbitrario e incluso irracional, la música popular se nombra y se inscribe en el cambio comercial.

El caso del folklore argentino que venimos analizando es un claro ejemplo de esto. El proceso que inicia con la publicación de la Zamba de Vargas por Chazarreta (1908) es parte de un movimiento que se extiende por lo menos hasta la década de 1940 y desembocará en una representación consensual de la "música argentina" configurada entre músicos y musicólogos, y dentro de la cual la zamba, como género, no jugará un rol menor. Será efectivamente, la danza argentina, el baile nacional, en contraste con danzas de Chile y Perú, fundamentalmente, a partir del reconocimiento de la zamacueca como tronco común. Es significativa la enunciación de Chazarreta sobre su zamba y que el contenido de "Vargas" relate esa historia y de esa forma. Que también es consensual, afirmativa. Cómo las tropas nacionales -que para Vega son "las fuerzas leales" (1981, p. 105)- defienden a la Patria del invasor, que además de bárbaro y asesino es fundamentalmente extranjero, chileno- desde esta perspectiva no importa si Salvatierra y su compañía eran pobres o hacendados. Tampoco si realmente simpatizaban con Taboada, si veían como sus iguales a

214 «Given that these theorists were content to deduce their 'definition' from Child's texts, it followed that they had to go on to deduce something like a social psychology of historic communities, and a cultural history to match. The 'elements' of the 'ballads', and ideas about the 'folk' who made or at least transmitted them, get blended into what is essentially an aesthetic analysis based on contemporary academic-literary values» (Harker, 1985, p. 125) [traducción del autor]

215 «theoretically incestuous process» (Harker, 1981, p. 146) [traducción del autor]

216 «new consensus in which divisions of class would lose their antagonistic qualities and exist only as differences between people who shared a fundamental Englishness» (Storey, 2016, p. 208) [traducción del autor] 
los Granaderos venidos de Buenos Aires, o si los sentían distantes y superiores. Todo eso, sobre todo las posibles simpatías que alguno tuviese con los varelistas, la probabilidad de que vecinos y amigos catamarqueños y riojanos formasen parte de ambos bandos, y de que pelearan una batalla que no entendían ni querían; todo eso se disuelve, se funde en una armonía graduada que orbita, que "resuelve" en la idea de nación, de "argentinidad esencial" que lucha por su libertad. Y que lo hace al son de una Zamba, que es -a partir de aquí será- la música argentina.

La zamba es muy argentina. No es como la cueca, que es tan andina, tan amplia, tan abarcativa, y que tiene un toque de cada región, de cada país. Pero son cucas, o marinera en el Perú. Pero la zamba es argentina. Entonces la idea de que viene de la zamacueca y es un desprendimiento más, es una idea que, bueno, puede tener cierta validez histórica. Pero en realidad no da cuenta esa idea de la entidad de la zamba, que es su sello, su personalidad, su carácter, su sutileza y su argentinidad. Es muy, pero muy argentina. Los argentinos estamos hechos de zamba (Juan Falú, en Irigoyen, 2014)

Es conocida la tozudez y fervorosidad con que Juan Falú instala cada vez que puede la discusión sobre la argentinidad del folklore y su sentido excluyente de ser la música popular, la única, que represente a nuestra sociedad. Son célebres sus objeciones al Rock nacional, el tango y la música tropical,217 sus capacidades de representar la identidad musical del país. Y está bien, son en tanto son las opiniones de un músico profesional. Pero lo que nos interesa aquí es ver cuáles son las nociones consensuales y afirmativas que, en un músico que incluso comulga con un pensamiento progresista y hasta diríamos de "izquierda", puede hacer que reproduzca todos los tópicos de negación del pueblo que venimos analizando como parte estructural del folklore. Incluso podríamos pensar que la figura de Atahualpa Yupanqui es producto de un pensamiento consensual, similar al que vimos expresado por Vega en referencia al empresario Antonio Mauri. Yupanqui es, de alguna forma, elevado al rango de representante del folklore argentino que, como vimos, es localizado en el noroeste del país. Si bien Yupanqui no es tal, sino que es Chavero, y es de Pergamino, Provincia de Buenos Aires, y por si fuera poco descendiente de vascos y de padre ferroviario, la idea consensual de que el folklore representa a la Nación en su totalidad, y de que el cantautor folklórico expresa el sonido de la tierra, como un médium, casi involuntaria e inevitablemente, oculta todos esos rasgos inconvenientes y convierte a Chavero en Yupanqui, en figura paradigmática de la autenticidad del folklore. En este caso, podemos ver hasta qué punto es totalmente irrelevante para la construcción del pueblo ficcional del folklore que sus músicos canten en contra de la explotación y sean afiliados del Partido Comunista. Una anécdota contada por Sergio Pujol ayuda además a considerar el papel de la industria cultural y los medios de radiodifusión en la creación del consenso folklórico. En ocasión del debut de la radio El Mundo de Buenos Aires en 1935, en los camarines reservados a sus artistas que actuaban en vivo, la estelar Azucena Maizani, cantante de tango, conversa con la figura del bolero Juan Arvizu. Es que se enteraron de que en los próximos días debutaría con un programa de música nativa una cantor llamado Atahualpa Yupanqui. «No se sabe bien de dónde procede Yupanqui. En una reciente nota en el diario Crítica, se lo había presentado como venido del Altiplano, aunque algunos mejor informados aseguran que nació cerca de Pergamino, donde habría aprendido a tocar la guitarra a la manera clásica. ¿Quián puede saberlo? Habrá que escuchar» (Pujol, 2013, p. 2013)

217 Solo como ejemplo recordamos la famosa discusión con Diego Boris sobre la creación del "Día nacional del músico" y la queja ante los organizadores de los actos políticos del "campo nacional y popular", que pasan cumbia y no folklore, que puede verse aquí: https://youtu.be/OT36WJXQEws?t=665 . No son chistes ni comentarios al pasar, sino parte de alegatos, conferencias y opiniones, en muchos casos profesionales requeridas por autoridades culturales y educativas para el diseño de políticas públicas sobre la música popular. De allí la trascendencia de las opiniones de Falú. 
Por un lado, está claro que la zamba, en tanto representación de la argentinidad, está construida en contraste excluyente con otras músicas. Músicas que según esta visión parten de «un uso miserable que destruye las tradiciones». Es decir que la zamba recordemos, producto de la imprenta, del espectáculo, de un músico profesional- es expurgada de todos esos elementos para pasar a significar una entidad autónoma, puramente sensible y estética. Pero aún más todavía, tenemos que pensar que el núcleo de la concepción está en esa frase en que, para justificar que la zamba es "muy argentina", se desvaloriza la "validez histórica". Es decir que la negación de la historia es necesaria para producir el consenso. O a la inversa: el análisis histórico producirá la anulación automática de toda pretensión que busque instalar un género musical homogeneizado, cristalizado, como representación fiel del mundo popular subalterno.

Uno de los padres de la zamba fue don Andrés Chazarreta que tocó en 1906, a pesar del rechazo del público, una zamba en un teatro por primera vez. Era la Zamba de Vargas, considerada la primera zamba argentina, de autor anónimo, e inspirada en la batalla del Pozo de Vargas [...] hay hipótesis que sostienen que la Zamba de Vargas fue el eslabón visible de la transformación de la cueca en zamba (Irigoyen, 2014, m.8:26).

En el fragmento con que continúa el documental del que proviene la cita de Falú, existen algunas inexactitudes en torno a la fecha de la presentación de Chazarreta, y a que el audio que acompaña la locución es en realidad la versión conocida como riojana de la zamba, es decir no la de Chazarreta sino la "recopilada" por Juan Adolfo Carrizo. Sin embargo, nuevamente puntualizamos que en este fragmento se reproduce el consenso en torno a que la Zamba de Vargas es la primera zamba argentina -aunque como vimos no era "zamba" lo de la batalla-, que es anónima -aunque Chazarreta es su padre- y que, dado el simbolismo patriótico que le da su participación en batalla, particulariza para siempre a la música argentina del tronco "extranjero" de la cueca. Es además una extraña forma de simbolismo instrumental, que suena la crónica y no la canta porque, como ya sabemos, faltan unos años para que Lombardi la escriba. Un criterio totalmente ajeno a las tradiciones populares que no representan de forma instrumental sucesos y crónicas, sino en forma de canción. El «rechazo del público» completa la presentación consensual de una música que, de tan auténticamente popular, termina siendo incomprendida por el pueblo.

\subsubsection{Agitando pañuelos en el país de Goofy}

En cuanto a imágenes consensuales se refiere, hay una fotografía que tal vez sintetiza visualmente estos aspectos que tienden a cristalizar nociones ocultando las condiciones. Es una estampa que muestra a Chazarreta y su conjunto tocando ante una pareja de bailarines que, agitando pañuelos, parecen expresar con la mayor autenticidad las tradiciones nacionales del sentir popular. Y si bien los músicos mantienen el extraño atavío propio de gentes urbanas, es una distracción menor, ya que los flanquean unos verdaderos gauchos. Sin embargo lo que realmente es disruptivo aparece cuando reconocemos a Walt Disney como el bailarín que domina el centro de la foto. 


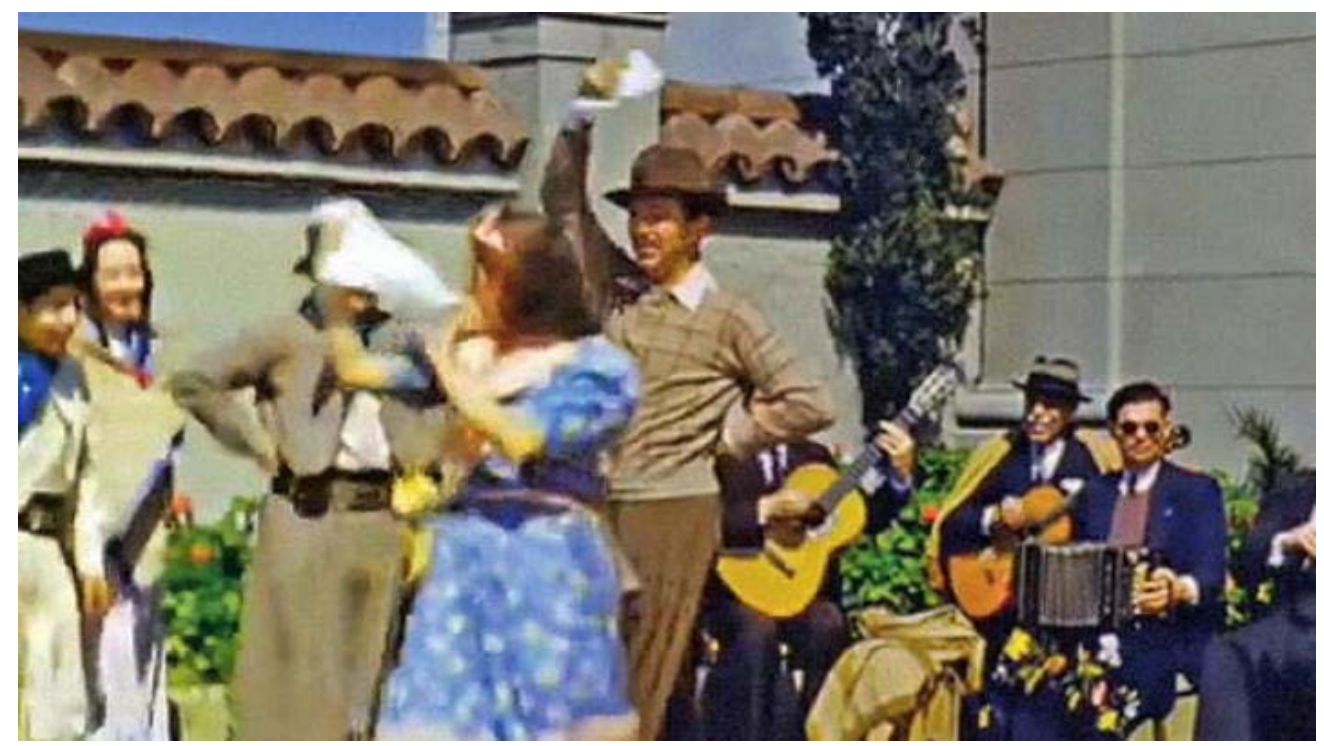

Walt Disney agitando pañuelos mientras baila una zamba junto a Anita Chazarreta. A la derecha, de sombrero y tocando la guitarra, don Andrés Chazarreta. Terraza del hotel Alvear Palace, Buenos Aires, 1941.

Disney había sido comisionado por el Departamento de Estado norteamericano para realizar un gira por América del Sur, en el marco de la política del Buen Vecino, y aparentemente con la intención de contribuir a que los países latinoamericanos se alinearan con EEUU en el contexto de la Segunda Guerra Mundial. Como fruto del viaje, Disney realizó una serie de películas animadas con temáticas "latinoamericanas", entre las cuales se destaca Saludos Amigos (Disney, 1942a), que incluye una performance de danzas nativas a cargo de Goofy personificado con el atuendo de los gauchos, quienes son, según nos explica otra película que cuenta el making of, «los vaqueros argentinos» ${ }^{218}$ (Disney, $1942 b, 13: 19)$. Es notable que al comienzo de la secuencia ${ }^{219}$ sobre Argentina, el famoso perro animado aparece vestido con bombacha y sombrero, en la desolada campaña, sentado sobre una montura, tocando la guitarra. La locución dice: «al caer la noche, a menudo encontramos al gaucho solitario en la inmensidad de la pampa». Pero súbitamente, la ejecución del "triste" se interrumpe, salta y entrecorta, y un movimiento de cámara nos muestra que en realidad lo que se escucha es un disco girando en una vitrola. El gaucho hacía playback.

${ }^{218}$ El ejemplo 49 comienza en el minuto 13:19 del video que puede verse aquí https://youtu.be/OGTCmiXURaA? $\underline{\mathrm{t}=799}$

219 La secuencia sobre Argentina de Saludos Amigos a la que hacemos referencia (ejemplo 50) puede verse aquí https://youtu.be/n3rz8vEW3vl 


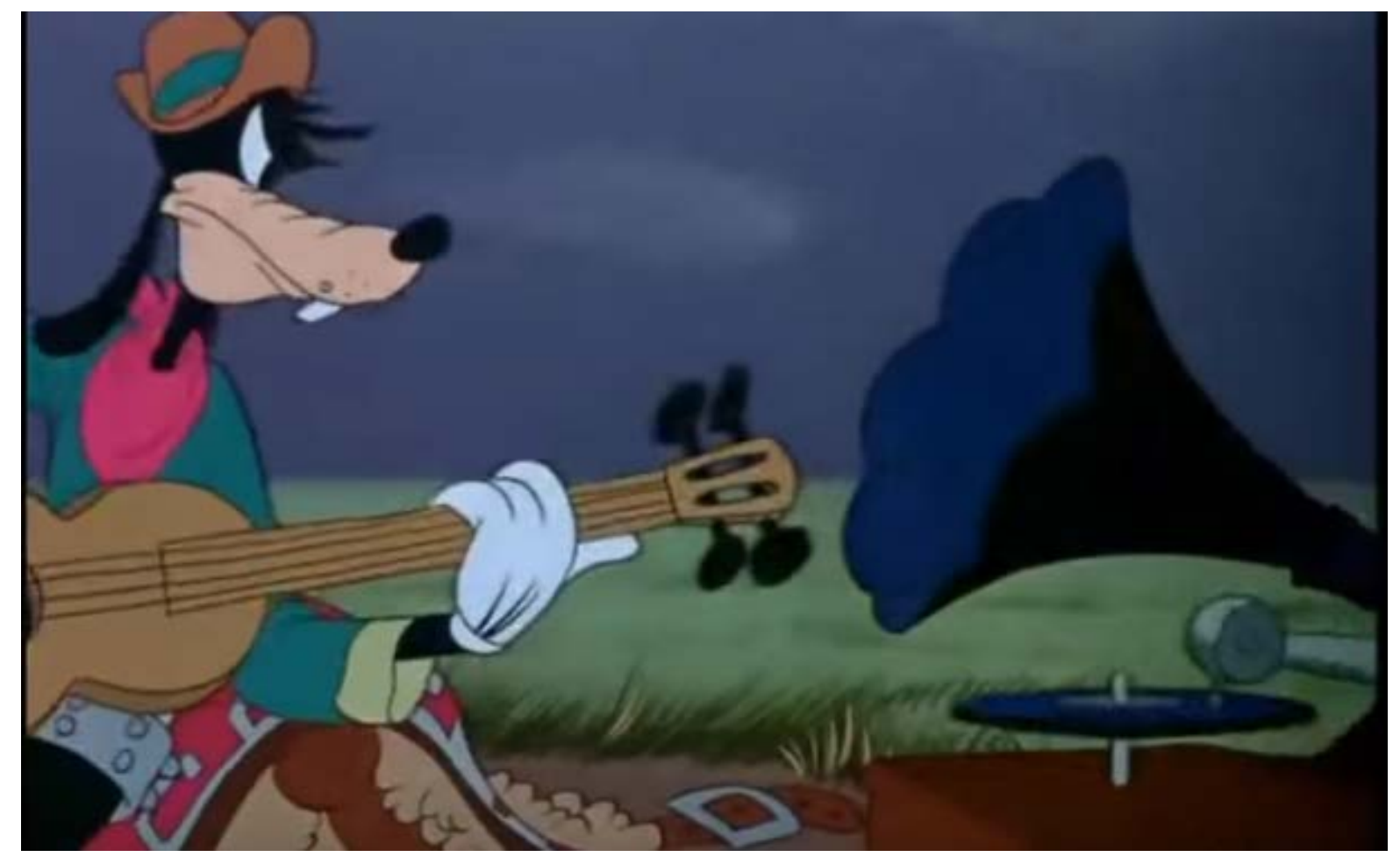

El gaucho Goofy contrariado una vez que se descubre el engaño de la vitrola (Disney, 1942a, 23:58)

Esta humorada puede tener cierta relación con que para el dibujante norteamericano "el profesor" Chazarreta haya sido apreciado como "una autoridad en música y bailes argentinos» (Disney, 1942b, 11:42). Vimos que en parte podemos explicar la construcción en torno a su figura y la recepción de sus espectáculos como verdadera muestra de la música popular de nuestro país, en base al auge del músico-empresario en los medios masivos y el hábil aprovechamiento de los canales de la industria cultural entre las décadas del 30 y el 50. Como en el caso de Inglaterra y su folksong, o de Estados Unidos y su blues "negro", es la industria cultural la que da forma a lo que, en el mejor de los casos, la academia cristalizará como definición consensual. En ambos ejemplos, las definiciones se alejan de la historia, a la que reemplazan por estereotipos. Las diferencias tal vez existan en el grado de exclusión que las definiciones de la academia proponen y en sus pretensiones. Más allá de eso, debemos tener en cuenta que son «los libros y las películas [las que] han hecho del gaucho un personaje romántico y con glamour» (Disney, 1942, 13:29).

\subsection{El folklorista y el juglar}

Ahora que sabemos que es música popular del siglo $\mathrm{XX}$, más precisamente del primer cuarto de siglo; que fue influenciada por dispositivos comerciales como el circo, la imprenta y los conciertos públicos; que no hay en ella ninguna supervivencia, ni tradición comunal que como reminiscencia habite en sus cadencias; que es música urbana, si necesitamos todavía ubicarla. Y que está más cerca de la metrópoli, de Buenos Aires, como menciona Walt Disney, que de la ciudad de Santiago o cualquier otra urbe del norte argentino; ahora que sabemos que los gauchos del bosque no existen, escuchemos nuevamente la Zamba de Vargas.

Para ello, imaginemos primero la ocasión musical, la gente entrando al teatro, en Santiago o en Buenos Aires, con una mezcla de incógnitas y prejuicios sobre la naturaleza del espectáculo, pero sobre todo con algún anhelo de entretenimiento, sin demasiadas pretensiones. En algún momento, la iluminación de la sala se atenúa y comienza... el 
cinematógrafo. Algunas películas cortas, sin sonido, tal vez sobre algunos hechos de actualidad, muy probablemente algún episodio cómico y desopilante. Tras lo cual se descorre el telón y aparece la elaborada escenografía de un paisaje distante, de una tierra mágica que pertenece al mito y la leyenda, sobre la cual unos personajes extrañamente ataviados personifican una escena imaginaria. Un conjunto de músicos que se parece mucho a otros que el público seguramente ya ha escuchado, comienza a tocar. Los personajes revelan su faceta de bailarines y así, con el baile, empieza la Zamba de Vargas.

La increíble pericia de los instrumentistas y sus floreos, la tensión constitutiva entre los planos, la fricción entre los planos sonoros que agrupan a distintos timbres; todo eso suena a música compleja, profesional. Son arreglos interesantes, que se basan en el sonido más que en la armonía. Como ya referimos antes, hay modos de toque que provienen de matrices históricas muy diversas, pero que no tienen problema en encontrarse y convivir, aún en conflicto, dentro de la misma música. El ritmo tiene una organicidad de bordes blandos, ya que pareciera que cada ataque está empujado, como si le costara hacerse sonar. Es difícil saber si estamos hablando del ritmo o de la textura, o si esa diferenciación analítica aquí tiene algún sentido. Lo que sí es seguro es que hay una compleja trama en donde el ajuste métrico perfecto no es buscado, en la que se superponen los floreos del piano y la flauta, por encima de la melodía principal del violín, que a su vez discrepa con la base del bombo, la guitarra, el bandoneón y también en parte el piano. Los instrumentos de este "fondo" nunca terminan de fundirse en un solo plano, porque se corren entre sí y se reconoce su carácter compuesto, aunque no suena nada artificioso. Parecen dar sentido a esa distinción que usa Quintero Rivera (2009) entre «el colectivo» y «el individuo», ya que se escucha que la particularidad del "toque" de cada instrumento contribuye al todo sin diluirse en el acompañamiento -palabra que nos suena extraña en este contexto. Lejos de ser un experimento o un galimatías de "pifies" acentuales, por el contrario funciona muy bien como sostén para el baile y su tensión interna, entre los dos órdenes temporales de diferente dimensión que se superponen, permite más que complica los floreos y quiebres de los zapateadores. Estos bailadores, más que seguir el ritmo, exhiben una «interpretación entre líneas» (Keil, 2001, p. 267) o hermenéutica, en dónde no hay nada que "contar", sino que la continuidad del movimiento está basada en un contratiempo no racionalizado, o mejor, una asincronía relacional, que se demora en los intersticios del patrón rítmico. Hay un fragmento fílmico en el que aparecen dos de los bailadores de Chazarreta que vimos antes en la fotografía, Enrique Suárez y Pedro Giménez, bailando malambo.220 Tiene sonido, por lo cual podemos escuchar con bastante claridad la relación entre los guitarristas y el zapateo en que se alternan ambos bailarines. Todo el interés radica en cómo se corren, casi diríamos "flotan" por encima del ritmo, ya de por sí complicado y compuesto, al punto tal que es muy difícil anticipar, aún cuando se conoce el género, los movimientos y la resultante sonora del zapateo. Es un desvío permanente, un groove (Keil, 2001) o un floreo (Quintero Rivera, 2009) que es muy frecuente también, por ejemplo, en los redobles de los bombistos en la chacarera, sobre todo en las introducciones, cuando se unen a lo que las guitarras ya vienen sonando. No podemos dejar de comentar que el filme de los zapateadores abre con una placa en la que se lee "genuinos bailarines norteños en un breve zapateado", luego de una imagen fija en que ambos "posan para la foto". Si aún nos vemos impelidos de territorializar, podemos decir además que el malambo, si algo no es, es santiagueño.

Toda esta trama de ajustes desajustados, de sonido-textura (Reynolds, 2010) en el cual las categorizaciones del análisis armonicocéntrico son más que insuficientes, podría caber en el concepto de discrepancias participatorias (Keil, 2001) que asociamos al musicar, porque de eso estamos hablando. Estas discrepancias tienen además una base

220 El ejemplo 51 puede verse aquí https://youtu.be/JOhxnetficU 
transcultural, y podrían servirnos de punto de partida para mejorar nuestra definición de mestizaje y eliminar de ella todo rastro racializante que lo confunda con el mesticismo. En el toque de los músicos y el movimiento de los bailadores de Chazarreta, en esa compleja red de diversidades de las que emerge una identidad sonora, habitan las fricciones de los procesos históricos que confluyen en toda música popular latinoamericana. Podemos pensar la difícil convivencia asincrónica de los timbres y los planos sonoros como parte de la heterología del mestizaje, en el cual se rehúye todo el tiempo a cualquier intento de síntesis, de fundirse en una totalidad estable. El complejo sonoro-textural-rítmico de la Zamba de Vargas es un buen ejemplo del aspecto "en suspensión" que proponemos considerar como rasgo de las músicas populares. Y el mestizaje, como concepto, es una categoría que puede ayudarnos a asir este fenómeno transicional que vive de la mezcla y la superposición desarticulada, y que habita en los pasajes.

La Zamba de Vargas es inescindible no solo de la ocasión socio musical, de la danza, del espectáculo performance. Es una música que ocupa un mismo espacio social con el cine, el circo y los demás espectáculos populares de principios del siglo XX. Es por eso inescindible de la industria cultural, y el público espera eso de la compañía en sus presentaciones, en donde lo telúrico es lo exótico, lo colorido, lo llamativo y lo impactante. Por eso la Zamba de Vargas no es lo "común", en el sentido de costumbre popular (Thompson, 2000). Si hubiese sonado cotidiano, corriente, aún manteniendo las connotaciones como sucede con el Himno Nacional; si hubiese significado eso en el público, aún en Santiago, la zamba y el espectáculo todo de la compañía jamás hubiesen tenido el éxito ni la trascendencia que tuvieron. El término trascendencia puede contribuir aquí también a caracterizar lo que hay de popular en Chazarreta. Su significación es también ambigua y se ha utilizado de múltiples formas, incluso en la estética clásica. Pero aquí preferimos considerarlo en un sentido social o incluso socializante, como hace Simon Frith (2014), en cuanto a que es parte del proceso de la ocasión social de la música, siendo en un mismo tiempo productor y consecuencia del musicar en términos de identidades, colectivas e individuales. Es decir que a partir de esta música se generan una serie de identidades intersubjetivas en todos aquellos que intervienen en el proceso, desde los músicos, el público, los intelectuales, los políticos, los empresarios, etc. $Y$ esos sentidos identitarios, individuales a la vez que colectivos, difusos más que vívidos o articulados -en el sentido de Gramsci-, vuelve socialmente trascendente la materialidad sonora, es decir, se proyectan como ocasión musical, social e histórica, a nivel individual pero al mismo tiempo, como configurador del colectivo. De ninguna manera podemos pensar esto como algo «extramusical» como pensaba Dahlhaus (1997) o «extraestético» como sostenía Vega (1944). Es parte de la música, y su potencia justamente reside en que no podemos explicarlo mediante ninguna «lógica interna de los materiales».

Como vimos, el folk(c)lore de Chazarreta es una de tantas músicas que en Occidente surgen en el mercado, lo que algunos llaman «folclor de masas» (González, 2014, p. 189) o «folclore profesional» (Madoery, 2010), aunque estas distinciones terminan, por acción u omisión, revitalizando la idea de un folklore no profesional, comunal y territorializado. Si bien las músicas de Chazarreta, a su tiempo, formaron parte del discurso dominante -en este caso, nacionalista- y fueron generadas en la dialéctica de los sectores hegemónicos con la industria cultural, evidentemente interpelaron a algún sustrato de los sectores populares, "hicieron pie" en un mundo popular subalterno que poseía formas profesionales y comerciales específicas y antiguas, como el espectáculo profesional popular, el circo criollo, mestizadas con tradiciones de más larga duración, como el carnaval y las danzas mulatas (Quintero Rivera, 2009) como la zamacueca, el candomblé o la habanera, junto a los cancioneros populares mestizos de la época colonial. Por eso estas músicas populares perduran. Si hubiesen sido meras ficciones del nativismo cosmopolita o del panamericanismo, como el Guarany de Carlos Gomes o el Goofy gauchesco, hubiesen 
acabado en efímeros recuerdos de artificiosas modas incomprensibles. Está claro que estas músicas no corresponden a los «gauchos del bosque» ni al «país de blancos» del Tucumán, aunque también incluyen contradictoriamente estos imaginarios y, a la larga, alteran su sentido para siempre. Tampoco descienden del payador "culto" que, como expusimos en el capítulo 3, representa otro desarrollo histórico popular (Fornaro, 2010) muy diferente aunque se lo incluye en la misma industria del Folk(c)lore, como también sucede con el Chamamé (Lezcano y Zubieta, 2017). ${ }^{221}$ Se inspiran en la imagen ficcional del gaucho pero se parecen más a las pantomimas del Moreira circense que a las elucubraciones de Lugones y sus payadores perseguidos de habla forzosamente "gauchesca". Pero no son eso. Son músicas populares latinoamericanas, justamente porque no proceden de premoldeados, ni responden sumisas -y se tensionan permanentemente-con los proyectos nacionalistas y la voracidad de la industria cultural transnacional. Las músicas populares folk(c)lóricas no son obedientes ante los estereotipos, aunque los toman todo el tiempo para "corromperlos". Porque la música popular, a su manera, es corrupta, porque es mestiza e impura. Existe porque se permite aquello a lo que la cultura "legítima" no se atreve, razón por la cual las clases hegemónicas elaboran complicados dispositivos de voyeurismo cultural, uno de los cuales es el folklore.

Que la zamba, la de Vargas o cualquiera de las que le siguieron, es parte de la música popular, en tanto manifestación que tensiona la realidad cristalizada, es dinamogénica (Andrade, 1984) y se permite mirar hacia el futuro en busca de esa «nueva realidad de civilización», ese "segundo mundo» posible, queda expresado en esta descripción de Liliana Herrero, justamente sobre la zamba:

a veces hay conversaciones con lo hecho, la interrogación es tan extraordinaria, que entonces sí aparece, no digamos algo nuevo, [sino] un horizonte auditivo diferente. Si yo abro o logro abrir un horizonte auditivo diferente, y bueno, entonces estamos diciendo "es posible otra cosa aparte de aquello que fue hecho". Es posible otra cosa (Irigoyen, 2014, min 22:26).

Es decir, únicamente a expensas de contravenir los mandatos de tradicionalistas y folkloristas, de abandonar el deseo por conservar supervivencias en pos de conversar con lo hecho -cosa completamente diferente-, haciendo ingresar la dimensión histórica, y creyendo en lo que de transformador y nuevo tienen las culturas populares, puede la zamba ser música popular.

Con mucho afecto hacia su padre, Agustín Chazarreta escribió una biografía-homenaje que se llama El juglar eterno. Es una designación muy interesante, como título de una semblanza sin demasiadas pretensiones de trabajo científico, como sí pasa con Vega y sus apuntes sobre los tradicionalistas, con sus folkloristas y sus trovadores. Es el testimonio de un hijo que ve en su padre a lo que fue un artista profesional recreando música popular, que es ser también creador. Alguien preocupado porque la música sea un entretenimiento y al mismo tiempo presente frente al público un elemento de identificación. Con menos romanticismo que en los folkloristas, en la biografía aparece también el relato de hasta qué punto la actividad de Chazarreta se puso en tensión con las autoridades gubernamentales o legítimas, tanto de las provincias como de la Nación. En ese sentido es claramente un juglar como los que estudiamos en el capítulo 2. En cambio el folklorista, que no es Chazarreta sino Vega, ve en la música que pone en escena don Andrés un descenso de la tradición de los trovadores. Para Vega, aquellos de los cuales Chazarreta extrae su inspiración o recopila sus músicas son los que usufructúan músicas anacrónicas, músicas extinguidas

221 El estudio que hacen estos autores sobre la configuración del Chamamé como género comercial de la música popular posee muchas similitudes, en cuanto a proceso socio histórico, a la historia de Chazarreta y la Zamba de Vargas. Es muy interesante cómo se menciona que todos los representantes del género triunfan en Buenos Aires mientras son desconocidos en su propia tierra correntina (Lezcano y Zubieta, 2017, p. 23). Otra tradición selectiva, en este caso cantada en guaraní y no en quechua. 
originarias del ámbito culto y que ahora, como supervivencias, permanecen en el ambiente popular. Un ambiente popular como gustan encontrar los folkloristas: comunal, amateur, iletrado, asistemático; prácticamente inconsciente. Vega, finalmente, revelando hasta qué punto llegan sus contradicciones, terminó creyendo también en esas "carretas orales» que tanto denostó ridiculizando a Cortazar. Aunque fuera más parecida a la carreta de Lancelot, el del poema del Chevalier de la charrette, que tanto cantaban los trovadores provenzales y que como vimos en el capítulo 3, para Vega son el contenido musical de los campesinos de América Latina. El de Vega es un doble amo, dominante y colonial. Así se revela en toda su intensidad el carácter afirmativo de los folkloristas y el modo en que transforman, editan, comodifican y critalizan una música que en realidad es actual y es vigente, porque es popular. Cuando pensemos en la historia de la música popular prefiramos al juglar de la urbe, a Chazarreta, incluso con su mistificación de la historia nacional. Y descartemos al folklorista.

Hemos visto que todos los conceptos y metodologías del folklore se configuran de modo consensual, ocultando o disimulando los procesos por medio de los cuales se producen y emergen las manifestaciones que se adjudican al folk. Sobre todo, la acción del mercado musical y sus productos impresos, escénicos y discográficos; pero también la huella del nacionalismo con la creación de su comunidad imaginada y su tradición selectiva, junto al etnocentrismo que clasifica racialmente a los pueblos. Como el folklore siempre orientó su búsqueda en función de la autenticidad, tuvo que construir sus objetos, que en la cultura popular jamás existieron.

¿Es el folklore entonces un mero invento? No, no es tan simple. El folklore es un acto de compresión de la música popular, necesario para hacer ingresar en el cambio económico a la música popular y para convertir a los sectores populares en subalternos, todo en la misma operación. Porque sólo así, en condición de dominación, puede existir un pueblo legítimo para los folkloristas. El folklore es, entonces, un modo de pensamiento sobre el pueblo, no una tipología musical específica. Por eso, el folklore no existe como tal, aunque sí existen los folkloristas. Deberíamos invertir el enunciado de Herder que nombra a esta sección, para comenzar a desarticular estas formas esencialistas de pensar las músicas populares. Porque el pueblo no es el folk. La lente que el folklore posa y mediante la cual pretende conocer es en realidad un espejo que refleja el travestismo de la burguesía anhelante y fascinada por disfrazarse de pueblo. La historia que cuenta el folklore, en todo caso, debemos leerla como la historia de la intervención de los sectores hegemónicos en la cultura popular, para editar sus manifestaciones y comprimir su cultura. La música popular entonces, al menos lo que aquí estamos intentando definir como tal, no es el folklore. 


\title{
Capítulo 5
}

\section{Ministriles transmodernos}

\author{
"Lo "popular" permanece como cultura, como costumbres, como economía, \\ como ecología debajo de todos los procesos, en particular cuando hay pueblos \\ premodernos (como los mayas, aymaras, quechuas, etc.), que acompañando la \\ modernidad irán más allá de ella (en la civilización transcapitalista, trans- \\ moderna, no pos-moderna que todavía es moderna, eurocéntrica, \\ metropolitana)» \\ Enrique Dussel (2006) \\ «Los europeos decian que en América los pájaros cantaban mal [...] \\ porque no cantaban como la alondra, el ruiseñor, que era el paradigma del \\ buen canto. Entonces esa alienación simbólica produjo una incapacidad \\ para mirar la realidad de forma directa» \\ Adolfo Colombres (1991)
}

Está claro que los juglares de los que nos ocupamos en el capítulo 2 no entran en las categorías de la compresión que aplica el folklore a la música popular: ni son sujetos colectivos ni el alma del pueblo, ni son anónimos tampoco; ni siquiera son más primitivos que los trovadores, a quienes entretienen primero y enseñan después. Sus modos heteróclitos de musicar, emergentes del pathos de la transformación y la recreación permanente, no pueden fijarse: son la expresión última de la dinámica popular. Sumemos a esto la confluencia de tradiciones y vertientes culturales en que se amontonan al menos prácticas del imperio romano, de la música andalusí y la tradición levantina, incluso los celtas y hasta los famosos bárbaros. Esto los hace transculturales. Los órdenes categoriales y clasificatorios de raza, origen, objeto o especie no pueden aplicarse en ningún caso a los juglares.

Recordemos que Hoppin (2000) dice de ellos que son los «incultos». Pero más aún que fuera de la cultura, están fuera de la sociedad. Como los migrantes clandestinos e indocumentados de nuestro tiempo, en su trashumancia carecen de todo derecho. Como señala Katrin Lengwinat, están fuera de las relaciones de la sociedad. Son los nadies del mundo medieval, lo cual los coloca en una proscripción permanente que les granjeó fama de ladrones y bandidos. En algunos casos, es probable que esto tuviera algún sustento. Nada más lejos que esas bandas de hombres alegres en las que nos hizo creer el romanticismo y su bucólica silvestre.

Pero además está el tema del profesionalismo. Recordemos que, según el folklore, la música popular, la verdadera, es amateur. De acuerdo al credo de James Child, por ejemplo, el profesionalismo es señal de corrupción de lo auténticamente popular. Y justo ahí están los juglares, rudos, rústicos, sí; perseguidos, aunque célebres y favoritos en las cortes. Y trabajando. Libres. Tal vez a costa de su proscripción. Un caso extraño de autogestión y autonomía económica en tiempos precapitalistas. El profesionalismo, entonces, diluye toda ilusión que podría quedarnos de explicar el musicar de los juglares desde la compresión conceptual y política del folklore. Si sumamos esta incompatibilidad epistemológica al desprecio histórico que los músicos profesionales recibieron de parte de la estética moderna, la musicología decimonónica y las demás formas de intervención hegemónica sobre la cultura popular, esta condición, la de profesionales, es tal vez la que mejor explica el silencio de la academia que arroja a estos músicos fuera de la historia. 
Es justamente esta condición socio económica la que va a permitirnos explicar que, en el ingreso a la modernidad y mientras los sectores dominantes de la sociedad buscan reformar la cultura popular interviniendo en ella (Burke, 2014, p. 295), los juglares buscarán honrar la profesión, es decir, consolidar su actividad económica, pero ahora dentro de las reglas de juego del mundo burgués. Para ello, deberían convertir drásticamente su infravalorada imagen de salteadores de caminos para transformarse en ciudadanos respetables de pleno derecho. Asunto que nos trae un nuevo debate, no menos complejo que los que venimos afrontando en este estudio: ¿continúan siendo populares estos músicos ahora decentes, voluntariamente devenidos en "ex-juglares"? ¿Pueden sus músicas aún ser consideradas populares, incluso cuando quienes las pagan son parte de las clases dominantes? ¿Qué queda de esas prácticas y formas de musicar de la cultura popular precapitalista una vez que sus músicos, ahora urbanos, se domestican en la modernidad burguesa?

Al ser contratados por banqueros, mercaderes, cortes o incluso la misma Iglesia, es relativamente sencillo apurar una respuesta contundente en contrario de la vigencia de lo popular; aspecto que resulta sospechosamente complementario con el folklore y sus tópicos acerca de las supervivencias no-vigentes, la reclusión rural, el primitivismo y lo consuetudinario como dominios específicos del pueblo que queda superpuesto, como un enclave de lo viejo, dentro del mundo moderno. Y todavía más, si tomamos en cuenta que a partir de la mencionada intervención hegemónica en la cultura popular en base a los valores de la cuaresma, muchas de las actividades carnavalescas, como los disfraces de campesinos, "gitanos", "moros", "salvajes" o "bárbaros" (por ejemplo en las falsas bodas campesinas que celebraba la aristocracia), se transforman en disfrute exclusivo de una clase privilegiada, y por tanto, se sustraen por apropiación de su carácter popular (Petzoldt, 1993, p. 162). Es una plebeyización aparente que esconde un nuevo ciclo de estilización, que en la música se da en las danzas que terminan conformando el estereotipo de la suite como piezas instrumentales "para escuchar". Es decir, un agrupamiento de danzas para no danzar, lo cual es todo un prodigio si pensamos que es un claro producto de la racionalidad moderna, esa que no admite las contradicciones. En este mismo movimiento cultural de intervención se da la reclusión en un establecimiento específico -el teatro de ópera, luego el café concert- (Attali, 2011, p. 91) del musicar popular y carnavalesco (Taruskin, 2005b, p. 29), lo cual produce sin ninguna duda grandes modificaciones en el gusto de los sectores medios y subalternos de la sociedad, y finalmente deriva en que «el Carnaval era más una representación que una presentación» (Muir 2001, p. 111).

Si bajo estos presupuestos hasta parece relativamente sencillo, digamos casi de sentido común, suponer que los músicos populares aceptarían mansa y sumisamente una nueva condición servil hacia la cultura que las élites producen -o mandan producir- para entretenimiento de las gentes vulgares, ¿cómo considerar el rol de los músicos indígenas y negro-africanos en la América dominada por la invasión colonial? La respuesta corta, y nuevamente la mayoritaria entre los musicólogos, es que los sectores subalternos coloniales se aprestaron "presurosos a aprender todo lo posible de la música europea» (Stevenson, 1970b), ya que tanto los negros "como los indígenas, aspirarían a sonar como europeos» (Vera, 2016, p. 668). Esta concepción del mundo subalterno latinoamericano es compatible con la de los folkloristas que, si no hacen comenzar todo desarrollo musical en el ambiente culto ultramarino, como pensaba Vega, ubican como piedra angular del "conglomerado folklórico argentino» de la actualidad a «la enseñanza musical de los indios» por parte los misioneros (Aretz, 2008, p. 17). Es muy sugestiva la recurrencia en que diferentes corrientes metodológicas e ideológicas de la historiografía musical -como el positivismo, el panamericanismo y el posmodernismo, por ejemplocomprimen o directamente silencian las prácticas populares, lo que acarrea una negativa a reconocer su existencia como cultura específica y, por supuesto, toda posibilidad de resistencia. 
En muy raros casos se nos habla de los elementos indígenas que se pueden haber introducido en la liturgia católica [...] y casi nunca o nunca se percibe al indio como un agente activo en la producción de una cultura musical: es un mero receptor y reproductor" (Waisman, 2019, p. 73)

Aquí consideramos que se despliega con mucha claridad, como proyecto historiográfico hacia la música, lo que Grignon y Passeron denominan un dominomorfismo, que pasa a producir una imagen de «la cultura del pobre como más pobre» (1992, p. 140).222 Se recuperan así las consideraciones que son relativas a las teorías que conciben a la cultura popular como válvula de seguridad o de escape del descontento social, que analizamos en torno al carnaval y su pervivencia en el capítulo 2. Es decir que una vez más, y ahora incluso para la producción de la música popular, se cargan las tintas en el sector dominante de la sociedad, a quien se le vuelve a atribuir en exclusividad la sofisticación, la complejidad, la profundidad, e incluso la inteligencia. Casi como si se tratara de una canción de trovadores, las diferentes versiones de la historiografía musical afirmativa hacen sonar el pathos de la distancia. Así «la fiesta se transforma en el ornamento privilegiado de los mecanismos de imposición ideológica de la corona española en América» (Pedrotti, 2017, p. 220), argumento similar a los que analizamos en el capítulo 2. Por ejemplo, veamos las similitudes en el enfoque afirmativo de la historiografía que se aboca a dos ámbitos en principio desconectados aunque contemporáneos: la ciudad renacentista y el mundo colonial andino. En un primer caso, se nos ofrece una explicación del sentido de afirmación del poder dominante que permea la sátira, la inversión y la fiesta popular renacentista:

En una variante de esta tesis [de la "válvula de seguridad"], Victor Turner, alumno de Gluckman, subrayó el carácter liminar [...] de tales ritos. El absurdo, la paradoja, la extravagancia y el comportamiento ilícito de los rituales de rebelión proporcionan un escape emocional, pero, teniendo en cuenta que este comportamiento queda apartado de la vida cotidiana mediante el calendario ritual, la rebelión demuestra en realidad la coherencia del orden social tal como es. Un joven artesano veneciano, al parodiar al Dogo, demostraba en realidad el carácter inevitable de la inferioridad política de todos los artesanos (Muir, 2001, p. 107)

Del mismo modo, se nos presenta un sentido legitimador en la aparición de prácticas musicales y dancísticas de marcado carácter indígena en las ocasiones públicas del Cusco colonial

[La fiesta de] Corpus era una recreación de la subyugación de la civilización andina por parte de los españoles, un desfile anual de la victoria en el que se requería la participación de los Inkas derrotados para reforzar la estructura de poder colonial. Por lo tanto la música y el baile nativos fueron elementos esenciales, desde una perspectiva hispana, para señalar a este "opositor festivo" [...] La distinción reside entonces en el corazón de la fiesta colonial: los

\footnotetext{
222 Casi podríamos hacer una extrapolación del siguiente análisis de la sociología legitimista de la cultura que nos permitiría aplicarlo a los estudios sobre la "música colonial" de Latinoamérica, de Stevenson (1968) a Baker (2008): "Los mapas sociológicos del espacio trazados siguiendo este principio presentan una imagen invertida del territorio social: la descripción minuciosa y explorada de las "regiones polares" contrasta con las zonas casi en blanco, que señalan, en la parte baja de la representación gráfica, las tierras desconocidas -por no decir prohibidas- habitadas por las clases populares. Todo ocurre como si el observador, situado en el vértice de la pirámide social, perdiese poder de discernimiento a medida que su mirada discurre hundiéndose hacia las zonas bajas de dicha pirámide: la rarefacción de la información pertinente se hermana bien con la indiferencia a las diferencias, a las variaciones y a las oposiciones cuyo conocimiento es la única vía para construir el espacio social de los gustos populares» (Grignon y Passeron, 1992, p. 139)
} 
contrastes entre la música hispana y la indígena reproducen los límites y las jerarquías en forma auditiva (Baker, 2008a, p. 46). ${ }^{223}$

En ambos casos se niega agencia alguna a los sectores populares, los cuales no sólo padecerían la imposición del orden social sino que además la aceptarían mansamente, casi con cierta ilusión ingenua, a cambio de que se les otorgue la fruslería de vestir sus trajes, pasear sus cuerpos y hacer sonar su música. De todo lo cual, una vez más repitiendo el moto positivista, no tenemos ni noticia. Creemos que es en esta encrucijada -la de las culturas populares a un lado y otro del Atlántico que corresponde con el mundo popular subalterno, durante la modernidad temprana- que se despliegan las condiciones ideológicas que permiten unificar en un mismo arco historiográfico (y político) la reforma de la cultura popular de la que habla Burke con el desarrollo de la ideología estética que habita en la musicología histórica y el folklore, que deberíamos pensar en relación con la historia de la música como una tercera fase de dicha reforma (Burke, 2014, p. 390). Todo como parte del despliegue del proyecto civilizador de la modernidad, que piensa en todo momento y toda instancia del conocimiento a las manifestaciones populares como "más pobres"

Si nos hubiésemos propuesto estudiar las necesidades sociales y las actividades sociales bajo sus formas más acabadas, deberíamos observarlas en las partes más altas de la sociedad. Pero nosotros quisimos estudiar las clases. Pues bien, no hay sin duda clase más homogénea que la obrera, precisamente porque en ella la vida social es más reducida, menos complicada, y también porque la distancia que la separa de los otros grupos es, en este sentido, muy marcada (Halbwachs, como se citó en Grignon y Passeron, 1992, p. 144)

Uno de los útiles que la historiografía musical esgrime para intervenir y dar cuerpo a esta reforma es el concepto de estilo, con toda su carga ideológica de origen tal cual la analizamos en el capítulo 1. En el caso de la etapa histórica que estamos considerando ahora, es decir los siglos XV a XVIII, es notable cómo a través de la utilización de conceptos muy difíciles de compatibilizar con las realidades sonoras a las que se los pretende aplicar, se consigue silenciar la "contaminación" de la cultura hegemónica que logran tanto los músicos populares urbanos europeos, como sus pares indígenas, mestizos, negros y mulatos en Latinoamérica. Nos referimos a términos como Renacimiento musical y Barroco colonial o hispanoamericano. En ambos casos el simple uso de la periodización estilística va a generar una invisibilización de los actores responsables de las manifestaciones sonoras que escapan a la afirmación cultural de los sectores dominantes. El Renacimiento, como concepto historiográfico, ha generado numerosos debates en torno a su aplicación a la historia musical, los cuales están lejos de haberse cerrado. Así lo testimonian estudios célebres, como el de Edward Lowinsky (1954) o más recientes como son los casos de Alan Atlas (2002, p. 781), James Haar (2006, p. 20) y Richard Freedman (2018, p. 22).224 El caso del Barroco colonial es menos cuestionado en general, al punto de que incluso se ha

223 «Corpus was a reenactment of the subjugation of Andean civilization by the Spaniards, an annual victory parade in which the participation of the defeated Inkas was required in order to reinforce the colonial power structure. Native music and dance were thus essential elements, from a Hispanic perspective, in marking out this "festive opponent" [...] authorities in civic festivities in the city center. Differentiation thus lay at the heart of the colonial fiesta: the contrasts between Hispanic and indigenous music reproduced boundaries and hierarchies in aural form» (Baker, 2008, p. 46) [traducción del autor]

224 El ensayo de Lowinsky fue pionero al discutir la pertinencia de la periodización del renacimiento en la historia musical. Si bien concluye en forma positiva, enumera una serie de reparos y aspectos sumamente específicos necesarios para poder hablar de una música renacentista, argumentando la filiación con el término de acuerdo con coincidencias muy generales filosóficas, literarias y de clase social con otros sectores artísticos más claramente "renacentistas". En los casos de Atlas y Freedman, cuyos volúmenes se titulan La música del Renacimiento, los autores plantean un recorrido por diferentes perspectivas a favor y en contra de la utilización del término Renacimiento como indicador de periodización en la música. Atlas incluso le dedica todo un capítulo. Haar, por su parte, directamente propone una utilización restringida del concepto de Renacimiento musical, que sólo es posible de aplicar al conjunto de prácticas de los maestros de capilla de tradición franco flamenca y su estilo internacional polifónico en la misa y el motete. 
querido homologar el eclecticismo estético del "barroco" con cierta característica heteróclita del mestizaje (Romero, 2001, p. 107). Si bien en la mayoría de los estudios sobre la música en Latinoamérica durante la invasión y dominio hispano-lusitano el concepto se toma de forma bastante acrítica, es incluso un término que, como desarrollamos en el capítulo 1, suele estar en cuestión para la misma música europea, hasta el punto de proponerse su destierro como indicador historiográfico (Taruskin, 2005a, p. 797)225

Estos problemas derivados de la periodización estilística inciden tanto en las imágenes históricas de la música europea como de la latinoamericana, ya que son producto de la historiografía afirmativa. Como tales han producido sesgos importantes y duraderos: la creencia en una línea genealógica que se transmite sin interrupciones entre los compositores entre 1450 y 1600, que configura una especie de carrera de postas mediante la cual se desarrolla paulatinamente 226 el lenguaje musical occidental, que no es otra cosa que la organización de alturas basada en el intervalo de tercera y que permite la emergencia del sistema tonal; o la implantación ultramarina de la música concertada, especialmente religiosa, con toda su sofisticación armónica y formal, producto del tesón de los compositores ibéricos -y de otros sitios de Europa- junto a la labor misional de monjes y otros religiosos en la tarea de enseñarle música a quienes por poco aprobaron ser considerados seres humanos aunque, claro está, en estado salvaje. ${ }^{227}$ Es sencillo deducir que ambos casos combinan las creencias más fuertes del paradigma estético musical moderno, junto con la ideología y métodos del positivismo musicológico: el personalismo, la obra, el armonicocentrismo, la partitura como hecho musical absoluto. E incluso en ambos

225 Véase la discusión al respecto en el capítulo 1 en el cual citamos a Taruskin y su proposición radical. Cfr. pp. 112-113.

226 El consenso musicológico sobre el Renacimiento musical ubica una tradición basada en la introducción de la tercera como intervalo consonante, la compartimentación de las áreas registrales en la música vocal y el desarrollo del contrapunto como composición simultánea, a partir de la influencia de la manera inglesa del siglo $\mathrm{XV}$ en los músicos borgoñones de finales de ese siglo, que a su vez influyen en los compositores flamencos de comienzos del XVI que, trabajando en el norte de Italia, terminan influyendo en los músicos nativos a finales de siglo, promoviendo las academias musicales italianas que inventarán la ópera y la música de concierto, ambas tonales. En este relato cuasi de hadas es patente el evolucionismo, asociado al personalismo y la centralidad exclusiva del componente armónico, que adquiere entidad considerado retrospectivamente desde la música absoluta de la modernidad tardía. El concepto asociado a este periodo de "regulación progresiva de la disonancia" es ya en sí mismo evolucionista y armonicocéntrico. Y tal cual lo vimos en nuestra discusión sobre la música medieval en el capítulo 1, es valorado únicamente en función de su contribución a la música posterior, como puede verse en esta cita: «Obrecht, Josquin e Isaak no nos sorprenden [...] La música de Josquin, especialmente, no nos resulta extraña ni remota, y tiene para nosotros, en esencia, la misma atracción que pueda tener la de Byrd, Bach o aun, digámoslo, Wagner. Josquin habla un lenguaje que podemos entender inmediatamente, porque se trata de un lenguaje que las sucesivas generaciones de compositores han heredado, enriquecido y legado directamente a nuestro tiempo [...] Pero si, pese a todo, empezamos a viajar, retrocediendo en el tiempo, a través del siglo $\mathrm{XV}$, saboreando su música a nuestro paso, esta sensación de contacto con el lenguaje musical se irá diluyendo poco a poco. Ockeghem es ya una figura equívoca; el Dufay de sus últimos años todavía tiene mucho que decirnos, y también podemos reconocer el lenguaje de Binchois y Dunstable. Y, de pronto, estamos ya en una tierra extraña: las postrimerías de la Edad Media» (Trowell, 2000, p. 16)

227 Que la música de América Latina en los siglos de la colonia se piensa en la academia como parte subordinada a la música española (o portuguesa según el caso) se puede comprobar de forma muy sencilla con un rápido índice de las obras que contienen los estudios más recientes sobre dicho repertorio. Para el caso mencionamos la Historia de la música en España e Hispanoamérica en 8 volúmenes, editados muy recientemente (entre 2009 y 2018) por el Fondo de Cultura Económica que, ya desde el título y plan de la obra, entienden lo americano como subunidad de la historia musical hispánica, y que además en Latinoamérica son un producto de importación ausente en las librerías; o el libro de John Walter Hill La música Barroca editado en inglés en 2005 por W. W. Norton \& Company, que dedica dentro del ya muy escueto capítulo sobre música española del periodo un apartado sobre sus "colonias" (Hill, 2008, p. 271). Hasta donde sabemos el único libro integral sobre la música de la América Latina de habla hispana durante la colonia, con planteo autónomo más allá de considerar como es natural los aportes ibéricos y europeos en la transculturación musical, es el flamante texto de Leonardo Waisman (2019), que de todas formas aborda muy tangencialmente el Caribe y prescinde del Brasil y las áreas francófona y angloparlante de la región. Además es parcialmente una recopilación de secciones que han integrado libros como los arriba mencionados, que subsumen lo americano como periferia musical de España. 
casos se introduce una concepción difusionista similar a la que vimos asociada al folklore, que busca el foco de origen del lenguaje armónico y compositivo. Es un detalle que en un caso se trate de Flandes -o Inglaterra, según quien lo formule- y en el otro sea la península Ibérica, que ya es considerada en general un espejo desfigurado de los estilos europeos más importantes, entre otros el de la misma Flandes, ${ }^{228}$ lo cual genera un interesante rebote conceptual en los dos temas que aquí nos ocupan. Todo lo relativo a la performance de los músicos, es decir los instrumentistas que tocan: sus usos del timbre, la textura y la articulación, la proyección en el espacio, el desvío temporal, la interacción con danzantes y participantes en la ocasión musical y social; en fin, todo lo que hasta aquí hemos venido asociando como rasgos de la integralidad de la música popular, son anulados y pierden toda trascendencia cuando segmentamos la historia musical mediante estas categorías de estilo que se enfocan en la "obra", artefacto que nada nos dice en términos del musicar.

En cambio, nos permitimos proponer una hipótesis según la cual los sectores subalternos de la modernidad temprana "contaminan" la cultura musical oficial, justamente como contracultura de inversión; un gesto de tensión en el campo de disputa que es la cultura popular, acarreando sus mundos sonoros, con sus prácticas, instrumentos y concepciones en torno al musicar. Para ello será necesario entonces, en ambos casos, comenzar por poner en cuestión las periodizaciones estilísticas en torno a la historiografía musical del periodo. Solo así podremos acceder a una perspectiva que nos permita reconocer las ocasiones musicales populares y sus sentidos litigantes y mestizos dentro del despliegue de la cultura moderna, ya que

Al irrumpir en la historia, estas masas traen consigo sus costumbres culturales, su modo de enfrentarse al mundo, su ingenua fe milenarista y su mitologismo, e incluso ciertas actitudes mágicas. En cierta medida, esta barbarización de la cultura y de la costumbre es un fenómeno inevitable (De Martino, 2008, p. 87)

\subsection{El Renacimiento, la música popular y la máquina de rebanar la historia229}

Tal como se ha referido en capítulos precedentes, las nociones comunes acerca de la música en la Edad Media están fuertemente atravesadas por toda clase de estereotipos y reduccionismos. Esto trasciende claramente la esfera de las artes y la música, al punto de que se han escrito libros sobre esta problemática, entre los cuales sobresalen los del historiador Jacques Le Goff o la historiadora Régine Pernoud, cuyo Para acabar con la Edad Media (1998) deconstruye un compilado de equívocos que solemos pensar sobre la mentada época. Tal vez el más importante de ellos es el que se reproduce en la misma denominación del periodo, que alude a ese estar en medio de lo que realmente tiene relevancia histórica. Una especie de demora, de latencia angustiosa, que refuerza la

\footnotetext{
228 Dado que el yerno de los Reyes Católicos no es otro que Felipe IV de Borgoña y por extensión Conde de Flandes, el acontecimiento de la formación de la capilla flamenca dentro de la corte española ha derivado en la construcción de una imagen histórica que supone la música ibérica del siglo XVI como copia o traslado del estilo internacional flamenco Por lo tanto la música de Latinoamérica, desde una concepción occidentalocéntrica y difusionista, será el subproducto de una periferia conquistada a su vez por la periferia. Son numerosos los estudios recientes que tienden a modificar esta concepción. Para el caso que nos compete en este trabajo -y esta sección en particular- pueden consultarse los trabajos reunidos en Bombi y otros (2005).
}

229 Si bien este apartado fue escrito con anterioridad, algunos fragmentos aparecen en el capítulo 8 "alto en las torres" (de mi autoría) en el volumen colectivo Sánchez, D. y Eckmeyer, M. "Historia del arte y la música medieval : nuevas perspectivas y enfoques" (Sánchez y Eckmeyer, 2019) 
percepción sesgada de una época en la que pasa poco, y lo que pasa lo hace lentamente. ${ }^{230}$

En música siempre fue difícil determinar qué quería decir exactamente el renacer que, como estilo, tendemos a creer que sucede a la Edad Media. Tal vez porque, como hemos visto en otros capítulos de este libro, en la Edad Media musical ocurren buena parte de las transformaciones y concepciones que sientan las bases de nuestra cultura musical actual. Pero más allá de las interpretaciones que podemos hacer desde el presente, hay datos más concretos: ninguno de los músicos de los siglos XV y XVI tuvo modelos concretos de la música de la Antigüedad, como sí ocurría con sus colegas poetas, escultores y arquitectos que en sus paseos por el campo esquivaban los restos de las cultura clásica o se sentaban en ellos para disfrutar de un almuerzo al aire libre. La referencia al Renacimiento en música fue siempre necesariamente indirecta. El ensayo epigonal de Edward Lowinsky Music in the culture of the Renaissance (1954) está dedicado específicamente a intentar esa definición y fundamentalmente a establecer las diferencias entre el Renacimiento musical y las músicas de la baja Edad Media. Una tarea ardua en la medida que nos mantengamos dentro de aquello que la historiografía musical positivista sentenció como repertorio digno de ser estudiado: la música culta, escrita en partitura, concordante con el ideal de obra, y con autoría plausible de determinarse. Si hacemos eso, las similitudes son más evidentes que las diferencias: tanto las músicas del Gótico como las del Renacimiento son, al menos en los papeles, vocales y a capela, contrapuntísticas, modales, y amantes de los efectos suspensivos, tanto armónicos como rítmicos. Todas además se organizan en base a músicas preexistentes, sacras o profanas, que se usan como cantus firmi o al menos como sujeto del contrapunto. Y en la comparación particular entre los siglos XIV y XV, las sonoridades verticales presentan similitudes extraordinarias en cuanto a su ambigüedad y oquedad. Dufay, tal vez el principal compositor del mainstream del siglo XV, mantuvo durante toda su obra la indeterminación de los registros vocales, utilizando muy rara vez el registro de bajo, y muchas de sus composiciones se sostienen en la técnica de la isorritmia, ese desarrollo gótico del siglo XIV (Atlas, 2002, p. 113)

Si en cambio elegimos decantarnos por los aspectos sociales o institucionales, no nos irá mucho mejor. Los principales héroes del Renacimiento musical provienen de la Iglesia, se entrenan primero como cantantes o capellanes para luego, en su carácter de maestros, convertirse en compositores de prestigio. Exactamente lo mismo que había sucedido con, por ejemplo, Perotín, el magister magnus de la composición polifónica parisina a inicios del siglo XIII, maestro musical de Notre Dame.

Sin embargo, la insistencia por descubrir un origen para la música tonal moderna -el repertorio realmente importante para la historiografía positivista- no se detuvo hasta encontrar algún antecedente que pusiera a la música renacentista a la altura de los desarrollos fundadores de la pintura, la poesía o la arquitectura contemporáneas. Y lo encontró fuera de la Europa continental, en Inglaterra, territorio hasta ese entonces absolutamente ausente de la historia musical medieval. Se pretendió que, justamente a causa de esta condición marginal, en su práctica habitaba esa mínima unidad armónica, ese gen primario del cual podría derivarse la evolución de la tonalidad: el uso del intervalo de tercera como consonancia, requisito fundamental para la construcción del acorde

230 Dice Le Goff (2007, p. 43) «La palabra y el concepto de Edad Media aparecen en el siglo XIV, en los textos de Petrarca y los humanistas italianos. Hablan de un medius tempus (tiempo del medio) (...) Se encuentra con toda claridad esta idea del medio en el inglés Middle Ages, en el español Edad Media o en el Mittelalter alemán, aunque los alemanes, con Alter, introducen, además del concepto de "edad", una connotación de "venerable" (...) En cambio el francés, se observa la evolución despectiva de la palabra moyen. Más en la línea de "mediocre" (...) se habla con cierto menosprecio de un resultado moyen, un espectáculo moyen, un nivel moyen, etc.» 
tríada. ${ }^{231}$ Se generaría así la leyenda de la práctica inglesa, ${ }^{232}$ un recorrido causalista cuasi epidemiológico: la presencia británica en el continente durante el siglo XIV provocaría la incorporación de ese localismo musical, el discanto inglés, en la tradición medieval del contrapunto francés. Síntesis que, a su vez, al inocularse en los geniales maestros borgoñones y flamencos, daría lugar a no menos de cinco generaciones de compositores. Un árbol genealógico que culmina convenientemente a fines del siglo XVI y que, al trabajar estos músicos mayoritariamente en las ciudades de Italia, se confunde con el mismo concepto de Renacimiento musical. ${ }^{233}$ Al punto que gran parte de los textos más célebres sobre el periodo articulan su índice únicamente a partir de los nombres propios de los compositores: aprehender los sujetos de estas magníficas personalidades se convierte así en sinónimo de comprender el cambio entre la Edad Media y la Edad Moderna en música.

No pretendemos aquí restar importancia al trabajo de estos músicos renacentistas ni, mucho menos, relevancia estética a sus producciones, muchas de las cuales son excepcionalmente bellas. Pero al tratar con la historia, está claro que esta argumentación tradicional resulta cuanto menos pobre. Pretender que del contacto entre dos o tres individuos dependa el ingreso de la música -de toda la música- a la modernidad es, por lo pronto, ingenuo. Si a esto sumamos el carácter fuertemente nacionalista de estas explicaciones, el sesgo se advertirá demasiado evidente: una cuenca latina y mediterránea que se arrodilla, derrotada, ante la supremacía "del norte" (Raynor, 1986, p. 47). Que no es un norte cualquiera, sino aquél que mejor representará el triunfo de la modernidad a escala mundial: la burguesía capitalista emergente, tanto británica como neerlandesa. Si bien desde hace tiempo se ha advertido y muy bien sobre este sesgo historiográfico en la musicología (Treitler, 1991), las explicaciones de este cuño aún permanecen inalteradas.

Como señala James Haar (2006, p. 23) podemos seguir utilizando la etiqueta renacimiento para referirnos a las músicas de estos compositores oltramontani. Pero sólo a condición de que abandonemos toda pretensión de abarcar con ese término la totalidad de

231 Por supuesto que el intervalo de tercera, o relaciones cercanas dentro del espectro de frecuencias, están presentes en multiplicidad de culturas a nivel mundial, anteriores, contemporáneas y posteriores a la Inglaterra medieval. Esta circunstancia deja fuera de juego a la propuesta positivista de la incepción de la tríada. Pero además, la música popular europea conocía este intervalo. El texto de Bukofzer, referido en el capítulo 3 , a la par de ser valiosísimo por el aporte documental sobre la polifonía popular medieval, puede leerse como un esfuerzo por refutar la idea de la presencia de terceras en la música popular para salvar así la explicación positivista del Renacimiento como estilo en música. Ver Bukofzer, M. (1940).

232 Traducido en ocasiones como manera inglesa o estilo inglés. El término deriva de la frase contenance anglois, mencionada por el poeta francés Martin le Franc en 1441-42, en un poema dedicado a Felipe, conde de Borgoña, para quien trabajaba, entre otros, Dufay. Este dato es el núcleo de la prueba documental para el desarrollo del concepto estilístico del Renacimiento musical como consecuencia de la influencia inglesa. A partir de este dato (¡un poema!) se dedujo un recorrido Inglaterra-Borgoña-Flandes-Italia que permanece hasta hoy como principal explicación histórica. Ejemplos paradigmáticos de esta historia de los estilos son el capítulo VI de Manfred Bukofzer (1960) o el capítulo 5 "England and the burgundian lands in the fifteenth century" de la primera edición de Grout (1960), que todavía subsiste sin cambios significativos como capítulo 8 en la séptima edición revisada por Peter Burkholder en 2006. Allí puede leerse que «el desarrollo de un nuevo estilo internacional de polifonía (está) en deuda con la influencia inglesa» (p. 205). Como es de esperarse el capítulo se centra en Dunstable y Dufay «quienes desde su época hasta la nuestra han sido considerados los más grandes compositores de su generación». Es interesante también que el ejemplo de "historia de los estilos" que desarrolla Jim Samson para explicar ese tipo de historiografía sea justamente la influencia de este estilo inglés sobre Borgoña y su mejor músico, Guillaume Dufay. Ver Samson (2009, p. 10). Que todos los musicólogos aquí mencionados pertenezcan a universidades y editoriales del área anglosajona no pareciera mera coincidencia en el marco de una defensa tan longeva como encendida del rol de la cultura inglesa en prender la chispa de la modernidad musical occidental.

233 Esta falacia por metonimia no es algo privativo de la música. En términos de historia general, y sobre todo en cuanto a lo cultural, lo económico y lo social, Le Goff nos recuerda «lo difícil que resulta tomar como modelo el caso italiano y medir con este rasero la totalidad de Europa» (2007, p. 60). De hecho, ante la pregunta de si considera al Renacimiento como un enemigo, el historiador francés responde «El Renacimiento en tanto máquina de rebanar la historia sí lo es; el Renacimiento como momento de civilización no ¡por supuesto que no!» (p. 51) 
las músicas de los siglos XV y XVI. Y agregamos: si convenimos además que debemos encontrar una serie de explicaciones más densas para determinar aquello que represente el ocaso de la música medieval (Strohm, 1990b, p. 269). Coleccionar las obras maestras de esta dinastía de compositores no es suficiente.

Este estatus explicativo deficitario, incapaz de superar las argumentaciones de la historia de los nombres o los nacionalismos, nos mueve a buscar en otros horizontes algunas explicaciones que permitan comprender mejor la transición histórica entre la música medieval y la moderna. Una posibilidad es tomar, a modo de hipótesis, la teoría de Jacques Le Goff (2008, p. 50) sobre la existencia de múltiples y sucesivos renacimientos a lo largo de una larga Edad Media, que incluirían entre ellos al renacimiento de los siglos XV y XVI.234 Basado en la historiografía de los Annales y la noción de larga duración, este modelo propicia la continuidad de una larga Edad Media, que podría extenderse hasta el siglo XVIII -idea que también suscribió Huizinga. Hemos visto en otros capítulos de este libro unos cuantos procesos que bien podrían pensarse como renacimientos: los tratados sobre música de la temprana Edad Media, la polifonía improvisada de los romanos y los carolingios, la música intelectual de las universidades medievales, entre muchos otros posibles.

Pero para la música, una larga duración que lleve la Edad Media hasta el siglo XVIII se torna inviable, pues es imposible soslayar la aparición del espectáculo público y la entrada de la música al mercado ocurridas entre el siglo XVI y el XVII. ${ }^{235}$ De todos modos, concebir al siglo XV como un eco de otros tantos movimientos de renovación ocurridos durante la Edad Media otorga un marco interesante para analizar las similitudes que, en materia musical, señalamos antes.

Otra posibilidad será tomar la revalorización del periodo bajomedieval o gótico que hace Arnold Hauser (1962) que, en sentido contrario, adelanta la cesura para emparentar definitivamente lo que habitualmente designamos como Baja Edad Media y Renacimiento

Sin duda es mucho mejor anticipar esta cesura fundamental, situándola entre la primera y la segunda mitad de la Edad Media, esto es, a fines del siglo XII, cuando la economía monetaria se revitaliza, surgen las nuevas ciudades y la burguesía adquiere perfiles característicos; pero de ningún modo puede ser situada en el siglo $\mathrm{XV}$, en el que, si muchas cosas alcanzan su madurez, no comienza, sin embargo, ninguna cosa nueva (p. 278).

En definitiva, para este autor el índice de cambio aparece de la mano de la economía urbana, cuya principal característica es la de ser una producción «de bienes que no se consumen dentro de la economía en que son producidos» (Hauser, 1962, p. 209). Si en este modelo reside la clave para reformular nuestra periodización musical tardomedieval, es preciso correr el foco de los elementos vinculados al desarrollo de lo tonal, y buscar aquello que mejor se corresponda con esta economía urbana. Nos encontraremos aquí con una unidad de organización musical, estudiada poco y fragmentariamente, que contrasta con la historia de los compositores ultramontanos: nos referimos a los músicos profesionales municipales, al servicio de las ciudades medievales. Estos músicos ejercieron una influencia decisiva para el desarrollo de la música instrumental moderna, que de otra forma parece irrumpir de forma misteriosa y repentina en el siglo XVII.

234 «La idea misma de "Renacimiento" (...) responde de un modo sorprendente a uno de los resortes fundamentales de la cultura medieval, para la que innovar consiste siempre en volver atrás, en acomodarse a las autoridades del pasado o la Antigüedad» (Le Goff, 2008, p. 50)

235 Aunque sí sean posibles, como veremos, establecer relaciones de larga duración, como la que hace Jacques Attali (2011) al vincular al ministril medieval con los compositores cortesanos del siglo XVIII como Haydn, en el sentido de que ambos son sirvientes domésticos. Pero es una periodización que sólo tiene validez en la medida que no salgamos de los palacios de la alta aristocracia. 
Está claro que el eje del noroeste, el de la influencia de los compositores flamencos, reviste gran importancia histórica. Pero existieron desde el siglo XIII en adelante otras rutas y redes que significan otros tantos polos de desarrollo musical (Polk, 1987, p. 160; Peters, 2000 , p. 202). «Si pretendemos desarrollar una imagen más completa de la vida musical del Renacimiento (...) debemos reconocer otros loci de actividad, una abanico de ciudades desde las cuales irradiaron técnicas y estilos que influenciaron a todos los mayores centros culturales de Europa» (Polk, 1987, p. 184)236.

Pero más aún: focalizar en el estudio de estos músicos no sólo mejorará nuestra comprensión de la casuística de aquello a lo que terminemos llamando Renacimiento. Lo que es tal vez mucho más interesante es que nos puede devolver cierto sentido de cohesión histórica a un período amplio y dinámico que va, por lo menos, desde fines del siglo XII hasta bien entrado el siglo XVI. Un esquema que pone en crisis la periodización tradicional de la musicología positivista y que puede significar, además, la posibilidad de periodizaciones que simultáneamente se centren en lo musical -en lugar de adoptar criterios de otras disciplinas- pero que eviten el dogma de la autonomía y fundamenten las explicaciones en las relaciones entre las prácticas musicales y la historia social. Tal vez de esta forma Renacimiento pase a significar un estilo interpretativo para algunas músicas históricas y ya no una designación ecuménica que pretenda sintetizar toda una época de la historia musical.

\subsubsection{La domesticación de los juglares}

Casi como un calco inverso de los compositores y maestros de capilla flamencos que constituyen el canon renacentista, aparecen estos otros músicos: instrumentistas, asalariados, reunidos en organizaciones gremiales o fraternales, improvisadores, renuentes por propia voluntad de la música en partitura o al menos con una relación conflictiva con la escritura musical.237 Y por sobre todo, hacedores en la performance de una música estrechamente vinculada a sus funciones sociales y culturales, entre las cuales una de las más importantes resultaba la de incluir a los sectores populares urbanos en la identidad de la ciudad. Como podemos apreciar, se trata de una colección completa de aspectos de los que han abominado la estética y la historiografía modernas: el anonimato y la ausencia de autor, la contingencia de la práctica improvisada, la imposibilidad del juicio desinteresado, la transmisión oral. Sin embargo es importante comprender que estos sujetos musicales configuran un tipo de agrupación de las más importantes para la época, equivalentes a las actuales bandas cívicas o tal vez, a las orquestas. Como veremos más adelante, el prestigio y hasta el honor de ciudades y regiones era simbolizado en sonidos por estos conjuntos, por lo cual su enorme cantidad y dispersión por toda Europa Occidental no debiera sorprendernos. "Para mediados del siglo XIV y a lo largo de todo el XV, los ministriles fueron un elemento muy visible y respetado de la sociedad medieval urbana»238 (Peters, 2000, p. 228)

236 «If we wish to develop a more complete image of Renaissance musical life (...) we must recognise a northern locus of activity, a ring of cities from which radiated techniques and styles which influenced all major cultural centres of Europe» (Polk, 1987, p. 184) [traducción del autor]

237 Existen polémicas acerca de si los músicos urbanos profesionales utilizaban la notación musical como componente habitual o esporádico en su trabajo. Alan Atlas (2002, p. 265) es de la opinión de que la escritura musical era parte integral del oficio de ministril. Maricarmen Gómez (1990), en cambio sostiene la hipótesis de que el arte de estos músicos era eminentemente performático y, por tanto, residía en la capacidad de improvisar, ornamentar y arreglar músicas. Como si se tratara de las improvisación que hoy hacen las bandas de jazz sobre un tema o standard, anotar en partitura los arreglos de los ministriles «hubiese significado fijar tan sólo una de las numerosas posibilidades que ofrecía su trabajo» (p. 215). Es decir que anotar la interpretación, fijarla, hubiese atentado contra las propias posibilidades laborales de los músicos urbanos profesionales.

238 «By the mid-fourteenth century and throughout the fifteenth century, minstrels were a highly visible and respectable element of medieval urban society» (Peters, 2000, p. 228) [traducción del autor] 
Sin embargo, por fuera de los círculos académicos especializados en estudiarlos y de las asociaciones de instrumentistas de viento ávidos por encontrar sus ancestros, éstos músicos, sus prácticas y sus formas de organización no están presentes en los textos sobre historia de la música, y muchísimo menos en los de música medieval, periodo en el cual aparecen sus primeras formas de organización. ${ }^{239}$ Algo hay con estos músicos que hace que se los margine sistemáticamente de la historia. Está claro que su presencia obscurece y contradice la ordenada exposición evolucionista (Carpentier, 1984) hacia la música tonal de la musicología positivista. Pero es justamente la ligazón con su origen histórico marginal lo que tal vez subyace en la potencia y persistencia del rechazo de estos músicos.

Como ya vimos en el capítulo 4, los músicos populares medievales son desterrados de la historiografía musical positivista. Vagabundos, proscritos, outsiders que habitan una marginalidad absoluta en términos de derechos (Guion, 2007, p. 2), los juglares son confundidos con delincuentes y salteadores de caminos, a todo lo cual se añade el condimento de lo diabólico, imprescindible para que la cultura medieval sancione definitivamente a estos sujetos y sus prácticas.

Tal como dice John Southworth en su reciente libro, The English Medieval Minstrel, "No es solamente que el estatus del juglar fuese bajo; para la mayoría de sus contemporáneos él estaba fuera de las normas comunes de aceptación social. En este sentido, era peor que un siervo; si la servidumbre ocupaba el lugar más bajo en la escala social medieval, el juglar no tenía ningún lugar en absoluto"'(Peters, 2000, p. 213).240

Recordemos sin embargo que la insistencia en la condena es aquello que nos da la mayor certeza de la permanencia de los músicos populares ambulantes durante toda la época medieval (Raynor, 1986, p. 57). Y consideremos además que sus músicas, fuertemente vinculadas con el carnaval, transitan esa amplia y borrosa franja en la que las prácticas simbólicas de origen precristiano o sectario se superponen y mixturan, no sin conflicto, con la religiosidad popular cristiana.

Pero será justamente con el objetivo de honrar la profesión que se dará paulatinamente la transformación de los trashumantes en músicos urbanos fijos. De tal modo que debemos pensar que los músicos urbanos medievales, habitualmente llamados ministriles, son una derivación, una rama subsidiaria, de los juglares y otros músicos populares itinerantes. Raynor (1986, p.57) ubica este proceso dentro de uno mayor, que denomina la domesticación de los juglares, el cual podemos pensar que comienza a partir del siglo IX. Esto significa por un lado el ingreso de los músicos populares a la esfera social medieval: conquistan derechos, su reputación aumenta, mejora su estándar de vida. Pero fundamentalmente el paso del nomadismo al sitio fijo, que conlleva ahora estar asociado a funciones mucho más específicas, implica en términos musicales una transformación importante: la especialización. Si el juglar era a un tiempo malabarista, cuentacuentos, actor y músico, ahora el ministril que fija residencia se especializa en tocar instrumentos musicales. Lo cual conlleva una impresionante mejora en las técnicas instrumentales, las

\footnotetext{
239 Tomando como ejemplo la colección de textos de la editorial Akal, que son traducciones de la prestigiosa serie de historia de la música de la editora neoyorquina Norton \& co., los volúmenes dedicados al Renacimiento (Atlas, 2002) y al Barroco (Hill, 2008) poseen una muy escueta mención. No así el tomo dedicado a la Edad Media (Hoppin, 2000). De igual modo la colección dirigida por Robertson y Stevens para Penguin Books (2000) hace referencia a estos músicos en el volumen dedicado al Renacimiento y no en el de Edad Media. Son muy raros los textos que abarquen o se dediquen al estudio de la música medieval y que incluyan a los músicos municipales. Hasta donde sabemos, solamente el ya citado Henry Raynor (1986) es el único que incluye la temática en el período y le dedica un capítulo completo.

240 «As John Southworth writes in his recent book, The English Medieval Minstrel, 'It is not just that the status of the minstrel was low; for very many of his contemporaries, he was altogether beyond the pale of social acceptance. In this respect, he was worse off than a serf; if the serf occupied the lowest place in the medieval hierarchy, the minstrel had no place at all'» (Peters, 2000, p. 213) [traducción del autor]
} 
posibilidades musicales, las técnicas compositivas y la fabricación y desarrollo de los propios instrumentos.

Pero domesticación alude no sólo al abandono de las malas costumbres en pos de abrazar una nueva civilidad, sino que también se emparenta con la noción del doméstico, es decir el sirviente. Y eso son los ministriles en un primer momento histórico (Attali, 2011, p. 28). Conquistar derechos significa servir a otro, a un poder. Autoridad que manda y ordena qué es lo que se debe tocar, cuándo y con qué instrumentos. En el servicio los músicos perderán la autonomía y, si se quiere, el carácter contrahegemónico y subversivo del juglar; pero simultáneamente se convertirán en instrumentistas especializados, respetados, alabados: por lo tanto en ciudadanos.

Si bien ya hemos visto en el capítulo 4 las implicaciones en el contexto cortesano de esta domesticación, retomaremos algunos puntos para diferenciarla de lo que ocurre en el contexto urbano bajomedieval, fundamentalmente burgués. Recordemos una vez más aquí que las denominaciones son inconsistentes, aunque es evidente que la tendencia a modificar las formas de nombrar y nombrarse de los músicos no fueron inocentes ni neutrales en la época. Si, como vimos, la nobleza es quien nombra a su sirviente domesticado y por lo tanto crea el concepto mismo de ministril (Raynor, 1986, p. 59), será interesante descubrir que en el ámbito urbano se utiliza el mismo término y su valor allí tampoco es indistinto.

Las ciudades medievales podían estar bajo el control de la nobleza, del clero o de la burguesía -comercial, financiera, manufacturera. Sin embargo en las actas y asientos contables medievales suele aparecer constantemente el término ministril (minstrel, menestrel, ministerialis, minstreel), independientemente de hacia quién ofrezcan obediencia y servicios, lo que como veremos en seguida implica diferentes funciones, repertorios y prácticas. Podemos intuir que se trata de una nomenclatura por negación, en base a la cual «los músicos profesionales tardomedievales que no eran clérigos ni estaban al servicio de la Iglesia son habitualmente denominados "ministriles"» (Strohm, 1990a, p.74). 241 O tal vez la uniformidad en el uso del término ministril haya provenido de la necesidad de dar cuenta de su estatus profesional, por lo cual «es posible que el cambio de nomenclatura [de juglar a ministril] en el siglo XIV refleje el cambio de función, del artista ambulante multipropósito al especialista que toca un único instrumento musical» (Gushee y Rastall, 2001, s/p).242 De todas formas, insistimos en que la terminología es inconsistente, utilizándose también el término juglar junto a otros términos locales, lo cual «más bien depende, en cada documento, del rango social de quien lo escribe, el idioma en cuestión, y la finalidad del escrito (contabilidad de la corte o la Iglesia, registros civiles, fuentes literarias, poesía, entre otros)» (Strohm, 1990a, p.74)..$^{243}$

Por lo tanto, y antes de ensayar una clasificación que distinga a los diversos tipos de músicos profesionales urbanos, establezcamos lo que todos ellos tienen en común, fundamentalmente aquellos que «presentan un gran contraste ante la imagen popular del juglar itinerante, que por fuerza vive en los márgenes de la sociedad» (Peters, 2000, p.

241 «Professional musicians of the later Middle Ages who were neither clerics nor employed by the church are usually referred to as 'minstrels'» (Strohm, 1990a, p.74) [traducción del autor]

242 «lt may be that the change in nomenclature (in the early 14th century) reflected a change in function, from the jack-of-all-trades entertainer to the specialist in playing a single instrument» (Gushee y Rastall, 2001) [traducción del autor]

243 «it rather depends, in each document, on the social status of the writer himself, the language used, and on the function of the document (church and court accounts, city registers, narrative sources, poetry, and so on)» (Strohm, 1990a, p.74) [traducción del autor] 
$228)^{244}$. Este tipo de estratificación social es la que parece recuperar Reinhard Strohm cuando afirma que

como la profesión siempre tuvo que luchar por su reconocimiento social, ante el rechazo constante de la Iglesia, la terminología en ocasiones refleja la diferenciación social. Podía haber una gran distancia entre un ministril vagabundo sin empleo fijo -el histrio- y el valet de chambre cortesano o faiseur (un poeta y compositor creativo) (1990a, p. 74).245

\section{Origen popular}

Aunque enfrentados laboralmente y deseosos de evitar que se los relacione con ellos, los músicos profesionales urbanos proceden de las filas de los músicos populares itinerantes, razón por la cual, aunque su estatus e imagen social cambien, contienen una memoria histórica que se expresa en los repertorios (fundamentalmente danzas de origen popular), los espacios de producción (lugares públicos, calles y plazas) y en muchas de las actividades y funciones sociales que desarrollan (el entretenimiento, la fiesta pública, etc.). Por esta razón, expresan una posición novedosa en el campo socio-musical: al tiempo que recuperan la tradición popular y la expresan, refuncionalizándola según el caso, también son vehículo de las músicas y espectáculos que las autoridades civiles presentan ante el pueblo, tarea que a veces alternan con sus funciones dentro de la corte.

Algunos trabajan en las cortes, (...) volviéndose íntimos de reyes y príncipes. [Otros] sirven como miembros de las bandas municipales (...) Todavía otros ministriles trabajaron como músicos independientes en pueblos y ciudades. Algunos más actuaban en solitario, cantando o tocando la vihuela, por ejemplo, para cualquiera que quisiera pagarles. Otros se asociaban con otros músicos para ganarse la vida tocando en bodas, banquetes y demás ocasiones donde la actuación musical fuera pertinente. Además existía aún una clase de vagos que se ganaba a duras penas su subsistencia deambulando de pueblo en pueblo (Mayer Brown \& Polk, 2001b, p. 99$)^{246}$

Ciertamente uno de los principales desafíos de los músicos una vez que se asientan en las ciudades, será la de diferenciarse definitivamente de esa "clase de vagos" y buenospara-nada. Todo el periodo entre el siglo XIII y el XVI puede leerse en términos del esfuerzo de los músicos urbanos por desprenderse de toda connotación que los relacione con la vida trashumante de los juglares y hacer que la música sea vista como una profesión honrosa. Acceder al estatus de ciudadano implica necesariamente ese contraste. De todas maneras, esto no debe interpretarse automáticamente como un proceso de estilización o distinción de las prácticas musicales, ya que existen numerosas continuidades entre la música de los juglares y la de los ministriles urbanos. Para el caso, podemos mencionar que las reuniones de los ministriles, especie de encuentros profesionales o congresos a los que se suele llamar escuelas de ministriles, ocurrían durante la cuaresma, «momento del año en el que aparentemente a los ministriles no se les permitía ejercer su profesión» (Gómez, 1990, p.

\footnotetext{
244 «presenting a striking contrast to the popular image of the itinerant minstrel who was forced to live on the outskirts of society» (Peters, 2000, p. 228) [traducción del autor]

245 «As the profession always had to struggle for social recognition, which the church, in particular, denied to it, the terminology sometimes reflected social differentiation. There could be a wide gap between a travelling minstrel without regular employment -the histrio- and the courtly valet de chambre or faiseur (a creative poet and composer)» (Strohm, 1990a, p. 74) [traducción del autor]

246 «Some worked at princely courts (...) became intimates of kings and princes. They could serve as members of a town band (...) Still other minstrels worked as freelance musicians in towns and cities. Some performed alone, singing and playing the fiddle, for example, for anyone who would pay them. Others banded together with several other musicians to earn living by playing for weddings, banquets, and other occasions when music was appropriate. There was also a class of itinerant ne'er-do-wells who eked out a bare subsistence wandering from town to town» (Mayer Brown \& Polk, 2001b, p. 99) [traducción del autor]
} 
$213)^{247}$. Recordemos que la cultura popular estaba asociada al carnaval, lo opuesto de la cuaresma (Attali, 2011, p. 36), por lo que esta prohibición también refuerza el nexo de los ministriles con la cultura popular.

Específicamente podemos observar dos muy importantes:

- la permanencia y el desarrollo del violín. Si bien, como veremos, son los vientos los instrumentos más característicos de los músicos urbanos, existen múltiples registros de violinistas integrando de alguna manera el cuerpo de los ministriles, sobre todo en los siglos XIV y XV (Polk, 1987, p.180; Gushee y Rastall, 2001, s/p; Raynor, 1986 , p. 86). La connotación popular del violín y su contraste con la viola como instrumento noble proviene ya de la Alta Edad Media, del rabel medieval, aunque todavía en 1556 el compositor académico francés Jambe de Fer condena a los violinistas en tanto músicos profesionales. Distingue al violín como inapropiado ya que «hay pocas personas que lo usan, excepto aquellas que obtienen un beneficio del mismo con su trabajo» a diferencia de la viola da gamba que utilizan «los caballeros, los comerciantes y otros virtuosos» (Hill, 2008, p. 89). Que los ministriles urbanos hayan mantenido el uso del violín a pesar de estas connotaciones, al punto que en algunas ciudades formaron un conjunto específico, como los Kunstgeiger de Leipzig (Raynor, 1986, p. 80) puede representar un indicio de que no renegaron de sus orígenes, al tiempo que buscaban acceder a un nuevo estatus social.

- la permanencia de las danzas populares en tanto tales, es decir que no son abordadas por un proceso de estilización como vimos en el caso de los trovadores, sino que mantienen características que las identifican con su raíz popular. En todo caso se observará que mejoran las técnicas instrumentales, se le añaden arreglos complejos y se hace más sofisticada la improvisación -práctica característica de los ministriles urbanos que también los asocia con los juglares- pero eso no implica que se esconda el origen popular de las músicas, ya que debe ser notorio para lograr algunas de las funciones principales de estos músicos, como la cohesión social.

Los waits de York, es decir los músicos municipales profesionales de esa ciudad inglesa que descienden directamente de la banda formada al menos en 1369, todavía tocan la danza bretona anónima An Dro Nevez. ${ }^{248}$ En el fonograma A golden treasury of ancient instruments (1989) interpretan una versión con bombarda y redoblante (pista 3) que puede resultar ejemplificadora: el ritmo es ágil y tiene un esquema binario, muy pulsado, con una cifra de tempo cercana a 133. La estructura es muy sencilla y se organiza en base a la repetición de una frase construida a partir de un intervalo de quinta y otro de cuarta, con una variación que llega al sexto grado -ascendido porque se trata del modo sobre re. En un segundo plano el tambor realiza un redoble constante sobre valores de la subdivisión, desplazando los acentos pero manteniendo la pulsación isócrona. La bombarda, en todas las repeticiones de la melodía, desarrolla infinidad de variaciones, ornamentaciones y pasajes muy virtuosos que no son otra cosa que improvisaciones sobre la melodía, de contorno más bien simple. Podemos ver que los elementos danzables se mantienen inalterados, se recupera una tonada popular de tradición oral muy difundida y, sobre este marco, el instrumentista puede improvisar demostrando su pericia técnica y su calidad como músico. Una forma de obtener distinción profesional sin renunciar por ello a entretener a los sectores populares. Es decir, haciendo bailar a la gente.

247 «apparently a time when the minstrels were not permitted to practice their profession officially» (Gómez, 1990, p. 213) [traducción del autor]

248 El ejemplo 52 puede escucharse aquí https://youtu.be/GZvaRwDkc98 


\section{Ciudadanía}

Los ministriles ingresan a una esfera de relaciones sociales legalmente reconocidas y más complejas, tanto con la sociedad en su conjunto como con sus empleadores y colegas. (Peters, 2000, p. 226). Esto incluía la protección legal, el derecho a la propiedad y a ejercer prácticas comerciales, ya que en el mismo momento en el que se los nombraba como músicos de la ciudad obtenían la carta de ciudadanía (Beukers, 1991, p. 14). De esta forma, abandonan la condición de proscritos presente en los músicos vagabundos e ingresan a una esfera de reconocimiento social que invierte hacia el final del periodo la valoración social de los músicos. Si el juglar estaba fuera de la sociedad y era menos que el pobre más pobre, hacia el siglo XVI los músicos urbanos profesionales organizados son prósperos y respetados, llegando en algunos casos a pertenecer al sector más alto de la ciudad, en términos económicos (Polk, 1987, p. 179; Peters, 2000, p. 215).

En el mismo fonograma de los waits de York encontramos una música muy contrapuntística, anónima, denominada mercantia 249 (pista 5), probablemente de mediados del siglo XV. Por un lado, llama la atención el nombre, que remite inmediatamente a la burguesía y la economía urbana mercantil organizada en cofradías a las que los músicos urbanos pretenden ingresar. Pero el aspecto sonoro de la pieza es lo que realmente configura una representación de los valores urbanos: una densa trama contrapuntística con permanentes trocados e imitaciones, llevada a cabo por un conjunto de cromornos (2 contraltos, 1 tenor y 1 bajo). A diferencia de la danza bretona, esta música es más bien lenta y acompasada, rehuyendo a la pulsación marcada en un estilo que se asemeja al de la música vocal de la época. Sin embargo es muy probable que la trama provenga de la improvisación, muy elaborada, sobre un tema tradicional transmitido por vía oral. Es claramente un certificado de ciudadanía de los músicos que los aleja definitivamente de la imagen de los juglares.

Para ser parte de la ciudad y honrar la profesión, los músicos urbanos establecen formas institucionales de agrupación profesional, como cofradías y gremios, desarrolladas a partir de una matriz germinal más espontánea conocida como escuelas de ministriles. El objetivo de esta práctica es obtener beneficios sociales, crear redes profesionales y establecer reglas y estándares que regulen y protejan su práctica (Guion, 2007, p. 2). Lo cual por supuesto redunda a su vez en la mentada valoración social de la profesión. Podemos juzgar el éxito de esta empresa al observar la estrecha relación identitaria que lograron desarrollar entre las instituciones musicales profesionales y la ciudad. Tanto es así que estos músicos terminaron por convertirse en su emblema sonoro, representando el honor y dignidad tanto de sus habitantes como de sus gobernantes.

\section{Relación de dependencia y cuentapropismo}

La relación socio económica definitoria de estos músicos es la dependencia de una autoridad que detenta el poder de la ciudad, la cual puede ser tanto la nobleza como el clero o, más frecuentemente, la burguesía. Al formar este tipo de corporaciones y colocarse voluntariamente bajo la órbita de gobernantes y autoridades civiles, los músicos accedieron a un grado mucho más elevado de aceptación social que sus colegas itinerantes (Slocum, 1995, p. 258).

«La primera petición de los instrumentistas de Brescia expresa su deseo de vincular su profesión a unas condiciones "dignas y destacadas", a lo que es "noble y elevado" (...) y se refiere con desdén a los intérpretes "infames, viles e inexpertos"» (Hill, 2008, p. 89). Como vemos, la búsqueda de diferenciación frente a los juglares es un asunto estrictamente

249 El ejemplo 53 puede escucharse aquí https://youtu.be/XfHG8fny5WI 
laboral que persigue -y en ocasiones logra- establecer un monopolio de los músicos municipales sobre toda la producción de la ciudad. Por eso, y a diferencia de los procesos de distinción operados durante la Alta Edad Media por la caballería feudal, los músicos urbanos recurrirán a la creación de organizaciones e instituciones que promuevan sus derechos y los equiparen con otras profesiones urbanas, ya legítimas y establecidas. Es decir que buscan confundirse entre los ciudadanos, participar del común, en lugar de establecer una distancia social más o menos artificial. Esta tal vez sea la razón por la cual sus prácticas musicales nunca abandonan el contacto con los antecedentes populares de los que se nutren, lo que les garantiza la posibilidad de interpelar a los sectores populares urbanos sin que esto interfiera con su búsqueda de promoción y prestigio social.

El fonograma Florentine Carnival - A Festival of Music for Lorenzo de' Medici del conjunto London Pro Musica (1998) comienza con un saltarello anónimo, titulado adecuadamente Fiorentina. ${ }^{250}$ Se trata de la música utilizada en las fiestas de Carnaval bajo el gobierno de Lorenzo de Médici en Florencia (1469-1492). Podemos imaginar a los ministriles de la ciudad tomando esta danza tradicional y recontextualizándola para convertirla en una fanfarria que señale el comienzo de las fiestas públicas. El tempo es moderado, posiblemente más lento que en su versión danzable. Pero lo que más llama la atención es que, sobre un ritmo simple y recurrente tocado por un tambor, los instrumentos de viento chirimías y sacabuche- entretejen una trama polifónica intrincada aunque sin resultar artificiosa. Es muy probable que todo el trabajo contrapuntístico fuese improvisado, aunque debemos tener en cuenta que los ministriles de los siglos XV y XVI manejaban la lectoescritura musical que, a veces, les servía para acceder a trabajos en la Iglesia, eventuales o fijos. El resultado sonoro es el de una música solemne y distinguida y bien puede funcionar de ejemplo del pacto representativo entre la ciudad, los gobernantes y sus músicos.

En la mayoría de los casos el contrato con la autoridad no significaba exclusividad alguna, por lo cual podían desarrollar también actividades musicales freelance o por cuenta propia, lo cual no se opone sino que afirma, aunque nos resulte contradictorio, el núcleo identitario de estos músicos caracterizado por el puesto fijo asalariado. Algunos además podían alternar tareas eventuales en la corte de autoridades seculares o eclesiásticas. Es evidente que algunos músicos podían ejercer todas o varias de estas profesiones:

Simon Requier, que fue un ministril, trompetero y pregonero público en Montpellier a principios del siglo XV, era propietario de una antigua y nueva casa de baños (...) En Avignon, el ministril Poncius Blaconi, que tocaba en procesiones durante los años 1430 tanto para la ciudad como para la confraternidad de Notre-Dame de la Major, era dueño de una casa de baños (...) aparentemente los ministriles urbanos del sur de Francia actuaban en múltiples contextos para lograr mantenerse a ellos y sus familias (...) La naturaleza de sus ocupaciones iba desde ser contratado por adelantado por unos cuantos meses a tocar en las calles con la esperanza de conseguir alguna audiencia y remuneración (Peters, 2000, p. 210)251

250 El ejemplo 54 puede escucharse aquí https://youtu.be/kFs6I07HTOg

251 «Simon Requier, who was a minstrel, tower-trumpeter and public crier in early fifteenth- century Montpellier, owned an 'old' and a 'new' bathhouse (...) In Avignon, a minstrel Poncius Blaconi, who performed in processions during the 1430s for both the city and the confraternity of Notre-Dame de la Major, owned a bathhouse (...) "Urban minstrels in southern France appear to have performed in a variety of settings to support themselves and their families (...) The nature of their employment ranged from being contracted months in advance (...) to playing on the streets in the hopes of drawing an audience and some remuneration» (Peters, 2000, p. 210) [traducción del autor] 


\section{Especialización y profesionalización}

Los músicos urbanos se especializan, es decir, son músicos antes que otra cosa. Además perciben un salario, esto es lo que los define como profesionales. Lo cual no impide que puedan tocar varios instrumentos e incluso cantar, que sus tareas musicales sean muy diversas e incluso las combinen con otras actividades laborales y económicas. Por ejemplo, sabemos que en Utrecht uno de los músicos municipales pertenecía en 1530 al gremio de los pescadores (Beukers, 1991, p. 14). Pero además, a medida que eran aceptados y su estatus social se elevaba, diversificaron sus actividades hacia negocios conexos con la profesión de músicos. Es paradigmática la tendencia a ser propietarios de posadas donde se tocaba música, para luego comprar viñedos y hacer el vino, que a su vez se vendía en las posadas. También era muy frecuente que los músicos fueran propietarios de casas de baños, al menos en el sur de Francia. Era costumbre que la gente de mayor nivel adquisitivo se bañara en estos establecimientos, que veían superada su función utilitaria para convertirse en centros de entretenimiento, donde se escuchaba música, se comía o se contrataban prostitutas (Peters, 2000, p. 210). 


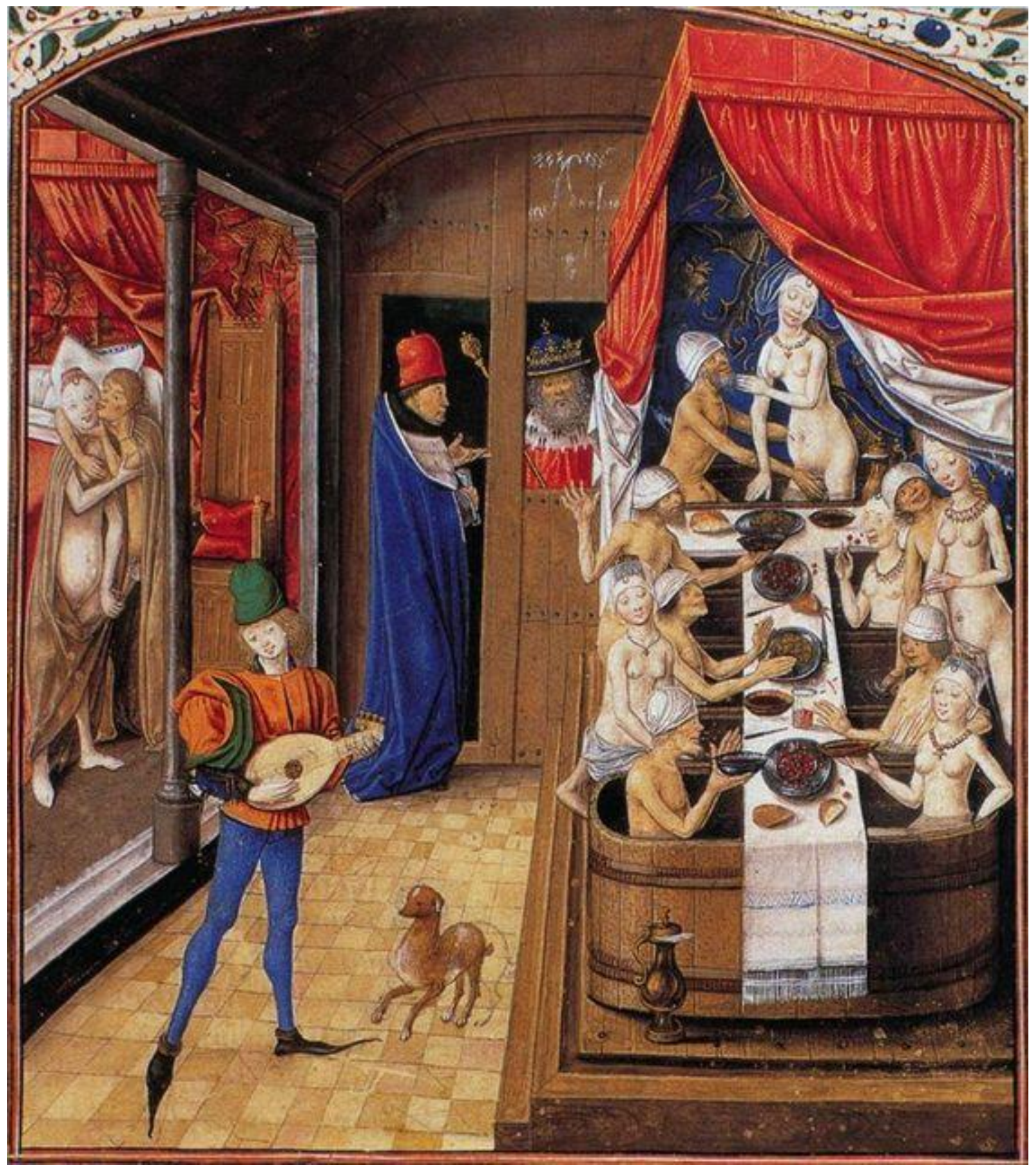

Presencia de los músicas en las casas de baños. Muchos eran propietarios de estos establecimientos.

Aún así, debemos considerar a los ministriles como especialistas. Esto derivará, como veremos, en la emergencia del conjunto o banda constituída por diferentes instrumentos que en el transcurso del periodo adquieren roles definidos, asociados a los instrumentos (posauner, pfiefer, tubatore, piffaro, etc.) o a los registros que tocan como especialidad (soprano, tenorista, etc.). De esta forma los ministriles ya al comienzo del periodo que estamos considerando «constituyen el conjunto mayoritario de instrumentistas de los siglos XIV y XV, incluso cuando otros grupos de personas cultivaron también el arte de tocar instrumentos» (Mayer Brown y Polk, 2001b, p. 98). ${ }^{252}$

252 «Minstrels constituted the largest group of instrumentalists in the fourteenth and fifteenth centuries, even though other classes of people also cultivated the art of playing instruments» (Mayer Brown y Polk, 2001b, p. 98) [traducción del autor]. 
Una consecuencia importante de la especialización será el desarrollo de músicas idiomáticas que se piensan, si no para los instrumentos particulares, al menos para familias o tipologías instrumentales. En el Cancionero de Glogauer, manuscrito musical del siglo XV de la región de Silesia, aparece una colección de canciones sin texto, que «pueden considerarse con toda probabilidad escritas específicamente para un conjunto instrumental» (Atlas, 2002, p. 270). Los títulos de las piezas suelen hacer referencia a nombres de animales, y entre ellas la de La cola de rata (Der ratten schwantz) presenta notas muy largas y sostenidas, sobre las cuales otras dos líneas van alternándose en melodías muy angulares repletas de saltos. Es bastante evidente lo poco cantable de la música, por lo cual, si además consideramos que las melodías escritas son la estructura sobre la cual los instrumentistas podrían luego improvisar ornamentaciones, es muy verosímil suponer que ya este manuscrito nos está mostrando música concebida especialmente para conjunto instrumental. Lo mismo ocurre con otros cancioneros de los siglos XV y XVI, como el Schedelsches Liederbuch y el Lochamer Liederbuch, ambos de Nuremberg, o el Cancionero de la Colombina de Sevilla.

La especialización suele asociarse al tipo de formación que reciben los músicos, que en el transcurso del periodo se modificará paulatinamente desde la transmisión y el intercambio oral más o menos sistemáticos de las escuelas de ministriles hasta la articulación de la relación educativa más habitual de la modernidad temprana, esto es la instrucción profesional mediante la relación maestro-aprendiz (Mayer Brown y Polk, 2001b, p. 99). Este proceso es absolutamente paralelo y relativo al desarrollo de las formas de asociación profesional de los músicos urbanos que presenta una secuencia histórica en tres etapas: las escuelas, las hermandades o cofradías y, finalmente, los gremios. De hecho, a medida que la organización de los músicos se hace más fuerte en una ciudad, el modelo más esporádico de encuentros anuales de formación -las escuelas de ministriles- ceden paso al establecimiento de lugares de enseñanza permanentes y fijos.

Algunas ciudades con una rica tradición musical, como París o Brujas, poseían también escuelas continuas de ministriles. Maestros musicales de diferentes especialidades brindaban instrucción, y los estudiantes no sólo incluían a aquellos que buscaban una introducción al arte musical, sino también a aquellos que necesitaban del consejo de algún famoso maestro (Gómez, 1990, p. 213) 253

Como consecuencia de la ausencia de profundidad en el estudio de estos músicos por la historiografía positivista, es frecuente encontrar que este factor, el formativo, se utiliza como indicador para identificar, por la negativa, a todos los músicos que no reciben instrucción «a través de las escuelas anexas a las catedrales e iglesias colegiatas, concebidas para la educación de los niños del coro» (Mayer Brown y Polk, 2001b, p. 98). Una vez más, el conjunto resultante reunirá una gran variedad y diversidad de sujetos y prácticas agrupados meramente por no pertenecer a la institución eclesiástica. Así «ministril se ha convertido en el término utilizado con mayor frecuencia por los autores modernos para designar al músico profesional que posee una formación y educación básicamente seculares» (Guion, 2007, p. $2)^{254}$

En el modelo musicológico hegemónico la música eclesiástica medieval se convierte en sinónimo y reaseguro de la tradición escrita en partitura y, por lo tanto, de música merecedora de ingresar en la narrativa histórica por propio derecho, en base a su identidad

253 «some cities with lively musical traditions, such as Paris or Bruges, also had continuous minstrel schools. Music teachers with different specialities gave instruction, and the students not only included those seeking an introduction to the art of music but also anyone who sought the advice of a famous teacher» (Gómez, 1990, p. 213) [traducción del autor]

254 «"Minstrel" has become the most frequent term that modern writers use to designate professional musicians of the Middle Ages with basically secular training and education» (Guion, 2007, p. 2) [traducción del autor]. 
y no a la ausencia de ésta. Lo que está por fuera de este modelo es lo profano, un otro que no responde a estos requisitos. De allí que se agrupen de este modo prácticas que guardan muy poca o nula relación entre sí, y solo las una el contraste con la música sacra que, si bien es la más artificiosa dada la ínfima porción de la sociedad que la practica y a su filiación con el modelo de la música de las esferas, se convierte en norma a partir de la cual juzgar a toda forma de producción posible.

Este reduccionismo ha derivado en importantes equívocos sobre la música del período que confunden ámbitos de producción musical muy diferentes. Un buen ejemplo de esto lo representa el texto de Bryan Trowell que forma parte del segundo volumen de la colección de historia de la música de la editorial Pelican, compilada por Alec Robertson y Denis Stevens. Es un texto sobre el Renacimiento en el cual se reproducen algunas de las problemáticas que mencionamos antes. Dentro del capítulo de Trowell existe un apartado denominado minstrels and minstrelsy (Trowell, 1978, p. 45) en el cual el autor amontona, como si fuesen la misma cosa, música de los troveros, de los minnesinger, de los meistersinger y de lo que aquí estamos denominando músicos municipales urbanos, los que quizás mejor se pueden asociar con la idea de minstrelsy. Es decir, se mezclan las músicas de reyes y príncipes con las de la burguesía y el pueblo llano sin hacerse ningún problema y pretendiendo que suenan igual. Pero lo realmente sorprendente es la traducción al español del texto que se llama los trovadores y la gaya ciencia (Trowell, 2000, p. 65), en la cual el traductor, independientemente de su pericia profesional, ${ }^{255}$ es notoriamente "hablado" -en sentido heideggeriano- por los preconceptos de la historiografía musical positivista y utiliza durante todo el capítulo el término trovadores en lugar de ministriles, incluso cuando se desarrolla la música de baile al aire libre (p.72).

Esta incidencia en los libros de texto y la potencia de su reproducción son una clara muestra de la necesidad de intentar una somera, aunque provisional, clasificación de los músicos que suelen reunirse bajo la denominación de ministriles, la cual ensayaremos a continuación.

\subsubsection{Ministriles y ministriles: los domésticos}

Si bien es esencialmente correcto utilizar un único término para reunir a los músicos profesionales no eclesiásticos de la Edad Media y el Renacimiento, «aunque la sociedad los requería para una multitud de propósitos, y por más que sus habilidades fueran tan variadas como sus estilos de vida y valores estéticos» (Strohm, 1990a, p.74)256, es necesario que hagamos una primera distinción importante dentro del conjunto de los ministriles. $Y$ es aquella relativa a discriminar a los músicos que revistan en la servidumbre de la aristocracia o -en menor medida- el clero.

La diversidad dentro de este conjunto de músicos en la Edad Media [...] requiere que toda discusión acerca del estatus socio-económico de los ministriles medievales de cuenta de subgrupos específicos. Además el cambio dramático dentro de la profesión hacia fines de la

\footnotetext{
255 De hecho es traductor al español de una de las versiones más difundidas de El origen de las especies de Charles Darwin.

256 «Although society needed them for many different purposes, and although their skills were as varied as were their lifestyles and aesthetic views» (Strohm, 1990a, p.74) [traducción del autor]
} 
Edad Media, relacionado con el surgimiento del patrocinio municipal, demanda que toda exposición sobre el tema incluya periodizaciones específicas (Peters, 2000, p. 213).257

Por supuesto estamos hablando, nuevamente, del ministril que ya vimos asociado a las cortes feudales trovadorescas. Recordemos que en su forma principal, al menos para lo que aquí estamos discutiendo, el ministril doméstico está asociado al mundo feudal y no al urbano. $Y$ aunque, como vimos, la gran aristocracia -en cuyas cortes se desempeñan los trovadores que son señores de estos ministriles- tienen relación e incluso dominio sobre el mundo urbano medieval, el locus del músico doméstico es el interior de la corte, proveyendo la música privada de la nobleza. Es en este ámbito en el cual se convierte en productor del vector de la distinción social y el pathos de la distancia. Y por ello estará asociado, en el lapso histórico que estamos considerando, con el desarrollo de los conjuntos de instrumentos bajos, es decir, de los instrumentos que hacen música suave: las cuerdas, sobre todo la viola o el laúd, y los instrumentos de teclado como el clavicordio o el órgano portátil, además de las flautas de pico. A estos habrá que sumar los canterini y otras clases de cantantes improvisadores, de cuya reunión podemos deducir la emergencia de la música de cámara del siglo $\mathrm{XVI}$, representada en especial por la chanson cortesana, la frottola y el madrigal.

Un segundo conjunto, diferente al anterior pero aún así pasible de reunirse bajo el concepto del doméstico, es el de los trompeteros de la nobleza. En este caso, los ministriles solían formar conjuntos de dos o más trompetistas y su función principal era señalar las actividades de sus señores, es decir sonar una fanfarria a modo de presentación, razón por la cual solían escoltarlos en sus viajes. En opinión de David Guion (2007, p. 1) los trompeteros sólo adquieren la forma de organización urbana recién promediando el siglo $\mathrm{XIV}$, por lo que son posteriores a las bandas cívicas municipales. Esto no debe llevarnos a la confusión de entender que surgen como imitación o copia de éstas últimas. Lo que sí es importante es que comprendamos su naturaleza contrastante a partir de las diferencias de función: aunque los trompeteros ejerzan en algún momento actividades más "artísticas", como tocar en reuniones sociales, su función principal, insistimos, es la de representar a la autoridad de la nobleza o el clero, tanto en el mundo feudal como en el urbano. Lo cual desarrolla un índice de distinción acústico en torno al privilegio sobre el derecho a utilizar la trompeta como señal. Tan codiciado y ostentoso se vuelve este recurso, que en algunos casos raya con lo estrafalario:

El duque de Borgoña llevaba un séquito de 12 trompeteros, cuyas obligaciones se reseñan con todo detalle en un documento descriptivo de su corte. Cuando se disponía a abandonar una ciudad debían ejecutar una fanfarria bajo sus balcones, a la hora señalada para el despertar; después, cuatro de ellos iban a dar la señal de ensillar los caballos en los cuatro extremos de la localidad. Tras el desayuno, el trompetero jefe acompañaba al duque hasta que sonaba la indicación de montar, y una vez todo a punto, hacía ejecutar el toque de "a caballo" y los diversos servidores de la casa se congregaban tras sus jefes. A la siguiente señal formaban ante el alojamiento del señor y a continuación los trompeteros tocaban la llamada final, momento en que el propio duque montaba en su caballo. La llegada a una ciudad se hacía con un ceremonial parecido (Trowell, 2000, p. 68).

La aparición en las ciudades obedece a que las cortes se trasladan a este ámbito a partir del lento declive del mundo feudal, y a que el poder, económico y político, pasará por las ciudades a partir del siglo XIV, recayendo en sectores de origen burgués que se aristocratizan, como ocurre en algunas de las ciudades italianas paradigmáticas del

257 "The diversity within this body of musicians in the Middle Ages (...) demands that any discussion of the socioeconomic status of medieval minstrels address specific sub-groups. In addition, the dramatic change of status within the profession of minstrelsy by the end of the Middle Ages, connected with the rise of civic patronage, demands that any discussion address specific time periods" (Peters, 2000, p. 213) [traducción del autor] 
Renacimiento. Allí también encontramos este tipo de ostentación un tanto exagerada en el uso simbólico de las trompetas en el ceremonial cívico. Los duques de Milán, la familia Sforza, que descendían de mercenarios y no de aristócratas, tenían un cuerpo de veinte trompeteros a mediados del siglo XV. En cambio Ercole d'Este, gran duque de Ferrara y descendiente de la nobleza romana y pariente de los duques de Baviera, tenía sólo ocho. (Atlas, 2002, p. 265). Según las crónicas de la época en el matrimonio celebrado entre Alfonso d'Este y Ana María Sforza, que uniría a ambas familias y ducados, las fanfarrias estuvieron a cargo de la sorprendente cifra de cuarenta y seis pares de trompetas, es decir noventa y dos músicos (Lockwood, 2009, p .154)

Este aspecto representativo produce la diferencia de estatus que hace que el ministril doméstico disfrute en general de beneficios que no poseen los músicos municipales: fundamentalmente un salario más alto y privilegios sobre cierta actividad o modo de ejercicio. En especial en territorios del Imperio Germánico los trompeteros aparecen en numerosos edictos que buscan imponer estos privilegios. En uno de estos actos imperiales, aunque algo tardío, puede leerse cómo se beneficia a la Kammeradshaft -la hermandad de los trompeteros- en detrimento de los Stadtpfeifer-los músicos municipales:

Dado que los trompeteros y tamborileros tocan únicamente para los Emperadores, Reyes, Príncipes Electores e Imperiales, Condes y otros señores de rango caballeresco, y personas de igual calidad, y por tanto no pertenecen en común a todos, ningún trompetero respetable, bajo amenaza de penalidades a ser resueltas por sus colegas, podrá tocar con juglares, vigías, cuidadores o similares... así como tampoco ningún juglar, apostador, torrero e incluso músico municipal (Stadtpfeifer) o ministril podrán tocar la trompeta o el tambor militar por fuera de sus escenarios, puestos o torres, así como tampoco podrán hacerlo en bodas, bautismos, bailes sociales, festivales eclesiásticos u otras reuniones similares ante Condes, Barones, ciudadanos y otros; tampoco deberán usar las trompetas -y tampoco los trombones a modo de trompetas- en las fanfarrias de procesiones (Aufzüge), bailes (o) para sonar la alarma (Collins, 2000 , p. 51). ${ }^{258}$

Si bien el documento es posterior al período que estudiamos (el edicto es de 1658), es igualmente revelador de las costumbres y el imaginario en torno a los músicos urbanos, especialmente en cuanto a la diferenciación o estratificación que se hace de ellos. A ojos del poder aristocrático, los trompetistas sobresalen entre los músicos, al punto de que se les permite tocar su instrumento en cualquier lugar con la sola excepción del puesto "natural" de los músicos municipales (las torres o la Iglesia). Ellos pueden intervenir en las fiestas populares junto a los demás músicos y artistas, pero tienen privilegios para tocar su instrumento en las celebraciones oficiales convocadas por la autoridad, sean solemnes o festivas. En síntesis, si el pathos de la distancia de la nobleza podía y acostumbraba tomar parte en la fiesta popular medieval, pero restringía el acceso de los sectores populares a la celebración cortesana, los trompeteros, en tanto representantes sonoros de la aristocracia, y por lo tanto sus domésticos, podían tomar parte en cualquier ocasión musical pero reservándose la exclusividad sobre el uso de su instrumento y sus actuaciones representativas. Ya en el siglo XVII y como maestro de la Thomaskirche de Leipzig, Schein fue amonestado por las autoridades por utilizar trompetas en la iglesia. El compositor intentó excusarse con argumentos musicales, pero por lo que se ve su explicación no le

258 «Because trumpeters and kettledrummers perform solely for the Emperor, Kings, Electoral and Imperial princes, counts and lords of knightly rank, and similar persons of quality, and therefore do not belong in common to everybody, no respectable trumpeter, under threat of penalty to be decided upon by the fellowship, shall perform with jugglers, tower watchmen, caretakers or the like... Nor shall any comedians, jugglers, gamblers, tower watchmen, or even any city pipers (Stadtpfeifer) or minstrels perform on trumpets or military kettledrums, outside of their stages, stands, or towers, or at weddings, baptisms, dances of rejoicing, church festivals, or other similar convocations for counts, barons, townsmen or others; nor shall they use them -and certainly not trombones as if they were trumpets- for processional fanfares (Aufzüge), dances (or) blowing alarms» (Collins, 2000 , p. 51) [traducción del autor] 
sirvió de mucho, ya que se le advirtió que no lo volviera a hacer y usara cornettos en lugar de las trompetas (Collins, 2000 , p. 59). No hay ninguna razón para suponer que el cornetto, un instrumento de madera con embocadura de copa -similar a la de la trompeta- tenga relación alguna con estas problemáticas. Pero dado que el auge del cornetto se da hacia el siglo XV y existiendo una permanente actitud por parte de los músicos de rechazar y rebelarse ante las prohibiciones que protegían a los trompeteros, uno se ve tentado a encontrar alguna ligazón.

Ya se trate del ministril cortesano al servicio del trovador, o del trompetero, la función principal del ministril doméstico continuará siendo la representación social de los sectores aristocráticos en pos de la distancia que ya analizamos, a la cual los trompeteros añaden un señalamiento de tipo heráldico, también ante todo representativo. Esto no implica en forma alguna que pudieran desempeñarse también en el ámbito eclesiástico, sirviendo a obispos u otras personalidades individuales de la Iglesia, o tomando parte en la música sacra. De hecho cantar siempre fue una habilidad requerida a los ministriles domésticos, existiendo incluso el ménestrel de bouche que podríamos traducir como ministril vocal. En la ciudad de Brujas hay constancia de que se contrataba a estos ministriles para cantar la misa polifónica. También podían convertirse en compositores de cierto renombre y especializarse en la chanson cortesana, como Baude Cordier o Mossèn Borra (Strohm, 1990a, p. 74).

Al subconjunto de los ministriles domésticos debemos pensarlos, entonces, como una primera derivación ascendente del juglar proscrito que se convierte en músico profesional. Lo que nos conducirá al tipo de relación más habitual entre los compositores del canon musicológico moderno: el mecenazgo. El considerar únicamente a este tipo de ministriles es tal vez una de las razones por las cuales el tan mentado fin del mecenazgo se ubica, para la historiografía positivista, recién en el siglo XIX. No es de extrañar, ya que esta perspectiva focaliza sus estudios en las élites y por lo tanto, antes de la revolución francesa, en el ámbito de las cortes en las que reina esta relación socio musical, ya se trate de Machaut, Isaac, Caccini o el Haydn de los Esterházy. En un sentido histórico -y no estilísticodebemos pensarlos a todos ellos como herederos de los ministriles domésticos.

\subsubsection{Músicos municipales profesionales}

El otro gran conjunto es el representado por aquellos que tal vez encarnan mejor la posición del ministril urbano profesional. Los llamaremos músicos municipales, con la idea de resaltar su carácter indisociable con la ciudad como unidad de análisis de este período histórico. Si bien en la mayoría de los casos estos músicos, reunidos en bandas, son contratados directamente por los ayuntamientos y otros tipos de asociaciones fundamentalmente burguesas -como las cofradías- también pueden estar al servicio de nobles y obispos. Lo que los distingue en verdad de los domésticos es que se convierten en el emblema de la ciudad antes que de la distancia que media entre la comunidad y la figura o posición social de sus gobernantes. Por este motivo, en dicha operación se buscará que todos los ciudadanos se vean representados, funcionando como dispositivo de cohesión social. $Y$ por tal razón, no deberá sorprendernos que encontremos el apogeo de estos músicos municipales en las ciudades burguesas libres -o en lucha por la autonomía-- del norte de Italia, los Países Bajos, el territorio germano parlante, el sur de Francia e incluso Inglaterra. El proceso político que conduce hacia la emergencia de la burguesía como actor social de relevancia en los siglos XV y XVI tiene su correlato sonoro en el desarrollo histórico de las bandas municipales. Este eje de análisis, como ya adelantamos, aglutina en un arco coherente todo el lapso que va del auge urbano del siglo XII al ocaso de las ciudades autónomas -y su derrota ante el poder monárquico-, declive que comienza en el siglo XVII. 
La unidad musical de los municipales es la banda cívica, un conjunto que a lo largo del período tiende a estabilizar su conformación, transformándose quizás en el primer grupo instrumental occidental en contener un orgánico regular y estandarizado. Desde Colonia hasta Nuremberg, pasando por Montpellier, Aviñón, Ferrara o Siena, y llegando a Arras, Utrecht o Brujas para terminar en Beverly y Londres, la banda de los músicos municipales se organiza en torno a los instrumentos de viento altos, o de mayor nivel sonoro, excluyendo, como ya vimos, a las trompetas. Al menos a partir de mediados del siglo XII, los registros contables de éstas y otras muchas ciudades «muestran la creación de un nuevo grupo importante para la vida de la ciudad (...) los instrumentistas de viento municipales» (Polk, 2004, p. 110). Al principio suelen contratarse a dos músicos para formar el conjunto cívico. Evidentemente la formación de estos conjuntos supone un gran desafío para las cuentas públicas de las ciudades medievales. Incluso algunas importantes como Berna podía mantener sólo un dúo aún en el siglo XIV. Al parecer París, Utrecht, Londres, Brujas, Nremberg o Dortmund, son algunas de las ciudades que en fecha relativamente temprana pueden darse el lujo de costear tres instrumentistas.

Superada la etapa incipiente, desde el final del siglo XIII el conjunto se estabiliza, por regla general en torno a una base de tres integrantes. Ya para el siglo XV la configuración de cuatro músicos se hace ubicua (Mayer Brown y Polk, 2001a, s/p). El instrumento que está en el núcleo del conjunto es la chirimía, una doble lengüeta antecesora del oboe moderno. Las primeras formaciones registradas son así dúos de dos chirimías, por lo general en registro contralto. A este par se agrega otro instrumento similar, pero en registro tenor: la bombarda. En correspondencia con la habitual disposición de la polifonía tardomedieval a tres voces, durante el siglo XIV esta será la conformación más difundida. Luego, en algún momento del mismo siglo este trío se ampliará a cuarteto con el añadido del sacabuche, un antiguo trombón a varas. No queda claro si desciende de la trompeta de varas simple, instrumento independiente de los trompeteros, o si es probable que ante las disputas entre éstos y las bandas, y las prohibiciones, los músicos municipales desarrollaran un instrumento capaz de imitar a la trompeta pero que no se pareciera a ella. Según Don Smithers (1973) los músicos municipales tocaban «unos instrumentos curiosamente enrollados hechos de forma tal de no parecerse a la trompeta, pero que de todas maneras sonaban igual que ésta» $\left(1973\right.$, p.114). ${ }^{259}$ Sería esta una manera de eludir las prohibiciones de los edictos en favor de los trompetistas y poder así diversificar y ampliar el sonido de los ensambles evitando las multas y castigos (Collins, 2000, p.52). Sea cual fuere la causa de la introducción del trombón, debemos considerar que la configuración típica de la banda de músicos municipales es la de dos chirimías, bombarda y sacabuche.

A este núcleo instrumental podían agregarse otros instrumentos, como las gaitas, los tambores e incluso algunos instrumentos de cuerdas (Polk, 2004, p. 111), además de otros vientos como el cromorno, el corneto, el bajón, la dulzaina, el rackett, entre otros. Numerosas fuentes iconográficas de la época muestran este tipo de conjunto, como por ejemplo el Eclesiastés de la Biblia de Borso d'Este de 1460, miniada por Taddeo Crivelli260, la pintura La boda de Adimari, de 1450261, o la Fuente de la eterna juventud de Cristoforo de Predis, de también ca. 1450.

\footnotetext{
259 «playing... curiously wound instruments made so as not to resemble trumpets but sounding none the less the same» (Smithers, 1973, p. 114) [traducción del autor]

260 Puede verse aquí https://commons.wikimedia.org/wiki/File:Bible_de_Borso_d\%27Este,Taddeo_Crivelli.jpg

261 Puede verse aquí https://www.agefotostock.com/age/es/Stock-Images/Rights-Managed/DAE-A2001210
} 


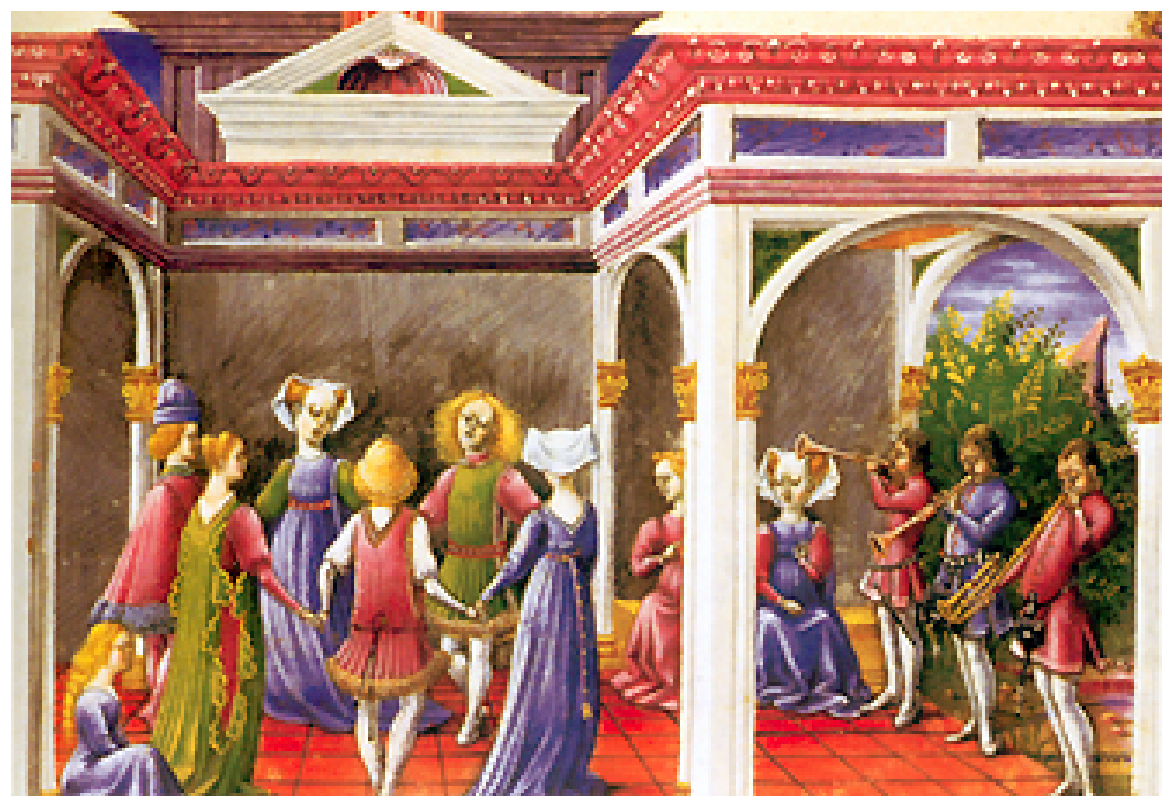

Detalle inferior del Eclesiastés en la Biblia de Borso d'Este en dónde vemos a un conjunto de ministriles

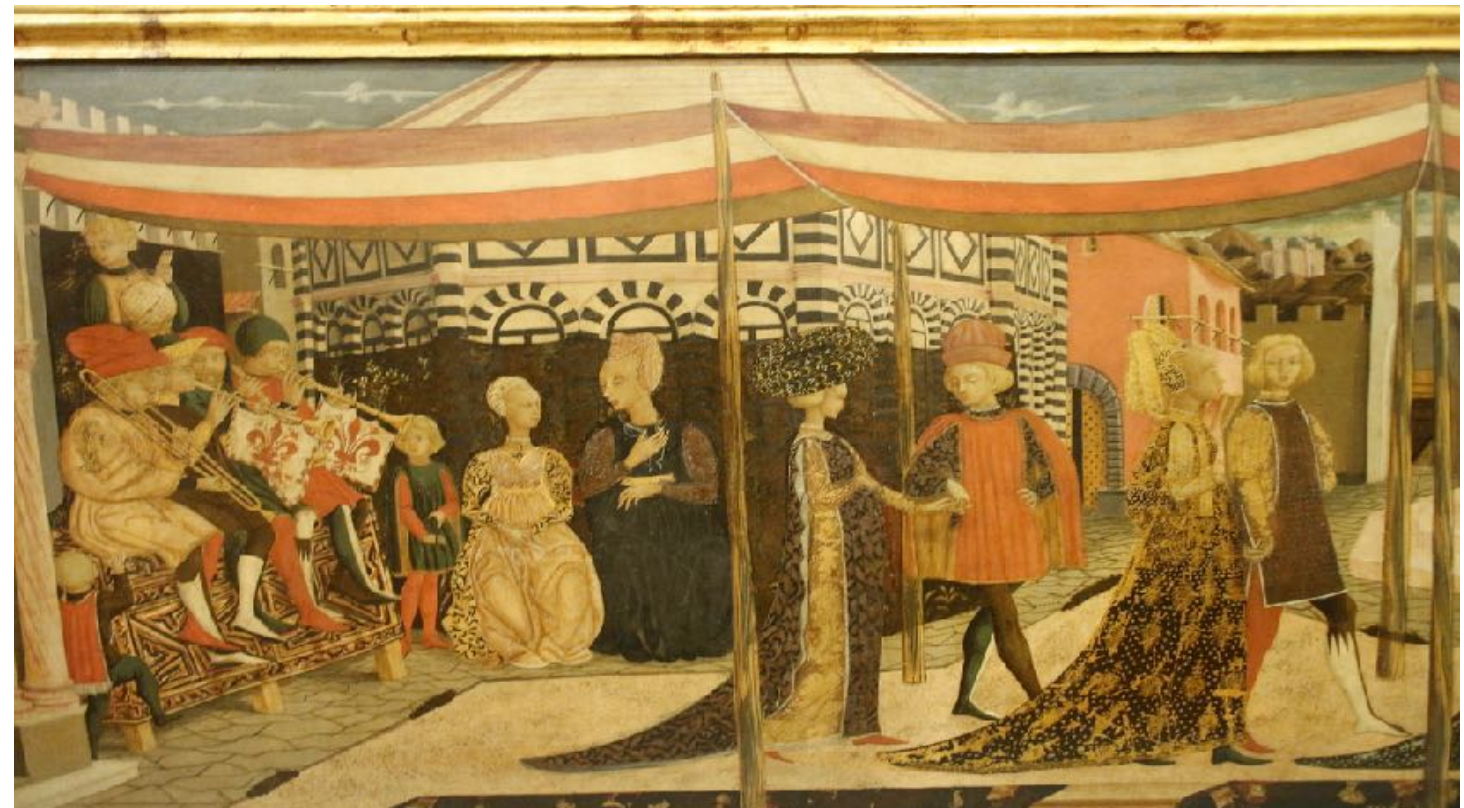

Detalle de la pintura La boda de Adimari o Cassone Adimari (Florencia, Galleria dell'Accademia), en dónde vemos a los músicos en una ocasión muy habitual: las fiestas sociales de las familias burguesas 


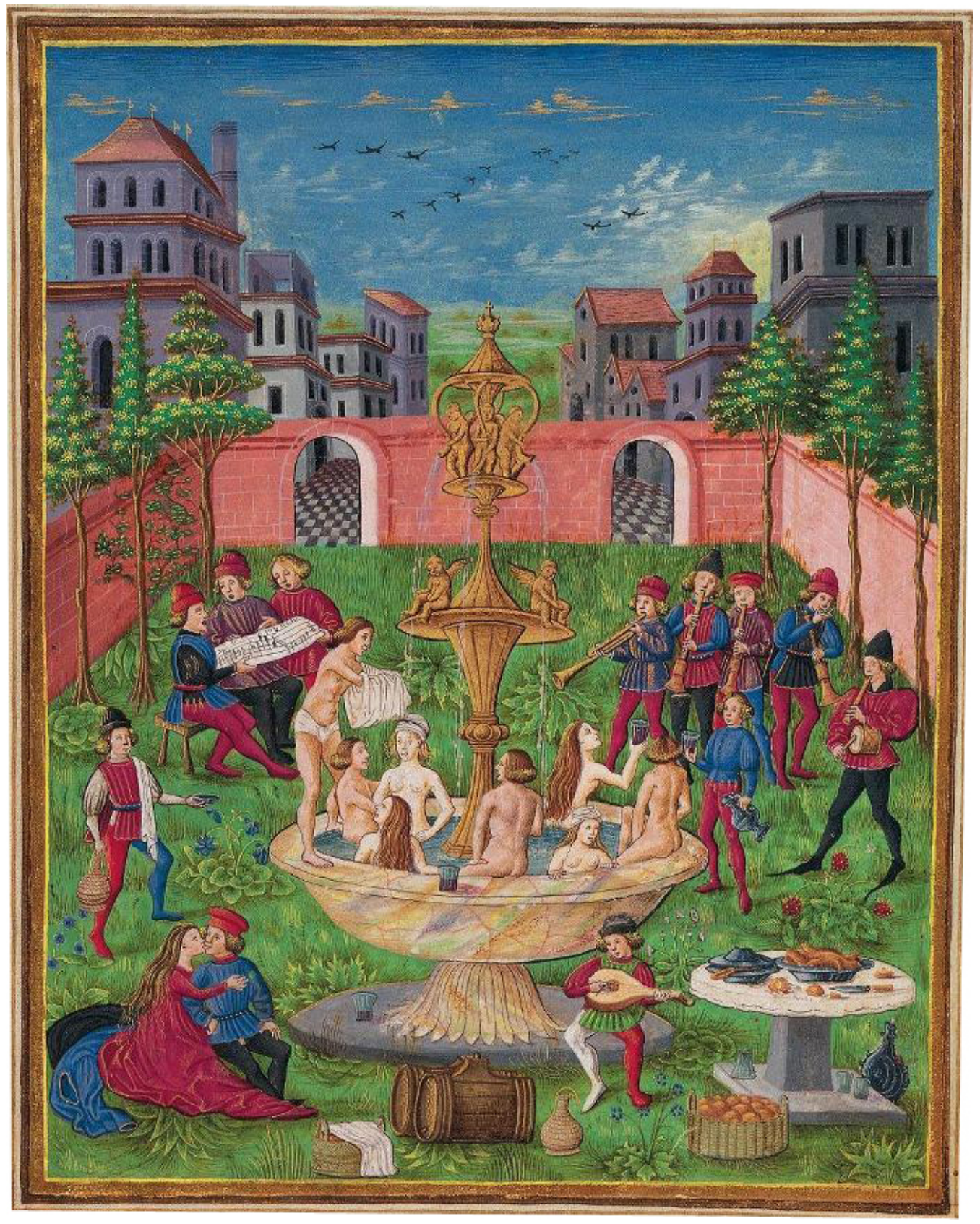

La Fuente de la eterna juventud de Cristoforo de Predis, con los ministriles a un lado y los cantantes del otro. ¿A qué lado mira la musicología histórica? Al juglar que está en primer plano seguro que no.

Como puede verse en estas y otras muchas imágenes, los ministriles municipales representan a la ciudad también desde su apariencia: visten de uniforme con los colores de la ciudad; se atavían con los correspondientes blasones, escudos e insignias; utilizan el nombre de la ciudad para individualizar al conjunto, de suerte que serán los York waits o los Nürnberger Stadtpfeifern; y lo más importante, son quienes encabezan y acaparan desde lo sonoro las ocasiones públicas mediante las que se articula el ritual y ceremonial de la ciudad, que fundamentalmente sirve para recordar la identidad frente a las demás ciudades y otros poderes como el Imperio o la Iglesia.

El orgullo cívico (con una buena dosis liberal de ostentación) estaba en juego, ya que sobre estos nuevos músicos recaía con claridad el propósito de representar el poder, la dignidad y la independencia de las ciudades. A los ejecutantes se les vestía apropiadamente con la librea [de la ciudad], se les proveía de grandes medallones de plata en los cuales aparecía el blasón 
de la ciudad, y sus instrumentos eran equipados con banderines pintados elegantemente (Polk, 2004, p. 110)262

Pero a diferencia de la representación social de ministriles domésticos, trompeteros y sus señores trovadores, los ministriles municipales despliegan un tipo de representación que, al menos como pretensión, busca incluir a la totalidad de la población de la ciudad. Se trata por lo tanto de un esfuerzo identitario colectivo, por más que sirva conscientemente para mantener el orden político de la ciudad y garantizar la aceptación y legitimidad del poder de sus gobernantes, muchas veces en crisis en base a la ausencia de una ascendencia nobiliaria. No debemos hacernos aquí ningún tipo de ilusión libertaria. De hecho, la fiesta cívica instituida por el poder de la ciudad se aparta del sentido bajtiniano del carnaval, incluso cuando asimila algunas de sus formas, suprimiendo enfáticamente cualquier característica subversiva presente en la fiesta popular. El matrimonio con el Mar del Dux de Venecia, o la fiesta de la explosión del carro en Florencia son buenos ejemplos. Se trata de un tipo de metáfora que busca "hacer creer en el orden consensual del mundo» (Attali, 2011). Podemos llamar por lo tanto representación identitaria a esta función social que vehiculizan los músicos municipales.

Esta representación armoniosa o armónica será, como sabemos, el gran paradigma del arte moderno y lo tomarán las monarquías absolutistas tanto como la burguesía. De hecho puede leerse la modernidad y su desarrollo estético en clave del proyecto para consolidar la hegemonía de las clases dominantes (Eagleton, 2006). Será una práctica común evidenciable en la música tonal y el teatro de ópera. Pero justamente por eso, encontrar de forma incipiente su articulación en los músicos urbanos medievales sea tal vez uno de los mejores indicadores que nos hablan de un sentido moderno de la música, que la aleja muy claramente de muchas concepciones medievales ya en el siglo XIII, reforzando la hipótesis de periodización que, a partir de Hauser, estamos ensayando aquí.

\section{Una falacia evolucionista: los músicos no son vigilantes}

Otra consecuencia de la marginalidad historiográfica en que el positivismo musicológico arrojó a los músicos urbanos profesionales, es la creencia de que sus prácticas responden exclusivamente a aspectos funcionales. Aquí función equivale a la posición estrictamente opuesta a la que ocupa lo estético. Se recupera así, una vez más, el programa de la modernidad al que hacíamos referencia, en cuanto a la instalación de lo armonioso como metáfora del orden social. Según Terry Eagleton, una de las claves para lograr esto fue el desarrollo de las ideas en torno al desinterés estético y la autonomía del arte (2006 p. 59). En musicología, esto condujo a que el repertorio privilegiado por la historiografía hegemónica sea la música absoluta, aquella que no contiene referencias explícitas a ningún fenómeno o circunstancia sino que es vehículo del absoluto que reside en la subjetividad del genio creador. De hecho, a partir de allí, se dividen los datos y fuentes entre aquellos musicales en contraste con los extra-musicales.

No es de extrañar entonces que cuanto más se adivina funcional la música de los profesionales urbanos tardomedievales, menos se la considere como importante a la hora de profundizar en su estudio. Existe en este caso un aspecto que no tiene ningún sustento documental, pero que sin embargo ha subsistido en la musicología durante prácticamente todo el siglo XX, y aún continúa reproduciéndose. Es la creencia en la evolución -palabra cara al positivismo- de los vigías y guardias de las ciudades, en músicos municipales.

262 «Civic pride (with a liberal dose of ostentation) was involved, as the newly added musicians were quite clearly intended to represent the power, dignity and independence of the cities. The players were dresser in appropriate livery, they were provided with large silver medallions bearing the crest of the city and their instruments were equipped with elegant painted banners» (Polk, 2004, p. 110) [traducción del autor] 
Existen numerosas fuentes históricas que señalan, por lo menos desde el siglo XII, que a los vigías de las torres y murallas de las ciudades se los proveía de algún instrumento de viento con el objeto de que pudiesen producir señales acústicas para avisar diferentes circunstancias: sonar la alarma ante algún peligro, saludar a los barcos y caravanas comerciales a las que se cobraba peaje, avisar de la visita de algún dignatario o comitiva importante, sonar la hora, señalar el comienzo y final de algún evento como una feria, competencia, etc. Si bien el instrumento que se les suministraba solía ser algún tipo de cuerno, se los designaba por su condición de vigías. Así aparecen en Inglaterra los wayts o wakemen -los que hacen la ronda- (Guion, 2007, p. 2) y en la región germana los türmer los torreros o que andan en la torre (Raynor, 1986, p. 61). En otros lugares, como los Países Bajos, se los menciona como sopladores (horn-blowers) (Beukers, 1991, p. 11). Dada la coincidencia en la utilización de instrumentos de viento altos y el carácter absolutamente funcional de estas actividades, sumado a alguna coincidencia terminológica -en Inglaterra las bandas municipales recibieron también el nombre de Waits-, se consideró natural que los conjuntos musicales profesionales eran una derivación evolutiva de los vigías. Tal asunción se hizo, insistimos, sin buscar prueba documental alguna y dando rienda suelta a todos los preconceptos de la estética clásica. Incluso en textos muy recientes se continúa con esta inferencia que ve una evolución únicamente a partir de coincidencias en los nombres o de los lugares en los que tocaban los músicos:

\begin{abstract}
En Inglaterra también podían encontrarse conjuntos de viento similares a los del Imperio, a los que se llamaba waits. Los vigilantes recibían el mismo nombre, lo que indica que en Inglaterra, así como en los territorios alemanes, los intérpretes de instrumentos de viento municipales habían trabajado alguna vez en atalayas, desde donde señalaban la hora o la existencia de algún peligro. En muchos lugares, los instrumentistas municipales continuaron tocando música desde atalayas, incluso después de haber renunciado a sus puestos de vigilantes (Hill, 2008, p. 179)
\end{abstract}

¿Es suficiente que el lugar desde donde toca habitualmente la banda municipal sea la torre para que extraigamos de allí un desarrollo histórico en el cual los instrumentistas, cuando se hacen músicos, renuncian a un trabajo que suponemos poco interesante? ¿Por qué no pensar que la torre o cualquier otro lugar elevado, visto desde dentro de la ciudad, es un buen escenario para una música pública que pretende llegar a toda la población, sin que por ello deduzcamos antepasados vigilantes para los instrumentistas? ¿Dónde más podría tocar la banda municipal para lograr tal objetivo, más cuando las torres de los ayuntamientos se ubican precisamente frente a la plaza principal de la ciudad, donde también estaba el mercado y ocurrían la enorme mayoría de eventos y fiestas cívicas? Salvo que pesara alguna prohibición -como en el caso de algunas cortes e iglesias- no hay ninguna razón para que entendamos que los músicos municipales elegían las torres porque habían sido vigilantes. Más si atendemos a la cronología, la cual nos indica que, si efectivamente ocurrió un cambio de función en los instrumentistas, no ocurrió en la misma generación sino a lo largo de varios siglos. ¿Es verosímil pensar que alguien que podría ser el bisnieto de un vigilante continuaría usando la torre un siglo y medio más tarde, para desarrollar una práctica musical muy distinta con una función social también diferente, tan sólo porque permanecía algún tipo de memoria simbólico emocional de la profesión? Como vemos, la evolución del vigilante en instrumentista suena bastante a cuento de hadas. 


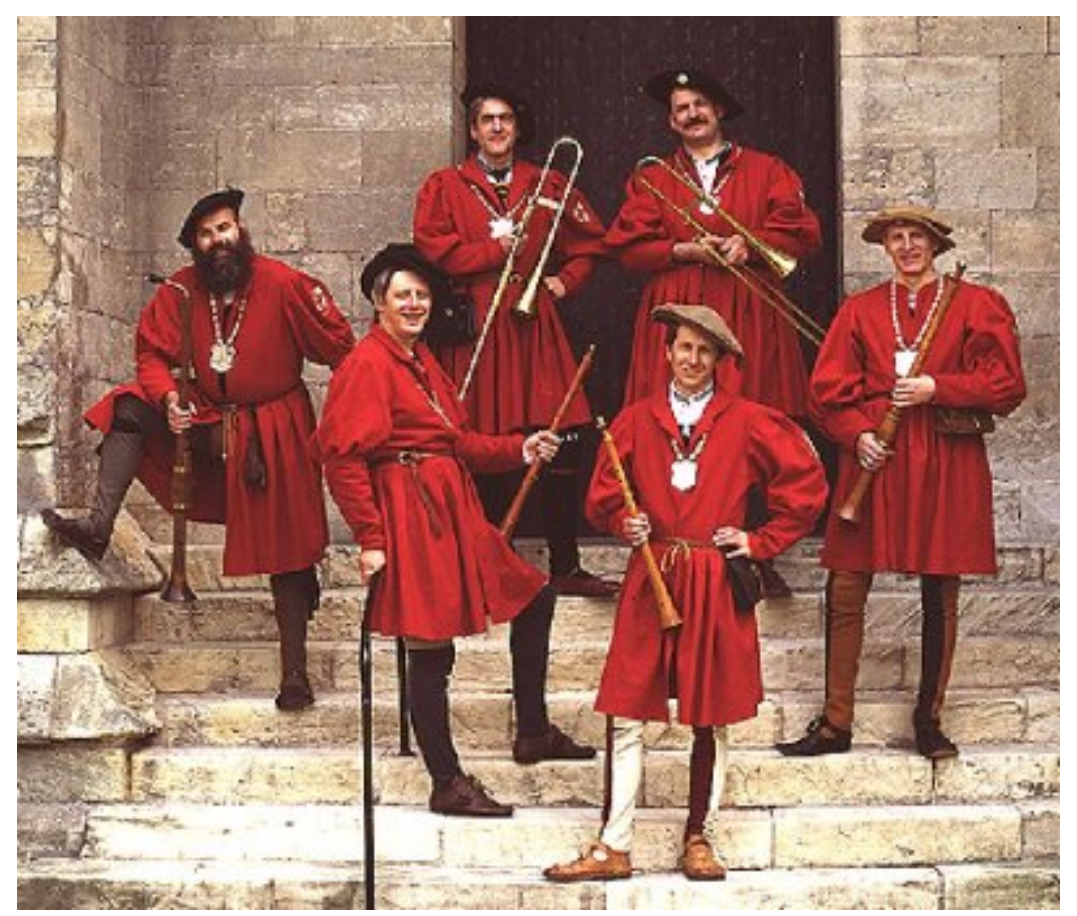

Los actuales waits de York vestidos con el uniforme y portando la insignia de la ciudad colgando del cuello

Richard Rastall (2006, p. 6) es categórico en su refutación de la teoría evolutiva de vigilante-a-ministril para el caso de Inglaterra. Haciendo una lectura crítica de los textos historiográficos de principios del siglo $X X$, ya fueran de aficionados anticuarios 0 historiadores profesionales, Rastall logra ubicar cuál sería la encrucijada de los equívocos que llevaron a desarrollar los relatos pintorescos sobre los músicos vigías. La pista residiría en una primera descripción hecha por E. K. Chambers en su muy famoso The medieval stage

Los ministriles también pueden encontrarse (...) al servicio de las corporaciones municipales. London, Coventry, Bristol, Shrewsbury, Norwich, Chester, York, Beverly, Leicester, Lynn, Canterbury, los tenían, por nombrar solo algunas. Reciben honorarios o cuotas fijas, visten la librea de la ciudad y un medallón de plata con el escudo de armas, tocan en todas las fiestas y ceremonias locales, y eran comúnmente conocidos como waits. Este término ya lo habíamos encontrado en uso en las cortes, y el Black Book que contiene las regulaciones de la casa de Eduardo IV nos informa que la principal función de un wait es la de "tocar la ronda", en verano y en invierno, a ciertas horas de la noche (Chambers, 1963, p.51) 263

Una lectura rápida de este texto puede llevar a la confusión de que tanto los waits municipales como los domésticos cumplían tareas de vigilancia. Pero Chambers deja muy en claro las diferencias entre las funciones de unos y otros. Naturalmente el equívoco se facilita por la utilización recurrente de la palabra wait. Pero una lectura atenta del párrafo no deja dudas de que se trata de dos tipologías de músicos diferentes. Pero aquí también, pensar que la vinculación entre los vigilantes y los ministriles deriva de una lectura poco concentrada es algo ingenuo, aunque sea lo que supone Rastall: «no se quién fue el primero que leyó mal este párrafo, pero la confusión resultante ha sido reproducida por

263 «Minstrels are also found (...) in the service of the municipal corporations. London, Coventry, Bristol, Shrewsbury, Norwich, Chester, York, Beverly, Leicester, Lynn, Canterbury, had them, to name no others. They received fixed fees or dues, wore the town livery and badge of a silver scutcheon, played at all local celebrations and festivities, and were commonly known as waits. This term we have already found in use at court, and the 'Black Book', which contains the household regulations of Edward IV, informs us that the primary duty of a wait was to 'pipe the watch', summer and winter, at certain fixed hours of the night» (Chambers, 1963, p.51) [traducción del autor] 
todos los historiadores de los ministriles durante el siglo $X X_{»}{ }^{264}$ (Rastall, 2006, p. 3). ¿En verdad todos los historiadores leyeron mal? Tal vez la desatención en la lectura resulta de una actitud historiográfica y esteticista que considera a estos conjuntos, y a los instrumentistas en general, como repertorio menor, poco interesante para ser historiado. Vale la pena recordar aquí la cita ya mencionada de Nicholas Cook (cfr. pág. 64), que se refería a la gran diferencia en el rol de compositores e intérpretes en la historia musical afirmativa, en la cual los segundos finalmente adquirían un rol de criados victorianos.

Otros autores, como Keith Polk, sostienen una posición intermedia referida a tradiciones divergentes según la región

En algunas áreas como el norte de Francia y Flandes, los ensambles de músicos municipales estuvieron originalmente ligados a los grupos de vigías. En otras regiones (Alemania y el este de los Países Bajos, por ejemplo) los ensambles urbanos parecen haber sido en cuanto a su carácter más exclusivamente musicales desde un principio (Mayer Brown y Polk, 2001b, p. $99)^{265}$

En esta línea Mariëlla Beukers señala que mientras es plausible la opinión de que en algunas zonas los ministriles hayan surgido de los vigías, torreros y pregoneros, no parece ser este el caso de Utrecht, ciudad holandesa que ella estudia. «Además de los vigías, a quienes se les suministraba una corneta [o trompa] y a quienes se menciona en los archivos como "cornistas [horn-blower] 266 de la torre de la Buurkerk", había además ministriles urbanos en servicio, al menos desde 1402» (Beukers, 1991, p.11).267 La autora infiere que si las tareas de los ministriles eran tantas y tan específicas, difícilmente pudieran ellos ser estos cornetistas que mencionan los archivos. La contratación de ministriles en Utrecht pareciera responder a fines musicales antes que de vigilancia, relativos a la representación identitaria que mencionamos antes. En esto parece coincidir Keith Polk acerca de las ciudades alemanas en donde, además de contratar a la banda de músicos municipales de chirimías y trombón para dicha función representativa, "la mayoría mantenía también un cuerpo de vigilantes en las murallas y las torres, algunos de los cuales (...) tocaban simples instrumentos de señales y no eran músicos, en ningún sentido relevante» (Polk, 1987, p. $162)^{268}$. Más allá de que aquí también Polk suscribe la teoría del vigilante-a-ministril para las ciudades flamencas (p. 165), los archivos de Utrecht muestran que por lo menos hasta la década de 1440 se registraron pagos independientes a la banda de ministriles y a los cornistas, vigilantes o pregoneros. También en el sur de Francia, en Montpellier, en la segunda mitad del siglo XIV hay constancia de que la ciudad empleaba por separado a un grupo de cinco ministriles, dos o tres trompetas y un pregonero (Peters, 2005, p. 109). Por

264 «I do not know who first misread this paragraph, but the resulting confusion has been repeated by every waithistorian of the twentieth century» (Rastall, 2006, p. 3) [traducción del autor]

265 «In some areas such as northern France and Flanders, civic wind ensembles seem to have originally been tied to watchmen ensembles. In other regions (Germany and eastern sections of the modern Netherlands, for example) town ensembles seem to have been from the beginning more exclusively musical in character» (Mayer Brown \& Polk, 2001b, p. 99) [traducción del autor]

266 En adelante traducimos "horn" por el término corno, aludiendo con este último al instrumento de metal de cuerpo cónico derivado de la utilización de cuernos de animales para generar señales a partir de insuflar aire en su interior. Es importante no confundirlo aquí con el cuerno de caza, ya que poseía funciones específicas que derivaron en otra clase de instrumentos, como el corno de postillón y la corneta postal.

267 «As well as these tower-guards, who were supplied with a horn and in the account-book were called 'hornblowers on the Buurkerk tower', there were also city minstrels in service as early as 1402» (Beukers, 1991, p.11) [traducción y énfasis del autor]

268 «Most also maintained a corps of watchmen on the walls and towers, some of whom (...) played simple signal instruments, and they were not musicians in any important sense» (Polk, 1987, p. 162) [traducción del autor] 
lo tanto, para las cuentas oficiales, eran oficios diferentes ejercidos por personas diferentes, que servían para funciones diferentes.

En Florencia la comune tenía a su servicio una escuadra de seis tubatores por lo menos desde 1297, y cada cuaderna de la ciudad tenía su propio banditore, cuya función era la de realizar anuncios oficiales ante el público mientras cabalgaba a través de la ciudad ataviado en rojo y verde, sosteniendo una corneta de plata. Para mediados del siglo XV Perugia empleó regularmente ocho cornetas, a quienes se les daba salario, caballo y uniforme. Su principal función era pregonar todos los pronunciamientos del gobierno (fare tucte ei bandemente) en las puertas de la ciudad, "de forma tal que puedan ser satisfactoriamente escuchados por todos" y se les pagaba especialmente por anunciar testamentos, donaciones y otros actos legales personales (Lockwood, 2009, p. 153)269

De hecho es posible que los cornistas hayan derivado en los trompeteros domésticos que describimos antes, pero no en los músicos municipales. En referencia a Dijon y el cuerpo tan importante de trompeteros que ya referimos, parece que hacia 1425 se le solicitó al duque de Borgoña que reemplazara las cornetas por trompetas en vista de la connotación más noble de éstas últimas, "ya que hoy en día a la corneta se la rechaza como símbolo del honor de la ciudad» (Bowles citado en Beukers, 1991, p. 11). Con el cambio de cornetistas por trompeteros provino todo el elaborado ceremonial que describimos unas páginas más arriba. Por lo tanto, si volvemos a nuestra distinción inicial, los vigías revistarían en el universo de los domésticos y no en el de los músicos profesionales. Que los trompeteros hayan suplantado a los cornistas no redimía a estos últimos de su baja condición: "Los escribas de Augsburg y Nuremberg, por ejemplo, fueron particularmente cuidadosos en referir a estos instrumentos como cornos y no trompetas» (Polk, 1987, p. 162), ${ }^{270}$ hecho perfectamente compatible con las prohibiciones y regulaciones del Imperio Germánico sobre los privilegios de las trompetas que ya mencionamos. Como sea que consideremos a los cornistas, está claro que los ministriles municipales «definitivamente no tienen nada que ver con las funciones de vigilancia» (Beukers, 1991, p. 12)

\subsubsection{Formas de organización de los músicos municipales}

Según vimos, Gretchen Peters nos advierte que, además de advertir la alta heterogeneidad de los ministriles urbanos, debemos también tener en cuenta los cambios que sufre este colectivo musical a través del tiempo. Uno de los indicadores en donde mejor podemos observar esto es en las sucesivas formas de organización profesional y las relaciones establecidas con la ciudad. Como ya adelantamos antes, este proceso histórico que, insistimos, abarca desde el siglo XIII al siglo XVI inclusive, puede resumirse en tres grandes etapas: las escuelas de ministriles, las confraternidades y los gremios. Si bien es cierto que la aparición de estas formas es sucesiva en el tiempo, al menos para las dos últimas, no debemos entender a ninguna de ellas como excluyente de las demás y mucho menos pensar que en todo lugar y al mismo tiempo las formas de organización eran las mismas. De hecho las escuelas de ministriles coexistieron y fueron compatibles tanto con

\footnotetext{
269 «In Florence the comune had a squad of six tubatores as early as 1297 , and each quarter of the city had its own banditore whose function was to make official announcements to the public while riding through the city, dressed in red and green, holding a silver trumpet. By the mid-fifteenth century Perugia regularly employed eight trumpeters, who were given salary, horse, and uniform. Their principal task was to make known all the pronouncements of the government (fare tucte ei bandemente) at the city portals, 'in such a way that they are satisfactorily heard by all', and they received special payment for announcing wills, donations, and other personal legal acts» (Lockwood, 2009, p. 153) [traducción del autor]

270 «Scribes in Augsburg and Nuremberg, for example, were particularly careful in referring to these instruments as horns and not trumpets» (Polk, 1987, p. 162) [traducción del autor]
} 
cofradías como con gremios. Una vez más la diversidad de los músicos urbanos debe advertirnos que no es posible hacer ningún reduccionismo lineal al respecto.

Las escuelas de ministriles que abarcan tanto el siglo XIV como el XV, se basan en el desarrollo profesional entendido como oficio o pericia, dado que aparentemente tenían como objetivo lograr una mejora técnica por parte de los músicos, lo que naturalmente redunda en una valorización de la profesión. Existe bastante consenso en entender que estas escuelas eran reuniones anuales que se desarrollaban en alguna ciudad fundamentalmente flamenca o alemana- a las que asistían ministriles de diferentes lugares de Europa. Como ya mencionamos, esto solía ocurrir durante la cuaresma, siendo muchas veces la semana de Pascua el momento en que los músicos emprendían el retorno a sus lugares de trabajo. (Gómez, 1990, p. 213). Como sabemos, los viajes en la Edad Media eran algo infrecuente, muy costoso y peligroso. Así que, a pesar de la tradición itinerante de sus antepasados juglares, los que podían asistir eran pocos, en general ministriles domésticos al servicio de un señor que les costeaba el viaje, o a lo sumo algún maestro o jefe de los conjuntos, cofradías o gremios municipales. Efectivamente a partir de que han quedado constancia de estos pagos podemos intuir que los principales objetivos que los ministriles buscaban en las escuelas de eran fundamentalmente dos: comprar instrumentos nuevos y aprender nuevas músicas y estilos interpretativos.

En marzo de 1386 el duque de Borgoña le pagó 400 francos por cabeza a siete ministriles de su corte, para que asistieran a la escuela de ese año y compraran instrumentos (...) en 1436, un oficial de justicia de Lille le pagó un adicional a varios de los ministriles de la ciudad para (ayudarlos a costearse el viaje a la escuela de Cambrai, para que aprendan nuevas canciones) (Gómez, 1990, p. 214).271

Aparentemente existía también una suerte de bolsa de trabajo que proveía información sobre posibles contrataciones.

Como hemos visto, si bien los ministriles domésticos y municipales sabían -y en ocasiones debían- manejar la lectoescritura musical, en general su repertorio era trasnmitido de forma oral, ya que gran parte de su oficio residía en tomar melodías tradicionales y sobre ellas improvisar ornamentaciones. Es por ello que según Maricarmen Gómez no debemos entender aquí escuela como una ocasión en la cual aprender o formarse como músico. "Una conclusión más lógica es que estaban destinadas a que [los músicos] tomaran contacto con nuevo repertorio» (1990, p. 214)272. Esto, evidentemente, mejoraba la profesión y facilitaba que se elevara la estima de los músicos a ojos de sus señores. Numerosas crónicas muestran hasta qué punto los patrones de los ministriles alababan su capacidad para tocar una misma música en varios estilos vinculados con diversas regiones y tradiciones interpretativas. Las escuelas de ministriles representaron, sin dudas, un paso decisivo en el proceso de profesionalización de los instrumentistas medievales.

Pero son las cofradías y los gremios las formas de organización realmente decisivas para la vida musical urbana y el paso al profesionalismo de los instrumentistas. En un sentido general podemos decir que estas organizaciones tenían como objetivo principal desarrollar el sentido de la honradez para la profesión, con la promoción social que esto suponía, según ya comentamos, para lo cual era indispensable establecer algún tipo de

271 «In March 1386 the Duke of Burgundy paid seven minstrels in his service 400 francs each for the schools of this year and for buying instruments (...) in 1436, a judicial officer from Lille gave several minstrels of the city additional money 'to help them afford the journey to the schools of Cambray, to learn new songs'» (Gómez, 1990, p. 214) [traducción del autor]

272 «a more logical conclusion is that they intended to become familiar with new repertory» (Gómez, 1990, p. 214) [traducción del autor] 
jerarquía entre los músicos que permitiera ordenar la práctica mediante una serie de reglas y obligaciones compartidas, pero que al mismo tiempo pudiesen aplicarse, estableciendo una ética profesional. «Al formar corporaciones que se colocaban espontáneamente bajo el poder de las autoridades civiles, los músicos, que como clase aún estaban fuera de la sociedad y la ley, podían procurarse así aceptación social y protección legal» (Schwab, $2001, s / p) \cdot 273$

También se buscaba la creación de cierto grado de beneficios sociales, como pensiones ante enfermedad o muerte de los músicos, garantizando el bienestar de los miembros de la organización y sus familias. Este es tal vez el sentido más específico de las cofradías y hermandades. Finalmente, un tercer pero tal vez más importante objetivo lo constituye la promoción de intereses monopólicos, es decir, obtener una regulación profesional de parte de las autoridades que permita la prohibición del ejercicio musical a todos aquellos que no pertenezcan a la organización. Y como el criterio para el ingreso a la institución profesional es la destreza y calidad de los músicos, esto redunda una vez más en elevar el prestigio de la profesión musical. Es un sentido estrictamente corporativo, similar tal vez al de las agremiaciones o colegios que regulan las profesiones liberales actuales. Este último objetivo es el que consiguen los gremios, sintetizando pero superando a su vez lo conseguido por las cofradías, y constituyendo por tanto un estadio superior de organización profesional.

\section{Confraternidades y cofradías}

Con el impulso de la economía europea y la expansión urbana del siglo XII los ministriles comienzan a organizarse en hermandades, cofradías o confraternidades, es decir corporaciones cívicas (Slocum, 1995, 258). En 1175, por ejemplo, se conforma la Confrérie des Jongleurs et des Bourgeois d'Arras, es decir la cofradía de los juglares y burgueses de Arras, importante ciudad comercial del norte de Francia situada estratégicamente en la ruta entre el paso de Calais y París, por un lado, pero también hacia Dijon -esto es Borgoñahacia el sur y de allí a Lyon y todo el norte de Italia.

La historia de esta corporación hunde sus raíces en la leyenda, pero es una historia de la que podemos extraer alguna información interesante, particularmente la relacionada con uno de los objetivos centrales de este tipo de organización: conseguir que la profesión de músico sea considerada digna y honrosa para la sociedad. La historia cuenta que la Virgen María se apareció por separado ante dos juglares ambulantes rivales y les indicó que fuesen a Arras a reconciliarse delante del obispo de la ciudad. Ya estando ambos en la iglesia la Virgen se apareció una vez más y le dió a los músicos una vela, la sainte chandelle. Como Arras estaba bajo el azote de la peste, al utilizar la cera derretida de la vela y aplicarla a los enfermos, éstos se curaron milagrosamente (Slocum, 1995, p. 259). La conmemoración de este suceso fue la excusa para la creación de la cofradía de los juglares y burgueses, entre cuyas funciones principales se encontraban naturalmente el organizar las festividades conmemorativas y construir un santuario para la vela. De hecho la torre de Arras de la sainte chandelle se convirtió en un sitio de peregrinación muy popular en el norte de Europa y la cofradía pudo explotar los beneficios económicos derivados de los numerosos visitantes. La cofradía era laica y aceptaba tanto hombres como mujeres, aunque, como se puede observar, era fundamentalmente religiosa. Esto es típico de muchas de estas corporaciones burguesas que inauguran un aspecto central de todo el periodo: la producción y el sostén del ceremonial religioso -la música incluida- por parte de organizaciones que están por fuera de la institucionalidad de la Iglesia. Este es un rasgo

273 «By forming a corporation that spontaneously placed itself under the power of its rulers or civic authorities, the musicians who as a class were still outside society and the law could procure for themselves social acceptance and legal protection» (Schwab, 2001) [traducción del autor] 
nodal que atraviesa tanto a los estilos musicales del gótico como a las músicas renacentistas de los maestros de capilla flamencos, además de la música instrumental municipal que estamos estudiando. Y por eso es interesante observar que en el origen de esta cofradía los juglares, personajes despreciados por la Iglesia y la sociedad, al urbanizarse y adoptar este rol cívico y piadoso de devoción religiosa, invierten la percepción social sobre su profesión y acceden a una nueva condición profesional y económica. El relato, aunque sepamos que es un mito, es el de la redención de los juglares vagabundos a través de la piedad burguesa y urbana. Todo un símbolo de la nueva época que se abre, precisamente y como ya dijimos, a fines del siglo XII y comienzos del XIII. Y que los músicos de la cofradía, ahora municipales, traducirán en sonidos para representar estos valores de la ciudad.

La integración de los músicos con los miembros de la clase media en la confrérie aporta evidencias de que algunos músicos obtuvieron un estatus social relativamente alto, e indica que la música se había establecido como un componente útil y deseable en la vida cotidiana de las ciudades de la europa medieval (Slocum, 1995, p. 259).274

En cuanto a los aspectos sociales o de socorros mutuos, la cofradía de Arras es paradigmática: los miembros de la cofradía participaban en los beneficios espirituales de la Iglesia, se les garantizaban los servicios fúnebres y se ayudaba a la manutención de los compañeros empobrecidos, enfermos o inválidos. Todo esto era posible mediante el pago de una cuota regular más una matrícula. Además existía un código de comportamiento con el fin de controlar el buen uso de estos beneficios (Slocum, 1995, p. 259).

Las cofradías de músicos se establecieron en primer término en las ciudades más grandes de Europa occidental. Por ejemplo en 1240 el rey Enrique III de Inglaterra aprobó los estatutos de la Fraternity of St Nicholas (Fraternidad de San Nicolás) de los clérigos de Londres. También en Inglaterra hay evidencia de una organización similar en Beverly hacia fines del siglo XIV. Este caso es interesante ya que si bien los estatutos más antiguos de la corporación son recién de 1555, existen relevantes fuentes indirectas que hablan de una costumbre muy antigua de los ministriles de reunirse en esa ciudad y designar un maestro 0 jefe «autorizado para recibir los pagos por los servicios de la fraternidad de ministriles» (Slocum, 1995, p. 261).275 Aún sin que sepamos cuán antigua era esta tradición, evidentemente no comenzó en el siglo XIV sino antes. Y además nos da la pista de que algunas cofradías pueden haber surgido de las escuelas de ministriles, como parece ser en este caso.

Las confraternidades inglesas también presentan, como en el caso de Arras, estatutos relativos a garantizar los servicios fúnebres para sus miembros y costear una misa en su nombre. También establecen un repertorio mucho más preciso de las situaciones en que un cofrade debe ser asistido en su manutención: se le otorgaba un estipendio semanal a cualquier músico que no pudiese ejercer la profesión producto de «caer en la pobreza, estar enfermo, ser víctima de robo, quedar lisiado, llegar a la vejez, perder alguna propiedad, ser injustamente encarcelado, o cualquier suceso repentino producto de la mano de Dios» (Slocum, 1995, p. 261). ${ }^{276}$ Además, profundizan en los aspectos morales y de

274 «The integration of musicians with members of the middle class in the confrérie gives evidence that a relatively high social status had been obtained by some musicians, and indicates that music had been established as a useful and desirable component of daily life in the towns of medieval Europe» (Slocum, 1995, p. 259) [traducción del autor]

275 «authorized to take names and to receyve customable dueties of the bretherin of the sade mynstralle fraternytie» (Slocum, 1995, p. 261) [traducción del autor]

276 «because of poverty, illness, robbery, maiming, old age, loss of property, false imprisonment or 'any sudden event by the hand of God'» (Slocum, 1995, p. 261) [traducción del autor] 
comportamiento entre sus miembros, estableciendo castigos y multas que llegaban a la expulsión de la cofradía y de la posibilidad de ejercer la profesión. Estas disposiciones tenían como objeto generar una relación estable y armoniosa entre los cofrades. También se establecía la posibilidad de préstamos de dinero entre los miembros siempre y cuando se pusiera algún objeto o propiedad como prenda de la deuda.

En 1288 se fundó la Nikolai-Bruderschaft (Hermandad de Nicolás) en Viena. Podemos tomarla también como modelo del sentido moral de estas cofradías ya que, según sus estatutos, los músicos se organizaban para la veneración de Dios a través de la música o, como a estos músicos gustaba identificarse, eine Bruderschaft zur Verehrung Gottes durch die Kunst, es decir una hermandad para la veneración de Dios a través del arte. El patrono de la hermandad era el Arcángel Miguel (Slocum, 1995, p. 262). Como vemos la observancia religiosa y la imagen de piedad son preocupaciones fundamentales, en términos sociales, de estas cofradías, en la búsqueda del reconocimiento para la profesión musical. Pero no son todavía organizaciones que protejan el lucro y los intereses económicos de los músicos, ni persigan imponer criterios de exclusividad en la práctica musical.

Incluso en ciudades más pequeñas como Marsella hay registros de organizaciones profesionales similares a las hermandades en el siglo XIV (Peters, 2000, p. 226). Con motivo de seguir al Papa en su cautiverio babilónico, unos mercaderes italianos fundaron en Aviñón a comienzos de ese siglo la confraternidad de Notre-Dame de la Major, que si bien no era una hermandad de músicos, los contrataba y les otorgaba los beneficios sociales típicos de estas instituciones (Peters, 2000, p. 204). También en la importante ciudad de Toulouse existió una cofradía al menos desde 1492 (Peters, 2005, p. 108)

En la ciudad italiana de Lucca sabemos de la existencia de una Societas seu compagnia (sociedad o compañía de músicos) hacia 1310. Y en Praga existen registros de una asociación de músicos judíos (Juden Spielleutezunft) que también incluía a mujeres entre sus miembros. Como en el resto de las confraternidades, un oficial o jefe de los ministriles (Oberspielgraf, roi des menestrels) era el responsable de resolver las contiendas y conflictos entre los músicos y hacer respetar el orden y la armonía de los conjuntos, lo que era valioso en un sentido moral, pero necesario en un sentido práctico musical, ya que estamos hablando de tocar en conjunto (Schwab, 2001, s/p).

Este aspecto fraternal de la profesión puede verse en otra característica de los músicos urbanos que es la de establecerse generalmente en un barrio o calle que terminan relacionados con la profesión musical. Así en Montpellier, a fines del siglo XIV, los ministriles vivían todos en los barrios de Saint Anne y Saint Paul. Esto puede deberse a varios motivos: la facilitación de las contrataciones a los músicos por parte de privados; la cercanía a sus lugares de trabajo -estos barrios mencionados estaban muy cerca del ayuntamiento, donde los ministriles tocaban a diario-; o a zonas con una alta concentración de locales en donde también trabajaban los músicos: posadas, baños públicos y prostíbulos (Peters, 2005 , p. 111). También las ciudades alemanas, como Leipzig, solían tener su Stadtpfeifergasse o Stadpfeiferalle (el callejón o calle de los ministriles). En París se agrupaban en torno a la rue des Jongleurs (calle de los Juglares). En esa ciudad se formó lo que tal vez sea el primer gremio musical en sentido estricto. Tal vez por esa razón, en el transcurso de de los siglos XIII y XIV, la calle fue rebautizada como rue des Ménétriers, es decir, de los ministriles (Slocum, 1995, p. 263) ¿Sería un señalamiento del cambio operado en el estatus social de los músicos de la ciudad? 


\section{Gremios}

Los gremios musicales mantienen prácticamente todas las prerrogativas de las cofradías, haciendo tal vez menor hincapié en subrayar los aspectos piadosos vinculados con la promoción de la religión. De todas maneras, continúan asociados a la figura de algún santo patrono como Julián, Nicolás, Miguel o Egidio Abad. De esta forma, en los estatutos del gremio de Montpellier, creado en 1353, aparece la preocupación por el bienestar de los colegas asociado a un sentido de responsabilidad, que se manifiesta en la voluntad de legar en los testamentos dinero, ropa a los compañeros del gremio y sus familias. También el cumplimiento de la última voluntad se expresaba en las relaciones interprofesionales, por ejemplo cuando «la viuda de un ministril solicitó ser enterrada en el lugar reservado para la tumba de otro músico, y comprometió a éste para que ejecutara su voluntad» (Peters, 2000, p. 224). ${ }^{277}$ En otras ocasiones, los músicos más prósperos realizaron donaciones de propiedades a colegas más pobres o a sus viudas, como lo ilustran las historias de tres músicos municipales que trabajaron en Montpellier a mediados del siglo XV: Petrus de Mala, Jacominus Mutonis y Jaufredus Julian:

En 1421, Petrus donó un viñedo a Jacominus, cuyo patrimonio en 1435 a efectos fiscales se estimó en la tercera parte del de Petrus. Este gesto quizá refleje la preocupación profesional por la situación de un compañero más pobre. En otra transacción, fechada en 1444, Petrus le compró una casa a la mujer de Jaufredus, un acto que deja entrever una red social que abarcaba a las familias de los ministriles (Peters, 2005, p.110)

Un rasgo que parece ser particular de los gremios es que, en función del proceso de especialización musical, los miembros comienzan a ser registrados por el o los instrumentos que tocan. De esta forma conocemos los nombres de varios músicos municipales asociados a sus instrumentos y podemos estar al tanto de las rutas por las cuales circulaban las redes profesionales de estos músicos. Por registros como estos sabemos de la presencia y el prestigio en Italia de los músicos alemanes que protagonizan una "invasión" análoga a la de los compositores flamencos: un grupo de instrumentistas alemanes que arribó a Florencia en 1384 fue encarcelado ante las protestas del gremio de los pifferi locales. Sin embargo un poco después, en 1401, la ciudad contrató a un tal Niccolò piffero de Alamagna, y a tal punto fue la preferencia por los extranjeros que hacia 1445 se reformaron los estatutos obligando a que sólo se pudiese contratar a músicos alemanes, de tal suerte que los pifferi durante el resto del periodo provinieron de Colonia, Basilea, Constanza o Augsburg (Polk, 1987, p. 176). La ciudad de Siena también contrató en 1409 como miembro de sus pifferi a Corrado da Alamania, desplazando a Fillipo di Polo da Venezia que había sido acusado de deshonesto. Un año antes se contrató como doméstico en el palacio a un trompetero que también era alemán. Poco después ante la partida de Corrado, que era tan admirado que se le había aumentado el salario, se lo reemplazó por otro chirimista, el también alemán Niccolò -o Nicolaus- da Strasburgo (D’Accone, 1997, p. 517) ¿Es el mismo de Florencia?

En Ferrara entre 1441 y 1481 vuelve a aparecer un Corrado de Alemagna piffaro. Este músico tenía el salario más alto entre todos los músicos del ducado, incluso mayor al de los trompeteros del duque Leonello d'Este. Se le encomendó además que fuese a Alemania a reclutar más colegas para llevarlos a Italia y otras ciudades de la península enviaban a sus pifferi para que Corrado les enseñara. No en vano una crónica de la época señala a los pifferi de Ferrara como «los mejores de Italia, y sobre todo a Corrado, su piffero de Alemania» (Lockwood, 2009, p. 157). A su muerte, Corrado fue reemplazado por otro alemán, Adam piffaro, nombramiento que incluye el registro de su instrumento $\mathrm{y}$, por

277 «A wife of a civic minstrel of Montpellier specified that she was to be buried at another minstrel's grave site and appointed him as the executor of her will» (Peters, 2000, p. 224) [traducción del autor] 
añadidura, del de Corrado: soprano piffaro. Su colega, Zoanne da Alemagna, es designado tenorista piffaro.

También en el sur de Francia, en Montpellier, se identificaba a los músicos con su instrumento, por lo cual sabemos que el conjunto cívico era integrado, alrededor de 1355 por cornetas, cornamusas y tambores (Peters, 2000, p. 223). En 1388, tras la muerte de uno de los Stadtpfeifer de Nuremberg, se nombró en el cargo a un nuevo músico, que se anotó como posauner, es decir trombonista. Y en Colonia, hacia 1372 se dejó constancia de los pagos a un tal Johannis trumpenario et fistulatoribus, o sea Juan el trombonista y vientista (Polk, 1987, p.170). Gracias a estos registros sabemos que en algún momento hacia fines del siglo XIV y principios del XV el ensamble de ministriles se compone regularmente de chirimías más un sacabuche, gracias a lo que Keith Polk llama «la introducción del trombón» 278 (1987, p. 167), proceso que va estrechamente relacionado con el desarrollo de los gremios y el celo en registrar la actividad musical.

Pero la real condición del gremio musical a inicios de la modernidad es la obtención de derechos exclusivos para la actuación musical pública (Schwab, 2001, s/p), estableciendo regulaciones oficiales que fuercen a los músicos que no forman parte del gremio -sobre todo a los juglares itinerantes- a abstenerse de ejercer la profesión, bajo amenaza de hacer cumplir este privilegio por medio de la autoridad civil. Este es el corazón que reside en la formación de los gremios musicales desde principios del siglo XIV, el establecimiento de un monopolio que permita a los músicos eliminar la competencia y poder así acceder a la diversidad de ocasiones, públicas y privadas, para las cuales se requería de música.

Como hemos visto, existieron formas de regulación de la actividad musical asociadas con determinados instrumentos, como los edictos imperiales destinados a crear un privilegio para los trompeteros y reservarlos así como emblema de la nobleza. Esto requería que estos músicos se registraran en la Kameradschaft, es decir una corporación local, en cada ciudad, que a su vez reportaba a una superintendencia u Oberkameradschaft en la ciudad de Dresden. La profesión del trompetero era así celosamente regulada y protegida, razón por la cual estaba terminantemente prohibido a sus miembros enseñar los secretos del oficio a personas que no estuviesen dentro de la organización gremial. (Schwab, 2001, s/p)

Pero es con la fundación en París de la Confrérie de St-Julien des Menestriers en 1321 que se desarrollan para la música los rasgos típicos de gremio comercial medieval, dotando a la organización profesional de una formalidad y estabilidad de la que carecían las cofradías anteriores. Los estatutos del gremio se diseñaron con el objetivo de proteger el lucro de los miembros de la institución. Con el objetivo de excluir a la competencia interna y externa lo más posible se definieron con claridad las tarifas respectivas según el tipo de ocasión y actividad, que en esta ciudad eran muchas y muy variadas: eventos en la corte, ceremonias religiosas o militares, bodas, banquetes, actuaciones públicas para el entretenimiento o las festividades, entre otras. (Slocum, 1995, p. 262).

También los códigos de comportamiento para los músicos se establecieron con mucho detalle y claridad. A las usuales disposiciones que bregaban por la convivencia armoniosa entre los miembros del conjunto, se agregaron el establecimiento de una jerarquización estricta que redundaba en los tipos de trabajos para los que cada músico podía ser contratado, y en las directrices en torno a la enseñanza del oficio y el comportamiento de maestros y aprendices. En principio se reglamentaba la cantidad de aprendices que un músico titulado podía tomar bajo su tutela. Éstos vivían con el maestro, quien era responsable por sus actos y conducta. Una vez que pasaban a ser oficiales titulados, podían intentar cubrir un puesto vacante o irse a otra ciudad a probar suerte. En Inglaterra o

278 «The inception of the trombone: 1350-1420» (Polk, 1987, p. 167) [traducción del autor] 
en el Imperio Germánico las estrictas normas para la promoción y admisión de los músicos municipales estaban reguladas incluso a nivel nacional. «Estas reglamentaciones mantenían el nivel, expulsaban a los ineficaces y deshonestos, quienes así se veían privados de un medio regular de ganarse la vida, e ideaban las pruebas que regían el ascenso de un grado al siguiente» (Raynor, 1986, p. 73)

Cumplir fielmente con las tareas y evitar que los músicos sean deshonestos es también la prerrogativa de los estatutos del gremio de músicos de Toulouse, que datan de 1492. Allí el control de la competencia es garantizado a través del pago de una matrícula para ingresar al gremio. Además todo músico extranjero que llegaba a la ciudad debía pagar un impuesto y presentarse ante los oficiales del gremio, quienes le indicarían la posibilidad o no de que pudiese tocar en público por dinero (Peters, 2000, p. 225). Está claro que los músicos más perjudicados por todas estas reglamentaciones a medida que se desarrollan los gremios, son los músicos ambulantes, es decir los juglares, además de los ministriles que pierden su puesto por alguna razón de índole moral.

Los músicos ambulantes siguieron siendo "pícaros y vagabundos" sin hogar, contra quienes se promulgaban las leyes (...) A medida que la música se hacía un hueco en la sociedad de clase media de las ciudades medievales, los juglares ambulantes eran cada vez más rechazados por sus colegas más afortunados que ocupaban posiciones seguras (Raynor, 1986, p. 62).

Los músicos pertenecientes a los gremios tenían por lo tanto asegurada su fuente laboral, gozando de privilegios por sobre cualquier tipo de competencia. Esto se establecía mediante un contrato, que en las ciudades alemana se denominaba Ordnung o Rolle, de tal forma que los músicos que allí aparecían, es decir los agremiados, pasaban a ser los Rollmusikanten, Ordnungen or Rollen (Schwab, 2001, s/p). En algunos casos, como en las ciudades alemanas de la Liga Hanseática, los músicos municipales no formaban parte del gremio, ya que estaban en un escalafón superior, en una posición análoga a la de los trompeteros por sobre los músicos municipales. En estos casos, los músicos del gremio tenían permitido trabajar sólo cuando los municipales no podían hacerse cargo de la tarea, porque ya tenían asignado un compromiso o porque al coincidir dos eventos participaban del más prestigioso y remunerativo. Esta era la forma en que se aplicaban con mayor frecuencia las disposiciones gremiales en todas las ciudades europeas: no tanto ejerciendo una exclusividad absoluta, sino incidiendo para que los agremiados y privilegiados se quedaran con las mejores contrataciones y posibilidades lucrativas.

Este principio de exclusión profesional, como vimos, sentó las bases para la especialización musical y el desarrollo de las técnicas instrumentales, haciéndolas cada vez más ricas y complejas. De las organizaciones profesionales de todo este período emergió un sinnúmero de instrumentistas que permitieron crear las condiciones, sin ir más lejos, para la producción de música instrumental autónoma durante buena parte de la modernidad. Como los miembros de otros gremios de artes y oficios, los instrumentistas buscaron proteger sus intereses regulando su práctica. $Y$ esto implicó el desafío de generar criterios, conceptos y términos que hasta ese momento no proliferaban en la teoría musical, deudora del pensamiento medieval temprano y que por lo tanto rechazaba a la música instrumental como parte del ars musica. A partir del siglo XIII comienza un cambio de concepción, que indudablemente posee relación con el desarrollo de los instrumentistas urbanos. Así aparecerán por ejemplo el tratado De inventione et usu musice de Johannes Tinctoris a fines del siglo XV, o el Musica getutscht de Sebastian Virdung en el siglo XVI, recopilando y clasificando lo que ya hace tiempo se daba en la práctica sonora.

Las regulaciones sobre el comportamiento, la membresía, la jerarquía y la formación, protegieron a los músicos cívicos de la competencia al tiempo que dignificaron la profesión y garantizaron la calidad, tanto sonora como moral. Para el siglo $\mathrm{XV}$, los músicos de origen 
popular, que habían sido perseguidos, proscritos y parias, eran ahora ricos y distinguidos ciudadanos europeos. Elevar la profesión, tanto en términos técnicos como morales y económicos, introdujo la modernidad en la práctica musical de los conjuntos instrumentales, sino antes, al menos en paralelo con el auge de los compositores y maestros de capilla. Una carta de ciudadanía que implicó, en definitiva, la profundización de la condición marginal de los músicos populares trashumantes, rechazados ahora por sus colegas especialistas urbanizados.

\subsection{La música en la dualidad urbana latinoamericana}

«En los puntos de feria, las calles se inundaban de pregones, procesiones y carnavales y las ventas y caseríos de fandangos y celebraciones» Antonio García de León Griego (2002)

A pesar de que en ocasiones hay equívocos acerca del asunto, la América colonizada por las metrópolis ibéricas posee, desde la conquista, una matriz fuertemente urbana, pues de hecho la misma España de la flamante y autodenominada "reconquista" 279 poseía esta particularidad dentro de todas las naciones cristianas dentro de la órbita romana, cuestión que traslada al otro lado del océano (Baker \& Knighton, 2011, p.1). La imagen de una América colonial "feudal" se corresponde más con el rechazo de lo hispánico por los criollos independistas que a una realidad histórica. Pero además, lo urbano ya era una realidad dentro de las sociedades estratificadas o "altas culturas" indígenas o matriciales (Camacho, 2010) antes de la conquista, como lo simbolizan las majestuosas Tenochtitlán o Quscu. De hecho, las ciudades indígenas como Tikal, Teotihuacan o Tiahuanaco tenían plena existencia incluso antes de nuestra era y se multiplicaron de forma inversamente proporcional a la retracción de la vida urbana durante la Europa feudal. Por lo tanto, debemos considerar la situación de la música urbana en Latinoamérica como una de sus bases identitarias y no como el subproducto de una modernidad que se sobreimprime superando a una esencia rural folklórica.

En el área hispánica la nueva sociedad fue, desde un principio, un conjunto de sociedades urbanas junto a las cuales las sociedades rurales se constituyeron como instrumentos económicos dependientes de las comunidades congregadas en las ciudades, cuyos sectores predominantes eran los beneficiarios de la explotación del mundo rural (Romero, 2001, p. 10)

Este carácter urbano hace que los conquistadores, en todo momento, se vean afanosos en la fundación de ciudades (Veracruz, Potosí, Lima, Buenos Aires), en la refundación y reconversión radical de las numerosas urbes y capitales indígenas que dan lugar a México o Cusco y hasta en la creación de trazas en damero dentro de contextos insólitos, como lo ilustran las reducciones o "pueblos de indios" en medio de la selva, en el área guaranítica (Paraquaria), el oriente de la zona andina (Chiquitos) y el Amazonas (Moxos o lquitos). Este despliegue fundador es orientado por lo que se conoce como doctrina o «concepto de las dos repúblicas» (Waisman, 2019, p. 26) que pretendía segregar en una sociedad dual el mundo urbano del centro "blanco" y su servidumbre "negra", de los suburbios y ranchos donde se nucleaba la población indígena sometida como mano de obra; «república de indios» a la que debemos añadir las mentadas doctrinas y reducciones. La ciudad colonial pretendía ser, entonces, dos ciudades, conectadas de forma estrictamente regulada por la

279 Si bien excede por completo los alcances de este trabajo, el problema de la invasión de los reinos unificados y católicos hispánicos sobre los vestigios del otrora esplendoroso (y pluricentenario) Al-ándalus, es un excelente ejemplo de la rebanadora histórica de Le Goff, que en este caso produce distorsiones evidentes si se comparan los tiempos relativos del gobierno visigótico frente al de los moros ¿Cómo pensar una reconquista sobre algo apenas configurado sino es generando una narrativa atemporal que transforme la cultura hispano-árabe en invasión, cuando claramente es permanencia y construcción autónoma de largo plazo? 
política económica de dominación y saqueo, pero cuyas comunidades debían existir de forma separada, evitando el contacto cotidiano de las costumbres y las presencias mixtas. Desde luego esto se manifiesta también en los ideales en torno a la producción musical.

El mundo sonoro virreinal estuvo formado por dos vertientes musicales: la peninsular, concentrada en las ciudades y las élites virreinales, y la americana, viva en los barrios humildes de las ciudades y los pueblos de indios (Turrent, 1993, p. 45).

Pero debemos advertir desde el comienzo en lo fútil de la empresa, o incluso en su fracaso absoluto, aunque es importante tener presente el ideal que anima esta política racializada. A lo que hay que agregar la superposición, en ocasiones bastante caótica, de políticas e intenciones muy contradictorias de parte del sector "blanco" colonizador, es decir, los conflictos entre autoridades de la corona, los delegados eclesiásticos, las órdenes religiosas, los encomenderos, los aventureros, los comerciantes y artesanos, etc. Todo esto tendrá importantísimas consecuencias para la realidad musical de la América colonial, aunque también deberíamos pensar que las diversas músicas que confluyen en la ciudad colonial forman parte de las fuerzas que producen su fisonomía social y cultural. Así, al pensar en las dos repúblicas, debemos considerar hasta qué punto no son también resultado de las ocasiones musicales que van confluyendo paulatinamente en la realidad transcultural latinoamericana.

Que el asentamiento español en nuestro continente sea una empresa principalmente urbana no hace sino revelar la intención colonial (Bermúdez, 2001, p. 167), ya que estas ciudades, en tanto instrumento fundamentalmente ideológico, son creadas para conseguir el estado de dependencia de Hispanoamérica que, como todo plan de dominación, estuvo, aquí y allá, en la modernidad temprana o en la era de la burguesía, asociado con una concepción -y una producción- de una sociedad y una cultura en términos homogéneos.

\begin{abstract}
El supuesto de la capacidad virtual de la ciudad ideológica para conformar la realidad se apoyaba en dos premisas. Una era el carácter inerte y amorfo de la realidad preexistente. La otra era la decisión de que esa realidad suscitada por un designio preconcebido no llegara a tener —no debía tener- un desarrollo autónomo y espontáneo [...] Era el riesgo del mestizaje y la aculturación. Y para preverlo, más aun que para prever el de posibles rebeliones, pareció eficaz constituir la red de ciudades, de sociedades urbanas compactas, homogéneas y militantes (Romero, 2001, p. 13)
\end{abstract}

Como vimos en el capítulo anterior en torno a los Estados Nación decimonónicos y su ideología racializada del folklore, son estas "garantías" de Hall las que, sumadas a la "raza" de Quijano, están en la vanguardia del ideal colonial, que es un ideal hidalgo a pesar que los conquistadores son, en el mejor de los casos, miembros de una aristocracia menor, desposeída y sin perspectivas en la península. Tal vez por eso es que subrayamos el carácter ideal de la concepción urbana colonial y de sus resultantes culturales y musicales. Puesto que muy pronto esta red de ciudades ideales advierte la emergencia, en su propio seno, de una urbe especular real en la que habitaba una sociedad también real, muy distante de ese ideal hidalgo homogéneo, en la cual deambulaban sin remedio los integrantes reales del mundo colonial: mundo de criollos y pardos, de indios y negros junto con los españoles. Un mundo heteróclito de mulatos, moriscos, zambos, coyotes, chinos, lobos y todo el caleidoscopio infinito, nunca acabado, cuya cualidad más estable es la de eludir sistemáticamente todos los intentos racializantes de definición y clasificación. Este proceso de emergencia de lo real urbano y sus castas -como los españoles decidieron llamarlas-280 «conducía, inexorablemente también, a su interpenetración y a la incierta

280 lo cual no deja de ser sintomático del "mundo al revés" (Cusicanqui, 2014, p. 21) ensayado en el momento andino colonial, ya que trastoca el adjetivo de "casto" invirtiendo su sentido originario del mundo cortesano europeo 
aventura desencadenada por los azares de la movilidad social» (Romero, 2001, p. 16). Así, cada ciudad adquiere un particularismo que las diferencia de las demás en función de las azarosas combinatorias culturales y sociales que se despliegan en cada zona, explicadas en parte, pero no totalmente, por las formas de producción económica que cada urbe adopta, por lo extensísimo del territorio colonial y su diversidad geográfica y climática, o por la actitud de integración o resistencia de los sectores sometidos.

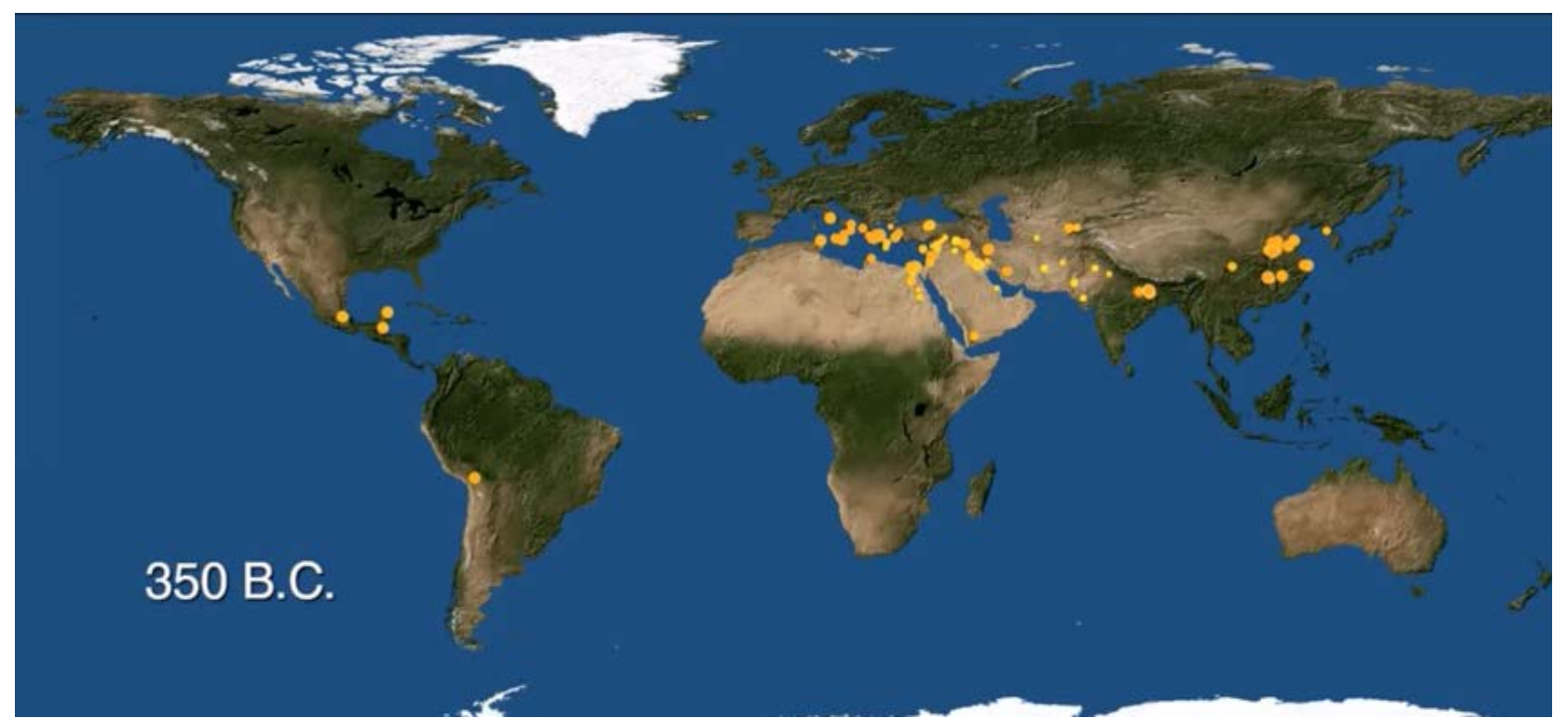

Un mapa del mundo a mediados del s.IV antes de nuestra era, en el cual podemos ver las ciudades de Teotihuacan y Tikal en América, al tiempo en que Europa adolece de grandes ciudades a excepción de Roma y el mundo helénico, pero que a su vez claramente pertenece a un universo urbano que se extiende hacia el este, hacia el oriente donde se yerguen las ciudades más imponentes y populosas. Tomado de metrocosm.com (2016).

Por esta característica urbana intrínseca tanto a la conquista como a la situación americana previa, la institución de los ministriles urbanos es una de las primeras configuraciones musicales que confluyen en América Latina, junto a la capilla catedralicia, en conjunción a todas las instituciones cívicas del mundo citadino, como los cabildos o las audiencias. Pero el que asoma en este universo colonial es un mundo urbano que plantea una característica nueva: es profundamente transcultural, quizás a un punto inédito en la historia, ya que quienes confluyen allí, los colectivos humanos, culturales, provienen de puntos geográficos muy remotos (Bermúdez, 2001, p 167): los indígenas, en su mayoría, son ya un colectivo heterogéneo y muy mestizado a instancias de siglos de migraciones, conquistas y sometimiento de unas culturas sobre otras; los españoles, que entran súbitamente y violentamente en contacto con los indígenas, no provienen de un territorio lindero sino del otro lado del océano, planteando una situación desconocida para, por ejemplo, el amplio territorio de la ruta de la seda que describe un arco transcultural en Oriente, sedimentado en base a largos procesos que depositaron capa sobre capa una realidad pluriétnica e intercultural. No debemos olvidar además que los "españoles" eran también los moros conversos, los sefardíes (Quintero Rivera, 2005) y un variopinto conjunto de poblaciones cristianas, algunas de ellas de mayor contacto con el área francófona que castellana (Aharonián, 1994); y también Nápoles y los Países Bajos eran "España" a inicios de la conquista, y pronto lo será además Filipinas, por lo cual encontraremos en Latinoamérica aventureros y músicos relacionados con todas esas coordenadas. Pero por si esto fuese poco, aparecen ya en el siglo XVI los africanos subsaharianos esclavizados, provenientes de muy diversos territorios y culturas, mezclados y vueltos a mezclar a propósito por los traficantes esclavistas y la lógica racial de explotación moderna (Quijano, 2014). 
A la transculturación del universo ibérico responsable de la dominación americana, que inmediatamente nos hace revisar el espejismo que solemos vislumbrar cuando imaginamos esa "Europa musical" que nos conquista, debemos sumar un aspecto del todo lógico pero generalmente descuidado, que se resume en una pregunta: "¿Cuál es la música de la tripulación de un velero lanzado al Atlántico?»(Aharonián, 1994, p.194). Los pobladores urbanos de las ciudades coloniales al inicio de la conquista provienen de sectores de condición humilde, aunque aventurera, codiciosa y dispuesta a prosperar. "Gentes sin tierra y sin nobleza, buscaban ambas cosas en el nuevo mundo» (Romero, 2001, p. 59). Esto hace difícil la hipótesis de Carlos Vega que vimos en el capítulo 3, quien suponía, a partir del análisis estilístico de partituras, que era música cortesana, incluso de los trovadores occitanos, la que venía en las bodegas de las carabelas. Nuevamente aquí se nos presenta con toda claridad la compresión de la musicología histórica que al descuidar los aspectos performativos de lo musical prescinde también del sentido común. Pero incluso en el caso específico de la conquista por parte de España, existen particularidades. Algunas tienen que ver con aspectos laborales o profesionales de los músicos: por ejemplo, el hecho de que al ser mucho más codiciadas las plazas de las catedrales peninsulares, los músicos que se trasladan desde España -y también de otros sitios de Europa- provienen de estratos bajos (Bermúdez, 2001, p. 168). Como veremos a continuación, las condiciones materiales y la infraestructura musical de las colonias americanas no ofrecían ningún atractivo para un músico español formado y con cierta reputación, por lo menos durante el primer siglo y medio de colonia (Urchueguía, 2012, p. 484). Además, en el caso particular de España, los ministriles no tenían una organización gremial que protegiera sus intereses (Vera, 2016, p. 651) como vimos para el caso de las ciudades italianas, alemanas o flamencas, por ejemplo. Esto también explica su bajo estatus social. Por lo tanto, ya desde los primeros momentos de la conquista llegan ministriles a este lado del Atlántico, pero quienes lo hacen son músicos segundones o que se desempeñaban en círculos poco vinculados a las instituciones más prestigiosas y oficiales; lo cual incluye también a los que provienen de las filas de músicos populares. Pero incluso si no queremos cortar camino tan rápido, existe otra particularidad ibérica: si bien como todo ministril los músicos peninsulares estaban habituados al contacto -y la práctica- de música en ocasiones festivas, en el caso particular de los músicos catedralicios españoles era frecuente que se desempeñaran en funciones profanas y públicas (Pedrotti, 2017, p. 91), obteniendo permiso de las autoridades para participar de las fiestas populares y «las músicas del pueblo» (Turrent, 1993, p. 41). Este es un aspecto importante que debemos sumar al carácter transcultural antes descrito para hacernos un cuadro del todo diverso y entrecruzado. Por lo tanto los músicos españoles, los de estratos bajos que mayoritariamente son quienes vienen a América, pero también los mucho más excepcionales de círculos más selectos, están habituados a todas las prácticas musicales, muy diversas, de su medio. Estos eran los músicos que más abundaban en la España de los primeros siglos de conquista, y de ahí el excedente que pasa a las colonias. Pero la música no se transmite exclusivamente por los profesionales del arte

Para imaginar un navegante de los siglos XVI al XIX es pues conveniente tener en cuenta a los navegantes de carne y hueso de nuestro tiempo ¿De qué música es portadora la tripulación de un barco: de música culta de vanguardia? En general no. Y esa es la clave para entender muchos misterios de los aportes de la vertiente europea en los procesos de mestizamiento de América (Aharonián, p. 195).

El anacronismo de Aharonián nos ayuda a recordar esas pintorescas imágenes de nuestra escolaridad en las que se mostraban los compañeros de don Cristóbal. Parafraseando el poema de Brecht sobre la construcción de Tebas, podríamos decir que la nobleza no es quien conquista el territorio americano, quien somete a sus pueblos, sino una soldadesca nutrida de vagabundos, aventureros, presidiarios, junto a miembros de otros estamentos que ya no tenían un lugar en el reino, aún siendo parte de los hijosdalgo. Durante prácticamente el primer siglo de conquista $-\mathrm{y}$ hasta que las políticas de Felipe II 
comenzaron a cuajar favoreciendo la inmigración de familias hidalgas que controlaran el tráfico de las riquezas de la corona- las colonias no escucharon músicas cortesanas ni existieron fiestas privadas como las que sostenía la nobleza española en la metrópoli (Turrent, 1993, p. 44). En cambio, como muchos de los aventureros que llegaban al "nuevo mundo" provenían de las clases medias, o de la nobleza de menor rango, trasladan también la práctica de una música doméstica basada en canciones acompañadas con vihuela o guitarra (Bermúdez, 2008). En las ciudades con población predominante de clases medias (artesanos y comerciantes) como por ejemplo Bogotá, este panorama socio cultural produce una presencia inusitada de instrumentos musicales asociados con la práctica doméstica de canciones populares. Así, la presencia del arpa, guitarra, vihuela, o el rabel se constata en todos los sectores sociales, incluso entre los indígenas y los esclavos negros ${ }^{281}$ (Bermúdez, 2001, p. 172).

\subsubsection{Partituras blancas, sonidos ch'ixi}

Debemos comprender que en las urbes latinoamericanas se instala con mucha fuerza el mandato del Concilio de Trento de 1563 que impele a utilizar todos los medios simbólicos visuales, dramáticos, escénicos, festivos, etc.- entre los cuales se destacan los medios musicales. Es así que la fiesta pública (Bermúdez, 2001, p 178) o, mejor aún, la festería (Vera, 2016, p. 668), pretende integrar a todos, lo cual aquí incluye a los indígenas y a los negros. Es un recurso no sólo frecuente, sino explícitamente incentivado desde las autoridades, que por supuesto presenta un uso propagandístico, inclinado además a la conversión a la fe cristiana de los americanos y los africanos, pero que también produce una situación específica sobre la música: no será en Latinoamérica un patrimonio reservado para las clases dominantes (Bermúdez, 2001, p. 167). La música será un hecho tendiente a lo universal y a la participación; por lo cual es importante resaltar que, de este lado del Atlántico, el modelo musical es el de la música pública y festiva, el cual incluso regula la música que los gobernadores y administradores disfrutan en sus residencias particulares. Es decir que en el mundo sonoro iberoamericano, incluso en las cortes virreinales, no se escuchan ecos de aquel pathos de la distancia trovadoresco que describimos en el capítulo 2.

Dentro de este panorama tan peculiar de lo "europeo" en América -y mediante la emergencia de esa ciudad real que se atraviesa en los planes del ideal segregacionistadebemos considerar la presencia, muy documentada por los cronistas desde los comienzos mismos de la colonización, de un mestizaje de tradiciones y prácticas musicales muy heterogéneas en las ocasiones públicas de la sociedad colonial. Uno de los aspectos más llamativos de esa condición heteróclita son los grupos vocales e instrumentales formados por esclavos negros (incluyendo profusamente la percusión) que tocan junto con músicos hispanos ante los indígenas que, a su tiempo, presentaban sus músicas y danzas con sus propios instrumentos (Bermúdez, 2001, p. 172). Pero hasta aquí deberíamos pensar que los grupos musicales actúan por separado, racializados, si no fuera porque también, desde el primer momento de la conquista, una vez que comprendieron la potencia -y necesidad- de la música en su proyecto civilizador de las Indias Occidentales, los invasores se encontraron con un panorama de escasez de músicos europeos formados para afrontar tamaña empresa. Recordemos que, ya desde el siglo XIV, se da en las principales urbes del viejo mundo un marcado cambio en pos de una profesionalización musical, es decir, de seleccionar a los músicos en función de su capacidad y ductilidad, incluso de su inventiva o despliegue técnico, en desmedro de las consideraciones morales, de pertenencia institucional o simbolismo de clase que eran la norma medieval $y$, entre otras cosas,

281 Por ejemplo Bermúdez menciona un sastre mulato que ya en 1614 tenía entre sus posesiones una guitarra; unos años después está documentado que un indio perteneciente a una confraternidad también poseía este tipo de instrumentos (Bermúdez, 2001, p. 172) 
condenaban a los juglares -es decir a los profesionales- a una proscripción social. Con lo cual, para una cultura invasora con la vara de la calidad bastante alta, la ausencia de músicos peninsulares con que hacer frente a todos los puestos y vacantes en América es un gran problema. El paradigma de la calidad profesional hace que se piense en el traslado de la infraestructura musical española: la capilla y sus ministriles. Pero, y aquí ya está operando con fuerza el proceso de mestizaje, las condiciones materiales y culturales de la conquista, de lo vasto y diverso del territorio y sobre todo de los pueblos indígenas a someter (Aharonián, 1994) hacen que el modelo institucional europeo deba ser fuertemente modificado (Urchueguía, 2012, p. 481). Esto nos dice mucho sobre el grado de distancia, tal cual ocurre en el emplazamiento de las ciudades, entre el plan civilizador basado en el ideal hidalgo y la realidad emergente de la producción musical americana. Debemos comprender que las condiciones materiales y de personal para la producción musical -materia irrelevante para la musicología afirmativa- no se parecían en nada a las de España, por lo cual las normas y planes musicales que encontramos en las crónicas y fuentes de parte de los conquistadores son más una orientación que una prescripción cumplida al pie de la letra. Lo que en Europa era norma, como la selección por concurso de oposición de los músicos, se suspende en América en la mayoría de los casos, por lo menos hasta bien entrado el siglo XVII (Waisman, 2019, p. 41). Más allá de la importación de textos de música y partituras, tráfico en que además se advierte una proporción mucho más alta de papeles de música e instrumentos ligados a la práctica doméstica y secular por el componente social de los conquistadores que mencionamos antes, llevará mucho tiempo y esfuerzo poner a funcionar una imprenta musical comparable con las de la metrópoli. Si sumamos a esto el fuerte acento evangelizador de la cultura musical colonial, nos encontramos con un repertorio que superpone, en un plano sincrónico, formas de producción que en Europa se considerarían históricas, lo cual lleva a algunos autores a la opinión de que la música colonial hispanoamericana es más medieval que moderna, y a la famosa formulación de Alejo Carpentier que opone al orden cronológico impecable de los estilos musicales europeos, la confusión desordenada y exuberante de la música latinoamericana (Carpentier, 1984).

El emergente más importante de esta situación es, a nuestro entender, la imposibilidad de una formación rápida y sistemática de músicos provenientes de las filas de los colonos. Lo cual genera como consecuencia que sea poco frecuente la institución de una banda permanente de músicos "de la ciudad" -y no ligados a la Iglesia- como describimos antes en referencia a las ciudades europeas (Waisman, 2019, p. 93). De aquel lado del Atlántico, las ciudades estaban asociadas claramente a la burguesía mientras que de este lado, si bien se forman cofradías de artesanos y otros gremios en las ciudades de españoles, éstas no tienen ni de cerca el poderío de sus modelos ultramarinos para costear cuerpos de ministriles cívicos permanentes. Por ende, se limitaban a la contratación de los músicos de parroquias cercanas, en casi todos los casos músicos indígenas. Este panorama de escasez e impotencia para imponer un ideal sonoro ante lo vasto del nuevo mundo no es exclusivo de la América hispano-lusitana, aunque sí lo peculiar es la solución a esta situación, que se da en línea con la lógica de explotación colonial. Como sabemos, ésta estuvo asentada fundamentalmente en la mano de obra indígena (Romero, 2001, p. 60) mediante la institución de la mita y el yanaconazgo a partir del "reconocimiento" del carácter humano de los nativos -vaya excusa para la explotación- más el agregado temprano aunque paulatino del tráfico esclavista de africanos que, a medida que decrece la población nativa -fundamentalmente por las espantosas condiciones de vida-, irá aumentando y funcionando como relevo. 282 De tal suerte que, mientras que por ejemplo en las trece colonias británicas del norte los presbíteros protestantes se entregan durante todo el

282 Juan Carlos Estenssoro propone como caso emblemático la ciudad de Lima, en la cual el $40 \%$ de la población hacia el siglo XVIII era de origen africano (Estenssoro, 1988, p. 161). 
período colonial a la obstinada e igualmente fútil empresa se enseñarles a cantar polifonía a unos muy desafinados colonos agricultores "blancos" (Small, 1989, p. 135) -prescindiendo totalmente de los indígenas mientras se los desplaza primero y se los genocida después-, en Hispanoamérica se emplea a los indígenas en la mayoría de los puestos musicales desde el comienzo mismo de la colonización (Urchueguía, 2012, p. 484). De este modo, se traslada el modelo jerárquico moderno que separa entre compositores y ejecutantes, así como entre teóricos y prácticos. Naturalmente, el oficio de ministril, es decir, instrumentista, es el que más recaerá en manos de indígenas y también de esclavos africanos. Podríamos ver aquí otra variedad de la línea racial de Miller (2010) que referimos en el capítulo 4: en conformidad con la sociedad de castas de las colonias españolas, se da un escenario de compositores y cantantes blancos y españoles, por un lado, frente a instrumentistas indígenas o negros por el otro. Por ejemplo, para el caso de la ciudad de Córdoba, Argentina, Clarisa Pedrotti traza el siguiente panorama descriptivo:

\begin{abstract}
Estos dos grupos estaban representados por dos sectores antagónicos de la sociedad: por un lado los cantores "blancos" en el universo colonial, cercanos a los sectores de la élite, clérigos y religiosos. Por el otro, los músicos instrumentistas o "ministriles" entrenados en la participación instrumental, negros, mulatos o pardos principalmente esclavos (Pedrotti, 2017, p. 91)
\end{abstract}

La diferencia social comentada más arriba que separaba a los ministriles españoles de sus colegas cantores y compositores más prestigiosos, se traduce en Latinoamérica en una diferencia racializada a partir de la etnicidad que se asociará con los ministriles, en su mayoría indígenas y también negros, pardos, mulatos y demás miembros de las castas (Vera, 2016, p. 651). Sin embargo vemos aquí otro pequeño desvío en el cruce transatlántico, ya que estos músicos racializados obtienen algunos beneficios de los que no gozan la enorme mayoría de sus congéneres, sobre todo si consideramos su condición colonial. En la mayoría de los casos, los indígenas que integraban los cuerpos de ministriles y capillas quedaban exceptuados de ciertas cargas tributarias que, por ejemplo en la zona andina, implicaban someterse a la mita (Waisman, 2019, p. 67). La razón de este "privilegio" -si es que podemos hablar en estos términos en una situación racializada y colonialprovenía del mundo prehispánico, en el que existían los músicos profesionales llamados pinkollori por los aymara (Vera, 2016, p. 619), taki kamayoq para los quechua (Estenssoro, 1992, p. 357), cuicani por los mexica (Martínez Miura, p. 233) o holpop por los Maya (Sánchez de Aguilar, 1639, p. 97). A la llegada de los españoles, tanto en la zona azteca como en el ámbito incaico los músicos no pagaban tributo y "gozaban de una alta consideración social» (Waisman, 2019, p. 63), lo cual los ubicaba en una situación completamente diferente de los restantes miembros de la comunidad. Esta exención de tributo configura una razón económica que tal vez haya sido en la colonia más importante que otras más legendarias, de carácter moral o religioso, a la hora de configurar la base de las constantes cédulas y regulaciones que tienen como objeto reducir y mermar la cantidad de instrumentistas en el ámbito colonial (Stevenson, 1990, p. 309).

La continuidad de esta condición tras la conquista produjo, sin embargo, una estratificación al interior de las comunidades nativas y permitió que los músicos indígenas tuviesen un medio preferencial de integración a la sociedad colonial (Vera, 2016, p. 651). Dado que las castas tenían prohibido formar parte del clero, el oficio de músico era realmente una profesión importante dentro del universo indígena. Así «la carrera musical ofrecía a los indígenas unos privilegios sociales y económicos que a menudo eran el primer peldaño en el escalafón de la estructura de poder de la colonia» (Baker, 2005, p. 184). De este modo, los músicos indígenas profesionales llegaban incluso a ganar algún dinero y eventualmente transformarse en propietarios, situación que vimos era parte del estatus alcanzado por los ministriles italianos, flamencos y alemanes. Este tipo de organización y 
prebendas lleva a Geoffrey Baker a suponer que las capillas musicales del Cusco deben haber funcionado como homólogos de los gremios profesionales de Europa (2005, p. 183).

Todo este panorama abarrotado de ministriles americanos fundamentalmente integrados por indígenas, mestizos, mulatos y/o africanos desde por lo menos el siglo XVI (Bermúdez, 2001, p. 176) nos lleva a preguntarnos de forma insoslayable por el sonido de este mestizaje tan particular. La documentación escrita, así como las imágenes, muestran a estos grupos formados por flautas, sacabuches y chirimías además de atabales, tambores y otros instrumentos de percusión. Pero no debemos olvidar que lo que esas fuentes nos ofrecen es la perspectiva de los colonizadores, quizás más vinculada con el ideal hidalgo que con la materialidad sonora circundante. Además, las formas de conceptualizar y nominar las prácticas, técnicas, instrumentos y costumbres de los indígenas por parte de los cronistas sólo nos hablan de la distancia conceptual y la dificultad descriptiva frente a un universo que al mismo tiempo resultaba barbárico y fascinante. Recordemos que para los cronistas del debut de Chazarreta en Santiago del Estero, el bombo legüero recibe el nombre de "caja provenzal" ¿Qué podemos esperar entonces de los cronistas españoles en América, no todos músicos, a la hora de encontrar nombres para los instrumentos nativos? No podemos exigir un preciosismo organológico a las fuentes, de forma tal que "flauta" o "chirimía" puede ser tanto la copia del modelo europeo como la forma de referirse a algún instrumento nativo desconocido por los conquistadores. ${ }^{283}$ La precisión en las descripciones sobrevendrá únicamente en los casos de un interés genuino o en la medida en que se relacione la práctica idolátrica con el uso de ciertos instrumentos, o incluso que la distancia -teórica- entre las dos repúblicas se ponga abiertamente en entredicho. Por ejemplo, estas últimas dos cosas ocurren en el proceso de extirpación de idolatrías en la zona andina a principios del siglo XVII, que requiere revisar las formas de interpretación de los evangelizadores y cronistas anteriores, quienes no habían advertido que los indígenas

tuviesen varios instrumentos con que se convocaban para las fiestas de sus huacas, o las festejaban, como son trompetas de cobre o de plata, muy antiguas y de diferente figura y forma que las nuestras, caracoles grandes, que también tocan, que llaman antari y pututu, y otros pincollos, o flautas de hueso y de cañas (Arriaga como se citó en Estenssoro, 1992, p. 376).

Por eso tenemos que considerar seriamente también el traslado de formas de producción sonora, de instrumentos e incluso de alguna configuración melódica de las prácticas indígenas a las músicas urbanas coloniales (Waisman, 2019, p. 43). Las agrupaciones de ministriles más convencionales aparecen de forma importante en la música de una institución de mayor relevancia dentro de la vida urbana colonial, como es la catedral. Por ejemplo, en la iglesia mayor del Cusco encontramos que

La catedral era la excepción en lo que se refiere a la organización musical y social debido a la variedad de su personal musical: se caracterizaba por una mezcla poco frecuente de etnias (cantores españoles, ministriles indígenas, incluso un trompetista ocasional negro), de profesiones (algunos músicos indígenas eran empleados de la catedral, otros prestaban su servicio como tributo, mientras que muchos de los cantores españoles eran sobre todo sacerdotes o seminaristas y su categoría profesional era, por tanto, algo compleja), y de clases (había un gran salto social entre los humildes ministriles y los músicos de elite españoles) (Baker, 2005, p. 179)

En el caso de esta ciudad la propia urbanización es una muestra del poderío colonial, lo que hace que tras la victoria militar (aunque aún precaria) de 1533 los españoles

283 Por ejemplo la intercambiabilidad entre "atabal" y "huehuétl" es frecuente en las crónicas de México. Del mismo modo tenemos que considerar cierto sincretismo organológico, como el que exhiben los instrumentos de los Quiché de Totonicapán, Guatemala, que poseen instrumentos de viento que combinan formas constructivas de las familias de madera y metal, en una clara reapropiación de los modelos europeos. 
construyeran las iglesias y edificios cívicos en un estilo peninsular sobre los cimientos de los templos y palacios incaicos como una muestra evidente y explícita de dominación (Baker, 2008, p. 19). Recordemos que la catedral de Cusco está emplazada sobre las ruinas del palacio de Wiraqucha, octavo Inka del Tahuantinsuyo, y completada además con piedras extraídas de otra construcción incaica, Saqsaywaman, donde se realiza todavía hoy la ceremonia del Inti Raymi, el culto al dios Sol. Por lo tanto la catedral cusqueña es un edificio concebido como indicador de la subordinación del mundo indígena ante los invasores y su fe cristiana. Es en todo sentido un edificio afirmativo, aunque no el único en la ciudad: el convento de Santo Domingo, otra institución que generó importante actividad musical en la época colonial contratando músicos indígenas (Baker, 2003), está literalmente construido, por cesión de Juan Pizarro, sobre los antiguos muros de la Qorikancha, un esplendoroso templo incaico dedicado a Inti.

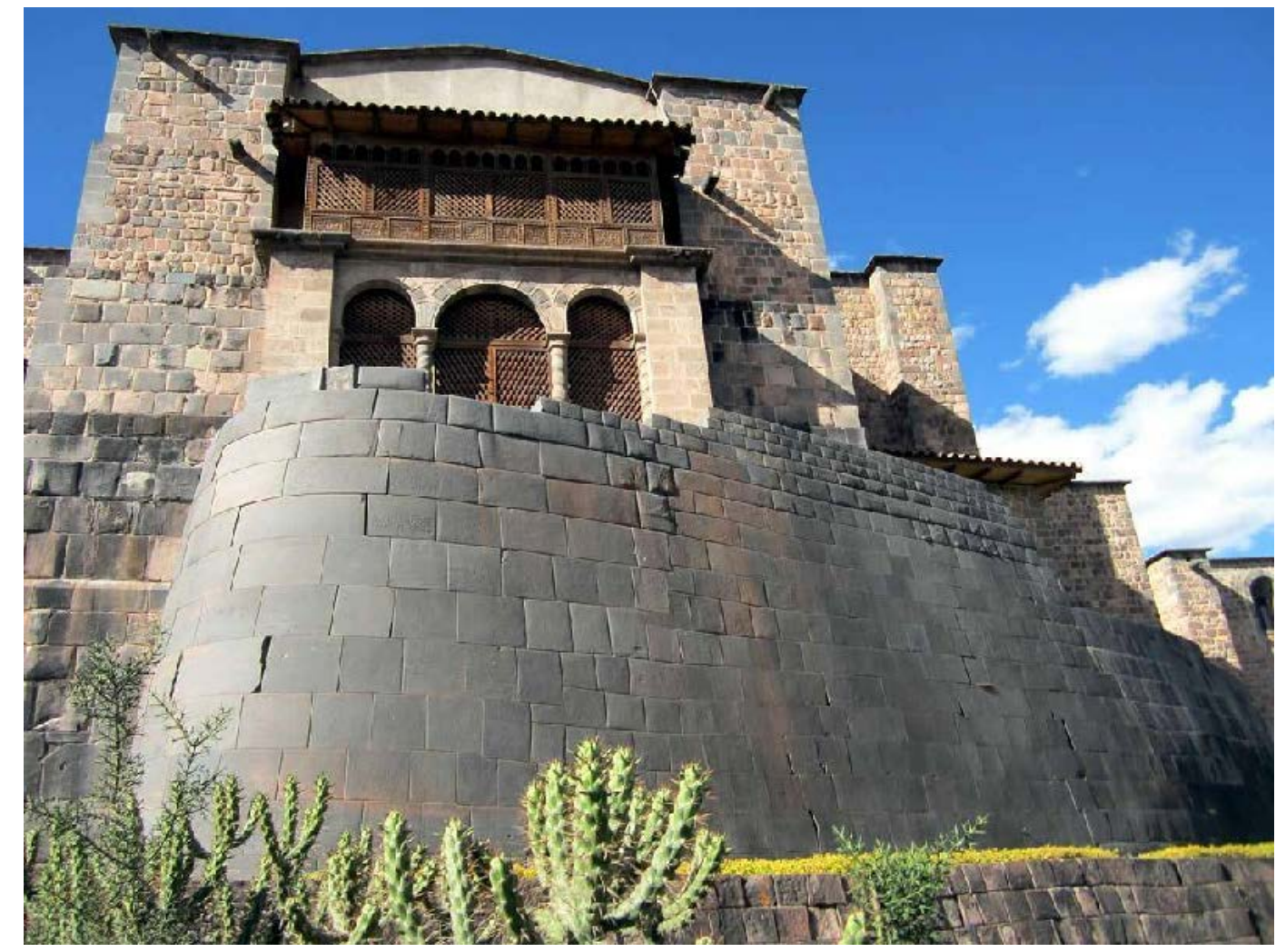

El convento de Santo Domingo de Cusco, Perú, debajo del cual puede verse todavía una parte del muro de la Qorikancha, el templo de adoración de Inti.

Sin embargo, como vemos en la imagen, esos cimientos se resisten a ser totalmente cubiertos -o encubiertos. Emergen como un recordatorio permanente, pétreo, de que allí hay también otra cosa. Subrayamos el tiempo verbal, ya que, como otra característica de estas ciudades coloniales, lo sincrónico y lo diacrónico forman parte de su identidad. Esto es interesante porque es parte de la concepción temporal andina. Según cuenta el músico boliviano Cergio Prudencio (2001) en el pensamiento andino existe una «noción de tiempo no solamente circular, sino también espacial. El pasado es todo lo que yo puedo contemplar, lo que puedo ver, porque forma parte de mi experiencia». Esta concepción es muy diferente al pensamiento cartesiano de la modernidad occidental, en el cual el tiempo se piensa como un flujo irreversible que discurre, como un río, en dónde el sujeto histórico viene a ser una suerte de navegante del tiempo. Veremos que esto tiene importantes consecuencias musicales, sobre todo en torno a lo que desde lo formal, pero no desde lo real, aparentará ser un comportamiento repetitivo del universo sonoro. $Y$ desde ya tiene consecuencias historiográficas, porque esta confluencia de la dimensión histórica con el 
tiempo presente nos lleva a tener que repensar las categorías de la historiografía musical. El orden progresivo y hegeliano de la musicología afirmativa, por ejemplo, con su sucesión ordenada y estrictamente sucesiva de estilos homogéneos, unitarios e internamente coherentes, no puede explicar en absoluto este panorama. Pero tampoco nos asiste aquí la concepción de supervivencias extintas. Aunque se pensaran como "vigentes", esas rocas no son supervivencias, restos arqueológicos o fósiles que nos hablan de otra época. Son parte de manera dinámica y cambiante, de la ciudad colonial. Aunque la traza urbana es consecuencia directa de la conquista, la configuración social que emerge en ellas «no era una sociedad análoga a la sociedad europea, sino, simplemente, una sociedad homóloga. Y como los elementos que la integraban eran esencialmente diferentes, su proceso de transformación era una constante amenaza del orden formal» (Romero, 2001, p. 114). Esta suerte de amenaza debemos pensarla, justamente, en términos performativos, es decir por fuera de la "ideología colonizadora" que, según Romero, es la que encontramos en los documentos oficiales que trazan el plan colonial. Es esa diferencia entre lo formal y lo real a la que nos referimos antes, que se manifiesta en la diversidad, la heterogeneidad, lo irreconciliable distinto que aparece en el día a día por las calles, que emerge de la vida cotidiana. Esto hace que esa intención segregadora de la política de las "dos repúblicas" sea simplemente eso, un plan ideológico permanentemente derrotado en el plano real de la vida diaria de la ciudad colonial. Justamente la presencia de los músicos indígenas $-y$ también de los negros- en la producción musical colonial, incluso de la catedral, presenta un panorama en donde «el mundo social y musical al que nos estamos refiriendo tiene poco en común con el mundo de la música catedralicia española» (Baker, 2005, p.179). Un carácter estrafalario, heteróclito, que resiste a la concepción artística unitaria de la modernidad europea (Escobar, 1991) atraviesa el paisaje sonoro de las ciudades reales, que aunque, como ya referimos, van diferenciándose entre sí, presentan este mismo punto de partida en que se superponen de forma aparentemente desordenada, incluso caótica, los más diversos elementos. Esta es la razón por la cual Leonardo Acosta nos habla de la singularidad de la conformación del conjunto instrumental en las músicas latinoamericanas, presentes de igual modo en las ciudades coloniales de las actuales Cuba, Panamá, Bolivia o Venezuela, integrado como vimos por músicos de las castas, que a su vez

interpreta[n] aires que no son españoles ni indígenas, aunque tienen de lo uno y lo otro. Es cierto que los instrumentos son de origen europeo, aunque es posible que no correspondan exactamente en forma ni sonoridad a sus ancestros lejanos o cercanos. Pero la manera de tocarlos es inconfundiblemente distinta, y nadie debe engañarse si un conjunto tal interpreta algo así como un vals o una mazurca; porque en realidad se trata de otra cosa (Acosta, 2006, p. 175).

Las consecuencias historiográficas de esto no podrían ser más evidentes. Es en la sonoridad, es decir en el musicar, donde debemos buscar el acontecer histórico de la música latinoamericana; los documentos convencionales -es decir escritos- nos entregan muchísima información pero pueden jugarnos una trampa al ofrecernos los elementos organizados de un modo absolutamente europeo: en las partituras encontramos una implacable jerarquía de las alturas y de la armonía, además de una concepción rítmica proporcional y métrica mientras que, en la realidad sonora, las texturas, los desfasajes, las articulaciones específicas y esa concepción temporal circular propondrán esa otra cosa. Esto se relaciona con una cualidad del pensamiento andino, que es su estructura trivalente, que hace que una afirmación no lo sea del todo, es decir, que sea permanentemente relativizada, lo cual resulta en que tanto ella como su opuesto puedan coexistir sin implicar una contradicción excluyente. Para el pensamiento occidental basado en el dualismo cartesiano tanto los fenómenos como los entes no resisten la contradicción: son o no son. En los modismos del habla de toda Suramérica (incluso en países con ideal blanco que su condición mestiza real pone permanentemente en entredicho) suele escucharse al final de 
una frase propositiva la palabra pero, ${ }^{284}$ que automáticamente relativiza el contenido de la afirmación. Esto impide las afirmaciones categóricas, lo cual vale tanto para el lenguaje verbal como para la música (Prudencio, 2001).

En este sentido las crónicas, en muchos casos de parte de indígenas de la élite formados por los españoles, nos presentarán una realidad en sí misma contingente. Para Silvia Rivera Cusicanqui es una derivación de la confrontación cultural y civilizatoria iniciada en la conquista. Situación de dominación que provocó históricamente que los discursos oficiales y públicos -los verbales- sean formas de no-decir. "Hay en el colonialismo una función muy peculiar para las palabras: las palabras no designan, sino encubren [...] De este modo, las palabras se convirtieron en un registro ficcional, plagado de eufemismos que velan la realidad en lugar de designarla» (Cusicanqui, 2014, p. 19). Si para la situación del mundo carnavalesco de la Europa medieval debíamos cuidarnos al abordar documentos y registros que siempre nos ofrecen la visión de los sectores hegemónicos, en el mundo colonial los dobles sentidos y las referencias indirectas se multiplican. Para esta misma autora, el proceso colonial ha obligado a desarrollar modos retóricos de comunicación, convenciones del habla que esconden más de lo que evidencian pero que a su vez orientan las prácticas divorciando la acción de la palabra pública. Por lo tanto, el esfuerzo por recuperar de lo presentacional aquello que ponga en crisis los discursos oficiales nos puede revelar un sentido no censurado de ese mundo subalterno. El desafío es encontrarlo en la música, en su materialidad sonora.

Debemos hacerlo a través de las apariencias, que permanentemente nos instan a que consideremos una analogía estilística entre la metrópoli y lo que emerge de su dominación territorial ultramarina, ya que existen las homologías formales -es decir en el plan, en la partitura- aunque ya no se parezcan tanto cuando se tocan. Evaluar la correlación entre las diferentes dimensiones temporales de esa configuración espacial americana, o encontrar esa manera "inconfundiblemente distinta" de tocar la música que se hace así real, es una tarea pendiente de la historiografía musical latinoamericana. Pero además es tal vez en la memoria histórica de la música popular de la región donde esa confluencia de los "ancestros cercanos y lejanos" se revele con mayor precisión, ya que es importante recordar que el mundo popular subalterno concebido por De Martino incluye los territorios dominados por la expansión occidental.

Parte de este carácter subalterno se inscribe en lo mestizo, que surge en esa encrucijada que tensa lo formal hacia lo real y se convierte en una amenaza al orden colonial, pues forma el vínculo concreto entre los mundos racializados que debían permanecer separados. Por eso Romero habla del «riesgo del mestizaje» que el ideal de las dos repúblicas pretendía contener. Porque los mestizos se manifiestan en el seno de las clases dominadas, contribuyendo a la inestabilidad del plan colonial, usufructuando ciertos beneficios de sus padres blancos, pero fundamentalmente amenazando con reemplazarlos. Es un sentido inestable, o mejor, contencioso, característica crucial de las sociedades latinoamericanas que surgen del proceso histórico colonial. Pero que aquí vuelve a acercar la idea de lo mestizo con la condición del mundo popular subalterno. En términos aymaras, ese universo mezclado, contingente, que habita en el territorio de disputa de la cultura popular, que deriva su identidad de lo ambiguo, puede pensarse como un mundo ch'ixi, mezcla abigarrada de lo mestizo. Lo mestizo, en tanto realidad cultural transicional que no se configura jamás por completo, nos acerca nuevamente a la concepción trivalente

284 En la zona portuaria bonaerense de la ciudad de Berisso (considerada capital de la inmigración europea contemporánea de italianos, lituanos o rumanos, es decir el paradigma más lejos al mestizaje imaginable) se escucha cotidianamente este modismo del "pero" final: "te parece que vamos al río, pero"; "vamos a comer, pero". De hecho la senadora y ex presidenta Cristina Fernández de Kirchner, oriunda de esa zona aunque para nada una persona que el ideal hidalgo ni el sueño liberal inmigratorio nos permitiría asociar con la noción de mestizaje, utiliza muy frecuentemente en sus discursos públicos ese modismo lingüístico. 
La palabra ch'ixi [refiere a] un color producto de la yuxtaposición, en pequeños puntos o manchas, de dos colores opuestos o contrastados [...] Es ese gris jaspeado resultante de la mezcla imperceptible del blanco y el negro, que se confunden para la percepción sin nunca mezclarse del todo. La noción ch'ixi, como muchas otras (allqa, ayni) obedece a la idea aymara de algo que es y no es a la vez, es decir, a la lógica del tercero incluido. Un color gris ch'ixi es blanco y no es blanco a la vez, es blanco y también es negro, su contrario [...] La potencia de lo indiferenciado es que conjuga los opuestos (Cusicanqui, 2014, p. 69)

\subsection{2 - El riesgo del mestizaje}

Si lo ch'ixi conjuga el mundo indio con su opuesto, en forma contenciosa e irresuelta, aunque a la vez posibilidad de transculturación, existe una denominación también para lo que, mezclado, se sintetiza o disuelve sin ofrecer tensión alguna. Esto es lo chhixi, que también connota la idea de pérdida de sustancia y "corresponde entonces a esa noción de moda de la hibridación cultural "light", conformista con la dominación cultural contemporánea» (Cusicanqui, 2014, p. 70). Esta otra condición de la mezcla, la de una sintética fusión híbrida, el crisol de razas, vendría justamente a representar la realización del ideal urbano español.

A pesar de todo diría que la música, el sonido y la performance fueron igualmente integrales en este proceso de colonización y urbanización en el Nuevo Mundo, con el ordenamiento de la ciudad [...] concebido y promulgado no sólo en términos verbales, sino también sonoros, ejemplificados en el concepto y la práctica de la armonía. La música europea, propagada por los misioneros españoles desde los primeros años de la conquista del Perú, sirvió tanto como herramienta y como metáfora para la armonización de las fuerzas sociales. La imposición de estructuras organizativas musicales y la inculcación de habilidades musicales europeas, especialmente la armonía, previamente desconocida en los Andes, formaron parte de los amplios esfuerzos para crear un orden temporal, espacial y social en las nuevas ciudades coloniales que se fundaban en el virreinato285 (Baker, 2008a, p. 20) [las itálicas son nuestras].

Esta es uan explicación en sintonía con la idea de síntesis híbrida, que concibe la realización completa del ideal urbano en una dominación como maquinaria implacable, sin disputas ni contradicciones. Y que por lo tanto hace impensable la agencia cultural de los grupos subalternos. Se parte aquí de un modelo relacionado con la idea de aculturación en la cual el esquema dominación/resistencia es visto en términos rígidos de enfrentamiento a todo o nada entre dos bloques monolíticos. Notemos la similitud de esta manera de concebir la alteridad colonial con los análisis sobre la relación entre el sector dominante y las clases subalternas que pusimos en crisis en el capítulo 4 ya que, precisamente, impedían cualquier formulación específica de la cultura popular. Desde el Romanticismo al positivismo folklorizante, se concibió al pueblo como sector intrínsecamente derrotado, a la defensiva, en un repliegue permanente, pero cuyas manifestaciones tendrían un sentido unívoco de oposición frontal y hasta de revuelta. Como vimos, tanto Gramsci como Hall -en realidad el segundo sigue los argumentos del primero- ven en esta forma homogeneizante el principal problema al concebir, especialmente, la cultura popular; que es diversa, inarticulada y no tiene una vocación declarativa, ni mucho menos es monolítica. La cultura popular, y en ella debemos buscar la cultura subalterna del mundo colonial, como vimos en Bajtín o en Ginzburg, pero también en Attali, encuentra su propia condición de posibilidad, es en la medida en que emerge de una circulación tensionante entre las capas de la

285 «Yet music, sound, and performance, I would argue, were equally integral to this process of colonization and urbanization in the New World, with the ordering of the city [...] conceived and enacted not only in verbal but also in sonic terms, exemplified by the concept and practice of harmony. European music, propagated by Spanish missionaries from the earliest years of the conquest of Peru, served both as a tool and as a metaphor for the harmonization of social forces. The imposition of musical organizational structures and the inculcation of European musical skills -especially harmony, previously unknown in the Andes- formed part of wider efforts to create temporal, spatial, and social order in the new colonial towns being founded across the viceroyalty» (Baker, 2008a, p. 20) [traducción del autor] 
estratificación social y cultural. Si ese movimiento se detiene, ya no tiene sentido hablar de ella. Tal vez, esto es «lo que pone malos a los socialistas» (Hall, 1984, p. 5), ya que demuestra que el pueblo no está permanentemente litigando un sentido único de rebelión, sino que en ocasiones puede adoptar incluso los anhelos de las clases hegemónicas - ¿no consiste en eso la hegemonía?- sin que por ello tengamos que pensar que los ideales de los sectores dominantes alcanzan por esta vía un cumplimiento material absoluto.

\begin{abstract}
Puede que este juicio nos haga sentir correctos, decentes y satisfechos de nosotros mismos [...] pero no sé si este parecer puede sobrevivir mucho tiempo como explicación suficiente de las relaciones culturales; [...] En última instancia, el concepto del pueblo como fuerza puramente pasiva es una perspectiva profundamente no socialista (Hall, 1984, p. 5).
\end{abstract}

Omitimos ex profeso algunas líneas del párrafo de Hall para aumentar la ambivalencia de su objeto de análisis. Porque es muy llamativo que sus reflexiones puedan aplicarse tanto a las concepciones de hibridación y cumplimiento de la aculturación en el proceso colonial, como para la cultura de masas contemporánea, que es la realidad cultural para la cual él las acuña. Es una similitud que surge del idéntico tratamiento que reciben por un lado las clases trabajadoras de nuestro tiempo en los análisis apocalípticos, como los sectores subalternos racializados del mundo hispanoamericano por el otro. En ambos casos el pueblo, es decir la inmensa y contradictoria variedad de parcialidades y colectivos que configuran el sujeto social de explotación y dominación por parte de los sectores hegemónicos, son concebidos en ambos casos como materia inerte, receptores de las políticas culturales de quienes los dominan. Los cuales además son caracterizados como implacables e infalibles, no presentan contradicciones ni disputan entre ellos. Esto también se traslada a la producción conceptual sobre la propia realidad. Es que «los sometidos no deben generar teoría sobre sí mismos; esa tarea le corresponde a sus amos. Y esto ocurre también en el terreno de la musicología» (Aharonían, 1994, p. 201). De hecho Cristina Urchueguía habla de una "suerte de segunda conquista» en referencia a la historiografía de la música catedralicia del mundo colonial, que busca los paralelismos evidentes con el modelo español. Pero la misma autora debe reconocer unas líneas más adelante que este paralelo no es una concreción sino una aspiración, puesta en cuestión por los maestros de capilla criollos y mestizos, "una evolución inevitable considerando que gran parte del personal musical que servía a la Iglesia eran criollos, mestizos e indios» (Urchueguía, 2012, p. 489). Este sentido de lo aspiracional nos lleva a considerar otro problema en la afirmación de Baker citada más arriba. Y es la de equiparar el plano teórico e ideológico de la conquista musical -que se expresa en las partituras, en los instrumentos importados, en el esquema institucional trasplantado- con el plano material y sonoro, que es una realidad fundamentalmente hostil a esos planes. Es decir, la mentada armonía, aspecto que coincidimos en considerarlo central ya que, como desarrollamos en el capítulo 1, es el rasgo específico de la cultura musical afirmativa de la modernidad, debemos entenderlo como parte de la ideología conquistadora, del ideal hidalgo, y por eso abstracto como podía serlo la teología cristiana para la evangelización o la organización civil y urbana para los planes coloniales. Lo que se impone es el ideal, lo cual no quiere decir que el sonido emergente de tal proceso coercitivo se corresponda con él. Más adelante vamos a desarrollar ejemplos específicos de esta distancia entre el ideal armónico y la materialidad performativa de los músicos herederos del proceso colonial.

Que sea un ideal no le quita fuerza a la argumentación en torno a la imposición de los paradigmas estéticos europeos. Tanto se instaló el ideal de la armonía en la teoría musical y musicológica, que persiste mucho más en la colonialidad del saber de la academia y los conservatorios antes que en las prácticas de los músicos latinoamericanos. Justamente, nos permitimos pensar que en la evasión, en la huida y en las adaptaciones de las prácticas subalternas al ideal armónico moderno se despliega lo que podríamos llamar resistencia. Y 
en tanto tal, sus dominios son todos aquellos espacios que el armonicocentrismo moderno dejó vacantes al omitirlos del centro de la definición musical mediada por la partitura: la dimensión material sonora de la performance, eso que al no tener un mejor término asociamos a la palabra timbre y que necesariamente se introduce también en la textura, en ciertos aspectos del ritmo y en los modos de producción sonora que agrupamos en la categoría de articulación. Como vemos, son aquello que en general relacionamos con la tarea de los intérpretes, es decir, de los músicos que producen sonido y no planes abstractos. Es en esta «interpretación» (Waisman, 2012) donde debemos buscar la especificidad subalterna latinoamericana. Aunque desde ya el término interpretación es aquí inconveniente, pues es válido únicamente en la dicotomía compositor/ejecutante que como sabemos es parte del modelo objetual y personalista moderno. Precisamente, el accionar performativo de los instrumentistas, de los cantores y de los bailarines de las músicas latinoamericanas se construyen en base a "diferencias" a partir de un canon, el que además no debe concebirse como estático sino que está en permanente cambio y recreación a partir de una modalidad de producción y circulación en la que «se crea a partir de un texto escrito, oído, recordado y recompuesto» (Bernand, 2014, p. 25). Procesos que, si bien parten del sonido, de la acción instrumental o vocal, de esos ejes interpretativos si se quiere todavía pensarlos así, no por ello dejan de afectar e introducir profundas modificaciones a lo que sí el canon sanciona: las melodías, los textos, la métrica del tiempo y la armonía.

Al discutir de esta forma el estatuto de lo que entendemos por música y asociarlo por ende a una concepción social/performativa, es decir al musicar, obtenemos un universo mucho más heterogéneo y variado de fuerzas y respuestas que no pueden reducirse a un esquema simplista de "resistencia/dominación", "Europa/América", "Mundo católico/mundo indígena", etc. que en muchas ocasiones ha derivado en un esquema maniqueo. Como consecuencia de la pérdida de agencia de los sectores subalternos y de la concepción de una aculturación completa triunfante, la temporalidad del mundo colonial se vuelve estática: tras el momento del choque inicial y la victoria de los invasores, se produce una aculturación que permanece sin cambios por lo menos hasta el período de las independencias y en la cual la cultura vencedora monopoliza la producción cultural.

Llevada a sus consecuencias extremas, la noción de "otredad" desemboca en lo incomunicable de cada cultura, hecho que desmiente la historia, en lo que concierne a la del mundo iberoamericano (Bernand, 2014, p. 26)

Esto es sintomático en las historias de la música, fundamentalmente las de índole nacionalista (Pérez González, 2010) que se escriben por países (historia de la música de Brasil, de México, etc.), en los que el capítulo «Música en la época colonial» no suele tener subdivisiones, y donde se presentan formando una unidad histórica músicas tanto del siglo $\mathrm{XVI}$ como del XVIII, siendo más frecuente la diferenciación geográfica en músicas de la sierra o el llano, de la selva o de los puertos. Esta relación "natural" con el ambiente y la ausencia de periodizaciones de índole histórica, hacen que se folklorice la historia musical colonial, incluso la de su música sacra, adquiriendo un estatus cuasi mítico como observamos en la concepción del pasado popular en el capítulo 4.

Uno de los historiadores que ha puesto en cuestión estas dicotomías monolíticas aplicadas al pasado colonial es Juan Carlos Estenssoro, que llamativamente forma parte del marco teórico referido por Baker. Este autor ha advertido en sus trabajos que el contexto andino durante la colonización es

un mundo de cambios rápidos, tanto de la población indígena y de sus creencias (sin que haya en ello ningún signo de empobrecimiento ni de humillación) como de la Iglesia, obligada a redefinir constantemente los contenidos de su práctica doctrinal (Estenssoro, 2001, 458) 
Este autor identifica múltiples fuerzas, o movimientos, como él los llama, que permiten ampliar la gama con la cual definir de modo más profundo tanto las relaciones como los cambios ocurridos en este universo colonizado, dentro de lo cual se desenvuelven las culturas indígenas y las demás subalternidades. El esquema de Estenssoro podría pensarse como una matriz de cuatro vértices en los cuales aparecen por un lado tendencias en el orden de la "fusión-asimilación», que expresan diferentes posiciones relativas a los conquistadores, como la evangelización e integración a la modernidad de los grupos indígenas y subalternos, e incluso la voluntad de conocer sus manifestaciones y formas de vida; pero en torno a este campo también hay que considerar a las parcialidades indígenas,

que reconocen el poder del dios cristiano en el triunfo efectivo de los españoles, están tan interesados en conservar sus antiguos ritos como en conocer los ritos católicos y las características del nuevo dios, ya sea para poder domesticarlo y hacerlo favorable a ellos, ya sea para combatirlo o contrarrestar su poder, ya sea finalmente para reproducir la religión católica sin necesidad de pasar por la intermediación de los españoles (Estenssoro, 2001, 458)

En este orden, podemos pensar las exenciones al trabajo forzado de los músicos a las que nos referíamos más arriba -que deberíamos ver como una suspensión del orden colonial- y por supuesto no debemos descartar el interés y hasta la fascinación de los grupos nativos ante ciertas formas simbólicas de los conquistadores, que no por ello los convierte en menos indígenas o especies de "malinches" del mundo musical. A este tipo de movimiento, Waisman lo describe como parte de las "resistencias a la separación» (2019, p. 76). La suya es una fórmula un tanto antipática que se recuesta demasiado en la figura del ladino y el yanacona, pero persigue mostrar la oposición de los indígenas a la segregación racializada, una dirección que debería explorarse mucho más en la historiografía musical latinoamericana de todos los momentos históricos. El caso de los payadores morenos que comentamos en el capítulo 3 es, a nuestro juicio, otro ejemplo de esta resistencia. Pero esta fuerza por la cual los indígenas, al menos parcialmente, buscan integrarse -es decir, subsistir- en la sociedad colonial, conlleva también agregados del mundo cultural indígena que se introducen como ruidos en la concepción armónica occidental. Un caso interesante es el del mantenimiento de la estructura social y profesional vinculada a la idea de parcialidad o ayllu del mundo incaico, que se homologa con, pero no se sintetiza en, la institución del gremio profesional de los instrumentistas que comentamos para el caso de los ministriles europeos. Incluso en el sentido de incorporar a las viudas de los músicos y preocuparse por beneficios y cierta seguridad social

ciertos ayllus acababan asociados a ciertos oficios o habilidades. [...] uno de ellos, que recibe el nombre de "Los Cantores», está compuesto por cinco cantores y tres viudas. La inclusión de las viudas permite reconocer una estructura social que unía a los músicos no sólo en el ámbito profesional [...] se indica que el trabajo de los cantores se dividía en partes iguales entre los ayllus, en lugar de concentrarse en uno sólo" (Baker, 2005, p. 183)

Además hay un funcionamiento de índole corporativa en donde las asociaciones de tipo ayllu-gremio se reparten el trabajo y los beneficios. Pero con el agregado de mantener una cosmovisión propia, ya que el ayllu expresa mucho más que una asociación profesional y de hecho introduce al grupo-clan en la proyección de universo de la cosmovisión andina. De hecho, las comunidades actuales de la zona aymara continúan configurando la tropa, que es la configuración básica del grupo instrumental, en base a la noción de la parcialidad ayllu, que expresa una identificación no sólo con el clan y el grupo social más inmediato, sino con la comunidad y el territorio. Tropa que se concibe a partir de un principio de complementariedad (Prudencio, 2001) en lugar del sistema jerárquico propio de la orquesta europea, basada a su vez en que ninguno de los músicos tiene todos los sonidos, lo que para nosotros serían todas las notas, aunque no se reduce sólo a la altura sino que involucra también lo tímbrico-textural. Es decir que en la cosmovisión andina, a través del 
principio que denominan arca-ira, que un músico no controle toda la gama sonora es positivo y algo buscado, ya que hace necesaria la participación de otros, lo cual convierte a la música ineludiblemente en un hecho social. Si bien los procedimientos son muy diferentes, podríamos hacer converger este principio con lo que Quintero Rivera (2009) llama lo dialógico en relación a las músicas afrodescendientes. En cualquiera de estos casos debemos entonces inferir que, aún cuando los indígenas o los esclavos fuesen instruidos en la lectoescritura musical y la polifonía europea, en estos movimientos de integración en dirección a la asimilación de Estenssoro, introducen formas de concebir la práctica musical y sonoridades que modifican irremediablemente a las músicas europeas, convirtiéndolas en otra cosa

A esto además debemos añadir otra fuerza o dirección de movimiento, cuyos vectores son opuestos al par fusión/asimilación y que Estenssoro denomina «rechazo-separación».

Del lado indígena puede manifestarse como un cuestionamiento del poder colonial y estallar de forma coyuntural en rebeliones o en movimientos religioso-sociales. Del lado de las autoridades eclesiásticas [...] Por medio de la legislación para impedir que la población indígena en su conjunto pudiera reproducir la religión católica de manera autónoma: el noreconocimiento de ser plenamente cristianos $y$, con ello, no tener acceso a todos los sacramentos (Estenssoro, 2001, p. 458)

Estas direcciones disruptivas frente a la asimilación pueden darse además de forma contradictoria y simultánea con los intentos de integración y fusión, tanto en los sectores coloniales como en las comunidades indígenas y las cofradías de negros. Pero en referencia al último asunto que menciona Estenssoro, notemos que la idea de la separación, o segregación para el caso, funciona en la medida en que tengamos grupos "puros", étnica y culturalmente homogéneos. Aquí es que podemos tomar, para recuperar la profundidad de sentido histórico que habita en estos cruces de espacios y prácticas tan ambiguos, la noción de "culturas bastardas» de Omar Rincón que adelantamos en la introducción como parte de la definición misma de lo popular. Así, a partir del carácter subversivo de la ambivalencia y lo sedicioso de lo corporal, que en nuestro caso presenta un componente perturbador en la indeterminación de lo racializado, Rincón hace un sancocho entre antecedentes académicos que le sirven para expresar esta condición performativa y a la vez resistente, mestiza y legitimadora que encontramos en los músicos subalternos coloniales

Foucault ya lo dijo todo, y entre lo más potente y simple es que para que haya poder debe haber resistencia y que las prácticas de resistencia son las que legitiman y joden, en simultáneo, al poder. Y las resistencias están llenas de juegos de sobrevivencia y en palabras de Michel de Certeau tienen que ver con esos juegos de los de abajo: las "marcas del hacer", las "maneras de practicar", las "tácticas" del cotidiano y las "inventivas del más débil": o sea, con esas resistencias móviles, inestables y fluidas (Rincón, 2015, p. 24)

De ahí que la realidad y los inconvenientes para estos planes de las autoridades provengan del mestizaje, al que claramente lo conciben como un problema, un riesgo. Los mestizos sí acceden al estatuto de cristianos plenos y por ende al sacerdocio. En el caso de la música, como mencionamos antes, ya desde el siglo XVI los maestros de capilla mestizos obtienen favores, incluso del mismísimo Felipe II, que otorga cargos y prebendas incluso en contra de la opinión de las autoridades del virreinato. ${ }^{286}$ Estos músicos, además de los españoles, serán contratados para componer -o reinventar- los villancicos y las músicas para la fiesta pública, especialmente el Corpus, que como veremos enseguida, es

286 Dos ejemplos tempranos de esta ruptura de la separación y la segregación son Gonzalo García Zorro y Diego Lobato de Sosa, quienes accedieron al cargo de maestros de capilla en el último cuarto del siglo XVI. EI caso de Lobato es significativo además porque era hijo de una de las esposas del inca Atahualpa, y su padre un capitán español (Stevenson, 1990, p. 313) 
una de las manifestaciones en que se despliega la sonoridad ch'ixi. Lo cual no debe resultarnos paradójico, pues «este doble movimiento de acercamiento y rechazo desplaza constantemente las fronteras entre idolatría y catolicismo, pero también las acerca cada vez más» (Estenssoro, 2001, p. 459)

En estos procesos en que se superponen y conflictúan las fuerzas de la integración y la asimilación frente a la resistencia y la segregación, Carmen Bernand utiliza un concepto de psicoanálisis para intentar develar las estrategias que los músicos indígenas y negros desarrollaron como formas de establecer relaciones entre sus prácticas y aquello que debían incorporar como nuevo. Se trata de la identificación, que nos reenvía a la producción de una cultura nueva, lo que Estenssoro llamará «cultura andina» y que nosotros preferimos entender como cultura ch'ixi, mestiza y mulata, pero que a la vez no es otra cosa que la producción de la transculturación, de una nueva realidad cultural que no se reduce a sus componentes, pero que mucho menos es una simple aculturación o mímesis de la cultura oficial por parte de los sectores subalternos

Hablar de identificación parece más acertado, cuando se trata de analizar la integración de las clases bajas en la sociedad estamental virreinal -una integración en posición subalterna, claro está [...] La identificación [...] no es mimetismo, sino un proceso mediante el cual un sujeto asimila un aspecto, una propiedad, un atributo del Otro y transforma parcialmente o totalmente su personalidad con relación a su modelo (Bernand, 2014, p. 28)

Estas identificaciones valen tanto para los sectores "blancos" como para las castas, de tal suerte que la variabilidad y multidimensionalidad de los movimientos en referencia a las fuerzas contrapuestas que mencionamos antes configuran una muy variada gama de posiciones y posibilidades emergentes en términos de manifestaciones culturales. Pues debemos compatibilizar esta diversidad de posiciones, a la vez subjetivas y colectivas o comunitarias, con la heterogeneidad de los mismos sectores que entran en conflicto en la conquista. Ambos aspectos, la heterogeneidad y cuotificación del mestizaje y la transculturación, junto con la tensión contenciosa entre las direcciones contrapuestas de asimilación y resistencia, configuran una verdadera matriz de posibilidades de las que emergen las músicas populares latinoamericanas. Matriz dinámica e inestable, añadimos. Tomando como unidad de análisis el Caribe, Quintero Rivera prefiere pensar este cruce de coordenadas como una tensión dialéctica que configura la identidad cultural de la región

Las diversas dominaciones coloniales imprimieron [a la región] un carácter de mosaico en sus prácticas culturales que salta a la vista aun en una primera mirada superficial: algunos hablan español, otros inglés, francés, créole o papiamento; algunos se presentan como católicos, otros como protestantes o practicantes del vodú o la santería [...] Pero con sólo arañar un poco esos múltiples carapachos (por lo demás, muy importantes) afloran elementos de una base cultural común, contradictoria, que se constituye en la tensión dialéctica entre ansias libertarias y realidades impuestas [...] Esta tensión dialéctica [...] fue, a mi juicio, el verdadero esqueleto cultural común (Quintero Rivera, 2005, p. 228)

Pero a esto todavía hay que agregar una dimensión más, que suele ser muy descuidada por la historiografía musical, si bien hay que reconocer lo extremadamente difícil de su estudio. Es lo que podríamos llamar retroalimentación o, como prefiere Marta Zátonyi, flujo y reflujo (2007) entre América y la Metrópoli, movimiento en el cual las prácticas de este mundo ch'ixi influencian también la música europea. $Y$ no nos referimos aquí a la disputa, un tanto quimérica, sobre el origen de algunos géneros como la zarabanda o la chacona. Si consideramos que lo que emerge del proceso colonial es «una nueva realidad de civilización», como proponía Fernando Ortiz o, si se prefiere, una cultura colonial como sugiere Estenssoro (1992, p. 354), da absolutamente igual la aparición a éste o al otro lado del Atlántico de un fenómeno cultural. Como explicó Enrique Dussel, el descubrimiento de América fue en realidad el descubrimiento del propio ego europeo, la toma de conciencia de 
sí en tanto confrontación con el otro descubierto y sometido. Por lo tanto, América cambia a Europa tanto como el viejo mundo interviene abusiva y alevosamente en nuestra región. La cultura y la música no pueden haber permanecido indiferentes ante semejante conmoción. Después de todo si, como sabemos, desde la historia económica y social América aporta muchas más riquezas que las que traen aquí los europeos ¿por qué con la música tendría esto que ser distinto?

\begin{abstract}
el cruce del Atlántico se hizo en los dos sentidos, y que en el trayecto de vuelta, los marineros, los pasajeros, y también partituras o notas, regresan con canciones, pasos de baile y melodías "americanizados" por las poblaciones negras y mestizas. En la península lbérica, a su vez, esas novedades son adoptadas y transformadas, porque la materia musical nunca es estática, por los músicos de la Corte, por los actores cómicos, por los dramaturgos o por los gitanos, que desempeñan un papel de "deconstrucción" comparable, aunque no semejante al de los negros americanos (Bernand, 2014, p. 33)
\end{abstract}

Sólo la afirmatividad que habita en la voluntad universalista de las élites independistas y liberales, como en el hispanismo de los nacionalismos -que como vimos en los capítulos 1 y 4 consiguieron perpetuarse en la academia y las instituciones musicales y musicológicasexplica que todavía hoy sigamos pensando en una sola dirección, en términos de las músicas que llegaron, y discutiendo en todo caso si estas fueron o no modificadas. Aquí, en la historiografía musical del siglo XXI en Latinoamérica, se da un rebote del riesgo de mestizaje que pareciera descomponer la sistematización de la investigación y lleva a que investigadores muy prestigiosos, como Baker o Waisman consideren opciones más unidireccionales y hablen incluso de un misticismo o «ideología del mestizaje» (Waisman, 2012)

algunos investigadores se desviven por encontrar con sus herramientas mentales clasificatorias dónde está lo andino, dónde lo occidental, qué es resistencia, qué aculturación. Quiénes, al estar de un lado u otro de la línea, serán los héroes o los traidores. Yo por mi parte no quiero hacer un juicio, pero sí proponer que estamos ante una falsa pregunta. Desde 1532 en adelante lo que tenemos es la formación de una sociedad colonial. La mejor manera de preguntarse sobre la producción cultural de esa sociedad será sin duda buscando las respuestas al interior de ella misma (Estenssoro, 1992, p. 354)

El proceso colonial, con todas sus contradicciones y ambivalencias entre las actitudes de asimilación y rechazo, que podríamos vincular a los juicios de condena y fascinación de que hablábamos en el capítulo anterior, terminará produciendo nuevos cantos y nuevas músicas a partir de propuestas que también son cambiantes y contradictorias: la cristianización o fusión de las músicas indígenas; la extirpación de todo resabio ruidoso e inarmónico; la construcción de una identidad "andina" homogeneizante del mosaico diverso de naciones indígenas. Ahora bien, si esto por un lado generó una mayor visibilidad de los contrastes en que se sustentó la sociedad de castas, ofreciendo esas "garantías epidérmicas» de las que hablaba Hall, es cierto también que todo este proceso acabó también por generar una identidad panandina supraincaica, fusionando identidades que, antes de la conquista, presentaban profundas diferencias $\mathrm{y}$, tal vez, favoreciendo así la emergencia de las rebeliones mestizas e indígenas del siglo XVIII. Es en ese proceso, que involucra tanto a los músicos profesionales que logran atravesar la segregación de las repúblicas como de aquellos confinados a los suburbios y los barrios "pardos", en las varias caras de la identificación, que también puede ser pensada como resistencia que los mismos sectores populares transitan de forma zigzagueante ante la opresión hispánica; allí es que debemos buscar la genealogía de la música popular latinoamericana, e «insistir en la larga duración de un proceso no sólo artístico sino político y social» (Bernand, 2014, p. 25)

Emergentes de esta nueva realidad cultural, pero al mismo tiempo pertenecientes al mundo popular subalterno, podemos pensar que los ministriles ch'ixi de Latinoamérica son 
trasnmodernos, ya que aportan novedad a partir de irrumpir «como desde la nada, desde la exterioridad alterativa de lo siempre distinto, de culturas que asumen los desafíos de la modernidad [...] pero que responden desde otro lugar» (Dussel, 2005, p. 17). La misma experiencia cultural cuestionada por su otredad es la que permite a estos músicos encontrar una performatividad que aportará propuestas sonoras imposibles desde una cultura europea moderna autónoma.

\subsection{3 - Los cuerpos grotescos del Corpus también pueden ser cobrizos}

En un interesante nexo con las ocasiones populares que hemos estudiado en capítulos anteriores, las nuevas sonoridades del mundo emergente de la situación colonial aparecen fundamentalmente en las celebraciones públicas de fiestas y ceremonias, configurando lo que es «en definitiva, la invención de una nueva estética que incorporó referencias al pasado indígena (montezumas, matachines, desfiles de Incas) y africano (bailes congos y de "negritos")» (Bernand, 2014, p. 33). Dentro de esta estética ch'ixi del mundo colonial que no es español ni es indígena -tampoco "africano"» el día de Corpus es una de las principales ocasiones festivas y musicales, públicas y urbanas, específica de la modernidad/ colonialidad. Puede entenderse justamente como una representación simbólica de la ciudad (Ramos López, 2005, p. 243). Es una procesión que recorre el espacio urbano y en cierto sentido lo señala; por un lado en términos de orden espacial, reforzando las funciones de cada institución, edificio, plaza, calle, etc. Pero también reconociendo las instituciones, corporaciones, cofradías, grupos sociales, culturales y étnicos de la ciudad (Baroja, 1984, p. 53). Este carácter general o global hace que la procesión -y la fiesta- no sean particulares, es decir, no se correspondan con ningún «espacio particular de ejecución» (Bernand, 2014, p. 34) y por lo tanto con un único sector de la sociedad. De allí que exista un interesante debate en torno al carácter hegemónico o popular de la fiesta. En un sentido, el Corpus es una ocasión en la que todos deben participar, ya que la totalidad de los sectores o instituciones deben estar representados. Esto lo acerca mucho al carácter universal del carnaval que mencionamos en el capítulo 2. De hecho, Julio Caro Baroja la incluye en su estudio sobre las «fiestas populares del verano» (1984) y por eso se decía que la «fiesta del Corpus requiere sainete de carcajada» (Cotarelo y Mori, como se citó en Bernand, 2014, p. 26). Pero por otro, lado cada grupo participa en tanto tal y del mismo modo cada individuo es parte de la fiesta en tanto pertenece a un sector particular, que se esfuerza por demostrar su particularidad en la misma participación performativa. En la fiesta del Corpus de la península lbérica (que comenzó el tráfico de africanos subsaharianos desde por lo menos el siglo VIII) desfilan asociaciones de negros y gitanos, con sus músicas y danzas propias: los llamados cabildos; situación que se traslada al orden colonial americano en donde veremos las cofradías y cabildos de negro. Éstos configuran instituciones que perduran tras la independencia y al funcionar como espacios de resistencia frente a la segregación y el blanqueamiento de los estados nación, inciden de forma notable en el desarrollo musical de las comunidades afrodescendientes (Roy, 2003, p. 21). Consecuencias de este proceso son las bandas de instrumentistas -fundamentalmente de viento- de "pardos" en el siglo XIX y la emergencia de los payadores y cantores argentinos "morenos" que discutimos en el capítulo tres. 


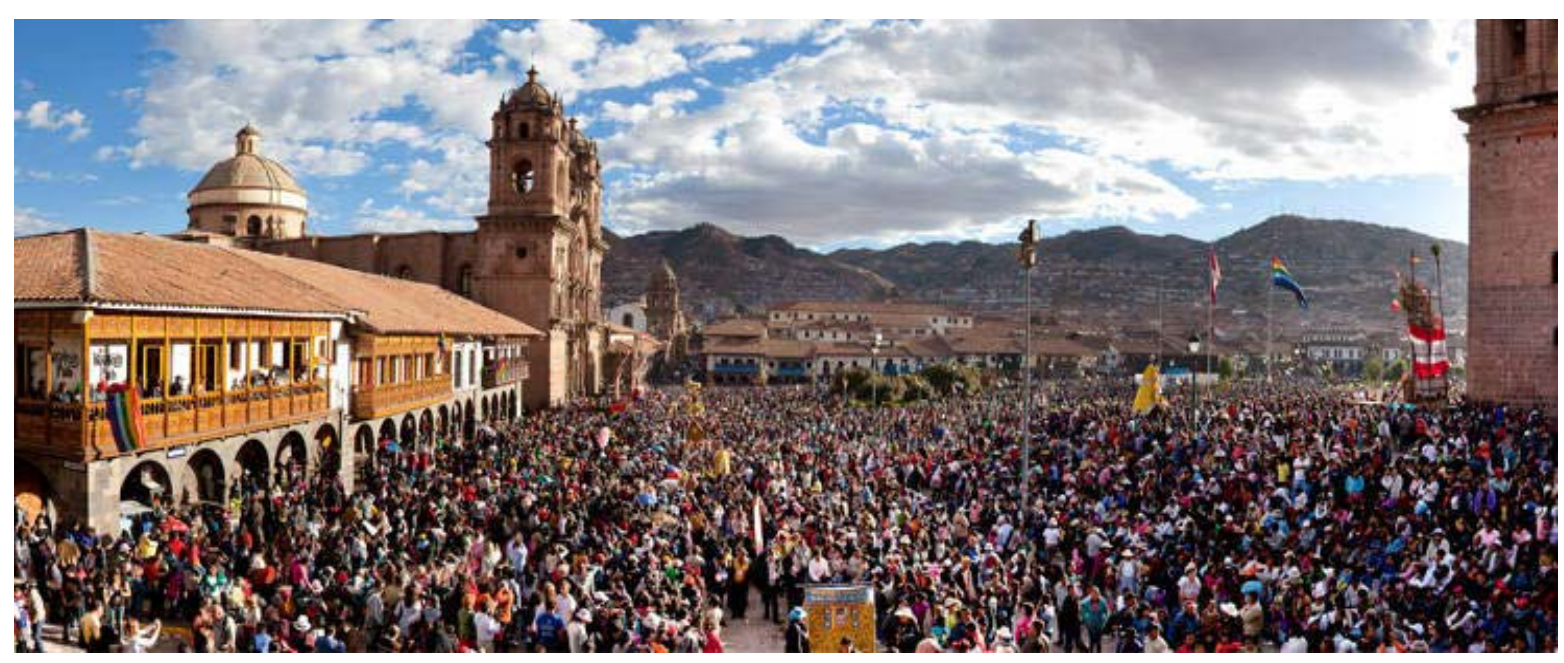

Una multitudinaria celebración del Corpus en el Cusco actual

Todo este carácter secular de metáfora de la organización social, sobre todo en un contexto como el hispánico, hace que esta festividad vaya diluyendo en la modernidad su significado religioso y adoptando uno mucho más cívico (Ramos López, 2005, p. 244). De hecho en fiestas como el Corpus esta distinción se torna un tanto abstracta, ya que desde sus primeras configuraciones «siempre combinó ambas esferas» (Vera, 2016, p. 665). Algo similar podríamos decir incluso del carnaval, tal cual lo hemos desarrollado antes con todas las connotaciones religiosas que contiene. Pero a diferencia de éste, tenemos que pensar al menos parcialmente en el Corpus como fiesta afirmativa, hegemónica, en tanto subraya las diferencias. Incluso podemos deducir que construye estereotipos sociales, culturales o étnicos, y deberíamos discutir allí si éstos proceden desde la óptica de las élites o desde una autopercepción más difusa. De hecho, en las ordenanzas y regulaciones sobre el Corpus hay una ambivalencia interesante que al mismo tiempo que intenta dar un sentido simbólico a los elementos carnavalescos -y por lo tanto admite que son necesarios-insiste en los recaudos para diferenciar el Corpus del Carnaval. En esto no debemos olvidar que la fiesta en la modernidad es controlada y/o producida desde los sectores que ostentan el poder urbano (Burke, 2014, p, 316). Pero todavía hay otro elemento a considerar en función de la hipótesis de Baker acerca del carácter meramente afirmativo de la fiesta de Corpus y es que en las descripciones, sobre todo del contexto peninsular, lo que se pretende diferenciar o estratificar de modo más explícito es la distancia entre los gremios comerciales y de artesanos, es decir las clases medias y esos hijosdalgo menores y desposeídos, frente a los grandes poderes de la Iglesia y la nobleza. No pareciera que la preocupación principal fuese dejar en claro el lugar del pueblo. Tal vez porque era un sobreentendido. Pero si ese fuera el caso, no hubiese requerido afirmar explícitamente mediante la fiesta el carácter subalterno de los sectores populares y racializados ni mucho menos construir la aparentemente sofisticada teoría de la válvula de seguridad en torno a la permisividad frente a lo carnavalesco y las manifestaciones de las "castas".

Esto se profundiza dado el concierto de lo más diverso y variado, desde el punto de vista musical, dancístico, etc, que habita la procesión del Corpus: desde el ordenado desfile de cuerpos militares, órdenes religiosas, junto a las cofradías y gremios profesionales, aparecen personajes bufonescos, cabezudos, mojigones, tarascas, enanos y todo un repertorio de lo grotesco festivo, en el cual figuran los vejigueros (Baroja, 1984, p. 53) con las connotaciones corporales que ya comentamos. Así, los elementos carnavalescos (podríamos tal vez hablar aquí de una carnivalización bajtiniana de la fiesta religiosa) son justificados por un lado en tanto alegría ante la venida del Corpus; en este aspecto se acercan mucho a la risa pascual y otros recursos que desde la autoridad eclesial aparecían vinculados con la cultura popular medieval. Pero también se construye una idea del 
sometimiento, la postración o dominación de esos sectores populares ante Dios y, por lo tanto, se afirma el poder de la Iglesia (Ramos López, 2005, p. 247). Ahora bien, a medida que avanza el proceso de la modernidad, pareciera que cada vez más el lugar reservado a los sectores populares y esas diversiones burlescas es el más distante, en la procesión y el orden del desfile, al de las autoridades civiles y religiosas de la ciudad: las máscaras, cabezudos y gigantones son en general quienes encabezan el desfile, a los que siguen los gremios y cofradías de artesanos y comerciantes, que separan lo carnavalesco de los sectores hegemónicos aristocráticos y eclesiales. Paulatinamente el Corpus será una representación de la estratificación de la ciudad. En España este proceso de reforma de la fiesta comienza en la segunda mitad del siglo XVI, en tiempos de Felipe II, pero cristaliza recién en el siglo XVIII, cuando se dictan una serie de decretos y prohibiciones en torno al Corpus que expresan que todavía en esa fecha los elementos carnavalescos y disruptivos estaban presentes. Un aspecto interesante de la descripción de un Corpus de la ciudad de Gerona citado por Pilar Ramos López es que los músicos que participan de los sectores medios y bajos en la procesión se corresponden con los ministriles urbanos descritos en el apartado anterior - «llevaban en las banderolas de sus instrumentos las armas de la ciudad» (2005, p. 245) - y se los llama joglars, lo que es interesante pues refuerza la circularidad entre lo carnavalesco, los juglares y los músicos profesionales urbanos. Pero otro elemento importante para el mundo hispánico e iberoamericano es que al conjunto se le da un nombre catalán: cobla. Recordemos que esta es la denominación para las bandas que acompañan la danza regional -o nacional, depende la perspectiva - de la sardana, que justamente tiene una zona de difusión intensa en la modernidad alrededor de Gerona. La sardana ${ }^{287}$ presenta las características fundamentales de las danzas de ronda que admite una cantidad virtualmente ilimitada de participantes, que comparte con muchas danzas populares de tradición medieval como el rondellus. Y como en éste, se admite también una cantidad de músicos y de "voces" altamente variable ${ }^{288}$ que a su vez participa mediante la repetición variada e intensificada de frases cortas y pregnantes. Se ha señalado el estrecho vínculo entre la amalgama de estos elementos y la proliferación de músicas estróficas en las que aparece una polifonía popular (Bukofzer, 1940). Pero además la cobla conserva hasta hoy un instrumental directamente relacionado con el mundo de los juglares y los ministriles urbanos: la tenora o xirimía, que es una especie de bombarda; el tible que es básicamente una chirimía (Baines, 1952); y el fabiol i tamborí, que no es otro que el instrumento dual de flauta de tres agujeros más tambor de los juglares que, recordemos, es un solo instrumento, ambiguo y desafiante de las categorías modernas de la organología. Waisman (2019, p. 127) por su parte encuentra muy sugestivo que la palabra "copla" aparezca en las crónicas de las doctrinas de indios y reducciones de Suramérica íntimamente relacionada con la mención a los grupos de ministriles de diversa conformación instrumental, lo cual nos abre otro camino analítico que podría ser fecundo en el cual los conjunto instrumentales mestizos, las danzas populares transatlánticas y los esquemas estróficos que introducen las coplas en las músicas populares latinoamericanas podrían tener más en común de lo que puede parecernos a simple vista.

\footnotetext{
287 Un registro de la ocasión de la sardana en Barcelona (la más famosa) con la actuación de una cobla puede verse aquí (ejemplo 55): https://youtu.be/XhKOBIZoyac

288 Es famosa la crónica de Giraldus Cambrensis, del año 1194, sobre un canto polifónico de carácter improvisatorio común entre los galeses: «Cuando hacen música juntos, no cantan sus cantos al unísono, como se hace en otras partes, sino en partes, con muchos modos y frases, de manera que en una multitud de cantantes... uno oye tantas canciones y diferenciaciones de voces como cabezas puede ver» (Boyd y Chalmers, 2008 , p. 641). Bukofzer relaciona esta práctica con la conocida canción polifónica -estrófica y de ritmo pulsado y danzable-sumer is icumen in. Es un ejemplo clásico de rondellus que puede escucharse como ejemplo 56 aquí https://youtu.be/vmrWX3B5sqo. Una curiosísima interpretación de esta canción que lleva al extremo nuestra afirmación de una cantidad de participantes "virtualmente ilimitada", es la que aconteció en la ceremonia de inauguración de los Juegos Olímpicos de Munich de 1972. Ejemplo 57: https://youtu.be/obPxAMiRiv4
} 
Una distinción conceptual importante en torno a la fiesta del Corpus latinoamericano está vinculada con determinar si lo que exhibe es diversidad o diferencia, aspecto que se presta a la interpretación más diversa a partir de los testimonios sobre la participación de «desfiles de Incas o de Muiscas, las danzas de Montezumas y de Pallas, las congadas con sus reyes negros, los salvajes con diademas de plumas, los gitanos u otros tipos» (Bernand 2014, p. 26). Si por un lado, cosa que acercaría la interpretación al carácter afirmativo y segregacionista, la exhibición racializada de un otro, confirmaría los fundamentos de la diferencia subalterna y lo indiscutible del imperio colonial, por el otro un carácter festivo más cercano a los tablados y corrales que a la catedral y el palacio -con la proliferación de lo bufo y los cuerpos grotescos, junto al ruido jocoso y el estrépito de la pandorga (Bernand, 2014 , p. 26), elementos que incorporan lo deforme e in-forme en lo visual y lo sonoro- no hacen otra cosa que amplificar la diversidad, señalar lo indisoluble de la contingencia del mestizaje y sobre todo perpetuar la ambigüedad que, como ya dijimos, es metáfora de la incapacidad de todo control.

Corpus y Carnaval constituyen las fiestas públicas urbanas por antonomasia del mundo colonial (Bermúdez, 2001, p. 179). Y en estas ocasiones podemos encontrar la participación de los músicos profesionales, incluyendo como dijimos a los mestizos, indígenas, mulatos y africanos, más allá de que sus congéneres racializados integren los colectivos procesionales más exotizados. "La presencia de indígenas desfilando en las calles, luciendo sus trajes nativos y arte plumario, era una escena muy familiar en las ciudades coloniales» 289 (Bermúdez, 2001, p. 180), aun cuando la fisonomía dominante es claramente hispana y está conducida, intervenida, por los sectores hegemónicos. Es interesante observar que en buena parte de la historiografía que recientemente se agrupa bajo la etiqueta de "musicología urbana" aparezca el moto de la válvula de escape como justificación de la fiesta cívica y su función de control social de los sectores subalternizados. «Esto parecería explicar que los indígenas tuvieran la oportunidad de exhibir su identidad y prácticas culturales mediante la ejecución de danzas autóctonas» (Vera, 2016, p. 667). En esta línea aparecen también algunas interpretaciones que hablan de negociación de prácticas culturales, fundamentalmente entre el mundo indígena y el de los conquistadores. Se trataría de un proceso en el cual las autoridades coloniales seleccionan cuidadosamente aquellas manifestaciones que no contienen resabios de idolatría y que por tanto serán vistas como más inocentes. Incluso cierta lectura de las fuentes parecería conducirnos a esta interpretación. Un caso que desarrolla Estenssoro $-\mathrm{y}$ que sirve de todos modos de base al planteo de Baker, que es diferente- es el de los cambiantes sentidos del término Taki en el mundo andino colonial. Para este autor, el término, además de modificar su sentido en el tiempo y en función de las diversas perspectivas de los interlocutores, es un término negociado (Estenssoro, 1992, p. 353).

La historia de los cambios en el término Taki es ilustrativa de esta discusión, ya que los sentidos del vocablo mutan desde un uso prehispánico basado en la integralidad (Escobar, 1991) en el que ocasión festiva, música, danza, exaltación, ingesta de alimentos y de alcohol, ofrenda religiosa, incluso designando simultáneamente al encargado de producir la fiesta, la música, la danza, etc.; en fin, el taki como ritual social integral, muta en la colonia desde pasar a inferir una especie de enfermedad idolátrica a baile inmoral sensual, acabando como un género musical folklórico territorializado durante el siglo XX. En la etapa colonial, la estrategia principal consiste en escindir taki de "baile", justamente en función de operar la depuración de esto último para solaz de los indígenas explotados, lo cual evidenciaría la negociación.

289 «The presence of Indians parading in the streets wearing native costumes and featherwork was a familiar sight in the colonial cities» (Bermúdez, 2001, p. 179) [traducción del autor] 
Esta voluntad de eliminar el concepto de baile de la raíz taki está relacionada seguramente con la necesidad no sólo de crear un lenguaje de la doctrina, sino también con [...] la necesidad de suprimir los takis de la vida de los indios reemplazándolos por nuevos bailes religiosos de origen europeo [...] ya que aquello que era designado tradicionalmente con ella era algo que debía desaparecer" (Estenssoro, 1992, pp-355-359).

Pero además es significativo que taki pasa de ser un vocablo polisémico e indeterminado a precisar una acepción unívoca, en general vinculada únicamente a "canto" o canción. Más allá de las importantísimas connotaciones coloniales y de la voluntad de sellar la opresión mediante la aculturación, lo que vemos aquí es cómo ya está operando con mucha potencia la compresión de las categorías de la modernidad, su esquema de particularización y especialización que rompe la integralidad de la ocasión musical. Si bien todavía la concepción de los doctrineros e inquisidores sobre el taki será funcional, es evidente que es necesario para el pensamiento occidental establecer el particularismo y estabilizar el término taki en una acepción, de paso la menos comprometedora en términos religiosos y morales. Es un esquema que nos abre la puerta a indagar una posible periodización que una mediante el accionar de las instituciones coloniales de la modernidad temprana el paso desde la cultura popular hasta la folklorización y la compresión musicológica de épocas más recientes.

El caso del taki es paradigmático por algo más: es un mestizo quien va a operar una de las primeras justificaciones de su transformación de ocasión integral en canto, de musicar a "música", basándose de paso en la noción de válvula de seguridad social. Aunque no sin cierta ambivalencia, hacia fines del siglo XVI las autoridades coloniales del virreinato del Perú experimentan una mutación en la consideración de los bailes y fiestas que se habían mantenido desde la época prehispánica, aun cuando habían sido cristianizados como estrategia para una evangelización más rápida y eficaz. El baile tanto de indios como de negros comienza a preocupar, fundamentalmente porque favorece la reunión social de los miembros de un mismo grupo identitario: el peligro de la delincuencia, el cimarronaje y la rebelión eran algo fácil de relacionar con las ocasiones festivas que quedaban por fuera de la regulación oficial. Esta actitud cambiante y ambigua es en parte análoga a la de las autoridades hegemónicas en torno a la fiesta popular europea que ya comentamos. Solo que aquí se racializa de una manera también homóloga con la situación en la península ibérica, aunque en la américa hispana este carácter se intensifica.

A comienzos de la evangelización del Perú en 1533 los conquistadores fuerzan las similitudes entre las manifestaciones indígenas y las que ellos portan o conocen, con el fin de reconvertir y cristianizar las prácticas prehispánicas, buscando en ellas alguna «analogía o afinidad formal con ciertas necesidades de las celebraciones cristianas» (Estenssoro, 1992, p. 361). De todas maneras, la distancia entre las concepciones sonoras de ambos mundos culturales es tan amplia que las más de las veces no logran este cometido de forma sencilla. Entonces recurren a una homologación que podríamos llamar de segundo grado: buscar similitudes con los "otros" exóticos que ya forman parte del mundo ibérico

\footnotetext{
Cuando las semejanzas generales no logran eliminar el exotismo, se recurre entonces a una comparación familiar con lo morisco. Así, pues, las zambras, como las folias, son danzas, instrumentos y fiesta ruidosa y alegre. Ya Francisco López de Gómara decía que el areito era "como la zambra de los moros". A comienzos del siglo XVII los bailes de los esclavos africanos son, para los jesuitas, "zambras" (Bernand, 2014, p. 27).
}

Pero algo cambia hacia fines del siglo XVI, siendo lo más llamativo que no preocupa tanto la detección de idolatrías traficadas o escondidas dentro del ceremonial cristiano cosa que ocurre por ejemplo en la misma fiesta del Corpus- sino que el interés se traslada al orden formal, incluso en aquellos bailes que habían utilizado para la cristianización por parte de la misma autoridad colonial. Si en este proceso se busca primero vigilar las 
manifestaciones que no habían sido asimiladas al control oficial, luego se combaten directamente todas estas manifestaciones a través de la emergencia de las prohibiciones y la extirpación de idolatrías que inician luego de la década de 1560. Y dentro de estos bailes y ocasiones la más anatemizada será el taki. La razón de esto podría ser la proliferación por esas épocas del fenómeno del Taki Unquy, movimiento de rebelión indígena de relativa trascendencia a fines del siglo XVI. Son interesantes en términos de integralidad y performatividad sus vinculaciones con la idea de trance, ya que la rebelión implicaba una suerte de depuración, purificación o reversa de la evangelización con el objetivo de retornar al estado espiritual prehispánico. Se lo suele traducir como enfermedad del baile, en donde la posesión por parte de la deidad que desplaza el mal de la evangelización cristiana es producido a través de la danza y la música. Frente a la concepción moderna occidental fundada en el divorcio de cuerpo-mente el Taki Unquy se vuelve intolerable, no sólo en tanto idolatría, lo cual ya era muy grave, sino porque hace salir del orden civilizador colonial, que exige un estricto control del cuerpo por parte de la razón, base y objetivo a la vez del sometimiento y la subalternización. Por lo cual la propia performance del Taki ya pone en cuestión ese orden colonial.

Del mismo modo que la racialización y el exotismo asimilado de forma contenciosa a la fiesta cívica no son exclusivos del contexto colonial latinoamericano, este horror a la enfermedad del baile también tiene sus antecedentes en la consideración hacia la cultura popular europea. El ejemplo más extravagante es la llamada coreomanía o baile de San Vito, esas "epidemias" colectivas en las que alguien comenzaba a bailar sin motivo alguno y misteriosamente otras personas se le unían, configurando una danza colectiva involuntaria que generaba alteraciones en el orden público, desfiguración de los ritos cristianos, alguna pequeña catástrofe como el derrumbe de puentes o incluso, como en el caso de los cuatrocientos frenéticos danzarines de Estrasburgo en 1518 (nótese lo cercano en términos históricos con el Taki Unquy), provocar la muerte masiva por agotamiento, paro cardíaco o locura extrema de los participantes. ${ }^{290}$ El terror a la falta de control racional sobre el cuerpo es de una evidencia tan extrema que podría usarse el concepto de la coreomanía como síntesis de la voluntad civilizatoria de la modernidad. Por último, aunque tal vez no tenga relación alguna, existe una danza afrocaribeña de los garífuna, en Honduras, llamada coreopatía, ${ }^{291}$ que además de presentar aspectos de lo que Quintero Rivera (2009) llama «el frenesí del baile» en relación a estas músicas, tienen un carácter carnavalesco de burla grotesca a las autoridades oficiales "blancas".

Volviendo al caso peruano, a partir de fines del siglo XVI los Takis aparecen recurrentemente en las disposiciones y prohibiciones relativas a la extirpación de idolatrías. En esto existe un aspecto del uso semántico importante: Taki se convierte en sí mismo, en virtud de ser un tipo específico de baile y ocasión musical, en sinónimo unívoco de idolatría, al nuclear como significante los aspectos negativos de la fiesta que se busca controlar: la borrachera, el frenesí, la aparente locura, el ruido, etc. Por eso, para llenar el hueco en el vocabulario asociado a lo indígena, será reemplazado lingüísticamente por "baile", al cual se entiende como cristiano y regulado, reformado (Estenssoro, 1992, 364). A partir de aquí aparece la homología con la reforma de la cultura popular moderna, en la cual emerge una

\footnotetext{
290 Las explicaciones sobre el fenómeno han generado toda una literatura legendaria y una multitud de mitos populares, que van desde considerar brotes masivos de meningitis, envenenamiento por escorbuto o gorgojos, hasta la picadura de la tarántula para el caso italiano, en donde había que danzar una tarantella para curarse. Para el caso del Taki Unquy también existen teorías muy recientes desde la patología, como la que lo relaciona con la intoxicación masiva a partir de la manipulación sin ningún tipo de protección del mercurio por parte de los indígenas en la explotación minera andina. Los argumentos son un tanto escasos, pero lo más llamativo es que sigue constituyendo un intento por racionalizar un fenómeno para el cual el occidentalocentrismo todavía no encuentra respuestas. Véase Santa María (2017).
}

291 Un ejemplo de coreopatía garífuna puede verse aquí como ejemplo 58: $\underline{\text { https://youtu.be/FkQ5KcKyHsc }}$ 
vez más la idea de la válvula de seguridad. Un monje dominico, Francisco de la Cruz realiza una serie de formulaciones que ilustran las ideas de asimilación que plantea Estenssoro: sólo conservando aquellos bailes que no son expresamente idolátricos es posible evitar aquellos que lo son, que quedan expresados en el nuevo uso del Taki. Pero aquí lo novedoso es la defensa vehemente de los bailes tradicionales, no sólo aceptando su existencia, sino como algo que es imprescindible rescatar porque «si a los yndios quitamos las cosas en que se recrean como son sus bailes sin ydolatria se bolveran a los demonios sus taquies a honrra del demonio y ydolatrarán» (como se citó en Estenssoro, 1992, p. 366). Lo importante y notable del caso es que lo que se fomenta es que los indígenas bailen a su modo, es decir, se promueve aparentemente aquello que identifica culturalmente a las castas subalternas.

De la Cruz termina en la hoguera condenado por un proceso inquisitorial, tal vez por su oposición a una aculturación radical (Estenssoro, 1992, p. 367). Pero quien toma el relevo será el notable cronista mestizo Felipe Huamán Poma. Al hablar de las fiestas utiliza como genéricos los términos pasqvas y dansas-taqui(es), si bien el primero está en letras mucho más grandes y el segundo aparece fijado como danza, es muy interesante ver esta homologación por parte del cronista. Además, inmediatamente se preocupa por despejar toda duda que pudiera quedar en torno al taki-danza: «no tiene cosa de hechisería ni ydúlatras ni encantamiento, cino todo huelgo y fiesta, rregocixo» (Guamán Poma, 1615, fl. 317). Luego en el mismo folio ensaya una formulación excepcional de la noción de válvula de seguridad asociada a la permisividad de las autoridades frente al regocijo popular. ${ }^{292}$

En estos huelgos que tienen cada ayllo y parcialidad deste rreyno no ay que dezille nada ni se entremeta ningún jues a enquietalle a los pobres sus trauajos y fiesticillas y pobresa que hazen cantar y baylar, comer entre ellos ${ }^{1}$ (Guamán Poma, 1615, fl. 317).

Más adelante insiste con esta concepción negociada de la fiesta y especifica que tiene cierto carácter universal, atravesando todos los sectores sociales. Nótese que el cronista refuerza la idea de que es imprescindible mantener estas fiestas para discriminar lo idolátrico y desterrarlo.

Todos tienen sus bocablos y fiestas y los Yungas, Chimo Capac, Ayanya, Nucaya, Puluya, Tomi Pampa, todo los quales estas fiestas no tiene ningún ydúlatrata [sic], cino huelgo y fiesta y rregocijo, ací los grandes como los rricos y pobres en todo el rreyno. Y ací le deje la justicia holgar. Por eso pongo todas las ydúlatras que tenían para que sean castigados de lo malo, de lo bueno se guarde (Guamán Poma, 1615, fl. 328).

Los bailes ceremoniales que defiende el cronista adquieren cierto carácter equivalente a lo carnavalesco europeo asociado a las fiestas religiosas, pues para Poma los hijos de los curacas debían bailar obligatoriamente estos taqui-danzas indígenas no idolátricos en el interior de la iglesia, delante del sacramento y de la imagen de la Virgen, so pena de castigo; esto es congruente con el carácter festivo de las ocasiones populares religiosas que hemos analizado en el capítulo 2, como la fiesta de los locos, del asno o del obispillo. Festejos íntimamente relacionadas con el carácter carnavalesco presente en la fiesta del Corpus, que se inicia en el siglo XIII. Lo cual hace más sorprendente aún que, vinculado con la crónica de Guaman Poma, aparezca el concepto -ahora indígena- de «mundo al revés» (Cusicanqui, 2015). ¿Es esto un universal? En absoluto, pero sí es un indicio de la

292 De pasada, Guaman Poma nos regala una descripción de la riquísima diversidad de ocasiones festivas, lo cual es impactante y debería ayudarnos a tomar dimensión de los complejo de la cultura popular prehispánica: «Es que llama taqui [danza ceremonial], cachiua [canción y danza en corro] a, haylli [cantos de triunfo] a, araui de las mosas, pingollo [flauta] de los mosos y fiesta de los pastores llama miches [pastor de llamas], llamaya [cantar de los pastores de llama] y de los labradores pachaca, harauayo [cántico], y de los Collas, quirquina, collina, aymarana [canciones y danzas aymaras], de las mosas, guanca, de los mosos quena quena [canciones y danzas aymaras]» (Guamán Poma, 1615, fl. 317). 
continuidad del mundo popular subalterno. La reforma del Taki, o su conversión en baile depurado y redimido no es un caso único en Latinoamérica, sino que forma parte de lo que para Carmen Bernand es una lingua franca que recorre todos los géneros musicales y dancísticos populares. Podríamos decir que es una nomenclatura de la transculturación, que tanto la musicología como el folklore, una mediante el recurso a los orígenes y el otro en función del descenso de los bienes, desaparecerán de la historia a partir de la construcción de un eurocentrismo culto que convierte en "españolas" todas estas manifestaciones y las piensa trasplantadas por copia barroca a las colonias del nuevo mundo/tabula rasa: "Las palabras de las canciones eran comprensibles en todos los virreinatos. Aparecen en toda Iberoamérica términos generales como "folías", "guineos", "fandangos" o "calendas"» (Bernand, 2014, p. 36). Así las denominaciones de las ocasiones musicales del mundo prehispánico, rituales en el espacio social que trascendían por mucho el mero ordenamiento sonoro, como mitote, tocotin, taki, o areito, se convierten en indicadores unívocos y estabilizados, aunque a la vez genéricos, para definir toda danza de indios transformada por la música occidental. La folklorización está a la vuelta de la esquina. Solo falta una interpretación desde un contexto más preocupado por determinar los orígenes y hontanares de las danzas de cada estado nación para cartografiar los bailes y sonidos que den sentido a la construcción homogénea de una identidad nacional. Pero para el período colonial lo importante, en tanto dimensión política, son estos cambios del ideal hidalgo frente a los rituales y ocasiones que ponen en peligro el buen gobierno, es decir, la propia dominación. La discusión en torno al baile y el taki conlleva para nosotros en la música una dimensión sonora: la distinción entre una manifestación popular "ruidosa" -se habla de los "instrumentos del diablo", en donde lo idolátrico es el timbre- versus una concepción occidental "armónica” de la música (Estenssoro, 1992, p. 375).

Consideraciones similares aparecerán también, con otras connotaciones y preocupaciones, en torno al universo sonoro afrodescendiente. En cualquier caso, toda esta dinámica compleja de mutación y cambio permanente del juicio y utilización de los conquistadores frente a las manifestaciones subalternas del mundo colonial, así como del reajuste constante de esas propias manifestaciones por parte de los sectores sometidos esto es lo que Estenssoro con jerga poscolonial llama "negociación"- no hacen otra cosa que manifestar de manera contundente lo complejo, diverso y sofisticado del universo de las manifestaciones sonoras presentes entre estos sectores subalternos. Un mundo desbordante de sonidos muy diversos, cuya muestra más palpable la podemos encontrar en lo que Prudencio llama «diversidad organológica» (2001), que no es solamente un catálogo de instrumentos excéntricos sino un muestrario de diferentes modos de concebir la producción sonora, los modos de acción y articulación y por supuesto las posibilidades combinatorias de todo ello. Si desplazamos por un momento a la organización tonal como centro de nuestra idea occidentalocéntrica de música y pensamos desde el sonido en sí mismo, como materia, un panorama instrumental tan caleidoscópico como el que encontramos emergiendo de las culturas mestizas y afrodescendientes en América nos evidencia necesariamente una trama compleja de formas de concebir la organización sonora. Es importante resaltar esto pues, como vimos en extenso en el capítulo 3, una de las coartadas más importantes del dominocentrismo, que produce el dominomorfismo, es quitar agencia a los sectores subalternos y entender que sus manifestaciones consisten en la copia que hacen de los sectores hegemónicos. Con el universo andino colonial pasa exactamente lo mismo. Aquí entra en juego lo que podríamos llamar la teoría de la mímesis, que subraya la sorpresa y maravilla de los europeos ante la reproducción de su música por parte de los indígenas y también de los africanos esclavos. Por ejemplo, en 1525 Fray Motolonia comentaba que los mexicas «son tan ingeniosos que no hay cosa que ven que no lo hacen más políticamente, hasta hacer vigüelas como en España y tapicerías como en Flandes». Pero lo que deberíamos preguntarnos, poniendo mínimamente entre paréntesis la perspectiva de la fuente, es ¿hasta qué punto se trata realmente de una «copia conforme 
al original»? (Bernand, 2014, p. 28). Tan cierto como que estos relatos se multiplican entre los cronistas es que la musicología los ha tomado frecuentemente de manera bastante literal. Un ejemplo de esto es el señalamiento de Stevenson que citamos al principio del capítulo, mediante el cual nos da a entender que hubo una premura, o al menos una predilección por parte de los indígenas y africanos por imitar la música europea y, por ende, abandonar sus propias prácticas. Es el sueño de la aculturación hecho realidad, que se potencia hasta lo increíble si lo articulamos con la teoría del descenso de los bienes del folklore difusionista de Vega. ${ }^{293}$ Vemos así cómo lo que nunca pasó de ser un ideal en la ciudad hidalga de los conquistadores -que requirió todo el período de ajuste y negociación, e incluso de la represión permanente al conflicto que le presentaban unas cambiantes sonoridades subalternas empecinadas en subvertir el orden colonial- en la producción musicológica y folklórica se materializa como verdad. Algo que se perpetúa e incluso profundiza en la musicología de lo que suele llamarse los estudios latinoamericanos, dentro de los cuales incluimos por ejemplo a Baker (Eckmeyer y otros, 2017b). En un artículo que coincide con la publicación de su tesis sobre el Cusco colonial, este autor critica profundamente el tipo de performance actual de la música colonial que pone en primer plano el mestizaje. Al hacerlo eleva aún más el tópico stevensoniano de la mímesis, afirmando que «[e]l mejor elogio que podía hacérsele a un grupo de músicos latinoamericanos era que no se pudiera distinguir entre ellos y un coro de una catedral europea» ${ }^{294}$ (Baker, 2008b, p. 443). Para Baker los músicos indígenas y africanos de lo que hemos denominado sonoridad Ch'ixi en referencia al cumplimiento del mestizaje tan temido por las autoridades españolas, desearon todo lo contrario a esto, tratando de lograr un reflejo de lo europeo, lo opuesto a lo que los conjuntos especializados en música colonial hacen hoy. Lo que estaría sustentando esta interpretación histórica, que se basa fundamentalmente en una lectura ideológica de las intenciones coloniales antes que en la realidad sonora entendida desde la performance, es la afirmación del orden colonial mediante la eliminación de todo atisbo de mestizaje. Si está claro que en el ideal de las dos repúblicas el mestizaje era visto como un peligro, los procesos dinámicos del mundo colonial hacen que, una vez comprobado el carácter quimérico de la pretendida segregación, las autoridades se entreguen a la tarea de regular el mestizaje. Un caso paradigmático es el del taki. Dentro de este proceso debemos ubicar también a la producción musical de las instituciones oficiales, entre ellas la de los ministriles mestizos y pardos.

\subsection{4 - Buscando lo negro de la negrilla de negro}

"No existe garantía en alcanzar una identidad racial esencializada de la que pensemos que es posible estar seguros, que resultará ser siempre mutuamente liberadora y progresiva en todas las otras dimensiones. Existe una política allí por la que luchar. Pero la invocación de una experiencia negra garantizada que esté detrás de ella no producirá esa política»

\footnotetext{
293 No podemos tratar aquí el tema, pero sería muy interesante abordar las conexiones entre los autores de la musicología del panamericanismo, que participan de conferencias en las cuales parecerían sedimentarse varios de los tópicos que se hacen continentales a partir de la década del '60: el positivismo, la historiografía estilística, la separación de la música popular del folklore, la discriminación de este último frente a la música indígena, etc. Algún indicio de esto puede encontrarse recorriendo los temas -y hasta los títulos- del número 81-82 de la Revista Musical Chilena, entre cuyos autores figuran Stevenson, Vega, Ayestarán o Sas, quienes coincidentemente participarán de la Primera Conferencia Interamericana de Musicología, en Washington, en 1963. Entre estos artículos aparece el del cubano Pablo Hernández Balaguer, muy contundente desde el inicio: «Los aborígenes cubanos murieron con su música y de ella, nada nos ha quedado». La revista puede consultarse aquí https://revistamusicalchilena.uchile.cl/index.php/RMCH/issue/view/1250. Sobre el panamericanismo y la dependencia musical puede verse Cannova (2018).

294 «the highest praise that could be bestowed on a group of Latin American musicians was that they were indistinguishable from a European cathedral choir» (Baker, 2008b, p. 443) [traducción del autor]
} 
Pero «los músicos españoles no estaban interesados en crear fusiones entre la música europea y la indígena»295 (Baker, 2008b, p. 443); el permanente conflicto entre las tendencias de asimilación y de resistencia hacen imposible que consideremos este ideal, a lo sumo plan musical, como una realidad sonora. Es una distancia que se hace muy evidente cuando comparamos el examen de una partitura catedralicia colonial de cualquier ejecución contemporánea que integre instrumentos junto al canto. Lo primero que se observa es que en lo anotado no figura la participación de los ministriles, aunque sabemos que allí estaban desde el primer momento de la colonia, tocando los instrumentos importados junto a otros nativos, al lado de las voces de los "blancos". Un ejemplo ilustrativo es el caso de un subgénero de los villancicos, denominado negrilla o villancico de negro, ya que en ellos aparece un remedo de lo que sería el habla del español por parte de los africanos. Existen numerosos ejemplos producidos a lo largo y ancho de la América colonial. Entre los que más polémica han desatado se encuentran los producidos bajo el puesto como maestro de capilla de Juan de Araujo, músico español de actuación en la zona andina, en opinión de Waisman (2019, p. 231) el músico del ámbito colonial más importante de fines del siglo XVII. Estamos justamente en el apogeo del periodo estudiado por Baker. Dentro de la producción relacionada con la actividad de Araujo en la catedral de La Plata (Sucre) encontramos la negrilla Los coflades de la estleya, transcrita por Stevenson como Los negritos para dos sopranos, coro y bajo continuo. Es decir, no aparecen los instrumentos de los ministriles ni sus usos específicos anotados en la partitura, lo cual no es de sorprender ya que, como vimos antes la práctica de las ciudades italianas o francesas, era la misma. Además los cronistas abundan en referencias a que los ministriles indígenas y africanos tocaban muy bien pero sin leer de partituras. Por lo tanto toda consideración del accionar de los músicos subalternos en esta música debe partir de una aproximación performativa. Tomaremos dos versiones de buena difusión, como son las de la Camerata Renacentista de Caracas, del CD 2 de la colección Música del pasado de América Latina (2003), ${ }^{296}$ y la del reconocido Ensamble Elyma de Gabriel Garrido, registrada en el fonograma El siglo de oro en el Nuevo Mundo (1993).297 Ambas presentan elementos de los que autores como Baker o Waisman tildan de exóticos y anacrónicos: en el primer caso, aparecen instrumentos de percusión, sobre todo un cajón peruano, junto a un clave y un bajón (el continuo de la partitura) y lo que parece ser una vihuela que apoya la armonía. El cajón abunda en síncopas y un patrón rítmico que superpone el orden ternario al binario, generando por lo tanto una connotación afrodescendiente. En cambio en la versión de Elyma el continuo es realizado por un órgano y cuerdas frotadas y además las voces presentan una emisión mucho más cubierta y homogénea, como las del modelo del coro de catedral europea referido por Baker. El elemento exótico está aquí presente con una tropa de aerófonos andinos -que parecieran ser sikus- que apoyan los finales de frase con que el coro responde a los solistas. Fundamentalmente en la copla-estribillo gulumbé, gulumbé, gulumbá.

Tomemos esta segunda versión y desechemos la más folklorizada de la Camerata de Caracas para explorar las consideraciones dominomorfistas sobre las negrillas. Para quitar agencia a los músicos subalternos, lo que se esgrime son dos argumentos: por un lado se plantea el interesante asunto de que este tipo de músicas, fundamentalmente en cuanto parodias lingüísticas de la jerigonza de los africanos al hablar español, ya estaba presente en la península ibérica antes de la conquista. La negrilla es, de esta forma, un género

295 «Spanish professional musicians were not interested in creating fusions of European and indigenous music» (Baker, 2008b, p. 443) [nuestra traducción]

296 El ejemplo 59 puede escucharse aquí https://youtu.be/ywRatyllS30

297 El ejemplo 60 puede escucharse aquí https://youtu.be/8 v5XcDK9HU 
preexistente al mestizaje. Waisman incluso afirma de manera categórica que se trata de un género en todo español (2012, p. 7) y además para nada popular, sino exclusivamente aristocrático (Waisman, 2019, p. 177) dado que en las fuentes aparece únicamente registrado por las clases hegemónicas. Este argumento vuelve a introducirnos en toda la potencia dominocéntrica que ya analizamos en el capítulo 2 en torno a la música de los juglares (registrada y estilizada por los trovadores) y evidencia hasta qué punto siguen vigentes las doctrinas del positivismo musicológico que analizamos en el capítulo 1.298 No insistiremos aquí más que en la consideración mnemotécnica que debemos hacer de toda notación anterior por lo menos a la llustración, además de considerar que, tal cual vimos en el caso del taki, las políticas hegemónicas para con la cultura del mundo popular subalterno no son lineales y pueden incluir, como bien lo expresa Estenssoro, la voluntad de asimilación más allá de los juicios puntuales. Pero volvamos al asunto de la negrilla como género español. Aquí surgen algunos problemas: primero el término español. Nada hay homogéneo en la cultura peninsular en el siglo XV, lo cual hace que tengamos que reforzar una vez más la idea de "vertiente heterogénea» (Aharonián, 1994, p. 191) en la cual coexisten culturas litigantes como la andalusí, la sefardí, la romá, junto con los negros africanos esclavizados como personal de servicio desde hacía siglos, que como todos los demás grupos mantienen sus costumbres culturales bajo la égida del califato de Córdoba hasta el reino de Granada. Además, por supuesto, de la cultura popular catalana y castellana, o la asturiana y gallega de, por caso, la ruta de Santiago. A esto hay que añadirle todavía el conflicto cultural interno de las clases aristocráticas y de las tradiciones hispanas en conjunción conflictiva con las flamencas. $Y$ también, de la mano aragonesa y catalana, la influencia de la cultura trovadoresca tardía ¿Qué de todo esto es España? ¿En cuál de estos sectores se referencia exclusivamente el estilo del villancico y la negrilla españoles? No cuestionar el estatuto de lo español o lo europeo como "garantía" de homogeneidad cultural, en los términos de Hall, produce este tipo de sesgos que, entre otras cosas, tienden a negar agencia a los sectores subalternos y profundidad y sofisticación a sus manifestaciones, sean éstos los pobres europeos, los indígenas, los moros, o los africanos esclavizados.

Por otro lado, como ya adelantamos, se plantea que la negrilla es una parodia denigrante que hacen los sectores hegemónicos sobre los subalternos. En parte esto se desprende del punto anterior, ya que la evidencia que se adelanta para afirmar la hispanidad de la negrilla se obtiene en general de la literatura del siglo de Oro -especialmente Quevedo- y los tratados teóricos de música, sobre todo el Melopeo y Maestro de Cerone (Santamaría, 2005). Todo este planteo no está exento de contradicciones ya que, por un lado, es muy conocida la presencia de manifestaciones que se creen de origen latinoamericano en la literatura, por ejemplo, de Cervantes: la chacona, la zarabanda (o sarabanda) y otras danzas "de las que vienen por la posta» (Aharonián, 1994, p. 197). Nuevamente, la discusión del origen es inútil, además de positivista, ya que lo que hay que considerar es la condición transcultural «además de transatlántica- del mundo iberoamericano, con sus abigarrados conflictos y su eclecticismo cultural que parcialmente nombramos en el párrafo anterior. Precisamente, si devolvemos agencia a los sectores subalternos veremos que, por ejemplo, la zarabanda es una danza popular transcultural, un producto del mundo popular subalterno, tanto de aquí como de allá. Si se quiere, podemos entenderla como iberoamericana, pero con la condición de que no sea España un punto focal en esa geografía. Y si así como la zarabanda luego es apropiada y estilizada por la aristocracia, y consecuentemente exportada a Francia y de ahí a Italia e Inglaterra para terminar formando

298 Tal vez sea en tono irónico, pero es llamativa la solicitud de «un poco de rigor positivista» que Waisiman esgrime contra colegas -como Zoila Gómez y Victoria Eli- que basan sus estudios sobre lo que el autor llama la americanidad de la música americana (vaya paradoja en el título de la ponencia) en el concepto de Mestizaje y la herencia de, por ejemplo, un Fernando Ortiz, a lo que el musicólogo cordobés denomina «ideología del mestizaje», en clara alusión despectiva (Waisman, 2012, p. 7) 
parte de la suite "barroca", la negrilla, con una suerte histórica completamente diferente, también es parte de un movimiento equivalente de flujo y reflujo (Zátonyi, 2007). Por otro lado, la presencia en Quevedo de una especie de sátira a lo que sería una fórmula fácil de crear el lenguaje que imita el habla de los negros, el bozal, se ha querido interpretar como evidencia de que éste es en realidad una invención ficcional de los sectores hegemónicos y no una imitación de algún dialecto real de los esclavos (Santamaría, 2005, p. 9). En la misma línea, que Cerone censure la negrilla y otros villancicos de tema "étnico" hace parecer que todo se trata de una discusión entre la élite, y que en ningún caso tiene injerencia ni rol alguno cualquiera de los sectores populares que son "víctimas" de la sátira.

Es muy extraño que, si todo esto fuese así, Araujo compusiera la negrilla que escuchamos, dado que era un ávido lector del Melopeo y maestro de Cerone, cuya observancia lo hubiese llevado a abandonar la burla racializada. Pero hasta aquí la crítica es en todo caso literaria y especialmente ligada al contenido, a los temas. A Baker, por ejemplo, le preocupa que en la negrilla aparezca una imagen alegre y divertida de los negros, ya que esto no haría más que evidenciar el silenciamiento de la dominación hacia los africanos. Waisman (Waisman, 2012, p. 8) sigue esta argumentación tanto como la de Carolina Santamaría que ya hemos referido, pero traslada el eje ahora al análisis musical, siguiendo el trabajo de ésta última. Si profundizamos en esta dimensión, veremos que lo que Santamaría analiza es básicamente la armonía y, de forma secundaria, el metro o compás y su relación con las acentuaciones de las melodías. Es comprensible, porque su punto de partida es comprobar la validez de los análisis de Stevenson, que no eran otra cosa que un traslado del modelo estructural funcional a los villancicos latinoamericanos. Nada se dice aquí, ni en el resto de la literatura citada, de lo presentacional, de los aspectos sonoros, el timbre, las articulaciones, en síntesis, de lo performativo. Si continuamos perpetuando el modelo que entroniza al compositor y relega la puesta en sonido de la música como mero aspecto contingente ¿qué rol van a tener los ministriles indígenas o negros que tocaban estas músicas? Si volviendo a la metáfora de Cook los ejecutantes de la música de concierto -blancos, profesionales, de clase media en el peor de los casosson los sirvientes victorianos, como referimos en el capítulo 1, ¿qué le queda a nuestros músicos aymaras, quechuas, mexicas, quichés, taínos entre tantos otros? ¿y qué lugar podrían tener en nuestras historias los esclavos limeños, habaneros y cordobeses? Para Waisman, el proyecto segregacionista se realizó únicamente en los conventos del mundo colonial (2019, p. 44). Esto coincide con que son una de las instituciones del Cusco colonial más estudiadas por Baker, siendo el principal sustento argumentativo en una publicación temprana vinculada a lo que sería su tesis (Baker, 2003) en donde describe una segregación racial a partir del color del velo, que ya no distingue entre novicias y monjas, sino entre españolas e indígenas. A su vez éstas son incorporadas fundamentalmente por sus cualidades vocales y musicales, que aquí podríamos suponer miméticas. Pero en el mundo exterior a los muros de los conventos coloniales

Surgieron allí plazuelas, donde se instalaron fuentes, y en las que empezaron a constituirse pequeños centros barriales, que congregaron grupos populares, a veces indígenas o negros. El fenómeno edilicio más importante fue la formación espontánea de suburbios, poblados en principio por esos y otros grupos marginales. A los barrios o "doctrinas" previstos en la trama original de México que proyectó Alonso García Bravo, se agregaron en los dos siglos siguientes otros, de los cuales los más importantes fueron el de Santa Cruz y el de Santiago Tlatelolco (Romero, 2001, p. 101)

En otros capítulos hemos utilizado la pintura de Pieter Brueghel como metáfora de los conflictos simbólicos que habitan la cultura popular, siguiendo los usos de Attali o Muir, entre tantos otros. En cambio Arnold Hauser desarrolló una lectura mucho más similar a la de Waisman o Baker, en dónde Brueghel lo que hace es mofarse de esos gordos y deformes tan vulgares, que no saben otra cosa más que satisfacer sus apetitos más primarios y 
evacuar sus miserias en plena calle. En esta vía Hauser llegó a considerarlo incluso equivalente al Greco, formando ambos parte del Manierismo, esa interesante invención de la historiografía estilística del siglo XX.

La pintura de Brueghel tiene en común también con el arte manierista su carácter antipopular. Esto ha sido en él tan poco apreciado como su estilo en general, que ha sido considerado como un naturalismo sano, ingenuo e inalterable. Se ha llamado al artista el "campesino Brueghel" y se ha caído en el error de pensar que un arte que describe la vida de la pobre gente está destinado también a ella, cuando en realidad la verdad es lo contrario (Hauser, 1962, p. 395)

Los términos de Hauser son prácticamente los mismos que los de Baker y Waisman. Consideremos que estamos hablando del historiador del arte que ha representado el símbolo de la historiografía social, sospechosa de marxista, y veremos hasta qué punto el paradigma de los estilos ha penetrado en nuestra imagen histórica del arte y la música. Este párrafo de Hauser es un ejemplo transparente del dominomorfismo. No estamos confundidos pensando que Brueghel fuese campesino, pobre, moro o indígena. De hecho, por si aún no es evidente, eso no tendría en nuestro análisis ningún tipo de interés. Sí, en cambio, podemos pensar que la actitud del pintor flamenco es la de aquél que se interesa lo suficiente por los sectores populares como para destinarl mucho tiempo en estudiarlos y así tematizarlos. Es lo opuesto de la actitud de los musicólogos cuando invisibilizan a los músicos de las castas, porque aquí Brueghel nos hace ver a esos cuerpos grotescos, hiperbolizados y bufos, en una actitud absolutamente carnavalesca que nos devuelve, mediante la deformación, una visión absolutamente popular de la realidad. Lo cual también eleva otra objeción a las preocupaciones de Baker sobre la negrilla. La cultura popular es la cultura de la risa, razón más que suficiente para que no pretendamos basar en una estética del sufrimiento subalterno una supuesta autenticidad étnica del arte popular. Pero hay incluso otra pintura de Brueghel, aparentemente mucho menos vinculada con la risa, casi una imagen decorativa. Es un paisaje en el que vemos un estuario con una ciudad a lo lejos, varios barcos a vela zarpando y en primer plano, de espaldas un labriego con su arado, un pescador y más lejos, un pastor con su rebaño. Se llama Paisaje con la caída de Ícaro (ca. 1560). Es desconcertante, pues lo que vemos no es el personaje mitológico que construye alas para volar hacia el sol, desafiando el destino que los dioses habían reservado para él, un simple mortal. Este desafío, como se ha querido ver también en otras figuras como Prometeo (Argullol, 1991), parece representar lo que por pueblo entienden los musicólogos del postcolonialismo y los estudios latinoamericanos: una fuerza que se opone, frontalmente, al yugo que la somete. ${ }^{299}$ Eso debería aparecer en la negrilla, la voz clara y contundente de una comunidad subalterna que se eleva, rugiendo, para barrer con los opresores. Reconozcamos que es una utopía seductora. El texto de Santamaría, por ejemplo, abunda en estos deseos. Pero como los autores que han estudiado la cultura popular que hemos examinado en este estudio nos dejan claro, muy pocas veces el arte popular se vale del recurso de tan explícito contenido. En todo caso son «dos grandes y persistentes contranarrativas» (Hall, 2010, p. 289) que intentan atraparnos en un juego interminable de oposiciones absolutas, que jamás ocurre en la vida cotidiana ni en la cultura popular. Tal vez por esto los sectores de la izquierda romántica son más propensos a identificarse con el arte culto y a evidenciar una incomprensión total del arte popular, sea que lo llamen folklore o mistificación de las masas. ${ }^{300}$ La historia de Latinoamérica, sobre todo para los sectores subalternos racializados, es la de una región atravesada de fuertes poderes extraños, invencibles en la guerra frontal.

299 Es muy indicativo, además de coherente con esta noción monolítica del pueblo, que el libro de Argullol que desarrolla el sentido cultural del mito de Prometeo lleve por subtítulo Un relato occidental..

300 «en la medida que las izquierdas de América sean a lo largo de estos cinco siglos preponderantemente coloniales en su accionar, esta situación generará a menudo grandes confusiones» (Aharonián, 1994, p. 200). 
Ante la violencia azarosa de una exuberante naturaleza fabulosa [...] y ante una historia violenta marcada por diversas dominaciones imperiales de las más poderosas naciones del globo [...] (entrelazada a los conflictos de una economía configurada esencialmente desde su propia génesis, por exigencias internacionales), el protagonismo de la cultura en la acción social ha sido uno de los lugares centrales que sectores importantes han encontrado para el ejercicio de su libertad (Quintero Rivera, 2005, p. 227)

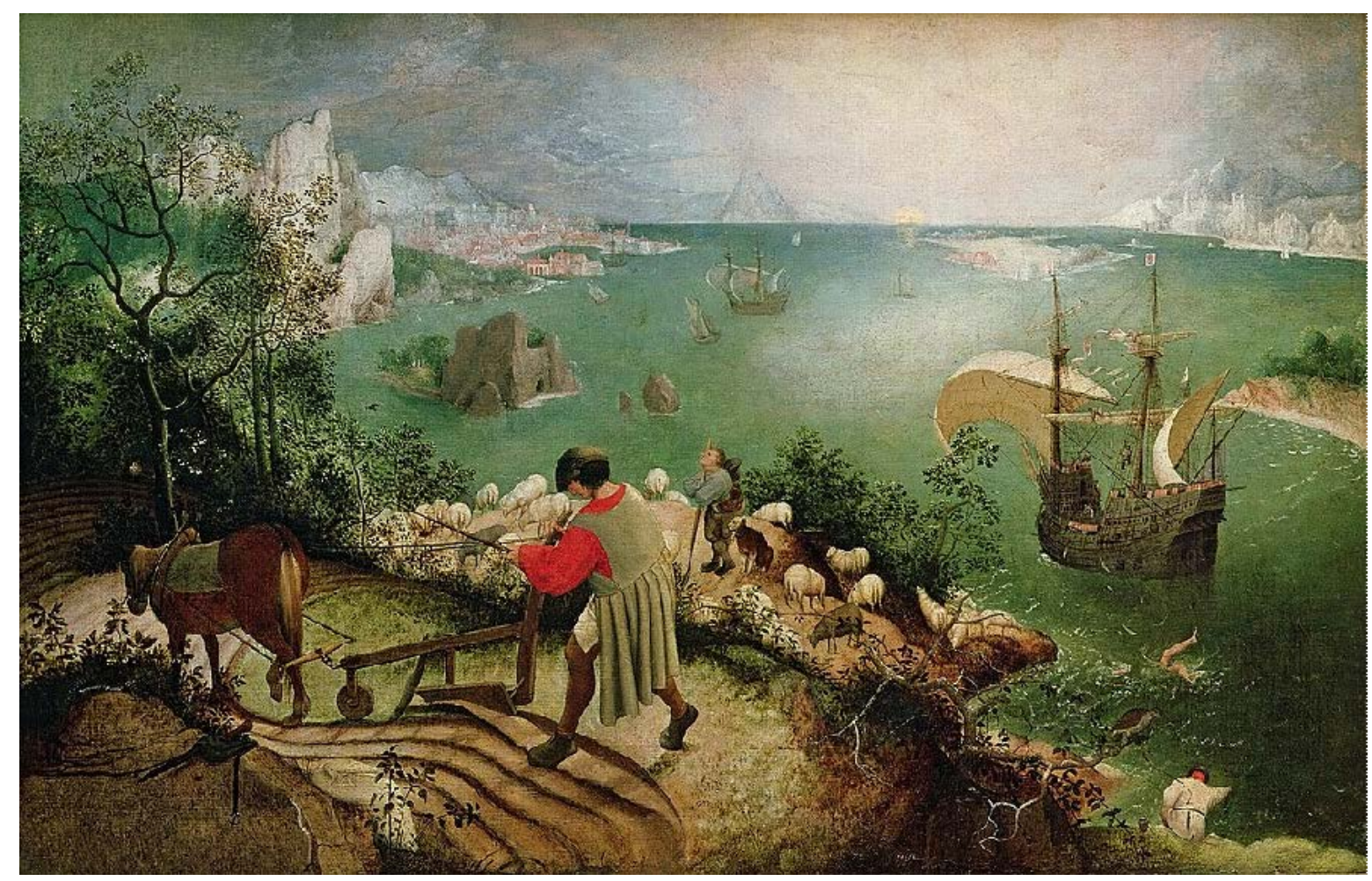

Pieter Brueghel el viejo "Paisaje con la caída de Ícaro", 1560

Lejos del juicio oposicional facilista, dentro de un artefacto estético que podríamos incluso encontrar complaciente, el cuadro de Brueghel introduce una perspectiva muy potente: si nos preguntamos dónde está Ícaro vamos a tener que esforzarnos en su búsqueda; y sólo al rato veremos, muy pequeñitas, unas piernas escuálidas asomando fuera del agua, entre el barco y el pescador. Ahí está el fatídico ser emplumado, ahogándose luego de que comprendiera, de la peor manera, cuál es su lugar en este mundo. Pero ese no es el pueblo. En cambio, los pastores, los campesinos, los pescadores, permanecen absolutamente indiferentes al drama divino. Están pensando en otra cosa. Incluso el pastor mira para otro lado, mientras el labriego y el pescador ni siquiera levantaron la mirada. Ninguno de los marineros del barco pareciera estar dispuesto a virar el navío para rescatar al héroe. Podríamos pensar que Brueghel está reflejando la insensibilidad de los sectores populares. W. H. Auden así lo puso en un poema en que nos deja entender que pare él el pueblo es insensible como los niños, o peor, como «los perros siguen su vida de perros y el caballo del torturador inocentemente se restriega el trasero contra un árbol». En cambio, si nos atrevemos a pensar que la caída de Ícaro puede ser insignificante, como en la poesía de Williams Carlos Williams que usamos de epígrafe, entonces la perspectiva cambia por completo. Los sectores populares son ahora el centro de la historia, no únicamente como contendientes empecinados de la cultura oficial, la única que pareciera merecer el centro del cuadro. En el cuadro de Brueghel, las figuras son el campesino, el pastor y el pescador. El pintor puede haber sido parte de la cultura oficial, pero restituye el protagonismo, en sus propios términos, que no son para nada indiferentes sino específicos como nos enseñó Bajtín. Una perspectiva frontalmente distinta a la de 
Hauser quien, recordemos, concebía al pueblo como esencialmente conservador, arrinconado por el avance de la modernidad en una pobreza material y cultural sin remedio.

El dominocentrismo hace que Baker proteste contra las interpretaciones contemporáneas de las negrillas, como las dos que escuchamos antes, al considerarlas falsas (fake ones) ya que con tanta alegría y ruido minimizan el "encuentro real" de esclavos y españoles. Lo cual, y en esto se revela su pertenencia al mundo anglosajón, lo lleva a sentenciar que las negrillas «fueron el blackface minstrelsy de su tiempo» (Baker, 2008b, p. 442). Como ya hemos explorado en el capítulo 4, lo único que emergió de la discusión por la autenticidad entre la blackface y el folklore -quien decía del primero justamente que era un fake- es una racialización todavía más profunda, territorializada y absolutamente comercial que condujo a la world music y el folk-market. Justamente Baker pretende vincular las interpretaciones de negrillas con el fenómeno de las músicas del mundo (2008b, p. 442). Habría que preguntarse si buscar la agencia y la autenticidad de los sectores populares en una proclama ideológica revolucionaria no reifica y objetualiza aún más a los sectores subalternos. En la medida en que es parte del mundo popular subalterno, la cultura popular "negra" es intrínsecamente contradictoria «y ello no se debe a que no hayamos luchado lo suficiente la batalla cultural» (Hall, 2010, p. 291). Por esta razón, ninguna de las expresiones vinculadas con el mundo afrodescendiente -que, insistimos, no es exclusivamente americano- no puede explicarse mediante una simplificación oposicional entre autonomía cultural y homogeneización, que es una nueva encarnación de la búsqueda de autenticidad. El carácter contradictorio que exhiben muchas músicas negras, que por momentos puede vestir un aspecto concesivo y hasta complaciente, es justamente lo que de minstrelsy tiene el blackface. Es comprensible que nuestras urgencias políticas nos impulsen a buscar juicios claros y contundentes en el análisis, pero pueden ser también un obstáculo para comprender lo contradictorio y complejo que emerge de las identificaciones culturales de las clases subalternas y populares. La apropiación compulsiva "desde arriba" y la racialización que conlleva la caricatura de los sectores populares pueden ser, en todo caso, el punto de partida del análisis, como intentamos demostrar en los capítulos 2 , con los trovadores, y 3 , con el folklore. Pero en ningún caso son una posición monolítica hacia los sectores populares ni mucho menos pueden explicar la totalidad del proceso histórico (Lott, 2013, p. 4). Poner en crisis las demarcaciones racializadas es una forma de oposición, que en tiempos coloniales puede ser explicada con el binomio de Estenssoro «rechazo-separación» frente al ideal hidalgo de las dos repúblicas. Una de las formas más profundas de esta «resistencia a la separación» es la que ejercieron los ministriles indígenas y negros en las catedrales y las instituciones oficiales (Waisman, 2019, p. 76), negando así que las únicas posibilidades para la participación de las culturas subalternas fuesen el gueto y la conservación de lo auténtico.

Pero entonces, de caber la posibilidad de que exista esa voluntad de colocar como protagonistas a los sectores subalternos en las negrillas, debemos ubicar algún elemento sonoro que nos de algunas pistas. El lenguaje de los textos de estos villancicos es sólo la epidermis, en la cual seguramente encontraremos un estereotipo, una especie de reduccionismo de las formas de comunicarse de las diferentes comunidades negras en el mundo hispano. De todas formas, es llamativo que las onomatopeyas, que para Santamaría no son más que ficciones sobre «vestigios imaginarios de dialectos africanos» (2005, p. 11), presenten analogías sonoras importantes con las palabras que encuentra Quintero Rivera en uso de las comunidades mulatas del Caribe, la mayoría de ellas destinadas a describir los tambores, su música, su danza y/o la ocasión, en un todo integral similar a la función polisémica del término taki: así tumba, bongo, conga, entre muchos otros, remiten a los gulumbé y gulumbá de Araujo. De hecho, si se busca una canción antillana que podría ser una proclama revolucionaria para el Puerto Rico actual, podemos encontrarla en la cultura popular del siglo XVII: Tumba la la la, tumba la la le, que en Poltorrico, escravo no quedé 
(baile antillano, siglo XVII,como se citó en Quintero Rivera, 2005, p. 217). Incluso está en bozal, por si faltasen más evidencias de la transculturación transatlántica.

Regresando al examen de Los coflades de la estleya, podemos encontrar en sus aspectos más estables entre las versiones escuchadas -que también aparecen en otras más diversas- un registro rítmico muy sugerente. En la articulación de todos los elementos intervinientes, voces e instrumentos, se percibe un constante deambular del pulso que agrupa unidades pequeñas, a valor menor al pulso, en células o paquetes de diferente e irregular cantidad, a veces de a dos y otras de a tres, con múltiples pausas y contratiempos entre los planos del continuo y de la voz. Desde la musicología, esto es interpretado como un traslado, a lo sumo más intenso, de la muy común hemiola o ritmo de sesquialtera, que además sería consecuencia del paso de la acentuación del latín a la del idioma castellano en la poesía cortesana peninsular. Como si fuese una reedición de la interpretación positivista frente a la irrupción de los ritmos pulsados en los organa medievales de Notre Dame, estos análisis desconocen las músicas que sonaban a la vuelta de la esquina 0 , como vimos en el capítulo 2, incluso dentro de la catedral y en el mismo altar. Práctica que continúa en Latinoamérica e incluso es llevada a cabo por comunidades relativamente hostigadas por el régimen colonial como, precisamente, las cofradías de negros. Música negra que también es posible que estuviese en España, si bien los africanos eran un minoría mucho más reducida que en América. Por lo tanto, así como preferimos interpretar con Georg Knepler, que la música catedralicia medieval incorpora el ritmo pulsado escuchando a los ministriles urbanos tocar en la plaza, nos parece mucho más verosímil que esta concepción ambigua e inestable sea una contribución litigante de los sectores subalternos, que incorporan una percepción del tiempo alternativa que evade el paradigma regular, métrico y racional de la música culta europea. Es «lo que podríamos definir como el sentido de antelación o retardo, en el flujo musical, de los apoyos rítmicos, sentido que el oído europeo asimila erróneamente al concepto de sincopa» (Aharonián, 1994, p. 199) Un elemento importante es que lo que para la sistematización racional culta es una alternancia en lo sucesivo, aquí se entiende como posibilidad simultánea no excluyente de dos o más órdenes rítmicos diferentes. Si bien la alternancia tiene antecedentes en España y en el Magreb, reforzando la percepción de una cultura ibérica compleja, diversa y transcultural

en todo caso, en ninguna de las expresiones musicales de alrededor del Mediterráneo encontramos atisbos de la increíble riqueza rítmica del joropo venezolano-colombiano, en el que refinamiento de la interrelación-oposición de lo ternario y lo binario llega a limites inimaginables para un oído europeo bien entrenado e inescribibles en el sistema europeo de escritura musical, en una permanente sensación de vértigo (Aharonián, 1994, p. 199).

Vértigo que se intensifica en la medida en que nos introduce en un terreno altamente contradictorio, en un doble sentido: por un lado tenemos la percepción dual del tiempo, de varios tiempos que se articulan simultáneamente pero se resisten a sintetizarse, a estabilizarse en una resultante homogénea; pero además lo contradictorio aflora en la utilización de materiales que no guardan relación con ninguna garantía de autenticidad de lo "negro". Dicho a modo de pregunta, ya que se trata de las sonoridades de lo negro ¿no podrían éstas manifestarse de un modo más explícito, más "puro", y nos evitamos toda esta discusión? ¿Por qué las músicas que históricamente se referencian como emergentes de la migración forzada mediante el tráfico esclavista no articulan con mayor claridad y definición lo que podría entenderse como sus elementos característicos? Aunque no hay una respuesta única a estos problemas, de lo que se trata, en el fondo, es de que son manifestaciones del mundo popular subalterno y por lo tanto, están irremediablemente destinadas a ser contradictorias, impuras, liminales. Las manifestaciones populares se dan en un campo de disputa complejo, expresando posiciones que nunca son polares. Si se quiere, representan puntos de negociación que, para el caso de lo americano, podríamos vincular a esos polos que describe Estenssoro para el proceso colonial, atravesados 
además por la dialéctica de Romero entre lo ideal y lo real. Esta complejidad contradictoria de posiciones, deseos y estrategias cambiantes, en el centro de las cuales aparece el proceso de identificación que referimos en Bernand y que es motor de la transculturación de Ortiz, es precisamente lo que hace que las culturas populares, y entre ellas la afrodescendiente, se enraíce por un lado en la experiencia popular y esté al mismo tiempo disponible para su expropiación por parte de los sectores hegemónicos. Están permanentemente «amenazadas por la incorporación o la exclusión» (Hall, 2010, p. 239). Al expresarse en el mestizaje y la mulatería, especies imposibles para la autenticidad, las formas contradictorias de la cultura popular no exhiben una etapa a superar, sino su propia matriz ambigua que justamente es la que permite su existencia real. Necesariamente, para perpetuarse y existir, las formas en que las comunidades subalternas -y dentro de ellas las negras- aparecen en las manifestaciones de la cultura popular "son deformadas, incorporadas e inauténticas» (Hall, 2010, p. 291). Porque en España o en América las manifestaciones afrodescendientes son parte de las culturas populares.

La aparente falta de autenticidad que escuchamos en las versiones de la negrilla de Araujo, y sobre todo en la segunda de ellas que ni siquiera tiene un cajón o un tambor, puede ser parte de lo que Quintero Rivera explica como «el tambor camuflado» $(2005, \mathrm{p}$. 201), que puede ser parte de la "controversia estratégica» (Hall, 2010, p. 291) que se resiste al análisis oposicional de lo auténtico versus lo inauténtico. Si bien Quintero desarrolla su concepto de camuflaje en torno al ámbito específicamente caribeño -e incluso portorriqueño- de la contraplantación, varias de las características de ese mundo cimarrón pueden ayudarnos a comprender algunas estrategias de los músicos mestizos y mulatos. Trasladando un uso hacia el mundo animal y canino, los conquistadores hablaban de cimarronería en cuanto al «escape a la domesticación» (Quintero Rivera, 2005, p. 218), situación que merece que la consideremos de forma compleja y no la restrinjamos únicamente a la situación concreta de una huida física de las locaciones de explotación, fueran estas las plantaciones, las minas, y claro está, las ciudades y los puertos, con sus instituciones oficiales. La huida es lo que define la cimarronería, en contraste con la idea de ataque frontal (Quintero Rivera, 2005, p. 231), lo cual muchos analistas esperarían de las manifestaciones musicales de los sectores subalternos. La huida es evasión, la cual habita también en las formas simbólicas contradictorias que configuran una marginalia dentro de las formas oficiales. Esto nos recuerda esos mundos sonoros ruidosos y subversivos de Attali que vimos en el capítulo 1, que contradecían desde las ilustraciones de los márgenes el contenido prescriptivo de los folios pretendidamente gregorianos. En el mundo cimarrón también se busca vivir al margen, eludiendo la confrontación directa, como el juglar medieval. $\mathrm{Y}$ en ambos casos esto produce un universo altamente vulnerable de manifestaciones contradictorias. Dentro de éstas la estrategia fundamental es el camuflaje, que justamente "permite evitar la confrontación con el poder» (Quintero Rivera, 2005, p. 240). Es muy interesante que el autor puertorriqueño vincule esta estrategia con el mundo de la máscara carnavalesca, lo cual refuerza la interpretación de lo subversivo en la cultura de la risa como forma satírica y de renovación, pero que no está necesariamente conducida a una modificación oposicional de las relaciones de poder. ${ }^{301}$ Justamente el camuflaje implica una situación de compromiso que pone en cuestión y limita los imaginarios de espontaneidad y valiente oposición que asociamos a una vida rebelde. Si los observamos más de cerca, estos ideales se vinculan más con lo caballeresco, y entonces con lo hidalgo y el sueño aventurero de los conquistadores, que con las aspiraciones y estrategias de los sectores subalternos del mundo colonial. «El camuflaje obliga a opacar adrede su luminosidad» (Quintero Rivera, 2005, p. 242). Esto hace que en las músicas los elementos disruptivos que podríamos vincular con tradiciones conflictivas hacia la modernidad

301 De hecho y de forma consistente con lo desarrollado en el capítulo 2, para Quintero Rivera el carnaval tienen implicancias «libertarias y conservadoras» $(2005$, p. 241) 
aparezcan en puntos focales aparentemente secundarios: los acompañamientos, las configuraciones tímbricas, los modos de emisión. En la versión de Elyma de la negrilla de Araujo, por ejemplo, dice mucho más la articulación frenética del órgano, muy rápida y percusiva, nutrida de ataques sucesivos y notas repetidas, o el intento del clave por reproducir lo que sería el rasgueo de una guitarra o una vihuela. Se acercan a la idea de repique presente en la interacción de los tambores afrodescendientes solistas con los que hacen la base, que dicho sea de paso es la figura en las músicas afrodescendientes más explícitamente etnologizadas. Con timbres radicalmente distintos a los del tambor, los instrumentos españoles en manos de ministriles pardos introducen «la vívida presencia afro de su negada constitución»(Quintero Rivera, 2005, p. 251).

Lo cimarrón incluye, además de lo negro, a los otros colectivos subalternos racializados por el orden colonial, los diversos pueblos indígenas y también los descendientes de moros y judíos escapados de España junto a otros sectores marginales "blancos". Todos ellos necesitan de igual forma camuflarse, evadirse, producir una huida de la domesticación. En la versión escuchada podemos entender así el ruido no tónico por «aglomeración de campos armónicos» (Prudencio, 2001) que incorporan los aerófonos al reforzar por duplicación la respuesta del coro. Una duplicación que no duplica, pues es más una mancha sonora, que bordea las alturas de las voces antes que intentar confluir con ellas. Lo cual responde a un modo particular de ejecución que podríamos llamar incisividad sonora. Una forma de articulación que expresa un modo de concebir el sonido alternativo a la racionalización tonal moderna. Ésto conlleva procedimientos técnicos específicos, como el ataque de diafragma y no de lengua en los vientos, referenciados con formas culturales determinadas, en este caso de la música aymara. La forma de ejecución entonces, que podemos suponer presente en los ministriles coloniales, introduce la cimarronería en el corazón mismo del dispositivo musical oficial. En el fondo y no en la figura aparece con mayor nitidez lo identitario subalterno, que está camuflado y es cimarrón, mestizo. Una máscara carnavalesca que, al mismo tiempo que opaca las garantías de las identidades sonoras, permite introducir a éstas y preservarlas dentro de las manifestaciones mestizas en donde, desde el margen y lo que aparentemente es menos importante, construyen una estrategia de resistencia. Tal vez no sea casualidad que la principal fuente de subsistencia de las comunidades cimarronas haya sido el contrabando.

\subsection{5 - Ichapekene Piesta, o los ministriles transmodernos de la selva tan distintos a los gauchos del bosque}

Los análisis musicales de Santamaría (2005), Stevenson (1990) o Waisman (2012), que polemizan entre sí, son un ejemplo de lo que venimos llamando compresión musicológica: ¿de qué manera podríamos dar cuenta de la música africana o de la africanidad en la música colonial si de lo único que hablamos es de "cadencia tonal", "modulación", "hemiola", "Fa mayor", "responsorial", "métrica", "sesquialtera", "secciones polifónicas" o, desde luego "mayor uso de síncopas"? En el instante en que cualquiera de estas músicas ingresaran a esas categorías, podemos estar seguros que abandonarían toda condición africana, americana, subalterna o popular. Por eso, lo único que permanece tras este tipo de análisis es un dominomorfismo, ya que ejerce un trastocamiento de categorías aplicando aquellas que, como ya analizamos, fueron acuñadas para una música que expresa el control de la naturaleza sonora (Small, 1989) de la racionalidad moderna, que desde la teoría persigue sistema-tizar la música (Quintero Rivera, 2005, p. 40) y está estrechamente vinculada con la representación de los sectores hegemónicos por sustracción de la cultura popular. Waisman sí advierte esto en relación a la historiografía de las reducciones o misiones destinadas a civilizar a los grupos indígenas marginales del mundo andino, como las diversas naciones de guaraníes o arahuacos de las regiones selváticas suramericanas. 
Si hemos de creer a los historiadores posteriores, el mundo musical de las reducciones era inmaculadamente europeo, el papel de los indios se reducía a reproducir las realidades sonoras importadas del mundo de los blancos. Una lectura atenta de las fuentes, sin embargo, nos muestra que especialmente en el caso de Mojos la participación de los neófitos se traducía en una práctica musical híbrida donde la tradición indígena dejaba una fuerte impronta. Más que en ninguna otra zona de Sudamérica, la participación de instrumentos, danzas y juegos nativos en la vida litúrgico-musical de las reducciones de Mojos era masiva y constante (Waisman, 2004, p. 18)

Este mismo autor (2019, p. 66) es de la opinión que el accionar de los jesuitas en las doctrinas periféricas de Cusco y Lima, y fundamentalmente en Juli en el lago Titicaca, sirvieron de modelo o "proyecto piloto" para el accionar musical en las reducciones de Moxos, lo cual nos abre una interesante hipótesis de conexión entre el mundo urbano colonial y estas periferias. Sabemos que en esos pueblos, una de las formas de "reducir a civilización", es decir introducir en la modernidad a los pueblos presentes en la zona selvática principalmente guaranítica -no incaica-, era precisamente la formación musical, tanto en la ejecución de instrumentos como en su fabricación, entre los cuales sobresalen aquellos de la familia del violín. Podríamos pensar, a modo de hipótesis, que si la música indígena chocaba frontalmente con la lógica organizativa de la modernidad tonal y métrica europea, si existía como era costumbre cultural de estos pueblos un nomadismo tanto social como sonoro -en los términos de la fonética sonora y la aglomeración de campos armónicos- los "misioneros" se afanaron sobre todo en introducir una justeza en la afinación de alturas puntuales junto con un respeto por la medida racional del tiempo. Todas cosas que pueden relacionarse con la organización del tiempo para el trabajo y su separación funcional del ocio, la especificidad de espacios para el culto, el descanso, las tareas laborales, la higiene, la comida, etc. Aristas de una colonialidad en los que la organización de la vida cotidiana pueden leerse como una intervención de la racionalidad moderna (Quintero Rivera, 2005). Así como se consideraba la condición nómada de los indígenas un factor de salvajismo, su establecimiento en las ciudades de la selva implicaba humanarlos. Aparece así una serie de órdenes de civilización (Waisman, 2005), dentro de la cual las coordenadas temporales y tonales de la música cumplían una función muy importante, en términos simbólicos pero además procedimentales.

Pero aun así, con toda esa colonialidad tan contundente, el programa no consigue completar ese objetivo. O por lo menos eso tenemos que deducir al escuchar al maestro de capilla de una de esas iglesias misionales desperdigadas en la selva de la frontera amazónica, en Santa Ana de Velasco, Bolivia. Se llama Januario Soriocó y es parte de la comunidad mestiza que heredó el influjo de los jesuitas y su programa civilizador. Januario toca el violín y canta y, como puede verse en el registro de video, ${ }^{302}$ lo hace en la iglesia misional, la misma que fue construida en el siglo XVII. Muy rápidamente nos damos cuenta de que su modo de tocar es esa otra cosa de la que nos hablaba Leonardo Acosta. El maestro está actuando en una ocasión religiosa, intercalando entre sus toques de violín oraciones a mitad cantadas y entonadas, si es que esas palabras dicen algo aquí. Toda la escena ocurre frente al altar $y$, si bien se advierte que en parte hay un público externo que ha venido a fotografiar y filmar al viejo músico, estas son ocasiones que forman parte de la vida cotidiana de esta comunidad, a la que con toda seguridad llamaremos indígena, pero que es profundamente cristiana y mestiza. Debemos descartar aquí toda pretensión de encontrar una confrontación frontal hacia la cultura occidental pues seguramente esta performance de Januario deriva de la instauración misional del orden temporal, herramienta de inclusión en la modernidad, a través de la cual «la existencia diaria de los indios estaba regida y signada por hechos musicales que actuaban como anuncios o marcadores de un ordenamiento de la existencia» (Waisman, 2005, p. 165)

302 El ejemplo 61 puede verse aquí https://youtu.be/KFu9XXFQuB0 


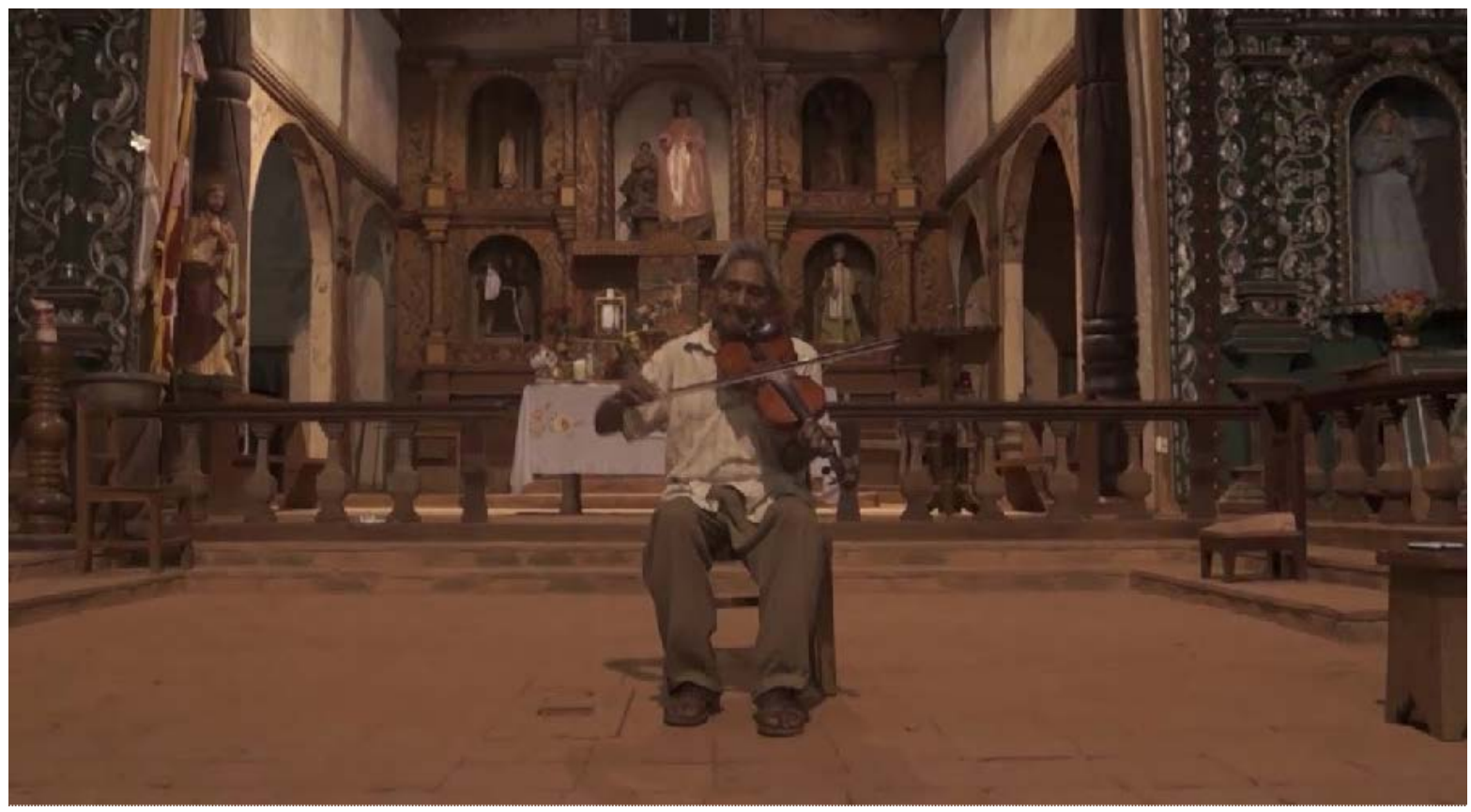

Januario Soriocó y su violín, delante del altar de la iglesia misional en Santa Ana de Moxos

Pero a pesar de todo eso, lo que se escucha es un interjuego de lo que parecen ser varias líneas o voces en ese violín selvático, descendiente de los que se fabricaban en la misma reducción, del cual emerge el cotejo de dos órdenes musicales que conviven en tensión. Una realidad textural y sonora que pone en crisis la pretendida confluencia armónica y resulta, por lo tanto, lo contrario del ideal del contrapunto, que seguramente es la norma compositiva que subyace a las partituras que alguna vez los jesuitas enseñaron en Santa Ana y que dieron lugar a la música que toca Januario. Pero no hay que confundirse, pues no hay nada que podamos llamar contrapunto en esta música. De lo que se trata es nuevamente de un camuflaje, pues en ese violín y en la sinuosidad de la voz podemos escuchar otra concepción del sonido y sus componentes, más cercana a aquello que habita aún hoy también en las tropas de aerófonos del área andina, que las reducciones se encargaron de conectar, justamente, con la selva del oriente boliviano. Por lo tanto, esta música tampoco es indígena, sino un emergente de la transculturación ch'ixi, del mestizaje producto de las identificaciones de los indígenas con la sociedad cristiana europea. De allí surge esta increíble variación del espectro de frecuencias, la inestabilidad del timbre y del rozamiento del arco con las cuerdas, la importante presencia de componentes armónicas lejanas que disuelven la tonicidad de las notas y generan una suerte de manchas sonoras. Pero lo más notorio, y que además también hace la voz aunque de manera diferida y variada por lo cual no coinciden, es un permanente arrastre entre las notas, como una suerte de barrido en el orden de las alturas que en muy pocas ocasiones se detiene y fija alguna "nota". Es una buena muestra de esas discrepancias participatorias que tomamos de Charles Keil (2001), pero que debemos también relacionar con esa idea del camuflaje y la máscara cimarrona, que evade la domesticación ubicándose en los pasajes, en los márgenes, en lo aparentemente menos importante, un pensamiento de frontera como es el pensamiento mestizo. Lo identitario, lo interesante, aquello en cuya trayectoria aparecen los más sutiles matices y variantes, es decir el foco sobre el cual pareciera demorarse la intencionalidad del ejecutante, es nuevamente el aspecto sonoro, textural y rítmico. Este último además, como también ocurría en la negrilla aunque de modo muy diferente, no responde a un orden métrico. De hecho aquí no pareciera existir la mensuración sino la sensación de una permanencia más que de un transcurrir, una especie de banda sonora de aquello que Rodolfo Kusch denominó estar siendo y que coincide con la concepción del 
tiempo de las comunidades indígenas de Bolivia (Prudencio, 2001). Esto explica además en lo melódico la ausencia de direccionalidad, al punto que la música parece avanzar y retroceder sin pretender llegar a ninguna parte.

Es comprensible que los cronistas no encontraran armonía en estos músicos y los describieran en función de las carencias: «ellos tienen flacas voces y no suenan si no es en alguna multitud, como también porque ellos mismos suplen el cantar y el tañer, y a esta causa tienen necesidad de descansar» (Informe de la Provincia del Santo Evangelio como se citó en Martínez Miura, 2004, p. 254). Sin embargo, la sensación alrededor de la producción musical de las reducciones, vigentes entre el siglo XVII y mitad del XVIII, es de una esplendorosa majestuosidad. De las capacidades musicales de doctrinas y pueblos de indios, tanto como de reducciones, se dice que «algunas son tan grandes y suntuosas que pueden competir con las catedrales [...] tienen sus sacristanes y sus cantores, con maestro de capilla y de escuela, indios que enseñan y cantan y tocan chirimías y flautas y cornetas y bajones» (Martín de Murúa Historia general del Perú 1616, como se citó en Martínez Miura, 2004, p. 255). Pero esto no debe distraernos del aspecto sonoro, que tal vez haya tenido fluctuaciones entre una aproximación mayor al ideal de armonía de los conquistadores, pero que muy probablemente haya sentado las bases de una práctica que informa lo que escuchamos en el violín de Januario y sus colegas que

aún hoy vemos en la zona de las antiguas misiones de Moxos (Bolivia), donde, en las misas, la línea melódica que ejecutan los bajunes ${ }^{303}$ presenta una escasa o nula relación armónica con el canto y demás instrumentos de origen europeo que suenan simultáneamente" (Vera, 2016, p. 620).

Es muy interesante que estos músicos participan de las fiestas públicas de la ciudad, cuya variedad y carácter popular puede verse en el documental La fiesta de San ignacio de Moxos $^{304}$ dirigido por Alfredo Ovando (1986) y musicalizado por un joven Cergio Prudencio. En la cinta puede verse lo convocante de la celebración de la misa, presidida por sacerdotes "blancos" pero musicalizada por los ministriles de San Ignacio, en donde vemos a Januario Sorioco y otros músicos que tocan flautas traveseras de caña y los bajones, además de cantar de un modo completamente similar a la grabación que analizamos previamente. Aquí vemos con mucha claridad, en el fervor religioso de los participantes, la concreción de esa identificación de la que habla Bernand en el vector de la asimilación hacia la cultura impuesta por la conquista. Pero luego de la misa, la celebración se abre al espacio público y se confunde con la construcción de máscaras para rendir culto a los antepasados, en el que conviven imágenes cristianas y de santos con animales y figuras del mundo mágico surgidas de una amalgama de elementos prehispánicos y europeos producida por la acción colonial. De igual forma las procesiones, sobre todo la Ichapekene Piesta, actualmente patrimonio de la humanidad, que es una festividad sincrética que reinterpreta el mito fundacional moxeño de la victoria jesuítica de San Ignacio de Loyola, asociándolo a las creencias y tradiciones indígenas, comienzan con una satirización burlesca de los heraldos españoles e incluyen en una amalgama extravagante a los famosos guerreros "macheteros" junto a otros personajes mestizos, como los Achus, dueños del monte, que si bien personifican a los antepasados que vuelven "de visita", visten sombrero y vestimenta occidental y usan máscaras que en algunos casos son llamativamente blancas. La procesión del santo exhibe también una especie de mojiganga que es el "farol", detrás del cual marchan los ministriles con sus instrumentos, tocándolos de

303 Vera se refiere aquí al Bajón Moxeño, un instrumento cuyo formato se asemeja a un sikus gigante, aunque más grande que un toyo. No es de caña, sino que está hecho de hojas de palmera enrolladas, las que configuran los tubos. La producción de sonido es diferente también, y el resultado es un timbre más ronco que el de los sikus. Tampoco debe confundirse con el moceño o moseño, que es un instrumento del área andina.

304 El ejemplo 62 verse aquí https://youtu.be/cLQNDIB4f w 
la misma forma que ante el altar de la iglesia. Incluso hay lugar para una danza de las trenzas a las que se llama, con transparente mestizaje, el sarao, que naturalmente remeda a las danzas del culto arbóreo, como la cucaña o el palo mayo de los europeos. Toda la celebración está conducida mediante la música, que no exhibe mayores diferencias entre un conjunto y otro y en la cual, además de los instrumentos de ministriles, aparecen multitud de tambores y cajas y los aerófonos de los macheteros, fundamentalmente el chuyu'i. De modo tal que no existe distinción entre sonoridades más indígenas (por ejemplo para el paso de los indios macheteros emplumados) y otras más europeas (como imaginaríamos que deberían sonar las músicas dentro de la iglesia). Esto nos puede decir mucho acerca de la participación de los sectores subalternos en la fiesta urbana, por ejemplo en el Corpus que comentamos antes. De hecho San Ignacio de Moxos tiene un gobierno bajo un cabildo indigenal y una organización gremial de artesanos y trabajadores que se asemejan mucho más al mundo colonial que al de la república.

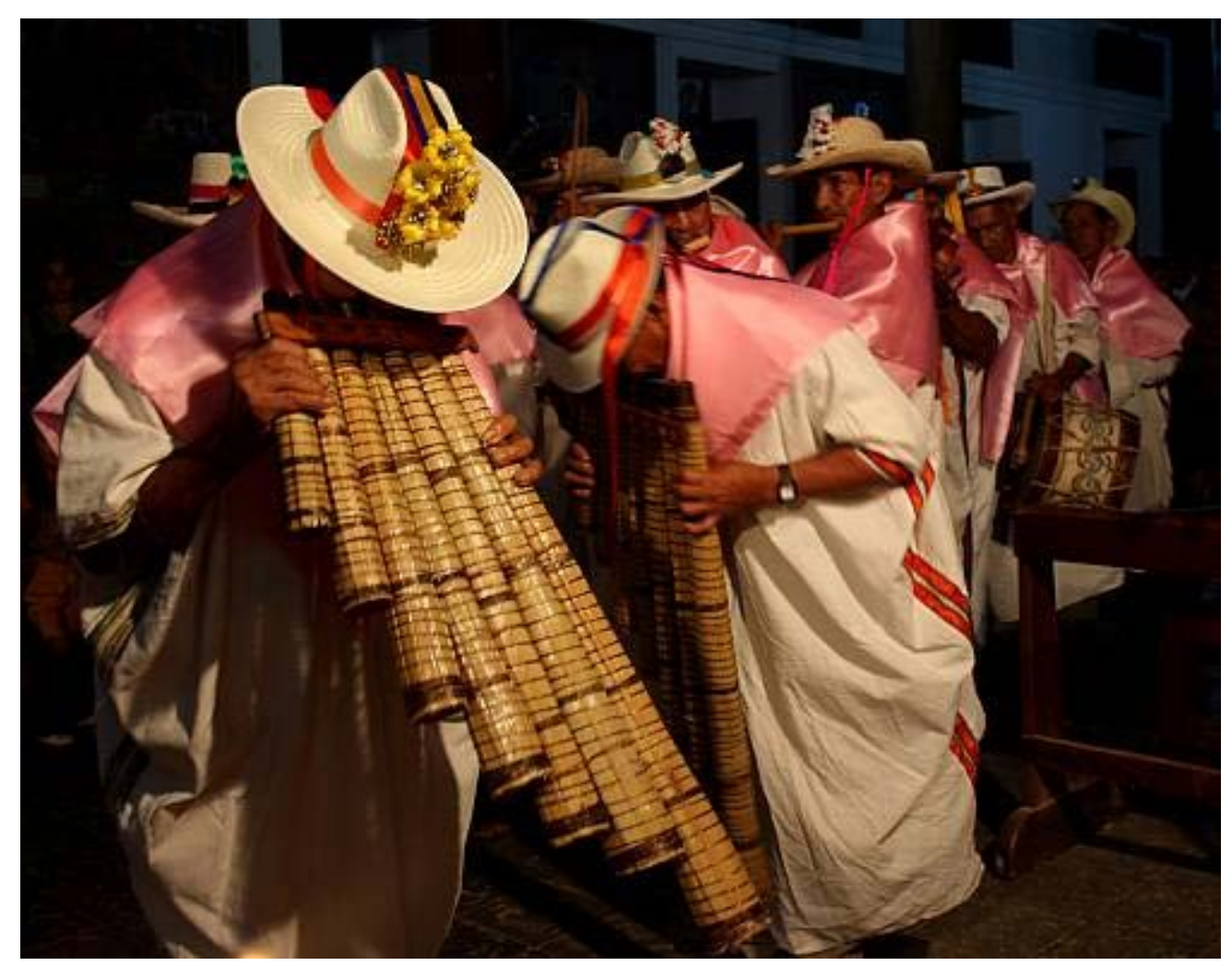

Músicos de San Ignacio de Moxos en la Ichapekene Piesta, dentro de la iglesia misional. En primer plano se observan los bajones de Moxos

Esto no necesariamente debe entenderse como anacronismo o primitivismo sino como la punta del ovillo de una línea historiográfica dinámica que merece ser explorada y estudiada, claro que con métodos distintos a los de la historiografía afirmativa. Una posibilidad es considerar el concepto de Flash Back de Cusicanqui, en el sentido de «una lectura del pasado, no como algo muerto y desprovisto de funciones de renovación, sino como un tiempo "reversible", es decir, un "pasado que puede ser futuro" (Cusicanqui, 2015, p. 78). Es muy llamativo que la idea de renovación a través de la recuperación histórica aparezca como justificación de la fiesta de Moxos, en el sentido que la revitalización en la fiesta del encuentro conflictivo de los antepasados, "blancos" e indígenas, permite un volver a nacer de la comunidad a través de la celebración. Un sentido que ya estaba presente, como vimos, en el carnaval y la fiesta popular medieval. La recuperación de lo histórico a través del análisis de las prácticas presentes en correlación con los datos del pasado colonial, una especie de volver a vivenciar las ocasiones musicales en una confluencia del pasado y el 
presente, aparecen en este pasaje de Waisman, cuando analiza los aportes indígenas a las músicas mestizas.

los maestros de capilla se movían entre dos -o varios- mundos. Por ende algunos de los rasgos estilísticos que hemos analizado no son exclusivos de Mojos [...] son hoy característicos del ámbito mestizo andino [...] hoy patrimonio de la cultura indígena y criolla de una vasta área andina, al menos desde Perú hasta el norte argentino [...] el Mojos indígena se nos presenta como mestizo y parcialmente andino [...] No me cabe duda que la contribución única y original de los mojeños era la manera en que ellos interpretaban las composiciones de raíz europea. Con esos medios profundamente creativos respondían al mensaje religioso y cultural que les proponían los padres jesuitas" (Waisman, 2004 p. 34)

\subsection{6 - La subversión del baile negro del obispo}

Hacia fines del siglo XVIII, tras la expulsión de los jesuitas y el cambio de dinastía en el trono español, la cultura urbana colonial comienza una lenta pero sostenida decadencia y fundamentalmente los cuerpos de ministriles se ven afectados en su estatus laboral. Las parroquias ya son incapaces de sostener un cuerpo de músicos estable y multitud de músicos profesionales deambulan buscando una posición que no encuentran. Si ya era mucho más bajo, en función del sistema de castas, el estatus de un ministril indígena frente a un europeo, la situación hacia fines de la época colonial es mucho más acuciante.

la iglesia parroquial del Hospital de los Naturales dice de sus cantores que "como no tienen chacras [granjas] de dónde comer, se mantienen por la voz dando vueltas por las iglesias", a la búsqueda de trabajo remunerado. En concreto, el escribano da detalles sobre lo insuficiente del sueldo de los cantores (Baker, 2005, p. 188)

Esto fuerza a los músicos a buscar trabajo en otros sectores y ocasiones musicales, potenciando mucho más las relaciones entre esos mundos musicales, nunca desconectados y siempre cimarrones y mestizos, que el ideal hidalgo había pretendido segregar. Como vimos para el caso de Moxos, en el ámbito de las comunidades este proceso tiende a difuminar o tornar abstractas las divisiones entre música sacra, música festiva o música popular, e incluso música ceremonial de carácter indígena. Cultura oficial y cultura popular, si ya estaban «en sancocho» (Quintero Rivera, 2005), lo están ahora mucho más. Por extensión, los saberes y técnicas de los músicos tienden a diversificarse en mayor grado, generando una vida musical muy dinámica. Este es precisamente el momento en que se compila un extraordinario documento musical de la vida andina en tiempos coloniales, como es el Códice de Trujillo, también conocido por quien lo encargó -o realizó-, el obispo Baltasar Jaime Martínez Compañón, quien se interesó en recorrer su diócesis entre 1782 y 1785, visitando territorios de los actuales departamentos de Piura, Lambayeque, Libertad, Cajamarca, Chachapoyas, San Martín y Loreto del Virreinato del Perú. 


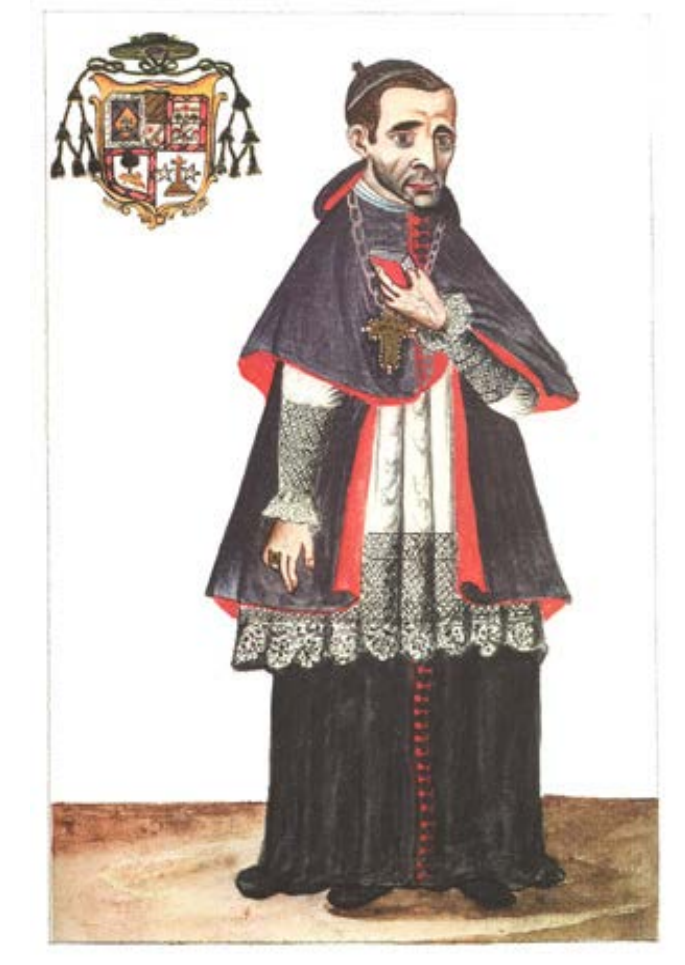

Baltasar Jaime Martínez Compañón retratado en su propio códice

Hay quienes dicen que el códice de Trujillo es uno de los primeros trabajos de etnografía en el Nuevo Mundo. Más allá de que es indudable que aquí hay un sentido exotizante y racializado, podemos tomar la comparación y pensar que las partituras con que registró algunas músicas del noroeste peruano son todo un trabajo de campo. Tanto si lo pensemos en base a lo que fue costumbre en el folklore decimonónico, que "embellecía" las músicas recopiladas, añadiendo armonías y "mejorando" la forma; o si lo asociemos con la tarea de los positivistas del siglo $\mathrm{XX}$, que registraron acríticamente en notación pautada unas músicas que jamás fueron concebidas desde el ordenamiento de alturas puntuales; en cualquier caso tenemos que renunciar a considerar esos registros como la actualidad y totalidad de las músicas que escuchó el obispo entre 1782-85. Más si coincidimos con Stevenson (1968, p. 314) en sospechar que tales partituras fueron escritas por el maestro de capilla de Trujillo, a quien tal vez le debamos la introducción de una concepción textural bipolar y concertada, que incorpora en todas las músicas una persistente línea de bajo muy "barroca". Por lo tanto no hay forma de que estas notaciones sean un «documento exacto» (Fernández Calvo, 2013, p. 346). Por el contrario, las coordenadas históricas nos obligan a renunciar aquí a toda concepción objetual de estas músicas, y a considerarlas a partir de un enfoque performativo.

Volviendo a la hipótesis de Leonardo Acosta, debemos estar advertidos, además, de que los instrumentos, las técnicas, incluso la presencia de partituras nos pueden llevar a extraviarnos en una ilusión en la que todo parece importado de Europa. Pero nada de eso: «escalas, modos, formas musicales, combinaciones armónicas pueden permanecer inalterables y, sin embargo, todo suena distinto» (Acosta, 2006, p. 182). Una "alteración semántica" que redunda en la alteración total de las funciones musicales. De lo cual podremos darnos cuenta sólo si consideramos el aspecto dinámico, la performance, el musicar. Es eso lo que suena distinto, lo que hace que lo que de heredado tenga la música popular latinoamericana transmute en otra cosa en donde las apariencias engañan. No por casualidad Quintero Rivera (2009) define al sonido (que no es igual a timbre) como uno de sus elementos definitorios. 
Volvamos a lo coleccionado por el obispo. Se nos presentan unas músicas a todas luces transculturales, ya se trate de cantos en mochica o villancicos que son en realidad cachuas, y que juegan con la contradicción que ya analizamos entre una prohibición de los rituales indígenas en tanto tales, como el taki, y la utilización permanente -y hasta obligada- de las manifestaciones subalternas en las fiestas del calendario cristiano colonial (Bermúdez, 2001, p. 180). Tomemos una de las menos evidentes. Por ejemplo, la partitura del folio 186 titulada Lanchas para baylar. Es una música instrumental que, curiosamente, para Carlos Vega (Fernández Calvo, 2013, p. 356) es un ejemplo de su mentada categoría de mesomúsica, por ser «melodías que no definen ninguno de los grandes estilos cultos o folklóricos». Es un análisis morfológico el que hace Vega, partiendo únicamente de la partitura y considerando las similitudes con las especies por él relevadas mediante idéntico método.

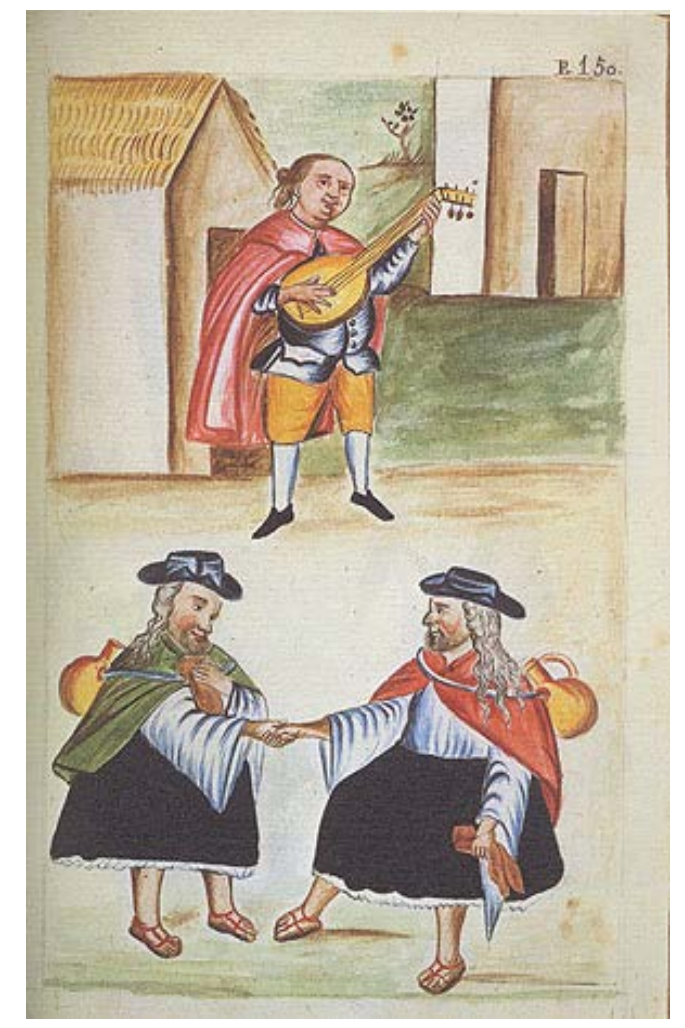

“Danza de hombres vestidos de muger", Códice de Trujillo, Vol II, fl. 175

Consideremos en cambio algunas performances. Tal vez una de las más conocidas es la versión de Capilla de Indias, de 2005, conjunto de música barroca de la Universidad Católica de Valparaíso. Tal presentación hace poco probable una filiación muy popular. Y sin embargo lo que en la partitura del códice es una melodía para violín con una contramelodía de bajo, se convierte en otra cosa: ya desde el comienzo existe una fuerte presencia de instrumentos de percusión, que durante toda la danza sostendrán una célula rítmica en permanente variación elaborada en torno a la superposición de temporalidades, tan frecuente en la música latinoamericana. En este caso es un orden binario frente a uno ternario, lo cual impide todo tipo de apoyo o reposo y refuerza el carácter danzable, corpóreo y por tanto absolutamente popular de esta música. Ese ritmo es a su vez reforzado por las guitarras que hacen rasguidos, es decir más ruido que sonidos armónicos y tonales, que por momentos se tornan en repiques sobre la base rítmica de la percusión. Si a esto sumamos los desvíos en las acentuaciones de la propia melodía, que genera una suerte de síncopa permanente, se configura un efecto dinamizador y de tensión que no nos muestra en absoluto la partitura. Y esta es quizás la versión más conservadora. Todos los 
elementos descritos no hacen más que potenciarse en la performance de 2013 del grupo ecuatoriano-holandés Música Temprana, ${ }^{305}$ en el que además el tempo es mucho más rápido y se observa una demarcación mucho mayor de las articulaciones, tanto del violín y la guitarra, como del charango y el cajón peruano que se incluyen en la versión. Pero todavía más extrema es la interpretación en vivo del ensamble colombiano Como era en un Principio, de 2017.306 El tempo aquí ya duplica al de la primera versión mencionada. Además los instrumentos se alejan aún más del manuscrito, dado que es un conjunto de guitarra, bandola y cuatro, con el agregado de unas maracas. Pero una vez más, lo distintivo es la manera de tocar, en donde lo percusivo y lo tímbrico son los aspectos más relevantes. De hecho, los rasguidos y la forma de puntear los instrumentos de cuerda remedan otras músicas que también superponen temporalidades y que están más cerca de nuestra concepción de música popular, como el joropo llanero.

En un cassette que contiene una grabación "de campo" de Coriún Aharonián, de 1985, se escucha un trío muy similar, con bandola, cuatro y contrabajo. Tocan músicas del Táchira y de los Llanos de Venezuela. Entre ellas Pajarillo y Chipola, ${ }^{307}$ que suena muy parecido a esa última versión de las Lanchas para Baylar. Al menos se parece en lo importante: en los rasguidos, en la manera de llevar el ritmo, en la superposición de temporalidades, en el sonido y las articulaciones, los toques. Por supuesto, no en las notas, las alturas, que son lo secundario en ambos casos. Como lo son también en la música popular cuando empezamos a sacarla de su compresión musicológica. Más aún en Latinoamérica, cuya conquista musical puede pensarse en términos de la imposición de la armonía (Baker, 2008) siendo tal vez una derivación tardía el armonicocentrismo de la musicología latinoamericana.

Algo parecido a ese Flash Back que comentamos antes surge en estas analogías. Y más aún cuando las canciones del códice de Trujillo son reapropiadas por músicos populares actuales. Tal vez pueda parecer una performatividad folklorizada, una «refrescante versión latinoamericana de la música antigua europea» (López, 2016, p. 291), pero existe actualmente una versión muy llamativa de la música que más se acerca a la negrilla dentro del códice, cuya partitura aparece en la estampa 178 bajo el título Allegro tonada El Congo a voz y Bajo para baylar Cantando.

\footnotetext{
305 El ejemplo 63 puede escucharse aquí https://youtu.be/bBGRbRq_BQg

306 El ejemplo 64 puede escucharse aquí https://youtu.be/xpwaQQ66Te4

307 El ejemplo 65 puede escucharse aquí https://youtu.be/Wu4ny-q-fKM
} 


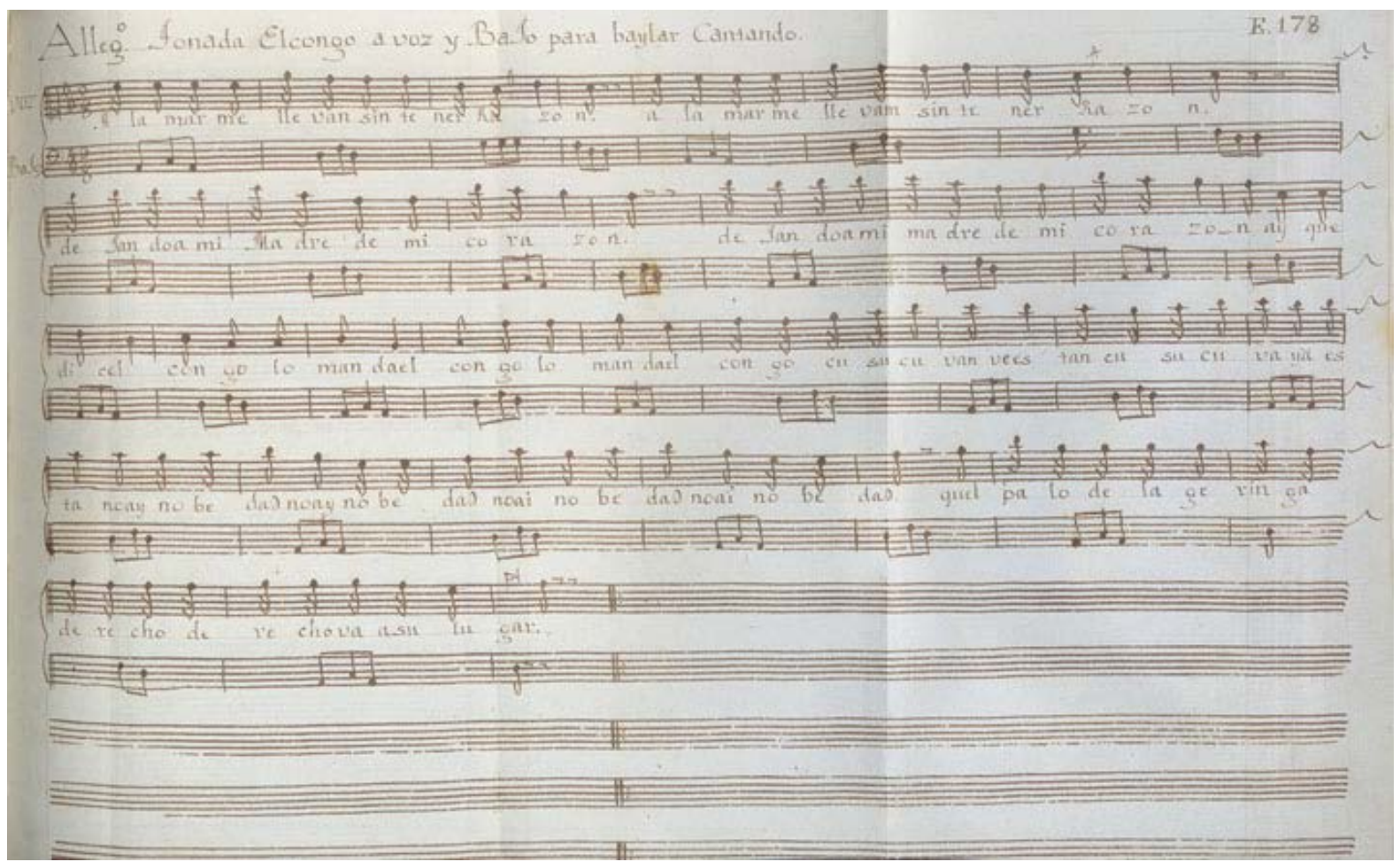

“Allegro tonada El Congo a voz y Bajo para baylar Cantando", Martínez Compañón, vol II, fl. 178

Pero la versión a la que nos referimos no es de un conjunto de música antigua, sino de la cantante popular Susana Baca. 308 Así como Mario de Andrade (1972, p. 166) comprendió que la dicotomía rural/urbano no tiene ningún sentido en América Latina, la música popular, desde por lo menos los tiempos de la conquista no puede pensarse «como folklore muerto o inmutable, como pieza de museo (en este caso, material para discos etnográficos), [sino en todo caso] como el proceso dinámico que hemos visto desplegarse ante nosotros» (Acosta, 2006, p. 192). Proceso dinámico que une como un hilo de plata las distintas músicas que venimos tratando en esta sección y que derivan, claro está, en lo que hoy entendemos como música popular. Es decir que a Susana Baca la estudian los Popular Music Studies aunque, por sus límites metodológicos, no pueden vincular su repertorio más que con una noción de folklore, ahistórico e inmutable, como lo rechazaba Acosta. Hay algo que sin embargo comparten estas músicas cuando son objeto de la compresión metodológica, tanto de la musicología histórica -como vimos para el caso de la negrilla- como en los fundamentos mismos de los PMS. Éstos en buena medida derivan de las teorizaciones de Theodor W. Adorno, lo cual no deja de ser paradojal en función de la conocida condena del teórico frankfurtiano hacia la música popular, a la cual le dedicó especialmente varios artículos para con el fin de denostarla.

Esa pérdida por compresión tiene que ver, por un lado, con el sonido; ya hemos desarrollado suficientemente el tema de hasta qué punto el aspecto matérico de lo sonoro queda absolutamente subsumido en las relaciones lógicas y abstractas de las alturas en la armonía. El otro elemento estigmatizado es el ritmo; en este ensañamiento aparecen los tópicos que en todo el derrotero de la cultura occidental fueron acuñados para rechazar al cuerpo como objeto de la cultura. Justamente Adorno relaciona explícitamente el ritmo de la música popular con un sentido opresivo que genera como resultado «un deseo de obedecer» (2002, p. 189). Los medios de estas manifestaciones sonoras son entendidos así como intrínsecamente represivos.

$308 \mathrm{El}$ ejemplo 66 puede escucharse aquí https://youtu.be/ghCfrurFdyY 
Este tipo obediente es el tipo rítmico [...] Cualquier experiencia musical de este tipo está basada en la unidad temporal de fondo de la música; en su "pulsación". Para esta gente, tocar rítmicamente significa tocar de modo que [...] se conserva la relación con el metro de base. Para ellos, ser musical significa ser capaz de seguir modelos rítmicos dados [...] Esta es la manera en que su respuesta a la música expresa de forma inmediata su deseo de obedecer (Adorno, 2002, p. 189).

Pareciera incluso que esta alienación rítmica disciplinadora, es incluso específica de la música afroamericana o afrodescendiente. Es de todas formas significativo que Adorno encuentre que "esta gente" no retiene, en su música, «la tensión necesaria entre sujeto y objeto, individuo y colectivo» (Paddison, 1982, p. 207). El camuflaje, la cimarronería y la identificación creemos que dan muestras claras de hasta qué punto los desarrollos musicales afrodescendientes ponen en cuestión el orden establecido y, en nuestro caso, se relacionan con el mundo al revés subalterno y específicamente andino. Por eso queremos aquí considerar a la tonada El Congo dentro de lo que Quintero Rivera (2009) llama las bailables músicas mulatas. Debemos advertir que aquí sí, lo que es totalmente excepcional, aparece tematizada explícitamente la rebeldía y oposición al sistema social. Pero en este caso quizás sea una ventaja, ya que en el cruce analítico entre la musicología histórica, el folklore y los PMS estas manifestaciones "contestatarias" suelen ser tildadas de engañosas, es decir, una mistificación.

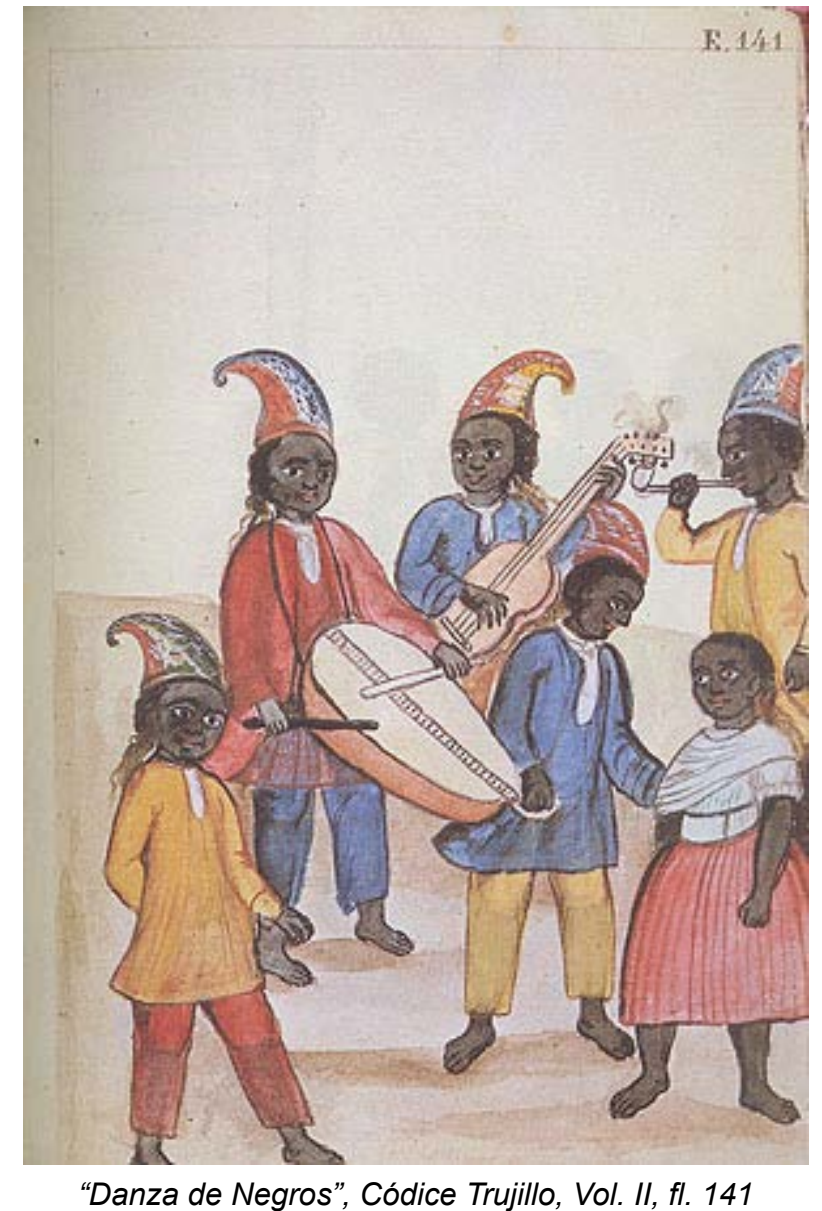

Retornemos a la versión de El Congo, que elegimos en su formato extendido y aparece como segunda pista en el álbum Del fuego y del Agua de 1992. En la versión que necesariamente trasciende ampliamente en el arreglo el esquema del continuo del Códice Trujillo, la canción reúne elementos de modalidades comunes a las músicas caribeñas como afroperuanas, todas ellas dentro de lo que solemos denominar lo afrodescendiente; músicas que con raras excepciones no han sido muy aprovechadas en los folklores 
nacionales, fundamentalmente porque aquí esconder su carácter urbano desde el momento inicial de la transculturación es prácticamente imposible. De hecho, el candombe es de Montevideo, el Samba-landó, de Lima, por no hablar de la habanera. Sin embargo no debemos perder de vista que, ya que este arreglo en particular se acerca al Samba Landó afroperuano, tenemos una interesante oportunidad de explorar una música registrada en el siglo XVIII colonial que entronca con danzas de las comunidades africanas, especialmente el lundum o lundu (Ortiz Oderigo, 2008) para emerger en la zamacueca que tanto discutimos en el capítulo 4. Todo lo cual no hace más que reforzar las conexiones, los pasajes y mestizajes que configuran los específico de las músicas populares latinoamericanas.

Los muchos rasgos que comparten estas músicas mulatas se escuchan inmediatamente desde el comienzo del arreglo de la "tonada del Congo", ya que la canción inicia con un patrón rítmico que se ha vuelto característico del landó.

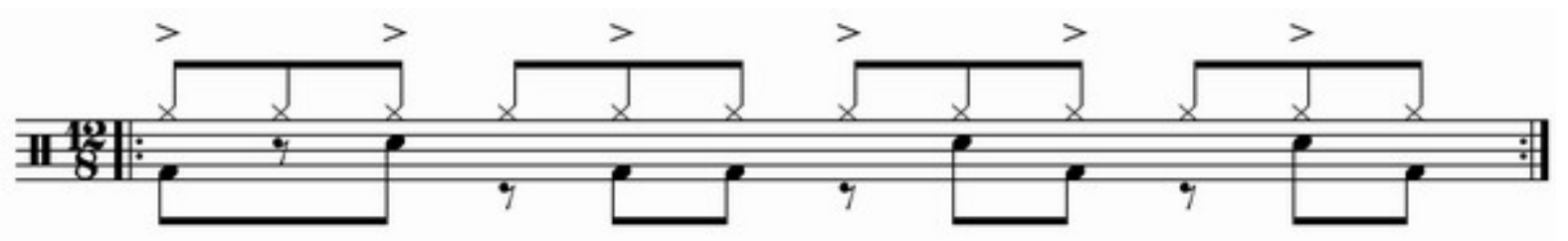

Por supuesto esta es una transcripción aproximada, casi tan lejana como la partitura del códice de Compañón, aunque el código es para nosotros más cercano que la cifra mediante continuo que todavía se utilizaba en el siglo XVIII. Nos permitimos utilizar el recurso en este caso para graficar esa polaridad conflictiva entre lo ternario y lo binario que mencionamos antes en relación a la negrilla. En este caso, ya sea que lo pensemos con los acentos que están aquí escritos, o que establezcamos un patrón en función de la alternancia del sonido grave y el agudo del cajón, está claro que aquí hay un conflicto entre grupos de dos y de a tres que además no se suceden de forma regular, sino que alternan por cantidades desiguales. Una opción de la sucesión de estos grupos es pensarlos como 2-3-3-2-2, lo cual nos llevaría a escribirlo como un $6 \times 4$, en otro tipo de reduccionismo, claro está.

Este esquema suele ser explicado como ritmo aditivo o superposición métrica, indicando en el primer caso un exotismo y en el segundo una contradicción entre lo ternario y lo binario. Nosotros preferimos la denominación del citado Quintero Rivera quien recupera el término de uso entre los músicos populares: la clave. Para este autor las músicas mulatas «simultáneamente son y no son Occidente» (2009, p. 69) y el concepto de clave está claramente del lado del no son. A diferencia de la organización métrica occidental basada en la división proporcional de la unidad y la regularidad acentual, las claves afrodescendientes conforman unidades de duración irregular, diseminando los acentos de acuerdo a conformaciones de tiempo variables y heterogéneas, tanto en lo sucesivo como en lo simultáneo. No es un flujo narrativo sino la sucesión de unidades discretas y diversas, en dimensión y en sentido: cuantos rítmicos, si se permite la analogía con la física. Cada una de estas unidades reúne el conflicto entre diferentes estratos o planos lo que, recurriendo a la terminología occidental, suele explicarse como superposición. Pero como vemos, la organización de las claves no responde en absoluto al concepto de métrica. Y mal haríamos en aplicarlo ya que solo sirve para comprimir el sentido rítmico de estas músicas: el compás o metro occidental es una estructura predeterminada, abstracta, organizada en un rígido esquema jerárquico antes de que los sonidos lo pueblen. Cuando nos referimos al ritmo en base a la métrica, los "detalles" que revelan escapando a la predeterminación son integrados y neutralizados porque se los entiende como síncopas o hemiolas: desvíos. Esto es lo que, por ejemplo, tienen de diferente muchas negrillas americanas con relación a la producción peninsular; las músicas de Gaspar Fernández, de Araujo o de García de 
Céspedes frente a las de Philippe Rogier o aún más las de Mateo Romero. En la música de estos últimos las hemiolas y síncopas son tales pues se confrontan esporádicamente contra un patrón métrico que se acepta como norma, la cual es siempre abstracta y preexistente al fenómeno musical. Aquí hay una diferencia que proviene de la matriz de racionalización occidental y su ritmo objetivado en torno al compás, que tendrá consecuencias y desarrollos ulteriores en la música culta antes que en la música popular.

Es otro indicador de cómo funciona la compresión conceptual de la música popular, al desplegar el aparato analítico generado en Occidente para producir y explicar la música culta. Desde esa perspectiva de escucha analítica, el ritmo de la música popular es considerado mera repetición y predeterminación, subestimando y desoyendo su carácter dinámico, heteróclito, expresión musical de una realidad habitada por la heterogeneidad de las diversas experiencias populares del tiempo. En contraste con toda estandarización, las claves presentan un conflicto permanente entre sus elementos, que ni siquiera pretende resolverse, del mismo modo que la sociedad transcultural que estas músicas habitan asume «la condición transitoria de la mezcla» (Podetti, 2004, p. 4).

La clave básica que transcribimos más arriba es puesta en sonido por un cajón y algunos tambores, que "rellenan" la subdivisión añadiendo aún un tercer nivel acentual que produce otro orden temporal superpuesto a los ya conflictivos de 2 y 3 agrupamientos. Sobre este fondo cambiante y caleidoscópico, imposible de considerarse "acompañamiento", aparece la voz con la melodía del Códice Trujillo, es decir, con una sonorización a partir del esquema, que es tomado por Baca como un modelo a elaborar. Si se quiere, aquí hay una conexión con el mecanismo del continuo que tan sólo expresa en lo escrito una posibilidad que debe ser realizada por el intérprete, a quien se otorga un amplio margen de maniobra. El fraseo vocal, que no se demora demasiado en las alturas aunque tampoco las camufla ni desdibuja, introduce un cuarto esquema rítmico en un claro pie ternario de relación cortolargo que, al ser mucho más estable y regular, choca con la inestabilidad del fondo percusivo. Es un buen ejemplo de lo que en este tipo de músicas "negras" se llama floreo o repiqueteo constante sobre el toque (el despliegue de la clave) que asumen los tambores. Aquí aparece realizada la naturaleza dialógica de estas músicas que siempre se organizan en torno a la alternancia entre tamboreros, cantantes y bailadores. Y en El Congo se percibe con claridad que, lejos de ser los que florean el centro de la música subordinando al resto, es el toque de la clave por los tambores quien subordina, quien mantiene la tensión y el interés en la repetición-que-no-repite. Dentro de los tambores existen además funciones, y mientras unos llevan el ritmo básico de la clave otros repican sobre aquél. Roles que habitualmente se denominan bomba o buleador y primo o subidor, que se asocian con lo femenino y lo masculino - de tal forma que la figura principal que subordina al resto es lo femenino. Este plano de los tambores a su vez es el que manda mediante el desarrollo completo de la clave y en conflicto dialógico con él, los bailadores, los instrumentos melódicos y el canto desarrollan sus descargas y voceos, mayormente improvisados.

A diferencia de lo que ocurre con la tradición europea, donde [...] los tambores fueron relegándose al papel de acompañantes, en estas músicas afrocaribeñas, marcadas por la zanja en continuidad temporal que representó la trata esclavista, continuaron siendo fundamentales para la elaboración musical. Ésta se genera sobre todo en el diálogo creativo entre bailador y tocador [...] entre el espacio y el tiempo. Los bailadores siguen el toque básico del buleador, mientras a nivel individual desarrollan variadísimos movimientos creativos en controversia improvisadora con el subidor. Es muy significativo culturalmente que en tipo de sociedad donde emergió esta música, su ritual simbólico comunicativo sea que el colectivo manda y el individuo florea (Quintero Rivera, 2009, p. 42).

Consideramos que todo esto es prueba suficiente de hasta qué punto, cifradas en estas músicas, en todas ellas y en su historia de cimarronería, de camuflaje y repiqueteo dialógico 
aparece la tensión contra las categorías de la modernidad y, sobre todo, de su variante colonial. Prácticamente no hay tema de la agenda de los movimientos disidentes o insurgentes de nuestra contemporaneidad que no hayamos al menos rozado en los párrafos anteriores y sobre todo en la referencia de Quintero Rivera. Lo cual podemos tomarlo como una invitación a replantearnos las relaciones sonoras del mundo colonial -y las del periodo republicano, por supuesto- así como nuestras categorías de análisis que todavía parecen exigirle a estas músicas un grado mayor de contracultura.

Pero todavía no termina la canción; ni tampoco las tensiones rítmicas ni los floreos ya que sobre toda la configuración mencionada ingresan más instrumentos con nuevos comportamientos. En el primer estribillo aparece un bajo -en realidad es un sintetizador en registro grave- que se apoya parcialmente en los acentos de la clave, pero omitiendo el primer tiempo, dando una sensación de tumbado. Todavía luego del estribillo ingresa la guitarra, haciendo un punteo de una especie de contramelodía de la voz, que se apoya exclusivamente en los contratiempos de la clave y además hace predominar las interrupciones y los huecos en su melodía. Una vez que vuelve la voz cantada, la guitarra se dedica a tocar unos acordes en ataques muy breves que también dialogan rítmicamente con el bajo y con la clave de percusión. El segundo interludio es, en este caso, del sintetizador -que podría haber sido un instrumento melódico, como el violín- que también hace una contramelodía de características similares, aunque no iguales, a lo que escuchamos de la guitarra. Como vemos, los planos rítmicos y texturales se multiplican, dando lugar a esa característica de la música popular que mencionamos en apartados anteriores vinculada a producir condiciones de posibilidad para la participación de una cantidad virtualmente ilimitada de elementos superpuestos.

Este tipo de recurso en el que los elementos individuales cambian su sentido constantemente a partir de su relocalización en torno a la clave y a las relaciones que se configuran entre ellos en lo simultáneo, se corresponde con otro principio rector importantísimo de las músicas afrodescendientes y que desafía tal vez con mayor contundencia la idea de estandarización: se trata de la intensificación por repetición.

Las músicas de tradición afroamericana se caracterizan por combinar simultáneamente, como la vida, la repetición y el cambio, en forma tal que las variaciones tenues en lo repetido vayan intensificando un crescendo que conduzca a un clímax que represente una variación o cambio radical (Quintero Rivera, 2009, p. 86)

Una vez superado el segundo estribillo, en el que la versión de Baca introduce un principio de "llamada y respuesta" con un coro sobre la frase y no hay novedad, la contramelodía del sintetizador pasa a convertirse en un elemento de mayor improvisación y repentismo, al tiempo que se introduce en una segunda sección que abandona el formato canción para pasar a otra configuración formal y textural: el soneo o descarga, relación de llamada y respuesta entre el coro y un solista improvisador, que en este caso es el teclado. Si tomamos la primera sección como un progresivo armado de la clave a partir de la aparición de los diferentes instrumentos sobre la presentación de la forma canción, con sus dos estrofas y el estribillo, todo lo cual se plantea mediante un paulatino enriquecimiento de la textura y un constante aumento de la intensidad, toda esa sección estructurada sobre la repetición permanentemente variada de la clave no hace otra cosa que conducirnos al clímax, que es justamente el arranque del soneo. Éste a su vez insistirá aún más en la repetición, ahora de un coro que -como en las negrillas- toma una onomatopeya de connotación afrodescendiente (sucu-sú-mambé) cuyas repeticiones se van acelerando e intensificando, contra lo cual se irá ampliando el rango de alturas de los soneos, que se multiplican ya que reaparece la guitarra compartiendo ese rol junto al teclado. Mediante el aumento de la densidad cronométrica, de la complejidad fundamentalmente rítmica de las descargas y una ampliación de los ámbitos registrales, sobre todo hacia el agudo en los 
solistas, se llega a un segundo clímax. Tras un retorno breve a la estabilización de la clave y una moderación de los solistas, y sin necesidad de cadencias ni otras redundancias, toda esta urdimbre tejida a lo largo de la canción finalmente se desarma de manera fugaz.

En toda esta curva formal se revela un indicador importante de estas músicas, que confronta con la noción occidental y sobre todo culta del desarrollo del material. La ausencia de esta concepción progresiva y hasta evolutiva, típica de la racionalidad moderna, es un rasgo de los más habituales en la música popular, y sobre todo en la afrodescendiente. Por eso proponemos generalizarla y adelantar que la repetición del material, pero específicamente mediante su intensificación en base a las tensiones de sus elementos internos, es un rasgo que no solo define a las músicas populares, sino que les permite exhibir rasgos disruptivos y divergentes. Si se quiere, como veremos, subversivos. Mediante la organización mulata, que es heredera del camuflaje de las músicas "negras" y mestizas coloniales, de sus identificaciones transculturales, podemos escuchar en sus propios materiales, como banda audible, la crítica hacia la dominación de los sectores subalternos. No necesitamos para descifrar esto ni siquiera mencionar el texto de la canción que, por si hiciera falta, dice entre sus estrofas «a la mar me llevan sin tener razón [...] Ay! no manda el Congo [...] el palo de la jeringa va derecho a su lugar». A pesar de estas proclamas creemos que la tonada El Congo dice mucho más en los sonidos que se descubren debajo de la máscara del texto.

Hay también otra historia musical que, a modo de cierre, quisiéramos brevemente comentar, ya que justamente se transformó abiertamente en expresión contestataria: el fandango que actualmente se circunscribe al área del estado mexicano de Veracruz. Autores como Camacho (2011) o Griego (2002) le confieren directamente un carácter de subversión al orden social. Si bien el Fandango es conocido como una danza española, otras hipótesis afirman su origen novohispano, entre otras muchas como mencionamos antes

Entre los bailes que, "de las Indias a Sevilla han venido por la posta", figuraban el capuchino, el zambapalo, el fandango, la gayumba, el zarandillo, el retambo, la zarabanda, el zarambeque, el paracumbé o cumbé, el guineo y la chacona, entre otros. Muchos de ellos fueron luego estilizados por grandes compositores de diversas épocas y latitudes (Ortiz Oderigo, 2008, p. 48)

Por otro lado es muy indicativo de la difusión y cuotificación del mestizaje y la mulatería, que a la danza que se llama justamente congo se la identifique como idéntica a la chica, que su vez se entiende como traducción lingüística de fandango, y que tendría extensión no sólo en los Andes, sino desde el Caribe hasta el Río de la Plata

Otra danza de origen africano es la chica, que en las islas de Barlovento, en el Congo y en Cayena llaman calenda y que los españoles llaman fandango (Moreau de St. Méry -1798 , como se citó en Ortiz Oderigo, 2008, p. 89)

Podemos decir que el fandango ya es, entre otras cosas, mexicano desde tiempos del sometimiento colonial (Katz, 2001). Aunque puede postularse en términos de dialogismo (Camacho, 2011, p. 45) es producto de un proceso histórico de apropiación, estilización y ocultamiento que comparte, por desgracia, con otras muchas músicas latinoamericanas, como la zarabanda o la chacona que ya mencionamos. Lista a la que a esta altura consideramos posible añadir la negrilla.

Descartando por improcedente toda discusión sobre el origen, lo importante aquí es el carácter afrodescendiente del fandango como expresión popular y musical, aspecto este último que como género pasó con el tiempo a conocerse como son jarocho. En este caso incluso cabría hablar de un particular sentido de mestizaje y mulatería: lo caribeño 
afroandaluz (Griego, 2002). Más que un tipo de música, el fandango «es un sistema de ocasiones musicales» (Camacho, 2011, p. 45) en el que las identificaciones y las contradicciones del orden colonial que discutimos en extenso con anterioridad aparecen como claros protagonistas. Estas ocasiones fueron producto de los oratorios, espacios de reunión con función ritual cristiana generados a partir de que las autoridades virreinales delegaran en los primeros siglos de la colonia la observancia de la liturgia en las familias patricias o criollas de las zonas más alejadas, como las plantaciones, ante la escasez de iglesias y personal eclesiástico, y en virtud de la magnitud de la tarea evangelizadora propuesta por la Corona. De esta forma, en estos lugares domésticos de reunión se dan cita las comunidades indígenas, los esclavos africanos, los españoles pobres, los ricos nobles o hacendados, los comerciantes. Todos portadores de tradiciones diversas que, al derivar estas experiencias en la configuración de la religiosidad popular tan habitual en Latinoamérica (Quintero Rivera, 2005, p. 234), dan lugar a prácticas musicales y dancísticas de carácter mestizo y/o mulato: zarambeques, jarabes, zapateados, jaranas, sonecitos, villancicos, tocotines que se van configurando a partir de la heterogeneidad, siempre conflictiva, de multitud de danzas y cantos africanos, indígenas, andaluces o castellanos. Provenientes de «todo género de gente [...] de distintas costumbres» (Camacho, 2011, p. 53).

Una vez prohibidos los oratorios en un proceso cuasi análogo al de los takis del Perú, y reencauzado el ritual en la Iglesia, el sistema de ocasiones permanecerá secularizado y se transformará en el emergente de la fiesta comunal subalterna: el fandango. Vinculado a la independencia, el sentido contrahegemónico del fandango se agudiza. Se puede ver, si se quiere, en las letras, prohibidas permanentemente por la institucionalidad colonial. Pero eso es la superficie. Hacer visible el cuerpo y colocarlo en el centro, poblarlo de manoseos, contoneos, gestos "indecentes" es en cambio parte del núcleo de la subversión que estos espacios proponen. Como vimos en el capítulo 2, el cuerpo y sobre todo su exhibición son un rasgo específico de la cultura popular, que justamente permite suspender la escisión de la cultura legítima occidental entre mente y cuerpo, razón y emoción

entrar en comunión con la vida de la parte inferior del cuerpo, el vientre y los órganos genitales, y en consecuencia también con los actos como el coito, el embarazo, el alumbramiento, la absorción de alimentos y la satisfacción de las necesidades naturales (Bajtin, 2005, p. 25).

Estos bailes mestizos son un conjunto signado por la integralidad con las músicas y toda la ocasión social. Tomemos como ejemplo una canción o «sonecito del país» prohibido por la inquisición y de constatable participación en el sistema del fandango: el Pan de xarabe ${ }^{309}$, fechado al menos hacia fines del siglo XVIII. La versión que de él hace el guitarrista argentino Gabriel Schebor junto a la cantante Mercedes García Blesa, ${ }^{310}$ basa su estructura en un esquema de rasgueo derivado del complejo rítmico del son jarocho: una clave en contratiempo sobre una pulsación ternaria

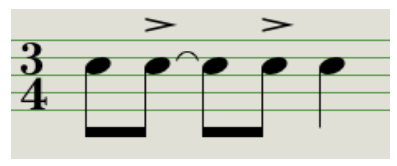

Más allá de que la versión exhibe un carácter lírico muy marcado y en ocasión de concierto de cámara, el efecto de circularidad e inestabilidad permanente que genera este esquema rítmico en su relación con la melodía de la voz impiden reunir a ambos planos y

309 Archivo General de la Nación, México, Inquisición, vol. 1297, exp. 3, año 1784.

310 El ejemplo 67 escucharse aquí https://youtu.be/Qj9qQXqEXfo 
estabilizarlos en una relación subordinada convencional. El rasguido de "acompañamiento" nos obliga a volver la atención hacia él constantemente, incluso cuando repite en toda la canción la misma secuencia armónica. Es un efecto similar al del joropo venezolano y tantas otras músicas populares latinoamericanas.

Pero el fandango no solo se actualiza en conciertos de música culta. Es una expresión vigente en las fiestas populares del estado de Veracruz. En marcada analogía con la fiesta de San Ignacio de Moxos, la fiesta patronal de Santiago Apóstol en la ciudad de Santiago Tuxtla contiene entre sus actividades uno de los despliegues más conocidos del fandango. Si tomamos un registro ${ }^{311}$ entre tantos que se realizan año a año, podremos advertir otras dimensiones que nos remiten muchísimo más a su carácter contrahegemónico. Para empezar, el instrumento principal, el más sonoro, es la tarima, sobre la cual se despliega el zapateo. Son únicamente mujeres las que bailan, en parejas, e instalan así la presencia absoluta de los cuerpos. Este es el plano principal, pero no hay centro en esta música. Esto se advierte en el registro, en el cual la cámara debe transitar permanentemente entre las bailadoras, los músicos y todo aquél que está participando en la ocasión. De hecho el recinto que se adivina una carpa, está hacinado de gente. Todos los que no bailan intervienen en la música, y aquí aparece el segundo plano, representado por jaranas de distintos registros y guitarras. Es imposible saber a ciencia cierta cuántos músicos son. Da la impresión que cada quien concurrió con su instrumento y que, independientemente del número, todos tienen un lugar en la participación. Esta sensación se refuerza por el comportamiento de cada instrumentista que, si bien está integrado en el colectivo -que es el que manda-, actúa individualmente. Todos basan su performance en la clave que mencionamos antes, pero la alteran constantemente con ornamentaciones, subdivisiones, aumentaciones y cuanto recurso de variación rítmico-tímbrica exista. A estos recursos de variación, curiosamente se les llama tangueos. La armonía se mantiene siempre en una secuencia muy simple de dominante y tónica con alguna excursión breve a la subdominante. Pero ningún instrumento está afinado exactamente como los demás, por lo que el efecto tímbrico es increíblemente diverso. Sobre esta base a su vez se suceden en alternancia las figuras, punteos espontáneos e improvisados que hacen los instrumentistas, con las versadas, fragmentos cantados improvisados sobre un tema común a toda la ocasión del fandango. Los cantantes que se alternan también son muchos y hay tanto hombres como mujeres.

Aquí, el sonido, la rugosidad de la diferencia de afinación, la rusticidad de los rasguidos que transforman los instrumentos de cuerda en percusión, los redobles sobre la tarima, no son detalles. Establecen la especificidad del musicar a través de las tensiones no resueltas que se expresan en las discrepancias participatorias. Son materiales en tensión dialógica permanente, prácticas dialogantes entre lo cantado, lo textural, lo rítmico, lo bailado, y que se interesan más por los contrarrelieves, por los huecos y los pasajes, que por las figuras protagónicas. Compartiendo rasgos con el resto de las músicas mulatas afrolatinoamericanas, podemos entender que en las ocasiones del fandango la elaboración musical no se basa, como en Occidente, en una única dimensión -la armónica. La música tonal europea es la que responde a un esquema newtoniano (Quintero Rivera, 2005, p. 48) integrado en relaciones infinitamente repetibles, funcionales y despersonalizadas: abstractas. En las músicas populares latinoamericanas, en cambio la relación dialógica entre melodía, armonía y ritmo implica [...] «una exploración entre las complejidades del ser y el convertirse. Y de aquí la importancia de la seducción en el baile [...] sin desenlace determinado» (Quintero Rivera, 2009, p. 84). Adorno hubiese querido decir de la música de vanguardia lo que Camacho describe a continuación del fandango:

311 Puede escucharse aquí https://youtu.be/plVXMr3XW-k 
De esa compleja diversidad emerge la unidad que supera las particularidades, que desdibuja la diferencia diluyendo las identidades previas [...] para después, como configuración inesperada, mixtura reciente, volver a diversificarse (Camacho, 2011, p. 45)

Como todas las músicas latinoamericanas que someramente tocamos a la pasada en esta sección, el fandango es urbano y desde tiempos coloniales fue practicado por profesionales, tanto músicos de la Iglesia como seculares. Da igual que fuesen españoles, indios, criollos o africanos, pues todos, aun permaneciendo en sus puestos oficiales, practicaron la cimarronería que produjo, mediante la huida y la evasión, pero también la identificación, el fracaso del ideal hidalgo. En cambio, todo aquello que los románticos y los positivistas colocaron como identificadores del folklore no lo encontraremos aquí. La pretendida comunalidad y anonimato no participan de ningún modo en el las músicas mestizas y mulatas. Tampoco impera aquí "primitivismo" alguno ya que, como vimos, existe un continuo proceso de cambio y mutabilidad históricos desde el mundo colonial hasta el las músicas populares de nuestra contemporaneidad. Lo cual nos lleva irremediablemente a impugnar, creemos que de forma definitiva, las pretensiones de musicólogos y folkloristas como la autenticidad y el "purismo". No hay forma de sostener esta búsqueda de lo "no contaminado" en las músicas populares latinoamericanas. Como expresó con claridad Simón Bolívar "Es imposible asignar con propiedad a qué familia humana pertenecemos [...] Nacidos todos del seno de una misma madre, nuestros padres difieren en origen y en sangre». Nuestras músicas expresan esa asunción. 


\section{Conclusiones}

«Mientras la cultura popular es siempre una realidad verificable, la cultura oficial resulta con demasiada frecuencia en nuestros países un simple proyecto ideológico» Adolfo Colombres (2007)

«Actuamos, en general, como si el pueblo fuera mudo, aunque hagamos todo lo posible para que no sea sordo» Eduardo Galeano (1981)

\subsection{Estamos en esto sólo por el dinero}

A principios de 1968, Frank Zappa y sus Madres de la invención editaron un disco para nada excepcional en su trayectoria, ya que estaba cargado de sátira e ironía. Fundamentalmente, como puede apreciarse en al arte de tapa, estaba pensado como una contracara del mítico álbum de los Beatles de 1967, Sgt. Pepper's Lonely Hearts Club Band. Es una especie de disco anti-pop, anti-sistema desde dentro del sistema, porque la actitud es más discursiva que sonora, como suele pasar con el rock y su permanente estratificación (Keightley, 2006). Pero la parte que más nos interesa es el título del disco: We're only in it for the money, es decir «estamos en esto sólo por el dinero». Preguntados sobre el tema durante una clase, los estudiantes de música de una universidad nacional aventuraron una hipótesis acerca de la composición irónica de Zappa: «la discusión es entre la música comercial y la música de verdad». Algo muy llamativo es que más de la mitad de esos estudiantes eran cursantes de la carrera de música popular.

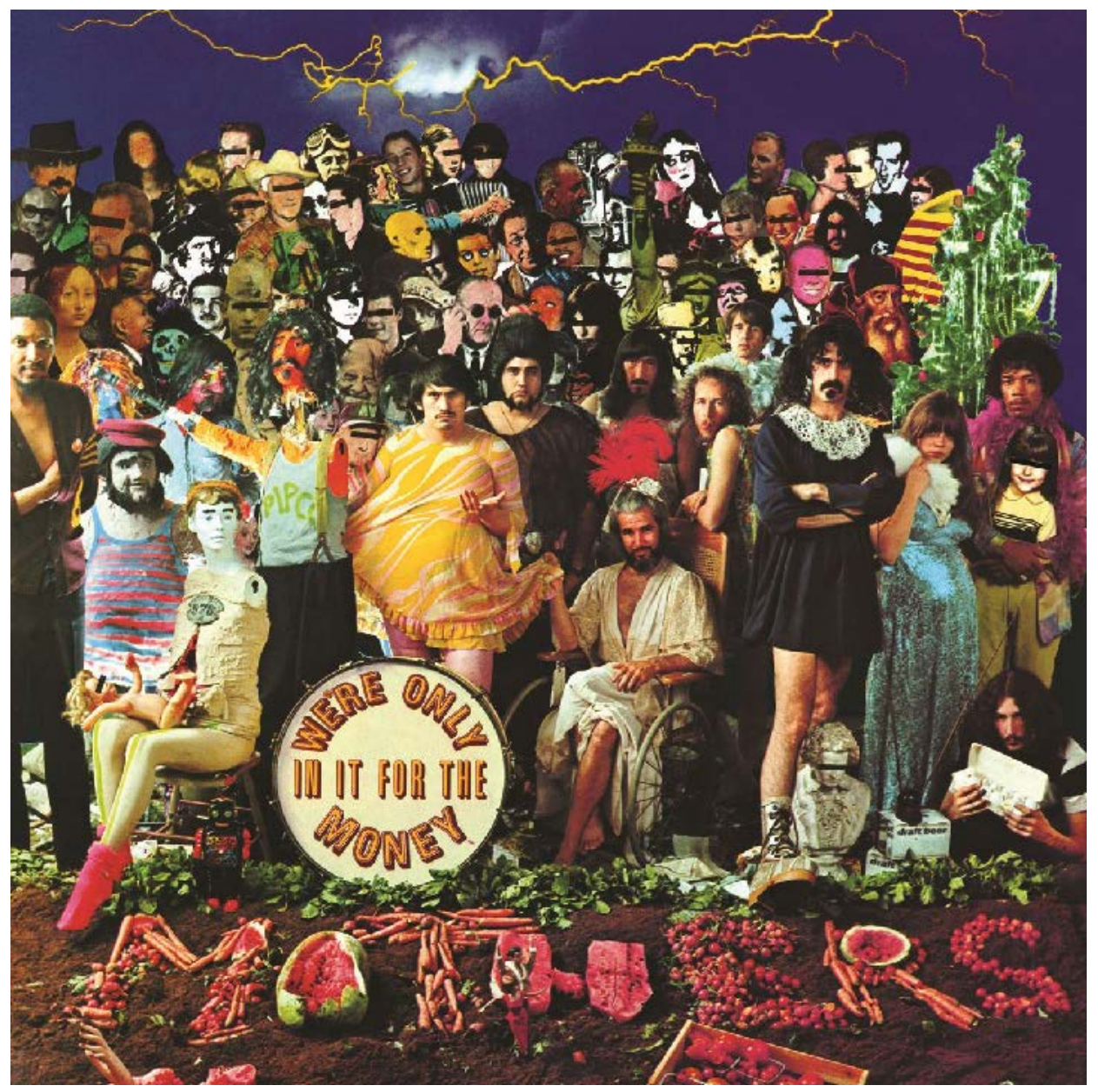


Queremos recuperar el hilo de la discusión que hemos desandado durante todo este estudio para abordar una síntesis final, comenzando por la consideración sobre el carácter profesional de los músicos que, a lo largo de la historia, ha planteado numerosas paradojas. Pues se ve que, aún hoy y para quien estudia música en una universidad, hacer música en tanto profesión está mal. O para decirlo en términos de folkloristas y musicólogos: es inauténtico.

Algo que comparten las figuras de Cercamon, Januario Soriocó, Higinio Cazón, Conrado Tedesco y la plétora de colegas suyos que están incluidos, sin nombre, en las historias que recuperamos durante los capítulos de este texto, es justamente que todos hicieron lo que hicieron por dinero, pues esa era su forma de vida. E incluso porque lograba para ellos un lugar de sentido dentro de la sociedad: los hacía parte, se convertían en sujetos de un colectivo social que los identificaba, al mismo tiempo que su tarea musical contribuía a la identidad de ese colectivo. Éste podía ser una ciudad, una parroquia en la selva, la comunidad en torno a un castillo, o un grupo racializado en una sociedad de castas; y, como vimos también, la antítesis de esto, de lo que todos querían salir, era la proscripción, el estar por fuera de la sociedad. Pero paradójicamente o no, nuestra cultura musical, parte de una cultura fundada en la asimilación y la integración de los sujetos en el colectivo (la nación, el estado, el mercado, etc.), celebra en los músicos justamente lo contrario a este movimiento gregario: la autosuficiencia y el aislamiento del compositor, contrariando su ser social por antonomasia, que además debe ocultar las relaciones económicas de su arte, pues, como vimos en el capítulo 1, la propia urdimbre de la obra musical culta depende de esa opacidad, de que se la salvaguarde de ser considerada una mera mercancía.

Es llamativo que esta preocupación por distinguir entre una música auténtica y otra artificiosa (en el siglo XX se dirá fetiche) haya aparecido precisamente en el momento en que emergió el mercado musical: la modernidad temprana. Richard Taruskin (2005b) recuerda que a comienzos del siglo XVI Giulio Caccini, compositor y cantante bajo mecenazgo de los Médici -es decir, un matricero en términos de Attali- recuperaba la noción de sprezzatura que había acuñado Baldassare Castiglione en su famosísimo tratado Il Cortigiano del s. XV. El objetivo de Caccini era denostar a los músicos profesionales que eran para él lo opuesto de este indicador cortesano, pues utilizaban recursos sonoros con el fin de hacer atractivo su arte (y así ganar dinero). Estos recursos los denominaba passaggii, y los definía como un cosquilleo superficial que, al ser lo contrario de lo profundo y emocional, sólo causan efecto en quienes no comprenden de música. Pero ¿qué cosa es la sprezzatura? Una traducción española del libro de Castiglione hecha en el siglo XVI contiene una nota explicando los vericuetos de esta palabra,

"La cual por agora nosotros la llamaremos desprecio". Así tradujo Boscan la palabra italiana sprezzatura, mas la castellana desprecio no ha llegado á tomar esta acepción, sino que se usan, para significar lo que la voz italiana da á entender, las palabras abandono, ó más propiamente naturalidad, $y$, en las artes, aquella facilidad dificultosa que es compañera inseparable de la belleza (Castiglione, 1873, p. 535).

En la concepción de Caccini y Castiglione, que es la concepción académica que también está presente en el mundo del rock y otros géneros estratificados, lo que se juega es mucho más que una posición estética. Son ideas que hablan de la composición social y económica, además de cultural; es decir del todo social, tal cual lo hemos referido a partir de los aportes de Eagleton, Attali, Small, Estenssoro o Quintero Rivera. Lo que se esconde detrás de esta discusión aparentemente estilística y de gusto es la condición de la libertad, en la particular y restringida versión que es constitutiva de las clases hegemónicas de la modernidad. «El desprecio hacia el virtuosismo revela un viejo prejuicio aristocrático, heredado de Aristóteles 
[...] para que así su condición de "hombres libres" no se viera comprometida mediante una infusión de profesionalismo servil» (Taruskin, 2005b, p. 23). El profesionalismo es vulgar, nos hace "comunes", y aquellos que adulan a los profesionales y los estimulan con el aplauso no hacen otra cosa que convertirse en gente de la misma calaña: el populacho herderiano, es decir la clase baja. Aquí hay un hilo de plata que recorre, oculto por sus propios practicantes, toda la historia de la música occidental, ya que, como vimos, el horror a lo común y a lo que lleva a la igualdad -que para la ideología de la modernidad/ colonialidad es lo contrario a la libertad, más allá de la proclama marsellesca- estuvo presente desde la misma época feudal en que los libros de historia de la música inician su prolijo relato.

Caccini expresó sus opiniones clasistas como era costumbre en su época, en el prefacio de un cancionero que, como también era habitual entre los académicos, se llama «la nueva música» (Le nuove musiche). Un título que, visto a la distancia, es un claro producto del marketing. Por eso es igualmente interesante que Taruskin encuentre al contenido del prefacio de Caccini como «una comparación sarcástica, e incluso extravagante» (Taruskin, 2005b, p. 24) cosa que podríamos decir también del disco de Frank Zappa, como atestigua una nota periodística en donde podemos leer que esta obra:

hizo que mucha más gente se riera de forma incómoda que cualquier otra [...] el álbum parodiaba todo [...] y fue un esfuerzo consciente del artista por lograr que los jóvenes de su tiempo se detuvieran a mirar un minuto cuán tonto era todo ${ }^{312}$ (Goldstein, 2007)

Omitimos del pasaje las referencias directas pues, si lo leemos así, no sabríamos con seguridad si el comentario crítico es hacia el disco de Zappa o al cancionero de Caccini. Lo que nos lleva a otro paralelismo: Le nuove musiche fue un éxito editorial dentro del auge de la música impresa de comienzos del siglo $\mathrm{XVI}$, sobre todo del tipo de canciones que componía -o vendía- Caccini (Carter, 1993) que, si lo consideramos en relación a las dimensiones del mercado musical de la época, estaríamos tentados de llamarlo masivo. Sin embargo, fue un éxito efímero, como todos los de su clase antes de que el siglo XIX inventara la noción de repertorio y explotara el pasado musical, como vimos que también hacía el folklore, fabricando una memoria popular. El verdadero éxito de Caccini, su nueva vida heroica, comienza a partir de que la historiografía musical señale como inicio de la música moderna el grupo aristocrático al que él pertenecía: la camerata de los Bardi o florentina. De estos héroes y su sprezzatura surgió en el relato afirmativo, la armonía tonal, la noción de espectáculo, la melodía cantable con acompañamiento, la idea de llevar a la música la estructura dramática de la poesía; si hubiesen inventado además la partitura, la orquesta y el piano, serían los padres fundadores absolutos de la música occidental.

De forma extrañamente similar We're only in it for the money llegó al puesto número 30 de la lista Billboard, aunque «obtiene su mayor impacto cuando los fanáticos del rock lo consideran históricamente» ${ }^{313}$ (Goldstein, 2007). Tal vez por esto las analogías entre Taruskin y Goldstein aún no terminan: «Para encontrar a los herederos de Caccini y su sesgo antipopular basta leer en el periódico local al crítico musical de turno y sus comentarios sobre interpretaciones y discos» (Taruskin, 2010.b, XXX) dice el primero, mientras que el segundo completa la descripción de Zappa y los Mothers: «con cuánta

\footnotetext{
312 «this record made more people laugh uncomfortably than any other I know of (until the Sex Pistols released Never Mind The Bullocks... 10 years later [...] The record parodied everything [...] and was Zappa's conscious effort to get the youth of the day to stop a minute and look at how silly everything was» (Goldstein, 2007) [traducción del autor]

313 «it has had its greatest impact when viewed historically by fans of rock music» (Goldstein, 2007) [traducción del autor]
} 
crueldad -pero con qué talento- una banda de esa época podía satirizar a otros músicos de su tiempo» ${ }^{314}$ (Goldstein, 2007).

En la memorable portada de Zappa aparece, entre tantas otras cosas, una curiosidad relevante: justamente a los pies del músico, en la parodia a la cubierta original de los Beatles, aparece el célebre busto de Ludwig Van Beethoven, casi un fetiche que encontró su lugar sobre el piano o la chimenea de los salones de la burguesía moderna. Pero en los bocetos de Zappa publicados por la revista Mojo se revela un dato que refuerza aún más la estratificación: la idea era colocar un busto del compositor vanguardista Edgard Varèse. Aunque como no pudieron conseguir ni fabricar uno para la toma fotográfica, el pétreo puesto protagónico quedó para el más trillado compositor de Bonn.

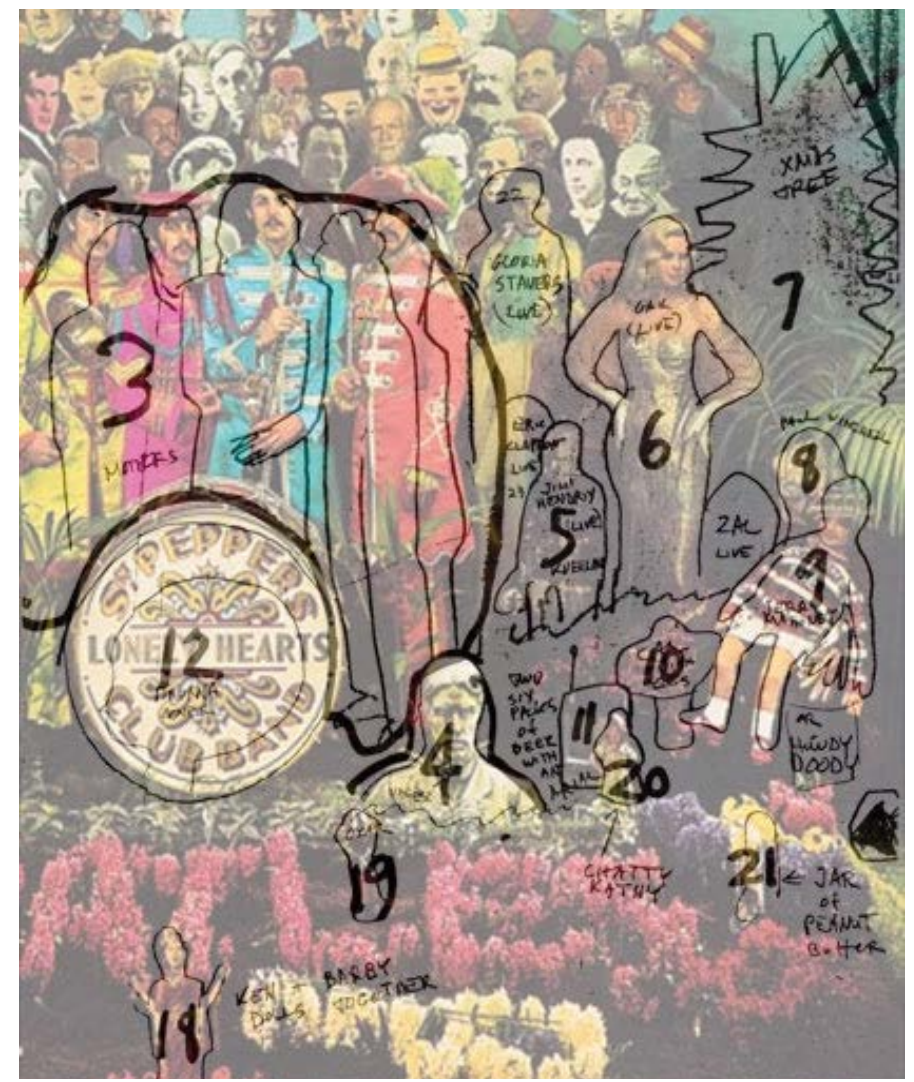

Boceto de la portada de We're only in it for the money sobre la fotografía original de los Beatles. Debajo del número 4 puede leerse la inscripción "Varese"

Pero si observamos la caracterización de los mismos Beatles en la carátula objeto de la parodia, existe un elemento más que curioso. Los músicos de Liverpool están caracterizados como los ministriles de nuestro estudio, de uniforme y cada uno de ellos portando un instrumento de viento, es decir, un conjunto de música "alta", si bien conformado por un instrumental más actual, aunque podríamos pensarlo como derivado de las chirimías y los sacabuches de la modernidad temprana.

314 «how mercilessly - and with great talent - a band from that era could spoof its musical brethren of the time» (Goldstein, 2007) [traducción del autor] 


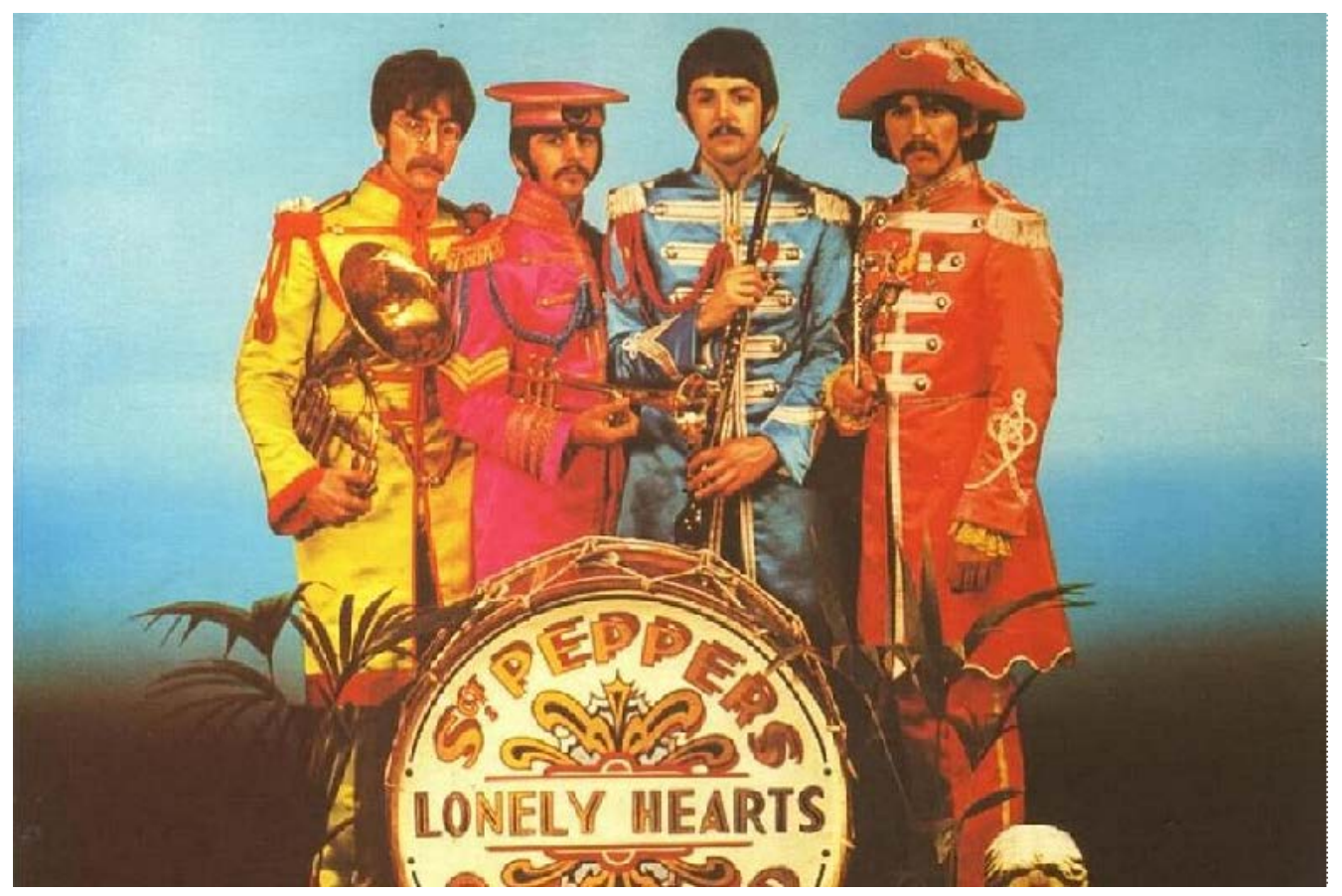

Los beatles como ministriles portando instrumentos "altos", en la fotografía de la portada de Sgt. Pepper's Lonely Hearts Club Band.

Cuando comenzamos esta investigación, nos propusimos como tarea la de encontrar evidencias de una práctica profesional de la música en el pasado que pudiéramos relacionar con la cultura popular. Como lo expresamos en los problemas de investigación que aparecen en la introducción, pensábamos que la dificultad sería trasladar al pasado de la larga duración la categoría de lo profesional, ya que según los Popular Music Studies (PMS) era ésta estrictamente actual para el caso de la música popular. Sin embargo, en el transcurso de la indagación se nos hizo evidente que el problema no era ese: los profesionales asomaban por todas partes y, como dejamos en claro en el caso de los ministriles europeos, existe abundante evidencia acerca de su profesión. Del mismo modo hay cuantiosos datos acerca de los músicos profesionales mestizos y pardos del mundo colonial americano, así como de los payadores del siglo XIX, de los artistas del circo criollo, de los maestros músicos de las reducciones indígenas, e incluso de esos proscritos juglares que, por ser tan anatemizados, terminan apareciendo por todas partes en las fuentes, incluso en los dibujos y miniaturas de los tratados musicales medievales más famosos, realizados por amanuenses de la mismísima institución eclesiástica.

Si encontrar a los profesionales no es demasiado complejo, el problema está en otro lado; no en la dificultad para encontrar respuestas a partir del pasado, sino, como advirtió Small (1999), en el tipo de preguntas que le hacemos a ese pasado histórico. Y en las herramientas que elegimos para buscar las respuestas.

Es evidente que la pregunta acerca de lo profesional en el pasado histórico no ha despertado interés en la historiografía musical. Para la musicología histórica, como vimos, es importante encontrar el estilo de los compositores para clasificar así las obras. Como éstas son producto de matriceros y no de trabajadores, la condición profesional no es un atributo de los sujetos de la historia de la música; los cuales incluso, en la magistral formulación del positivismo de Dahlhaus terminan siendo las mismas obras-objeto antes que los compositores-matriceros. Si la historia de la música «debe ser una historia de las obras» (Dahlhaus, 1997, p. 36) y de su clasificación mediante la categoría a-social, apolítica y por ende a-histórica del estilo, en su relato no aparecerán los profesionales del 
sonido pues estos se explican fundamentalmente a partir de las relaciones sociales y económicas mediante las cuales produjeron el capital simbólico que los vinculó a las comunidades en que se desempeñaron. Si los juglares y los ministriles fueron profesionales es porque pudieron interpelar desde el sonido al conjunto de la sociedad de su tiempo y, especialmente, a los sectores subalternos, ya fuese para producir esa inversión carnavalesca del sentido o para potenciar los vínculos de las mayorías dentro de la comunidad, incluso cuando esto implicó identificaciones y procesos de asimilación al diseño sociopolítico de los sectores hegemónicos. Esto hace que sus prácticas musicales sean intrínsecamente sociales, imposibles de estudiarse e interpretarse -en un sentido hermenéutico- por fuera de las ocasiones musicales en las que están inmersas. Es decir que existe un estrecho vínculo que hace que las prácticas musicales, las músicas, sean específicas del ritual social que contribuyen a configurar ¿Podríamos preguntar por algún sentido más auténtico de la producción musical? Justamente la autenticidad que no funciona con la música popular -aunque en realidad creemos que no funciona con ningún tipo de música- es la que pregunta por los orígenes. Y eso nos lleva a una segunda conclusión de las prácticas profesionales en el mundo subalterno, y es que son dinámicas. Es decir que modifican esas relaciones que generan el juego intersubjetivo o dialógico entre los músicos y el conjunto social, sus sentidos simbólicos y sus funciones socioculturales. Por lo tanto, es evidente que son históricas, pero sólo en la medida en que entendamos que la historia no consiste en encontrar el big-bang, el momento fundante para después desentenderse del devenir en el tiempo de los fenómenos y las prácticas. Esta búsqueda de orígenes es un rasgo habitual en la historiografía musical afirmativa, que revela su compromiso con el positivismo ya que, recordemos, la historiografía francesa acuñó el concepto de larga duración para oponerla al positivismo y su obsesión con los orígenes.

Pues bien, las músicas populares se dan en la larga duración y por eso sus temporalidades históricas suelen ser lentas, superpuestas y difusas frente a pretensiones cronológicas puntillosas. Los cambios en las prácticas musicales del mundo popular subalterno son lentas, plagadas de imbricaciones y micro-transformaciones, aspecto íntimamente relacionado con el carácter dialógico de la creación. Pero además involucran otras temporalidades que se relaciones de manera contenciosa con la teleología de la modernidad occidental y su esquema evolutivo de progreso. Es el tiempo, por ejemplo, de los ciclos de renovación y renacimiento, como vimos asociados al segundo mundo carnavalesco de la música popular medieval. En ese tiempo se forja un sentido profundamente alternativo del concepto de "renacimiento" que se vincula más con la presencia de los antepasados y la posibilidad de dialogar con ellos en el presente a partir de la ficcionalidad de la música y la performance, que con la recuperación descontextualizada de doctrinas teóricas para genera un arte nuevo, como el de Caccini y sus coetáneos. En cambio, la temporalidad de referencia del mundo al revés popular está basada en el tiempo íntimo, de una-otra escucha interna que en lugar de racionalizar el sonido leyendo una partitura silente, escucha los ritmos orgánicos del cuerpo; pues por eso las músicas populares son antes que nada bailables (Quintero, 2009): las laude medievales y las canciones de los peregrinos, el fandango caribeño afroandaluz y el saltarello de los ministriles, los congos y o las lanchas coloniales. Es también la temporalidad circular de las sociedades andinas en las que se vuelve a la vivencia de los acontecimientos históricos, en la medida en que no se los escribe sino que se los pone en acto a través del canto y la danza; en realidad de la fiesta integral (taki, mitote, areito, tocotín) mediante la cual, como en los jailli andinos, la historia se hace presentacional, performance. Incluso es un tiempo heteróclito, que admite la contradicción que en las culturas andinas se manifiesta con el tercero incluido, y en las culturas afrodescendientes mediante el reconocimiento de la posibilidades de que algo sea "esto $y$ aquello", lo propuesto junto con su opuesto; así aparece la posibilidad rítmico-textural múltiple de las músicas mestizas, afrodescendientes y criollas de Latinoamérica que recogimos en las descripciones del capítulo 3 -las payadas 
de las "negras rebuscotas" de Echeverría, como Núñez, Nieto o Cazón- en el blues comprimido por Lomax del capítulo 4 y en el variado cimarronaje musical del capítulo 5.

Las múltiples dimensiones experienciales del tiempo popular, éstas que encontramos en el musicar que pudimos estudiar y las muchas otras que esperan ser consideradas en historias populares futuras, conforman ese "pasado hecho de futuros» del tiempo reversible del que habla Cusicanqui en sus flashbacks; si tuviésemos que hacer una de esas líneas de tiempo que hacemos los profesores de historia de la música, tendríamos que ponerle una flecha en cada dirección posible, pues la historia popular va simultáneamente para adelante y para atrás. De hecho, no deberíamos pensar en hacer ninguna línea, pues el tiempo se acerca al espacio en el mundo popular subalterno, subversión grotesca que invierte y vuelve ambiguas las divisiones estrictas entre las dimensiones cartesianas. Debemos pensar en otras formas de periodizar la historia, de modo tal que nuestras explicaciones, nuestros relatos narrativos del pasado sean compatibles y respetuosos con estas formas divergentes de temporalidad. La dinámica histórica de la música popular reúne de manera conflictiva temporalidades litigantes, contrastantes, incoherentes estilísticamente; es una materia en permanente movimiento que se escurre y escapa de los límites de las cartografías y las cronologías.

Justamente este dinamismo multidimensional del tiempo histórico popular es lo que el folklore confundió -o mejor, quiso confundir- con un estatismo ahistórico, construyendo ese tiempo mítico primigenio que nuevamente pretende configurarse en un big.bang, ahora del pueblo. Pero como éste debe ser homogéneo y rechazar las contradicciones, pues necesita buscar una esencia que lo distinga de las demás naciones pero sobre todo de los sectores populares vivos, en la concepción del volk se debe eliminar toda posibilidad multidimensional. Esta homogeneidad, que se crea a partir de una racialización, concepto análogo al estilo musicológico, requiere de una voz igualmente compacta y por eso necesita acuñar la noción de comunalidad y asignarle agencia creativa. Esto implica que los profesionales -para la perspectiva folklórica- sean considerados in-auténticos. Así como para el pensamiento académico que habita el paradigma de la musicología histórica los profesionales son despreciables, aplicando así la acepción hispana de la sprezzatura, el folklore desprecia la existencia de estos músicos, ya que no pueden ser considerados parte del volk: son ese otro de la turba chillona, ofensiva, que se resiste a convertirse en el sustento mítico de la nación burguesa moderna.

\subsection{Balada para un juglar}

Algunos autores recientes han intentado problematizar desde el propio folklore estas concepciones, introduciendo la distinción de lo que llaman el «folklore profesional» (Madoery, 2010) o "folklore moderno» (Kaliman, 2006) para referirse a las prácticas referenciadas con el folklore y su concepción sobre la transmisión y la agencia comunitaria, pero que se insertan en los circuitos mediatizados y tecnológicos similares a los que abordan los PMS.

El adjetivo "profesional" permite distinguir el conjunto de prácticas musicales, sus géneros y artistas de, por un lado, el folklore como forma particular de circulación de saberes y bienes culturales y por el otro, de aquellos músicos y prácticas que no buscan insertarse en los circuitos profesionales, que podrían denominarse como amateurs (Madoery, 2010, p. 15).

Si bien esto permite dar cuenta de la trayectoria de artistas profesionales del género musical fonográfico «folclore», la distinción que introduce el término profesional no modifica la consideración de la perspectiva folklorizante hacia el pasado sonoro del mundo popular subalterno. Por el contrario, se refuerza la escisión entre músicas con/sin historia que configuró el punto de partida de nuestra investigación, al subsumir el folclore profesional 
dentro de las categorías de lo que los PMS entienden por música popular. Esta es una concepción que podría confluir con la idea de «folclor de masas» de Juan Pablo González (2014, p. 189) o directamente la identificación de folclor con «industria» que hace Leonardo Waisman (citado en Mendívil, 2016, p. 57). Todo es popular music y por lo tanto, música actual, contemporánea, que no perturba la calma de los hontanares folklóricos que siguen mitificando las danzas y canciones subalternas. Las referencias más actuales sobre lo folklórico indagan precisamente en la identificación con las categorías de la historiografía afirmativa, intentando encontrar el autor desconocido de unas canciones convertidas en objeto.

Hoy en día se acepta que las canciones folclóricas, igual que las canciones de arte, tienen autoría, aun cuando sean anónimas, y no son creaciones "colectivas", aunque la comunidad influya directamente al aceptarlas o rechazarlas. Se sabe también que no todas las canciones son antiguas y que los repertorios folclóricos experimentan cambios constantes. Estos cambios pueden ser espontáneos (innovaciones) o bien estimulados por el contacto con otro grupo de personas (aculturación), de manera que se componen nuevas canciones y las viejas se desechan o reciben un uso distinto (Myers y Wilton, 2008, p. 1012)

Subrayemos la identificación igual que en las canciones de arte que aparece en el pasaje de este prestigiosísimo diccionario musical. Lo cual nos devuelve a esa convergencia ideológica entre musicología histórica y folklore que abordamos en el capítulo 3 y hace que sus categorías específicas sean significativamente equivalentes. Justamente por eso hay algo en el rechazo a lo profesional que directamente fue enarbolado por los folkloristas, fundamentalmente esos cazadores/creadores de baladas como James Child o Cecil Sharp, ansiosos como vimos en el capítulo 4 de "limpiar" de todo vestigio de profesionalismo las músicas transmitidas de forma oral. Alan Lomax decía que «la imprenta mató a la balada» (Kuralt, 1991), especificando que esos vestigios procedían de un tipo de profesionalismo -el de los músicos urbanos que estudiamos en el capítulo 5- que se vinculaba con una industria ya presente desde el siglo XVI: la imprenta musical de canciones populares (en un sentido de circulación pero también de clase social) relativa a dispositivos como los panfletos, los pliegos sueltos, los libros de cordel o los trovos, muy presentes en la América Latina colonial (Bernand, 2014). Es curioso que el mismo Simon Frith tiene presente que el mercado musical, el de la música popular, se remonta al siglo XVI (Frith, 2006), cosa que luego contradice -y esta sí es una contradicción que no permite convivencia- con sus indicadores con que define la popular music. Podría argumentarse que aquí no hay medios, que no es una música medial, y por lo tanto no habría industria cultural. Pero es un argumento débil: la producción es en serie, el fin es amplificar la cantidad mediante el abaratamiento de los costos de producción; y se pretende una circulación masiva adecuando tanto el contenido de las canciones como los formatos de circulación y medios de difusión. En concreto, lo que estos trovos venden son las letras, los textos de invención, asociados a tonadas y melodías reconocibles por cualquier miembro de la comunidad de referencia, de forma tal que pueda adecuar el texto a esa melodía acompañándose con algún instrumento popular. Para refrescarle la memoria, el vendedor (un buhonero callejero) canta las canciones mientras las ofrece a viva voz; y para hacer irresistible el producto, los textos de las canciones abarcan un abanico de temas que van desde las más escandalosas novedades políticas a la picaresca erótica, pasando por la moralidad o lo burlesco. Todo este mecanismo hace que Nils Grosch (2005) se permita analizar un corpus al que le llama música popular, en el sentido de mediatizada, en el ámbito de la denominada "Galaxia Gutenberg». Este tipo de materiales impresos es también encontrado en la América Latina colonial tanto por Egberto Bermúdez (2008) como por Carmen Bernand (2014). La clave para poder incorporar estos repertorios a la discusión sobre la cultura musical popular se encuentra, en opinión de estos autores, en la circulación entre la cultura oficial y la cultura escrita, proceso que presenta una alta intensidad en Latinoamérica y que podemos vincular con los análisis que hemos abordado en los casos 
de los payadores del capítulo 3 o de las músicas argentinas del capítulo 4, que se vinculan con el abordaje de la cultura popular de Jesús Martín-Barbero para los siglos XIX y XX. Es muy significativo que Bernand ligue estrechamente estos silencios sobre las músicas populares del pasado con el moto de la autenticidad: «las relaciones entre lo escrito y lo oral han sido constantes, por lo menos desde la época de Juan del Encina. Luis de Góngora ha contribuido con sus villancicos a varias piezas "populares". Éstas, acaso, ¿serían inauténticas?» (Bernand, 2014, p. 44). Recordemos que en realidad, las canciones de los pliegos sueltos, folletos y libros de cordel son las baladas de los folkloristas, la fuente de la cual emanaba el recuerdo oralizado de los informantes del trabajo de campo. Situación muy poco indagada en el ámbito latinoamericano, que requerirá en el futuro de un profundo trabajo de investigación. Simplemente aquí queremos presentar estas evidencias para comprender que el folklore es un modelo teórico ideológico aplicado al fenómeno musical, que decide convertir la memoria popular proveniente de múltiples fuentes (las prácticas, las ocasiones, pero también las formas impresas) en un artefacto estético con propósitos fundamentalmente políticos, aunque también económicos, de acuerdo a la formulación del folk market que tomamos de Adolfo Colombres. Precisamente debemos recordar que parte del consenso de la folksong, situación que se replica en la recepción de Chazarreta por las élites argentinas, es eliminar editar y ocultar, es decir encubrir, los posibles vestigios pasados de una acción del mercado musical o la industria sobre la formación del repertorio presente en la memoria del mundo popular subalterno. El folklore, y volvemos en esto hacia lo que discutimos en el capítulo 4, no es una simple falsación de lo popular. Es más que eso. Es compresión ya que introduce en el cambio, en la reificación del fenómeno sonoro, a las prácticas específicas del mundo popular subalterno.

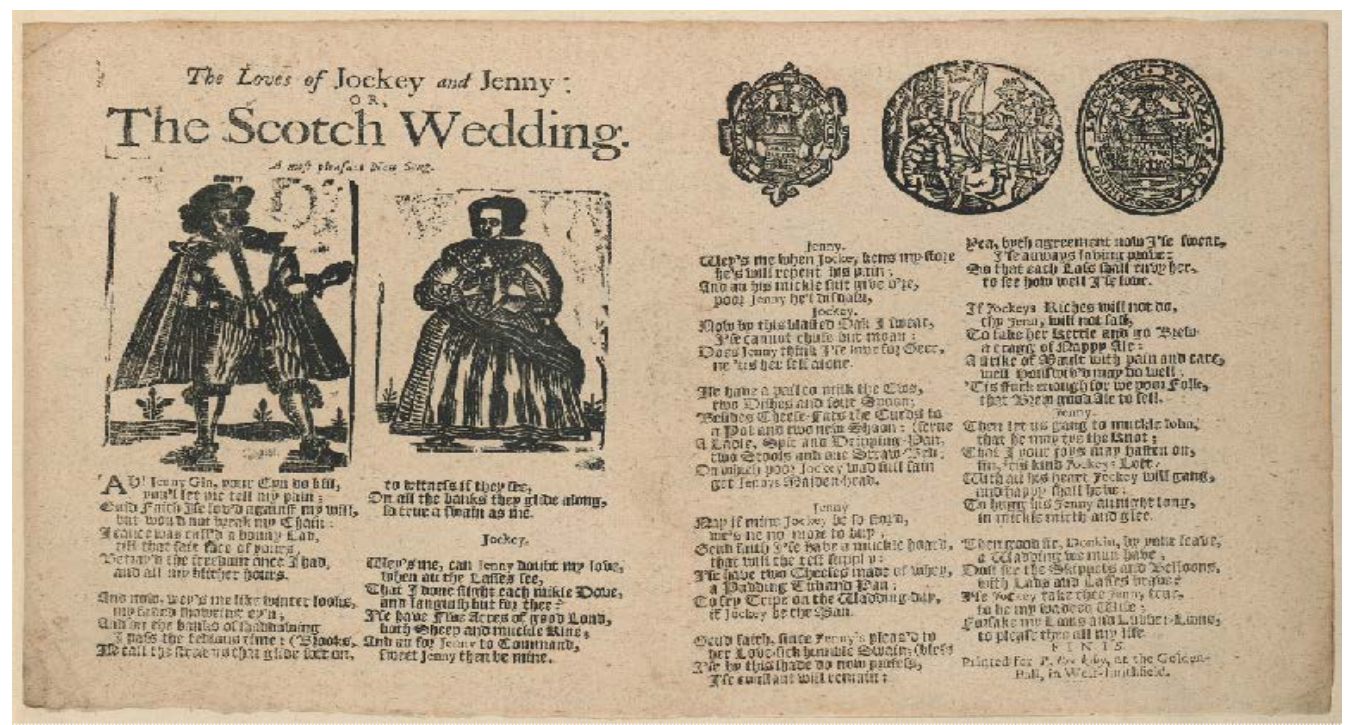

Una balada inglesa del siglo XVI cuyo texto satiriza las costumbres de Escocia. Debajo del título puede verse la indicación "a pleasant new song", lo cual implica que la tonada era de invención y debía aprenderse de oído del vendedor callejero que comercializaba estos pliegos sueltos 


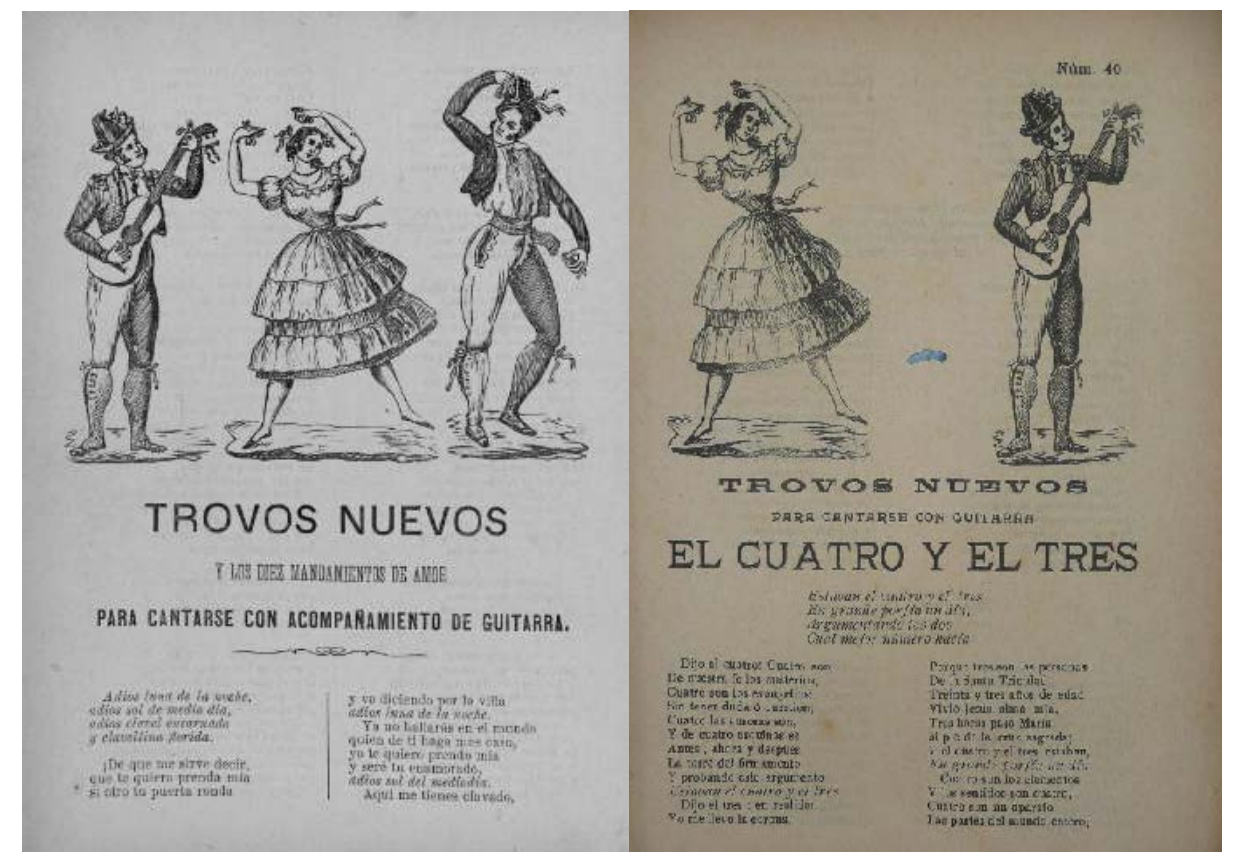

Trovos (pliegos de cordel) del siglo XIX de circulación en América Latina con canciones para acompañarse con la guitarra. La presencia de este tipo de formato en nuestra región se remonta al mismo siglo XVI.

Esta modalidad operativa no se restringe al folklore sino que también aparece en la música culta patrocinada por las mismas élites mediante el nacionalismo musical, que toma prestada esa idealización que el folklore hace del volk. Pero incluso podríamos pensar en otras ramificaciones de esta identidad ideológica común: es muy sugerente en este sentido el estudio de Simon Reynolds (2016) acerca de cómo se manipula actualmente la memoria colectiva mediatizada en la música popular $-\mathrm{y}$ también en la cultura popular en sentido amplio- a través de las operaciones de revitalización del pasado cercano, produciendo una "retromanía" que acerca cada vez más al presente el umbral histórico del pasado revisitado. Reversión -en el sentido de versión pero también de ir hacia atrás en el tiempo- que constituye, naturalmente, una nueva forma de edición, análoga a las del folklore y la musicología histórica. Incluso es sintomático que la categoría que aparece identificada con los procedimientos "retro" sea, ni más ni menos, que el estilo, indicador que también aparece frecuentemente aplicado en los estudios de los PMS, reforzando la convergencia epistemológica que es, como decimos, antes que nada ideológica y presenta conexiones con intereses mercantiles y comerciales en los tres campos. De esta urdimbre estrecha, de estos intercambios e identidades categoriales y epistémicas, surge la compresión de la dinámica del mundo popular subalterno. El folklore, en tanto discurso sobre el pueblo, en tanto orden categorial y clasificatorio, es entonces parte de la cultura oficial, tanto como lo es la historiografía más etnocéntrica y legitimista de la musicología histórica. Al contrario del folklore, estas relaciones y vinculaciones estrechas entre los espacios sociales específicos de sentido musical son justamente uno de los argumentos centrales en los que se basa la adscripción al presente $-\mathrm{y}$ no a la historia- que hacen los PMS sobre la popular music. Recordemos que este campo de los estudios determina como rasgo intrínseco de la popular music a lo tecnológico, lo mediatizado y lo comercial, pero restringiendo estas tres dimensiones únicamente al siglo $\mathrm{XX}$, en función de una estrecha relación entre la industria fonográfica y la multiplicación de la circulación de la música popular. Por lo tanto se introduce como requisito para que una música sea entendida como popular el hecho que debe pertenecer a una sociedad que "ha sufrido el impacto de la modernización» (Middleton, 1990, p. vi). Además de tergiversar de una forma muy simplista las posibles implicaciones históricas de términos como "mercado", "tecnología" y "moderno", se generan múltiples problemas en regiones que salen del mundo angloamericano para el cual han sido acuñados estos términos, como por ejemplo Latinoamérica, cuya entrada -o 
salida- a la modernidad es aún materia de discusión, como advirtiera García Canclini (1997). Aunque el consenso musicológico de la academia latinoamericana se haya adecuado gustosamente a la propuesta, a contramano de la tradición que entendía la música popular vinculada al pasado en todo caso folklórico de nuestra región (como en el caso de Mario de Andrade o el mismo Ayestarán, que no terminó de incorporar la mesomúsica de Carlos Vega) en lo que podría, a partir de un problema de traducción, representar un caso de imposición del lenguaje (González y Smith, 2012, p. 28) o incluso de «conquista disciplinar» (Salvatore, 2016) del campo de la musicología:

[música popular] Se trata de una práctica musical urbana o urbanizada, que es definida por su masividad, mediatización y modernidad. De este modo, quisimos diferenciarnos de las prácticas musicales tradicionales, comunitarias y orales [...] una música mediatizada, masiva y modernizante (González, 2008, p. 4)

La música popular es actual, tiempo presente. Se generó así «una conceptualización presentista de la música popular, en el sentido de que históricamente no va mucho más atrás de mediados del siglo XX» (Johnson, 2018, p. 15).

Para muchos autores, la música popular descrita, dictada por la moda, dura al máximo tres generaciones. Ésta se opondría a la música tradicional, que tiene larga duración y, como el mito, se declina en múltiples variantes ¿Sobre qué se fundan estas afirmaciones? (Bernand, 2014, p. 44)

\section{3 ¿Qué hacemos con el pueblo? Las tres modernidades de la historiografía musical}

Quisiéramos hacer una inversión carnavalesca de la famosa fórmula de Dipesh Chakrabarty (2008): para este autor, el pasado de los sectores subalternos se resiste a la historiografía; sin pretender negar lo atinado de esta afirmación proveniente de la subalternidad, nosotros en cambio queremos proponer como aserto que es la historiografía musical la que se resiste a considerar como históricas las prácticas musicales populares.

Si el folklore introduce a la música popular en el cambio, y si las categorías de las que se sirve son funcionales al modelo epistémico de la musicología afirmativa, entonces es posible que podamos reconstruir una genealogía histórica de la reforma de la cultura popular, pasible de ser periodizada, en donde un punto de partida posible de la narrativa sea el pathos de la distancia feudal, como formulación temprana de la estratificación, condición necesaria para la configuración de espacios sociales específicos de actuación musical. Luego sobreviene la reforma como proyecto de intervención, de disputa dentro del espacio de la cultura popular, expresado en nuestra indagación por la ciudad de la modernidad temprana y el ideal hidalgo de las dos repúblicas en la América colonial. Pero si fundamentalmente ésta última etapa conlleva ya como programa cultural moderno la intención de crear una cultura afirmativa, la transposición de la afirmatividad burguesa que proponemos para la historiografía musical nos permitirá considerar al folklore y a la musicología histórica como una etapa histórica superior del proceso de reforma de la cultura popular por parte de los sectores hegemónicos. Como parte de una historia popular de la música, los folkloristas y los musicólogos son posibles de considerarse objeto de estudio, junto a sus ideas sobre la música, la cultura y el pueblo. Este derrotero histórico, aunque desorganizado cronológicamente, es en parte uno de los resultados que observamos luego de nuestro trabajo. Si al comenzar el mismo -y tal cual puede observarse en el planteamiento de los problemas e hipótesis de investigación que figuran en la introducciónpartimos desde el conocimiento de que se trataban de dos -o más- temáticas relacionadas pero paralelas (la crítica historiográfica por un lado y el estudio concreto de las músicas populares por el otro), en el transcurso del trabajo, y a medida que iban apareciendo 
regularidades y vínculos diacrónicos entre materiales similares, nos dimos cuenta que se trataba de una sola, aunque muy amplia, historia. Una prueba ejemplar de esto fue justamente encontrar que aquello se esforzaban por "depurar" los folkloristas era, precisamente, la acción de los músicos urbanos de la modernidad temprana, incluidos los ministriles, y que muchos de éstos formaban parte de esos informantes que aportaban las evidencias para la construcción del corpus del folklore. Fue en verdad un hallazgo encontrar que, además de esos personajes añejos y cansinos que constituyen el estereotipo del informante, aparecían cantantes de feria, instrumentistas profesionales, juglares trashumantes, mientras que como repertorio folklórico se camuflaban canciones puestas en circulación por músicos profesionales que, en el mejor de los casos, pasaban a la transmisión oral aficionada varios años más tarde, hasta aparecer en el registro de campo de los investigadores. Esta confluencia y contigüidad de las músicas y los sujetos de la historia musical reforzó además la presunción de que el propósito del folklore era, al menos parcialmente, crear una imagen del pueblo y un repertorio popular "autorizado" para los propósitos de la sociedad moderna.

De igual modo, fue algo no esperado encontrarse con que algunos nombres ilustres entre los investigadores aparecían mencionados tanto entre los folkloristas como entre los musicólogos, haciendo que lo que suponíamos una excepcionalidad (en el caso de Vega y Ayestarán, por ejemplo) fuese en realidad una constante. Nos quedaba claro desde un primer momento, y así lo expresamos en la introducción, la identidad de clase de musicólogos y folkloristas. Pero encontrarlos trabajando en ambos campos nos devolvió una imagen mucho más compacta de lo que suponíamos, haciendo que la escisión epistemológica entre las dos disciplinas que caracterizamos como punto de partida fuese más artificiosa aún, pues al contrario de lo que presumimos inicialmente, ésta no obedece a una problemática de nichos académicos sino específicamente a la proyección ideológica de la modernidad sobre la música. Es decir, la musicología histórica derivó en un corpus disciplinar distinto del folklore no por conveniencias y disputas académicas sino por convencimiento de sus practicantes, que siempre consideraron que ambos repertorios eran cosas bien diferenciadas. Lo cual, y como tercer arista, resultó muy coherente que fuera funcional hacia -o consecuencia de- las necesidades clasificatorias del mercado musical, fundamentalmente del que se consolida en la cultura burguesa del siglo XIX.

La mancomunión de folkloristas, musicólogos, críticos, editores y compositores, sumada luego a la de los primeros productores fonográficos, deben ser consideradas como una totalidad, compleja pero articulada, en la cual lo que por un lado se vislumbra como afán de generación de categorías conceptuales, resulta ser, en su contracara, función racionalizadora para producir criterios de producción comercial y consumo estandarizados de la(s) música(s). En este sentido, encontramos muy sugestivas ciertas simultaneidades: la generación del código armónico tonal junto a la aparición de los dispositivos de comercialización escénica de la música culta, que resultan en el término "obra" y la emergencia de la afirmación de la personalidad artística, constituyen luego la base de la musicología estilística que sale a defender la "sociedad abierta" de sus enemigos anticapitalistas en pleno siglo XX. Del mismo modo el auge de los cancioneros folklóricos y la producción de categorías en torno al pueblo auténtico constituyen la base de la racionalización y objetualización de las músicas populares con el fin de hacerlas ingresar al mercado; situación que se produce primero con los cancioneros impresos para uso doméstico y que termina de eclosionar -incluso de explotar-con el advenimiento de la fonografía y los medios radiofónicos. Para llegar a esto fue necesario deconstruir los métodos de ambas disciplinas pues, como vimos, su carácter afirmativo consiste precisamente en cifrar estas intenciones en sus propios útiles de conocimiento, al tiempo que ocultan de manera formidable sus propósitos. 
Creemos a su vez, y la mención a los medios fonográficos nos da el pie para decirlo, que existe una continuidad, al menos presuntiva, también entre musicología histórica, folklore y Popular Music Studies. Si bien, como expresamos en la introducción, este es un colectivo muy diverso y por lo tanto nuestra hipótesis puede sonar injusta, consideramos que existe en buena parte de los estudios sobre la popular music una huella que recoge por un lado los artefactos, métodos y categorías de ambas disciplinas afirmativas. Pero además, asunto que pudimos comenzar a atisbar en un trabajo paralelo a la elaboración de esta tesis (Eckmeyer, 2018), la figura epigonal de Theodor W. Adorno en las bases de los PMS, sea para apoyar o cuestionar sus concepciones, representa un formidable punto de articulación, especialmente entre las categorías de la musicología -como la idea de obra, la centralidad de las alturas y la autenticidad- y la reflexión crítica que concibe al mercado musical como generador de la música popular. Además es posible intuir que el desinterés -la sprezzaturade Adorno por lo popular le produjese una ingenua credulidad en torno al folklore, creyendo en la especificidad de lo que James Harker denominara fakesong. De lo cual puede deducirse que los PMS se desentienden de lo que se terminó llamando folklore más por medio de una tradición académica -aparentemente "crítica"- que por la reflexión específica de los repertorios musicales en cuestión. De hecho, un aspecto llamativo que quisiéramos profundizar en futuros trabajos se revela en la escasa problematización de lo "popular" o del concepto de "pueblo" por parte de los PMS. Como referimos en la introducción, por regla general el tema es rápidamente dispensado aduciendo que no se puede relacionar determinadas músicas con sectores sociales específicos. Lo cual es plausible, pero no por ello clausura toda indagación, según creemos haber demostrado a lo largo del texto. Pareciera que los PMS tratan de sacarse el problema de lo popular de encima, de modo asombrosamente compatible con la actitud del folklore. Sin ir más lejos, el número 2 de la revista Popular Music -cuyo número 1 citamos en la introducción- contiene un debate sobre el tema a modo de foro entre varios de los más ilustres fundadores de la tendencia, que lleva un significativo título que es posible traducir así: "¿Podemos deshacernos del "pueblo" en música popular?»315 (The International Advisory Editors, 2005). Esto prácticamente permite que cerremos el círculo de las tres disciplinas: si la musicología histórica directamente señala que la Música no es popular, y el folklore dictamina que el pueblo no es el pueblo, podríamos pensar que para los PMS la música popular no es popular ni es del pueblo. Más allá de este dato cuasi pintoresco contenido en un título extravagante, resaltamos el carácter tentativo de estas reflexiones, cuyos vínculos presuntivos creemos que permiten entrever un camino de indagación a continuar en futuros trabajos.

No obstante estos resguardos, queremos proponer como modelo teórico sobre las disciplinas que incluimos en nuestra definición de la historiografía musical -la musicología histórica, el folklore y los Popular Music Studies- un grado de convergencia epistemológica y al menos parcialmente ideológica, fundamentalmente entre las dos primeras. Esto hace participar a los PMS solo tangencialmente en la caracterización como afirmativa de esta historiografía musical. Esa ideología, que produce la compresión de la música popular al tiempo que la introduce en el mercado como valor de cambio, reservándole un lugar en la cultura entre lo primitivo y lo momentáneo, entendemos que puede ser designada como modernidad (Dussel, 2007), en términos de proyecto civilizatorio, y nutrida de todos sus sesgos específicos: racial, de clase, de género, entre otras relaciones de opresión (Grosfoguel, 2014).

Para establecer esta convergencia, cuyos argumentos y evidencias creemos haber expuesto in extenso durante el trabajo, queremos tomar como base la conceptualización que Florencia Garramuño utilizó para establecer la relación, al mismo tiempo académica y mercantil, en torno a las músicas (y literaturas) populares y vanguardistas de Sudamérica al

315 «Can we get rid of 'the popular' in popular music» (The International Advisory Editors, 2005) 
insertarse en el mercado transnacional de principios del siglo $\mathrm{XX}$ : a este proceso de rechazo y fascinación -actitudes que encontramos tanto en el folklore como de la musicología- lo llamó la «modernidad primitiva» (Garramuño, 2007). Fue para nosotros muy interesante descubrir que Julius Reder Carlson eligiera aplicar este concepto a la emergencia de Andrés Chazarreta y su compañía de música nativa, desplazando lo que Garramuño focalizaba en repertorios de la musicología histórica (la vanguardia) o de los PMS (el tango) hacia la problematización del folklore, su condición de música comercial y fonográfica y la apelación al pasado de la tradición.

Creemos que este aporte dual de Garramuño/Carlson, que explicita las contradicciones inherentes a la cultura afirmativa al promocionar estética y comercialmente lo que al mismo tiempo se rechaza u oculta, puede extenderse a las actitudes de las restantes disciplinas, puntualizando en cada caso el vector o dimensión que funciona en cada campo como concepto base. De este modo encontramos que la musicología se funda en una genealogía cuasi aristocrática que deriva el prestigio de la continuidad y extensión histórica hacia el pasado, resultando su paradigma una modernidad histórica; por su parte la apelación a la comunalidad, la oralidad -o lo iletrado- y concretamente el primitivismo formulan la modernidad primitiva del folklore; mientras que el acento en convertir a las tecnologías de la grabación y difusión radiofónica en sinónimo de "tecnología", desconociendo la especificidad tecnológica de otros medios musicales del pasado histórico y utilizando la tecnología resultante como fundamento y explicación unicausal de la mercantilización musical, hacen de los PMS una modernidad tecnológica. ${ }^{316}$

De esta suerte de arreglo de dimensiones específicas (lo histórico, lo primitivo y lo tecnológico) surgen los sesgos de cada disciplina, ya que la hiperbolización de cada dimensión produce la atrofia de las otras: si el folklore es antes que nada primitivo, entonces no puede ser histórico y sus medios rudimentarios no serán considerados tecnología; si la música culta adquiere su valor estético en función de su longeva historia, entonces ya no será primitiva, porque es "superior", pero su historicidad y clasicismo no podrán confundirse con los medios técnicos, urdidos con fines mercantiles y no estéticos. Si la popular music es antes que nada un subproducto de la tecnología fonográfica y del mercado, su alcance será lo momentáneo, y por lo tanto no será ni histórico ni primitivo, pues sus medios son demasiado modernos para confundirse con los hontanares de la música.

Como una propuesta para continuar en futuras investigaciones, consideramos importante dejar mención de que un potencial esfuerzo que atravesara y pusiera en crisis el sincronismo del funcionamiento de estas tres modernidades, podría producir un conjunto de miradas -o escuchas- divergentes que podrían generar explicaciones diacrónicas pero también sincrónicas hoy ausentes en las historias de la música. Si consideramos brevemente el momento mismo de eclosión de estas modernidades, veremos que los hitos de sus repertorios siempre se estudian por separado, limitando el análisis a la vez que se abstraen las músicas de sus ocasiones de referencia, vínculo que, como mencionamos antes, contiene en nuestra opinión una potencia histórica y explicativa de mucho valor. Por ejemplo solemos pensar en la música de las vanguardias históricas únicamente mediante las categorías que hacen al análisis de su lenguaje interno, es decir desde una modernidad

316 Por supuesto reconocemos que varios de los practicantes de los PMS han presentado posturas críticas frente a la modernidad. Pero a nuestro favor queremos señalar que, en su mayoría, lo han hecho desde lo que podría englobarse como las posiciones posmodernas. Al respecto los autores identificados con el colectivo "modernidad/colonialidad" han propuesto la consideración de lo posmoderno como parte de la modernidad, incluso como un segmento crítico pero desde el interior de la misma: «posmodernidad que es todavía un momento final de la modernidad» (Dussel, 2005, p. 16). Recogemos esta interpretación de lo posmoderno para ubicar a los PMS en todo caso en relación directa, incluso crítica, con la modernidad. De hecho su acento en los medios tecnológicos pueden considerarse un culto a uno de los hitos fundantes de lo moderno en el siglo XX, como son la cultura de masas y específicamente las industrias culturales de la comunicación y el entretenimiento. 
histórica. Pero ¿qué consecuencias historiográficas surgirían si considerásemos el auge de los medios de grabación y reproducción de la música en relación con el hermetismo de la segunda escuela vienesa y su rechazo del mundo moderno? ¿Qué otras escuchas nos habilitaría un estudio profundo de los modelos e ideologías del folklore acerca de las músicas de Debussy, de Stravinsky, o incluso de Williams o más tarde Ginastera? ¿Cambia el jazz si lo hacemos retroceder hacia el minstrel show, o incluso el café concert, ambos asuntos erigidos como contracara del folklore desde donde surge el blues que a su vez informa al jazz? ¿Por qué las historias de la música culta de principios del siglo XX no incluyen las modificaciones que la grabación introdujo en las prácticas compositivas, interpretativas y de producción musical, así como los cambios en los roles y criterios de orquestación? ¿Puede estudiarse de forma sincrónica el rock y la música electroacústica, ambos emergentes de las tecnologías de grabación pero también de categorías históricas de larga duración? En un libro reciente relacionado con las perspectivas de los PMS, su autor propone utilizar la categoría sincrónica de momento en reemplazo de la idea, mucho más diacrónica y hasta evolucionista del movimiento artístico (Weisbard, 2008). Si bien la definición de lo popular en tanto momentáneo es convergente con ese presentismo de los PMS que mencionamos antes como uno de sus límites, enfoques así pueden ser una posibilidad de que comencemos a establecer relaciones en las simultaneidades de diversos campos de estudio. Estas son sólo algunas discusiones que deseamos abrir aquí para hacerlas disponibles con la esperanza de que encuentren alguna vía en futuras indagaciones.

\subsection{Algunos indicadores para (re)pensar la música popular en la historia}

\subsubsection{El cuerpo de la performance como forma popular}

Es justamente a contramano de la fragmentación disciplinar, y considerando la cuestión específica de las relaciones entre los espacios sociales de circulación y producción musical, que podemos extender la dimensión histórica de la música popular, a condición de que aceptemos como tal cosa aquello que trasciende el objeto: en la medida que establezcamos agencia a los sujetos en términos de mediaciones, al modo de la notable tesis de Martín Barbero, y consideremos sus prácticas de performance como destino de nuestro análisis, es decir, equivalente a la noción de forma que la musicología y el folklore convirtieron en objeto-obra. Creemos haber producido suficientes argumentos a lo largo de nuestro estudio acerca de estos tópicos, al punto de permitirnos afirmar que mediante el traslado del foco de análisis de los objetos a los sujetos, pero únicamente considerando a éstos en tanto seres sociales actuantes en una ocasión de sentido colectiva y cultural, insertos en un ritual social o musicar y estableciendo intersubjetividades dialógicas, puede encontrarse en las fuentes históricas suficientes evidencias para abordar un estudio profundo y de largo alcance de las músicas de los sectores subalternos en la larga duración.

La actuación de los sujetos de la música popular, que encarnan sus procedimientos, sus poéticas y sus formas presentacionales, es posible en la medida en que contiene una diversidad de prácticas y sentidos incluso contradictorios. De hecho se puede afirmar que "esta forma de cultura musical popular dependía y sigue dependiendo de la relación de tensión con las formas de música elitistas, es decir, no populares» (Grosch, 2005, p. 593). Es una pirueta conceptual interesante pues, para este autor, para que dicha litigiosidad tenga existencia debe contar con formas de mediación. Pero para que estos medios tuviesen efecto en términos populares debían ofrecer la capacidad de trascender los ámbitos sociales específicos de las respectivas prácticas musicales. Como esto es lo que los PMS atribuyen en forma mayoritaria al boom de la industria discográfica de principios del siglo XX, encontrar en el pasado un caso similar nos permite extender la consideración 
de "lo popular" en términos históricos. Pero Grosch detiene las posibilidades de su marcha retrospectiva en la época de la aparición de la imprenta de tipos móviles (2005, p. 594). Bernand, como vimos, también se detiene en el siglo $\mathrm{XV}$, ubicando la circulación en el proceso que a lo largo de los capítulos estudiamos como intervención de los sectores hegemónicos en la cultura popular. Lo que en realidad surge de estos aportes es lo que, tal cual desarrollamos en los capítulos 2 y 5 , Jacques Attali caracterizó como circulación social de la música, asociándola a las prácticas musicales de los juglares y los ministriles. Así el nomadismo de los músicos se transforma en circulación social, mediación musical, que a su vez se convierte en un nomadismo de los sonidos, que se articulan en el fenómeno sonoro y no configuran un objeto cristalizado; que son recreados de forma dinámica y continua y no son propiedad de un autor aislado y autónomo; que evaden la fijación de las alturas y se despliegan en un continuum espectral y tímbrico. A riesgo de abundar, quisiéramos traer nuevamente a la atención del lector el fragmento de Attali que referimos en el capítulo 2, citando ahora el texto en extenso, ya que a nuestro juicio abre la puerta para continuar en el futuro la investigación sobre el pasado de la música popular, atendiendo a estos cruces y ramificaciones que convergen en el sujeto histórico

\begin{abstract}
El juglar carece de empleo fijo; se desplaza para proponer sus servicios a domicilio. El "es" la música y el espectáculo del cuerpo. Él la crea, la porta y organiza, él solo, toda su circulación en la sociedad. Los consumidores de música pertenecen indistintamente a todas las clases sociales: campesinos en ocasión de fiestas cíclicas y bodas, artesanos y cofrades en las fiestas del santo patrón y de los banquetes anuales, burgueses, nobles. Un juglar puede muy bien actuar una noche para una boda aldeana y la siguiente noche en un castillo, en donde come y duerme con los sirviente (Attali, 2011, p. 26)
\end{abstract}

Consideramos que en el análisis de las ocasiones musicales festivas del pasado histórico que emprendimos en este trabajo, pudo entreverse que el sujeto histórico es la música, confundiéndose incluso con las formas de mediación: el cantante callejero con las baladas, el juglar con la máscara o el ministril con la ciudad, la casta y hasta la evasión cimarrona, de este y del otro lado del Atlántico. Lo cual, a diferencia de los límites que se trazan Grosch y Bernand nos permite extender todavía más atrás, hacia el umbral histórico mismo de la cultura occidental, la emergencia de la música popular.

\title{
6.4.2 Mestizaje y nomadismo.
}

La circulación de las prácticas de la música popular aparecen íntimamente relacionadas con la condición de nomadismo que es a un tiempo de los seres y de los sonidos que habitan el mundo popular subalterno y configuran esa voz que podía constituir la oportunidad de los excluidos para presentar sus propias ideas (Burke, 2014, pp. 288-290). Considerar una equivalencia entre los sujetos performativos y la música, a partir del concepto de musicar hace que la condición de los primeros sea parte de la definición de la especificidad musical. Esto nos llevó, especialmente en el capítulo 2 pero también en el 4 a la hora de confrontarlo con el folklore, a buscar el nomadismo en las músicas. Como intentamos expresar mediante los análisis, este nomadismo sonoro, presente fundamentalmente en esa categoría tan interesante de las «discrepancias participatorias»que a un tiempo vincula la resultante sonora con la práctica activa de los sujetos actuantes, sean estos músicos, bailarines o público-, este interés de las prácticas populares por las transiciones y los pasajes, identificación con lo diverso y múltiple, nos llevó a considerar, a contramano de nuestras presunciones iniciales, la extensión del carácter mestizo como conceptualización de toda la música del mundo popular subalterno. Como señala Antoine Nouss, si al comienzo se piensa que el nómada, por su periplo y su caminar es potencialmente mestizo, es decir, conlleva un anuncio del mestizaje al atravesar los límites, las fronteras de la territorialización; en realidad lo que se nos revela cuando observamos las prácticas populares es que el mestizo es nómada, es decir, no hay nomadismo sin 
mestizaje (Laplantine y Nouss, 2007). Un buen ejemplo que atraviesa las fronteras conceptuales de la musicología histórica es el que abordamos en el capítulo 1 en torno a las músicas del caminar y peregrinar. Si por un lado ponen en cuestión o invierten las categorías clasificatorias usuales en la historiografía de la música medieval, por el otro podemos ver que la materialidad del sonido, su misma producción caminante que hace confluir las prácticas de diferentes localizaciones y sujetos históricos, es ya poblada desde antes de su inicio por un mestizaje, que es su misma condición de posibilidad. Este carácter transicional que obtura cualquier discusión sobre los orígenes, haciéndola obsoleta, pudimos verlo también en referencia a las músicas americanas encontradas en el tiempo colonial. La pregunta por la negrilla, sobre el lugar de origen en tanto big-bang se reveló estéril, derivando en las disputas superficiales y eternas que son tan comunes en torno al patrimonio y la música popular: ¿de dónde es la diablada, de Oruro, de Puno, de la Tirana? ¿No es más interesante indagar sobre las conexiones históricas de estas ocasiones, sus puntos de contacto y su diversidad que les otorgan una identidad múltiple? ¿Cuánto mejor suena el tango una vez que se saldó, con corrección política más que con historiografía, la nacionalidad de Gardel? ¿De verdad vamos a seguir pensando que el árbol de Cucaña del carnaval de lquitos es una copia del rito arbóreo medieval europeo? Y de ser así ¿En qué mejora nuestro conocimiento y recepción de las ocasiones carnavalescas latinoamericanas?

Poder saltar sobre las fronteras que nos imponen estas preguntas es la real potencia del mestizaje en tanto pensamiento. Un modo curioso y paradojalmente desracializado de pensar, que surge a partir de la redención de un término conceptual acuñado para el sometimiento y el despojo. Una palabra que ha recibido todos los tipos de manoseos, utilizaciones, violencias y maltratos imaginables, en consonancia con aquellos seres a los que describió y describe: los pardos, los impuros, los intermedios, los "del montón", que son también sin nombre, como los músicos y performers históricos del mundo popular subalterno. El mestizaje disuelve toda potencia residual de la noción de autenticidad. Y lo hace mediante la estrategia de la cimarronería y el camuflaje: con la evasión, eludiendo los contrastes duros, mediante la ambigüedad, la incompletud, lo informe, lo contradictorio a partir de la recreación y la creación plurisubjetiva y pluritemporal.

Esto no hace a sus manifestaciones menos potentes ni mucho menos críticas frente a la cultura dominante y sus dispositivos. Por eso insistimos con la inversión del modelo epistémico de la historiografía musical, que las prácticas sonoras subalternas introducen por su propia presencia: la ausencia del autor, la imposibilidad de contener el musicar en la forma/objeto, la imposibilidad de la autonomía estética, son otras tantas cuestiones favoritas del repertorio de la historiografía que se revelan vacías de sentido ante el musicar transcultural del mundo popular. Y también el territorio, que en la musicología es también el estilo, se hace inútil frente al nomadismo de la música popular. Los bordes que salta el mestizaje, una vez que éste es reapropiado como concepto propositivo, naturalmente son producto de un modo de pensar derivado de los nacionalismos que revisamos en torno al folklore y la convergencia con el positivismo que habita la musicología histórica. Ahora bien, así como para la Modernidad territorio y armonía son dos elementos altamente vinculados e imprescindibles para pensar la dominación, situación que comparten las músicas analizadas y que en definitiva define el mundo popular subalterno, el mestizaje es también la cancelación de la armonía, entendida en su doble juego de lógica sonora y de cohesión o consenso social. Porque el nomadismo no solo pone en cuestión la noción de territorio, sino también la de desplazamiento; porque el movimiento mestizo del nómada es permanente y no conoce moradas ni destinos; por lo tanto si desplazarse es ir de un lugar a otro, como ocurre en la forma tonal de la obra/objeto de la musicología, no hay desplazamiento en la práctica nómada y mestiza de la música popular. A diferencia de ésta, la música tonal culta es narrativa y derivada de la concepción teatral propia del mercado del espectáculo 
moderno (Small, 1989). Eso hace que la ópera moderna no sea popular y una canción mulata, aparentemente repetitiva que se intensifica en su heterogeneidad dialógica, sí lo es. El nómada no sabe a dónde va, ni su música se dirige a ninguna parte. Pero sabe que va, y por eso, es en sí mismo la circulación permanente de lo simbólico.

Dijimos en reiteradas oportunidades que el mestizaje es conflictivo, litigante. Es una especie que no resuelve sus contradicciones y mantiene, dinámica e inestable, su heteronomía. Por eso decimos que las manifestaciones de la música popular no pueden entenderse como bienes -pues no son cosas ni objetos- o saberes -ya que son más que eso, ocasiones y rituales- de los cuales el imaginario estatuto civil y comercial del folklore o la musicología hace que pertenezcan al pueblo o que, aún peor, éste haga de ellos un usufructo. Es decir que la reflexión elitista de Hoppin (2000) sobre los juglares y las "canciones de otros hombres» o los comentarios entre paternalistas y etnocéntricos de Vega (1944) acerca del usufructo de bienes ajenos «por descenso», en realidad no hablan de la música popular en ningún sentido. Aunque describen muy bien el estatuto epistemológico y político de estos investigadores. Por lo tanto nos han revelado algo importante, que se desprende de nuestros análisis críticos sobre la musicología y el folklore: la música popular es un espacio de disputa de sentido. Así como el juglar nómada y el ministril indígena atraviesan las fronteras y se instalan en la corte o en la catedral para introducir el ruido en el musicar, el espacio que configura la música popular tampoco pertenece al pueblo. Es moldeado y conformado de forma ambigua y heterogénea por los deseos intereses y emociones de ese colectivo tan heteróclito que son las clases populares, pero está igualmente atravesado, moldeado, intervenido y observado, constantemente, por los sectores hegemónicos. Al punto que, como nos mostraron Bajtín, Burke, Hall o Bernand, no podemos concebir lo popular por fuera de la estratificación que proponen los sectores dominantes.

De ahí la idea de disputa, de algo contencioso y litigante que oscila entre fuerzas muy disímiles y contradictorias, como las que definió Estenssoro en su modelo para describir los procesos históricos del mundo colonial andino. Es una litigiosidad en la cual la música, como parte de la cultura popular, se vale de estrategias igualmente heterogéneas y mestizas: la risa grotesca, el ruido en la performance que conlleva un opacamiento de la forma, la textura de la voz y de los instrumentos utilizados de formas disruptivas, el ocultamiento y camuflaje de las sonoridades subversivas entre las lógicas constructivas de la música culta, el cruce incongruente de géneros, tradiciones o formatos, la evasión de las fronteras pretendidamente estilísticas y étnicas, entre tantas otras estrategias que evitan la confrontación directa y problematizan o cuestionan por rodeo, de manera elíptica.

\subsubsection{Carácter dialógico}

Esto hace que la música popular sea además dialógica, en dos sentidos: por un lado establece estos vínculos estrafalarios, excéntricos y heterodoxos entre aquello que no debería juntarse. Al hacerlo cuestiona de forma presentacional la sociedad estamental medieval, la plutocracia mercantil moderna, la sociedad de castas colonial e incluso la misma institución de la esclavitud. Queremos en esto evitar confusiones en nuestra afirmación: dialógico no significa que dialoga, sino todo lo contrario: exhibe las tensiones no resueltas y contradictorias, acercando en la exposición del conflicto aquello que la cultura oficial había concebido sosegada pero estrictamente separado: eso es el pathos de la distancia, el ideal hidalgo colonial, el folklore o la negación de lo popular en la musicología de los estilos; son simplemente modos, muy potentes, de segregación, que han intentado establecer la legitimidad de la diferencia mediante la imposición de consensos, término que encontramos directamente opuesto al carácter dialógico de la música popular. 
Pero las prácticas sonoras del mundo subalterno son también dialógicas en un sentido específico, el de sus formas de producción musical, al establecer relaciones en todos los órdenes del musicar: entre los sonidos y sus medios de articulación, convencionales y divergentes; entre las técnicas apropiadas de la música armónica occidental y el emergente transcultural de las memorias populares de sus vertientes; entre los diferentes sujetos intervinientes en la ocasión musical, sean músicos, bailarines, participantes, oyentes, etc.; entre las músicas y sus procedimientos compositivos y performáticos, que existen en circulación en las diferentes clases y sectores sociales, articulando la "circulación" conflictiva que detectó Attali (2011) en los juglares; en la permanente dinámica de los roles, que se solapan y superponen permanentemente, haciendo que cada músico redefina y contextualice su parte incidiendo en aspectos que en otros contextos, como el de la música culta, serían entendidos como parte estructural de la composición, y por lo tanto se reservarían al matricero y no a los sujetos actuantes. Es por ello que, sin rehusar el conflicto, las músicas populares suelen invertir la carga de los roles (principal y subordinado) como en los ejemplo de Quintero Rivera del "colectivo" y el "individuo", a los que hicimos referencia en el capítulo cinco (Cfr. pág. 391).

Podríamos hacer aquí una analogía entre las posiciones del compositor y el intérprete, por un lado, y las voces del autor y el héroe analizadas por Bajtín (XXX), en las que en función de detectar cierta independencia o autonomía del segundo frente a las intenciones del primero, encontraba un carácter dialógico, que incluso identificaba con cierta modernidad de la literatura. Pero él se refería a una modernidad muy diferente a la que venimos analizando en este trabajo, ya que para este autor el mundo capitalista, lo que aquí hemos identificado como Modernidad Occidental, rechazaba el dialoguismo en pos de un monologismo de presencia hegemónica, una suerte de estandarización a raíz de la cual todos terminan diciendo lo mismo, sean parte del pueblo o de las clases hegemónicas. Podríamos de hecho considerar a ese monologismo como la base incluso epistémica que llevó a Vega a considerar la continuidad histórica entre la música culta y la popular, o a Dahlhaus y la musicología a creer que en la estética clásica de las obras residía la clave de todo el arte sonoro. Justamente la condición dialógica, que creemos con Bajtín que es parte constitutiva de la música popular -en tanto parte de la cultura popular- asegura la ruptura del monologismo y la estandarización, ya que exhibe inevitablemente una pluralidad de lenguajes, conciencias y manifestaciones, permitiendo que la tensión y los conflictos que forman parte de la identidad popular se desplieguen en toda su intensidad sin resolverse ni disimularse. De ahí la identificación que proponemos entre mestizaje, o cultura del mestizaje, y música popular.

Las fuerzas del mestizaje popular son dos: la carnivalización y la nomadización. Entre ambas logran invertir los propósitos, las herramientas y los sentidos de la cultura oficial. Pero es importante que adquieren dos dimensiones que, precisamente, las hacen populares: la condición vivencial, participatoria y universal, en el sentido de lo común, para todos; y el rechazo a la imposición de los territorios -geográficos, productivos, políticos, económicos, raciales, sociales, etcétera- que la cultura oficial hace sobre los sujetos. La condición proscrita del juglar junto a la chillona grotesca de sus instrumentos in-formes; la identificación ruidosa del ministril urbano -blanco, indígena, mulato, etcétera- con los rituales oficiales mediante la inestabilidad de sus "instrumentos altos"; los ordenamientos sonoros entre los violines mestizos y el canto indígena; la relación entre los tambores y los bailadores de las músicas mulatas, y entre los mismos tambores o entre los instrumentos y el voceo del cantante; todos ellos son formas dialógicas específicas de la música popular. Pero al mismo tiempo, de una manera ambigua en la cual no podemos separarlas de forma estricta, son metáforas del orden social, sea de su establecimiento real o de una concepción utópica y de liberación. 


\subsection{4 integralidad y trascendencia}

Lo cual nos lleva a un último aspecto de esta lista muy provisoria que apenas ha asomado en la indagación preliminar de algunas -pocas- músicas del mundo popular subalterno. $Y$ queremos definirlo acudiendo a un concepto adelantado, aunque de forma un tanto difusa, por Ticio Escobar, que podríamos llamar integralidad. Como expresamos en los indicadores anteriores, la localización de la música popular en los sujetos, en su corporeidad, su nomadismo y su carácter dialógico, hace que sea insostenible aislar el fenómeno musical de las ocasiones de sentido en las que ocurre. Justamente de esa estrecha vinculación emerge el sentido íntimamente histórico que posee la música popular y que reconfigura nuestras nociones habituales derivadas del esteticismo de la historiografía afirmativa: la música se convierte en musicar y el contexto desaparece, no para favorecer la autonomía, sino para asociar de forma indeleble los aspectos sonoros específicos, la recreación performativa, la generación de forma por intensificación, etc., con las coordenadas sociales, políticas, económicas y culturales de la ocasión musical. Para expresarlo mediante una comparación, podríamos pensar que si para el folklore lo importante era el vínculo indisoluble entre música y territorio, en nuestra concepción de la música popular esa relación se explica entre música y localización histórica. De allí que si consideramos a las prácticas populares como «máxima intensificación de la experiencia comunitaria» (Escobar, 1991, p. 109) asome un rasgo socialmente integral de las músicas populares en contraste con la noción de unicidad que la cultura oficial reserva para la obra de arte, su estilo y la personalidad del autor, terna que se refugia en un espacio autónomo de vacío social.

Como ya desarrollamos en el capítulo 4, esta integralidad es a la vez trascendente, pero en un sentido muy diferente a la noción de trascendencia de la estética moderna, fundamentalmente de Kant. Justamente el filósofo prusiano al considerar como trascendente al sujeto creador, lo erigía como autor de artefactos autónomos, que no podían explicarse mediante el recurso a su vínculo con el tejido histórico y social, que en el mejor de los casos se convierte en contexto. Por algo esta es la estética clásica. En otro gesto de inversión carnavalesca, la música popular es trascendente precisamente por lo contrario, al no poder separarse de su sentido en tanto proceso de la ocasión social de la música, siendo en un mismo tiempo productora y consecuencia del musicar en términos de identidades. Es decir que a partir de las músicas subalternas históricamente localizables se generan una serie de identidades intersubjetivas en todos aquellos que intervienen en el proceso dialógico: los músicos, el público, los intelectuales, los políticos, los empresarios, etc. Identidades que son a su vez individuales y colectivas simultáneamente, ambiguas y difusas, transitorias, precarias o provisionales, antes que fijas y fuera de la dinámica histórica, como pretende la estilización musicológica o la racialización folklórica. Vale la pena recordar aquí que para Vega lo popular es trascendente en la medida que se lo oculte. Estas identidades populares colectivas e individuales hacen que la materialidad sonora, las configuraciones y formaciones que habitan el cuerpo de sus practicantes, sean así socialmente trascendentes.

\subsubsection{Lo transcultural como continuidad y potencialidad transmoderna}

Este sentido de la trascendencia también puede entenderse en cuanto a la cualidad de circulación social que planteamos más arriba y que refiere a la potencialidad de establecer vínculos como característica de las músicas populares. La contradicción, lo liminal, lo deforme, lo no terminado, la risa grotesca, lo ambiguo, lo camuflado, son formas de lo popular que se exhiben continuas y aparecen tanto en la cultura popular europea como en la de los territorios coloniales y sometidos. La idea de conflicto que asociamos a lo mestizo contribuye a esto, ya que como recuerda Adolfo Colombres la cultura popular expresa la 
conciencia compartida de un conflicto común y contribuye a superarlo $(2007$, p. 98). Este es el sentido extensivo que hace que las manifestaciones tan diversas y contrastantes de mundos aparentemente muy dispersos puedan confluir en la noción del Mundo Popular Subalterno de Ernesto De Martino. Mundo de la inversión carnavalesca, que ofrece esa segunda vida del pueblo y que también aparece en el Mundo al Revés del universo profético incaico que en las crónicas mestizas, como las de Guaman Poma, introducen un elemento disruptivo y potencialmente conflictivo dentro del orden colonial. Esta es la continuidad que encontramos en las músicas populares estudiadas. A diferencia de la continuidad folklórica que procede de la territorialización del pueblo y sus manifestaciones, la continuidad transcultural emerge de la desterritorialización forzosa de los colectivos dominados y revierte su signo introduciendo un sentido programático de la mixtura, el sancocho (Quintero Rivera, 2005) y lo mestizo. La continuidad transcultural se erige en una posición que reclama reabrir la discusión sobre el sentido de la totalidad en un sistemamundo (Castro-Gómez, 1999) que el posmodernismo se ufanó de haber clausurado con la cancelación de los grandes relatos. Mientras disciplinas potencialmente críticas, como la etnomusicología o la new musicology continúen por la senda de la fragmentación, el multiculturalismo y la globalización, sus muchos e imprescindibles aportes no penetrarán en la afirmatividad de la historiografía musical, afectando sólo superficialmente el debate sobre las músicas.

La transculturación, como vimos en los casos musicales analizados, es lo opuesto a la aculturación, pues es la nueva realidad cultural que, en un momento histórico y bajo coordenadas sociales específicas, emerge de la litigiosidad del campo de disputa que es la cultura popular. Permite pensar así, por ejemplo, que el repertorio objetual armonicocéntrico de la hegemonía colonial es intervenido -o mejor subvertido- y vuelto al revés mediante la reconfiguración transcultural de las prácticas sonoras de los sometidos, sean indígenas, negros, moros, o simplemente excluidos sociales. De forma tal que el proceso transcultural modifica a un tiempo las músicas que impone el conquistador desde lo formal y las prácticas y cuerpos desde los cuales se litiga con esas formas. Ya nada será lo mismo, aunque la reversión temporal del flashback historiográfico (Cusicanqui, 2014) permite introducir nuevos sentidos al pasado histórico que vuelve a emerger en las problemáticas contemporáneas de los sectores populares.

La transculturación, como posibilidad de pensar las relaciones entre vertientes culturales conflictivas y distantes, pero además como proceso dinámico, es decir, de permanente mutación histórica es, según Ramiro Podetti, una interesante alternativa de explicación mundial frente a la globalización. Si por un lado la transculturación expresa la condición transitoria de la mezcla, es lo mestizo ch'ixi contencioso, entonces «no se centra solo en la propia identidad, porque esa identidad misma está cuestionada. Por definción, es una identidad en crisis. Se realiza en la polaridad identidad-alteridad» (Podetti, 2004, p. 4). De esta forma, frente a la fusión híbrida que propone la globalización, en un multiculturalismo que sólo puede servir para legitimar aún más la cultura hegemónica de la colonialidad, la transculturación es un resguardo contra la fijación racializada y cuestiona precisamente esa -y cualquier otra- dominación cultural.

Como creemos que se hizo evidente durante el abordaje de las músicas en este trabajo, estas consideraciones sobre la localización en el cuerpo y los sujetos, el mestizaje y nomadismo, la circulación conflictiva entre espacios sociales, la integralidad de las ocasiones musicales, en síntesis, la omnipresencia de la performance y la materialidad sonora en la música popular, nos llevó a adoptar una metodología y un formato de presentación que, aunque ahora nos resulta cuasi natural, creemos que es algo novedoso en la historiografía musical. Fundamentalmente en la necesidad de considerar a las 
músicas en su materialidad sonora, en su timbre, formas de articulación y texturas, dominios tradicionalmente relegados en las historias de la música.

Nos gustaría pensar que estas dimensiones, estos indicadores que problematizan la situación contenciosa y ch'ixi de las prácticas del mundo popular subalterno, junto al estudio crítico y teorización de las historiografías afirmativas de la música, pueden aportar a la configuración de lo que quisiéramos llamar una perspectiva transmoderna de la historiografía musical. Una suerte de pensamiento de frontera o «fronterizo crítico» (Mignolo, 2009) que abra el camino al abordaje en relación conjunta y crítica de las músicas presentes en nuestra sociedad, enriqueciendo y profundizando en las indagaciones y explicaciones. Una perspectiva que además, y fundamentalmente, pueda pasar a las aulas y contribuir a densificar lo que a todas luces sigue constituyendo una de las áreas más conservadoras del conocimiento musical.

Aunque tal vez las cosas estén cambiando. Hoy los estudiantes ya son mucho menos tolerantes a las dimensiones de la Modernidad y se muestran al menos incrédulos frente al discurso patriarcal y etnocéntrico y ante el dominomorfismo que todavía suele desprenderse de los textos y programas universitarios de Historia de la Música. Probablemente, parafraseando las consideraciones de Álvaro García Linera sobre la precaria vigencia del conservadurismo político en Latinoamérica, podamos decir que se trata ya de una musicología zombie, que apenas arrastra los últimos jirones de sus categorías afirmativas. Esperamos ansiosos dedicarnos a una tarea que no nos obligue ya más a contrastar y rebatir de forma permanente sus anacrónicas categorías y métodos. Algo que Gloria Anzaldúa sintetizó de forma magistral, precisamente a partir de considerarse transcultural y mestiza

Una postura antagónica obliga a la persona a un duelo entre opresor y oprimido; atrapada en un combate mortal, como el policía y el delincuente, ambos reducidos a un denominador común de violencia [...] Toda reacción es limitada por aquello contra lo que reacciona, y depende de ello [...] Pero no es una forma de vida. En algún momento, en nuestro camino hacia una nueva conciencia, tendremos que abandonar la orilla opuesta [...] $O$ tal vez decidamos desentendemos de la cultura dominante, desecharla por completo como una causa perdida y cruzar la frontera hacia un territorio totalmente inédito. $O$ podríamos seguir otro itinerario. Las posibilidades son numerosas una vez que hayamos decidido actuar y no reaccionar contra algo (Anzaldúa, 2016, p. 250). 


\section{Anexos}

\section{Bibliografía referida}

Acosta, L. (2006) Música y descolonización. Caracas: El perro y la rana.

Adler, G. (1911) Der Stil in der Musik. Leipzig: Breitkopf \& Härtel.

Adorno, T. (2002). Sobre la música popular. Guaraguao, 6(15), 163-201. Recuperado de http:// www.jstor.org/stable/25596308

Adorno, T. W. (2009). Disonancias: Introducción a la sociología de la música. Madrid: Akal.

Aharonián, C. (1994). Factores de identidad musical latinoamericana tras cinco siglos de conquista, dominación y mestizaje. Latin American Music Review / Revista De Música Latinoamericana, 15(2), 189-225. doi:10.2307/780232

Alén Lascano, L. (1972) Andrés Chazarreta y el folklore. Centro Editor de América Latina.

Alianza Editorial (2019) Historia de la música occidental [Sitio Web] https://www.alianzaeditorial.es/ libro.php?id=4099519\&id_col=100508\&id_subcol=100515 Consultado el 16 de marzo de 2019

Allen, W. D. (1962). Philosophies of Music History. Dover Publications.

Alvarenga, O. (1984 [1947]) Orígenes de la Música Popular Brasileña. En Gómez, Z. Musicología en América Latina, La Habana: Arte y Literatura.

Andrade, M. de (1984) Evolución social de la música brasileña. En Gómez García, Z. (1985). Musicología en Latinoamérica. La Habana: Editorial Arte y Literatura.

Anzaldúa, G. (2016). Borderlands: La frontera: La nueva mestiza. Capitán Swing Libros.

Aretz, I. (2007). América Latina en su música. Siglo Veintiuno Editores.

Aretz, I. (2008). El folklore musical argentino. Buenos Aires: Melos.

Argullol, R. (1991). El fin del mundo como obra de arte: Un relato occidental. Destino.

Arzáns de Orsúa y Vela, Bartolomé (1705?), "Historia de la villa imperial de Potosí: riquesas incomparables de su famoso cero, grandesas de su magnanima poblacion, sus gueras civiles y casos memorables " Latin American Travelogues. Brown Digital Repository. Brown University Library. https://repository.library.brown.edu/studio/item/bdr:372536/

Atlas, A. W. (2002). La música del Renacimiento: La música en la Europa occidental, 1400-1600. Madrid: Akal.

Attali, J. (2001) "Ruidos: Transcripción de la conferencia en el ICA". Londres, Mayo. Recuperado de http://www.eumed.net/cursecon/textos/2005/attali-ruidos.htm

Attali, J. (2011). Ruidos: Ensayo sobre la economía política de la música. México: Siglo XXI.

Aubry, P. (1910) Trouvères et troubadours. París: Alcan.

Baines, A. (1952, 03). Shawms of the Sardana Coblas. The Galpin Society Journal, 5, 9. doi: $10.2307 / 841406$

Bajtín, M. (2003) Problemas de la poética de Dostoievski. México: Fondo de Cultura Económica.

Bajtín, M. (2005). La cultura popular en la Edad Media y en el Renacimiento: El contexto de François Rabelais. Madrid: Alianza Editorial. 
Baker, G. (2003). Music in the Convents and Monasteries of Colonial Cuzco. Latin American Music Review / Revista De Música Latinoamericana, 24(1), 1-41.

Baker, G. (2005) "Parroquia, cofradía, gremio, ayllu" en Bombi, A y otros, Música y cultura urbana en la edad moderna, PUV, Valencia

Baker, G. (2008a). Imposing harmony: Music and society in colonial Cuzco. Duke University Press.

Baker, G (2008b). Latin American Baroque: Performance as a post-colonial act? Early Music, 36(3), 441-448. doi:10.1093/em/can082

Baker, G., \& Knighton, T. (2011). Music and urban society in colonial Latin America. Cambridge University Press.

Barber, D. (1997) A musician's dictionary. Michigan: Sound and vision

Barberà, A. R., \& Espinosa, C. S. (2010). A tres bandas: Mestizaje, sincretismo e hibridación en el espacio sonoro iberoamericano. Museo de Antioquia.

Baroja, J. C. (1984). El estío festivo: Fiestas populares de verano. Madrid: Taurus.

Beard, D., \& Gloag, K. (2005). Musicology: The key concepts. Routledge

Beckles Willson, R. (2009) "Music Theory”, en Harper-Scott, J. P. E y Samson, J. An Introduction to Music Studies, Cambridge University Press.

Belinche, D. y Larregle, M. E. (2006) Apuntes sobre apreciación musical. La Plata: EDULP

Belinche, D. (2010) "América, la tierra donde sopla el viento" Revista La Puerta. FBA-UNLP. Octubre 2010

Benjamin, W. (2008). Tesis sobre la historia y otros fragmentos. Itaca.

Bermúdez, E. (1982). La pobreza del positivismo. https://www.academia.edu/33884388/ La_pobreza_del_positivismo_el_quehacer_musicologico_en_Am\%C3\%A9rica_Latina

Bermúdez, E. (1985) Historia de la música vs. historia de los músicos. Revista de la Universidad Nacional de Colombia, Bogotá.

Bermúdez, E. (2001) "Urban musical life in the European Colonies: Examples from Spanish America, 1530-1650" en Kisby, F. Music and Musicians in Renaissance cities and towns, Cambridge University Press

Bermúdez, E. (2008) "'A una hembra se lo cogí': un raro documento de la cultura popular (¿y musical?) del período colonial en la Nueva Granada (siglo XVIII)". Ensayos. Historia y teoría el arte. No. 14, 1. Bogotá, Universidad Nacional de Colombia.

Bernand, C. (2014) "Identificaciones: músicas mestizas, músicas populares y contracultura en América (siglos XVI-XIX)". Historia Critica No. 54, Bogotá, septiembre - diciembre. ISSN 0121-1617 pp 21-48

Beukers, M. (1991). 'For the Honour of the City' Utrecht City Minstrels between 1377 and 1528. Tijdschrift Van De Vereniging Voor Nederlandse Muziekgeschiedenis, 41(1), 3.

Bhabha, H. K. (2013). El lugar de la cultura. Ediciones Manantial.

Bianconi, L. (1986). El siglo XVII. Historia de la música. Turner.

Blache, M. (1981). "Conceptualización del folclore en hispanoamérica y en la Argentina". Ponencia, las palmas de gran canaria. Recuperado de http://estetica.uc.cl/images/stories/ Aisthesis1/Aisthesis15/ conceptualizacion $\% 20$ del $\% 20$ folklore $\% 20$ en $\% 20$ hispanoamerica $\% 20 y \% 20$ en 20 la $\% 20$ argentin a_marta\%20blache.pdf 
Boecio (2009). Sobre el fundamento de la música. España: Ed Gredos.

Bohlman, Ph, (1988) The Study of Folk Music in the Modern World. Indiana University Press.

Bolaños, C. (2007) Origen de la música en los Andes. Instrumentos musicales, objetos sonoros y músicos de la región andina precolonial. Lima: Congreso de la República.

Bourdieu, P. (2002). La distinción: Criterio y bases sociales del gusto. Taurus.

Boyd, M. y Chalmers, K. (2008) "Gales", en Latham, A. (comp.) Diccionario enciclopédico Oxford de la Música. México: Fondo de Cultura Económica

Bregel, Y. (2003) An historical atlas of central Asia. Boston. Brill.

Brett, P., Wood, E., \& Thomas, G. C. (2006). Queering the pitch: The new gay and lesbian musicology. New York: Routledge.

Bringmann, K. (1994). "El triunfo del emperador y las Saturnales de los esclavos en Roma", en Schultz, U. La fiesta: De las Saturnales a Woodstock. Alianza Editorial.

Bukofzer, M. (1940). Popular Polyphony in the Middle Ages. The Musical Quarterly, 26(1), 31-49.

Bukofzer, M. F. ([1947]1986). La música en la época barroca: De Monteverdi a Bach. Madrid: Alianza.

Burke, P. (2003). Formas de hacer historia. Madrid: Alianza.

Burke, P. (2014). La cultura popular en la Europa moderna. Alianza Editorial.

Calahorra Martínez, P. (2003) "El canto de los peregrinos de Santiago de Compostela" en Calahorra Martínez, P. y Prensa Villegas, L. (coord.) El canto gregoriano y otras monodias medievales / VI Jornadas de Canto Gregoriano. De la monofonía a la polifonía. Ed. Institución Fernando el Católico.

Camacho Díaz, G. (2010). Culturas matriciales del México profundo. En Recasens, A. A tres bandas: Mestizaje, sincretismo e hibridación en el espacio sonoro iberoamericano. Akal.

Camacho Díaz, G. (2011) Del oratorio al fandango: la subversión del orden social. en Aguilera, M. O. (2011). Las músicas que nos dieron patria: Músicas regionales en las luchas de independencia y revolución. Programa de Desarrollo Cultural Regional de Tierra Caliente.

Cámara Landa, E. (2015). Estudios sobre la obra de Carlos Vega. Gourmet Musical.

Cannova, M. P. (2016). “Con voz de Gigante. Canción, Televisión, Historia y Política”. Revista Metal (N. ${ }^{\circ}$ 2), julio, pp. 85-96. La Plata: Papel Cosido. Disponible en http://papelcosido.fba.unlp.edu.ar/ ojs/index.php/metal/article/view/189/379

Cannova, M. P. (2017) ¿Qué nos muestra la televisión latinoamericana de la música popular de Nuestra América? [Tesis Doctoral] Recuperado de http://sedici.unlp.edu.ar/handle/10915/62590 .

Cannova, M. P. (2018). Fue lo que empezó una vez, lo que después dejó de ser. Promoción musical y dependencia cultural en Latinoamérica. Armiliar, (2), e004. La Plata: Papel Cosido. Disponible en http://papelcosido.fba.unlp.edu.ar/ojs/index.php/armiliar/article/view/608

Cantó, A. (1962) "Andrés A. Chazarreta y su Orquesta Nativa". Notas para el fonograma Zamba de Vargas, AVE-394, RCA-Víctor, Buenos Aires.

Carabetta, S. M. (2008). Sonidos y silencios: En la formación de los docentes de música. Ituzaingó, Buenos Aires: Ed. Maipue.

Carpentier, A. (1984). "América Latina en la confluencia de coordenadas históricas y su repercusión en la música”. En Gómez García, Z. (1984). Musicología en Latinoamérica. La Habana: Ed. Arte y Literatura. 
Carpentier, A. (2004). La música en Cuba. Editorial Letras Cubanas.

Carr, E. H. (2006). ¿Qué es la historia? Barcelona: Ariel.

Carredano, C., \& Rodríguez, V. E. (2010). Historia de la música en España e Hispanoamérica. Fondo de Cultura Económica.

Carrizo, J. A. (1926). Antiguos Cantos Populares Argentinos (Cancionero de Catamarca). Buenos Aires: impresores Silla hnos.

Carrizo, J. A. (1934). Cancionero popular de Jujuy. Tucumán: Universidad Nacional de Tucumán.

Carter, T. $(1993,07)$. 'An Air New and Grateful to the Ear': The Concept of 'Aria' in Late Renaissance and Early Baroque Italy. Music Analysis, 12(2), 127. doi:10.2307/854269

Castiglione, B (1873) Los cuatro libros del cortesano, Madrid: Librería de los Biblófilos.

Castro-Gómez, S. (1999) Pensar (en) los intersticios: Teoría y práctica de la crítica poscolonial. Bogotá: Pontificia Universidad Javeriana

Cattin, G. (1979). El Medioevo, primera parte. Colección Historia de la música, tomo 2. Madrid: Turner.

Chakrabarty, D. (2008). Al margen de Europa: Pensamiento poscolonial y diferencia histórica. Tusquets.

Chambers, E. K. (1963) The medieval Stage. Londres: Oxford Universtiy Press.

Chamosa, O. (2012). Breve historia del folclore argentino: 1920-1970; identidad, política y nación. Buenos Aires: Edhasa.

Chartier, R. (2007). La Historia o la lectura del tiempo. Barcelona: Gedisa.

Chase, G. (1967). Recordando a Carlos Vega. Revista Musical Chilena, 21(101), p.36-48.

Chazarreta, Agustín (1965). El Eterno Juglar. Andrés Chazarreta, su vida y obra. Buenos Aires: Ricordi Americana.

Citron, M. J. (2000). Gender and the musical canon. Urbana: University of Illinois Press.

Claro Valdés, S. (1967) Hacia una definición del concepto de musicología: Contribución a la musicología hispanoamericana. Revista Musical Chilena. 100, (julio-septiembre), pp. 8-25.

Clayton, M., Herbert, T., \& Middleton, R. (2012). The cultural study of music: A critical introduction. New York: Routledge.

Clemencic, R. (1980) Notas al CD “La Fete de l'Ane”. Arles: Harmonia Mundi.

Cocks, W. A, Baines, A. C. y Cannon, R. D. (2001) "Bagpipe" en Sadie, S. (Ed.) The New Grove Dictionary of Music and Musicians 2nd Ed. New York: Oxford University Press.

Cohen, R (2003) Alan Lomax: Selected writings, 1934-1997. New York: Routledge.

Collins, T. A. (2000, 04). 'Of the Differences between Trumpeters and City Tower Musicians.' The Relationship of Stadtpfeifer and Kammeradschaft Trumpeters. The Galpin Society Journal, 53, 51.

Colomb, J. C. R. (1886) "Imperial Federation, map of the world showing the extent of the British Empire in 1886". [Mapa reproducido en línea] Recuperado de https://collections.leventhalmap.org/ search/commonwealth:x633f896s 
Colombres, A. (1991) ponencia en el panel "América Latina: Encuentros y desencuentros". Publicado en Jalif de Bertranou, C. A. (comp.). Actas de las Jornadas de Pensamiento Latinoamericano. Mendoza: Ediunc. pág. 32.

Colombres, A. (2004) Teoría transcultural del arte. Hacia un pensamiento visual independiente. Buenos Aires: Del Sol.

Colombres, A. (2007) Sobre la Cultura y el Arte Popular. Buenos Aires: Del Sol.

Cook, N. (2001). De Madonna al canto gregoriano: Una muy breve introducción a la música. Madrid: Alianza.

Cook, N., \& Everist, M. (2010). Rethinking music. Oxford: Oxford University Press.

Cortazar, A. R. (1959) Esquema del Folklore. Columba: Buenos Aires.

Cullin, O. (2005). Breve historia de la música en la Edad Media. Barcelona: Paidós.

Cusicanqui, S. R. (1986). Oprimidos pero no vencidos: Luchas del campesinado aymara y qhechwa de Bolivia, 1900-1980. Instituto de Investigaciones de las Naciones Unidas para el Desarrollo Social.

Cusicanqui, S. R. (2014). Ch'ixinakax utxiwa: Una reflexión sobre prácticas y discursos descolonizadores. Retazos.

Cusicanqui, S. R. (2015). Sociología de la imagen: Miradas ch'ixi desde la historia andina. Tinta Limón.

D'Accone, F. A. (1997). The civic muse: music and musicians in Siena during the Middle Ages and the Renaissance. University of Chicago Press.

D’Arezzo, G. ([1026] 1904) Micrologus. Roma: Desclee, Lefebvre y S. Edit. Pont.

Dahlhaus, C. (1997). Fundamentos de la historia de la música. Barcelona: Gedisa.

Danto, A. C. (2010). Después del fin del arte: El arte contemporáneo y el linde de la historia. Paidós.

De Andrade, M. (1972) "A música e a canção populares no Brasil. Ensaio críticobibliográfico" [1936] en Oneyda Alvarenga (ed.) Ensaio sobre a música brasileira. São Paulo: Livraria Martins Editora

De Martino, E. (2008). El Folclore progresivo y otros ensayos. Museu d'Art Contemporani.

De Sousa Santos, B. (2014). Epistemologías del sur. Madrid: Perspectivas. Akal.

DeNora, T. (2004). Music in everyday life. Cambridge: Cambridge University Press.

Di Sarli, N. (2013). Historia del teatro en el período fundacional de la plata (1890-1930): identidad urbana y proyecto artístico. [Tesis de Maestría inédita]. Facultad de Bellas Artes. Recuperado de http://sedici.unlp.edu.ar/handle/10915/36340

Díaz, B. (2013) El teatro presentacional como espacio de subversión y reinvención política. El sótano, revista virtual de artes escénicas. (8) Recuperado de: https://docplayer.es/28953628-Elsotano-numero-8-revista-virtual-de-artes-escenicas-a-b-r-i-l-type-text-type-text-type-text.html

Díaz, C. (2005) "El lugar de la "tradición" en el paradigma clásico del folklore argentino", en: Música popular, exclusión/inclusión social y subjetividad en América Latina, (VI Congreso de la IASPM$A L)$.

Donas, E. (2015) "Problematizando la canción popular: un abordaje comparativo (y sonoro) de la canción latinoamericana "comprometida" desde los 
años 1960" Nuevo Mundo Mundos Nuevos , Images, mémoires et sons, mis, 11 de junio [En línea] recuperado de https://nuevomundo.revues.org/67824

Duarte Loza, A. (2018) Arte historiofónico: metamorfosis y dialéctica de una historiofonía del folclore argentino. Ponencia presentada en el 2do. Congreso de Música Popular, Facultad de Bellas Artes, U.N.L.P., Jueves 4 de Noviembre.

Dufourcq, N. Breve historia de la música. (1963). Fondo de Cultura Económica.

Dussel, E. (1994). 1492: El encubrimiento del otro: Hacia el origen del "mito de la modernidad": Conferencias de Frankfurt, octubre de 1992. Plural editores.

Dussel, E. (2005), "Transmodernidad e Interculturalidad (interpretaciones desde la Filosofía de la Liberación), disponible en: http://red.pucp.edu.pe/ridei/wp-content/uploads/biblioteca/090514.pdf

Dussel, E. (2006). 20 tesis de política. Siglo XXI.

Dussel, E. (2007). Política de la liberación. Historia mundial y crítica. México: Siglo XXI.

Eagleton, T. (2006). La estética como ideología. Madrid: Trotta.

Echeverría, E. (1979 [1871]) El matadero. Buenos Aires: Editorial Arte y Literatura

Eckmeyer, M. (2014). "Entre la música de las esferas y la sordera del genio". La Plata: Actas del las 6as Jornadas de Investigación en Disciplinas Artísticas y Proyectuales. FBA-UNLP.

Eckmeyer, M. (2018). «El que se mete con mi barrio me cae mal». Alternativas analíticas a la estandarización en música popular. Clang, (5), e005. https://doi.org/10.24215/25249215e005

Eckmeyer, M. (2019) "La historia de la música como cultura afirmativa. Variaciones musicales sobre Herbert Marcuse". Arte e investigación, 15. https://doi.org/10.24215/24691488e018

Eckmeyer, M., Trebuq, C., Messina, M., Barsanti, M., Kendziur, M. (2018) Intensas, integrales, transculturales y trascendentes. Para una ampliación histórica del concepto de música popular presentado en las Primeras Jornadas de Ciencia, Técnica y Arte. La Investigación en la Uader. Universidad Autónoma de Entre Ríos, 3 y 4 de octubre

Eckmeyer, M., Zucherino, L., Dalponte, G. y Maggio, M. (2017a) Conceptos intrusos: genealogía histórica de la centralidad de la organización de las alturas en música popular o ¿Por qué la armonía sigue siendo tan importante para estudiar música popular? Actas del $1^{\circ}$ Congreso Internacional de Enseñanza y Producción de las Artes en América Latina - CIEPAAL, La Plata

Eckmeyer, M., Trebuq, C., Dávila Feinstein, J., Barsanti, M. (2017b) Desde el norte o en el sur. Una aproximación a las diferencias metodológicas y significaciones políticas en las historiografías musicales contemporáneas sobre latinoamérica. Actas del $1^{\circ}$ Congreso Internacional de Enseñanza y Producción de las Artes en América Latina - CIEPAAL, La Plata

Eco, U. (1976). Apocalípticos e integrados. Perspectiva.

Eco, U. (1990). Obra Abierta. Barcelona: Ariel.

Eco, U. (2002). La definición del arte. Barcelona (España): Ediciones Destino.

Eli, V. (2010). "Nación e identidad en las canciones y bailes criollos" en Carredano, C., \& Rodríguez, V. E. (comp.) Historia de la música en España e Hispanoamérica. Fondo de Cultura Económica.

Elias, N. (2012). El proceso de la civilización investigaciones sociogenéticas y psicogenéticas. Fondo de Cultura Económica.

Ellis, K. (2009) "The sociology of music", en Harper-Scott, J. P. E y Samson, J. An Introduction to Music Studies, Cambridge University Press. 
Escobar, T. (1991) "El mito del Arte y el mito del Pueblo" en Acha, J., Colombres, A., \& Escobar, T. . Hacia una teoría americana del arte. Ed. del Sol.

Estenssoro Fuchs, J. C. (1988) "Música y comportamiento festivo de la población negra en Lima colonial" Cuadernos Hispanoamericanos, núm. 451-452 (enero-febrero), pp. 161-168, Madrid: Instituto de Cooperación Iberoamericana

Estenssoro Fuchs, J. C. (1992) "Los bailes de los indios y el proyecto colonial", Revista andina, 10(2), Cuzco.

Estenssoro Fuchs, J. C. (2001) "El simio de Dios: Los indígenas y la iglesia frente a la evangelización del Perú, siglos XVI-XVII" en Bulletin de I'Institut français d'études andines, 30 (3)

Etkin, M. (1984) "Reflexiones sobre la música de vanguardia en América Latina". En Gómez García, Z. Musicología en Latinoamérica. Editorial Arte y Literatura.

Evans, R. (2004) Cómo leer música. Madrid: EDAF.

Falck, D. y Haines, J. "Bernart de Ventadorn [de Ventador, del Ventadorn, de Ventedorn]" en Sadie, S. (ed.) The New Grove Dictionary of Music and Musicians 2nd Ed. New York: Oxford University Press.

Fanon, F. (1963). Los Condenados de la Tierra. Fondo de Cultura Económica.

Farberman, Judith. (2010). Tres miradas sobre paisaje, identidad regional y cultura folclórica en Santiago del Estero. Prismas, 14(1), 71-93. Recuperado de http://www.scielo.org.ar/scielo.php? script=sci_arttext\&pid=S1852-04992010000100004\&lng=es\&tlng=es.

Fassler, M. E. (2014). Music in the Medieval West. W. W. Norton.

Feinmann, J. P. (2010). La filosofía y el barro de la historia: Del sujeto cartesiano al sujeto absoluto comunicacional. Buenos Aires. Ed. Planeta.

Feld, S. (1994) "Notes on World Beat", en Keil, Ch. y Feld, S. Music Grooves: essays and dialogues. University of Chicago Press

Fernández Calvo, D. (2013) La música en el códice del obispo Baltasar Jaime Martínez Compañón. Revista del Instituto de Investigación Musicológica "Carlos Vega”, 27.27

Fiske, J. (2009). Understanding popular culture. Routledge.

Fornaro Bordolli, M. (2010) "De improviso: el canto payadoresco, expresión de origen hispano en el área rioplatense" en Recasens Barberà, A. (comp.) A tres Bandas: mestizaje, sincretismo e hibridación en el espacio sonoro iberoamericano, Akal,.

Fornaro Bordolli, M. (2011) Teoría y terminología en la historia de la música popular uruguaya: los primeros cincuenta años. En Araújo Duarte Valente, H.; Hernández, O.; Santamaría-Delgado, C. y Vargas $\mathrm{H}$. ¿Popular, pop, populachera? El dilema de las músicas populares en América Latina. Actas del IX Congreso de la IASPM-AL. Montevideo: IASPM-AL y EUM

Foucault, M. (2002). Historia de la locura en la época clásica. México: Fondo de Cultura Económica.

Foucault, M. (2010). La arqueología del saber. México, D.F.: Siglo Veintiuno.

Frazer, J. G. (2011[1922]). La rama dorada: Magia y religión. Fondo de Cultura Económica.

Freedman, R. (2018). La música en el Renacimiento. Akal

Frith, S. (2004). Popular music. critical concepts in media and cultural studies. Routledge. 
Frith, S. (2006). "La industria de la música" en Frith, S., Straw, W., \& Street, J. La otra historia del rock: Aspectos clave del desarrollo de la música popular: Desde las nuevas tecnologías hasta la política y la globalización. Ediciones Robinbook.

Frith, S. (2014) Ritos de la interpretación: Sobre el valor de la música popular Entornos. Buenos Aires: Paidós.

fRoots (2019) "About fRoots" (página web). Recuperado de https://frootsmag.com/about-froots

Fubini, E. (2005). La estética musical desde la antigüedad hasta el siglo XX. Madrid: Alianza Editorial.

Gadamer, H. G. (2001) “Lenguaje y Música” en Schröder, G y Breuninger, H. Teoría de la Cultura. Un mapa de la cuestión. Buenos Aires: FCE.

Galeano, E. (1981). La revolución como revelación. Triunfo, XXXV (13), p. 60-64. Recuperado de https://gredos.usal.es/bitstream/handle/10366/52130/RTXXXV N13 P60-64.pdf? sequence $=1$ \&isAllowed $=y$

García Canclini, N. (1987) “Ni folklórico ni masivo ¿Qué es lo popular?” en Diálogos de la comunicación, No. 17 ISSN 1813-9248

García Canclini, N. (1992). Culturas híbridas: Estrategias para entrar y salir de la modernidad. Sudamericana.

García Canclini, N. (1997) Culturas híbridas y estrategias comunicacionales, en revista Estudios sobre las culturas contemporáneas, junio, año/vol III, número 005, Universidad de Colima, Colima, México

Garramuño, F. (2007). Modernidades primitivas: Tango, samba y nación. Fondo de Cultura Económica.

Gelbart, M. (2007). The invention of "folk music" and "art music": Emerging categories from Ossian to Wagner. Cambridge University Press.

Ginzburg, C. (1986). El queso y los gusanos: El cosmos según un molinero del siglo XVI. Madrid: Muchnik Editores.

Ginzburg, C. (1993). El juez y el historiador: Consideraciones al margen del proceso Sofri. Madrid: Anaya \& Mario Muchnik.

Goehr, L. (1992). The imaginary museum of musical works an essay in the philosophy of music. Oxford: Clarendon Press.

Goldstein, M. (2007) Cover Story - Frank Zappa's "We're Only In It For The Money", cover by Jerry Schatzberg. RockPoP Gallery [publicación digital]. Recuperado de: https:// rockpopgallery.typepad.com/rockpop_gallery_news/2007/10/cover-story-fra.html

Gombrich, E. (2004). Breve Historia De La Cultura. Oceano De Mexico.

González, J. P (2014) Pensar la música desde América Latina, Gourmet Musical, Buenos Aires.

González, J. P. (2008) Los estudios de música popular y la renovación de la musicología en América Latina: ¿La gallina o el huevo?. TRANS-Revista Transcultural de Música 12 (artículo 15).

González, L. J., \& Smith, D. (2012, 02). How did popular music come to mean música popular? IASPM@Journal, 2(1-2), 19-33. doi:10.5429/2079-3871(2011)v2i1-2.3en

Goodall, H. (2001) Big Bangs: Five Musical Revolutions. Londres: Vintage Books

Goodall, H. (2019) Biography [Sitio web] Recuperado de http://www.howardgoodall.co.uk/about 
Goyena, H. y Cirio, N. (2015) Notas al CD Danzas y Canciones Argentinas. Versiones orquestales de registros de campo. Buenos Aires: Instituto Nacional de Musicología Carlos Vega.

Goyochea, Pedro (2009). La Zamba de Vargas. La Rioja Cultural.

Gómez, M. (1990). Minstrel Schools in the Late Middle Ages. Early Music, 18(2), 213-216.

Gómez, M. (2009). Historia de la música en España e Hispanoamérica I: De los orígenes hasta C. 1470. Madrid: Fondo de Cultura Económica.

Gómez, M. A. (2013). La música en el cine de Ingmar Bergman. Ediciones Universidad de Salamanca.

Gómez García, J. M. (2005) “iLibertad o con gloria morir! Himnos nacionales en Latinoamérica” en Francisco Colom (ed.): Relatos de nación. La construcción de las identidades nacionales en el mundo hispánico., vol. 2. Iberoamericana. Vervuert

Gómez García, Z. (1985). Musicología en Latinoamérica. Editorial Arte y Literatura.

Gramsci, A. (2000). Cuadernos de la cárcel, volumen 6. México: Era.

Gramsci, A., (2011). ¿Qué es la cultura popular? Valencia: Publicacions de la Universitat de València.

Gregory, E. D. (2006). Victorian songhunters: The recovery and editing of English vernacular ballads and folk lyrics, 1820-1883. Maryland: Scarecrow Press, Inc.

Griego, A. G. (2002). El mar de los deseos. Siglo Veintiuno Editores.

Griffiths, P. (2009) Breve Historia de la Música Occidental. Akal Ediciones.

Grignon, C., \& Passeron, J. C. (1992). Lo culto y lo popular: Miserabilismo y populismo en sociología y en literatura. Madrid: Ediciones de La Piqueta.

Grimson, A. (2012) Mitomanías Argentinas. Cómo hablamos de nosotros mismos. Buenos Aires: Siglo XXI.

Grosch, N. (2005) “¿Música popular en la galaxia Gutenberg? Un intento de reinterpretación desde la perspectiva de la historia de los medios", en: Música popular, exclusión/inclusión social y subjetividad en América Latina, (VI Congreso de la IASPM-AL),

Grosfoguel, R. (2014) "La descolonización de la economía política y los estudios poscoloniales: transmodernidad, pensamiento descolonial y colonialidad global" en De Sousa Santos, B. Epistemologías del Sur. Madrid: Akal

Grosfoguel, R. (2018). ¿Negros marxistas o marxismos negros?: una mirada descolonial. Tabula Rasa, (28), 11-22. Doi: https://doi.org/10.25058/20112742.n28.1

Grout , J. (1960) A history of Western music, New York: Norton

Grout, D. J. (1984). Historia de la música occidental. Madrid: Alianza Editorial.

Grout, D. J. (1986). Historia de la música occidental. Madrid: Alianza Editorial.

Gruzinski, S. (2007). El pensamiento mestizo: Cultura amerindia y civilización del Renacimiento. Paidós Ibérica.

Guaman Poma de Ayala, F. (1615) El primer nueva corónica y buen gobierno .København, Det Kongelige Bibliotek, GKS $22324^{\circ}$. Facsímil digital del manuscrito autógrafo http://www.kb.dk/ permalink/2006/poma/info/es/frontpage.htm

Guion, D. (2007) Wind bands in towns, courts, and churches from the Middle Ages to the Baroque. Journal of Band Research, 42(2), 19 
Günther, Robert, (1982). Las culturas musicales de Latinoamérica en el siglo XIX. Tendencias y perspectivas. Regensburg: Gustav Bose Verlag.

Gushee, L. y Rastall, R. (2001) "Minstrel”, en Sadie, S. (Ed.) The New Grove Dictionary of Music and Musicians 2nd Ed. New York: Oxford University Press.

Haar, J. (2006) The Concept of the Renaissance. En Haar, J. (Ed.) European Music, 1520-1640. Woodbridge: Boydell Press.

Hadjinicolau, N. (2005). Historia del arte y lucha de clases. Siglo XXI.

Hall, S. (1984). “Notas sobre la deconstrucción de 'lo popular”. En Samuel, Ralph (ed.) (1984). Historia popular y teoría socialista. Barcelona: Crítica.

Hall, S. (2010) Sin Garantías. Quito: Universidad Andina Simón Bolívar

Hall, S. (2015) "Raza: el significante flotante" en Intervenciones en estudios culturales (1) pp. 9-23.

Hanslick, E. (1947) De lo bello en la música. Buenos Aires: Ricordi Americana.

Harker, D. (1981). Francis James Child and the 'Ballad Consensus'. Folk Music Journal, 4(2), 146-164.

Harker, D. (1985) Fakesong. Milton Keynes: Open University Press.

Harrison, S. (2005) Cómo apreciar la música. Madrid: Edaf.

Hauser, A. (1962) Historia social de la literatura y el arte. Madrid: Guadarrama.

Hauser, A. (1974). Literatura y manierismo. Ediciones Guadarrama.

Haynes, S. (2001) "Marcabru [Marcabrun, Marchabrun, Panperdut]", en Sadie, S. (ed.) The New Grove Dictionary of Music and Musicians 2nd Ed. New York: Oxford University Press.

Hayward, B. (1988) Notas al CD "La messe des fous". París: BNL productions.

Hepokoski, J. (1991, 04). The Dahlhaus Project and Its Extra-Musicological Sources. 19th-Century Music, 14(3), 221-246. doi:10.2307/746536

Herder, J. G. (1967) Sämtliche Werke (ed. de B. Suphan), 25, Hildesheim.

Herndon, M. y McLeod, N. (1979) Music as Culture. Indiana: Norwood Editions.

Hesmondhalgh, D., \& Negus, K. (2012). Popular music studies. UK: Hodder Education.

Hill, J. W. (2008). La música barroca: Música en Europa occidental, 1580-1750. Madrid: Akal.

Hobsbawm, E. J. (2015). The invention of tradition. Cambridge: Cambridge University Press.

Honorable Cámara de Diputados de la Nación (1884) Sesión de apertura - Mayo 6 de 1884.

Recuperado de: https://www.hcdn.gob.ar/secparl/dgral_info_parlamentaria/dip/archivos/

1884_Mensaje_presidencial_Roca.pdf

Hoppin, R. (2000) La música medieval. Madrid: Akal.

Horkheimer, M., \& Adorno, T. W. (2001). Dialéctica de la ilustración: Fragmentos de filosofía. Editorial Trotta.

Hornbostel, E ([1905] 2001) "Los problemas de la musicología comparada" en Cruces, F. y otros (ed.) Las culturas musicales. Ed. Trotta.

Huseby, G. V., \& Plesch, M. (2013). Analizar, interpretar, hacer música: De las Cantigas de Santa María a la organología: Escritos in memoriam Gerardo V. Huseby. Gourmet Musical Editions.

Huyghe, R. (1967). El arte y el hombre. Buenos Aires: Larousse. 
Ingenieros, J. (1957) Sociología Argentina. Buenos Aires: Elmer.

International Folk Music Council (1955), Journal of the International Folk Music Council 7, 23.

Jacobelli, M. C. (1991). Risus paschalis: El fundamento teológico del placer sexual. Planeta.

Johnson, B. (2018) "Problematising popular music history in the context of heritage and memory" en Baker, S., Strong, C., Istvandity, L., \& Cantillon, Z. The Routledge Companion to Popular Music History and Heritage. Routledge.

Jünger, E. (1990) El trabajador. Dominio y figura. Barcelona: Tusquets.

Kaliman, R. (2006) Criollos y criollismo en la industria del folclore musical. Revista de Investigaciones Folclóricas. Vol. 21: 88-93.

Kaltenecker, M. (2004). El rumor de las batallas: Ensayo sobre la música en la transición del siglo XVIII al XIX. Paidós.

Katz, I. (2001) "Fandango" en Sadie, S. (ed.) The New Grove Dictionary of Music and Musicians 2nd Ed. New York: Oxford University Press.

Keightley, K. (2006) "Reconsiderar al Rock", en Frith, S. y otros, La otra historia del Rock, Barcelona: Robinbook.

Keil, C. $(1978,09)$. Who Needs "The Folk"? Journal of the Folklore Institute, 15(3), 263.

Keil, Ch. (2001) "Las discrepancias participatorias y el poder de la música" en Cruces, F. y otros (ed.) Las culturas musicales. Ed. Trotta.

Kerman, J. (1985). Contemplating music: Challenges to musicology. Cambridge, Mass: Harvard University Press.

Kerman, J., Tomlinson, G., \& Kerman, V. (2015). Listen. New York: W. W. Norton \& Company.

Kinder, H., Hilgemann, W. \& Hergt, M. (2007) Atlas histórico mundial. Madrid: Akal

King, J. (1985) El Di Tella y el desarrollo cultural argentino en la década del sesenta. Buenos Aires: Editorial Gagaglione.

Korsyn, K. E. (2003). Decentering music: A critique of contemporary musical research. Oxford: Oxford University Press.

Krappe, A. H. (1929) The Science of Folklore. New York: Barnes \& Noble.

La Gaceta, (2016) Pepe Podestá se despide de las tablas 4 de septiembre de 2016. Tucumán, Recuperado de https://www.lagaceta.com.ar/nota/697433/sociedad/pepe-podesta-se-despidetablas.html

Lacarra de Miguel, J. M. (1966) Las peregrinaciones a Santiago en la Edad Moderna. Príncipe de Viana, Año $n^{\circ} 27, N^{\circ} 102-103$, págs. 33-46

Lander, E. (comp.) (2000) La colonialidad del saber: eurocentrismo y ciencias sociales. Perspectivas latinoamericanas. Buenos Aires: Clacso.

Lang, P. H. (1963 [1941]). La Música en la civilización occidental. Eudeba

Langer, S. K. (1957). Philosophy in a new key: A study of the symbolism of reason, rite and art. Harvard University Press.

Langer, S. K. (1966). Los problemas del arte: Diez conferencias filosóficas. Buenos Aires: Infinito.

Lanza, A. (1986). El Siglo xx: Tercera parte. Madrid: Turner. 
Laplantine, F., y Nouss, A. (2007). Mestizajes: De Arcimboldo a zombi. Buenos Aires, Argentina: Fondo de Cultura Económica.

Le Goff, J. (2007). En busca de la Edad Media. Buenos Aires: Paidós.

Le Goff, J. (2008). Una larga Edad Media. Buenos Aires: Paidós.

Le Goff, J. (2016). Realmente es necesario cortar la historia en rebanadas? FCE - Fondo de Cultura Económica.

Leach, E. E. (2009) "Popular Music", en Harper-Scott, J. P. E y Samson, J. An Introduction to Music Studies, Cambridge University Press.

Leichtentritt, H. (1945) Música, Historia e Ideas. Madrid: Espasa Calpe

Lengwinat, K., (2006) El pueblo no inventa nada en sus canciones. Procesos de apropiación intersocial. Revista de la Sociedad Venezolana de Musicología (SVM), Año VI, Julio-Diciembre, $\mathrm{N}^{\circ} 11$.

Leuchter, E. (1946) Ensayo sobre la evolución de la música en occidente. Buenos Aires: Ricordi Americana.

Lévi-Strauss, C. (1987) Antropología estructural, I. Barcelona: Paidós

Lezcano, C. M., y Zubieta, J. P. (2017). Industria chamamé. Corrientes: Moglia Ediciones.

Locatelli de Pérgamo, A. M. (2007) "Raíces Musicales”, en Aretz, I. (ed.) América Latina en su Música. México: Siglo XXI.

Lockwood, L. (2009). Music in Renaissance Ferrara, 1400-1505: The creation of a musical center in the fifteenth century. Oxford University Press.

Lomax, A. (1956). Folk Song Style: Notes on a Systematic Approach to the Study of Folk Song. Journal of the International Folk Music Council, 8, 48. doi:10.2307/834750

Lomax, A. (1959, 12). Folk Song Style. American Anthropologist,61(6), 927-954. doi:10.1525/aa. 1959.61.6.02a00030

Lomax, A. (1968). Folk song style and culture: With contributions by the cantometrics staff and with the editorial assistance of Edwin E. Erickson. New York: Transaction Books.

López, M. (2016). Performatividades Folklorizadas: Visiones Europeas De Las Músicas Coloniales. Revista De Musicología, 39(1), 291. doi:10.2307/24878550

Lott, E. (2013). Love and theft: Blackface minstrelsy and the American working class. Oxford University Press.

Lowinsky, E. E. (1954, 10). Music in the Culture of the Renaissance. Journal of the History of Ideas, 15(4), 509.

Madoery, D. (2010) "El Folclore profesional. Una perspectiva que aborda las continuidades". Actas del IX Congreso de la IASPM-AL, Caracas, Venezuela. Publicado en: http://iaspmal.net/ ActasIASPMAL2010.pdf

Madrid, A. (2010) "Música y nacionalismos en Latinoamérica". En Barberà, A. R., y Espinosa, C. S. (2010). A tres bandas: Mestizaje, sincretismo e hibridación en el espacio sonoro iberoamericano. Madrid: Akal.

Marcuse, H. (1967[1937]). Cultura y sociedad. Buenos Aires: Sur.

Marcuse, H. (1973). Contrarrevolución y revuelta. Ciudad de México: Joaquín Mortiz. 
Mariño Pego, C. y Salgado López, J. I. (2005) "Cornamusas y otras gaitas en el Camino de Santiagoapuntes para un inventario iconográfico". Flumen: Revista de la Escuela de Magisterio de Huesca, $N^{\circ} 9$, págs. 169-180

Martínez, F., Massa L. Messina, M. Zucherino, L. Eckmeyer, M. (2010). Un trio olvidado. Consideraciones en torno al estudio de la música de juglares, ministriles y goliardos. La Plata, UNLP: Actas de las V Jornadas De Investigación En Disciplinas Artísticas Y Proyectuales (JIDAP).

Martín-Barbero, J. (1991). De los medios a las mediaciones. Convenio Andrés Bello.

Martín-Barbero, J. (2002) "Culturas Populares" en Altamirano, C. Términos críticos de sociología de la cultura. $\mathrm{P}<$ aidós.

Martínez Miura, E. (2004). La música precolombina: Un debate cultural después de 1492. Barcelona: Paidós.

Mayer Brown, H. \& Boydell, B. R. (2001) "Bladder Pipe”, en Sadie, S. (Ed.) The New Grove Dictionary of Music and Musicians 2nd Ed. New York: Oxford University Press.

Mayer Brown, H. \& Polk, K. (2001a) "Alta”. En Sadie, S. (Ed.) The New Grove Dictionary of Music and Musicians 2nd Ed. New York: Oxford University Press.

Mayer Brown, H. \& Polk, K. (2001b) “Instrumental music, c. 1300-c. 1520”. En Strohm, R. \& Blackburn, B. J. (Eds.) The new Oxford history of music. Londres y New York: Oxford University Press.

Mayer-Serra, O. (1984) "Panorama de la Música Hispanoamericana (Esbozo interpretativo)". En Gómez, Z. Musicología en América Latina, La Habana: Arte y Literatura.

McClary, S. (1991). Feminine endings music, gender, and sexuality. Minneapolis: University of Minnesota Press.

McKinnon, J. W., Sadie, S., \& Fenlon, I. (1989). Man \& music. Macmillan.

Mendívil, J. (2016). En contra de la música: Herramientas para pensar, comprender y vivir las músicas. Gourmet Musical Ediciones.

Merriam, A. ([1977] 2001) "Definiciones de «musicología comparada» y «etnomusicología»: una perspectiva histórico-teórica" en Cruces, F. y otros (ed.) Las culturas musicales. Ed. Trotta.

metrocosm.com (2016) The history of urbanization, 3700 BC - 2000 AD. [artículo en línea]. Recuperado de http://metrocosm.com/history-of-cities/?ref=youtube

Meyer, L. B. (2956). Emotion and meaning in music. Chicago: University of Chicago Press.

Michaud, E. (2017) Las invasiones bárbaras. Una genealogía de la historia del arte. Adriana Hidalgo.

Micheletto, K. (2010) Mucho Más que el Patriarca. Página/12 del 24 de abril. Recuperado de https://www.pagina12.com.ar/diario/suplementos/espectaculos/3-17728-2010-04-24.html

Michels, U. ([1985]1992). Atlas de música. Madrid: Alianza.

Middleton, R. (1990). Studying popular music. Open Univ. Press

Middleton, R. y Horn, D. (1981) "Preface. Folk or Popular? Distinctions, Influences, Continuities". Popular Music, 1, 1-2.

Mignolo, W. (2009) “El lado más oscuro del Renacimiento" Universitas humanística no. 67 enerojunio 
Mignolo, W. (2017). Desobediencia epistémica: Retórica de la modernidad, lógica de la colonialidad y gramática de la descolonialidad. Ediciones del Signo.

Miller, K. H. (2010). Segregating sound: Inventing folk and pop music in the age of Jim Crow. Duke Univ. Press.

Miranda, R. (2011). La Música en Latinoamérica. México: Secretaría de Relaciones Exteriores.

Monmonier, M. (2010). Rhumb Lines and Map Wars: A Social History of the Mercator Projection. University of Chicago Press.

Moore, A. F. (2008). Analyzing popular music. Cambridge Univ. Press.

Mosse, G. L. (1997) La cultura europea del siglo XIX. Barcelona: Ariel.

Muir, E. (2001). Fiesta y rito en la Europa moderna. Madrid: Complutense.

Mundy, S. (1982) Historia de la música. De los instrumentos primitivos a la música electrónica. Ediciones Plesa.

Myers, H. y Wilton, P. (2008) "Música folclórica", en Latham, A. (comp.) Diccionario enciclopédico Oxford de la Música. México: Fondo de Cultura Económica

Negus, K. (1997). Popular music in theory: An introduction. University Press of New England.

Negus, K. (2005). Los Géneros musicales y la cultura de las multinacionales. Paidós.

Nettl, B. (1985). Música folklórica y tradicional de los continentes occidentales. Madrid: Alianza Editorial.

Nietzsche, F. (2001). La genealogía de la moral: Un escrito polémico. Alianza Editorial.

Ogilvy, J. D. (1963, 10). Mimi, Scurrae, Histriones: Entertainers of the Early Middle Ages. Speculum, 38(4), 603-619. doi:10.2307/2851658

Ortega Peña, R y Duhalde, E. L. (1966) Felipe Varela contra el imperio británico: las masas de la unión americana enfrentan a las potencias europeas. Buenos Aires : Sudestada.

Ortega Peña, R y Duhalde, E. L. (1967) Folklore argentino y revisionismo histórico : la montonera de Felipe Varela en el cantar popular. Buenos Aires : Sudestada.

Ortega y Gasset, J. (1937) La rebelión de las masas, Madrid: Espasa- Calpe.

Ortiz, F. (1940). Contrapunteo Cubano del Tabaco y el Azúcar (Advertencia de sus contrastes agrarios, económicos, históricos y sociales, su etnografía y su transculturación); prólogo de Herminio Portell Vila; introducción por Bronislaw Malinowski. La Habana: Jesus Montero.

Ortiz Oderigo, N. (2008) Esquema de la música afroargentina. Caseros, Buenos Aires: Eduntref.

Paddison, M. (1982, 01). The critique criticised: Adorno and popular music. Popular Music, 2, 201.

Palao Gómez, J. A. (2008) Sobre el mestizaje de la pastorela de Marcabrú. [artículo en línea] Recuperado de https://abenyusuf.wordpress.com/2008/02/07/sobre-el-mestizaje-de-la-pastorelade-marcabru/

Palisca, C. V. ([1968]1983). La música del barroco. Buenos Aires: Victor Leru.

Paraskevaídis, G. (1999) "La investigación musical en su laberinto", Conferencia de clausura del Primer Foro de Investigación, Universidad de los Andes, Santa Fe de Bogotá, 22 de octubre.

Parry, Ch. H. (1896) The Evolution of the Art of Music. Londres: Kegan Paul, Trench, Trübner \& Co.

Parry, Ch. H. (1911) Style in musical art. Londres: MacMillan 
Partridge, R. (2008) "Gaita”, en Latham, A. (comp.) Diccionario enciclopédico Oxford de la Música. México: Fondo de Cultura Económica

Pascall, R. (2001) "Style", en The New Grove Dictionary of Music and Musicians 2nd Ed. New York: Oxford University Press.

Pascual, J. (2008) Guía Universal de la Música Clásica. Barcelona: Robinbook.

Pedrotti, C. E. (2017). Pobres, negros y esclavos: Música religiosa en Córdoba del Tucumán, 1699-1840. Editorial Brujas.

Pelinski, R. A. (2000). Invitación a la etnomusicología: Quince fragmentos y un tango. Akal Ediciones.

Pernoud, R. (1998). Para acabar con la Edad Media. Palma de Mallorca: Medievalia.

Peters, G. $(2000,10)$. Urban minstrels in late medieval southern France: Opportunities, status and professional relationships. Early Music History, 19, 201.

Peters, G. (2005) "Las redes sociales y profesionales de los ministriles de Montpellier, 1350-1500". En Bombi, A.; Carreras, Juan J.; Marin, Miguel A. (Comp.) Música y cultura urbana en la Edad Moderna. Publicaciones de la Universidad de Valencia.

Petzoldt, L. (1994). "Fiestas carnavalescas. Los carnavales en la cultura burguesa a comienzos de la Edad Moderna", en Schultz, U. La fiesta: De las Saturnales a Woodstock. Alianza Editorial.

Pickett, Ph. (1992) Notas al CD "The feast of fools" London: Decca.

Piston, W. (1991) Armonía. Barcelona: Labor.

Plaza, G. (2000) "El legado de Andrés Chazarreta". La Nación del 24 de marzo. Recuperado de https://www.lanacion.com.ar/10298-el-legado-de-andres-chazarreta

Podetti, R. (2004) "Mestizaje y transculturación: la propuesta latinoamericana de globalización", Comunicación presentada en el VI Corredor de las Ideas del Cono Sur, 11 al 13 de Marzo, Montevideo, Uruguay.

Polk, K. $(1987,10)$. Instrumental music in the urban centres of Renaissance Germany. Early Music History, 7, 159.

Polk, K. (2004). German instrumental music of the late Middle Ages: players, patrons and performance practice. Cambridge University Press.

Ponce, M (1919) "El folklore musical mexicano" en Revista Musical México, t. 1, núm. 5, 15 de Septiembre de 1919

Popper, K. (1957). La sociedad abierta y sus enemigos. Buenos Aires: Paidós.

Pujol, S. A. (2013). Cien años de música argentina: Desde 1910 a nuestros días. Editorial Biblos.

Pérez González, J. (2010). Las historias de la música en Hispanoamérica (1876-2000). Bogotá: Universidad Nacional de Colombia.

Pérez González, J. (2011). Música Popular en las historias de la música latinoamericanas del fin de siglo XIX e inicios del siglo XX: Historia de un concepto. En Araújo Duarte Valente, H.; Hernández, O.; Santamaría-Delgado, C. y Vargas H. ¿Popular, pop, populachera? El dilema de las músicas populares en América Latina. Actas del IX Congreso de la IASPM-AL. Montevideo: IASPM-AL y EUM

Pérez González, J. (2015) "Mário de Andrade y Carlos Vega: el estudio de la música popular", Ensayos. Historia y teoría del arte, Vol. XVIII, No. 26 (enero-junio 2014), pp. 38-62. Bogotá, D. C., Universidad Nacional de Colombia 
Pérès, M. (1986). "Old Roman Chant, 7th-8th Centuries, Byzantine period". Notas acompañando el CD del Ensemble Organum, Harmonia Mundi.

Pérès, M. (2004). "Compostela. Ad vesperas Sancti lacobi". Notas acompañando el CD homónimo del Ensemble Organum, Harmonia Mundi.

Prudencio, C. (2001) "Conceptos y rasgos de la música de las comunidades de los departamentos de La Paz, Oruro y Potosí. [Inédito] Transcripción de la conferencia magistral ofrecida en el marco de las Jornadas de Música Contemporánea, Facultad de Bellas Artes, La Plata, Argentina

Quijano, A. (2014). Textos de fundación. Ediciones del Signo.

Quintero Rivera, A. (1994) De la fiesta al festival: los movimientos sociales para el disfrute de la vida en Puerto Rico. Diálogos de la comunicación, 38. Recuperado de http://dialogosfelafacs.net/ wp-content/uploads/2015/38/38-revista-dialogos-los-movimientos-sociales.pdf

Quintero Rivera, A. (2005). ¡Salsa, sabor y control! sociología de la música "tropical". México: Siglo Veintiuno.

Quintero Rivera, A. (2009). Cuerpo y cultura: Las músicas "mulatas" y la subversión del baile. Madrid: Editorial Iberoamericana..

Ramos López, P. (2005) "Música y autorrepresentación en las procesiones del Corpus en la España Moderna". En Bombi, A.; Carreras, Juan J.; Marin, Miguel A. (Comp.) Música y cultura urbana en la Edad Moderna. Publicaciones de la Universidad de Valencia.

Rastall, R. (2006) The origin of the Town Waits, and the myth of the watchman-turned-musician. [artículo online] Recuperado de: http://www.townwaits.org.uk/essays/waitsorigin.pdf

Raynor, H. (1986). Una historia social de la música. Desde la edad media hasta Beethoven. Madrid: Siglo XXI.

Recasens, A. (2010). A tres bandas: Mestizaje, sincretismo e hibridación en el espacio sonoro iberoamericano. Akal.

Reder Carlson, J. D. (2013) “¿Una modernidad primitiva? Andrés Chazarreta, el folklore argentino y los medios masivos de comunicación”. Letra. Imagen. Sonido L.I.S. Ciudad mediatizada Año IV, \# 9. Buenos Aires

Reese, G. ([1940-54]1988). La música en el Renacimiento. Madrid: Alianza Editorial.

Reese, G. ([1940]1989). La Música en la Edad Media: Con una introducción sobre la música en la Edad Antigua. Alianza.

Reynolds,S. (2010). Después del rock. Psicodelia, postpunk, electrónica y otras revoluciones inconclusas. Buenos Aires: Caja Negra Editora.

Reynolds, S. (2016). Retromanía: La adicción del pop a su propio pasado. Buenos Aires: Caja negra.

Reynoso, C. (2006). Antropología de la música: De los géneros tribales a la globalización. Editorial SB.

Rigueiro García, J. (2015) Carta de Guido dirigida al monje Miguel acerca de un canto desconocido. Mar del Plata: UNMdP - GIEM.

Rincón, O. (2015) "Lo popular en la comunicación: <culturas bastardas + ciudadanías celebrities>" en Amado, A. y Rincón, O. (Coords.) La comunicación en mutación: remix de discursos. Bogotá: Friedrich-Ebert-Stiftung.

Riquer, M. D. (1983). Los trovadores: Historia literaria y textos. Editorial Ariel. 
Robert, G. (1999) Notas al CD del conjunto Perceval, "Printemps du plaisir au Moyen-Age", Arion París, 1999

Robertson, A., y Stevens, D (Comp.) (2000). Historia general de la música. Madrid: Istmo.

Rodríguez, R. (2019) AntropoMúsica de ida y vuelta - conferencia en la La Facultad de Geografía e Historia de la Universidad de Sevilla [archivo de video] Recuperado de https://www.youtube.com/ watch?v=alcHIKpV9vs\&t=1451s

Rojas, R. (1921) "El coro de las selvas y las montañas" en La Nación del 18 de marzo. Buenos Aires

Romero, J. L. (2001). Latinoamérica: Las ciudades y las ideas. Siglo Veintiuno Editores.

Rosa, J. M. (2011) Lanzas contra fusiles. [Artículo online]. 4 de junio. Recuperado de http:// elfrentenegro.blogspot.com/2011/06/lanzas-contra-fusiles.html

Rose, S. (2005) "Music in the Market-place" en Carter, T., Butt, J. (eds.) Cambridge History of Seventeenth Century Music, Cambridge University Press.

Rosen, C. (1986). El estilo clásico: Haydn, Mozart, Beethoven. Madrid: Alianza.

Rouget, G.(1985). Music and trance: A theory of the relations between music and possession. The University of Chicago press.

Roy, M. (2003). Músicas cubanas. Akal.

Rubio, H. (2008) "No toda música es arte" en Rubio, H., \& Sammartino, F. Músicas populares: Aproximaciones teóricas, metodológicas y analíticas en la musicología argentina. Univ. Nacional de Córdoba.

Ruiz, I. (2015) "Lo que no merece una guerra ... Una revisión teórico-metodológica", en Cámara Landa, E. (comp). Estudios sobre la obra de Carlos Vega. Gourmet Musical.

Saarinen, Th. (1987) Centering of mental maps of the world [Discussion Paper] University of Arizona, Department of Geography and Regional Development.

Sammartino, F. y Rubio, H. eds. (2008) Músicas populares. Aproximaciones teóricas, metodológicas y analíticas en la musicología argentina. Universidad Nacional de Córdoba.

Samson, J. (2009) "Music History" en Harper Scott J. P. E. y Samson J. An introduction to Music Studies, Cambridge University Press

Samuel, R. (1984). Historia popular y teoría socialista. Editorial Crítica.

Sánchez, D. y Eckmeyer, M. (2019) Historia del arte y la música medieval : nuevas perspectivas y enfoques. La Plata : EDULP Universidad Nacional de La Plata

Sánchez Canedo, W. (2010) Sin purezas y con Mezclas. Las cambiantes identidades sonoras negro-africanas de Bolivia, en Recasens Barberà, A. (comp.) A tres Bandas: mestizaje, sincretismo e hibridación en el espacio sonoro iberoamericano, Madrid: Akal.

Sánchez de Aguilar, P. (1639). Informe contra idolorvm cvltores del obispado de Yvcatan, dirigido al rey n. señor en su real Consejo de las Indias. Versión electrónica: https://www.biblioteca.org.ar/ libros/89960.pdf

Sandoica, E. H. (2004). Tendencias historiográficas actuales: Escribir historia hoy. Madrid: Akal.

Santa María, L. A. (2017). Taki onqoy: epidemia de intoxicación por exposición al mercurio en Huamanga del siglo XVI. Rev. perú. med. exp. salud pública, vol.34, n.2, pp.337-342. 
Santamaría, C. (2005). Negrillas, negros y guineos y la representación musical de lo africano. Cuadernos de música, artes visuales y artes escénicas. 2(1). Bogotá. Pontificia Universidad Javeriana.

Santos, M. (1986) Espacio y Método, Geo Crítica. Cuadernos Críticos de Geografía Humana, Universidad de Barcelona. Año XII. Número: 65. Septiembre de 1986. Recuperado de http:// www.ub.edu/geocrit/geo65.htm

Santos, M. (2000) La naturaleza del espacio. Técnica y tiempo. Razón y emoción. Barcelona: Ariel

Sarmiento, D. F. (1915) Conflicto y armonías de las razas en América (con una exposición de sus ideas sociológicas por José Ingenieros). Buenos Aires : "La Cultura Argentina".

Schultz, U. (1994). La fiesta: De las Saturnales a Woodstock. Alianza Editorial.

Schwab, H. W. (2001) "Guild". En Sadie, S. (Ed.) The New Grove Dictionary of Music and Musicians 2nd Ed. New York: Oxford University Press.

Schávelzon, S. (2015) Plurinacionalidad y Vivir Bien/Buen Vivir. Dos conceptos leídos desde Bolivia y Ecuador post-constituyentes. Ediciones Abya-Yala, Quito-Ecuador.

Scott, D. (2003). From the erotic to the demonic: On critical musicology. Oxford: Oxford University Press.

Scott, D. (2014) "Invention and interpretation in popular music historiography". En Helms, D. y Phelps, T. (Hg.), Geschichte wird gemacht: zur Historiographie populärer Musik. Bielefeld: Transcript Verlag.

Segato, R. L. (2015). La crítica de la colonialidad en ocho ensayos: Y una antropología por demanda. Prometeo libros.

Selden Pratt, W. (1905) The history of music. New York: Schrimer

Shreffler, A. C. $(2003,10)$. Berlin Walls: Dahlhaus Knepler, and Ideologies of Music History. The Journal of Musicology, 20(4), 498-525. doi:10.1525/jm.2003.20.4.498

Slocum, K. B. $(1995,10)$. Confrérie, Bruderschaft and Guild: The formation of musicians' fraternal organisations in thirteenth- and fourteenth-century Europe. Early Music History, 14, 257.

Small, C. (1989). Música, sociedad, educación: Un examen de la función de la música en las culturas occidentales, orientales y africanas, que estudia su influencia sobre la sociedad y sus usos en la educación. Madrid: Alianza Editorial.

Small, C. (1998). Music of the common tongue: Survival and celebration in African American music. Hanover, NH: University Press of New England.

Small, C. (1999) El musicar: un ritual en el espacio social. Revista Transcultural de Música, núm 4

Small, C. (2010). Musicking: The meanings of performing and listening. Middletown: Wesleyan Univ. Press.

Smithers, D. L. (1973). The music and history of the baroque trumpet before 1721. Dent.

Solana de Quesada, A. (2014) Dum pater familias o Canto del Ultreia [Sitio Web] Recuperado de http://xacopedia.com/Dum_pater_familias. Consultado el 20-2-2019

Soler, J. (1987). La música: De la época de la religión a la edad de la razón. Barcelona: Montesinos.

Solie, R. A. (1993). Musicology and difference: Gender and sexuality in music scholarship. Milton Keynes UK: Lightning Source UK. 
Stan, L. (2016) Entretien avec Marcel Pérès sur le pèlerinage et la musique du Codex Calixtinus. ANASTASIS. Research in Medieval Culture and Art. Vol. III, Nr. 1/ May.

Stanley, G. (2001) "Historiography" en The New Grove Dictionary of Music and Musicians 2nd Ed. Oxford University Press, New York.

Stevenson, R. M. (1968) Music in Aztec \& Inca Territory, University of California Press.

Stevenson, R. M. (1970a). Philosophies of American music history: A lecture delivered in the Whittall Pavilion of the Library of Congress, January 9, 1969. Washington: Louis Charles Elson memorial fund.

Stevenson, R. M. (1970b). Renaissance and Baroque Musical Sources in the Americas. Secretaría General de la Organización de Estados Americanos.

Stevenson, R. M. (1990) "La música en la América Española Colonial” en Bethell, L. (1990). Historia de América Latina. 4: América Latina colonial: Población, sociedad y cultura. Barcelona: Crítica

Stobart, H. (2009) "World Musics" en Harper-Scott, J. P. E y Samson, J. An Introduction to Music Studies, Cambridge University Press.

Storey, J. (2002). Teoría cultural y cultura popular. Octaedro.

Storey, J. (2016) The Making of English Popular Culture. Abingdon: Routledge.

Strohm R. (1990a) Music in Late Medieval Bruges. Wotton-under-Edge: Clarendon Press.

Strohm R. (1990b) The Close of the Middle Ages. McKinnon J. (ed.) Antiquity and the Middle Ages. Man \& Music. Londres: Palgrave Macmillan.

Taruskin, R. (1996) El movimiento de la autenticidad puede convertirse en un purgatorio positivista, literalista y deshumanizador. Quodlibet: revista de especialización musical, $n$. 5, pp. 44-59, ISSN 1134-8615

Taruskin, R. (2005.a). The Oxford history of western music; Volume 1: Music from the earliest notations to the sixteenth century. Oxford: Oxford University Press.

Taruskin, R. (2005.b). The Oxford history of western music; Volume 2: The Seventeenth Century. Oxford: Oxford University Press.

Taruskin, R. (2010). The danger of music: And other anti-utopian essays. Berkeley: University of California Press.

Terán, O. (2008). Historia de las ideas en la Argentina: Diez lecciones iniciales, 1810-1980. Buenos Aires: Siglo XXI.

The International Advisory Editors (2005). Can We Get Rid of the 'Popular' in Popular Music? A Virtual Symposium with Contributions from the International Advisory Editors of "Popular Music". Popular Music, 24(1), 133-145. Retrieved from http://www.jstor.org/stable/3877598

Thompson, E. P. (2000). Costumbres en Común. Barcelona: Crítica.

Thompson, E. P. (2012). La formación de la clase obrera en Inglaterra. Madrid: Capitán Swing.

Tomlinson, G. (1993). Music in Renaissance magic: Toward a historiography of others. Chicago: University of Chicago Press.

Treitler, L. (1981). Oral, Written, and Literate Process in the Transmission of Medieval Music. Speculum, 56(3), 471-491. doi:10.2307/2847738

Treitler, L. (1990). Music and the historical imagination. Cambridge (Mass.): Harvard University Press. 
Treitler, L. (1991, 01). The Politics of Reception: Tailoring the Present as Fulfilment of a Desired Past. Journal of the Royal Musical Association, 116(2), 280-298.

Treitler, L. (1996). Toward a Desegregated Music Historiography. Black Music Research Journal, 16(1), 3. doi:10.2307/779374

Trowell, B. (1978) Minstrels and Minstrelsy. En Robertson, A. \& Stevens, D.(Comp.) The Pelican history of music. Renaissance and Baroque. Londres: Pelican.

Trowell, B. (2000). Los trovadores y la gaya ciencia. En Robertson, A., \& Stevens, D (Comp.). Historia general de la música. Madrid: Istmo.

Turone, G. (2015) Historia musical del pozo de Vargas. [Artículo online]. Recuperado de http:// jovenesrevisionistas.org/historia-musical-de-la-batalla-de-pozo-de-vargas/

Turrent, L. (1993). La conquista musical de México. Fondo de Cultura Económica.

Ugarte, M., \& Sanjurjo, L. (2008). Emergencia: Cultura, música y política. Ediciones del CCC, Centro Cultural de la Cooperación Floreal Gorini.

Urchueguía, C. (2012) “La colonización musical de Hispanoamérica” en Gómez, M. (comp.) Historia de la música en España e Hispanoamérica, vol.2. De los Reyes Católicos a Felipe II. Madrid: Fondo de Cultura Económica

Valladares, L (1970) Canciones Arcaicas del Norte Argentino, Buenos Aires: Ricordi Americana

Van Der Meer, R. (1995) Carpeta de Música. Ediciones Destino

Van Der Werf, H. (2001) "Jeu-parti”, en Stanley, G. The New Grove Dictionary of Music and Musicians 2nd Ed. New York: Oxford University Press.

Vega, C. (1941) La música popular argentina. Canciones y Danzas criollas. Tomo segundo: fraseología. Buenos Aires: Imprenta de la Universidad.

Vega, C. (1944). Panorama de la música popular argentina: Con un ensayo sobre la ciencia del folklore. Buenos Aires: Instituto Nacional de Musicología Carlos Vega.

Vega, C. (1977a) "Acerca del origen de las danzas folklóricas argentinas". Revista del Instituto de Investigación Musicológica "Carlos Vega", Nº 1, p. 9-10

Vega, C. (1977b) "El Canto de los Trovadores en una Historia Integral de la Música". Revista del Instituto de Investigación Musicológica "Carlos Vega", № 1, p. 20 a 32

Vega, C. (1981) Apuntes para la historia del movimiento tradicionalista argentino. Buenos Aires: Secretaría de Cultura. Instituto Nacional de Musicología Carlos Vega.

Vega, C. (1985) "La música de los trovadores" Revista del Instituto de Investigación Musicológica "Carlos Vega" No. 6. pp. 5-33.

Vega, C. (1997) "Mesomúsica. Un ensayo sobre la música de todos". Revista musical chilena v.51 n.188 Santiago.

Vega, Carlos (2010) Panorama de la música popular argentina ( $2^{\circ}$ edición). Buenos Aires: Instituto Nacional de Musicología Carlos Vega.

Vera Aguilera, A. (2016) "Música en Hispanoamérica durante el siglo XVII" en Torrente, A. (ed.) La música en el siglo XVII. Madrid: Fondo de Cultura Económica.

Veyne, P. (1984). Cómo se escribe la historia ; Foucault revoluciona la historia. Madrid: Alianza Editorial.

W. W. Norton \& co. (2019) A History of Western Music [sitio web] https://books.wwnorton.com/ books/webad.aspx?id=4294997281. Consultado el 16 de marzo de 2019 
Waisman, L. (2004) "La contribución indígena a la música misional en Mojos (Bolivia)". Memoria Americana. Cuadernos de Etnohistoria (12). Universidad de Buenos Aires.

Waisman, L. (2005). "La música en la definición de lo urbano: los pueblos de indios americanos" en Bombi, A y otros Música y cultura urbana en la edad moderna, PUV, Valencia

Waisman, L. (2012) "La Americanidad del Barroco Americano: Quimeras, Pretensiones y Perspectivas”. Primer Congreso-festival Internacional «Música Barroca Iberoamericana», Lima.

Waisman, L. (2019). Una historia de la música colonial hispanoamericana. Gourmet Musical Ediciones.

Walser, R., \& Berger, H. M. (1992). Running with the devil: Power, gender, and madness in heavy metal music. Middletown, CT: Wesleyan University Press.

Wasserman, F. (2016) "Élites y construcción del orden social y político". Conferencia en la Biblioteca Nacional en el marco de la muestra "El complejo proceso de construcción del Estado nacional argentino". Recuperado de https://www.youtube.com/watch?v=kNERjrlr0CY\&t=2229s

Weber, W. (2011) La gran transformación del gusto musical. Fondo de cultura económica.

Weisbard, E. (2008). Listen again: A momentary history of pop music. Duke University Press.

White, H. (2010). Metahistoria: La imaginación histórica en la Europa del siglo XIX. México: Fondo de Cultura Económica.

Williams, R. (2000). Marxismo y literatura. Península.

Williams, R. (2015). Sociología de la cultura. Paidos.

Wilson, B. (1992) Music and Merchants The Laudesi Companies of Republican Florence. Oxford: Clarendon Press

Wright, L. (1981). Review: Troubadours by Clemencic Consort, Early Music, 9(1), 134-137.

Wölfflin, H. (2007 [1915]). Conceptos fundamentales de Historia del Arte. Espasa

Ynoub, R. (2015) Cuestión de Método - Tomo I. Cengage Learning, México.

Zátonyi, M. (2002). Una estética del arte y el diseño de imagen y sonido. CP67.

Zátonyi, M. (2007). Arte y creación: Los caminos de la estética. Buenos Aires: Capital Intelectual.

Zátonyi, M. (2011). Juglares y trovadores: Derivas estéticas. Buenos Aires: Capital Intelectual.

Zea, L. (1986). América Latina en sus ideas. Siglo XXI Editores.

Zárate Toscano, V., y Gruzinski, S. (2008). "Ópera, imaginación y sociedad. México y Brasil, siglo XIX. Historias conectadas: Ildegonda de Melesio Morales e II Guarany de Carlos Gomes". Historia Mexicana, 58(2), pp-803-860.

\section{Discografía}

Alla Francesca (1996) "Richard coeur de Lion" [Disco compacto], Opus 111, Paris

Atrium Musicae (1976) "Musica Ivcunda” [Disco compacto], Hispavox, Madrid.

Baca, S. (1992) "Del fuego y del agua" [Disco compacto], Elephant Records

Berry Hayward Consort (1988) "La messe des fous" [Disco compacto], BNL productions, París. 
Camerata Renacentista de Caracas (2003) "Música del pasado de América Latina" CD n.2 [Disco compacto], Caracas, Fundación Camerata de Caracas

Clemencic Consort (1980) "La Fete de l'Ane" [Disco de vinilo], Harmonia Mundi, Arles.

Clemencic Consort ([1977] 1998) "Troubadours" [Disco de vinilo], Harmonia Mundi, Arles.

Corvus Corax, (1989) "Ante Casu Peccati” [Disco compacto] Falcone Musikverlag

Corvus Corax, (1995) "Tritonus" [Disco compacto] Falcone Musikverlag

Ensamble Elyma y Gabriel Garrido (1993) "El siglo de oro en el Nuevo Mundo" [Disco compacto]. Symphonia, Bolonia.

Ensemble Organum (2004) "Compostela. Ad Vesperas Sancti lacobi" [Disco compacto]. París: Ambroisie.

Gothic Voices (1990) "The marriage of heaven and hell" [Disco compacto], Hyperion, London

Gérard Zuchetto (S/F) "La troba” Vol 1 [Disco compacto], Trova-vox, Montseret, S/F

I Ciarlatani ([1996] 2008) "Codex Manesse” [Disco compacto], Christophorus, Heidelberg

La Reverdie (1991) "Bestiarium: animals in the music of the Middle Ages" [Disco compacto], Nuova Era, Udine.

La Reverdie (1994) "Chi vol lo mondo despreççare". En Laude di Sancta Maria. Veillée de chants de dévotion dans I'Italie des Communes [Disco Compacto] Nantes: Arcana. 34

London Pro Musica (1998) Saltarello 'Fiorentina'. En A Florentine Carnival - A Festival of Music for Lorenzo de' Medici. [CD] Londres: IMP Classics.

Martin Best Consort (1982) "The Dante troubadours" [Disco compacto], Nimbus, Monmouth.

Martin Best Consort (1995) "Forgotten Provence" [Disco compacto], Nimbus, Monmouth.

Micrologus (1999) "Chi vol lo mondo despreççare". En Cantico della Terra [Disco Compacto] París: Opus.

Micrologus (1999) "In festa" [Disco compacto], Micrologus Ed., Spello

New London Consort, Philip Pickett (1991) "The Pilgrimage to Santiago" [Disco compacto], London: Decca.

New London Consort, Philip Pickett (1992) “The feast of fools”, [Disco compacto], London: Decca.

New Orleans Musica Da Camera (2000) "The Cross Of Red" [Disco Compacto] Label: Centaur Records

Perceval (1999) "Printemps du plaisir au Moyen-Age" [Disco compacto], Arion París

Sequentia (1992) "Donnersöhne - Sons of Thunder" [Disco compacto], Freiburg: Deutsche Harmonia Mundi.

Studio der Frühen Musik ([1970] 1985) "Troubadours \& trouvers" [Disco de vinilo], Teldec, Hamburg

Studio der Frühen Musik ([1976] 2000) "Vox Humana" EMI [Disco compacto], Cologne.

The Dufay Collective (1995) "Miri it is: Songs \& Instrumental Music from Medieval England" [Disco compacto] Chandos, Colchester.

The York Waits (1999) An Dro Nevez. En A golden treasury of ancient instruments [Disco compacto], Badminton, RU. Saydisc Records. 
The York Waits (1999) Mercantia. En A golden treasury of ancient instruments [Disco compacto]. Badminton, RU. Saydisc Records.

Tubb, E. (2009) "The troubadour and the nunn. Sacred and Secular Reflections on the Feminine Mystery from the middle ages to the Renaissance" [Disco compacto]. Etcétera

Zoltán, A. (2010) "The last of the Troubadours" [Producción independiente].

\section{Referencias en video}

D'Angiolillo, J. (2010) Hacerme Feriante. [Documental en video]. Buenos Aires. Independiente.

Disney, W. (1942a) Saludos Amigos. [Film de animación]. EEUU. Walt Disney Company.

Disney, W. (1942b) South of the border with Disney, [Documental cintematográfico]. EEUU. Walt Disney Company.

Ghez, S. (2012) "Tras los pasos de..." [Serie de TV. 12 episodios.] Canadá. Kultur Films Inc.

Gordon, Rich (2014) "How to play the bagpipes: Part 1" [Video en línea] https://www.youtube.com/ watch?v=GszZJgX_dvg consultado el 7 de junio de 2019

HuntleyFilmArchives (2013) Leadbelly And Lomax, 1940's -- Film 429 [archivo de video] Recuperado de https://www.youtube.com/watch?v=w-t9YIYa_S8\&t=138s

Irigoyen, A. (2014) El origen de las especies. La Zamba. [Documental televisivo] Argentina: Canal Encuentro. Recuperado de https://www.youtube.com/watch?v=AXXtS569mFU

Kuralt, Ch. (1991) "Charles Kuralt interviews Alan Lomax" [Video en línea] Recuperado de https:// www.youtube.com/watch?v=Zdj0pmQMTQI\&t=179s

Mignona, S. (2010a) "Siglo XIX, los proyectos de nación. Capítulo VIII, generación del '80" [Documental televisivo] Argentina: El perro en la luna para Canal Encuentro. Recuperado de: https://www.youtube.com/watch?v=QJjETT6ENrw\&t=649s

Mignona (2010b) "Siglo XIX, los proyectos de nación. Capítulo IX, Centenario" [Documental televisivo] Argentina: El perro en la luna para Canal Encuentro. Recuperado de: https:// youtu.be/yZfdOFhEZ8k

Ovando, A. (1986) "La fiesta de San Ignacio de Moxos" [Documental televisivo] Bolivia: Nicobis producciones. Recuperado de https://www.youtube.com/watch?v=cLQNDIB4f_w

Sorkin, A. (1999) "The west wing” [Serie de televisión] EE.UU: NBC. 